


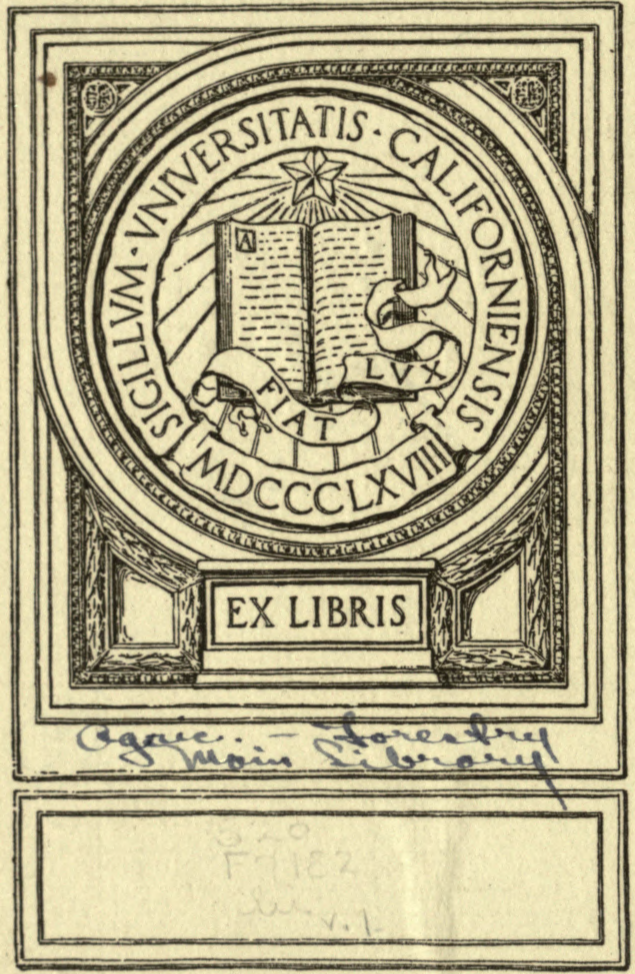





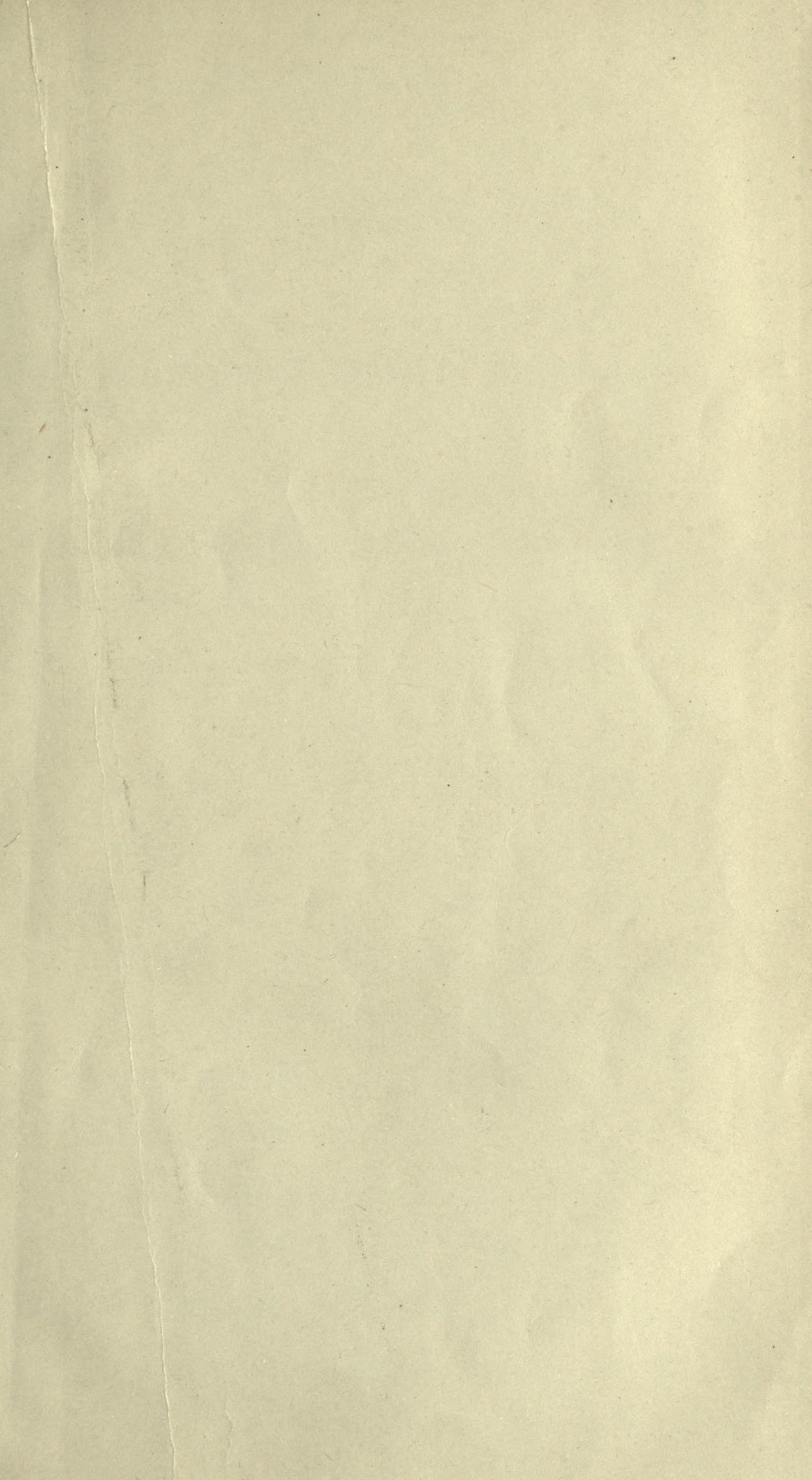



FORESTRY PAMPHLETS

"1

IUIMBER INDUSTRY

\section{VOI. I.}

1912.

'American tumber in Foreign Markets. Vol.

$$
\text { XI. } 1897 \text {. }
$$

$\gamma$ Influence of Forestry upon the Lumber Industry. By Overton $\mathbb{\pi}$. Price, 1902.

3 Sawmill Statistics. U. S. F. S. Cir. $10 \%$

+ Record of Wholesale Prices of Iumber. Based on actual sales made F. O. B. Mill for Each quarter of the Calendar Year, 1910. U.S.F. S.

$\zeta$ Record of Tholesale Prices of Iumber. U. S. F. S. Based on actual sales made $F$. o. B. for January, February and March, 1911.

6

Record of Wholesale prices of Irumber. Based on actual sales made F. O. D. Mill for April, May and June, 1911.

Record of Tholesale Prices of Lumber. Based on acturl sales made F. O. B. Mill for July, August and September, 1911. 

\&

Record of Wholesale Prices of Iumber.

Based on actual sales made F. O. B.

for Each Wuarter of the Calendar Year

1911.

a

Record of Wholesale Prices of Lumber. Based on Actual Sales made F. O. B. for

January, February and March, 1912.

${ }^{10}$ Record of Wholesale Prices of Lumber. Based

on Actual Sales made F. O. B. Mill fur

July, August and september, 1912.

"Exports of Farm and Forest Products, 1909-

1911, by Countries to which consigned. Bur.ostatiotics

U.S. Bulletin No. 96, 1912 .

IVAmounts and Kinds of Wood Used in the Manu-

facture of Boxes in the United states.

The Nat'l Ass'n of Box hanufacturers,

In cooperation with United Btates Dept.

of Agriculture. By J. C. Nellis, U.S.

F. S. 


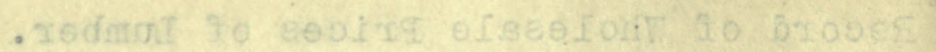

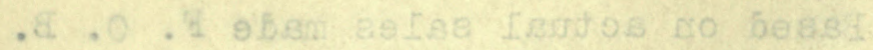

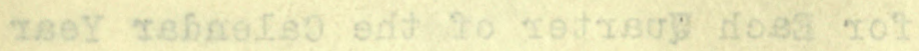

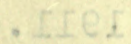

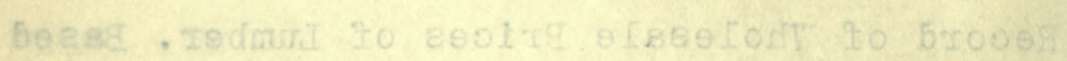

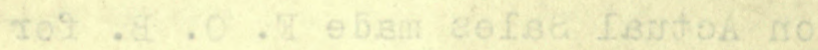

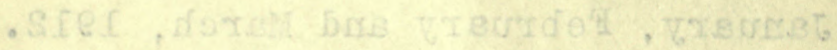

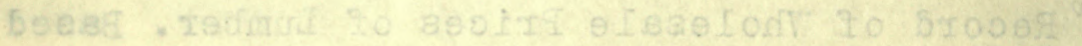

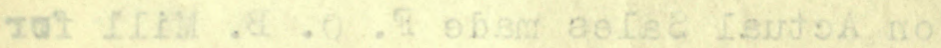

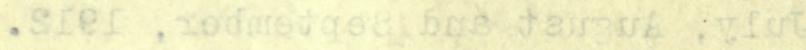

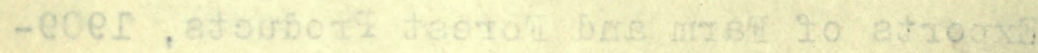

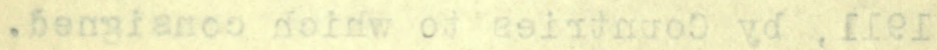

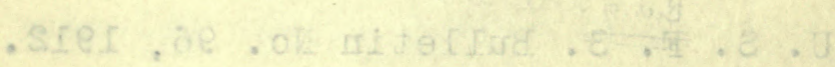

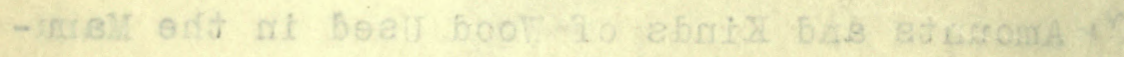

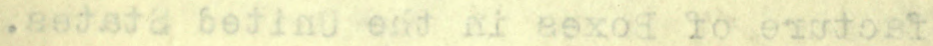

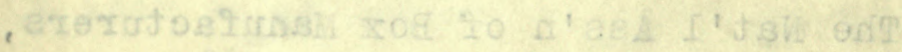

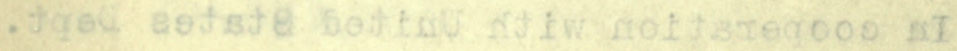

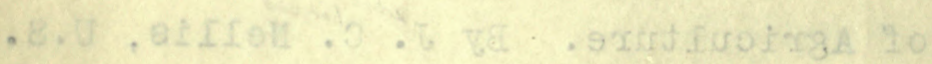

\section{8}




\title{
SPECIAL CONSULAR REPORTS.
}

\section{Wraten Mulpors \\ AMERICAN LUMBER \\ IN \\ FOREIGN MARKETS.}

\author{
VOL. XI.
}

Issued from the Burean of Statisties, Department of State, in 1894. Reissued, with Supplementary Reports, from the Burean of Foreign Commerce, Department of State, in 1897.

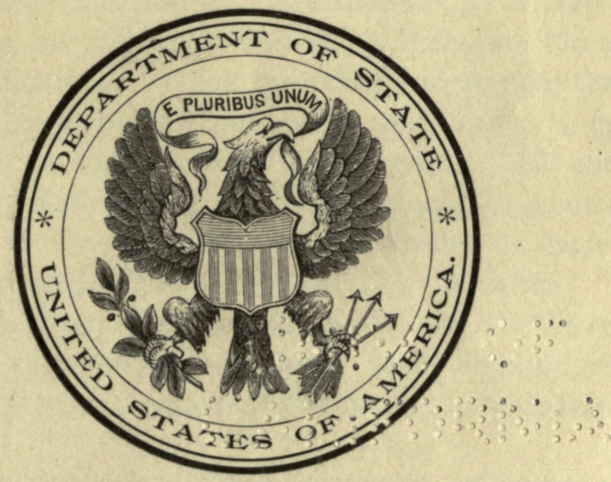

WASHINGTON :

GOVERNMENT PRINTING OFFICF.

1897. 



\section{VALUES OF FOREIGN COINS.}

The following statements show the valuation of foreign coins, as given by the Director of the United States Mint and published by the Secretary of the Treasury, in compliance with the first section of the act of March 3, I 873, viz: "That the value of foreign coins, as expressed in the money of account of the United States, shall be that of the pure metal of such coin of standard value," and that "the value of the standard coins in circulation of the various nations of the world shall be estimated annually by the Director of the Mint, and be proclaimed on the Ist day of January by the Secretary of the Treasury."

In compliance with the foregoing provisions of law, annual statements were issued by the Treasury Department, beginning with that issued on January $\mathbf{r}, \mathbf{1 8 7 4}$, and ending with that issued on January $\mathbf{1}, \mathbf{1} 890$. Since that date, in compliance with the act of October I, I890, these valuation statements have been issued quarterly, beginning with the statement issued on January $\mathbf{r}, \mathbf{r} 89 \mathbf{r}$.

These estimates "are to be taken (by customs officers) in computing the value of all foreign merchandise made out in any of said currencies, imported into the United States."

The following statements, running from January I, I874, to April r, 1894, have been prepared to assist in computing the proper values in American money of the trade, prices, values, wages, etc., of and in foreign countries, as given in consular and other reports. The series of years are given so that computations may be made for each year in the proper money values of such year. In hurried computations, the reductions of foreign currencies into American currency, no matter for how many years, are too often made on the bases of latest valuations. When it is taken into account that the ruble of Russia, for instance, has fluctuated from 77.17 cents in 1874 to 37.2 cents in April, 1894, such computations are wholly misleading. All computations of values, trade, wages, prices, etc., of and in the "fluctuating-currency countries" should be made in the values of their currencies in each year up to and including $\mathbf{r} 890$, and in the quarterly valuations thereafter.

To meet typographical requirements, the quotations for the years 1876 , $\mathbf{1} 877, \mathbf{1} 879, \mathbf{1 8 8 1}$, and $\mathbf{1} 882$ are omitted, these years being selected as showing the least fluctuations when compared with years immediately preceding and following.

To save unnecessary repetition, the estimates of valuations are divided into three classes, viz: (A) countries with fixed currencies, (B) countries with fluctuating currencies, and (C) quarterly valuations of fluctuating currencies. 
A.-Countries with fixed currencies.

\begin{tabular}{|c|c|c|c|c|}
\hline Countries. & Standard. & Monetary unit. & $\begin{array}{l}\text { Value in } \\
\text { terms of } \\
\text { United } \\
\text { States } \\
\text { gold. }\end{array}$ & Coins. \\
\hline Argentine Republic*.... & Gold and silver... & Peso .......... & $\$ 0.96,5$ & $\begin{array}{l}\text { Gold-Argentine }\left(\$ 4 c^{8} 8,4\right) \text { and } 1 / 2 \\
\text { Argentine; silver-peso and di- } \\
\text { visions. }\end{array}$ \\
\hline Austria-Hungary $\dagger \ldots$ & Gold ........................... & Crown.................... & $.20,3$ & $\begin{array}{l}\text { Gold }-20 \text { crowns }(\$ 4.05,2) \text { and } \text { io } \\
\text { crowns. }\end{array}$ \\
\hline Belgium.... & Gold and silver... & Franc................... & $. x, 3$ & $\begin{array}{l}\text { Gold-ro and } 20 \text { franc pieces; sil- } \\
\text { ver }-5 \text { francs. }\end{array}$ \\
\hline Brazil .............. & Gold .......................... & Milreis ............... & $.54,6$ & $\begin{array}{l}\text { Gold }-5, \text { ro, and } 20 \text { milreis ; sil- } \\
\text { ver }-1 / 2, x \text {, and } 2 \text { milreis. }\end{array}$ \\
\hline Chileł........... & Gold and silver.... & Peso... & $.9 x, 2$ & $\begin{array}{l}\text { Gold-escudo }(\$ 1.82,4) \text {, doubloon } \\
(\$ 4.56,1) \text {, and condor }(\$ 9.12,8) \text {; } \\
\text { silver-peso and divisions. }\end{array}$ \\
\hline Cuba.. & ......dc & .......do.... & $\cdot 92,6$ & $\begin{array}{l}\text { Gold-doubloon }(\$ 5.01,7) \text {; silver- } \\
\text { peso. }\end{array}$ \\
\hline Denmark... & Gold ........................ & Crown..................... & $.26,8$ & Gold-ro and 20 crowns. \\
\hline Egypt..... & (n.....do....................... & $\begin{array}{l}\text { Pound (I0o pias- } \\
\text { ters). }\end{array}$ & $4.94,3$ & $\begin{array}{l}\text { Gold-ro, } 20,50 \text {, and roo piasters : } \\
\text { silver-1, } 2,10 \text {, and } 20 \text { piasters. }\end{array}$ \\
\hline Finland.... & ........do........ & Mark..................... & $.19,3$ & $\begin{array}{l}\text { Gold-ro and } 20 \text { marks ( } \$ 1.93 \text { and } \\
\$ 3.85,9) \text {. }\end{array}$ \\
\hline France......... & Gold and silver.... & Franc..... & $.19,3$ & $\begin{array}{l}\text { Gold }-5, \text { 10, } 20,50 \text {, and roo francs ; } \\
\text { silver }-5 \text { francs. }\end{array}$ \\
\hline Germany ............. & Gold ....................... & Mark...................... & $.23,8$ & Gold -5, ro, and 20 marks. \\
\hline Great Britain..... & 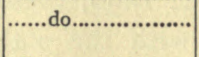 & Pound sterling..... & $4.86,6 \frac{1}{2}$ & $\begin{array}{l}\text { Gold-sovereign (pound sterling) } \\
\text { and half sovereign. }\end{array}$ \\
\hline Greece............... & Gold and silver.... & Drachma.... & $.19,3$ & $\begin{array}{l}\text { Gold }-5 \text {, ro, } 30,50 \text {, and roo drach- } \\
\text { mas; silver }-5 \text { drachmas. }\end{array}$ \\
\hline $\mathrm{Ha}$ & .......do.... & Gourd & $.96,5$ & Silver-gourde. \\
\hline Italy... & ........do..................... & $\ldots . . . . . . . . . . . .$. & $.19,3$ & $\begin{array}{l}\text { Gold- } 5 \text {, ro, } 20,50 \text {, and roo lire ; } \\
\text { silver }-5 \text { lire. }\end{array}$ \\
\hline Libe & Gold & Dolla & $1 . \infty$ & \\
\hline Netherlands 3 ..... & Gold and silver.... & Florin..... & $.40,2$ & $\begin{array}{l}\text { Gold-ro florins; silver- } 1 / 2, x \text {, and } \\
2^{1 / 2} \text { florins. }\end{array}$ \\
\hline Portugal....................... & Gold ...................... & Milre & 1.08 & Gold-1, 2, 5, and ro milreis. \\
\hline 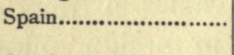 & Gold and silver.... & Peseta.................... & $.19,3$ & $\begin{array}{l}\text { Gold }-25 \text { pesetas; silver }-5 \text { pese- } \\
\text { tas. }\end{array}$ \\
\hline Sweden and Norway... & Gold & 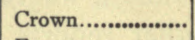 & $.26,8$ & Gold -10 and 20 crowns. \\
\hline Switzerland.......... & Gold and silver.... & Franc.................. & $. x, 3$ & $\begin{array}{l}\text { Gold }-5,10,20,50 \text {, and roo francs: } \\
\text { silver-5 francs. }\end{array}$ \\
\hline Turkey.. & & Piaster...... & $.04,4$ & $\begin{array}{l}\text { Gold-25, } 50,100,200 \text {, and } 500 \\
\text { piasters. }\end{array}$ \\
\hline Venezuela ... & Gold and silver.... & Bolivar................. & $.19,3$ & $\begin{array}{l}\text { Gold }-5, \text { ro, } 20,50 \text {, and roo boli- } \\
\text { vars ; silver- } 5 \text { bolivars. }\end{array}$ \\
\hline
\end{tabular}

* In 1874 and 1875 the gold standard prevailed in the Argentine Republic. Its currency does not appear in the statements again until $r 88_{3}$, when the double standard prevailed, and the peso attained a fixed value of 96.5 cents.

† On reference to the table of "fluctuating currencies," it will be seen that Austria had the silver standard up to and including the quarter ending July $\mathbf{r}, \mathbf{r} 89_{2}$. The next quarter (October $\mathbf{r}$ ) inaugurated the gold standard (see note under table of "fluctuating currencies").

†The gold standard prevailed in Chile until January $\mathbf{x}, \mathbf{r} 890$. The value of the peso has been the same under both standards.

3 The Netherlands florin, as will be seen in the "fluctuating" table, became fixed in value (40.2 cents) in เ88a. 


\section{B.-Countries with fuctuating currencies, 1874-9o.}

\begin{tabular}{|c|c|c|c|c|c|c|c|c|}
\hline \multirow{2}{*}{ Countries. } & \multirow{2}{*}{ Standard. } & \multirow{2}{*}{ Monetary unit. } & \multicolumn{6}{|c|}{$\begin{array}{l}\text { Value in terms of the United States gold dollar on } \\
\text { January I- }\end{array}$} \\
\hline & & & 1874. & 1875. & 1878. & 1880. & 1883. & 1884. \\
\hline $\begin{array}{l}\text { Austria-Hungary }{ }^{\star} \text {. } \\
\text { Bolivia.................. }\end{array}$ & 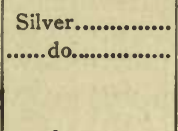 & $\begin{array}{l}\text { Florin ................. } \\
\text { Dollar until } \\
\text { 188o; bolivi- } \\
\text { ano there- } \\
\text { after. }\end{array}$ & $\begin{array}{r}\$ 0.47,6 \\
\cdot 96,5\end{array}$ & $\begin{array}{r}\$ 0.45,3 \\
.96,5\end{array}$ & $\begin{array}{r}\$ 0.45,3 \\
.96,5\end{array}$ & $\begin{array}{r}\$ 0.4 x, 3 \\
.83,6\end{array}$ & $\begin{array}{r}\$ 0.40, x \\
.8 x, 2\end{array}$ & $\begin{array}{r}\$ 0.39,8 \\
.80,6\end{array}$ \\
\hline Central America... & Silver.................................... & Peso.................. & $\mid \begin{array}{l}\cdot 96,5 \\
\text { r. } 61\end{array}$ & $.9 x, 8$ & $.9 x, 8$ & $.83,6$ & (n........... & $\cdots \cdots$ \\
\hline olombia.. & 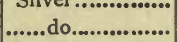 & $\begin{array}{l}\text { Halkwan tael.... } \\
\text { Peso..................... }\end{array}$ & .0 & $.96,5$ & $.96,5$ & $.83,6$ & $.8 x, 2$ & $.80,6$ \\
\hline Ecuador. & 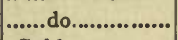 & ......do................. & $.96,5$ & $.9 x, 8$ & $.91,8$ & $.83,6$ & $.8 x, 2$ & $.80,6$ \\
\hline Egypt†..... & Gold..... & $\begin{array}{l}\text { Pound ( } \text { ( o o } \\
\text { piasters). }\end{array}$ & (................ & ................. & $4 \cdot 97,4$ & $4.97,4$ & 4.90 & 4.90 \\
\hline India. & Silver... & Rupee................ & $.45,8$ & $.43,6$ & $.43,6$ & $\cdot 39,7$ & $\cdot 3^{8,6}$ & $\cdot 3^{8}, 3$ \\
\hline apan & $\left\{\begin{array}{l}\text { Gol } \\
\text { Sil }\end{array}\right.$ & Yer & $\{\cdot 99,7$ & $.99,7$ & $.99,7$ & $\cdot 99,7$ & …............ & ........... \\
\hline & 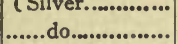 & Dollar.. & $1.04,7^{1}$ & $.99,8$ & $\cdot(\cdots . . . . . . . .$. &......... & $\begin{array}{l}.87,6 \\
.88,2\end{array}$ & $\begin{array}{l}.86,9 \\
.87,5\end{array}$ \\
\hline$\cdots$ & Gold and silver.. & Florin .................... & $\mid \begin{array}{c}1.04,7 \frac{1}{2} \\
.40,5\end{array}$ & $\begin{array}{l}\cdot 99,0 \\
\cdot 3^{8}, 5\end{array}$ & $\begin{array}{l}\cdot 99,0 \\
.38,5\end{array}$ & $\begin{array}{l}.90,9 \\
.40,2\end{array}$ & ................ & $\begin{array}{l}.07,5 \\
\cdots \ldots \ldots \ldots . .\end{array}$ \\
\hline eru... & Silver............... & Sol..................... & $.92,5$ & $.9 x, 8$ & $\cdot 9 x, 8$ & $.83,6$ & $.8 \mathrm{r}, 2$ & $.80,6$ \\
\hline Russia... & .......do.. & Ruble................ & $\cdot 77,17$ & $7.73,4$ & $.73,4$ & $.66,9$ & .65 & $.64,5$ \\
\hline Tripoli... & .......do.. & $\begin{array}{l}\text { Mahbub of } 20 \\
\text { piasters. }\end{array}$ & $.87,09$ & $.82,9$ & $.82,9$ & $\cdot 74,8$ & $.73,3$ & $\cdot 72,7$ \\
\hline \multirow[t]{2}{*}{ Countries. } & \multirow[t]{2}{*}{ Standard. } & \multirow[t]{2}{*}{ Monetary unit. } & \multicolumn{6}{|c|}{$\begin{array}{c}\text { Value in terms of the United States gold dollar on } \\
\text { January I- }\end{array}$} \\
\hline & & & 1885. & 1886. & x887. & I888. & I88g. & x8go. \\
\hline Austria- $\mathrm{H}$ & Silver................. & Florin................ & $\$ 0.39,3$ & $\$ 0.37, x$ & $\$ 0.35,9$ & $\$ 0.34,5$ & $\$ 0.33,6$ & $\$ 0.42$ \\
\hline Bolivia... & $\ldots . .000$. do & $\begin{array}{l}\text { Dollar until } \\
\text { r880; bolivi- } \\
\text { ano t here- } \\
\text { after. }\end{array}$ & $\cdot 79,5$ & $\cdot 75,1$ & $\cdot 72,7$ & $.69,9$ & .68 & .85 \\
\hline a... & .......do................. & Peso................... & .................. & ................... & $\ldots \ldots$ & $.69,9$ & .68 & .85 \\
\hline$\ldots$ & .......do...................... & .......do.................. & $.79,5$ & $.75, x$ & $\cdot 72,7$ & $.69,9$ & .68 & .85 \\
\hline Ecua & .......do................. & $\ldots . .$. do................. & - $\cdot 79,5$ & $\cdot 75, \mathrm{I}$ & $\cdot 7^{2}, 7$ & $.69,9$ & .68 & .85 \\
\hline 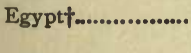 & Gold.................... & $\begin{array}{l}\text { Pound ( } \text { ( o o } \\
\text { piasters). }\end{array}$ & 4.90 & 4.90 & $4.94,3$ & $4.94,3$ & $4.94,3$ & $4.93,3$ \\
\hline India.......... & Silver................. & Rupee............... & $\cdot 37,8$ & $\cdot 35,7$ & $\cdot 34,6$ & $.33,2$ & $\cdot 3^{2,3}$ & $.40,4$ \\
\hline Japan........... & $\left\{\begin{array}{l}\text { Gold........... } \\
\text { Silver }\end{array}\right.$ & \} Yen.................... & $\{\ldots \ldots \ldots .$. & . $\cdots . . . . . . .$. & $\cdot 99,7$ & $\cdot 99,7$ & $\cdot 99,7$ & $\cdot 99,7$ \\
\hline Mex & CSilve & Doll & $\begin{array}{l}.85,8 \\
.86,4\end{array}$ & $.8 x$ & $\cdot 78,4$ & $\cdot 75,3$ & $\cdot 73,4$ & $\cdot 91,7$ \\
\hline Peru.. & Silver................. & Sol...................... & $.80,4$ & $.81,0$ & $\cdot 79$ & $\cdot 75,9$ & $\begin{array}{c}-73,9 \\
68\end{array}$ & $.92,3$ \\
\hline & ......do................. & Ruble................ & $.63,6$ & $\begin{array}{l}.75,1 \\
.60,1\end{array}$ & $.58,2$ & $\begin{array}{l}.69,9 \\
.55,9\end{array}$ & & .68 \\
\hline Tripoli.................. & .......do.do.mon.......... & $\begin{array}{l}\text { Mabbub of } 20 \\
\text { piasters. }\end{array}$ & $\cdot 7 x, 7$ & $.67,7$ & $.65,6$ & .63 & $.6 x, 4$ & $.76,7$ \\
\hline
\end{tabular}

- The silver standard prevailed in Austria-Hungary up to 1892 . The law of August 2 of that year (see Consular Reports, No. 147, p. 623) established the gold standard.

t The Egyptian pound became fixed in value at $\$ 4.94,3$ in $\times 887$.

$\$$ The Netherlands florin fluctuated up to the year 1880 , when it became fixed at 40.2 cents. 
C.-Quarterly valuations of fuctuating currencies, $1891-94$.

\begin{tabular}{|c|c|c|c|c|c|c|c|c|c|}
\hline \multirow{2}{*}{ Countries. } & \multirow{2}{*}{ Monetary unit. } & \multicolumn{4}{|c|}{ 189x. } & \multicolumn{4}{|c|}{ r8g2. } \\
\hline & & Jan. $x$. & April r. & July $x$. & Oct. x. & Jan. $x$. & April x. & July $x$. & Oct. x. \\
\hline & s Gold crown...... & & & & & & ...................... & & $\$ 0.20,3$ \\
\hline Aust & \{ Silver florin .... & $\$ 0.3^{8, x}$ & $\$ 0.36,3$ & $\$ 0.36,3$ & \$o. 35,7 & $\$ 0.34, x$ & \$o. 32,8 & $\$ 0.32$ & ................... \\
\hline Bolivia.. & Silver boliviano. & $\cdot 77, \mathrm{x}$ & $\cdot 73,5$ & $.73,6$ & $.72,3$ & $.69, x$ & $.66,5$ & $.64,9$ & $.6 x, 6$ \\
\hline Central America... & Silver peso......... & $\cdot 77,1$ & $.73,5$ & $\cdot 73,6$ & $\cdot 7^{2}, 3$ & $.69, x$ & $.66,5$ & $.64,9$ & $.6 x, 6$ \\
\hline Chi & \{ Shanghai tael. & I. $x_{3}, 9$ & $1.08,5$ & $x .08,7$ & x. 06,8 & $x .02, x$ & $.98,2$ & $.95,8$ & $.9 x$ \\
\hline Cint & \{ Haikwan tael.. & $x .27$ & I. 20,9 & $x .2 x$ & x. 18,9 & 1. 13,9 & $x .09,3$ & $1.06,7$ & $x .01,3$ \\
\hline Colombia................. & Silver peso......... & $\cdot 77, x$ & $\cdot 73,5$ & $.73,6$ & $\cdot 72,3$ & $.69, \mathrm{x}$ & $.66,5$ & $.64,9$ & $.6 x, 6$ \\
\hline Ecuador................... & 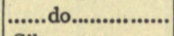 & $\cdot 77, x$ & $\cdot 73,5$ & $.73,6$ & $\cdot 72,3$ & $.69,1$ & $.66,5$ & $.64,9$ & $.6 x, 6$ \\
\hline India & Silver rupee ....... & $\cdot 3^{6,6}$ & $\cdot 34,9$ & .35 & $.34,3$ & $\cdot 3^{2,8}$ & $\cdot 3 x, 6$ & $.30,8$ & $.29,3$ \\
\hline 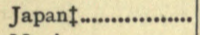 & Silver yen ......... & $.83, x$ & $\cdot 79,2$ & $\cdot 79,3$ & $.77,9$ & $.74,5$ & $\cdot 7 x, 6$ & $.69,9$ & $.66,4$ \\
\hline Mexico..................... & Silver dollar..... & $.83,7$ & .80 & .80 & $\cdot 78,5$ & .75 & $\cdot 72,2$ & $\cdot 70,4$ & $.66,9$ \\
\hline Peru....................... & Silver sol ........... & $\cdot 77, x$ & $\cdot 73,5$ & $.73,6$ & $\cdot 72,3$ & $.69,1$ & $.66,5$ & $.64,9$ & $.6 x, 6$ \\
\hline Russią̧................... & Silver ruble ....... & $.6 x, 7$ & $.5^{8,8}$ & $.58,8$ & $\cdot 57,8$ & $.55,3$ & $.53, x$ & $.5 x, 9$ & $.49,2$ \\
\hline Tripoli.................... & Silver mahbub.. & $.69,5$ & $.66,3$ & $.66,4$ & $.65,2$ & $.62,3$ & .60 & $\cdot 5^{8}, 5$ & $.55,5$ \\
\hline 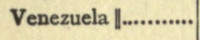 & Silver bolivar.... & $.15,4$ & $.14,7$ & $.14,7$ & $.14,5$ & $.13,8$ & $.13,3$ & .13 & $.12,3$ \\
\hline
\end{tabular}

\begin{tabular}{|c|c|c|c|c|c|c|c|}
\hline \multirow{2}{*}{ Countries. } & \multirow{2}{*}{ Monetary unit. } & \multicolumn{4}{|c|}{ 1893. } & \multicolumn{2}{|c|}{1894.} \\
\hline & & Jan. I. & April r. & July $r$. & Oct. $\mathbf{x}$. & Jan. $\mathbf{x}$ & April r. \\
\hline Bolivia....... & Silver boliviano................ & $\$ 0.6 x, 3$ & $\$ 0.6 x$ & $\$ 0.60,4$ & $\$ 0.53,1$ & $\$ 0.5^{1,6}$ & $\$ 0.46,5$ \\
\hline Central America.... & Silver peso......................... & $.6 x, 3$ & $.6 \mathrm{I}$ & $.60,4$ & $.53, \mathrm{I}$ & $\cdot 5^{1}, 6$ & $.46,5$ \\
\hline & $\{$ Shanghai tael................... & $.90,6$ & $.90, x$ & $.89,2$ & $\cdot 78,4$ & $\cdot 76,2$ & $.68,6$ \\
\hline Chinaf... & \{ Haikwan tael................... & I. or & $1.00,4$ & $.99,4$ & $.87,4$ & $.84,9$ & $.76,5$ \\
\hline Colombia... & Silver peso............................. & $.6 \mathrm{r}, 3$ & $.6 x$ & $.60,4$ & $.53, x$ & $.5^{1}, 6$ & $.46,5$ \\
\hline Ecuador...... & 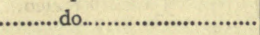 & $.6 \mathrm{r}, 3$ & $.6 x$ & $.60,4$ & $.53, \mathrm{x}$ & $.5 x, 6$ & $.46,5$ \\
\hline India & Silver rupee......................... & $.29,2$ & .29 & $.28,7$ & $.25,2$ & $.24,5$ & $.22,1$ \\
\hline 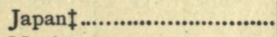 & 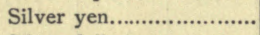 & $.66, x$ & $.65,8$ & $.65, \mathrm{x}$ & $.57,3$ & $.55,6$ & $.50,1$ \\
\hline Mexico............................... & Silver dollar.................... & $.66,6$ & $.66,2$ & $.65,6$ & $.57,7$ & $\cdot 5^{6}$ & $.50,5$ \\
\hline 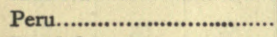 & Silver sol.......................... & $.6 r, 3$ & .61 & $.60,4$ & $.53,1$ & $\cdot 5 x, 6$ & $.46,5$ \\
\hline 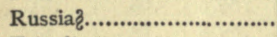 & Silver ruble........................... & $.49, \mathrm{I}$ & $.48,8$ & $.4^{8,3}$ & $.42,5$ & $.4 \mathrm{I}, 3$ & $\cdot 37,2$ \\
\hline 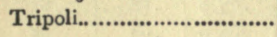 & Silver mahbub.................. & $.55,3$ & .55 & $.54,5$ & $.47,9$ & $.46,5$ & $.4 \mathrm{I}, 9$ \\
\hline
\end{tabular}

*Austria-Hungary had the silver standard up to August, 1892 (see note to "fluctuating" table B).

†China (silver). The Haikwan tael is the customs tael, and the Shanghai tael that used in trade. Consul-General Denny (Consular Reports No. 43, p. ${ }^{116}$ ) says: “The value of the tael varies in the different ports of China, and every port has two taels, one being the Government, or Haikwan, tael, in which all duties have to be paid, and the other the market tael, the former exceeding the latter by some II per cent."

$\ddagger$ Gold is the nominal standard in Japan, but silver is practically the standard. The fixed value of the gold yen is 99.7 cents.

? The gold ruble is valued at $\mathbf{7 7 . 2}$ cents. Silver is the nominal standard, but paper is the actual currency, and its depreciation is measured by the gold standard.

I The Venezuelan bolivar became fixed in value ( 19.3 cents) on January $\mathbf{x}, 1892$. 


\section{FOREIGN WEIGHTS AND MEASURES.}

The following table embraces only such weights and measures as are given from time to time in Consular RePORTS and in Commercial Relations:

Foreign weights and measures, with American equivalents.

\begin{tabular}{|c|c|}
\hline Denominations. & Where used. \\
\hline Almude............... & Portugal......................................... \\
\hline Ardeb.................. & Egypt............................................ \\
\hline Are & Metric....................................... \\
\hline Arobe......................... & Paraguay ..................... \\
\hline Arratel or libra................................... & Portugal....................... \\
\hline Arroba (dry)..................................... & Argentine Republic ....... \\
\hline Do............ & Brazil ........................... \\
\hline Do.n.................... & Cuba..................................... \\
\hline Do........................ & Portugal................................ \\
\hline Do....... & Spain..................................... \\
\hline Do......... & Venezuela .............................. \\
\hline Arroba (liquid).... & Cuba, Spain, and Venezuela........... \\
\hline Arshine ................. & Russia ................................... \\
\hline Arshine (square)... & .................. \\
\hline Artel..................... & Morocco........................ \\
\hline Baril......... & Argentine Republic and Mexico....... \\
\hline Barrel........ & Malta (customs)....................... \\
\hline Do...... & Spain (raisins) \\
\hline Berkovet..... & Russia ....................... \\
\hline Bongkal..... & India.......................... \\
\hline Bonw w....... & Sumatra............ \\
\hline Bu......... & Japan \\
\hline Butt (wine)... & Spain......................... \\
\hline Caffiso ......... & Malta ..................... \\
\hline Candy ... & India (Bombay)............ \\
\hline Do... & 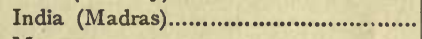 \\
\hline $\operatorname{ar} . . . . .$. & Morocco....................................... \\
\hline Do..... & Syria (Damascus).......................... \\
\hline Do....... & Turkey........................ \\
\hline Cantaro (Cantar)... & Malta............................ \\
\hline Carga ............ & Mexico and Salvador...................... \\
\hline Catty ....... & 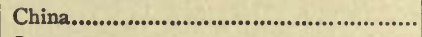 \\
\hline Do & Japan \\
\hline Do... & Java, Siam, Malacca..... \\
\hline Do.......... & 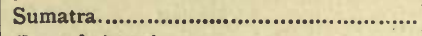 \\
\hline Centaro............. & Central America............................... \\
\hline Centner............ & Bremen and Brunswick................... \\
\hline Do... & Darmstadt....................................... \\
\hline Do...... & Denmark and Norway..................... \\
\hline Do....... & 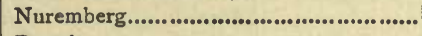 \\
\hline Do....... & Prussia............ \\
\hline Do...... & Sweden.............. \\
\hline Do....... & Vienna.......................... \\
\hline Do........... & Zollverein.................................. \\
\hline Do.......... & Double or metrlc......................... \\
\hline Chlh.... & China...................... \\
\hline Coyan...oes.. & Sarawak... \\
\hline & Siam (Ko \\
\hline
\end{tabular}

American equivalent.

4.422 gallons.

7.6907 bushels.

$0.0247 \mathrm{r}$ acre.

25 pounds.

r.orr pounds.

$25.3 \times 75$ pounds.

32.38 pounds.

25.3664 pounds.

$32.3^{8}$ pounds.

25.36 pounds.

25.4024 pounds.

4.263 gallons.

28 inches.

5.44 square feet.

I.12 pounds.

20.0787 gallons.

II. 4 gallons.

roo pounds.

$36 \mathrm{r} .12$ pounds.

832 grains.

$7,096.5$ square meters

0.1 inch.

140 gallons.

5.4 gallons.

529 pounds.

500 pounds.

II 3 pounds.

575 pounds.

124.7036 pounds.

I 75 pounds.

300 pounds.

x. $333^{T} / 3\left(x^{1} / 3\right)$ pounds

1. 3 I pounds.

r.35 pounds.

2.12 pounds.

$4.263^{1}$ gallons.

II 7.5 pounds.

Iro.24 pounds.

110.11 pounds.

112.43 pounds.

ris.44 pounds.

93.7 pounds.

123.5 pounds.

110.24 pounds.

220.46 pounds.

14 inches.

3,098 pounds.

2,667 pounds. 
Foreign weights and measures, with American equivalents-Continued.

\begin{tabular}{|c|c|c|}
\hline Denominations. & Where used. & American equivalent. \\
\hline Cuadra.... & Argentine Republic............................... & 4.2 acres. \\
\hline 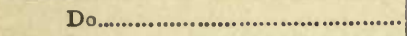 & 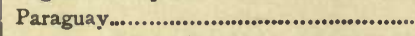 & 78.9 yards. \\
\hline 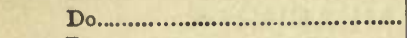 & Paraguay (square)................................... & 8.077 square feet. \\
\hline 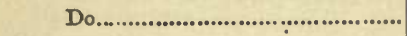 & Uruguay $\ldots . . . \ldots \ldots \ldots \ldots \ldots \ldots \ldots \ldots \ldots \ldots \ldots \ldots \ldots \ldots \ldots \ldots \ldots \ldots \ldots$ & Nearly 2 acres. \\
\hline Cubic meter.............................................. & Metric...................................................... & $35 \cdot 3$ cubic feet. \\
\hline 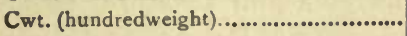 & 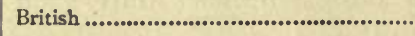 & 112 pounds. \\
\hline 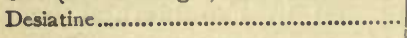 & 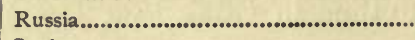 & 2.6997 acres. \\
\hline 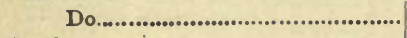 & 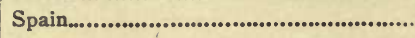 & I. 599 bushels. \\
\hline 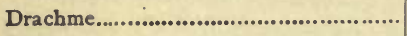 & Greece & Half ounce. \\
\hline 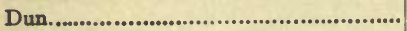 & 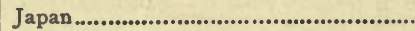 & $I$ inch. \\
\hline Egyptian weights and measures.............. & (See Consular Reports No. I44.) & \\
\hline 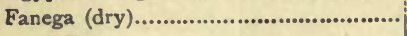 & Central America & I. 5745 bushels. \\
\hline 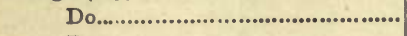 & 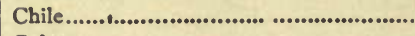 & 2.575 bushels. \\
\hline 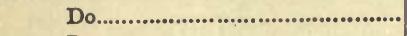 & 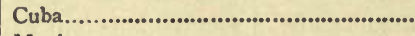 & I. 599 bushels. \\
\hline Do & 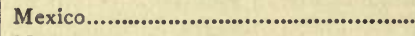 & I. 54728 bushels. \\
\hline (............................. & 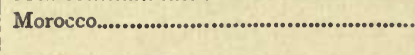 & $\begin{array}{l}\text { Strike fanega, } 70 \text { lbs. } \\
\text { full fanega, ir8 lbs. }\end{array}$ \\
\hline 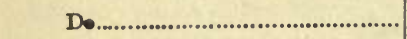 & 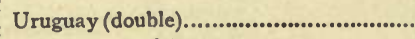 & 7.776 bushels. \\
\hline 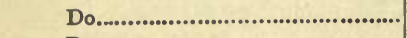 & 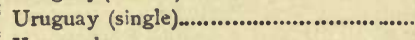 & 3.888 bushels. \\
\hline Do................................................ & 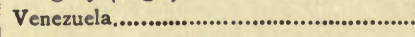 & I. 599 busbels. \\
\hline Fanega (liquid)........................................ & Spain & I6 gallons. \\
\hline 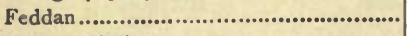 & Egypt & x.03 acres. \\
\hline 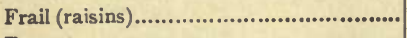 & Spain & 50 pounds. \\
\hline 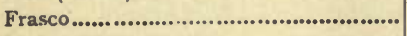 & 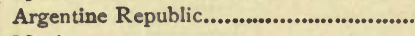 & 2.5096 quarts. \\
\hline 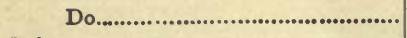 & 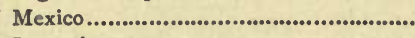 & 2.5 quarts. \\
\hline 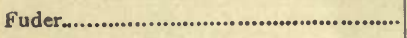 & Luxemburg ................................................. & 264.17 gallons. \\
\hline 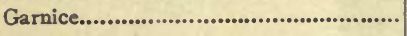 & 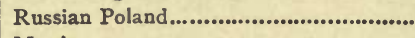 & 0.88 gallon. \\
\hline Gram & 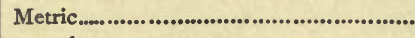 & 15.432 grains. \\
\hline 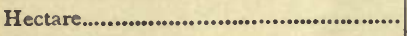 & $\ldots . . . . . . . d o$ & $2.47 x$ acres. \\
\hline Hectoliter: & & \\
\hline (2) & (.............................. & $2.83^{8}$ bushels. \\
\hline (2) & 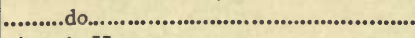 & 26.417 gallons. \\
\hline 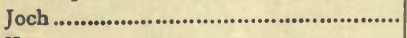 & 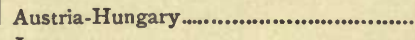 & $\mathrm{r} .422$ acres. \\
\hline Ken & 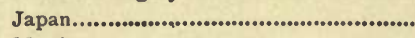 & 4 yards. \\
\hline 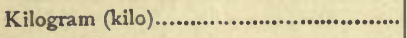 & 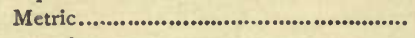 & 2.2046 pounds. \\
\hline 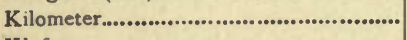 & $\ldots \ldots$ do & $0.62 \times 376$ mile. \\
\hline 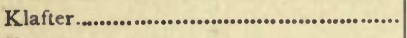 & 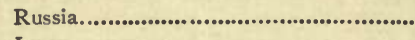 & $2 \times 6$ cubic feet. \\
\hline 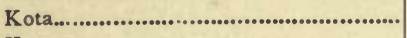 & Japan & 5.13 bushels. \\
\hline 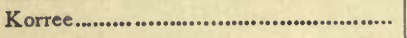 & 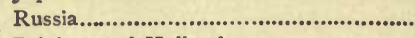 & 3.5 bushels. \\
\hline 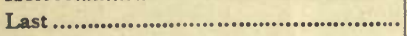 & Belgium and Holland .............................. & 85.134 bushels. \\
\hline 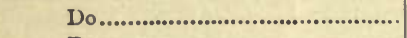 & 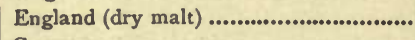 & 82.52 bushels. \\
\hline 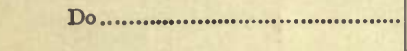 & 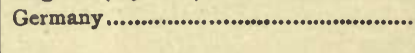 & $\begin{array}{l}\text { metric tons }\left(4,4^{80}\right. \\
\text { pounds). }\end{array}$ \\
\hline (n).............................. & Prussia ............. & 112.29 bushels. \\
\hline 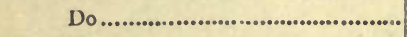 & 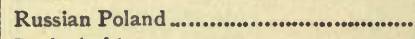 & xx $3 / 8$ bushels. \\
\hline Do ............................................ & Spain (salt) $\ldots \ldots \ldots \ldots \ldots \ldots \ldots \ldots \ldots \ldots \ldots \ldots \ldots \ldots \ldots$ & 4,760 pounds. \\
\hline 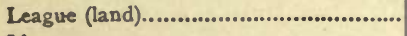 & Paraguay & 4,633 acres. \\
\hline 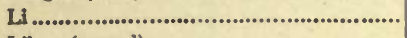 & 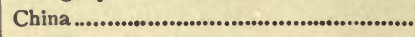 & 2,115 feet. \\
\hline 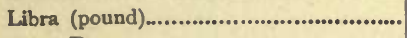 & Castilian.................................................... & 7,100 grains (troy) \\
\hline Do $\ldots \ldots \ldots \ldots \ldots \ldots \ldots \ldots \ldots \ldots \ldots$ & Argentine Republic ................................. & I.0127 pounds. \\
\hline Do $\ldots \ldots \ldots \ldots \ldots \ldots \ldots \ldots \ldots \ldots \ldots \ldots \ldots \ldots \ldots \ldots \ldots$ & 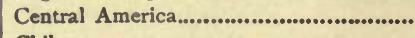 & r.043 pounds. \\
\hline Do & Chile.......ens....................................................... & r.or4 pounds. \\
\hline Do & Cuba & x.or6r pounds. \\
\hline 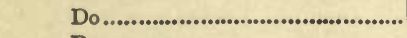 & 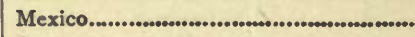 & 8.02465 pounds. \\
\hline Do & 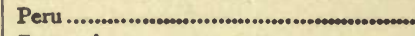 & $8.0 \times 43$ pounds \\
\hline 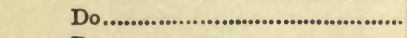 & 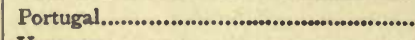 & x.orr pounds. \\
\hline 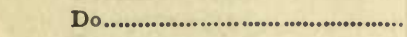 & Uruguay $. . . . . . . . . .000 . \ldots \ldots$ & x.0x43 pounds. \\
\hline 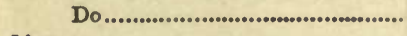 & 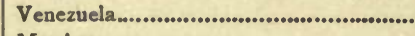 & x.or6r pounds. \\
\hline 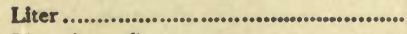 & Metric ....................................................... & I.0267 quarts. \\
\hline e (poun & 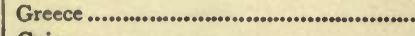 & $x . x$ pounds. \\
\hline Do. & Guiana & x.079x pound \\
\hline
\end{tabular}


Foreign weights and measures, with American equivalents-Continued.

\begin{tabular}{|c|c|c|}
\hline Denominatio & Where used. & American equivalent. \\
\hline oad.. & England (timber)................ & $\begin{array}{l}\text { Square, } 50 \text { cubic feet, } \\
\text { unhewn, } 40 \text { cubic feet; } \\
\text { inch planks, } 600 \text { super- } \\
\text { ficial feet. }\end{array}$ \\
\hline Manzana ..... & 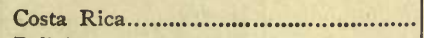 & If acres. \\
\hline Marc........................ & 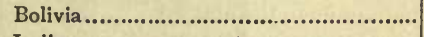 & $0.5 \circ 7$ pound. \\
\hline Maund........................ & 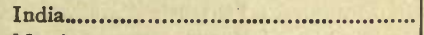 & 827 pounds. \\
\hline Meter.......................... & 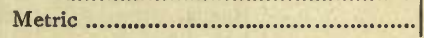 & 39.37 inches. \\
\hline Mil....... & 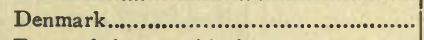 & 4.68 miles \\
\hline Do...... & 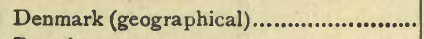 & $4.6 \mathrm{x}$ miles. \\
\hline Morgen ............. & Prussia ............................ & 0.63 acre. \\
\hline Oke................... & 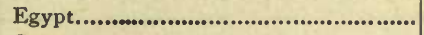 & 2.7225 pounds. \\
\hline Do.. & 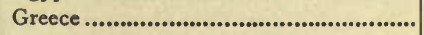 & 2.84 pounds. \\
\hline Do..................... & 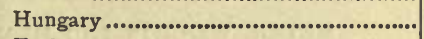 & 3.0817 pounds. \\
\hline Do........................ & 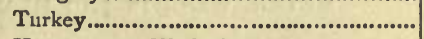 & $2.854 \mathrm{I}^{8}$ pounds. \\
\hline ..................... & Hungary and Wallachia.......................... & 2.5 pints. \\
\hline Pic............ & 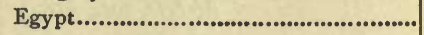 & $2 \mathrm{x} 1 / 4$ inches. \\
\hline cul...... & 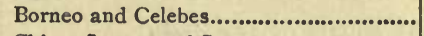 & r 35.64 pounds. \\
\hline (................... & China, Japan, and Sumatra..................... & I $33 \mathrm{I}^{\mathrm{T}} / 3 \mathrm{por}$ \\
\hline n................... & 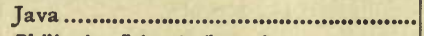 & $135 . x$ pounds. \\
\hline ..................... & Philippine Islands (hemp)...................... & 139.45 pounds. \\
\hline - & Philippine Islands (sugar) ...................... & I 40 pounds. \\
\hline ie............... & Argentine Republic................................. & 0.9478 foot. \\
\hline ................. & 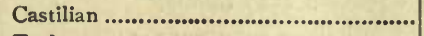 & 0.91407 foot. \\
\hline 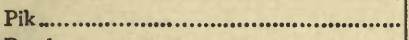 & 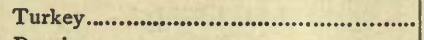 & 27.9 inches. \\
\hline 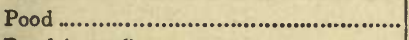 & 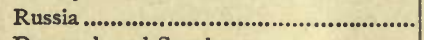 & 36.112 pounds. \\
\hline 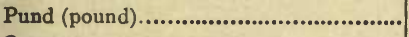 & Denmark and Sweden.............................. & 1.10 \\
\hline ( & 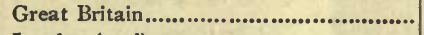 & 8.252 bushels. \\
\hline ..................................... & London (coal) $\ldots \ldots \ldots \ldots \ldots \ldots$ & 36 bushels. \\
\hline intal..... & Argentine Republic................................. & ror. 42 pounds. \\
\hline Do..... & 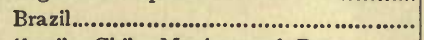 & I30.06 pounds. \\
\hline 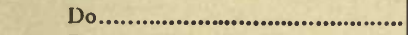 & Castile, Chile, Mexico, and Peru............. & ror. $6 \mathrm{r}$ pounds. \\
\hline ..................................... & Greece & 123.2 pounds. \\
\hline (........................ & New foundland (fish) ............................ & $x x_{2}$ pounds. \\
\hline Do..... & 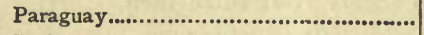 & xoo pounds. \\
\hline Do & 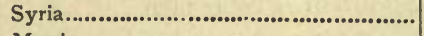 & I25 pounds. \\
\hline Do .......................................... & 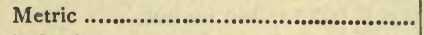 & 220.46 pounds. \\
\hline 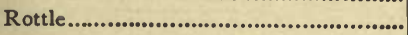 & 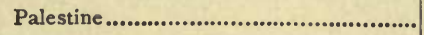 & 6 pounds. \\
\hline (n............................ & 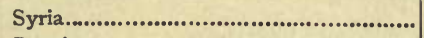 & $53 / 4$ pounds. \\
\hline Sagen .................................................. & 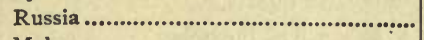 & 7 feet. \\
\hline 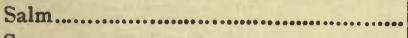 & Malta & 490 pounds. \\
\hline 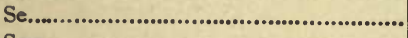 & 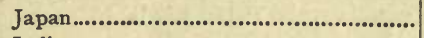 & 3.6 feet. \\
\hline 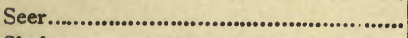 & 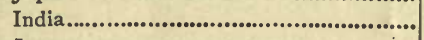 & I pound $x_{3}$ ounces. \\
\hline Shaku ................................................ & 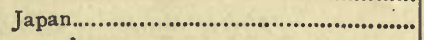 & so inches. \\
\hline 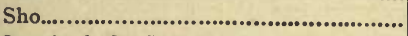 & 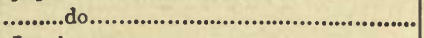 & x.6 quarts. \\
\hline Standard (St. Petersburg).................... & Lumber measure.......................................... & I 65 cubic feet. \\
\hline 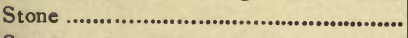 & 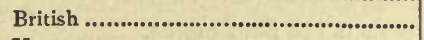 & $x_{4}$ pounds. \\
\hline Suerte..................... & Uruguay.................. & $\begin{array}{l}2,700 \text { cuadras (sed cua } \\
\text { dra). }\end{array}$ \\
\hline Tael ............. & 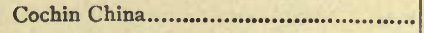 & 590.75 grains (trey). \\
\hline ................................. & 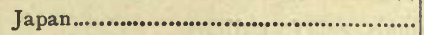 & 0.25 acre. \\
\hline To...... & 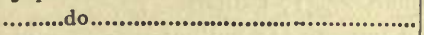 & 2 pecks. \\
\hline 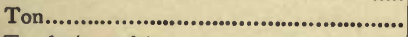 & 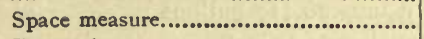 & to cubic feet. \\
\hline Tonde (cereals)..................................... & 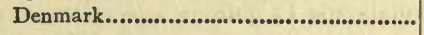 & 3.94783 bushels. \\
\hline 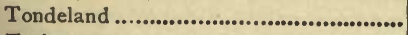 & $\ldots \ldots \ldots$ do & x.36 acres. \\
\hline 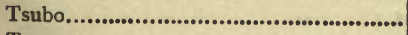 & 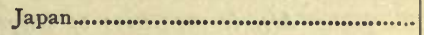 & 6 feet square. \\
\hline Tsun.......................................................... & 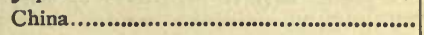 & $x .4 x$ inches. \\
\hline 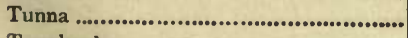 & 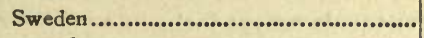 & 4.5 bushels. \\
\hline Tunnland..... & ..........do..... & 1.22 acres. \\
\hline Vara......... & Argentine Republic... & 34. 1208 inches. \\
\hline Do...... & 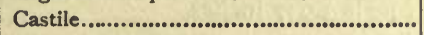 & $0.914 \times 17$ yard. \\
\hline Do.... & Central America... & $3^{8.874}$ inches. \\
\hline
\end{tabular}


Foreign weights and measures, with American quivalents-Continued.

\begin{tabular}{|c|c|c|}
\hline Denominations. & Where used. & American equivalent. \\
\hline Vara. & \multirow{10}{*}{ 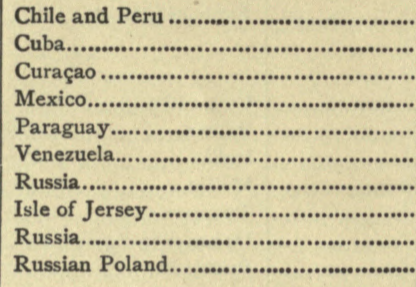 } & \multirow{10}{*}{$\begin{array}{l}33.367 \text { inches. } \\
33 \cdot 3^{8} 4 \text { inches. } \\
33 \cdot 375 \text { inches. } \\
33 \text { inches. } \\
34 \text { inches. } \\
33.3_{4} \text { inches. } \\
2.707 \text { gallons. } \\
7 \times .1 \text { square rods. } \\
\text { o.663 mile. } \\
4 x .98 \text { acres. }\end{array}$} \\
\hline 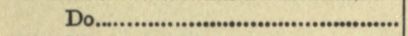 & & \\
\hline Do.................................................... & & \\
\hline 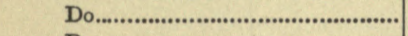 & & \\
\hline 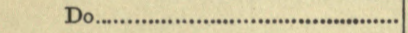 & & \\
\hline 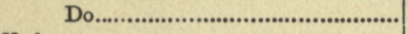 & & \\
\hline Vedro & & \\
\hline 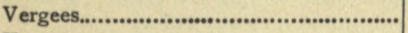 & & \\
\hline Verst............................................................. & & \\
\hline 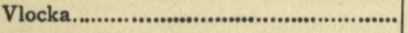 & & \\
\hline
\end{tabular}

\section{METRIC WEIGHTS AND MEASURES.}

Metric weights.

Milligram ( $\frac{1}{1000}$ gram) equals 0.0154 grain.

Centigram ( $\frac{1}{100}$ gram) equals 0.1543 grain.

Decigram ( $\frac{1}{10}$ gram) equals $\mathbf{I} .5432$ grains.

Gram equals 15.432 grains.

Decagram (Io grams) equals 0.3527 ounce.

Hectogram (100 grams) equals 3.5274 ounces.

Kilogram ( 1,000 grams) equals 2.2046 pounds.

Myriagram (I0,000 grams) equals 22.046 pounds.

Quintal (100,000 grams) equals 220.46 pounds.

Millier or tonnea-ton ( $1,000,000$ grams) equals $2,204.6$ pounds

Metric dry measure.

Millimeter ( $\frac{1}{1000}$ liter) equals $0.06 \mathbf{r}$ cubic inch.

Centiliter ( $\frac{1}{100}$ liter) equals 0.6102 cubic inch.

Deciliter ( $\frac{1}{10}$ liter) equals 6.1022 cubic inches.

Liter equals 0.908 quart.

Decaliter (Io liters) equals 9.08 quarts.

Hectoliter (100 liters) equals 2.838 bushels.

Kiloliter (I,000 liters) equals $\mathbf{1} .308$ cubic yards.

\section{Metric liquid mcasure.}

Millimeter ( $\frac{1}{1000}$ liter) equals 0.27 fluid ounce.

Centiliter ( $\frac{1}{100}$ liter) equals $0.33^{8}$ fluid ounce.

Deciliter ( $\frac{1}{10}$ liter) equals 0.845 gill.

Liter equals 1.0567 quarts.

Decaliter (1o liters) equals 2.6417 gallons.

Hectoliter (100 liters) equals 26.417 gallons.

Kiloliter (I00 liters) equals 264.17 gallons.

\section{Metric measures of length.}

Millimeter ( $\frac{1}{\log \sigma}$ meter) equals 0.0394 inch.

Centimeter ( $\left(\frac{1}{100}\right.$ meter) equals 0.3937 inch.

Decimeter ( $\frac{1}{10}$ meter) equals 3.937 inches.

Meter equals 39.37 inches. 
Decameter (10 meters) equals 393.7 inches.

Hectometer (I00 meters) equals 328 feet $\mathbf{I}$ inch.

Kilometer (1,000 meters) equals 0.62137 mile $(3,280$ feet ro inches). Myriameter (10,000 meters) equals 6.2137 miles.

Metric surface measures.

Centare (I square meter) equals $\mathbf{r}, 550$ square inches. Are (I00 square meters) equals 119.6 square yards. Hectare (Io,000 square meters) equals 2.471 acres.

$655 \mathrm{~A}-\mathrm{II}$ 



\section{CIRCULAR.}

Department of State,

Washington, December 15, 1893.

To the Consular Officers of the United States:

GENTLEMEN : You are hereby requested to prepare reports for publication showing in what manner the lumber exports from this country may be increased.

The following interrogatories cover the principal points upon which information is desired:

(1) What are the native woods? (If any of these are of an uncommon variety describe them.)

(2) What are the kinds of lumber used and which are preferred?

(3) What is the amount of lumber imported from other countries (Name the countries.)

(4) If any import duty is laid upon foreign lumber, what is the amount?

(5) What are the prices of lumber?

(6) Give a general description of the climate of your district?

Information is also desired concerning the extent of general building, shipbuilding, and railroad huilding in your district.

All suggestions concerning the methods to be pursued to extend the foreign trade (already considerable) of this country in lumber will be of value.

I am, gentlemen, your obedient servant,

EDWARD H. STROBEL,

Third Assistant Secretary.

The foregoing circular was sent to the following consulates, given iv the order of the publication of their replies:

Africa: Madeira (Funchal), Sierra Leone, South Africa (Cape Town), and Zanzibar. America:

Dominion of Canada: New Brunswick and Nova Scotia (Halifax).

Mexico: La Paz, Mazatlan, Nogales, and Vera Cruz.

Central America: British Honduras (Belize), Guatemala, and Salvador (San Salvador).

South America: Argentine Republic (Buenos Ayres), Brazil (Rio de Janeiro), Chile (Valparaiso), Colombia (Barranquilla and Colon), Dutch Guiana (Paramaribo), Ecuador (Guayaquil), West Indies (St. Thomas).

Asia:

British Asia: Ceylon and India (Calcutta).

China: Amoy, Canton, Hongkong (British), and Tien-Tsin.

Japan; Nagasaki, and Osaka and Hiogo.

Java (Batavia).

Siam (Bangkok).

Turkey in Asia: Palestine (Jerusalem) and Syria (Beirut).

Australasia: Now Zealand (Anckland), New South Wales (Sydney), South Anstralia (Adelaide), Tasmania (Hobart), and Victoria (Melbourne). 
Europe:

Austria-Hungary: Anstria-Hungary (Triest) and Bohemia (Prague).

France: Bordeanx and Marseilles.

Germany : Bavaria (Nuremberg), Bremen, Frankfort-on-the-Main, and Hamburg. Norway: Christiania.

Portugal: The Azores (Fayal).

Russia: Riga.

Turkey in Europe: Constantinople.

United Kingdom: Birmingham, Dundee, Falmouth, Glasgow, Hull, Leeds, Liverpool, and Newcastle-on-Tyne.

Polynesia: Hawaiian Islands (Honolulu), New Caledonia (Noumea), Samoa (Apia).

The following consulates, to which the circular was also sent, have failed to report up to the date of going to press :

Antwerp, Archangel, Bathurst, Bergen, Bogota, Bombay, Callao, Gorée-Dakar, Gnaymas, Kanagawa, London, Managua, Monrovia, Montevideo, Saigon, San Juan del Norte, Santo Domingo, St. Martin, and Singapore.

\section{DYEWOODS.}

On December 20, 1893, the consuls of the United States in Brazil, British Guiana, British Honduras, Colombia, Costa Rica, Cuba, Haiti, Honduras, Jamaica, and Mexico were instructed to report upon the dyewood industries of their respective districts. Reports, in answer to the instruction mentioned, were received and published in Consular Reports Nos. 162 and 166, for March and July, 1894. 


\section{AMERICAN LUMBER IN FOREIGN MARKET'S}

\section{AFRICA.}

\section{MADEIRA.}

NATIVE WOODS.

Of native trees the til is the largest and handsomest. It has shining, deep green leaves. The wood is brown, marked with dark veins, and is susceptible of high polish. It is in much demand for furniture, boxes, walking sticks, and souvenirs generally. Newly eut, til has a disagreeable odor and can be used only when well seasoned.

The vinhatico is a fine tree. The wood is red and much used for furniture. It is often called Madeira mahogany.

The aderno grows to the height of 60 feet and is used for cask staves. The wood is white.

Azevinho and perado are closely allied trees, and are common species of holly. The wood is white and is used for inlaid work. They attain a height of 15 to 20 feet.

None of the foregoing trees are found elsewhere, except in the Canaries. The pao branco is a handsome tree, attaining a height of 50 feet. It has a hard white wood, and is in much demand for keels of boats. It grows readily from the seed. It is not found elsewhere except in the Canaries and Azores.

The folhado is a fine tree, attaining a height of 60 feet. In summer it is full of white, sweet-scented flowers. Its wood is tough and of light weight. It is of great interest to botanists, belonging to a genus of which all the species, except this, are American.

These are about all the native woods that are used for manufacturing.

KINDS OF LUMBER USED.

The kinds of lumber used and preferred here are spruce, and white and pitch pine. 
IMPORTS AND DUTIES.

All the lumber used here comes from the United States and Nova Scotia.

The import duty upon foreign lumber is as follows:

\begin{tabular}{|c|c|c|}
\hline Kinds and sizes. & Duties. & $\begin{array}{l}\text { Local tax } \\
\text { (additional). }\end{array}$ \\
\hline 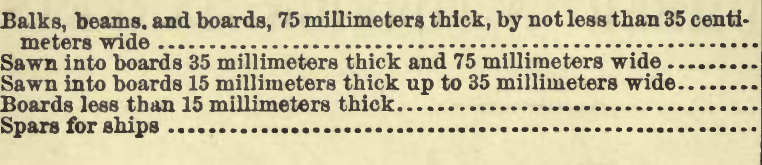 & $\begin{array}{r}\text { Oubio meter. } \\
\$ 1.40 \\
2.80 \\
4.00 \\
6.00 \\
3 \text { per cent ad } \\
\text { valorem. }\end{array}$ & $\begin{array}{r}\text { Oubio meter. } \\
\$ 0.20 \\
.32 \frac{1}{.32} \\
.321 \\
.32 \frac{1}{2} \\
\ldots \ldots\end{array}$ \\
\hline
\end{tabular}

Balks, beams, and boards are those imported in greatest quantities.

\section{PRICES AND CLIMATE.}

The prices of lumber here are from 2 cents to 6 cents per superficial foot, 12 by 1 inches. I give a general description of the climate, as taken from "Climate and Resources of Madeira," by Michael C. Grabham, M. D., F. R. G. S.

Madeira has a mean annual temperature of $67.3^{\circ}$; the average heat of summer is hardly more than $70^{\circ}$, whilst the mean temperature of the winter season is always above $60^{\circ}$. The extreme heat of summer is seldom more than $77^{\circ}$ in the hottest part of the day, whilst in winter the lowest possible temperature is hardly under $50^{\circ}$ in the coldest part of the night. The range of temperature during the day and night is likewise marked by the same moderation. Varying from 5 to $15^{\circ}$ and averaging $9 \circ$, the mornings and evenings are almost always cool and refreshing, and the decline of temperature is constantly gradual and continuous, without any sudden depression at sunset.

In the winter season we have our greatest atmospheric dryness, and the solar rays are not then excluded by any dense shield of watery vapor. As the spring advances the moisture of Madeira is increased, and the solar rays are greatly intercepted; but, eventually, in the summer the northeast wind arises, in latitudes far north, and reaches this region in moderate dryness.

I should remark that in Madeira the dampest atmospheres occur during the warmest weather. We know nothing of the cold damp of northern climates, nor has any fog or surface mist a place in this climate.

The annual rainfall is 29 inches; I believe that estimate to represent fairly the average amount, and moreover, it closely coincides with the deductious of others. There are, however, considerable variations; in some years the whole amount has not reached 20 inches, while in other years it has exceeded 40 inches, but an amount between 25 inches and 30 inches may be looked for with tolerable certainty.

It is by no means clear that the annual fall of rain has been affected by the destruction of the forests.

Here I may state that in Funchal there has been no change in one hundred and thirty years, and that the recorded rainfall is now exactly what it was when the fall of rain was first measured. The rain usually commences in October in heavy showers. The autumn rains are variable in amount and duration. After a few days, a period of fine weather is to be expected; but November and December are generally interspersed with rain days. The winter rains are quite tropical in character, the water falling in dense intermitting showers, and generally unaccompanied by wind. 
In December, 1867, one of my rain gauges, holding $2 \frac{1}{2}$ inches, filled and overflowed in a single night. The month of January is often without rain, and then is, perhaps, the driest and pleasantest month of the year. Sometimes, however, it counts many days of rain. February, likewise, is uncertain, and has been in my experience the wettest, windiest, and most unsettled month. March usually brings much fine weather, but rain sometimes falls on several days. April and May arespring months with occasional showers. June is almost invariably cloudy. July, August, and September are cloudless months of unbroken sunshine. The wet weather of Madeira is seldom lasting, and in the entire winter there are few consecutive rainy days.

Annually there are eighty days in which rain falls. The fall of snow upon the mountains generally happens in January or February; it seldom lies long upon the hills. Snow is seldom seen upon the mountains lower than 3,000 feet above Funchal; and it has probably never been known to lie nearer in altitude than 2,500 feet.

GFNERAL BUILDING.

There is nothing doing here in the way of general building. In the line of ship building nothing but small boats are constructed.

We have one short railway, of about 3 miles, from the city to the top of the mountain.

Thomas C. Jones,

Consul.

FunOHAL, February 21, 1894.

\section{SIERRA LEONE.}

NATIVE WOODS.

Native woods used in building here are oak, whismore, brimstone, teak, mahogany (two varieties), rosewood (fine quality), and black walnut. These are durable woods that will withstand insects and weather.

\section{KINDS OF LUMBER USED.}

The native woods are used in the framing and outside works, and American pine for finishing. The nicest finish is obtained by using rosewood.

\section{IMPORTS OF LUMBER.}

During the year $1893,855,971$ feet of pine lumber were received at this port from the United States. No other country sends lumber to Sierra Leone.

\section{DUTY AND PRICES.}

The import duty on lumber is $7 \frac{1}{2}$ per cent ad valorem, invoice price.

The present prices of lumber in this market are: Sawed lumber, lineal measure, 1 inch thick, board measure, $\$ 40$ per 1,000 feet; clear pitch pine, planed on one side, $\$ 60$; if tougued and grooved, $\$ 80$. 


\section{CLIMATE.}

The climate is variable. The rainy season begins about the middle of June and lasts until about the middle of November. The rainfall is notsteady. It averaged about twelve days in a month in 1892. In September, 1893, it was seventeen days. In 1893 the rains were a little over the average. The temperature ranges, the year round, between $75^{\circ}$ and $95^{\circ}$, rarely getting above $95^{\circ}$, and always falling at night to $80^{\circ}$ or a little below. The climate is damp and unhealthy near the seaboard.

\section{GENERAL BUILDING.}

For general building the material commonly used is stone, of which there is an abundance here. It is soft and porous when first dug out of the grouvd, but hardens by exposure. It is of a light brown color, and lighter than brick. The architecture here is of the old Spanish style, the main entrance being, in some instances, in the back of the house.

\section{EXTENSION OF LUMBER TRADE.}

As regards the methods of increasing the lumber trade here, competition is needed. There are only two firms here dealing in lumber, which is but a brauch of their other mercantile business. A lumber dealer here with sash and door and planing mill would find a good trade. There is nothing of the kind here; no machinery in the colony but "sewing machines," and those are English. There is no shipbuilding nor railroads in the colony. There are no Americans here to introduce American articles. The American goods here are handled by French and English merchants, who know but little of the United States and its people.

BOLDING BOWSER,

SterrA LeONe, January 20, 1894.

Consul.

\section{SOUTH AFRICA.}

NATIVE WOODS.

The principal native woods of South Africa are as follows: Yellowwood (2 kinds), black and white ironwood, stinkwood, olyreuhout (olive), assagai, white pear, kerschout (candlewood), white alder, etc. None of these woods grow in sufficient quantities to cut any figure in lumber problems, except the following: Yellow wood, which somewhat resembles poplar, though it is harder and has a cross grain, and stinkwood, which is more like our American walnut, and has many colors and shades when polished.

\section{KINDS OF LUMBER USED.}

As regards the kind of lumber used and preferred here, I would say that poplar, basswood, pine shelving, and walnut take the lead. 


\section{IMPORTS OF LUMBER.}

I have not been able to learn the amount of lumber imported, but nearly all that comes is from the United States and Australia. In connection herewith I attach a clipping from the Cape Times of the 8th instant:

Those who are interested in the promotion of the Colonial timber trade will be somewhat alarmed to hear of the arrival from Australia of a cargo of timber, much of it consisting of wagonwood and other forms of manufactured timber which can be produced in the Colony. The cargo was brought by the ship Esempio, which arrived here from Hamelin on Tuesday, and consisted of 1,638 pieces of timber, 5 bundles of pickets, 2 bundles of laths, 2 bundles of shingles, 1 bundle of spokes, and 16 bundles of felloes, for this port, and 3,612 pieces of timber for Port Elizabeth.

\section{DUTY AND PRICES.}

The import duty is 4 cents per cubic foot.

The prices of lumber are as follows:

Yellow-wood planks (native) ............................per cube.. $\$ 0.60$

Stinkwood planks (native) ........................................ .84

Walnut, 1 -inch board ....................................... 126.00

Ash, 1-inch board............................................... 61.00

Poplar, plain, 1-inch board................................do... 40.00

figured, 1 -inch board.................................. 80.00

\section{Climate.}

The climate of this district is hot and dry during November, Decem. ber, January, and February; occasional rains in March; a good deal of rain in April, May, June, and July, while August, September, and October (spring months), are delightful in every way. No snow or frost ever comes, and flowers are in bloom all through the year. The northern part of the district (in the South African Republic and Orange Free State) enjoys a little cooler weather during the winter months, but is flooded with water at this season.

\section{GENERAI BUILDING.}

There is a good deal of general building all through the district, and some railroad building west from Beira to Salisbury, though the number of miles to be finished this year is only 45. I know of no ship. building.

\section{EXTENSION OF LUMBER TRADE.}

Considerable wood has lately been ordered from the Puget Sound district for use at Kimberly and other inland points. The removal of our tariff on wool, which is largely produced here, will doubtless stimulate this section to purchase American products in return, and Amer. ican interests in mining and trade generally are already large in this locality. 


\section{ACKNOWLEDGMENT.}

D. Isaacs \& Co., of Cape Town, have kindly supplied me with prices, etc. They employ about 200 men in the manufacture of furniture, and import directly from the United States.

C. H. Benedict,

CAPE Town, March 12, 1894.

\section{Consul.}

\section{ZANZIBAR.}

NATIVE WOODS.

The native woods used in building are mangrove and cocoanut. Besides these, there are the mango and a small fir.

$$
\text { IMPORTS, DUTY, AND PRICES. }
$$

Very little lumber is imported, and that little comes from England and India.

There is no import duty on lumber. The price varies greatly, and depends on the supply and exchange.

\section{CLIMATE.}

The climate is tropical, Zanzibar being $6^{\circ}$ south of the equator. There is a long and a short rainy season, and a hot and cool season. During the latter, the thermometer averages about $80^{\circ}$.

\section{GENERAL BUILDING.}

There is no ship or railroad building, except that at Tanga, 75 miles north of here. A railroad is now being commenced; all materials for its construction come from Germany.

All houses, except native swahili huts, are built of coral rock and lime. For ceilings and roofs, mangrove poles are laid across and coral rock and native cement filled in. Doors between rooms are unusual. Outside doors are mostly made of teak, brought from Bombay. Native huts are made of a framework of mangrove poles tied together the spaces between poles being filled in with mud; the roofs are of cocoanut leaves.

There is not a single wooden house in Zanzibar or vicinity. It would be impossible to live in them on account of the heat.

\section{EXTENSION OF LUMBER TRADE.}

The quantity of lumber used is so limited that it would not be profitable to export from the United States to this place. 


\section{AMERICA.}

\section{DOMINION OF CANADA.}

\section{NEW BRUNSWICK AND NOVA SCOTIA.}

I inclose circular from the house of Hon. J. B. Snowball, Chatham, New Brunswick, relating to the lumber trade in the maritime provinces for 1893. Mr. Snowball is a senator representing New Brunswick in the upper Dominion house, and issues a similar circular yearly, which is generally copied into the newspapers as authoritative on the matter to which it relates.

\section{DARIUS H. INGRAHAM,} Consul-General.

HALIFAX, January 11, 1894.

Chatham, New Brunswick, Canada, December 30, 1893.

The winter of 1892-93 proved the most favorable for log-getting of any we have had for many years, consequently we had a much larger output for the force employed than was anticipated. Spring freshets were poor, and driving expensive. About 10,000,000 superficial feet of logs were left in the brooks.

Notwithstanding the favorable season, the export from this port fell off $12,000,000$ superficial feet from last year. And while the exports from St. John were 10,000,000 more than in 1892, still the exports for the province show a decrease of $13,000,000$. The increased export from Nova Scotia is caused by the excessive quantity of birch deals shipped from that province.

The present winter is the most severe experienced here for twenty years. Snow is now deeper all over eastern Canada than any time last winter. Operations in this district were entered into on a limited scale, and with an anticipated production of 25 per cent less than last year, but the severe weather is likely to reduce the production below this estimate, and next year's export from this port must be small.

The proposed United States tariff, if adopted for wood goods, will have an indirect beneficial effect on the trade of this section of New Brunswick. Freight rates from eastern New Brunswick to United States ports are so high in comparison with those from St. John and Bay of Fundy ports that our trade in that direction is about nil, excepting in laths and shingles, but under the proposed tariff the export of a considerable portion of the southern and western portions of this province is likely to be attracted to American ports, leaving more of the transatlantic trade to be supplied from this section. 
France, Spain, and Mediterranean ports have taken a larger portion of our exports this year than formerly, and if the "favored nation" treaty is ratified, as it will probably be at once, between France and Canada, a larger portion of our export is likely to go to that country, to the great relief of the English market, and with a fair prospect of better prices for spruce.

Thestock of merchantable deals wintering here is 7,600 in St. Petersburg strndards," against 7,000 standards last year and 11,000 standards in 1891. Logs are 4,000 standards against 3,000 last year.

Shipments from Miramichi for twelve years, from 1882 to 1893, inclusive.

[Superticial feet.]

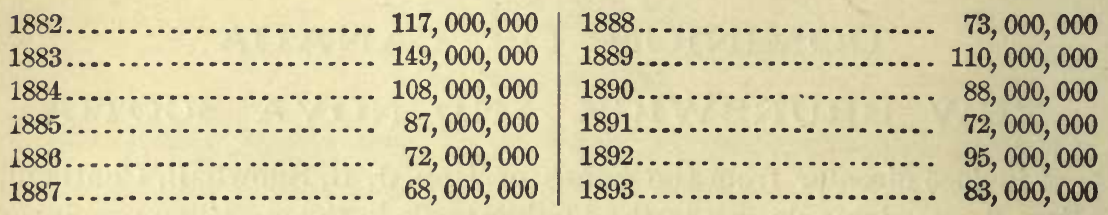

Exports of Miramichi lumber, 1893.

\begin{tabular}{|c|c|c|c|c|c|}
\hline Whither exported. & $\mid \begin{array}{c}\text { Num. } \\
\text { ber } \\
\text { vessels. }\end{array}$ & Tons. & $\begin{array}{l}\text { Deals, scant- } \\
\text { ling, ends, } \\
\text { and boards. }\end{array}$ & Palings. & Spool wood. \\
\hline reat Britain : & & & Super. feet. & Pieces. & \\
\hline $\begin{array}{l}\text { Ayr ......... } \\
\text { A berdovey }\end{array}$ & 1 & $\begin{array}{l}604 \\
332\end{array}$ & $\begin{array}{l}556,059 \\
346,679\end{array}$ & & \\
\hline Bowling... & 3 & 1,787 & 768,585 & & 793,083 \\
\hline Barrow..... & 5 & 5,619 & $5,716,990$ & & \\
\hline $\begin{array}{l}\text { Birkenhead ... } \\
\text { Cardiff ....... }\end{array}$ & $\begin{array}{l}1 \\
3\end{array}$ & $\begin{array}{r}586 \\
2,252\end{array}$ & $\begin{array}{r}553,000 \\
1,982,000\end{array}$ & …................ & \\
\hline Fleetwood... & 2 & 1,738 & 947,695 & 898,025 & \\
\hline Garston... & 3 & 1,841 & 711,301 & $1,486,400$ & \\
\hline Greenock & 1 & 739 & - . & (.). & 503,439 \\
\hline $\begin{array}{l}\text { Glass } \\
\text { Liver }\end{array}$ & 15 & $\begin{array}{r}374 \\
18.190\end{array}$ & $\begin{array}{r}381,386 \\
19,650,298\end{array}$ & $\begin{array}{r}4,800 \\
13,600\end{array}$ & \\
\hline London... & 2 & 1,144 & $\begin{array}{r}952,076 \\
95\end{array}$ & $\begin{array}{c}13,000 \\
\ldots . . . . .\end{array}$ & \\
\hline Newport. & 2 & 1,839 & $1,603,073$ & $\cdots$ & \\
\hline Prestou Do & 1 & 439 & 445,000 & 4,800 & \\
\hline Penartl & $\frac{1}{2}$ & 1,143 & $\begin{array}{r}954,000 \\
\end{array}$ & $\cdots \cdot \cdot$ & \\
\hline $\begin{array}{l}\text { Plym } \\
\text { Swan }\end{array}$ & $\begin{array}{l}2 \\
2\end{array}$ & $\begin{array}{l}1,340 \\
1,298\end{array}$ & $\begin{array}{l}1,100,205 \\
1,138,678\end{array}$ & $\cdots \cdot$ & \\
\hline Silloth Doc & 2 & 1,105 & $1,076,296$ & $\cdots$. & \\
\hline Whitehave & 1 & 421 & 400,314 & & \\
\hline Total. & 49 & 42,791 & $39,333,633$ & $2,407,625$ & $1,296,522$ \\
\hline Ireland: & & & & & \\
\hline Belfast. & $\begin{array}{r}1 \\
19\end{array}$ & 17,350 & $16,747,673$ & 159,353 & \\
\hline Coleraine... & 1 & 251 & 265,358 & & \\
\hline Cor & 1 & 490 & 432,242 & & \\
\hline Dublin . & 8 & 6,037 & $5,495,108$ & $\cdots$ & \\
\hline $\begin{array}{l}\text { Dur } \\
\text { Dur }\end{array}$ & 2 & 508 & 533,331 & $\cdots$ & \\
\hline Londonderry & 3 & 2,279 & $2,120,127$ & 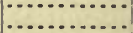 & \\
\hline Larne...... & 4 & 2,135 & $2,099,353$ & $\ldots$ & \\
\hline Newry & 1 & 936 & 904,346 & $\ldots$ & •. \\
\hline $\begin{array}{l}\text { Tralee. } \\
\text { Waterfo }\end{array}$ & $\begin{array}{l}1 \\
2\end{array}$ & $\begin{array}{r}528 \\
1,274\end{array}$ & $\begin{array}{r}444,723 \\
1,180,078\end{array}$ & ..... & .. \\
\hline Tater & & & & & \\
\hline Total.. & 44 & 32,356 & $30,850,877$ & 159,353 & ........ \\
\hline $\begin{array}{l}\text { France: } \\
\text { Cette. }\end{array}$ & & & & & \\
\hline Marseilles & 4 & 2,377 & $2,192,231$ & & \\
\hline $\begin{array}{l}\text { Cette....... } \\
\text { Marseilles.. }\end{array}$ & 1 & 1,159 & $1,382,672$ & & \\
\hline Port Vendre & 1 & 598 & 569,846 & & \\
\hline Tot & 7 & 5,066 & $4,964,239$ & $\cdots$ & $\cdots$ \\
\hline
\end{tabular}

" Standard equals 165 cubic feet. 
Reports of Miramichi lumber, 1893-Continued.

\begin{tabular}{|c|c|c|c|c|c|}
\hline Whither exported. & \begin{tabular}{|c|} 
Num. \\
ber \\
vessels.
\end{tabular} & Tons. & $\begin{array}{l}\text { Deals, scant- } \\
\text { ling, ends, } \\
\text { and boards. }\end{array}$ & Palings. & Spool wood. \\
\hline \multirow{7}{*}{ 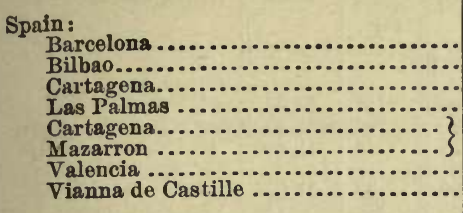 } & & & Super. feet. & Pieces. & Pieces. \\
\hline & 3 & 2,150 & $1,953.229$ & -.... & (....... \\
\hline & 1 & $\begin{array}{r}426 \\
358\end{array}$ & 418,343 & (............ & (.............. \\
\hline & $\begin{array}{l}2 \\
1\end{array}$ & $\begin{array}{r}1,358 \\
289\end{array}$ & $\begin{array}{r}1,264,063 \\
285,695\end{array}$ & (n................... & 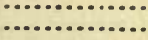 \\
\hline & 2 & 1,642 & $1,348,802$ & & - \\
\hline & 1 & 832 & 746,336 & .... & ....... \\
\hline & 1 & 192 & 168,023 & $\cdots$ & $\cdots$ \\
\hline Total...$\ldots \ldots \ldots$ & 11 & 6,889 & $6,184,491$ & 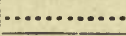 & $\because$ \\
\hline \multirow{3}{*}{ 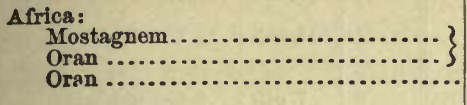 } & & & & & \\
\hline & 1 & 641 & 608,082 & & \\
\hline & 1 & 780 & 722,172 & ….. & \\
\hline Total.......................... & 2 & 1,421 & $1,330,254$ & & \\
\hline
\end{tabular}

Distribution by ports of St. John shipments, December 1, 1892, to December 1, 1893.

\begin{tabular}{|c|c|c|c|c|}
\hline Whither exported. & $\begin{array}{l}\text { Number } \\
\text { of ves- } \\
\text { sels. }\end{array}$ & Tons. & $\begin{array}{l}\text { Deals, scant- } \\
\text { ling ends, } \\
\text { and boards. }\end{array}$ & Timber. \\
\hline 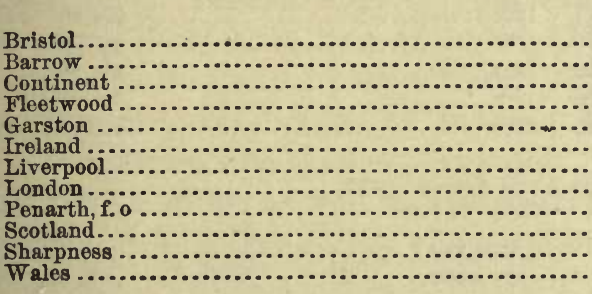 & $\begin{array}{r}3 \\
1 \\
6 \\
11 \\
6 \\
54 \\
33 \\
12 \\
13 \\
7 \\
6 \\
14 \\
\end{array}$ & $\begin{array}{r}3,728 \\
1,843 \\
3,734 \\
14,477 \\
6,953 \\
40,490 \\
47,055 \\
16,269 \\
14,879 \\
6,621 \\
9,066 \\
15,984\end{array}$ & $\begin{array}{r}\text { Super. feet. } \\
3,472,852 \\
2,422,400 \\
3,573,604 \\
14,462,277 \\
7,004,811 \\
38,968,156 \\
42,788,326 \\
2,845,616 \\
13,082,537 \\
5,746,545 \\
8,426,545 \\
13,859,665 \\
\end{array}$ & 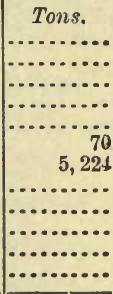 \\
\hline Total. & 166 & 181,099 & $156,652,334$ & 5,294 \\
\hline
\end{tabular}

Shipments from St. John to transatlantic ports for the past sixteen years.

\begin{tabular}{|c|c|c|c|c|c|c|c|}
\hline \multirow{2}{*}{ Years. } & \multirow{2}{*}{$\begin{array}{c}\text { Total deals, } \\
\text { etc. }\end{array}$} & \multicolumn{2}{|c|}{ Timber. } & & \multirow{2}{*}{$\begin{array}{c}\text { Total deals, } \\
\text { etc. }\end{array}$} & \multicolumn{2}{|c|}{ Timber. } \\
\hline & & Birch. & Pine. & & & Birch. & Pine. \\
\hline 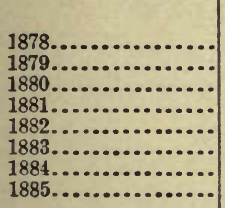 & $\begin{array}{l}\text { Super. feet. } \\
188,168,610 \\
153,279,357 \\
215,485,000 \\
210,281,730 \\
201,413,717 \\
181,517,932 \\
164,829,825 \\
152,543,026\end{array}$ & $\begin{array}{r}\text { Tons. } \\
7,989 \\
11,548 \\
16,035 \\
5,134 \\
7,576 \\
11,778 \\
14,006 \\
13,769\end{array}$ & $\begin{array}{l}\text { Tons. } \\
2,493 \\
3,237 \\
2,441 \\
1,734 \\
3,332 \\
3,883 \\
3,836 \\
3,686\end{array}$ & 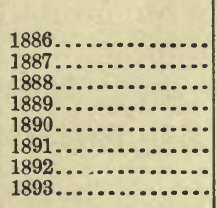 & $\begin{array}{l}\text { Super. feet. } \\
138,934,392 \\
118,450,590 \\
153,184,187 \\
180,167,488 \\
132,608,516 \\
122,242,682 \\
146,529,309 \\
156,653,334\end{array}$ & $\begin{array}{r}\text { Tons. } \\
7,354 \\
5,197 \\
4,721 \\
7,221 \\
1,311 \\
5,004 \\
10,200 \\
5,294\end{array}$ & $\begin{array}{r}\text { Tons. } \\
4,313 \\
1,587 \\
457 \\
487 \\
4,317 \\
\hdashline \ldots \ldots . . \\
\hdashline \ldots \ldots . . .\end{array}$ \\
\hline
\end{tabular}


Total transatlantic shipments of New Brunswick, 1892, compared with 1893.

\begin{tabular}{|c|c|c|c|c|c|c|c|c|}
\hline \multirow[b]{2}{*}{ Ports. } & \multicolumn{4}{|c|}{1892.} & \multicolumn{4}{|c|}{1893.} \\
\hline & $\begin{array}{l}\text { Nnm- } \\
\text { ber of } \\
\text { ves- } \\
\text { sels. }\end{array}$ & Tons. & Deals, etc. & Timber. & $\begin{array}{l}\text { Num- } \\
\text { ber of } \\
\text { ves- } \\
\text { sels. }\end{array}$ & Tons. & Deals, etc. & 'rimber \\
\hline Miramichi. & 134 & 103,565 & $\begin{array}{l}\text { Super, feet. } \\
94,907,523\end{array}$ & $\begin{array}{c}\text { Tons. } \\
228\end{array}$ & 113 & 88,523 & $\begin{array}{l}\text { Super. feet. } \\
85,230,472\end{array}$ & Tons. \\
\hline St. John..... & 164 & 165,207 & $146,529,309$ & 10,250 & 166 & 181,099 & $156,653,334$ & 5,294 \\
\hline Bathurst ..................... & 17 & 10,746 & $9,866,015$ & & 18 & 11,810 & $10,176,000$ & \\
\hline $\begin{array}{l}\text { Dainoumple } \\
\text { Camp }\end{array}$ & 48 & 25,615 & $22,568,604$ & 805 & 32 & 21,054 & $17,610,211$ & 341 \\
\hline Richibucto (including & & & & & & & & \\
\hline $\begin{array}{r}\text { Buctouche) } \ldots \ldots \ldots \ldots \\
\text { Shediac } . . .\end{array}$ & $\begin{array}{l}29 \\
23\end{array}$ & $\begin{array}{l}13,877 \\
11,278\end{array}$ & $\begin{array}{l}13,002,512 \\
10,156,333\end{array}$ & a....... & $\begin{array}{l}22 \\
25\end{array}$ & $\begin{array}{l}11,188 \\
13,099\end{array}$ & $\begin{array}{l}10,557,663 \\
11,763,215\end{array}$ & $\ldots \ldots \ldots$ \\
\hline Sackville (including Baie & 200 & 11,210 & $10,100,000$ & & & 10,000 & $11,800,210$ & \\
\hline $\begin{array}{c}\text { Verte) } \\
\text { Outports of Moncton. }\end{array}$ & 24 & 13,775 & $14,576,566$ & & 21 & 14,395 & $13,382,475$ & \\
\hline $\begin{array}{l}\text { Hillsboro, Harvey, } \\
\text { Cocagne................ }\end{array}$ & 16 & 13,712 & $13,542,949$ & & 8 & 7,040 & $6,870,085$ & …... \\
\hline Total.. & 455 & 357,775 & $325,149,811$ & 11,307 & 405 & 348,208 & $312,243,485$ & 5,737 \\
\hline
\end{tabular}

The transatlantic shipments from the Province of New Brunswick for the past ten years were:

\section{[Superficial feet.]}

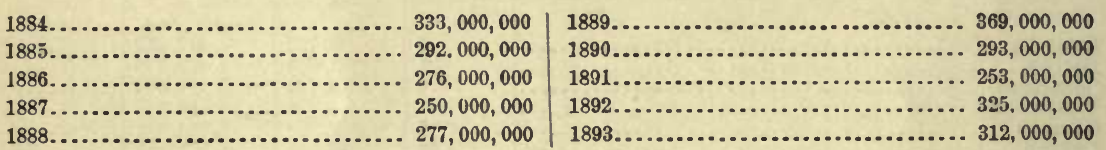

Shipments from Nova Scotia, 1893.

\begin{tabular}{|c|c|c|c|c|}
\hline Ports. & $\begin{array}{r}\text { Number } \\
\text { of vessels. }\end{array}$ & Tons. & Deals, etc. & $\begin{array}{l}\text { Birch } \\
\text { timber. }\end{array}$ \\
\hline 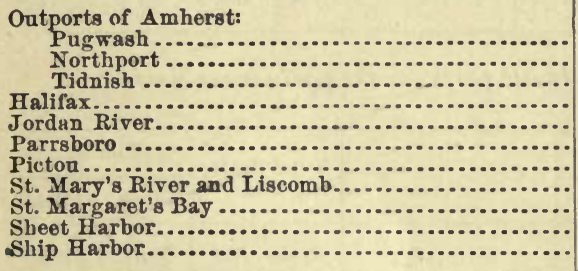 & $\begin{array}{r}10 \\
6 \\
9 \\
64 \\
1 \\
39 \\
20 \\
7 \\
5 \\
2 \\
3\end{array}$ & $\begin{array}{r}6,467 \\
6,860 \\
9,281 \\
39,456 \\
524 \\
44,426 \\
12,990 \\
4,823 \\
2,935 \\
1,403 \\
1,460\end{array}$ & $\left\{\begin{array}{r}\text { Super. feet. } \\
17,300,010 \\
34,352,656 \\
415,108 \\
40,7 ! 12,496 \\
6,888,000 \\
4,315,680 \\
2,593,698 \\
1,316,092 \\
1,279,200\end{array}\right.$ & 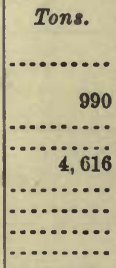 \\
\hline Total $\ldots \ldots \ldots \ldots \ldots \ldots \ldots \ldots \ldots \ldots \ldots \ldots \ldots \ldots \ldots \ldots \ldots \ldots \ldots$ & 166 & 130,625 & $109,252,930$ & 5,606 \\
\hline
\end{tabular}

Shipment of deals from Nova Scotia to transatlantio ports.

[Superficial feet.]

\begin{tabular}{|c|c|c|}
\hline $1883 \ldots \ldots \ldots \ldots \ldots \ldots \ldots \ldots \ldots \ldots \ldots \ldots$ & $77,918,000$ & 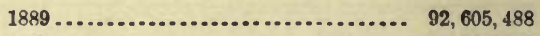 \\
\hline $1884 \ldots \ldots \ldots \ldots \ldots \ldots \ldots \ldots \ldots \ldots \ldots \ldots \ldots \ldots \ldots \ldots$ & $69,159,000$ & $1890 \ldots \ldots \ldots \ldots \ldots \ldots \ldots \ldots \ldots \ldots \ldots \ldots \ldots, \quad 99,512,924$ \\
\hline $1885 \ldots \ldots \ldots \ldots \ldots \ldots$ & $79,647,765$ & 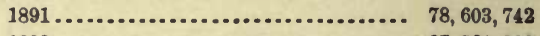 \\
\hline $386 \ldots \ldots$ & $87,280,125$ & ... 87, 861, 398 \\
\hline $387 \ldots \ldots$ & $82,959,589$ & $\ldots \ldots \ldots \ldots \ldots \ldots \ldots \ldots$ \\
\hline & $85,070,005$ & \\
\hline
\end{tabular}




\section{MEXICO.}

\section{LA PAZ.}

\section{NATIVE WOODS.}

Lower California, being divested of natural forests of pine and other timber, such as could be made useful for mining, shipbuilding, the manufacture of household articles, and for house material, is entirely dependent upon the Pacific ports and markets of the United States for stipplies.

The native woods, existing in some of the valleys of the peninsula, are of no importance and can not be made available for any building purposes. The soil and climate are not adapted to timber-growing. This, together with the scarcity of rains and the lack of running streams, precludes it from ever becoming a timber country.

Boxwood, vainoro, sorrillo, yellowwood, Brazil or dyewoods of several kinds, ironwood, palo blanco, torote, and several others, found chiefly in the valleys, form the nucleus of the principal woods of the country. Some have fine grain, capable of high polish, but the trees are too small in size for the timber to be of any utility. Nevertheless the high range of mountains, running through the middle of the country, is more wooded than the lowlands. Palm trees of majestic heights, oak, pine, and fir, as well as the Hueribo, a gigantic tree and a species of cedar, can be seen in the gulches and crests of the mountains, which offer so many difficulties as to be out of reach for all practical purposes.

\section{IMPORTS OF LUMBER.}

The imports of lumber are exclusively from Oregon, Washington, and California. Redwood, pine, and white cedar are the kinds imported and preferred. About 2,000,000 feet of lumber are required to meet the yearly consumption.

PRICES.

The following are the wholesale and retail prices per foot of lumber:

Ordinary lumber of different dimensions.......................... Planed of different dimensions ................................. 5 and 6 Pine flooring of different dimensions.................................. 6 and 7 White cedar of different dimensions .................................. 10 and 12

DUTY.

The import duty on pine lumber is as follows: Pine flooring, $\$ 1$ for 100 square meters; white planed cedar, 2 cents per kilogram; all others, common redwood and pine lumber, are on the free list. 
IMPORTS, PRICES, AND DUTY.

Red and white pine are the only kinds of lumber imported, and these sell well. The price of lumber at present is from $\$ 70$ to $\$ 75$ per 1,000 feet, the duty being only $\$ 1$ per 1,000 feet. The high price is due to exchange.

More lumber would be consumed, and its price would be less if shipbuilding and railroad-building were going on, but the only consumption is for small carpenter work.

\section{OLIMATE.}

Nature has done for this district all that could be desired in regara to climate. It is truly delightful, being one of the most equable that can be found on the continent, its atmosphere being unsurpassed for purity.

The dry season, which lasts from November to June, is the coolest part of the year, the barometer maintaining an average of $78^{\circ} \mathrm{F}$; t the rainy season is somewhat warmer than the dry season, but is so tem. pered by the clouds and rain that a wonderful uniformity is maintained throughout the year, the thermometer rarely reaching $92^{\circ} \mathrm{F}$., and then only for a short time.

MaZatlan, January 31, 1894.

ARTHUR DE CIMA, Vice-Consul.

\section{NOGALES.}

NATIVE WOODS.

The native woods are common pine, black and white oak, mesquite, ironwool, and cedar. The pine is only suitable for lumber.

Pine and redwood lumber are mostly used.

\section{LUMBER IMPORTS AND PRICES.}

Lumber is imported from the United States only.

Common pine sells for $\$ 35$ per 1,000 ; flooring, $\$ 42$; redwood dressed, $\$ 45$ to $\$ 55$, and shingles, $\$ 5$ per 1,000 . The above prices are in Americall money.

\section{Climate.}

The climate of this district is such that outdoor work can be per formed during the entire year, and it is considered very healthful.

\section{IMPORTS OF LUMBER.}

Nearly all the lumber use in this district comes from California and Washington, via Guaymas.

$665 \mathrm{~A} \longrightarrow 2$ 


\section{GENERAL BUILDING.}

Qnite a number of buildings are now being constructed in Nogales, but there is no construction of railroads at present in this district.

\section{EXTENSION OF TRADE.}

With the excessive American duty removed on lead ores, and the return to an ad valorem duty on cattle, I believe that Sonora would become a much greater purchaser of American products in the future. There are merchants in Hermosillo and Graymas who purchase from $\$ 100,000$ to $\$ 500,000$ worth of merchandise annually, yet very few of our commercial salesmen go beyond Nogales, thus leaving all this immense business to be secured by our European competitors.

Reuben D. George, Vice-Consul.

Nogales, December 30, 1893.

\section{VERA CRUZ.}

NATIVE WOODS.

The native woods are: Mahogany, ebony, cedar, almond, hazel, balsam, passion flower, guachichil (a hard wood), also, laurel, weeping willow, manchinille, birds-eye, violet wood, rosewood, lignum vitx, primrose, sopota both white and black (a wood of fine grain), indigo. Annatto, Brazil wood, logwood, green ebony, mastic, mangrove, fustic: tawney wood, mountain hyssop, archil, madder. All these woods grow in this consular district, but only a few of them are much used.

\section{KINDS OF LUMBER USED.}

The kinds used are: For building purposes cedar, mahogany, and yellow pine. The pine comes from the United States and is preferrea to native lumber. My observation leads me to suppose that cedar and mahogany are used, where heavy timber is required, and pine whereever inch lumber is used. More pine is used than cedar and moro cedar than mahogany. Some of the other woods are used in the manufacture of chests and fine furniture, but these are too expensive for ordinary use.

\section{IMPORTS OF LUMBER.}

There is no lumber imported from any foreign country but the United States, and all lumber from there consumed here, comes from Pascagoula, except that used in the manufacturing of soap boxes, which comes in shooks from the port of New York, being put together here.

There is quite an extensive trade in this kind of material. 
PRICES.

The prices of lumber in Vera Cruz are: Pine, rough, wholesale, $\$ 36$, retail $\$ 45$ per 1,000 ; dressed, tongued and grooved, wholesale, $\$ 37$, retail, $\$ 50$ per 1,000 . It is generally $\$ 5$ to $\$ 10$ per 1,000 , higher at other ports in this district. These prices are in Mexican money. The Mexican dollar at present is worth only 55 cents American.

\section{CLIMATE.}

The climate adjacent to Vera Cruz is moistand hot, and, for about seven months of the year, unhealthy. There is a difference of opinion as to the climate north and south of this port, but I would say moist and warm, but more healthy. Forty to 50 miles inland from the coast the climate is mild and all that could be desired; about 80 miles inland Mount Orizaba is seen covered with snow at all times of the year. Thus it will be observed that in this consular district we have, within a less distance than 100 miles, land level with the sea and the highest peak in North America, with climate corresponding to the different altitudes.

\section{GENERAL BUILDING.}

House building, on a small scale, consumes considerable of the pine lumber brought from the United States. The ship-building carried on here consists of the making of sailboats and rowboats only, the largest not exceeding 60 tons burden. The construction of the Tehuantepec Railway is now under way, there being something like 125 miles completed on the Atlantic side, with, perhaps, an equal number of miles on the Pacific side.

\section{EXTENSION OF LUMBER TRADE.}

I can make no suggestions that would help to extend the lumber trade between the United States and this country; for I notice that all the lumber imported comes from the United States, and unless the natives can be induced to build better houses and more of them, or Americans come, take land, and settle here, the trade in American or any other kind of lumber will not improve.

Charles Schaefer,

Vera CRUz, January 30, 1894.

Consul. 


\section{CENTRAL AMERICA. BRITISH HONDURAS.}

NATIVE WOODS.

It is difficult to suggest in what manner the lumber exports from the United States to this colony may be increased, as nearly all the lumber used for building purposes at present is American. The native woods used in building houses and boats form but a very small item in the total, because, until very recently, only one sawmill was in operation here, and that was mainly used by the firm who own it for their own private purposes. Two new sawmills have been erected in the past two years, and they bid fair to compete with the United States for a share of the lumber business, as there are undoubtedly many fine varieties of woods suitable for all purposes to be found in the forests of this colony.

Of cabinet woods, besides the well-known mahogany and cedar, there is an abundant supply, as will be seen from the inclosed list of woods, which is by no means an exhaustive one.

\section{KINDS OF LUMBER USED.}

The kinds of wood principally imported are white and pitch pine and cypress, all of which are used in house and boat building.

\section{IMPORT DUTIES AND PRICES.}

No lumber is imported from any other country than the United States.

A duty of $\$ 1$ per 1,000 feet on rough and $\$ 1.50$ on dressed lumber is collected by the Government.

Lumber in the rough sells here for $\$ 50$ per 1,000 feet and dressed lumber at $\$ 55$ to $\$ 60$.

\section{OLMMATE.}

The climate of this country is generally very healthy and although yellow fever, cholera, and smallpox have, on one or two occasions, visited its shores, these diseases have never originated here, but were always brought in, and were readily stamped out. The types of these diseases, when they have existed here, seem to have been much milder than in other countries, especially the first-named disease. Vaccination is compulsory and hence but few of the inhabitants of towns died from smallpox during its last visit in 1891, when it was brought here from Peten, in Guatemala, the deaths being confined almost entirely to the 
Indians, whom it has hitherto been found difficult to reach for the purpose of vaccination. This, however, has been to a very large extent remedied and a more thorough system has been established. Cholera has not been known in this colony since 1866 and on that occasion it was brought here in a ship from South America. The following extract from an article written by Alexander Hunter, esq., late colonial surgeon, will convey a fair idea of the climate of this country:

The characteristrc features of the climate of British Honduras during the greater portion of the year are a most equable temperature, with strong easterly breezes in the summer months or dry season; an absence of rain for three or four months from the end of January; and in the winter months cold northerly winds, which are generally dry and bracing; and land winds, fortunately not continuous, which usually bring a great deal of moisture from the neighboring collections of water, and much rain. Exposed to the full influence of the trade winds, the whole coast may be considered as unexceptionally healthy during their continuance, while the temperature does not vary more than $6^{\circ}$ or $8^{\circ}$ during the twenty-four hours. The atmosphere is dry, indeed it would be difficult to point out any place in the West Indies in which the humidity is so inconsiderable. During the rainy season, the commencement of which is variable, there are sometimes short periods of calm, in which, although the temperature is not appreciably heightened, the feeling of heat is great; but, fortunately, these calms are of rare occurrence and of short duration. The rainfall is variable; but from observations extending over a period of twentyfive years, the general average for a year is found to be between 40 and 50 inches.

The country around Belize is swampy and covered with dense mangrove bushes; but as these swamps communicate freely with the sea, and as they are constantly being filled and emptied by the flow and ebb of the tide, the malarious emanations, which under other circumstances would be sure to follow, are prevented by the mechanical, and perhaps chemical, changes which these collections of water undergo. This circumstance, combined with the frequency and strength of the sea breezes, forms the principal reason for that remarkable immunity from miasmatic diseases which the population enjoys, and which is all the more extraordinary when it is considered that all the essentials for the evolution of these noxious emanations exist, viz, heat, moisture, and decaying animal and vegetable matter.

\section{GENERAL BUILDING.}

House building has increased to a very great extent during the past ten years, especially among the poorer classes who, by means of the fruit trade which was established between this colony and New Orleans some thirteen years ago, have been enabled to erect their own dwellings.

Boat and schooner building has also increased to a great extent from the same cause, though the growing state of the logwood and other industries has contributed thereto.

Railroad building has not been engaged in, and it is difficult to say whether British Honduras will ever be blessed by the civilizing influences of the iron horse.

JAMES LEITCH,

Consul.

Belize, March 5, 1894. 
THE WOODS OF BRITISH HONDURAS.

[Printed inclosure in Consul Leitch's report.]

The rise and progress of the colony of British Honduras has been indissolubly connected with the fortunes of its trade in timber and dyewoods.

Sub umbra floreo, in allusion to the mahogany tree, is the motto gratefully chosen by the colonist; but it is to the humbler denizen of the forest, the logwood shrub, that the colony owes its first recognition and early celebrity as a British plantation or settlement.

The chief industry of the colony is woodcutting, which has now been carried on for over two hundred years, and as a result much of the finest timber within easy reach of the principal rivers and their creeks has been cut down; but there are still vast tracts of virgin forests in the interior, abounding in some of the finest timber trees to be found in any part of the world. The difficulty is that they are beyond the reach of rivers, and, until the iron horse is introduced to solve the problem of bringing out our woods and stimulating the production and export of the old staples of the colony, must continue so. However, the fact remains that the quantity of wood exported maintains a fair average of the transactions for the last hundred years. ${ }^{1}$ Indeed during the last ten years the average shipments have been more than doubled. The improved price of mahogany in 1883 stimulated its production, but the export, as in the case of logwood, depends upon market prices.

Mahogany (Swietenia mahogani).-The best qualities of mahogany come from the limestone soils to the north of Belize, those from the south being deficient in density and fine grain. In the present century a tree was cut, by a Mr. Charles Craig, of Honduras, the trunk of which yielded a $\log$ of 15 tons wejght. It measured 5,168 superficial feet, squaring 57 inches by 64 . The log was truckerl out by Mr. Craig, and the limbs of it would probably when "manufactured"-that is, prepared for shipment-more than pay all expenses. ${ }^{2}$

Reliable returns are not procurable further back than 1802 , when $2,250,000$ feet are mentioned as the quantity exported; 1803, 4,500,000 feet; 1805, 6,481,000 feet. In 1824 it had kept the same figure; in 1840 it was reduced to $4,500,000$ feet, but there had been overexportation in the few years preceding, and stocks had accumulated in the home markets; in 1837, for example, there were shipped from Belize $8,500,000$ feet. The same mistake was made in 1845-'46. In the first of these years the returns show $9,919,507$ feet, and in 1846 the enormous increase of $13,719,075$ feet. A portion of these annual quantities was wood cut outside of the limits. The depression in the years $1848,1849,1850$ is not difficult to account for. In 1874 the the quantity had come down to the old figure of about 6,000,000 feet, and in 1878 lower still, 3,146,582 feet. The cost of cutting down and getting ready for shipment is about from $\$ 40$ to $\$ 50$ per thousand feet. ${ }^{1}$

Cedar (Cedula odorata).-Growing with the mahogany, it is a member of the same family. The export of this wood from the colony has greatly increased within the last few years. In 1876 the number of feet shipped was 18,923; in 1883, 469,144; in $1884,348,341$; in $1885,277,111$; in $1886,132,498$. In the colony the trunks of the largest trees are hollowed out to make dorays and pitpans, for which purpose they are admirably adapted on account of the light and durable character of the wood.

Logwood (Decandria monogynia).-This wood really comes next to mahogany in export value. It is found in rather moist lands, and grows luxuriantly in the swamps to the north and west, where it forms immense thickets.

The stem is crooked, and grows 16 to 24 feet high, seldom thicker than a man's thigh, the branches also crooked and irregular, thorny; leaves winged, and flowers pale yellow. The trunks are perpendicularly ribbed, and when cut down the outer white or sapwood is removed, leaving only the reddish or dark heartwood, which is 
cut into convenient logs suitable for shpment. It is claimed for Honduras logwood that it is superior to that grown in Jamaica and St. Domingo, and that its market value is fully 40 per cent higher. The yield of this wood is almost inexhanstible, as it seeds freely, and can be recut in ten to fifteen years. Its original value was $£ 100$ per ton, then $£ 40$; in $1825, £ 16$; and it is now quoted at $£ 5$ to $£ 7$. Its export from the colony in 1713 to 1716 was 5,740 tons; in 1824 , over 4,000 ; in $1874,9,210$ tons, The average for the last ten years has been 16,000 tons.

Its production for shipment requires less capital than mahogany, and is frequently undertaken by small capitalists employing small gangs, who pay a royalty for cut. ting on the estates.

It is brought down the rivers in "bark logs," or floating cradles made of the cub. bage palm, and in dorays, in which it is also conveyed along the coast.

Amongst the other woods of the colony are-

The Sapodilla (Achias sapota).-This is a most durable wood, difficult, on accsuns of its extreme hardness, to work, but it does work up haudsomely in furniture. rhe tree grows tall and free from branches, and one variety bears a sweet fruit with a rough rind, the naseberry, the seeds of which are used as a diuretic. It is much used locally for uprights and beams in house carpentry, but owing to the greas weight of the logs can not be floated down the rivers to the ports. If this dilticulty of transportation be overcome-say by the introduction of railways-this wood must find its way to European and other markets in much larger shipments than is the case now. At present it can hardly be said to be exported. Ture are two varieties, the black and the red, one rather scarcer than the other and not half so lofty, although about the same girth. It is a tree which grows abundantly in Honduras.

Rosewood (Dalbergia sp.).-A very heavy, rich, dark-reddish wood, very desirable for cabinet purposes, and plentiful in the colony, growing to a height or 50 feet, with a girth of 36 to 38 inches. Owing to its weight it is dificult to transport by water, an obstacle to the exportation of many of the native furniture woods yet to be overcome; about 150 to 200 tons are probably the average exportation. The socalled Bastard Rose is a distinct variety, the wood of which w rks up much redder in color; and there is another illegitimate of the family, the l'ix, tound in the colony.

Sam or salmwood (Jacaranda sp.).-A brown, very durable wood. On account of its being avoided by all kinds of insects, it is much appreciated for lining wardrobes, etc. It would, therefore, be very suitable for specimen cases for cullectors of natural history objects, especially entomological specumens. The tree grows 50 feet high, with an average diameter of 2 feet. It is not exported.

Ziricote is by some considered a description of rosewood. Mr. Morris, director of the Botanical Garden, Jamaica, who made a professional tour through the colony a few years ago, at the request of the colonial government, states it to be scarce, but it is abundant in the northern district. It is only exported in small quantities. The same authority classes it amongst other timbers of the colony as yet unclassified and unknown to commerce.

Fustic.-A yellow dyewood; is well known to commerce and the trade; the Morus tinctoria. It is used locally for furniture work, and about 100 tons are annually exported.

Poisonwood.-Of so-called roisonwood there are apparently three varieties, but "Chechem" is simply the Indian name for all kinds of wood locally so designated. The trees are so named on account of their secreting an acrid juice which, dropping on the skin of the woodcutter, blisters it; and a local authority, a writer in the Colonial Guardian, reviewing the preliminary exhibition in Belize, describes the "Chechem" as a kind of Upas, to be under the shade of which for any time inflames the skin of the face and the eyes. The writer calls the wood of the same tree the "King of Woods," but he means of cabinet woods. The trees of the black variety are large and umbrageous, and both kinds grow abundantly in the region, the height averag- 
ing between 80 and 100 feet, diameter 24 to 30 inches. The white variety of "Chechem" appears to be the largest in its growth.

Santa Maria (Calophyllum calaba).-Very suitable for shingles and heavy machine work and buildings; its seeds also yield an abundant oil adapted for lamps. It is unsurpassed for shipbuilding. Height, 80 feet; diameter, 24 inches. The wood is hard and durable, and is used in the construction of mahogany trucks.

Mahol (Paritum elatum).-Yields a darkish-green wood of great value, as also the celebrated Cuba bast, an article of commerce prepared from the inner layers of the bark.

Balsam (Myroxylon tolifera).-Average height 40 feet and diameter 20 inches. It resembles both mahogany and sapodilla, the latter most in color of the wood. Both the gum and bark are used medicinally.

Bullet, or Bully Tree.-Height 60 to 80 feet, with a diameter of 18 inches. Plentiful. Wood not very workable, and therefore not much used. Tree yields a resinous gum.

Timber-8weet.-A low, stout tree, bearing a yellow berry; 25 to 30 feet in height, 24 to 30 inches diameter. Wood light; not used.

Madre Cacao (Erythrina umbrosa). - A plentiful tree. Height 40 to 50 feet, 15 inches in diameter. A fine hard wood, much used in house posts, and also as a shade in coffee and cacao plantations. Mr. Morris suggests as a preferable shade for cacao the India-rubber plant, giving more shade and very profitable to the planter. Grows easily from slips.

Bastard Rosewood.-Plentiful. Grows to 40 or 50 feet, 12 inches in diameter. Wood takes a high polish and is very tough.

White Maya.-A very tough wood, and takes a polish. The tree grows 60 feet, with 20 inches in diameter.

Calabash (Crescentia cujete).-A pretty growing tree, with the leaves peculiarly arranged on the branches (subpinnate). The edible pulp of the large round nut is hollowed out, and drinking cups are made of the shell.

Cabbage-bark Tree.-Grows plentifully, 40 fect by 15 or 20 inches; the wood hard and durable, used in house building and in the composition of trucks or spokes, \&c.

Cinnamon, Wild.-Plenty of it; 30 feet by 16 to 18 inches diameter. Bark only used.

Buttonwood.-Extensively usedl ocally to burn; is occasionally introdnced as a variety in iulaid-cabinet work or veneering. The tree is not above 20 feet by 16 or 18 inches thick, and grows in swampy places. Used for ships' timbers.

Salaam.-A hard, durable wood, little known. Locally used for furniture, inlaid work, and capable of taking a fine polish.

Blackheart.-The tree attains a height of $30 \mathrm{feet}$, with a diameter of 12 inches. Wood hard, yellowish-brown in color, with a deep-colored heart. Takes. a high polish.

Billy Webb.-In local nse only. Height, 30 feet; diameter, about 24 inches. Used in constructing mahogany slides and trucks. It is plentiful, and an exceedingly tough wood.

Grandy Betty.-Grows plentifully; 40 feet by 12 inches. Wood not in use. Leares used for a decoction.

Boy's Job.-Plentiful; 30 or 40 feet by 18 inches. A tough, hard wood; not in use; except the leaves medicinally and for suake bites.

John Crow.-Plentiful; 35 feet by 16 inches. Not used.

Pigeon Plum.-Plentiful; 40 to 50 feet by 12 to 15 inches.

Allspice (Pimento) (Eugenia pimenta).-A favorite wood for walking sticks. Its seeds are known and appreciated as a spice everywhere. The tree grows plentifully in the colony; 50 feet in height and 20 inches in diameter.

Fiddlewood (Citharexylum melanocardium).-Grows abundantly. A straight tree with copious foliage and branches, 50 to 60 feet in height, 5 feet in diameter. Little used. 
Dogwood (Piscidia erythrina).- This is a tree of the genus Cornus, of which there are several species, exceedingly hard, called, also, dogwood. Javin is a variety of this wood with an Indian name. The trees grow large and straight, 80 to 100 feet, 24 to 30 inches diameter, and the wood of both is used for rollers of native sugarmills, etc. Javin is slightly the hardest.

Granadilla.-Not to be confounded with the vine granadilla bearing a luscious fruit. This tree grows 80 feet high, and is 2 feet thick. It produces a hard, durable, finely grained red timber, and is abundant in the region. It rises 50 feet without a limb, and is therefore a conspicuous forest tree. The wood is used in furniture and house decoration.

Ironwood (Laplacea hamatoxylon).--Every timber region has its own ironwood. This is an exceedingly hard, dark reddish wood, with a very fine grain. Tree 25 feet high, 10 inches in diameter.

Polewood.-So called, as it is used for poles to propel canoes and rivercraft in shallow places; height, 60 to 80 feet, 10 to 12 inches diameter. Grows straight and regular and is a little used in house carpentry.

Axmaster.-A tree the woodman takes his hat off to or gives it the go-by when he can. A dark wood taking a shining polish, 40 feet by 18 inches diameter. Not much used; the tree blunts the ax and the wood resists a nail.

Lignum vitoe.

Pix or pij.-Two bastard varieties of $L$. vitce, evidently. The fruit is scarce, and is not used when found here, at all events. It attains a height of 40 feet, and is 12 inches thick, as a rule, when grown. Plentiful, straight-bodied, 40 feet in height, 10 inches diameter. Timber used for fence posts, and the twigs make very lasting thatch.

Teabox.-A slender tree, not used, producing an edible berry and leaves, of which a decoction, "bush tea," is made. Thirty feet high, 10 to 12 inches diameter.

Prickly yellow.-Plentifully found. A straight-growing tree, 30 feet in height, 5 or 6 inches in diameter. Wood used for hoe and other agricultural tool handles.

Silly Young.-A large tree of 100 feet growth, producing durable house timber, which is also used for slides to slide mahogany and cedar logs.

Goodluck.-A fine hardwood, looking like dark-brown satin when polished. Probably a variety of the salmwood.

Redwood.-A strong-bodied tree of 60 to 80 feet growth and 12 inches thick. Wood hard and durable, used for fence posts and in house building, and lasting well.

Turtle bone.-A ponderous and bard wood, light yellow, taking a fine polish. Growing to a height a little under 20 feet; diameter, slight; very tough, and something like logwood.

Wild Provision (Pachira aquatica).-A common tree in moist places and river banks, bearing a fruit the size of a small pumpkin, the seeds of which are edible. Used for fencing posts, etc.

Craboo or Crabew (Byrsonima spicata).-A common tree, bearing a small, acid fruit, in size between a black currant and gooseberry, which, when sweetened, makes a pleasant, wholesome drink. The bark is also locally used medicinally.

My Lady.-Grows nearly 100 feet high and 18 inches to 2 feet diameter. A yellow wood, taking a fine polish; used both in house carpentry and cabinetwork.

Mangrove, Red (Rhizophora mangle).

Mangrove, black (Rhizophora sp.).

Mangrove, White (Laguncularia racemosa).-The manggi of the Malays. It grows along the seashore and river banks, rooting in the mud, the seeds germinating even while attached to the branches. The cays or islands in the Bay of Honduras are densely covered with it. The wood is used to burn and the bark as an astringent. It is also used in horise building and occasionally in cabinetwork, also for shipbuilding, in which it has a great local repute, furnishing "knees" that require little molding into the necessary shaje. Average growth, 30 to 50 feet; the black is the 
lowest in stature. Red mangrove, 60 to 80 feet; white, 80 feet; black, 50 feet. Diameter of all, 20 inches.

Mayflower.-This is a deciduous tree, and takes a fine polish; has a profusion of purp.e blossoms in May, and is a handsome tree, wide-spread, and growing to 70 or 80 feet. Used for yokes.

Botan (Palmetto) (Sabal $8 p$ ). - The leaves are used for thatch, the stem for staking and piles; 60 feet by 5 inches.

Bullhoof.-Plentiful; 80 to 100 feet, 24 inches diameter. Grows straight; not used. Yash Nick.-A beautiful cabinet wood.

Oak (probabiy Quercus virens).-A short, scrubby tree, 30 to 40 feet, 12 to 15 inches diameter, of which the wood is not used. The bark is used in tanning.

Walknaked (i.e., with its bark off).-Plentifully found, growing 40 to 50 feet high; a tough, unworkable wood; not in use.

Bribbi.-Plentifully found, growing about 50 feet. An umbrageous tree, with an edible berry. The wood is not used much.

Cabbage-palms (Euterpe montana, Areca oleracea, and Oreodoxa regia).-The mountain cabbage, the trunk of which is used, especially by Caribs, in constructing dwellings and for logwood rafts, called "bark logs."

Cabbage palms (Oreodoxa oleracea). - White and red varieties, both growing 80 to 100 feet, diameter 12 inches; outside very hard, and taking a good polish. Very durable; used in house building.

Cahoun Palm (Attalea Cohune).-The tree averages 55 feet in height; valuable for its oil-bearing nuts.

Cocoanut Palm (Cocos mucifera).-The use of this familiar tree of the tropics as a furniture material is, perhaps, not generally known; it id very prettily polished; 60 to 80 feet.

Tuberuce.-Much used in constructing canoes.

Crammati.-The bark of this tree is used medicinally and the tree as a furniture wood.

Yemery or Emery.-Much used for canoes.

Gombolimbo (Symphonia sp.).-A tree of 60 to 80 feet stature, 20 to 24 inches diameter; plentiful, and yielding a gum. The leaves are used as a decoction.

Ramun or Ramon (Trophis americana).-Its foliage makes fodder for cattle, but is only used when bread nut can not be obtained. It is abundant, growing 50 feet high, 20 inches diameter; wood not used.

Cockspur (Acacia spadicifera) is armed with formidable spines, one at the base or each leaf and branch, 2 inches long.

Wire Beer (Psidium 8p.).-A wild guava; plentiful; height, 40 feet; diameter, 8 to 10 inches. Wood not much used.

Water Wood.-Plentiful, at a height of 50 feet, growing straight; wood used for dwelling houses.

"Knock-me-Back."-A small tree of 25 feet elevation, found in swampy places growing plentifully. Wood used in house building. At the end of each leaf there is an extension into a prickle or thorn, hence the local appellation.

"Drunken Bayman."-Abundant, but not used; grows straight, 60 feet high, with a diameter of 20 inches.

Wild Tamarind (T. indica). - A most umbrageous, handsome tree, the fruit of which is well known, covering a wide space, and plentiful in the colony, 80 to 100 feet in height. The wood is used for doreys, pitpans, etc.; also for truck wheels.

Bread Nut (Brosimum alicastrum).-Grows 80 to 100 feet by 24 to 30 inches. Furnishes good fodder for cattle.

Glas:y Wood.-A tall, slim tree, the wood of which is very tough. It grows 60 to 80 feet high, 12 to 18 inches in diameter; used for beams and wall plates in house building.

Iguana Blossom.-A tree so named from its being frequented by a genus of lizard-Iguana tuberculata of Laurenti-which, being herbivorous, feeds on the blossoms. 
The original Carib name is guana, and these Indians, or their mixed descendants in Honduras, eat the animal which is common to tropical America, hence the tree is often corruptly similarly named. It is looked upon by some as a mere variety of madre cacao.

Negrito.-A straight grower, with a resemblance to a pine, 80 feet in height, 20 inches diameter. Its stem is nsed for masts of vessels.

Cashaw (Prosopis juliflora).-A fodder tree common in the West Indies and neighboring countries, but requires caution in using. If an animal is fed on the pods when the seeds are germinating the germination is continued in the animal's intestines, and if not relieved of its last meal the poor beast dies. Breeders of stock therefore eliminate it from their pastures. (Morris states that Prosopis yields alsc, a gum resembling gum arabic, and the wood of it is hard and durable.)

The Cashew (Anacardium occidentale) is a favorite plant on account of its edible seeds, which grow peculiarly, namely, at the end of the beautifully colored swollen stalk. The tree belongs to the sumac (Rhus) family, and the fleshy stalk, besides being eaten, makes a pleasing preserve and also a pleasant drink. (Morris: Prosopis yields also a gum resembling gum arabic, and the wood of it is hard and durable.)

Satinvood.-A hard lemon-colored local variety of a well-known furniture wood, which emits a slight fragrance, takes a lustrous polish, and is a great favorite with cabinetmakers and furniture connoisseurs. The origin of the name is obvious, and the local species grows to a height of 30 feet, with a diameter of 2 feet. That it is inferior to its Indian congener few who view it worked up in articles of furniture will consider. It is plentiful in British Honduras.

Beewood.

\section{Palmettos, Called here "pimentos."}

The Salt-water Pimento (Bactris 8p.).-Much used in staking wharves, resisting well the action of water, 40 feet by 4 inches diameter. Blossom used to stuff pillows, cushious, etc. The palmetto is plentiful and much used locally.

The silver pimento is covered with long spiky thorns. Tree grows 20 feet high by 3 to 4 inches diameter. Wood tough, and used in house building.

\section{WITHES, OR IIANAS.}

Locally known as "Tie-ties," and very useful to the woodmen and hunters, often supplying the place of rope and string. These parasites climb the tallest trees, and hang in graceful festoons. or drop jerpendicularly from the branches of their supporters. They vary in thickness from less than that of a little finger to that of the thickest part of a man's thigh, and are frequently armed with formidable thorns.

Water Tie-Tie.-So called from the circumstance that in the driest weather the thirsty traveler, if he is experienced in woodcraft, can obtain water from it by rapidly cutting off a section of the parasite by two quick cuts with his machete, and holding the section perpendicularly.

Chew-Stick Tie-Tie.-Twigs of this vine are used by the natives of all the races in the colony as a substitute for the tooth-brush and powder of more highly advanced countries. It is also used in place of yeast to start fermentation in making ginger and spruce beer, etc.

The Pine (Pinus cubensis). - It is estimated that about one-third of the area of British Honduras at present known is composed of pine-ridge country.

The chief plant of the pine ridges of the colony. The timber is used only to a small extent, locally, for building purposes, owing, it is said, to the difficulty experienced in sawing it. The wood is heavy, and if seasoned properly might be very durable. For railway sleepers, the pine wood should prove most valuable; and if sawmills were provided, much timber now imported could be supplied from the native woods, and large quantities of pine might be profitably exported. 


\section{GUATEMALA.}

\section{NATIVE WOODS.}

The principal woods of this country are red cedar, mahogany, cypress, and a pine used for framing purposes, somewhat similar to the Oregon pine, but vastly inferior.

\section{KINDS OF LUMBER USED.}

The principal woods imported are California redwood, for finishing purposes, and Oregon pine, for framing and flooring.

\section{IMPORTS OF LUMBER.}

There is no lumber imported from any other country except the United States, the amount of lumber from there being over 2,500,000 feet per annum.

\section{DUTIES AND PRICES.}

There is no import duty on lumber.

The prices of lumber vary from $\$ 90$ to $\$ 120$ (Guatemala silver*) per 1,000 feet at the present time, according to the rates of freight, which fluctuate more or less on account of competition.

\section{CLIMATE.}

The climate of Guatemala is as a rule salubrious. It is very warm upon the coast, but becomes much cooler in proportion to the altitude, and on the table lands of the city of Guatemala the climate may be described as being very even.

\section{GENERAL BUILDING.}

As regards shipbuilding, there is none. There is some railroad building going on in the Republic, a line being in course of construction from Puerto Barrios, on the gulf side, to the city of Guatemala.

\section{EXTENSION OF LUMBER TRADE.}

Referring to the methods to be pursued to extend the lumber trade of the United States with this Republic, I desire to state that the very high rate of exchange, high freights, exorbitant port charges in the shape of landing and pier charges, customs duties, etc., are very much against any increase of this trade.

\section{Lynch Pringle,}

\section{Consul-General.}

Guatemala, January 4, 1894.

* The Guatemala dollar (peso) was valued at 51.6 cents by the U. S. Treasury on January 1, 1894. 


\section{SALVADOR.}

\section{NATIVE WOODS.}

The native woods are as follows: Balsam, from which the balsam of Peru is obtained, and which is wholly a Salvadorean product; cahoba (mahogany); red cedar; ceiba, a 5-leaved silk-cotton tree; cola de pava, an inferior kind of volador; conocaste, a very large hard-wood tree, used for railroad ties, flooring, etc.; granadillo, brittle and speckled, worked mainly into canes, etc.; guachipilin, a solid, strong wood, used for ships; lignum vitæ; laurel, different from ours, in the bark it resem. bles our oak, it is springy and easy to work; mora, a fustic; madre cacao, a durable wood, which petrifies in damp. ground; nispero (the medlar tree); nogal (the walnut); pino, the common and pitch pine; pochote, a species of cedar with thorny bark; quebracho (break-ax), so called from its hardness, used for fences, etc.; quita calzon (trowserstearer), used for construction; roble, an inferior kind of oak; ron ron, resembles the guachipilin, but is rougher; tatascame, called the low climate tree, grows in great altitudes, and is used for beams, etc.; varillo, a hard, fibrous, dense-grained wood, good for building timber; volador has a white bark, but is not a birch, used in the manufacture of primitive cart wheels; zapotillo, the sapota tree; ebano (ebony), very scarce; copinol, a yellow, strong wood, out of which the native sugarcane mills are made.

In addition to the foregoing, there are the tropical fruit trees and, chief of all, the coffee trees, from which, however, nothing is made in the shape of lumber, except walking canes and some other small articles. Some of the foregoing woods are known under different names in the adjoining countries.

\section{KINDS OF LUMBER USED.}

The kinds of lumber used and preferred are:

Native.-Cedro, conacaste, cahoba, pochote, guachipilin, and laurel.

Foreign.-Oregon pine and California redwood, and spruce (ceiling) from Canada, imported by way of Europe.

\section{IMPORTS OF LUMBER.}

The quantity of lumber imported is about 700,000 feet from the United States (California) and about 50,000 feet from Canada (via Europe), though it varies greatly from year to year. Our trade with Salvador has largely increased within the last two years.

This republic has an area of only about 9,600 square miles, while its population is 700,000 , or about 85 to the square mile, which is twenty times as dense as that of any other of the Central American States. This makes timber land very scarce, and what little there is of it is 
often inaccessible, because of the lack of roads, so that it is generally cheaper to import lumber than to buy it here. There exists, however, some prejudice against our lumber on the ground that it can not withstand this climate, but this prejudice is unwarranted and is passing away.

\section{DUTIES AND PRICES.}

There are nominally no import duties laid upon lumber, but by an order of the president, recently issued, a "loan" of 25 cents in gold is collected on every 100 pounds. I am endeavoring to have this order revoked.

Lumber is worth in the country, at the place where it is sawed, about 80 pesos $(\$ 37.20)$ per 1,000 , taking cedar for a basis, and by the time it reaches the markets of the principal towns, with the present facilities of transportation, from $100(\$ 46.50)$ to 150 pesos $(\$ 69.80)$ per 1,000 . American lumber can be laid down here, without the profit, for 80 pesos* $(\$ 37.20)$ rough to 100 pesos $(\$ 46.50)$ finished.

\section{CLIMATE.}

The climate of Salvador is tropical, but on the mountains and plateaus, upwards of 1,500 feet above the sea level, it is healthful and agreeable. From that height down toward the valleys of the interior, or toward the coast it becomes hotter and correspondingly unhealthful, particularly in the beginning and toward the close of the rainy season (May and October).

\section{GENERAL BUILDING.}

In the principal towns, in the time of peace, there is always building going on, although not to a large extent. The houses are, however, all of wood, owing to the frequency of earthquakes. No shipbuilding is carried on, except the repairing of small boats or launches, which are brought whole or in pieces from the United States, The railroads in course of construction are those of La Ceiba-Santa Tecla, 6 miles, and the Ateos-Santa Ana line, 40 miles. These are propressing slowly. Two new lines are proposed, one from La Union to San Miguel, and the other from La Libertad to San Salvador, each about 35 miles long. The Government is building a custom-house, hospital, and barracks at Acajutla. A California company has a contract ( $\$ 160,000$ in gold) to construct a bridge across the Lempa River.

\section{EXTENSION OF LUMBER TRADE.}

So long as Americans study the wants of this country and fulfill them, so long can they contest the lumber trade here. The natives do

*The peso was worth, accos ding to U.S. Treasury valuation, 46.5 cents on April 1, 1894. 
not know how to assort, care little how they season the lumber, and it is almost impossible to get from them good dimensions. The one thing to be feared by us is the reinstatement of exorbitant freight rates.

ALEXANDER L. Pollock,

Consul.

SAN SALVADOR, March 5, 1894.

\section{SOUTH AMERICA.}

\section{ARGENTINE REPUBLIC.}

\section{NATIVE WOODS.}

In regard to the native woods of the Argentine Republic, I have to state that I have already furnished the Department with a full and detailed report. It was published in Vol. x, No. 34, p. 849, of Consular Reports. It not only gives the distribution of the forests of the country from Tierra del Fuego northward to the region of the tropics (latitude $20^{\circ} \mathrm{S}$., longitude $58^{\circ} \mathrm{W}$.), but it describes the peculiarities and uses of the various woods, including the belts on the eastern slopes of the Andes, the subtropical trees of Salta and Oran, and the immense timber resources of the Gran Chaco, Misiones, and the Argentine Mesopotamia, together with the estimate of the future lumber trade of the Argentine Republic. The statements and descriptions of trees in that report are as applicable and apposite to-day as when they were written, and they include the specific gravity of the most important trees; so that, instead of rewriting the facts of that report, I suggest that it be made a supplementary report hereto, ${ }^{*}$ as containing matters of considerable interest to those who are now seeking information on these subjects.

The number of species of trees in the Argentine Republic is stated to exceed 500, though of course many of these are mere shrubs or arborets. Of the more important woods, over 100 species were exhibited at the recent Columbian Exposition at Chicago, and these exhibits, being sections or blocks sawed from the trunks, and in most cases polished, have been presented to the Philadelphia Industrial Exhibition, where they can now be seen in all their marvelous beauty; and I presume the catalogue which accompanies them includes full descriptions.

Of those native woods wnich have, up to the present time, been more generally utilized either for constructions or for cabinet work or industrial purposes, the following are the most important:

Algarrobo.- The zone of this useful tree is very extensive, since it embraces the following provinces and territories: Corrientes, Santa Fé,

* The report referred to will be found immediately following this report. 
Catamarea, Cordoba, Jujuy, Salta, Mendoza, San Luis, Rioja, Tucuman, Entre Rios, Santiago del Estero, Chaco, Formosa, and Pampa Central. Its varieties are the white, the yellow, the black, the red, the gray, and the violet. Its size differs according to the variety, its height being from 5 to 12 meters (16.4 to 37 feet), and its diameter from 12 inches to 3 meters $(9.76$ feet). Its uses are varied and important, being used greatly in carpentry work, in the turning lathe, in cabinet work, in shipbuilding, etc. Its fruit constitutes an important part of the food of the poorer classes in the interior of the Republic. It is also fed to cattle, and they rapidly grow fat from its consumption. A drink called la aloja is likewise prepared from it, which is very intoxicating. The outside bark is employed for dyeing purposes, giving a bright red color. The wood resists the action of sun and water without cracking, and with the application of a little oil, is almost indestructible.

Red quebracho.-This valuable tree is found in the extensive zone formed by the following provinces and territories: Salta, Santiago del Estero, Cordoba, Santa Fé, Corrientes, Chaco, Formosa, etc. It grows to a height of 15 meters (49.25 feet), with a diameter of $1 \frac{1}{2}$ meters (4.923 feet). The color of the wood is very dark red. Its uses are various and valuable. As sleepers or ties for railway tracks, it is preferred to all other known woods, and the railways of the country, with the exception of those which have iron sleepers, are constructed with this class of timber. It also possesses very powerful tanning properties, and for that purpose it is employed in all the tanneries of this part of the Argentine Republic, the amount employed at present reaching 50,000 tons per annum. For this purpose it is also exported to Europe in great quantities. In the form of posts for fences it is also greatly employed. It is also used for turners' work, and for columns, beams, heavy bridge timbers, etc. It is used everywhere in the country, both on account of its hardness and its durability. It is likewise susceptible of an exquisite polish, and is extensively used for cabinet work, for doors, window sills, stairs, etc.

White quebracho.-This variety, also greatly appreciated, is found in the following provinces and territories: Salta, Catamarea, Santiago del Estero, Santa Fé, San Luis, Cordoba, Rioja, Tucuman, Corrientes, Chaco, and Formosa. It grows to about the same proportions as the red quebracho. The color is a yellowish white. It is employed for various purposes, such as shoe lasts, carriage and cart spokes, hubs of wheels, carriage and cart beds; also in all kinds of turners' work, in all which works 4,000 or 5,000 tons are annually consumed in this city.

Cedar.-This valuable wood is principally found in the territory of Misiones, though to some extent cedar forests exist in parts of the provinces of Salta, Jujuy, Tucuman, Corrientes, and Catamarca. Thie trees reach to a height of 15 to 28 meters.(49.21 to 91.86 feet), with a diameter of 1 meter (3.94 feet). Its color is bright red. Owing to the easier and cheaper transportation by means of the Parana River, 
nearly all that is used here and all that is shipped abroad is brought down from Misiones. Lately considerable of this wood has been sent to the United States. It is employed here in the construction of doors, windows, lattice work, wardrobes, counters, etc., and is greatly appreciated.

Nandubay.-The forests of this valuable timber tree are mostly in Entre Rios, Santa Fé, Cordoba, San Luis, Corrientes, and the territories of the Chaco and Formosa. Its great use is for posts for wire feneing, owing to its great specific gravity and its durability.

Cibil.-The Cibil is found in the following provinces and territories: Jujuy, Salta, Tucuman, Catamarca, Corrientes, Chaco, Misiones, and Formosa. There are three varieties, the white, the red, and the black. It grows to a height of 20 meters ( 65.62 feet), and its diameter is little less than a meter for the largest trees. In the provinces the bark is used for tanning purposes, and its wood is employed as beams, bridge timbers, and for domestic purposes. It is rich in rubber gum, but no efforts have yet been made to utilize it.

Gayaibi.-This tree is found in the zone formed by the province of Corrientes and the territories of Formosa, Chaco, and Misiones. The varieties are the white, the gray, and the black. It attains to a height of 12 meters (39.37 feet), and has a diameter of one half meter (19.68 inches). It is greatly esteemed by the natives. It is used for tool handles, and also for oars, masts for small vessels, cooperage, cabinet work, etc. It is flexible and yet very strong.

Laurel.-Laurel is found in the following provinces and territories: Jujuy, Salta, Tucuman, Corrientes, Catamarca, Chaco, Formosa, and Misiones, and presents three varieties-the white, the yellow, and the black. It reaches a height of from 10 to 20 meters (32.81 to 65.62 feet), and its diameter ranges from a quarter to three quarters of a meter (9.84 inches to 2.46 feet). It has exquisite veins running through the wood, and quite competes with walnut. It is extensively used for cabinetwork; also, owing to its great strength, for naval construction, and for the wood parts of agricultural machinery.

Walnut.-The walnut (nogal) is found in the zone formed by the following provinces: Jujuy, Salta, Tucuman, Mendoza, Cordoba, and Rioja. There are two varieties-the black, probably originally imported into the country, and the native, or white, which is a very light brown color. It is used in the interior for cabinetwork.

Rosewood.-This fine wood (palo de rosa) grows only in the territory of Missiones. It reaches a height of 15 to 20 meters (49.21 to 65.62 feet). It is the usual rosewood of commerce, takes an exquisite polish, and is principally used for eabinetwork and furniture. Very little, however, comes to this market, as the foreign variety can be procured more readily and much more cheaply.

Mahogany. - This valuable wood (jacarandá) is found only in the iar northeastern part of the country, and principally in the territories of the 
Chaco and Formosa. It grows to a height of 5 meters (16.41 feet), and its diameter is about 18 inches. Owing to its scarcity, it is not greatly used here, the imported article taking its place in this part of the country.

Tipa.-This tree grows principally in the following provinces and territories: Jujuy, Salta Tucuman, Corrientes, Chaco, and Formosa. There are three varieties-the white, the red, and the yellow. The trees grow to a height of 15 to 25 meters (49.21 to 82.02 feet), and it attains to a meter (39.37 inches) in diameter. It is employed for various purposes by carpenters, and in the fabrication of yokes, plows, and the handles of tools and agricultural instruments. There is quite a demand for it also for cabinetwork, as it takes a beautiful polish.

Palo blanco.-This tree, whitewood, as it is called, is found in the following provinces and territories: Jujuy, Salta, Tucuman, Santa Fé, Corrientes, Chaco, Formosa, and Misiones. There are eight varieties, according to slight differences of color. Its height ranges, according to the variety, from 3 to 15 meters ( 9.85 to 49.21 feet), and its diameter is only from 10 to 60 centimeters (3.94 to 23.62 inches). It is used for a variety of purposes, and is best known in turners' work and the wood of iron machinery; also, for chairs and fine furniture. Its grain is very compact, and varnish produces upon it a beautiful effect.

Palo amarillo.-This tree, yellowwood, as its name signifies, is found in Corrientes, Santa Fé, Tucuman, Salta, Jujuy, Catamarca, Chaco, and Misiones. It attains to a height of 12 meters (39.37 feet), with a diameter of half a meter (19.68 inches). It is variously employed in turners', carpenters', and cabinet makers' work, and is much appreciated.

Palo moro.-This is the Argentine mulberry, and is found in the following provinces and territories: Salta, Corrientes, Misiones, Chaco, and Formosa. Its height varies from 10 to 20 meters (32.81 to 65.62 feet), and its diameter from 50 to 75 centimeters (19.68 to 27.56 inches). The color of the wood is bright yellow. It has a fine, compact grain, beautifully veined, and, when varnished, produces fine effects when used in cabinetwork.

Viraro.-This wood is embraced in the zone which includes the provinces of Corrientes, Catamarca, Jujuy, and Tucuman, and the territory of the Chaco. Its height varies from 14 to 25 meters (45.10 to 82.02 feet), and its diameter from 60 to 75 centimeters (23.62 to 27.56 inches). Its color is a very dark brown. It is employed in carpentry and in wagon and carriage work. It is not very abundant, and it brings high prices in the market.

Calden.-This is found in the provinces of Entre Rios, Corrientes, Cordoba, and San Luis, and the territory of the Central Pampa. It reaches a height of only 3 to 12 meters ( 9.84 to 39.37 feet), and a diameter of 30 to 70 centimeters (11.81 to 27.56 inches). Its color is bright red. It is a useful wood, and is not only employed in carpentry but its 
bark is used for tanning purposes and its chips for dyestuffs. It is also used for fencing and for railroad fuel.

Tatané.-The zone of this tree comprehends the provinces of Salta, Jujuy, Tucuman, Corrientes, and Santa Fé, and the territories of Chaco, Misiones, and Formosa. Its height varies from 10 to 16 meters (32.81 to 51.66 feet), and its diameter from 20 to 50 centimeters (7.87 to 19.68 inches). Its color is a golden yellow. It is employed in carpentry, cabinetwork, and turners' work in the places where it grows. But little of it reaches Buenos Ayres.

Virapitá.-This tree is found in the following provinces, to wit: Santa Fé, Corrientes, Chaco, Formosa, and Misiones. Its height is from 16 to 20 meters (51.66 to 65.62 feet), and its diameter from 20 to 40 centimeters (7.87 to 15.75 inches). Its color is a silver-gray. It is used in carpentry work, cabinetwork, and turners' work. It is especially sought after for axles and spokes for wagons and carriages; also for beams and sleepers, and its chips are made use of for dyestuff.

Pacará.-This tree is found in the zone formed by the following provinces and territories, to wit: Jujuy, Salta, Tucuman, Santa Fé, Corrientes, Chaco, Formosa, and Misiones. It attains to a height of from 10 to 20 meters (32.81 to 65.62 feet), and a diameter of from 1 to 2 meters (39.37 to 78.74 inches). The color is very dark red. It is used in carpentry work, and from its dimensions is admirably adapted for beams, joists, sleepers, etc. It also makes beautiful flooring, window frames, turners' work, and furniture.

Espina de corona.-This tree, the "crown thorn," is found in the province of Corrientes and in the territories of the Chaco, Misiones, and Formosa. It reaches a height of from 10 to 15 meters (32.81 to 49.21 feet), and a diameter of about 1 meter (39.37 inches). The color of the wood is yellowish gray. It is used in carpentry work, and especially for fine furniture.

Molle.-This fine tree, with its several varieties, is scattered through the following provinces and territories: Salta, Jujuy, Cordoba, Uatamarca, Tucuman, San Luis, Mendoza, Corrientes, Pampa Central, Chaco, and Formosa. Its principal varieties are the white, the red, the black, the "del monte," the sweet, the violet, and the Peruvian. It varies in height from 4 to 10 meters (13.12 to 32.81 feet), and from 25 centimeters to 1 meter ( 9.84 to 39.37 inches) in diameter. Its color varies from a dark gray to a black brown. The tree has valuable turning properties. The wood is variously used. From the fruit of the "molle dulce" is made a liquor called aloja.

Guayacán.-This tree is found in the extensive zone formed by the following provinces and territories, to wit: Salta, Tucuman, Catamarca, Riòjà, San Juan, Mendoza, San Luis, Santiago, Cordova, Corrientes, Chaco, and Formosa. There are 2 varieties. Its height varies from 4 to 15 meters ( 13.12 to 49.21 feet) and its diameter from 10 to 40 centimeters ( 3.93 to 15.75 inches). The color of the wood is black. For 
turners' work, for moldings, and for veneering it is a magnificent wood. It is sought after for walking sticks. It is one of the hardest woods in the country and its endurance is wonderful.

Palma.-The palma is found in the following provinces and territories, viz, Cordova, Entre Riòs, San Luis, Santa Fé, Corrientes, Chaco, and Formosa. There are several varieties, the red, the white, and the black. It grows to a height of from 6 to 22 meters (19.68 to 72.18 feet) and has a diameter of from 25 to 30 centimeters (9.84 to 11.81 inches). The color varies from gray to gray black. In the Chaco and Corrientes the tree is greatly used, being employed for roofing of the "toldas," "ranches," and nearly all other rural constructions. It is also used for bridge flooring, for fences, for joists, and for telegraph posts. There are great forests of this tree along the Bernujo River, in the Chaco.

Uranday.-This tree is found in the following provinces and territories, viz: Salta, Jujuy, Catamarca, Corrientes, Misiones, Chaco, and Formosa. The varieties are the white, the black, and the curly. It grows to a height of from 15 to 20 meters (49.21 to 65.62 feet), with a diameter of about 1 meter (39.37 inches). Its color varies from a silvergray to a gray black. It is used in the woodwork of all sorts of tools, for handles, for brushes, for moldings, etc. It is also employed for joists, beams, sleepers, posts, etc. It is hard and durable and is greatly esteemed in the country.

Lapacho.-This tree is principally found in Salta, Jujuy, Tucuman, and Misiones. The varieties are the yellow, the white, the red, the curly, and the black. Its height is from 15 to 30 meters (49.21 to 98.43 feet) and its color varies from a greenish gray to a gray black. It is used for the spokes of wheels, for which purpose it is claimed to be the best wood in the world. It is also a beautiful wood for cabinetwork, and is greatly used for turner's work and fencing; likewise for dyestuffs. It is regarded as one of the most valuable trees which grow in the Argentine forests, and there is a general demand for it.

Guayabo.-This tree is found in the zone formed by the following provinces and territories, viz: Santa Fé, Entre Riòs, Corrientes, Chaco, and Misiones. It grows to a height of 15 meters (49.21 feet) with a diameter which varies from 50 to 75 centimeters (19.68 to 29.53 inches). Its color is red, with veins of yellow and black. There is a variety also of a bright gray color. It is admirable for cabinetwork, for fine furniture, for turners' work, and for veneering. Its bark is used for tanning purposes. Its fruit is very aromatic and is used for jellies, deserts, ete.

Inga.-Forests of this tree are found in the following provinces and territories, viz: Entre Riòs, Santa Fé, Corrientes, Misiones, and Formosa. It presents two varieties, called the bitter and the sweet inga. The "bitter" attains to a height of 10 to 15 meters (32.81 to 49.21 feet), with a diameter of 40 to 75 centimeters ( 15.75 to 29.53 inches). The "sweet" reaches to a height of only 4 to 6 meters (13.12 to 19.78 feet) and a diameter of 20 centimeters ( 7.87 inches). The wood of the first-named 
variety is brownish gray; of the second, greenish gray. It is used in turners' work. The fruit of the tree is edible.

Palo de lanza.-The "lance wood" embraces the zone formed by the following provinces and territories, viz: Solla, Santa Fe, Misiones, Chaco, and Formosa. It grows to a height of 15 meters (49.21 feet) with a diameter of 50 centimeters (19.68 inches). The color of the wood is a bright gray. It is used for turners' work, for chairs, for handles, etc.

Petcriby.-This tree grows principally in the provinces of Santa Fe and Corrientes and in the territories of Misiones and Chaco. Its height varies from 15 to 18 meters (49.21 to 58.22 feet), with a diameter of 30 to 50 centimeters (11.81 to 19.68 inches). The color is a bright brown, very similar to walnut. It is used for cabinetwork, for furniture and other carpentry work. It is also employed for beams, joists, etc.

Cheñar.-The zone of this tree is quite extensive, being found in greater or less quantities in all parts of the country; but especially in the following provinces and territories, viz: Cordoba, Jujuy, San Luis, Santa Fé, Tucuman, Santiago, Pampa Central, and the Chaco. It grows to a height of 5 or 6 meters (16.44 to 19.68 feet) with a diameter of 50 centimeters (19.68 inches). It is used in all kinds of carpentry work.

Falo ribera.-This tree, "river wood," is quite abundant in the territories of the Chaco and Formosa, and especially along the Bermijo River. It attains to a height of 12 to 18 meters (39.37 to 49.21 feet), a diameter of 50 to 80 centimeters ( 19.68 to 31.50 inches). It is not yet very well known in Buenos Ayres, as it is rather inaccessible to the woodchoppers. Its color is rather unique-dark cinnamon, with reddish veins. When polished it presents a magnificent surface, and, combined with other woods, in cabinetwork, produces beautiful effects. When better known, it will evidently be sought after.

Alamo blanco.-This is the white, or "aspen," poplar of the United States. It is found all over the Argentine Republic, and, as with us, it is used for all sorts of purposes. Being about the only light wood in the country, it is employed in carpentry work, for packing-boxes, for common furniture, for broom liandles, and for many other purposes. It grows without any attention, and immense plantations are everywhere to be seen. It is especially used by estancieros for belts of timber around their habitatious, to break the force of the wind and thus protect their flocks.

Alamo Carolina.-This is nothing more than our ordinary cottonwood, which grows with such wonderful luxuriance on the low banks and islands of the Mississippi River. It may be indigenous to this country, but I think the tree was imported from us by Dr. Sarmiento, when he was minister to the United States. On the prairies and pampas of the Argentine Republic, on account of its rapid growth, it is greatly appreciated, and is regarded as a much better wood, owing to its heavier body, than the white poplar. As it is easily worked, it is used for all sorts of carpentry purposes. 
Willow.-This tree grows very generally all over the Republic, and especially along the water courses. It covers the islands of the Delta of the Panama River. It furnishes nearly all the firewood of the eity of Buenos Ayres. Every three years it is cut for that purpose, and new trees spring up from the stumps. It is likewise used for common furniture, for turners' work, for wooden shoes, etc.; and as it flourishes with a rapid growth in the timberless regions of the country it is regarded as one of the most useful trees of the Republic.

\section{SPECIES AND VARIETIES, AND THEIR EXPLOITATION.}

I have thus, according to request, enumerated thirty-six different species of native trees, all indigenous to the Argentine Republic; and, as has been seen, some of these species have several distinct varieties, the whole number amounting to at least forty, so that really the above enumeration includes not less than seventy-six varieties of Argentine woods. The catalogue might be still further extended; for many other " unusual" varieties are known to exist, though I am not just now able to describe them.

It will be observed that many of these woods, not having yet been properly classified, still bear the names given them by the Guarani Indians or the early Spanish settlers. Likewise it will be borne in mind that it is only in the far western, northwestern, and northern portions of the country that the timber plantations of the Argentine Republic are to be found-in many cases over a thousand miles from tide water. The Atlantic side of Patagonia is a desert; the territory of the Pampa is in great part destitute of trees, and the Province of Buenos Ayres and the southern portion of that of Santa Fé are also in the natural state without other vegetation than the grasses, though of late years vast artificial plantations have been made in all directions through the interior. Furthermore, it is be considered that all the woods I have enumerated above, except it mas be the willow and the poplars, are what are called "hard" woods, whose specific gravity in almost all cases is greater than that of water.

With such classes of woods to deal with, and with the great forests of the country so far removed from the seaboard, especially from Buenos Ayres, which is the great receiving and distributing focus of the Argentine Republic, some idea may be entertained of the labor of getting the timber resources of the interior to market. Yet the exploitation of the timber trees of the upper provinces and territories, especially along the Parana and Paraguay rivers, has been going on with more or less persistency for a great many years; and the choppers and the sawyers, without government officials to molest or make them afraid, have used their privileges with so little care and consideration that in some parts of the interior, especially along the water courses, the havoc and wholesale destruction have been shameful. So little respect, indeed, was paid to the national forests that, a few years ago, the government 
enacted a law prohibiting the cutting of timber on the public lands except by special permission which had to be paid for, and then the work was required to be done under special conditions. Though the timber thieves still get in their work in the remote places, there is now more system and somewhat more care displayed in getting out lumber.

\section{NATIVE ESTIMATE OF ARGENTINE WOODS.}

As showing the estimate which the more intelligent portion of the Argentine people place upon their forest riches, I translate the following from a recent issue of the Buenos Ayres Nacion:

Our national forests present a superabundant element of riches; and, if wise laws are made to protect their production, in a few years the Republic will be able to get along without importing foreign lumber and be prepared even to export all kinds which are suitable for city or rural constructions or as auxiliary to other important industries. Among the five hundred varieties which have been catalogued there are many woods of great value; and there is no object or use or necessity or industrial purpose which can not be supplied by some of the classes of these woods. At present, however, it must be confessed that these great forest riches are but slightly appreciated by the majority of our people. What a wonderful source of wealth they would be if they were the possession of some more enterprising nation! The greater part is of spontaneous growth and owes nothing to the hand of man, which from time immemorial has, on the contrary, done all it could to destroy what nature has provided for the country.

Science, reason, and common intelligence condemn the manner in which the forests of the nation have been exploited. Without entering into details, it is suffcient to say that the damage and destruction under the present system are greater to the country than the profits. Everybody sees the manner in which, despite the law on the subject, the natural forests are being ruined, but how few apply the remedy against the devastation which is going on.

\section{THE SAWMILLS AND SAWYERS OF THE COUNTRY.}

The number of sawmills in the country are now numbered by thousands, and they are quite generally distributed, not only along the shores of the upper rivers, but in the interior provinces. On this subject I translate from a recent number of the Buenos Ayres Prensa the following:

There is one industry in the Republic which at least can count on an extraordinary number of establishments of every magnitude, from the least with a single mule power (movido porla perezosa mula) to those of the largest dimensions, stocked with the very best machinery which the world affords. We refer to the sawmills of the country. There is no province or territory, whether in the north or the south, which does not count on a large number. It may be stated as a fact that the woods of the country furnish labor for a larger number of artizans and laborers than that of any other industry. In the Province of Santiago del Estero, no less than 5,000 workmen are employed in no less than 200 different establishments, most of them in the Sierras, getting out quebracho sleepers for railways, white quebracho beams for constructions, woods of other descriptions for cabinet work, and joists and scantlings and boards of other timbers, besides the large amount of fuel for the numerous railways of that vicinity. In the Province of Tucuman there is even a larger number of lumbermen and a larger number of establishments. In the Province of Cordova the working up of the algorroba forests sustains a still greater number of sawmills and employés, 
which throw npon the market monthly millions of "breadths and lengths" (Pierrits y cabazales) bedsteads, knees, square knees, and various other products of the algorroba and other hard-wood trees. The Province of Santa F6, not only in the neighborhood of its cities, but in its various colonies, has a large number of sawmills and carpenters; and especially in that portion of its territory which adjoins the Gran Chaco, there is a large population whose principal occupation is working the red quebracho forests, as it is from this province that the greater part of the quebrache chip, used in Europe for dye woods, are obtained. In the province of Entre Rios, likewise, there is a considerable number of well established mills, besides a still larger number of moving circular sawmills, which are now penetrating to the very center of the immense forests of that part of the Republic, turning out all kinds of lumber and hard wood. And the same is the case in the Province of Corrientes, where there are extensive forests of quebracho and other choice timber. But in the territories of the Chaco, Formosa, and Misione, the lumbermen and the sawmills are especially to be found. The amount of capital invested in the lumber trade, in those parts of the Republic, reaches to millions of dollars; and the establishments there are commensurate with the vast wealth of timber of the most valuable varieties, which are to be found there. The lumber business of the provinces of Salta, Jujuy, Rioja, Catamarca, San Louis, Mendoza, and San Juan, though of much less importance, owing to their distance from a marketable outlet, is yet very considerable, as all the lumber of every kind and description which they use is furnished by their own forests. Here in the city of Buenos Ayres, though the lumber and woods must all be transported here, there are thirty-nine sawmills and seven hundred and forty-three carpenter shops. Besides there are numerous similar establishments in the cities of La Plata, Chirilcoy, Tigre, San Fernando, Bahia Blanca, San Nicolas, Campana, and other places.

\section{THE LUMBER INDUSTRY.}

I am not able to state-for no census has ever been taken-the total number of workmen and laborers engaged in the lumber industry of the Argentine Republic; but the following table, which has been prepared with considerable care, gives an approximation of the number of persons thus employed for the year 1892:

\begin{tabular}{|c|c|c|c|}
\hline Place. & Number. & Place. & Number. \\
\hline 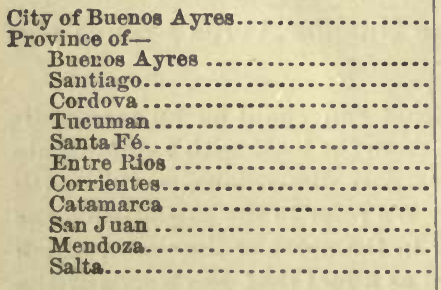 & $\begin{array}{r}12,000 \\
6,000 \\
5,000 \\
5,000 \\
4,000 \\
5,000 \\
3,000 \\
2,000 \\
1,000 \\
1,000 \\
1,000 \\
1,000\end{array}$ & 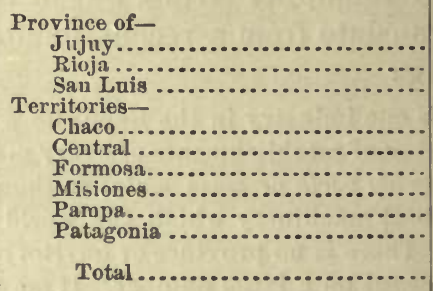 & $\begin{array}{r}500 \\
500 \\
500 \\
750 \\
500 \\
800 \\
750 \\
250 \\
250 \\
50,800\end{array}$ \\
\hline
\end{tabular}

\section{ANNUAL LUMBER OUTPUT.}

In regard to the output of the lumber industry in the interior provinces, it is not possible to give any figures. That there is an exchange of trade between the sawmills and the provincial centers of population, which in the course of the year amounts to several millions of dollars, is evident from the fact that all the houses, habitations, galpones, barus, 
fences, corrals, and the ordinary furniture and carpentry work of the people are entirely constructed from timber of the native forests. While the cost of transportation, except it be along the great rivers, precludes the exportation of the native woods, the same reason prevents the use in the far interior of the soft woods of other countries. Buenos Ayres is, however, advantageously situated in this respect, since it is enabled not only to receive the valuable cabinet woods of the Chaco and Misiones by means of chatas and other river craft, but also, at moderate freights, the pines and spruces of North America. The quantity of hard woods which find a market here in Buenos Ayres is increasing every year, as the industries of the place find additional use for them. The receipts for 1892, according to the custom-house returns, were as follows:

\begin{tabular}{|c|c|c|c|}
\hline & Class of woods. & Quantity. & Value. \\
\hline \multicolumn{4}{|l|}{ Hard wood: } \\
\hline \multicolumn{2}{|l|}{ Slabs.... } & $\begin{array}{l}108,208 \\
330,074\end{array}$ & $\$ 324,624$ \\
\hline \multirow{2}{*}{\multicolumn{2}{|c|}{ 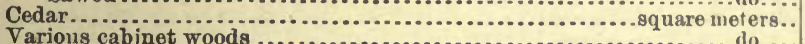 }} & $239,634,871$ & $1,198,17$ \\
\hline & & $1,387,930$ & $1,110,334$ \\
\hline \multicolumn{2}{|c|}{ 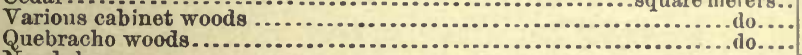 } & 386,755 & $\begin{array}{l}114,501 \\
193,387\end{array}$ \\
\hline \multicolumn{2}{|l|}{$\begin{array}{l}\text { Nandubay: } \\
\text { One-haif posts ..... }\end{array}$} & 1.577 .175 & 473,152 \\
\hline \multirow{2}{*}{\multicolumn{2}{|c|}{$\begin{array}{l}\text { Posts } \\
\text { Quebracho blocks. }\end{array}$}} & 785,544 & 392,772 \\
\hline & & $23,416,669$ & 468,333 \\
\hline \multicolumn{2}{|l|}{ Total } & & $4,318,187$ \\
\hline
\end{tabular}

\section{INDUSTRIAL ESTABLISHMENTS IN BUENOS AYRES.}

These figures are for a year in which there was unusual depression in the industrial establishments of this city, and I am sure, with the return of the normal condition of business, the figures would double the value. But of course it is not merely the native woods which are worked in this city. The immense shipments of the soft woods from North America contribute materially to the total quantity used by the workers in wood in this vicinity. The latest statistics (1857) in regard to the number of such establishments in Buenos Ayres are:

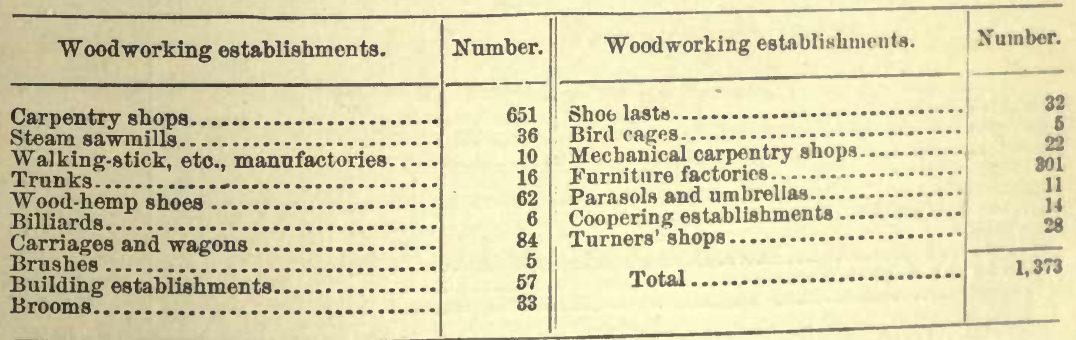

Since the above date, the number of these various establishments has greatly increased, and there are now to be added to them a number of boat yards, where all classes of water craft, from whaleboats to largesized steamers, are constructed and fitted out. 


\section{EXPORTS OF NATIVE WOODS.}

In regard to exports of lumber from the country, there is as yet very little to be said. As we have seen, while the upper territories and provinces are an unbroken forest of primeval proportions, in which are to be found hundreds of varieties of hard woods, susceptible of the very finest polish and presenting the most exquisite colorings, yet the country is almost devoid of the soft woods of commerce. There are pines in the territory of Misiones and along the eastern slopes of the Cordilleras of Patagonia, but they are quite inaccessible to market. Years hence, with the development of the country, they may come to the front. At present the only woods which are shipped abroad are the hard woods of the upper Paraná. Orving to their specific gravity, it is impossible to float the logs, and so they are brought down in chutes or are loaded from the banks directly in sailing vessels bound for Europe. The first movement towards the export of Argentine woods was made in 1875. Since then the annual shipments to foreign markets have been:

\begin{tabular}{|c|c|c|c|}
\hline Year. & $\begin{array}{l}\text { Export } \\
\text { value. }\end{array}$ & - & $\begin{array}{l}\text { Export } \\
\text { value. }\end{array}$ \\
\hline 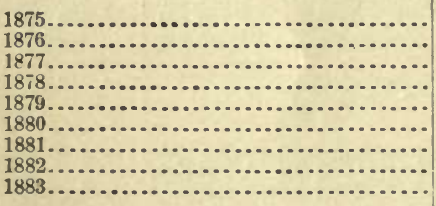 & $\begin{array}{r}\$ 29,171 \\
10,541 \\
57,090 \\
14,943 \\
58,793 \\
36,403 \\
272,613 \\
222,358 \\
257,887\end{array}$ & 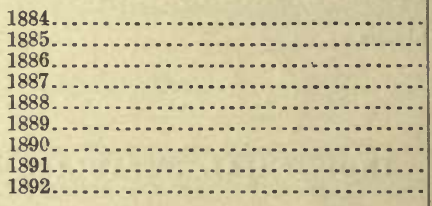 & $\begin{array}{r}\$ 390,848 \\
339,022 \\
326,623 \\
330,214 \\
781,793 \\
799,257 \\
1.413,224 \\
2,145,510 \\
1,066,819\end{array}$ \\
\hline
\end{tabular}

It is evident from these custom-house returns that the greater portion of the lumber and precious woods of the country are made use of here at home. The value of the forest exports for 1891 amounted to about 8 per cent of the total exports. In 1892 it amounted to about $4 \frac{1}{2}$ per cent of the total exports. The exports of these years embraced the following items:

\begin{tabular}{|c|c|c|}
\hline \multirow{2}{*}{ Exports of lumber, woods, etc. } & \multicolumn{2}{|c|}{ Value in- } \\
\hline & 1891. & 1892. \\
\hline 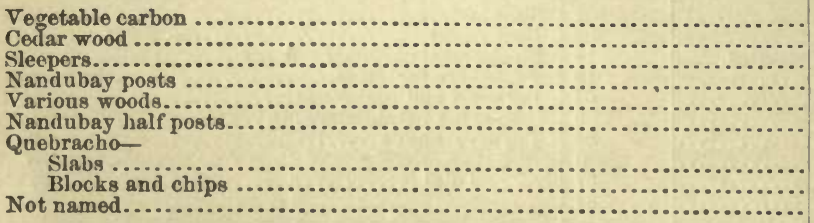 & $\begin{array}{r}\$ 299,484 \\
72,825 \\
173,835 \\
14,633 \\
181,152 \\
110,121 \\
630,419 \\
615,209 \\
57,827\end{array}$ & $\begin{array}{r}\$ 257,485 \\
44,892 \\
56,964 \\
5,862 \\
27,079 \\
34,917 \\
87,864 \\
529,847 \\
21,909\end{array}$ \\
\hline 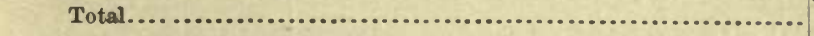 & $2,145,505$ & $1,066,819$ \\
\hline
\end{tabular}

All these shipments went to European ports, except a small portion of the cedar and of the quebracho, which was sent to the United States 
as an experiment and to try the market. I do not think, however, the result of the ventures was at all successful.

Speaking in general in regard the business of exporting lumber and hard woods from the Argentine Republic, it may be said that it has not been profitable in the past, and it has to be managed on a different basis to reach to any great proportions in the future. The great drawback to a successful prosecution of the industry results from the fact, in the first place, that even the most accessible forests are so remote from tide water that the cost of freight is out of proportion to that for which the hard woods of Central America and portions of Brazil can be sent to market. It is true that, at certain seasons of high water ocean-going vessels can be loaded far up the Parana, and even Paraguay, and thus convey their cargoes, without breaking bulk, to their trans-Atlantic destination. But in many cases, the lumber has to be brought down in small craft, or latas, and reshipped, thus making another handling necessary. And in the second place the appliances for handling logs and heavy timber on the upper rivers are so primitive and the laborers so inefficient that the getting out of it is very expensive.

\section{IMPORTS OF LUMBER.}

As long as the people of this part of the Argentine Republic, for ordinary carpentry and building purposes, are able to procure the pines and spruces from North American ports with as little trouble and expense as they have been doing in the past, it is not probable that there will be very great attention paid to the heavy hard woods of this country. Of course the shipments of North American soft woods vary according to the demands of the trade. When everything is "booming" the requirements of the country are greater than when there is general stagnation in business. The crisis, which has been so severe for several years past, has been especially felt in house building, house furnishing, estancia fencing, and general construction; and the receipts of lumber from abroad, which reached their highest figures in 1889, have since then shown a great contraction.

The following table, which I have in great part compiled from the official returns, shows the vaiue of the importations of lumber into the Argentine Republic since the year 1870, inclusive:

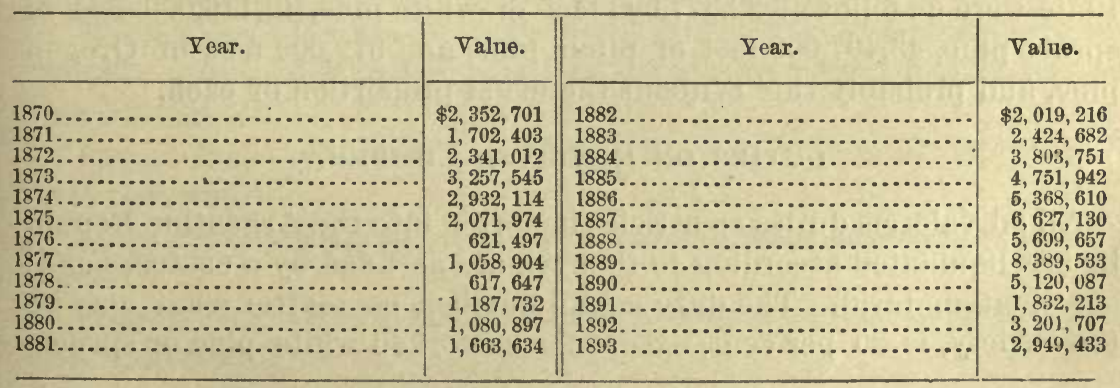


It is hardly necessary to state that a very large proportion of the lum. ber imported into the country comes from the United States. The returns of imports for 1893 by countries have not yet been published by the statistical office, but I give below those for 1892:

Importations of pine lumber for 1892.

\begin{tabular}{|c|c|c|}
\hline Country. & Qnantity. & $\begin{array}{c}\text { Official } \\
\text { value. }\end{array}$ \\
\hline 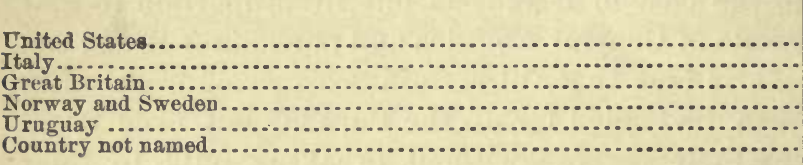 & $\begin{array}{r}\text { Sq. meters. } \\
6,683,846 \\
5,261 \\
141,783 \\
27,998 \\
184,026 \\
75,131\end{array}$ & $\begin{array}{r}\$ 2,788,521 \\
2,151 \\
59,814 \\
11,479 \\
65,419 \\
21,818\end{array}$ \\
\hline Total.... & $7,118,045$ & $2,949,202$ \\
\hline
\end{tabular}

Importations of woods for 1892.

\begin{tabular}{|c|c|c|c|c|c|}
\hline Country. & Quantity. & $\begin{array}{l}\text { Official } \\
\text { value. }\end{array}$ & Country. & Quantity. & $\begin{array}{l}\text { Official } \\
\text { value. }\end{array}$ \\
\hline 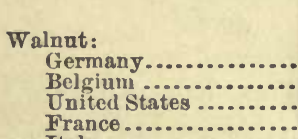 & $\begin{array}{r}\text { Square } \\
\text { meter8. } \\
2,982 \\
61,062 \\
4,475 \\
7,234\end{array}$ & $\begin{array}{r}\$ 2,982 \\
61,062 \\
4,475 \\
7,234\end{array}$ & \multirow{6}{*}{ 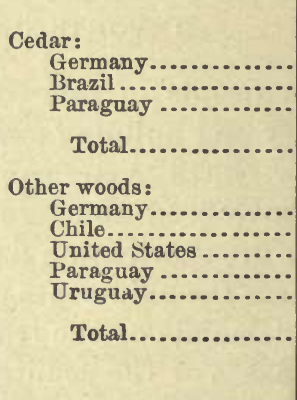 } & $\begin{array}{r}\text { Square } \\
\text { meter8. } \\
10 \\
192 \\
160,381\end{array}$ & $\begin{array}{r}\$ 4 \\
63 \\
61,537\end{array}$ \\
\hline 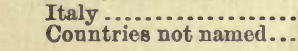 & $\begin{array}{r}2,461 \\
9\end{array}$ & $\begin{array}{r}2,461 \\
9\end{array}$ & & 160,583 & 61,604 \\
\hline Total. & 78,223 & 78,223 & & \multirow{2}{*}{$\begin{array}{r}449 \\
19,066 \\
12,227 \\
377,651 \\
18,610\end{array}$} & \multirow{2}{*}{$\begin{array}{r}359 \\
7,217 \\
9,770 \\
75,946 \\
7,769\end{array}$} \\
\hline $\begin{array}{l}\text { Oak: } \\
\text { Belgium .............. } \\
\text { United states........ } \\
\text { Uruguay ............ }\end{array}$ & $\begin{array}{r}2,831 \\
11,360 \\
183\end{array}$ & $\begin{array}{r}2,265 \\
9,088 \\
164\end{array}$ & & & \\
\hline \multirow{2}{*}{ Total ................ } & 14,374 & 11,517 & & \multirow{2}{*}{428,004} & \multirow[t]{2}{*}{101,16} \\
\hline & & & & & \\
\hline
\end{tabular}

The total number of square feet of lumber imported into the Argentine Republic in 1892 was 7,799,229, of a total official value of $\$ 3,201,707$, gold.

The custom-house returns do not distinguish the different kinds of pine which are embraced in the above figures for 1892, and I have no means of finding out. For the year 1893, however, I observe from Norton's U. S. Shipping List that the pine shipments to the River Plate were as follows: $32,377,000$ feet of white pine, $42,116,000$ feet of spruce pine, $43,497,000$ feet of pitch pine, and 972,000 feet of Oregon pine, and probably this is about the usual proportion of each.

\section{DUTIES ON IMPORTED LUMBER.}

All ad valorem duties on articles imported into the Argentine Republic are liquidated according to their values as fixed by a custom-house or valuation tariff. The duty on all lumber, no matter what may be the variety, is 25 per cent, except for unworked white pine or spruce, 
in which case the duty is only 5 per cent. I quote from this tariff as follows:

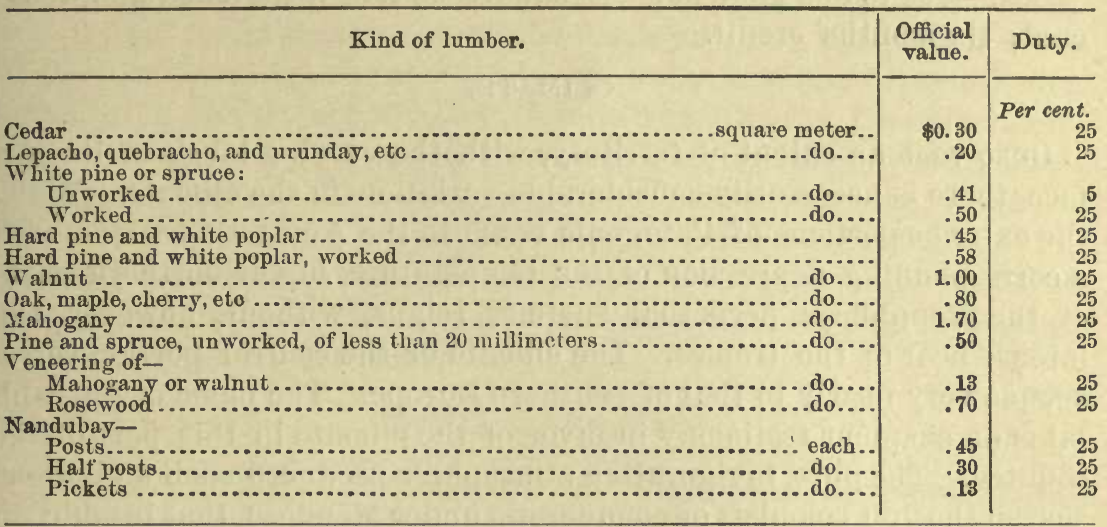

It will be seen from this tariff that while the Canada white pine or spruce unworked pays a duty of only 5 per cent on a valuation of 41 cents per square meter, the hard pine of the United States is required to pay a duty of 25 per cent on a valuation of 45 cents per square meter, a discrimination which on its face appears very unjust to the shippers of lumber from the United States, and which has already created no little comment down here.

In the case of pine lumber there is allowed 6 per cent for breakage and rot; for other kinds of lumber in boards, 3 per cent, and for veneering, 5 per cent for breakage.

For unworked lumber, valued by the square meter, 25 millimeters are allowed, and for worked lumber 22 millimeters. In the case of veneering no allowance is made. For lumber which comes as "deck load," no allowance is made for its wet or damaged condition.

\section{PRICES.}

The prices in this market for imported lumber depend, of course, a good deal on the supply and demand at any given time. A large number of arrivals together or in quick succession very perceptibly influences the figures for which cargoes can be sold. The scale of prices at present, as given to me by Messrs. C. S. Roberts \& Co., are as follows:

White Pine.-Deck load, $\$ 36$; No. $8, \$ 41$ to $\$ 42$; good shippers, $\$ 51$ to $\$ 52$; selects, $\$ 68$ to $\$ 69$ gold per 100 square meters dispatched; six months' credit.

Spruce Pine. $-\$ 26$ to $\$ 27$ gold per 100 square meters dispatched; six months' credit.

Hard Pine.-\$41 gold per 100 square meters dispatched; six months' oredit.

Oregon Pine. $-\$ 28$ to $\$ 30$ gold per 100 square meters dispatched; six months' credit. 
Walnut.-\$195 gold per 100 square meters dispatched and delivered in buyer's yard; six months' credit.

Oak. $\$ 80$ to $\$ 95$ gold per 100 square meters dispatched and delivered; six months' credit.

\section{CLIMATE.}

In so vast an extent of territory, with the varying levels of its surface, there is necessarily considerable variation in the climate. While the extreme portions of Patagonia reach to the Antarctic regions, with a corresponding depression of the temperature, in the northern parts of the Republic a perpetual summer reigns, without, however, the intense heat of the tropics. The climate of the central portion corresponds very nearly to that of southern Europe. The name of the capital is an eloquent testimony in favor of the climate in this part of the country. The pure, invigorating atmosphere produced such an impression on the first colonists or conquerors, under Mendoza, that in addition to the indispensible saint's name they affixed that of "Good Airs" (Santa Maria de Buenos Aires), a designation which all the pampa provinces fully deserve. This part of the Argentine Republic, however, is not a perpetual spring, much less a perpetual summer. The seasons here are quite clearly defined, and if the mercury seldom reaches even to the freezing point, it is none the less a fact that the bleak winds and cold rains of the winter months not only make heavy clothing and warm fires exceedingly desirable, but not unfrequently kill the fruit blooms of the peach and other fruit trees.

According to the meteorological reports of Dr. Tome, the distiguished American scientist in charge of the National Observatory at Cordova, the following is the mean monthly temperature of Buenos Ayres, the thermometer used being the centigrade, the readings of which can be reduced to those of the Fahrenheit by the usual formula, $\mathrm{F}=\frac{9}{5} \mathrm{C} .+32$. I also add the mean monthly readings of the early barometer in millimeters.

\begin{tabular}{|c|c|c|c|}
\hline Month. & Fahrenheit. & Centigrade. & Barometer. \\
\hline 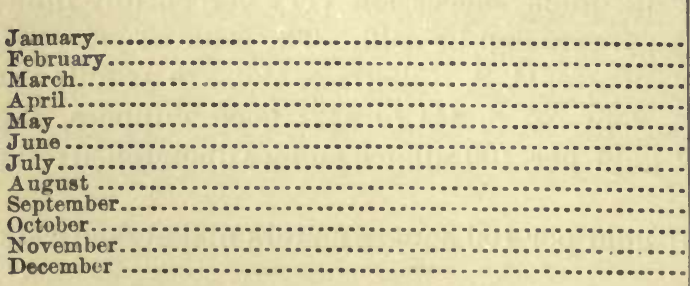 & \begin{tabular}{r|} 
Degrees. \\
75.63 \\
74.19 \\
70.25 \\
62.43 \\
56.62 \\
52.05 \\
49.68 \\
53.15 \\
56.64 \\
62.35 \\
68.36 \\
73.29
\end{tabular} & $\begin{array}{r}\text { Degrees. } \\
24.24 \\
23.44 \\
21.25 \\
16.94 \\
13.68 \\
11.14 \\
9.82 \\
11.75 \\
13.69 \\
16.85 \\
20.20 \\
22.94\end{array}$ & \begin{tabular}{|r} 
Millimeters. \\
$\mathbf{7 5 8 . 3 7}$ \\
$\mathbf{7 5 9} .14$ \\
$\mathbf{7 5 9} 92$ \\
$\mathbf{7 6 1} .99$ \\
$\mathbf{7 6 1 . 8 1}$ \\
$\mathbf{7 6 2 . 7 3}$ \\
$\mathbf{7 6 5 . 4 2}$ \\
$\mathbf{7 6 2 . 6 9}$ \\
$\mathbf{7 6 3 . 0 4}$ \\
$\mathbf{7 6 1 . 3 1}$ \\
$\mathbf{7 6 0 . 2 5}$ \\
$\mathbf{7 5 7 . 8 8}$
\end{tabular} \\
\hline $\begin{array}{l}\text { Mean } \ldots \ldots \ldots \ldots \ldots \ldots \ldots \ldots \ldots \ldots \ldots \ldots \ldots \ldots \ldots \ldots \ldots \ldots \ldots \ldots \ldots \ldots \ldots \ldots \ldots \ldots \\
\text { Maximum. } \\
\text { Minimum }\end{array}$ & $\begin{array}{r}62.80 \\
106.04 \\
36.60\end{array}$ & $\begin{array}{r}17.11 \\
37.80 \\
-2.00\end{array}$ & $\begin{array}{l}761.10 \\
780.00 \\
742.00\end{array}$ \\
\hline
\end{tabular}


These computations were made from observations taken in 1880 , but they are equally good at present, owing to the very slight variations in the daily readings for any year.

In regard to the seasons, it will be borne in mind that, being south of the equator, they are exactly opposite to those of the United States, viz: Spring, September, October, November; summer, Decenber, January, and February; autumn, March, April, and May; winter, June, July, and August. The seasons, however, run into each other so imperceptibly that in reality the year here may be divided into two seasons; the warm, which extends from October to April, inclusive, i. e., seven months; and the cool, which extends from May to September, inclusive, i. e., five months.

\section{GENERAL BUILDING.}

In regard to the construction of the buildings of this country, the houses, in the early days of its history, met the necessities of the people in a very primitive way. No particular consideration was given to the modern idea of comfort. Very little wood entered into their construction. Mud bricks and a very poor article of mortar were the principal ingredients, and the style was the old-fashioned one-story, shambling house, with a flat, or "azotea," roof, also of brick, constructed after the manner of the Moorish dwellings of early Spain, with a court in the center. As this was before the era of coal shipments from England, and there was little wood in the country nearer than the Gran Chaco, they made no fireplaces or other provision in the houses for fires; and the inhabitants, in a comfortless way, when the winter was upon them, huddled around an iron brasera of smouldering charcoal set in the mid. dle of the room, or went without fire altogether. Butwith the opening of the coal trade with Great Britain, and the utilization of the upper river forests, there has gradually been a great change in the architecture and conveniences of the houses of Buenos Ayres, and during these late years, in their general appearance, in their internal arrangements, and in the use of fireplaces, grates, stoves, and furuaces the houses remind one of the dwellings and business blocks of the cities of the United States.

As to the extent to which general building is carried on in Buenos Ayres at the present time, it may be said that this branch of industry is at present somewhat depressed. There is no activity in house-building, ship-building or railway-building. In all these interests the country for the last three or four years has been so severely affected by the financial crisis, which has not only caused the Government to default, but many business men to go into bankruptey, that there has been a decided let-up in all classes of construction. Indeed, during the "boom" which preceded the crisis, building of all kinds was so greatly overdone that that branch of business was among the first to feel the effects of the stringency. 
Railway construction is quite at a standstill. Last year only 639 kilometers of track were laid, the total number of kilometers in the whole country now being 12,920 (8,028 miles), representing a total capital of $\$ 429,582,917$.

Shipbuilding never has amounted to much in the River Plate, and the f'w river craft are of no great significance. Still there are several shipyards where extensive repairing, refitting, and refurnishing are done, and these always seem to have "plenty to do."

Housebuilding, especially here in Buenos Ayres, during the years from 1886 to 1890 , had a great development along with the great activity in real estate. The number of transfers of real estate in 1890 in this city was 9,340 , embracing $9,700,971$ square meters, for the aggregate sum of $\$ 80,862,716$ paper currency, equal to about $\$ 25,000,000$ gold. For some unexplained reason the annual municipal statistics do not state the number of building permits or buildings erected each year, and hence I am not able to give any figures on the subject; but a very large proportion of the transfers each year are made with a view to the erection of buildings upon the lots. There has been no census of Buenos Ayres since 1887, and at that time the following were the building statistics of this city:

Brick houses.............................................. 24, 065

Wooden houses .............................................. 2, 084

Mixed houses ............................................... 7,613

Public edifices .................................................. $\quad 193$

Houses in course of construction .................................. 489

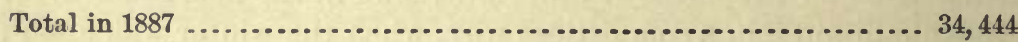

Assuming that 500 is the average number of houses annually erected, it would appear that the present number of distinct habitations in Buenos Ayres is about 37,500; and as it is claimed that the number of dwellers to a house in this city, including conventillos or constructions for the poor, is 15, it follows that the present population of Buenos Ayres is 562,500. The number claimed by the municipality is 582,000.

House-building, however, as we have seen, is not the only use to which North American and native lumber and woods is applied. A large quantity is consumed in paling and picket fencing; in the manufacture of chairs and other furniture, now made here in the styles of France, England, and the United States, but which, owing to the increased duties recently placed upon foreign furniture, it is no longer possible to import without a loss; in the manufacture of dry goods and packing boxes; in the manufacture of barrels, hogsheads, and other coopers' work, though there is still a very large trade in American "shooks;" manufacture of shoe lasts; of all sorts of turners' work; of carriages, carts, and wagons; of boats and naval construction and repairs; and for a thousand other objects, for which with the growth of manufactures in this city the multiplied necessities of life call into requisition the different varieties of wood and lumber. 


\section{IMPORTERS OF AMERICAN LUMBER.}

In concluding this report, it may be well to state that the most important and best known importers of North American lumber and dealers in native woods are the following:

C. S. Roberts \& Co., Callo San Martin, No. 76.

Thomas Drystale \& Co., Calle Moreno, No. 438.

J. \& J. Drysiale \& Co., Calle Peru, No. 440.

Shaw Bros., Calle Piedras, No. 76.

J. Shaw \& Sons, Calle Venezuela, No. 860.

George Bell \& Sons, Calle Defensa, No. 649

C. S. Bowers \& Co., Calle Cuyo, No. 472.

Lahusen \& Co., Calle Peru, No. 23.

Shaw, Miller \& Co., Calle Alsena, No. 471.

Warden \& Co., Calle Belgrano, No. 573.

And the list might be further extended. All necessary information in regard to the methods pursued here in the lumber trade, or in regard to the disposition of cargoes will be readily furnished to the lumber dealers and exporters of the United States upon application by letter to any of the above-named houses.

\section{E. L. BAKER,}

Consul.

\section{Buenos AYres, March 3, 1894.}

\section{SUPPLEMENTAL REPORT.}

\section{THE WOODS OF THE ARGENTINE REPUBLIC.}

BOTANY OF THE COUNTRY.

As yet there has been no complete scientific exploration of the regetation of this country; but the sulject has occupied and is still occupying the atteution of a number of well known scientists, srme of whom are making their investigations under the special patronage of the National Government. Of course the fruit of their labors in regions so remote and so wild can not be gathered in a day, but already no little headway has been made in the botanical survey of the country, and most important results, not only in the collection of specimens, but in the classification of trees, have been obtained. It appears that the first systematic study of the vegetation of the Argentine Republic was made by Dr. Lorentz, who was called from Germany to fill the, chair of botany in the University of Cordova. He was succeeded in the same cliair by Dr. Hieronymus, also of Germany, who has made the most complete collection of woods in the country that is to be found anywhere, and who informs me that he has now in press a report of the results of his studies. This, of course, is not yet accessible, and hence I am not able to profit by his labors. The information which $I$ have embodied in this report has been obtained from a "report on the vegetation of the Argentine Republic," by Dr. Lorentz; from the late volumes of M. Martin de Moussy, in French, on the "geographical and statistical description of the Argentine Republic ;" from a work on "the Argentine Republic," in German, by Sr. Ricardo Nap, formerly in charge of the Argentine national statistical office, and from information which I have derived directly from Prof. A. P. 
Burns, an American now resident in this country and in eharge of the national powder establishment at Rio Cuarto, all of which sources of information are supplemented by my own observations in various exeursions through the different parts of the country. It is proper, however, to state that there are still many portions of the Repnblic, especially the formations of the Gran Chaeo and Misiones, about whose flora very little is yet scientifically known, while much of our knowledger of other parts of the country may be only superficial.

\section{DISTRIBUTION OF FORESTS.}

I wonld premise by stating that the distribution of forests in the Argentine Republic is very unequal. While some parts are thickly eovered with timber, other portions, though abounding in rich and succulent grasses, are entirely devoid of trees, corresponding in this respect to our Western plains. Other parts, again, are almost without soil, and sterile, exhibiting only the scantiest manifestations of a stunted vegetation, while still others are covered to a more or less extent with boskets of low shrubs or brushwood. Extending, however, as the Argentine Republic does, from Cape Horn on the southern extremity of Terra del Fuego (latitude $56^{\circ}$ south, longitude $67^{\circ}$ west), almost within the antarctic circle, to the regions of the tropics (latitude $20^{\circ}$ south, longitude $58^{\circ}$ west), the great diversity of vegetation in its 45,392 square geographical leagues of area can well be understood. On this account the surface of the country has been divided by some naturalists * into not less than nine different formations, corresponding to the species of flora which they afford, and to the physiognomy of their vegetation in general. While noticing these distinct groups it is not, however, necessary to do more than give a ver. general description of them, since some of them contain nothing which can be dignified with the name of timber. For the purposes of this sketch, which has nothing to do with the classification of the flora of the country, much less with their structural eomposition or physiological peculiarities, but simply with "the products of the forests," i. e., their economic uses, as affording timbers, fiber, dyestuffs, tanning materials, etc., it is much more convenient to follow the geographical divisions which naturally present themselves, since thus their localities can be better identified and understood.

TERRA DEL FUEGO AND THE ADJACENT ISLANDS.

I begin, then, at the southern extremity of the continent, which includes Terra del Fuego and the numerous adjacent islands. In regard to this region, which has never been fully explored, I am able to present but fow data, for the reason that so little is yet known as to its flora. It is, however, reported to be most densely covered with forests, composed almost entirely of leeehwood (Fagus betuloides) and winter's bark. This beech keeps its leaves all the year, having a foliage of a peeuliar brownish-green color, with a tinge of yellow. Prof. Darwin, who visited Terra del Fuego in 1832, $\uparrow$ says it is almost impossible to find an asre of land not covered by the densest forests. He deseribed the country as a mountainous land, partly submerged by the sea, so that deep inlets and bays occupy the place where valleys should exist. The trees, which covered the mountain sides from the very water's edge, reach to an elevation of between 1,000 and 1,500 feet, and are succeeded

"Prof. Lorentz divides the vegetation of the Argentine Republic into the following formations: (1) Formation of the Puna; (2) subtropical formation; (3) formation of the Chaco; (4) monte formation; (5) formation of the Pampa; (6) Patagonian formation; (7) formation of antarctic forests; (8) Paraguayan formation, and (9) Mesopotamian formation.

tA Naturalist's Voyage Around the World, by Charles Darwin, M. A., page 210, et seq. 
by a band of peat with minute alpine plants, and this again is succeeded by the line of perpetual snow, which, in the Straits of Magellan, descends to between 3,000 and 4,000 feet. There is but little level land, and where this happens to be the case, the surface is in many places a mere bed of swampy peat. Indeed, even within the forest, the ground is concealed by a mass of slowly putrefying vegetable matter, which, being soaked with water, yields to the foot.* On the eastern side, however, there are some open meadows fit for pasturage or cultivation.

\section{FORESTS NORTH OF THE STRAITS OF MAGELLAN.}

These magnificent forests extend northward from the Straits of Magellan along the Andes on both slopes to about $34^{\circ}$ of sonth latitude. In fact it is not yet known definitely where they do terminate on the eastern or Patagonian slopes. Besides the almost impenetrable forests of beech trees, there is a thick underwood, consisting of a species of Berberis and other antaretic species, and the same thick layer of turf, which is so universal in Terra del Fuego. Indeed, excepting the timber and the turf, the vegetable kingdoin produces here no useful objects whatever. Nevertheless, in the hands of an energetic and laborious people, these forests of beeches could be exploited and made a source of untold wealth; but civilization has not yet penetrated these primitive regions.

\section{EASTERN SLOPES OF THE SOUTHERN ANDES.}

Further north, along these eastern slopes of the Cordilleras, in the neighborhood of the sources of the Rio Negro, there are forests of stately pines and wild apple trees, and it is here that the Patagonian Indians have their permanent settlement, in the midst of wide, open plains extending out from the sierras, well watered and clothed in most luxuriant grasses. Capt. Musters, who penetrated these forests in 1869 , speaks of them as "uniformly dense;" the trunks of the pine trees reaching a height of 60 to 100 feet, and entirely bare of branches for two-thirds of their height.t His descriptions, however, of the woods and rivers are too superficial to give us a clear idea of the flora of these regions. The Argentine Government is now exploring all the country along the eastern slopes of the Andes, with a view to opening it up to settlement and improvement. A report on the vegetation is now in press and will soon be issued.

- Prof. Darwin describes an ascent he made of one of the mountains of this country, from which I take the following: "I was anxious to reach the summit of Bank's Mountain to collect alpine plants, for flowers in the lower part are few in number. We followed a water course till it $d$ windled away, and we were then compelled to crawl blindly among the trees. These, from the effects of the elevation and of the impetuous winds, were low, thick, and crooked. At length we reached that which from a distance appeared like a carpet of fine green turf, but which to our vexation turned out to be a compact mass of little beech trees about 4 or 5 feet high. They were as thick together as box in the border of a garden, and we were obligel to struggle over the flat but treacherous surface. After a little more trouble we gained the peat and then the bare slate rock. We obtained a wide view over the surrounding country; to the north a swampy moorlund extended, but to the south we had a scene of savage magnificence well becoming Terra del Fuego. There was a degree of mysterious grandeur in mountain behind monntain, with the deep, intervening valleys, all covered with one thick mass of forest. The atmosphere, likewise, in this climate, where gale succeeds gale, with hail, rain, and sleet, seems blacker than anywhere else. In the Straits of Magellan, looking due sonthward from Port Famine, the distant channels between the mountains appeared from their gloominess to lead beyond the confines of the earth."

tSee At Home with the Patagonians, by C. G. Musters, pages 113 to 160. 
FORESTS OF THE CORDILLERAS OF PATAGONIA.

The line which separates the plains of Patagonia from this fertile mountain region, with its wealth of timber, is very sharply defined. Beginning at Cape Negro, Magellan Straits, at latitude $53^{\circ}$ south and longitude $75^{\circ} 50^{\prime}$ west, it runs west-northwest to the northeast extremity of Otway Water, following the channel of Fitzroy Passage and the northern shores of Skyning Water to longitude $72^{\circ}$, and then extends along eastern shores of Desolation Sonnd and Kirke Water; running thence due northward towards Lake Viedora, Lake Argentina, and Lake St. Martin, which are, respectively, the sources of the rivers Santa Cruz, Sheven, and Chicos, which traverse the territory of Patagonia and empty into the Atlantic Ocean. Beyond these it continues northward to the sources of the Rio Negro, which waters, with its numerous branches and affluents, a large territory stretching along the base of the Cordilleras towards the province of Mendoza. Señor Morena,* who has explored the Rio Santa Cruz to its head waters, speaks generally of the "immense virgin forests" which he found at the base of the mountains. But the entire region of Patagonia eastward of these timbered districts is a succession of sterile plains, which rise from the coast, one above the other, like terraces, $t$ uniformly about 300 feet high, and are traversed occasionally by ravines and flat-bottom depressions, some of which contain salt lakes. These wastes stretch away in dreary uniformity without a break to the far horizon, preseuting a barren landscape so grim and so monotonous as to fill the traveler with a feeling of awe. The formation of the land is tertiary, resting on porphyry and quartz, ridges of which often protrude through the surface. In some parts they are capped by layers of lava. The soil is sandy and covered with water-worn stones, with here and there an isolated tuft of grass, withered and gray, whilst a peculiar gloom is further added to the melaneholy of the scene by the somber hue of a straggling, stunted bush, thejume (Salicernia), which grows in considerable quantities, and which is described as a fit offspring. in its blackness and ugliness, of such uncongenial soil. $\ddagger$ Further than this, if we except the calafate (Berberis axifolia), also a miserable thorny shrub, which, however, would anywhere else be admirably adapted for live fencing, there is nothing on these arid plains which can be called timber, thongh in the valleys of the rivers, especially those emptying into the ocean north of $40^{\circ}$ of latitude, there is a species of willow (Salix humboldti$a n a)$ which grows to very large proportions, and, in the absence of anything better, is used for building puposes.

\section{THE TREELESS REGIONS OF THE PAMPA.}

The river Colorado, which empties into the Atlantic Ocean in latitude $39^{\circ}$, is the northern boundary of Patagonia, on the north side of which begin what are known as the Argentine pampas, $\oint$ the soil of which is a complete contrast to that of the former region. They occupy the entire area of the province of Buenos Ayres and extend into those of Santa Fe, Cordova, San Luis, and Mendoza. They seem to be uniformly level, but these boundless plains rise gently in every direction from the sea, at first at the rate of about one foot per mile, and then more, until the large plateaux near the Cordilleras attain an elevation of 2,000 feet above the level of the sea, and ultinately terminate in the high parks of the Andes. The character of the

* Viaje a la Patagonia Austral, 1876-'77, por Francisco P. Morena, p. 460.

+ Darwin accounts for the regularity with which these plains rise one above the other by the supposition that the land has been raised in a mass from under the sea, the upheaving movement having been interrupted by at least eight long periods of rest, luring which the sea ate deeply back iuto the land, forming, at succssive levels long lines of escarpments, which separate the diflerent plains.

‡"Wanderings in Patagonia," by Julius Beerbohı, 1876, pp. 22 and 105.

$\$$ In the language of Quichee Indians "pampas" means level. 
soil corresponds to the inclination, as though the continent had been formed by some great flow of waters depositing bowlders and rocks near the mountains, then districts of pebbles and water-worn stones, then coarse gravels and sands, and lastly the finer sands and clayey deposits which cover the great alluvial plains, and which are evidently the débris of the crystalline rocks of the mighty range of the Andes leveled and sorted by the action of water. The surface of all this vast area is covered by the richest of succulent grasses, but normally it is without a tree or a ligneous plant. It is a magnificent pasture ground, but its flora is poor and monotonous. It is remarkable that a soil on which timber grows so luxuriantly when planted should from time immemorial be so totally destitute of forests. The only exception is that in the sierras of Tandil, 200 miles south of Buenos Ayres, there is a region of dense brushwood called carmamoel (Colletia cruciata), which grows about the height of a man, and which has no leaves, but is covered with sharp thorus in the shape of a cross. And another exception consists in a strip of woods which extends from the latitude of Buenos Ayers down along the Atlantic coast composed principally of good-sized trees of the tala coronillo and espinillo, which are used forvarious economical purposes. As a proof that the soil of the pampas is perfertly adapted to arboreous vegetation, $I$ would mention that in various parts there are now extensive belts of cultivated timber, among which is the peach tree, which produces both fruit and fuel; also several species of the Eucalyptus, the Robinia, the Paradise tree, and the Lombardy poplar, all of which grow with facility and rapidly, and are used not only for shade but for many economical purposes. There is one tree indigenous to the pampas which I should mention from its singular character. I refer to omber (Percunia divica). At a distance it is one of the most attractive objects. It grows to immense proportions, with gnarled roots and knots projecting up and around the trunk in all manner of fantastic shapes, and affords a wide-spreating shade of dark velvety leaves, a most refreshing resort for the siesta of a weary traveler; but for the rest it is utterly worthless. Its wood is really not ligneous, having neither fiber nor consistency, and resembling punk or a sponge more than anything else. These trees, if trees they may be called, do not grow in forests, but only singly and isolated, here and there at long intervals, being landmarks on the far horizonsentinels, as it were, of the pampa.

\section{THE TREES OF THE EASTERN SLOPES OF THE ARGENTINE ANDES.}

Where the pampas approach the western mountains, all along the outlying slopes of the Cordilleras of the Andes, but distinct and isolated from them, and extending nortliward to the confines of Bolivia, there is a formation partly composed of open forests and partly of shrubs and ligneous plants, which the scientists have designated by the name of the Monte formation. It embraces a great part of the western slopes of the seven Andine provinces, to wit, Mendoza, San Luis, San Juan, Rioja, Catauarca, Jujuy, aud Salta. Prof. Groesback, in his celelorated work, the "Vegetation of the Earth," calls it the "Chañar Steppe," from the arborets of that name which are so generally distributed through it. The trees which constitute this formation consist principally of species of prosopis, nimosa, and acacia. They are at first found in rather diminutive forms, and bristle with scattered branchesprovided with thorns or thorny leaves, but as you reach the higher elevations, where the "Puna formation" proper is found, the extended plains and broad valleys are thickly woorled with immense specimens of the same type of trees, growing far up on the mountain sides. In some parts, and especially in the sierras of San Luis and Cordova, these forests are so beautiful and picturesque in their arrangement that they look like artificial parks.

Among the most noted of the trees which characterize these everchanging landscapes is the algarrobo (Prosopis alba), specific gravity 0.740 . The size of this species varies, according to locality, from mere bushes to quite lofty trees, branching, however, at a short distance above the ground, with thin tops of feathered leaves. 
While the timber is much esteemed for construetion, its fruit, which is a pod of sweet pulp, is an excellent food for cattle. The natives also make a species of bread out of it called patao, and also extract a liquor from it which when new is quite refreshing, but after fermentation is very intoxicating, and hence is a favorite beverage at some of their social meetings.

The nandubay (Acacia cavernia) is a small tree, whose hard and heavy wood make it much sought after for fence and telegraph posts. It is said to be almost indestructible, neither air, water, nor earth having any effect upon it. It produces a fruit which contains a great deal of tannin, and is also employed as a black dye. Specific gravity, 1.100 to 1.221 .

The Acacia molinifornus bears a fruit also much sought after by cattle, thongh most of the species are characterized by such enormous thorns that in some parts the woods are almost impenetrable. I would add that a gum exudes from these trees which I believe could be made into gutta percha if the proper processes were employed.

Another very important tree found in this formation is the quebracho, the most frequent variety of which in these forests is the white (aspidosperma quebracho). It is of middle size, with oblong, thorny leaves. It forms great forests in some districts, and its timber is very useful for various purposes, and latterly has been applied in the xylographic art. It takes an exquisite polish. Specific gravity, 0.880 .

The moyes or molles is also a valuable evergreen tree and exceedingly beautiful in its appearance. One species produces a fruit from which is prepared a sweet, aromatic, refreshing liquor; another variety bears a berry from which incense is manufactured, and still another is used for tanning purposes, while a fourth variety (alvarillo del campo) is noted for its savory and refreshing fruits, which are very similar to plums, and only the more agreeable because they contain a certain aftertaste of bitter almonds. Specific gravity, 0.520 .

The chañar (Gurliaca decorticans) is found everywhere throughout the submountainous regions, and its wood is much appreciated on account of its firmness and durability. It produces a sweet and savory fruit, and has the peculiarity of annually renewing its bark. Near the tropics it attains large proportions, though its trunk is irregular. Specific gravity, 0.568 .

\section{GIANT CACTI FORISTS}

There are many other trees in this formation, but they are small and have no value for timber purposes; and also a great variety of shrubs and brushes, to say nothing of vines, parasites, epiphytes, airplants, etc., though they do not come within the scope of this sketch. I must, however, refer to the family of the cactece, which are as strange in form as abundant in distribution. They attain to immense proportions, some of them reaching a height of 40 feet, with trunks in proportion, and their wood is used in different industries and also in the mines. In a late visit to the northern provinces I passed through a forest of these gigantic cacti. It was one of the strangest and most weird sights that can well be imagined. They stood in groups. Here they frowned upon us spherical and spirated with formidable thorns nearly a foot long, and yet from their grooved sides radiating most delicate flowers; there they rose in tall fluted columns like ancient ruins, or with their long-jointed arms in menacing attitude, looked like giant witches beckoning you to stop; and yonder through the vista they were trailing like huge serpents over fallen trees or coiling in the crevices of the ontcropping rocks. The largest species is the cereus, the flowers of which are white; those of the opunciae are orange color or yellowish red, while the serpent-formed cactece have lively red flowers. One species produces the tunas or "figs of Algiers," some breed the cochineal insects, the cultivation of which is now carried on to some extent in Tucuman, and which, if proper methods were adopted, could be made of great importance to the country. At present the 
natives gather the eggs of the insects and make them into dry compressed balls or cakes, weighing about a half pound each, which they sell for $\$ 1$ apiece for commercial purposes.

\section{THE GREAT SUBTROPICAL FORESTS.}

We now approach what is designated by Moussy as the "tropical" and by Prof. Lorentz as the "subtropical" forests. This formation is the garden of the Argentine Republic, and presents to us landscapes of such magnificence and fertility that we seem to be wandering in an enchanted wilderness. It exists in the high table-lands on the eastern ranges of the Cordilleras and their branches, whose waters are drained by a thousand streams and water courses towards the Parana and its great affluents. These plains and watersheds are all adorned with the rankest of tropical forests, which pass to the northward beyond the confines of the provinces of Salta and Jujuy into the territory of Bolivia, thus reaching to the latitude of $21^{\circ}$ south.* Nearly all the varieties of trees which characterize the preceding formations are here found in more accentuated proportions, while it is rich with the magnificence of a hundred additional species, many of them so covered with epiphites and airplants that it is sometimes difficult to discover the verdure of the tree to which they are attached; and both trees and plants producing flowers of many brilliant colors. Gigantic liañae twine around the trunks and drop their air-roots to the ground, while their branches reach out and involve the branches of other trees in the vegetable mesh. Sometimes trees are seen growing upon other trees, their roots buried in the dust, which through centuries has been accumulating at the foot of the branches. On one occasiou, in climbing to the heights of the Sierra Aconquija, in the vicinity of Tucuman, I undertook to penetrate this wealth of vegetation which fairly filled the gorges leading to the table-lands above, and where for ages the sunlight has been shut out from the earth by leagues upon leagues of arboreal giants; but the wild and tangled mass of undergrowth disputed every foot of approach, and I had to relinquish the attempt.

It seems almost impossible to exaggerate the wealth of timber which is found in these high latitudes. There is hardly a tree bnt possesses some special value for particular purposes. There is in the University of Cordova a very rich display of many of the varieties, being sections taken from the trunks and polished. They nniformly exhibit an exceedingly fine grain, embracing every shade of color, from the richest rose to the deepest green, from the darkest ebony to the lightest cream, some with most exquisite veins and others with manifold variegated hues. In any ,ther country than this they would be esteemed as precious woods, equaling and rivaling those of Central America or Brazil, but they are at present so remote from market that for commercial purposes many of them are yet almost valueless. I

* On crossing the Rio de las Piedras, a river of the province of Salta, we entered at once the territory of Oran, the extreme northern limit of the Republic, which lies just above the tropic of Capricorn; our path still lying through dense forests, whose stems were frequently rendered completely invisible by reason of the close clasp of the thick and tangled mass of creepers which, in full flower, not alone from summit to base, but roofing the lofty vault with superb campanulate rounded heaps of blue, white, violet, and rose, emitted overpowering but delicious perfumes. * * * Our course was soon arrested by another river, the Santa Maria, and on reaching its further bank we entercd the densest forest I ever saw ; not the cathedral-like columnar-stemmed trees, rising 70 or 80 feet without a limb, and then surmounted by a branched, leafy, floral dome, such as I had seen in other parts of the country, but an impenetrable mass of entwined, gnarled, fantastio plant development, confusing trunks, branches, foliage, and flowers in one inextricable melange from top to bottom. Two growths contributed to this effect; one superior, of massive size and impending, the other inferior and consisting principally of wild orange groves, etc.(White's Note Book of a Naturalist, vol. xI, p. 307.) 
could hardly undertake, within the limits of a sketch like this, to give a detailed description of all the trees composing the magnificunt forests of the province of Tucuman and the valleys of Salta and Oran, so admirably fitted, as they are, for the purposes of the engineer, the builder, the cabinetmaker, the shipwright, the tanner, and the dyer. I can only assume to mention a few of the most important, so far as Prof. Lorentz and others have identified them; though in some instances the scientific names may not be entirely reliable, since in the different parts of the country the same popular name is given to trees which differ very materially and sometimes have nothing in common save the indigenous name. Besides those which I have already referred to as especially characterizing other portions of the Republic, but which are also found in this zone, I would mention the following as the most common and most magnificent:

The laurel (Nectandra porphyria), which is a very beautiful tree, with a huge trunk and a dense crown of pinnated leaves, growing to the height of 60 or 70 fect.* There are several species, all of which are abundant and valuable, especially for cabinetwork, and one of which contains camphor in its leaves; it rivals ebony in color and polish. Specific gravity, 0.580 to 0.845 .

The tipa (Macharium fertile), also possessing a splendid form and rising to the height of 150 feet, with a straight trunk, which branches about 70 feet from the ground. In the spring it is covered with papilionaceous flowers, producing a beautiful effect from a distance; easily worked; used for railway plant. Specific gravity, 0.660 .

The nogal (Fulgans nigra), very similar to the European walnut, and producing an edible fruit, and, on account of the ease with which it can be worked and the fine justrous polish it takes, it is mnch used in cabinetwork. Specific gravity, 0.538.

The ramos, two varieties (Cupania uruguensis and $C$. vernalis), greatly resembling the nogal in appearance and uses, but very hard, indeed almost impermeable. Specific gravity, 0.576 .

The cedro (Cedrela braziliensis). There are several varieties, ali producing a most beautiful wood, soft and easily worked, and therefore in great demand, being used for furniture, and resembling mahogany in its polish and the rich veins which it possesses. Specific gravity, 0.480 to 0.740 .

The mato (Eugenia mato and $E$. uniflora), two magnificent species of the Myrtace, with myrtiform leaves and edible fruit of the size of a cherry. The wood is rich in its colors and is used in decorative carpentry. Being tough and flexible, it is also much used for poles to carriages. Specific gravity, 0.890 .

The palo de San Antonio (Myrcine floribunda), a tree of majestic proportions in the primitive forests, and producing excellent building timber. Specific gravity, 0.695.

The lanza (Myrcene marginata), also a very majestic tree, and takes a beautiful polish, thus making it desirable for furniture. Specific yravity, 0.738.

The lapacho (L. bignonaca), belonging to the genus Tecoma, a tree of great dimensions and very beautiful. It would be almost impossible for the vegetable kingdom to present a more imposing spectacle than these gigantic trees when their branches, dark and leafless during the winter, are covered in the spring with millions of yellow or rose-colored flowers, which precede the sprouting of the leaves. The wood is of a green color, hard, heavy, and solid, and susceptible of a very fine polish. It

"Mr. White, in his Notes of a Naturalist, says: "Throughout the forests of Tucuman the laurel is everywhere found, sometimes forming extensive forests, in wiose recesses numerous freebooters found, of yore, shelter and safe concealment. Imagine gigantic trunks, some 9 feet in diameter, jostling one against the other and rising perpendicularly 70 feet, crowned with an ample and elegant nimbus. Beyoud the mere grandeur and poetry of the scene, the centuries that these patriarchs have scored their bark, what an inexhaustible commercial and medicinal wealth for future ages!" Vol. xI, p. 139. 
is greatly appreeiated in all kinds of constructions. It has the property of becoming petrified upon exposure to the air, sand, or water.

The bark possesses coloring material, and several different dyes are made from it. specific gravity, 1.072 .

The palo borracho (Chorisia insignes), a very singular tree, * with a swollen, ovalshaped trunk, covered with blunt, quadrangular thorns, digitated leaves, large white flowers, and the fruit full of a species of white cotton of little coherent fibers, used for making cloth, lampwick, etc. The form of this tree is one of the most singular to be seen in the country.

The urundey, a species of bignoniacea, a very abundant tree, and produces a most excellent wood. It is imperishable, polishes exquisitely, and makes beautiful furniture. There are two kinds: the black with white veins, and the white with jasper, black, and yellow veins; thus producing a very unique veneering. The wood is used for joists, pillars, columns, and ship-timbers, and is the best timber known for railway ties and sleepers; also excellent for axletrees on aceount of its resistance and inflexibility. The tree reaches the height of 100 feet and a diameter of 8 feet. Its leaves are lanceolated, and its bark, which is not very thick, is preferred for tanning hides. Owing to the difficulty of transporting them, the lumbermen do not fell the largest trees. Specific gravity, 1.092 .

Palo blanco, a large tree whose wood is of a straw color, whereas the bark is whitish. In spite of its great height and circumference large timber cannot be procured from it, for the reason that the trunk is deeply fluted, having somewhat the appearance of a Corinthian column. Its wood is very highly grained, and resists friction with such persistence that it is consiclered the very best material for ship-blocks. The wood is aromatic and similar to mahogany in its color and quality. Specific gravity, 1.010 .

The titane, of which there are two varieties, the white and the yellow; much used in the construction of fine furniture. The bark possesses a piquant juice. The tree attains to the height of about 50 feet and is about 1 to 3 feet in diameter. The wood, which polishes beautifully, has the advantage that it neither swells nor shrinks according to the state of the temperature. Specific gravity, 0.650 .

The cibil (Pipldàemia cibil). There are several varieties of these acacias, the white, the red, ete., all of which, thongh found elsewhere, reach to large proportions in the subtropical forests, attaining a height of 40 feet and a diameter of 2 feet. The bark is rich in tannin and is in great demand for that purpose. The wood is very hard and takes a lnstrous polish. Specifie gravity, 0.854 to 0.956 .

The espinillo (Acacia cavenia), a different tree from the shrub of the south, but a

* Proceeding over some low hills, a very peculiar looking tree presented itself, which the natives call palo borracho (drunken tree), but the Indians eall yuchen, standing about 50 feet high and spreading from the erown branches eovered with digitated leaves, dotted here and there with large white flowers whose naked stems before branching expand into one immense egg-shaped form fully 20 feet in height and 24 feet in eireumference, sounding hollow when struck, and whose bark is covered with hard, short, qualrangular, blunt spines. The specimen I here saw was certainly full grown, and this remarkable tree is only found on elevated, rocky ground. The inhabitants of this province (Catamarca) and Santiago, seoop out the spongy eenter and use the hollow barrel-like stem as a storehouse, whilst in some parts of South America the stems are cut in half, and form eapacious Dutch-like canoes. 'The seed-pods, likewise of egg shape, and about the size of the human fist, contain abundance of cottony fibrous down, from which are manufactured cloth, candlewick, and pillows, which latter, besides being delicately soft and springy, have proved beneficial to consumptive patients. When they get matted, exposure to the sun soon renders thein once more puffy and elastic. (Cameos from the Silver Land, by Ernest William White, F. Z. S. London, 1882.) 
magnificent variety of the family of Leguminosa, having no thorns and producing an excellent wood for various purposes. Specific gravity, 0.766 .

The mora, a very large tree, with heavy yellow wood, which grains beautifully, and on being worked takes the color of the richest mahogany, and is greatly used for the manufacture of the best furniture. The tree produces an edible fruit. Specific gravity, 0.93 i to 1.090 .

The quebracho colorado (Loxopterygium lorentzii). Quite a different tree from the Q. blanco found elsewhere. It is very abundant througliout the northern portions of the Argentine Republic. The wood is a deep red, and remarkable for its extreme harduess and weight. It is almost indestructible. Since the discovery of the country it has never been found rotten or decayed, no matter in what position, in air, earth, or water, it might be placed. It forms a most important article of commerce, and, owing to the immense size to which it grows, upwarcls of 200 feet with 10 feet of diameter, is used for ship-timber, beams, spiles, joists, bridges, etc., and makes most encluring railway sleepers and ties. It also takes an exceedingly fine finish, and is greatly in demand in carpentry work for doors, window-frames, cabinets, etc., the luster being equal to that of rosewood. In wood engraving it takes the place of boxwood. Specific gravity, 1.234 to 1.392 .

There are miny other valuable trees of the largest size found in this part of the country, among them the quina-quina, which produces an aromatic resin, and whose bark is used as a fever antidote and tonic; the cascaion, with a red and lustrous bark; the palo mortero, very similar to the tipa already described; the pacay, the sinquillo, the mayana itara, and others not yet classified, all of which furnish most valuable timber, each one with some certain quality for certain uses, such as building, turning, furniture, eabinet-work, etc., but I have no descriptions of them. In the subtropical forests, which we are considering, there are also numerous smaller trees, nearly all of them hard wood, bearing a rich foliage and exceedingly ornamental; also a great variety of arborets, bushes, climbing plants, etc., many of them exquisite color ing in their leaves and fiowers, but it hardly comes within the object of this sketch to mention them.

In the mounta ins of the Andes, beyond the chain of the Aconquija, and on the plopes of the Cordilleras proper, is found in extensive forests the pine tree (Podicarsus augustifolia). It is of medium height and of compact erown, but it is not similar to the European pine. The inhabitants utilize the timber, but there is no demand for it, on account of its inaccessibility to the market, and it is at present of but little importance in the economy of the country.

\section{TIMBER RESOURCES OF THE GRAN CHACO.}

Along the eastern borders of the subtropical regions whose forests $I$ have been describing, lies an immense territory, in some parts reported to be arid and waste for want of water, bnt in others filled with a succession of rivers, and in time destined to be one of the most valuable portions of the Argentine Republic. It is called the "Gran Chaco." It exteuds from the Parana to Bolivia, and is separated on the east from Paraguay by the river of the samo name. The last Argentine census gave it a superficial area of 621,000 square kilometers, but as its limits have not set been fixed with the neighboring provinces, its real area can not yet be determined. It is divided by the river Vermejo into two almost equal parts, one called the "Chaco Austral " and the other "Chaco Boreal," the last extending to latitude $20^{\circ}$ south, and bounded on the north by the Bolivian province of Chiquitos. The "Chaco Boreal" is composed of an uninterrupted plain elevated about 400 foet above the level of the sea, with a heavy soil of humus, and is divided into the most beautiful forests with intervening meadows as if made on purpose for the raising of cattle. The Austral or Southern Chaco lies between the Vermejo on the north, the Parana on the east, and the province of Santa F' on the south. It is also completely level and is richly ondowed by nature, not only with a deep soil but with most maguificent 
forests. As yet these vast regions are almost exclusively occupied by wild Indians. A large portion has never been explored, and hence but little is yet known of the interior with its treasures of vegetable wealth. Only where it skirts along the Parana and Paraguay rivers, with here and there a small clearing and settlement, the nucleus of a number of agricultural colonies, has anything been scientifically determined in reference to its timber resources. As far, however, as its fastnesses with their succession of small rivers and watercourses have been penetrated they are found to be covered with the densest forests of lofty trees descending down to the river line. The growth may not be quite so noble and sky-piercing as that which is found in the forests of Tucuman and Oran, but it embraces, so far as is now known, quite the same varieties and an equal abundance. And the region possesses this immense advantage, that by means of the great watercourses flowing along its eastern borders and the smaller streams, including the Vermejo and Pilcomayo, which penetrate its interier and which are found to be navigable for many hundreds of miles, all its vast wealth of precious woods and valuable timber is rendered accessible not only to Buenos Ayres, but, as ocean ships can load along its banks, also to the markets of the world, without the necessity of transshipment. As I have said, the more elevated portions of the Chaco present a lanilscape like a park where clumps of woods alternate with open meadows. The lower parts are covered with continuous forests and an undergrowth which in some places is so dense as to make it impossible to penetrate into the interior. But the woodchoppers are at work, and the quantities of all kinds of precious woods which are shipped down the rivers are becoming greater and greater every year. As yet the greatest demand in this market is for the quebracho of both varieties, which finds a use in almost every kind of construction. The algorrobo is also in great request, as likewise the nandubay, immense quantities of the posts of which tree are used for wire-fencing on the Pampas. Besides what comes to Buenos Ayres, however, there are ship loads after ship loads, which are exported directly to Germany and France, and there made into the most costly articles of furniture, or sawed up into veneering which rivals anything which comes from Brazil or Central America. I have said that nearly all the varieties of trees which $I$ have heretofore described as belonging to the subtropical forests are also to be found in the Chaco. There are also numberless varieties which seem to be especially indigenous to that region. Among these are the following:

The blanco grande, a beautiful tree which grows to the height of 25 feet and is 18 inches in diameter. Its wood possesses a very fine fiber, and is used for mechanical . moldings, and also for cabinet work. Specific gravity, 0.720 .

The caranda. It belongs to the family of the algorrobos. It grows to the height of 30 to 40 feet, with a trunk of 18 inches in diameter. The color of its wood is violet, very solid, and of an excellent grain, and valuable for furniture and cabinet work. Specific gravity, 1.197.

The carapay (Acacia altramentaria), a large and beautiful tree. The bark is used for tanning hides and is an important article of commerce. The wood is red, with black veins, which polishes exquisitely and is used for fine furniture, cabiliet work, and veneering. The wood is very durable and is excellent for railway sleepers. Specific gravity, 0.977 to 1.180 .

The cuiru, one of the tallest trees to be found in the Chaco. It attains a height of over 150 fcet, with a diameter of not more than 4 feet. Excellent for masts, yard:urms, rafters, etc. Specific gravity, 0.580 .

The timbó. This is also a large tree, having a height of 70 to 80 feet and a diameter of 3 to $3 \frac{1}{2}$ feet. It is a soft wood of about the consistency of pine, though in color it resembles cedar. It is greatly used and makes excellent flooring, weather boarding, etc., having the good quality of not warping, though flexible and light. Specific gravity, 0.425 .

The palma (Copernica campestris). Several varieties, and especially the black and the yellow palm, are found in the Chaco, where they occupy large tracts in forests 
by themselres. They attain to a height of 30 to 40 feet, with a trunk of 1 to 2 feet. These varieties are also found in the province of Corlova. Fans are made of the leaves, and its fruit is very sweet and much sought after by animals as well as men. Sweetmeats are also made of the dried dates, from which likewise a species of rum is distilled. The timber is not worth much, except for corrals and other fencing. The effect produced by these immense forests of palm trees, with their trunks all bare and their round thick crowns, all exactly uniform, is very picturesque and inviting. Specific gravity, 0.960 .

The guayaivi. This tree grows to the height of 30 to 40 feet, with a foot diameter. It produces a very white wood with a black heart, and owing to its strength is used for lance heads, oars, handles of tools, etc. Specific gravity, 0.907.

Besides these trees there are other's equally well known, such as the mora, the olmo or elm, the blanquillo, the cinal, the peterebi, but I have no description of them, and others still whose Indian uames, wuch less their botanical, I am not able to give. Indeed, so little is yet known in regard to the foreste of the Chaco, that Prof. Lorentz still calls it a terra incognita, so far as science is concerned. The number of smaller trees, arborets, shrubs, etc., which occupy that vast region have also yet to be studied, though there is one, called the chaquar, of the family of Bromeliacere, which is a characteristic plant of great atility to the Indians. They make ropes, house lines, and cloths of different kinds with its fiber, and especially shirts or ponchos, which serve as cuirasses, being impervious to arrows; also fishing nets, baskets, etc. They also eat its bulbs, and its fruit serves as a very piquant condiment. The vinagrilla is another shrub which produces a pod as acid as vinegar. The pirchuna is used for the manufacture of brooms. The alamisca bears a berry, which is said to possess the intensest bitter known. The avarillo produces a delicious almond.

\section{FORESTS OF THE ARGENTINE MESOPOTAMIA.}

We now come to the Argentine Mesopotamia, as all that tract of country is called which is embraced between the Uruguay and Parana rivers, extending from the island of Martin Garcia, opposite Buenos Ayres, north ward to the borders of Brazil, a region of over 1,000 miles in length, and varying from 50 to 200 in breadth. It comprehends the provinces of Entre Rios and Corrientes, the territory of Misiones, and the Republie of Paraguay, as also the thousands of islands which dot the two great rivers named. The vegetation of the shores of the Uruguay in great pirt consists of forests composed of a palm tree called the coco yatai, also the coco australis and other species of the cocoa-nut tree, also a bamboo called tacuará, and the inga, a very large tree of the Mimosa family, while farther up the river, approaching the "Misiones," are found the urundey, the lapacho, the timbo, etc., but they do not attain to a very massive growth until about the trenty-eighth degree, from which point northward the vegetation exhibits an extraordinary development, quite corresponding to that of Brazil. The shores and islands of the Parand River, having a soil less argillaceons than those of the Urugnay, present a different arboreal growth. The delta of the Parana abounds in willows, one variety of which, called the sarandi, is a very rapid grower, and is used for fire wood. There is also a most exuberant growth of wild peach trees and orange groves. The former is also used for fire wood, while the fruit finds a market in Buenos Ayres. The oranges of the littoral are rather sour, though they improve upon being transplanted. The bitter orange, which also grows here, is used for the manufacture of a favorite beverage. As we advance up the river the islands more and more exhibit the characteristics of the Chaco formation.

If now we penetrate into the interior of the Argentine Mesopotamia, we will find forests of the harder and more useful species, such as the talas, the chañares, the algorrobos, the quebrachos, the vivaros, the naudubays, etc., all of which varieties line the watercourses and fill the bottom lands of Entre Rios, and form to the north west 
the great forest of Montiel, which covers the sixth part of that province. The province of Corrientes is even more wooly, and with a more tropical development, until we reach "Misiones" and the neighboring Republic of Paraguay, which offer a wealth of timber, rivaling anything that can be found even in the far-famed regions of Oran, not only in dimensions, but also in the fineness of the grain. Most of the varieties which compose the forests of the Gran Chaco are also indigenous to the "Misiones" and Paraguay, while there are a great number of new species, many of which having never been scientifically classified, still flourish under the names given them since time imnemorial by the Guarané Indians.

During the recent Argentine National Exposition held in Buenos Ayres, there was on exhibition a most magnificent collection of the various woods which are found in the aboveregions, consisting of lateral sections of the trees, exquisitely polished so as to exhibit the grain and texture. The collection was credited to Paraguay, but it corresponds equally well to the upper portions of the province of Corrientes and the territory of Misiones, and as it embraces nearly or quite all of the valuable timbar indigenous to those regions, I give the list complete accorling to the names by which the trees are locally known.

\section{TREES OF THE MISIONES AND PARAGUAY.}

1. Sapyy, a large tree suitable for various uses.

2. Ib!ra-yu-quazu, large and grows to a grand height with dense foliage; timber valuable for builling purposes.

3. Laurel amarillo, the yellow laurel, also an immense tree, beautifully grained, and nsef $u$ l in all kinds of eonstruction.

4. Quebracho, like that found in other subtropical regions, very hard and heavy and quite indestructible; serves for various purposes.

5. Ibyrí-pitá, a large tree with very hard wood, used in carpentry work.

6. Cedro colorado, the red cerlar, a very light wood which is as soft as satin, employed in cabinetwork, and resembles mahoginy in its beautiful veins.

7. Timbó, a large and bushy tree with white wood, very light, and the natives make canoes of it.

8. Lapacho piruzú, a variety which has exceedingly fine fibers, used for cabinetwork and other constructions of the first class.

9. Lapacho, the same valuable tree which has heretofore been referred to.

10. Urundey-mi, a tree of ordinary size, but much used for various purposes in carpentry work.

11. Guayaybi, a small, flexible tree, used for handles of tools and other things.

12. Curupay-guazit, a tree of graud proportious, used for the manufacture of furni. ture, owing to the fine polish it takes.

13. Curupay-rau, rather a small tree, used for cabinetwork.

14. Urupiu pita, fine grained, and used for the same purposes as the preceding.

15. Yuqueri-busu, ah immense tree, used in heavy constructions and house-carpentry.

16. Ibyra-poroite, of ordinary size, bnt very fine grain, and useful for cabinetwork.

17. Urupiu-mi, a very large tree, whose timber is used for planking and furniture.

18. Camba-acá, a small tree with exceedingly hard wood; has various uses.

19. Espina de corona, an immense tree; wourl very hard; in general use for heavy timbers, but takes a beantiful polish, and valuable for various purposes.

20. Arrayan, of ordinary size, used in decorative carpentry.

21. Incienso. 'This is the incense tree, so called from the pungent smell of the resin which exudes from it; a very large trec, used for caloinetwork.

22. Guabirá, a large tree which bears a delicious fruit; the timber used in carpentry work and for other purposes.

23. Iba-hai, a tree of rather large proportions, whose timber takes a fine polish and is useful in cabinetwork.

24. Yatayrá, large, but of little use. 
25. Caohoveti-glazui, the same.

26. Aquai, a large tree which produces an excellent fruit and whose timber is employed for various purr.oses.

27. Ibará-ró. This tree likewise produces fruit and finds a general use for furuiture and carpentry work.

28. Granadilla quazú bears a fruit, but its timber is little used.

29. Tatare, a tree of ordinary size; its bark is used for dyeing purposes and its timber for all kinds of carpentry work, having a beautiful grain which takes a fine polish.

30. Corupicay, large and resinous; makes beautiful furniture.

31. Tembetary-negro, a large tree with dark wood that is handsomely veined; used for furniture.

32. Ingá-blanco, also used for furniture.

33. P'etereby, a large tree with wide-spreading branches, producing a heavy timber, which is used in constructions and building.

34. Aratren-quazû, ordinary size and bears a pleasant fruit; not much used.

35. Ibirayí-quazú, a very large tree, whose timbers are much used for heavy building purposes.

36. Yagua-ratay, of little use, though a hard, compact wood.

37. Taperibá, large and bushy, used also in heavy constructions.

38. Ibira-pépé, the same.

39. Timbaly, very straight and tall-wood white; used for beams, axle-trees, etc.

40. Navanjo-agrio. This is the bitter-orange tree; heavy, and used for cabinetwork.

41. Tembetery-blanco, large, with very light wood of a white color; not much used.

42. Cupay, very large proportions; the wood exceedingly fragrant, richly veined, and used for cabinetwork.

43. Parapary, large tree, producing a very fine-grained wood, which takes a beautiful polish; used in all kinds of carpentry work.

44. Nandapá-mi, very similar to the above.

45. Guiray, the same.

46. Urundey-mi, a very large tree, close-grained, which polishes well; used for cabinetwork and other purposes.

47. Guiavi-8aise, a large tree, which works easily and is used for many purposes.

48. Curupay-raú, moderate size; wood used for cabinetwork.

49. Ibyra-pita, a very large tree, whose timber is valuable and used for building purposes.

50. Ibirayu-grande, grows to a great height, and is used for cabinetwork.

51. Incierso-amarillo, a tree of great proportions, which serves for the manufacture of furniture and railway carriages.

52. Urundey-para, a large tree, greatly admired for the beautiful veins of its wood, nsed for fine cabinetwork and also for wood engraving on account of its hardness and fineness of grain.

53. Taperiba-guazu, a tree of immense proportions, and whose lumber is used for building and other purposes.

54. Guayaybi-blanco, not of very large size, bnt its wood is very flexible; useful in carpentry work.

55. Ibyra-ró, rather a large tree, in general use for various constructions.

56. Laurel-negro, also a large tree, whose timber is beautifully veined, the wood being almost black; used for fine cabinetwork.

57. Tatane, a large tree whose bark is used for coloring, and whose wood is much esteemed in carpentry work.

58. Iba-poroiti, a tree which bears a delicious fruit, and whose wood, very fine grained, is used for cabinetwork.

59. Iba-hai, very similar to the above; its wood is used for inlaid or mosaic work.

60. Caahobety colorado, very tall and slender, whose wood is used for beams, axlotrees, etc. 
61. Ibyra-hobi, also a tall, slender tree, and used for like purposes as the preceding.

62. Curupay-hu, a large tree, whose timber is used for furuiture and other things.

63. Campeche, of large size, and very dark-colored wood, which takes a fine polish, and is used for cabinet and other work.

64. Palo de lanza, of ordinary size, but possesses a very fine wood, and is ased for finest cabinetwork.

65. Palo-rosa-colorado, the darkest colored rosewood; used for veneering and finest grarles of furniture.

66. Timbo-colorado, a large tree, easily worked; wood used for making wagons and railway cars.

67. Guayaibi-blanco, a tree of ordinary size; used for furniture, etc.

68. Guayacan, rather a small tree, but its wood is extremely hard and used for many purposes.

69. Tatayiba, a very large tree with beautiful dark wood, which is used for furniture, cabinetwork, etc.

70. Palo Tanto, of ordinary size; used for various purposes.

71. Iba pobo, a large tree which is much user for elegant cabinetwork, owing to its beautiful veins.

The uncivilized names of the most of these trees may not be very attractive reading, but it is almost awe-inspiriug to wander through the immense primeval forests in which these arboreal mouarchs stand as solemn wituesses of the centuries which have passed since they began their growth. *

The valuable timber which they represent is almost too remote from market to be available yet; but one is impressed with the bountiful provision which nature has made for the future wants of mankind.

Those districts of the Misiones which border on the Upper Parana river are, in some places, especially distinguished by extensive forests of caoba, the celebrated mahogany tree of commerce, as also the rosewood (palo de rosa), so generally used for veneering, though there are manv other trees which take an equal polish and are fully as handsomely veined. There are two species of the rosewood tree, known in the country as the male and female. The wood of the first is the hardest and most difficult to polish, and has no veins; while that of the other is much softer, is of rather a more pronounced red color, with very dark veins, and furnishes to the cabinetmaker a most esteemed material. The tree is of great circumference, and its specific gravity is 0.700 .

The cedar of the Misiones is principally found in that portion bordering on Corrientes. There are three varieties, distinguished from each other by color of the woorl, but all equally adapted to the purposes of commerce. Specific gravity, 0.572.

The pine of the Misiones is generally found in immense forests by itself. It, however, like many of the other valuable woods of this region, harlly yet enters into commerce, notwithstanding the excellence of its timber, for the reason that more accessible forests offer other woods as an abundant compensation. Specific gravity, 0.410 .

In the forests of Paraguay and Misiones is also to be seen the famous evergreen tree (Ilex paraguayensis), which produces the yerba-mate, the universal beverage of the natives, and the export dnty on which, in great part, affords the national revenue of Paraguay, the Government having the exclusive monopoly of the trade.

* Speaking of the arborescence of the Misiones, Mr. White, in his Note-book of a Naturalist, says: "Although I had bcen accustomed to the vast and imposing forests of Salta, Jujuy, and especially Oran, this region struck me as even more luxuriant, not in such arboreal magnificence, but in universal density and impenetrability; indeed, the exuberance of timber is such that the very names of the trees are as yet unknown to Europeans, and even the majority of those with which they have become familiar are only recognized by their Indian vocables. (Vol. II, p. 421.) 
In these magnifieent forests are also to be found orange and pineapple groves, as likewise almost every other variety of tree and shrub bearing the delieious fruits of the tropics. I am told that the orange is not indigenous to these regions, but was introduced shortly after the Spanish conquest by the Jesuits, who, until their expulsion by order of Philip II, oceupied all this portion of the country. The tree is now, however, universally distributed. Some of the orange groves I have visited in the neighborhood of Villa Oceidental, Gran Chaco, and near Asuncion, Paraguay, were indeseribabiy beautiful, the enormous trees being bowed down by the weight of their delicious golden produce, while the ground beneath was covered with the fallen fruit. In the season the oranges are sent by boat-load to Buenos Ayres and Montevideo. They are also used for distillation and for feeding pigs and eattle, besides being largely eonsumed by the natives. Owing to the enormous quantities produced, they have, however, but little money value in Paraguay, and over in Buenos Ayres, a distance of over 1,000 miles, I have seen them sometimes sold for about 50 cents a bushel.

THE FUTURE OF THE TIMBE TRADE OF THE ARGENTINE REPUBLIC.

I have thus completed a cursory note, which I believe to be reliable, of the several arboreal formations into which the Argentine Republic, with its immense extent from north to south, is naturally divided, beginning with the antaretic forests of beech, which oecupy the greater part of Terra del Fuego and the lands adjacent to the Straits of Magellan; noting the vast pineries, as yet wholly undeveloped, which skirt the entire eastern slopes of the Patagonian Andes; following these to where tho "Monte" formation marks the development of the hard woods; describing the principal trees of the great subtropical forests of Tucuman, Salta, and Oran; glancing at the wealth of timber which literally eovers the immense unexplored regions of northern and southern "Chaco," and finally passing in review the marvelous variety of valuable woods which are found in the thousand miles of territory which lies between the Parana and Uruguay rivers, called the Mesopotamia of the Argentine Republic. The sketch or eompilation is not intended as exhaustive of the subject. It could be very greatly extended, though there are still vast outlying regions of forests about which little, if anything, is yet definitely known. The report, however, is sufficient to explode the generally prevailing idea that the Argentine Republic is entirely a pampa or prairie country and lacking in timber resources, an impression which has gained credence from the fact that the province of Buenos Ayres, which abroad is generally taken for the whole country, is to a great extent destitute of trees; and by the further fact, which seems to be an anomaly, that a very large part of the lumber used here is still imported from the United States.

In spite of this, however, as I have shown, the greater portion of all the northern aud northwestern provinces is occupied by forests of timber, which not only in their enduring qualities but in their fineness of fiber, smoothness, and beauty of coloring will compare favorably with those of any country in the world. Indeed, in their suseeptibility to the highest degrees of polish, and in the striking varieties and combinations of their tints, it is doubtful if any other country has woods that fully equal them. As I have said, the full extent of this arboreal wealth is not yet known, and we must still wait for a scientific description of a very large proportion of the country which contains these marvelous timber resourees. It is eviclent, however, that in the more or less remote future, when the increasing popnlation of the Argentine Republic has come face to face with these outlying virgin forests, and railways and a more extensive system of river navigation place a greater commercial valne upon the work of the woodehopper and the lumberman, the markets of the world, which are just now beginning to realize the undeveloperl wealth which these forests represent, will be astonished at the amount of precious woods and valuable timber, suitable for every variety of work, which this conntry will be able to supply. Europe is now driving the entering wedge in the mammoth timber trees 
which skirt the shores of the Upper Parana, and the ship-loarls, which in the last few years have gone forward to the cabinet and fine-furniture maunfactories of France and Germany, have so greatly exceeded the expectations as to their value as to make them more anxious for greater supplies. Indeed it will not be surprising if the tables will yet be turned, and even the United States, after having quite exhausted her own forests in supplying the foreigu demand, will, in time, be compelled to look to the Argentine Republic for a considerable portion of its lumber.

E. L. BAKkR,

Consul.

Buenos Arres, June 20, 1883.

\section{BRAZIL.}

\section{RIO DE JANEIRO.}

\section{NATIVE WOODS.}

The magnificence of the forests of Brazil and the variety of the woods they contain would demand a far more extensive treatment of the subject than is admissible in an essentially commercial report. In Amazonas alone, 30 kinds of timber for building and 13 for cabinetmaking are said to exist, while the rest of this vast country presents an enormous variety of the most luxuriant trees, useful for their timber as well as for sundry other purposes. If they are not used as they merit it is owing to the scarcity of labor and the want of proper means of communication, making in the most cases the native dearer than the imported woods. I will therefore only mention those commonly em. ployed for building and other uses.

The peroba, the tupinhô, for naval construction; the páo brazil (Brazil wood), the cabiuna (brown rosewood), the cedro (cedar), the massaran$d u b a$, the sapucaia, and the laurel are much employed in the lining of vessels. The páo d'oleo, the gonçalo alves, the black and brown canella, the licurana, and the iron wood ( $p a ́ o$ ferro) are also used for ship construction.

The peroba, the cedro, the vinhatico, the páo d'oleo, the jacaranda, the páo marfim (ivory wood), the páo setim (satin wood), the ebony, the licurana, and the ipé are used in cabinet and joiner work.

\section{KINDS OF LUMBER IN USE.}

The kinds of lumber preferred are the American and Swedish pine and the native canella and peroba for construction, and the native. vinhatico jacaranda for cabinet and joiner work.

$665 \mathrm{~A} \longrightarrow 5$ 


\section{IMPORTS AND DUTIES.}

The imports of pine lnmber at Rio de Janeiro were as follows during the years 1890, 1891, and 1892:

\begin{tabular}{|c|c|c|c|}
\hline From- & 1890. & 1891. & 1892. \\
\hline 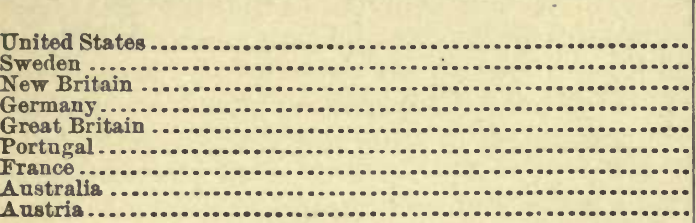 & $\begin{array}{r}\text { Cub. meters. } \\
43,788 \\
13,180 \\
2,832 \\
1,296 \\
90 \\
12 \\
6\end{array}$ & $\begin{array}{r}\text { Oub. meters. } \\
70,035 \\
29,196 \\
4,200 \\
4,401 \\
594 \\
6,384 \\
\ldots\end{array}$ & $\begin{array}{r}\text { Oub. meters. } \\
42,870 \\
11,226 \\
5,142 \\
\ldots \ldots \ldots \\
726 \\
3 \\
9 \\
9 . \ldots \ldots \\
\end{array}$ \\
\hline 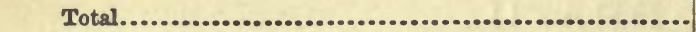 & 61,704 & 114,810 & 59,979 \\
\hline
\end{tabular}

The quantities of beams, masts, etc., and cabinet woods imported are not available, but they are not large. The greater part of the beams and masts are imported from the United States and the cabinet woods from England and Germany.

The import duty laid upon foreign lumber is as follows:

\begin{tabular}{|c|c|c|}
\hline \multirow[b]{2}{*}{ Description. } & \multicolumn{2}{|c|}{ Duties on- } \\
\hline & $\begin{array}{l}\text { American } \\
\text { lumber. }\end{array}$ & $\begin{array}{l}\text { All other } \\
\text { lumber. }\end{array}$ \\
\hline 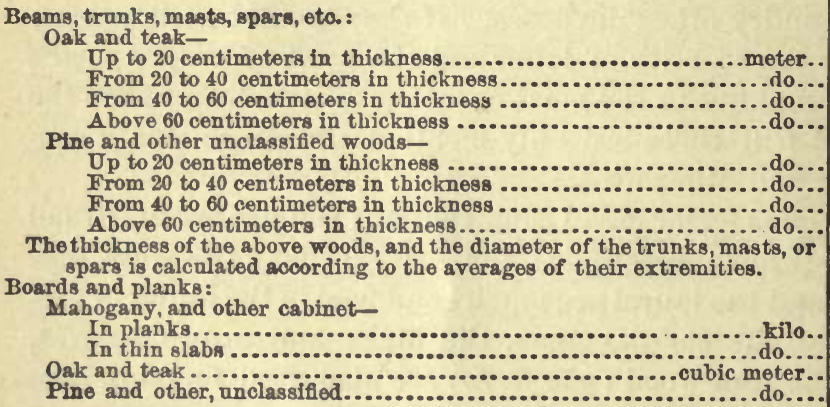 & $\begin{array}{r}\text { Milreis. } \\
\mathbf{1 . 5 7 5} \\
\mathbf{3 . 6 0 0} \\
\mathbf{7 . 4 2 5} \\
\mathbf{1 3 . 5 0 0} \\
.832 \\
\mathbf{1 . 8 0 0} \\
\mathbf{3 . 8 2 5} \\
\mathbf{7 . 0 8 7}\end{array}$ & $\begin{array}{r}\text { Mrilreis. } \\
2.100 \\
4.800 \\
9.900 \\
18.000 \\
1.110 \\
2.400 \\
5.100 \\
9.450\end{array}$ \\
\hline
\end{tabular}

Pieces of wood coming already cut, prepared, or adjusted for building houses or sheds, or for any other civil and naval purposes, pay from the United States $33 \frac{3}{4}$ per cent, from other countries 45 per cent ad valorem; and any others from the United States 54 per cent, and from other countries 72 per cent ad valorem.

It is impossible to reduce the duty into United States currency owing to the rapid fluctuations in the value of the Brazil milreis.

\section{PRICES.}

The prices of lumber here, as elsewhere, are subject to the law of supply and demand and, it may be added in this case, to the fluctuations 
in the value of the milreis. The market prices, duty paid, are to-day for pitch pine, 65 milreis per dozen planks, 14 feet by 9 by 3 inches: white pine, 205 reis * per foot; Swedish pine, 60 to 70 milreis per dozen planks, 14 feet by 9 by 3 inches. These prices are subject to 6 per cent discount. To-day's exchange $9 \frac{3}{16}$ pence per milreis, or say $18 \frac{3}{8}$ cents United States currency 90 days on London. The market is actually reported dull, with weak demand and the prices low. The stock of timber, paid for at more favorable rates of exchange, is large, and retailers only cover immediate wants in view of the possibility of an amelioration of exchange.

\section{CLIMATE.}

Brazil extends to the north beyond the equator and to the south still more beyond Capricorn, and its climate is naturally varied. Hot weather predominates, but is modified according to the different latitudes in which it makes itself felt, and is influenced by the position, but principally by the elevation, of the land. It is intense under the equator (on the Amazonas), much less severe in the states of the center, mitigated on the coast by regular breezes, and progressively reduced to a mild temperature in the most southern states, but specially in Rio Grande do Sul. There are two seasons in all that part of the country from Amazonas southward, inclusive of the state of Sao Paulo, the dry and the rainy, while in the states of Parana, Santa Catharina, and Rio Grande do Sul, four seasons are distinguished, but not so strongly characterized as in the United States. In Minas-Geraes, Matto-Grosso, and Goyaz, the climate differs according to the elevation and the latitude of the various parts of these immense states.

\section{GENERAL BUILDING.}

General building; it is feared, will not be carried on as extensively during the next iew years as was the case since 1889. Ship building is of no special corsequence in this country.

The length of railroads in construction, under study and to be studied, was January 1, 1892, in kilometers:

\begin{tabular}{|c|c|c|c|c|}
\hline Roads. & $\begin{array}{l}\text { In con- } \\
\text { struction. }\end{array}$ & $\begin{array}{l}\text { Under } \\
\text { study. }\end{array}$ & $\begin{array}{c}\text { To be } \\
\text { studied. }\end{array}$ & Total. \\
\hline 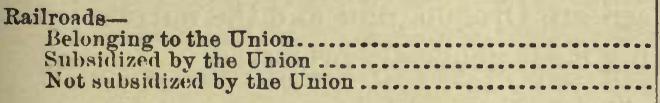 & $\begin{array}{r}964 \\
2,048 \\
1,174\end{array}$ & $\begin{array}{r}595 \\
5,965 \\
2,132\end{array}$ & $\begin{array}{r}485 \\
12,337 \\
6,731\end{array}$ & $\begin{array}{r}2,044 \\
20,350 \\
10,037\end{array}$ \\
\hline Total .................. & 4,186 & 8,692 & 19,553 & 32,431 \\
\hline
\end{tabular}

* There are 1,000 reis in the milreis. 
As will be observed by the statistical figures of the imports of Rio de Janeiro for the three years from January 1, 1890, to December 31, 1892, American lumber is taking the lead over all other foreign lumber; the only means to increase the lumber trade of the United States with this country would, therefore, be to equalize, as much as possible, ocean freight rates with the rates from European ports.

JoHN T. LFwIS, Vice Consul-General.

RIO DE JANEIRO, April 24, 1894.

\section{CHILE.}

\section{NATIVE WOODS.}

The native woods of Chilè are rauli, roble, cypress, luma, lingue, laurel, alamo, and alerce.

The two most important and mostused of these are rauliand roble; the first, resembling our cedar, is used mostly in the manufacture of furniture and also extensively in interior finish for buildings, it being susceptible to a high degree of polish, pliable, and easily worked by machinery.

The roble is the most plentiful of all the woods here, and corresponds to our oak, being, however, much finer grained, harder, and consequently offers more resistence to machinery. The specific gravity of this wood precludes the possibility of its being rafted, which necessitates handling by rail; this in a measure will always prevent its competing to any great extent with lumber imported from the United States, as the forest section is very mountainous and, consequently, it is difficult to get the logs to the mills and the lumber from the sawmills. This wood is better allipted to framework than any other purpose.

The one other wood worthy of mention is the cypruss, which is well adapted to the manufacture of railway ties, and is principally used for that purpose, the supply, however, is small.

\section{KINDS OF LUMBER MOST USED.}

The kinds of lumber most used are Oregon pine and the native rauli and roble, the Oregon pine being most generally preferred. 


\section{IMPORTS.}

The quantities of lumber imported during the last three years wert as follows:

\begin{tabular}{|c|c|c|c|}
\hline Kinds and whence imported. & 1890. & 1891. & 1892. \\
\hline 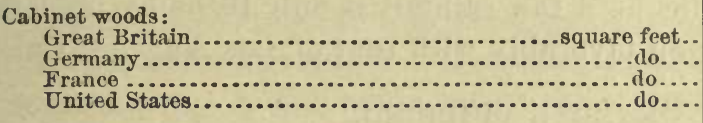 & $\begin{array}{r}2,409 \\
568 \\
\ldots \ldots \ldots \\
2,072,648\end{array}$ & $\begin{array}{r}8,000 \\
\ldots \ldots \ldots \\
\ldots \ldots \\
46,273\end{array}$ & $\begin{array}{r}220 \\
\ldots \ldots \ldots \ldots \\
29,526\end{array}$ \\
\hline & $2,075,625$ & 54,273 & 39,746 \\
\hline 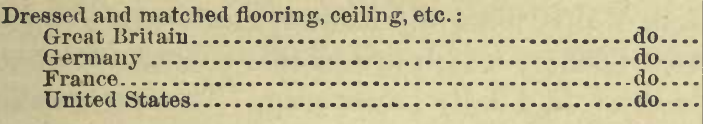 & $\begin{array}{r}4,449 \\
\ldots \ldots \ldots \ldots \\
\ldots \ldots \ldots \ldots \\
488,647\end{array}$ & $\begin{array}{r}\ldots \ldots \\
\hdashline 39,876\end{array}$ & $\begin{array}{r} \\
\quad \ldots 93 \\
\ldots \ldots \ldots . . . \ldots \\
1,161,831\end{array}$ \\
\hline Total .......................... & 493,096 & 739,876 & $1,162,824$ \\
\hline 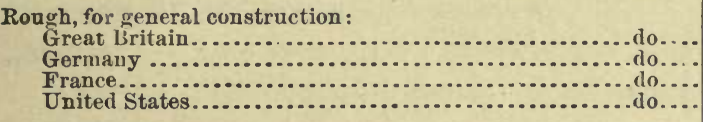 & $\begin{array}{r}2,312 \\
22,033 \\
5,755,217\end{array}$ & $\begin{array}{r}244,948 \\
\ldots \ldots \ldots \ldots \\
\ldots \ldots \ldots \\
3,811,010\end{array}$ & $\begin{array}{r}75,942 \\
4,467 \\
9,862,555\end{array}$ \\
\hline ........do.... & $5,779,562$ & $4,055,958$ & $9,942,964$ \\
\hline 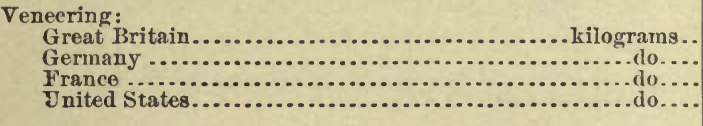 & $\begin{array}{r}1,748 \\
5,251 \\
219 \\
\cdots\end{array}$ & $\begin{array}{r}3,226 \\
185 \\
\ldots \ldots \ldots \ldots \ldots \\
\ldots \ldots \ldots \ldots \ldots \\
\end{array}$ & $\begin{array}{r}653 \\
2,438 \\
\ldots \ldots \ldots \\
1,896\end{array}$ \\
\hline Total ........... & 7,218 & 4,411 & 4,987 \\
\hline
\end{tabular}

DUTY.

The principal obstacle in the way of increasing our trade with Chile is the import duty, which is on rough lumber 15 per cent ad valorem; dressed and dressed and matched, 25 per cent; veneering, 35 per cent; and the fine woods for cabinetwork free. I may add that the present system of appraising makes the import duty on rough lumber $\$ 10.47$, and on dressed and dressed and matched $\$ 19.46$ per 1,000 feet, ('hile paper currency (a dollar at the present rate of exchange being worth 25 cents United States gold).

\section{PRICES.}

The prices of lumber are as follows: Oregon pine, rough, $\$ 110$ per 1,000 feet; dressed and matched, $\$ 130$, and half-inch ceiling, $\$ S 0$; roble, framing, $\$ 70$; and rauli dressed and matched, $\$ 100$.

It is probably safe to say that the American exporter will always find a market in Chile, as the forests, which cover an estimated area of 90,000 square miles, consist principally of roble, which, as I have previously mentioned, is not calculated to come in strong competition with American lumber.

The product of the sawmills in most instances is transported by carts to the railroads for shipment, and as the roads are very bad, lengths of roble longer than 24 feet are seldom sawed. As the rauli tree is a very short one, the lengths are never longer than 12 or 14 feet. 


\section{CLIMATE.}

A description of the climate in this consular district would be valueless in this connection, as the lumber section begins at Malleco, about 400 miles south, and extends to the Straits of Magellan. The average rainfall there is 106 inches, and the climate cold and disagreeable eight months in the year, while here the rainfall is only 16 inches and the climate is mild, comparing favorably with that of Los Angeles, Cal.

\section{GENERAL BUILDING.}

Chilian cities-Santiago, Valparaiso, and Concepcion-are growing rapidly, especially the two former, which are in this consular district. The demand for lumber is brisk and daily increasing. There is no shipbuilding in Chile, and at present railway construction is at a standstill.

JAMES M. DOBBS,

Valparaiso, May 1, 1894.

\section{Consul.}

\section{COLOMBIA.}

\section{BARRANQUILLA.}

\section{NATIVE WOODS.}

Colombia is a vast lumber producing country; in many portions of the interior huge forests, many hundreds of miles square, cover its face, representing woods of different values.

To name all the woods of Colombia would be to make an extensive catalogue. The principal, however, are cedar, guayacan, carreto, roble, campano, mahogany, ceiba, and brazil. They may be classified as follows:

Cedar.-This is the most common wood in use. It is easily worked, and possesses a bitter quality, which is a preventive against an insect called the comejen, a species of wood ant, very destructive to many other kinds of wood. In house construction, excepting for flooring beams, cedar is universally used.

Guayacan.-This is the lignum vitæe, and is very hard. It is used principally for railroad sleepers, and thousands are shipped to Cuba, to the Isthmus of Panama, and Central America. This wood resists the penetration of spikes, and holes have to be bored before they can be driven. It is of dark color, with occasional light streaks running through it.

Carreto.-This is a light-colored wood, also very hard, and is destructive to carpenters' tools. It is used in timbers for construction, the ends which enter the walls being usually charred or dipped in coal tar, as a 
preventive against rot. Timber of Carreto will last for centuries. Being a handsome wood, capable of receiving a fine polish, it is used in furniture, such as presses, counters, trunks, and household objects.

Roble.-This is a softer wood, of light color, and very tough. It pertains to the family of the oak. It is used to a considerable extent in the mannfacture of furniture.

Campano.-Trees of this wood grow to an immense size and height, and are hewn and dug out into canoes and boats of very considerable dimensions. A well-made native canoe, sometimes 90 feet in length, is really a work of art.

Mahogany. - This is a handsome wood of rich, dark color, but is inferior in grain to that of Santo Domingo or Honduras. It is not extensively used.

Ceiba.-This is a wood of rather a light rosy tint, and is used in the manufacture of household articles.

Brazil.-This tree grows in some parts of Columbia.

Fustic.-The common fustic of commerce grows extensively in the interior.

The working of timber into beams and boards by native workmen is usually accomplished with the old-fashioned cross-cut saw, and a species of uncouth pattern of the old Spanish ax.

\section{KINDS OF LUMBER USED.}

As to "what kind of lumber is preferred," that entirely depends on the use to which it is put; as cedar for house construction, carreto for timbering, and guayacan for sleepers.

\section{IMPORTS AND DUTY.}

No lumber is imported from any other country than the United States

Formerly quite a quantity of yellow pine was brought from some ports of the Southern States, in sailing vessels entering the river, but of late the very high rate of exchange (205 per cent premium), has nominally stopped importation. When timbers of great length are required yellow pine meets the want.

Undressed lumbur pays no duty; dressed lumber (a board planed and tongued and grooved), pays $1 \frac{1}{4}$ cents per kilo.

\section{CLIMATE.}

The climate of this consular district is delightful. During the October rain and December "northers," I have known the thermometer to go as low as $74^{\circ} \mathrm{F}$., while during the warmer season, in the most favored part of this city-for instance where this consulate is located-I have never seen it rise above 880 . 


\section{GENERAL BUILDING AND PRICES.}

There is neither shipbuilding nor railroad construction in this district. To-day rough lumber may be quoted at 18 cents per superficial foot; dressed lumber at 20 cents, Colombian paper.

The outlook is not favorable to an increased trade in foreign lumber.

BARRANQUILLA, April 25, 1894.

\section{E. P. Pellet, Vice and Deputy Consul.}

\section{COLON.}

NATIVE WOODS.

There are no native woods here for building purposes, the villagers being the only ones who employ rough native sticks in the erection of their huts.

\section{KINDS OF LUMBER USED.}

The kinds of lumber used are yellow-pine scantlings and timbers and white-pine boards, planed or rough, in almost equal proportions.

A small quantity of California red pine is imported by the Panama Railroad Company, and used exclusively in the reconstruction of their cars.

\section{IMPORTS OF LUMBER.}

All the lumber used here is imported from the United States.

\section{DUTY AND PRICES.}

There is no import duty on lumber entered at this port.

The prices of lumber vary very much on account of the constant fluctuation of exchange. It is, however, safe to quote the following rates for the present in Colombian silver per 1,000 feet,* viz:

Yellow pine, $\$ 70$ to $\$ 75$ for average sizes; for heavy timbers special prices in proportion. White pine, $\$ 70$ to $\$ 80$.

\section{CLIMATE.}

The climate of this district from the middle of December to the mid. dle of March is dry with prevailing north winds; the rest of the year it is rainy and damp.

\footnotetext{
"The Colombian silver peso $=46.5$ cents on April 1, 1894.
} 
GENERAL BUILDING.

At present there is very little house building going on, on account of the depressed state of affairs in general, and there is not now, nor has there ever been, any shipbuilding here.

The Panama Railroad Company has 47 miles of laid track between Panama and this city, but there is no railroad being built within this consular district.

J. L. Pearcy, Consul.

Colon, January 19, 1894.

\section{DUTCH GUIANA.}

NATIVE WOODS.

The following are the principal woods of Dutch Guiana: Jawalidani, kakaralli, wallaba, blackheart, greenheart, accouribroad, purpleheart, ironwood, cabacalli, mimusops (balata), cedar, lancewood, simiri, mora, salic, deteruca, lignum-vitæ, and mahogany.

\section{IMPORTS, DUTY AND PRICES.}

The annual imports of lumber amount to about $\$ 20,000$, viz: From the United States, $\$ 15,000$; from British Guiana, $\$ 5,000$.

The duty on lumber is as follows: Pitch pine, 80 cents per cubic yard; white pine, 60 cents per cubic yard; planks, 24 feet or more, 60 cents per hundred; planks under 24 feet, 40 cents per hundred.

Present price of lumber: Pitch pine, $\$ 48$ per thousand; white pine, $\$ 40$ per thousand.

\section{OLIMATE AND PUBLIO BUILDING.}

The climate of Dutch Guiana is divided into three seasons, two wet and one dry. The "small" wet season commences in December and ends in April. The "great" wet season runs from April to July, and the dry season from July to December.

The thermometer averages about $83^{\circ} \mathrm{F}$. The average annual rainfall is 95 inches. For the last ten years it has rained, on an average, on 204 days in each year.

There is neither shipbuilding nor railroad building in this colony.

H. LOVEJOY,

Vice-Consul.

Paramaribo, February 23, 1894. 


\section{ECUADOR.}

\section{NATIVE WOODS.}

The following table exhibits a great variety of valuable woods found in Ecuador, in the province of Guayas alone, and particularly about Chougan, Balzar, Fama, and Puná.*

The table shows the local names, the color, length of log which may be cut from a tree, and the number of years each is calculated to endure.

Several of these woods are unique cabinet woods. I have indicated the general uses for which they may be severally employed, and in another place some further particulars about some of them.

As far as I can find out, there is no timber here like our pine which can be used to make the light planks in general use in house building, etc. Consequently, pine lumber is imported here from Mississippi, shipped from the port of Biloxi.

List of native woods.

\begin{tabular}{|c|c|c|c|}
\hline Local names. & Color. & Size.a & Durability. \\
\hline Fine cabinet woods: & & Feet. & Years. \\
\hline Roble ................ & White. & & \\
\hline Figueroa .... & Red.... & 20 & 25 \\
\hline Cabicu ......... & .... do .. & 30 & 100 \\
\hline Cedro ................. & ....do ... & 30 & 16 \\
\hline Guasango ........ & .... do ... & 10 & Everlasting. \\
\hline Caoba ................. & ...do ................. & 25 & 16 \\
\hline 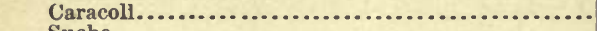 & White and yellow .. & & 12 \\
\hline $\begin{array}{l}\text { Suche } \ldots \ldots \ldots \ldots \ldots \ldots \ldots \\
\text {. }\end{array}$ & Gold ................ & 25 & 12 \\
\hline $\begin{array}{l}\text { Posts and underground woods: } \\
\text { (iusyacan } \ldots . . . . . . . . . . . .\end{array}$ & & & \\
\hline Medera Negra............ & Black.. & 30 & $\begin{array}{l}50 \\
50\end{array}$ \\
\hline Alganobo ...... & Cotiee... & 15 & Everlasting. \\
\hline 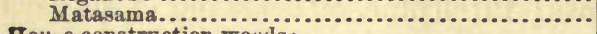 & Yellow .... & 20 & 50 \\
\hline 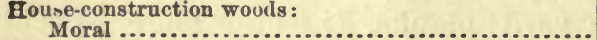 & & & \\
\hline Armarillo.............. & ....do $\ldots$ & $\begin{array}{l}45 \\
45\end{array}$ & 50 \\
\hline Guachapeli....... & Red.... & 25 & 50 \\
\hline 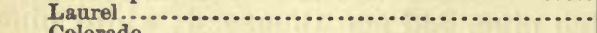 & Dark .... & 25 & 50 \\
\hline Colorado & Red..... & 55 & 14 \\
\hline 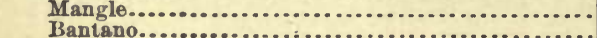 & ........... & 55 & 14 \\
\hline 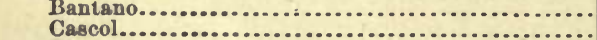 & Yellow .............. & 20 & 25 \\
\hline 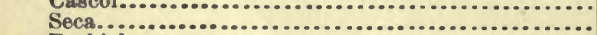 & $\begin{array}{l}\text { White........ } \\
\text { Yellow }\end{array}$ & 20 & $\begin{array}{l}30 \\
30\end{array}$ \\
\hline Pechiche & White................ & 15 & 30 \\
\hline 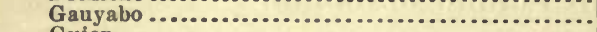 & ...do do.............. & 30 & 30 \\
\hline Guion & Red................. & 15 & 14 \\
\hline $\begin{array}{l}\text { Coquinto } \\
\text { Canelo } . . . .\end{array}$ & White...... & 15 & 30 \\
\hline Balsamo & Yellow...$\ldots \ldots \ldots$ & $\begin{array}{l}35 \\
45\end{array}$ & $\begin{array}{l}40 \\
50\end{array}$ \\
\hline 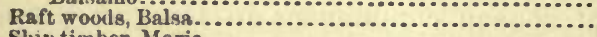 & White.................. & 60 & \\
\hline Ship timber, Maria.......... & Yellow ...... & 65 & 30 \\
\hline
\end{tabular}

a Size is the length of a $\log$ which can be cut from a tree.

The foregoing woods are all found in the province of Guayas, in which Guayaquil is situated.

Of the woods in the provinces of Esmeraldas and Monchi, on the upper coast, and of those in the southern provinces of Del Oro and

"Consul-General Dillard acknowledges his indebtedness to Senõr Don Ignacio Robbs for valuable statistics used in the preparation of this report. 
Toja, I have no sufficient information (the woods named are most likely found in all those provinces), nor have I any information about the woods of the Cordilleras, nor of those in the regions known as the Ariente-the virgin forests of the upper Amazons.

Guayacan.-This valuable wood endures alike in the open air as under ground. On account of the frequency of earthquakes, most of the houses are built upon great posts, which are sunk deeply into the ground and are extended to the second story of the building. The bottom parts of these posts are of guayacan, which extend 4 or 5 feet above ground and the upper part of the posts are of mangle, which can be renewed when it decays. The two parts of the posts are attached together by a most ingenious mortise joint. The guayacan is used for all purposes where wood is used under ground or in water.

Mangle.-This wood is in universal use-for the upper part of posts and for all the joists, plates, and studding of houses. Its lasting quality differs with its situation. In the shade above ground it endures, say fourteen years, and in the ground, sixteen years, but in the open air, exposed to the sun, it lasts only three or four years.

Balsa.-The renowned balsas (or rafts) (the most unique water craft in the world) are constructed of this wood, hence its name. This craft (made of balsa logs, stripped of the bark and fastened together with vines) has always been in use by the Indians on this coast. . The tradition is that the progenitors of the Indians, who inhabited this country before the Incas appeared, as well as at the time of the Spanish conquest, reached the shores of Ecuador in balsas-most probably from the Isthmus of Panama. At all events the balsa has, from time immemorial, been the water craft of the Indians of Ecuador. They float up and down the rivers and bayous (esteros) with the tide, transporting their produce and returning home. Some build their cabins on their balsas, which thus become their only homes. They do not fear to go to sea in their balsas, for it is impossible to sink them.

The balsa wood is very white, soft, strong, and floats like a cork.

I regret that my lack of information prevents me from going into particulars about others of the most rare and valuable woods mentioned in the table. I write only of those which I see in use every day.

KINDS OF LUMBER USED.

The kinds of lumber preferred are the guayacan, mangle, and imported pine-each for its particular purpose.

Bamboo. - The bamboo is of universal use for ceilings in house building. The matter in the joints being carefully cut out, the cane, from 4 to 6 or more inches in diameter, is flattened out and made like a plank. It not only serves all the purposes of the best quality of lath, but is usually the only weatherboarding of the rear of houses. It is also the flooring material for respectable country houses and for all native cabins. 


\section{IMPORTS AND PRICES.}

The lumber imported at Guayaquil during the year 1893 amounted to $1,600,000$ feet, all from the United States and all dressed lumber. E. Rohde \& Co. were the importers. Very little lumber is imported at the other ports of the Republic.

\section{DUTY AND PRICES.}

The import duty on lumber is one-half centavo (say one-fourth cent, American gold) per kilogram, plus 30 per cent ad valorem.

Lumber sells in Guayaquil at from $7 \frac{1}{2}$ to 9 centavos per foot, say $\$ 37.50$ to $\$ 45$ per thousand.

\section{CLIMATE.}

This country is called Ecuador because the equator covers it-Quito, the capital, being almost on the line, and Guayaquil being scarcely two degrees south of it. The vegetation, however, is not tropical; at least it is not tropical in the great valley of the Guayas. The climate is hot, but from May to December, the dry season, the heat is tempered by an almost constant southwest breeze, the Chonduy, and by clouds. For months at a time, the sun will notbe seen, although during that time, it does not rain a drop. From December till May, the rainy and sickly season, when it is not raining the sun frequently comes out with great force right overhead, but during the dry season, there are weeks of weather which one word will probably describe-delicious.

\section{GENERAX BUILDING.}

Houses are constantly being built in Guayaquil, but the amount of imported lumber used in their construction is not very great. Shipbuilding is limited to small craft. The river steamboats and the launches used in the port are generally imported from the United States and put together here.

Railroad building, it is thought, will soon begin. There are only about 50 miles of railroad in operation in the Republic-that which runs from Duran (across the river from Guayaquil) to Chimbo, at the foothills of the mountains. There is a short line in course of construction at Mochala, and a survey has recently been made for the extension of the line from Chimbo towards Quito. This is a great undertaking which awaits capital and enterprise.

GUAYAQUiL, April 24, 1894.

GEo. G. DrLl 4 RD, Consul-General. 


\section{DANISH WEST INDIES.}

\section{NATIVE WOODS.}

The following list of woods grown in the Danish West India Islands is given by Mr. Carl Berg:

Acacia macrantha.

Avicennia nitida.

Beurreria succulenta.

Bucida buceras.

Bumelia euncata.

Condalia ferrea.

Ademanthera Pavoniana.

Mamea Americana.

Capparis cynophallophura.

Colubrina reclinata.

Creecendia aryete.

Eugenia floribunda.

Eugenia pallens.

Erithalis fructicosa.

Exterme caribean.

Coccoloba punctata.

Coccoloba niven.

Coccoloba uvifera.

Jacrivia arborea.

Libidibia coriaria.

Leucaena glauca.
Maytenus lævigatus.

Picræna excelsa.

Pictetia squamata.

Pimenta vulgaris.

Piscidia erycthrina.

Randia acubeada.

Ranolfia nidita.

Swietunia Mahogeni.

Thespesia populnea.

Thevetia nevifolia.

Zanthoxylum flavum.

Zanthoxylum Clava Herculi.

Zanthoxylum Ochroxylum.

Croton.

Acacia nudiflora.

Guafiacum officinale.

Canella alba.

Chrysophyllum mierophyllum.

Psidium guava.

Sapota sideroxylon.

Besides the above-mentioned woods, which are used for building purposes and furniture (botanical names only are given), there can be found about 350 varieties that are used for medicinal and other purposes.

\section{KINDS OF LUMBER USED.}

The principal woods used here are pitch pine, white pine, and spruce, the first being preferred for housebuilding, because ants, which destroy the spruce in a few years and the white pine in time, do not touch hard pine. White pine is used for house trimmings. Spruce is used but little, if at all. Southern pine and oak, in small quantities, are used for the repair of ships which touch here in distress. Nearly all these woods are imported from the United States.

The native woods are generally of small growth, fit for building boats, wharves, and small vessels. Furniture is also made of native woods. 


\section{IMPORTS OF LUMBER.}

The following statement shows the imports of lumber at St. Thomas for the years ending March 31, 1891, 1892, and 1893:

\begin{tabular}{|c|c|c|c|c|c|c|}
\hline \multirow{2}{*}{ Whence imported. } & \multicolumn{2}{|c|}{1891.} & \multicolumn{2}{|c|}{1892.} & \multicolumn{2}{|c|}{1893.} \\
\hline & Quantity. & Value. & Quantity. & Value. & Quantity. & Value. \\
\hline 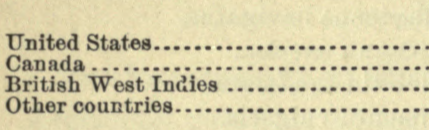 & $\begin{array}{r}\text { Feet. } \\
634,218 \\
29,455 \\
5,644 \\
1,116 \\
\end{array}$ & $\begin{array}{r}\$ 11,035 \\
458 \\
169 \\
89 \\
\end{array}$ & $\begin{array}{r}\text { Feet. } \\
407,791 \\
107,368 \\
2,700 \\
1,175 \\
\end{array}$ & $\begin{array}{r}\$ 5,611 \\
1.496 \\
71 \\
251 \\
\end{array}$ & $\begin{array}{r}\text { Feet. } \\
259,133 \\
185 \\
221 \\
125 \\
\end{array}$ & $\begin{array}{r}\$ 5,619 \\
87 \\
50 \\
28 \\
\end{array}$ \\
\hline Total..................... & 670,433 & 11,751 & 519,034 & 7,429 & 259,664 & 5,784 \\
\hline
\end{tabular}

\section{DUTY AND PRICES.}

The import duty is 3 per cent on declared invoice value of all goods.

Pitch pine is sold at $\$ 30$ to $\$ 35$, and white pine from $\$ 35$ to $\$ 40$ per 1,000 feet. Spruce and oak are imported by ship carpenters solely for their own use in repairing ships, ete., and are not for sale.

\section{CLIMATE.}

The climate of the Danish West Indies is in general healthful, the islands being situated in latitude $17^{\circ}$ to $18^{\circ}$ north and nearly in the strength of the northeast trade winds, which blow nearly the entire year, the thermometer in the winter months ranging from $70^{\circ}$ to $8 u^{\circ}$, and in summer, $80^{\circ}$ to $90^{\circ} \mathrm{F}$.

\section{GENERAL BUILDING.}

All the large houses here are built of brick and stone, with wood floors, windows, doors, etc. Small houses are built entirely of wood, with stone foundation about 10 feet high. Small fishing boats and row boats are built of the native woods. No large vessels are built here. There are no railroads within my consular district.

\section{EXTENSION OF LUMBER TRADE.}

As will be seen from the statement of imports, the United States leads all other countries.

I can offer no suggestions, as I see no means of further extending the trade of American lumber in these islands.

J. H. STEWART,

Consul.

St. Thomas, West Indies, March 9, 1894. 


\section{A S IA.}

\section{BRITISH ASIA.}

\section{CEYLON.}

NATIVE WOODS.

There are 156 varieties of useful timber classified in Ceylon, as will be seen by the inclosed publication, List of the Principal Timber Trees in Ceylon.*

\section{IMPORTS OF LUMBER.}

The timber (all wood is called timber here) imported in 1892 was teak logs from Burma, to the value of $\$ 112,600$; and from Great Britain, creosoted pine or fir railroad sleepers, value, $\$ 7,000$. The quantities are unknown.

All timber is free of duty.

\section{PRICES.}

The timber mostly used here for house building and furniture making is sold as follows: Teak, $\$ 1.23$ to $\$ 1.33$ per cubic foot, in planks and scantlings; jack wood and nadun 1-inch thick planks, from 6 inches to 24 inches wide, from 5 to 10 cents per sauare foot; scantlings, from 58 cents to $\$ 1$ per cubic foot; logs, from 42 to 50 cents per cubic foot; satinwood, in round logs, purchasable from Government, 33, 55, and 67 cents per cubic foot, and for satinwood, sawn to planks, 11 cents per cubic foot are added to the log prices. Ebony, in logs, $\$ 25$ to $\$ 45$ per ton, according to quality.

\section{CLIMATE.}

The climate is humid. The rainfall on the west coast is about 100 inches per annum, and amongst the hills of the interior it is sometimes upwards of 250 inches. The east coast is somewhat dryer, say 30 to 110 
inches per annum, but imported lumber of any description is not wanted there, as the forests abound in ebony, satinwood, and various other valuable timber trees.

For full particulars of rainfall, see Appendix B,* and as regards temperature, the heat is absolutely and always tropical.

\section{GENERAL BUILDING.}

Wooden houses are very rarely built in Ceylon; most of the better-class habitations are of brick, and wood enters into their construction only for the frames of the roof, doors, and windows, and occasionally for upstair floors-teak, jack, and satinwood are mostly used for these purposes, and there is no wood in the United States that could be profitably substituted for them.

There is no shipbuilding and very little railroad building; and what with native woods, and creosoted pine, for sleepers, and teak for carriages, all of the railroad demands for lumber are fully supplied. There is in fact an abundance of valuable timber always for sale; say, ebony and satinwood, which, if properly handled, would pay for exportation to the United States.

CeYlon, January 27, 1894.

W. MOREY,

Consul.

\section{Seasoning TImber.}

[Extract from the publication entitled List of the Principal Timber Trees in Ceylon, by A. Mendis Lenanayke. Translated by Consul Morey.]

To season timber so that it may become one-fifth more durable than in its ordinary state, observe the following instructions of Thomas Tredgold, esq., civil engineer, Fellow of the Institution of Civil Engineers, etc., of Newcastle-on-Tyne:

When timber is felled, the sooner it is removed from the forest the better; it should be removed to a dry situation, and placed so that the air may circulate freely about each piece, but it should not be exposed to the sun and wind. Square timber does not rift or split so much as that which is ronnd; and when the size of the tree will allow, if beans are to be used the full size of the tree, it would be a good preservative against splitting to bore them through from end to end, as is done in a waterpipe. It is irregular drying which causes timber to split, and this method assists in drying the internal part of the beam without losing much of its strength, and at the same time it would lighten it considerably.

On account of the time required to season timber in the natural way, various methods have been tried to effect the same purpose in a shorter time. Perhaps the best of these is to immerse the timber in water as soon as it is cut down, and after it has remained about a fortnight in water, but not more, to take it out and dry it in an airy place.

For protecting timber against white ants, to every gallon of water add 3 ounces of croton taglium seeds, 3 ounces margosa bark, 3 ounces sulphur, 2 ounces of blue vitriol. Immerse the timber until it ceases to absorb the water, and afterwards take out and dry in an airy situation. 


\section{INDIA.}

NATIVE WOODS.

The most notable native woods for timber are the teak (Tectona grandis) and the sal (Shorea robusta). The teak is indigenous to both peninsulas of India. In certain localities the supply may be considered inexhaustible.

Teak.-Teak reaches a girth of 10 to 15 feet, and has a clear trunk of 70 or 80 feet to the first limb. In British Burmah teak exceeds in value all other trees combined. The sapwood of teak is white and small. The heartwood, when cut green, has a pleasant and strong aromatic fragrance and a beautiful dark golden color, which on seasoning soon darkens into brown, mottled with darker streaks. The timber retains its fragrance to a great age, the characteristic odor being apparent whenever a fresh cut is made. Teak is a wonderfully hard wood, exceedingly durable and strong, and, once seasoned, does not split, crack, warp, shrink, or alter in shape. It owes its chief value to its great durability, which is ascribed, probably with justice, to the circumstance that it contains a large quantity of fluid resinous matter, which fills up the pores and resists the action of water. At the Karli caves, near Poona, there is teakwood work 2,000 years old which seems perfectly good at the present day. Teak lumber from different localities varies greatly in åppearance, weight, and strength. Teak weighs about 40 pounds per cubic foot. It is used in India for construction, bridgemaking, sleepers, and for manufacturing furniture. It is exported to Europe chiefly for building railway carriages, for shipbuilding, for making decks and lower masts, and for the backing of armor plates on ironclads. It is peculiarly useful for the latter purpose owing to the resinous matter which it contains, acting as a preventive against rust, the wood neither affecting the iron nor being affected by it. It is far superior to oak in this respect. The trade in teak is very large and important, and, notwithstanding the competition of other materials, shows no signs of diminution.

Sal.-The sal tree (Shorea robusta) is one of the most valuable timber trees in India. The sapwood is distinct, is small in amount, and not durable. The heartwood is brown in color, finely streaked with dark lines, coarse grained, hard, strong, and tough, with a remarkably cross-grained and fibrous structure. The fibers of successive concentric circles do not run parallel but at oblique angles to each other, so that when the wood is dressed the fibers appear interlaced. It does not season well, but splits and warps in drying, and even when thoroughly seasoned absorbs moisture with avidity in wet weather, increasing one-twenty-fourth in bulk and correspondingly in weight. During the process of seasoning it dries with great rapidity on the surface, with superficial flaws from nnequal shrinkage. Sal, when thoroughly $065 \mathrm{~A}-\ldots$ 
seasoned, stands almost without a rival as a timber for the qualities of strength, elasticity, and durability, which qualities it retains, without being sensibly affected, for an immense length of time. The average weight of the seasoned sal is about 55 pounds to the cubic foot. This timber is the one most constantly used in Northern India. It is in quest for beams, planking, railings for bridges, doors and window posts for houses, for gun carriages, for the bodies of carts, and, above all, for sleepers for railways. In Assam it is used for boat building. Owing to the fact that when unseasoned it is not floatable, difficulty is experienced in getting the lumber out in the log. This is overcome, however, by floating the logs either with the assistance of floats of light wood or with bamboos.

Artocarpus.-The Artocarpus chaplasha grows in Burmah and Eastern Bengal. The wood is brownish-yellow, moderately hard, evengrained, tough, durable, and seasons well. It seems to get harder and heavier as it gets older. It is used for various purposes, and is very superior for use under water.

Bamboo.-The bamboo, while in reality a grass, forms the most important portion of the minor forest produce of all forest divisions and one that increases in value every year. It would occupy a volume to enumerate by name all the uses to which the native bamboo stems are put. To the inhabitants of the regions where the bamboo luxuriates it affords all the materials required, not only for the erection but the furnishing of the ordinary house. Certain species are more serviceable for posts, others are more adapted for basket work, but with one or two species every requirement can be met. It is cut up and split into bands of every size and thickness, so as to allow of its being manufactured into mats of any degree of quality, from the finest to the coarse mats so extensively used for walls in housebuilding. Hollow bamboos are cut at the nodes lengthwise, and then opened out and flattened into slabs, which may be used for the seats of chairs, tops of tables, beds and other articles of furniture. The large Karen houses, each of which constitutes a village in itself, being large enough to contain 200 or 300 persons, are constructed entirely of bamboo. The greater part of the people of eastern India and the Malay peninsula live in bamboo houses. Bridges are built of bamboo in all parts of India. If in good condition they may be ridden over with perfect safety. The larger hollow species are used for aqueducts, water pails, pots, cups, and other vessels. A single joint of a green bamboo is often used for boiling the family dinner of rice. All sorts of agricultural instruments are also made of bamboo and the appliances for spin. ning cotton and wool, and also for reeling silk, are often constructed entirely of this material. The Assamese make fishhooks of bamboo.

Teak and sal are the most important sources of lumber, while bamboo is used more than all kinds of timber combined, for many of the uses to which lumber would be applied in other countries. Teak is preferred in all cases where permanency is required. 
IMPORTS OF LUMBER.

The imports of lumber at Calcutta, for 1892-1893, were as follows from the different countries:

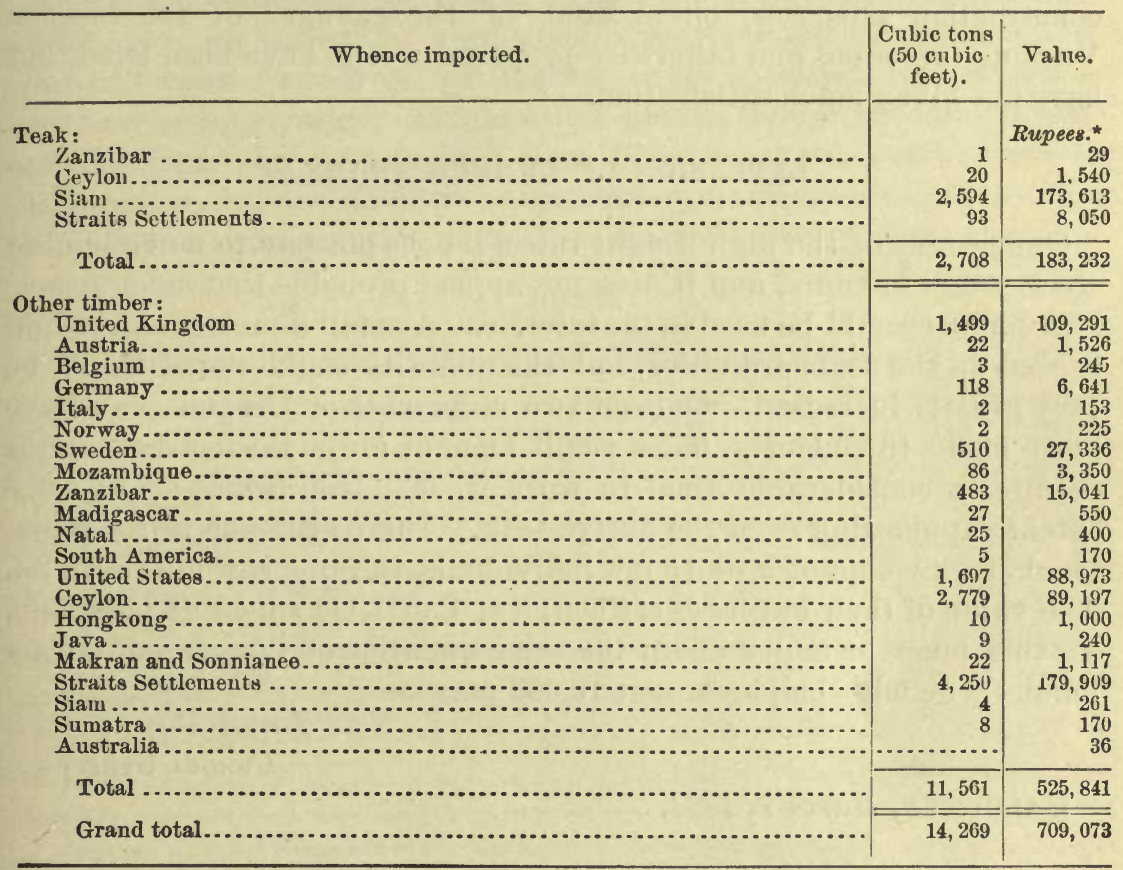

* On April 1, 1894, the value of the rupee, according to the U. S. Treasury, was 22.1 cents.

\section{DUTY AND PRICES.}

There is no import duty on lumber from any country.

In the Calcutta market the prices of lumber per cubic ton (50 cubic feet) are as follows: Teak, 85 to 100 rupees $(\$ 18.78$ to $\$ 22.10)$; sal, of superior quality, 125 to 150 rupees $(\$ 27.62$ to $\$ 33.10)$; sal, of inferior quality, 60 to 75 rupees ( $\$ 13.26$ to $\$ 16.75$ ); Oregon pine, 50 to 60 rupees (\$11.05 to $\$ 13.26)$.

\section{CLIMATE AND GENERAL BUILDING.}

The climate of India is tropical. Up country it is hot and dry, and in Bengal and eastern India, hot and damp.

But little lumber is used in building in Bengal, such as is used being principally teak. Other timber would not be safe on account of the white ants and borers, which eat out and honeycomb other timber in every direction. The walls of the houses of the better classes are of brick, with teak beams, the roofs being cemented. The native houses are more cheaply built with walls of bamboo stems and matting, plas. tered with mud, and thatched roofs. 
The shipbuilding of India is practically of no moment. In railroad building, there were opened to traffic last year $395 \frac{1}{2}$ miles of line. The total railway mileage of India is $20,272 \frac{1}{2}$. The officials of the Indian railways endeavor, wherever possible, to use iron for crossties and for construction purposes, on account of the ravages of the insects. Various creosoted and otherwise prepared woods have been tried, but have not given much satisfaction.

\section{EXTENSION OF LUMBER TRADE.}

On account of the high freight rates, it does not pay to move lumber about much in India, and it does not appear probable that much American lumber could be used in the interior. A small quantity can be and is used in the seaboard cities, but the quantity could not, I think, be very greatly increased. One or two shipments of Oregon pine have been made to Calcutta, but a small amount gluts the market, and it requires a considerable time to work it off. Iron beams are to some extent supplanting even the native teak. There are some thirty registered stock companies, and a few individuals, running sawmills in India. The value of their output is estimated at $12,031,111$ rupees $(\$ 2,656,765)$. To this must be added about the same quantity of lumber got out by hand. The mills employ about 10,000 persons.

VAN LFER POLK, Consul-General.

Calcutta, March 7, 1894.

\section{CHINA.}

\section{AMOY.}

\section{NATIVE WOODS.}

The native woods are nearly the same as in the United States, and include pine, oak, cedar, cherry, chestnut, ash, whitewood, and locust. Native woods well known in the United States are bamboo, teak, ebony, ironwood, boxwood, and camphor wood.

\section{KINDS OF LUMBER USED.}

Pine is the favorite lumber, especially in the form of "Foochow poles," which are long trunks, stripped of bark and branches. Almost equally popular is the bamboo. Teak is used, wherever the expense will allow, in house and naval construction, on account of its resistance to decay, to white ants, and to boring insects. 


\section{IMPORTATIONS.}

It is very difficult to obtain figures as to the importation of lumber. So much comes into port in the form of dunnage, ballast, loans, and spare pieces-none of which are recorded by the customs-that no accurate estimate can be made. Thus, the Amoy customs reports of 1892 give the imports of hard-wood planis at 4,507 , valued at $\$ 2,375$; imports under "sundries" of lumber are not specified. In the market we have camphor wood in trunks and planks from Formosa, poles and planks from the interior and from Foochow, hard woods from the Philippines, Borneo, the Straits Settlements, and South China. Upon the whole the importation of lumber can not be very large.

DUTY.

The duty on imported lumber and tumber is as follows:

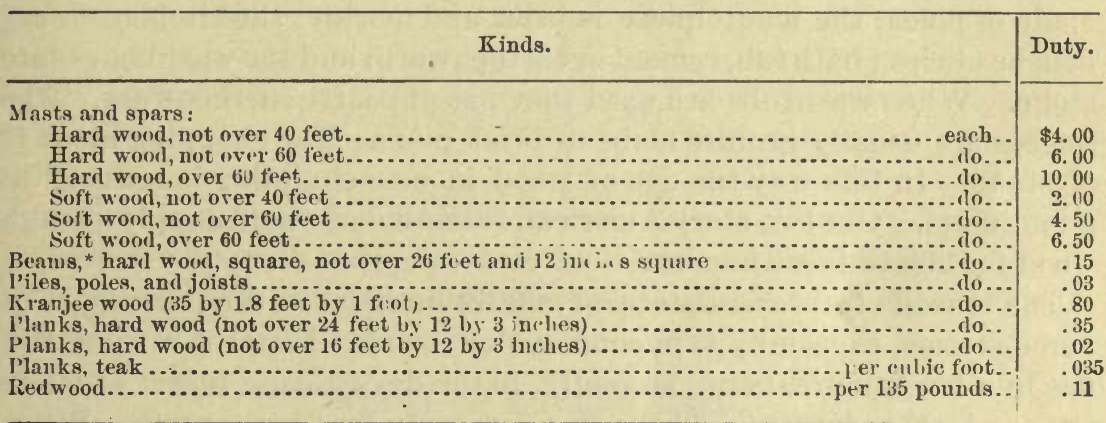

Soft wood planks, 6 inches aud over in thickuess, 5 per cent ad valorem.

* Five per cent ad valurem or optional.

\section{CLIMATE.}

The climate of Amoy is tropical and unhealtliy. The city is a nest of smallpox in winter and of cholera in summer. The weather is never cold. Snow has fallen once in fifty years. In summer the thermometer is at about $85^{\circ} \mathrm{F}$. for five months. In winter it averages about $60^{\circ} \mathrm{F}$. The hygrometric conditions are peculiar. Sometimes the air is so dry as to be unpleasant, while at others it is saturated with moisture. In the latter state sugar and salt, if exposed to the atmosphere, become liquid, woolens become wet and moldy, leather is levoured by fungoid growth, and floors, walls, and ceilings are covered with water.

Wood shrinks considerably in the dry season, and expands rapidly and powerfully in the wet season. For this rea-on doors and windows either rattle in their casings or are opened with great difficulty.

\section{GENERAL BUILDING.}

Although the housebuilder of China, especially Southern China, uses brick, tile, stone, and cement in every possible manner, even going 
so far as to construct 95 per cent of all floors of these materials, and avoids the use of wood as far as he can, there is still a large and everincreasing trade in lumber. It is used in architecture, shipbuilding, furniture-making, box-making, coffin-making, church decoration, and theater-framing. It is not used in house-framing or bridge construction by reason of storms and white ants; nor in sheds, wharves, plank roads, fences, and railings.

Building never stops. Chinese houses are not made to last. Not one in a thousand will last thirty years unless constantly repaired. They contain from two to forty rooms each and are usually one story in height. The foundations are cut granite; the walls cheap brick, covered with mortar and kalsomined; the roof is tiled with red tiles; the floor is tiled or bricked; the casings of doors and windows are generally granite; the windows are barred with wooden, iron, or granite bars; the doors are made of planks, with heavy cross pieces; the roof and beams are made of poles; the mantelpiece is brick and mortar; the kitchen, stone; benches, brick; bath tub, cement or earthenware; and the washboards are stone. When washtubs are used they are of coarse earthenware. The settees are usually granite slabs or brick piers. The chopping block is of stone. In this way the use of wood in housebuilding is reduced to a minimum. One two-story American frame house would supply enough wood for 200 Chinese houses.

The reason of this odd state of affairs lies first in the prevalence of fierce storms, especially typhoons, which would shatter a wooden edifice in a few minutes; and, secondly, in the devastating power of white ants and other insects. There is no remedy for these pests. When they get into a roof beam the beam must come down and a new one be used in its place, otherwise the roof may come down any moment and crush the entire household.

In shipbuilding the Chinese prefer their own woods and their own system to ours. Of a hundred foreign ships, condemned and sold in this district, only one was ever utilized by the natives for maritime purposes.

There may be a good field in this district for tea wood; that is, the thin sawn boards with which they make tea boxes. At least 1,000,000 boxes are made here every year. They are made by hand and marketed in shooks like shingles. A modification of the shingle machine would turn these out at a much lower cost and produce a far better article. If the woods would serve the purpose, I doubt not but that the California redwood and the Uregon pine might be worked up into tea wood and form a profitable commodity. If freights and insuranco added to prime cost destroyed the apparent profit, there might still be a chance here for the ingenious shingle machines of the Pacific coast.

William E. S. Fales,

Vice-Consul in charge.

AMoY, April 12, 1894. 


\section{CANTON.}

Nearly all of the timber used in buildings is brought from Borneo, and is a heavy, hard wood, something like teak; it is sawed here as required. From the adjoining province of Kuang Si, some soft wood is brought for fuel, and some for beams, door and window casings, boxes, etc. There are no trade statistics available as to the quantity imported. Little or no American lumber reaches this market. The destructive action of white ants upon all kinds of wood, and especially upon soft wood, is awful, and is a serious feature in buildings.

\section{Charles Seymour,}

Canton, March 12, 1894.

\section{Consul.}

\section{HONGKONG.}

\section{NATIVE WOODS.}

There are no trees indigenous to the island of Hongkong.

Its present well-wooded condition is due entirely to artificial afforesttation.

\section{KINDS OF LUMBER USED.}

China fir, for flooring, door and window frames, rafters, and scaffolding. There are forty-eight varieties of hard wood imported from the Philippine Islands, viz: Acle, agajac, amogins, antipolo, annbing, apition, aranga, baucal, bauaba, bausalagque, bauoyo, baticulin, batitiuan, betis, calamansaseay, calimbajim, columpit, camagon, culasi, cedar, dalinoe, daugay, dingeas, doliton, dougon, guijo, ipit, labuan, lanete, macasin, manguchapuy, malarujat, malasaguin, malatapay, molare, narra, pæna, palomaria, palma brava, palo maria de playa, taughili, tindalo, tindu-pantay, tucan-calo, tuog, supa, uban, yacal.

Of these Aranga, Molave, and Yacal are the only varieties in constant demand for house, ship, and wharf building purposes.

Molave is especially adapted for rudders, stem and stern posts, and piles, being practically weatherproof and not attacked by worms.

Aranga and Yacal are chiefly used for flooring, planking of wharves, and the outside planking of ships.

From Borneo are obtained Yacal, Kruen, and Serayat.

Kruen is largely used for the sheathing and casing of electric wires in houses.

Serayat is consumed in large quantities by the manufacturer of socalled "camphor-wood trunks." The grain resembles closely that of the genuine camphor wood, and when the Serayat has been steeped 
in a solution of camphor, dried, and polished, only an expert can distinguish between the genuine and the counterfeit. Teak, China fir, and the genuine camphor wood are imported from the interior of China. A small quantity of Oregon pine is brought from the United States. This is at present used only for repairing ships and replacing masts and spars. The quantity is comparatively small, the bulk of it being brought by one vessel, a bark of about 800 tons, which makes one voyage a year.

\section{DUTY AND PRICES.}

Hongkong being a "free port," there are no import duties and no custom-house; hence it is absolutely impossible to obtain any statistics of the amount of lumber imported from other countries.

Oregon pine sells for about $\$ 30$ per 1,000 feet. The various hard woods bring from 60 cents to $\$ 1.25$ a cubic foot, according to quality.

\section{CLIMATE.}

We have practically only two seasons in the year, the dry and the rainy. The first lasts usually from September or October to February, inclusive, the second during the rest of the year. The heaviest rainfall is usually in June, when the heat is oppressive. After the 1st of July the humidity of the atmosphere greatly diminishes, and although the temperature during July and August averages $80^{\circ}$ to $81^{\circ} \mathrm{F}$. (the maximum for last year being $93.9^{\circ}$ ), the heat is by no means unbearable for persons properly clothed.

During July, August, and September Hongkong is subject to frequent circular storms or typhoons, which usually arise in the Philippines and travel northward up the Formosa Channel and the east coast of China, occasionally proving very destructive to life and property, particularly if they bend to the westward and go inland.

From October to January is usually the pleasantest part of the year, closely resembling the New England autumn or Indian summer. The lowest temperature recorded in 1892 was $44.2^{\circ} \mathrm{F}$.

Although the city is built on a rocky hillside, malaria is very prevalent; but this is chiefly attributable to the entire absence (until recently) of drainage. Under the present enlightened régime there is no doubt that Hongkong should become, like Singapore, a recog. nized sanitarium for those debilitated by malaria or bowel diseases.

W. E. HuN', Consul.

HoNGKoNG, February 22, 1894. 


\section{TIENTSIN.}

NATIVE WOODS.

There is really very little timber grown in the vicinity of Tientsin, or in the Provinces of Chihli, Shantung or Shansi. A considerable amount of elm, however, used here by the natives, for sinall repairs to houses, junks, etc., comes from the country in the neighborhood of Peking.

So far as I can discover there are no uncommon varieties of wood in the large section of China north of the Yellow River or Hwang-ho.

For centuries there has been no recorded policy in China for the protection of forests. The result is that the country is almost barren of timber, few trees escaping the woodman's axe sufficiently long to reach maturity.

Sometime ago the viceroy of the Province of Chihli, Li Hung Chang, who resides at Tientsin, realizing the situation, which was forced upon his notice by undertakings under his control requiring large and heavy timber, offered a bonus to encourage villagers in the cultivation of trees, but the few attempts that were made proved futile.

China is, therefore, wholly dependent upon other countries for lumber required in enterprises of any magnitude-a fact worthy of attention.

\section{KINDS OF LUMBER USED.}

For wharves, jetties, and many works on the Imperial Railway of Northern China, requiring lumber of considerable lengih and thickness, Oregon pine has scarcely a competitor. Its only rival is the cheaper and commoner pine from Korea, used where medium sized timber is needed. In railway construction in Northern China, to the discussion of which I shall devote a special paragraph, Oregon pine is used for all temporary bridge structures, for roofing, and for building freight cars. Teak is the wood employed at present in constructing passenger cars. Two cargoes of Oregon lumber, by sailing vessels, were bought by the Imperial Chinese Railway Company last year, and I am informed that another cargo is soon to arrive.

About eleven years ago Oregon pine was for the first time imported direct from Victoria, British Columbia, and from Port Townsend, but previous to that time a considerable supply of this wood reached Tientsin, via Shanghai and Hongkong. Even now it is so imported at intervals.

So far, then, as soft wond is concerned, we may safely assume that Oregon pine is safe from rivalry.

There is a large market here for hard wood, which market is untouched except from Vladivostock, Russia; Sandakan, Borneo; 
Laquimanoc, Philippine Islands. The hard wood from Russia is generally small, ranging in size from 12 by 12 up to 16 by 16 inches by 25 to 30 feet in length, and is known as hakmatak. But this hard wood is not a dangerous competitor to the hard woods from Borneo and the Philippine Islands, the Russian Government frequently refusing to allow it to be exported, as it is in demand for the Siberian Railway.

Of Borneo woods the best is billian, and for strength and durability this wood can scarcely be surpassed. It bears exposure well, and seems almost indestructible. When newly cut, billian resembles oak, but with age and exposure it becomes as black as ebony. Samples of this wood have been shown me weighing 70 pounds per cubic foot. Other Borneo woods imported are russock, kapore, and serayah. The lastmentioned wood has a strong resemblance to soft mahogany, and is used for all purposes for which pine is suitable, and for furniture. Although serayah is soft, and therefore easily worked, it is very strong, tough, and heavy, weighing, on an average, 43 pounds per cubic foot. Borneo woods average in size 12 by 12 to 14 by 14 inches by 30 feet in length. If the question of expense is laid aside, one can with difficulty obtain Borneo woods 20 by 20 inches and 30 feet in length.

I am satisfied that, taking everything into consideration, the hard woods preferred in northern China come from the Philippine Islands. Of these, it has been estimated there are 30 varieties that have been brought from time to time to Tientsin. The best-known Philippine wood is the teak-like molave, which is grown from 11 to 22 feet in length and 12 to 24 inches square. Special lengths of this wood from 30 to 35 feet can be obtained to a limited extent at considerable extra cost. Molave is an excellent wood for resisting the action of the climate, which at times is very dry and at others very wet. It is also especially valuable for work on the surface or underground, as it is impervious to the action of the lime with which the soil around Tientsin is impregnated. This wood, as well as another variety known as bausalaque, is in general use for all purposes where an extra strong and durable wood is required.

The Chinese use a considerable quantity of hard wood yearly for general purposes and for repairing temples around Peking and in building and maintaining in order the imperial mausoleums. Work on the temples and tombs requires, not infrequently, wood 20 to 30 inches square by 40 to 60 feet in length, and Tientsin merchants, whenever they are able to supply such wood free from knots, cracks, and other defects, religiously observe the privilege of naming their own price.

Large quantities of small, soft-wood planks are frequently imported from Japan. These planks are very cheap. A Japanese soft-wood plank measures approximately 7 feet in length by 12 to 14 inches in width by 1 inch in depth, and is sold for 12 to 13 tael cents, or, at pres. ent low exchange, $8 \frac{1}{2}$ to $9 \frac{1}{4}$ Americau cents. 
IMPORTS OF LUMBER.

Hard wood.-It is extremely difficult to locate the exact source of all the hard wood that comes to Tientsin, but it may be assumed that it is mainly shipped from Borneo, the Philippine Islands, and Russia. I have not discovered that hard wood comes from other quarters than those mentioned, although occasional shipments of Borneo woods come from Singapore.

Soft wood. -The following table of the imports of wood for 1889, 1890, 1891, 1892, and 1893, made up from the imperial maritime customs returns, gives but an imperfect idea of the sources and quantities of soft wood imported. A considerable portion of soft wood is transshipped at Chinese ports, before reaching Tientsin. This is a source of annoyance to the customs officials, who can not avoid making mistakes in separating the importation of native from foreign woods. A strenuous effort is made to do so as is shown by the divisions in the table. It is regrettable that this table does not convey a fair idea of the trade, as the customs do not take cognizance of timber imported for Government undertakings, of which the principal is the railway supplies, for such enterprises are passed duty free. Shipments from the United States destined for Tientsin could be more accurately ascertained at the ports of loading. Soft-wood logs come from Korea as mentioned above and a great number of soft-wood planks come from Japan.

In 1893 the railway imported from Japan 44,991 sleepers or ties. C. W. Kinder, esq., engineer in chief of the railway company, informed me that Japan sends most of the sleepers, quotations from the United States and Canada being too high, owing to the freight.

I am also well informed that a great number of the soft-wood planks returned as coming from Chinese ports are in reality sent from Japan and transshipped at Shanghai.

Table of imports.

\begin{tabular}{|c|c|c|c|c|c|}
\hline Description. & 1889. & 1890. & 1891. & 1892. & 1893. \\
\hline Hardwood beams: & & & & & \\
\hline From foreign countries ............... pieces.. & 5,912 & & & & 137 \\
\hline $\begin{array}{l}\text { From Hong kong and Chinese ports... } \\
\text { Hardwood logs: }\end{array}$ & 579 & 2,447 & 1,565 & 539 & 18 \\
\hline From Hongkong and Chinese ports....do.... & & & & *33, 795 & 150 \\
\hline $\begin{array}{l}\text { Hardwood planks: } \\
\text { From Hongkong and Chinese ports....d }\end{array}$ & 1,086 & 102 & & & \\
\hline $\begin{array}{l}\text { Native wood from Chinese ports............. } \\
\text { Softwood planks: }\end{array}$ & 9,364 & 225 & 1,096 & 1,121 & $\cdots$ \\
\hline $\begin{array}{l}\text { Soltwood planks: } \\
\text { From foreign countries .......... square } f\end{array}$ & 537,506 & 397,104 & 476,982 & $3: 36, n 61$ & 235,768 \\
\hline $\begin{array}{l}\text { From Hongkong and Chinese ports....do.... } \\
\text { Native wood from Chinese ports...... do... }\end{array}$ & $1,601,504$ & $1,035,918$ & $1,412,363$ & $862.291\}$ & $1,629,181$ \\
\hline $\begin{array}{l}\text { Native wood from Clijuese ports......... } \\
\text { Soft-wood beams and logs : }\end{array}$ & 553,313 & 557,530 & 626,455 & 354,0195 & $1,0 \sim 0,10$ \\
\hline From foreign countries $\ldots \ldots \ldots \ldots \ldots$ pieces.. & 1,607 & 923 & & & 2,850 \\
\hline $\begin{array}{l}\text { From Homgkong and Chinese ports.... do.... } \\
\text { Native wood from Chinese ports....... do.... }\end{array}$ & & & 22,939 & 4,846 & (n............ \\
\hline
\end{tabular}

* Cubic feet. 


\section{DUTY.}

The duty on importations of wood, except those destined for Government enterprises, which are duty free, is 5 per cent ad ralorem. This is not, however, the only charge that a cargo of lumber has to bear. The bar at the mouth of the river Peiho, which vessels drawing more than $11 \frac{1}{2}$ to 12 feet can not get over, necessitates lighterage. Lighterage charges are heavy, being 2.75 taels * $(\$ 2.10)$ per 1,000 superficial feet, from outside the bar, and 1.75 taels $(\$ 1.34)$ per 1,000 superficial feet from inside the bar to the foreign settlement at Tientsin.

Tientsin is situated 27 miles in a straight line from the mouth of the Peiho River, where there is a small settlement called Taku. The Peiho is a narrow, shallow, muddy river, and the distance from Tientsin to its mouth, by its meandering course, is about 50 miles. Tientsin is closed to navigation during the months of December, January, and February on account of the ice, which blocks the entrance to the Peiho during these months.

\section{PRICES.}

If entire cargoes are taken, the prices are naturally cheaper than those given below, which are current for lumber now on hand. It should also be borne in mind that, owing to the recent heavy drop in exchange, shipments made now can not compete by at least 30 per with the stock on hand. Oregon pine 10 by 10 to 20 by 20 inches by 30 to 50 feet can be obtained for 37.50 to 38 taels ( $\$ 28.69$ to $\$ 29$; tongued and grooved Oregon pine planking is now quoted at 31 taels $(\$ 23.72)$ per 1,000 superficial feet. Vladivostock hardwood is quoted at 23 cents per cubic foot; Borneo hard wood, 65 cents per cubic foot; Philippine hardwood, 84 cents per cubic foot; Koean soft wood, 15.3 cents per cubic foot; Japanese planks, 9 to 10 cents each. Borneo and Philippine hard wood, in sizes over 12 inches square, bring more according to size than the prices above given.

\section{CLIMATE.}

Tientsin has a cold, dry winter, the thermometer falling frequently to zero. The summers are extremely hot, with frequent intervals of heavy rains, accompanied by great humidity, and the thermometer has been known to register in the shace as high as $110^{\circ} \mathrm{F}$. The spring and autumn months are agreeable in temperature, the transition from winter to summer and vice versa being gradual. The climate is considered a fairly healthful one.

\section{SHIPPING AND EXCHANGE FACILITIES.}

As a means of developing the lumber trade of the United States with this section of China, attention should be given to what might be called "useful tonnage."

"Haikwan (customs) taels $=76.5$ cents-U. S. Treasury valuation on April 1,1894 . 
Sailers that draw about twelve feet when the deck load is taken off, and that can carry as many logs as possible, without a heavy propor. tion of "broken cargo," or planks and laths (which latter always sell badly and reduce the profits on the venture), and that are about 400 tons measurement, are cousidered by experienced 'Tientsin merchants to be handiest and best. A vessel of the above description with a 6 -foot deck load should bring 450,000 superficial feet to the bar, and 300,000 up to Tientsin itself, the vessel being lightened of 150,000 feet to enable it to get over the bar.

There are no difficulties in the way of financing shipments, as the prominent banks of China are represented at this port.

The following foreign houses interested in American trade are established here: Carlowitz \& Co., Collins \& Co., Cordes \& Co., William Forbes \& Co., Hatch \& Co., Jardine, Matheson \& Co., Mackenzie \& Co., E. Meyer \& Co., Philippot \& Co.; and Wilson \& Co. The firm most exten. sively interested in lumber here is William Forbes \& Co.

\section{GENERAL BUILDING.}

Railvoay construction.-During the last year rails were laid to Shan Hai Kwan, a distance of 180 miles from Tientsin, by way of Taku. Shan Hai Kwan is on the Gulf of Pechihli at the eastern terminus of the Great Wall, and the road is apt to stop here for the present as funds are in great demand at Peking for the festivities soon to occur, on the occasion of the Empress Dowager's sixtieth birthday. The first 80 odd miles of this road to Shan Hai Kwan are under the control of the China Railway Company and lead up to the Kaiping coal mines. These mines are the chief reason for this road, from the mines to Taku. The remaining 100 or less miles belong to what is known as the Imperial China Railway, of which Li Hung Chang is the director-general.

It is intended in time to push the Imperial Railway beyond the Great Wall in a northerly direction through Manchuria to Moukden and Kirin, in the neighborhood of the Russian frontier, a distance of about 450 miles from Shan Hai Kwan. This contemplated extension will require many temporary wooden bridges.

It is the imperial policy to replace all temporary bridges and works by steel structures and solid masonry.

The progress of railway extension in this consular district will be noted from time to time in iny general reports to the Department. As the only railway in this vast Empire, its development will undoubtedly be carefully watched by those interested in railroad construction.

The Kaiping coal mines above mentioned are the only considerable mines in China worked by foreign methods and machinery.

$$
\text { SHERIDAN P. READ, }
$$

Consul.

Tientsin, February 27, 1894. 


\section{JAPAN.}

\section{NAGASAKI.}

\section{NATIVE WOODS.}

Kiyaki, the hardest wood of Japan, resembling oak in fiber and capable of high polish, is used chiefly for fine work and for frames of ships. It is becoming very scarce, the price within the past few years having doubled. Hinoki, the finest kind of pine, is used in better class house building, furniture, for lacquerware, and for building Shinto temples. Sugi, fine cedar, principally used in house and shipbuilding. Aka matsu and kuro matsu, ordinary pines, decay rapidly under exposure to the atmosphere; used in common work. Kashi no ki, a species of oak, very scarce and small; used only for finest work. Kuso no ki, camphor wood; used for frames of ships, boxes, etc. Taki (bamboo), exists in considerable quantities, and, as elsewhere, is considered the most useful of woods.

\section{KINDS USED, AND IMPORTS.}

The wood most commonly used is pine.

The annual imports of lumber are about as follows: From Oregon, $\$ 30,000$; from Philadelphia, $\$ 49.50$; from India (teak), $\$ 86,686$; from China, $\$ 10,000$; total, $\$ 126,735.50$.

\section{DUTIES AND PRICES.}

The duty on imported lumber is 5 per cent ad valorem.

The prices are as follows:

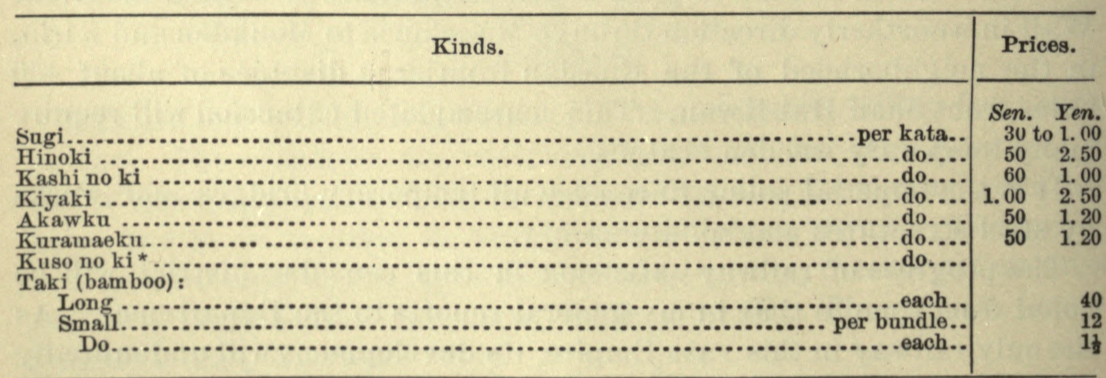

The kata $=14$ feet long and 5 inches wide and thick; the yen $=53 \frac{1}{2}$ cents American; 100 sen $=1$ yen.

* Used only for the extraction of its oil. None in the market.

\section{CLIMATE.}

At Nagasaki the thermometer ranges from $30^{\circ}$ to $98^{\circ} \mathrm{F}$., showing marked differences from places in the same latitude in the United 
States. The climate nearly resembles that of Charleston, S. C. Continuous hot weather begins about June and lasts until the middle of September.

\section{GENERAL BUILDING.}

With the exception of native junks, the only shipbuilding in this district, to any extent, is done by the Mitsu Bishi Company. There is a line of railroad running from Moji to Kumamoto, a distance of about 120 miles. There has been but little increase in railway mileage for the last six years.

The Mitsu Bishi Company, who have their engine and shipbuilding works at A kenoura, opposite Nagasaki, are the largest and, I believe, the only importers of Oregon lumber, as yet, in this district. They import quantities to the value of about 30,000 yen yearly, in lengths of 30 to 40 feet by about 3 to 6 inches; this is specially prepared and ordered six months in advance. The price for Oregon pine would be about $\$ 39$, gold, per 1,000 superficial feet in Oregon; delivered here, about $\$ 50$, gold.

The Mitsu Bishi Company have built during the past year 3 steamers, registered tonnage, 500 each, with triple expansion engines; speed, 10 to 11 knots; 1 vessel of 1,500 tonnage, triple expansion, 11 knots; and one of 2,000 tons, triple expansion, 11 knots. All of these are of the highest class, registered at Lloyd's $100 \mathrm{~A} 1$.

\section{EXTENSION OF LUMBER TRADE.}

Large quantities of lumber have been exported to China from Kiashiu, but the amount is steadily decreasing. As far as the Island of Kiushiu is concerned, the rapid destruction of the native forests is rendering wood more and more scarce, with a corresponding steady advance in price from year to year; it is therefore only a question of time when lumber, especially seasoned pine from the Northern Pacific coast, will find a large and growing market in Southern Japan.

W. H. ABERCROMBE, Consul.

NAGASAKI, February 5, 1894.

\section{OSAKA AND HIOGO.}

NATIVE WOODS.

The principal native woods in this consular district are pine, cypress, beech, chestnut, oak, and the fir, of which there are many varieties. In the production of lumber and timber for building, these woods supply almost the entire needs of the country.

There is one variety of the cypress family (the hinoki) which is 
especially valuable and highly prized. The wood of the hinoki is generally very white, sometimes slightly pink, very fine grained, tough, with little resin, and free from knots. The tree is found chiefly on the mountain sides, and flourishes in a soil composed of granite or volcanic rock. It has long been regarder as sacred, and is planted in many places along the roadside, and forms beautiful avenues leading to temples. The trunks are straight, having a circumference of from 12 to 13 feet and a height of from 100 to 120 feet. The wood is used in the construction of temples, for the oruamental decoration of the most expensive houses, and is preferred for lacquer ware.

There is another wood called kiaki, which by some is said to belong to the family of the beech, by others to that of the oak, but the grain is not so fine as that of the beech and the specific gravity is less than that of the oak. The tree resembles the beech in the color of its bark and general appearance, and resembles the oak in the grain of the wood. The kiaki is regarded as furnishing the best building timber in Japan, but, being expensive, is used mostly for joiner work.

There are three varieties of the fir, which furnish the usual building wood for houses, the sugi, momi, and matsu; the latter, being the strongest, is also used in bridge building. Extensive forests of these woods are cultivated by private individuals, and as the trees grow rapidly, the wood is much cheaper and more abundant.

It is estimated in official reports that of the entire acreage of Japan 23 per cent is covered by mountain forests, owned entirely by the Government, and 18 per cent by cultivated forests, the property of private owners.

\section{PRICES AND IMPORTS.}

The price of the above-named lumber is as follows per square foot: Kiaki, 54 sen; hinoki, 54; momi, 20; matsu, 25; and sugi, 21.

At the present rate of exchange 100 sen (one yen) equal $53 \frac{1}{2}$ cents United States gold.

\footnotetext{
Imported from-

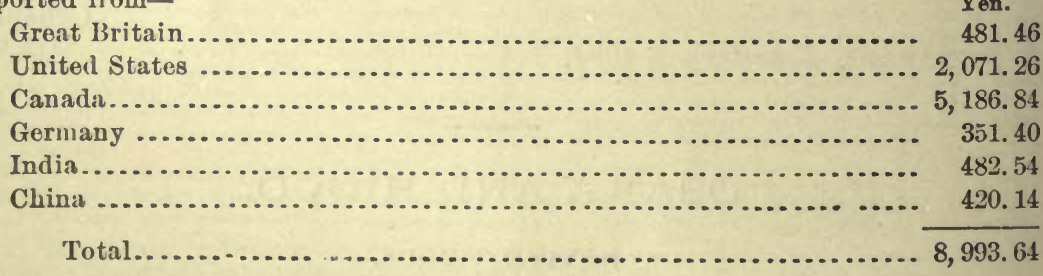

The imports of foreign lumber at Osaka amounted to a little less for the same period. Foreign lumber is used at both ports in relaying the decks of foreign constructed vessels and in refurnishing their masts and spars. A small amount of Indian teak and other high-priced woods are imported for the manufacture of furniture.
} Imports of lumber in 1893. 


\section{CLIMATE.}

The highest maximum of temperature at Hiogo for the past seventeen years was $96^{\circ} \mathrm{F}$, but that was exceptional, as the mercury seldom reaches $94^{\circ}$. The lowest maximum temperature during the same period was $23^{\circ}$; this was also exceptional, as the mercury seldom falls below $26^{\circ}$. The average yearly rainfall is 47.41 inches.

E. J. SMithers,

Consul.

Hiogo, February 1, 1894.

NETHERLANDS-INDIA.

JA VA.

NATIVE WOODS.

The principal woods of Java are teak, iron wood, red wood, rasamala, and cocoa.

Teak wood is of the same species as that of India, is of a dark yelowish color, with fine grain, and is the common wood used for all kind of buildings.

Iron wood is very much the same as ebony; hard as iron, from which it takes its name, and very heavy, sinking in water. It is proof against all insects.

Red wood is red in color, and also very hard, with fine grain. It is not used much in Java for building purposes, as it is not a durable wood.

Rasa-mala is very much like red wood in color, but much more valuable, and is used for pilings for buildings where a solid foundation is required, as it is proof against all insects, such as white ants, etc., which destroy most woods.

Cocoa wood is almost black, with yellow stripes. When old it is used by the natives, but is of little value for building, as it soon decays when exposed or when in the ground.

There are many other kinds of woods, but little is known about them, as they are not used.

\section{KINDS OF LUMBER USED.}

There are two kinds of lumber used, teak and Singapore planks, the former being preferred for its durability; the latter are used by the Chinese for building, but they soon decay and are also destroyed by the white ants.

$665 \mathrm{~A} \longrightarrow 7$ 
IMPORTS OF LUMBER.

About 20,000 feet of Singapore lumber are imported monthly into this district from the Straits Settlement and from Siam.

\section{DUTY AND PRICES.}

There is no duty on lumber. There are no regular price lists issued. Teak is generally bought by the log and Singapore wood by the 100 planks. A teak log 9 feet by 15 inches sells usually for $\$ 3$, and Singapore planks for $\$ 25$ per 100 , the plank being 15 feet long, 1 foot wide, and 1 inch thick.

\section{CLIMATE.}

The climate of Java may be divided into the following seasons: The East monsoon, or dry season, from April to October, is dry and hot during the day, with a temperature of nearly $90^{\circ}$, and damp and chilly at night, when the temperature is about $80^{\circ}$; the West monsoon, or wet season, prevails from October to April, when the temperature ranges from $80^{\circ}$ to $85^{\circ}$ during the day and night, with a very damp and close atmosphere and almost continuous rain. This season is generally much healthier than the dry season. During this rainy season epidemics are unknown.

\section{GENERAL BUILDING}

With the exception of the Javanese houses in the country, which are coustructed of bamboo, nearly all the buildings in Java are of brick and lime, the doors and windows being generally of teak.

Where buildings are constructed on pilings, the native woods, such as rasa mala, or ironwood, are always used.

Vessels exceeding $\mathbf{1 0 0}$ tons register are seldom built of wood in Java, but such vessels as are built of wood are always built of teak.

Where wooden railway sheris are erected they are generally of teak; a few have frame of teak and Singapore wood for planking.

In former years cargoes of pitch-pine timber and spruce spars were imported from the United States, but for a number of years such importations have ceased, there being no demand for these woods.

Government warehouses built within the last few years are of iron, or iron frames and roofing, and brick walls. Private warehouses are built of brick, with tile or iron roofing.

All petroleum warehouses must be built of brick, and not less than 100 meters from any other building.

Batavia, March 22, 1894.

B. S. RAIRDEN, Consul. 


\section{SIAM.}

\section{NATIVE WOODS.}

The principal woods found in Siam are teak, rosewood, ebony, taback, and bamboo.

Teak is too well known to require a description. It is used exten. sively in Asia and Europe in shipbuilding, and considerable has been shipped from this port to San Francisco in 1893.

The rosewood and ebony are about like woods of this character found in other parts of the world. The former is of the finest variety, how. ever, while the latter is somewhat inferior in color and size to a firstclass grade of this wood.

Taback, in grain and color, is somewhat like the maple found in the United States. It is, however, brittle and soft and is not considered durable. There are other woods, but of minor importance.

\section{KINDS OF LUMBER USED.}

Teak and a common variety of lumber, imported from Singapore, somewhat like pine, but very much inferior, are about the only varieties of lumber used in Siam.

\section{IMPORTS OF LUMBER.}

It is impossible to give figures in answer to this question since the customs returns do not show it. Lumber is received under the head of miscellaneous goods and therefore may be classed along with any. thing and everything. The quantity is not large however, probably less than $\$ 15,000$ worth annually.

\section{DUTY AND PRICES.}

The import duty laid upon foreign lumber is 3 per cent ad valorem.

The prices of lumber are as follows: Square teak logs and planks range from 80 to 90 cents per cubic foot, according to dimensions; and unhewn or rough logs range in price from $\$ 8$ to $\$ 16$ per log.

"Singapore planks or lumber" (so called, as it is imported from that place, to which it is brought from the Malay Peninsula) is used here in building sheds and cheap shanties; the principal dimensions are 10 by 6 by $\frac{1}{2}$. It is sold by the 100 planks, or pieces, at from $\$ 4$ to $\$ 5$.

Rosewood is sold by weight, at from $\$ 1$ to $\$ 2$ per picul (133 pounds). "Ebony," small sized logs-not pure black-is exported to China only, where it is used for making chopsticks. It ranges from 50 cents to $\$ 1$ per 133 pounds.

All the above prices, which are wholesale, fluctuate from 30 to 40 per cent, according to supply and demand. 
CLIMATE.

The climate of Siam, while tropical, varies, for its territory extends from about $2^{\circ}$ to $19^{\circ}$ latitude north. The temperature in any part, however, rarely gets below $60^{\circ} \mathrm{F}$., and generally averages between $90^{\circ}$ and $100^{\circ} \mathrm{F}$.

\section{GENERAL BUILDING.}

The building in Siam is limited, and is generally confined to this city. The upper classes among the natives build upon European plans, while the lower classes live in small bungalows, built of bamboo.

Shipbuilding is not carried on to any extent. The largest ships constructed are lighters of probably 100 tons displacement. The most of this kind of work is limited to building steam launches and rowboats.

\section{EXTENSION OF THE LUMBER TRADE.}

I believe it hardly possible to open up a market for American lumber in Siam, except, possibly, in some of the cheap varieties, which would necessarily have to be brought here at a low rate of freight, and it should be impervious to white ants, which are very destructive in this country.

Railroad building I have mentioned in a separate paper herewith inclosed.*

ROBERT M. BOYD,

BANGKOK, February 21, 1894.

\section{Vice-Cunsul-General.}

\section{TURKEY IN ASIA.}

\section{PALESTINE.}

\section{NATIVE WOODS.}

Palestine, within historic times, has never been a wooded country. At present there are practically no native woods suitable for building purposes. The celebrated oak and terebinth, which once covered the highlands with considerable forests, are now represented by a few dwarfed specimens of their kind. The olive still lines the hillsides and valleys, but does not furnish any building material, being used solely in the manufacture of olivewood ornaments and trinkets.

\section{KINDS OF LUMBER USED.}

There is very little wood used in the construction of buildings of any kind. Stone, which is so abundant, is used for every part of the struc- 
ture. A very few of the modern building's are having woơden fioors and ceilings. For this purpose pine is generally used. There is no reason why native woods should not be grown to an extent to supply the local demands. The present administration cares nothing for tree culture or economy of forests. On this account, 99 per cent of all lum. ber used is imported from foreign countries or from other districts of Turkey.

The native woods are olive, oak, orange, and fir, which are used almost entirely for fuel.

Quite a box trade has grown up at Jaffa, boxes being necessary for the shipping of the oranges grown there. The kinds of lumber wanted for this, and also for the small demand for building purposes, are pine and fir.

\section{IMPORTS OF LUMBER.}

The value of the lumber annually imported at the port of Jaffa is from $\$ 60,000$ to $\$ 100,000$. This lumber comes from Austria, Sweden, and other parts of Turkey. Austria controls the great bulk of the import trade, sending to Jaffa nearly three-fourths of all the lumber entered there. From Jaffa it is distributed to such other places as desire it.

\section{DUTIES AND PRICES.}

The amount of duty upon imported lumber is 8 per cent ad valorem. The price ranges from $\$ 8$ to $\$ 10$ per cubic meter. From 6,000 to 10,000 cubic meters are imported annually at Jaffa.

\section{CLIMATE.}

The climate of Palestine is generally warm. There is a wet and dry season. The wet season corresponds to the winter months in our Northern States. The summers are very dry and hot.

\section{GENERAL BUILDING.}

There is some activity in general building, but there is no ship or railroad building now going on in this district.

\section{EXTENSION OF LUMBER TRADE.}

No American wood has as yet found its way into Palestine. This is probably due to the long transportation necessary; but there seems to . be no reason why, with direct communication between American ports and Jaffa, our dealers should not compete successfully with those of other countries, and acquire their share of the lumber trade of Palestine.

EDWIN S. WALLACE,

Consul.

Jerusalem, February 3, 1894. 


\section{SYRIA.}

\section{SYRIAN-AMERICAN COMMERCIAL RELATIONS.}

The general question of increasing the exports of American lumber is of great moment in the timber-growing States, but special attention should be challenged by a country as much in need of lumber as is Syria and this entire section of the Orient.

The distance is, of course, the principal if not the controlling reason why American enterprise has not been felt in the East; but the inex. haustible supply, together with the cheapness of American lumber, should recognize no barrier, and should create a demand and provide a means of supplying that demand in any direction and in all countries. No better time could be seized for this purpose than the present.

In the old days of sailing vessels there was considerable exchange of oriental stuffs for American lumber, which came direct from the United States and was highly valued here, but the modern facilities afforded by English steamships and the more convenient French and Austrian coasting vessels have absorbed nearly all commerce with Syria and have certainly cut off direct communication with the United States. Syrian merchants fear to open up business relations so far away from home, where they are not known and where they do not know the parties with whom they would be dealing; but it is entirely within the range of strict business expectations to foresee that the closer relations fostered by the recent World's Fair and also nurtured each year by the extending tide of tourist travel, will call for a full and friendly interchange of commercial commodities between the East and West, as represented by Syria and the United States.

There is wealth in abundance here among the well-to-do classes, as represented by the Sursock Freres and by Tueni \& Sons, who are leading bankers, and by Moussa Freige, by Bustros \& Son, and other large dealers in eastern securities and goods. The largest dealers in lumber in Syria are Joseph Khasho \& Fils and B. Audi \& Co., of Beirut. These men and their associates would readily take American products and materials if brought here direct; or they would soon fall in line and import for themselves if an experiment were successfully made and they could feel sure of mutually beneficial and reciprocal transactions. This class of merchants was not represented in Chicago, as they prefer European cities for business purposes, by reason of partial residence and years of custom; but those well informed and observant Syrians, of whom Khalil Sarkis, editor of the Beirut Public Opinion (Lisan el Hal) is a fair representative, and who spent many months in the United States in 1893, were so profoundly and enthusiastically impressed by the resources and modern improvements of the country, as well as with its immensity and general attractiveness, that they are and will continue 
to be influential and hearty factors in promoting personal and commercial interchanges between Syria and the United States.

Syria presents no greater material need to-day than that which might be fully met by American forests, and if the dealers of such great pinegrowing States as Michigan and Georgia would venture so far from their base of supplies they could open up a new and valuable market for their lumber, which can easily compete with eastern woods for ornamental purposes, and for cheapness and lasting service, such as flooring, ceilings, and general housebuilding, is unequaled. Northern and Southern States could all find a demand for their rich and abundant forest supplies in a land where lumber is scarce and where fine woodwork is appreciated as it is nowhere else.

THE NATIVE WOODS.

Syria is comparatively a poorly wooded country by reason of the continued use through centuries of the native lumber and the utter carelessness of most of the changing occupants of the land in replacing the forests as they were destroyed by time and the hand of man. The famous cedars of Lebanon, which were the chief glory of the mountains in the time of Solomon, have nearly all disappeared, and of the oldtime forests naught now remains except a few groves which adorn the southern slopes and northern valleys of these historic mountains.

The special varieties of native woods known in this part of the Turkish Empire are the cedar, nut, oak, apricot, mulberry, willow, poplar, and pine.

The cedar is very rare and difficult to obtain on account of the prohibition placed a few years ago by the authorities on cutting or destroying any tree, shrub, or spray in the Lebanon cedar groves.

The nut wood, which is valuable on account of its rich luster and beantiful color, is used for making rare and fine household furniture and for general ornamental woodwork. It is well adapted for carving purposes, and is frequently set with mother-of-pearl and is also used for coating objects made of common woods.

The oak is usually devoted to the manufacture of agricultural implements. It is too rare in Syria for use in general house building, and does not compare with nut wood for ornamental purposes.

The apricot wood, which has a reddish shade, is of little use owing to its poor quality.

Willow and mulberry are, also, of inferior quality, but are used in towns for making objects of little value, while in the country they find frequent use as window shutters, blinds, and baskets.

Poplar and pine beams, owing to their exceptional length, are specially used as horizontal supports for roof coverings in Damascus and the mountain villages. Pine, oak, and wild cedar are also used in the construction of the small boats used on this coast for hauling, fishing, and pleasure craft. These woods make the native lumber, but other varieties are imported. 


\section{IMPORTS OF LUMBER.}

The imported woods are fir, wild cedar, red pine, beech, mahogany, nut, and pelissander or ebony. The wild cedar and the fir are preferred over all other varieties for building purposes, while the nut, beech, mahogany, and pelissander are preferred for ornamental woodwork, furniture, etc.

Fir constitutes the largest amount of lumber imported into this country. It is imported from Austria. Special care is taken with this fine wood and with forests generally in Austria, and it is their boast, after observing the waste of wood and the wholesale destruction of forests in the United States, that Austrian forests will some day be supplying the Uniter States with lumber.

The annual imports of each foreign variety are approximately estimated to be, on an average, as follows: Fir wood from Austria, 300 wagons or car loads; wild cedar from Caramania, 90,000 pieces; red pine from Caramania, 25,000 pieces; beech from Anatolia and the Black Sea, 10,000 pieces; mahogany, ebony or pelissander, and nut woods from different parts of Europe, 40 cases, containing each 500 sheets, leaves, or pieces.

\section{IMPORT DUTIES.}

The customs duty imposed on lumber imported from foreign countries into Syria is 8 per cent ad valorem. Lumber is also subjected to other local duties upon. landing, viz, municipal duty, 2 paras (2 mills) per piece; and wharf duty, 4 paras ( 4 mills) per piece.

\section{PRICES.}

Fir boards or planks, which usually measure 4 meters ( 4.3745 yards) long by 25 centimeters (9.84 inches) wide, and 25 millimeters ( 0.984 inches) thick, are worth from $7 \frac{3}{4}$ to $11 \frac{3}{4}$ piasters (27 to 42 cents).

Wild cedar wood costs from 70 to 80 cents per piece. Red pine is worth from 53 to 67 cents per piece.

These two last varieties are imported in the shape of either rafters measuring 5.468 yards long by 6.299 to 7.086 inches wide and 3.149 to 3.54 inches thick, or laths measuring 3.281 yards long by 9.84 to 11.811 inches wide and 3.937 to 5.905 inches thick.

Beams of fir or red pine imported from Trieste and Caramania, measuring 6.56 to 8.74 yards long by 9.842 to 11.81 inches wide, cost from $\$ 2.90$ to $\$ 3.86$ each, while the beams having $9.8 \pm$ to 10.936 yards in length and 13.78 to 15.748 inches in width, are worth $\$ 9.65$ to $\$ 11.58$ each.

Beech laths, measuring 4.374 yards. long by 4.72 inches wide and 4.72 inches thick are worth from 96 cents to $\$ 1.12 \mathrm{each}$.

The average price of a box of mahogany or nut wood containing each 500 sheets is about $\$ 70$, while the box of pelissander (ebony) is 
worth about $\$ 200$. These sheets or leaves measure as a rule 2.187 yards long by 19.68 to 23.62 inches wide.

Other kinds of native wood can not be subjected to even an approximate value, having no definite measure and having endless shapes and forms.

\section{CLIMATE.}

The great extent of Syria furnishes a variety of temperatures even in the same season, but it may be said of the eastern coast of the Mediterranean that it can boast the most favored semitropical climate of the East, if not of the world. No frost ever comes to the coast, while the peaks of Lebanon, in full view, are crowned with snow all the year. It is possible therefore for residents to obtain any temperature they may desire. Tropical trees, fruits, and vegetables flourish in the balmy air and rich soil; and while seaside residents resort to the neighboring mountains in the hot and damp summer months for health and pleasure, it is safe to affirm that this climate is as equable and healthy as any similarly situated in the world. A perfectly pure and abundant water supply from the mountains is the best safeguard for Beirut against cholera or climatic ills, and this district is comparatively free from infectious and contagious Oriental diseases. The year is divided into the dry and rainy seasons; the heaviest rains falling in December, January, and February; the annual rainfall varying from 30 to 45 inches. The thermometer ranges from $85^{\circ}$ to $35^{\circ} \mathrm{F}$. on the coast and from $80^{\circ}$ to $30^{\circ}$ F. in the mountains. The Lebanon slopes are temperate and agreeable in climate all the year round.

\section{GENERAL BUILDING.}

The building up of Beirut, in the past two decades, from an old Oriental town into a great modern city should designate it as the miracle city of the Mediterranean. It may well claim a great future, for its widening streets and rising halls now mark the site of what must be one of the principal emporiums of the entire East, when its railroad system is completed to the fields of the Hauran and possibly to the Persian Gulf. Its people are alive to the situation, and general building and public improvements show the result of devotion and enterprise on the part of officials and residents. Nearly every house in the city and in this district is constructed of stone on account of the scarcity of wood, as already stated, and also because the immense mounds of sand here are as convenient for mortar as the quarried bowlders of Lebanon are ready for reunion into solid and shapely structures.

Shipbuilding is not a large industry here, but small sailing and fishing boats are constructed in numbers for harbor and coastwise use. The harbor itself is being very greatly improved, so that ships can come into port and land their cargoes and passengers at any seasonsomething that is not possible in every port of the Mediterranean. 
This magnificent and extensive harbor work is being done by a wealthy French company, and the same company has the concessions for the Beirnt, Damascus and Hauran Railway, a line which is now being rapidly pushed to completion and which will be in operation next year. This railroad, the first in Syria, will not only furnish an easy approach for tourists to Damascus, one of the oldest cities in the world, and give its famous bazaars an avenue to the world's commerce, but will also openup the Hauran, the richest and most inexhaustible grain country in the East. This system of internal improvements is under the personal management of Count Edmond de Perthuis and M. René Emond, who are backed by abundant capital from Paris.

This new railroad runs through the most picturesque scenes of the Lebanon Mountains and touches many of the thriving and beautiful villages which are the health and pleasure resorts of Beirut residents and even of people of wealth from Alexandria and Uairo.

\section{EXTENSION OF LUMBER TRADE.}

The wonderful growth of Beirut attracts many foreign importations. Syrians welcome any improvements and machinery from the United States.

If American capitalists would send a few ships direct to this port, even at the risk of small returns at first, a rich harvest would be reaped later on. Lumber, at lower prices than the Austrian imports, offers a readier return than any other American product, because this land is almost bare of forests; and direct shipments of the superior timber of the United States should easily compete with European lumber in spite of distance.

Syrian wools, silks, fruits, licorice, and the fine workmanship of Damascus could be taken back in return, and there is no reason why a direct line of merchant steamships to Syria would not pay Americans as well as Englishmen.

Acquaintance and confidence will stir the Syrian merchants to action, and if they are once started and are assured that their wools and the products of their silk looms will find a sure market they will be glad to cross the seas and exchange products with the United States. They are particularly anxious for lumber, cheap woods for flooring, ceilings, and general building purposes.

Thomas R. Gibson,

BeIrut, F'ebruary 15, 1894.

Consul. 


\section{AUSTRALASIA.}

\section{NEW ZEALAND.}

NATIVE WOODS.

The principal woods are here mentioned in the order of their usefulness and value. It has been ascertained beyond question that certain native timbers possess greater durability when grown in particular situations than in others. For example, north of the Auckland isthmus a native tree, known as hinau, affords a small proportion of heartwood, and is therefore considered of little value; in the province of Wellington the proportion of heartwood in the same tree is large, and the timber is highly valued for its durability. The Northern rata (Metrosideros robusta), one of the most useful woods in New Zealand, when grown in moist places produces timber of an inferior quality to that grown in ordinary situations, being liable to dry rot; in fact, the fungus is often found on this timber, grown in moist places, before it is eut down. It is well known that kahikatea (white pine), grown in dry places, affords more durable timber than when grown in swamps; although, at the same time, inferior to much of the swamp timber for bearing transverse strains. This rule applies pretty generally to nearly all the native woods grown in swamp lands here.

In view of the importance of having in all cases suitable timber for public works, it is advisable that it should be cut down under the direction of some competent person, so that unsuitable timber, whether defective from having grown in situations not naturally adapted for the particular kind required, or from not having arrived at maturity, might be rejected at the outset, thereby insuring against poor material and guaranteeing the most satisfactory results.

The names of the different trees herewith, falling as far as the order could be maintained, are given as follows: English names first, native names second, and botanical names third. In most cases the English and native names are the same.

Kauri (Dammara Australis).-The kauri is certainly the finest tree in New Zealand, and produces by far the most valuable timber. It is, however, restricted to the northern part of the north island, and does not occur in any quantity south of latitude $38^{\circ}$, although solitary trees are met with a little further south. It attains a height of 120 to 160 
feet and upwards. Clean symmetrical trunks may be seen from 50 to 80 , or even 100 feet in length, varying from 5 to 12 feet and upwards in diameter.

The timber has acquired a reputation above all other New Zealand timber from its value for masts, spars, and other purposes of naval architecture, which, about the commencement of the present century, led to its being exported for use in the British dockyards.

In this colony, except for general building purposes, its use has been chiefly confined to the north island, where there is abundant evidence of its durability for more than forty years in some of the old mission buildings at the Bay of Islands, the weatherboarding of which to this day exhibits no signs of decay. Kauri has been employed, in conjunc. tion with totara, for the upper timbers of the Auckland wharf, the largest work of its kind in the colony, and with most satisfactory results. Braces, stringers, and tie beams are in good condition after being eighteen years in use. Recently an old pier, built twenty-three years ago, was removed, and most of the timbers, afterwards employed in the construction of a railway in the vicinity of Auckland, were found to be perfectly sound; some, of course, were decayed.

It is used for ties in coal and gold mines, for tramways, telegraph poles, and curbing for sidewalks, with the most satisfactory results. An instance is given where it had been used for eighteen years for curbing in front of the Government House in Auckland, and when removed found to be perfectly sound. It is not so well adapted for piles for marine wharves or bridges or jetties, as it is attacked by the teredo as soon as the bark is decayed; and, althongh squared timber will resist the teredo for a longer period, it is found that kauri is inferior for such purposes to other New Zealand woods. A steady export of kauri is carried on chiefly with Tasmania, Australia, and Mauritius; it is, in fact, the only New Zealand timber exported to any considerable extent. Kauri resembles the California redwood in nearly every particular, except that kauri is, perhaps, finer and closer grained.

Totara (podocarpus totara). - The totara is found throughout the colony, usually attaining its greatest dimensions on rich alluvial lands or on dry hillsides of low elevation.

Large specimens are found north of Auckland, but it does not occur in abundance until after passing the southern limit of the kauri, viz, 380. Although not equal in size to the largest specimens of the kauri, trees are occasionally found from 8 to 10 feet in diameter, 4 to 6 feet being about the average size; height, 40 to 70 feet. From the extensive area which it occupies, it has been more generally used than the kauri, and is the chief timber employed for building purposes in the province of Wellington, where it occupies a similar position to that held by the kauri in the Anckland province.

According to experiments made by competent engineers it has been demonstrated that totara ranks below kauri in point of strength, at 
the same time it is scarcely, if at all, inferior to it in durability. The general unanimity of opinion in its favor is remarkable, some considering it superior to kauri for general purposes, but this opinion is only found where totara is cheaper and more plentiful than kauri.

For piles for marine wharves and bridges, etc., it is regarded by those who have used it as one of the most valuable timbers known. In addition to its great durability, it has the power of resisting the attacks of teredo for a considerable period, especially if driven with the bark intact. It is said, and I believe truly, that trees felled during the growing season will resist the attacks of teredo for a longer period than those felled during the winter months. In some quarters this advantage is questioned, though it is positively stated by many who have had long experience in this respect that totaro piles driven with the bark on are absolutely free from perforation by teredines while the bark remains intact. The heart of totara will resist the teredo still longer. It frequently happens that when totara piles are driven the sap-wood is attacked and thoroughly perforated, after which the teredo dies, being unable to make any impression on the heartwood until it has been subjected for a longer period to the action of the sea water, when the mollusk resumes possession, and the destruction of that portion of the wood exposed to its ravages is a mere matter of time.

It may be fairly estimated that kauri and totara afford more than two-thirds of the indigenous timber employed for buildings and constructive works in the colony. Both are extensively used for general building purposes and exhibit practically the same amount of durability; kauri, however, is more easily worked and takes a higher finish.

Rimu (red pine).-A tree from 40 to 80 feet high; trunk, 3 to 5 feet in diameter. It is found throughout the colony, but in greater abundance in the Middle Island and in the southern part of the North Island. It is better adapted for housebuilding purposes than for constructive works. Whenever it has been exposed to the action of the weather, except in housebuilding, it has given no satisfaction. Although it can not be considered a suitable timber for outside work, its great strength and the facility with which straight logs of large dimensions can be obtained, enable it to be used with advantage for heavy beams, girders, etc., under cover.

Kahikatea (white pine).-This tree grows from 50 to 100 feet high and upwards, with trunk 2 to 4 or even 5 feet in diameter. It is found in nearly all the forests of the colony, but in greater abundance in swampy districts. It is not regarded as being of any great value, especially for outdoor work, but when used inside, if kept free from contact with the earth and in a perfectly dry situation, it lasts fairly well.

Matai (black pine).-Found throughout the colony, but not in any considerable quantities in some portions of the North Island. It usually attains a height of from 50 to 70 feet, with the trunk from 2 to 
4 feet in diameter, and affords a timber of great durability, which is used for a variety of purposes, such as piles for bridges, wharves, and jetties; bedplates for machinery, millwrights' work, house blocks, railway ties, etc.

Miro (also called black pine).-Of similar distribution to the last, which it closely resembles. It is easily distinguished when in fruit, as the fruit is solitary instead of spicate. The cross section of the timber shows the heartwood star-shaped and irregular. It appears, however, to be specially adapted for use in positions where it is partially exposed to the influence of sea-water, and under these circumstances exhibits great durability. As a rule it is not esteemed a durable wood, except under the above conditions.

Tanekaha (Phyllocladus trichomanoides).-A straight, handsome treo 50 to 60 feet high, trunk rarely exceedingly 3 feet in diameter; common in hilly districts in the North Island, and quite abundant in the province of Auckland. The timber is white, dense, and heavy, closely resembling in everything but size, it is said, the best crown memel of Europe. No particular tests have been applied up to the present to ascertain its strength and elasticity, but it is believed to be one of the strongest and most durable timbers in the colony. The wood appears to be specially adapted for railway ties and highway bridges, etc. An instance of its durability is given by a civil engineer, who says he has seen tanékaha used in water-tanks at the Bay of Islands after being eighteen years in use.

Cedar; Pahautea (Libocedrus bidwillii). - A handsome conical tree 60 to 80 feet high, 2 to 3 feet in diameter, producing a dark red closegrained timber of great durability, but inclined to be rather brittle. Found on the central ranges of the North Island, and sparingly throughout the South Island, but never below 1,000 feet. This particular timber has been largely used in the construction of railways in the South Island, with satisfactory results. It has been known to last in good condition as piles in dikes and bridges and fencing posts for over twenty years. For fence posts it is preferred to totara, but this claim is evidently ill-founded. It is, also, largely used for the manufacture of furniture.

Teatree; Manuka (Leptospermum oricoides).-This tree attains a height of 40 to 50 feet, with trunk 15 to 30 feet in length and 1 to 2 feet in diameter; wood, hard and dense, much used for house blocks, fencing rails, and especially valued for small marine piles. This timber is largely used throughout the colony for piles in the construction of jetties, wharves, etc., where timber of larger dimensions is not required. It exhibits greater durability in marine structures than when driven for land or fresh-water bridges. When used for land piles it has been found to decay at the ground level in about six years. On the other hand, piles in marine works in Auckland and other parts of the colony have been found to be perfectly sound after being twenty years in use. 
In one New Zealand district (Otaga) itis considered to resist the attacks of teredo better than any other wood. In this respect I may remark that experience has taught that the teredo is more active and consequently more destructive in some sections of the country than in others, so that the claim of superior resisting powers against the ravages of this insect may not be well-founded. It has, also, been ascertained that piles cut during the growing season resist the attacks of teredo much longer than those cut in the winter.

Puriri (Vitex littoralis). - This tree grows to a height of from 40 to 60 feet, with a trunk from 3 to 5 feet and upwards in diameter. It has been appropriately styled the New Zealand teak; it is, in fact, closely allied to the Asiatic teak, and affords a timber of great density and extreme durability, closely resembling lignum-vitæ in general appearance. In durability it probably excels all other New Zealand timbers. The growing tree is subject to the attacks of the larva of the puriri moth, which bores holes sometimes three-eighths of an inch in diameter, but the durability of the timber is not directly affected; it is never attacked when once worked up. It has been largely used in housebuilding. In some houses now considerably over thirty years old the wood is still in a perfectly sound condition. Posts of the heart-wood which have been in the ground for twenty years are still sound and good.

Black birch; Hutu-Tawhui (Fagus fusea). - The true black birch is a splendid tree. It ascends the mountains from the sea level to 3,000 feet. The tree is usually from 60 to 90 feet in height, with a trunk from 3 to 8 feet in diameter. In many districts it is abundant, and forms a large portion of the forest. Its use is pretty general in upper timbers for railway construction, bridges, jetties, mine timbers, etc., and has given uniform satisfaction. It has been used for piles in marine works, and it is said to be very durable, offering great resistance to teredo.

White birch (Fagus solandii).-This tree, as also the red birch (Fagus menziessii), has the same distribution over the colony as the black birch and practically the same general characteristics, so far as size, elasticity, durability, and general usefulness are concerned. These woods, black, white, and red birch, are so well known that a more extended notice of their relative worth as building materials, etc., would probably afford no information that would be considered valuable.

Polutukawa (Metrosideros lucida).-This tree is almost peculiar to the province of Auckland, where it is abundant on rocky coasts, sometimes attaining a height of 70 feet or more, but with a comparatively short trunk, 2 to 4 feet in diameter, and numerous massive, tortuous arms. Its peculiar forms, combined with its great durability, renders it specially adapted for the purposes of the shipbuilder, and it has usually formed the framework of the numerous vessels built in the northern province. For this purpose it is much esteemed, and is considered superior to the northern rata (Metrosideros lucida), which in many 
localities enters very largely into the shipbuilders' trade. Hitherto it has not been used much in constructive works, but its density and great durability must render it valuable for the framing of dock gates, sills, etc. It has never been known to be perforated by teredos, except in the most superficial manner. It has an exceedingly rich, deep-green foliage, and blossoms about Christmas every year. The flowers are a beautiful deep red, large and rose-shaped, and very numerous. It looks very fine when in full bloom. It is only found along the seacoast of the North Island.

Ironbark; rata (Metrosideros lucida).-This is usually found in hilly situations, but descends to the sea level in the extreme south. It is a handsome tree, 30 to 60 feet high; trunk usually from 2 to 5 feet in diameter; often very short. The timber resembles the preceding, but is less dense in texture and has the advantage of splitting freely. It has been used in shipbuilding in the South Island, and has lately been utilized in the building of railway freight cars, for which its great strength and durability render it well adapted.

Rata (Metrosideros robusta). - This tree is almost confined to the North Island. Height, 60 to 100 feet; diameter of trunk, 5 to 12 feet and upwards. The timber resembles the preceding in its appearance and is equally dense and durable, while it can be obtained of much larger dimensions, so that it affords greater facilities for the construction of railway cars, etc. It is used for shipbuilding, but for this purpose it is found to be inferior in durability to the pohutukawa, although it can be more easily procured in some situations. It will doubtless in time be more frequently substituted. One peculiarity of this tree is that it begins to grow at the base of another tree around which it entwines itself like a woodbine, which it very much resembles in general appearance. It continues to encircle the larger tree, embracing it so tightly that it ultimately kills it, after which the rata continues to grow, taking the place of the original by absorption-that is, it assumes control and becomes merged with the old tree, which has lost its identity.

Hinau (Eloeocarpus dentatus).-Common throughont the country. Used largely for railway ties, mine timbers, fencing-posts and rails, and occasionally for bridges. One fault found with it is that it appears to split too freely for the latter purpose. The timber is of a light dullbrown color, very tough, strong, and durable.

Kowhai (Sophora tetraptera).-Found in all parts of the colony, varying in size from a small shrub to a tree 30 to 40 feet high, with a trunk 1 to 3 feet in diameter. It is alleged that the timber closely resembles the European laburnum, and is of great strength and durability; but the supply of large timber is limited, it being often no more than a bush. It is generally used for house blocks, railway ties, fencing-posts, rails, and piles. It has been found to be perfectly sound after being in use for more than twenty years. 
Maire Tawhake (Eugenia Marie).-A small tree about 40 to 50 feet high, 1 to 2 feet in diameter. Common in swampy land in the North Island. Timber compact, heavy, and durable. Used for jettying, piles, fencing, railway ties, etc.

Tawhero (Weinmannia racemosa).-This is a small tree 30 to 40 feet high, 1 to 3 feet in diameter. It is often called black birch, and is even substituted for that timber, to which it is greatly inferior in strength and durability. Its bark is much used for tanning.

Rewa-Rewa (Knightia excelsa).-This is always considered a perishable timber. It is used principally as an ornamental wood by cabinetmakers, and inlayers, and workers in fancy and ornamental woodwork generally. It is a bright, yellowish wood, with large, soft grain, capable of high polish. Generally useless, except for ornamental purposes.

Tipau (Myrsine salicina). - This has been used only in places where good timber is scarce. It is not considered durable, although highly valued for inlaying, veneering, etc.

Taraire (Nesodaphne taraire). - This is a very handsome tree 40 to 50 feet high, trunk 1 to 2 feet in diameter. Timber compact and capable of taking a fine surface, but not durable when exposed. It is largely used for shingles and is much esteemed by cabinetmakers because of its softness, even grain, and high polish when worked.

Mungeao (Tetronthera calicaris).-A small tree, most plentiful north of the Auckland Isthmus. Height about 40 feet. Timber close grained and extremely tough. Utilized largely for the manufacture of ship's blocks, etc.

Black Maire (Olea cunninghamii) and Maire (Santalum cunninghamii).These afford fine-grained timber of great density, and are extremely durable. All are commonly called "Maire," alike by settlers and natives. Black Maire usually attains the largest dimensions, and is sometimes found 40 feet high or more. Santalum, of this species, is the least of the group. All the different kinds are confined to the North Island, and are most plentiful in the province of Auckland. There are three different kinds of these trees, but two only are worthy of mention here.

Kohe Kohe (Dysoxylum spectabile).-This is a handsome tree, with the trunk 2 to 4 feet in diameter; heart wood reddish, tough, but not durable. The wood is occasionally used by the cabinetmaker, but is not as well known as it deserves to be.

Titoki (Alectryon excelsum).-This tree is generally distributed through the colony, except perhaps in the extreme south. It affords a tough close-grained wood, well adapted for the purposes of the machinist, but is not durable when exposed.

Kawaka (Libocearus doniana).-A splendid tree from 60 to 100 feet high, the trunk from 3 to 5 in diameter. Up to the present the timber has not, I believe, been generally used except for fencing, but $665 \mathrm{~A}-8$ 
there is no doubt in the minds of those familiar with it that it will prove equally durable with its congener, $L$. bidwillii, already noticed.

Manoao (Daerydium colensoi).-This is a small tree 30 to 40 feet high found in various parts of the country, but has scarcely been used except locally for house building, although well known even to the natives as being one of the most durable timbers in the colony.

Pukatea (Atherosperma nova Zealandiac).-This is a striking tree, frequently found 150 feet high, with a trunk of from 3 to 6 feet and upwards in diameter. It is common in swampy places. Timber soft, but apparently durable in water. It has been used in Auckland for boat building, but is not greatly valued.

There are several other trees that might be mentioned, but so far they have not been found to be of any commercial value, therefore their inclusion in this report would not afford any useful information.

I am much indebted to a work published by Mr. Ashley Hunter, $\mathbf{O}$. E., on the "durability of New Zealand timber." The work mentioned is very complete, giving as it does in detail the durability and strength of the different woods referred to. But the details are too minute and elaborate to be included in a general report of this kind. I send with this report 13 samples of the New Zealand timber which are most esteemed for their commercial value and usefulness. *

\section{KINDS OF LUMBER USED.}

Kanre timber largely enters into all kinds of construction work in the North Islands in preference to any other kind. It is admittedly superior for general purposes, and is used in all kinds of building and constructed works, from a window sash to the masts and spars of a vessel.

For boat building, Oregon pine and spruce are occasionally used for spars and sculls. For the latter purpose the best selected Oregon pine only is used, and costs laid down here, duty paid, about 10 cents per superficial foot.

Most of the American lumber used in this county is imported from Melbourne and Sydney; but Oregon pine imported from either of the above colonies costs, laid down here, about $\$ 6.30$ per 100 superficial feet.

American hickory and ash are largely used for coach building in this country, and give the greatest satisfaction. Hickory and ash are preferred to all other woods for coach and carriage building, and would be more generally used if less expensive. It has been found impossible to use the above-mentioned woods in the shipbuilding trade owing to the cost being excessive. Small quantities of hickory and ash were imported direct from New York last year, but just how much I have been unable to ascertain. There is an average of one sailing vessel a month leaving New York for New Zealand ports, in addition to

"Samples filed in the Department. 
the mail steamers, which make four weekly trips between San Francisco, Honolulu, Samoa, Auckland, and Sydney. It is possible a general agency for American lumber might be profitably established in this colony, thereby avoiding the middleman's percentage in Sydney and Melbourne, which materially increases the cost to the consumer here, a result which naturally tends to discourage the use and importation of American timber.

\section{IMPORTS AND DUTY.}

There is very little lumber imported from abroad to this colony. Last year 45,540 superficial feet were imported from the United Kingdom, valued at $\$ 1,710$. The duty on lumber is 48 cents per 100 superticial feet.

\section{PRICES.}

The following price list which I obtained from the Kauri Timber Company, of Auckland, will show the prevailing prices here. This company owns the largest sawmill in the colony, and has practically a monopoly of kauri timber.

\section{Retail prices current.}

[Subject to alteration without notice at the company's yards, Auckland and Onehunga.]

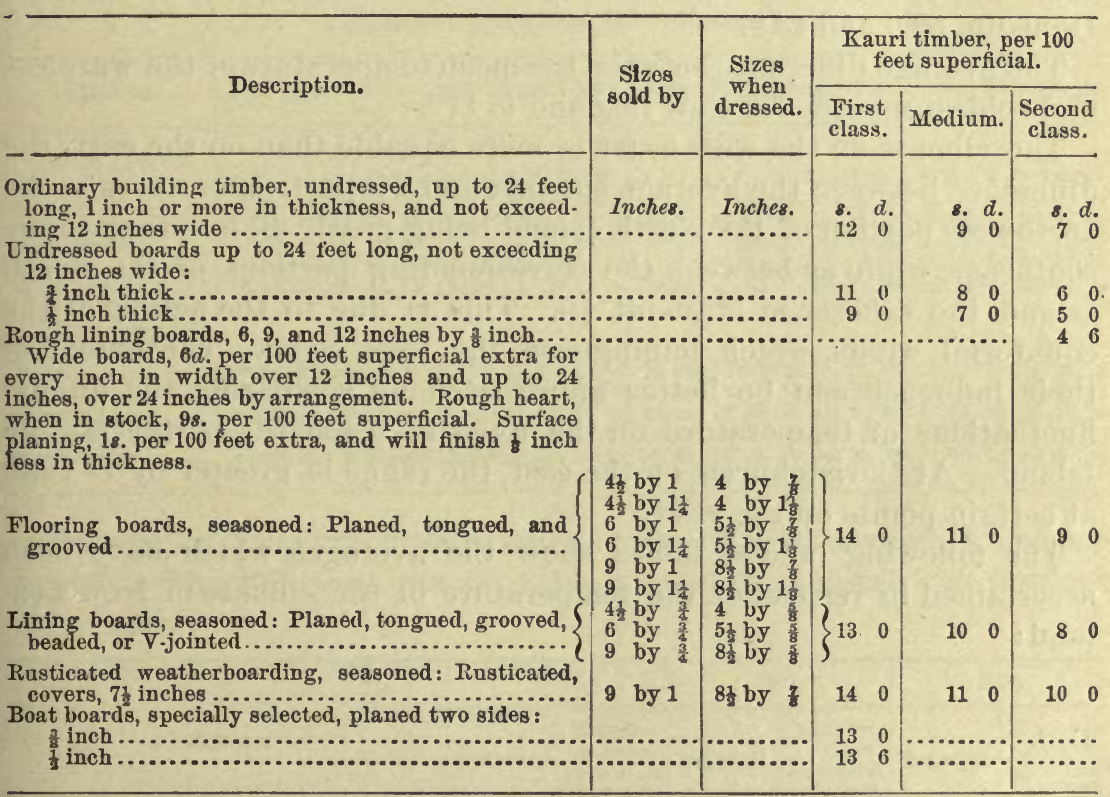

The above prices are for timber in the yard.

N. B. - Special discounts to builders and contractors. Orders for lengths can not be guaranteed, but will be supplied as near as possible. Orders for specially selected or strictly all heart, will be charged 18. per 100 feet superficial extra. First-class timber is free from shakes or large knots, and not over one-third of any piece clean sap (free from pin holes). Medium is all or any part clean sap, free from pin holes, but in special sizes not always available. Second class is all or part sap, with pin holes and other defects. Orders for long lengths, $6 d$. per 100 feet superficial extra for every foot additional in length from 25 feet up to 34 feet; above that length by arrangement. Flooring and rusticated weather boards, minimum length, 8 feot. 


\section{CLimate.}

Meteorological observations have been made ever since the founding of the colony - at first of an irregular character, and made only with a view of comparing the climate of New Zealand with that of other countries. It was not, however, until 1859 that systematic observations were undertaken by a Government department. There are over 60 stations at which rainfall and weather are recorded.

Temperature.-The climate in many respects, it is said, resembles that of Great Britain. It is, however, far more equable, the extremes of daily temperature varying throughout the year by an average of $20^{\circ}$ only, while London is 70 colder than the North Island of New Zealand, and $4^{\circ}$ colder than the Middle Island. The mean annual temperature of the North Island is $57^{\circ} \mathrm{F}$, and of the Middle or South Island $52^{\circ}$ F., that of London and New York, it is said, being $51^{\circ}$.

The mean annual temperature of the different seasons for the whole colony is: In spring, 55०; in summer, $63^{\circ}$; in autumn, $57 \circ$, and in winter, $48^{\circ}$. The following are the means for the two warmest and the two coldest months in the principal localities, with their differences (Fahrenheit):

Auckland, 69.6 and 53.1; Nelson, 63.6 and 45.9; New Plymouth, 64.7 and 49.03; Christchurch, 65.2 and 44.3; Wellington, 64.6 and 47.8; Dunedin, 58.0 and 43.2.

The average difference between the mean temperature of the warmest and coldest months for New Zealand is $17^{\circ}$.

The climate on the west coast is more equable than on the east, the difference between the average summer and winter temperatures in the northwest portion of the North Island being nearly $4^{\circ}$ less than in the southeast, while as between the corresponding portions of the South Island the difference is about 70. This is due to the action of the equatorial winds, which impinge on the west coast. The extent of their influence can be better appreciated by comparing the annual fluctuations of temperature on the opposite seaboards of the Middle Island. At Christchurch, on the east, the range is greater by $7 \circ$ than at certain points on the west.

The following official tables show the averages which have been ascertained in respect of the temperature of the climate of New Zealand: 
Comparative Temperatures of New Zealand.

\section{I.-General abstract.}

\begin{tabular}{|c|c|c|c|c|c|c|c|c|c|c|c|c|}
\hline \multirow[b]{2}{*}{ Stations. } & \multirow[b]{2}{*}{ 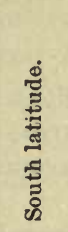 } & \multirow{2}{*}{ 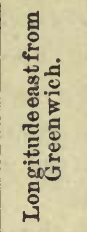 } & \multirow{2}{*}{ 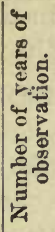 } & \multirow[b]{2}{*}{ 㟧 } & \multirow[b]{2}{*}{ 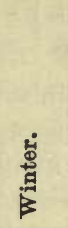 } & \multirow[b]{2}{*}{ 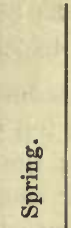 } & \multirow[b]{2}{*}{ 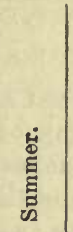 } & \multirow[b]{2}{*}{ 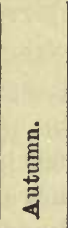 } & \multirow{2}{*}{ 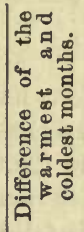 } & \multicolumn{2}{|c|}{$\begin{array}{l}\text { A verages } \\
\text { of yearly } \\
\text { extremes. }\end{array}$} & \multirow{2}{*}{ 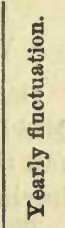 } \\
\hline & & & & & & & & & & 竎 & 咅 & \\
\hline Nor & & & & & & & & & & & & \\
\hline & $\begin{array}{rr}35 & 1 \\
36 & 50 \\
39 & 4 \\
39 & 29 \\
41 & 16 \\
39 & 56\end{array}$ & $\begin{array}{rr}173 & 28 \\
174 & 51 \\
174 & 5 \\
176 & 55 \\
174 & 47 \\
175 & 6\end{array}$ & $\begin{array}{r}10 \\
20 \\
14 \\
10 \\
14 \\
\mathbf{3}\end{array}$ & $\begin{array}{l}59 . \\
59 .\end{array}$ & & $\begin{array}{l}58.28 \\
57.56 \\
55.94 \\
57.74 \\
54.50 \\
53.31\end{array}$ & $\begin{array}{l}66.56 \\
66.92 \\
6.58 \\
66.20 \\
62.24 \\
63.31\end{array}$ & $\begin{array}{l}61.52 \\
61.16 \\
58.82 \\
57.02 \\
56.66 \\
57.12\end{array}$ & $\begin{array}{l}15.12 \\
16.02 \\
15.66 \\
19.26 \\
14.76 \\
16.70\end{array}$ & $\begin{array}{l}89.10 \\
88.52 \\
86.90 \\
90.00 \\
78.44 \\
86.00\end{array}$ & $\begin{array}{l}31.82 \\
33.26 \\
30.02 \\
32.10 \\
32.18 \\
29.00\end{array}$ & \\
\hline & & & & & & & & & & & & \\
\hline enstown & $\begin{array}{rr}41 & 16 \\
42 & 42 \\
43 & 2 \\
42 & 33 \\
45 & 52 \\
46 & 17 \\
45 & 2\end{array}$ & $\begin{array}{l}16820 \\
16539\end{array}$ & $\begin{array}{r}11 \\
10 \\
9 \\
12 \\
17 \\
14 \\
3\end{array}$ & $\begin{array}{l}50.36 \\
51.01\end{array}$ & $\begin{array}{l}46.58 \\
45.50 \\
37.40 \\
43.52 \\
43.52 \\
42.26 \\
40.01\end{array}$ & $\begin{array}{l}54.50 \\
51.62 \\
46.04 \\
53.24 \\
50.54 \\
51.26 \\
50.92\end{array}$ & $\begin{array}{l}62.78 \\
59.18 \\
54.86 \\
61.52 \\
57.20 \\
58.10 \\
64.02\end{array}$ & $\begin{array}{l}55.76 \\
53.06 \\
48.56 \\
53.60 \\
51.80 \\
50.00 \\
52.31\end{array}$ & $\begin{array}{l}17.10 \\
14.76 \\
18.18 \\
18.72 \\
15.30 \\
16.92 \\
21.25\end{array}$ & $\begin{array}{l}82.04 \\
74.12 \\
78.08 \\
88.16 \\
84.74 \\
83.84 \\
84.60\end{array}$ & \begin{tabular}{|l}
27.32 \\
28.22 \\
12.38 \\
25.16 \\
29.84 \\
20.12 \\
23.21
\end{tabular} & 61.39 \\
\hline
\end{tabular}

\section{II.-Daily range of temperature.}

[Difference of the mean daily extremes.]

\begin{tabular}{|c|c|c|c|c|c|c|c|c|c|c|c|c|c|}
\hline Stations. & Dec. & Jan. & Fob. & Mar. & A pril. & May. & June. & July. & Ang. & Sept. & Oct. & Nov. & Year. \\
\hline North Is & $\circ F$. & $\circ F$. & $\circ F$. & $\circ F$. & $\circ F$. & $\circ F$. & ${ }^{\circ} F$. & ${ }^{\circ} F$. & $\circ F$. & $F$. & - $F$. & F. & \\
\hline
\end{tabular}

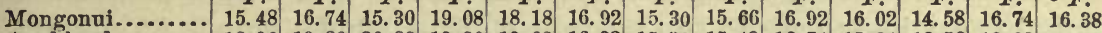
\begin{tabular}{l|l|l|l|l|l|l|l|l|l|l|l|l|l|l} 
A uckland.......... & 18.90 & 19.80 & 20.88 & 19.80 & 19.08 & 16.92 & 15.30 & 15.48 & 16.74 & 15.84 & 16.56 & 18.00 & 17.82
\end{tabular}

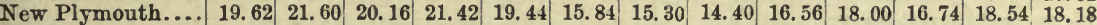

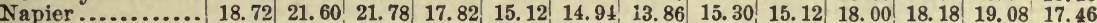

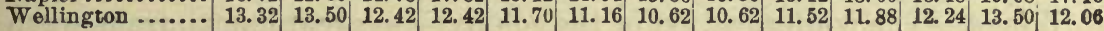

South Island.

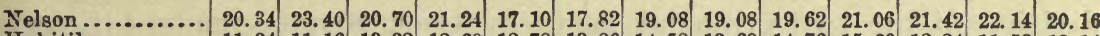

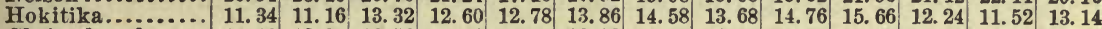

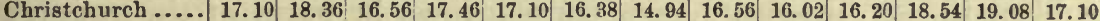
\begin{tabular}{ll|l|l|l|l|l|l|l|l|l|l|l|l|l|l|l|l} 
Dunedin $\ldots \ldots \ldots \ldots .$. & 16.20 & 15.66 & 15.66 & 15.12 & 13.68 & 11.52 & 10.44 & 10.62 & 12.06 & 13.32 & 13.68 & 15.30 & 13.68
\end{tabular}

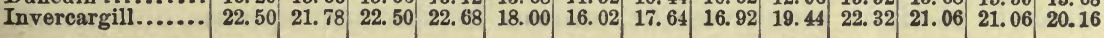

Rainfall.-The rainfall varies much at the different stations from year to year. The following official table shows the rainfall for the last three years:

\begin{tabular}{|c|c|c|c|c|c|c|}
\hline \multirow[b]{2}{*}{ Station. } & \multicolumn{2}{|c|}{1890.} & \multicolumn{2}{|c|}{1891.} & \multicolumn{2}{|c|}{1892.} \\
\hline & Rainfall. & $\begin{array}{l}\text { Number } \\
\text { of days } \\
\text { on which } \\
\text { rain fell. }\end{array}$ & Rainfall. & $\begin{array}{c}\text { Namber } \\
\text { of days } \\
\text { on which } \\
\text { rain fell. }\end{array}$ & Rainfall. & $\begin{array}{l}\text { Namber } \\
\text { of days } \\
\text { on which } \\
\text { rain fell. }\end{array}$ \\
\hline 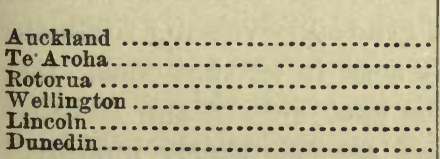 & \begin{tabular}{r|} 
Inches. \\
46.100 \\
64.110 \\
50.411 \\
45.230 \\
14.836 \\
27.984
\end{tabular} & $\begin{array}{l}176 \\
129 \\
162 \\
165 \\
104 \\
155\end{array}$ & \begin{tabular}{r|} 
Inches. \\
36.040 \\
43.270 \\
48.940 \\
35.125 \\
20.575 \\
32.734
\end{tabular} & $\begin{array}{r}149 \\
119 \\
132 \\
166 \\
98 \\
151\end{array}$ & $\begin{array}{r}\text { Inches. } \\
41.331 \\
54.080 \\
66.230 \\
67.656 \\
27.883 \\
47.552\end{array}$ & $\begin{array}{l}177 \\
144 \\
166 \\
184 \\
124 \\
160\end{array}$ \\
\hline
\end{tabular}


The anuual average rainfall at the 4 principal stations in New Zealand for the ten years ending December, 1892, was-

North Island :

Auckland ..................38.881

Wellington.............48.296
Middle Island:

Lincoln.................... 26.190

Dunedin.................... 36.863

Daily obserrations have been discontinued at Hokitika, on the west coast of the Middle Island, since 1880; but for ten years, 1871 to 1880 , inclusive, the annual rainfall there averaged 122.990 inches; the greatest rainfall for any one of those years having been 154.446 inches and the smallest 96.170 inches.

The greatest rainfall in any twenty-four hours during the year 1892 occurred at Dunedin, 5.400 inches, on February 8.

The observations that have been taken show that the northern part of New Zealand is within the influence of the subtropical winter rainfall, the probability of rainfall in winter in that part of the colony being twice as large as iu summer.

In the south, however, the rainfall, though irregular, is distributed more equally over the year. The chief difference to be observed is that on the west coast spring rains prevail, and on the east coast summer rains; while in the middle of the colony the driest season is antumn, and in the south it is winter and spring.

The contrast between the east and west coasts in the matter of rainfall is as striking as the difference in temperature. Thus, in the North Island, Napier on the east has only half the amount of rain that falls in Taranaki on the west. But the Middle Island, with its longitudinal range of lofty mountains, exhibits this feature in a still more marked manner, for the rainfall on the west is nearly five times that on the east. The excess of precipitation on the coast is clearily illustrated by the distribution of the glaciers on the opposite sides of the range; those on the west slope have an excessive supply of snow, and descend to a line where the mean annual temperature is $50^{\circ} \mathrm{F}$., while on the east slope they descend only to the mean annual temperature of $37^{\circ}$. The winter snow line of the "Southern Alps" on the east side is 3,000 feet and that on the west side 3,700 feet.

Periods of lasting drought are almost unknown in New Zealand, and only in two instances do the records show a whole month at any station without rain.

Winds.-The configuration of the colony-its great length from north to south, compared with its breadth, its extent of coast line, and the division of the two principal parts by Cook Strait-renders it very subject to sea breezes. As a consequence, in parts of the country there is at times much violent motion in the atmosphere, and windy days are prevalent.

Owing to the fact that most atmospheric disturbancespass from west to east, with the center of the depression to the south of New Zealand, there is a marked prevalence of westerly winds throughout all seasons, but they are much modified by the form of the land. When the center passes to the north of New Zealand, the result is that the northeast winds impinge on the east coast, bringing rain, followed by cold southeasters, with heavy storms of rain and snow during winter in the south. The more common westerly winds begin in the north-northwest, with very heavy rain on the west coast, and gradually veering to southwest, when fair bright weather invariably sets in on that coast, but the same southerly wind, sweeping along the east side of the islands, brings heavp, strong weather, locally known as "southerly busters," 
which, from the shape of the coast, reach the region of Cook Strait as southeast storms. All the other winds are either land or sea drafts, with light, fine weather, or are moderate winds produced by the circu. lation of the atmosphere around anticyclonic areas of high barometric pressure, which are found to be far more persistent in their influence than the fast-moving cyclonic or low-pressure areas.

The number of days on which there were gales or high winds in 1892 at each station was as follows:

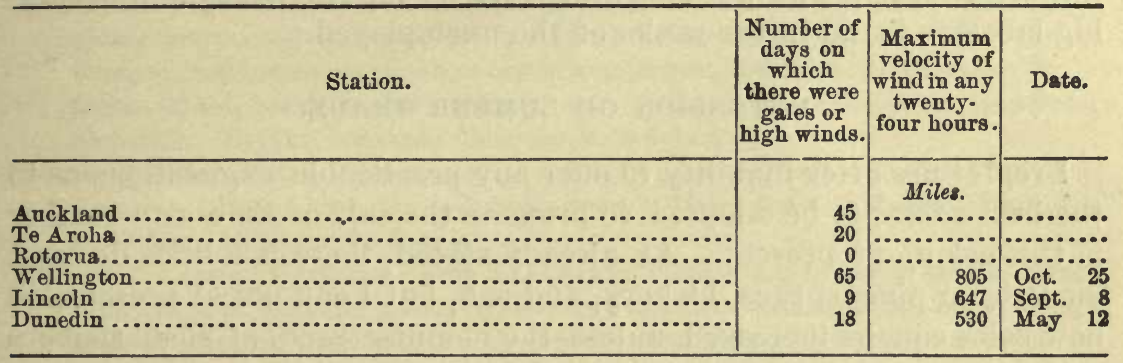

Wellington, by reason of its position near the narrowest part of Cook Strait, is peculiarly subject to wind.

Thunderstorms.-Thunderstorms are most frequent when the changes of wind are most suddenly felt, from the moist equatorial currents to the cold polar currents of the southwest. On the west coast of New Zealand they are most frequent in spring, except southwest of Otago, where, during winter, thunderstorms are of almost daily occurrence.

Generally speaking, the climate of the colony is unild and pleasant. In the Middle Island it is, however, considerably colder than in the North Island particularly in the vicinity of the higher mountain ranges, upon which snow remains the whole year round. The climate of the North Island, or, at least, the northern portion of it, is semitropical in its character. Vegetation and tree foliage appear to grow without interruption throughout the various seasons. As a matter of fact, there are no well-defined seasons, such as spring, summer, autumn, and winter, in this part of the North Island. There is a wet season, which is supposed to be the winter, but in this respect it would be diffcult to distinguish between summer and winter, as it rains almost as much in one season as in the other. Hence it is that there is scarcely any perceptible cessation in the growth of vegetation in consequence of the constant rainfall.

\section{GENERAL BUILDING.}

General building is not prosperous at present, owing to the depres. sion that has prevailed here for a number of years past. But the prospect is brightening, and indications are very encouraging that in the near future the building trade will soon again assume a healthier aspect. 
Large vessels are not often built in this country, the shipbuilding being practically confined to large-sized schooners and the smaller craft generally.

Railway building is very limited at present and has been since the colony has ceased to borrow. There are no new lines projected, nor is there any likelihood that there will be for some time to come. There are, however, several extensions in course of construction or completion, but even these are not being pushed very vigorously, being largely utilized for the purpose of affording work for the real needy and deserv. ing laborers found in the ranks of the unemployed.

\section{EXTENSION OF LUMBER TRADE.}

I regret my utter inability to offer any practicable suggestions as to the best means to be adopted to promote the sale of American lumber in this colony at present. As already stated, there is a little demand for Oregon pine, spruce, hickory, and ash, but I can not at present see how sales can be increased unless the manufacturers of such timbers are prepared to establish a general agency for the colony, and even then they must be prepared to sustain a loss for a time. The woods above mentioned are well known and their superiority fully appreciated, but I question whether the establishment of an agency here, in consequence of the limited population of the colony and the small demand for sucb supplies, would pay. I merely offer the suggestion, but do not recommend it.

Jno. D. ConNolly, Consul.

AUCKLAND, February 24, 1894.

\section{NEW SOUTH WALES.}

\section{NATIVE WOODS.}

The following list embraces, I think, the entire catalogue of what are now recognized as the commercial timbers of New South Wales, classified by competent authority. The first is the botanical, the second, in parenthesis, the vernacular name:

Avicennia officinalis, Verbenacæ (mangrove): An erect, low branching tree; timber is valuable on account of its inlocked fibcr; used for knees of boats, stonemasons' mallets, and bullock yokes. Habitat, tidal estuaries, New South Wales. Height, 20 to 30 feet; diameter, 20 inches.

Banksia integrifolia, Proteaceæ (honeysuckle): Timber coarse grained and tough; used for knees and ribs of boats, bullock yokes, etc.; takes a good polish. Hab., open and scrub forests, northern and southern coast districts, New England, etc.; plentiful. Height, 40 to 50 feet; diameter, 1 to 2 feet.

Casuarina glauca, Casuarinæ (swamp oak): Timber tough and strong; used for shingles, staves, and fence posts. Hab., interior and coast districts; usually in damp situations; plentiful. Height, 60 to 80 feet; diameter, $1 \frac{1}{2}$ to 2 feet. 
Casuarina torulosa, Casuarinæ (forest oak): Timber handsome, sometimes remarkably heavy; valuable for cabinet work, shingles, etc.; excellent fuel. Hab., open forests from Illawarra to the Richmond River, westward to New England and Bathurst. Height, 80 feet; diameter, 2 feet.

Cedrela anstralis, Meliaceæ (red cedar): Timber very valuable, dark red, and often beautifully marked; light, easily wrought, and durable; much used and valued for furniture, patterns, and all kinds of fittings in house and shipbuilding. Hab., brush forests northern and formerly in southern coast districts; becoming scarce; efforts now being made to conserve and propagate this timber. Height, up to 100 and even 200 feet; diameter, up to 6 and even 10 feet (exceptionally).

Dysoxylon Fraserianum, Meliaceæ (rosewood): Timber rose scented, red, strong, closegrained, and durable; mnch valued for furniture-making, ship-building, turnery, and indoor work, etc.; one of the largest and best of indigenous timber trees. Hab., brush forests northern and southern coasts districts; moderately plentiful. Height, 100 feet; diameter, 4 to 6 feet.

Eucalyptus botryoides, Myrtaceæ (bastard mahogany): Timber strong and durable, used for felloes of wheels and boat knees. Hab., coast districts. Height, 40 to 50 feet; diameter, 24 inches.

Eucalyptus creba, Myrtaceæ (grey ironbark): Timber hard, heavy, tough, strong, inlocked, and durable; used for poles and shafts of carriages, spokes of wheels, railway sleepers, etc. Hab., open forests, northern and southern coast districts, extending some distance inland. Height, 100 to 150 feet; diameter, 2 to 5 feet.

Eucalyptus longifolia, Myrtaceæ (woollybutt): Timber strong and durable; used for wheelwrights' work, fencing, felloes, spokes, shafts, honse building. Hab., open forests, on rich alluvial flats, coastal districts; plentiful. Height, 100 to 150 feet; diameter, 3 to 5 feet.

Eucalyptus macrorrhyncha, Myrtaceæ (stringybark): Timber excellent for house carpentry, flooring boards, fencing, etc. Hab., open forests, chiefly west of the dividing range.

Eucalyptus microcorys, Myrtaceæ (tallowwood): Timber strong, handsome, and durable; very useful for building purposes, and especially for flooring boards; used also for palings, etc. Hab., coast districts. Height, 100 to 150 feet; diameter, 6 to 8 feet.

Eucalyptus pilularis, Myrtaccaæ (blackbutt): Timber excellent for house carpentry, ship building, and for any purpose where strength and durability are required. Hab., open forests from Twofold Bay to the Hastings River, and extending a considerable distance inland. Height, 100 to 200 feet; diameter, 3 to 8 feet.

Eucalyptus paniculata, Myrtaceæ (she or pale ironbark): Timber much valued, hard, tough, strong, unlocked, and durable; used for bridges, sleepers, railway carriages, beams, poles of bullock drays, piles, spokes of wheels, etc. Hab., open forests, northern and southern coast districts; plentiful. Height, 100 to 150 feet; diameter, 4 to 5 feet.

Eucalyptus populifolia (red box): Timber hard, close grained, and durable; used for posts and building purposes, mauls, railway sleepers, etc.; handsome wood when polished. Hab., on dry, stony ridges, southern and western interior districts; moderately plentiful. Height, 40 to 50 feet; diameter, 24 inches.

Acacia Cunninghamii, Leguminosæ (bastard myall): Wood close grained; useful for cabinet purposes. Very homogeneous. Analysis of bark-tannin, 9.13 per cent; extract, 1.15 per cent. Hab., northern scrub forests and New England; moderately plentiful. Height, 20 to 30 feet; diameter, 9 to 12 inches.

Acacia decurrens, Leguminosø (green wattle): Timber light, tough, and strong, excellent fuel. Bark rich in tannin; varying from 25 to 35 per cent. Hab., northern and southern coast districts; pleutiful. Height, 20 to 50 feet; diameter, 6 to 9 inches. 
Acacia doratoxyion, Leguminosæ (currawang): Timber dark-colored, hard, heavy tough, close-grained, and durable; used for gates, buggy poles, furniture, etc., and formerly used by the Aboriginese for spears and boomerangs; leaves eaten by stock. Hab., dry, stony ridges, southern, southwestern, and western interior districts; moderately plentiful. Height, 20 to 30 feet; diameter, 6 to 12 inches.

Acacia homolophylla, Leguminosæ (curly yarran): Timber much sought after for turnery work. Wood hard and fragrant; very durable. Hab., central and western New South Wales. Height, 20 to 30 feet; diameter, 6 to 12 inches.

Acacia melanoxylon. (R. Br.) Leguminosæ (blackwood): Timber hard and closegrained; considered one of the most valuable woods; much prized for furniture, general cabinet work, carriage building, billiard tables, etc. The figured wood is cut into veneers; when polished it closely resembles walnut wood. Hab., the extreme south only of New South Wales. It is abundant in Tasmania and Victoria. Height (in New South Wales), 50 to 80 feet; diameter, 18 to 24 inches.

Acacia Oswaldi, Leguminosæ (umbrella bush): Timber faintly scented, dark-colored, hard, heavy, close-grained, and durable; useful for turnery and cabinet work; a dense shade tree; leaves eaten by stock. Hab., open plains, Lachlan, and other interior districts; not plentiful. Height, 15 to 20 feet; diameter, 6 to 9 inches.

Acacia pendula, Leguminosæ (myall): Timber hard, close-grained; in an unpolished state it preserves a peculiar fragrance of violets, and is in consequence in much request for making glove, handkerchief, and other fancy boxes, and tobacco pipes. Hab., central and western New South Wales. Height, 30 to 40 feet; diameter, 18 to 20 inches.

Acacia penninervis, Leguminosæ (hickory or mountain hickory): Timber hard, moderately heavy, close-grained, and durable; used for cabinet purposes, and the bark for tanning. Hab., brush forests, northern and southern coast districts and Blue Mountains; plentiful. Height, 30 to 40 feet; diameter, 12 to 18 inches.

Acacia salicina, Leguminosæ (koobah, or native willow): Timber close-grained, tough, heavy, dark-brown, and nicely marked; takes a high polish; used in furniture and cabinet-making. Hab., portions of central, and in western New South Wales. Height, 30 to 50 feet; diameter, 12 to 18 inches.

Angophora subvelutina, Myrtace» (broad-leaved apple tree): Timber moderately heavy, tough, and very hard when dry; used for wheel-naves, bullock yokes, posts, and rails; dresses and polishes well. Hab., northern rivers and southern coast districts. Height, 70 to 80 feet; diameter, 24 to 36 inches.

Aphananthe phillipinensis, Urtice» (elm): Timber light in color, close-grained; used for ceilings, linings, etc. Hab., northern New South Wales. Height, 80 to 90 feet; diameter, 15 to 18 inches; not plentiful.

Arancaria Cunninghamii, Coniferæ (hoop or colonial pine): Timber strong and durable, but soon decays when exposed to alternate damp and dryness. Is largely nsed, and as a cheap, soft wood yields spars 80 feet to 100 feet long; pale in color. Hab., northern New South Wales. Height, 150 to 200 feet; diameter, 24 to 48 inches.

Alphitonia excelsa, Rhamneæ (red ash): Timber hard, firm, and close-grained. Hab., brush forests of coast districts of New South Wales. Attains a height of 100 feet.

Banksiaintegrifolia, Proteacer (white honeysuckle): Timber tough and strong; used for boat knees and ribs, bullock yokes, etc. Hab., open and scrub forests, northern and sonthern coast districts; plentiful. Height, 40 to 50 feet; diameter, 1 to 2 feet.

Backhousia myrtifolia, Myrtaceæ (grey myrtle or lavewood): Timber close-grained, hard, and durable; used for tool handles, mallets, and is suitable for turnery. Hab., banks of creeks and damp situations; northern and southern districts moderstely plentiful. Height, 30 to 40 feet; diameter, 12 to 18 inches. 
Backhousia sciadophora, Myrtaceæ (myrtle): Timber hard, close-grained ; not generally used or known, but considered likely to be suitable for wood engraving, turnery, etc. Hab., mountain scrub forests, northern coast districts; plentiful in places. Height, 80 to 90 feet; diameter, 2 feet.

Ceratopetalum apetalum, Saxifrageæ (coaehwood): Timber fragrant, light, soft, tough and close-grained; nsed for cabinetwork, boat and coach building. Hab., in gullies northern and southern coast districts. Height, 50 to 70 feet; diameter, 12 to 24 inches.

Casuarina suberosa, Casuarieæ (black oak): Timber useful for cabinetwork; used for bullock yokes, mauls, tool handles, shingles. Hab., coastal and inland. Height, 40 to 50 feet; diameter, 18 to 24 inches.

Cupania semiglanca, Sapindaceæ (black ash): Timber, hard, tough, close-grained, elastic; not much used. Hab., brush forests, northern and southern coast dístricts; not plentiful. Height, 40 to 50 feet; diameter, 1 to $1 \frac{1}{2}$ feet.

Cryptocorya obovata, Laurineæ (sycamore, or she beech): Timber light, soft, and durable; used for flooring boards, staves, and inside house carpentry. Hab., brush forests, northern coast districts; not plentiful. Height, 60 to 70 feet; diameter, 2 to 3 feet.

Dysoxylon muelleri, Meliaceæ (turnip-wood): Timber red, easily wrought, and durable; used for cabinetwork, cigar boxes, and interior fittings, etc. When fresh cutit emits an odor similar to that of a Swedish turnip. Hab., brush forests, northern coast districts; not plentiful. Height, 100 to 120 feet; diameter, 3 to 4 feet.

Dysoxylon fraserianum, Meliaceæ (rosewood): Timber resembles "red cedar." It is beautifully marked, and suitable for cabinetwork, etc. Fragrant. Hab., northern coast districts. Height, 80 to 100 feet; diameter, 2 to 3 feet.

Daphnandra micrantha, Monimiaces (a yellow wood): Timber fragrant; yellow, when fresh, close-grained, easily wrought, and takes a good polish; used for cabinetwork, etc.; bark intensely bitter. Hab., brush forests, northern coast districts; plentiful in places. Height, 100 to 120 feet; diameter, 3 feet.

Doryphora sassafras, Monimiaceæ (sassafras): Timber is somewhat soft, but suitable for the inside lining of houses and some kinds of furniture, also for packingcases; the wood is fragrant, and disagreeable to all kinds of vermin. Light in weight when seasoned, and light colored. Hab., coastal districts. Height, over 50 feet; diameter, 24 to 36 inches.

Eucalyptus Baileyana, Myrtaceæ (a stringybark): Timber very tough, suitable for tool handles, etc.; not much used. Hab., open 4 forests, on ridges, north coast distric ts; not plentiful. Height, 50 to 100 feet; diameter, 2 to 3 feet.

Eucalyptus microcorys, Myrtaceæ (tallow-wood): Timber of a greasy nature, strong and durable; used for flooring and general purposes, boatbuilding, etc. Hab., northern open forests, coast districts; plentiful. Height, 100 to 150 feet; diameter, 36 to 72 inches.

Eucalyptus microtheca, Myrtace» (coolibah): Timber'hard, heavy, and close grained; useful in building, but not much used. Hab., plains, subject to variation, seldom on the banks of running streams; Lachlan and Darling River districts, extending to the Barrier Ranges. Height varies greatly, sometimes little better than a shrub to 50 feet.

Eucalyptus pilularis, Myrtaceæ (blackbutt): Timber excellent for honse carpentry, bridge-planking, ships' decks, paving cubes, etc.; is coming greatly into favor, and is consequently used largely; is a valuable species of Eucalyptus, straight in grain, moderately heavy. Hab., open forests from Twofold Bay to the Hastings River, and extending some distance inland. Height, 100 to 200 feet; diameter, up to 15 feet (exceptionally).

Eucalyptus polyanthema, Myrtaceæ (bastard box): Timber remarkably tough, hard, and elastic; used'for naves, felloes, and spokes of wheels, agricultural implements, 
bridge work, etc. Hab., open forests, usually on banks of creeks and damp situations in the southern coast and interior districts; moderately plentiful. Height, 50 to 60 feet; diameter 2 to 3 feet.

Encalyptus saligna, Myrtaceæ (flooded gum, blue gum): Timber strong and durable, splendid wood, in good repute for building purposes, as it does not readily take fire, and is one of the straightest in the grain and easiest to work of the Eucalyptus timbers; it is also used for shipbuilding, ship planks, wheel naves, felloes, etc.; timber varies; supposed due to situation and soll where growing. Hab., open forests on banks of creeks, and rich, moist, alluvial soil; northern and sonthern coast districts; plentiful. Height, 100 to 120 feet; diameter, 36 to 60 inches.

Eucalyptus sideroxylon, Myrtaceæ (red ironbark): Timber highly esteemed for strength and durability, and much used for large beams, girders, sleepers, drawpoles, fuel, and other purposes, in which strength and durability are required. Hab., open forests northern and southern coast districts, and central districts, New South Wales; plentiful. Height, 100 to 150 feet; diameter, 3 to 5 feet.

Eucalyptus sideroxylon, Myrtaces (mugga): Timber soft in character when compared with other ironbarks; is not plentiful, being found in small belts or patches; chiefly in central New South Wales, Macquarie, and Bogan River districts; does not grow to any size.

Eucalyptus tereticornis, Myrtaceæ (red gum): Timber hard, heavy, close grained and durable; used for posts and rails of fences; bridge, house, and ship building, wheelwrights' work, etc. Hab., open forests, northern and southern coast districts. Height, 80 to 100 feet; diameter, 36 to 48 inches.

Eucalyptus 7irgata, Myrtaceæ (mountain ash): Timber tough, durable, and elastic, splits freely; used for staves of casks, shingles, poles, shafts of drays, palings, rails, and rough buildings. Hab., open forests, southern coast districts and Blue Mountains; plentiful. Height, 100 to 150 feet; diameter, 3 to 4 feet.

Eugenia Ventenatii, Myrtaceæ (myrtle): Timber close grained and tough; used for tool handles, ribs of boats, and the flooring boards of verandas. Hab., brush forests, Hastings, Macleay, Clarence, and Richmond rivers. Height, 40 to 60 feet; diameter, 24 to 36 inches.

Flindersia Oxleyana, Meliaceæ (light yellow wood]: Timber strong, durable, fine grained, and of good color; used in boatbuilding, cabinetwork, and to many purposes to which cedar is applied; useful wood for fancy work, owing to palo yellow color; resembles beech; suitable for hand-screen making, buggy shafts, etc.; not plentiful. Hab., northern brush forests, New South Wales. Height, 80 to 100 feet; diameter, 24 to 42 inches.

Flindersia Beunettiana, Meliaceæ (bogum-bogum): Timber close grained, nseful for saddle-making, staves, etc.; not much used. Hab., northern districts, New South Wales. Height, 70 to 90 feet; diameter, 18 to 26 inches.

Flindersia Schottiana, Meliaceæ (ash): Timber hard, close grained, prettily marked, and of a pale yellow color; nsed for shingles and staves and for cabinetwork. Hab., Hastings River, New South Wales. Height, 30 to 60 feet; diameter, 18 to 30 inches.

Frenela robusta, Coniferæ (white or common pine): Timber is very full of knots, polishes well, and shows to advantage; has a camphoraceous odor; varies in color from light to dark brown; is very durable, and resists white ants to a great extent; of a brittle nature; used for building in central districts, lining-boards, and ceilings. Hab., central and western Now South Wales. Height, 60 to 70 feet; diameter, 18 to 24 inches.

Frenela Macleayana, Coniferæ (Port Macquarie pine): Timber light and nseful; nsed for indoor purposes, weatherboards, deals, battens, etc. Hab., northern New South Wales. Height, 20 to 30 feet; diameter, 6 to 12 inches. 
Gmelina Leichhardtii, Verbenaceæ (white beech): Timber strong, durable, and easily worked; prized for decks of vessels, flooring of verandas, etc.; light colored, and useful for turning and furniture-making; one of the most useful of our timbers. Hab., brush forests, northern and southern coast districts; not very plentiful. Height, 120 to 150 feet; diameter, 36 to 60 inches.

Melaleuca leucadendron, Myrtaceæ (white tea-tree): Timber hard, heavy, and close-grained; said to be imperishable underground. Hab., northern and southern coast districts; plentiful. Height, 50 to 60 feet; diameter, 24 to 36 inches.

Melia composita, Meliaceæ (white cedar): Timber soft, easily worked; wood from matured trees is found to be fairly durable; splits easily; handsomely marked and polishes well; much valued for staves and the finer kinds of coopers' work; a beautiful flowering and foliaged shade tree; suitable for plantiug in public parks in warm situations. Hab., brush forests, northern coast districts; moderately plentiful. Height, 80 to 100 feet; diameter, 3 to 4 feet.

Olea paniculata (marble wood) : Timber hard, close grained, and durable; heartwood nicely mottled; used for staves, and suitable for cabinetwork and turnery. Hab., brush forests, northern and southern coast districts; not plentiful. Height, 40 to 50 feet; diameter, 2 to $2 \frac{1}{2}$ feet.

Petalostigma quadriloculare, Euphorbiaceæ (native quince): Timber hard, close grained, and durable; prettily marked, but not used. Hab., open forests on margins of brush forests, northern coast districts; not plentiful. Height, 10 to 12 feet; diameter, 6 inches.

Rhodamuia argentea, Myrtaces (white myrtle): Timber hard, fine grained, and dura. ble; suitable for carving, turning, fancy, and cabinetwork, etc. Hab., brush forests, northern coast districts; moderately plentiful. . Height, 80 to 100 feet; diameter, 2 to 3 feet.

Syncarpia leptopetala, Myrtaceæ (turpentine myrtle): Timber hard, heavy, and durable; used for turnery, etc. Hab., gullies, northern coast districts; not plenti. ful. Height, 50 to 60 feet; diameter, 24 inches.

Syncarpia laurifolia (turpentine): Timber hard, heavy, strong, and durable; used extensively for piles; used also for posts, shipbuilding, sleepers, and general building purposes; a difficult wood to burn, and very durable underground. Hab., in gullies, northern and southern coast districts, and Blne Mountains; plentiful. Height, 100 to 150 feet; diamoter, 36 to 60 inches.

Stenocarpus salignus, Proteaceæ (red silky oak, beefwood): Timber highly appreciated and now scarce; used for making furniture, picture frames, walking sticks, venters, and the finer kinds of coopers' work. Color, red-brown, and somewhat mottled; somewhat hard in texture, but easily worked. Hab., northern coast districts and Illawarra, Now South Wales. Height, 30 to 50 feet; diameter, 18 to 24 inches.

Tristania conferta, Myrtaces (brush box): Timber hard and durable, heavy, and close grained; used for bridge and housebuilding, shipbuilding, plow beams, wheelwrights' work, etc., and largely planted for shadle purposes in towns. Hab., open forest ridges, northern coast districts. Height, 80 to 120 feet; diameter, 36 to 60 inches. Plentiful.

Tristania suaveolens, Myrtaceæ (broad-leaved water gum): Timber remarkably strong, elastic, tough, close grained, and durable; used for mallets, tool handles, cogs for wheels, posts, etc. Hab., open and brush forests, northern coast districts; moderately plentiful. Height, 60 to 80 feet; diameter, $1 \frac{1}{2}$ to 2 feet.

Tarrietia argyrodendron, Sterculiaceæ (ironwood): Timber white, close grained, hard, and durable; used for building purposes and staves. Hab., brush forests, northern coast districts; plentiful. Height, 80 to 100 feet; diameter, 3 to 4 feet.

Vitex lignum-vitæ, Verbenace» (lignum-vitæ, or white beech): Timber valuable and useful, durable, close grained, and does not shrink in drying, much used for decks of vessels and veranda floors; suitable for turnery and cabinetwork. 
Hab., brush forests, northern coast districts; not plentiful. Height, 70 to 80 feet; diameter, 24 inches.

Zanthoxylum brachyacanthum, Rutaceæ (satinwood, a yellow wood): Timber bright, soft, silky, close grained, easily wrought; used for cabinetwork, etc. Hab., brush forests, northern coast districts, Now South Wales; not plentiful. Height 40 to 50 feet; diameter, 10 to 15 inches.

Castanospermum australe, Leguminosæ (black bean, or Moreton Bay chestnnt): Timber resembles walnut wood; is dark colored, handsome, close grained, and durable; used for cabinetwork; is coming into more general use than formerly, as its qualities are better known; a valuable timber and shade tree, and very ornamental; stock-owners destroy this tree, owing to their cattle being poisoned by eating its seeds; the seeds are soaked in water, roasted, and eaten by the aborigines. Hab., brush forests, northern coast districts; moderately plentiful. height, 120 to 130 feet; diameter, 4 to 5 feet.

Dysoxylon Fraserianum, Meliacex (rosewood): Timber resembles red cedar. It is beautifully marked, and suitable for cabinetwork, etc.; fragrant. Hab., northern coast districts. Height, 80 to 100 feet; diameter, 2 to 3 feet.

Dysoxylon Muelleri, Meliaceæ (red bean): Timber red, easily wrought, and durable; used for cabinet-work, cigar boxes, interior fittings, etc. When fresh cut it emits an odor similar to that of a Swedish turnip. Hab., brush forests, northern coast districts; not plentiful. Height, 100 to 120 feet; diameter, 3 to 4 feet.

Eucalyptus rostrata, Myrtaceæ (red gum): Timber strong, hard, heavy, close grained, and durable; almost impervious to white ants and teredo; used for ship and boat building; piles, flooring boards, weather boards, planking, railway sleepers, bridges, wharves, and building purposes generally; one of the best and most valuable hardwoods. Hab., open forests, chiefly on river banks; and rich alluvial flats subject to inundation; Murray and Edwards rivers, and most of the rivers of the interior; plentiful. Height, 100 to 200 feet; diameter, 3 to 5 feet.

Elæocarpus grandis, Tiliaceæ (mountain ash): Timber, white, tough, soft, close grained, and easily wrought; used for building purposes, etc. Hab., brush forests, northern coast districts; moderately plentiful. Height, 100 to 150 fect; diameter, 4 to 5 feet.

Gmelina Leichhardtii, Verbenace» (beech): Timber strong, durable, and easily worked; prized for decks of vessels, flooring of verandas, etc.; light-colored, and nseful for turning and furniture-making; one of the most useful of our timbers. Hab., brush forests, northern and southern coast districts; not very plentiful. Height, 120 to 150 feet; diameter, 36 to 60 inches.

Owenia cepiodora (onion wood): Timber valuable for cabinetwork; of a red color and prettily marked, sometimes very handsome; is durable; when freshly cut it emits a peculiar odor. Hab., brnsh forests, northern coast districts; not plentiful. Height, 100 to 124 feet; diameter, 3 to 4 feet.

Rhus rhodanthema, Anacardiaceæ (yellow cedar): Timber close grained and durable; takes a good polish ; suitable for carving, turning, cabinet and fancy work. Hab., brush forests, northern jeoast districts; not plentiful. Height, 50 to 60 feet; diameter, 2 to 3 feet.

Of course there are many other timbers in New South Wales, but believing it is the design of the Government to have reports cover only the space necessary for information which is of practical use, I selected those varieties now having commercial value.

Besides the above native woods, there are large quantities of pine, fir, cedar, and redwood consumed in this and other Australian colonies, though, owing to the prevailing dullness and the large stocks on hand, the demand is very light. 


\section{LUMBER MOST USED.}

For uses requiring long and strong timbers, say for scaffolding, joists, rafters, and the like, especially where uniform strength is needed without too great weight, "Oregon pine," or what is known in the Pacific States as " fir," is most highly prized and most extensively used. It comes chiefly from Washington and Oregon, and in the rough state.

Redwood is a favorite timber for inside work, as it works so much more easily than the native woods and finishes as finely. It is imported in the rough and dressed at the local mills.

As a rule the native woods of Australia are very hard and heavy. While many of them take a very fine polish and can be richly finished, they are hard to work and to handle. Ironbark stands first on Lloyd's estimate as a shipbuilding timber.

For flooring the Kauri pine of New Zealand, of which there are considerable forests, is regarded as very good, and is much in use, though it is inferior to the fir of the Pacific States when the latter is sawed with proper regard to the grain. The Kauri pine has little strength, as there seems to be a lack of continuity of fiber, and it is certainly less durable than fir.

There are complaints that the Oregon pine (fir) flooring, when worn sometime, splinters or scales up, but that comes from its being sawed without proper regard to grain. The Australians want the best of everything, and I feel confident that the long, clear flooring of the Pacific Northwest fir, sawed properly and dressed to, say 4 inches in width, would take the market-when there is one.

For cabinetwork, carriages, carts, vehicles, and most machinery the strong and heavy native woods are chiefly used, while for cooperage the timbers of New Zealand and Tasmania are preferred.

\section{IMPORTATION OF LUMBER.}

The importations of 1893 were $8,118,925$ superficial feet of dressed lumber, valued at $\$ 271,036$, and the importations were distributed as follows:

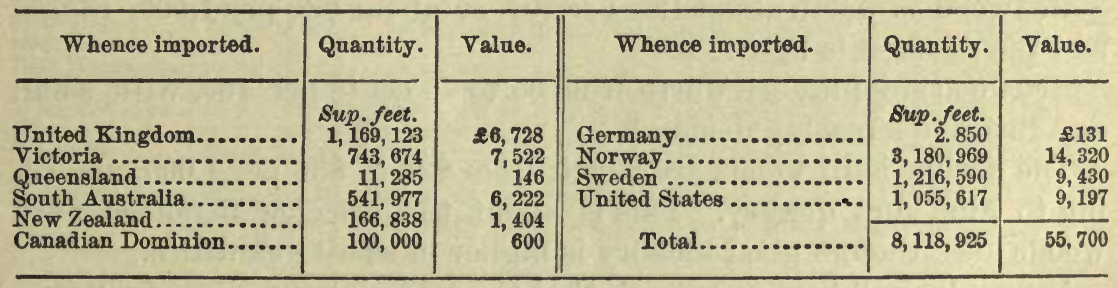

Of rough or undressed lumber (all of what we in the United States call "lumber" is here called "timber," and it is reckoned by the hundred superficial feet instead of by the thousand) there was imported in the 
same year $59,543,868$ feet, valued at $\$ 1,729,396$, and the importations were distributed as follows:

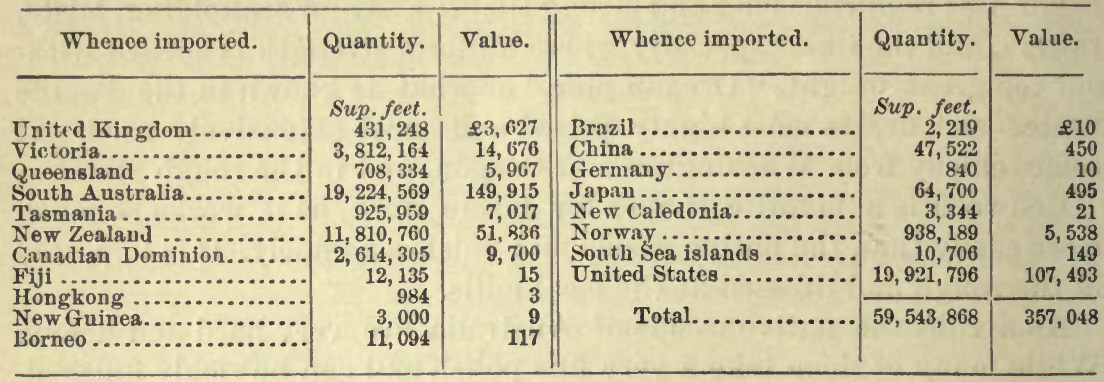

Upon careful inquiry I find that a great portion of the timber for which South Australia has the credit, in the tables of importations, is really from Oregon and Washington, and taken to the Broken Hill mines in New South Wales through South Australia, entered at Adelaide or Fort Price.

\section{DUTY.}

There is an import dnty of $3 s$. per 100 superficial feet, or about $\$ 7.20$ per 1,000 on dressed lumber, and $\$ 3.60$ per 1,000 on rough lumber. This duty does not apply to ash, hickory, oak, sycamore, or sandal wood, when undressed. On palings the duty is $1 s$. per 100; laths, $9 d$. per 1,000 ; shingles, $1 s$. per 1,000 ; pickets, $1 s$. per 100 feet, superficially dressed; doors, sashes, and shutters, $2 s$. each.

\section{PRICES.}

At present (March, 1894) times are dull, cousumption is very light, the stocks on hand are large, and prices are low. "Oregon pine," which means the Puget Sound, or Oregon, fir, is worth but 8s. per 100, or say $\$ 20$ per 1,000 in the local market, by eargo. Freights are now very low, but $27 s .6 d$., or $\$ 6.87$ per 1,000 , and with a duty of $\$ 3.60$ per 1,000 , it leaves but $\$ 9.53$ per 1,000 for the purchase of the lumber, and the profit, insurance, commission, etc. This is a poor outlook for our Pacific slope lumber trade in Australia.

Redwood is worth about $12 s$. per 100 , or about $\$ 30$ per 1,000 , rough, and the demand is light.

Redwood shingles are worth from 65 to 75 cents per 100, with small and rather decreasing demand.

The native hard woods are worth from $\$ 24$ to $\$ 36$ per 1,000 , according to kind and quality. This is about the price of imported hard woods also, though good hickory is higher in small quantities.

It may be well here to remark that the prices above given for "Oregon pine," $\$ 20$ per 1,000 , is low, but it is the price (given me by a custom house officer and an American shipmaster) received for a cargo just from Port Blakely, on Puget Sound. I incline to think this price 
very low, possibly the lowest reached but no lower than given me by local dealers.

\section{CLIMATE.}

Sydney is situated in latitude $33^{\circ} 51^{\prime}$ south and longitude $151^{\circ} 13^{\prime}$ east. It is well known by all observers that the climate in the south temperate zone is more equable and salubrious than in like latitudes in the northern hemisphere, and while, owing to local causes, there are great differences in the humidity of districts not widely separated, there is a remarkable evenness of temperature ranging through the seasons.

I think the following table taken from "The Year Book of Australasia" for 1893 answers the question in a most concise form:

\section{Climate of New South Wales during the year 1892.}

[Contributed by H. C. Russell, esq., B. A., O. M. G., F. R. S., F. R. M. s., eto., government astronomer for New South Wales.]

\begin{tabular}{|c|c|c|c|c|c|c|c|c|c|c|c|c|c|c|}
\hline \multirow[b]{2}{*}{ Stations. } & \multirow[b]{2}{*}{ 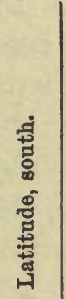 } & \multirow[b]{2}{*}{ 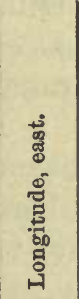 } & \multirow[b]{2}{*}{ 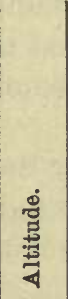 } & \multirow[b]{2}{*}{ 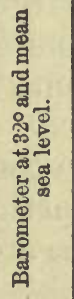 } & \multicolumn{5}{|c|}{ Temperature. } & \multirow[b]{2}{*}{ 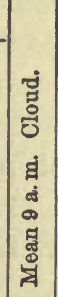 } & \multirow[b]{2}{*}{ 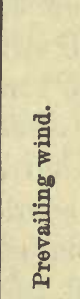 } & \multicolumn{3}{|c|}{ Rainfall. } \\
\hline & & & & & 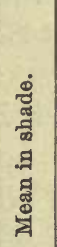 & 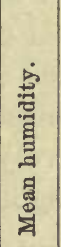 & 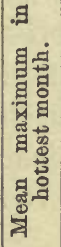 & 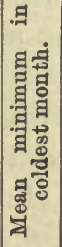 & 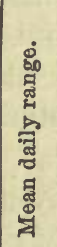 & & & $\begin{array}{l}\text { तై } \\
\text { हैं } \\
\text { Hี }\end{array}$ & 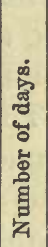 & 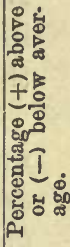 \\
\hline & & $\stackrel{\circ}{147.0}$ & 572 & 30.039 & 60.8 & & & & & & & & & \\
\hline & 30.32 & 151. 38 & 3,278 & 30.047 & $\begin{array}{l}00.8 \\
56.5\end{array}$ & $\begin{array}{l}14.0 \\
74.8\end{array}$ & 82.6 & $\begin{array}{l}30.1 \\
32.3\end{array}$ & $\begin{array}{l}24.8 \\
23.7\end{array}$ & $\begin{array}{l}4.0 \\
4.9\end{array}$ & W. & $\begin{array}{l}29.050 \\
44.930\end{array}$ & 116 & $\begin{array}{r}+5 \\
+40\end{array}$ \\
\hline & 33.24 & 149.37 & 2,200 & & 56.1 & 78. 7 & 89.5 & 26.6 & 28.9 & 4.5 & SW. & 31.290 & 117 & \\
\hline & 30.3 & 145.58 & 349 & 30 & 70.0 & 69.3 & 107.7 & 38.1 & 29.5 & 2.1 & NE. & 8. & 37 & -53 \\
\hline ge. & 35.12 & 150.45 & 175 & 75 & 61.3 & 73.6 & 75.3 & 46.4 & 13.7 & 6. & SF & 57. & 128 & +10 \\
\hline & 36.12 & 149.9 & 2,637 & 30. & 53.3 & 75.8 & 83.9 & 27.3 & 25.7 & 6.6 & NW. & 23 & 112 & +20 \\
\hline D & 35.32 & 145.2 & 320 & 8 & 61.6 & 73.1 & 97.7 & 31.3 & 32.7 & 3. & SW. & 16. & 75 & -2 \\
\hline Du & 32.18 & 148.33 & 863 & & 63.4 & 71.4 & 94.8 & 34.5 & 27.4 & 2.7 & E. & & 90 & +26 \\
\hline Ede & 37.0 & 149.59 & 107 & 11 & 59.7 & 83.1 & 75.3 & 44.6 & 14.9 & 5.5 & SW. & 41.680 & 127 & +15 \\
\hline For & 33.27 & 148.5 & 808 & 30 & 62.5 & 75.7 & 95.2 & 36.2 & 24.6 & 1.3 & NW. & 25.240 & 86 & +18 \\
\hline G & 34.45 & 149.45 & 2,129 & 30.035 & 56.7 & 76.8 & 84.8 & 32.9 & 23.1 & 3.5 & W. & & 8 & -4 \\
\hline on & 29.43 & 152.56 & & & 68.9 & & 91.6 & 44.8 & 24.2 & 3.6 & SE. & 52.840 & 111 & +38 \\
\hline & 34.30 & 444.56 & 305 & 30 & 63.7 & | 73.4 & 95. & 36 & 27.0 & 3. & S. & & 8 & ? \\
\hline Inv & 29.48 & 151.10 & 1,953 & 30.034 & 60.8 & 72.9 & 85.4 & 36.6 & 20.3 & 3.9 & S. & & 9 & +3 \\
\hline & 35 & 148 & 4,640 & 30.067 & 45.3 & 74.9 & 71. & 22.8 & & 4.9 & NW. & & 159 & -12 \\
\hline & 32.47 & 151.35 & 98 & & 59.4 & & 86.3 & 33.9 & 25.7 & 4.1 & SE. & & 126 & +56 \\
\hline ria. & 33.36 & 150 & 3,490 & 29.958 & 53.2 & 75.0 & 76 & & 17.9 & 5. & W. & & 132 & +33 \\
\hline Mad & 32.35 & 149 & 1,500 & & 63.7 & 79.0 & 92.1 & 36.0 & 24.9 & 4.4 & W. & 34. & 87 & +27 \\
\hline To & 32.55 & 151.50 & & 30.049 & 63.6 & 72.0 & 78.7 & 47. 1 & 12.5 & 4.9 & S. & 71. & 215 & +49 \\
\hline & 33 & 14 & 2,891 & & 55.8 & & 81.5 & 35.4 & 17.5 & 4.2 & NE. & 42.270 & 121 & +9 \\
\hline rie. & 31.25 & 152.54 & & 30.027 & 63.4 & 84.0 & 80.0 & 44.0 & 17.2 & 4. & SW & & 0 & +27 \\
\hline & 33.51 & 151.13 & 146 & & 62.5 & 78.1 & 78. 3 & 46.5 & & 5. & NE. & & 189 & +37 \\
\hline & 35. & 147.24 & 615 & 30 & 61.7 & 74.0 & 99.0 & 31.1 & 32.1 & 3. & E. & 20. & 88 & -10 \\
\hline & & 14 & 522 & 30.079 & 68.5 & 67.0 & & 40.0 & & 2.4 & $\mathrm{~N}$ & & 64 & -30 \\
\hline War & 29.35 & 150.37 & 1,106 & & 61.6 & 73. & 89.7 & 33.7 & 26.6 & 3.3 & $\mathrm{NW}$. & 37.460 & 79 & +28 \\
\hline We & 34.8 & 142. & 144 & & 60.9 & 73.0 & 89.9 & 32.3 & & 3.8 & NNE. & & 66 & +7 \\
\hline Wil & 31.31 & 143. & 246 & & 64.4 & 56.0 & 101.9 & 32.2 & 33. 7 & 2.6 & S. & 7.890 & 37 & -32 \\
\hline Wollongong . & 34.25 & 150.56 & 67 & 30.040 & 61.9 & 71.0 & 80.1 & 43.9 & 19.1 & 4.1 & SW. & 58.330 & 120 & -36 \\
\hline
\end{tabular}

\section{GENERAL BUI LDING.}

There is very little building of any kind now going on in New South Wales. In the rural districts there is little imported lumber used, even 
in prosperous times, as local mills furnish native timber cheaper than the imported article can be procured.

For fencing, the material is prepared by splitting the free grained gums; for building, either brick or native wood is used; while for roofing, corrugated iron is now chiefly preferred. This material is much cheaper than slate, considerable cheaper than shingles, and with the convenience with which it is placed, as well as transported, it is rapidly becoming the roofing material of the country. Even in the cities, many fine buildings are roofed with it, and nearly all the porches, verandas, barns, and outhouses are covered with this not unattractive and very suitable material.

There are practically no buildings going up in the cities of Australia anywhere, nor can there be in the near future. I am informed that in Melbourne there are 20,000 empty houses waiting tenants, and surely of the 83,000 dwellings in Sydney there are a few thousand beyond the necessities of the population. Most of the timber used in the mines is from the native forests, though in former days there was considerable Oregon pine used at Newcastle and Broken Hill. The demand at Broken Hill still continues, as I am informed that several vessels during the last few months arrived at South Australia with lumber from the Pacific coast for these mines.

There is no shipbuilding proper in New South Wales, but for the numerous small craft extensively constructed here, the long, strong, and clear timbers from the Oregon pine are most available and considerably used.

There is very little railroad building going on in this colony, and the timbers used are wholly native. There are probably nowhere timbers so durable or suitable for railroad ties, called here sleepers, or for bridge building, as the local native woods. So me of these timbers have many merits; not only are they very strong and very durable, but some varieties, notably iron bark, are almost fireproof.

For car-building purposes the native woods are well adapted. They finish very smoothly, are strong, and take a fine polish.

\section{TRADE OUTLOOK.}

As to how we may increase our lumber trade with Australia, I would first remark that there is little hope of increase until a revival of business.

However, I would suggest that it is in our power to secure a greater portion of the existing trade by beating our competitors in quality. While laying no claim to special knowledge on that point, I have carefully examined the lumber from many of our States and from many countries, and I feel quite confident that the Oregon pine (fir), carefully selected from the forests of western Washington or Oregon and sawed with judgment, will furnish a class of lumber which for clearness, 
strength, and soundness is very far superior to any of the soft woods that come from Norway or New Zealand. The dealers and cousumers here are good judges, and they want the best there is. With them it is cold business.

Then it seems to me that owing to the hardness and great weight of native woods here, our light, tasteless, and odorless spruce should be used exclusively for fruit-packing purposes, whether the package be a crate, a box, or a barrel. Considering lightness, neatness in color, tastelessness, and all the qualities necessary for packages for eatables, $I$ believe the Pacific slope spruce much superior to any other material available for this market.

There is another suggestion I venture to make regarding a possible increased lumber trade in these colonies, and that is a reciprocal exchange of timbers or remission of duties. Our merchantable timbers are soft; theirs are hard. Ours are suitable for cottages, buildings, floorings, scaffoldings, joists, shipbuilding, etc., while theirs are superior for pavements, furniture, fine implements, etc. Sydney is better paved than any American city; save Washington. It is almost entirely paved with wooden blocks. A careful test of many years has been made. Experiments with different woods, as well as various metal and stone cubes, on the chief streets where there is the heaviest and most continued traffic, have been made, and the wood pavement has proved its great superiority.

It seems that turpentine, black butt, mahogany, and tallowwood have proved the better woods for the purpose. As compared with blue-stone cubes, the stone wears at the rate of 1 inch per year, and the better woods but one-twelfth of an inch. Besides being much more durable, they are less noisy, less destructive to vehicles, easier ou horses, and in every way more desirable.

Add to this the fact that they are also cheaper, and that a wood pavement makes a drive superior to asphalt, and why should our people not enjoy this luxury? There may be climatic objections in many American cities, but there certainly are not any on the Pacific coast.

Considering population, the people of New South Wales are the greatest commercial people on earth. They believe in trade. They are anxious for a market for every merchantable product of the country. I believe if our people would open up a market for the hard woods of this country, if they would experiment with and finally use this New South Wales paving material, which I believe to be the best in the world in suitable climates, it would result in reciprocal trade and give our lumber dealers the market of this country.

There are two other suggestions that I desire to make relative to our trade with Australasia, a little outside of the circularinstructions, but I think not so foreign to the subject as to subject me to criticism, and one is that our people should be not only very careful in the shipment of all articles for this market, but they should be sure that every article 
is as good as represented and fully equal to the sample. A few unscrupulous or careless dealers have aroused a feeling of suspicion against our countrymen, so there is a little prejudice to overcome and our competitors are not slow in using the advantage given them. The merchants of England claim these markets as their right, and the national pride, if not prejudice, of these people predisposes them to favor their own countrymen, while France and Germany are striving, by subsidies and low prices, to increase their trade here, so that Americans are compelled to rely upon the merits of their wares and the enterprise of their agencies.

But what is more needed to extend our trade than anything else, other things being equal, is that our strong exporting firms, merchants, manufacturers, etc., should establish agencies in this country, with active, wide-awake, honest, enterprising, Americans in charge, to handle and display American goods and keep American ideas, wares, enterprise, and inventions constantly before the people.

In transportation we have the advantage over any other country, and our people should have, and will have when they deserve it, 40 per cent of the trade of Australasia, instead of 3 per cent as now.

GEO. W. BeLL,

Consul.

SYDNEY, March 27, 1894.

\section{SOUTH AUSTRALIמ.}

NATIVE WOODS.

Apart from other characteristics, the trees of South Australia are not as tall as those which are found on the northeast and west of this territory. The eucalypti do not exceed 100 feet to 120 feet in height. Among the twenty species of eucalypti which appear in the extratropical parts of south Australia there are only a few varieties which are held in special estimation.

They are commonly called red, white, and blue gum, stringy bark, and peppermint. These are used for various purposes, such as building, rough carpentry, wheelwright's work, and for fuel. The red gum (Euca. lyptus rostrata) is very hard and solid, weighing about 62 pounds to the cubic foot, and when properly seasoned is impervious to the white ant; it is, however, most difficult to work up. The stringy bark ( $E$. obliqua) has its habitat principally on the hills. It sheds its bark in long fibrous strings, which loosen and droop down as they become detached by the newly-formed bark underneath. This process gives to the trunks of the trees a ragged, untidy appearance. The stringy 
1 ark grows so straight that the young trees are much used for seaffold poies, spars, etc., in which length, strength, toughness, and straight. ness are required. The wood of these trees makes excellent palings and shingles because it splits evenly and readily. It is also used largely for fencing rails and sometimes posts, but it soon perishes in the ground, and the white ant destroys it rapidly. As fuel it is not good. When dry it burns away fiercely; when green or damp it can with difficulty be got to burn at all, unless mixed with other more combustible wood. The blue gum ( $E$. dumosa) is valuable for all sorts of work, and for fuel as well. The white gum ( $\boldsymbol{E}$. viminalis) is generally inferior in durability; it does not resist white ants, and when green or damp it is worse even than stringy bark as fuel. The peppermint ( $E$. odorata) is a hard wood, useful for ordinary purposes, and very serviceable as fuel.

The red gum is widely distributed. It is never far distant from water, and its stately branches are almost invariably noticeable on the margin of creeks and water courses in the north.

All eucalypti, indeed most Australian trees, are remarkable for their naked appearance. The boughs in their gray outlines are always distinctly traceable through the foliage, which is smooth and shiny. From a distance the leaves scarcely seem to depend from the boughs. The trees for their size throw little share, and the thick branches of some varieties often drop off suddenly on a perfectly calm, hot day, to the certain destruction of anything that may happen to be beneath. These trees give a special monotony to the scenery of South Australia.

The wood of the acacia is useful only for cabinet work, but the blackwood (Acacia melanoxylon) has better qualities for purposes of that nature. This tree, however, is common in the southeast, while it is rare near Adelaide. It is more common still on the eastern side of the border. Another species of acacia, the wattle of the colonists ( $A$. pycnantha), at one time neglected, but now largely cultivated, is valuable for the gum which freely exudes from it. Its bark, bought in England as mimosa bark, is one of the best of the kinds used for tanning purposes. There are other kinds of acacia which are also valuable for tanning, but none are equal to the wattle.

The she-oak (Casurina stricta) is remarkable in appearance. Its fronds do not shape as ordinary leaves; they appear as continuations of the branches. It never reaches any, great height, and is almost funereal in aspect. The wind rushing or sighing through these trees causes a mournful whistling or wailing sound, according to its force. All kinds of cattle eat the fronds greedily. The wood is tough and splits tolerably even. It makes excellent spokes for wheels, handles for hammers, etc., and is used also for turning work and in cabinetmaking. As fuel it is excellent.

The tea trees (Melaleuca and Leptospermum) mostly inhabit low damp situations, and are to some extent valuable because of the durable nature of their wood when used underground, or perhaps in water. It 
is close-grained and hard, and when dry heavy. It is generally sound at the heart. The wood of the native pines of this province (Frenela robusta and $F$.rhomboidea) are not durable, and are little used except for fences or for fuel. The Banksia marginata, or honeysuckle, is oceasionally used for cabinet work, and the Myoporum acuminatum, although soft, is tongh, and forms excellent knees for boats.

The late Dr. Schomburgk, director of the botanic garden, Adelaide, from whose writings the foregoing account has been mainly derived, remarks upon the absence of native edible fruits, "of which there are none deserving the name except a few berry-bearing shrubs belonging to the orders Epacridae and Santalacca, Astroloma and Leucopogon, the principal species of which, the native currant of the colonists (Astroloma humifusum) and the so-called native peach, with a succulent pericarp and a hard, bony, much pitted endocarp (the quondong), are all :jouth Australia can boast of. There is also a deficiency in eatable root-bearing plants." There is one of which little notice has been taken-the muntree. It grows along the ground, and produces a berry of a size somewhat smaller than that of the ordinary Barcelona nut. The smell and taste are strong, and like that of an apple. It may be found on the banks of the Inman and Hindmarsh rivers, on Yorkes Peninsula, and in many other spots where sandy soil and moisture exist. The shoot withers rapidly when separated from the parent plant.

One peculiarity of the eucalypti has not been noticed, and that is their extraordinary vitality. As long as a strip of bark is continuous from the ground up to the branches, the tree lives. Thus trees many feet in diameter at and above the bole, hollowed out by the ravages of insects or by fire, leaving cavities large enough to shelter several persons, live and put forth their leaves as if nothing had ever occurred to interfere with their growth. Dr. Schomburgk, however, points out that when eucalypti trees die they begin to die from the topmost branches. The leaves fall off, and nothing but dry twigs and sticks are left until the end comes. The gum trees of all kinds are subject not only to the attacks of insects which destroy them, but to the visitation of a vegeta. ble parasite called the mistletoe. It attaches itself to the branches and hangs down in long pendulous vitiform bunches, and is not unlike the mistletoe of the oak. When it attacks a tree the death of that tree is only a question of time.

The sandalwood tree, which grows in abundance on Yorkes Peninsula, is short, but produces solid and strong wood. When freshly cut down it has an agreeable odor, which lasts for a long time, but becoming more and more faint as the trunk dries. It is useful for many purposes. It also does duty as firewood. Those who have read in Eastern tales about chambers being scented with burning sandalwood, and imagine that a perfume of a pleasant nature must be the result, would be com. pletely disillusioned by the combustion of our sandalwood. This wood is known even in China as a deadly foe to mosquitoes. This is not sur. 
prising, for anyone who has had the good or ill fortune to camp by a sandalwood fire in the bush will give his elear testimony to the fact that the smell of the burning wood is bad. It is not too much to say that it verges on the insufferable. Some specimens of the timber have been sent to England, and some were forwarded to the Paris Exhibition in 1871, but they have not attracted attention.

After noticing the general features of the flora of South Australia the author above referred to says:

Notwithstanding the little apparent difference in the formation of its surface, soil, and climate, the flora of South Australia introduces itself to the observer in its geographical extension by special and peciliar forms of plants in regions. These are the forest land, scrub land, grass land, and the intra-tropical regions.

The region of the forest land in South Australia occupies most of the mountain districts, and extends along the base of the mountain chains. The forests have not the fullness and lofty growth of those of other countries. The underwood is of medium size, more open and less difficult to penetrate. The forests are of less extent, and are intercepted by tracts of grass land. The encalypti are the most predominant forest trees; the stringy bark often forms whole forests in some mountain districts, but is seldom seen on the plains.

The trees of the forests do not appear crowded, and seldom do the branches of a tree reach those of a neighboring tree. The declivities of the mountain ranges are for the most part similarly timbered, the trees sometimes extending to the summits; often ouly one-half or two-thirds of the remaining part being grassed, with here and there copses of low shrubs, and stunted and much ramified trees. Often the whole declivities are grassed without even a shrub or tree.

Another feature of the table-land in the hill districts is the appearance of occasional hills clothed only with a covering of tussocky grasses, amongst fragments of ironstone quartz and sand, destitute of all other vegetation, except small scattered trees of the Causarina stricla, C. glauca, and the peppermint (Eucalyptus odorata).

The level table-land is generally covered with grass, but is deficient in shrubs. Here scattered are to be seen the most stately and majestic specimens of eucalyptus. Such table-lands have a park-like appearance, and the trees standing seemingly at measured distances, single or in small clumps, as if planted by a landscape gardener. The soil of these table-lands is, generally speaking, very rich and produces abundant crops of cereals. The underwood of the forests is most represented by the following genera: Correa, Alyxia, Prostranthera, Grevillea, Hakea, Isopogon, Exocarpus, Acacia, Banksia, Cassia, Calythrix, Pomaderris, Leucopogon, Leptospermum, Daviesia, Dillwynia, Eutaxia, Platylobium, Puitenaea, and shrubby eucalyptus.

"The beautiful genus Epacris, which is only represented in South Australia by one species ( $E$. impressa, frequently covers whole mountain ridges and declivities: when in bloom the different shades of color of its flowers produce an effect not readily described.

Among the most useful of the public institutions in South Australia is the woods and forest department. It was established about fourteen years ago, and was then called the forest board. Its organization, however, was not very successful, and its functions were transferred to an officer as head of a department under ministerial control. The change has proved to be beneficial, and forest planting in South Australia has been attended with the greatest success.

For forest purposes the colony has been divided into 4 districts, the northern containing 9 forests, covering 121,979 acres, the central dis- 
trict includes 8 forests, containing 21,647 acres, the western district has 10 forests, spread over 16,269 acres, and the southern district has 10 forests, with an area of 55,474 acres; altogether 215,369 acrus. The total area under operations in 1892 was 10,185 acres.

Young trees raised in the plantations are freely distributed, 372,1 2 having been spread over the colony in this way in 1890-91, and 322,383 in 1891'92. At the present time there are close upon a million of young trees available for distribution. The actual expenditure of the department for the fourteen years ending in June, 1892, was $£ 104,097$, and the revenue derived from the sale of trees, posts, railway sleepers, etc., amounted to $£ 103,340$. The small excess of $£ 799$ as expenditure over revenue during a term of sixteen years does not give an indication of the value of the forests' reserves and their contents. Many thousands of posts for fencing purposes and sleepers for railway construction have been supplied from the forest reserves, and the supply of available timber now growing in the forests is equal, without further planting, to all the requirements which are likely to arise in the colony for many years to come.

Many varieties of timber trees are grown in the plantations which are suitable for purposes other than those of railway and fencing works. Trees suitable for the manufacture of furniture and cabinet work of different kinds are grown there in perfection. Among them may be mentioned the American ash (Fraxinus Americana), which has succeeded beyond all expectation. Some of the trees were felled at the early age of ten years, and the timber after drying, was made up into various articles, such as buggy poles, tables, chairs, Indian clubs, mallets for driving tent pegs, constables' staves, trapeze bars, wickets, buggy naves, etc. Many of the samples were used for turnery, and in every case the results were most satisfactory. The wood is reported "to be unrivaled in toughness and adaptability for turning, as it stands working to the very outside and to the smallest dimensions of any timber without exhibiting any tendency to break off."

In 1891 "a consignment of the best American-grown ash was received by Messrs. Marshall \& Cu., and their toreman, after comparing the Australian-grown timber with it, unhesitatingly gave it as his opinion that the Australian article was equal to the American or anything received from any part of the world of the same kind of timber, being a better color and tougher, and working up equal to satin wood, while it never deadens from being polished, and always keeps its color."

The Pinus insignis has also been grown with the most satisfactory results. It possesses the special merit of requiring less dressing with the plane than any other deal, as a surface can be obtained much more readily thereon. It takes a good polish, is very tough, and does not split on exposure, which is a great advantage in connection with manufacturing purposes.

Mr. Gill, the conservator of forests, regards these results " as encour- 
aging in the highest degree, giving, as they do, most satisfactory proof of the progress already attained in the acclimatization of some valuable exotic timbers, and also as indicating what may be expected in later years when these timbers shall have been properly matured."

\section{KINDS OF LUMBER USED.}

The principal lumbers used are Oregon pine, which is preferred because it is most suitable in every respect for building and for its cheapness, and Jarrah and Tasmanian blue gum hard woods.

\section{IMPORTS OF LUMBER.}

The amount of lnmber imported is obtained from the latest statisti. cal returns (1892), and the names of the countries are as follows:

\begin{tabular}{|c|c|c|c|c|c|}
\hline Kinds and wh & $\begin{array}{l}\text { Quanti- } \\
\text { ties. }\end{array}$ & Value. & Kinds and whence imported. & $\begin{array}{l}\text { Quanti- } \\
\text { ties. }\end{array}$ & Value. \\
\hline 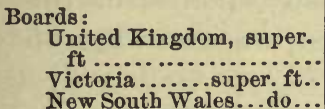 & \multirow{4}{*}{$\begin{array}{r}209,500 \\
183,539 \\
17,500 \\
36,600 \\
178,500 \\
89,500 \\
800 \\
151,800 \\
362,400 \\
4,704,200 \\
100,000 \\
3,785\end{array}$} & \multirow{4}{*}{$\begin{array}{r}\$ 8,425 \\
6,635 \\
1,270 \\
1,170 \\
4,050 \\
1,445 \\
25 \\
4,870 \\
13,000 \\
138,370 \\
4,000 \\
35,825\end{array}$} & $\begin{array}{l}\text { Sleepers: } \\
\text { Victoria.........number.. } \\
\text { Western Australia..do... }\end{array}$ & $\left\{\begin{array}{r}992 \\
89,422 \\
90,414 \\
\end{array}\right.$ & $\begin{array}{r}\$ 250 \\
79,785 \\
80,035 \\
\end{array}$ \\
\hline Western Australia .. do ... & & & Total .. & 170,828 & 160,070 \\
\hline 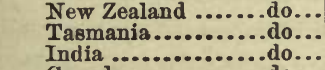 & & & $\begin{array}{l}\text { Shingles: } \\
\text { Tasmania ... }\end{array}$ & 16,600 & 100 \\
\hline $\begin{array}{l}\text { Canada ...... } \\
\text { Russia ...... } \\
\text { Norway and } \\
\text { Germany ... } \\
\text { United State }\end{array}$ & & & $\begin{array}{l}\text { Spars and quartering: } \\
\text { United Kingdom. loads.. } \\
\text { Victoria ...........do... } \\
\text { New South Wales ..do... } \\
\text { Western Australia..do... }\end{array}$ & \multirow{3}{*}{$\begin{array}{r}125 \\
217 \\
34 \\
4,554 \\
111 \\
5,213 \\
9 \\
34 \\
443 \\
9 \\
6,337 \\
\end{array}$} & \multirow{3}{*}{$\begin{array}{r}1,760 \\
3,225 \\
830 \\
75,175 \\
1,225 \\
51,135 \\
125 \\
590 \\
2,505 \\
135 \\
92,130 \\
\end{array}$} \\
\hline Total .. & $6,028,124$ & 219,085 & T & & \\
\hline $\begin{array}{l}\text { eals and bs } \\
\text { United I } \\
\text { Victoria } \\
\text { New Sou } \\
\text { Western }\end{array}$ & $\begin{array}{r}254 \\
71 \\
2 \\
1\end{array}$ & $\begin{array}{r}5,640 \\
1,100 \\
30 \\
15\end{array}$ & $\begin{array}{l}\text { India ............... } \\
\text { Singapore ............... } \\
\text { Canada ............. } \\
\text { Norway and Swede } \\
\text { United States..... }\end{array}$ & & \\
\hline & & 525 & Total........ & 17,086 & 228,835 \\
\hline $\begin{array}{l}\text { Tasn } \\
\text { New } \\
\text { Indi } \\
\text { Sing } \\
\text { Cana }\end{array}$ & $\begin{array}{r}1,046 \\
1,124 \\
31 \\
25 \\
8,062\end{array}$ & $\begin{array}{r}8,420 \\
16,500 \\
460 \\
250 \\
81,690\end{array}$ & $\begin{array}{l}\text { Spokes, in the rough: } \\
\text { Victoria....... number.. } \\
\text { New South Wales ...do... } \\
\text { Tasmania.............do... }\end{array}$ & $\begin{array}{r}50 \\
48,193 \\
1,300 \\
\end{array}$ & $\begin{array}{r}5 \\
2,380 \\
30 \\
\end{array}$ \\
\hline Rus & $\begin{array}{r}990 \\
10822\end{array}$ & $\begin{array}{r}16,500 \\
155,935\end{array}$ & Total...... & 49,543 & 2,415 \\
\hline $\begin{array}{l}\text { Norway and } \\
\text { Germany } \\
\text { United State }\end{array}$ & $\begin{array}{r}10,822 \\
8 \\
3,785\end{array}$ & $\begin{array}{r}155,935 \\
115 \\
46,660 \\
\end{array}$ & $\begin{array}{l}\text { Staves, in the } \\
\text { United Kin } \\
\text { Victoria... }\end{array}$ & $\begin{array}{r}4,818 \\
21,228\end{array}$ & $\begin{array}{r}3,520 \\
550\end{array}$ \\
\hline Total & 26,236 & 840 & & $\begin{array}{r}3,000 \\
89,388\end{array}$ & $\begin{array}{r}90 \\
1,970\end{array}$ \\
\hline $\begin{array}{l}\text { Isaths: } \\
\text { New South Wales, num. }\end{array}$ & & & & & $\begin{array}{r}580 \\
6,175 \\
\end{array}$ \\
\hline & $\begin{array}{r}2,000 \\
152,400\end{array}$ & $\begin{array}{r}15 \\
375\end{array}$ & Total & 180,401 & 12,885 \\
\hline United States & $\begin{array}{l}408,000 \\
222,750\end{array}$ & $\begin{array}{l}645 \\
675 \\
\end{array}$ & $\begin{array}{l}\text { All other lumber: } \\
\text { United Kingdom..loads.. } \\
\text { Victoria ................... }\end{array}$ & 333 & $\begin{array}{r}10 \\
6,215\end{array}$ \\
\hline Total ...... & 785,150 & 1,710 & & $\begin{array}{r}838 \\
3,345\end{array}$ & \\
\hline $\begin{array}{l}\text { Palings: } \\
\text { Victoria .........number.. } \\
\text { Western Australia..do... } \\
\text { Tasmania................. } \\
\text { Canada ................. } \\
\text { United States.......do... }\end{array}$ & $\begin{array}{r}25,200 \\
102,800 \\
659,140 \\
56,400 \\
30,300\end{array}$ & $\begin{array}{r}760 \\
2,830 \\
17,850 \\
685 \\
410\end{array}$ & $\begin{array}{l}\text { New Zealail } \\
\text { Tasmania... } \\
\text { Singapore.. } \\
\text { Canada .... } \\
\text { Germany... } \\
\text { United Stat }\end{array}$ & $\begin{array}{r}377 \\
1,015 \\
1,475 \\
4 \\
4,542 \\
31 \\
30,429 \\
\end{array}$ & $\begin{array}{r}9,395 \\
14,685 \\
21,870 \\
40 \\
21,235 \\
40 \\
458,830 \\
\end{array}$ \\
\hline Total & 873,840 & 22,535 & Total.. & 41,359 & 613,410 \\
\hline
\end{tabular}

- The load equals 50 cubic feet of square timber; 40 cubio feet of unhewn timber; and 600 superficial feet of 1-inch planks.

Ho qualification of quantities given. 
Imports of lumber-Continued.

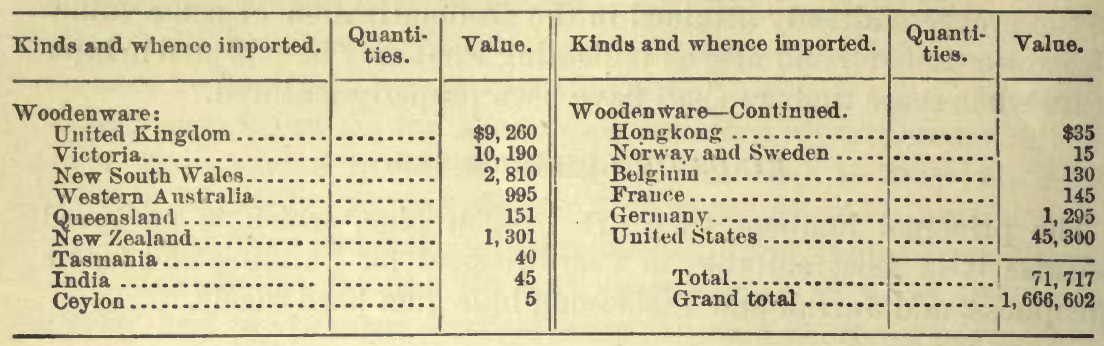

\section{DUTY AND PRICES.}

The duty on lumber entering South Australia, following the order in the foregoing import table, is as follows: Boards, 36 cents per 100 superficial feet; deals and battens. 60 cents per load; laths, 24 cents per 1,000 ; palings, 12 cents per 100 ; sleepers, free; shingles, 12 cents per 1,000; spars and quarterings, 60 cents per load; spokes, in the rough, free; staves, in the rough, free; all other, free; wooden ware, 25 per cent.

The wholesale prices of lumber at Fort Adelaide are as follows:

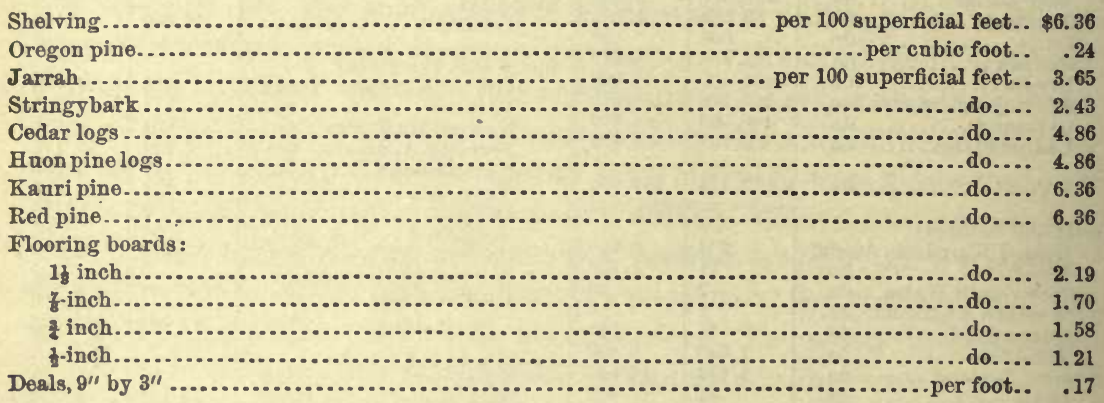

\section{OLIMATE.}

The climate of South Australia, although occasionally somewhat try ing in the summer months, is unquestionably one of the most agreeable and healthful in the world. It has been compared with that of the south of Spain. Its skies have been justly described as surpassing those of Italy. The purity and dryness of its atmosphere are quite equal to similar climatic characteristics which prevail in the best portions of Algeria. In fertility of soil it is not inferior to that of the most favored districts in those sunny lands. The enormous territory which is embraced within the limits of South Australia proper, having an area of about 380,070 square miles, or $243,244,800$ acres, naturally includes considerable climatic differences. The climate on the hills and on the highlands is temperate and genial, and not marked by an excess of cold during the winter months. On the plains the summer weather is 
most felt, for, as the winter and spring rains cease, they become dry and hot and unfavorable to the growth of many plants which belong to cooler countries. On the hills almost all the fruits and vegetables which grow in Europe and in the more temperate regions of Asia, as well as many that are indigenous to Africa and America, thrive splendidfy. The productiveness of the colony depends to a very great extent upon the rainfall, and that varies remarkably, not only in different localities but in different seasons. Thus the rainfall at Mount Lofty, 8 miles south from Adelaide, in 1889, amounted to 67.010 inches; in 1859 it was 32 inches. At Parallana, in the far north, in 1888, it was 1.710 inches, and in 1885 it had been 20.405. In some parts of the north, such as Lake Frome, only 5 inches were recorded. The average rainfall in the whole of the agricultural districts of south Australia, from Melrose to Cape Northumberland, in 1890 was 26.646 inches, the mean from previous years being 21.476. The highest total was in 1889, when 30.874 inches were recorded at the Adelaide observatory; and the lowest in 1876, when no more than 13.434 inches were noted at the same place. It is somewhat strange that the heaviest rainfall known in the colony should not have been followed by something approaching to a corresponding increase in the harvest; yet, in 1863, with a rainfall in Adelaide of less than 24 inches, the yield was nearly double that which was secured in 1889 , when the rainfall was nearly 31 inches. This noticeable discrepancy, however, may be ascribed to causes not altogether dependent on the actual quantity of rain that descends. The time of the year at which the rains set in, their duration, the temperature which immediately follows upon the rains when they continue late and come down upon the verge of summer, and the early visita. tion of north winds, which in the summer are hot, have their share in influencing the quantity of the yield. Other circumstances, not meteorological, have also their effect on the harvest.

The observations of the rainfall which occurs in the various parts of the colony are recorded at 368 stations. At several of these the daily range of the barometer and thermometer are noted, with all the particulars, which accurately describe the meteorological conditions of the place. These are forwarded to the central station, where, under the direction of C.Todd, esq., postmaster-general and government astronomer, they are collated, tabulated, and prepared for publication. By means of the telegraph, which extends from Adelaide to the Indian Ocean on the north, to Melbourne and Sydney on the east, almost to the extreme north of Queensland on the northeast, and from Aclelaide to Northwest Cape in western Australia, the Government astronomer is able to publish weather forecasts, which being generally reliable are alike interesting and useful to the public, and are eagerly looked for in the columns of the daily journals.

From this it will be seen that this colony (as well as the other colonies whose meteorological records are collected and made up on the 
same system) is in a position to furnish daily accounts of meteorological phenomena which occur over most of the continent that can be regarded as authentic. The record of the rainfall dates back as far as 1839, when it was commenced by the late Sir George Kingston, formerly speaker of the honse of assembly, and who kept it up till within a very short period of his death, in 1880 . The record at the observatory was commenced in 1856 , since when its operations have been gradually extended all over the province, so that its meteorological arrangements are as complete as it has been possible to make them.

The postmaster-general and astronomer to the colony published in 1876 a paper which gave interesting particulars of the climatic peculiarities of south Australia, as well as a detailed account of the observatory and its appliances. Since the publication of that memoir the climate of the colony has not sensibly changed. There have been irregularities in the seasons, or rather irregularities in the special phenomena of those seasons, especially of late years, which should, if duly weighed by those who are interested in the culture of the land, whether as fruit-growers, vignerons, market gardeners, or producers of grain, largely influence the horticulture and agriculture of the future.

In the memoir on the climate which has been referred to Mr. Todd says:

The observations at the observatory satisfactorily represent the climate of the plains for some distance north and south of Adelaide, but in the Mount Lofty ranges, close by, the citizens can in an hour or two find a much lower temperature, and twenty minutes by, railway will carry them to the invigorating breezes of the gulf; and, except when kept back by strong easterly and northerly winds, the sea breeze sets in soon after $10 \mathrm{a} . \mathrm{m}$. and sweeps across the plains, tempering the heat during what would otherwise be the hottest hours of the day.

The hottest months in the year are December, January, and February, when the temperature on the plains frequently exceeds $100 \mathrm{in}$ the shade. November and March are also hot; bnt the nights, especially in the former month, are cooler, and the heat is seldom of long duration, rarely reaching 100 in the shade, and, coming in suddenly with a strong hot wind, is followed quickly by a change to cool, or even cold, weather. A few hot days occasionally occur in October; but, even in the hottest months, especially in December, the weather is often broken by cloudy cold intervals, with strong sonthwest winds, veering gradually to south and southeast. This state of things will continue for several days, during which the wind from the southeast will usually freshen towards sunset, a bank of cloud forming over the Mount Lofty ranges, with cold nights, the temperature falling rapidly after sunset. The duration of these southeastern winds appears to depend upon the weather on the eastern coast, and the presence of the bank of clond on the ranges, and the persistence and force of the wind, often indicate gales and rain on the coasts of New South Wales and Queensland, althongh the weather here may be fine and clear overhead. As the easterly wind moderates it gradually hauls to the north, and alternate land (easterly) and sea (sonthwesterly) brcezes set in with fine weather, getting warmer and warmer, till another spell of extreme heat is experienced. The heat is sometimes followed by rain, especially in the earlier part of the season, setting in with the surface and light wind at northeast, but the upper current north west. This is usually presaged by aggregatious of cirro-cumuli, which close up and form a bank 
with a hard sharply-defined outline, gradually spreading over the sky, the clouds at the same time increasing in density as they change their character, with scud forming beneath. The rain increases as the wind veers to the northwest, and often extends over a large area to the north and is sometimes accompanied with heavy thunder and lightning, usually terminating with a gale from the southwest. The same thing occurs in the winter; but the wind at that season hangs longer about the west, often backing to the northwest, with heary rain and wind. These are usually our heaviest and most widely diffused falls, the rains from the southwest seldom extending far inland.

The summer may be regarded as extending from October to March. After that mouth the temperature falls rapidly, very rarely reaching 90 in the shade. * * * The weather during April and a great part of May is simply perfection, and the same applies to most of the winter and till the end of October. Although corresponding to the autumn or early winter of Europe it is virtually spring, when vegetation, refreshed by the first rains after the drought of summer, bursts into fresh life, and the whole surface of the land is clad with verdure. Heavy rains frequently fall in May, and the greatest downfalls usually occur in that mouth. The coldest months are June, July, and August, but the mean temperature is not very low. The cold is sometimes much felt in the winter months, because of the coutrast it emphasizes between the summer weather and the genial temperature which prevails in other portions of the year. Frosts occasionally occur on the plains, and frequently on the hills. Ice, perhaps a quarter of an inch thick, is occasionally noticeable in shallow surface pools, but this rarely if ever survives an hour's sumshine: Snow has sometimes fallen at Mount Lofty and on other high summits in the ranges, and at other times a few miles north of Kooringa, which is 1,560 feet above the level of the sea. Snow is, however, quite phenomenal in south Australia, and the drift does not remain on the ground for more than an hour or two, whenever it does occur.

In writing on the subject of the course of the seasons and weather forecasts, late Sir George Kingston gave the following as the results of his observations extending over forty years:

The heaviest rain throughout the year may be expected with a wind at about northeast, the rain commencing to fall gently and the wind light, both gradually increasing as the latter veers around to the north, and thence to the north west, when the violence of both wind aud rain has much increased. After this the wind may be expected to draw around to the west, when the rain generally ceases, or at least rarely falls except in heavy squalls and showers, and the weather clears up. The time occupied by a continuous fall of rain, as thus described, rarely amounts to twelve hours. The wind will, however, frequently hang at about west, with a few points of variation to the south and north for some days, during which period rain occurs in showers if to the south, and more steadily in proportion to the northing of the wind. The heaviest rains, assuming a tropical character, may be expected after a hot northeast wind drawing round to the northwest, at which point an inch of rain and upwards has often fallen within the hour, accompanied with heavy thunder and lightning; or, as in October, 1854, the rain is represented by tremendous bailstorms, the hail assuming the form of flat pieces of ice.

As regards the use of the barometer in forming a judgment on the weather to be expected, I have to observe that the barometer invariably begins to fall with a northeast wind, continuing to fall as the wind increases in violence and draws round by the north, northwest, and westerly, at or about which point it reaches its lowest figure. The barometer generally begins to rise with the least southing in the wind. Now, althongh a low barometer thus agress with the heaviest fall of rain, it is impossible to draw certain conclusions from it as to probability of rain or otherwise unless, indeed, when the wind is violent, as then, even with every appearance or heavy cloudy weather, rain rarely occurs. Calm, murky weather, accompaniod iny 
a low state of the barometer, is the most favorable indication of rain. I have fre quently seen the barometer at its lowest point (as observed by me), 29.3, blowing hard, and accompanied by clondy weather, when no rain has fallen; on the other hand, I have known some of the steadiest and most copious rains to occur with the barometer at 30.2 and falling, the wind light or nearly calm.

I may add that generally during fine weather a land and sea-breeze alternates during the twenty-four hours. After sunset the wind generally blows from about sontheast to east, dying away about daylight, and a light southwest wind springs up about 9 a. m., but, failing to do so, the land wind towards morning draws round from east to northeast by north to northwest, and west towards the af ernoon; and should it hang to the north of east, with a falling barometer, it is a certain precursor of a hot wind.

It may not be uninteresting to add here that, when Sydney was visited by tremendous storms and floods from the 19th to the end of July, 1860, the weather here was then usualiy fine for the time of the year; the barometer was, during all that time, above 30 inches and very steady, oscillating slightly each day, its whole range not exceeding 0.2 ; the wind was very light, from southeast to northeast and northwest. I did not record a drop of rain all that time, an unprecedented event at that period of the year.

The winds, according to Mr. Todd, during the summer tend generally on all sides to the heated interior, which may be roughly described as a vast plain broken by a few ranges, none of which are of any great size or magnitude; on the south coast, the wind being southeast and south varied by occasional south west gales following a hot wind from the northeast and north, whilst further worth and round the north coast, the northwest monsoon for some months before and after the summer solstice presses down south with varying force, often making itself felt as far south as the Macdonnell ranges an the southern edge of the tropics in the center of the continent. North of the Macdonnell ranges the winds during the summer season are variable, southeast and northwest winds alternating with calms, and heavy electrical storms with rain prevail with increasing intensity north wards to the coast. South of the Macdonnell ranges southeast winds prevail during the greater part of the year, but in the summer they are often influenced by the northwest tropical current, and then veering to the northeast and north will sweep over south Australia as a hot wind, the birthplace of which seems to be, speaking approximately, somewhere about latitude 26. Our experience of the climate of the interior of Australia is as yet but limited, but the stations on the great overland telegraph now furnish accurate daily reports of the weather, direction of upper currents, and rainfall. These reports show that the prevailing wind, except during the middle of summer, is southeast.

In connection with Sir George Kingston's "weather forecasts," the following observations from Mr. Todd may be read with interest:

I have long been of opinion that the southerly dip of the monsoon largely influences the climate of South Australia proper, as well as that of Victoria. In seasons of drought, or when the summer in the interior is dry, the northwest monsoon rains thin off and rarely reach the center in occasional storns. But when the monsoon is strong and blows well home, the tropical rains and thunder will stretch right across the continent well into the northern country of South Australia to within about 200 or 300 miles of Adelaide, and occasionally these tropical rains will reach the south coast. A wet season in the interior will probably coincide with a hot summer in South Australia and Victoria, whilst a cool summer in the latter, where strong polar currents keep the temperature down and the southeast winds are powerful, will denote or coincide with a dry summer in the interior and a weak northwest monsoon. The winter rains of the south, it may be remarked, thin off at about $3^{\circ}$ or $4^{\circ}$ north of Adelaide, rarely penetrating to latitude 28 , and summer rains are 
not to be depended upon far south of the tropics. Between those parallels is a wide belt of $5^{\circ}$ or $6^{\circ}$ having an uncertain rainfall, subject to droughts, very seldom getting rain during the winter, but mostly depeuding on summer thunderstorms, the frequency and intensity of which, it is not improbable, may be found closely to coincide with the maguetic cycle of eleven and a quarter years, which is believed to determine the frequency of aurori magnetic storms and solar spots. This, of course, is conjectural, and is not to be accepted till proved by increased experience.

From the foregoing a tolerably accurate conception of the South Australian climate may be formed. There is one thing, however, which deserves some notice here. In many published articles in newspapers and magazines the hot winds of Australia, and especially of South Australia, have been mentioned in highly colored terms. They have been described as terrific, and have been dwelt upon as though the climate of this province was somewhat worse than tropical. It is quite true that hot winds are not pleasant; in fact, they are enervating, and whilst they last are exceedingly exhausting to persons who are in a feeble state of body; but they seldom last for more than a few days, and when the westerly breezes which succeed them set in, sometimes suddenly, all the bodily malaise which they may have caused quickly disappears. They have, however, a most beneficial effect in purifying the atmosphere. They destroy noxious germs which may float about in the air, and otherwise do an immense amount of good. At the same time their effect upon tender plants is severe, and all kinds of flowers and shrubs which are not hardy or tolerably well protected from them droop and shrink, and are slow to recover their strength until a much cooler temperature prevails.

Even with the drawback of occasional hot winds, there is seldom such severe heat in the summer as to prevent persons from following their ordinary occupations out of doors. There are only forty-five days in the year, taking the average of thirty-four years, 1857 to 1890 , on which the temperature rises above 90. The Guvernment astronomer has noted this fact, and states that this climate, "beautiful as it really is, affording as it does the great number of pleasant days on which outdoor pursuits can be carried on with buoyancy of spirits is a wee bit dry, a fact which vegetation on the plains in our summer season sufficiently attests. The clearness or transparency of the atmosphere is something wonderful and owing to its dryness, except on hot-wind days, it is seldom oppressive unless one is lazy. Cricket matches are played with the usual enthusiasm before crowds of spectators with the thermometer ranging between 90 and 100 in the shade, and the writer has ridden 50 miles in a day with the thermometer as high as 110 without much inconvenience or distress; the secret of which is that these high temperatures are always accompanied by such an extreme dryness of the air that perspiration affords instantaneous relief. When a fierce hot wind is blowing and the thermometer stands. at perhaps something over 100 , the wet bulb thermometer stands at 65 , and it is this whicb 
enables persons to bear the heat of summer and carry on their usual pursuits with less inconvenience and discomfort than is felt in damp climates, where the temperature may be $15^{\circ}$ or $20^{\circ}$ lower but nearly saturated with aqueous vapors, as at Port Darwin, where during the rainy season of the northwest monsoon the thermnmeter may stand at only 88 , whilst the wet bulb indicates 86 . Such an atmosphere, we need hardly say, is far more enervating than the hot and dry air of the Adelaide plains."

One peculiarity of the Australian climate is the occurrence of drought. Droughts are either general, that is to say, they affect the whole of the Australian continent in a greater or less degree, or they are partial, that is confined within limited areas. South Australia is probably more subject to visitations of this kind than other portions of Australia, owing, to some extent, to the absence of high mountain ranges in the interior. The causes of these droughts have been very carefully investigated by the official heads of the meteorological departments in the principal colonies, and as far as their observations have been extended they are generally in accord upon the subject.

\section{GENERAL BUILDING.}

General building is at a standstill at present. Those houses now being erected consist of a small class of residences of about four rooms, built of stone, of which the majority of buildings are constructed.

The timber used in railroad building is grown locally, and is obtained from South Australian Goverument forests, and consists chiefly of the eucalyptus class.

\section{EXTENSIONS OF LUMBER TRADE.}

I can not offer any suggestion concerning the methods to increase the lumber trade with this province, now already considerable.

\section{Chas. A. Murphy,}

ConsularAgent.

ADELAIDE, March 8, 1894.

\section{TASMANIA.}

\section{NATIVE WOODS.}

The principal native woods of Tasmania are the various species of gum (Eucalypti), the myrtle (Fagus cunninghami), the Huon or Maequarie Harbor pine (Bacrydium franklinii), and the blackwood or lightwood (Acacia melanoxylon).

The gum timber is all hard and dense. As a rule it shrinks considerably, and warps and twists, and for interior work is used for floors 
alone. For this purpose it is exceedingly durable. It is used universally for frame houses, joists and beams, piles, and decking for bridges, wharfs, etc. The Huon pine is a very valuable and durable wood, but it is comparatively scarce and dear; for this cause it does not supplant the imported timber. The lightwood is used mainly for furniture and interior fittings.

\section{KINDS OF LUMBER USED.}

The lamber used, and which is preferred, is principally Swedish, imported in the form of "deals," and tongued and grooved linings. American redwood and shelving and Oregon pine are used to a limited extent, and the Kauri pine of New Zealand more largely.

\section{IMPORTS OF LUMBER.}

In 1891 the total imports of timber were $5,335,000$ superficial feet, but with the prevailing depression and consequent suspension of building, it is expected that the quantity will be materially diminished this year.

As much of the timber comes through the colonies of Victoria and New South Wales, the original source of supply can not be given with accuracy. Probably about 850,000 superficial feet came from the United States, 3,235,000 superficial feet from Sweden, and 1,250,000 superficial feet from New Zealand, in 1891.

\section{DUTY AND PRICES.}

There is no duty on timber 3 inches thick or over; under that pays 60 cents and $\$ 1.21$ per 100 superficial feet.

At the present time the values of all kinds of timber are abnormally low: American red wood, $\$ 4.01$; Oregon, $\$ 2.67$, duty paid (60 cents) in both cases; American shelving, $\$ 6.08$ duty paid (\$1.21); all per 100 superficial feet. The native gum flooring boards, tongued and grooved, are sold at $\$ 3.04$ per 100 superficial feet.

\section{CLIMATE.}

The climate of the island varies, owing to its mountainous character, but it is temperate and equable throughout, the mean yearly average range probably not exceeding $68^{\circ} \mathrm{F}$.

\section{GENERAL BUILDING.}

General building has been fairly active until now. It does not seem probable that much recovery will take place for some time.

Railroad building is also suspended and is not likely to be resumed, except in a small way; in any case, very limited quantities of imported timber would be used in construction. 


\section{EXTENSION OF LUMBER TRADE.}

With a population of only about 150,000 , the trade in American timber is not capable of much extension, but the expected development of the mineral deposits may, before long, lead to expansion.

A. G. Webster,

HOBART, February 20, 1894.

Consul.

\section{VICTORIA.}

\section{BUSINESS DEPRESSION.}

In the closing months of the year 1889 what is known as the "land boom," which for the preceding three or four years had caused a large increase in the consumption of building materials, collapsed, and as importations of lumber, based on the same rate of consumption being kept up, continued to eome in for a long time, the market for timber has been suffering ever since from the accumulation so caused and the absence of any revival in the trade to clear it off.

Carpenters or timber workers are in a very unhappy condition at the present time. 'The managing partner of one of the largest timber houses here says that not more than one-third of the business done in their trade two years ago is being done now. In one large establishment which gave work to 150 men in 1892 only 48 hands are now employed, and these only at half time. To put it in another way, two years ago the firm was paying $£ 500(\$ 2,430)$ a week in wages, now they are paying under $£ 100(\$ 486)$. The figures are representative of the condition of the trade generally. Moreover, in the boom time a crowd of firms came into existence which are no longer in evidence-firms begotten of prosperity which adversity as readily suppressed. It is calculated that at least 30 shops of that character have been closed in the city.

Literally nothing is required in the trade in Melbourne, which embraces half the population of the colony, but there is a small demand for prepared timber from the country which keeps city mills slightly employed. But for the country business and the butter trade, which utilizes for boxes about 2,000,000 super feet of silver pine annually, the timber industry would be at a complete standstill.

The timber required for the butter trade has to be imported from New Zealand, there being, it is said, no sufficiently odorless wood in this colony.

\section{NATIVE WOODS.}

The native woods of the colony are all very hard and not well adapted for building, though admirable for other purposes. 
The following trees of the Eucalyptus tribe are the most important:

The red gum tree (Eucalyptus rostrata), the timber of which is one of the most highly esteemed among the Eucalypti in all Australia, being heavy, hard, strong, and extremely durable, either above or under ground, or in water. For these reasons it is very much prized for fence posts, piles, and railway sleepers. For the latter purpose it will last at least a dozen years, and, if well selected, much longer. The late commissioner of railways reported that sleepers were found quite sound after being twenty-four years in use. It is not to be surpassed in endurance for wood bricks in street paving and for tramways.

The blue gum tree (Eucalyptus globulus) furníshes a first-class wood. Shipbuilders can get keels of the timber 120 feet long; besides this, it is used for planking and many other parts of the ship. Experiments on the strength of various woods, instituted by the Government botanist, proved the wood of the blue gum tree, in an average of eleven tests, to be about equal to the best English oak, American white oak, and American ash. Blue gum wood is very extensively used by carpenters for all kinds of outdloor work, joists and studs for wooden houses; also for fence rails, telegraph poles, railway sleepers (lasting nine years or more), for shafts and spokes of drays and a variety of other purposes.

The iron bark tree (Eucalyptus lencoxylon) furnishes a most valuable timber, showing great strength and hardness, and much prized for its durability. It is largely employed by wagon builders for wheels and poles, and is also used by turners for rough work. It proved to be the strongest of all the woods hitherto subjected to test by the Government botanist, bearing nearly twice the strain of American oak and ash, and excelling hickory by about 18 per cent. It is much recommended for railway sleepers and extensively used in underground mining work. It is likewise very extensively employed for the handles of axes and other implements by Victorian manufacturers.

Besides the Eucalypti, the evergreen beech (fagus Cunninghami) and blackwood (acacia melanoxylon) are the most important timber trees, the latter especially being found admirably adapted for the manufacture of railway carriages; also for furniture, which is almost indistinguishable from that made of the best walnut.

\section{IMPORTS OF LUMBER.}

In consequence of the native woods being hard, and therefore not easily worked, it is necessary to import almost all the timber required for building purposes. 
The following table gives the importations of lumber for the past eight years, and whence imported:

\begin{tabular}{|c|c|c|c|c|c|c|}
\hline \multirow[b]{2}{*}{ Year. } & \multicolumn{3}{|c|}{ Baltic, United Kingdom, and Canada. } & \multicolumn{3}{|c|}{ Colonial. } \\
\hline & $\begin{array}{l}\text { Flooring, } \\
\text { lining, and } \\
\text { weather. } \\
\text { bourds. }\end{array}$ & Red deals. & $\begin{array}{l}\text { Spruce and } \\
\text { Baltio white } \\
\text { deals. }\end{array}$ & Kauri pine. & $\begin{array}{c}\text { Red and } \\
\text { white pine. }\end{array}$ & Cedar. \\
\hline 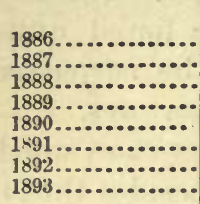 & $\begin{array}{r}\text { Super. feet. } \\
\mathbf{5 4}, 135,023 \\
26,405,838 \\
51,052,077 \\
49,960,908 \\
56,743,271 \\
36,367,258 \\
23,477,951 \\
13,368,894\end{array}$ & $\begin{array}{r}\text { Super. feet. } \\
24,026,436 \\
17,259,012 \\
22,063,392 \\
25,118,280 \\
28,072,319 \\
10,039,821 \\
1,197,471 \\
746,914\end{array}$ & $\begin{array}{r}\text { Super. feet. } \\
3,755,499 \\
762,795 \\
2,589,675 \\
3,006,263 \\
2,354,118 \\
3,268,213 \\
2,289,093 \\
1,482,008\end{array}$ & $\begin{array}{r}\text { Super. feet. } \\
8,951,118 \\
7,888,104 \\
14,493,927 \\
15,551,906 \\
12,914,750 \\
13,845,346 \\
5,531,846 \\
3,838,585\end{array}$ & $\begin{array}{r}\text { Super. feet. } \\
90,000 \\
531,300 \\
2,866581 \\
529,900 \\
715,727 \\
1,723,684 \\
1,707,891 \\
2,523,199\end{array}$ & $\begin{array}{r}\text { Super. feet. } \\
3,849,577 \\
2,921,141 \\
2,159,183 \\
1,401,232 \\
1,255,753 \\
989,936 \\
868,681 \\
47,620\end{array}$ \\
\hline \multirow[b]{2}{*}{ Year. } & \multicolumn{6}{|c|}{ Dnited States and Canada (west coast). } \\
\hline & $\begin{array}{l}\text { Flooring, } \\
\text { lining, and } \\
\text { weather- } \\
\text { boards. }\end{array}$ & Red deals. & $\begin{array}{l}\text { Spruce and } \\
\text { white deals. }\end{array}$ & Kauri pine.* & $\begin{array}{l}\text { Red and } \\
\text { white pine. }\end{array}$ & Cedar. \\
\hline 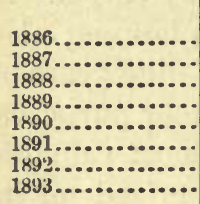 & $\begin{array}{r}\text { Super. feet. } \\
31,341,179 \\
24,515,087 \\
55,487,694 \\
35,220,629 \\
35,426,131 \\
20,337,733 \\
13,603,638 \\
1,170,760\end{array}$ & $\begin{array}{r}\text { Super. feet. } \\
955,779 \\
1,273,590 \\
1,431,957 \\
1,376,109 \\
1,767,797 \\
816,857 \\
1,286,356 \\
270,948\end{array}$ & $\begin{array}{c}\text { Super, feet. } \\
(\dagger) \\
(\dagger) \\
(\dagger) \\
(\dagger) \\
2,508,933 \\
2,979,910 \\
1,680,570 \\
238,057\end{array}$ & $\begin{array}{r}\text { Super. feet. } \\
2,481,066 \\
2,098,444 \\
3,973,558 \\
4,939,101 \\
1,173,208 \\
1,478,266 \\
813,162\end{array}$ & $\begin{array}{r}\text { Super. feet. } \\
\mathbf{4}, 068,327 \\
\mathbf{2}, 841,650 \\
\mathbf{4}, 861,419 \\
\mathbf{5}, 332,382 \\
3,337,429 \\
\mathbf{3}, 726,476 \\
\mathbf{2}, 119,738 \\
\mathbf{4 2}, 370\end{array}$ & $\begin{array}{r}\text { Super. feet. } \\
401,150 \\
450,030 \\
468,450 \\
380,814 \\
189,933 \\
244,894 \\
134,064 \\
17,245\end{array}$ \\
\hline
\end{tabular}

Laths, pickets, and doors from the United States, Canada, and the Baltio.

\begin{tabular}{|c|c|c|c|}
\hline Year. & Laths. & Pickets. & Doors. \\
\hline 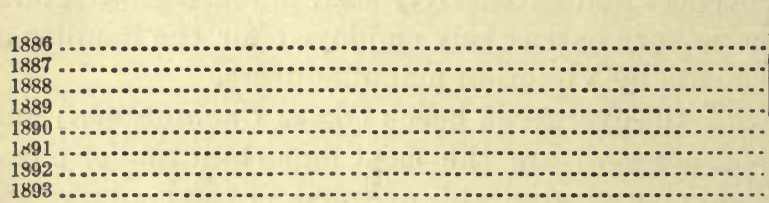 & $\begin{array}{r}\text { Bundles. } \\
167,342 \\
122,202 \\
132,175 \\
97,622 \\
86,503 \\
11.721 \\
17,344 \\
1,740\end{array}$ & $\begin{array}{r}\text { Bundles. } \\
158,397 \\
116,255 \\
202,400 \\
194,832 \\
156,325 \\
53,800 \\
51,432 \\
3,000\end{array}$ & $\begin{array}{r}\text { Number. } \\
16,457 \\
6,627 \\
9,774 \\
1,563 \\
1,182 \\
303 \\
1,760 \\
501\end{array}$ \\
\hline
\end{tabular}

\section{DUTY.}

The duties on timber in this colony may be summarized as follows:

Oregon (Puget Sound) fir:

12 by 6 or equivalent............................................per 100 superficial feet.. $\$ 0.36$

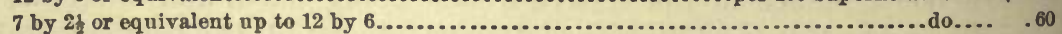
Shelving and tongue-and-groove sheathing (American), flooring, lining, and weatherboards

(Baltic) ...................................................... per 100 sujerficial feet.. . .36

Timber cut into shapes for niaking boxes.................................... per cubic foot.. $\quad .12$

Timber not otherwise enumerated, of sizes under 7 by $2 \frac{1}{2}$...............per 100 superficial feet.. $\quad .97$

Laths........................................................................per M.. 1.21

Piokets:

Undressed................................................................do... $\quad 12$

Dressed..................................................................per 100.. .12

Shingles......................................................................... per M.. .18 
Doors, skirtings, and moldings are charged heavy duties, intended to be prohibitory.

The following descriptions are free of duty: Clear pine, sugar pine, California redwood, undressed, 1 inch thick and over; ash, oak, hickory, walnut, whitewood, and sycamore, undressed; Baltic red and white deals, 7 by $2 \frac{1}{2}$ and upwards; Australian and New Zealand pines of all sizes, undressed.

The duty on Oregon fir, 7 by $2 \frac{1}{2}$ and over, was first imposed on July 29, 1892, and at the same time the duty already existing on sizes under 7 by $2 \frac{1}{2}$ was doubled, both at the instance of the local hard-wood dealers, who contended that Oregon unduly interfered with their product.

\section{PRICES.}

The market price of American timber is slightly better at present than during the past two years, and is as follows: Oregon, new stock, $\$ 25.54$ to $\$ 26.76$; old stock, $\$ 21.89$ to $\$ 23.11$; redwood, $\$ 35.37$ to $\$ 36.49$; sugar pine, $\$ 53.53$ to $\$ 58.39$.

I am informed that the stock of Oregon held by trade hands is very large, and owing to the small demand for timber of all descriptions the reducing process proceeds very slowly.

\section{PUBLIC BUILDING.}

Railroad building is practically at a standstill for want of available funds, and, except in station buildings, no imported timber is used in railway construction.

Shipbuilding is not an industry in this colony; a few vessels have been built of iron, and barges, etc., for the harbor trust, but exclusively of local woods.

\section{EXTENSION OF LUMBBER TRADE.}

The merits of Oregon timber, for which a decided preference is shown, are fully recognized by the people here, and the demand for it is commensurate with the building being carried on.

The result of my interviews with the timber merchants of this city, as to what manner the lumber exports from the United States to this colony may be increased, is, therefore, that the return of brighter times, which is confidently expected in the near future, must be awaited before the demand for American lumber can be increased.

\section{DANIEL W. MARATTA,}

MelbouRne, March 1, 1894.

Consul-General. 


\section{EUROPE}

\section{AUSTRIA-HUNGARY.}

\section{NATIVE VS. AMERICAN WOODS.}

From the very best information I can gather, this country is not quite yet ready to use American lumber to any great extent. The American lumber exporters should realize that here in Europe their only competitors, especially for German, French, and Italian consumption, are the Austro Hungarian lumber dealers.

Up to the present time, nearly all of the staves used for wine in France and Italy, passed through the hands of the Austrian merchants, and the same can be said of those used in the breweries of Germany. The forests remaining in Austria proper, are nearly all used up, and it is from the Hungarian portion of this empire that most of the lumber is exported. The Hungarian forests are mainly owned by the Government, and city and village communes.

About three years ago, the Government, which controls the cutting of forests in Hungary, curtailed the number of trees to be felled, so that at their annual sales less lumber was offered than was required for home and export wants. Some well informed parties maintain that this was a ruinous policy to pursue, as it not only fictitiously advanced the value of Jumber in Austria, but it compelled lumber dealers to look elsewhere for a good portion of their wants, thus hastening the introduction of foreign lumber, which might have been delayed some ten or twenty years.

At the same time when this happened, many breweries were being started in Germany and the demand for staves in Italy and France was unusually great. Since then the prices of lumber have fallen. This is undoubtelly due to a lesser demand, and to the introduction of American lumber.

"To sum up the matter," as a very well informed lumber dealer explained: "We do not fear the United States for consumption for the next thirty or forty years; we have also enough oak in this empire to carry on a large export trade for ten years to come. At the end of this time our supply will be so reduced that it will be impossible for us to compete with the United States in foreign markets. The only way 
that the Austrian lumber dealers can maintain their foreign business, will be to acquire forests in the United States."

That there is much truth in the above statement is plainly to be seen, inasmuch as from my personal knowledge I know of three different firms who have sent their representatives to the United States to acquaint themselves with the condition of the lumber trade and to buy up forests. Although not yet exporting much therefrom, they are preparing to do so in the future. The only kinds of wood, that Americans could sell in this empire, are lumber for shipbuilding purposes in the seaport towns of Trieste, Pola, and Fiume, and certain kinds which could be used for veneering purposes, such as very fine grades of oak, walnut, etc. It must be borne in mind that fine furniture manufactured here, is not made of solid oak, or other hard wood as in the United States, but mostly of soft wood veneered. Pine thoroughly seasoned and then veneered is used even for the best furniture.

The time is very near when the entire European market will be compelled to look to the United States for most of its lumber. Let us in the meanwhile husband our resources; let the destructive extravagance in the extinction and waste of our forests, cease; our wealth herein is enormous, but we have so much that we do not know how to value it.

Staves for the wine merchant must be split; the sides must not, while the tops can be cut. Again, for beer purposes, both sides and tops must be split, it being claimed that staves cut and not split make leaky barrels. As wine barrels are usually laid on their sides, the pressure on their tops is not apt to be great, and for this reason wine barrel tops can be cut instead of split.

It is most important that American manufacturers should realize the necessity of sending properly made goods to foreign markets. Some years back the first shipment of staves into Switzerland made leaky barrels, and to-day Swiss business men are afraid to purchase American staves, unless accompanied with a guarantee. And this additional very important fact must be kept in view, that this trade, which is bound to come, should be held by American merchants, and not permitted to pass into the control of foreign corporations.

\section{PRICES.}

Great quantities of oak railroad ties are made here, the shapes mostly furnished are 2.50 meters long, the top 15 to 17 centimeters, (meter = 39.37 inches; centimeter $\frac{1}{100}$ of a meter), the bottom 24 to 25 centime. ters in width, and 15 centimeters high.

Prices vary according to locality; the Hungarian Staatsbahn paid for the last 30,000 , recently ordered, 56 cents each, and for some smaller ones, 2.20 meters long, 36 cents. Soft lumber ties are about 30 per cent cheaper. 
The prices of the lumber here in the Vienna market range about as follows:

Pine timbers for roof, 10 by 13 to 16 by 18 centimeters broad, and 10 meters long, 13 to 14 florins* per cubic meter; 18 by 20 to 21 by 24 centimeters broad, and 10 meters long, 14 to 16 florins per cubic meter; 18 by 24 centimeters broad, and 6 to 8 meters long, 13 to 15 florins per cubic meter. Pine boards, according to quality, 15 to 22 florins; oak boards not assorted, 38 to 45 florins.

Staves for hectoliter (barrels which hold 100 liters), one-fourth hectoliter, 1 to 1.60 florins; one-half hectoliter, 1.50 to 2.30 florins; 1 hectoliter, 2.40 to 3.30 florins.

Staves for transportation: Barrels containing from 3 to 13 hectoliters, 2 to 2.10 florins per hectoliter. Staves for storage: Barrels containing from 20 to 80 hectoliters, 2.20 to 3.40 florins.

\section{EXPOR'I'S OF LUMBER.}

The following table shows the export of lumber from Austria-Hungary for the first eleven months of 1893:

Timber:

Metric centners.t

Raw, hard. 595,622

Raw, soft.

$8,059,049$

Hewn, hard 322, 709

Hewn, soft

788,737

Staves.

Railroad ties.

1, 401, 299

481,690

Sawn wood, hard

810,930

Sawn wood, soft

5, 780, 531

Timber, not European.

105

Total

$18,240,672$

Most of the above went to France, Germany, Spain, Italy, Switzerland, Greece, Egypt, Holland, Belgium, Bulgaria, and the British Dominions on the Mediterranean Sea.

\section{IMPORTS OF LUMBER.}

The following table shows the imports of lumber into Austria-Hungary for the first eleven months of 1893:

Timber:

Raw, hard

Metric centners.

Raw, soft 92,559

Hewn, hard. 151,714

Hewn, sof

Stares (from the United States direct) 27,330 35,029 39,727

Railroad ties (nearly all from Russia) 142,640

49,635

Sawn wood, hard (from the United States direct). 135,298

Sawn wood, soft (from the United States direct) 61,358

Timber (from the United States direct) 33,470

All other

769,160

Total imports.

- The consul-general estimates the florin at 39 to 40 centa.

† Metric centner $=220.46$ pounds. 
The lumber described "all other" was nearly all transshipments from German ports, but it should be noted that the timber was not grown in Europe.

VIENNA, February 21, 1894.

\author{
MAX JUDD, \\ Consul-General.
}

\title{
BOHEMIA.
}

NATIVE WOODS.

Bohemia is well supplied with forests of heavy trees, the Boehmerwald region being specially noted for same. The woods in Bohemia can be divided into three classes: (1) Pine forests; (2) leaved, or hard forests; (3) mixed forests. The prevailing species of the coniferous trees are the spruce, fir, the pine, and the larch. Among these the spruce predominates.

Of the deciduous trees the prevailing species are beech, oak, and birch, the beech predominating. Among the mixed species are found poplar, alder, elm, basswood, chestuut, aspen, and maple.

In Bohemia between 1,300 to 1,400 sawmills are operated, which are driven either by steam or water power, the majority by water power. Only few of the larger steam mills can be favorably compared with American mills; the rest are small affairs, many of them having one circular or one upright saw. The whole annual production of the Bohemian forest is estimated at $6,250,000$ cubic meters, consumed as follows:

Cubic meters. *

Lumber 835,000

Building purposes .......................................... 900,000

Fiber (for packing, upholstering, and under carpets) $\ldots \ldots \ldots \ldots \ldots \ldots \ldots \ldots 600,000$

Railroad ties............................................... 220, 000

Staves.................................................. 60,000

Shingles ................................................... 22, 000

Parquetts (French flooring) ................................ 20,000

Wooden wire (such as matches, etc.)............................ 20,000

Building canal boats ........................................ 16,000

Wooden shoes ............................................... 6,000

Telegraph poles................................................. 4,000

Resonant purposes (such as violins, etc. )......................... 1,200

Lead pencils ................................................... 600

The balance is made up of firewood.

The leading kinds of lumber used are spruce and pine. The preference is given to spruce. It is used for all kinds of building purposes, furniture, etc. The pine is used for railroad ties. The principal lumber market is the city of Prague, which is situated nearly in the center of the country, on the river Moldau, and convenient to all the lumber 
districts. Most of the timber comes from Boehmerwald, which is in southwestern Bohemia, and the remainder from the mountain regions in the northeast and narth west of Bohemia. It is brought down on the rivers Elbe and Moldau and their tributaries. Bohemia exports considerable timber to Dresden, Leipsic, and Magdeburg, and certain quantities of logs are yearly serit to Hamburg for shipbuilding. A good deal of the lumber goes to Austria proper, and to southern Germany, mainly to Niiremberg and Mayence. The transmission of timber and logs to Germany is done on the river Elbe, except that to south Germany, which is forwarded by railway.

Some lumber is brought into Bohemia from Galicia, which import is explained as follows: A number of Bohemian capitalists own large tracts of timber land, with sawmills thereon, in Galicia, and the demand for lumber there is very limited, consequently it is forwarded to Bohemia, where it finds a ready market and better prices.

Then again, the Galician Government sells yearly at public auction certain lots of standing timber with the proviso that it must be manufactured into lumber in that country. Such lots of timber are generally purchased by Bohemian dealers at low prices. Besides, the labor in Galicia is cheaper than in Bohemia, and they thus acquire cheap lumber, which they bring to their Bohemian lumber yards.

\section{IMPORTS OF LUMBER.}

There is no lumber imported from the United States into Bohemia direct. Some American black walnut is used here, mainly for veneering, but this is imported from Hamburg. I have visited a lumber firm in this city that advertises American lumber for sale and inquired what kind and how much they handle, and whether they import it directly, etc. The information I have received was that recently they bought a carload of American black walnut and pitch pine from Hamburg for a trial, but were unable to say how it was going to sell. It is said that in Prague some years ago American walnut sold cheaper than the Tyrolean walnut, but now it is the other way. The trouble with the American lumber seems to be that its price is too high when it reaches here in consequence of its indirect importation. It is bought from middlemen either at Hamburg or Bremen, and in that way it passes probably through three or four hands before it reaches the consumer. It is admitted by the lumber dealers here that the market for American lumber in Bohemia alone is not large enough to warrant American lumber dealers profitable shipments. Still, I am of the opinion that a good market could be opened for American lumber, such as black walnut, elm, and others that are not produced here, by establishing an agency at Prague that would extend to the Empire of Austria-Hungary. The demand would be sufficient to warrant large ship- 
ments, for the importation would be made direct, by which the costs of the present system of importation would be greatly lessened. I am satisfied that the trado would result in mutual benefit.

On account of the small amount of lumber imported into Bohemia, there are no separate statistics kept.

\section{DUTY AND PRICES.}

All kinds of lumber, timber, or logs are admitted into the Empire of Austria-Hungary free of import duty.

\section{PRICES.}

Statement shoving the prices of spruce and pine boards per 100 pieces, 5.7 meters (6.233 yards) long, and of the thickness and width specified.

\begin{tabular}{|c|c|c|c|c|c|c|c|}
\hline \multicolumn{4}{|c|}{ Edged boards. } & \multicolumn{4}{|c|}{ Boards not edged. } \\
\hline \multirow{2}{*}{$\begin{array}{l}\text { Thick- } \\
\text { ness. }\end{array}$} & \multirow{2}{*}{ *Width. } & \multicolumn{2}{|c|}{ Value. } & \multirow{2}{*}{$\begin{array}{l}\text { Thick- } \\
\text { ness. }\end{array}$} & \multirow{2}{*}{ Width. } & \multicolumn{2}{|c|}{ Value. } \\
\hline & & $\begin{array}{c}\text { First } \\
\text { quality. }\end{array}$ & $\begin{array}{l}\text { Second } \\
\text { quality. }\end{array}$ & & & $\begin{array}{c}\text { First } \\
\text { quality. }\end{array}$ & $\begin{array}{l}\text { Sccond } \\
\text { quality. }\end{array}$ \\
\hline $\begin{array}{r}m m_{13} \\
13 \\
13 \\
13 \\
20 \\
20 \\
20 \\
26 \\
26 \\
26 \\
40 \\
40 \\
40 \\
53 \\
53 \\
53 \\
80 \\
80 \\
105 \\
105\end{array}$ & \begin{tabular}{|r|}
$m m$. \\
132 \\
158 \\
181 \\
132 \\
158 \\
184 \\
132 \\
158 \\
184 \\
263 \\
290 \\
316 \\
263 \\
290 \\
316 \\
290 \\
316 \\
316 \\
342
\end{tabular} & $\begin{array}{r}\$ 8.12 \\
10.15 \\
12.18 \\
11.39 \\
13.80 \\
16.24 \\
15.02 \\
18.67 \\
22.33 \\
54.81 \\
62.93 \\
71.05 \\
74.30 \\
85.26 \\
93.38 \\
120.17 \\
133.98 \\
176.61 \\
192.85\end{array}$ & $\begin{array}{r}\$ 6.48 \\
8.12 \\
9.74 \\
9.94 \\
11.37 \\
13.80 \\
12.18 \\
15.02 \\
18.27 \\
44.66 \\
50.75 \\
54.81 \\
58.87 \\
66.99 \\
73.08 \\
99.47 \\
109.62 \\
144.13 \\
156.31\end{array}$ & $\begin{array}{r}m m_{1} \\
13 \\
13 \\
13 \\
20 \\
20 \\
20 \\
26 \\
26 \\
26 \\
26 \\
26 \\
26\end{array}$ & $\begin{array}{r}m m . \\
132 \\
158 \\
184 \\
132 \\
158 \\
184 \\
132 \\
158 \\
184 \\
211 \\
316 \\
342\end{array}$ & $\begin{array}{r}\$ 6.90 \\
8.93 \\
10.55 \\
10.15 \\
12.99 \\
15.02 \\
12.99 \\
16.24 \\
20.30 \\
23.55 \\
40.60 \\
44.66\end{array}$ & $\begin{array}{r}\$ 5.68 \\
6.48 \\
7.71 \\
8.53 \\
10.55 \\
12.99 \\
10.94 \\
12.99 \\
16.24 \\
19.49 \\
34.51 \\
36.54\end{array}$ \\
\hline
\end{tabular}

* 26 millimeters $=1$ inch.

The price of boards 6 meters ( 6.56 yards) long or over is 5 per cent higher.

The following is the price of planks of different kinds, which are sold per cubic meter:

Alder. $\$ 10.15$ to $\$ 15.43$

Basswood

12.18

16. 24

Beech

8.12

White beech

16. 24

Maple

16. 24

Oak 


\section{CLIMATE.}

The climate of Bohemia is humid and salubrious. The range of the thermometer is given as follows (Fahrenheit):

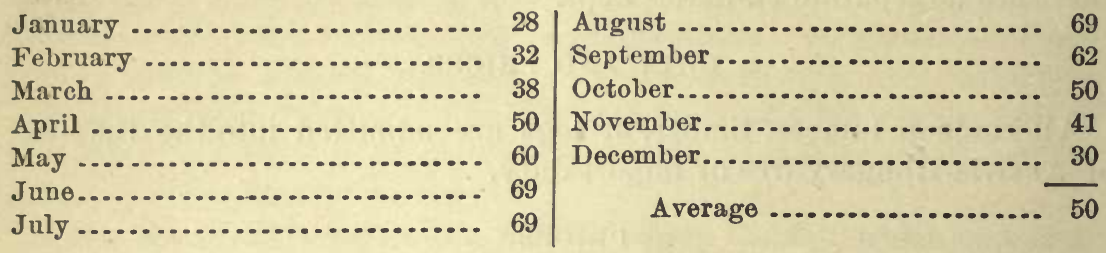

The longest day in the year is sixteen hours ten minutes. The prevailing winds are northeast and east in April, north in May, northwest in June, west and southwest in July and August, east in September, southeast in November, and southwest in December. The east and northwest winds bring clouds and dampness.

\section{GENERAL BUILDING.}

The dwellings, business and farm houses are generally built of brick or stone, and so are all other constructions. Very little wood building is carried on in Bohemia.

There are no ships built in this district. Canal-boats are built at Budweis and Worlik on the river Moldau. They are very lightly constructed, serving simply for one trip down the stream. On their arrival in Hamburg or Bremen, they are sold either in whole or broken up, part sold for lumber and the rest for firewood. I was informed that there is very little freight carried back from the seaports to Bohemia, and that it would not pay to tow the empty canal-boats back against the stream, consequently they are disposed of as stated. About 30 of such canalboats are constructed yearly at the above-named places.

The construction of new lines of railroad in Bohemia is now very limited, only short branch lines being built here and there. Most of the ties made here are used for replacements, and the yearly consumption averages about $10,000,000$. The ties are of pine or oak. They are 8 feet long, 5 inches thick, and 7 inches wide.

The price of pine ties is from 40 to 49 cents, and of oak 81 cents each. The pine ties before they are used are impregnated with a preparation of sulphuric acid in such way that the fluid is forced into every pore of the tie, which is afterwards covered with tar. So prepared, they last on the track from six to seven years.

JOHN KAREL, Consul.

Pragte, January 31, 1894. 


\section{AMERICAN AND HUNGARIAN OAK.}

[From the Pester Lloyd, of Prague, of February 1, 1894.-Translated by Consul Karel.]

When, about eight years ago, the news leaked out that a French association had decided to purchase a large tract of oak forests in the Caucasus, some fear was felt by our home dealers in oak wood. That enormous tracts of oak forest exist in the Caucasus is well known, and the apprehension that the competition of this oak would become dangerous to our home production was, therefore, justifiable. Forttunately that fear passad away without having caused any other injury than that the French association, with which an Austrian firm was also interested, met with a decided failure.

The French association sent at that time several experts for careful examination of the Caucasian oak forests. The investigation lasted six months, and the report of the delegates, headed by a member of a Vienna firm, was made in enthusiastic language, describing the magnificent virgin oak stock, and praising the excellent quality and grand dimensions of the oak trunks. The calculation made promised vast returus, but the real outcome has been disappointing to those directly interested.

The fear of Russian competition is therefore disposed of -for the present, at least; but a more serious danger is threatened from American competition.

The Americans are a practical people. Through premature alarm of the market a depression of prices in oak wood would have been anticipated, and they desire to profit by the high prices in Europe as much and as long as possible.

To begin with, official instructions* were issued from Washington to all American consuls in Europe, directing them to collect facts regarding the production and consumption of lumber, parti sularly regarding oak timber, its peculiarity, and availableness. Theseinstructions were carried out with astonishing thoroughness. Every one of the more important firms dealing in oak wood in Austria and Hungary received judicious interrogatories from the American consuls. In case of insufficient answers, the consuls applied for further information.

The Americans went to work very quietly, guided by the information obtained regarding the availability of the oak, and what followed? Reports came from London, Antwerp, Rouen, Hamburg, showing that American oak was brought and offered on the market of those places for fuel and sawing purposes. Our home firms dealing in oak wood did not notice this competition, because at the beginning it was of such small proportions. But gradually its importance began to be perceptible, and at the present day there are considerable importations of American oak, especially the so-called "German coopers' wood."

Staves for a vessel containing from 80 to 100 eimers (the eimer $=14.94$ wine gallons) have been sold in Germany at 95.2 cents per eimer. The demand for barrels for breweries was so great that our exporters, in consequence of the continual increase in the value of oak forests, and in view of the fant that, for such large-sized staves, the oak trees were becoming scarcer, were obliged to raise their prices. Suddenly there appeared stave wood of American origin on the German market. The shipments from the United States to Hamburg increased and the prices went down little by little.

A shipment of several hundred thousand so-called "French staves," of American origin, arrived in Bordeaux. Thus American competition is trying to get hold of this important line of business also.

In the English lumber market the shipments of American oak timber for sawing are steadily increasing. In London, Liverpool, and Glasgow this oak timber, which

* The answers to these instructions were published by the Department of State, under the title "The Stave Trade in Foreign Countries." 
is of extraordinary quality and dimensions, makes successful competition with the Slavonian wainscoting. Last year it happened for the first time that more than 30 per cent of the Slavonian wainscoting production remained unsold, and had to be ${ }^{8}$ tored by the owners, partly on the docks in England and partly in Fiume, and consequently the effects are already felt. In former years the wainscoting was immediately sold at the annual forest sales after the timber had been bought from the Government. It formed the quasi basis of the forest acquisitions, because in that way the money was returned the quickest, but this year there are still severil lots unsold.

It is a well-known fact that our country has, during the last thirty years, experienced many surprises from the United States. Not only have American grain, bacon, and lard caused depression in our agricultural products, but in wood we have also felt the burden of American competition, which is known, so far, only to initiated circles. It is true that this coupetition concerned one kind of wood, which does not play such a part in the world's market as does our oak wood; we mean the great depression, about fifteen years ago, in the value of larchwood. From 1870 to 1880 the Carinthian larch wood was very much sought after and sold as dear as oak. For certain purposes preference was given to it. The Imperial and Royal arsenal at Pola used great quantities of it annually until the American pitch pine made its appearance and crowded out the larchwood not only from the world's market but from our home market. The arsenal in Pola has been importing for many years American pitch pine, which is superior in quality to larch, besides being sold in huge dimensions and, according to our ideas, at extremely low prices.

The price of larchwood fell continually and the high-priced forest tracts covered with larch timber in Carinthia have been so reduced in value that they are almost down to the level of the common pine-wood forests, while formerly they were valued five times as high, and even more. And now the United States appear very quietly in the world's markets as a competitor with our oak, which causes great uneasiness among our home oak trade.

In consequence of the low price of land in the United States; the fact that no labor has been expended in forest production; the highly developed means of communication, waterways extending everywhere, which are the cheapest neans of transportation, etc., the Americans have great advantages over us; therefore, it is evident that this competition has all the qualifications of becoming a great danger to our oak-wood export. This danger, on account of the extraordinary spirit of enterprise of the American people and their unlimited individual liberty, is no longer theoretical but actually confronts us. One Vienna firm dealing in German coopers' wood followed carefully the transaction of the American oak-wood workers. A member of that firm made a trip to the United States for that purpose. This firm took along 400 skillful and able wood-cutters from our maritime conntry. These men worked, at what was there considered the very low price of $\$ 1.50$ to $\$ 2$ per day, the most choice and magnificent oak timber in great quantities.

Another Vienna firm sent a representative to the United States for the purpose of studying the oak-wood exploitation there. A Buda-Pesth house is on the point of doing the same. All this is certainly praiseworthy, but what can a single individual accomplish in such case? It would be advisable for all the Austrian and Hungarian firms dealing in oak wood to unite and send an expedition on a large scale to the United States for the purpose of studying minutely this dangerous competition. The money question for such expedition would hardly be any obstacle, and assistance from the Government, in the form of recommenclations to the Austro-Hungarian consuls in the United States, would not be wanting. If only a part of what is said of this American competition is true the same fate which met our larch wood will meet our oak. It is therefore for the interest of all the dealers in oak, and especially for the Hungarian State, because it owns the largest oak forests, to fit out such an expedition without delay. 


\section{FRANCE. \\ BORDEAUX.}

NATIVE WOODS.

The woods found in this vicinity are oak, chestnut, walnut, poplar, maple, apple, acacia, fir, cedar, buttonwood, and horse chestnut. There are no trees growing in this latitude of uncommon variety. Towards the south in the vicinity of Nice and along the littoral of the Mediterranean, are to be found certain tropical plants. These, however, serve for decorative purposes only.

\section{KINDS OF LUMBER USED.}

In the vicinity of Bordeaux are found numerous pine forests. Great quantities of hewn pine are used as supports in coal mines in France, but very little is used for building purposes. The greater part of the lumber employed for building in this, and possibly in other parts of France, is imported from Germany, Austria, Italy, Belgium, Switzerland, Roumania, and Turkey. Norway and Sweden are also important shippers of wood to France.

\section{IMPORTS.}

In 1857 the importation of lumber into France for building purposes was valued at 9,151,000 francs; in 1876, at 41,978 francs; and in 1889, at $34,824,426$ francs. Great quantities of fir come from Norway and Sweden, and oak from Russia. The city of Bordeaux is a very important port in the lumber trade.

\section{DUTY AND PRICES.}

The duty charged on lumber per 210.46 pounds, is as follows: Unsawn, 19.3 cents; sawn, thirty one-hundredths inch thick or over, 29.9 cents; sawn, less than thirty one-hundredths inch, 33.8 cents.

The price of lumber varies to such an extent in this market that it would be almost impossible to give any definite figures. It is certain, however, that the United States with its boundless forests and facilities for working up and transporting lumber would find an excellent market in this city. As a proof at hand, I may state that there are already one or two houses selling no inconsiderable quantities of lumber from the United States; and for the benefit of exporters, I attach hereto a list of lumber merchants who I think would be prepared to handle the American article. 


\section{OLIMATE AND GENERAL BUILDING.}

The climate in this part of France is mild, though the winters may ve considered somewhat damp and rainy, and sometimes even rigorous; the summers, on the contrary, are dry and hot.

Although the Garonne River, on which Bordeaux is situated, is a fine, broad tidal waterway, the shipbuilding industry does not flourish here. There does exist a shipbuilding establishment for the construction of war vessels, but these, it is needless to say, are built of steel.

My advice to American exporters would be to send a representative to this city to study the condition of the market and offer the home material at somewhat more advantageous prices than those paid for European lumber used here. This could be readily done, and still leave a wide profit for the American shipper.

LUMBER DFALERS IN BORDEAUX.

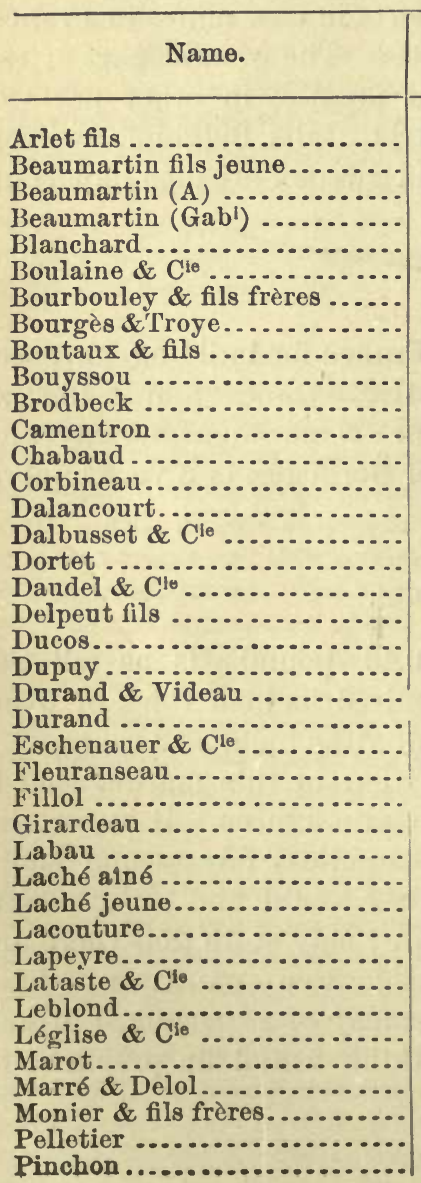

Address.

Rue des Lauriers, 1.

Chemin de Gessac, 2 et 4 (Talence).

Rue de Lamourous, 6.

Rue Tanesse, 35.

Rue Henri IV, 16.

Rue de Cursol, 22.

Rue Millière, 50, and rue Leberthon, 63.

Quai Deschamps, 52 (La Bastide).

Rue .lean-Burguet, 13.

Rue st. Bruno, 69 .

Quai Deschamps, 36 et 37 (La Bastide).

Quai Deschamps, 24 (La Bastide).

Conrs dlu Médoc, 30.

Cours de Cicé, 59.

Boulevard de Caudéran, 209.

Conrs d'Alsace-et-Lorraine, 17.

Chemin d'A rès, 32 et 34.

Rne du Jardin Public, 197 à 215.

Avenue Thiers, 45 (La Bastide).

Quai de Qneyries, 73 et 74 (La Bastide).

Rue Lagrange, 79 et 99.

Cours d'Aquitaine, 87 et 89.

Rue du Petit-Goave, 22 et 24.

Quai des Chartrons, 24.

Cité Monneyra, $5^{\text {bis }}, 7$ et 9.

Allées de Chartres, 59.

Cours St. Louis, 59.

Quai Jeschamps après la Passerelle.

lue Henri IV, 42.

Rue Henri IV, 96-98.

Rue du Port, 3.

Rue St. Bruno, 104, and rue Ligier, 9 et 11.

Rue Delord, 60.

Rue Poirier, 6.

Rue La faurie-de-Monbadon, 69.

Avenue Thiers, 19 (La Bastide).

Rue Reignier, 2.

Rue de Lachassaigne, 67 ot 69.

Rue Vital-Carles, 18.

Quai de Queyries, 35. 
Lumber dealers in Bordeaux-Continued.

\begin{tabular}{|c|c|}
\hline Name. & Address. \\
\hline 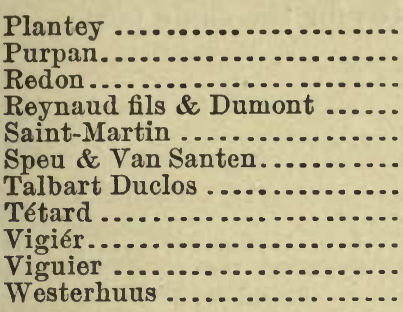 & $\begin{array}{l}\text { Quai de Queyries, } 61-65 . \\
\text { Rue Lagrange, } 147 . \\
\text { Rue Lagrange, } 99 . \\
\text { Rue Calvé, } 43-45 . \\
\text { Rue d'Ornano, } 145 . \\
\text { Cours d'Albret, } 103 \text {. } \\
\text { Rue du Parlement St. Catherine, } 18 . \\
\text { Quai Deschamps, } 32 . \\
\text { Cours Journu-Auber, } 44 . \\
\text { Ruai de Queyries, } 80 \text { à } 83 \text { (La Bastide). } \\
\text { Quai des Chartrons, } 110 .\end{array}$ \\
\hline
\end{tabular}

J. M. WILEY,

Bordeaux, May 19,1894.

Consul.

\section{MARSEILLES.}

NATIVE WOODS.

France does not consume for house-building purposes proportionately the same amount of lumber as is used in the United States, but nevertheless her native woods by no means supply the quantity annually demanded. Dwelling houses of every degree, and indeed structures for whatever purpose intended, are in the main built of stone or, at least in the construction of walls, of broken stone and brick and cement, leaving an outer surface with an appearance as nearly as possible similar to sandstone. Even in the matter of flooring, particularly in southern France, while hard and soft wood are to some extent employed, the material generally liked and usually employed is the red hexagonal tile, common to southern countries. Joists, doors, casings, and, as above stated, some flooring are of wood.

The native woods are walnut, white oak, evergreen oak, eucalyptus, olivewood, some pine, and Corsican boxwood. The characteristic features of these are, of course, generally known, excepting as to the eucalyptus, a detailed report on which was recently sent from this consulate to the Department.

\section{KINDS OF LUMBER USED.}

The lumber usually employed in building operations is pine, most of which is imported from Russia and Sweden. For the making of furniture, an industry of great proportions at Marseilles, the woods preferred are American, Circassian, and French walnut, rosewood, malogany, maple, whitewood, thuya, and boxwood.

$665 \AA-11$ 


\section{IMPORTS.}

The following tables have been prepared, the first giving the total lumber imports, in log and sawed, into Marseilles during the year 1893; the second the imports from the United States for the same period:

Oak:

Imports from all countries.

Unsquared trunks

Tons.

Squared, 80 millimeters thick and orer-

Railway sleepers.................................... 868

Other ............................................. 1,021

80 to 35 millimeters thick ............................. 573

Under 35 millimeters thick .......................... 170

Total........................................ 3,045

Walnnt:

Unsquared trunks ...................................... 157

Squared, 80 millimeters thick and over....................... 1, 188

80 to 35 millimeters thick ................................. 97

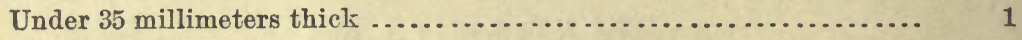

Total....................................... 1,443

Other woods:

Unsquared trunks ...................................... 411

Squared, 80 millimeters thick and over-

Railway sleepers ...................................... 40

Other ............................................ 175

Total........................................... 626

Sawn lumber:

80 to 35 millimeters thick and orer-

Russian ........................................... 5,154

Swedish ......................................... 4, 645

Other ........................................ 5,767

35 millimeters thick and under-

Russian .......................................... 2,917

Swedish.............................................. 6,478

Other ........................................ 5,719

Total........................................... 30,680

Clapboards :

Oak-

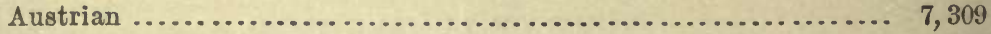

American............................................ 163

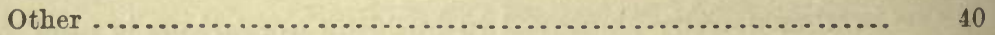

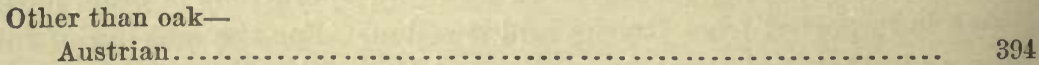

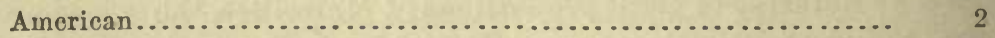

Other.............................................. 256

Total.................................... 8,164 
Cabinet woods, blocks and logs, 2 decimeters thick and over:

Tons.

Box

Mahogany

Other

Other under 2 decimeters thick.

Total

Odoriferous wood

Dyewoods, in logs :

Brazilian

Mexican

Haitien

All other countries

Total

Paving blocks

\section{Imports from the United States.}

Oak lumber for construction, squared or sawn, being 0.08 meter and more,

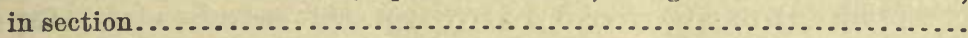

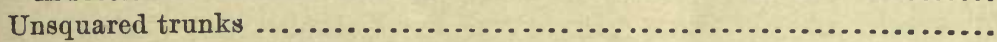

Squared wood:

0.035 meter and under, in section

0.035 to 0.08 meter, in section...

0.08 meter or above, in section ........................... 5,209

Oak clapboarding ............................................ 163.5

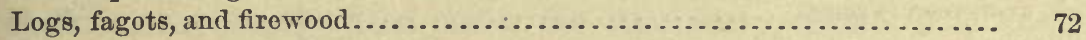

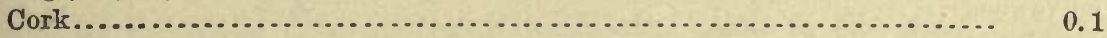

Charcoal from wood. .......................................... 6

Cabinet wood 0.2 meter and more in thickness :

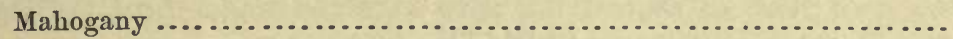

Other wood .............................................

Total

\section{DUTY.}

The following table shows the import duties on lumbers of various sorts, as fixed by the latest French tariff.

Duties on foreign lumber under the present French tariff.

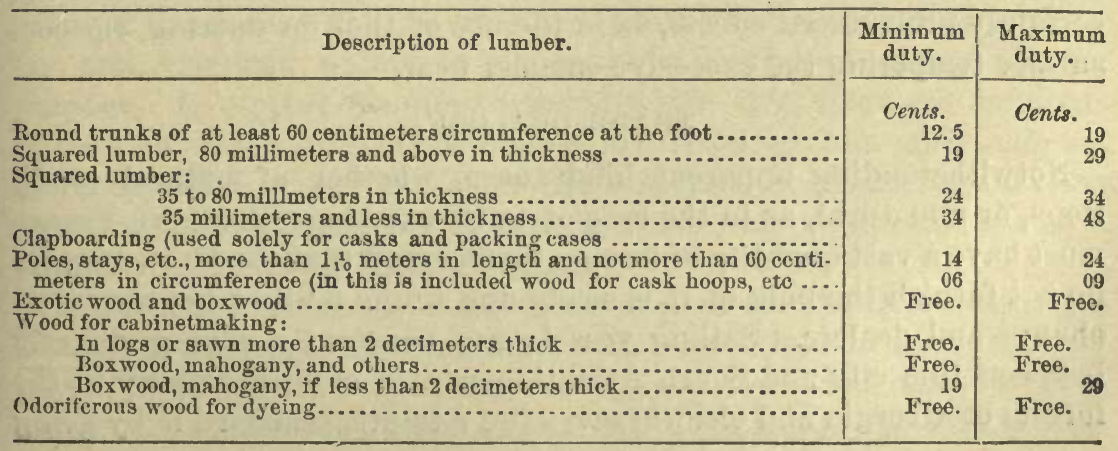




\section{PRICES.}

The appended table, prepared after obtaining prices from many dealers, gives, approximately, the selling prices of various sorts of lumber in the market of Marseilles:

\section{Average prices of the chief kinds of lumber at Marseilles.}

Walnut wood:

French ...........................per ton of 1,000 kilos... $\$ 28.90$ to $\$ 38.60$

Circassian.......................................... 48.25 to 67.55

American ....................................per foot.. $\quad .10$

Maple.............................................do..... 10

Rosewood ..................................... per pound.. .05

Mahogany .........................per ton of 1,000 kilos.. $\quad 57.90$

Ebony:

Macassar .......................................... 48.25

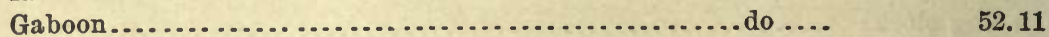

Madagascar......................................... 67.55

Ceylon .......................................... 86.85

Facaranda:

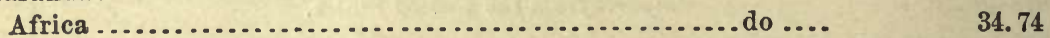

Indies .......................................... do ... 73.34

White wood (America)......................per cubic meter.. $\quad 231.60$

Boxwood:

Persia .........................per ton of 1,000 kilos..

Corsica ......................................... do ...

77. 20

23.16

Oak, white:

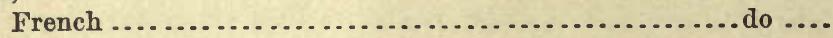

13.51

Hungarian ......................................... 28.95

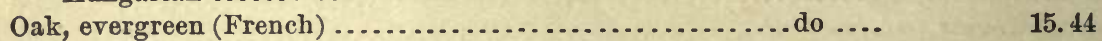

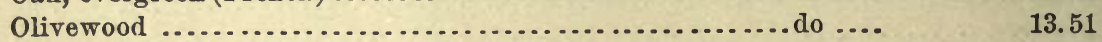

Eucalyptus............................................. 13.51

Thuya............................................... $\quad 675.50$

CLIMATE.

The climate at all seasons is very nearly perfect. Winter, if indeed any season here can be properly so denominated, is sufficiently mild to remind one of early spring in the corresponding American latitude. July and August are very warm, but there is generally a cool wind from the sea, which renders life agreeable even at this, the most unpleasant season in Provence. As to what influence these conditions exercise over building operations it is difficult to estimate; but there are certainly pronounced effects, as in the use of tiles for flooring, the cool surface tempering the excessive summer heat.

\section{TRADE OUTLOOK.}

Notwithstanding apparent hindrances, whether of natural conditions, or unnatural, as in the case of tariff exactions, Southern France must have a vast quantity of foreign lumber, and that the United States do not furnish the bulk of it is solely due to the fault of her own mer. chants and dealers. Sailing vessels are constantly plying directly between this eity and South Atlantic ports, in close proximity to the forests of Georgia and elsewhere on the Atlantic seaboard if by going 
there business can be secured. Transportation rates by these vessels has been reduced to such figures that the cost of shipment of lumber from New York, or Savannah, or Pensacola to Marseilles and Toulon, unlike formerly when it was the chief item of expense, is now often less than that of transportation to the seaboard. The great difficulty in the way of enlarging the American lumber trade here, and this unfortunate impediment operates in the same manner with reference to American commodities in general, is not that the market is lacking or in any sense unwilling, but that there is a complete misunderstanding in the United States of French business methods and habits, an error which often goes so far as to seriously undertake to convert the French system to American, rather than take advantage of situations as they are found. It should not matter to an American that a Frenchman prefers to weigh his wheat by old-fashioned "steelyards" rather than by the carload in transit, moving at the rate of 20 miles an hour. And if he prefers to buy wheat to-day at a fixed price at so much per bushel to be delivered six months or a year hence, and is naturally skeptical of a commercial system wherein the values of commodities in six months or a year depend, not on supply and demand, but on the influence of "corners" and "deals," we have only ourselves to blame that the Russian merchant, appreciating the situation, has well-nigh driven our wheat from this market by taking advantage of this dissatisfaction with the ups and downs of Chicago and New York boards of trade. The Udessa dealer sends a French-speaking agent to Marseilles with instructions to sell wheat under the conditions prevailing in France, not by the trade rules in vogue in Russia. And in the same manner the Russian and Swedish lumber merchants come in person, learn the situation, and make contract with the people in their own language. The American, on the contrary, writes to his consul for the names of people dealing in particular lines of goods. The names are sent, and the American merchant writes a letter in English, inclosing a price list beginning: "We quote, etc., so much per ft.f. o. b.," as if expecting the Frenchman to learn English, and then master the intricacies of American trade abbreviations.

In a word, there is a large field here for American lumber exports. Pine, poplar, and oak are used in certain features of housebuilding referred to herein. The manufacture of furniture is an enormous indus. try, and American walnut is highly appreciated and wanted for the purpose. In a great manufacturing city like this, there are hundreds of uses for which all sorts of lumber are required, but which can not be enumerated here. At Toulon are situated the great shipbuilding concerns of the French Government, and the bulk of imported material should come from the United States.

To secure these markets American dealers should send here repre sentatives who speak the language, with instructions to study the business system of the people, and to sell in accord with it rather than endeavor to bring the French to our way of thinking. Letters in Eng- 
lish are of no avail. An earnest effort in the proper way can secure the lumber market of Southern France to the United States. Claude M. Thomas,

Marseilles, May 19, 1894.

Consul.

\section{GERMANY.}

\section{IMPORTS OF LUMBER.}

The importation of lumber into Germany during 1892 is given as follows:

Lumber, raw or cut only with the ax or saw in cross sections, with or without bark, 54,174,000 marks; lumber, cut in longitudinal sections or otherwise cut than in cross section, $45,640,000$ marks; lumber, cut or sawed, but not planed, in the longitudinal section (so-called "kantholz"), 40,200,000 marks; making the total value, 140,014,000 marks, or $\$ 33,323,000$.

Of the whole importation of lumber into Germany about $70,000,000$ kilograms came from the United States.

\section{DUTIES.*}

The import duty on foreign lumber in Germany is as follows:

\begin{tabular}{|c|c|c|}
\hline Description. & $\begin{array}{l}\text { Non-treaty } \\
\text { countries. }\end{array}$ & $\begin{array}{c}\text { Most fav. } \\
\text { ored } \\
\text { nations. }\end{array}$ \\
\hline Lumber, raw, cut with the ax or saw in cross sections only, with or withont & Marks. & Marks. \\
\hline 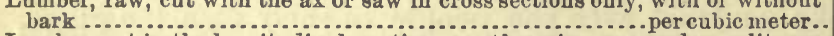 & 1.20 & 1. 20 \\
\hline $\begin{array}{l}\text { Lumber, cut in the longitudinal section, or otherwise prepared or split, per } \\
\text { cubic meter. }\end{array}$ & 2 & \\
\hline $\begin{array}{l}\text { Boxwood, cedar, ebony, mahogany, and cocoa..................... } \\
\text { Lumber, sawn in the longic meter. }\end{array}$ & .60 & .60 \\
\hline blocks (so-called "kantholz") .............................. per cubic meter.. & 6.00 & 4.80 \\
\hline Cnt cedar............................................... per 100 kilos.. & .25 & .25 \\
\hline 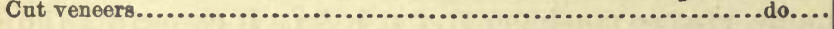 & 6.00 & 5.00 \\
\hline
\end{tabular}

HAMBURG, February \%, 1894.

Charles H. Burke, Acting Consul.

* Consul-general Mason, of Frankfort on the Main, gives the following statement of duties per ton:

[Schedule A: Rates conceded to most favored nations, includes the United States. Schedule B: General rates of duty assessed on timber from nontreaty countries.]

\begin{tabular}{|c|c|c|}
\hline \multirow{2}{*}{ Description. } & \multicolumn{2}{|c|}{ Schedule. } \\
\hline & A. & B. \\
\hline Class 1. Wood, raw or rough hewn with ax or saw, with or withont bark, and & Perton. & Perton. \\
\hline $\begin{array}{l}\text { oak staves } \\
\text { Class } 2 \text {. Lnmber and timber marked in the direction of the longitudinal axis, or } \\
\text { prepared or ent otherwise than by rough hewing; barrel staves not included }\end{array}$ & $\$ 0.50$ & $\$ 0.50$ \\
\hline $\begin{array}{l}\text { in class 1; unpeeied osiers and hoops, hubs, felloes, and spokes....................... } \\
\text { Class 3. Sawed fumber, unplaned boards, sawed cantlewood, and other articles }\end{array}$ & .75 & 1.00 \\
\hline 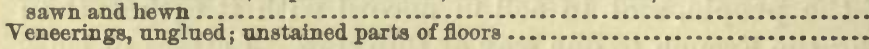 & $\begin{array}{r}2.00 \\
11.90\end{array}$ & $\begin{array}{r}2.28 \\
14.20\end{array}$ \\
\hline
\end{tabular}




\section{BAVARIA.}

NATIVE WOODS.

The principal native woods of the Kingdom of Bavaria are pine, fir, oak, red and white beech. Stone pine, white pine, larch, alder, ash, maple, birch, nut, aspen, elm, and linden are also produced, but in less quantities.

\section{KINDS OF LUMBER USED.}

Pine, fir, oak, and beech are principally used for lumber, the first two being preferred.

\section{IMPORTS OF LUMBER.}

No statistics exist in reference to the importation of lumber into Bavaria, but of pine and fir only very little is imported.

American pitch pine, walnut, and teak are largely imported into Bavaria, especially for railroad wagons and furniture, and cedar in considerable quantities for lead pencils.

Oak staves and oak boards, the latter for parquetry, are mainly imported into Bavaria from Austria-Hungary, and nutwood from Italy and Switzerland.

\section{PRICES.}

The following prices are paid for lumber in Nuremberg, viz: Pine, fir:

Unwrought..........................marks per cubic meter.. 15 to 20

Sawn or cut..................................................... 35 to 30 Oak:

Unwrought ................................................. 40 to 70

Sawn or cut........................................ do... 80 to 110 Beech:

Unwrought ............................................ 12 to 30

Sawn or cut.............................................. 30 to 40

CLIMATE.

The climate in Bavaria is moderate. The average temperature is as follows: Spring, $46 \frac{1}{2}{ }^{\circ} \mathrm{F}$.; summer, $64^{\circ}$; autumn, $47^{\circ}$; winter, $31^{\circ}$.

GENERAL BUILDING.

General building was carried on on a large scale until two years ago. Since that time it has decreased enormously. Shipbuilding in Bavaria is of no importance, but much lumber is used for railroad building. The largest railroad wagon factory of Bavaria, "Maschinenbau Actiengesellschaft Nürnberg," is in this city (Nuremberg), and I am informed that this company consumes about 5,000 to 6,000 cubic meters of lumber a year, one-half of which is native, the other half foreign, mostly American, bought through Hamburg, Amsterdam, and Antwerp houses. 
I was told that until recently (cedar for lead pencils excepted) hardly any direct purchases from the United States were made by Bavarian firms, but always through Hamburg, Amsterdam, Rotterdam, or Antwerp houses. The imports of these American woods are composed of pitch pine, teak, walnut, etc. Cedar has always been imported direct.

\section{EXTENSION OF LUMBER TRADE.}

From my information I am led to believe that owing to the richness of the Bavarian woods a large import trade into this district of woods which grow here in abundance can hardly be expected, but in other kinds the American trade, already of importance, might be considerably extended, either by communicating directly with large manufacturing establishments, such as the wagon factory before mentioned, or by establishing branch houses or agencies at Hamburg and other sea. ports, and through these pushing the trade.

Another large railroad wagon factory in Bavaria is the Maffei'sche Maschinenfabrik, in Munich.

NUREMBERG, February 8, 1894.

SigMUND DÜNKELSBÜHLER, Vice and Deputy Consul.

\section{BREMEN.}

NATIVE WOOD.

The native woods are common pine, German and Scotch fir, oak, beech, poplar, ash, and alder.

\section{KINDS OF LUMBER USED.}

For building purposes Scotch fir, Indian and pitch pine are usedpitch pine is preferred for flooring. Wagon makers and turners use poplar, oak, beech, and alder. Cabinetmakers use German pine for common furniture, but prefer Italian and American walnut and mahogany for fine furniture.

\section{IMPORTS OF LUMTER.}

The quantity of lumber imported is about 200,000 tons $(50,000$ standards) per annum. It is imported from Norway, Finland, Sweden, Russia, German Baltic Sea, and the United States. All the pitch pine used here, and some walnut, is American.

The importation of lumber in the year 1892 was as follows, in standards of 165 cubic feet:

Sweden................................................... 15, 263

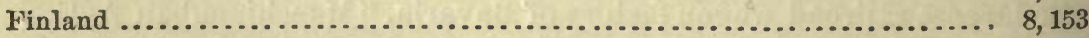

Russia................................................ 14, 391

East Prussia .............................................. 6, 813

Norway............................................... 5, 395

United States......................................... 4,705

Total.......................................... 54,720 


\section{PRICES.}

The following prices, dr.ty included, are paid for lumber per standard or 4 tons:

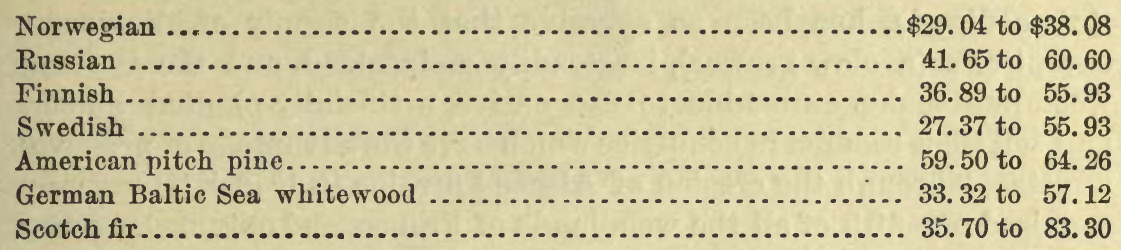

GENERAL BUILDING.

During the years 1891 and 1892875 houses were built in the city of Bremen, representing a value of $10,424,126$ marks $(\$ 2,480,942)$.

There are several railroads in contemplation from Bremerhaven and Cuxhaven, and some branches in Oldenburg. No railroads have been built in this district during the last five years.

The following table gives the total number of vessels built in this district during the years 1888 to 1892 :

\begin{tabular}{|c|c|c|c|c|c|c|}
\hline \multirow[b]{2}{*}{ Year. } & \multicolumn{2}{|c|}{ Steamers. } & \multicolumn{2}{|c|}{ Other vessels. } & \multicolumn{2}{|c|}{ Total. } \\
\hline & $\begin{array}{l}\text { Num. } \\
\text { ber. }\end{array}$ & Tonnage. & $\begin{array}{l}\text { Num- } \\
\text { ber. }\end{array}$ & Tonnage. & $\begin{array}{l}\text { Num- } \\
\text { ber. }\end{array}$ & Tonnage. \\
\hline 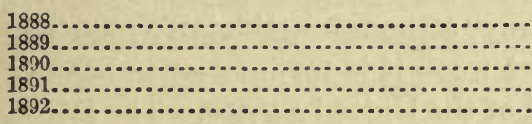 & \begin{tabular}{r|}
3 \\
7 \\
6 \\
14 \\
20
\end{tabular} & $\begin{array}{l}1,253 \\
1,989 \\
4,113 \\
2,803 \\
6,743\end{array}$ & $\begin{array}{r}4 \\
9 \\
11 \\
8 \\
6\end{array}$ & $\begin{array}{r}\mathbf{3}, \mathbf{5 5 5} \\
\mathbf{9}, 767 \\
11,163 \\
10,361 \\
\mathbf{1 3}, 048\end{array}$ & $\begin{array}{r}7 \\
16 \\
17 \\
22 \\
26\end{array}$ & $\begin{array}{r}4,808 \\
11,756 \\
15,276 \\
13,164 \\
19,791\end{array}$ \\
\hline
\end{tabular}

There are six shipbuilding companies in this consular district, but only a few of them are now in operation. The building of ships has considerably decreased during the past year and several of the shipyards have kept up their work only to give employment to their men. The ships so built were not ordered and are still for sale.

Hugo M. StaRkLoff,

Consul.

Bremen, January 31, 1894.

\section{FRANKFORT-ON-MAIN.}

NATIVE WOODS.

The principal native woods are oak, white walnut, beech, white birch, ash, the Lombardy and silver poplars, and, most important of all, three evergreens, viz, the red pine (Fichte), the black fir (Tannenbaum), and the Scotch fir, which is called in German "Kiefer." All these trees 
are planted and grown under the admirable forestry system of Germany, which has been described in detail in previous consular reports.* There are no longer any primitive forests of any consequence in this country, but the forestry laws, which make the State the guardian of its woodlands, has been so effective that the supply of all woods, except oak (a slow grower), is steadily maintained, and the German wood-pulp makers are able to use native, artificially-planted timber, and sell their product in countries which have the advantage of primeval forests. Through the cession of Alsace-Lorraine in 1870-71, Germany acquired one-fifth of all the woodlands of France, and obtained thereby a vast supply of valuable timber. Of the above mentioned varieties the most rapid grower is the silver poplar, which in good situations attains at an age of 20 years a diameter of from 20 to 24 inches.

\section{KINDS OF LUMBER USED.}

The principal kinds of lumber used are the following: Oak for flooring, parquetry, doors, window casings, stairways, and the general interior finishing of the best class of buildings, also for furniture and the wooden parts of agricultural and other machinery.

Ash for flooring, paneled wainscoting, for railway and street cars, machine frames, the handles of agricultural utensils, and for the cheaper grades of dining and chamber furniture.

Walnut for furniture and cabinetwork, the same as in the United States. The white walnut of Germany, although artificially planted, is plentiful and cheap, but as a cabinet wood it is far inferior in beauty and richness to the black walnut wood of the United States. The latter is imported in considerable quantities for furniture, organ cases, and tables for sewing machines and typewriters, which acquire thereby the appearance of American origin.

Florida cedar is imported for the manufacture of lead pencils and penholders. Of late years the cheaper grades of pencils and penholders have been made in Germany from California and Oregon redwood, but these are specialties which employ only a limited quantity of material.

Pitch pine from the Carolinas was used here in past years for window sash and for cottage furniture, but it is said to shrink after manufacture so as to make bad joints, and so far as can be ascertained it is no longer used to any important extent.

Poplar is used for many kinds of boxes and packing cases, as well as for certain parts of cars and carriages where lightness is especially desirable.

Railway ties are made of oak, beech, and fir, but at the present low prices of metal wooden ties are being gradually replaced by ties of 
iron and steel. Few new railways are in construction, and the principal demand for ties is for repairs to the lines already in operation.

Building lumber, viz, rafters, sheathing for slate and tiled roofs, doors, and window frames, painted wainscoting, and the underlaying of parquetry floors, is uniformly of pine and fir. Frame houses, shingled roofs, weatherboarded walls, board or picket fences, and wooden sidewalks are all practically unknown in German cities and villages, and as iron joists and girders and fireproof stairways are now exclusively used in all good buildings the use of lumber or timber of any kind in building is reduced to a minimum. The trusses and framework of roofs, rafters, and beams of sizes larger than 6 inches square are generally made by hewing with broadax, the straight, slender young pines which grow so profusely in the Government forests.

Oaken split staves are used for wine and beer barrels and kegs and for the large casks used in breweries and wine cellars. The smaller staves, up to a length of 4 or 5 feet, are obtained in Germany or imported from Austria-Hungary and Kussia. But large oak trees are becoming scarce and costly in most parts of Europe, and the larger class of oaken staves, those from 5 to 10 feet in length, are now imported in considerable and steadily increasing quantities from Missouri, Arkansas, and Tennessee. The best American oak staves are exceedingly tough in fiber, clear and even in grain, and so far as can be ascertained are uniformly preferred by all German coopers who have used them to the large staves of European origin. There are but fow large oak trees left in Germany that are available for cutting, and their value may be inferred from the fact that a single tree which was cut some months ago in the Spessart, a forest region near Frankfort, was sold for 1,200 marks $(\$ 285)$.

\section{IMPORTS OF LUMBER.}

The amount of lumber imported into Germany in 1892, and during the first eleven months of 1893, was as follows, in metric tons of 2,240 pounds.

Imports of 1892.

\begin{tabular}{|c|c|c|c|c|}
\hline Country. & $\begin{array}{l}\text { Timber, } \\
\text { round or } \\
\text { rough } \\
\text { hewn }\end{array}$ & $\begin{array}{c}\text { Squared } \\
\text { logs. }\end{array}$ & $\begin{array}{c}\text { Sawn } \\
\text { lumber. }\end{array}$ & $\begin{array}{c}\text { Oak } \\
\text { stares. }\end{array}$ \\
\hline \multirow{6}{*}{ 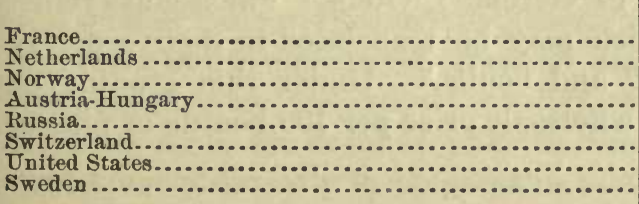 } & $\begin{array}{l}\text { Tons. } \\
12,928\end{array}$ & $\begin{array}{l}\text { Tons. } \\
. . . . . . .\end{array}$ & $\begin{array}{l}\text { Tons. } \\
. . . . . . . .\end{array}$ & Tons. \\
\hline & $\begin{array}{r}13,134 \\
4,082\end{array}$ & $\cdots$ & $\begin{array}{r}4,830 \\
32,042\end{array}$ & .............. \\
\hline & 720,561 & 153,224 & 169,509 & 32,046 \\
\hline & $1,038,114$ & 352,504 & 218,537 & 2,159 \\
\hline & $\begin{array}{r}1,308 \\
11,972\end{array}$ & 4,382 & $\begin{array}{r}2,224 \\
53,224\end{array}$ & $\dddot{7}, 720$ \\
\hline & & 40,288 & 296,011 & \\
\hline Total ... & $1,802,349$ & 550,398 & 776,426 & 41,925 \\
\hline
\end{tabular}


Imports first eleven months 1893.

\begin{tabular}{|c|c|c|c|c|}
\hline Aastria-Hungary.. & $\begin{array}{l}\text { Tons. } \\
604,647\end{array}$ & $\begin{array}{l}\text { Tons. } \\
101,896\end{array}$ & $\begin{array}{l}\text { Tons. } \\
132,249\end{array}$ & $\begin{array}{l}\text { Tons. } \\
33,366\end{array}$ \\
\hline Rnssia................. & 911,875 & 394,981 & 167,471 & 2,308 \\
\hline Netherlands $\ldots \ldots \ldots \ldots \ldots \ldots \ldots \ldots \ldots \ldots \ldots \ldots \ldots \ldots$ & $\begin{array}{r}10,041 \\
3,457\end{array}$ & (n.......... & $\begin{array}{r}2,868 \\
30,270\end{array}$ & (n......... \\
\hline $\begin{array}{l}\text { Norway.. } \\
\text { Sweden.. }\end{array}$ & $\begin{array}{l}3,457 \\
\ldots . . .\end{array}$ & 38,279 & 317,631 & $\ldots . . .$. \\
\hline United States................................ & 13,186 & 4,376 & 40,319 & 8,096 \\
\hline France $\ldots \ldots \ldots \ldots \ldots \ldots \ldots \ldots \ldots \ldots \ldots$ & 6,826 & $\cdots \ldots \ldots \ldots$ & (............. & (........... \\
\hline Total. & $1,550,032$ & 539,532 & 690,808 & 43,770 \\
\hline
\end{tabular}

There were also imported in 189217,944 tons of boxwood, of which 9,760 tons came from the West Indies, 3,099 tons from the United States, and the remainder principally from the East Indies and Africa. In the foregoing statistics the difference between classes 1 and 2, i. e., "timber, round or rough hewn," and "squared logs," is this: The first class includes beams, piles, and ship timber imported in the general form in which it is to be used, while class 2 includes the blocks and. logs which have been squared to save freight and duty on waste mate. rial, and which are imported for the special purpose of being sawn into veneers or other forms of fine lumber for cabinetwork or building purposes. The reason for this latter method of importation will be apparent when the classification and rates of duty in each class are explained.

\section{PRICES.}

The prices of lumber in Germany are based upon classifications and methods of measurement, which are somewhat difficult to clearly explain. The American unit of measure per "thousand feet," is not used in this country. Timber is sold by the cubic meter, equal to 35.3 cubic feet; and sawed lumber is sold at retail by the piece and at wholesale by the hundred pieces. This latter system will be illustrated by the following tabular price list, showing the wholesale rates at which pine and fir building Jumber are now offered for delivery at Frankfort by lumbermen who have sawmills in the forests of Bavaria, Würtemberg, and Baden. These are therefore the prices with which American building lumber would have to compete, exclusive of duty, if introduced into this market.

The subjoined list shows the four standard grades or qualities, which are designated, respectively, in German: "Rein," "ausschuss-rein," "gute," and "ausschuss," which may be translated in their order as "clear," "half clear," "good," and "culls." Under this grading or classification of qualities, the wholesale price per 100 boards or pieces, 
16 feet long, from 1 to 2 inches thick, and from 6 to 14 inches wide, per cubic meter, are as follows:

\begin{tabular}{|c|c|c|c|c|c|}
\hline $\begin{array}{l}\text { Thick- } \\
\text { ness. }\end{array}$ & Width. & Clear. & $\begin{array}{l}\text { Half } \\
\text { clear. }\end{array}$ & Good. & Culls. \\
\hline $\begin{array}{r}\text { Inches. } \\
1 \\
1 \\
1 \\
1 \\
1 \\
1 \\
1 \\
1 \\
1 \\
11 \\
1 \frac{1}{2} \\
2\end{array}$ & $\begin{array}{r}\text { Inches. } \\
6 \\
7 \\
8 \\
9 \\
10 \\
11 \\
12 \\
13 \\
14 \\
12 \\
12 \\
12\end{array}$ & $\begin{array}{r}\$ 17.37 \\
19.99 \\
24.03 \\
28.08 \\
35.22 \\
41.65 \\
48.79 \\
53.55 \\
58.31 \\
69.02 \\
83.30 \\
111.86\end{array}$ & $\begin{array}{r}\$ 14.75 \\
16.89 \\
19.75 \\
22.84 \\
29.03 \\
33.55 \\
39.74 \\
42.60 \\
46.88 \\
54.74 \\
64.26 \\
88.06\end{array}$ & $\begin{array}{r}\$ 13.09 \\
14.99 \\
17.61 \\
20.46 \\
25.94 \\
29.27 \\
35.46 \\
38.31 \\
41.88 \\
44.50 \\
53.31 \\
70.92\end{array}$ & $\begin{array}{r}\$ 10.47 \\
12.37 \\
14.99 \\
17.61 \\
20.70 \\
23.32 \\
27.13 \\
29.03 \\
31.41 \\
33.79 \\
40.69 \\
54.26\end{array}$ \\
\hline
\end{tabular}

The subjoined price list is for units of 100 pieces, 16 feet long, but of special thicknesses other than 1 inch.

\begin{tabular}{|c|c|c|c|c|c|c|c|c|}
\hline \multirow{2}{*}{ Quality. } & \multirow{2}{*}{$\begin{array}{l}\text { Thick- } \\
\text { ness. }\end{array}$} & \multicolumn{7}{|c|}{ Inches in width. } \\
\hline & & 6. & 7. & 8. & 9. & 10. & 11. & 12. \\
\hline $\begin{array}{l}\text { Unsorted B, clear . } \\
\text { Do......... } \\
\text { Good A. clear.... } \\
\text { Box boards ....... }\end{array}$ & 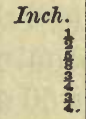 & $\begin{array}{r}\$ 6.42 \\
7.14 \\
10.23 \\
8.80\end{array}$ & $\begin{array}{r}\$ 7.85 \\
8.80 \\
11.90 \\
10.47\end{array}$ & $\begin{array}{l}\$ 9.15 \\
10.71 \\
13.80 \\
12.37\end{array}$ & $\begin{array}{r}\$ 11.42 \\
12.85 \\
16.66 \\
14.99\end{array}$ & $\begin{array}{r}\$ 13.80 \\
15.70 \\
20.94 \\
18.08\end{array}$ & $\begin{array}{r}\$ 16.42 \\
18.80 \\
23.56 \\
20.70\end{array}$ & $\begin{array}{r}\$ 19.04 \\
21.42 \\
29.03 \\
23.56\end{array}$ \\
\hline
\end{tabular}

Terms on all sales under the foregoing lists, three months' payment, or $1 \frac{1}{2}$ per cent discount for cash These prices would be equivalent to about $\$ 30$ per 1,000 feet for clear pine lumber 1 inch thick, 12 inches wide, and 16 feet long. Whether American lumber can stand the freight and import duty, besides commissions, is the main question which American exporters will readily decide. Oregon pine and redwood from the Pacific coast have been imported to Bremen, Düsseldorf, Cologne, and some other ports of the lower Rhine, but it does not appear that any has come so far inland as Frankfort.

In respect to its pine lumber supply Frankfort occupies the advantageous position of being the first large city on the River Main, down which are rafted vast quantities of logs and lumber from the forests of Bavaria. Part of the logs are sawed in the woods where they are cut, but a large proportion are peeled and rafted down in whole tree lengths to Frankfort, where they are either hauled out and sawed or the smaller rafts are joined together and continue their voyage down the river to the numerous sawmills along the Rhine from Cologne to Duisburg, or to Holland, where they are either sawed for lumber and ship timber or are used as piles in the dike and dock constructions which are constantly in progress in that country. Germany is thus an exporter as well as an importer of logs and lumber, the exports under two classes, mostly pine and fir, amounting in 1892 to 276,473 tons. 


\section{OLIMATE.}

The climate in this district is similar in mean temperature, rainfall and general character to that of southern Indiana or Kentucky. The extremes of heat and cold are, however, less marked here than in any corresponding climate in the United States.

\section{GENERAL BUILDING.}

There is no wooden boat or ship building of any consequence in this district. There are still many wooden vessels in service on the Rhine, but they belong mainly to the older class; the new barges and steamers, which carry most of the traffic on thatriver and its tributaries, are made of iron and steel.

\section{EXTENSION OF LUMBER TRADE.}

In respect to the hard and more valuable woods, the field which is offered in Germany to American exporters is much more promising.

The American black walnut is superior to any cabinet wood found in this country, and there is already a considerable import of that material, chiefly in the form of rough-hewn squared logs, which are landed at Hamburg, under the minimum duty of 50 cents per ton, and sold at auction to dealers and consumers, who saw them up into the required sizes and forms. The advantage gained by this form of importation applies similarly to all other woods. The squared $\log$, which is entered at a duty rate of 50 cents per ton, would, if sawed into boards, be dutiable at $\$ 2$ per ton, or $\$ 11.90$ per ton if sawed into veneerings. But, on the other hand, few cabinetmakers are able to judge with certainty from outside examination what the interior quality of a large walnut or bird's-eye maple log may be, and many therefore prefer to buy their walnut and other fine lumber ready sawed and seasoned. Black-walnut timber for the German market may be of first or second quality, from 8 to 16 feet long, 6 to 18 inches wide, and $1,1 \frac{1}{4}, 1 \frac{1}{2}$, and 2 inches thick. The same dimensions apply to ash lumber designed for furniture and house-finishing purposes.

Oak flooring is largely used in this country, but the imported material must compete in price with the home-grown supply and with the oak of Austria and Russia, and whatever business is done in this line must be based on close profits. Oak or ash flooring is rarely laid straight and parallel, but is cut up into lengths of 20 to 24 inches and laid in "herringbone" or other simple patterns on an under sheathing of pine. For this purpose the oak stuff need be only 4 or 5 inches wide, and is readily furnished by small trees such as grow plentifully in some districts of Germany. Oak lumber sent to this country should be, unless otherwise specified, an inch thick, from 4 to 6 inches wide, from 4 to 16 feet long, and seasoned until its weight does not exceed 
4,000 pounds per 1,000 feet. The duty would be 20 cents per 100 kilos, or about $\$ 3.63$ per 1,000 feet. Russian oak is imported and sold by the Handelsgeschäft at Berlin, and in order to meet this double competition American oak lumber would have to be landed at Rotterdam or Antwerp for about $\$ 45$ per 1,000, freight to destination and German import duty being additional and subsequently paid by the commission merchant or importing consumer. Ash lumber will have to be similarly landed for from $\$ 35$ to $\$ 40$ per 1,000 feet. Veneerings of bird's-eye maple or fine walnut and red birch have also been imported to some extent and are much liked, but the high duty, $\$ 11.90$ per ton, renders them rather expensive.

There is also a steady and growing demand for American oak staves of the sizes from 4 to 10 feet in length, which are used by coopers in the wine districts along the Rhine and the Moselle, as well as in Baden and Würtemberg. It is worthy of note that such staves for the German market should be somewhat thicker than those of similar lengths used at home. This is for the reason that European oak is less tough and strong than American, and the coopers here have become accustomed to thicknesses which Americans have found to be disproportionate and unnecessary. The German coopers are, however, confirmed in their notions, and it will be well to concede half an inch of extra thickness to this prejudice. Dressed staves of smaller sizes, in which the item of labor forms a large part of the cost of production, can apparently be made as cheaply in Germany as in the United States.

Carriage lumber, hubs, spokes, felloes, etc., are imported from our country to some extent, but mainly by parties in Berlin, who keep a large stock and send traveling salesmen to sell supplies to carriage-builders, who in case of large purchases frequently go or send a competent foreman to Berlin, where the wood is selected, piece by piece. It is quite probable that a capable agent or local commission merchant in southern Germany could establish direct relations between American exporters and the principal carriage-makers in this section, but it would be necessary to send only selected wood, every piece of which is up to standard, for any defect in quality would be detected and soon break up a direct trade with consumers.

For the development and maintenance of direct exports of American lumber of any kind to western Germany, no agency would be so effective as an energetic, clever salesman, familiar with the German language and local methods of business, equipped with samples and authorized to receive trial orders from dealers and consumers under specified guaranties and conditions. If prices and qualities were found satisfactory, a trade could soon be established that would in the end take care of itself. If the sending of such agents is not found feasible, the next best method would be to enlist the services of local commission merchants, who should be authorized to make sales on the terms of payment that are offered by dealers who sell native or imported European woods. Exporters who may wish to open correspondence 
with an experienced and capable commission merchant in this city, who has already introduced with some success several kinds of American lumber, are referred to Mr. Erwin Roelker, No. 33 Hochstrasse, Frankfort.

FrANKFORT, February 3, 1894.

\author{
FraNK H. MASON, \\ Consul-General.
}

\title{
HAMBURG.
}

\section{NATIVE WOODS.}

The native woods of the Hamburg consular district are oak, red beech, red and white pine, alder, ash, and poplar. Oak is principally used for ship, mill, and bridge building, while beech is generally employed by house-builders and carriage manufacturers.

Imports of lumber into Hamburg.

\begin{tabular}{|c|c|c|c|c|c|}
\hline \multirow{2}{*}{ Whence imported. } & \multicolumn{2}{|c|}{1892.} & \multirow{2}{*}{$\begin{array}{c}\text { Average } \\
\text { value. }\end{array}$} & \multicolumn{2}{|c|}{1891.} \\
\hline & 100 kilos. & Mark8. & & 100 kilos. & Marks. \\
\hline \multicolumn{6}{|l|}{ Building material. } \\
\hline $\begin{array}{l}\text { United States, on the Atlantio. } \\
\text { British North America......... }\end{array}$ & 47,429 & 328,770 & & 198 & 2,050 \\
\hline 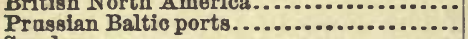 & 107,335 & 619,180 & $\ddot{6}$ & $\begin{array}{r}1,597 \\
131,238\end{array}$ & $\begin{array}{r}13,500 \\
817,220\end{array}$ \\
\hline 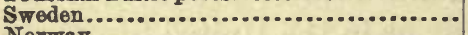 & 142,027 & 616,070 & 4 & 122,000 & 555,050 \\
\hline Norway $\ldots \ldots \ldots \ldots \ldots . . . . . . . .$. & 76,353 & 316,080 & 4 & 57,732 & 257,070 \\
\hline $\begin{array}{l}\text { Russian Baltio ports } . . . \ldots \ldots \ldots . . \\
\text { Other countries .............. }\end{array}$ & 26,682 & 140,390 & $\overrightarrow{5}$ & 38,665 & 168,610 \\
\hline Other count & 1,024 & 6,040 & 6 & 189 & \\
\hline \multirow{2}{*}{$\begin{array}{l}\text { Total by sea....................................... } \\
\text { From the Upper Elbe and by }\end{array}$} & 400,850 & $2,026,530$ & 5 & 351,619 & $1,814,780$ \\
\hline & & & & 13 & \\
\hline \multicolumn{6}{|l|}{ Staves. } \\
\hline United States, on the Atlantio & 8,725 & 83,220 & 10 & 5,037 & 47,440 \\
\hline British North Ame & 169 & 2,000 & 12 & 146 & \\
\hline Sweden..................... & 6,168 & 42,170 & 7 & 4,553 & 32,310 \\
\hline Bremen .................... & 349 & 3,960 & 11 & 318 & 3,090 \\
\hline Other countries ...... & 249 & 2,790 & 11 & 251 & 2,490 \\
\hline \multirow{2}{*}{$\begin{array}{l}\text { Total by sea.................................... } \\
\text { From the Upper Eibe and by railway .... }\end{array}$} & 15,660 & 134,140 & 9 & 10,305 & 86,260 \\
\hline & 15,421 & 123,370 & 8 & 43,001 & 344,010 \\
\hline \multirow{5}{*}{ 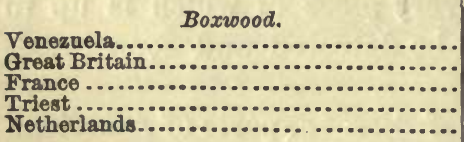 } & & & & & \\
\hline & $\begin{array}{r}10 \\
565\end{array}$ & 39.640 & 10 & 1,842 & $\begin{array}{l}13,040 \\
35,190\end{array}$ \\
\hline & 1,191 & 16,570 & 14 & 190 & 4,180 \\
\hline & 388 & 4,960 & 13 & 196 & 4,900 \\
\hline & 103 & 2,350 & 23 & & \\
\hline Total by sea.................................. & 3,257 & 63,620 & 20 & 3,669 & 57,310 \\
\hline \multicolumn{6}{|l|}{ Walnut. } \\
\hline United States on the Atlantic. & $1,133,100$ & $2,136,740$ & 189 & $1,726,993$ & $3,455,070$ \\
\hline Asia Minor....... & 14,903 & 35,700 & 240 & 15,138 & 37,130 \\
\hline Britieh East India .................. & $\begin{array}{r}2,529 \\
76\end{array}$ & 3,140 & 124 & 2,169 & 2,000 \\
\hline Russian ports on Blac & 76,319 & 271,390 & 356 & 84,784 & 327,010 \\
\hline Turkey in Europe............. & $\begin{array}{l}15,151 \\
15,911\end{array}$ & $\begin{array}{l}44,600 \\
29,370\end{array}$ & $\begin{array}{l}294 \\
185\end{array}$ & $\begin{array}{l}12,804 \\
39,671\end{array}$ & $\begin{array}{l}23,750 \\
85,490\end{array}$ \\
\hline 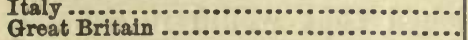 & $\begin{array}{r}10,811 \\
8,647\end{array}$ & $\begin{array}{l}29,370 \\
26,960\end{array}$ & 312 & 34,151 & $\begin{array}{r}80,490 \\
105,860\end{array}$ \\
\hline France ...................... & 11,392 & 23,930 & 210 & 23,610 & 83,380 \\
\hline 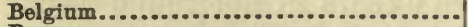 & 3,096 & 12,700 & 410 & & 2,560 \\
\hline Bremen ....................... & 1,362 & 3,160 & 232 & 133 & 510 \\
\hline Netherlands............. & 993 & 2,590 & 261 & 3,817 & 11,510 \\
\hline Other countries & 503 & 1,600 & 318 & 1,105 & 3,170 \\
\hline Total by sea & $1,283,906$ & $2,591,880$ & 202 & $1,945,130$ & $4,137,440$ \\
\hline Erom the Upper Elbe ar & 2,218 & 4,480 & 202 & 8,276 & 17,630 \\
\hline
\end{tabular}


Imports of lumber into Hamburg-Continued.

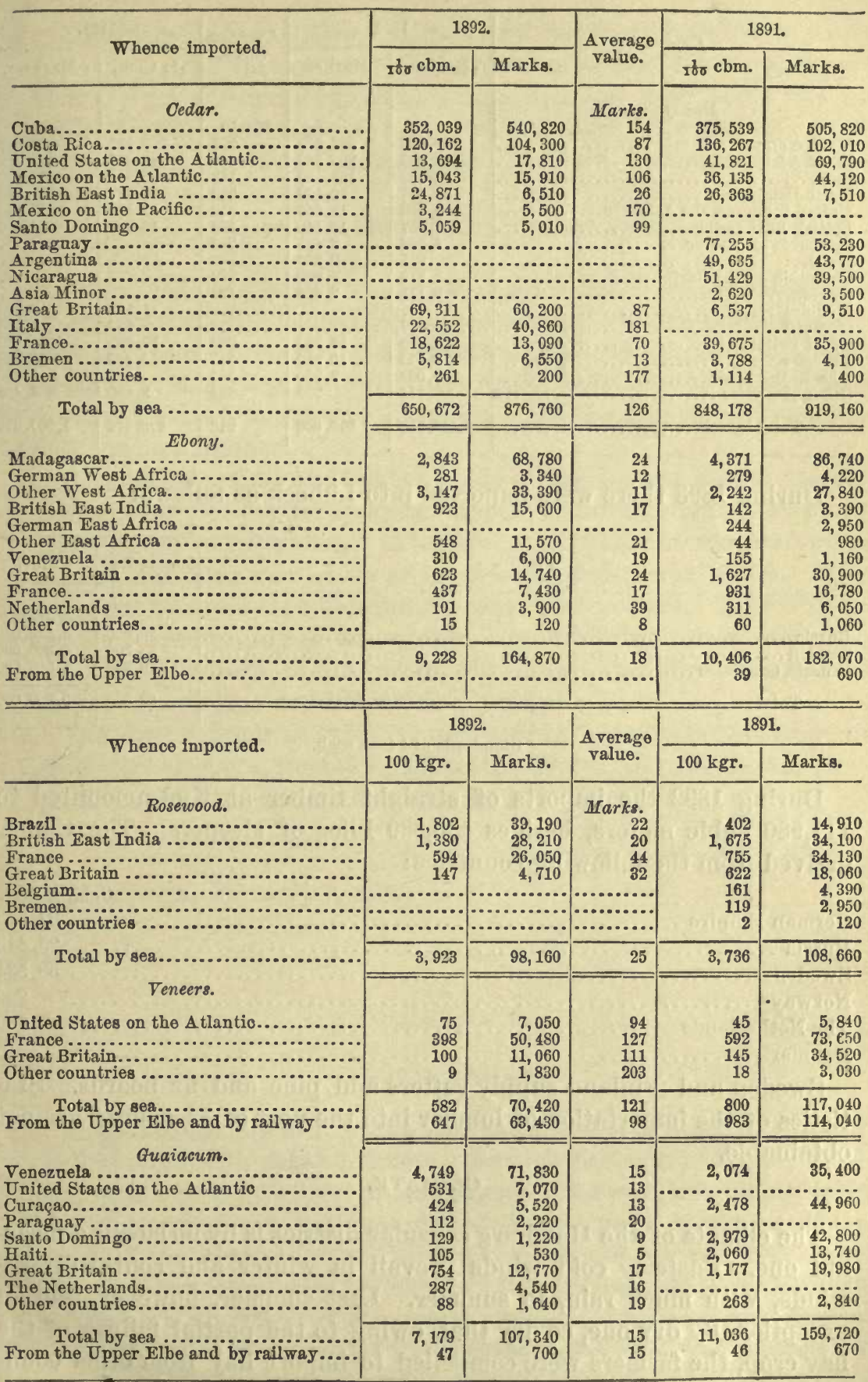


Imports of lumber into Hamburg-Continued.

\begin{tabular}{|c|c|c|c|c|c|}
\hline \multirow{2}{*}{ From- } & \multicolumn{2}{|c|}{1892.} & \multirow{2}{*}{$\begin{array}{c}\text { Average } \\
\text { ralue. }\end{array}$} & \multicolumn{2}{|c|}{1891.} \\
\hline & ริे $\mathrm{Cbm}$. & Marks. & & Iริช $\mathrm{Cbm}$. & Marks. \\
\hline Mahogany. & & & Marks. & & \\
\hline Mexico on the Atlantio & 149,666 & 386,670 & 258 & 208,320 & 532,090 \\
\hline West Africa .... & 120,035 & 223,380 & 186 & 145,768 & 817,610 \\
\hline 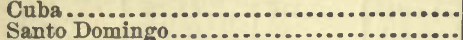 & 76,108 & 124,100 & 163 & 95,787 & 195,230 \\
\hline Domingo........................ & $\begin{array}{r}21,024 \\
5,209\end{array}$ & $\begin{array}{l}50,120 \\
16,640\end{array}$ & $\begin{array}{l}238 \\
319\end{array}$ & 89,777 & $\begin{array}{r}251,690 \\
42,640\end{array}$ \\
\hline & $\begin{array}{l}0,209 \\
8,857\end{array}$ & $\begin{array}{l}16,640 \\
16,140\end{array}$ & $\begin{array}{l}319 \\
182\end{array}$ & $\begin{array}{l}13,426 \\
16,787\end{array}$ & $\begin{array}{l}42,640 \\
29,230\end{array}$ \\
\hline Columbia on Pacific. & 4,208 & 8,420 & 200 & .............. & \\
\hline$\because \ldots \ldots \ldots \ldots$ & 875 & 3,230 & 370 & ............ & 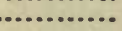 \\
\hline 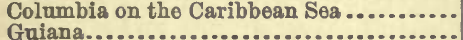 & $\begin{array}{l}1,710 \\
2,141\end{array}$ & 3,060 & 179 & 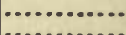 & (n) \\
\hline $\begin{array}{l}\text { Guian } \\
\text { Madei }\end{array}$ & 2,141 & 2,000 & 121 & $\cdots \cdots \cdots$ & 3,70 \\
\hline Cur & & 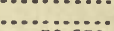 & & 993 & 2,500 \\
\hline •........................... & 21,425 & 56,250 & 263 & 23,987 & 80,250 \\
\hline 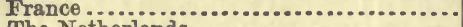 & 6,872 & 16,950 & 247 & 18,485 & 47,260 \\
\hline 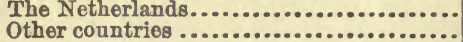 & $\begin{array}{r}2,089 \\
114\end{array}$ & $\begin{array}{r}7,950 \\
290\end{array}$ & $\begin{array}{l}381 \\
254\end{array}$ & $\begin{array}{r}449 \\
3,453\end{array}$ & $\begin{array}{l}1,230 \\
4,440\end{array}$ \\
\hline & & & & & \\
\hline Tots & 420,333 & 915,800 & 218 & 618,374 & $1,507,870$ \\
\hline
\end{tabular}

During 1893 there were imported into Luibeck as follows:

\begin{tabular}{|c|c|c|}
\hline From- & Standards.* & Value. \\
\hline $\begin{array}{l}\text { Russia } \\
\text { Sweden } \\
\text { Prussia, coastwise }\end{array}$ & $\begin{array}{l}20,000 \\
32,500 \\
10,500\end{array}$ & $\begin{array}{l}\text { Marks. } \\
3,500,000 \\
4,800,000 \\
1,500,000\end{array}$ \\
\hline Total ................... & 63,000 & $9,800,000$ \\
\hline
\end{tabular}

* Standards of 4 tons each.

During 1892 the imports of straight timber at Kiel amounted to 117,980 cubic meters, besides 436,880 kilos of sleepers. The timber arrived from the following countries:

Cubic meters.

German Empire ............................................. 37, 823

Russia ................................................... 25, 413

Sweden.................................................. 53, 534

Norway .................................................... 226

The Netherlands.............................................. 969

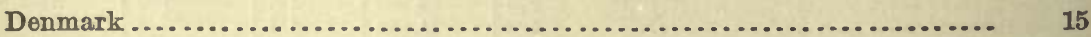

Sweden and Finland supply rafters and pine and fir boards. Statistics of the importation of lumber into the port of Flensburg are not obtainable.

\section{CLIMATE.}

The climate of the Hamburg consular district is by no means a pleasant one. Easterly cold winds prevail in winter and southwesterly winds, with much rain, in summer. Last summer, however, was an exceptionally dry one, so dry that, owing to the partial failure of the hay crop, the farmers were compelled to import hay from other countries, the United States being among these. 


\section{GENERAL BUILDING.}

Considerable house, ship, and railroad building is carried on in this district, and in this respect I would refer to the enormous growth of the cities of Hamburg, Altona, and Kiel, the new North Sea and Baltic Canal, with its many locks, bridges, and railways, and to the shipbuilding yards of Hamburg, Kiel, Lübeck, Flensburg, and Rostock.

\section{EXTENSION OF LUMBER TRADE.}

I find that the general opinion of those engaged in the importation of lumber from the United States is that the American dealers do not pay sufficient attention to the desires and wishes of the German importers; that they very often ship qualities inferior to those ordered, and are inclined to class as prime what the German dealer would call only medium lumber.

In order to extend the lumber trade of the United States the shipments of inferior lumber must be stopped, as far as practicable, so as to allow prices to recuperate. At the close of 1892 the stock of walnut logs in Hamburg was 1,400; at the close of 1893 it was 10,000. This is sufficient to supply the demand for some time to come. Notwithstanding this overstocking of the market, I am told that prime walnut logs are always salable at fair prices, the larger the logs the better the prices. Small logs are difficult to get rid of.

The low freights at which small sailing vessels carry lumber, and especially sleepers, from Sweden to the North Gerinan ports, almost preclude the competition of countries as far distant as ours.

Chas. H. BuRKe,

Vice and Acting Consul.

HAMBBURG, February 7, 1894.

\section{NORWAY.}

\section{NATIVE WOODS.}

Southeastern Norway, where this consulate is located, was formerly well covered with natural forests. Lumber has, consequently, for several centuries past been a staple export. Norway, as a whole, is still well wooded, and it is estimated that 77,000 square kilometers ( 24 per cent) of the superficies of the country are still covered with forests. But they have gradually become very thin in many districts, especially on the high mountains and in marshy places. In the western districts, along the extensive seacoast, the forests have now disappeared altogether, and the only woods left are at the inner extremity of the deep and narrow fjords, sometimes over $\mathbf{1 0 0}$ miles from the open sea. 
In earlier times, when wood had no value as an article of commerce, and when people had not yet begun cutting down the forests recklessly, about half of the country was wooded and the forests covered many sections now perfectly treeless. There were even forests of large oaks and other valuable trees which have now almost disappeared. The present decline in the forests is due to an excessive consumption of wood for fuel, and fencing in land, as well as to large fires in many districts.

The native woods of Norway are chiefly pine or spruce (Abies excelsa), fir (Pinus silvestris), birch (Betula odorata), and alder (Alnus incana), The two first, of which the great forests exclusively consist, grow abundantly everywhere in eastern and northern Norway, even up to the seventieth degree north latitude. Trees between one hundred and one hundred and fifty years old show a considerable size, but those now felled and floated down the rivers to the mills are generally of small dimensions, showing the rapid decline in the forests.

\section{EXPORTS OF LUMBER.}

The aggregate value of the Norwegian forests was lately estimated at about $\$ 110,000,000$, and they are supposed to give employment to nearly 14,000 persons. In 1892 , for which year we have the latest official statistics, the total export of lumber of all kinds amounted to $1,894,586$ cubic meters, consisting of planed and sawed lumber, hewn timbers, pit props, and other round timber, staves, and firewood.

In the above figures are, however, included about 300,000 cubic meters of lumber of Swedish production imported into Norway to be manufactured in the mills and reexported to foreign countries.

The total value of the lumber exports in 1892 was estimated at $\$ 7,461,120$.

The principal markets to which Norwegian lumber was exported in the said year were as follows:

\begin{tabular}{|c|c|c|c|}
\hline \multicolumn{4}{|c|}{ Cabic meters. } \\
\hline & $1,232,123$ & Sweden $\ldots \ldots \ldots \ldots \ldots \ldots$ & \\
\hline ral & 136,096 & Den & 40 \\
\hline .. & 127 & Afr & 56 \\
\hline$\ldots \ldots \ldots \ldots$ & 116 & & 37,487 \\
\hline & 67,332 & Anstralia & 24,659 \\
\hline
\end{tabular}

Though the forests of Norway, having no legal protection, have been carelessly cut down all over the country, it does not seem likely that lumber from the United States will be needed in the near future beyond the small amount now imported chiefly for the shipyards, and valued in 1891 at $\$ 38,056$, and in 1892 at $\$ 15,196$.

\section{KINDS OF LUMBER USED.}

Pine wood is extensively used for house-building, fences, fuel, and lately to a great extent in the manufacture of pulp for paper mills. A 
great exportation of same for foreign paper mills has also lately sprung up.

Fir is a harder and more expensive wood than pine, and is commonly used in ship and house building and for furniture. The shipyards, which have fewer wooden vessels on the docks year after year, still import some foreign woods, such as pitch pine, oak, and teak, chiefly from Russia, the German provinces on the Baltic, and also from the United States.

\section{IMPORTS OF LUMBER.}

The lumber of all kinds imported into Norway in 1892 from foreign countries is given in the official statistical tables as follows:

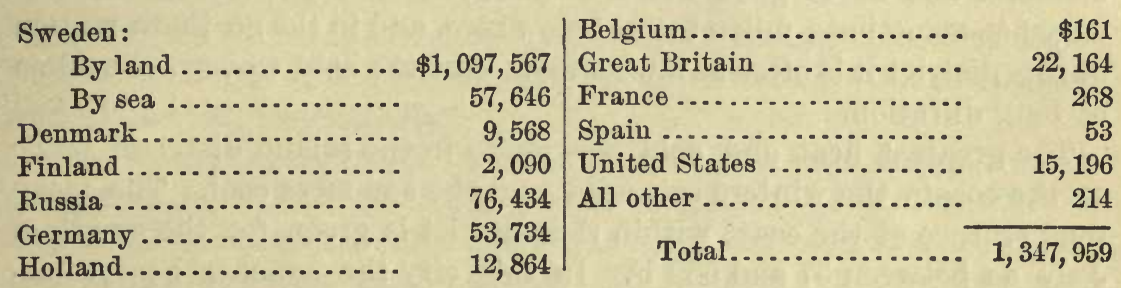

\section{DUTY AND PRICES.}

There is no import duty on lumber in this country, nor has any export duty been levied since July 1, 1893.

The prices quoted in this market for the different kinds of lum. ber exported can not easily be given, but those quoted in the offcial statistics published for 1892 are, as I understand, correct, being based on reliable statements made at the principal exporting places, and prices have not on an average undergone any noteworthy change since then.

Planed lumber, all kinds.

Per cubic meter.

Sawed lumber:

Planks, deals, boards ................................... 4.82

Boards of inferior quality .................................. 3.59

Spars................................................... 3.75

Telegraph poles............................................ 3.62

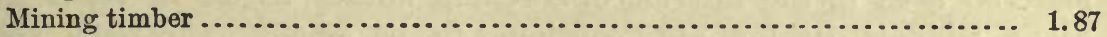

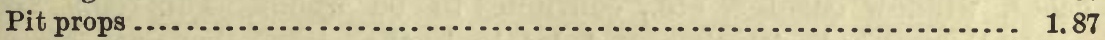

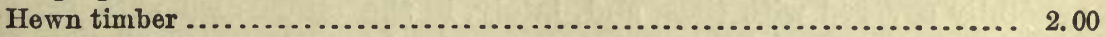

Balk, French poutrelles, and similar ............................... 3.62

So-called Danish lumber .......................................... 2.40

Packing-box shooks ......................................... 4.95

Staves, ordinary, sawed ........................................ 3.48

Staves of birchwood, sawed.................................... 5.89

Logs for the manufacture of cellulose ............................ 1.60

Small wood, cut full, etc......................................... 1.60 


\section{CLIMATE.}

This district lies between the fifty-eighth and the sixty-second and one-half degrees north latitude, and is bounded on the south by the Skager-Rack and sheltered from the sea by numerous small islands scattered along the coast and extending to the Swedish border. On the northeast and west it is surrounded by chains of high mountains, some of which rise to over 8,000 feet. The yearly mean temperature on the coast is between 42 and $44^{\circ} \mathrm{F}$., but declines to $41^{\circ}$ in this city, which is situated at the head of the long Christiania Fjord and has more of an inland climate.

While the winters are generally mild on the coast, where the thermometer has never gone below $5^{\circ}$ above zero, in Christiania the mercury has sometimes fallen to $22^{\circ}$ below zero, and in the northern section of this district it is often as low as $40^{\circ}$. But the cold waves are seldom of long duration.

The greatest heat and cold are found in the inland districts, while on the coasts the winters are mild and the summers cool. The mean temperature of the coast within this district is given for the month of Jnly as between 57 and $63^{\circ} \mathrm{F}$. In this city the summer heat sometimes rises to $90^{\circ} \mathrm{F}$.

The difference noted in atmospheric temperature between the inland district and the coast, also applies to the dampness of the air. The average humidity on the coast is, as a rule, much greater than farther up in the country. Everywhere the greatest humidity prevails during the winter, and the month of May is marked by great dryness. The amount of annual rain at Christiania is only 0.5 meter to 2 meters at Bergen on the western coast, and it falls even to 33 centimeters on the mountains to the north of this district. Heary fogs often occur here in winter. Neither wind nor rain is of great force or duration in this district. Thunderstorms are of rare occurrence in this section of Norway.

\section{GENERAL BUILDING.}

Wood is generally used for housebuilding, owing to its abundance and cheapness, even in cities of some importance. In the principal cities, however, Christiania, Bergen, and Drontheim, there are great restrictions laid on its use and brick houses are now the rule. The material used in the interior of dwelling houses, as for floors, staircases, window casings, etc., continues to be wood. The roofs are generally covered with tiles, and, lately, in the cities also with slate.

Shipbuilding has from time immemorial been one of the principal industries of this conntry, and the interesting copy of the ancient Viking ship of a thousand years ago, which was lately sailed over from Norway to the World's Fair at Chicago, bears witness to the great skill of the old Norse shipbuilders. At the end of 1892 the Norwegian merchant marine numbered 7,506 vessels, of an aggregate 
tonnage of $1,744,993$ tons, manned by 58,631 seamen. The greater part of these vessels were built in Norway, and the addition to homebuilt vessels in 1892 was 105 vessels ( 78 sailing vessels and 27 steamers), with a tonnage of 25,969 tons.

Shipbuilding during the last five years gives the following figures:

\begin{tabular}{|c|c|c|c|c|}
\hline \multirow{2}{*}{ Year. } & \multicolumn{2}{|c|}{ Sailing vessels. } & \multicolumn{2}{|c|}{ Steamers. } \\
\hline & Number. & Tonnage. & Number. & Tonnage. \\
\hline 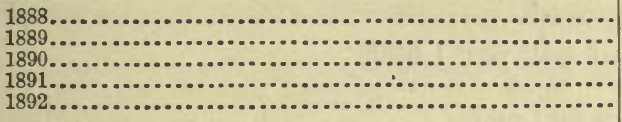 & $\begin{array}{l}37 \\
56 \\
98 \\
93 \\
78\end{array}$ & $\begin{array}{r}9,369 \\
7,096 \\
12,646 \\
17,442 \\
17,148\end{array}$ & $\begin{array}{r}7 \\
20 \\
39 \\
39 \\
27\end{array}$ & $\begin{array}{r}2,038 \\
6,285 \\
12,142 \\
12,028 \\
8,821\end{array}$ \\
\hline
\end{tabular}

In 1892,14 steamers of 9,792 tons, and 110 sailing vessels of 58,352 tons were bought of foreign countries, at an estimated value of $\$ 663,568$ and $\$ 1,120,508$, respectively.

The Norwegian railroads, the greater part of which lie within this district, had, up to June 30,1893 , a total length of 1,562 kilometers, of which 950 kilometers were of narrow gauge (1.067 meters) and 592 kilometers of wide gauge ( 1.435 meters). Their aggregate cost was about $\$ 35,000,000$. Railroad-building is now going on in several districts of southern Norway, and only a few days ago the Storthing voted about $\$ 13,500,000$ for the construction of new lines in different sections of the country.

GerH. GADE,

Consul.

Christiania, March 3, 1894.

\section{PORTUGAL.}

\section{THE AZORES.}

NATIVE WOODS.

Owing to the very limited quantity of lumber imported or consumed there is little to report of interest upon this matter within the Azores. The native woods are scarcely worthy of mention with the exception of the "Faia," a small tree, from which the name of the island "Fayal" is said to be derived. It is this tree which furnishes the firewood of this island. Its grain and its natural color, somewhat resemble the wood of the butternut. As this tree never grows to be much more than a large shrub it is seldom used except for firewood. Some pine is also grown here, but so small in amount and so poor in quality as to be unworthy of consideration. 


\section{KINDS USED AND IMPORTED.}

Northern or white pine and Southern pine are the principal timbers used. The imports amount to about 200,000 feet yearly at Fayal, and probably not more than 500,000 feet to all the Azores-all from the. United States.

\section{DUTY AND PRICES.}

An import duty of about $\$ 11$ per 1,000 feet, varying a little with the dimensions of the lumber, is imposed.

The lumber is retailed at about $\$ 42$ per 1,000 .

\section{CLIMATE.}

The climate is temperate and equable and similar to that of the Bermudas, but with cooler summers. The atmosphere is humid. The range of the thermometer (Fahrenheit) during the summer is generally from $70^{\circ}$ to $76^{\circ}$ or $78^{\circ}$ rarely rising above $80^{\circ}$ or falling below $68^{\circ}$. During the winter its range is generally from $60^{\circ}$ to $64^{\circ}$ or $66^{\circ}$, but during the north winds, which are not prevalent, it frequently falls below this, but rarely as low as $50^{\circ}$, although during the tempestuous weather of the afternoon of the 10th instant, during a slight fall of hail, the thermometer fell for a short time to $45^{\circ}$, but such an occurrence I am told is rare.

\section{GENERAL BUILDING.}

Building operations are very limited. A few boats for fishing and for communication with the adjacent island of Pico, are built here, but rarely any larger boats.

There are no railroads unless the two might be so called that are in use in the construction of the breakwaters that are being built at Fayal and at St. Michaels, which are only a little longer than the length of the breakwater upon which they are used.

The few buildings being constructed are of stone with the smallest possible amount of wood finishings.

LeWIS DeXTer,

Consul.

FAYAL, January 18, 1894.

\section{RUSSIA.}

\section{RIGA.}

NATIVE WOODS.

This is one of the largest lumber exporting districts of Russia, the value of its lumber exports amounting to about $\$ 6,000,000$ per annum. 
The native woods are: White wood of superior quality, being finegrained and mostly free from knots, and redwood (yellow), mostly of an inferior class.

There are no uncommon kinds of wood; very little oak, save in Volhynia, but some birch and alder.

\section{KINDS OF LUMBER USED.}

The white wood is preferred for lumber, the red being used more for sleepers and square timber.

\section{DUTY AND PRICES.}

The import duty is about $\$ 7.50$ per standard of 165 cubic feet.

The prices at present are as follows, per standard: 3 inches by 12 inches and 11 inches, $\$ 35$ per standard; 3 inches by 9 inches and 11 inches, $\$ 32.50$ per standard; 3 inches by 8-7 inches and 11 inches, $\$ 25$ per standard; 1 inch, about 10 per cent dearer.

\section{CLIMATE.}

The climate is somewhat like the Canadian, perhaps a little milder.

\section{GENERAL BUILDING.}

The building of small wooden sailing vessels on this coast is very limited, and only wood of the country is used in their construction.

$$
\text { N. P. A. BORNHOLDT, }
$$

Consul.

RIGA, January 15, 1894.

\section{TURKEY IN EUROPE.}

NATIVE WOODS.

The native woods in this consular district are ash, beech, chestnut, cypress, hickory, lime, maple, oak, pine, poplar, sycamore, and walnut. Of these only the pine (yellow and white), oak, and beech are used for lumber to any considerable extent.

\section{LUMBER USED AND PRICES.}

All lumber is sold in the rough, but that suitable for dressing mostly used is white and yellow pine, with some oak for flooring and naturalwood finish. For frame stuff and rough lumber oak and pitch pine are the most commonly used. The lumber on sale here is sawed quite different from that in the American market. The white pine is sold in joists from 2 to $3 \frac{1}{2}$ inches thick by 8 to 12 inches wide, and of various 
lengths, from 10 to 26 feet. These pieces are resawed by hand with a whipsaw to the desired size for sash, doors, flooring, moldings, and other finishing material. This class of lumber varies in price according to quality and size, the larger pieces being preferred. It is sold by the piece, but the price in square feet measure is from $\$ 16$ to $\$ 19$ per 1,000 feet. The boards used for siding, partitions, and other purposes are pine, both yellow and white, and are sawed about three-eights and three-fourths of an inch thick by 10 to 12 inches wide, and from 10 to 16 feet long. When comparatively elear of knots they sell at $\$ 23.75$ to $\$ 26$ per 1,000 feet, according to length and thickness, but when full of knots and of short lengths sell as low as $\$ 11$ per 1,000 feet. Frame material is generally sold in beams from $4 \frac{1}{2}$ to $12 \frac{1}{2}$ inches square, of various lengths, up to 37 feet. The oak beams, best quality, sell at $\$ 24$ to $\$ 27$ per 1,000 feet. The pine frame lumber is sold in similar sizes and is resawed by hand for rafters, studding, etc., and sells for from $\$ 22$ up to $\$ 28$ for best quality and long pieces. Pine flooring dressed on one side sells at $\$ 28$ to $\$ 32$ per 1,000 feet. The best grade is not entirely clear of knots and the cheapest contains some black knots.

\section{LUMBER IMPORTED AND DUTY.}

The lumber imported is mostly from the Black Sea ports; a small quantity is imported from Sweden, but none from the United States. That from Roumania and Austria is preferred by the carpenters. The latest official figures obtainable on the imports of lumber are as follows:

\begin{tabular}{|c|c|c|}
\hline Year ending March 13- & Pieces. & Value. \\
\hline 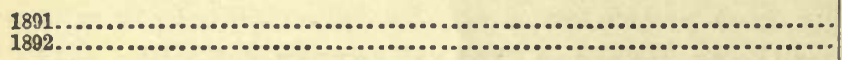 & $\begin{array}{l}4,564,868 \\
8,211,051\end{array}$ & $\$ 1,139,300$ \\
\hline
\end{tabular}

The duty on foreign lumber imported into Turkey is uniformly 8 per cent ad valorem. The Turkish Government charges a tax of 20 per cent ad valorem for cutting timber in the forests of Turkey, and 12 per cent ad valorem duty on lumber when shipped from one province to another. These charges have greatly injured the production of home lumber and the owners of forests are making an effort to get relief, but with no apparent prospects of success.

\section{CLIMATE AND GENERAL BUILDING.}

This part of Turkey has usually a very temperate climate, but, at long intervals, the winters are quite severe.

Owing to numerous disastrous conflagrations, the authorities of Constantinople have prohibited the construction of wooden buildings, but in other parts of the Empire no such prohibition exists, and wooden 
structures are the general rule. There is a reasonable amount of general improvement in Turkey, but very little shipbuilding and but few railroads are being built. The railroads already completed are substituting irou for wooden ties.

\section{TRADE OUTLOOK.}

The prospects are not flattering for the extension of the sale of Amer. ican lumber in this district, owing to prices and want of shipping facilities, yet with a proper effort it might be made successful. Architects with whom I have conversed, are of the opinion that American lumber, owing to its uniformity, thereby saving labor, would be eagerly sought after by the builders if once introduced in this market.

Owing to the prejudice against innovation in the lumber business and the suspicion with which the native dealers look upon all foreigners, together with the peculiar mode of selling by the piece, it has been with the greatest difficulty that I have obtained sufficient reliable information for this report.

LUTHER SHORT, Consul-General.

Constantinople, April 26, 1894.

\section{UNITED KINGDOM.}

\section{BIRMINGHAM.}

\section{NATIVE WOODS.}

The native woods of England are oak, elm, ash, beech, poplar, fir, walnut, chestnut, plane, holly, sycamore, hawthorne, birch, pine, lime, willow, box, larch, maple, cherry, yew, aspen, and hazel.

\section{KINDS OF LUMBER USED.}

Timber is used chiefly in building and fencing, for shipbuilding, wagon and carriage making, and the manufacture of furniture.

In building, oak is used for the better classes of work, such as staircases, window sills, doors, lintels, joists, beams, etc. It was formerly used largely for floors and wainscoting. Elm is used for purposes which are to bear extreme wet and dryness, such as water mills, waterworks pipes, pumps, and coffins. Ash is used for spear handles, carts, wheelbarrows, plows, harrows, axletrees, and oars. Beech is used for many kinds of furniture, such as chairs, stools, and bedsteads. Poplar is used for all sorts of white wooden vessels, and being very light, soles and heels for shoes. Willow is used for basket making. Holly is a very hard white wood with a close grain, and is used for dressing boxes 
and other fancy articles. Walnut is largely used for drawing and dining-room furniture of the better class. The lumber of the fir tree is called deal, and is used largely for flooring, doors, windows, frames, and in ordinary building no other wood is used for this purpose. Boxwood is used for engraving upon, and the turner finds it most useful for mathematical instruments, pegs, screws, tops, chessmen, etc., being very hard and readily taking polish.

\section{IMPORTS OF LUMBER.}

The chief sources of supply are the north of Europe, especially the countries on the Baltic, Norway, Sweden, Russia, Germany, and the British North American Colonies and the United States. Considerable supplies are also drawn from Belgium, Spain, and the West Indies.

Mulhall gives the value of the timber consumed yearly in Europe as $£ 190,250,000$, and in the United States, $£ 77,400,000$. The consumption per head in Europe is 41 cubic feet; in the United States, 58 cubic feet. Timber and gold are, according to the same authority, almost the only articles which have not declined in value in the last decade.

The lumber imported into the United Kingdom from 1889 to 1892 is shown in the following table:

\begin{tabular}{|c|c|c|c|c|}
\hline Kinds. & 1889. & 1890. & 1891. & 1892. \\
\hline $\begin{array}{l}\text { Hewn ............ } \\
\text { Sawn or split .. } \\
\text { Staves .......... }\end{array}$ & $\begin{array}{r}\text { Load8.* } \\
2,393,223 \\
5,319,326 \\
170,086\end{array}$ & $\begin{array}{r}\text { Loads. } \\
2,278,171 \\
4,778,676 \\
156,003\end{array}$ & $\begin{array}{c}\text { Loads. } \\
2,250,692 \\
4,379,060 \\
129,987\end{array}$ & $\begin{array}{l}\text { Loads. } \\
2,469,139 \\
5,090,798 \\
136,063\end{array}$ \\
\hline Total ... & $7,882,635$ & $7,212,850$ & $6,759,739$ & $7,696,000$ \\
\hline
\end{tabular}

- A load equals 50 cubic feet of squared timber.

The total imports from the United States in 1892 were as follows, in loads: Hewn, 165,418; sawn or split, 407,854 ; staves, 22,761 ; total 596,033 .

\section{PRIOES.}

Lumber and timber is sold by the load, the cubic foot, the square foot, the foot run, the ton, the pound or the number of pieces, so that it is difficult to fix a basis, owing to its lack of uniformity.

\section{Climate.}

The climate is temperate and is noted for its sudden changes. There is a good deal of rain and moisture in the atmosphere. The average temperature in winter is about $40^{\circ}$, and in a hot summer as high as $90^{\circ}$ and $92^{\circ}$, and in an ordinary summer about $75^{\circ}$.

\section{GENERAL BUILDING.}

There is no shipbuilding in this district, but there are extensive wagon works such as the Midland Wagon Company, the Birmingham 
Wagon Company. Timber is extensively used in the Black Country here, that is, the district between Wolverhampton and Birmingham, for supporting the roofs of workings in pits.

\section{EXTENSION OF LUMBER TRADE.}

It seems to me from my observation and as the result of inquiries, that more of our lumber might find a market here for use in making furniture if close attention were given to the matter by our manufacturers, but the radical differences in tastes and customs would render necessary a close study of the local conditions here. Most of the wooden utensils used in housekeeping are made in the United States and find a sale here at good prices.

George F. PARKer, Consul.

BIRMINGHAM, January 30, 1894.

\section{DUNDEE.}

\section{NATIVE WOODS.}

The native woods are oak, ash, elm, beech, birch, larch, spruce fir, and silver fir; the first five varieties mentioned being hard woods. Of these oak, ash, and elm are mostly used for agricultural implements, wagons, carts, wheels, and van making purposes, for all of which they are well adapted. Beech is used mostly for wheelwright work, such as cogs for wheels and carpenters' planes, and tools of various kinds; birch is principally used by turners for making bobbins, spools, etc.; larch is used largely for fencing purposes, and also by cartwrights in making shafts, sides, and bottoms of carts, and although not a hard wood, it is considered a very good wood for wear and strength; spruce fir and silver fir are chiefly used for fencing and coal-pit sleepers. None of them are of a lasting quality, and are only used for these and like purposes which are of a temporary nature.

\section{IMPORTS OF LUMBER.}

Most of the wood used in this district comes from the Baltic and neighboring ports, and these are generally known in the trade here as "Baltic woods." Navigation on the Baltic is open only from May to December, so that the full supply has to be imported during this period.

From the ports of Archangel and Cronstadt is shipped a very fine quality of red and white deals and battens, boards, etc., in sizes from 4 by 1 to 11 by 3 ; these are considered the best Baltic woods imported.

Norway sends only a very low quality of red or white deals or bat- 
tens; its forests of good wood having been exhausted, it now draws large supplies from Sweden to keep its mills going.

Sweden sends large quantities of red and white deals and battens, and also baulk timber from 6 to 12 inches square. The Swedish wood ean be had of very fine quality, and it is graded in quality from 1 to 6 , the first four qualities being supposed to be entirely free from rot. The sizes usually sent from there run from 4 by 1 to 12 by 4 , and the Swedish shippers pay more particular attention to the wants of their customers than do any other shippers.

Germany sends red timber, in large quantities, which is rather coarse, but of a healthy nature and strong fiber. Germany, also, ships large quantities of fir for railroad sleepers, which are cut to size before being shipped.

Woods from the United States are now largely superseding some of the former, notably beams and wood for churches, halls, etc., and sawn pitch pine logs which are of very fine quality and cut to dimensions required. American oak, for wagons is also largely imported, as well as all sorts of woods used in the manufacture of hubs, spokes, and felloes. Canary, or American white wood, is growing in favor, and if it could be got in longer lengths - say from 24 to 34 feet or upwardsit would doubtless be used more extensively, as it would then be suitable for ship decks, etc., the short lengths in which it is now being received rendering it unsuitable for these purposes.

It would be hard to say which kinds of lumber are preferred, the use of the various kinds being solely dependent upon the quality and price, keeping in mind the particular purpose for which it is to be used.

Timber was imported into this district during 1893 as follows, in loads of 50 cubic feet:

\begin{tabular}{|c|c|c|c|c|c|c|c|}
\hline Imported into- & $\begin{array}{l}\text { Hewn } \\
\text { timber. }\end{array}$ & $\begin{array}{l}\text { Sawn } \\
\text { timber. }\end{array}$ & Total. & Imported into- & $\underset{\text { timber. }}{\text { Hewn }}$ & $\begin{array}{c}\text { Sawn } \\
\text { timber. }\end{array}$ & Total. \\
\hline \multirow{2}{*}{$\begin{array}{l}\text { Aberdeen............ } \\
\text { Arbroath ............ } \\
\text { Dundee............. } \\
\text { Lerwick ........... } \\
\text { Montrose........ }\end{array}$} & \multirow{2}{*}{$\begin{array}{r}7,314 \\
468 \\
8,530 \\
81 \\
2,532\end{array}$} & \multirow{2}{*}{$\begin{array}{r}41,143 \\
2,873 \\
48,264 \\
473 \\
22,690\end{array}$} & \multirow{2}{*}{$\begin{array}{r}48,457 \\
3,341 \\
56,794 \\
554 \\
25,222\end{array}$} & $\begin{array}{l}\text { Perth............. } \\
\text { Peterhead ......... } \\
\text { Wick............. }\end{array}$ & $\begin{array}{r}1,199 \\
697 \\
532\end{array}$ & $\begin{array}{l}6,073 \\
9,169 \\
2,162\end{array}$ & $\begin{array}{l}7,272 \\
9,866 \\
2,694\end{array}$ \\
\hline & & & & Total ........... & 20,453 & 132,853 & 154,200 \\
\hline
\end{tabular}

No statistics are available showing these imports by countries, but it is estimated that of the 56,794 loads imported into Dundee, 4,500 came from Canada and 5,000 from the United States.

\section{PRICES.}

The prices of lumber vary considerably; during the past ten years there has been a steady increase.

The following tables give the prices of the best qualities imported into this district: 
Russian:

Archangel-

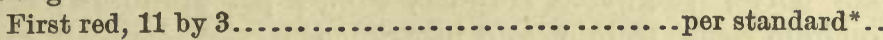

$\$ 68.12$

First red, 9 by 3 .......................................

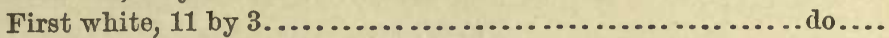

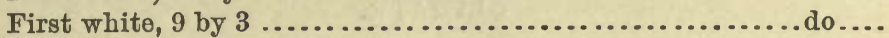

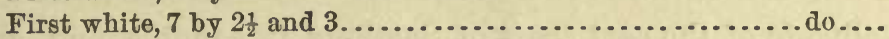

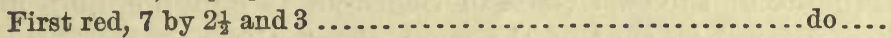

\section{Cronstadt-}

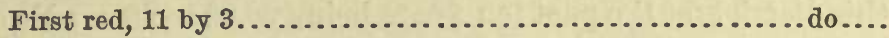

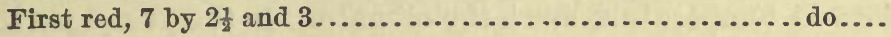

First white, 11 by 9 .................................

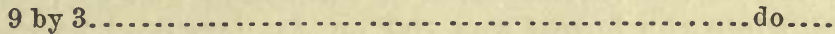

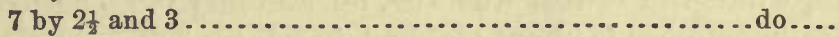

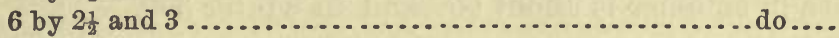

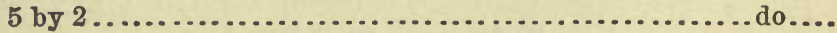

Swedish:

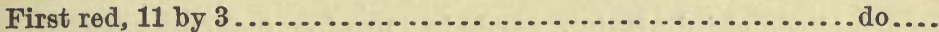

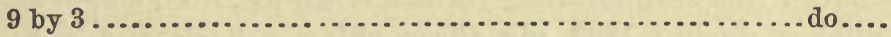

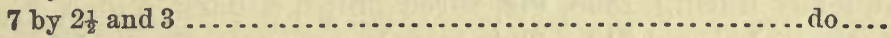

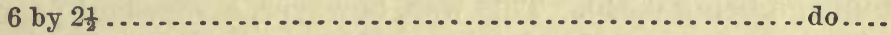

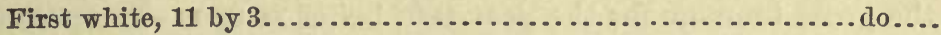

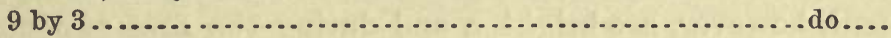

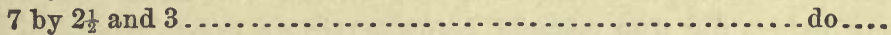

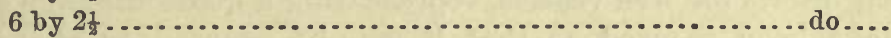

Baulk timber-

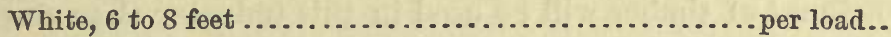

Red, 9 to 12 feet.......................................

Norwegian:

White deals .................................... per standard. .

Battens .................................................

German:

9 by 11 red barlk timber, 29 to 30 feet long................per load..

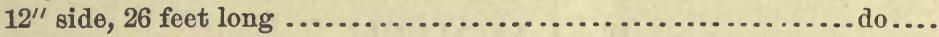

Oak straights, 18 feet average..............................

\section{Canadian:}

Yellow pine, prime logs, $20^{\prime \prime}$ on side ................ string measure..

Prime deals, 14 inches wide........................ per standard..

11.18

14.69

19.46

Elm ................................................. per load..

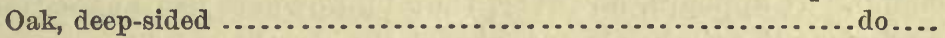
American :

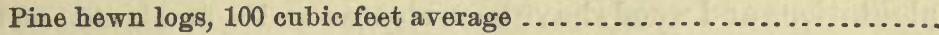

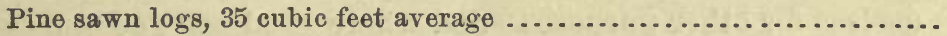

Prime pitch pine lumber, 1 to $1_{\frac{1}{2}}$ inch thick ............ per standard..

Large canary or white wood logs....................... per load..

Walnut (generally badly made) ...............................

The foregoing prices are qualified as follows: Free on board at Archangel, freight to Dundee $\$ 9.73$, per standard; free on board at Cronstadt, freight to Dundee, $\$ 6.27$ per standard; free on board at Swedish ports, freight to Dundee, $\$ 5.84$ per standard; free on board in Norwegian ports, freight to Dundee, $\$ 4.86$ per standard; German

"The standard equals 165 cubic feet; the load, 50 cubic feet. 
lumber prices include costs, freight and insurance; free on board in Canadian ports, freight to Dundee, $\$ 10.94$ per standard; American prices include costs, freight, and insurance.

\section{CLIMATE.}

The climate of the east coast of Scotland is equable, and, generally speaking, drier than that of the west coast, the average annual rainfall in this district for the past ten years being 26.05 inches. No extreme variations in temperature mark the climate. In the year 1893 the highest reading of the thermometer in the shade was $86^{\circ}$, registered on June 18, while the lowest was $19{ }^{\circ}$, on January 6 . The average temperature in summer is about $60^{\circ}$ and in winter $39^{\circ}$.

\section{GENERAL BUILDING.}

There are three shipbuilding yards in Dundee, from which there were five launches during 1893, viz, three ships, a bark, and a barge, the gross tonnage being 6,340. This was, however, a very bad year for the trade, the gross tonnage for the year 1892 being 21,990. The prospects at present, however, are brighter, and during the first two months of this year orders for five vessels, representing a gross tonnage of 6,661 tons, have been secured, so that it may be counted on that a much larger amount of timber will be used in this industry than during the past year.

JOHN M. SAVAGE,

DUNDEE, April 20, 1894.

Consul.

\section{FALMOUTH.}

\section{NATIVE WOODS.}

The supply of native woods, elm and ash, chiefly, is about equal to the demand. It appears, however, that landowners are neglecting to plant as fast as the timber is cut, especially on the duchy properties, where plantations and woods have been cleared and none planted on land that is useless for other purposes-and where good ash and elm can be grown. Others are planting larch fir, which makes rapid growth here. Besides the elm, ash, and fir, oak, beech, chestnut, and poplar grow here.

\section{KINDS OF LUMBER USED.}

The principal kinds of foreign lumber used are red and white fir from Norway and Sweden; yellow, red, and pitch pine, oak, spruce, mahogany, hickory, ash, walnut, birch, and elm from America, and mahogany from Africa. Other woods not so generally used are teak, maple, cedar, lignum-vitæ, rosewood, American whitewood, Oregon pine, kaurio pine, and greenheart. 


\section{IMPORTS AND PRICES OF LUMBER.}

Lumber is imported from Norway, Sweden, Russia, Finland, Africa, Australasia, East and West Indies, and all parts of America.

The current wholesale prices, landed, are as follows:

Quebec:

Yellow pine...............................cubic foot.. $\$ 0.30$ to $\$ 0.60$

Red pine......................................do... . $32 \quad .40$

Oak .............................................do.... .60 .68

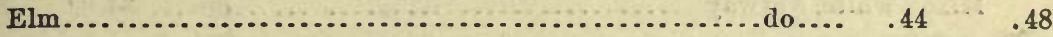

Ash ............................................... .36 .48

Birch ...................................... do... . $32, \quad .42$

St. John....................................... $.28 \quad .36$

Nova Scotia.................................... . $24 \quad .28$

Deals and yellow pine:

First quality ................................. standard.. $97.20 \quad 121.50$

Second quality..................................... $72.90 \quad 80.19$

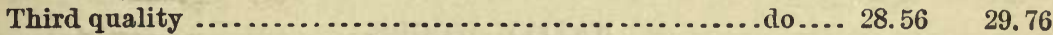

United States:

Pitch pine, hewn ..........................cubic foot.. $.24 \quad .30$

Pitch pine, sawn ..................................... .24 .28

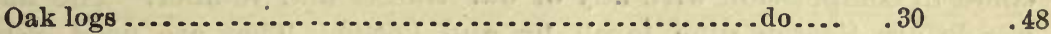

Teak, East Indies .................................load ${ }^{*} . .46 .14 \quad 51.00$

Greenheart.......................................do...29.16 34.02

Mahogany :

San Domingo.............................. foot of 1 inch.. $.09 \quad .14$

Cuba.............................................. .08 .12

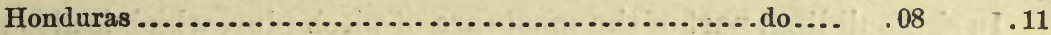

Mexico............................................. .07 .07 13

Cedar, Havana..................................do... 07.09

Walnut:

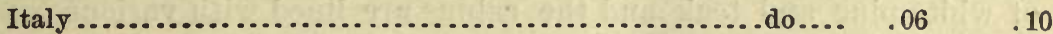

United States ...................................do... .06 .06 10

Maple(bird'seye)................................cubic foot.. $.60 \quad .84$

Rosewood:

Rio de Janeiro .................................ton.. $41.28,53.46$

Bahia............................................ 29.16 43.74

Lignum-vitæ:

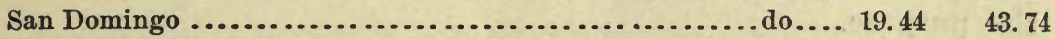

Haiti ......................................do... 14.58 29.16

Timber:

Riga .................................... $.32 \quad .36$

Stettin.......................................... .32 .38

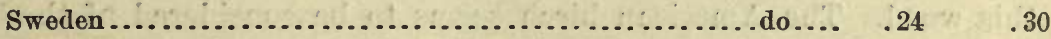

Norway .......................................do...., . $20 \quad .22$

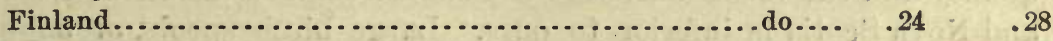

Oak, Dantzic .......................................... .44 .48

Wainscot logs:

Riga............................................... .96 1.02

Memel ........................................do.... .96 1.02

*A load of lumber is usually 50 cubic feet of squared timber; 40 cubic feet of unhewn timber; and 600 superficial feet of inch planking. (See report from Now. castle-upon-Tyne.)

$665 \mathrm{~A} \longrightarrow 13$ 
Deals :

First, Archangel ....................... standard hundred.. $\$ 80.19$

First, St. Petersburg .............................. 65.61

$\$ 87.98$

Second, St. Petershurg ............................. 51.03

75.13

Wyburg ........................................ 41.31

58.30

Gefle............................................ 48.60

46. 17

Gothenburg........................................ 46.17

53.46

Finland ....................................do... 41.31

53.46

48.60

Prepared flooring:

Red, Norway ........................................ 43.74

Mixed white, Norway

do.... 34.62

46. 17

36.45

Falmouth, February 26, 1894.

HoWARD Fox.

\section{GLASGOW.}

NATIVE WOODS.

The native woods of Scotland cut but little figure, as they do not come in competition with any of our timber and lumber: The native woods are Scotch pine, larch, fir, and beech. They are used only in limited quantities for cheap articles; the timber is short, small, and knotty.

\section{KINDS OF LUMBER USED.}

In shipbuilding, part of the masts are of pitch pine, which is also used for flooring of decks, and for ceiling and sheathing. Elm is sometimes used for ceiling and sheathing. The deck houses are generally built of white pine and teak and the cabins are lined with various woods, teak, principally, in my observation. As nearly, if not all, the ships built on the Clyde are now made of iron, the consumption of lumber and timber in shipbuilding has materially decreased, compared with the time of wood shipbuilding. Oak is used extensively in the building of railway carriages; 80 per cent of the oak imported is used for this purpose.

White birch is preferred for spool wood by the thread manufacturers. This comes mostly from Maine, and since I have been in charge of this consulate every American vessel reporting to me has been loaded with this wood. The American birch seems to be considered of the best quality and the most marketable. The birch from Sweden, Norway, and Nova Scotia is inferior to ours. Large birch spools, or bobbins, manufactured in Sweden and Norway are used here. These might be displaced by the same size of manufactured spools from our birch. The thread-makers generally prefer to buy their spools ready-made and direct from the manufacturers. Some sycamore, or plane, and ash are also used in the manufacture of spools. 
All the houses here are built of stone, and wood is only used in the interior, pine, principally. Oak and maple are used in public and expensive private buildings; hickory is used only in mechanical appliances and golf sticks. White wood or poplar is used for cabinetwork; the only superior wood which displaces it is red cedar, which is more expensive. The pine most sought after comes from the western coast of the United States, and is called here Oregon pine.

\section{IMPORTS OF LUMBER.}

I have had some difficulty in getting certain information upon this subject. The collector of customs here could not give it, unless he made a special compilation. I find, however, in a return to the House of Commons of trade and navigation, the quantity of lumber and timber, and value of the same, imported into the United Kingdom for the eleven months ending November 30, 1893, which I here give:

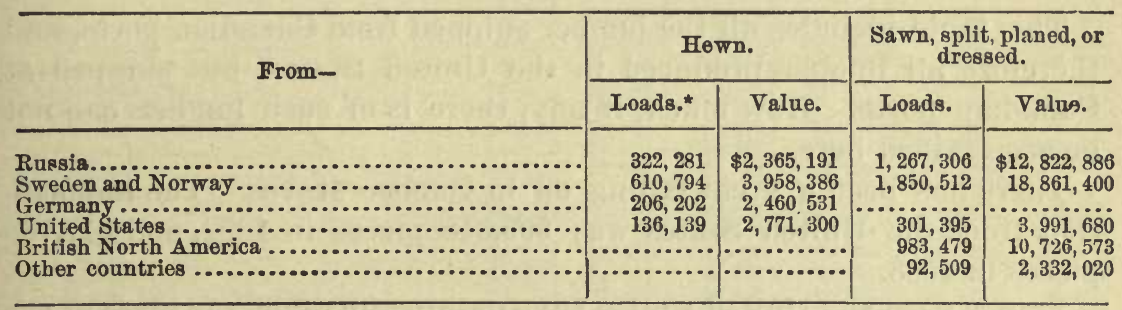

* A load equals 50 oubic feet of squared timber; 40 cubic feet of unhewn timber; 600 superficial feet of inch planking.

The following statement shows the amount and value of hewn wood and timber imported during the first eleven months of the years given:

\begin{tabular}{|c|c|c|}
\hline Year. & Loads. & Valne. \\
\hline 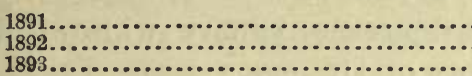 & $\begin{array}{l}295,290 \\
393,780 \\
301,395\end{array}$ & $\begin{array}{r}\$ 4,009,038 \\
5,308,426 \\
3,991,683\end{array}$ \\
\hline
\end{tabular}

Our principal competitors in hewn timber are Sweden and Norway, Russia, Germany, and British North America, in the order named; and in manufactured lumber, Sweden and Norway, Russia and British North America, in the order named.

It will be noticed that 1893 falls below both 1891 and 1892, perceptibly 1892, in value of the imports from the United States.

The timber and lumber from Russia is principally white and red fir. It is used for flooring ceiling, and sheathing, and is considered inferior to American pine.

The timber from Germany is mostly fir also, but none of it comes to the west coast of Scotland.

The timber and lumber from Sweden and Norway are also fir, of much the same character and quality as that from Russia. 
As far as this part of Scotland is concerned, our chief competitor is British North America. The supply from Canada and the British possesions consists of yellow and red pine, oak, elm, ash, and birch. It is shijped in the log, and also in deals, battens, and boards.

I find from the published statements of some of the principal lumber-dealers that the import of lumber into the Clyde from British North America for the following years was as follows:

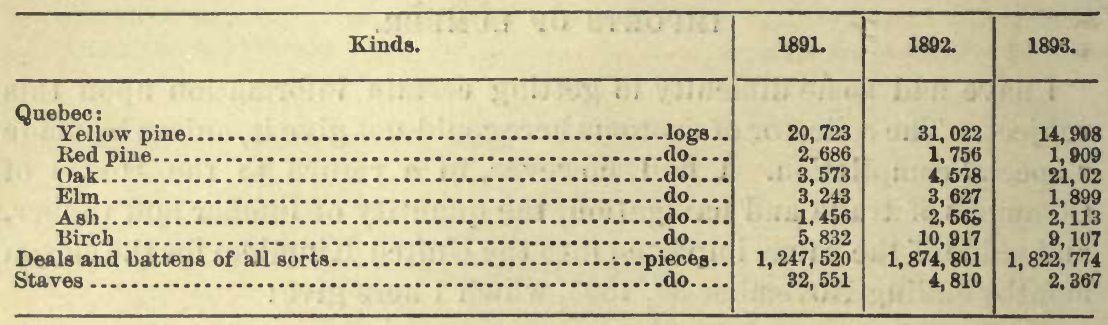

This table includes all the lumber shipped from Canadian ports, and therefore all lumber produced in the United States, but shipped at Canadian ports. How mich, if any, there is of such lumber can not be ascertained here.

There has been a great falling off in Quebec staves. The importation from the United States was 999,348 pieces in 1892 , and 817,785 pieces in 1893.

Staves from the United States have practically taken the place of the Quebec article. Large quantites of staves are, however, brought into the Clyde coastwise of which no account is kept.

The imports into the Clyde in 1893, as compared with 1892 , show the following percentagedecrease: Wany and square yellow pinelogs, 50 ; oak $\operatorname{logs}, 50$, although the imports from the United States show an increase; elm and birch, 15 each; sawn pitch pine, 25; ash, which comes mostly from the United States, shows a slight decrease; canary whitewood and poplar, 1,059 logs in 1893, a decrease of 118 logs.

Walnut, which comes entirely from the United States, shows an increase of 33 per cent over 1892, but the wood was of au inferior quality. Maple, which was almost entirely from the United States, shows 330 logs for 1893, an increase of 26 logs.

The imports of pitch pine for the last three years were as follows:

\begin{tabular}{|c|c|c|c|}
\hline Year. & $\begin{array}{l}\text { Hewn } \\
\text { logs. }\end{array}$ & $\begin{array}{l}\text { Sawn } \\
\text { logs. }\end{array}$ & $\begin{array}{l}\text { Pieces } \\
\text { deals. }\end{array}$ \\
\hline $\begin{array}{c}1891 \\
1892 \\
1893\end{array}$ & $\begin{array}{l}2,390 \\
2,457 \\
1,909\end{array}$ & $\begin{array}{l}38,310 \\
77,518 \\
56,717\end{array}$ & $\begin{array}{l}60,635 \\
57,920 \\
23,956\end{array}$ \\
\hline
\end{tabular}

It has been impossible to get any figures as to the quantity of lumber imported from the United States into the Clyde, except in the fow instances which I have given, but no doubt the import in 1893 was 
smaller than that of 1892. The following table shows the stocks of timber on hand in the Clyde ports for several years.

Comparative statement of stocks of timber, etc., on hand in the Clyde ports, from Greenock to Glasgow, inclusive, from 1889 to 1893.

\begin{tabular}{|c|c|c|c|c|c|}
\hline$:$ & 1889. & 1890. & 1891. & 1892. & 1893. \\
\hline \multicolumn{6}{|l|}{ Quebec: } \\
\hline Wany board wood & 658,043 & 692,691 & 585,107 & 853,265 & 674,957 \\
\hline $\begin{array}{l}\text { Square yellow pine } \\
\text { Red pine........... }\end{array}$ & $\begin{array}{l}783,569 \\
186,409\end{array}$ & $\begin{array}{l}452,673 \\
133 ; 249\end{array}$ & $\begin{array}{r}263,679 \\
88,286\end{array}$ & $\begin{array}{r}496,067 \\
52,153\end{array}$ & $\begin{array}{r}351,171 \\
77,751\end{array}$ \\
\hline Oak logs ... & 378,836 & 289,658 & 217,087 & 284,326 & 242,252 \\
\hline Elm ....... & 123,776 & 78,130 & 87,231 & 124,638 & 67,350 \\
\hline $\mathrm{Ash} \ldots \ldots \ldots$ & 92,658 & 24,362 & 26,912 & 28,724 & 40,585 \\
\hline $\begin{array}{l}\text { Hickory ..... } \\
\text { Maple...... }\end{array}$ & 1,632 & 15845 & $\begin{array}{r}8,366 \\
13,676\end{array}$ & $\begin{array}{r}4,857 \\
15\end{array}$ & $\begin{array}{r}5,629 \\
15,485\end{array}$ \\
\hline Pine deals: & 10,170 & & & & \\
\hline First quality. & 468,803 & 163,486 & 155,320 & 293,571 & 311,417 \\
\hline Second quality & 160,560 & 89,646 & 27,992 & 104 & 109,417 \\
\hline Third quality. & 411,878 & 182,972 & 197,691 & 212,334 & 457,285 \\
\hline Fourth quality. & 421,028 & 449,105 & 226,937 & 267,329 & 139,183 \\
\hline Spruce deals & 171,075 & 423,239 & 35,961 & 313,849 & 188,103 \\
\hline \multicolumn{6}{|l|}{ St. John and lower p } \\
\hline Spruce deals ... & 230,307 & 151,045 & 249,026 & 177 & 328,677 \\
\hline Pine deals & 204,693 & 121,897 & 251,893 & 173,572 & 135,324 \\
\hline Birch logs & 73,225 & 83,752 & 46,900 & 106,748 & 85,166 \\
\hline Walnut $\log s . .$. & 22,165 & 1,789 & 37,686 & 18,503 & 32,085 \\
\hline Whitewood logs & 7,701 & 130 & 30,004 & 10,271 & 11,660 \\
\hline Greenheart ... & 19,745 & 2,302 & 16,637 & 62,302 & 78,041 \\
\hline Teak logs ..... & 769,803 & 822,447 & 492,601 & 711,722 & 564,516 \\
\hline \multicolumn{5}{|l|}{ Pitch pine: } & 38,001 \\
\hline Hewn & 275,867 & 440,001 & 228,167 & 294 & 189,771 \\
\hline Sawn . & 964,722 & 858,691 & 272,126 & 911,400 & 739,545 \\
\hline Planks.. & 15,794 & 26,006 & 15,297 & 74,121 & 17,380 \\
\hline Oak planks .......... & 64,731 & 29,501 & 25,134 & 83,262 & 33,437 \\
\hline Kauri pine, $\log s$ and planks. & 17,651 & 174,999 & 141,653 & 90,315 . & 93,923 \\
\hline $\begin{array}{l}\text { Mahogany ......... } \\
\text { Staves: }\end{array}$ & & 534 & 380 & 480 & \\
\hline $\begin{array}{l}\text { Staves: } \\
\text { Pipe............... }\end{array}$ & \multicolumn{5}{|c|}{ Staves: } \\
\hline Puncheon ............................ & 43 & 47 & 4 & 37 & 18 \\
\hline 200 & & & & & \\
\hline
\end{tabular}

Wany board wood:

\section{PRICES.}

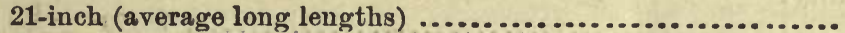

20-inch (average long lengths)

Per cubic foot. $\$ 0.62$

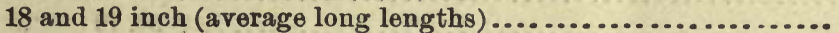

$\$ 0.58$ to .60 $.56 \quad .58$

Short timber:

Prime, 20 and 21 inch, average.........................

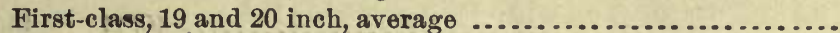

Second quality, 18 to 20 inch, average ......................

White pine:

Prime deck planks, 50 to 55 feet, average..................

Good, fair average, 35 to 50 feet, average ....................

Fair average, 35 to 45 feet, average........................

Square board wood, 35 to 40 feet, average ...................

Red pine, 40 feet, average

$.56 \quad .58$

$.51 \quad .54$

$.28 \quad .36$

$.48 \quad .52$

$.30 \quad .36$

$.23 \quad .27$

$.34 \quad .36$

$.36 \quad .39$

Oak:

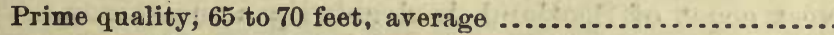

Second quality, 65 to 70 feet, average......................

Plank .............................................

Elm, 45 to 60 feet, average .................................

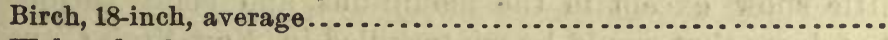

Walnnt lumber .........................................

Logs, 21-inch, average, prime 
Ash :

Per cuble foot.

14 to 15 inch, average $\$ 0.42$ to $\$ 10.48$

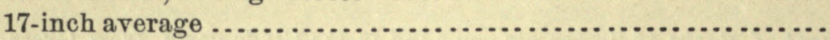

Canary, whitewood, or poplar, 14 to 15 inches ...................

Maple

Pitch pine:

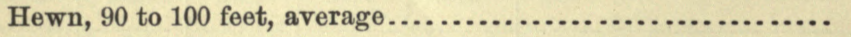

Poor quality, 65 to 70 feet, average.......................

Sawn:

40 feet, average ..................................

35 feet, average ......................................

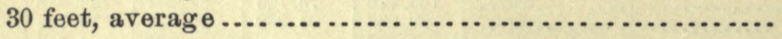

Deals............................................

Staves:

Heavy hogshead, 1 inch, average .......................

Prime hogshead, 1 inch, average.......................

Barrel, 1 inch, average...............................

$4 \frac{1}{2}$ feet pipe, 1 inch average, (good quality) .................

$.26 \quad .30$

$.21 \quad .24$

.25

.24

$18-2$

Per 1,200 pieces.

$\$ 126.52$

109. 49

65. 69

180.00

Deals, first quality :

* St. Petersburg standard.

Broad $\$ 97.00$ to $\$ 134.00$

11-inch

$97.00 \quad 117.00$

Nondimensions .

53.00

68.00

Ends

80.29

94.58

Deals, second quality :

Broad ................................................ 80.29

88.80

11-inch

73.59

80.29

Nondimensions .

53.53

68. 13

Ends

50.18

56.73

Deals, third quality :

11-inch

45.00

48.69

Nondimensions

31.62

40.14

Ends

34.00

40.14

Deals, fourth quality :

Broad

36. 79

40.14

11-inch

33.44

36. 79

30.10

32. 84

Ends

26. 76

30. 10

Red-pine deals:

Fine.

40.14

45.00

Ordinary

30.10

40.14

Spruce deals :

Regulars

30.10

36. 79

Nondimensions

26. 76

33.44

\section{CLIMATE.}

Glasgow is situated as to latitude in $56^{\circ}$ north. The climate of this city and the west coast of Scotland is decidedly a moist one. The rainfall is large, and a week without rain or Scotch mist is an excep. tion. It is cooler in summer and warmer in winter than New York. There is but little snow except in the mountains, and many shrubs thrive here out of doors that would be winterkilled in New York City. 
There is a great deal of fog both in summer and winter, and a perceptible dampness most of the time.

\section{GENERAL BUILDING.}

General building of stores and dwellings for the last year has been up to the average. The city is growing rapidly, and many new buildings are in process of erection.

One of the great industries of Glasgow and vicinity is shipbuilding. This industry has been depressed for the last few years, and for the last year the depression has increased. It is stated by a careful compiler that the outlook for building on the Clyde is about the same for 1894 as it was in the beginning of the season for 1893 .

With the contracts lately secured and the vessels now on the stocks the tonnage on hand is estimated at 188,000 , compared with 208,000 January 1, 1893, 274,000 January 1, 1892, 297,000 January 1, 1891, and 322,000 January 1, 1890.

There is some railway building going on in western Scotland. An extensive subway for tram cars has been in process of construction under Glasgow for the past two years. The cars will probably be propelled by a stationary motor.

The Caledonian Railway is also building a branch about 20 miles in length, a portion of it running underground beneath this city. A railroad is also under process of construction into the western Highlands from Helensburg, opposite Greenock, to Fort William, about 75 miles in length.

\section{EXTENSION OF LUMBER TRADE.}

There is complaint made generally by lumber importers here that exporters from America-the exporters of British possessions as well as the United States-do not send lumber of the quality promised before shipment or up to the standard upon which advances to shippers are made. All shipments should be fully up to the samples shown or promises made as to the quality.

Importers here are afraid to deal with new men or to enlarge their orders beyond old and tried firms with whom they have had dealings and whose honesty they have proved.

American lumber has no serious competitor except some kauri pine from New Zealand, and that not in large quantities, but of very superior quality, so the contest for the Clyde markets lies in reality between British North America and the United States. It may be that the former has a larger supply of first-class pine from which to send its product abroad; and it has also another advantage in that its people are of the same nation as Scotland, for Canada is largely peopled by Scotchmen. A third advantage to Canada is our want of American bottoms in which to convey our lumber. 
Still, as far as spool wood, staves, and white pine are concerned, the preference among dealers here is for the timber of the United States, and in oak, maple, ash, and whitewood we now have the lead.

If our dealers will make renewed efforts to enlarge their trade with the western coast of Scotland and will always send a quality of lumber up to the standard of the orders given, I think our trade can be materially increased and very speedily.

Depending upon America for her principal lumber depot from which to draw supplies, Scotland furnishes an inviting field for the enterprise of our lumber exporters, and I am satisfied that, with the proper energy and with honorable dealing, our people ought to hold their own, at least, with Canada in the lumber markets here.

\section{ACKNOWLEDGMENTS.}

I am much indebted in the preparation of this report as to prices of lumber and stocks on hand, as well as other items in relation to the lumber trade, to Messrs. Edmiston and Mitchells and Allison Cousland \& Co., lumber importers of Glasgow.

ALLEN B. MORSE,

GLASGOW, January 18, 1894.

Consul.

\section{HULL.}

\section{NATIVE WOODS.}

The district within my official observation is not a wooded country, and yields but little timber. The land for the most part, especially in the Holderness division of Yorkshire, lies very low, and is not very favorable to the growth of timber. In and around Hull there is much humidity in the atmosphere, and the whole district is much exposed to the northeast winds.

With regard to native woods, the only timber that seriously com. petes with America is the English oak, which is considered to be of a hardness and durability superior to any other, unless it be the American live oak, which, however, is never seen here except as a sample.

\section{KIND OF LUMBER USED.}

The kind of lumber from the United States which is most in use in England is pitch pine. It is extremely resinous and hard. It is used for piles and in building, but not to any great extent. Pitch pine, although more durable without creosote than Baltic wood, does not take creosote so well. This is attributable to the quantity of resin in pitch pine, which has what local experts call "more nature in it" than Baltic timber. 
American oak is largely used in the construction of railway carriages, and is chiefly cut into scantlings.

Oregon timber is chiefly fir. It is very large and, in the opinion of local timber merchants, has valuable properties, but they say it is too expensive for general use in consequence of the high freight.

Fancy woods from the United States, such as birch and walnut, are largely used, and there is nothing in England to compete with them.

Canadian yellow-pine timber and deals are largely consumed, but not to the extent of former years. Baltic woods are being greatly substituted for them by reason of their nearness and hardness, and the increased cost during late years of the Canadian pine. Canadian birch, walnut, elm, and oak are used to a considerable extent.

The substitution of iron for wood in shipbuilding has interfered very much with the use of North American shipbuilding woods. This, however, applies almost altogether to Canada, inasmuch as the quantity of American wood for shipbuilding purposes is very small, so small that the leading timber merchant in Hull spoke of it as scarcely worth mentioning.

The use of pitch pine has now become so general that the trade in balk timber with the Baltic has shrunk into comparatively small compass. The import of pitch pine is entirely from the United States, and, as it is now used in building and for a variety of purposes, there is every likelihood of an increased consumption.

\section{IMPORTS OF LUMBER.}

The import from the United States is very much larger than formerly, and continually increasing, whilst from Canada it is not so large as it used to be. This latter fact is accounted for by the use of Baltic woods in place of the more expensive Canadian woods. The forests in the northern districts of Canada, which consist almost entirely of pine timber, have been so much thinned that timber has become more valuable as standing trees.

The Baltic, the White Sea, Canada, and the United States are the great sources of supply for the timber market in Hull and the district. The United States are holding their own, displacing the Baltic timber, and the Quebec red pine, which has almost ceased to come. The latter of all other woods is most like the pitch pine.

The woods most commonly used in this district by English timber merchants are ash, oak, and elm. As before stated, in East Yorkshire the country has been almost cleared of wood, and the same remark would apply to North Yorkshire. The chief imports are from the Baltic, and consist of red and white wood. These woods are generally used for building purposes all over England. The imports of American pine and spruce are much larger on the west coast than on the east coast-the latter being small in comparison. As far as pine is concerned, its qualities and uses have been already indicated. Spruce is 
imported on the west coast principally because of the great industries, such as the cotton and woolen industries, which require packing cases, etc. On the east coast the country is mainly agricultural and the oonsumption of timber is chiefly for building purposes, for which the Baltic woods are preferred. The latter are cheaper and said to be more suitable. The Baltic woods come in longer lengths, and for building purposes are considered to be more durable than either pine or spruce. The oak most used is from Sweden and Odessa.

Formerly a quantity of lathwood used to be imported from Quebec and St. John's into Hull, Liverpool, and Bristol, but of late years little or none has come. The only reason given for this is that the Riga and St. Petersburg lathwood is considered to be better.

According to one authority there is very little hard wood used in Hull. In yellow-pine deals the trade is likely to decrease in the local market for the reason that the prices are being considerably advanced on account of the increased consumption in the United States, hence there is a demand for pine deals from Sweden. Pitch pine finds an increasing consumption and is likely to further increase, according to the authority just alluded to, because it is so cheap.

The Hull Chamber of Commerce gives the total imports of timber during the last ten years, as follows:

\begin{tabular}{|c|c|c|c|c|c|c|c|}
\hline Year. & $\begin{array}{l}\text { Hewn } \\
\text { timber. }\end{array}$ & $\begin{array}{l}\text { Deals, } \\
\text { battens, } \\
\text { etc. }\end{array}$ & Staves. & Year. & $\begin{array}{c}\text { Hewn } \\
\text { timber. }\end{array}$ & $\begin{array}{c}\text { Deals, } \\
\text { battens, } \\
\text { otc. }\end{array}$ & Staves. \\
\hline $\begin{array}{l}1884 \ldots \ldots \ldots \ldots \\
1885 . \ldots \ldots \ldots \ldots \\
1886 \ldots \ldots \ldots \ldots \\
1887 \ldots \ldots \ldots \ldots\end{array}$ & $\begin{array}{r}\text { Load } \delta_{. *}^{*} \\
92,087 \\
93,235 \\
101,912 \\
119,565 \\
124,045\end{array}$ & $\begin{array}{l}\text { Loads. } \\
320,815 \\
367,447 \\
325,432 \\
351,892 \\
388,321\end{array}$ & $\begin{array}{r}\text { Loads. } \\
1,319 \\
1,879 \\
3,221 \\
5,696 \\
2,557\end{array}$ & $\begin{array}{l}1889 \ldots \ldots \ldots \\
1890 \ldots \ldots \\
1891 \ldots \ldots \\
1892 \ldots \ldots \\
1893 \ldots \ldots\end{array}$ & $\begin{array}{l}\text { Loads. } \\
159,863 \\
162,681 \\
165,107 \\
174,045 \\
107,862\end{array}$ & $\begin{array}{l}\text { Loads. } \\
452,650 \\
383,135 \\
371,607 \\
412,269 \\
407,758\end{array}$ & $\begin{array}{r}\text { Loads. } \\
3,312 \\
1,595 \\
1,395 \\
1,605 \\
3,680\end{array}$ \\
\hline
\end{tabular}

*A load equals 50 cnbic feet of square timber; 40 cubic feet of unhewn timber; 600 superficial feet of wide planking.

The imports of deals and timber have shown a marked and steady increase except in the year 1893, when, from several unfavorable conditions, the trade received a severe check. No sooner had the Baltic trade opened tuan the dockers, timber men, and deal carriers struck work at the instance of the Dockers' Union. This strike (a report upon which I transmitted to the Department of State*) lasted some seven weeks, during which time a large proportion of the seamen refused to sign on. The dockers' strike was followed by an extensive strike among the coal miners, which paralyzed once more the whole trade of the Humber ports. The timber trade suffered in common with all the other trades of the port with the result that there was, during the year, a total reduction of 66,000 loads of hewn timber as compared with 1892 , and sawed timber deals, etc., fell very considerably from the same causes. There is, notwithstanding, every reason to believe that the import trade will completely recover in 1894 . 
GENERAL BUILDING.

Concerning building operations in Hull and the consequent consumption of wood used in this connection, it would appear that, taking an average, there are 800 houses built per annum. In the construction of these Baltic timber is used. An increase of domestic buildings is not anticipated, that is to say, to any extraordinary extent. The town council has formulated a new and more stringent code of building regulations, which will tend to check speculative building and increase the cost of construction. Wooden buildings are likely to become fewer and fewer under the new regulations. Moreover, wood paving, which has been largely used in the streets, now appears to be discouraged by the municipal government, and seemingly there will not be much extension in this direction.

Since the construction of the Hull and Barnsley Railway, which was opened in 1884 or 1885 , there has been no railway enterprise of any moment, nor is there any probability of new undertakings or extensions for some time to come. The acquisition of the dock estate by the Northeastern Railway will result in the immediate renovation of much plant, which must involve considerable orders for wood. At the same time, with regard to warehouses on the estate, there is ample accommodation for present requirements.

In shipbuilding, wood becomes less and less in demand. Iron is almost wholly used except as regards fittings. The fishing fleet of the port, which aggregates over 400 vessels of different sizes, consists almost entirely of steam trawlers constructed of iron. The result is that very few wooden craft are built. Even the small river and dock vessels, called lighters and keels, are being built of iron. The tendency is wholly in the direction of iron and steel for shipbuilding purposes.

Having regard to the distance of the American ports, the difference in the rates of freight, and the fact that in the lumber trade with the north of Europe steamers are becoming increasingly employed, it is difficult to suggest any means of stimulating the development of imports from the United States. It is purely a question of competition which can only be determined by the prices which may rule for the time being. As before mentioned, there will in all probability be a demand and preference for the fancy woods from the United States.

\section{EXTENSION OF LUMBER TRADE.}

The two great staple trades of Hull are the seed-crushing and timber trades, and the port has hitherto enjoyed preeminence in both, so far as the northeast coast of England is concerned. Hartlepool has for some years been a keen rival, and Hull merchants have been much aggrieved by the preferential charges of the Northeastern Railway Company in favor of Hartlepool. This company, however, has acquired by purchase the docks owned by the Hull Dock Company, so that the 
whole of the water acreage of the port is vested in the railway proprie. tors, with the exception of the Alexandria dock, which is the property of the Hull and Barnsley Railway Company. Under the altered cir. cumstances, and seeing that the Northeastern Company has now such a vast interest in Hull, it is anticipated that, so far as local facilities for developing the timber trade go, the dock and railway owners will do all they can to promote an industry which forms such a great and integral part of the commercial life of Hull. On the score, therefore, of dock accommodation, shipping facilities, and railway charges it may be taken as a fact that there is no prospective discouragement of the timber trade. It is thought by some authorities, and those of the very highest standing, that the Manchester ship canal will eventually rob Hull of no inconsiderable share of its timber trade with the West Riding of Yorkshire and the midland counties. The diversion of traffic would affect in a corresponding measure the Humber ports, Grimsby and Goole, although the latter port is not a great timber-importing place. It is, however, impossible at present to say with any degree of confidence what influence the canal may have upon the timber trade. Much, of course, will depend upon the action of the local railway companies, and the purchase of the Hull docks would suggest that the Northeastern, which is a very powerful company, will adapt itself to the altering needs of the port.

BYRON G. DANIELS, Consul.

HULL, January 23, 1894.

\section{LEEDS.}

NATIVE WOODS AND KINDS OF LUMBER USED.

The native woods are ash, elm, poplar, larch, beech, sycamore, and oak.

The kinds of foreign lumber preferred, are Baltic red and white wood, and Canadian pine and oak.

\section{IMPORTS $\triangle$ ND PRICES.}

I can not give any estimate of the imports into this district. Large quantities come from Russia, Finland, Sweden, and Canada.

Woods are sold by the standard, which is 165 cubic feet, sawed into planks. Baltic white wood will vary from $\$ 30$ to $\$ 50$ per standard, according to size and quality; red wood, from $\$ 37.50$ to $\$ 82.50$, according to size and quality; and Canadian pine, from $\$ 45$ to $\$ 125$. Quebec oak, about 75 cents per cubic foot in the log; pine, about 50 to 60 cents per cubic foot in the log. Baltic lumber is principally sawed. 


\section{GENERAL BUILDING.}

There is only the ordinary building usual in an English city, all of orick or stone. Wood is used only for interiors; hence much less lumber is required than in countries where wooden or frame houses are com. non. In general building Baltic wood is mostly used and a great deal of the very cheapest of it in the poorer houses. There is no railroadbuilding going on in this district, and, as this is an interior point, of sourse no shipbuilding, though there are a few canal boats built here.

\section{EXTENSION OF LUMBER TRADE.}

I should say the best way to increase trade with the United States would be for the mill owners and lumber dealers to send a full line of samples with the lowest prices to the lumber merchants of this counbry. There is an impression here that the American oaks are not of first-class quality, and very little is known of the long-leaf or yellow pine of the southern part of the United States, the Norway pitch pine being in common use and near at hand to the ports on the east coast of England and Scotland, through which ports it is distributed to all interior points.

\section{NORFLEET HARRIS,}

Consul.

LEEDS, March 7, 1894.

\section{LIVERPOOL.}

NATIVE WOODS.

The native woods used in this district are very numerous, but very few come into competition with woods from other countries. The chief native woods are oak, ash, sycamore, elm, birch, hickory, and fir.

\section{KINDS OF LUMOBER USED.}

The most extensively used are oak and fir, and they are also the most valuable woods; the former are used for railway carriages, building, etc.

\section{IMPORTS OF LUMBER.}

The following table, calculated at the end of the import seasons of 1891,1892 , and 1893, shows the quantities and descriptions of lumber imported at this port during the years named, and the countries from which imported, but do not include furniture woods: 
TIMBER, DEALS, ETC.

\begin{tabular}{|c|c|c|c|}
\hline Kinds and countries. & 1891. & 1892. & 1893. \\
\hline \multicolumn{4}{|l|}{ United States: } \\
\hline Oak......... & & 273,947 & 374,441 \\
\hline Oak planks ...... & $1,768,000$ & $1,265,000$ & $1,276,000$ \\
\hline ..............staubic feet.. & 2,506 & $\begin{array}{r}3,168 \\
4,090\end{array}$ & $\begin{array}{r}3,182 \\
3,002\end{array}$ \\
\hline Pregon pine (logs and planks) ....................... pieces... & $\begin{array}{r}3,885,000 \\
82,000\end{array}$ & $4,920,100$ & $\begin{array}{l}3,092,000 \\
114,000\end{array}$ \\
\hline Californian redwood... & & 150,000 & 183,000 \\
\hline ....................... & 238,000 & 300,000 & 311,000 \\
\hline \multicolumn{4}{|l|}{$\begin{array}{l}\text { British North America: } \\
\text { Quebeo- }\end{array}$} \\
\hline Yellow pine.... & 857,000 & $1,142,000$ & $1,173,000$ \\
\hline Wany board. & 73,000 & 15,000 & 4,000 \\
\hline $\begin{array}{l}\text { Oak............ } \\
\text { Elm......... }\end{array}$ & 128,000 & $\begin{array}{l}223,074 \\
110,000\end{array}$ & $\begin{array}{r}286,940 \\
94,000\end{array}$ \\
\hline ................ & $\begin{array}{r}128,000 \\
21,000\end{array}$ & $\begin{array}{r}110,000 \\
27,000\end{array}$ & $\begin{array}{l}94,000 \\
53,000\end{array}$ \\
\hline Deals, pine, spruce & 27,767 & 32,005 & 28,577 \\
\hline New Brumswick and United States spruce deals........ dlo.... & 54,160 & 61,445 & 69,031 \\
\hline Birch logs and planks.......... & 657,000 & $1,085,000$ & $1,003,000$ \\
\hline $\begin{array}{l}\text { St. John pine .. } \\
\text { Other parts- }\end{array}$ & 73,000 & 15,000 & 4,000 \\
\hline Pino ....... & 4,000 & 25,000 & 1,000 \\
\hline 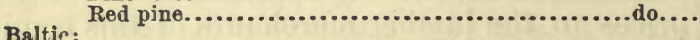 & \multicolumn{3}{|c|}{ (2) } \\
\hline Fir timber... & 413,000 & 210,000 & 117,000 \\
\hline ........................ standards.. & $9,8 \pm 7$ & 8,501 & 8, , 882 \\
\hline Flooring boards... & 15,684 & 13,928 & 15,352 \\
\hline 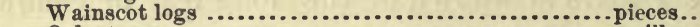 & 1,511 & 3,109 & 3,897 \\
\hline 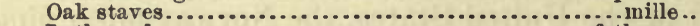 & 130 & 111 & 257 \\
\hline 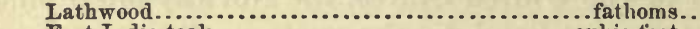 & 313 & 503 & 234 \\
\hline East India teak ...................... & 163,000 & 207,000 & 161,000 \\
\hline Green heart and more & 196,000 & 192,000 & 117,000 \\
\hline
\end{tabular}

FURNITURE WOODS (1893).*

\begin{tabular}{|c|c|c|c|}
\hline Kinds and country. & Quantity. & Feet. & $\begin{array}{l}\text { Average } \\
\text { feet per log. }\end{array}$ \\
\hline \multirow[t]{2}{*}{ 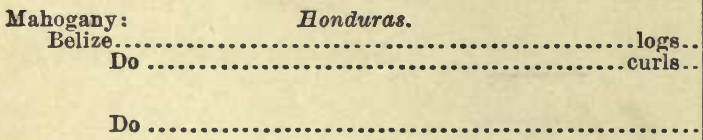 } & $\begin{array}{r}7,184 \\
338\end{array}$ & $\begin{array}{r}2,174,747 \\
27,772\end{array}$ & $\begin{array}{r}302 \\
\cdots\end{array}$ \\
\hline & $\begin{array}{r}7,522 \\
5\end{array}$ & $\begin{array}{r}2,202,519 \\
+6 \frac{1}{2}\end{array}$ & \\
\hline \multirow{2}{*}{ 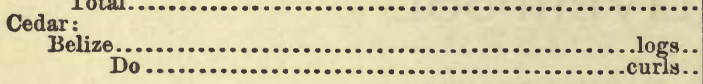 } & 7,527 & & \\
\hline & $\begin{array}{r}151 \\
5\end{array}$ & 43,194 & $\ldots \ldots$ \\
\hline Total............. & 156 & 02 & $\cdots$ \\
\hline 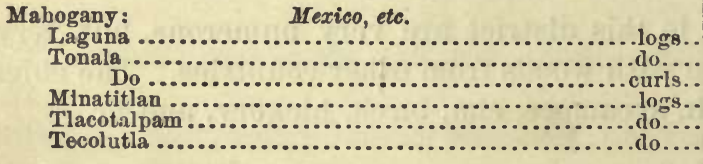 & $\begin{array}{r}1,719 \\
874 \\
10 \\
286 \\
82 \\
51\end{array}$ & $\begin{array}{r}879,600 \\
219,254 \\
2,304 \\
100,399 \\
23,946 \\
17,579\end{array}$ & $\begin{array}{l}511 \\
251 \\
\\
351 \\
292 \\
344\end{array}$ \\
\hline 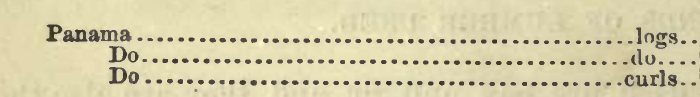 & $\begin{array}{r}3,022 \\
1,837 \\
126 \\
52\end{array}$ & $\begin{array}{r}1,243,082 \\
551,054 \\
56,820 \\
4,054\end{array}$ & 3 \\
\hline 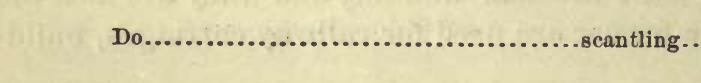 & $\begin{array}{r}5,037 \\
226\end{array}$ & $\begin{array}{r}1,855,010 \\
12,417\end{array}$ & $\because$ \\
\hline 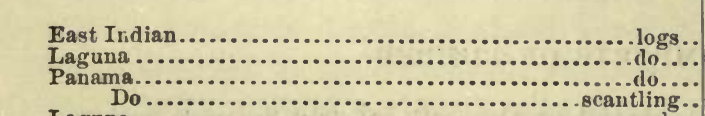 & $\begin{array}{r}5,263 \\
29 \\
414 \\
287 \\
112\end{array}$ & $\begin{array}{r}1,867,427 \\
19.353 \\
228,536 \\
86,100 \\
7,815\end{array}$ & $\begin{array}{r}667 \\
552 \\
300 \\
\ldots . . .6\end{array}$ \\
\hline 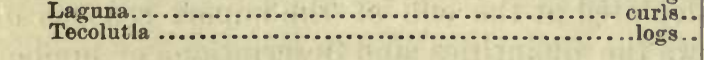 & & - $\cdots \cdots \cdots$ & $\ldots \ldots$ \\
\hline $\begin{array}{r}\text { Panama } \ldots \ldots \ldots \ldots \\
\text { Do } \ldots \ldots \ldots \ldots\end{array}$ & $\begin{array}{r}6,263 \\
75 \\
897\end{array}$ & 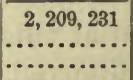 & $\begin{array}{l}+983 \\
+99 \%\end{array}$ \\
\hline Total..... & 7,235 & & \\
\hline
\end{tabular}

* As giren in a printed statement transmitted by the consul.

t Tons. 
FURNITURE WOODS (1893)-Continued.

\begin{tabular}{|c|c|c|c|}
\hline Kinds an & Quantity. & Feet. & orago \\
\hline 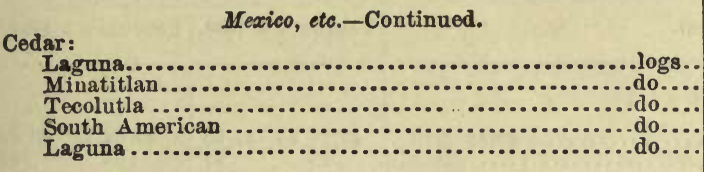 & $\begin{array}{r}74 \\
66 \\
6 \\
61 \\
11\end{array}$ & $\begin{array}{r}31,354 \\
29,266 \\
3,312 \\
6,224 \\
6,065\end{array}$ & $\begin{array}{l}423 \\
443 \\
552 \\
102 \\
551\end{array}$ \\
\hline $\begin{array}{r}\text { South } \text { American ....... } \\
\text { Do ............. }\end{array}$ & $\begin{array}{r}218 \\
67 \\
542\end{array}$ & $\begin{array}{r}76,221 \\
{ }^{*} 60 \frac{1}{4} \\
\ldots \ldots \ldots\end{array}$ & @ $\cdots$ \\
\hline Total................. & 827 & $\ldots \ldots \ldots \ldots$ & $\ldots$ \\
\hline 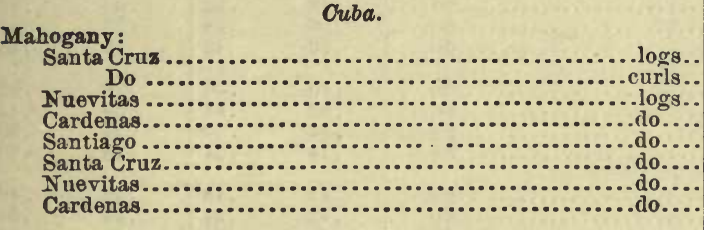 & $\begin{array}{r}633 \\
29 \\
884 \\
360 \\
316 \\
1,239 \\
1,753 \\
67 \\
\end{array}$ & $\begin{array}{r}51,420 \\
964 \\
78,603 \\
39,349 \\
48,543 \\
82,474 \\
142,026 \\
9,057\end{array}$ & $\begin{array}{r}81 \\
89 \\
109 \\
153 \\
66 \\
81 \\
135\end{array}$ \\
\hline Total. & 5,281 & 452,436 & \\
\hline 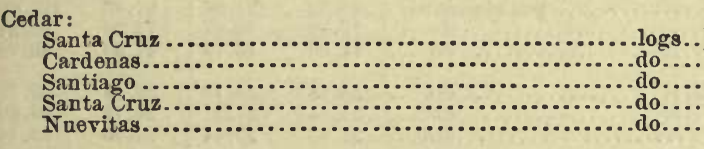 & $\begin{array}{r}1,089 \\
100 \\
41 \\
1,003 \\
276\end{array}$ & $\begin{array}{r}76,477 \\
19,218 \\
5,656 \\
76,200 \\
21,600\end{array}$ & $\begin{array}{r}70 \\
192 \\
138 \\
76 \\
78\end{array}$ \\
\hline Total & 2,509 & 199,151 & - \\
\hline 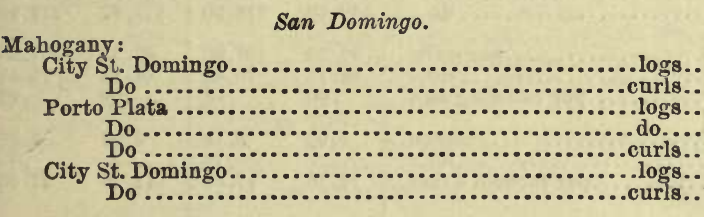 & $\begin{array}{r}1,939 \\
1,111 \\
979 \\
476 \\
900 \\
232 \\
50\end{array}$ & $\begin{array}{r}185,714 \\
10,180 \\
196,053 \\
36,944 \\
10,019 \\
13,019 \\
813\end{array}$ & 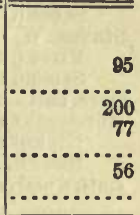 \\
\hline 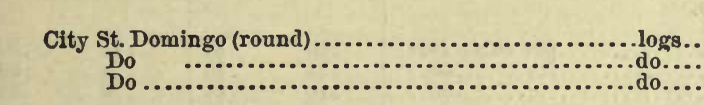 & $\begin{array}{r}5,687 \\
148 \\
40 \\
391\end{array}$ & $\begin{array}{r}452,742 \\
* 21 \\
* 9 \\
* 20\end{array}$ & $\begin{array}{ll}\cdots \cdots \\
\cdots \cdots \\
\cdots \cdots\end{array}$ \\
\hline Total.. & 6,266 & $\ldots$ & ..... \\
\hline 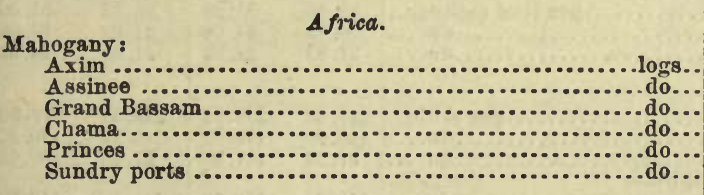 & $\begin{array}{r}4,423 \\
3,732 \\
1,212 \\
515 \\
317 \\
1,136\end{array}$ & $\begin{array}{r}1,920,908 \\
1,662,442 \\
415,467 \\
164,155 \\
84,911 \\
437,552\end{array}$ & $\begin{array}{l}434 \\
448 \\
343 \\
318 \\
267 \\
385\end{array}$ \\
\hline Chiefly from Axim and Assignee. & $\begin{array}{r}11,335 \\
543\end{array}$ & $\begin{array}{r}3,685,435 \\
241,222\end{array}$ & $\ldots$ \\
\hline From Axim, eto.... & $\begin{array}{r}11,878 \\
202\end{array}$ & $\begin{array}{c}4,926,657 \\
\ldots \ldots \ldots \ldots \ldots\end{array}$ & $\begin{array}{r}414 \\
\ldots \ldots\end{array}$ \\
\hline Sundry ports (round). & $\begin{array}{r}12,080 \\
121\end{array}$ & $\ldots \ldots \ldots \ldots$ & $\cdots$ \\
\hline Total. & 12,201 & $\ldots \ldots$ & …...... \\
\hline 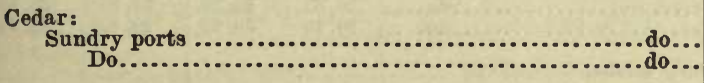 & $\begin{array}{r}15 \\
1\end{array}$ & 16,799 & $\begin{array}{r}453 \\
\cdots\end{array}$ \\
\hline$\cdots$ & 16 & & \\
\hline
\end{tabular}


PRICES.

Statement showing the prices of lumber and timber at Liverpool in 1893 and 1891.

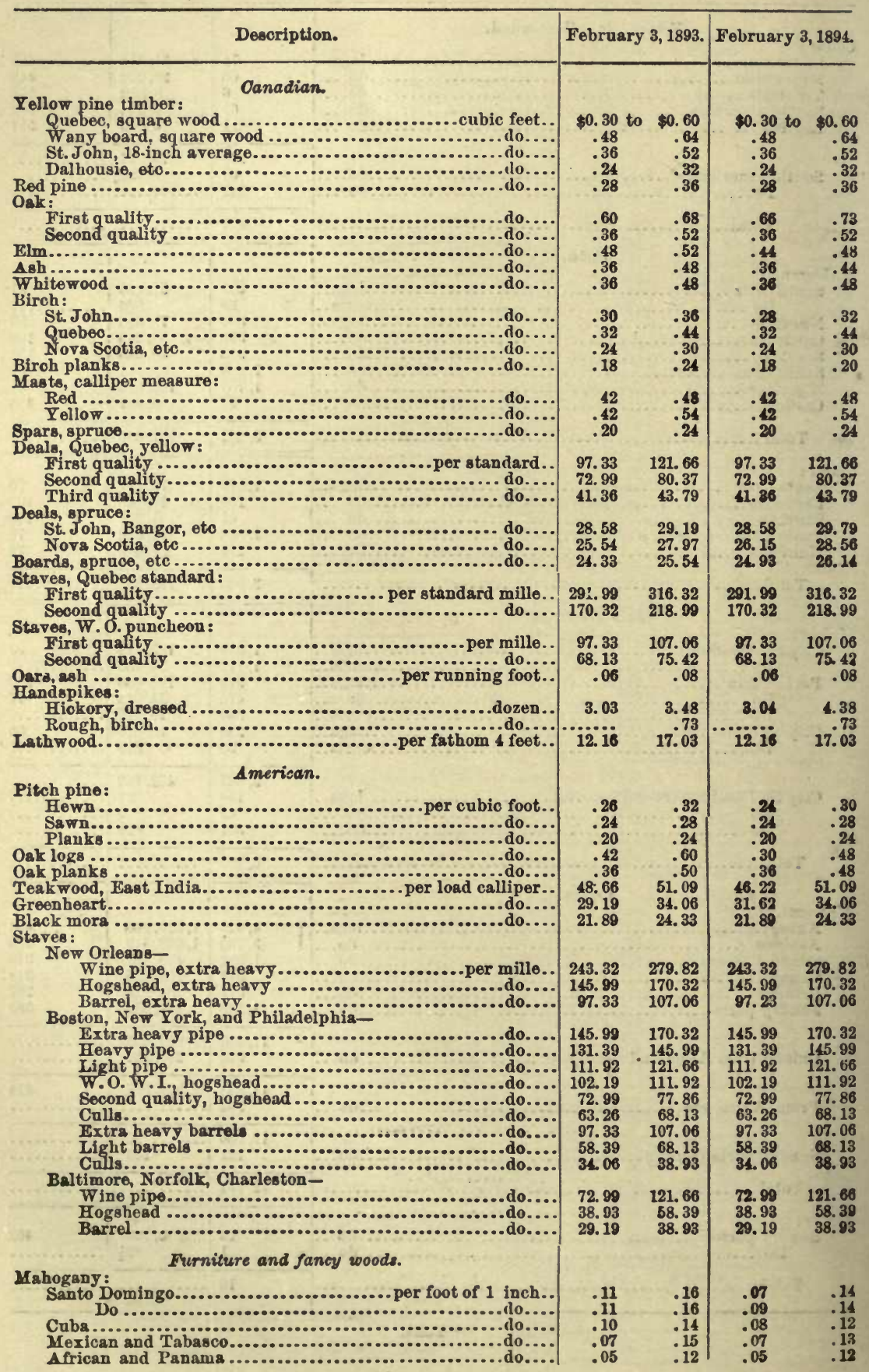


Statement showing the prices of lumber and timber at Liverpool in 1893 and 1891-Cont'd.

Description.

Furniture and fancy woods-Continued.

Cedar: Havana, etc................................ per foot of 1 juch. Pencil cedar .................................. per cubic foot. Satinwood:

Santo Domingo........................ per foot of 1 inch. Walnnt:

lnut: $\quad$ etcos

Italian, eto........................... per foot of $1 \mathrm{inch}$.

Circassian burrs ................................ per ton.

American burrs...................................... per cubic foot.

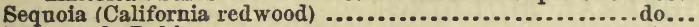

Rosewood: Bahia .................................... per ton .

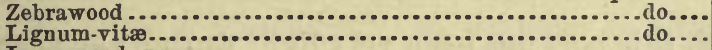

Lancewood spars:

Large sizes, fresh ................................each...

Medium and small sizes, fresh ............................

Timber:

Miscellaneous.

Riga, red.................................. per cubic foot.

Dantzic:

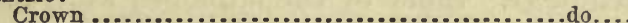

Memel:

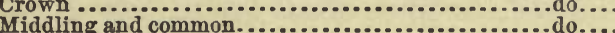

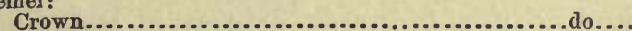

Middling and common ...........................do...

Stettin ............................................ do....

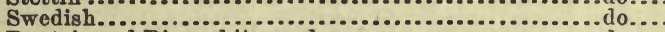

Dantzic and Riga whitewood.......................... (lo...

Norway mining timber............................. do...

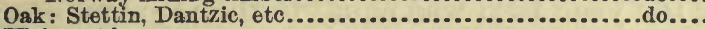

Wainscot logs:

Riga and Memel-

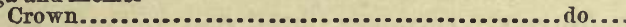

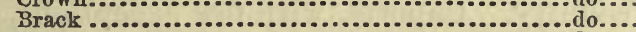

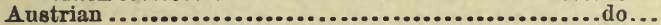

Spars, Norwegian ....................................... do ...

Deals, redwood ......................................do...

Archangel and Onega, red-

First quality ........................... per standard . Second quality ......................................

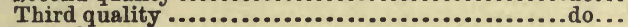

St. Petersburg:

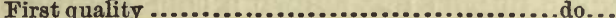

Second quality .......................................

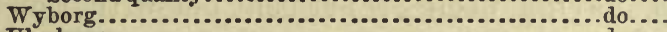

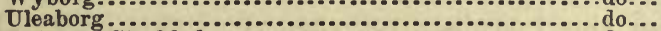

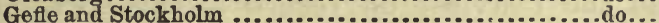

Gothenberg............................................

Whitewood-

Crown.............................................do...

Palings :

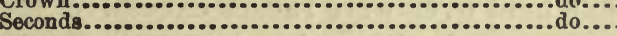

Spruce,

5 feet by 1 inch .........................per 1,200 pieces.

$4 \frac{1}{2}$ feet by $\frac{3}{8}$ inch .................................. do...

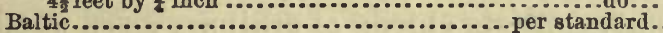

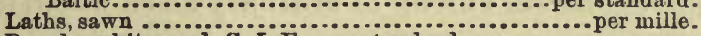

Boards, whitewood, C. I. F., per standard:

Flooring, planed-

First and second quality, mixed ....................... Third quality, mixed

Rod, nnplained.

Lathwood, per fathom, 6 feet wide, 6 feet high:

Dantzic-

6 feet long

.

St. Petersburg and Rigna-

8 foet long

4 feet long

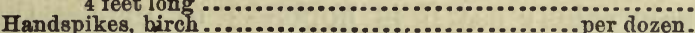

Treenails, locust ......................... per mille of 21 inches.

Oak staves:

Dantzic, crown, pipe ................per mille of 1,200 pieces..

Memel............................................... do....

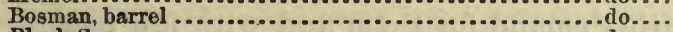

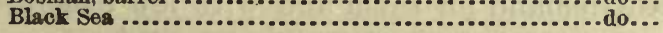

\begin{tabular}{|c|c|c|c|}
\hline Februar & 1893. & February & 1894. \\
\hline $\begin{array}{c}\$ 0.08 \text { to } \\
.48\end{array}$ & $\begin{array}{r}\$ 0.09 \\
.73\end{array}$ & $\begin{array}{l}\$ 0.07 \text { to } \\
.48\end{array}$ & $\begin{array}{r}\$ 0.10 \\
.73\end{array}$ \\
\hline $\begin{array}{r}.12 \\
19.46\end{array}$ & $\begin{array}{r}.18 \\
29.19\end{array}$ & $\begin{array}{r}.08 \\
19.46\end{array}$ & 29.19 \\
\hline $\begin{array}{r}.06 \\
24.33 \\
.60 \\
532 \\
53.53 \\
21.89 \\
19.46\end{array}$ & $\begin{array}{r}.10 \\
97.33 \\
1.21 \\
68.13 \\
68.13 \\
26.76 \\
43.79\end{array}$ & $\begin{array}{r}.06 \\
24.33 \\
.60 \\
.44 \\
29.19 \\
21.89 \\
19.46\end{array}$ & $\begin{array}{r}.10 \\
97.33 \\
1.21 \\
58.48 \\
58.39 \\
26.76 \\
43.79\end{array}$ \\
\hline $\begin{array}{l}2.43 \\
1.21\end{array}$ & $\begin{array}{l}3.77 \\
1.82\end{array}$ & $\begin{array}{r}1.82 \\
.97\end{array}$ & $\begin{array}{l}2.43 \\
1.46\end{array}$ \\
\hline .32 & .36 & .32 & .36 \\
\hline $\begin{array}{l}.36 \\
.30\end{array}$ & $\begin{array}{l}.44 \\
.36\end{array}$ & $\begin{array}{l}.36 \\
.30\end{array}$ & $\begin{array}{l}.44 \\
.36\end{array}$ \\
\hline $\begin{array}{l}.40 \\
.30 \\
.32 \\
.24 \\
.24 \\
.20 \\
.44\end{array}$ & $\begin{array}{l}.44 \\
.36 \\
.38 \\
.30 \\
.26 \\
.22 \\
.48\end{array}$ & $\begin{array}{l}.40 \\
.30 \\
.32 \\
.24 \\
.24 \\
.20 \\
.44\end{array}$ & $\begin{array}{l}.44 \\
.36 \\
.38 \\
.30 \\
.26 \\
.22 \\
.48\end{array}$ \\
\hline $\begin{array}{l}.97 \\
.60 \\
.85 \\
.18\end{array}$ & $\begin{array}{l}.03 \\
.73 \\
.97 \\
.28\end{array}$ & $\begin{array}{l}.97 \\
.60 \\
.85 \\
.18\end{array}$ & $\begin{array}{r}1.03 \\
.73 \\
.97 \\
.28\end{array}$ \\
\hline
\end{tabular}

80.29

60.82

46. 22

\subsection{9}

51.08

41.36

41.36

48. 66

46.22

34.06

29.19

85.16

80.29

$65.69 \quad 60.82$

\begin{tabular}{l|l}
51.08 & 46.22
\end{tabular}

$72.99 \quad 65.69$

58. 39

46. 22

48.66

53.53

51. 08

51.08

41.36

41. 36

48.66

46. 22

38.93

31.62

35.06

29.19

19.46

13.38

23. 11

3. 04

21.89

15.80

27. 98

3.65

19.46

13. 38

23.11

3.01

35.27

34.66

28. 58

29. 19

26. 76

35. 27

31.62

24.33

27.98

29.19

21.89

27. 98

20.67

38.93

19.46

36.49

18. 24

1.33

31. 62

1.21

948.96900 .30

$948.96 \quad 900.30$

121. $66 \quad 97.33$

\begin{tabular}{l|l}
102.19 & 97.33
\end{tabular}
32.84

27. 37

29.11

85. 16

65.69

51.08

72. 99

58. 39

46. 22

48. 60

51.08

38.93

31.12

21. 88

15. 80

27.98
3.65

36.41

21.81

38.93

19.41

31.62

$948 . \%$

948.9

121. 61

102. 18 
CLIMATE.

The climate of Liverpool, though variable, is remarkably mild, com. pared with that of other places on the same parallel of latitude. The variation in temperature is not very great, railway and river traffic being carried on with little interruption all the year round, and the river is never frozen over in the severest winter. Neither extremes-heat or cold-are experienced, but the atmosphere is moist.

\section{GENERAL BUILDING.}

Wooden ship-building at this port has been very light during the year 1893 , only 5 steamers, ranging from 5 to 20 tons, having been built, 4 of which were for foreign governments and one for the British Government. There were also 6 wooden barges of 20 tons each, built of pitch pine for the British Government. Some of the launches were of teak and some of pitch pine.

The railway carriage and wagon industry centers in Birmingham, where the principal works are located, and there is practically nothing done in this consular district in carriage or wagon building.

The timber business for the year 1893 was equal to the previous one; but a want of confidence was shown in sympathy with the unsatisfactory general trade of the country. Imports, with few exceptions, were not excessive, the greatest excess being in spruce deals.

\section{AMERIOAN WOODS.}

Pitch pine.-The aggregate import has shown a considerable falling off during the year 1893, having been 37 per cent below that of the previous year, which was the heaviest on record at this port. $\mathrm{Th}_{e}$ consumption compared favorably with the import, though less than the previous year. Still, stocks held over were rather excessive.

Hewn wood.-The season opened with a heavy stock of this wood, and although there was a large consumption, prices ruled very low, and the present stock, which consists chiefly of ordinary-sized wood, is heavier than for some years.

Savon timber.-There has been a marked falling off in the import; but the consumption was large-much of it, however, of a forced character; consequently, the stock held over was much smaller than on the previous year, but the trade complain that the stock is still excessive. It is hoped, therefore, that shippers will make an effort to curtail the production; otherwise, dealers here say it is hopeless to expect the market to assume a healthy tone in the near future.

Deals.-These did not meet with very ready sale in this market; in fact, there seems very little demand for them and with few exceptions those imported for stowage purposes are sufficient to meet the demand. 
Boards.-Boards of prime quality and cut to special sizes are getting more in favor here, and an increasing business has been done at what are stated to be fairly remunerative prices.

Oak.-The importation of logs has been large, chiefly from New Orleans and Mobile. Some of it was of fine quality, but the bulk is stated to be of medium to common quality, and therefore claimed by the dealers as difficult to sell, with the result that much of it had to be stored in the yard. Where sales were effected, very low prices were obtained. The stock is heavy.

Planks. - The importation of planks was heavy, and consisted largely of "wagon scantling," the business in which has increased very considerably of late years; but the demand has been languid, although the prices for prime quality and good specifications have been fairly maintained. Common quality was difficult to handle, and the prices ruled low. The opinion here is that the manufacture generally has improved; but the people in the trade suggest that more care should be taken in shipping prime parcels free from culls. The present stocks of planks, including a large proportion stored in outside depots, amount to about 400,000 cubic feet, which is considered much too heavy.

Boards.-During the year boards arrived freely. When of good quality and cut on the quarter, they met with fair sales. Other descriptions than this are not wanted.

Wainscot billets.-These have ceased to be imported.

Satinwood. - The import was moderate, chiefly from Mobile and New Orleans. It did not, however, meet with ready sale, and the prices were very low.

Whitewood.-The importations of whitewood were larger than the previous year. Logs and planks of really good quality sold freely at fair prices, but at the close of the year logs declined in value. An increasing business was also done in boards, principally of the best quality, which are most in demand here. Stocks held over are moderate.

Hickory.-Several parcels were brought over, which, when in the round log with the bark on and fresh, commanded what is claimed to be fair prices, viz, from 36 cents to 60 cents per foot.

$A s h$.- This wood was imported more freely, and found fair sale at from 30 to 48 cents per foot. Only the fresh wood of good size and color is in demand here at all.

Cherry wood. -The importation has been very limited, and realized about 66 cents per foot. Consumers like this wood, and if regular supplies could be depended on, it would find greater favor with them.

Staves.-The total import of all descriptions from the United States has been 3,182 mille, against 3,169 mille during 1892 . There has been a demand throughout the year for New Orleans wine pipe, hogshead, and barrel staves, and stocks on hand are more moderate. The W. O. W. I. were freely imported from Boston, New York, and Philadelphia, especially towards the close of the year, the consequence being that stocks have 
accumulated to a considerable extent. There is poor demand, and prices have fallen, with a tendency to further decline.

Walnut.-There was a very heavy import of walnut, but much of it was of small to medium sizes, and stated to be of poor quality, and consequently brought low prices. Good-sized wood of the best quality was in active demand, and commanded throughout the year full price.

Satin walnut.-This was imported in moderate quantities from New Orleans and Mobile of good size and quality, and a few parcels of round logs from Newport News of inferior quality. The sales, however, were poor and prices low.

Mahogany. - Of the furniture woods imported into this port mahogany is by far the most extensive. The greatest quantity comes from Africa, as shown by table heretofore quoted. Complaints are made, however, that shipments bave been sent along quite regardless of the wants of the trade. The rapidity with which this business has increased is simply marvelous; hence my reason for referring to it here. In the year 1890 only 257,000 feet (superficial) were imported; this year there were not less than 4,984,000 feet came forward, which is nearly equal to the entire import from all other countries. Next to Africa comes Honduras as a mahogany-shipping country, the import therefrom being the heaviest for several years and nearly double that of last year, but it all went into consumption and left the market bare. Good quality, straight and sizeable wood, always meets with ready sale, and the prices were fairly maintained.

JAMES E. NEAL,

Liverpool, March 6, 1894.

Consul.

\section{NEWCASTLE-ON-TYNE.}

NATIVE WOOD.

The native woods of this region are of the usual hardy growth of this latitude, and are principally oak, ash, elm, pine, willow, poplar, sycamore, etc.; but little native lumber is made in England.

KINDS OF LUMBER USED.

The lumber principally used here is pitch pine, white and red fir, oak, walnut, and deals.

\section{IMPORTS OF LUMBER.}

The chief importation of lumber into Great Britain is from Norway and Sweden and ports on the Baltic, and for this part of England, the east coast, notably the Tyne ports, Sunderland, Hartlepool, Hull, and 
Grimsby. The quantity of lumber imported into the Tyne for the year ending December 31, 1893, was as follows:

\begin{tabular}{|c|c|c|c|c|c|}
\hline Kinds. & Germany. & Russia. & $\begin{array}{l}\text { Norway } \\
\text { and } \\
\text { Sweden. }\end{array}$ & \begin{tabular}{|c|} 
United \\
States of \\
America.
\end{tabular} & Canada. \\
\hline 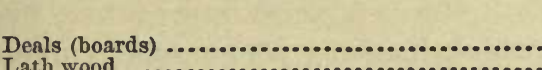 & $\begin{array}{l}\text { Loads. } \\
\mathbf{3}, 794\end{array}$ & $\begin{array}{r}\text { Loads. } \\
10,626 \\
1,566\end{array}$ & $\begin{array}{l}\text { Loads. } \\
44,228 \\
173\end{array}$ & $\begin{array}{l}\text { Loads. } \\
2,683\end{array}$ & $\begin{array}{r}\text { Loads. } \\
\quad 3,619\end{array}$ \\
\hline $\begin{array}{l}\text { Lath wood. } \\
\text { Sleepers.... }\end{array}$ & 83 & $\begin{array}{l}1,566 \\
877\end{array}$ & 17,510 & (n............ & ............... \\
\hline 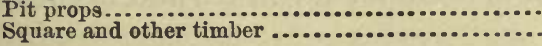 & $\begin{array}{l}3.984 \\
2,553\end{array}$ & 4,849 & $\begin{array}{l}54,155 \\
12,474\end{array}$ & 16,844 & $\cdots, \ldots, \ldots$ \\
\hline
\end{tabular}

Notk.-A load of lumber is usually 50 cubic feet of squared timber; 40 cubio feet of unhewn timber and 600 superficial feet of inch planking.

\section{PRICES.}

The average prices of the sorts mentioned are: Deals and battens, from $£ 5$ to $£ 8$ 8s. per standard of 165 cubic feet, known as St. Petersburg standard; planed boards, about $£ 88$ s. to $£ 1010 s$. per standard; square timber, depends on size of log; pine, average sizes, 1s. $6 d$. per cubic foot up to $2 s$. $6 d$. for large size; railway ties, sold by size, about $6 s$. per 72 running feet.

\section{GENERAL BUILDING.}

This consular district is one of the most important shipbuilding districts in the United Kingdom, but the material used is exclusively iron. No important structures of wood are ever erected in England.

\section{EXTENSION OF LUMBER TRADE.}

The trade here is a very old-established one, and the dealers are well aware of all the world's sources of supply. The cost to deliver here is the principal question to consider, and in this the sea freight cuts the chief figure. For the class of lumber here mentioned the long Atlantic voyage can not be expected to successfully compete with the shorter one from the adjacent ports of the Baltic.

WM. S. OAMPBELL,

Consul.

NeWCastle-on-Tyne, February 15, 1894. 


\section{POLYNESIA. \\ HAWAIIAN ISLANDS.}

NATIVE WOODS.

The koa is the only native wood which has any commercial value. This wood is comparatively rare, and is used for furniture and decorative purposes.

\section{KINDS OF LUMBER USED.}

The kinds of lumber used here are Puget Sound fir, spruce, and cedar; California redwood, oak, ash, and hickory.

\section{IMPORTS AND DUTY.}

All the timber used here is imported from the United States. About $15,000,000$ feet are imported annually.

There is no import duty on American lumber. A duty of 10 per cent is exacted on lumber from other countries.

\section{PRICES AND OLIMATE.}

Puget-Sound fir sells for from $\$ 18$ to $\$ 20$; spruce (clear-surfaced), $\$ 37$, and cedar, $\$ 80$ to $\$ 100$ per 1,000 feet. Oak and ash (for carriage work) costs $\$ 160$, and hickory $\$ 200$ per 1,000 .

The climate is mild and pleasant.

\section{GENERAL BUILDING.}

There is no shipbuilding in this country; there is, however, a small amount of ship-repairing.

Railroads are built from time to time on the various plantations on the Islands, and are used for conveying the sugar cane from the fields to the mills.

Honolulu, April 28, 1894.

\section{ELLIS Mills,}

Consul-General.

\section{NEW CALEDONIA.}

\section{NATIVE WOODS.}

The native woods of New Caledonia may be classed as follows:

Ornamental and fruit trees, among which may be included all the palm kind.

The orchidaceæ are numerous in the woods of the colony. 
Useful woods for building, furniture, or mechanical purposes are numerous, but being mostly situated in places difficult of access form but a small item in the local industries. The coniferous sorts, which are to a small extent worked, are the kaori (Dammara moorea), which is the giant tree of the colony; the Araucaria cookii, which give straight but knotty spars from 30 to $\mathbf{4 0}$ meters; the Araucaria Ruleii, which are found in the southern part of the island, and attain about the same size as the Araucaria cookii, the Storckellia prancheri, white, rosygrained, used for joinery work; the Intzia melibai of the Isle of Pines, very good for furniture.

The hard wood kinds, used in ship and house buildings, are numerous; the Melaleuca glaberrima, and Mulaleuca leucodendron are examples.

The principal hard redwood trees are as follows: The Pleurocalyptus deplanchei, good heavy wood of a density of 1.165; the Spermolepis tannifera, the Grevillea gillivragi; the Stenocarpus haurifolius, a beautiful furniture wood; the Weinmannia parviflora, denominated white oak-its bark is rich in tannic principles; the Calophyllum montanum (tamanon), one of the most useful trees here, is used in cabinet-making.

There are numerous other species, but they are of little importance in a commercial sense.

\section{IMPORTS OF LUMBER.}

The lumber preferred is that from the United States-Oregon and Washington, from which the largest quantity of wood employed in this colony is imported, say 2,000 tons yearly.* In 1893, however, there was no direct importation from the United States, as the stock on hand at the end of 1892 was considerable.

New Zealand supplies about 200 tons of kouri annually, and New South Wales about the same quantity of hard wood (blue and red gam).

\section{PRICES AND CLIMATE.}

The different sorts of lumber from all countries are sold here at from 90 to 120 francs (\$17.37 to $\$ 23.16$ ) per ton.

The climate of New Caledonia is tropical, but moderate and healthy, resembling the climate of the Hawaiian Islands.

\section{GENERAL BUILDING.}

The colony is making fair progress in housebuilding, but very little in shipbuilding. There are no railroads yet.

\section{EXTENSION OF LUMBER TRADE.}

The only method left to be tried here for the extension of the trade of this colony with the United States in lumber, as well as in other American goods, is the establishment of an American house of business at

\footnotetext{
* The ton mentioned in this report is the French cubic meter $=35.3$ cubic feet.
} 
Noumea. In my opinion there is a fair opening for such a house here, more especially if direct communications with the Pacific States were to be created.

\section{ACKNOWLEDGMENTS.}

I am greatly indebted to Mr. A. Jeanneney, who has lived in this colony for several years as a Government officer attached to the transportation department, and one of the most scientific men of New Caledonia, for much of the information contained in this report.

\section{LE MESCAM, Consular Agent.}

NOUMEA, March 15, 1894.

\section{SAMOA. \\ KINDS OF LUMBER USED.}

There is very little domestic lumber used, there being no mills here, and any that is made is sawn out by hand. The favorite building lumber is Oregon pine and California redwood. New Zealand kauri is preferred for boat building.

\section{IMPORTS AND DUTY.}

New Zealand is the only other country besides the United States from which lumber is imported into these islands. The total imports for the year ending June 30, 1893, amounted to 86,000 feet.

The import duty on lumber is 2 per cent ad valorem.

\section{PRICES AND OLIMATE.}

Rough lumber sells here for about 4 cents per foot; surfaced lumber from 5 to 7 cents.

The climate of this district is hot and damp. We seldom have three weeks without rain. The dry season, if it can be called so, is from May to October. During the other months storms may be expected, sometimes gales, and occasionally hurricanes.

\section{GENERAL BUILDING.}

Considerable building goes on here all the time. There are always one or two houses in course of construction, and repairing is constantly going on. This climate is very severe on buildings. The wood, where near the ground, or exposed to sun and rain, rots in about three years.

No shipbuilding is carried on, but many boats are built every year. 


\section{NATIVE WOODS.}

The following is a descriptive list of Samoan woods:

\begin{tabular}{|c|c|c|c|c|c|c|}
\hline $\begin{array}{c}\text { Name of } \\
\text { tree. }\end{array}$ & Quality. & Color. & $\begin{array}{c}\text { Diame- } \\
\text { ter. }\end{array}$ & Helght. & Use. & Remarks. \\
\hline Ifiai .... & Soft.. & Whitish yellow... & $\begin{array}{l}\text { Feet. } \\
3 \text { to } 4\end{array}$ & $\begin{array}{l}\text { Feet. } \\
40 \text { to } 60\end{array}$ & Firewood ......... & $\begin{array}{l}\text { Edible nut (chest. } \\
\text { nnt). }\end{array}$ \\
\hline Ifilolo....... & Harl ... & Mahogany. & $\mathbf{3}$ & 60 & Furnitureand dye & \\
\hline la $\ldots \ldots$ & Medium & Lighter I & 3 & 60 & .... do ................ & \\
\hline $\begin{array}{l}\text { Ifisangd .... } \\
\text { Fetau ...... }\end{array}$ & $\begin{array}{l}\text { Hard ... } \\
\text { H a r } \ddot{\mathrm{d}}, \\
\text { carl } \bar{j} .\end{array}$ & $\begin{array}{l}\text { Darker mahogany } \\
\text { Red, yellow, and } \\
\text { white streaks. }\end{array}$ & $\begin{array}{l}3 \\
2\end{array}$ & $\begin{array}{l}60 \\
20\end{array}$ & $\begin{array}{l}\text { Boat knees reneer } \\
\text { and ornamental }\end{array}$ & \\
\hline Manaui..... & Medium & Light gray ....... & 1 & 30 & $\begin{array}{l}\text { work. } \\
\text { Furniture and } \\
\text { veneer. }\end{array}$ & \\
\hline Talie & Har & Gray & 4 & 80 & ....do ............... & \\
\hline La & Sof & Reddish & 2 & 20 & No use ....... & \\
\hline$\vec{M}$ & Har & Reddish brown .... & 3 & 50 to 60 & Furniture ......... & \\
\hline Tamann .... & Medium & Red cedar .......... & 3 & 60 & :...do $\ldots \ldots \ldots . . .$. & \\
\hline Pan ......... & Hard .... & Dark pink....... & 3 & 60 & War clubs......... & Good for carving. \\
\hline $\mathrm{Fa}$ & $\ldots$ & Gray and yellow . & 3 & 20 to 30 & Knees, stems, and & \\
\hline Milo.. & ... do & $\begin{array}{l}\text { Variegated, dark } \\
\text { and light streaks }\end{array}$ & 8 & 20 to 30 & .... do .............. & Good for orns \\
\hline Tauanave... & Medium & $\begin{array}{l}\text { Brown, red, black, } \\
\text { a n d w hit e } \\
\text { streaks. }\end{array}$ & 8 & 20 to 30 & $\ldots$....... & $\begin{array}{l}\text { Makes nose and } \\
\text { mouth b le } \mathrm{d} \\
\text { when workingit. }\end{array}$ \\
\hline Mamala & $\ldots c$ & Blood red........... & 3 & 50 & Furniture ... & \\
\hline$\cdots$ & $\mathrm{Ha}$ & Red & 3 & 50 & ...do ....... & \\
\hline & & w $\ldots \ldots \ldots$ & 3 & 80 & $\begin{array}{l}\text { Firewood } \\
\text { Boat building......... }\end{array}$ & \\
\hline ali.... & $\ldots d$ & Black............... & 4 & 80 & Gateposts .......... & Does not rot in the \\
\hline $\mathrm{Tg}$ & & $\mathrm{D}$ & 2 to 3 & 60 & Furnitare ... & \\
\hline & Sof & Light. & 3 & 70 & No use........ & Fruit tree. \\
\hline u... & Ha & Pink. & $\mathbf{3}$ & 60 & War clubs.... & \\
\hline As & & Red. & 1 & 20 to 30 & Wharf piles....... & $\begin{array}{l}\text { Bastard } \\
\text { wood. }\end{array}$ \\
\hline Tavae ... & Medium & Light yellow ..... & 3 & 50 & Boat boards... & Similar to white \\
\hline Mamalava.. & Soft. & White. & 2 & 80 & Shingles. & Similar to white \\
\hline Mangrove .. & Hard & Rosewood. & 1 & 18 & Dye, firewood, & \\
\hline & 7. & Light. & 1 & 30 & Gateposts ......... & \\
\hline & & & & & & \\
\hline
\end{tabular}

W. BLACKLOCK,

Vice-Consul-General.

APIA, April 24, 1893. 



\section{SUPPLEMENT.}

The following reports are reprints from the regular issues of the monthly consular reports, and embrace everything relative to wood and timber published by the Department subsequently to the issuance of the foregoing Special Consular Reports, American Lumber in Foreign Markets.

\section{AMERICAN LUMBER IN CHINA.}

Consul-General Jernigan, of Shanghai, under date of December 9, 1896, says an important article of import at Shanghai is American lumber. To date, this has principally consisted of pine lumber from the States of Oregon and Washington, though considerable redwood from California also finds an appreciative market, as does timber from British Columbia. The eastern part of China is almost denuded of trees, causing the native supply of lumber to be very limited. The regions back of Fuchau furnish considerable, not suitable for building purposes, in a foreign sense, but affording the means of a large traffic between the natives. It is from the Fuchau regions that the wood for making coffins is mostly obtained, the superstition of the Chinese permitting only certain kinds to be used for this purpose. From Hunan and other parts of western China large quantities of pine are cut and rafted down the Yangtze River, but as a rule it is of a very inferior quality. Some wood finds its way from the interior to Canton. Teak and other varieties of hard wood are imported from the East Indies, Siam, and Burmah, and some pine timber comes from Japan. Recently a lot of railroad ties were bronght from Japan to Tien-Tsin. The rapid growth of Shanghai, and more especially the building of large cotton mills and silk filatures here and in other cities, have largely increased the import of pine timber during the past two years. This will appear from the following table:

\begin{tabular}{|c|c|c|c|c|}
\hline \multirow[b]{2}{*}{ Kinds. } & \multicolumn{2}{|c|}{1894.} & \multicolumn{2}{|c|}{1895.} \\
\hline & Quantity. & \begin{tabular}{|c|} 
Value in \\
United States \\
gold.
\end{tabular} & Quantity. & $\begin{array}{c}\text { Value in } \\
\text { United States } \\
\text { gold. }\end{array}$ \\
\hline 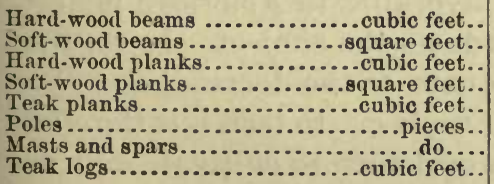 & $\begin{array}{r}286,036 \\
3,086,805 \\
447,557 \\
13,643,944 \\
24,878 \\
5,139 \\
2,774 \\
33,598\end{array}$ & $\begin{array}{r}\$ 141,414 \\
44,450 \\
161,121 \\
196,473 \\
11,942 \\
2,056 \\
221,920 \\
16,127\end{array}$ & $\begin{array}{r}344,396 \\
4,380,371 \\
501,468 \\
18,769,599 \\
20,353 \\
9,872 \\
127 \\
947\end{array}$ & $\begin{array}{r}\$ 137,758 \\
63,078 \\
180,528 \\
270,282 \\
9,769 \\
3,949 \\
20,320 \\
203\end{array}$ \\
\hline
\end{tabular}


One of the largest lumber dealers at Shanghai furnishes the following statement of sales of pine lumber made by the principal lumber firms for the years 1893-1896:

Square feet.

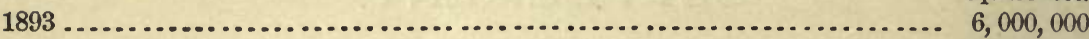

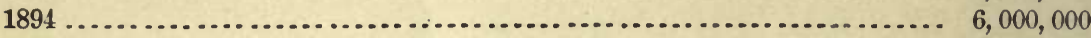

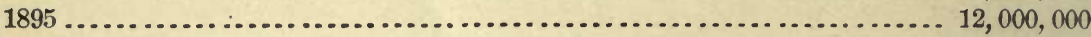

1896

$14,000,000$

The customs returns for $\mathbf{1 8 9 6}$ are not yet published, but it is estimated that between $20,000,000$ and $30,000,000$ square feet of timber were imported during the year just closed and that there were about $11,000,000$ square feet on hand. As stated, the greater quantity of the lumber comes from the United States, and the quantity imported amounted in 1896 to $14,000,000$ square feet and in 1895 to $9,149,789$ square feet. In this connection, these important facts may be noticed: The mills for whose construction the greater quantity of the lumber was imported are now completed, no extensive building operations are planned for 1897 , and the figures given above show the market fairly supplied for ordinary demands. Dealers express the opinion that on this account the imports for 1897 will be small, but nevertheless the lumber market of China will rule favorable for American lumber, and with the more extensive introduction of western machinery and the consequent need for proper buildings the demand will steadily increase. The opening of China by railroads and the spread of western civilization will make more substantial and comfortable houses a desideratum, and the construction of such will require the use of foreign timber. Houses of foreign style have already become so popular with the natives at Shanghai that Europeans who are called here in the discharge of their duties find it difficult to secure houses for their families, and rents have, since 1894, advanced about 20 per cent. Much building is now being done to meet this need, and if the demand for the current year should not be so large as formerly, I should advise a careful study of the lumber market.

I. R. Jernigan, Consul-General.

Shanghat, December 9, 1896.

\section{AMERICAN LUMBER IN DENMARK.}

The conditions in Denmark seem so favorable to American lumbermen that I deem it best to say a few words on the subject. In the first place, the local supply is wholly inadequate to the demand, and Denmark depends on outside sources for her timber. In fact, it is the effort both of the Government and landed proprietors to cultivate and not cut down the forests. 
The lumber trade is principally supplied from Norway, Sweden, and the United States. American white oak is held in the highest esteem here, being far superior to the Danish article, which is scarce and poor in quality. One firm which I consulted carries only American oak, and is of opinion that this particular wood has splendid chances in the markets of Denmark. It is more in demand than any other American wood. Walnut, poplar, and pitch pine have also good chances here. Elm and ash are not so much used. They have been imported, but are of no importance now. Boards, planks, and sawed lumber are generally preferred and have the quickest sale.

All lumber shipped for sale in Danish markets should be thoroughly dried and seasoned, and American dealers will find it to their interest to bear this fact in mind. For instance, it is said that green walnut logs must be kept two years before using. Oak is used for furniture, shipbuilding, and house building, and should be shipped in planks and boards unless otherwise specially ordered. Walnut is used for furniture, and should always be shipped in boards. Pine is used for ship and house building; poplar for veneering, billboards, and furniture, also in the manufacture of pianofortes and carriages. Poplar is also used largely for stoppers to beer kegs, liquor barrels, etc. There is much demand for this wood, and it may be shipped in boards or logs. Maple, I think, also has a future here for veneering and inlaid work.

There is no duty on oak imported into Denmark. Other woods pay

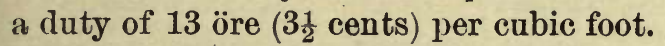

The opening of the free port of Copenhagen affords a good opportunity to American dealers. Lumber shipped in bulks ean be stored at low rates in the ample yards of the free port and from there be distributed to the various ports of the Baltic, according to the demands of trade.

The free port being considered foreign territory, there is no duty on goods entering to be reshipped on sale. Only when sold for use in Denmark will the customary duty be exacted.

The following are some of the principal lumbermen in Copenhagen: Th. \& O. Bröchner, Store Kongensgade 63; A. Uhr. Hensen \& Co., Agents, Österbrogade 3; Aubertin \& Co., Nörrebrogade 177; Westphal, Thedin \& Co., Nörrebrogade 209; Emil Mottlan, Nörrebrogade 116. American dealers can correspond directly with these firms as to prices, terms, etc.

Copenhagen, December 12, 1894.

ROBERT J. KiRK, Consul. 


\section{AMERICAN LUMBER IN FRANCE.}

Consul Germain, of Zurich, writes September 25, 1895: I have the honor to inform you that my report on "Swiss Market for American Woods," printed in Consular Reports No. 175 (April, 1895), pages 509-515, has been copied and published by several French and German trade journals, and thus circulated among interested European parties in that line. I am in receipt this day of a letter, which I inclose, and, translated, reads about as follows:

Mr. Eugene Germain,

Maubeuge, Nord, France, September 23, 1895.

United States Consul, Zurich, Switzerland:

We know that you have made a special and very complete study of the question of American woods. Would it please you to cause useful information to be given us to facilitate our wood importations? As the first important point, we can inform you that our firm ean, if need be, furnish a guaranty of $1,000,000$ franes $(\$ 200,000)$. This is said to indicate to exporters that they can be at full ease as regards our solvency or responsibility.

Thanking you in advance, etc., we remain,

LEGRAND \& JEANNESSON.

This letter, if given publicity, would, I believe, result in business to some of our wood exporters.

\section{AMERICAN LUMBER IN SWITZERLAND.}

In looking over the Swiss custom-house statistics I find that, although most of the cantons of this mountainous country have extensive and fine forests, they are not sufficient to supply Switzerland with the necessary timber and lumber. In fact this country imported last year (1893) $18,200,099$ francs $(\$ 3,502,619)$ of woud and manufactures of wood, while the exports of the same amounted only to about $4,000,000$ francs $(\$ 772,000)$, showing a surplus of imports over exports of over $14,000,000$ francs $(\$ 2,762,000)$, in which amount the United States participated only with 189,679 francs $(\$ 36,608)$.

It is evident that the United States could secure a greater share of this Swiss trade, and in order to find out how the Swiss market could be extended to our products in this line I addressed communications to some of the interested parties, viz, dealers and importers in wood and manufacturers of boats, carriages, furniture, etc., housebuilders, etc., asking their opinion. I now beg to submit, for the benefit of our people in that line of trade, what parties here say regarding the kinds of wood required, prices, etc. I also add a tabulated statement showing the total Swiss imports during 1893 of the different kinds of lumber, timber, etc., compared with the imports from the United States during the same period, the principal sources of supply, and customs duties. 
Imports of wood and manufactures of wood into Switzerland during the year ending December 31, 1893.

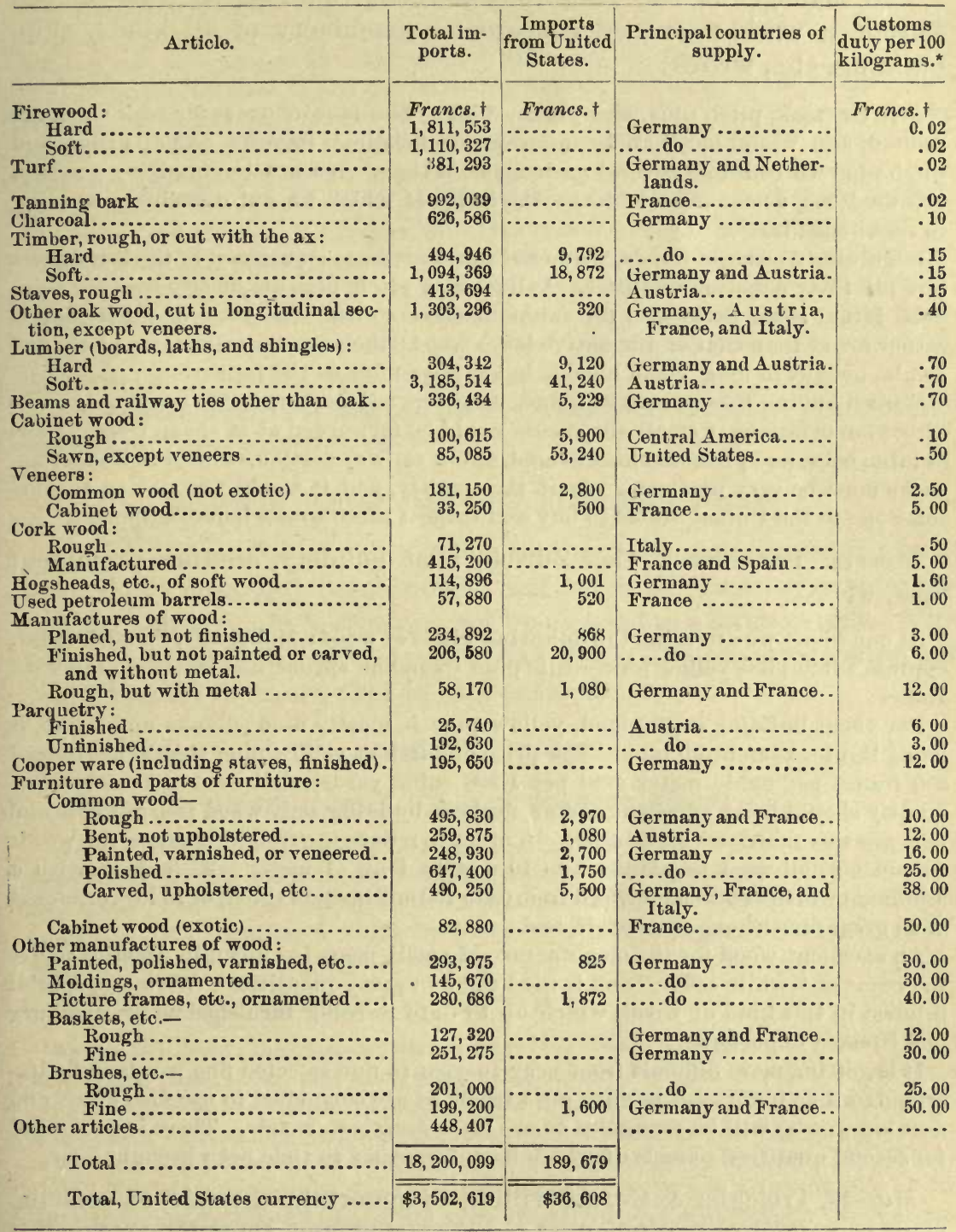

* 100 kilograrus $=220.46$ pounds .

$\dagger 1$ franc $=19.3$ cents.

Duties are paid on the gross weight.

Switzerland's exports of wood and manufactures thereof amount to $4,126,826$ francs $(\$ 796,477)$, of which amount the United States had 49,676 francs $(\$ 9,587)$, mostly consisting of wood carvings. 


\section{SHIPBUILDING.}

The manager of the Maschinenfabriken von Escher Wyss \& Co., Zurich, a world-renowned concern for machinery of all kinds, shipbuilding, etc., writes:

We use teak, pitch pine, and yellow pine. The requirements for teak wood are limited, and would hardly offer inducements for direct imports, but of yellow and pitch pine we consume several carloals at a time. We are buying these goods in boards, laths, or square-cut blocks, the latter of which we cut ourselves according to requirements.

Regarding Anerican woods, we do not purchase same ou account of the low figures but for their superior qualities. Yellow and pitch pine are mostly used for shipdeck laths; some little also for cabinetmakers' work. The price of pitch pine is rather lower than that of the native larch wood; the same contains more pitch, and can be bought in long, clean blocks, but is not 80 fine as the former.

We are buying these woods at Genoa, Antwerp, or Hamburg. We could only make direct importations if small shipments could be forwarded at as cheap freight rates as large ones, aud prices made delivered, at our railway station, subject to inspection, as we must be very particular about the quality, and it would not pay us to send some one to the United States to bny and inspect these woods before shipment.

Messrs. Treichler \& Co., Zurich, boat builders, another prominent firm, write:

At our wharf we are using the following kinds of wood: Mahogany, Spanish cedar, cypress, pitch pine, yellow pine, white pine, Canadian spruce, and teak from the West Indies.

For yacht building in England, yellow pine is mostly used (planks and laths), it being lighter than pitch pine. The price of pitch or yellow pine should not exceed 200 francs per cubic meter ( $\$ 40$ per 1.308 cubic yards), delivered at Zurich. The quality should be an excellent one, as, for boat building, only wood free of knots and in every way faultless can be used. In order to reduce the freight charges, the woods should be delivered in planks 6 to 10 meters long ( 1 meter $=39$ inches), with a minimum width of 0.35 meter, and from 60 to 150 millimeters thick, or in logs or blocks of as great dimensions as possible, and ax-cut.

An excellent wood for the manufacture of small boats is known in America under the name of "white celar," and is used there in great quantities. We take a special interest in this kind of wood, which up to date is being furnished us by Hamburg and Bremen importers.

It is getting more difficult from year to year to find selected fine woods in Switzerland; other industries besides ours (such as are compelled to use fine, clear, and durable woods) will be compelled to use more American woods. There is no market for second qualities, parcels of which have from time to time been brought over.

Messrs. Treichler \& Co. are willing to undertake the sale, on commission, of yellow and pitch pine, white cedar, and Canadian spruce, if American wood exporters would make trial shipments to Switzerland, and they can at any time furnish satisfactory references.

\section{WAGONS AND CARRIAGES.}

\section{Mr. J. C. Geissberger, Zurich, carriage manufacturer, writes:}

American woods for the manufacture of carriages have for years been imported into Switzerland, but in an indirect way only, through Berlin, Hamburg, and English commission houses. 
This has reference to hickory woods required in the manufacture of wheels, as hubs, spokes, and fellies. The hubs are imported either in a rough state or finished; the spokes aro imported ready for use, and so are the fellies (finished, bent, and assorted in sizes to meet requirements).

For the other parts of our carriage manufactures, we also use walnut, acajon, and white wool, in boards of 10 millimeters $(0.3937$ inch $)$ thickness.

As to prices, we have to pay the following figures, delivered: Hubs, in the rough, made of American rock elm (sets of four), 9.40 francs (\$1.81). Prime hickory spokes, $1 \frac{8}{8}$ inches, 40 francs $(\$ 7.72)$ per hundred; $1 \frac{1}{2}$ inches, 42.50 francs $(\$ 8.20)$ per hundred; $1 \frac{5}{8}$ inches, 45 francs $(\$ 8.69)$ per hundred; $1 \frac{8}{4}$ inches, 47.50 francs $(\$ 9.17)$ per hundred. Prime hickory fellies, bent, 38 to 50 millimeters (1.5 to 1.97 inches) thick and 90 to 95 centimeters (35.43 to 37.4 inches) high (set of four), 13 to 15 franes ( $\$ 2.51$ to $\$ 2.90$ ); 38 to 50 millimeters thick and 110 to 140 centimeters ( 43.31 to 55.12 inches) high (set of four), 15.65 to 19.40 francs ( $\$ 3.02$ to $\$ 3.74$ ). Walnut planks, 3.60 to 4.80 francs $(69$ to 93 cents) per square meter (10.7642 square feet); acajou planks, 6 to 10 francs (\$1.16 to $\$ 1.93$ ) per square meter; white wood, about 2.25 francs ( $43 \frac{1}{2}$ cents) -all delivered free on board at Zurich and duty paid.

Mr. Geissberger is ready to import direct from America, if prices and terms are made satisfactory.

WOOI MATERIALS FOR FLOURING MILLS.

Mr. A. Millot, Zurich, writes that his requirements demand almost exclusively pine and beech woods, and these he uses in considerable quantities, other kinds of woods not being used to a large extent. Pine boards cost here 55 to 60 francs $(\$ 10.61$ to $\$ 11.58)$ per cubic meter, and beech boards 75 francs $(\$ 14.48)$ per cubic meter.

\section{LUMBER DEALERS.}

Messrs. R. Gintzburger \& Co., Romanshorn, write:

We have imported Florida pitch pine in an indirect way; we are, however, ready to make direct imports if prices are satisfactory. We can handle a shipload at any one time. The woods mostly required are red and white pine of first quality in boards of 5 to 6 inches in width by 1 inch thick; also in larger dimensions. We are also buyers of other varieties of wood.

\section{-Mr. Gottfried Baumann, Zurich, writes :}

As far as I know, the consumption of American woods here is restricted to walnut, niahogany, palissander, and pitch pine. The latter has been brought in direct of late in the shape of lumber. I hardly think that American wood could be imported with profit for bnilding purposes, because native timber, sawerl with angular edges, is sold at Zurich at about 37 to 40 francs $(\$ 7.14$ to $\$ 7.72)$ per cubic meter (35.316 cubic feet). Something might be done in American oak, but only in thick planks of first quality, at about 75 to 80 francs ( $\$ 14.48$ to $\$ 15.44$ ), delivered at Zurich. Large quantities of this article are being imported from Hungary.

Special attention is called to the communication of Messrs. Gebrueder Masera, at Winterthur, a large lumber firm making direct imports of American pitch pine, etc. They write as follows:

It is our opinion that American wood exporters could largely increase their sales in Switzerland, especially if they would offer such varieties of wood as can be brought into competition with the native woods. As long as American exporters seek a market for expensive woods only, no satisfactory results are obtainable, even if the 
quality is superior to that of the native woods. The wood trade of this country demands a great deal of the cheaper varieties.

The only American wood generally known here is the pitch pine, aud we dare say that the increase in the imports of this wood is due to the efforts of our firm, made for years past in this direction. Unfortunately, prices are always much higher than those for similar native woods, and, for this reason, their use is limited. In some cases, pitch pine is preferred on acconnt of its suitable climensions, or where wood containing a great deal of pitch is required for special purposes. This wood will always find a good sale for parquet floors, but only in the better qualities, and if prices could be lowered a little the sales conld be unch increased. Second qualities, as have sometimes been sent here, are not wanted, and it is in the interest of American exporters to ship only first qualities if they want to increase the demand.

Other American woods can be need, provided the qualities are as good and prices not higher than that of woods most in use here.

Switzerland imports great quantities of oak boards from the most remote sections of Hungary, etc., unfiuished parquetry especially. The freight charges on these shipments are just about double the freight charges from America to Switzerland, when sent in shiploads. If, therefore, the American oak wood can be used for parqnet flooring, as we suppose must be the case, and the raw product can be bought as cheap in the United States as in Hungary and Russia, the American product, no doul,t, will find ready sale in large quantities.

The native beech is also much used for parquetry, being as durable as oak and one-third cheaper. If America furnishes a wood similar to our beech, which is very hard, sales would be still more extensive than in oak wood.

As to dimensions and quality of oak and beech friezes, they should be as follows: Thickness, 27 millimeters (1.06 inches), with at least 1 to 2 millimeters surplus measure; length, mostly 60 centimeters (23.6 inches), or between 50 to 70 centimeters (19.7 to $27 \frac{1}{2}$ inches), with 3 to 5 centimeters surplus measure; width, mostly 12 centimeters ( 4.7 inches), or between 11 to 12 centimeters, with 3 to 5 millimeters surplus measure. The quality required is the perfectly air dried, clear of knots and spots, and of even color. The cuts mist, of course, he strictly parallel. As to prices, oak friezes will command about 40 to 50 per cent more, and beech friezes 30 to 40 per cent less, than pitch-pine flooring, delivered, freight and duty paid, in Switzerland.

There is also some demand for a cheap soft wood for flooring, which must also be perfectly free of knots, at a price not to exceed the price of first-class quality of native pine, which is sold about two-fifths cheaper than pitch pine.

I would suggest that American exporters address Messrs. Gebrueder Masera, this firm being the largest of Swiss wood importers. They are ready and willing to give any information desired regarding their own requirements, or on other woods needed here as lumber, for the manufacture of tables and chairs, box lumber, staves for hogsheads, etc.

\section{STAVES.}

Statisties show that Switzerland imports annually about 600,000 francs $(\$ 115,8(00)$ worth of rongh staves and finished cooper articles. The staves most in demand are of the smaller sizes, varying from 34 to 75 centimeters (13 to 29 inches) in length. Hungary supplies most of them. These staves are split and trimmed with the ax, and not sawed; they vary in width from 4 to 11 inches.

W. Weiss, Thalacker, Zurich, is the principal stave importer in this district. 


\section{RAILROADS AND S'TREET PAVING.}

For railroad building, wooden ties are gradually being replaced by iron ties, the latter being cheap and more durable.

Swiss cities have begun to pave their streets with wooden blocks, and, if results prove satisfactory, the use of wooden paving blocks will be increased.

\section{HOUSE FINISHINGS.}

During the two years 1893-1894 not less than 1,180 new houses have been erected in the city of Zurich alone, and although not much timber is used, stone and iron being the principal materials, a large quantity of wood is worked up for finishing purposes, as, for instance, for parquetry flooring, sashes, window frames, stairs, etc.

Parquet floors are very extensively used in this country, such being found in almost every house in Swiss cities. There are quite a number of factories in Switzerland that make parquet flooring a specialty for home as well as for export requirements.

Messrs. Haldimann, Wissler \& Co., Goldbach, Canton Berne, write:

We think that in a few years some of the American woods will play an important rôle in the Swiss markets. So far.the Swiss parquetry factories have been getting their supplies from IInngary, mostly, however, through Genoa, Antwerp, or Hamburg commission houses.

Pitch pine, cut in longitudinal sections (long friezes), sells in sizes of 25 to 33 millimeters thick at 90 to 95 francs per cubic meter ( $\$ 18$ per 1.308 cubic yards) delivered free on board track at Swiss stations.

Some American oak is also imported from time to time. If American exporters are desirous of competing with the Hungarian oak, they must sell the Swiss parquetry factories friezes, 25 to 33 millimeters ( 0.98 inch to 1.3 inches) thick and 30 centimeters to 2 meters (11.8 to 78.4 inches) and more in length, at a price not to exceed 100 to 155 francs ( $\$ 19.30$ to $\$ 29.91)$ per cubic meter, according to quality and dimensions, delivered and duty paid.

Other American woods, such as mahogany, hickory, walnut, etc., are imported for the manufacture of furniture.

Mr. Ferdinand Haldimann is the president of the Swiss Association of Parquetry Manufacturers, and this gentleman is willing to give interested parties all the necessary information, with a view to enter into direct trade relations, especially in the line of oak friezes, samples of which he solicits.

\section{CABINET WOOD FOR FURNITURE FACTORIES.}

\section{Messrs. Wolff \& Aschbacher, furniture makers of Zurich, write:}

American woods mostly imported into Switzerland are walnut, oak, palissander, mahogany, rosewood, etc., all being delivered in the shape of logs, lumber, or planks with angular edges.

We are aware that there are still a number of other American woods fit for the inanufacture of furniture, and up to the present time not imported, but are said to be rather cheap-that is to say, they are sold at abont the same prices which we have to pay here for our native woods, namely, 130 to 220 francs $(\$ 25.09$ to $\$ 42.40)$. 
It would be well for exporters to send samples of furniture panels with crossettes, the panels to be abont 15 centimeters in width to 20 centimeters in length (5.9 to 7.9 inches). This would give us an idea whether they wonld answer our purposes. We do not import direct, our requirements in American woods being small, but we purchase, as needer, from importers.

Another firm says that unfinished furniture, as frames, etc., in the rough might be imported to advantage, and asks for catalogues of such material.

Regarding household and office furniture of American make, the transportatiou expenses and customs duties are against us, yet something might be done in the line of fine furniture, which, as a rule, was for years imported to this district from Paris, but owing to the prohibitory tariff now being imposed on goods of French origin, the imports of such articles are restricted, and I am confident that business could be worked up with the American article.

From some of these communications it may be readily seen that more American woods are imported into this country than appears from the statistics, the bulk being bought from German or English importers; but if A merican exporters would make an effort to establish direct relations with dealers and large consumers. here they would not only save commissions, but no doubt largely increase sales.

It would be well to mention to American exporters that goods sent to Switzerland must be accompanied by a certificate of origin, and that the customs duties, which are specific, are collected invariably on the gross weight.

ZURICH, January 11, 1895.

Eugene Germain, Consul.

\section{SUPPLEMENTARY REPOR'T.}

While gathering the necessary information on American woods in Switzerland I ertered into correspondence with several Swiss firms. working up American and other woods, and incorporated a synopsis of answers received in my report. To day I am in receipt of a communication from the Swiss furniture firm of Meyer-Mueller \& Co., Winterthur and Zurich, which reached me after my report had gone forward.

This firm being a prominent concern, I give a translation of their letter:

Answering yours of January 5, we beg to inform rou that, up to date, to our knowledge, no ready-made American furniture has been introduced into Switzerlani, but we are of opinion that unfinisher American furniture in the rough (in pieces) could be introduced to advantage.

We have seen several Swiss furniture manufacturess who visited the World's Fair at Chicago, and from these we learn that American furniture manufacturers sell unfinished furniture and ship it knocked down. Wo think such furniture would find a realy market in this country, and could be finished in Switzerland to suit the tastes, as to color and finisl, of the swiss people. 
We would therefore thank you to put us in communication with one or two firstclass American furniture factories, with a view of making arrangements to try the venture and get a trial shipment.

The kind we manufacture are parlor, sitting-room and bedroom, and office furniture. As to our responsibility, we refer you to the Zuercher Bankverein, Zuerich, and the bank in Winterthur.

Eugene Germain, Consul.

ZURICH, February 1, 1895.

\section{AMERICAN LUMBER IN URUGUAY.}

The lumber trade of the United States with Uruguay and the Argentine Republic presents incongruities which can not but be harmful to the lumber interests of our country. To prove the truth of this it is necessary only to show the difference between the prices received by the lumber mill and the price the consumer has to pay for it here and to explain the reasons of the extraordinary difference.

The best means of demonstrating the above will be by giving an exhibit of a cargo sold here, with such explanations as will enable anyone interested in the matter to form an opinion for himself. Before proceeding further it is well to state the range of prices at which pitch or yellow pine lumber has been offered and the figures at which this lumber is generally sold to the consumer. The lowest offers known to me as made from the United States to the importers here is $\$ 19$ per 1,000 feet delivered in the port of Montevideo or Buenos Ayres, and the average price paid for pitch pine by the consumer is from $\$ 40$ to $\$ 50$ per 1,000 feet.

These Governments levy a duty for the privilege of allowing this lumber to be landed here almost equal to the amounts which the miller realizes for the original value of the raw material plus all the work and expenses of preparing it and getting it ready for shipment; this, too, in the face of the fact that this country produces no timber which could take the place of our pine; that it must be purchased from us, because it is neerled and is the cheapest in the market in spite of all the additional charges put on, thereby furnishing these Governments a source of revenue on an article the export of which destroys our pine forests uselessly and leaves the lumber manufacturer poor.

The following exhibit is of an account of sale for a cargo of pitch (yellow) pine lumber sold and shipped direct by the mill with intervention of their representative here:

Account of sale of a cargo of pitch pine per bark —, for - Montevideo.

Feet.

According to M. M.'s invoice ................................ 564,149

According to measurement of public measurer here, as per contract.... 564,116

Less reduction for sap, short measure in some dimensions, ancl on deck

load ........................................... 34,988

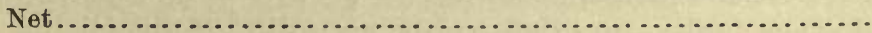

529,128 
529,128 feet, at $\$ 25$ per 1,000 feet.............................. $\$ 13,228.30$

Freight, at $\$ 12$ per 1,000 feet, according to charter party.

$6,129.70$

Total

Discount at 8 per cent on $\$ 6,000$ paid in cash by buyer on account

of freight, six months ............................. $\$ 240.00$

Measurer's bill, 25 cents per 1,00 ) feet ................... 141.02

Discount on note of buyer, at six months, at 7 per cent per

annum, and other expenses, stamps, telegrams, etc ......... 463.49

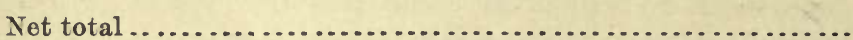

844.51

$6,254.09$

This amount was paid over in cash by telegraphic transfer in New York the same day of settlement here, with deduction of $\$ 10.45$ for cable expenses to bank.

The lumber trade here has so far been practically divided into two distinct branches, one being the importer, the other the dealer. The importer buys and contracts probably in conjunction with his New York commission merchant when and wherever the opportunity is most favorable, using capital to the best advantage in the markets at home, picking up bargains whenever lumber manufacturers are forced to make sacrifices, etc., and selling in cargo lots afloat, at time of shipment, to the lumber dealers here, who keep a regular stock on hand for dis tribution to the consumer.

It will be easily understood that the importers are very few in number in any one of these countries, and that it is to their benefit to keep the dealer as much as possible in the dark regarding the import lum. ber trade, and thus subject to themselves. With this object in view, a lot of customs and practices were inaugurated, which made it almost a matter of impossibility for an outside manufacturer or dealer in lumber to sell direct to the dealer here on account of the numberless vexations he was subjected to. Unless he knew and avoided these obstacles, or had some one here who could do this for him, he would come out loser at the end.

These practices apparently favor the actual dealer, but, in fact, the importer has been the one benefited, because they gave him entire control of the importing business and proved to be his safeguard against outside intrusion.

The methods of sales to dealers here are about the following: The lumber is sold and delivered on six months' credit from the time it has been officially accepted by the dealer, according to the various other customs hereinafter mentioned, viz:

1. The dealer is expected to be notified by wire immediately when the ship bringing the cargo he bought from the importer (or seller) is ready to sail, so as to give him time to dispose of all he can to his customers during the time of the voyage, a matter of not less than sixty days.

2. All lumber sold is supposed to be dry, clear of any sap, splits, knots, and other faults-in other words, according to the custom here, 
it is supposed to be faultless. If any faults are found in any plank, beam, etc., the proportion thereof is assessed against the seller by the public inspector appointed for such cargo.

3. All lumber, before it is accepted by the dealer, has to undergo an inspection and measurement by a public inspector, who is jointly chosen by seller and buyer, or each one has the right to name one separately. These inspectors measure the cargo and assess the percentage of reduction to be claimed, according to the lumber standard of this port, from the seller. According to this standard, no cargo can be brought here without some claim against it, the lowest amounting to about 4 per cent; but if it goes over 10 per cent, the buyer has the privilege of rejecting the entire cargo. Snch inspection is paid for half each by the buyer and the seller, and amounts to 50 cents per 1,000 feet.

4. As all the lumber is sold delivered here, the freight, of course, has to be paid by the seller, which means a cash outlay of sometimes more than the manufacturer gets for his lumber. The rate of freight rums on an average from $\$ 10$ to $\$ 14$ per 1,000 feet, $\$ 12$ being a fair average. Of course, arrangements can generally be made with the buyer to pay the freight on delivery of the cargo, but in any such case he will claim the percentage (discount) for the advance so made of said freight, and it goes toward reducing the a tual price at which the lumber is nominally sold. It is the same with six months' time notes which the seller receives from the buyer in payment of the purchase. These notes can be discounted so long as the buyer is considered good, but this further reduces the actual price supposed to have been realized for the lumber.

Next comes the Goverument with its duty, which amounts to $\$ 8.25$ per 1,000 feet on pitch or yellow pine and about $\$ 15$ on white pine, and is calculated as follows: On a valuation fixed by the Government on pitch pine of $\$ 30$ per 1,000 feet for import purposes, no matter whether it has cost in reality perhaps only half of that, a duty of 20 per cent is charged, and, besides, about $\$ 2.25$ per 1,000 feet additional customhouse charges.

It will be seen that the freight and duty alone on pitch pine generally amount to $\$ 20$ and more; consequently, the dealer here, in selling to the consumer at from $\$ 40$ to $\$ 50$ per 1,000 feet, has a margin of from $\$ 20$ to $\$ 30$ to bedivided between the lumber manufacturer, the importer, and himself.

The manufacturer, in consideration of furnishing the actual material, being under the heavy expense of manufacturing, making all the advances until the article is marketable, and, finally, running the risk of losses of all kinds, has to content himself with about one-third of this division, and is satisfied if the New York commission merchant offers him at home this much. The importer, together with his commission merchant, running hardly any risk, satisfies himself for the outlay of his money for the time being with about one-sixth of this and grows independently rich on it, leaving to the actual dealer here the balance of 
three-sixths, with which the latter party is able to make himself quite comfortable.

That the importer, the dealer, the freighter, and the Government here are doing well on a business of this kind, goes without saying, but our manufacturer at home, having commenced business as a young man on a piece of timber land, and having worked hard all his life, finds himself when he has grown old, poor and without any resources, as the land from which the timber has disappeared without benefit to him is valueless without it.

What steps should be taken to remedy these hardships falling upon the producer in this brauch of industry, are for him to decide; but it would seem that a directconnection between the manufacturer and the actual dealer were preferable to the way this business has been done so far; or, still better, if the parties interested in the lumber-milling business would join together and establish rules of their own in order to protect themselves, and at the same time guard against the useless destruction of the timber wealth of our country without compensating benefit.

\section{Edgar Schramm, Consul.}

Montevideo, April 30, 1896.

\section{ASPEN WOOD FOR MATCHES.}

The manufacture of matches in Germany, which has risen to be an industry of importance, employs pine, poplar, aspen, linden, and birch woods. Of these woods, aspen has proved itself indispensable in the mauufacture of matches by reason of its natural qualities and the ease with which it can be worked up. It is distingnished by its large structure, ready combustibility, freedom from knots, and uniformity of substance.

The flame of a match, as is well known, is conveyed to the wood from the igniting composition by sulphur, as in the case of lucifers, into which the splints are dipped. In the case of Swedish matches the sulphur is substituted by paraffin. The sulphur, where this is used, remains on the outside of the wood and dries at once. The paraffin, however, must penetrate into the wood, partly because the matches would otherwise stick to each other, but principally because the paraffin becomes fluid again at even low degrees of heat and would penetrate the igniting composition and render it useless. For safety matehes, therefore, a wood is required which has light and spongy pores, as found only in the aspen, whose bright white color further gives it an agreeable appearance. Poplar has a gray color and is brittle; birch wood becomes yellow and is seldom obtainable in stont logs. These woods are also slow of combustion. Pine and fir woods take up little parafiun, owing to the resin they contain. 
In order to keep the pores as open as possible, and also to work up the wood to the greatest advantage, the aspen splint is produced by flaking. Aspen possesses the quality of being flakable to a very high degree. The flaking is done by causing a knife to revolve round a log which rotates on its own axis. The wood is divided into ribbons of the thickness and width of a match. These ribbons are laid evenly, one above the other, and cut into square splints. In consequence of the uniformity of the annual layers, aspen wood produces perfectly homogeneous ribbons or splints. This is not the case when other kinds of wood, like fir, etc., are flaked. The absence of all structure or grain further enables aspen. wood to be Haked into thin shavings, which are worked by other machines into the familiar match boxes. Just this fact that both match splints and box shavings can be produced by one machine from one material calls for the employment of aspen wood. Attempts have been made to flake fir and pine woods as substitutes for aspen, but it is not known that any results of importance have been obtained. The reason why the last-mentioned woods can not be flaked is, probably, because of the difference in the annual rings between the spring and fall wood-that is, between the inside of the ring and its extreme outside the difference is too great. The fall wood is too solid, the spring wood too soft, and the annual rings are of varying thicknesses, according to the location of the tree, while, even in the case of pine, the knife is apt to slip and cut ribbons of unequal thickness. In the case of aspen wood each ribbon is like the other, a circumstance which is of the utmost importance for the further processes.

Match manufacturers require that the aspen wood should be free from rotten pith and, as far as possible, free from knots-free from pith, otherwise the wood can not be fixed in the flaking machine; free from knots, because the wood round the knots is decayed. The wood should further be straight grown and of loose texture. The aspen is available for match making as soon as the trunk has a diameter of 8 inches. The demand is greatest for trunks with a diameter of 10 to 20 inches. To attain this size a period of twenty-five to sixty years is necessary, according to the nature of the soil, position, etc. Trunks from twenty to thirtyfive years old are preferred to younger growths for the reason that the method of manufacture produces the same amount of waste, whether the trunks be small or large.

The match factories which employ aspen wood are mostly situated in Silesia, Pomerania, Schleswig-Holstein, Bavaria, Rhine Province, Alsace-Lorraine, Rhine Palatinate, and the Duchy of Anhalt. These factories use on the whole $4,000,000$ to $5,500,000$ cubic feet of aspen wood annually, of which about $3,500,000$ cubic feet are imported from Russia.

The Silesian factories, mostly through dealers, procure their wood from Upper Silesia, Poland, Galicia, and Hungary. To procure wood from the districts of Königsberg and Gumbinnen is unprofitable, 
because the freight is considerably higher than from Cracow or the Tatra. Regular direct purchases in Upper Silesia are not possible, for the reason that there are no large compact stocks of trees, and the various individual forests only produce a few earloads each, which are too dear when account is taken of the personal attendance requisite to purchase. The cubic meter (35.316 cubic feet) of aspen wood, delivered free at railway station, costs from 17 to 26 marks ( $\$ 4.05$ to $\$ 6.19)$, according to quality-aspen of 25 to 50 centimeters diameter, 26 marks (\$6.19); of smaller diameter, 20,21 , and 24 marks $(\$ 4.76, \$ 5$, and $\$ 5.71)$. The wood from Poland, Galicia, and Hungary is not essentially dearer than the wood from Upper Silesia. Where grown it costs 10 to 14 marks (\$2.38 to \$3.33), and, although the customs duty has to be added to this, the higher price is compensated for by the superior quality of the wood. The freight rates are various. Ten thousand kilograms (22,146 pounds) contain abont 12 to 14 cubic meters (424 to 615 cubic feet), the freight for which from Upper Silesia would be about 50 to 60 marks ( $\$ 11.90$ to $\$ 14 .: 8$ ), and from Poland and Galicia, about 120 marks $(\$ 28.56)$.

For the factories in Pomerania the principal sources of supply are Riga, Kovno, Libau, Windau, and St. Petersburg, where dealers do a lively trade. The wood is felled in the forests, brought down to the sea, and shipped when water communication is open. It is sold in the form of logs from 3 to 7 meters (16.4 to 23 feet) in length, with both ends cut smooth. The ports through which aspen wood is imported are Königsberg, Danzig, Kolberg, Riigenwalde, Flensburg, Liibeck, Amsterdam, Antwerp, Stettin, and Bremen. The prices for Russian wood vary according as the wood comes rafted or unrafted to the market. Unrafted wood costs delivered in Bremen, including the customs duty of 1.20 marks, 25 marks (\$5.95); rafted wood, 21 marks (\$5). Such prices, however, are only good for contracts for the whole year; in other cases they are about 10 per cent higher. The freight rates by direct steamer from Riga are 16 to 18 pfennigs (3.8 to 4.3 cents) per cubic foot, and from Kovno, via Lappienen-Königsberg, by lighter, about 10 pfennigs (2.4 cents) per cubic foot delivered in Danzig. The prices are advancing from year to year.

The factories in Anhalt use native wood partly, from the neighboring forests, and partly Russian wood, via Stettin. The price is 28 to 30 marks (\$6.66 to $\$ 7.14)$.

For Westphalia the wood is shipped in steamers from Riga to Amsterdam and thence by rail. The cubic foot delivered in Amsterdam costs from 71 to 86 pfennigs ( 17 to $20 \frac{1}{2}$ cents), according to quality.

In Alsace-Lorraine the wood is taken from native forests, but it is no longer very thick and can not be flaked, but must be planed. The stocks have been freely felled in the last ten or fifteen years, and no care has been taken to replace them. In consequence of the enormous expense the wood of East Prussia is out of the question for the Alsa- 
tian factories, which are, therefore, in a very difficult position. Prices here have risen 10 to 15 per cent in late years and are still rising.

The factories in Schleswig-Holstein procure Russian wood via Libau and Königsberg. The freight rates from the former eity are 5 marks (\$1.19) and from the latter 6 marks (\$1.43) per cubic meter $(35.316$ cubic feet). The price for wood, duty paid, is 20 to 21 marks $(\$ 5.76$ to $\$ 6)$ per cubic meter.

In the Rhine Palatinate Russian wood is partly used, which costs 34 marks (\$S.09) per cubic meter, duty paid and delivered free.

The factories in the Hundsriick use aspen wood from the forests in Nassan, Bavaria, and the Eifel. Russian wood is too expensive. The wood is procured in logs of 2 meters ( 6.5 feet) in length.

In Bavaria, where the wood is also becoming scarce, native wood from Upper and Lower Bavaria is used. The wood is furnished sawed in lengths of 2 meters ( 6.5 feet), as logs of such lengths enjoy lower freight rates.

The rapid decrease of the native stocks of the aspen, and the subsequent enhancement of the prices of this raw material, together with the difficulty of obtaining it, led a number of chambers of commerce to memorialize the Minister of Agriculture and Forestry and petition him to cause the foresters in whose districts match factories are located to pay more attention to the growth of the aspen. A similar representa. tion has been made by parties concerned to the French authorities. The Russian manufacturers seeing their advantage over their German and French colleagues, were not slow in petitioning their own Government to prohibit the exportation of aspen wood.

This European scramble for aspen wood can well be settled by supplying these factories with wood from the United States, where the aspen is yet an ubiquitous tree, used but little for mechanical purposes.

IMPORT'S AND EXPORTS OF MATCHES.

In connection with the above, the following tables, showing the value of matches imported into and exported from Germany in 1893, will be of interest:

\section{Imports.}

Sweden $\$ 30,762$

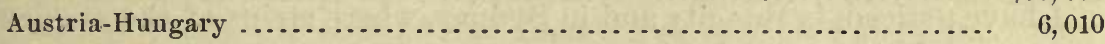

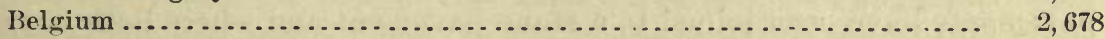

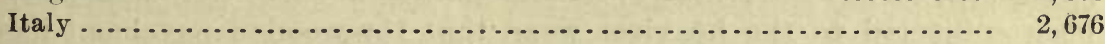

Total 
Exports.

\begin{tabular}{|c|c|c|c|}
\hline To- & Value. & To- & Value. \\
\hline Europe, Asia, and Africa: & & America: & \\
\hline Netherlanas........... & $\$ 65,688$ & Central American republics & \\
\hline $\begin{array}{l}\text { Belgium ........ } \\
\text { Greece........ }\end{array}$ & $\begin{array}{l}63,014 \\
23,800\end{array}$ & Brazil ${ }_{\text {Haiti }}^{\text {Ba. }}$ & $\begin{array}{r}11,186 \\
9,282\end{array}$ \\
\hline 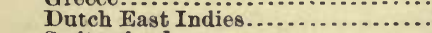 & 22,134 & 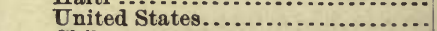 & $\begin{array}{l}y, 282 \\
2,618\end{array}$ \\
\hline 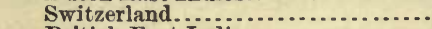 & 14,756 & 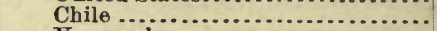 & 1,666 \\
\hline British East India................ & 11,900 & Venezuela ...................... & 1,190 \\
\hline West A frica $\ldots \ldots \ldots \ldots \ldots \ldots \ldots$ & 10,710 & Argentine Republic ............... & 952 \\
\hline $\begin{array}{l}\text { Great Britain } \ldots \ldots \\
\text { Austria-Hungary } \ldots \ldots \ldots\end{array}$ & $\begin{array}{r}10,472 \\
9,282\end{array}$ & $\begin{array}{l}\text { Colombia } \\
\text { Ecuador }(\ldots \ldots \ldots\end{array}$ & $\begin{array}{l}952 \\
714\end{array}$ \\
\hline Italy................................ & 8,568 & Uruguay ${ }^{\prime}, \ldots \ldots$ & 476 \\
\hline Turkey ........ & 1,190 & West Indies ................. & 238 \\
\hline Total & 238,514 & Total & 50,542 \\
\hline Other countries... & 4,874 & Grand total. & 293,930 \\
\hline
\end{tabular}

TheOdore M. Stephan,

ANNABERG, March 22, 1895.

Consul.

\section{AUSTRALIAN WOODS FOR STREET-PAVING.}

At the present time, when this country is recovering from the recent financial cyclone, and when the business outlook is daily growing more promising, it is not inappropriate to consider by what means the commerce between the United States and the Australian colonies can be increased to mutual advantage.

It has occurred to me that a large and protitable business can be done between the two countries by the shipping to the United States of wood blocks for street-paving. The advantages to be derived are manifold.

Wood pavements are admittedly the best in the world, and of late years they have only been abandoned in the United States owing to the fact that no wood of native growth could be found that would stand the wear and tear of the heavy traffic in our large cities.

In this country one is compelled to notice and give the palm to the street pavements made from blocks of red and blue gum, a wood grown in this country, which have proved to be equal to all requirements.

I have noticed, in this city and in Sydney, where strips of the wonden pavements have been joined to a stone pavement and where both have been subjected to the heaviest wear, that the wooden pavement has worn even better than the stone, and, where the two pavements join, the edges of the wood blocks are not even chipped or worn.

It is a pity that our country, which is so far ahead of other lands in many respects, should be so far behind in this matter of street-paving.

Can we not adopt the Australian wood blocks to advantage? If a fair trial could be given by some of our cities, I am sure that it would result in the adoption of Australian timber for street-paving in the United States and thus open up a new industry between the two countries. 
Perhaps the very best timber obtainable for this purpose is the Tas. manian blue gum. This has worn here for six or eight years. In all that time no repairs have had to be made, and the pavements are as good to-day as when laid.

The Tasmanian government is interested in the matter, and have taken active steps to place samples before our contractors and municipal authorities.

An American exporting and importing firm doing business here, with a branch in New York City, recently visited Hobart, the capital of Tasuania, and laid the matter before the premier. They were most courteously received, and at their suggestion the premier caused to be shipped to them in New York samples of these blocks, which can now be seen at the office of Messrs. Trowbridge \& Terry, 531 Broadway.

While these hard woods are plentitul here, it must be remembered that the cost of freight, etc., would bring them to New York at a price probably no lower than cedar blocks can be obtained at home; but consideration must be given to their durability and vast superiority.

It is not unlikely that in view of opening up this trade with the colonies and at the same time benefiting our own land, arrangements might be made to admit these blocks free of duty.

The demand at home will be endless and the supply here inexhaustible, and the benefits resulting from the adoption of these blocks apparent. For instance, all sailing vessels coming to this port from the United States are, in nearly all cases, obliged to go to other ports seeking return cargoes. Should the wood blocks be accepted and used in the United States, these vessels could all get return freights here, and thus the trade between the two countries would be profitably increased.

Daniel W. Maratta, Consul-General.

Melbourne, January 12, 1894.

\section{A VALUABLE TREE IN NEW CALEDONIA.}

From time to time I have received requests from citizens of divers Southern States for seed of the niaouli tree of New Caledonia. This tree (Melaleuoa leucodendron) is the characteristic wood of this country. It blooms in January and June. Its wood is of a reddish color and hard. It works well, more especially for wheelwright purposes. It has a suberous or cork-like bark, and replaces cork in some of its usages. The leaves are employed for medical purposes; when distilled; they give an essence which is a powerful antiseptic. It is generally admitted that the exceptional salubrity of New Caledonia is due to the essence of this wood. The vicinity of swamps is not dangerous to health here. It is probable that the above facts are known to some 
residents of the United States, hence the requests for seed which have reached me. I send a small parcel of the niaouli seed to the Department of Agriculture through the United States dispatch agent at San Francisco. The seed is still mostly attached to the boughs in its pods. These should be bruised before planting. Each pod contains a large quantity of seed, which are very small and shaped like a comima. They should be sown in the spring in hotbeds of light earth, well watered at all seasons, and always kept from frost. The young plants are ready for transportation in fifteen months after sowing, when no more care is necessary in climates not subject to frost.

L. Le Mescam, Commercial Agent.

Noumea, May 14, 1894.

\section{LUMBER IN COSTA RICA.}

The native woods principally utilized as lumber consist of two or three varieties of cedar, as well as several cheaper and less durable woods unknown in northern countries.

Of imported lumber, pine is the only kind used in any quantity, with some oak brought for use of the railroad in its repair shops. The principal objection to pine and other foreign lumber is that in a very few years it is attacked by insects, which eat through the stoutest pieces and completely destroy them.

The value of lumber imported from the United States during the year 1893 was $\$ 3, \$ 16$ in American gold.

There is an import duty of, say, $2 \frac{1}{2}$ cents in American currency per kilometer (2.2046 pounds) on lumber such as boards, rafters, and for construction purposes generally.

According to a Government decree dated July 28, 1890, all lumber for construction imported for use in Port Limon is free of duty till July $29,1895$.

Cedar is worth about $\$ 6$ and mahogany about $\$ 8$ (American money) per ton of 40 cubic feet.

In view of the small demand for foreign lumber and the condition of general building at the present time, there is very little to be suggested in the way of extending trade. Sawmills are being erected in different parts of the country, and native woods are well adapted for most local building purposes.

HARRISON R. WiLliams,

Consul.

SAN José, July 2, 1894. 


\section{LUMBER IN QUEBEC.}

Consul Philip B. Spence, of Quebec, under date of January 8, transmits a circular prepared by J. Bell Forsyth \& Co., showing the supply, export, and stock of timber and deals at that port in 1894, from which the following extracts are given. The figures cover up to December 1 .

\begin{tabular}{|c|c|c|c|}
\hline Description. & Supply. & Export. & Stock. \\
\hline 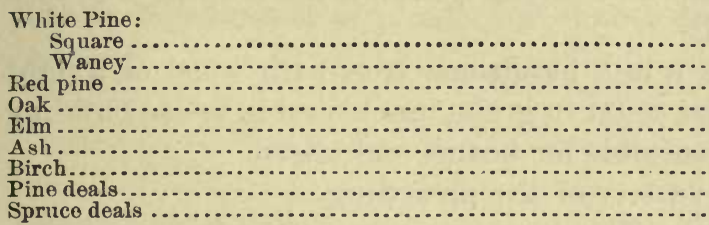 & $\begin{array}{r}\text { Feet. } \\
838,246 \\
2,288,663 \\
59,835 \\
1,276,869 \\
528,761 \\
183,626 \\
131,191 \\
647,408 \\
3,447,856\end{array}$ & $\begin{array}{r}\text { Feet. } \\
3, \mathbf{4 6 8 , 6 0 0} \\
146,120 \\
937,840 \\
128,880 \\
134,929 \\
189,920 \\
479,700 \\
3,462,800\end{array}$ & $\left\{\begin{array}{r}\text { Feet. } \\
1,656,993 \\
1,610,571 \\
282,084 \\
699,205 \\
244.145 \\
99,659 \\
13,242 \\
63,624 \\
579,774\end{array}\right.$ \\
\hline Total... & $9,402,455$ & $8,948,789$ & $5,249,297$ \\
\hline
\end{tabular}

\section{The circular says:}

We note with regret a continued decrease in the business of the port. The growing scarcity of some descriptions of timber and the advanced cost of others have reduced the supply on the one hand and limited the export by diminishing the consumption on the other.

The concession of the use of steam in taking on board timber, obtained by the shipping merchants from the ship laborers, in connection with steamers, has resulted in the transfer of an increased proportion of the export carrying trade from sail to steam, and has to some considerable extent checked the tendency to send timber from Montreal by steamer in preference to shipping from Quebec.

The market this season for South American lumber has been fairly active, both direct from the Province of Quebec and via Portland, Boston, and other North American ports. From the ports of the maritime provinces the spruce trade to the Argentine Republic has been unusually active, and from Montreal heavy shipments of pine to same destination were made near close of season. Prices range as follows: Spruce, $\$ 11$ to $\$ 13.50$ per 1,000 feet, B. M., according to specification; pine, $\$ 17.50$ per 1,000 feet, B. M., for common to $\$ 50$ for clear.

Owing to the depression in the United States, the lumber market there has not been as good as expected, still all good lots of spruce suitable for that market have realized about the same price as in 1893, and manufacturers expect an increase of at least $\$ 1$ per M. for the 1895 cut.

Freights opened at about 16s. Clyde and 18s. Liverpool for sail from Quebec, and at 40s. for deals by steam from Montreal. Timber rates remained without any change till advanced insurance toward end of season prevented timber shipments except by steam, for which the rates ruled from 62s. to 70s. per Petersburg standard intake, according to port of discharge. Steam freights from Montreal were greatly depressed during the greater part of the season, and for some time rates previously unheard of, such as 30s. for Glasgow, Avonmouth, and Liverpool, with 35s. for London, were current, closing at some advance, especially for Liverpool. 


\section{LUMBER TRADE OF THE STRAITS SETTLEMENTS.}

In the dense jungles that still cover a vast portion of the Malay Peninsula and the adjacent islands there exist many rare and valuable forest trees indigenous and peculiar to this region. Of these I shall proceed to enumerate and briefly describe the nine best known lumber-yielding varieties.

Seriah (hopea).-This is a tall, handsome tree, with wood of a light red color, resembling coarse cerlar in grain, much used in house building for joinery work, but not suitable for beams and joists.

Mercanti.-An inferior variety of the preceding.

Jelulong (dyera costulate).-This is a large tree, with soft, white wood, used for models, cases, and work where strength and durability are not essential.

Darrou (sideroxylon sundaicum).-A heavy, close-grained wood, resinous and aromatic, which, though well adapted to carpenters' work, does not resist exposure to the weather sufficiently well to admit of being used to advantage in exterual constructions.

Balan (not scientifically determined).-A fine, large forest tree, 60 to 100 feet in height and 3 to 6 feet in diameter, with hard, heavy, closegrained, tenacious wool of a light brown color, much used for joists and beams and for all purposes where strength and durability are required.

Tampinis (sloetia sideroxylon).-A close-grained wood of rich brown color, susceptible of a high polish, and closely resembling mahogany; most highly prized for joinery and building purposes on account both of its great durability and of the fact that it is not affected, as are other woods, by the ravages of the white ant, so destructive to timber in these latitudes.

Karangie (dialum indicum).-A tall, handsome tree, often found growing to a height of 60 feet, with a diameter of 4 feet. Its wood is hard, dark colored, clurable, and often finely grained. It is used for furniture, and, to a certain extent, for building purposes.

Damarlant (canarium species).-One of the great Malayan forest trees, especially plentiful in the neighborhood of Penang, where it is much used for house building. Its wood is light colored, close grained, and lustrous, and is admirably suited for beams and joists on account of its great transverse strength and stiffiness.

Mirabou (afzelia palembanica).-A large, majestic, leguminous forest tree, with tough, stiff, durable, beautifully grained wood, susceptible of fine polish, and well adapted to furniture making. 
The kinds most extensively handled as lumber in this market and the prices per ton of 50 eubic feet are the following:

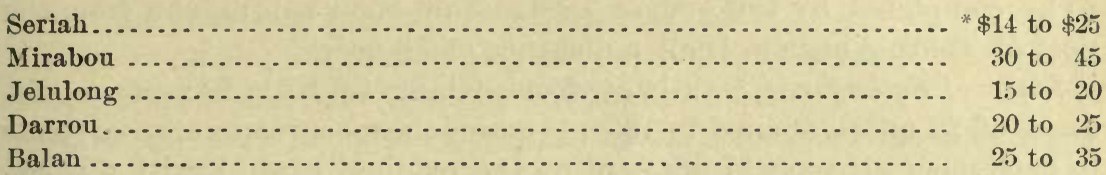

In addition to the above, there is considerable teak wood imported here, mainly from Burmah and Siam, which commands on the spot from $\$ 40$ to $\$ 65$ (Mexican) per toll.

The value (in Mexican dollars) of the exports and imports of the Straits Settlements of planks and timber during the year 1893 was as follows:

EXPORTS.

\begin{tabular}{|c|c|c|c|c|}
\hline Kind. & Singapore. & Penang. & Malacca. & Total. \\
\hline 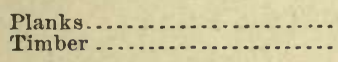 & $\begin{array}{r}\$ 492,788 \\
382,450\end{array}$ & $\begin{array}{r}\$ 99.094 \\
35,245\end{array}$ & $\begin{array}{l}\$ 425 \\
\cdots\end{array}$ & $\begin{array}{r}\$ 592,307 \\
417,695\end{array}$ \\
\hline Total .... & 875,238 & 134,339 & 425 & $1,010,002$ \\
\hline
\end{tabular}

IMPORTS.

\begin{tabular}{|c|c|c|c|c|c|}
\hline & Kind. & Singapore. & I'enang. & Malacca. & Total. \\
\hline $\begin{array}{l}\text { Planks.. } \\
\text { Timber. }\end{array}$ & & $\begin{array}{c}\$ 181,108 \\
141,337\end{array}$ & $\begin{array}{r}\$ 48,468 \\
47,499\end{array}$ & $\begin{array}{r}\$ 8,542 \\
6,672\end{array}$ & $\begin{array}{r}\$ 238,118 \\
195,508\end{array}$ \\
\hline Tota & & 322,445 & 95,967 & 15,214 & 433,626 \\
\hline
\end{tabular}

From the above tables it will be seen that the lumber exports of the whole of this colony exceeded the imports by $\$ 576,376$ (Mexican). The imports of lumber here are mainly from Burmah, Siam, and Dutch India; the exports to Arabia, Bombay, the Malabar coast, Hongkong, China ports, French Indo-China, German New Guinea, Mauritius, Siam, Sumatra, and North Borneo. There is no import duty imposed upon lumber of any description in this colony.

The climate of the Straits Settlements is moist and tropical, with an annual rainfall of from 88.48 inches to 126.29 inches, an average mean temperature of between $80.5^{\circ} \mathrm{F}$. and $82.1^{\circ} \mathrm{F}$., and no perceptible change of seasons throughout the year.

At present there is but little being done here in the way of general building, and shipbuilding is confined to the construction of launches and native junks and to the repairing of steam and sailing vessels.

In the Straits Settlements proper there are no railways. Those constructed, or in course of construction in the Native Protected States of the Malay Peninsula, are as follows:

State of Perak.-A railway from Port Weld to Taiping (8 miles) was opened in 1885; an extension to Kanumberg, opened in 1890; to Uln 
La'petang in 1892, and a survey is now completed as far as Kuala Selama. The Kintu Valley Railway has been begun, and is expected to be completed by the end of 1894. This road will extend from the port of Telok Auson to Ipoh, a distance of 50 miles.

State of Salangor.-A railway from Klang to Kula Lumpor, a dis tance of 22 miles, opened in 1886, is one of the most remunerative roads in existence. It pays 17 per cent on the original capital, with a working expenditure of 46 per cent of the gross receipts. An extension to Rawang, Serandah, and Kuala Kubu, a total distance of 38 miles, is under construction.

State of Sungeillgoing.-A railway $24 \frac{1}{2}$ miles in length, from Port Dickson to Seremban, was opened in 1891.

Considering the vast sources of supply which it has so much nearer at hand, I do not see that there is any opening in this market for the extension of trade in American lumber. I believe, however, that our sawmilling machinery might be introduced here to advantage.

E. Spencer Pratt,

Consul-General.

SINGAPORE, July 2, 1894.

\section{LUMBER IN WESTERN INDIA.}

NATIVE WOODS.

The principal native woods are teak, rosewood, and walnut. Rosewood, or blackwood, is largely used for yokes, cart-wheels, plows, knee timbers for boats, handles for knives, etc. It is also used for cabinetmaking. In its wild state the tree attains a height of 60 to 80 feet, with a girth ranging up to 20 feet. It is fine-grained, strong, and heavy; reight per square foot, 50 to 54 pounds.

East Indian walnut generally grows very fast, attains a height of 50 to 65 feet, and a girth of 6 to 10 feet; weight of wood per cubic foot, 40 to 60 pounds. It is used for picture frames, sugar-cane crushers, oil mills, etc.

Teak is one of the most valuable woods used in India; it does not warp, and the white ants, which are most destructive insects in India, do not touch it. The wood lasts many years, and changes in appear. ance as it grows old. In an old Hindoo cave, about 90 miles from Bombay, there is a ceiling lined with teakwood which is said to have been in position twelve hundred years. Teakwood is mostly used for slipbuilding, construction of houses, and cabinetmaking. It is the best lumber to be found for making furniture.

\section{GENERAL BUILDING.}

In the Presidency of Bombay there were $154 \frac{1}{4}$ miles of railway uncier construction in the official year 1892-93, and 1,256 $\frac{3}{4}$ miles surveyed and 
under survey. All the railroad companies have their own car shops and build their own ears. Iron sleepers are largely used in place of wood. Locomotives are imported from England.

There is no shipbuilding of any consequence; only small steam and sailing craft of not over 200 tons burden are built.

Buildings (with but few exceptions) are of stone, and the majority of the large public buildings, and many business and private houses, show fine architectural skill. As a rule, they are large and airy.

\section{CLIMATE.}

The climate here is tropical. The seasons are divided as follows: December to March (121 days) is the cold season; April and May (61 days) are hot and dry; June to September (122 days) is the rainy season, and October and November (61 days) are hot and damp. The tempera. ture ranges from $70^{\circ} \mathrm{F}$. to $98^{\circ} \mathrm{F}$, rarely above $92^{\circ} \mathrm{F}$. Humidity ranges from 69 per cent in the cold season to 88 per cent in the rainy season. During June, July, August, and September (the rainy season), which is called the "monsoon" period, clothing, leather, and ironwork are damaged or destroyed by the action of the elements, unless the greatest care is taken.

\section{PRICES OF LUMBER.}

Blackwood or rosewood per ton, at Cochin, $\$ 15$ to $\$ 22$; other ports, $\$ 6$ to $\$ 12$. Cut in the forest, prices are from $\$ 3$ to $\$ 15$ per ton. The rate of transport to coast (floating in streams) is nil.

Teakwood per cubic ton: Burma teak cut lumber, 1 by 1 inch by 3 feet and upward, $\$ 16 ; 2$ by 6 inches by 3 feet and upward, $\$ 22$; beams, $\$ 17.50$ to $\$ 28$; logs (per 10 hundred weight) $\$ 2.50$; Singapore teak, beams, and planks, $\$ 18$.

Norwegian deal boards, 6 by $\frac{3}{8}$ inches by 12 to 24 feet, $\$ 21$ per cubic ton; Hull deal boards, 6 by 1 inches by 12 to 24 feet, $\$ 21$ per cubic ton; American deal boards, 6 by 1 inches by 12 to 24 feet, $\$ 21$ per cubic ton.

\section{CUSTOMS DUTY.}

The duty on timber from foreign countries is 5 per cent, to which must be added a city (Bombay) custom duty of $2 \frac{1}{2}$ per cent.

\section{IMPORTS AND EXPORTS.}

The imports and exports of teak into and from Bombay during the fiscal year ending March 31, 1892-93 were as follows: Imports, 70,914 cubic tons, valued at $\$ 807,918.98$; exports, 8,490 tons, valued at $\$ 144,487.50$.

Imports and exports of all other timber, in 1892-93 were: Imports, 7,846 cubic tons, valued at $\$ 55,583.23$; exports, 1,553 cubic tons, valued at $\$ 13,633.62$.

Вомвау, June 22, 1894.

H. J. Somyer, Jr., Consul. 


\section{TIMBER INDUSTRY OF THE ARGENTINE REPUBLIC.}

In my former reports I have made frequent reference to the wonderful timber resources of the Argentine Republic. They consist entirely of hard woods, susceptible of the finest polish, and specially adapted to eabinet and other fine work. For years they have found a considerable market in Europe, though the expense of developing them-as they are found only in the far interior provinces and in the Chaco regions of the Paraná and Paraguay rivers-prevents them from coming into more general use. In the last few years, also, there has been much inquiry for red quebracho chips and extract, for tanning purposes, and it is believed that a large business could be done by enterprising eapitalists in meeting this demand. The timber industry, however, during the past year has shown no increase in activity, though shipments to Europe have been quite steady, while the home consumption of these magnificent woods by the wood manufacturers now located here is beginning to assume considerable importance. In the following table I give the value of annual exports of Argentine hard woods from 187.j to 1895 :

\begin{tabular}{|c|c|c|c|}
\hline Year. & Value. & Year. & Value. \\
\hline 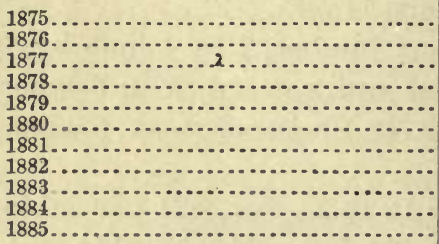 & $\begin{array}{r}\$ 21,171 \\
10,541 \\
57,090 \\
14,943 \\
58,793 \\
36,403 \\
272,613 \\
222,358 \\
257,887 \\
394,848 \\
339,022\end{array}$ & 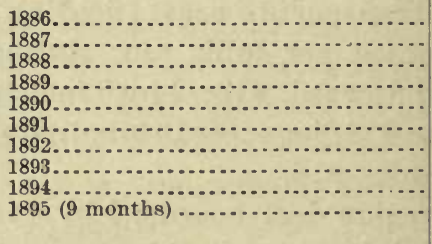 & $\begin{array}{r}\$ 326,623 \\
330,214 \\
781,793 \\
799,257 \\
1,413,224 \\
2,145,510 \\
1,066,819 \\
1,618,220 \\
1,511,145 \\
1,603,203\end{array}$ \\
\hline
\end{tabular}

The exports of the extract of "quebracho Colorado" for the first nine months of 1895-the first time its export has appeared in the eustomhouse returns-amount to the sum of $\$ 238,042$. The exports of red quebracho chips or chunks (rollizos) in 1893 amounted to 63,297 tons, valued at $\$ 632,970$; in $1894,74,358$ tons, valued at $\$ 743,582$; for the first nine months of $1895,127,330$ tons, valued at $\$ 1,273,298$, thus show. ing the inereasing demand for this timber for tanning purposes. Nearly all these shipments were destined for Great Britain.

Besides this foreign demand for the red quebracho, the demand for it at home continues to increase. In addition to the use of it for cabinetwork, furniture, doors, sills, window frames, etc., the immense timbers are employed for sleepers, beams, joists, bridges, and other like purposes. And now the streets of Buenos Ayres are being paved with red quebracho parallel-opipedons with most satisfactory results.

Several years ago a movement was made to send the red cedar of the Misiones to the United States, and several cargoes were shipped, but 
the expense of getting the timber to the banks of the Parana River and thence down to tide water, to say nothing of ocean freights, soon proved that there was no money in the enterprise.

I have heretofore referred to the company organized in this city to bring the woods of Terra del Fuego to Buenos Ayres. I understand that the project is being worked with some success. The timber received from there has the name of "caique." It is easily worked, and excellent for furniture. Here it goes under the name of "guindo." It is destined to have a good demand.

The manufacture of furniture here is an established industry. It began in 1890, when a prohibitive tariff was put upon the machinemade furniture of the United States, and it has so extended that now all the best styles and qualities of foreign furniture and cabinetwork are turned out in this city.

Buenos Ayres, January 24, 1896.

E. L. BAKER, Consul.

\section{TIMBER RESOURCES OF SPAIN.}

But little attention is paid in Spain to the cultivation and care of forests, although they are sorely needed in almost every province, not only to supply the requirements of commerce and trade, but also to adorn the landscape, to invigorate the soil, and to preserve the crops from the devastations of droughts and floods. As a rule, such forests as do exist in Spain are remote from the littoral towns and cities, and they are, therefore, of comparatively small value, except as fuel for local purposes, inasmuch as the railway facilities for transportation are small and the freights are high. Rich as Spain is in nature's gifts, she will always remain undeveloped so long as she fails to bring the productive regions of her soil into rapid and cheap communication with her cities and towns and with the rest of the world. A country in which the trains run only 15 or 20 miles an hour can never compete with a country in which they run 30 or 40 miles an hour; nor can a country in which the freight rates are practically prohibitive compete in her own littoral markets with countries that can ship to them prod uce and goods at easy and advantageous rates. The distance from Barcelona to the French frontier is 103 miles. To cover that distance, it takes the express train nearly six hours; that is to say, the train goes at the rate of about 17 miles an hour, and Barcelona, be it remembered, is the largest port of Spain. Furthermore, it costs more to bring goods from Saragossa (about 200 miles from Barcelona) than by ship from England. If ever Spain realizes the importance of rapid transit, there is absolutely no reason why she should not take a good position among the wealthy and prosperous nations of the world. The wealth she has always derived from her colonies has made her indifferent to the wealth that work and intelligence could secure from her own soil, and she will doubtless remain indifferent until she is forced by 
necessity to become introspective and develop her peninsular resources. She will then be able to cut down her importations very materially, especially those of minerals, cereals, and wood. Her importations of wood amount now to about $\$ 7,000,000$ annually. Of that sum, $\$ 2,500,000$ is paid for staves, most of which come from the United States. The remaining $\$ 4,500,000$ is employed in the purchase of pine from Finland, Sweden, and the United States, fir from Canada, beech from Hungary, elm from Austria, mahogany from Mexico, walnut from Italy, and from the storehouses in Havre, Bordeaux, and Marseilles considerable quantities of cedar, ebony, and sandalwood.

That a great variety of trees can be easily grown in Spain may be inferred from the fact that the following species are to be found here and are apparently thriving:

The palmetto (el palmito), found in Andalusia, Murcia, Valencia, and Catalonia.

The spruce fir tree (pinabete), a tree very common in France and Germany and very useful in building, is found in Spain in only Aragon and Catalonia.

The pine (pino) is of six kinds in Spain-el pino piñonero, used in naval construction and in earpenter work, and quite abundant in Andalusia and Castile; el pino silvestre, which grows to a height of 90 feet and is seen in the north and west of Spain; el pino negro, a wood easily polished, growing in the north of $\Lambda$ ragon and Catalonia; el pino negral de Cuenca, which grows in nearly all the mountainous regions of Spain; el pino carrasco, which is not so tall as the other kinds, and which makes good boards, being found principally in Murcia and Valencia, and also in Catalonia and Aragon; and el pino negral de Segovia, a dark pine, very common throughout the peninsula, but not very strong or elastic.

The elm tree is of two kinds-Ulmus campestris and Ulmus montana-and is seen in many parts of Spain in valleys and near rivers and in the promenades of some cities. The wood is hard and elastic and is used in making carts and machinery.

The white poplar (alamo blanco), a very common tree in all parts of Spain and much used by carpenters.

The yew tree (el tejo), hard and compact, and found in Sierra Nevada, in the Pyrenees, and in Asturias. It is used by ebonists and turners.

The black poplar tree (chopo), light in weight and serviceable as poles and handles and in the mannfacture of paper. This is one of the few trees that are cultivated in Spain.

The beech tree (haya), which grows to a height of 120 feet and forms large forests in the mountains of Navarre, Asturias, Logroño, Leon, and Santander, and grows in Burgos, Saragossa, Lerida, and Vizcaya.

The chestnut (el castaño) is useful in making staves, boards, doors, anl windows. It is seen chiefly in Galicia, Asturias, Santauder, Vazcongados, and Catalonia. 
The oak (el robla) grows in every province of Spain, and is a favorite for naval work, machinery, furniture, carts, casks, and barrels.

The cork tree (el alcornoque) is a great source of wealth to Spain, and forms large forests in Gerona, and is abundant in Cordova, Algeciras, Tarifa, Malaga, and Estremadura. As the forests of Gerona are near the coast, immense quantities are easily exported from there. I uring the year 1895 the exportations to the United States alone amounted to $\$ 305,884.90$ from Gerona and to $\$ 208,015$ from the other cork districts of Spain. Some of the forests are natural and some are cultivated; all thrive equally, and are probably the finest in the world of their kind.

The evergreen oak (encina) is also a very common tree in nearly all the provinces of Spain. Its wood is hard, compact, and strong, and is used in small piece work.

The birch tree (abadul), although ordinarily found in cold climates, grows well in the Pyrenees and is seen as far south as Madrid. The wood is used for domestic utensils, and its branches make good hoops for casks and barrels, as does also the wood of the hazelnut tree (avellano), which flourishes on the easteru coast of Spain.

Wood that can be easily polished is also found in the various provinces of Spain, such, for instance, as the walnut (nogal), juniper (enebro), white mulberry (la morera), wild olive (acebuche), the pear tree (peral), the apple tree (manzana), the orange tree (naranjo), the almond tree (almendro), and the lemon tree (limonero).

As yet no great efforts have been marle to test the eucalyptus tree in Spain, but there are some fine specimens of the globulus species in Catalonia, and also, I hear, in Malaga.

France is the only continental nation that seems to attach sufficient importance to the advantages to be derived from the cultivation of trees, and her experiments with the eucalyptus have already attracted some attention liere, and seem destined to encourage the Spanish peo. ple to take a livelier interest in enriching and beautifying the vast tracts of their territory that are as bare of foliage as are "the lone and level sands."

Herbert W. Bowen, Consul-General.

BarCelona, November 15, 1896.

\section{WOOD INDUSTRIES OF SPAIN.}

There is so little woorl in Spain that the small boy knows nothing of the joys of whittling, and develops no ambition to become a carpenter. The result is that the carpenters are few, and their shops are not well provided with modern tools and machinery. From molds and lathes, scarcely $\$ 600,000$ worth of goods are turned out a year in all Spain. The hest shops are in Barcelona and Seville. 
In Barcelona there are also many furniture factories. Beds and chairs are produced in large quantities, and the common kinds are very cheap. Much wood is imported into Spain for ornamental articles, and also considerable expensive furniture is procured, entirely finished, from France. The most famous woodwork in Spain is that of images, which, for centuries, have been carved here with signal success, and are always in great demand in the South American republics.

So far as I can learn, Barcelona is the only Spanish city that produces billiard tables, balls, and cues. They are not worthy of comparison with the same articles manufactured in the United States, but they have to serve their purpose because of the high protective duties.

Spain being a great wine country, barrels and casks are made in large numbers. Most of the staves come from the United States and Austria. The wood for corking purposes is produced in Spain. She has large cork forests. In the provinces of Gerona and Barcelona corks are made annually to the value of about $\$ 8,000,000$; moreover, $\$ 6,000,000$ worth of cork wood is anuually extracted from the forests in those provinces. In Andalusia there are also extensive cork forests, but American purchasers would do well to secure their corks from the province of Gerona, as there orders can be more rapidly and satisfactorily filled.

Very little attention is given in Spain to cultivating forests, and yet the constant freshets and inundations throughout the peninsula should make the advisability of planting trees apparent. Lately, some desultory attempts to introduce the encalyptus have been made, and very likely in time this wonderful tree will be found to be worth more to Spain than are any of her colonies.

Herbert W. Bowen, Consul-General.

BarCelona, August 24, 1895.

\section{WOODS OF PARAGUAY.}

Of next importance to the yerba industry in this country is its timber. Immense forests of various classes of woods are to be met with in all parts of Paraguay, whether it be inland or on the shores of the two greater rivers, the Alto Parana and Paraguay. These woods are chiefly exported in the shape of squared logs, and are transported considerable distances, often as much as 40 or 50 miles from the interior to the railway, or sent down the rivers in rafts or large barges. They are now finding ready markets in Rosario, Buenos Ayres, Montevideo, and Europe, more especially in Germany, Belgium, and France. They may be divided into two classes, viz, hard woods (madera de ley), which do not float, and soft woods, whose specific gravity, as a rule, is less than that of water.

The hard woods are chiefly used by the railways for sleepers, bridge 
work, and general railway construction; the lighter woods, with the exception of cedar and petereby-negro, are sawn up into planks, chiefly in Asuncion, and in Sonth America, to a great extent, take the place of pine, which wood, being imported from Europe and North America, is expensive.

The hard woods of this country will compare favorably with any wood in the world in durability and strength. It is well known that some of them, after being under ground or in water from fifty to seventy years, or even longer, are found to be perfectly sound, with only a slight superficial corrosion, and for this reason there are now large orders from Buenos Ayres and Montevideo for wood of this class for piles, which can be supplied at a less cost than pitch or creosoted pine. There are other hard woods, close grained and yet elastic, which compare favorably with the English oak and the American hickory, and others, again, which resist the wood borers and are uninflammable.

As regards the soft woods, the chief export is cedar (cedro). Paraguayan cedar is far superior and commands a higher price than the cedar found in the northern parts of the Argentine Republic. It is richer in color and more durable than its bigger-growing brothers to be found in Tucuman and in the Argentine and Brazilian Misiones. The best cedar hitherto exported to Europe has come from Cuba, but the supply from there is now practically exhausted, and the rerolution has put an entire stop to its exportation for the present.

Petereby-negro is a wood whose value it is difficult to overestimate. It takes a fine polish, is handsome for furniture, and is of great durability. It is highly scented and extremely light. Some of the most beautiful pieces of furniture I have seen have been made of this wood. In appearance it is not unlike American walnut, and it is also to be had with a wavy grain (crespo).

Among.the various palms which are to be found in great quantities in the Paraguayan Chaco, I must not forget to mention the red and black palms. They are extremely hard and will often turn the edge of the best-tempered ax. The black palm makes a magnificent veneer, taking a beautiful polish, and when in water or under ground it is practically everlasting.

Large quantities of a small brush-like tree called espanillo, and another called algaroba (the latter scarce), are cut up into posts and sent to Buenos Ayres for fencing; and although sometimes they are not more than 2 or 3 inches in diameter, they will last under ground forty or fifty years.

I give a list of the principal woods and some of their various uses:

Curupay.-A hard, red, heavy wood of great strength, lasting for many years underground or in water. It is chiefly of this wood that piles for docks and bridges are made, and a large demand exists for it for sleepers. The bark is used for tanning. Its price, put in Asuncion, is 45 cents (gold), 34 inches (Spanish yard) by 10 by 10 . 
Curupay-ria.-A species of curupay of greater weight-bearing power, but inclined to crack when exposed to the sun.

Urunday-mi.-All that applies to curupay applies to this; also the price.

Urunday-pará.-A hard wood of little or no value. I insert this as a warning to purchasers not to confound it with urunday-mi.

Tinibó.-A light wood, not unlike cedar in grain, and as it often grows to an immense size, it is much used for dugout canoes and troughs for water and treacle. It is used also for shingles for roofing. But little of this wood is exported.

Tatajibá (Sp-mora)._A hard, yellow wood, used for sleepers, but, in my opinion, overrated on account of its decaying when in moist earth.

Tataná.-A handsome yellow hard wood. It makes an excellent veneer, is very durable underground, and resists insects and fire. It would be difficult to overestimate this wood. It is much sought after by shipbuilders for shoulders and stem and stern posts.

Guayabi.-Very Hexible and elastic; greatly used here for bullock yokes and ax handles, being preferred to the hickory of North America.

Petereby blanco.-A light wood; of little use except when cut up for rough boxes.

Petereby negro.-One of the best woods in the country. It is much used for masts on account of its great length. The price of this, put in Asuncion, is 55 cents (gold), 34 by 10 by 10 inches.

Palo santo.-Only found in the Paraguayan Chaco. Much used for its chemical properties and for fancy work in lathe turning.

Quebracho negro.-The king of hard woods. The signification of the name is "ax breaker." There is no wood known to surpass it for durability and longevity either in earth or water. It is sent to Europe for tanning purposes. It fetches as much as $\$ 10$ (gold) a ton in Buenos Ayres.

Quebracho blanco.-Has almost the same properties as the other, but is of no use for tanning. A tonic is made from the bark, said to be beneficial in pulmonary diseases.

Lapacho.-Erroneously supposed to be what is kuown in Brazil and other parts as greenheart. Immense quantities of this are shipped to Buenos Ayres for railway and shipbuilding purposes. It is a greenishyellow wood, which does not readily crack, and is of immense strength. It is not good for piles or damp soil. The "crespo" or curled class has a beautiful appearance, and makes handsome, but heavy furniture. I would warn purchasers of its extreme inflammability. Its price in Asuncion is 35 cents (gold), 34 by 10 by 10 inches.

Ibyrapyté.-An overrated wood much exported to Buenos Ayres for railway carriage and shipbuilding. It is heavy and hard and impervious to the direct action of water, but unless very well seasoned warps considerably.

Iviraro (bitter).-One of the best woods of the country; close grained, 
not unlike oak in appearance. It has this great advantage-it does not crack and is invariably sound in its heart. This wood is used by the natives for the hubs or boxes of wheels and fellies, and these nativemade wheels are, as a rule, made without iron tires, proving the extreme hardness and durability of the wood, for the roads in Paraguay are of the roughest description. This wood I can with safety recommend to shipbuilders, carriage makers, and carpenters; it is durable, strong, and easily worked. The price, put in Asuncion, is 55 cents (gold), 34 by 10 by 10 inches.

Ivirarómi.-A fine, closer-grained class than the above, somewhat scarce, therefore commanding a high price. It is invaluable for engraving blocks.

Incienso.-The sap of this is the incense of commerce, but for some reason there is no trade in it except for local purposes. Of late there has been a demand for the wood for parquet flooring, on account of its scent, durability, and hardness. Price, 45 cents (gold), 34 by 10 by 10 inches, but seldom to be had more than 12 by 12 inches square.

Palo blanco.-One of the commonest and tallest trees of Paraguay. This wood takes its name from its bark and not from the color of the wood, which is whitish yellow, with a strain of black. Although heavy, it is largely used here and in Buenos Arres instead of pine. It is practically everlasting when not exposed to wind and weather. It has this great advantage-dry rot and borers never touch it. It is easily worked. Price, 35 cents (gold).

Cedro.-The price of this wood is rising in leaps and bounds. It is just now particularly in demand on account of the Cuban revolution, and it would be difficult to exaggerate its value in the immediate future, as the quantity now left is very limited. For durability and for retaining its scent it is thought to be superior to any other cedar hitherto used in the manufacture of cigar boxes and receptacles for the preservation of apparel from the depredations of insects. The price, put in dsuncion, is 60 cents (gold), 34 by 10 by 10 inches.

I have delayed forwarding this report on account of the nonarrival of samples of the woods I describe. The minister of the interior ordered samples to be sent to the consulate free of charge, but as yet they have not been delivered.

Asuncion, June 5, 1896.

Samuel W. Thomé, Consul. 



\section{N D EX.}

American lumber in foreign conntries:

Africa-

Madeira ................................................

Sierra Leone....................................... 7

South Africa............................................ 8

Zanzibar .......................................... 10

America-

Canada:

New Brunswick and Nova Scotia........................ 11

Mexico:

La Paz ............................................. 15

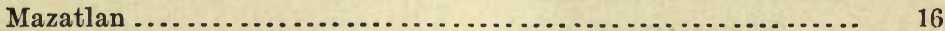

Nogales............................................. 17

Vera Cruz .......................................... 18

Central America :

British Honduras ................................... 20

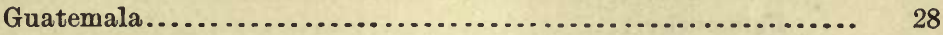

Salvador.............................................. 29

South America:

Argentine Republic............................... 31

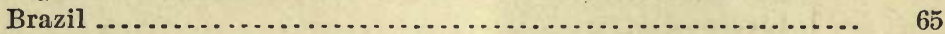

Chile ................................................ 68

Colombia ............................................ 70

Colon .............................................. 72

Dutch Guiana....................................... $\quad 73$

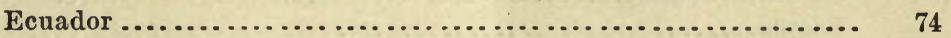

Danish West Indics ................................. 77

Asia-

British Asia:

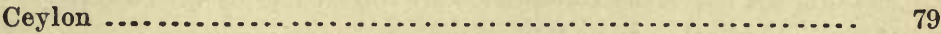

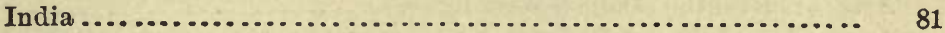

China-

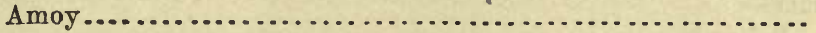

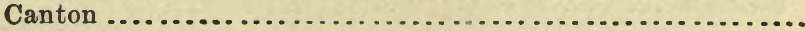

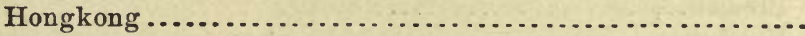

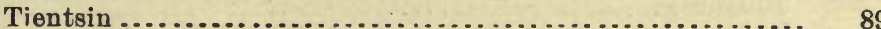

Japan-

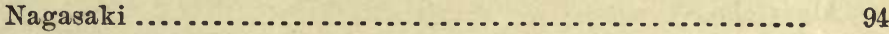

Osaka and Hiogo ................................. 95

Netherlands-India :

Java.............................................. 97

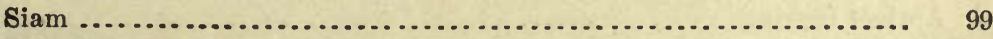

Turkey in Asia:

Palestine ......................................... 100

Syria ......................................... 102 
American lumber in foreign countries--Continued.

Australasia-

New Zealand

New South Wales...................................... 120

South Australia ...................................... 132

Tasmania.............................................. 144

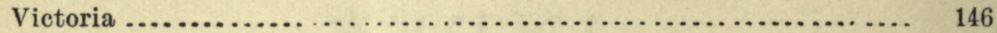

Europe-

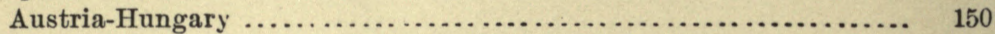

Bohemia.......................................... 153

France:

Bordeaux......................................... 159

Marseilles ............................................ 161

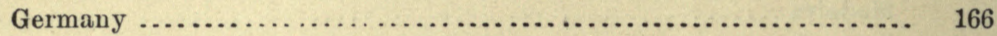

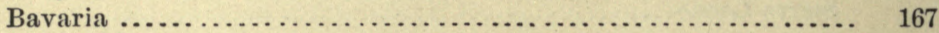

Bremen............................................ 168

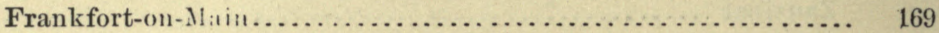

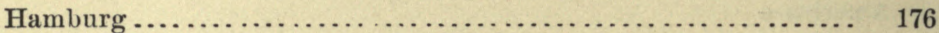

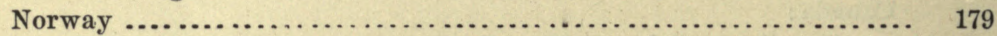

Portugal:

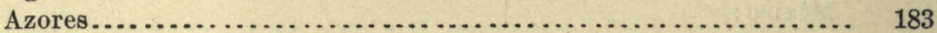

Russia:

Riga ............................................... 184

Turkey in Europe................................... 185

United Kingdom:

Birmingham ...................................... 187

Dundee................................................ 189

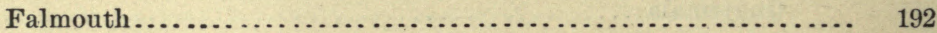

Glasgow............................................... 194

Hull.............................................. 200

Leeds .............................................. 204

Liverpool.......................................... 205

Newcastle-upon-Tyne.............................. 212

Polynesia-

Hawaiian Islands.................................... 214

New Caledonia ........................................... 215

Samoa................................................. 216

Principal native woods (only the woods most important to commerce are named, though numerous others which could not be included without making the index too voluminous are referred to by the consuls):

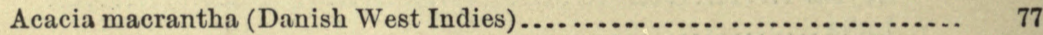

Accouribroad (Dutch Guiana).............................. 73

Alder-

Bohemia................................................. 153

Bremen................................................. 168

Hamburg........................................... 176

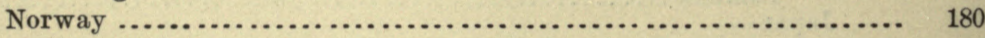

Algarrobo-

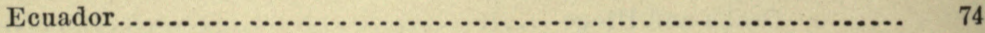

Argentine Republic...................................... 31

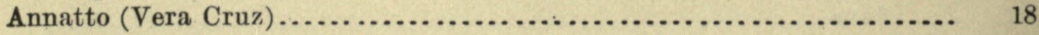

Apricot (Syria) ........................................... 103

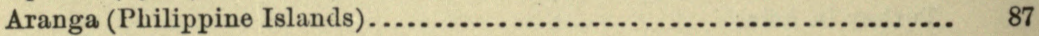


Principal native woods-Continued.

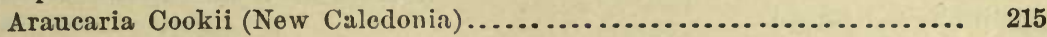

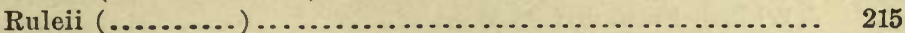

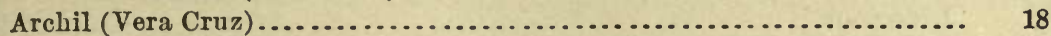

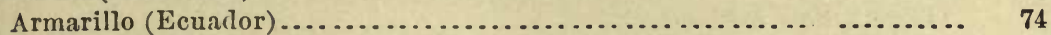

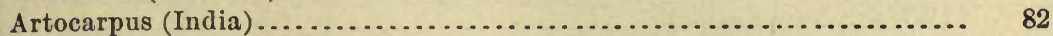

Ash-

Bavaria .............................................. 167

Birmingham....................................... 107

Bremen............................................... 168

China ............................................. 84

Dunilee............................................... 189

Falmouth ........................................... 192

Frank fort-on-Main .................................. 169

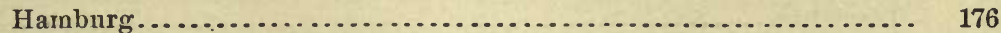

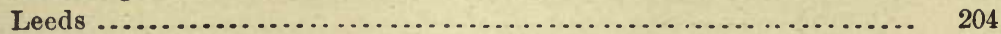

Liverpool ........................................... 205

Newcastle-on-Tyne .................................... 212

(Mountain), New South 11 : 1 les........................... 126

Turkey in Europe .................................. 185

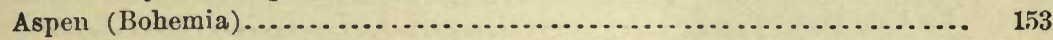

Azevinho (Canary Islands, Malvira) ........................ 5

Balsam-

Ecuador............................................. 74

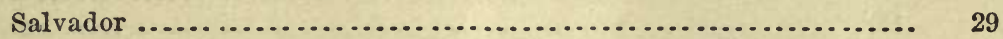

Bamboo-

China .................................................. 84

India...................................................... 82

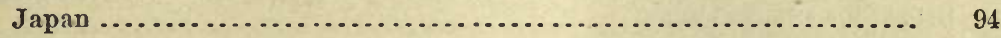

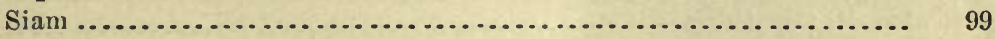

Banksia-

Now South Wales .................................. 120, 122

South A ustralia .................................... 134

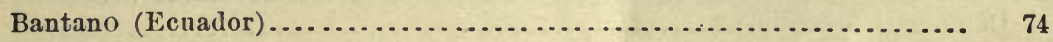

Basswood (Bohemia) ....................................... 153

Beech (red and white)-

Bavaria .......................................... 167

Birmingham ........................................ 187

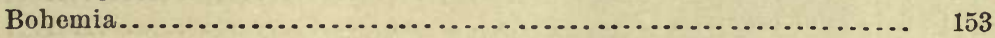

Bremen............................................. 168

Dundee............................................. 189

Falmouth .......................................... 192

Frankfort-on-the-Main ................................ 169

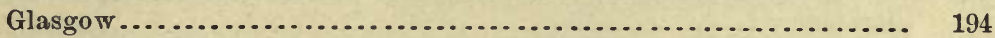

(Red), Hamburg.................................. 176

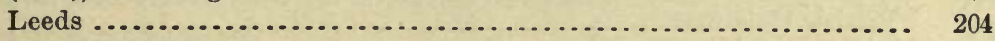

New South Wales.................................... 126

(White), New South Wales............................. 125

Osaka and Hiogo ...................................... 95

Turkey in Enrope.................................... 185

Birch-

(Evergreen), Victoria ................................ 147

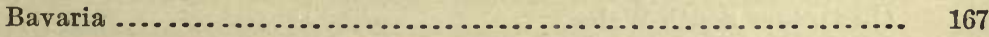

Birmingham....................................... 187

Bohemia ........................................... 153

Dundee............................................... 189 
Principal native woods-Continued.

Birch-Continued.

(White), Frankfort-on-Main ............................. 169

Liverpool............................................... 205

(Black), New Zealand .................................. 111

(White), New Zealand ................................ 111

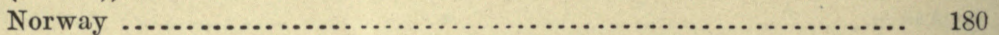

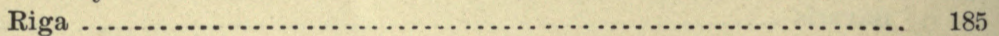

Bird's-eye (Vera Cruz) ......................................... 18

Blackbutt (New South Wales) ............................ 121, 123

Blackheart (Dutch Guiana) .................................. 73

Blackwood-

South Australia........................................... 133

New South Wales..................................... 122

Tasmania................................................... 144

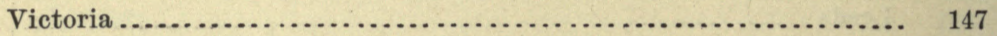

Box (brush) (New South Wales) ............................. 125

Boxwood-

Birmingham ........................................... 187

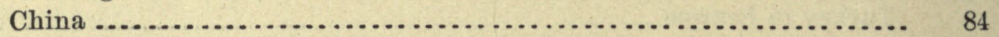

La Paz, Mexico ......................................... 15

(Corsican), Marseilles................................... 161

Brazil wood-

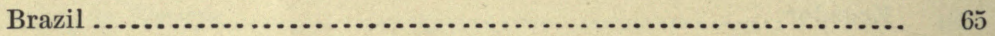

Colombia .................................................... 71

La Paz, Mexico ............................................ 15

Mazatlan ................................................. 16

Vera Cruz ............................................... 18

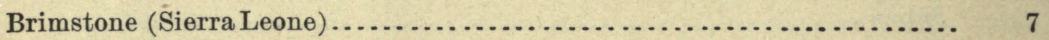

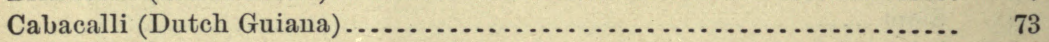

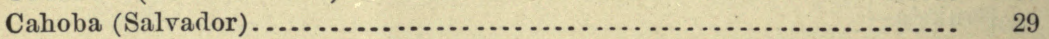

Calden (Argentine Republic) .................................. 34

Calophyllum montanum (New Caledonia) ........................ 215

Campano (Colombia) ...................................... 71

Camphor wood-

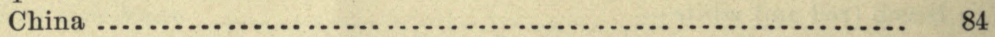

Japan .................................................. 94

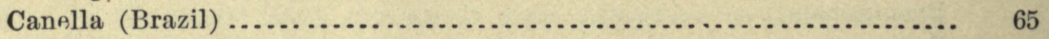

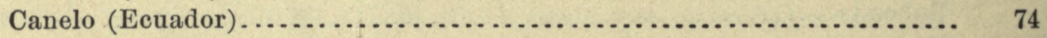

Carreto (Colombia) ........................................ $\quad 70$

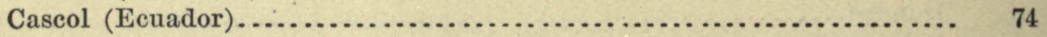

Cedar-

Argentine Republic....................................... 32

Bordeaux................................................. 159

Brazil .................................................... 65

British Honduras........................................ 22

China ...................................................... 84

Colombia....................................................... 70

Dutch Guiana ............................................ 73

Ecuador...................................................... 74

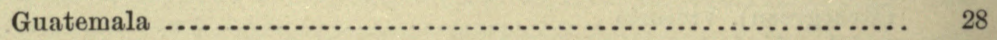

Japan ..................................................... 94

(Red), New South Wales................................. 121

(Yellow), New South Wales ............................... 126

(White), New South Wales ................................. 125 
Principal native woods-Continued.

Cedar-Continued.

New Zealand ................................................ 110

Nogales............................................... 17

Salvador................................................... 29

Syria ............................................. 103

Vera Cruz ................................................. 18

Ceiba-

Colombia .............................................. 71

Salvador ............................................... 29

Cherry (China) ......................................... 84

Chestnut-

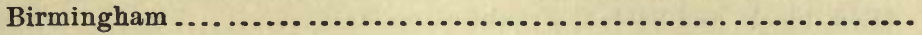

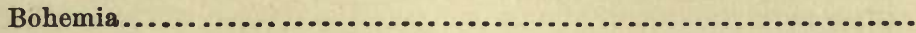

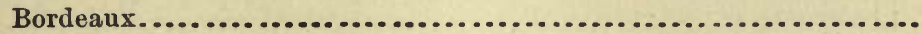

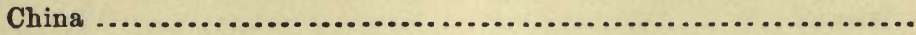

(Moreton Bay), New South Wales..............................

Osaka and Hiogo...........................................

Turkey in Enrope. ........................................

Cheña (Argentine Republic) ..................................

Cocos (Java) .............................................

Cocoanut-

Samoa.

South Africa

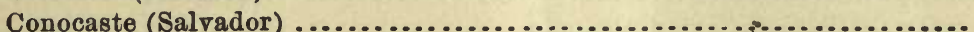

Coquinto: Ecuador ...........................................

Cypress-

Chile.

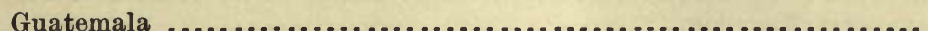

Osaka and Hiogo.........................................

Turkey in Europe. ..........................................

Deteruca (Dutch Guiana) ..................................... 73

\section{Ebony-}

Brazil

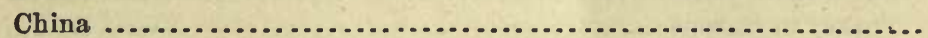

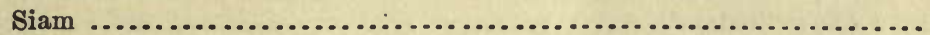

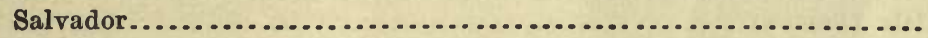

(green) Vera Cruz ........................................ 18

Bavaria .......................................... 167

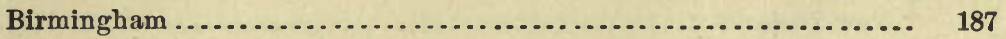

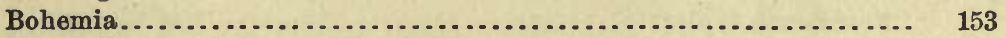

Dundee.................................................. 189

Falmouth .............................................. 192

Leeds ................................................... 204

Liverpool ................................................. 205

Newcastle-on-'Tyue ....................................... 212

Tien-Tsin ................................................. 89

Eucalypti-

New South Wales................................... 121, 123, 124

South Australia .............................................. 132

Tasmania............................................ 144

Victoria ............................................... 147

Eugenia palleus (Danish West Indies) ............................. 77

$655 \mathrm{~A}-17$ 
Principal native woods-Continued. Page.

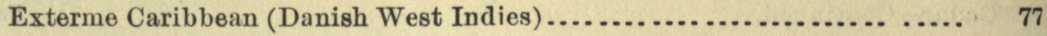

Faia (Azores) ............................................... 183

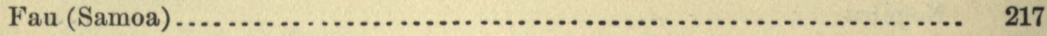

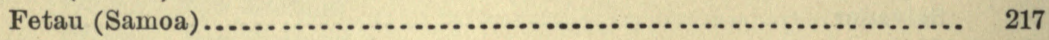

Fir -

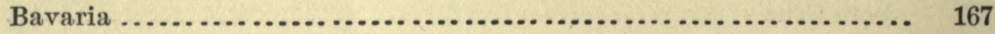

Birmingham .......................................... 187

Bohemia................................................. 153

Bordeaux ............................................. 159

(German and Scotch) Bremen ............................ 168

Dundee...................................................... 189

(Red, black, and Scotch) Frankfort-on-Main................... 169

Glasgow............................................. 194

Liverpool.............................................. 205

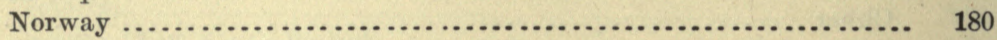

Osaka and Hiogo ...................................... 95

Fustic-

British Honduras......................................... 23

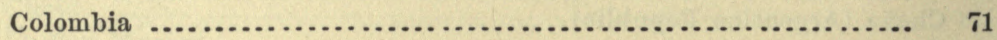

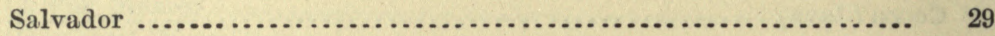

Vera Cruz .............................................. 18

Gauyabo (Ecuador) ......................................... 74

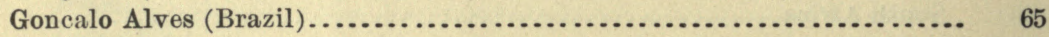

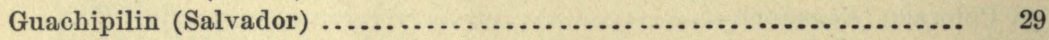

Grevillea Gilleviaji (New Caledonia) .......................... 215

Greenheart (Dutch Guiana) ................................ $\quad 73$

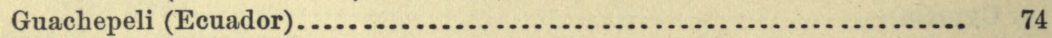

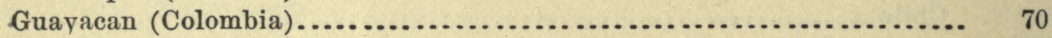

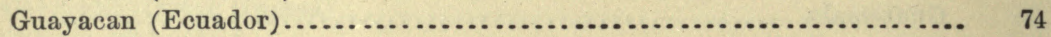

Guion (Ecuador) .............................................. 74

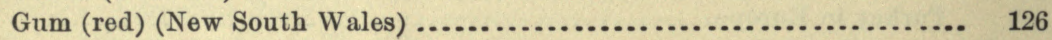

Hickory-

Liverpool.............................................. 205

New South Wales........................................ 122

Turkey in Europe......................................... 185

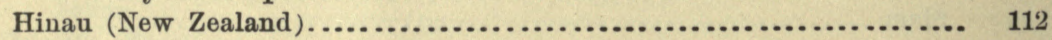

Ifilcle (Samoa) .............................................. 217

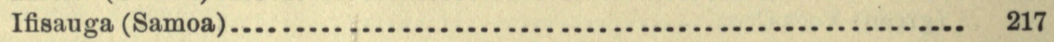

Ifiulu (Samoa) .............................................. 217

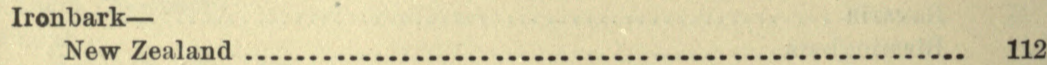

New South Wales.......................................... 121

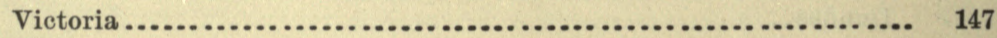

Ironwood-

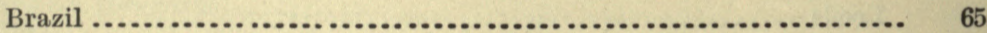

British Honduras .......................................... 25

China ..................................................... 84

Dutch Guiana ........................................... 73

Java ..................................................... 97

La Paz, Mexico ............................................. 15

Nogales................................................. 17

New South Wales........................................ 125

South Africa ............................................... 8

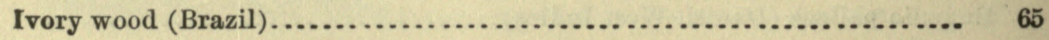


Principal native woods-Continued.

Page.

Jawalidani (Dutch Guiana) .................................. 73

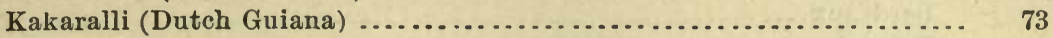

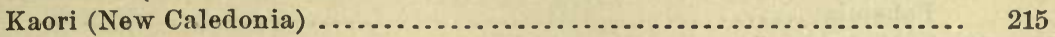

Kauri (New Zealand) ...................................... 107

Kiyaki-

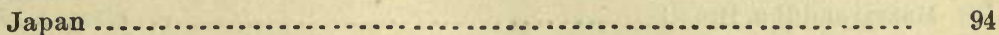

Osaka and Hioo .............................................. 96

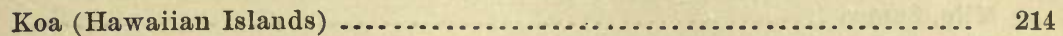

Kowhai (New Zealand) ..................................... 112

Lancewood (Dutch Guiana).................................. $\quad 73$

Lapacho (Argentine Repúblic) ............................. $\quad 36$

Larch-

Birmingham....................................... 187

Bohemia............................................. 153

Dundu ............................................... 159

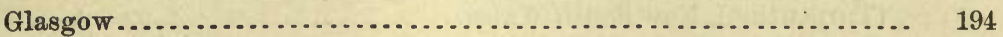

Leeds................................................ 204

Laurel-

Argentine Republic .................................... 33

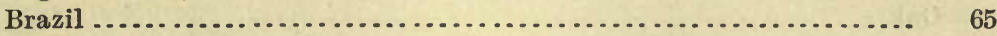

Chile ..................................................... 68

Ecuador .............................................. 74

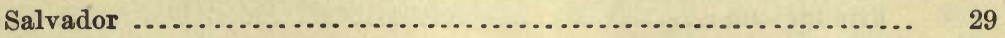

Licurana, Brazil.................................... 65

Lignum-vitæ-

Dutch Guiana........................................ 73

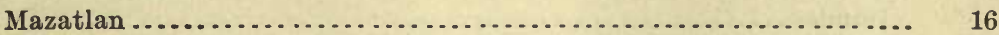

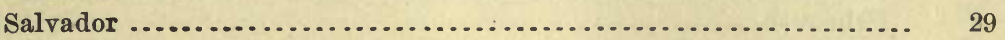

Vera Cruz.............................................. 18

Lime, Turkey in Europe ................................ 185

Linden (Bavaria) ....................................... 167

Locust (China)......................................... 84

Logwood-

British Honduras ...................................... 22

Vera Cruz.............................................. 18

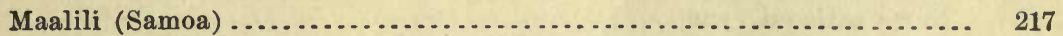

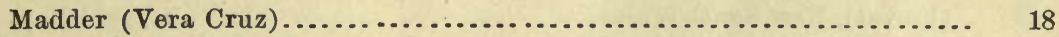

Mahogany-

Argentine Repnblic.................................... 33

British Honduras..................................... 20

Colombia.............................................. 71

Dutch Guiana............................................ 73

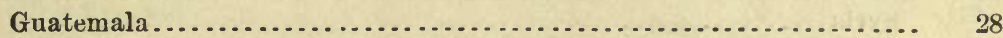

(Bastard), New South Wales............................. 121

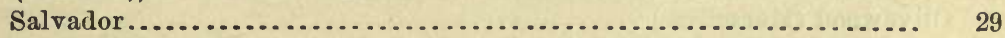

Sierra Leone ........................................... 7

Vera Cruz............................................... 18

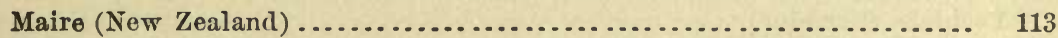

Mangle (Ecuador) ........................................ 74

Mangrove-

British Honduras ........................................ 25

New South Wales.......................................... 120

Samoa ................................................. 217

Vera Cruz .............................................. 18

Zanzibar ................................................. 10 
Principal native woods-Continued.

Maple-

Bordeaux................................................. 159

Bohemia.................................................... 153

Maria, Ecuador ............................................... 74

Mastic, Vera Cruz............................................. 18

Massaranduba, Brazil. ......................................... 65

Melaleuca leucodendron, New Caledonia .......................... 215

Milo, Samoa ............................................ 217

Mimusops (balata), Dutch Guiana............................. $\quad 73$

Molave, Philippine Islands.................................... 87

Mora, Dutch Guiana ........................................ 73

Moral, Ecuador............................................... 74

Mulberry, Syria ............................................ 103

Myrtle-

(Gray), New South Wales ................................. 122

(Turpentine), New South Wales............................ 125

Tasmania.............................................. 144

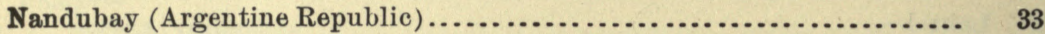

Nut (Syria) ................................................. 103

Oak-

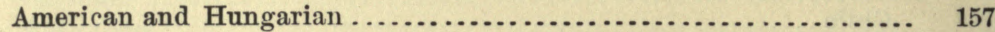

Bavaria................................................. 167

Birmingham ........................................... 187

Bohemia................................................ 153

Bordeaux............................................... 159

China ..................................................... 84

Dundee..................................................... 189

Falmouth................................................. 192

Frankfort on Main ...................................... 169

Hamburg ............................................. 176

Hull................................................. 200

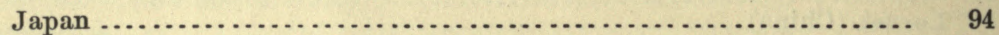

Leeds......................................................... 204

Liverpool................................................ 205

(White and evergreen): Marseilles ............................ 161

New Castle on Tyne ....................................... 212

(Forest), New South Wales................................. 121

(Swamp), New South Wales................................. 120

Nogales.............................................. 17

Osaka and Hiogo ........................................... 95

Riga..................................................... 185

Sierra Leone............................................ 7

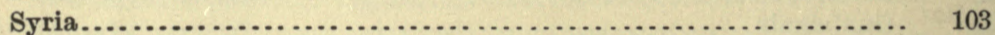

Turkey in Europe ......................................... 185

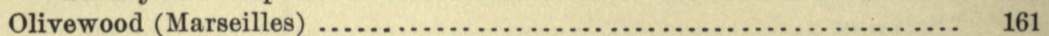

Pacara (Argentine Republic) .................................... 35

Páo d’oleo (Brazil) ............................................. 65

Pechiche (Ecuador) .............................................. 74

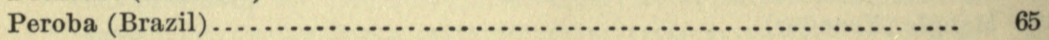

Perado (Canary Islands, Maderia).............................. 5

Pictetia squamata (Danish West Indies) ......................... 77

Pine-

Birmingham.......................................... 187

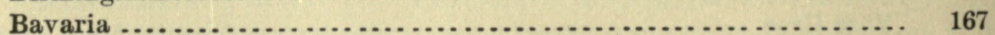


Principal native woods-Continued.

Pine-Continued. Page.

Bohemia............................................... 153

Bremen.............................................. 168

China ................................................... 84

Glasgow............................................ 194

Guatemala ........................................... 28

(Red and white), Hamburg............................. 176

Japan ............................................. 94

Marseilles........................................... 161

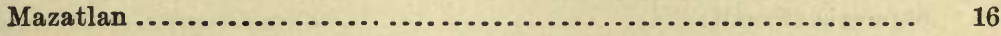

Newcastle-on-Tyne ................................. 212

Nogales............................................ 17

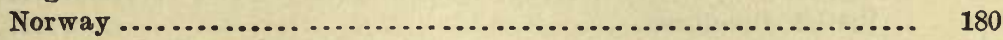

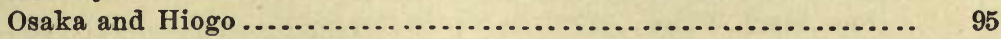

(Hoop), New South Wales............................. 122

(Black), New Zealand.............................................. 110

(Red), New Zealand.................................... 109

Syria............................................. 103

Tasmania............................................. 144

Turkey in Europe....................................... 185

Pinns insignis (South Australia)............................. 136

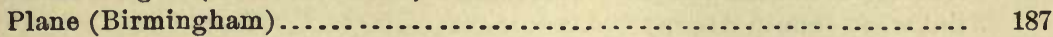

Pleurocalyptus deplanchei (Now Caledonia).................... 215

Pochote (Salvador) ......................................... 29

Pohutukawa (Auckland) .................................... 111

Poplar-

Birmingham ........................................ 187

Bohemia ............................................ 153

Bordeaux........................................... 159

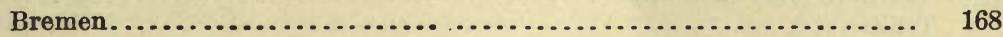

Falmonth........................................... 192

Frankfort-on-the-Main ................................ 169

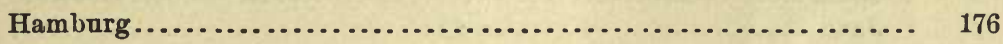

Leeds................................................. 204

Greencastle-on-Tyue ................................ 212

Syria............................................. 103

Turkey in Europe................................... 185

Pukatea (New Zealand)................................. 114

Puriri (New Zealand) ..................................... 111

Purpleheart (Dutch Guiana) ................................ 73

Quebracho (red, white): (Argentine Republic) .................. 32

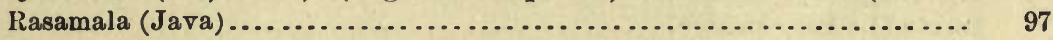

Rata (New Zealand)........................................ 112

Rauli (Chile)......................................... 68

Redwood-

British Honduras...................................... 25

Java ................................................. 97

Riga ............................................... 185

Roble-

Chile.................................................. 68

Colombia.............................................. 71

Ecuador................................................. 74

Rosewood-

Argentiue Republic..................................... 33

Brazil .................................................... 65 
Principal native woods-Continued.

Rosewood-Continued. Page.

British Honduras ...................................... 23

Siam ................................................. 99

Sierra Leone........................................... 7

Vera Cruz............................................ 18

New South Wales..................................... 121

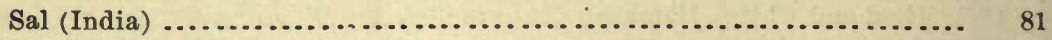

Salic (Dutch Guiana) .................................... 73

Sandalwood (South Australia).............................. 134

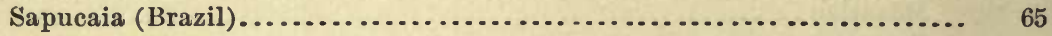

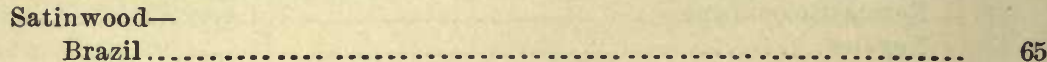

British Honduras...................................... 27

New South Wales ..................................... 126

Seca (Ecuador) ....................................... 74

Simiri (Dutch Guiana)..................................... 73

Spermolepis tannifera (New Caledonia) ....................... 215

Spruce-

Bohemia.............................................. 153

Dundee................................................. 189

Stenocarpus haurifolius (Now Caledonia)...................... 215

Stinkwood (South Africa).................................... 8

Swietunia Mahagoni (Danish West Indies) ..................... 77

Sycamore (Turkey in Europe) ................................. 185

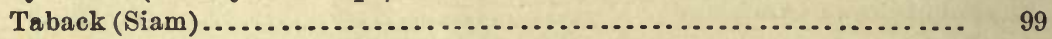

Tallow wood (New South Wales) ............................... 121

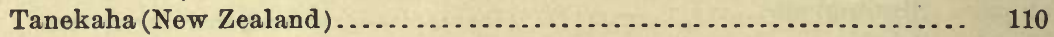

Tauanave (Samoa) ......................................... 217

Tawhero (New Zealand).................................. 113

Teak-

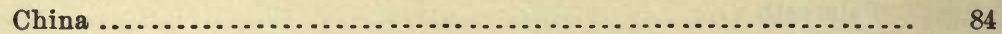

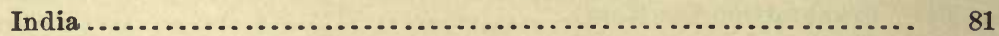

Java................................................... 97

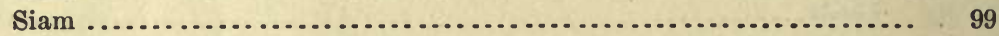

Seirra Leone............................................ 7

Tea tree-

(White), New South Wales ............................ 125

New Zealand ......................................... 110

South Australia........................................ 133

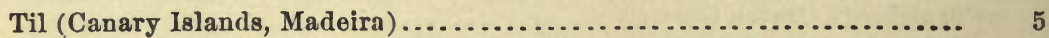

Tipa (Argentine Republic) ................................... 34

Torote (La Paz, Mexico) ....................................... 15

Totara (New Zealand) ..................................... 108

Turpentine (New South Wales) ............................. 125

Vinhatico (Canary Islands, Madeira) .......................... 5

Violet-wood (Vera Cruz) .................................... 18

Wallaba (Dutch Guiana) ................................. $\quad 73$

Waluut-

Argentine Republic ...................................... 33

Birmingham.......................................... 187

Bordeaux............................................ 159

(White), Frankfort-on-the-Main.......................... 169

Marseilles .............................................. 161

(Black), Sierra Leone. ................................. 7

Turkey in Europe.................................... 185 
Principal native woods-Continued.

Wattle-

New South Wales...................................... 121

South Australia........................................ 133

Weinmannia parriflora (New Caledonia) $\ldots \ldots \ldots \ldots \ldots \ldots \ldots \ldots \ldots \ldots \ldots .215$

Whismore (Sierra Leone) ..................................... 7

Whitewood-

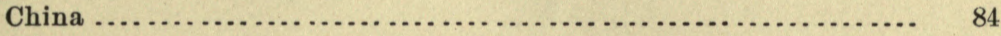

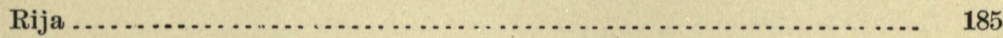

Willow (Syria) ......................................... 103

Woods of Argentine Republic ................................. 49

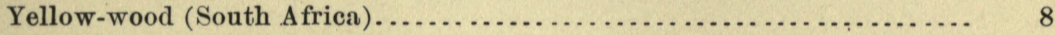

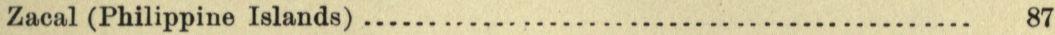

SUPPLEMENTARY REPORTS.

American lumber in China .................................. 219, 220

American lumber in Denmark ............................... 220, 221

American lumber in France ...................................... ${ }_{222}$

American lumber in Switzerland ............................... 222-228

American lumber in Uruguay ................................ 229-232

Aspen wood for matches ...................................... 232-236

Australian woods for street paving............................... 236

A valuable tree in New Caledonia.............................. 237

Lumber in Costa Rica............................................ 238

Lumber in Quebec ............................................ 239

Lumber trade of the Straits Settlements . . . . . . . . . . . . . . . . . . . 240-242

Lumber in western India.................................... 242, 243

Timber industry of the Argentine Republic....................... 244, 245

Timber resources of Spain ................................... 245-247

Wood industries of Spain ....................................... 247

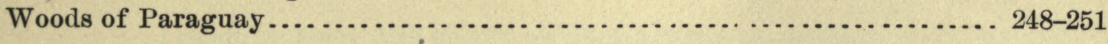





\section{Walter Mulford}

\section{INFLLENCE OF FORESTRY IPON THE LLUBBER INDILSTRY.}

BY

OVERTON W. PRICE,

Assistant Forester, Bureau of Forestry.

[Reprint from Yearbook of Department of Agriculture for 1902.] 


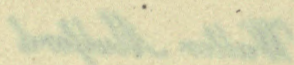




\section{CONTENTS.}

Development of the lumber industry -...... Page.

Some results to be

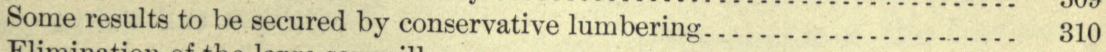

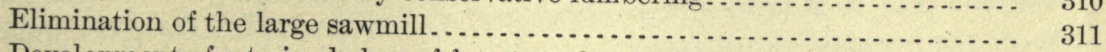

Development of a trained class of forest workers. $\ldots \ldots \ldots \ldots \ldots \ldots \ldots \ldots \ldots . . \quad 311$

Influence of forestry upon the prices of lumber. $\ldots \ldots \ldots \ldots \ldots \ldots \ldots \ldots \ldots \ldots . .312$

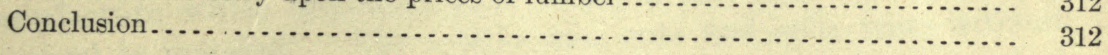

\section{ILLUSTRATIONS.}

Plate XXX. Fig. 1.- Whip sawing in the Kentucky Mountains. Fig. 2.A modern sawmill in the Sierras, California ........... $\quad 310$ XXXI. Cut-over Red Fir land $\ldots \ldots \ldots \ldots \ldots \ldots \ldots \ldots \ldots \ldots \ldots \ldots . . \quad 310$ XXXII. Fig. 1.-The result of lumbering and fire in Minnesota. Fig. 2.-Logging Red Fir in Washington............. 310 



\title{
THE INFLUENCE OF FORESTRY UPON THE LUMBER INDUSTRY.
}

\author{
By Overton W. Price, \\ Assistant Forester, Bureau of Forestry.
}

DEVELOPMENT OF THE LUMBER INDUSTRY.

The development of the lumber industry in this country is without parallel. It now ranks fourth among the great manufacturing industries of the United States, and represents an invested capital of about $\$ 611,000,000$ and an annual outlay of over $\$ 100,000,000$ in wages. It affords through its three great branches-the logging industry, the sawmill industry, and the planing-mill industry - a means of livelihood to considerably over a million persons. The annual value of the products, which has multiplied nearly ten times in the last half century, is $\$ 566,000,000$. But although the rapid development of the lumber industry has had far-reaching results in furthering every branch of manufacture which depends upon wood, it has been fundamentally unsound in principle. The settler who cuts and sells trees without forethought from land fit only for forest growth has not enriched himself in the long run. The havoc which has been wrought in the forests of the United States has turned trees into money, but has put the balance on the wrong side of the sheet by rendering vast areas unproductive. It is the history of all great industries directed by private interests that the necessity for modification is not seen until the harm has been done and its results are felt. This fact has been emphasized in the lumber industry -in the earlier days by the instinctive feeling of the colonist against his natural enemy, the forest, and later by the remarkable inducements offered by lumbering for present profit only. The first settlers had two objects in view in their attack upon the forest-the one to clear land for their farms, the other to procure wood for their buildings, fuel, and fences. As the tide of colonization rose, and as the uses for wood in manufacture increased in number and extent, lumbering rapidly assumed the proportions of a business enterprise, and from supplying only personal wants it became profitable to supply also those of others. With an apparently inexhaustible supply of timber available, and with an insistent and growing demand, the lumber industry came to offer remarkable opportunities for money making. Step by step with its development improvement in tools and machinery took place. The changes that enterprise and ingenuity have wrought in the American sawmill are no less wonderful than those which have taken place in the 
American locomotive. From "whip sawing," in which the boards were sawed out by hand, to the modern steam sawmill, with its railroad (PI. XXX), its planing mill, and its cut of nearly half a million board feet per day, is a long step-but it has not taken much over fifty years to accomplish it. In effective methods for the harvesting and manufacture of lumber the American lumberman has no superior, nor is he equaled in his disregard for the future of the forest which he cuts.

\section{SOME RESULTS TO BE SECURED BY CONSERVATIVE LUMBERING.}

It is natural that the lumberman should not turn eagerly from a system whose only aim is to secure the highest possible present profit from the forest to one which includes provisions for the production of a second crop upon the lumbered area. Under conservative methods lumbering becomes a legitimate industry for the production as well as for the consumption of its staple. It no longer offers, however, the short cut to fortune which it proved to be so long as an abundance of timber rendered the old methods of lumbering possible. It is difficult for lumbermen generally to realize that the time for practical forestry has fully arrived. But signs more significant than any existing statistics point to the imminent failure in the supply of certain timbers in the United States. From the data available, there is no way to foretell accurately the time necessary to exhaust this supply of merchantable timber at the present rate of consumption. A good many estimates of the merchantable timber standing have been made, some of which have already proved fallacious. To predict accurately how long it will be before the United States is confronted by a timber famine would require first of all a knowledge of the composition, quality, and condition of the forests, which it would take many years to obtain. At present such an estimate is of little practical value. We do know that the supply of timber of many kinds is failing, of other kinds is almost exhausted, and of others is practically gone; that Black Walnut is no more to be had except in small quantities and at enormous expense; that first-growth White Pine is growing rapidly to be a rarity on the market; that where the supply of spruce for pulpwood and for lumber for the next ten years is to be found is a grave question before the lumbermen to-day. The list of woods accepted as merchantable lengthens from year to year, species hitherto considered valueless being har vested more and more willingly as the result of the exhaustion of more valuable kinds. In spite of steady improvement in tools, logging outfits, and mill machinery, all tending to cheapen the cost of iumbering, the price of lumber increases steadily and rapiliy. These are facts more significant than predictions in terms of years of the life of the lumber industry. The exact period for which the existing supplies are sufficient is a matter of 


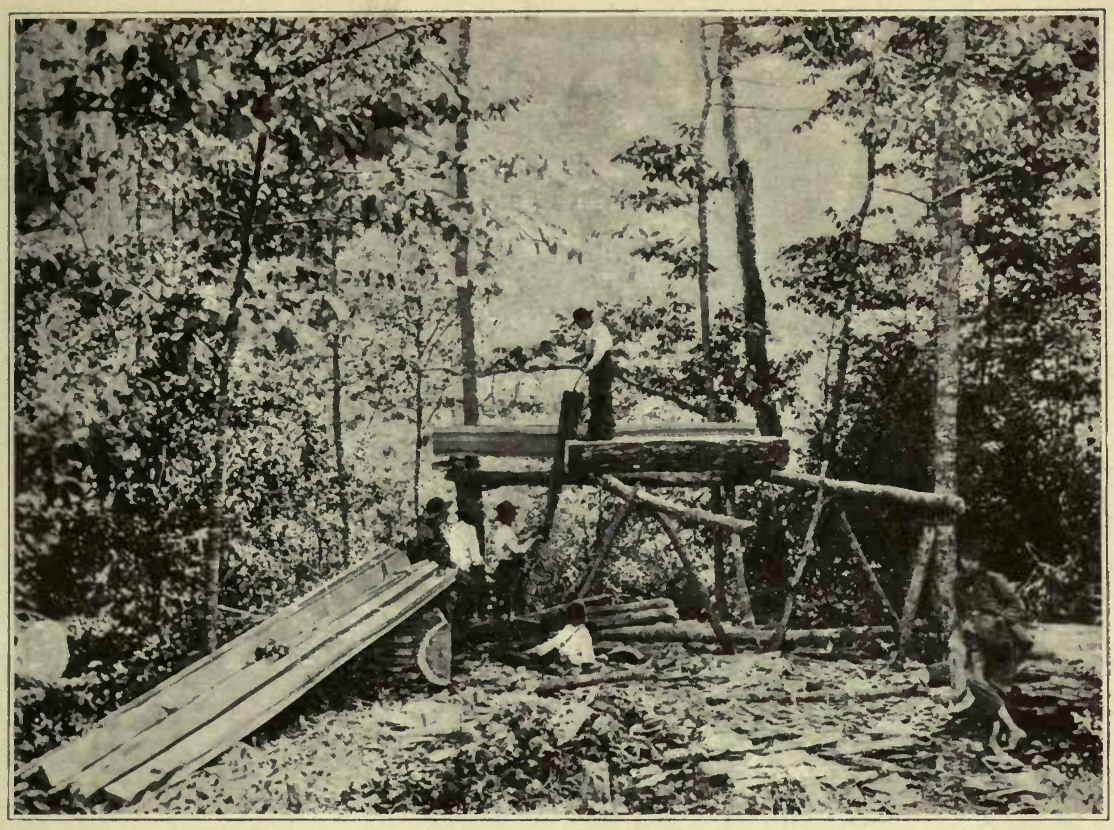

Fig. 1. -Whip SAWING in the Kentucky Mountains.

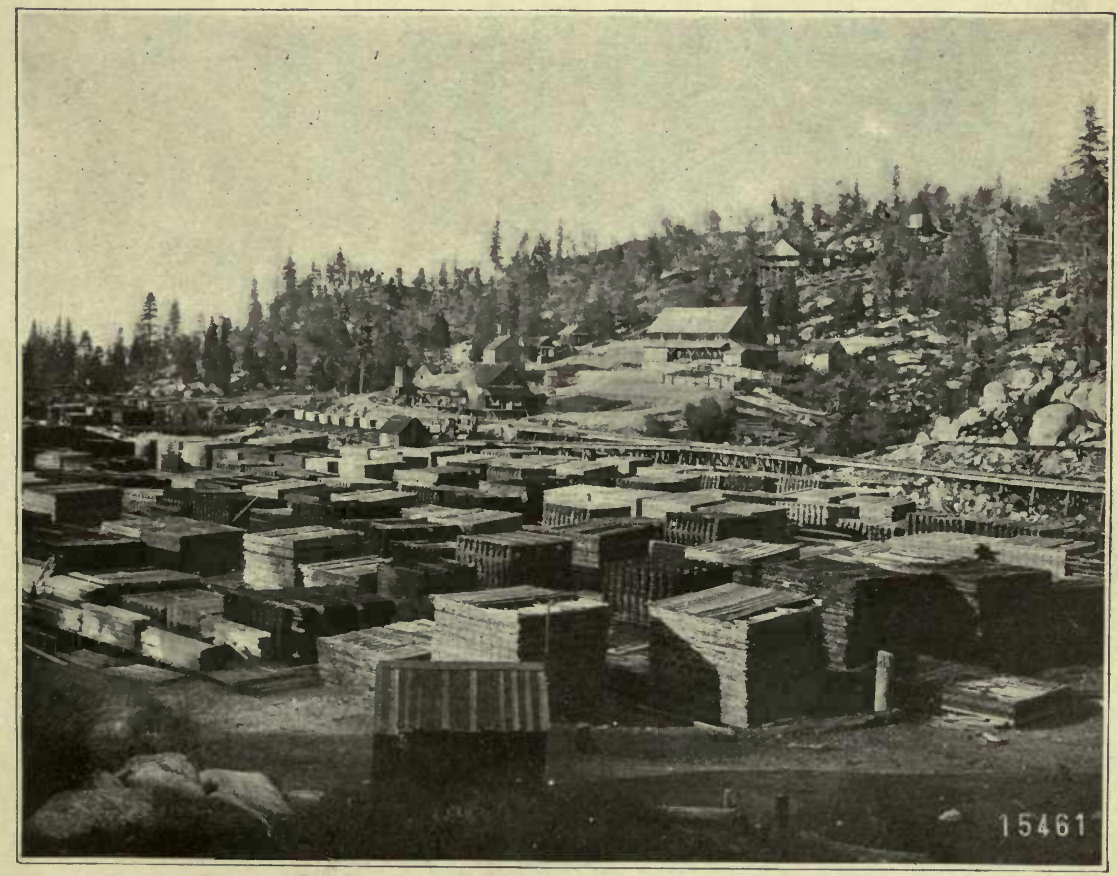

Fig. 2.-A Modern Sawmill in the Sierras, California. 


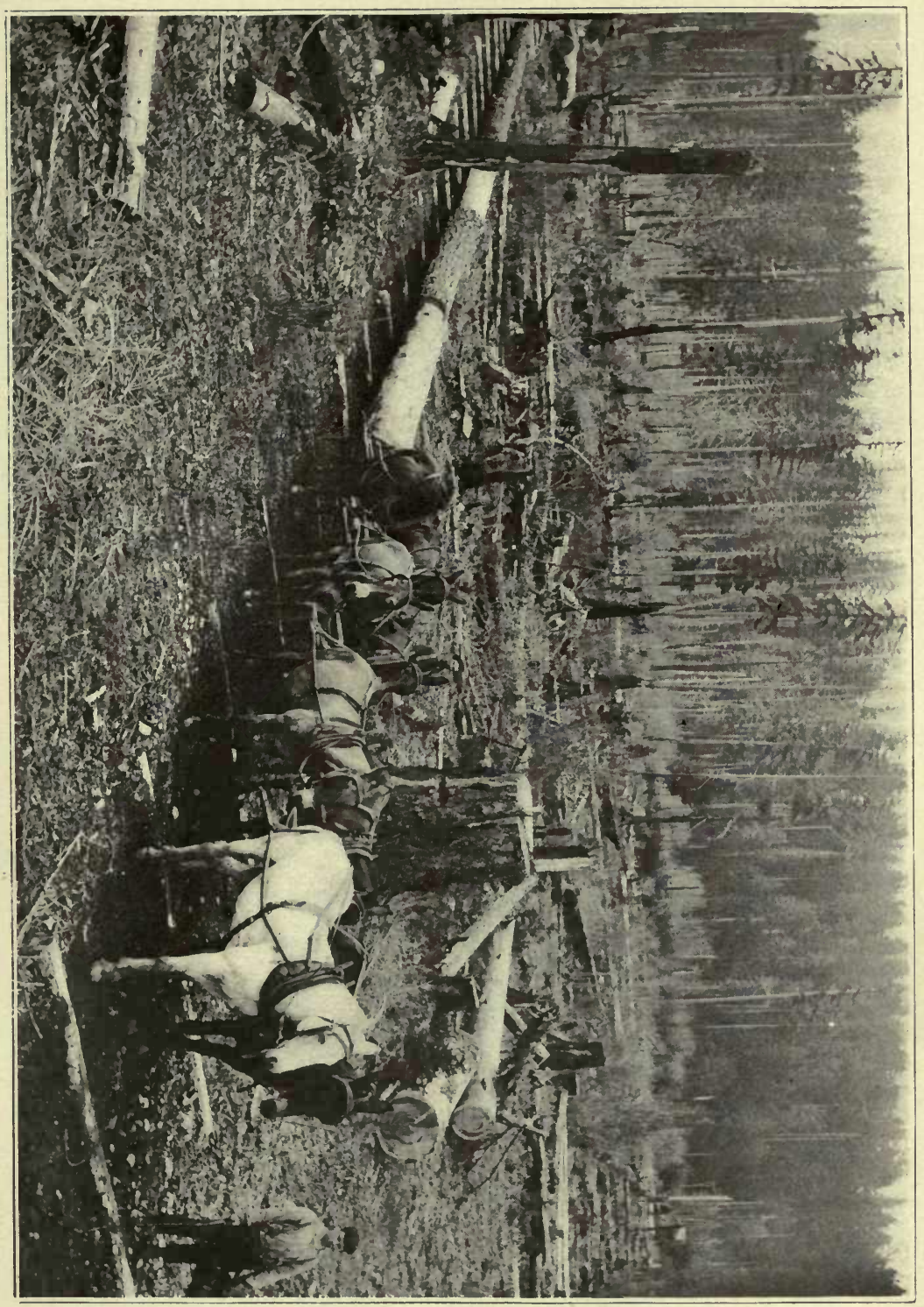





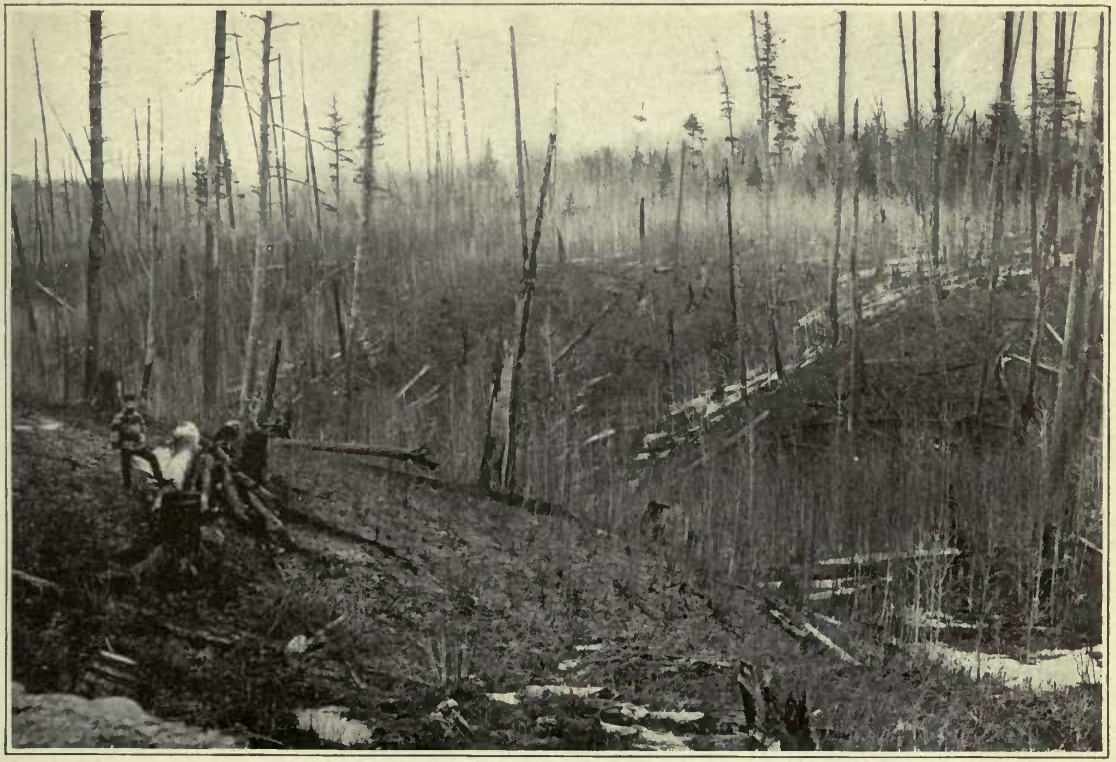

Fig. 1.-The Result of LUmbering and Fire in Minnesota.

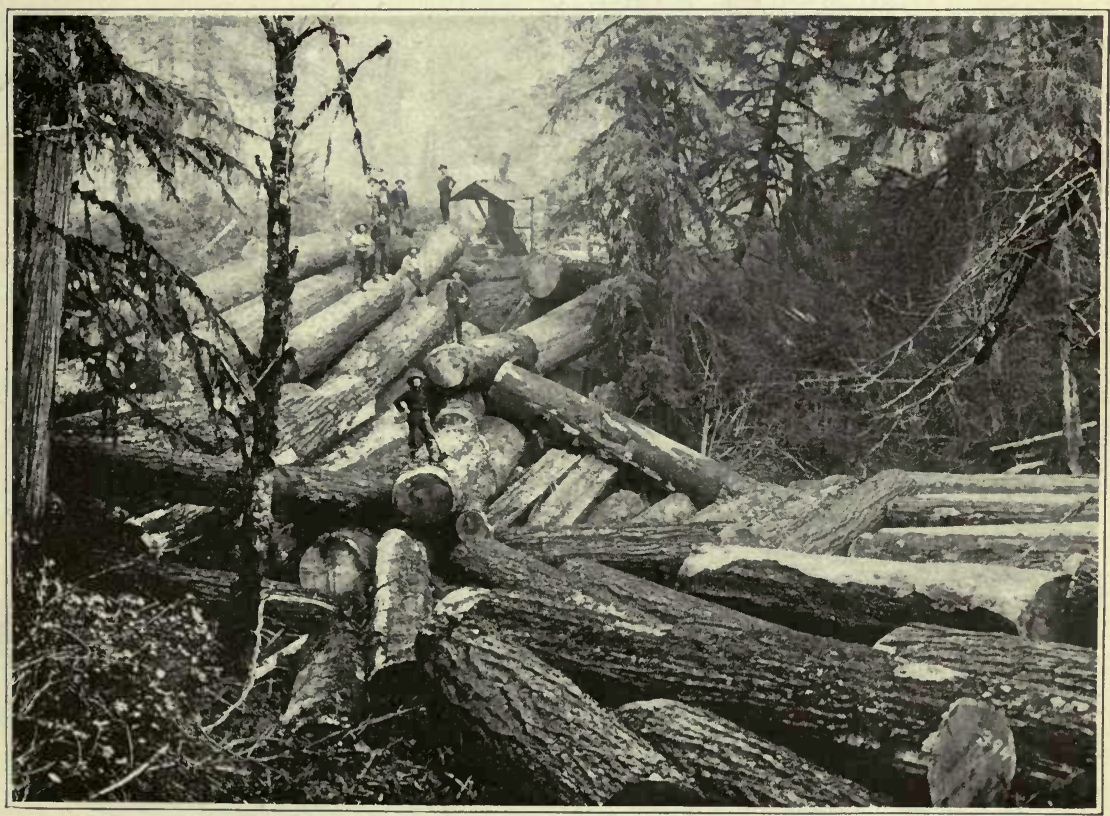

FIG. 2.-LOGGING RED FIR IN WASHINGTON. 

detail. The vital point lies in the crisis which the lumber industry is approaching in the exhaustion of the material on which its existence depends. (See Pls. XXXI and XXXII.)

\section{ELIMINATION OF THE LARGE SAWMILL.}

The general application of forestry to forest lands owned by lumbermen will probably result in the gradual elimination of the large sawmill and the substitution of those of moderate size. The mammoth milling plant will be rare when only second growth is left to supply it, for the area of timber land sufficient to produce the logs necessary to run such a plant is enormous. It is reasonable to expect that the mill of moderate size, supplied by a forest whose production is equal to the mill's annual capacity, both under the same management, will become more and more the rule. The very existence of the enormous mill is the result of an abundance of timber resources, which exist no longer except in a very few sections. In Europe the longcontinued application of conservative measures in lumbering has resulted in a distribution and type of sawmill little known in this country. Sawmills of large size do not exist, but in their stead small sawmills, for which water generally supplies the power, are distributed throughout the country wherever the local demand is sufficient to keep them running. Their annual cut is for the most part exceedingly small, according to our standards, and sufficient only to supply the wants of the immediately adjacent country. The mills saw largely on order, and the fact that their construction is permanent and their motive power cheap enables them to run intermittently without loss. The results are upon the whole exceedingly satisfactory. The man who wants lumber gets it promptly, and without paying an added cost for long transportation. The antiquated construction of European sawmills is often such that the American lumberman would find in them but a proof of his superior ingenuity; but the European distribution of milling plants has its strong advantages in several ways.

\section{DEVELOPMENT OF A TRAINED CLASS OF FOREST WORKERS.}

The general application of conservative methods in lumbering will inevitably result, as has been the case in Europe, in the development of a permanent class of men trained to forest work. Under present methods this result can never be attained to the same degree. The lumbering in one community is generally so short-lived that there is neither time nor necessity to train up a body of men on the ground to carry out the work. The result is that Maine and Michigan woodsmen are found working in the hardwoods of the Southern Appalachians; loggers from Wisconsin and Minnesota are helping to cut the redwood on the Pacific coast; and in each of the great timber regions there is a mingling of lumbermen from several of the others. The effect has been to develop, by constant labor at their trade under widely varying 
conditions, a force of men who are unequaled for enterprise and skill in their profession; but the system has very largely failed in what is of infinitely greater importance to the permanent welfare of the lumber industry - the upbuilding throughout the country of a stable class of workers in the woods, locally trained and carrying on their work each in his own community. The advantages of such a condition lie in an equitable geographieal distribution of labor, in the wholesome influence throughout the country of a class whose means of livelihood is forest work, and in the fact that all the operations of lumbering may in this way be conducted more cheaply than in any other.

\section{INFLUENCE OF FORESTRY UPON THE PRICES OF LUMBER.}

The effect upon the prices of lumber which will result from the application of forestry to the lumber industry will be strongly marked. The wide fluctuation characteristic of lumber values to-day is much more the result of conditions within the industry itself than of variations in the demand for the product of the forest. The uncertainty of available supplies, the lack of true proportion between stumpage values and lumber values, the speculative features which the industry now presents, have all tended to produce an exceedingly unstable and abnormal fluctuation in the prices of lumber, with a marked disposition toward rapid increase. Under forestry the speculative element can not exist. The cost of producing timber, plus a legitimate profit, will be the basis upon which the value of it will be fixed. The annual output of the country will be no longer a matter of conjecture, and a steady and normal range of prices for lumber will be the inevitable result.

\section{CONCLUSION.}

The influence of forestry upon the lumber industry is not a matter of conjecture. The details will have to work themselves out, but the broad results of conservative forest policy on the part of private owners are plain. The lumber industry in the United States is approaching a crisis. There is no more doubt that conservative methods will be applied to lumbering in this country than there is of the development of irrigation, of regulation of grazing, of the application of improved methods in agriculture, or of any other modification to which private as well as public interests point the way. How long it will be before the results of practical forestry make themselves generally felt it is impossible to foretell; but the fact remains that there will be established in this as in other countries in which conservative lumbering has followed wasteful lumbering a legitimate and permanent industry, characterized, as has been stated, by conditions under which speculation can not exist. Prices will continue normal and steady, and the quantity of timber produced will be the main factor in regulating consumption. 


\section{United States Department of Agriculture,}

\section{FOREST SERYYCE-CKRGULAR 107. \\ GIFFORD PINCHOT, Forester.}

\section{SAWMILL STATISTICS.}

A compilation of the reports received from over 10,000 sawmills in the United States upon their operations in 1905 gives the accompanying table, in which are shown the proportion of lumber kilndried and the proportion surfaced, the amount of slab wood sold, and the proportion of logs cut on lands belonging to the sawmill operators. No figures along these lines are available for New York, and none are given for several of the States in which the cut was very small.

The States in which the largest proportion of lumber is kiln-dried by manufacturers are South Carolina, with 51.3 per cent; North Carolina, with 36.5 per cent; Florida, with 35.9 per cent; Alabama, with 34.8 per cent; and Georgia, with 30.6 per cent. In other States the amount is less than 30 per cent. Altogether, 1,642 mills reported the use of dry kilns.

A large amount of the pine cut in the South is kiln-dried in order to reduce its shipping weight, and this is especially true of loblolly or North Carolina pine. Kiln-drying is practiced to a less extent in the Rocky Mountain and Pacific coast States, and very little lumber is kiln-dried by the sawmill operators in the hardwood region or where the cut is principally by portable mills. For the country as a whole, about 15 per cent of the lumber cut is kiln-dried at the mill.

A much larger proportion of the cut is surfaced at the mills than is kiln-dried. Of the mills reporting, more than 3,900 surfaced a portion of their cut. For the country as a whole, at least 35 per cent is surfaced before it is shipped. In this respect Iowa leads, with 77.2 per cent surfaced; but this is because most of the lumber cut in that State is in a few big mills along the Mississippi which operate exclusively on northern pine. Aside from Iowa, the States in which the larger proportion of the cut is surfaced at the sawmill are Texas, with 71.7 per cent; Louisiana, with 60.3 per cent; Idaho, 59.4 per cent; Montana, 55.2 per cent; and Arkansas, with 50.6 per cent. In all the other States less than half the cut is surfaced by the sawmill operators, and, as in kiln-drying, a relatively small proportion of the total cut is surfaced in the hardwood regions.

Some 4,000 mills reported sales of slab wood totaling $3,503,287$ cords. Washington leads in this respect, with 559,231 cords, followed by Michigan, with 523,518 cords; Wisconsin, with 368,478 cords; and Virginia, with 213,522 cords. It is probably safe to assume that this 
slab and waste wood brought on an a verage $\$ 1$ a cord; hence its sale was a considerable source of revenue to many mills.

The percentage of sawed logs which were cut from holdings of sawmill operators is shown in the last column. Considering only the important lumber-producing States, it is interesting to note that the proportions of output reported as sawed from logs cut on the lands owned by the sawmill operators range from 97.4 per cent in California to 34.5 per cent in Washington. The lumber companies in California do their own logging largely on their own holdings, and get but a relatively small quantity of logs from other sources. In Washington most of the logging is done by firms which buy stumpage and deliver logs to the sawmills for a fixed contract price, so that in this case the operator of a mill may own little or no timberland.

Saumill statistics, 1905.

\begin{tabular}{|c|c|c|c|c|c|c|}
\hline State. & $\begin{array}{l}\text { Mills re- } \\
\text { porting. }\end{array}$ & $\begin{array}{c}\text { Average } \\
\text { cut. }\end{array}$ & $\begin{array}{l}\text { Per cent } \\
\text { of lum- } \\
\text { ber kiln- } \\
\text { dried. }\end{array}$ & $\begin{array}{l}\text { Per cent } \\
\text { of lum- } \\
\text { ber sur- } \\
\text { faced. }\end{array}$ & $\begin{array}{l}\text { Slab wood } \\
\text { sold. }\end{array}$ & $\begin{array}{l}\text { Per cent } \\
\text { logged } \\
\text { on own } \\
\text { land. }\end{array}$ \\
\hline Alabama... & $\begin{array}{r}\text { Number. } \\
326\end{array}$ & M feet. & 348 & $27 ?$ & Cords. & \\
\hline Arkansas ........... & 466 & 3,194 & $\begin{array}{l}34.8 \\
28.4\end{array}$ & $\begin{array}{l}37.3 \\
50.6\end{array}$ & $\begin{array}{r}127,536 \\
42,909\end{array}$ & $\begin{array}{l}79.6 \\
77.5\end{array}$ \\
\hline 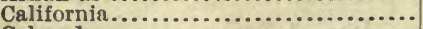 & 175 & 6,066 & 9.5 & 34.6 & $39, \div 88$ & 97.4 \\
\hline 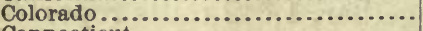 & 52 & 1,091 & & 23.5 & 3,880 & 65.2 \\
\hline Connecticut.$\ldots \ldots \ldots \ldots \ldots \ldots \ldots \ldots \ldots$ & 93 & 751 & .2 & 5.1 & 19,110 & 87.6 \\
\hline 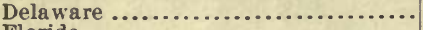 & 29 & 423 & & 8.8 & 3,860 & .96 .5 \\
\hline Florids $\ldots \ldots \ldots \ldots \ldots \ldots \ldots \ldots \ldots \ldots$ & 123 & 5,350 & 35.9 & 33.8 & 35,550 & 85.4 \\
\hline 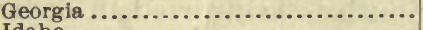 & 349 & 2,042 & 30.6 & - 27.3 & 26,945 & 92.4 \\
\hline 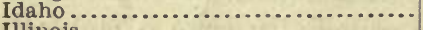 & 54 & $\mathbf{3}, 939$ & 12.5 & 59.4 & 7,608 & 36.4 \\
\hline 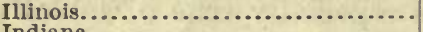 & 174 & 684 & .7 & 27.5 & 20,282 & 34.6 \\
\hline Indiana $\ldots \ldots \ldots \ldots \ldots \ldots \ldots \ldots \ldots \ldots$ & 461 & 764 & 2.1 & 5.9 & 168,426 & 58.7 \\
\hline Iowa......................... & 30 & 4,316 & & 77.2 & 33,520 & 31.9 \\
\hline Kentucky................... & $4: 26$ & 1,091 & 2.1 & 15.5 & 25,245 & 47.9 \\
\hline & 236 & 9,720 & 28.6 & 60. & 66,242 & 85.5 \\
\hline 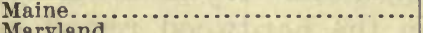 & 373 & $1,9 \subset y$ & 1.1 & 23.7 & 186,202 & 45.8 \\
\hline & 114 & 1,436 & 26.1 & 32.2 & 20,664 & 94.2 \\
\hline Massachusetts .... & 251 & 1,007 & & 25.3 & 39,934 & 65.7 \\
\hline & 437 & 3,935 & 4.5 & 16.6 & 523,518 & 62.9 \\
\hline & 174 & 11,068 & 1.1 & 39.8 & 165,001 & 36.2 \\
\hline & 355 & 3,660 & 29.3 & 34. & 33,509 & 82.5 \\
\hline 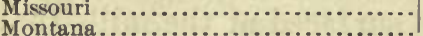 & 225 & 1,610 & 11.6 & 36. & 19,291 & 79.7 \\
\hline $\begin{array}{l}\text { Nontana } \ldots \ldots \ldots \ldots \\
\text { New Hampshire } \ldots \ldots \ldots \ldots\end{array}$ & 23 & 8,230 & 3.4 & 55. & 13,573 & 44.2 \\
\hline & 278 & 1,226 & 2.3 & 21.5 & 29,606 & 61.9 \\
\hline & $\begin{array}{r}66 \\
671\end{array}$ & 268 & 36 & 13. 3 & 9,510 & 82.6 \\
\hline 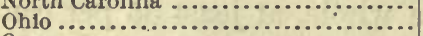 & $\begin{array}{l}671 \\
541\end{array}$ & $\begin{array}{r}1,610 \\
613\end{array}$ & $\begin{array}{r}36.5 \\
1.6\end{array}$ & $\begin{array}{l}22.4 \\
11.3\end{array}$ & $\begin{array}{r}68,931 \\
\end{array}$ & 68. 5 \\
\hline Oregon & 319 & $3,9.58$ & 15.5 & $\begin{array}{l}11.3 \\
46.2\end{array}$ & & 51.1 \\
\hline Pennsylvania $\ldots \ldots \ldots \ldots \ldots \ldots \ldots \ldots$ & 714 & 1,957 & 2.1 & 13.4 & $\begin{array}{l}190,036 \\
176,689\end{array}$ & 53.8 \\
\hline 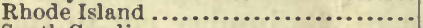 & 16 & 878 & & 7.7 & $\begin{array}{r}170,009 \\
1,210\end{array}$ & $\begin{array}{l}73.9 \\
78.6\end{array}$ \\
\hline 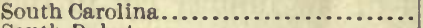 & 205 & 2,275 & 51.3 & 25.6 & 33,415 & 88.4 \\
\hline 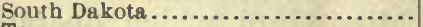 & 15 & 767 & .2 & 18.1 & 1,923 & 94.1 \\
\hline 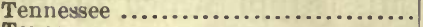 & 495 & 1,093 & 4. 7 & 17.1 & 40,734 & 50.8 \\
\hline 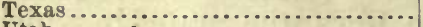 & 165 & 5,636 & 26.0 & 71.7 & 10,234 & 85.4 \\
\hline 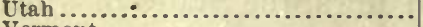 & 21 & 172 & $\ldots$ & 18.2 & 245 & 98.1 \\
\hline Vermont............................... & 287 & 929 & 4. 7 & 40. & 56,154 & 52.8 \\
\hline Virginia ............................ & 458 & 1,562 & 24.0 & 22. & 213,522 & 89.9 \\
\hline Washington...$\ldots \ldots \ldots \ldots \ldots \ldots \ldots \ldots$ & 557 & 7,033 & 15.2 & 35. & 559,231 & 34.5 \\
\hline 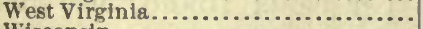 & 285 & 2,361 & 2. 4 & 14.2 & 18.267 & 67.6 \\
\hline Wisconsin ............ & 407 & 6,249 & $2 . \overline{5}$ & 37. & 365,478 & 50.4 \\
\hline Wyoming .... & 14 & 311 & .2 & 24. & 540 & 81.1 \\
\hline Total. & 10,460 & & & & $3,503,287$ & \\
\hline
\end{tabular}

Approved:

JAMES Wirsox,

Secretary.

Wasinington, D. C., June 3, $190 \%$. 


\section{FORESTRY LIBRARY}

- 1910-12 CPan. Amberndetry 7 .

U. S. DEPARTMENT OF AGRICULTURE FOREST SERVICE

\section{RECORD OF}

\section{WHOLESALE PRICES OF LUMBER}

(PER 1,000 FEET B. M.)

Based on actual sales made F. O. B. Mill for

APRIL, MAY and JUNE, 1909. 



\section{PREFATORY NOTE}

The Forest Service has two main purposes in collecting and compiling this record of $\mathrm{f} . \mathrm{o}$. b. mill prices: first, to have a continuous statistical record of such prices of the various commercial woods; and, second, to show, in contrast to market prices-which include the important items of freight charges and selling costs-just what the manufacturers of lumber receive for their product at the mill. The prices given are wholesale, based on actual sales f. o. b. mill, for delivery outside of local territory. Only a few representative grades and the mill run are included. $\mathrm{By}$ mill run is meant the average of all grades of lumber produced. The record is compiled by states, and is made up from reports received from approximately 2,000 of the largest manufacturers scattered throughout the country. It will be published quarterly.

The Forest Service wishes to acknowledge the courtesy of the manufacturers for their prompt and efficient coöperation. Their assistance has been of great value in making the record complete accurate, and promptly available for distribution. 


\begin{tabular}{|c|c|c|}
\hline & SPECIES & GRADE \\
\hline 1 & Cedar, Western Red. & Beveled Siding No. $1,1^{\prime \prime} \times 6^{\prime \prime}$. \\
\hline 2 & Do... & Shop No. $2,1^{\prime \prime}$ and $1 \frac{1}{2}{ }^{2} \times 8^{\prime \prime}$. \\
\hline$\overline{3}$ & ............ & Shingles, Perfection, $18^{\prime \prime}$ \\
\hline $\begin{array}{l}4 \\
5\end{array}$ & $\cdots \cdots \cdots \cdots \cdots \cdots$ & $\begin{array}{l}\text { Shingles, Extra Clear, } 5 / 2^{\prime \prime}-16^{\prime \prime} \ldots \ldots \ldots \ldots \ldots \ldots \\
\text { Star-A-Star, } 6 / 2^{\prime \prime}-16^{\prime \prime}, \ldots \ldots \ldots \\
\end{array}$ \\
\hline 6 & 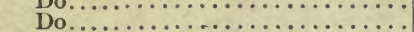 & 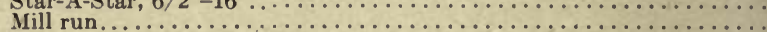 \\
\hline 7 & 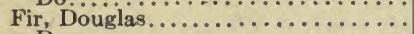 & Flooring No. 1 , v. g. $\mathrm{i}^{\prime \prime} \times 4^{\prime \prime}$ \\
\hline 8 & 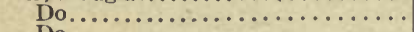 & 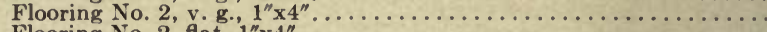 \\
\hline 9 & $\ldots \ldots \ldots \ldots \ldots$ & 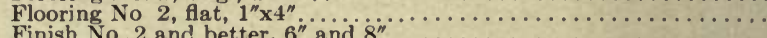 \\
\hline $\begin{array}{l}10 \\
11\end{array}$ & $\ldots \ldots \ldots \ldots \ldots \ldots \ldots$ & $\begin{array}{l}\text { Finish No. } 2 \text { and better, } 6^{\prime \prime} \text { and } 8^{\prime \prime} \ldots \ldots \ldots \ldots \ldots \ldots \ldots \ldots \ldots \\
\text { Drop Siding, No. } 2 \text { slash }{ }^{\prime} \ldots \ldots \ldots \ldots \ldots \ldots \ldots\end{array}$ \\
\hline 12 & Do. & 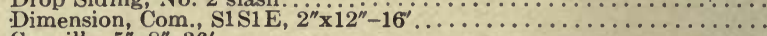 \\
\hline 13 & $\ldots \ldots \ldots \ldots$ & 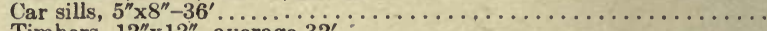 \\
\hline 14 & . $\ldots \ldots \ldots \ldots \ldots$ & 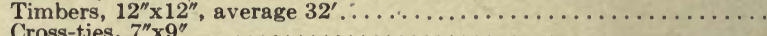 \\
\hline $\begin{array}{l}15 \\
16\end{array}$ & $\ldots \ldots \ldots \ldots \ldots$ & 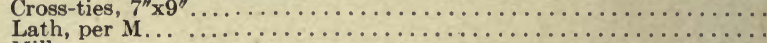 \\
\hline 17 & Do. & $\ldots \ldots \ldots \ldots \ldots \ldots \ldots \ldots \ldots \ldots \ldots \ldots \ldots \ldots$ \\
\hline 18 & Fir, Wh & 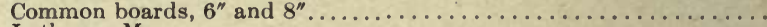 \\
\hline 19 & $\cdots \cdots \cdots \cdots \cdots$ & 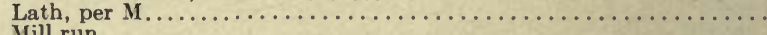 \\
\hline $\begin{array}{l}20 \\
21\end{array}$ & $\begin{array}{l}\text { Do..... W, Western..... } \\
\text { Hemlock, }\end{array}$ & 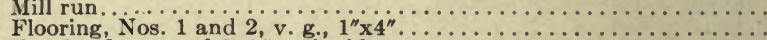 \\
\hline 22 & Do.................... & Finish, Nos. 1 and $2,5^{\prime \prime}$ and wider. \\
\hline 23 & $\ldots \ldots \ldots \ldots \ldots$ & Dimension, No. 1 Com., $2^{\prime \prime} \mathbf{x}^{\prime \prime}$ to $2^{\prime \prime} \mathbf{x}^{\prime \prime} \ldots \ldots \ldots \ldots \ldots \ldots \ldots \ldots \ldots \ldots \ldots \ldots \ldots$ \\
\hline $\begin{array}{l}24 \\
25\end{array}$ & $\ldots \ldots \ldots \ldots \ldots \ldots \ldots \ldots$ & $\begin{array}{l}\text { Shiplap, } 1^{\prime \prime} \\
\text { Shop No. } 1,1{ }^{\prime \prime}{ }^{\prime \prime}{ }^{\prime \prime} \text { and wider } \ldots \ldots \ldots\end{array}$ \\
\hline 26 & Do.. & 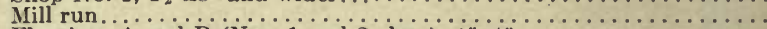 \\
\hline 27 & Larch, Western & Flooring, $A$ and $B$ (Nos. 1 and 2 clear), $1^{\prime \prime} \times 4^{\prime \prime}$. \\
\hline 28 & Do.. & Finish, $\mathbf{A}$ and $\mathbf{B}$ (Nos. 1 and 2 clear), $1^{\prime \prime} \times 8^{\prime \prime}$. \\
\hline 29 & Do & Drop siding, $A$ and $B$ (Nos. 1 and 2 clear), $1^{\prime \prime} \times 6^{\prime \prime} \ldots \ldots$ \\
\hline 30 & Do & Common boards, No. $2,1^{\prime \prime} \times 8^{\prime \prime}-16^{\prime} \ldots \ldots \ldots \ldots \ldots \ldots \ldots \ldots \ldots \ldots \ldots \ldots \ldots \ldots \ldots \ldots$ \\
\hline 31 & Do. & Dimension, No. 1 Com., $2^{\prime \prime} \mathrm{x}^{\prime \prime}-16^{\prime} \ldots \ldots \ldots \ldots \ldots \ldots \ldots \ldots \ldots \ldots$ \\
\hline 32 & $\cdots \cdots$ & 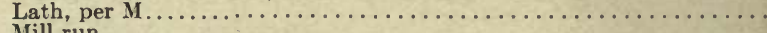 \\
\hline 33 & Do....... & $\ldots \ldots \ldots \ldots \ldots \ldots \ldots \ldots \ldots \ldots \ldots \ldots \ldots \ldots \ldots$ \\
\hline $\begin{array}{l}34 \\
35\end{array}$ & $\begin{array}{l}\text { Pine, Sugar. } \\
\text { Do........ }\end{array}$ & $\cdots \ldots \ldots \ldots \ldots \ldots \ldots \ldots \ldots \ldots \ldots \ldots \ldots$ \\
\hline $\begin{array}{l}30 \\
36\end{array}$ & $\begin{array}{l}\text { Do. } \\
\text { Do. }\end{array}$ & 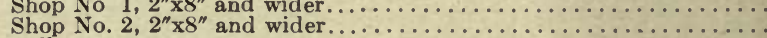 \\
\hline 37 & Do. & 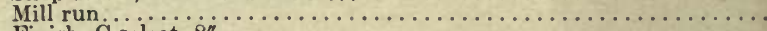 \\
\hline 38 & Pine, & 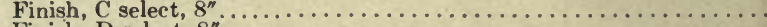 \\
\hline 39 & Do (Idaho White). & 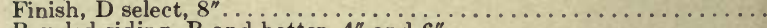 \\
\hline 40 & Do. & Beveled siding, $\mathrm{B}$ and better, $4^{\prime \prime}$ and $6^{\prime \prime} \ldots \ldots \ldots \ldots \ldots \ldots \ldots \ldots$ \\
\hline $\begin{array}{l}41 \\
42\end{array}$ & Do... & $\begin{array}{l}\text { Beveled siding, } \mathbf{C}, 4^{\prime \prime} \text { and } 6^{\prime \prime} \text { ind }{ }^{\prime \prime}{ }^{\prime \prime} \cdots \cdots \\
\text { Common boards, No. } 2,6^{\prime \prime} \text { and }\end{array}$ \\
\hline 43 & Do. & Mill run \\
\hline 44 & Pine, Western & Flooring, $\mathrm{B}$ and better (Nos. 1 anc \\
\hline 45 & $\begin{array}{c}\text { Do (Including Western Pine, Cal- } \\
\text { ifornia White Pine, New } \\
\text { Mexico White Pine) }\end{array}$ & $\ldots \ldots \ldots$. \\
\hline 46 & $\ldots \ldots$ & Finish, C select, $8^{\prime \prime}$ \\
\hline & & Beveled siding, $B$ and $b$ \\
\hline 48 & Do. & Beveled siding, $\mathrm{C}, 4^{\prime \prime}$ and $6^{\prime \prime} \ldots$ \\
\hline 49 & Do. & . $\ldots \ldots \ldots \ldots \ldots \ldots \ldots \ldots$ \\
\hline $\begin{array}{l}50 \\
51\end{array}$ & $\begin{array}{l}\mathrm{D} \\
\mathrm{D}\end{array}$ & Shop No $2,6 / 4 \ldots$ \\
\hline 52 & Do. & 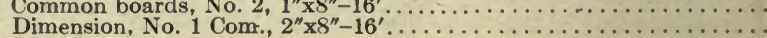 \\
\hline 53 & Do. & 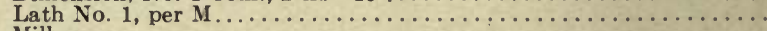 \\
\hline 54 & Do. & $\ldots \ldots \ldots \ldots \ldots \ldots \ldots \ldots \ldots \ldots \ldots \ldots$ \\
\hline 55 & Redwoo & Clear, $6^{\prime \prime}$ to $12^{\prime \prime}, 10^{\prime}$ to $20^{\prime}$ \\
\hline 56 & & 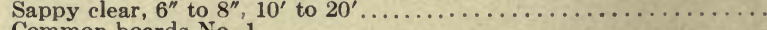 \\
\hline 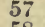 & & ....................... \\
\hline 58 & Do & 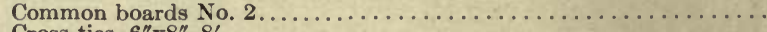 \\
\hline 59 & Do & . $\ldots \ldots \ldots \ldots \ldots \ldots$ \\
\hline 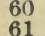 & $\begin{array}{l}\mathrm{Dc} \\
\mathrm{Dc}\end{array}$ & Shingles No. 1, per M........ \\
\hline 62 & & $\cdots \cdots \cdots \cdots \cdots \cdots \cdots \cdots \cdots \cdots \cdots$ \\
\hline 63 & Spruce & $\begin{array}{l}\text { Mill run.................. } \\
\text { Firsts and seconds, elear, } 12^{\prime \prime} \text {. }\end{array}$ \\
\hline 64 & Do (Western Spruce). & 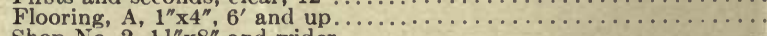 \\
\hline 65 & Do $\ldots \ldots \ldots \ldots$ & 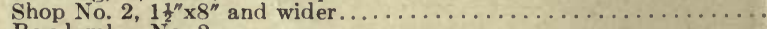 \\
\hline $\begin{array}{l}6 \\
6\end{array}$ & Do. & lumber No. $2 \ldots \ldots$. \\
\hline & ........ & 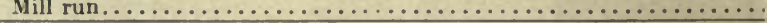 \\
\hline
\end{tabular}




\begin{tabular}{|c|c|c|c|c|c|c|c|}
\hline & Colorado & California & Oregon & Washington & Idaho & Montana & \\
\hline $\begin{array}{r}1 \\
2 \\
3 \\
4 \\
5 \\
6 \\
7 \\
8 \\
9 \\
10 \\
11 \\
12 \\
13 \\
14 \\
15 \\
16 \\
17 \\
18 \\
19 \\
20 \\
21 \\
22 \\
23 \\
24 \\
25 \\
26 \\
27 \\
28 \\
29 \\
30 \\
31 \\
32 \\
33 \\
34 \\
35 \\
36 \\
37 \\
38 \\
39 \\
40 \\
41 \\
42 \\
43 \\
44 \\
45\end{array}$ & 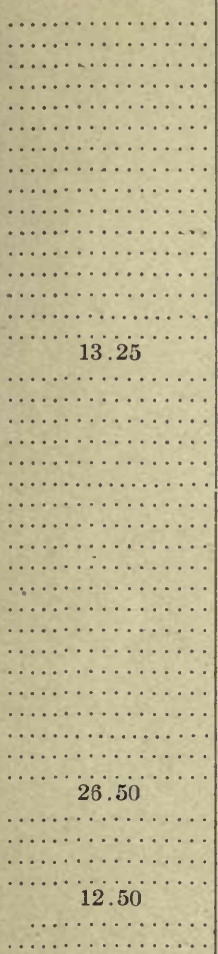 & 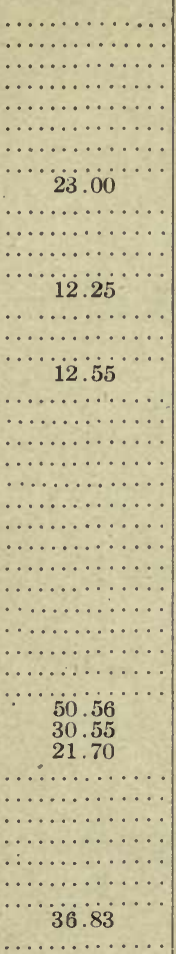 & 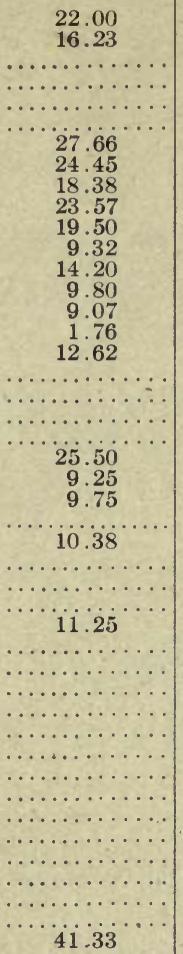 & 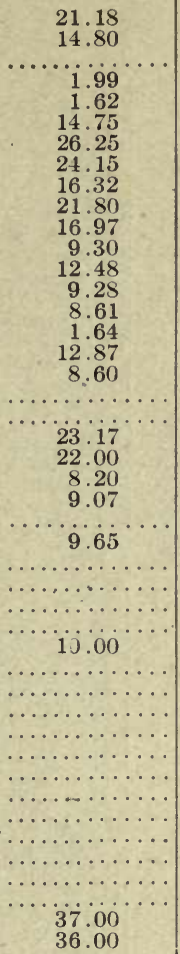 & 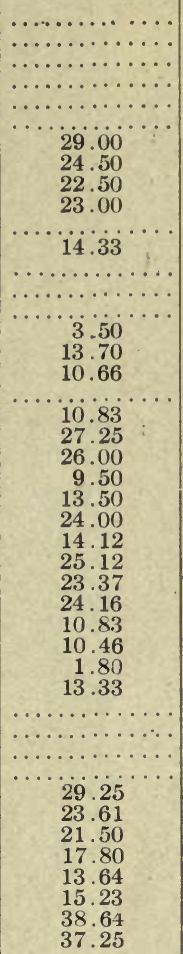 & 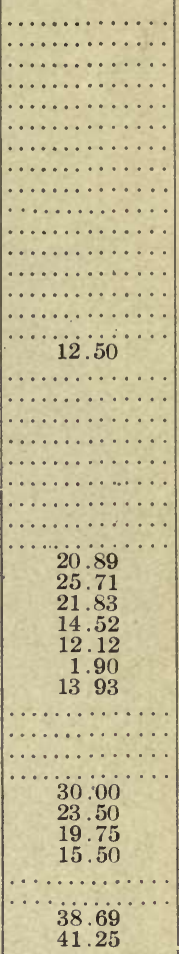 & $\begin{array}{r}1 \\
2 \\
3 \\
4 \\
5 \\
6 \\
7 \\
8 \\
9 \\
10 \\
11 \\
12 \\
13 \\
14 \\
15 \\
16 \\
17 \\
18 \\
19 \\
20 \\
21 \\
22 \\
23 \\
24 \\
25 \\
26 \\
27 \\
28 \\
29 \\
30 \\
31 \\
32 \\
33 \\
34 \\
35 \\
36 \\
37 \\
38 \\
39 \\
40 \\
41 \\
42 \\
43 \\
44 \\
45\end{array}$ \\
\hline $\begin{array}{l}45 \\
47 \\
48 \\
49 \\
50 \\
51 \\
52 \\
53 \\
54 \\
55 \\
56 \\
57 \\
58 \\
59 \\
60 \\
61 \\
62 \\
63 \\
64 \\
65 \\
66 \\
67 \\
\end{array}$ & 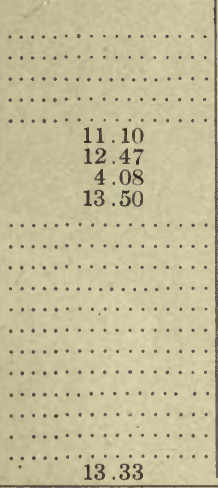 & 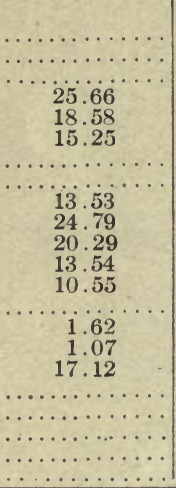 & 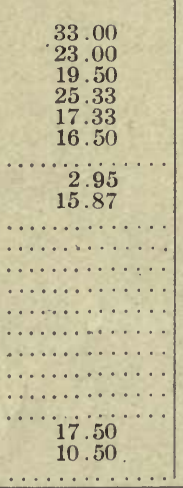 & 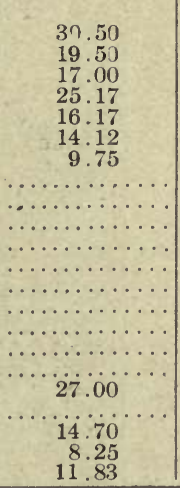 & 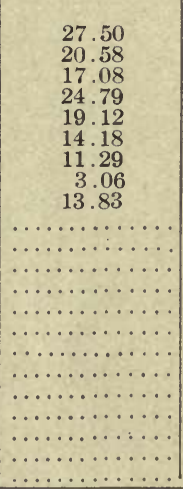 & 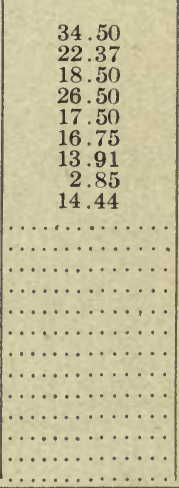 & $\begin{array}{l}46 \\
47 \\
48 \\
49 \\
50 \\
51 \\
52 \\
53 \\
54 \\
55 \\
56 \\
57 \\
58 \\
59 \\
60 \\
61 \\
62 \\
63 \\
64 \\
65 \\
66 \\
67\end{array}$ \\
\hline
\end{tabular}


Hemlock

Do (Lake States)

Do

Do.

Do.

Do...

Do (Eastern and West Virginia)

Do...

Do.

Do.

Do.

Do.

-Pine.

Do (North Carolina)

Do..

Do.

Do.

Do.

Do.

Pine, white

Do.

Do.

Do.

Do.

Do.

Do.

Do.

Do.

Do.

Pine, yellow

Do (Mississippi Valley Mills).

Do.

Do.

Do.

Do.

Do.

Do.

Do.

Do.

Do.

Pine, yellow

Do (Atlantic Coast Mills)

Do.

Do.

Do.

Do.

Do.

Do Merch. grade (Sail)

Do.

Do

Do

Do

Spruce (Eastern)

Do..

Do

Do.

Do.

Do (Adirondack)

Do.

Do

Do.

Do.

Do (West Virginia)

Do...

Do

Do. $2^{\prime \prime}$ piece stuff, S1S1 E, $2^{\prime \prime} \times 4^{\prime \prime}-16^{\prime}$

Boards, No. 1, S1 S, $1^{\prime \prime} \times 8^{\prime \prime}-16^{\prime \prime}$

Timbers, rough, $4^{\prime \prime} \times 4^{\prime \prime}$ to $8^{\prime \prime} \times 8^{\prime \prime}-16^{\prime}$

Fencing No. 1, S1S, $1^{\prime \prime} \times 6^{\prime \prime}$

Lath No. $1,3 / 8^{\prime \prime}-4^{\prime}$

Mill run

$8 / 4$ merch. piece stuff, $16^{\prime}$

$4 / 4$ merch. $6^{\prime \prime}$ and $8^{\prime \prime}-16$

$4 / 4$ merch. $10^{\prime \prime}$ and $12^{\prime \prime}-16^{\prime}$

$4 / 4$ merch. boards, $6^{\prime \prime}$ and up, S1S, elipped, $12^{\prime}, 14^{\prime}$ and $16^{\prime}$

$4 / 4$ boards, No. $2,1^{\prime \prime} \times 4^{\prime \prime}-12^{\prime \prime}, 6^{\prime}-20^{\prime}$

Nill run, mill culls out.

Mill culls.

Mill run.

Flooring, No. $2,1^{\prime \prime} \times 4^{\prime \prime} \times 10^{\prime}-16^{\prime}$

Flooring, No. $3,1^{\prime \prime} \times 4^{\prime \prime} \times 10^{\prime}-16^{\prime}$

ander.

Roofers, 1"x8", D. \& M

Partition No. $1,13 / 16^{\prime \prime} \times 32^{\prime \prime}, 10^{\prime}-16^{\prime}$

No. 1 edge $4 / 4$, under $12^{n}$

Box edge 4/4, under $12^{n}$

Mill run...

Selects $\mathrm{C}$ and better, 5

Inch finish, $10^{\prime \prime}$ (M. L.).

Shop No. 1, 8/4 (M. L.).

Shop No. $3,5 / 4$ (M. L.)

Beveled siding, $\mathrm{C}, 6^{\prime \prime}-16^{\prime}$

Boards No. 2, $1^{\prime \prime} \mathrm{xS}^{\prime \prime}-16^{\prime}$

Boards No. $3,12^{\prime \prime}, 10^{\prime}-20^{\prime}$.

Boards No. 4, $8^{\prime \prime}$ and under, $10^{\prime}-20^{\prime}$

Fencing No. 2 , S1S, $6^{\prime \prime}-16^{\prime}$

Lath No. 1

Lath No. 1 (mixed)

Mill run

Flooring, B, v. g., $13 / 16^{\prime \prime} \times 31^{\prime \prime}$

Flooring, $B$ and better, flat, $13 / 16^{\prime \prime} \times 3 t^{\prime \prime}$

Finish, $\mathrm{B}$ and better, $6^{\prime \prime}$ and wider.

Dimension No. 1 , S1 S1 E, $2^{\prime \prime} \times 8^{\prime \prime}-16^{\prime}$.

Com. boards No. 1 , S2S, $1^{\prime \prime} \times 10^{\prime \prime}$

Timbers, S1S1 E, 4" $\times 4^{\prime \prime}-16^{\prime}$

Car sills, $51^{\prime \prime} \times 91^{\prime \prime}-36^{\prime}$

Car siding, $\mathrm{B}$ and better, $1^{\prime \prime} \times 4^{\prime \prime}$ and $6^{\prime \prime} \times 9^{\prime \prime}-18^{\prime}$

Car siding, $\mathrm{B}$ and better, $1^{\prime \prime} \times 4^{\prime \prime}$ and $6^{\prime \prime} \times 10^{\prime \prime}-20^{\prime}$

Com. car lining, No. 1, $1^{\prime \prime} \times 6^{\prime \prime} \times 10^{\prime}-20^{\prime}$

Lath No. 1,3

Mill run.

Finish, B and better, $6^{\prime \prime}$ and wider

Flooring, $\mathrm{B}$ and better, heart rift, $13 / 16^{\prime \prime} \times 2 \frac{1}{2}$ "

Flooring, B and better, sap rift, $13 / 16^{\prime \prime} \times 2 z^{\prime \prime}$

Flooring, B, heart rift, $13 / 16^{\prime \prime} \times 2 \frac{1}{2}^{\prime \prime}$.

Flooring, B, sap rift, $13 / 16^{\prime \prime} \times 2 \frac{1}{2}{ }^{\prime \prime}$

Flooring, B, sap flat, $13 / 16^{\prime \prime} \times 3 t^{\prime \prime}$

Com. boards, No. 1 , S2S, $1^{\prime \prime} \times 10^{\prime \prime} \times 10^{\prime}-16^{\prime}$

Com. boards, No. 2, S2S, $1^{\prime \prime} \times 10^{\prime \prime} \times 10^{\prime}-16^{\prime}$ Plank and dimensions:

Sizes $2^{\prime \prime} \times 6^{\prime \prime}$ to $8^{\prime \prime} \times 8^{\prime \prime}$, average $24^{\prime}$

Sizes $2^{\prime \prime} \times 9^{\prime \prime}$ to $10^{\prime \prime} \times 10^{\prime \prime}$, average 24

Sizes $2^{\prime \prime} \times 12^{\prime \prime}$ to $12^{\prime \prime} \times 12^{\prime \prime}$, average $24^{\prime}$

Sizes $2^{\prime \prime} \times 14^{\prime \prime}$ to $14^{\prime \prime} \times 14^{\prime \prime}$, average $24^{\prime \prime}$

Sizes $2^{\prime \prime} \times 16^{\prime \prime}$ to $16^{\prime \prime} \times 16^{\prime \prime}$, average $24^{\prime}$

Iill run.

Merch. frames $9^{\prime \prime}$ and under, $24^{\prime}$ and under

Merch. frames $10^{\prime \prime}$ and $12^{\prime \prime}, 24^{\prime}$ and under.

Merch. random $10^{\prime \prime}$ and $12^{\prime \prime}, 70^{\prime}$ and up.

Merch. $2^{\prime \prime} \times 7^{\prime \prime}$ and under, $10^{\prime}$ to $24^{\prime}$

Merch. $2^{\prime \prime} \times 8^{\prime \prime}$ and up, $10^{\prime}$ to $24^{\prime}$

Lath, $1_{\mathrm{B}}^{\mathrm{s} \prime \prime}$

Mill run.

Mill run, mill culls out.

No. 1 and clear

No. 2

No. 3

Mill culis .

Mill run

Merch. frames $3^{\prime \prime} \times 4^{\prime \prime}$ to $8^{\prime \prime} \times 8^{\prime \prime}, 10^{\prime}-16^{\prime}$

Merch. frames $2^{\prime \prime} \times 12^{\prime \prime}$ to $12^{\prime \prime} \times 12^{\prime \prime}, 10^{\prime}-16$

Boards, merch., $1^{\prime \prime} \times 12^{\prime \prime}, 10^{\prime}-20^{\prime}$

Boards, box, $1^{\prime \prime} \times 4^{\prime \prime}-12^{\prime \prime}$

Mill run 


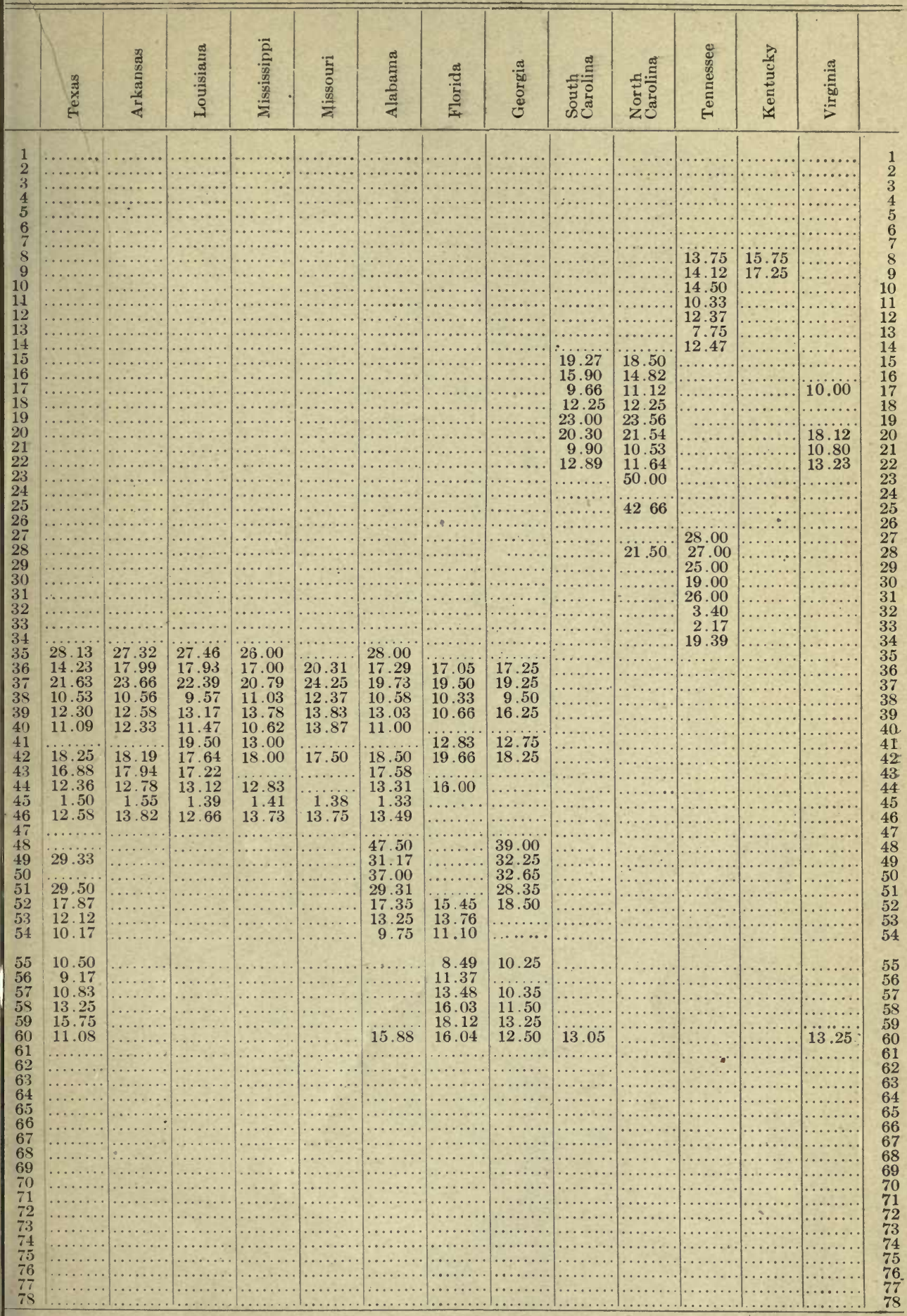




\section{Hemlock}

Do (Lake States)

Do.

Do..

Do.

Do.

Hemlock

Do (Eastern and West Virginia).

Do......

Do.

Do...

Do.....

Do.

Pine.

Do (North Carolina).

Do.

Do.

Do.

Do.

Do.

Pine, white.

Do...

Do.

Do.

Do.

Do.

Do.

Do.

Do.

Do.

Do.

Pine, yellow

Do (Mississippi Valley Mills)...

Do.

Do.

Do.

Do.

Do.

Do.

Do

Do.

Do.

Pine, yellow

Do (Atlantic Coast Mills)

Do

Do

Do

Do

Do

Do.

Do Merch. grade (Sail)

Do

Do.

Do

Do

Spruce (Eastern)

Do

Do.

Do.

Do.

Do (Adirondack)

Do....

Do. .

Do...

Do

Do (west Virginia)

Do...

Do

Do. $2^{n}$ piece stuff, S1S1E, $2^{\prime \prime} \times 4^{\prime \prime}-16^{\prime}$

Boards, No. 1, Sis, $1^{\prime \prime} \times 8^{\prime \prime}-16^{\prime}$

Timbers, rough, $4^{\prime \prime} \times 4^{\prime \prime}$ to $8^{\prime \prime} \times 8^{\prime \prime}-16^{\prime}$

Fencing No. $1, \mathrm{~S} 1 \mathrm{~S}, 1^{\prime \prime} \mathrm{x} 6^{\prime \prime}$

Lath No. $1,3 / 8^{\prime \prime}-4^{\prime}$

Mill run.

$8 / 4$ merch. piece stuff, $16^{\prime}$

$4 / 4$ merch. $6^{\prime \prime}$ and $8^{\prime \prime}-16^{\prime}$

$4 / 4$ merch. $10^{\prime \prime}$ and $12^{\prime \prime}-16^{\prime}$

$4 / 4$ merch. boards, $6^{\prime \prime}$ and up, Sis, clipped, $12^{\prime}, 14^{\prime}$ and $16^{\prime}$

$4 / 4$ boards, No. $2,1^{\prime \prime} \times 4^{\prime \prime}-12^{\prime \prime}, 6^{\prime}-20^{\prime}$

Mill run, mill culls out

Mill culls.

Mill run.

Flooring, No. $2,1^{\prime \prime} \times 4^{\prime \prime} \times 10^{\prime}-16^{\prime}$

Flooring, No. $3,1^{\prime \prime} \times 4^{\prime \prime} \times 10^{\prime}-16^{\prime}$

Dimension (air dried), $2^{\prime \prime} \times 8^{\prime \prime}-16^{\prime}$ and under

Roofers, $1^{\prime \prime} \times 8^{\prime \prime}, 1$. \& M.

Tartion No. 1, 13/16"x3

Box edge $4 / 4$, under $12^{\prime \prime}$

Mill run.

Selects $C$ and better, $5 / 4$ (M. L.)

Inch finish, 10" (M. L.)

Shop No. 1, 8/4 (M. L.)

Shop No. $3,5 / 4$ (M. L.)

Beveled siding, $\mathrm{C}, 6^{\prime \prime}-16^{\prime}$

Boards No. 2, 1"x $8^{\prime \prime}-16^{\prime}$.

Boards No. 3, 12", $10^{\prime}-20^{\prime}$

Boards No. 4, $8^{\prime \prime}$ and under, $10^{\prime}-20^{\prime}$

Fencing No. 2, S1S, 6" $16^{\prime \prime}$

Lath No. 1.

Lath No. 1 (mixed).

Mill run.

Flooring, B, v. g., $13 / 16^{\prime \prime} \times 3 j^{\prime \prime}$

Flooring, $B$ and better, flat, $13 / 16^{\prime \prime} \times 3$

Finish, B and better, $6^{\prime \prime}$ and wider

Dimension No. 1 , S1S1 E, 2"x $8^{\prime \prime}-16^{\prime}$

Com. boards No. 1, S2S, $1^{\prime \prime} \times 10^{\prime \prime}$.

Timber, S1S1 E, $4^{\prime \prime} \times 4^{\prime \prime}-16^{\prime}$

Car sills, 51"x91" $-36^{\prime}$

Car siding, $\mathrm{B}$ and better, $1^{\prime \prime} \times 4^{\prime \prime}$ and $6^{\prime \prime} \times 9^{\prime \prime}-18^{\prime}$

Com. car lining, No. $1,1^{\prime \prime} \times 6^{\prime \prime} \times 10^{\prime}-20^{\prime}$

Lath No. 1, ${ }_{8}^{\prime \prime}$

Mill run.

Finish, $B$ and better, $6^{\prime \prime}$ and wider

Flooring, $B$ and better, heart rift, $13 / 16^{\prime \prime} \times 21^{\prime \prime}$

Flooring, $B$ and better, sap rift, $13 / 16^{\prime \prime} \times 2 \frac{1}{2}$

Flooring, B, heart rift, $13 / 16^{\prime \prime} \times 2 \frac{1}{2}^{\prime \prime}$

Flooring, B, sap rift, $13 / 16^{\prime \prime} \times 2 \frac{1}{2}$

Flooring, B, sap flat, $13 / 16^{\prime \prime} \times 3 t^{\prime \prime}$

Com. boards, No. 1, S2S, $1^{\prime \prime} \times 10^{\prime \prime} \times 10^{\prime}-16^{\prime}$

Com. boards, No. 2, S2S, $1^{\prime \prime} \times 10^{\prime \prime} \times 10^{\prime}-16^{\prime}$

Plank and dimensions:

Sizes $2^{\prime \prime} \times 6^{\prime \prime}$ to $8^{\prime \prime} \times 8^{\prime \prime}$, average $2^{\prime}$

Sizes $2^{\prime \prime} \times 9^{\prime \prime}$ to $10^{\prime \prime} \times 10^{\prime \prime}$, a verage $24^{\prime}$

Sizes $2^{\prime \prime} \times 12^{\prime \prime}$ to $12^{\prime \prime} \times 12^{\prime \prime}$, a verage $24^{\prime}$

Sizes $2^{\prime \prime} \times 14^{\prime \prime}$ to $14^{\prime \prime} \times 14^{\prime \prime}$, average $24^{\prime}$

Sizes $2^{\prime \prime} \times 16^{\prime \prime}$ to $16^{\prime \prime} \times 16^{\prime \prime}$, average $24^{\prime}$.

Mill run

Merch. frames $9^{\prime \prime}$ and under, $24^{\prime}$ and under

IIerch. frames $10^{\prime \prime}$ and $12^{\prime \prime}, 24^{\prime}$ and under.

Merch. random 10" and $12^{\prime \prime}, 10^{\prime}$ and up.

Merch. $2^{\prime \prime} \times 7^{\prime \prime}$ and under, $10^{\prime}$ to $24^{\prime}$

Merch. $2^{\prime \prime} \times 8^{\prime \prime}$ and up, $10^{\prime}$ to $24^{\prime}$.

Lath, 1 1" $^{\prime \prime}$

Mill run.

Mill run, mill culls out.

No. 1 and clear.

No. 2.

No. 3

Mill culls.

Mill run.

Merch. frames $3^{\prime \prime} \times 4^{\prime \prime}$ to $8^{\prime \prime} \times 8^{\prime \prime}, 10^{\prime}-16^{\prime}$

Merch. frames $2^{\prime \prime} \times 12^{\prime \prime}$ to $12^{\prime \prime} \times 12^{\prime \prime}, 10^{\prime}-16^{\prime}$

Boards, merch., $1^{\prime \prime} \times 12^{\prime \prime}, 10^{\prime}-20^{\prime}$

Boards, box, $1^{\prime \prime} \times 4^{\prime \prime}-12^{\prime \prime}$ Mill run 


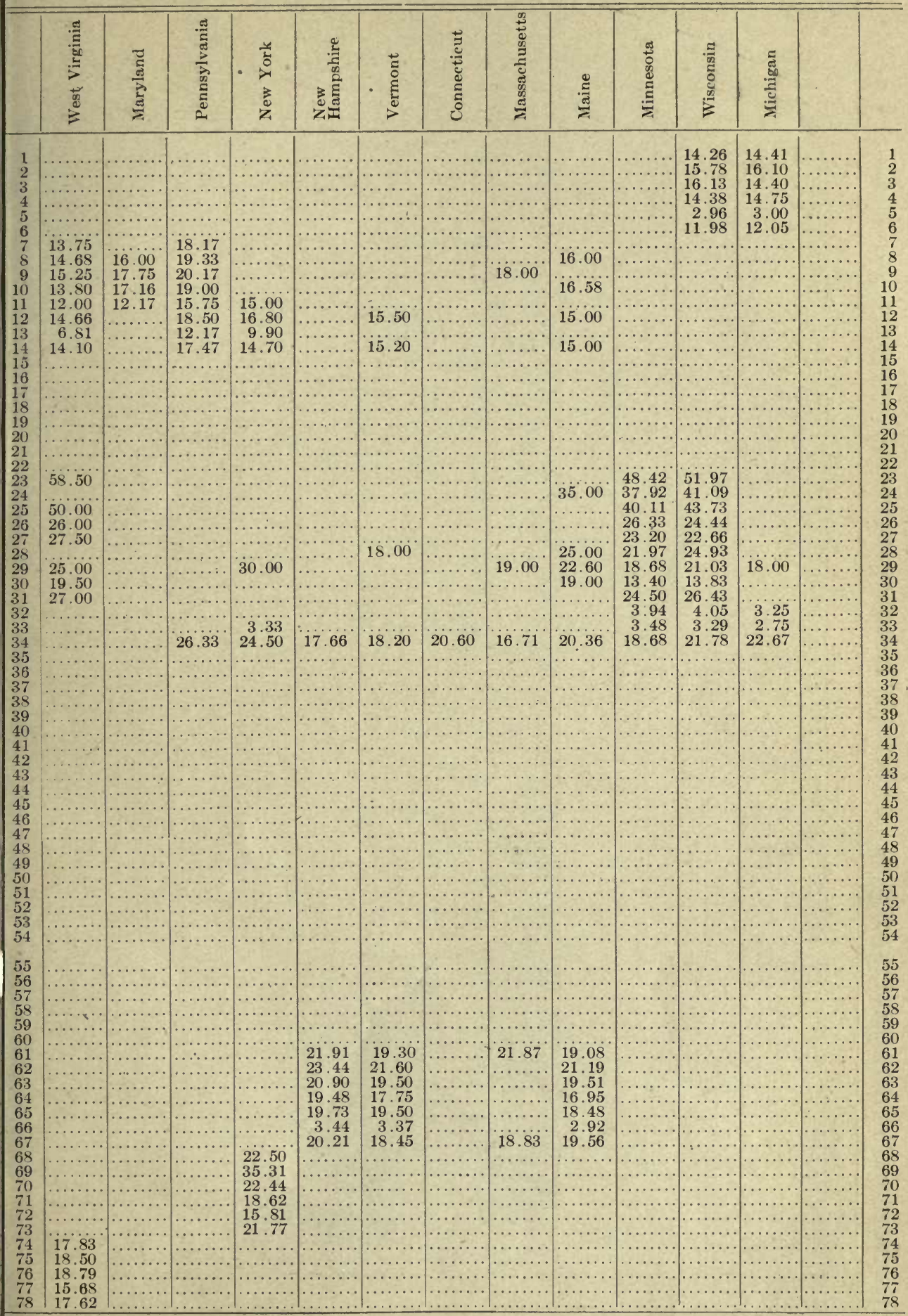




\begin{tabular}{|c|c|c|}
\hline & SPECIES & GRADE. \\
\hline 1 & sil. & Firsts and seconds $4 / 4$ \\
\hline 2 & 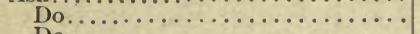 & $\ldots \ldots \ldots \ldots \ldots \ldots \ldots \ldots \ldots \ldots \ldots \ldots$ \\
\hline$\overline{3}$ & $\ldots \ldots \ldots \cdots \cdots \cdots$ & $\ldots \ldots \ldots \ldots \ldots \ldots \ldots \ldots \ldots \ldots \ldots$ \\
\hline $\begin{array}{l}4 \\
5\end{array}$ & 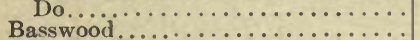 & 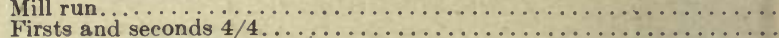 \\
\hline 6 & 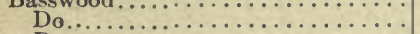 & 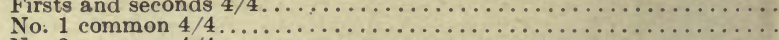 \\
\hline 7 & 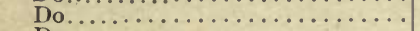 & 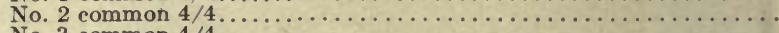 \\
\hline & 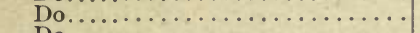 & 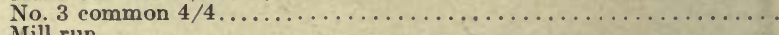 \\
\hline 9 & 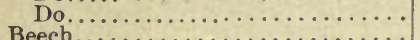 & 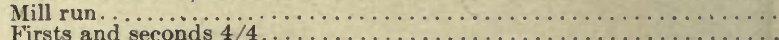 \\
\hline 10 & 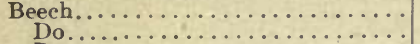 & 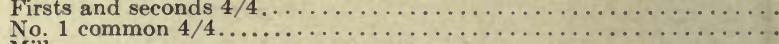 \\
\hline 12 & $\ldots \ldots \ldots \ldots \ldots \ldots \ldots$ & 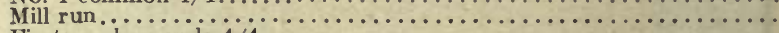 \\
\hline 13 & Birch, unselected.............. & 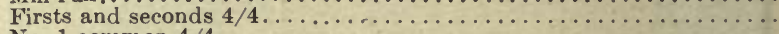 \\
\hline 14 & 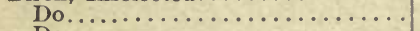 & 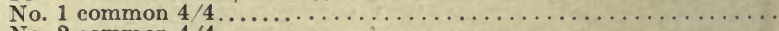 \\
\hline & 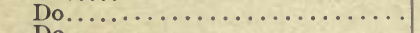 & 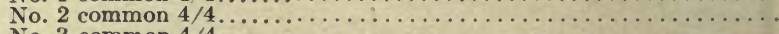 \\
\hline 16 & 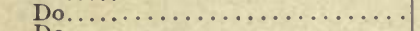 & 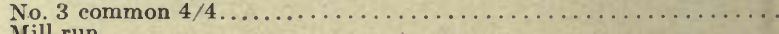 \\
\hline 17 & 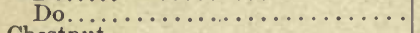 & 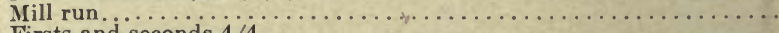 \\
\hline 18 & Chestnut.................... & 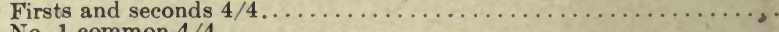 \\
\hline 19 & & 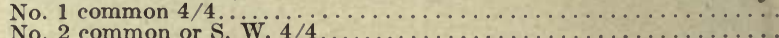 \\
\hline 20 & 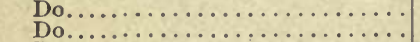 & $\begin{array}{l}\text { No. } 2 \text { common or } \mathrm{S} \text { c } \mathrm{W} .4 / 4, \ldots \\
\text { No. } 3 \text { common } 4 / 4, \ldots \ldots\end{array}$ \\
\hline 21 & $\ldots \ldots \ldots \ldots \ldots \ldots \ldots \ldots \ldots$ & 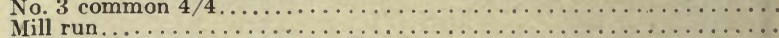 \\
\hline 23 & 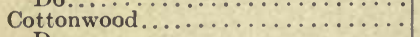 & 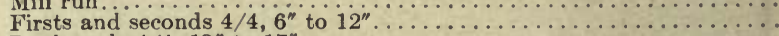 \\
\hline 24 & 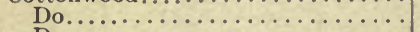 & 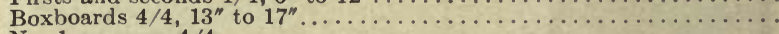 \\
\hline 25 & $\ldots \ldots \ldots \ldots \ldots \ldots \ldots$ & 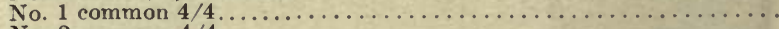 \\
\hline 26 & Do..................... & 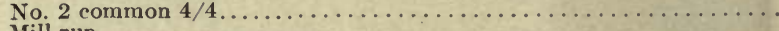 \\
\hline 27 & Do..................... & 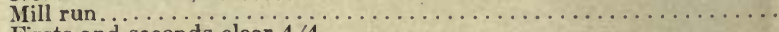 \\
\hline 28 & Cypress................... & 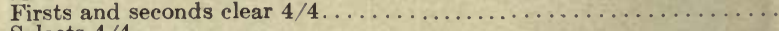 \\
\hline 29 & Do $\ldots \ldots \ldots \ldots \ldots \ldots \ldots \ldots \ldots \ldots \ldots \ldots \ldots$ & 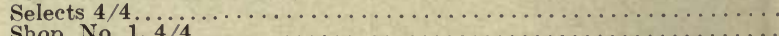 \\
\hline 30 & & 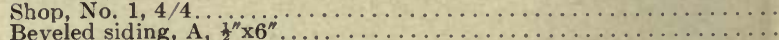 \\
\hline $\begin{array}{l}31 \\
32\end{array}$ & 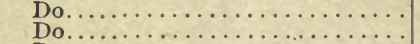 & $\begin{array}{l}\text { Beveled siding, } A,{ }^{\frac{1}{2}} \mathrm{x}^{\prime \prime} \ldots \ldots \ldots \\
\text { No. } 1 \text { common } 4 / 4 \text {, random widths. } \ldots \ldots \ldots \ldots \ldots \ldots \ldots \ldots \ldots \ldots \ldots \ldots \ldots\end{array}$ \\
\hline $\begin{array}{l}32 \\
33\end{array}$ & $\begin{array}{l}\text { Do } \ldots \ldots \ldots \ldots \ldots \ldots \ldots \ldots \ldots \ldots \ldots \ldots \ldots \ldots \ldots \\
\text { Do } \ldots \ldots \ldots \ldots \ldots \ldots \ldots\end{array}$ & 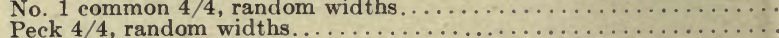 \\
\hline 34 & 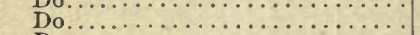 & 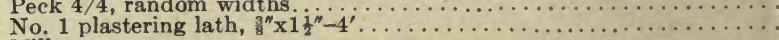 \\
\hline 35 & $\ldots \ldots \ldots \ldots$ & 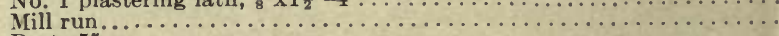 \\
\hline 36 & Cypress, shingles.............. & 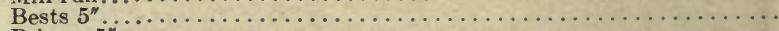 \\
\hline 37 & Do $\ldots \ldots \ldots \ldots \ldots \ldots \ldots$ & 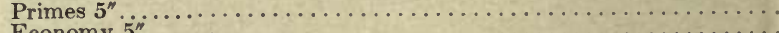 \\
\hline $\begin{array}{l}38 \\
39\end{array}$ & $\ldots \ldots \ldots \ldots \ldots \ldots \ldots \ldots$ & 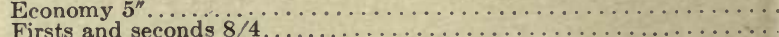 \\
\hline $\begin{array}{l}39 \\
40\end{array}$ & $\cdots \cdots \cdots \cdots \cdots \cdots \cdots \cdots$ & 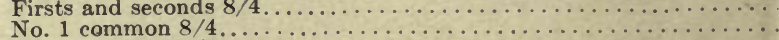 \\
\hline 41 & $\ldots \ldots \ldots \ldots \ldots$ & 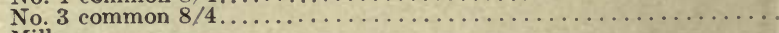 \\
\hline 42 & Do...... & … \\
\hline 43 & Elm, soft.... & 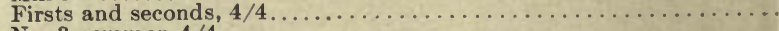 \\
\hline 44 & $\cdots \ldots \ldots \ldots \ldots$ & 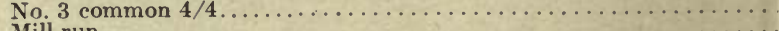 \\
\hline 45 & Gom, red $\cdots \cdots \cdots \cdots \cdots \cdots \cdots \cdots$ & 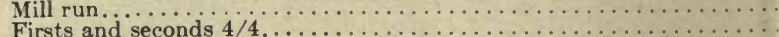 \\
\hline & 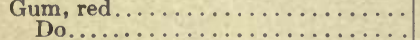 & 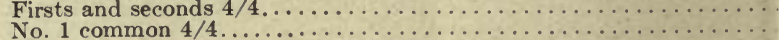 \\
\hline 48 & $\ldots \ldots \ldots \ldots \ldots \ldots \ldots$ & \\
\hline 49 & Gum, sap.............. & 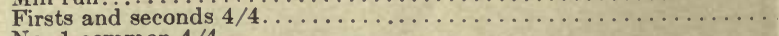 \\
\hline 50 & Do....................... & 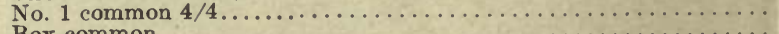 \\
\hline 51 & Do............... & 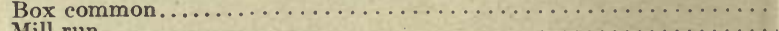 \\
\hline 52 & $\ldots \ldots \ldots \ldots \ldots \ldots$ & 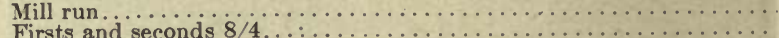 \\
\hline 54 & 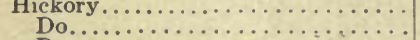 & 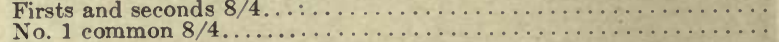 \\
\hline 5 & $\ldots \ldots \ldots \ldots+\cdots \cdots \cdots$ & 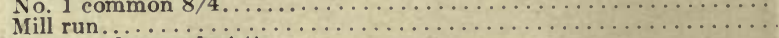 \\
\hline 56 & $\ldots \ldots \ldots \ldots \ldots$ & 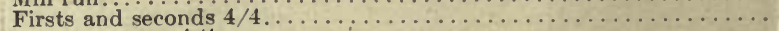 \\
\hline 5 & Do.. & 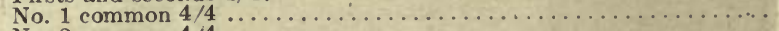 \\
\hline & Do & 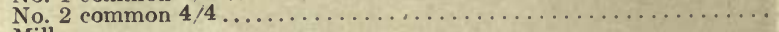 \\
\hline 5 & Do. & 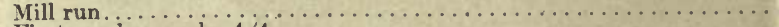 \\
\hline 6i & $\ldots \ldots \ldots \ldots \ldots \ldots$ & 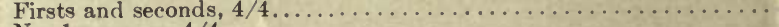 \\
\hline 6 & $\ldots$. & \\
\hline & $\ldots \ldots \ldots$ & $\ldots \ldots \ldots \ldots \ldots \ldots \ldots \ldots \ldots \ldots \ldots \ldots \ldots$, \\
\hline 6 & Do. & 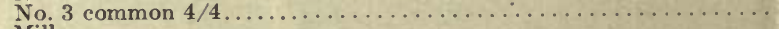 \\
\hline 64 & Do.... & 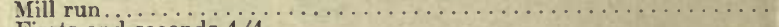 \\
\hline 65 & Oak, quartered............. & 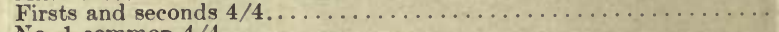 \\
\hline $6 f$ & $\cdots \cdots \cdots \cdots$ & 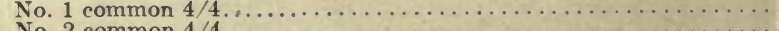 \\
\hline $\begin{array}{l}67 \\
69\end{array}$ & Do... & on 4 \\
\hline 69 & Ponlar... & 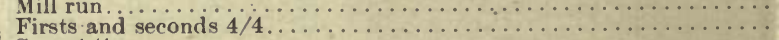 \\
\hline 70 & Do & 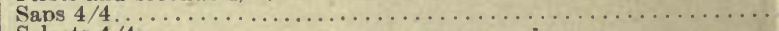 \\
\hline 71 & & $\ldots \ldots \ldots \ldots \ldots \ldots \ldots \ldots \ldots \ldots \ldots \ldots$ \\
\hline $\begin{array}{r}72 \\
73\end{array}$ & Do................ & 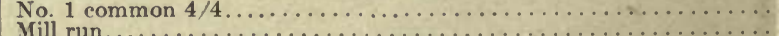 \\
\hline 74 & Tupelo (Bay Poplar). & 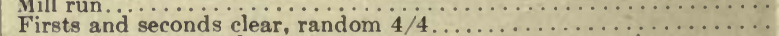 \\
\hline 75 & 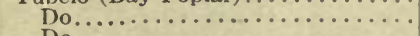 & 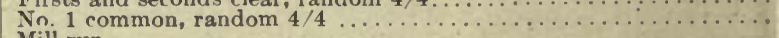 \\
\hline 76 & & $\ldots \ldots \ldots \ldots \ldots \ldots \ldots \ldots \ldots \ldots \ldots \ldots$ \\
\hline
\end{tabular}




\begin{tabular}{|c|c|c|c|c|c|c|c|c|c|c|c|c|c|}
\hline 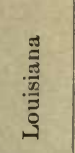 & 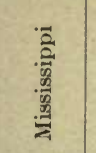 & 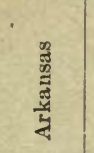 & 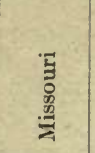 & 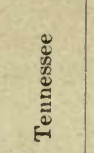 & 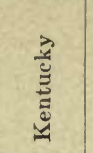 & $\frac{3}{2}$ & 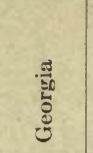 & 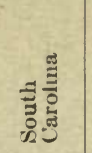 & 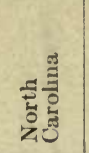 & 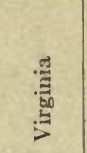 & 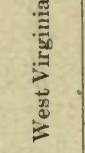 & $\frac{.}{0}$ & \\
\hline & 37.16 & 35.00 & 36.83 & 40.91 & 8.00 & & & & 37.50 & 38.00 & 42.00 & 40.70 & \\
\hline & 21.58 & 21.66 & 23.73 & 25.09 & 22.55 & & & & 26.50 & 26.75 & 28.85 & 27.18 & \\
\hline & 11.50 & 10.50 & 12.50 & 13.64 & 13.83 & & & & 13.00 & 12.40 & 14.25 & 16.71 & \\
\hline & 29.33 & 22.00 & 25.33 & 22.18 & 25.66 & & & & 17.00 & & 22.50 & 29.47 & \\
\hline & $\ldots \ldots \ldots$ & .......... & $\ldots \ldots \ldots$ & 32.31 & 28.80 & $\cdots \cdots$ & & & 32.50 & $\cdots$ & 37.00 & 30.25 & \\
\hline & & $\ldots \ldots \ldots$ & & 21.81 & 20.00 & $\ldots \ldots \ldots$ & & & 23.33 & & 27.33 & 22.25 & \\
\hline$\ldots$ & & & & 14.79 & 14.00 & $\ldots \ldots \ldots$ & $\ldots \ldots$ & $\ldots$ & 16.00 & & 14.66 & 16.00 & \\
\hline$\cdots$ & $\cdots$ & $\ldots \ldots \ldots$ & & 9.81 & 9.50 & ........ & $\ldots$ & & 9.00 & & 10.66 & & \\
\hline$\cdots$ & $\ldots \ldots$ & ...... & $\ldots \ldots \ldots$ & 20.43 & 20.50 & ......... & $\ldots \ldots \ldots$ & $\begin{array}{ll}\cdots \\
\cdots\end{array} \ldots \ldots \ldots \ldots$ & 21.00 & 21.00 & 21.25 & 20.62 & \\
\hline$\cdots$ & $\cdots \ldots \ldots$ & $\ldots \ldots \ldots$ & $\ldots \ldots \ldots$ & $\ldots \ldots \ldots$ & $\ldots \ldots \ldots$ & $\ldots \ldots$ & $\ldots \ldots \ldots$ & $\ldots \ldots \ldots$ & $\ldots \ldots \ldots$ & $\ldots \ldots$ & $\ldots \ldots \ldots$ & 16.50 & 10 \\
\hline$\ldots$ & $\cdots \cdots \cdots$ & $\ldots \ldots \ldots$ & $\ldots \ldots$ & $\ldots \ldots \ldots$ & अä & $\ldots \ldots \ldots$ & $\ldots \ldots \ldots$ & $\ldots \ldots \ldots$ & $\ldots \ldots \ldots$ & $\ldots$ & & 13.50 & 11 \\
\hline$\cdots$ & $\cdots \ldots \ldots$ & $\ldots \ldots \ldots$ & $\ldots \ldots \ldots$ & $\ldots \ldots \ldots$ & 13.38 & $\ldots \ldots \ldots$ & $\ldots \ldots \ldots$ & $\ldots \ldots \ldots$ & $\cdots$ & $\cdots$ & 11.12 & 15.65 & 12 \\
\hline . & $\cdots \cdots \cdots$ & $\cdots \cdots \cdots$ & $\cdots \cdots \cdots$ & $\ldots \ldots \ldots$ & $\ldots \ldots, \ldots$ & $\ldots \ldots \ldots$ & $\ldots \ldots \ldots$ & $\ldots \ldots \ldots$ & $\ldots$ & . & 26.37 & $\ldots \ldots$ & 13 \\
\hline$\ldots$ & $\cdots$ & $\ldots \ldots \ldots$ & $\ldots \ldots \ldots$ & $\ldots \ldots \ldots$ & $\ldots \ldots \ldots$ & $\ldots \ldots \ldots$ & $\ldots \ldots$ & $\ldots \ldots \ldots$ & . & . & 17.00 & 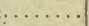 & 14 \\
\hline & $\cdots \cdots \cdots$ & $\ldots \ldots \ldots$ & $\ldots \ldots \ldots$ & $\ldots \ldots \ldots$ & $\ldots \ldots \ldots$ & $\ldots \ldots \ldots$ & $\ldots \ldots$ & $\ldots \ldots \ldots$ & $\cdots$ & $\because$ & 10.25 & & 15 \\
\hline$\cdots$ & $\cdots \cdots \cdots$ & $\cdots \ldots \ldots$ & $\ldots \ldots \ldots$ & $\ldots \ldots \ldots$ & $\ldots \ldots \ldots$ & $\ldots \ldots \ldots$ & $\ldots \ldots \ldots$ & $\ldots \ldots \ldots$ & . & ( & 7.87 & & 16 \\
\hline & & & $\cdots \cdots$ & 37.57 & 37.83 & $\cdots \cdots$ & 33.50 & 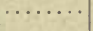 & & & 14.33 & & 17 \\
\hline & & & . & 25.23 & $\begin{array}{l}35.83 \\
25.88\end{array}$ & $\begin{array}{l}\ldots \ldots \\
\ldots \ldots \\
\ldots\end{array}$ & $\begin{array}{l}33.50 \\
22.50\end{array}$ & $\cdots \ldots \ldots$ & 38.00 & 34.00 & 37.64 & 41.50 & 18 \\
\hline & $\cdots$ & & $\ldots \ldots$ & 13.82 & 13.50 & . & $\begin{array}{l}22.50 \\
13.00\end{array}$ & $\begin{array}{c}\ldots \ldots \ldots \\
\ldots \ldots \ldots\end{array}$ & 27.66 & 24.00 & 27.46 & 29.50 & 19 \\
\hline$\cdots$ & & & $\ldots \ldots$ & 8.09 & 7.50 & & & $\ldots$. & 12.33 & 11.70 & 13.50 & 15.43 & 20 \\
\hline & & & & 16.00 & 18.12 & $\cdots$ & 14.75 & $\ldots \ldots \ldots$ & 8.33 & 8.17 & $\begin{array}{r}8.22 \\
15.91\end{array}$ & 1983 & 21 \\
\hline & $\begin{array}{l}25.12 \\
39.62\end{array}$ & $\begin{array}{l}24.45 \\
41.50\end{array}$ & $\begin{array}{l}26.00 \\
40.73\end{array}$ & $\ldots \ldots \ldots$ & $\ldots \ldots$ & ... & $\ldots \ldots \ldots$ & $\ldots \ldots \ldots$ & . & $\cdots \cdots$ & $\begin{array}{l}10.81 \\
\ldots . . \ldots \ldots\end{array}$ & $\begin{array}{l}19.85 \\
31.50\end{array}$ & $\begin{array}{l}22 \\
23\end{array}$ \\
\hline & $\begin{array}{l}39.62 \\
18.00\end{array}$ & $\begin{array}{l}41.50 \\
19.50\end{array}$ & $\begin{array}{l}40.73 \\
18.92\end{array}$ & $\cdots$ & & $\cdots$ & $\ldots \ldots \ldots$ & $\ldots$ & . & $\ldots \ldots \ldots$ & $\ldots \ldots \ldots$ & $\ldots \ldots$ & 24 \\
\hline & 15.00 & $\begin{array}{l}19.50 \\
14.75\end{array}$ & $\begin{array}{l}18.92 \\
14.56\end{array}$ & $\cdots$ & & $\ldots$ & $\ldots \ldots \ldots$ & $\cdots$ & . & . & $\ldots$ & T & 25 \\
\hline & 19.66 & 21.00 & $\begin{array}{l}14.56 \\
22.00\end{array}$ & & & $\ldots$ & & & & . & & & 26 \\
\hline .96 & 33.00 & 33.16 & $\begin{array}{l}22.00 \\
34.32\end{array}$ & & & 36.50 & & & & & & 20.66 & 27 \\
\hline 1.74 & 28.00 & 28.66 & 29.32 & & & 30.60 & & $\begin{array}{l}36.66 \\
32.00\end{array}$ & & . . & & $\ldots$ & 28 \\
\hline IS. 22 & 18.25 & 19.21 & 19.54 & & & 21.25 & & $\begin{array}{l}32.00 \\
21.16\end{array}$ & & & & & 29 \\
\hline 20.22 & . & & & $\cdots$ & & & $\cdots$ & $\begin{array}{c}21.16 \\
\ldots \ldots\end{array}$ & & & & & 30 \\
\hline 6.25 & & 14.00 & 12.50 & & 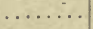 & 15.60 & & 18.83 & & & & & $\begin{array}{l}31 \\
32\end{array}$ \\
\hline 5.54 & 10.50 & 7.37 & 8.32 & . & $\ldots$ & 9.87 & $\ldots$ & 9.00 & & & & & 33 \\
\hline $\begin{array}{r}2.82 \\
2 .\end{array}$ & & 2.75 & & $\ldots$ & & 2.35 & . & 2.70 & & & $\sigma^{\circ}$ & & 34 \\
\hline 3.14 & 21.54 & 3.08 & $\begin{array}{r}15.5 \\
\ldots \ldots\end{array}$ & . & & 4.61 & & $\ldots$. & 18.75 & & & & 35 \\
\hline 2.25 & $\begin{array}{l}\cdots \\
\ldots \ldots\end{array}$ & 2.08 & $\begin{array}{l}\cdots \\
\ldots \ldots\end{array}$ & $\cdots$ & & $\begin{array}{l}4.01 \\
3.27\end{array}$ & $\ldots$ & $\cdots$ & $\ldots \ldots$ & & $\begin{array}{l}\cdots \\
\cdots\end{array}$ & & $\begin{array}{l}30 \\
37\end{array}$ \\
\hline 1.41 & & 1.23 & $\ldots \ldots \ldots$ & $\ldots \ldots \ldots$ & $\ldots$ & 1.75 & $\cdots$ & $\because$ & $\cdots$ & & & & 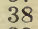 \\
\hline ... & $\ldots \ldots \ldots$ & $\ldots \ldots$ & $\ldots \ldots \ldots$ & $\ldots \ldots \ldots$ & $\ldots \ldots \ldots$ & $\ldots \ldots$ & $\ldots \ldots \ldots$ & $\ldots \ldots \ldots$ & $\ldots \ldots$ & $\ldots \ldots \ldots$ & $\ldots \ldots$ & 18.00 & 3 \\
\hline & $\cdots \cdots \cdots$ & $\cdots$ & $\ldots \ldots \ldots$ & $\ldots \ldots \ldots$ & $\ldots \ldots \ldots$ & $\ldots \ldots \ldots$ & $\ldots \ldots$ & $\ldots \ldots \ldots$ & $\ldots$ & . & & $\cdots$ & 40 \\
\hline$\cdots$ & $\ldots \ldots \ldots$ & $\begin{array}{l}-\mu \ldots \\
\ldots \ldots\end{array}$ & $\ldots$ & . & & $\begin{array}{c}\ldots \ldots \ldots \\
\ldots \ldots \ldots\end{array}$ & $\begin{array}{l}\ldots \ldots \ldots \\
\ldots \ldots \ldots\end{array}$ & $\begin{array}{l}\ldots \ldots \\
\ldots \ldots\end{array}$ & $\ldots$ & & & 16.50 & $\begin{array}{l}41 \\
42\end{array}$ \\
\hline & $\ldots \ldots$ & $\ldots \ldots$ & 29.25 & $\ldots \ldots$ & 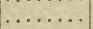 & & & $\because 1$ & & & & 27.50 & 43 \\
\hline$\cdots$ & $\ldots$ & $\ldots \ldots$ & 15.75 & $\ldots \ldots$ & . & $\ldots \ldots \ldots$ & $\ldots \ldots \ldots$ & $\ldots \ldots \ldots$ & $\ldots$ & & $\cdots$ & 18.20 & 44 \\
\hline & & & 14.66 & & ๑ & $\cdots$ & . & $\ldots \ldots \ldots$ & & & $\ldots \ldots$ & 19.30 & 45 \\
\hline$\cdots$ & 24.75 & 22.39 & 23.66 & 26.00 & 22.50 & $\ldots \ldots \ldots$ & $\ldots \ldots \ldots$ & $\ldots \ldots \ldots$ & $\Gamma$ & $\ldots$. & -2 & $\ldots$ & 46 \\
\hline$\cdots$ & 15.25 & 12.50 & 13.66 & 16.00 & & $\ldots \ldots \ldots$ & $\ldots \ldots \ldots$ & $\ldots \ldots \ldots$ & . & & $\cdots$ & & 47 \\
\hline$\cdots$ & 15.70 & 11.75 & 15.00 & & 12.25 & $\ldots \ldots \ldots$ & $\ldots$ & $\ldots \ldots \ldots$ & $\cdots$ & $\cdots$ & . & & 48 \\
\hline$\ldots$ & 15.70 & 14.44 & 15.40 & 17.62 & $\ldots \ldots \ldots$ & $\ldots \ldots \ldots$ & $\ldots \ldots \ldots$ & $\ldots \ldots \ldots$ & $\ldots \ldots$ & & $\ldots \ldots$ & . & 49 \\
\hline$\cdots$ & 12.62 & 11.05 & 12.25 & 13.12 & $\ldots \ldots \ldots$ & $\ldots \ldots \ldots$ & $\ldots \ldots \ldots$ & $\ldots \ldots \ldots$ & . & $\ldots \ldots$ & $\ldots$ & $\ldots \ldots \ldots$ & 50 \\
\hline$\cdots$ & 10.60 & 8.50 & 9.91 & 10.51 & $\ldots \ldots \ldots$ & $\ldots \ldots \ldots$ & $\ldots \ldots \ldots$ & $\ldots \ldots$ & $\ldots \ldots$ & $\ldots \ldots$ & $\ldots \ldots$ & $\ldots$ & 51 \\
\hline$\because$ & 12.36 & 13.30 & 11.64 & $53 \quad 50$ & & $\ldots \ldots \ldots$ & $\ldots \ldots \ldots$ & $\ldots, \ldots \ldots$ & $\ldots \ldots$ & $\ldots \ldots \ldots$ & $\ldots \ldots$ & & 52 \\
\hline $\begin{array}{l}\cdots \\
\ldots\end{array}$ & $\begin{array}{l}50.83 \\
24.00\end{array}$ & $\ldots \ldots$ & $\begin{array}{l}44.75 \\
23.33\end{array}$ & $\begin{array}{l}53.50 \\
28.00\end{array}$ & $\begin{array}{l}47.00 \\
27.66\end{array}$ & $\ldots \ldots \ldots$ & $\ldots \ldots \ldots$ & $\ldots \ldots \ldots$ & . & $\ldots$ & $\ldots$. & 40.90 & 53 \\
\hline$\cdots$ & $\begin{array}{c}24.00 \\
\ldots \ldots \ldots\end{array}$ & $\cdots \cdots$ & $\begin{array}{l}23.33 \\
31.00\end{array}$ & $\begin{array}{l}28.00 \\
30.50\end{array}$ & $\begin{array}{l}27.66 \\
24.00\end{array}$ & $\ldots \ldots \ldots$ & $\ldots \ldots \ldots$ & $\ldots \ldots \ldots$ & $\ldots$ & . & & 27.00 & 54 \\
\hline$\cdots$ & $\begin{array}{l}\ldots \ldots \\
\ldots \ldots\end{array}$ & $\cdots \cdots$ & $\begin{array}{c}31.00 \\
\ldots \ldots\end{array}$ & 22.50 & $\begin{array}{c}24.00 \\
\ldots \ldots\end{array}$ & $\cdots$ & $\ldots \ldots \ldots$ & $\ldots \ldots$ & . & $\ldots$. & 28.00 & 32.20 & 55 \\
\hline$\cdots$ & ..... & $\begin{array}{c}\ldots \ldots \\
\ldots \ldots \ldots\end{array}$ & $\ldots \ldots$ & 14.00 & $\cdots \cdots$ & $\ldots \ldots \ldots$ & $\ldots \ldots \ldots$ & $\ldots \ldots \ldots$ & $\cdots$ & & 20.50 & 21.33 & 5 \\
\hline & & & & 9.00 & & $\ldots \ldots \ldots$ & $\ldots \ldots \ldots$ & $\cdots$ & . & & 13.62 & 18.12 & 5 \\
\hline$\cdots$ & & 14.33 & 15.40 & 11.00 & 15.00 & & & & 13 & 13.50 & $\begin{array}{r}9.12 \\
13.18\end{array}$ & $\begin{array}{lll}1 & \end{array}$ & \\
\hline$\ldots$ & 36.50 & 35.18 & 35.85 & 38.58 & 36.75 & & 32.50 & 36.50 & 37.75 & 35.33 & 38.31 & $\begin{array}{l}17.92 \\
39.85\end{array}$ & 6 \\
\hline$\ldots$ & 20.40 & $21 . \cap 0$ & 22.37 & 24.21 & 23.69 & . & 22.50 & 23.00 & 25.50 & 24.00 & 27.22 & 27.00 & 6 \\
\hline$\ldots$ & 10.83 & 10.23 & 12.81 & 13.44 & 13.77 & $\ldots$ & 12.50 & $\ldots \ldots \ldots$ & 12.50 & 12.00 & 15.19 & 17.00 & 6 \\
\hline$\cdots$ & 7.00 & 5.65 & 7.18 & 7.39 & 8.22 & $\ldots$ & $\ldots \ldots \ldots$ & $\ldots \ldots \ldots$ & 8.50 & 8.00 & 8.38 & 11.14 & 63 \\
\hline$\ldots$ & 23.34 & 20.00 & 19.91 & 18.06 & 21.30 & $\ldots$ & $\ldots \ldots \ldots$ & $\ldots \ldots \ldots$ & 17.50 & $\ldots .$. & 21.50 & 27.50 & 64 \\
\hline$\ldots$ & 60.80 & 56.66 & 68.80 & 66.68 & 63.77 & $\ldots \ldots \ldots$ & $\ldots \ldots \ldots$ & $\ldots \ldots \ldots$ & $\ldots \ldots$ & & 67.00 & 67.50 & 65 \\
\hline ... & 31.75 & 33.50 & 43.60 & 40.25 & 39.73 & $\ldots \ldots$ & $\ldots \ldots$ & $\ldots \ldots \ldots$ & $\ldots$ & $\ldots$ & 40.00 & 42.75 & 66 \\
\hline$\ldots$ & 14.66 & 15.57 & 25.25 & 20.18 & 21.50 & $\ldots \ldots \ldots$ & $\ldots \ldots \ldots$ & $\ldots \ldots$ & $\ldots$ & $\ldots$ & 21.66 & 23.69 & 67 \\
\hline$\ldots$ & 40.05 & 39.00 & 50.50 & 46.86 & 41.66 & $\ldots \ldots \ldots$ & & $\ldots \ldots \ldots$ & & & & 42.50 & \\
\hline & 40.50 & $\ldots \ldots$ & $\ldots \ldots$ & 51.66 & 44.07 & $\ldots \ldots \ldots$ & 43.50 & $\ldots \ldots \ldots$ & 49.95 & 46.75 & 48.64 & 49.75 & 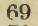 \\
\hline & 33.50 & $\ldots \ldots \ldots$ & $\therefore$ & 35.31 & 34.37 & $\ldots \ldots \ldots$ & 35.00 & $\ldots \ldots$ & 35.25 & 32.00 & 35.44 & 37.33 & 70 \\
\hline & $\cdots \cdots$ & . & . & $\begin{array}{l}36.00 \\
28.40\end{array}$ & $\begin{array}{l}32.86 \\
26.00\end{array}$ & & 29.50 & 2000 & 32.00 & & & $40 . r 0$ & \\
\hline & $\cdots$ & $\cdots$ & & 29.20 & 22.75 & & $\begin{array}{l}29.00 \\
\ldots \ldots \ldots\end{array}$ & $\begin{array}{c}29.00 \\
\ldots \ldots \ldots\end{array}$ & $\begin{array}{l}28.50 \\
23.50\end{array}$ & 26.75 & $\begin{array}{l}31.46 \\
27.50\end{array}$ & 31.75 & 72 \\
\hline & $\cdots$ & ........ & 12.83 & $\ldots \ldots \ldots$ & $\ldots \ldots \ldots$ & $\ldots \ldots \ldots$ & $\ldots \ldots \ldots$ & $\ldots \ldots \ldots$ & $\ldots \ldots \ldots$ & $\ldots \ldots$ & $\ldots \ldots$ & $\cdots \ldots \ldots$ & 1 \\
\hline & $\cdots$ & 14.00 & & & & & . & $\ldots \ldots$ & 11.83 & 1 & 30 & & \\
\hline & & & & & & & & 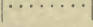 & 11.83 & & & & \\
\hline
\end{tabular}


Ash

Do...

Do...

Basswood

Do.

Do.

Do...

Beech.

Do.

Birch, unselected

Do..

Do..

Do

Do.

Chestnut

Do.

Do...

Do

Cottonwood

Do...

Do

Do.

Cypress.

Do....

Do.

Do.

Do

Do

Do.

Cypress, shingles

Do.

Do

Elm, rock

Do.

Do

Do

Elm, soft

Do.

Gum, re

Do.

Do..

Gum, sap

Do.

Do.

Do.

Hickory

Do.

Maple.

Do.

Do.

Do.

Oak, plain

Do.

Do.

Do.

Oak, quartered

Do...

Do.

Poplar

Do.

Do.

Do.

Tupelo (Bay Poplar)

Do.
Firsts and seconds 4/4.

No. 1 common $4 / 4$.

No. 2 common $4 / 4$

Mill run.

Firsts and seconds $4 / 4$

No. 1 common $4 / 4$

No. 2 common $4 / 4$

No. 3 common $4 / 4$

Mill run.

Firsts and seconds $4 / 4$

No. 1 common $4 / 4$.

Mill run.

Firsts and seconds $4 / 4$

No. 1 common $4 / 4$

No. 2 common $4 / 4$

No. 3 common $4 / 4$

Mill run.

Firsts and seconds $4 / 4$

No. 1 common $4 / 4$

No. 2 common or S W. $4 / 4$

No. 3 common $4 / 4$

Mill run.

First 3 and seconds $4 / 4,6^{\prime \prime}$ to $12^{\prime \prime}$

Boxboards 4/4, $13^{\prime \prime}$ to $17^{\prime \prime}$

No. 1 common $4 / 4$

No. 2 common $4 / 4$

Mill run.

Firsts and seconds clear $4 / 4$

Selects $4 / 4$

Shop, No. $1,4 / 4$

Beveled siding, A, $\frac{1}{2} " \times 6^{\prime \prime}$

No. 1 common $4 / 4$, random widths.

Peck 4/4,-random widths

No. 1 plastering lath, $\frac{31}{8} \times 1 \frac{1}{2}{ }^{\prime \prime}-4^{\prime}$

Mill run.

\section{Bests 5}

Primes $5^{\prime \prime}$

Economy $5^{\prime \prime}$

Firsts and seconds $8 / 4$

No. 1 common $8 / 4$.

No. 3 common $8 / 4$.

Mill run.

Firsts and seconds, $4 / 4$

No. 3 common $4 / 4$

Mill run

Firsts and seconds $4 / 4$

No. 1 common $4 / 4$.

Mill run.

Firsts and seconds $4 / 4$

No. 1 common $4 / 4$.

Box common.

Mill run.

Firsts and seconds $8 / 4$

No. 1 common $8 / 4$.

Mill run.

Firsts and seconds 4/4

No. 1 common $4 / 4$

No. 2 common $4 / 4$

Mill run.

Firsts and seconds, 4/4

No. 1 common $4 / 4$.

No. 2 common $4 / 4$

No. 3 common $4 / 4$.

Mill run

Firsts and seconds $4 / 4$

No. 1 common $4 / 4$.

No. 2 common $4 / 4$.

Mill run.

Firsts and seconds $4 / 4$

Saps $4 / 4$

Selects $4 / 4$

No. 1 common $4 / 4$

Mill run.

Firsts and seconds clear, random $4 / 4$.

in. 1 लmmon, rand om 4/4

Mill run. 


\begin{tabular}{|c|c|c|c|c|c|c|c|c|c|c|c|c|c|}
\hline$\stackrel{\frac{n}{0}}{\Xi}$ & 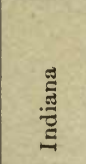 & $\frac{a}{3}$ & 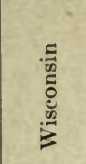 & 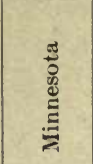 & 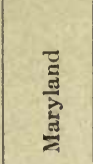 & 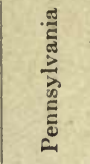 & $\begin{array}{l}\frac{1}{5} \\
\frac{1}{2} \\
z \\
z\end{array}$ & 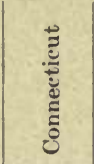 & 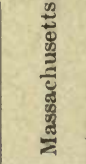 & 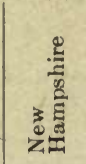 & ह & 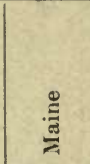 & \\
\hline & 0 & 5 & 60 & 0 & 60 & & & & 30.00 & & 20.00 & & \\
\hline & & & & & & & & & ....... & & & & \\
\hline & & .33 & 1.00 & 17.00 & 19.00 & & & & $\cdots$ & & 00 & & \\
\hline & .66 & 22.10 & 21.41 & & 26.00 & & 25.00 & 21.86 & 19.00 & & .00 & & \\
\hline$\ldots$ & 3 & 36.71 & 35.81 & 31.66 & $\ldots \ldots$ & & 36.00 & & $\ldots \ldots$ & & .00 & 30.00 & \\
\hline & $\begin{array}{l}.43 \\
.33\end{array}$ & $\begin{array}{l}30 \\
37\end{array}$ & $\begin{array}{l}09 \\
23\end{array}$ & $\begin{array}{l}17 \\
00\end{array}$ & $\ldots \ldots \ldots$ & 2 & 0 & & & & $\ldots \ldots$ & $\ldots \ldots$ & \\
\hline & 10.50 & .16 & 12.67 & 13.66 & & & 12.50 & & & & & & \\
\hline & 24.33 & 22.40 & 21.53 & 18.50 & 22.33 & & 28.25 & 19.66 & & 19.00 & 19.33 & & \\
\hline & .66 & 18.40 & ...... & *....... & . & 16.00 & 24.43 & & $\cdots$ & $\cdots$ & 18.33 & & \\
\hline & 00 & 14.75 & & & & & 17.90 & & & * & & & \\
\hline 16 & 16.33 & 24 & & & & 19.25 & 16.31 & 17.16 & & 12.00 & 16.40 & 14.00 & \\
\hline & $\ldots \ldots \ldots$ & 2 & .36 & 27.66 & & & 32.70 & 24.00 & & $\ldots \ldots \ldots$ & 18.00 & 22.00 & \\
\hline & & 2 & 16.36 & 17.83 & & 33 & 21.66 & & $\cdots$ & $\ldots \ldots \ldots$ & $\cdots$ & $\ldots \ldots$ & \\
\hline & & 13.71 & 11.13 & 13.71 & & 15.66 & 16.16 & 11.50 & $2 x^{2}$ & $-\quad=2=$ & & 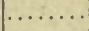 & \\
\hline & & 9.43 & 8.59 & 7.83 & & 12.00 & 11.66 & & & & & & \\
\hline & & 15.29 & 15.75 & 14.50 & & & 23.05 & 60 & 16.00 & 14.00 & 19.00 & 16.66 & 17 \\
\hline & $\cdot 37$ & $\cdots$ & $\cdots$ & $\cdots$ & 38.66 & & 39.00 & 21.50 & 19.33 & $\cdots$ & $\cdots$ & … & \\
\hline 00 & 00 & $\cdots$ & $\ldots \ldots$ & $\ldots$ & 28.00 & 55 & & 19.66 & . & . & & 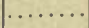 & \\
\hline $\begin{array}{l}.00 \\
\ldots \ldots\end{array}$ & 14.50 & $\cdots$ & $\cdots \cdots$ & $\cdots$ & 14.00 & 16 & & $\cdots$ & $\ldots \ldots$ & $\cdots$ & & . & \\
\hline$\ldots$ & $\ldots \ldots \ldots$ & $\cdots \cdots$ & $\ldots \ldots$ & $\cdots$ & $9: 00$ & 14.00 & & & & & & & \\
\hline 1.60 & $\ldots \ldots \ldots$ & ...... & $\cdots \cdots$ & . & $\ldots \ldots$ & 18.67 & 18.50 & 16.00 & 18.00 & & 17.00 & & \\
\hline 2.33 & & $\cdots$ & $\ldots \ldots$ & . & $\cdots$ & $\cdots$ & - & $\cdots$ & ........ & $\cdots$ & $\cdots$ & & \\
\hline 7.33 & & & $\cdots$ & $\cdots$ & $\cdots$ & 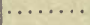 & $\cdot$ & & $\ldots \ldots \ldots$ & $\cdots$ & & . & \\
\hline 4.83 & - & & $\cdots \cdots$ & . & . & $\cdot$ & - & & $\ldots \ldots$ & $\cdots$ & 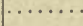 & $\because$ & \\
\hline & $\cdots$ & …... & ...... & & 1. & . & 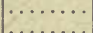 & & $\ldots$ & $\ldots \ldots \ldots$ & & & \\
\hline 1.66 & .... & ..... & ...... & & $\cdots$ & & $\cdots$ & & & & & & \\
\hline 9 & $\ldots \ldots \ldots$ & $\ldots \ldots$ & ..... & $\ldots \therefore$ & $\ldots \ldots$ & ( & ...... & 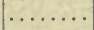 & $\ldots \ldots$ & & & & 2 \\
\hline 0 & $\ldots \ldots \ldots$ & $\cdots \cdots$ & $\cdots \cdots$ & $\ldots \ldots \ldots$ & $\ldots \ldots$ & $\cdots$ & $\ldots$ & $\ldots$ & ... & $\cdots$ & & & 3 \\
\hline$\cdots$ & $\ldots \ldots \ldots$ & $\cdots \cdots \cdots$ & $\cdots \ldots \ldots$ & $\cdots \ldots \ldots$ & $\cdots \ldots \ldots$ & $\cdots \cdots$ & $\ldots \ldots$ & $\cdot$ & $\cdots$ & $\ldots \ldots$ & . & * & \\
\hline 8.75 & & $\cdots$ & $\cdots \cdots$ & $\cdots \cdots \cdots$ & $\ldots \ldots \ldots$ & $\cdots$ & $\cdot \cdots$ & & $\ldots \ldots$ & $\cdots$ & & & se \\
\hline & & $\ldots \ldots$ & & $\ldots$. & $\cdots$ & & & & ..... & . & & .. $>$ & \\
\hline 9.26 & $\ldots \ldots$ & $\ldots \ldots \ldots$ & $\ldots$ & $\ldots$ & $\ldots$ & $\ldots \ldots \ldots$ & ...... & $\ldots \ldots$ & $\ldots \ldots$ & $\ldots \ldots \ldots$ & . & $\cdots$ & \\
\hline ...... & $\cdots \cdots$ & $\cdots \cdots$ & $\cdots \cdots$ & $\ldots \ldots \ldots$ & $\ldots \ldots \ldots$ & $\ldots \ldots \ldots$ & $\ldots \ldots$ & $\ldots \ldots$ & $\ldots \ldots$ & $\ldots \ldots$ & . & $\ldots \ldots$ & \\
\hline$\ldots .$. & $\cdots \cdots$ & $\ldots \ldots$ & & $\cdots \ldots \ldots$ & $\ldots \ldots \ldots$ & $\ldots \ldots \ldots$ & $\ldots \ldots$ & $\ldots \ldots \ldots$ & $\ldots \ldots \ldots$ & $\ldots \ldots \ldots$ & . & $\cdots \ldots \ldots$ & 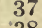 \\
\hline .. & 27.50 & & 39.75 & & $\cdots$ & . & $\cdots \cdots$ & $\cdots \cdots$ & $\ldots \ldots \ldots$ & $\ldots \ldots$ & 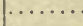 & $\ldots \ldots$ & \\
\hline & 26.66 & & 27.75 & . & . & . & & & . & $\ldots$ & & .. & \\
\hline & & 10.00 & 9.70 & & . & & & & I. & . & & 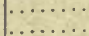 & 4 \\
\hline & 50 & 27.13 & 24.00 & & & & & & & & & & 4 \\
\hline & 22.60 & 33.50 & 29.00 & & & & & & & & & & 4 \\
\hline & 16.75 & 10.94 & 9.62 & & & & & & & & & & 4 \\
\hline 5.75 & 17.62 & 20.75 & 16.88 & & & & 22.50 & 15.00 & $\cdots$ & $\cdots \cdots$ & & . & 4 \\
\hline 3.00 & ........ & $\ldots \ldots$ & $\ldots \ldots$ & $\ldots \ldots \ldots$ & $\ldots \ldots$ & $\cdots$ & $\ldots \ldots$ & $\ldots \ldots$ & $\ldots$ & $\ldots$ & & $\ldots$ & 4 \\
\hline 14.50 & & $\ldots \ldots$ & $\ldots \ldots$ & $\ldots \ldots \ldots$ & $\ldots \ldots$ & & $\ldots \ldots$ & ..... & $\ldots \ldots \ldots$ & $\ldots \ldots$ & & $\cdots$ & 4 \\
\hline 14.37 & & ..... & $\ldots \ldots$ & $\ldots \ldots \ldots$ & $\ldots \ldots$ & & $\ldots \ldots$ & . & $\ldots$ & $\cdots$ & & & 4 \\
\hline 15.50 & .33 & $\ldots \ldots$ & $\ldots \ldots$ & $\ldots \ldots \ldots$ & $\ldots \ldots \ldots$ & & ...... & & . & $\because$ & & & 4 \\
\hline 11.33 & 13.00 & ..... & $\cdots \ldots$ & $\cdots \ldots \ldots$ & $\ldots \ldots$ & ..... & $\cdots \cdots$ & $\because$ & $\ldots \ldots \ldots$ & . & & $\ldots \ldots \ldots$ & 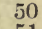 \\
\hline & & $\cdots$ & $\cdots$ & $\ldots \ldots$ & $\ldots \ldots$ & $\cdots$ & $\cdots \cdots$ & & $\cdots$ & $\cdots$ & & $\begin{array}{c}\cdots \\
\text {. }\end{array}$ & \\
\hline 1. & & $\cdots$ & $\cdots$ & 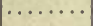 & . & & $\ldots \ldots$ & & $\cdots$ & & & & 3 \\
\hline 4.66 & & & . . & . & 1 & & & & & & & $\cdots$ & 5 \\
\hline 7.28 & 3 & $\cdots$ & & $\ldots \ldots \ldots$ & $\cdots$ & & 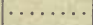 & 2 & $\ldots$ & & & & ? \\
\hline 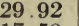 & 3 & & & & & & & & . & & & & \\
\hline D & .29 & & .50 & & & 38 & 26.22 & 15.00 & & & 21.00 & & \\
\hline 2.50 & & 17.50 & .50 & & & 1 & 19.20 & & & & & & \\
\hline $11+2$ & 0 & & .42 & & & & 5.00 & & & & & & \\
\hline & 1 & 15.38 & & & & & 50 & & & 18.50 & 18.50 & 17.50 & \\
\hline & & & .66 & & 6 & & 0 & & & $\cdots$ & $\ldots \ldots$ & $\ldots .$. & \\
\hline & & & 0 & 0 & 6 & & 5 & 2 & & & & & \\
\hline & 35 & & 0 & & 0 & & .75 & 20.38 & & & & & \\
\hline & & & & 0 & 11.33 & & 16.25 & & & & & & \\
\hline & & 24.62 & 28.43 & 24.50 & $\cdots \ldots$ & 22.09 & 23.83 & 24.22 & 20.40 & 19.50 & 20.00 & & \\
\hline & & $\ldots \ldots$ & $\cdots$ & $\ldots \ldots$ & $\cdots$ & $\cdots$ & $\cdots \cdots$ & $\ldots$. & $\ldots \ldots$ & $\ldots \ldots$ & $\ldots \ldots$ & $\ldots \ldots$ & \\
\hline & & & $\ldots$ & c. & t & $\cdots$ & $\ldots$. & $\ldots$ & $\ldots \ldots$ & $\ldots \ldots$ & $\ldots$ & ..... & \\
\hline & & & .. & . & .. & $\cdots$ & $\cdots$ & $\ldots$ & $\ldots \ldots$ & $\ldots \ldots$ & $\cdots$ & $\ldots \ldots$ & \\
\hline & & & . & $\cdots$ & $5^{\circ}$ & & $\ldots \ldots$ & $\cdots$ & $\ldots \ldots$ & & $\ldots$ & $\cdots \cdots \cdots$ & \\
\hline & & & $\cdots \ldots$ & $\cdots \cdots$ & ... & & ..... & & 0 & & & & \\
\hline & & $\ldots \ldots$ & $\ldots \ldots$ & $\ldots \ldots \ldots$ & & & $\ldots$ & & . . & & & 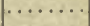 & ( \\
\hline & & $\cdots \cdots$ & $\cdots$ & $\cdots \cdots$ & & & & & & & & & \\
\hline & & $\cdots \cdot$ & $\cdots$ & $\cdots$ & & & & $\cdots$ & & & & 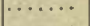 & \\
\hline & & $\cdots \cdots$ & $\cdots \cdots$ & $\cdots \cdots$ & $\cdots \cdots$ & 22.03 & 20.00 & & $\cdots$ & & 0.00 & $\cdots \cdots$ & 7 \\
\hline & & $\cdots$ & $\cdots \cdot$ & $\cdots \cdots$ & $\cdots$ & $\cdots$ & $\ldots$. & . & $\cdots$ & & $\cdots$ & & \\
\hline & & & & 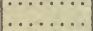 & & & & & & & & & 7 \\
\hline
\end{tabular}





\section{Walter Mulford}

U. S. DEPAR'TMENT OF AGRICULTURE FOREST SERVICE

RECORD OF

\section{WHOLESALE PRICES OF LUMBER}

(PER 1,000 FEET B. M.)

Based on actual sales made F. O. B. Mill

for

EACH QUARTER OF THE CALENDAR YEAR 1910 


\section{PREFATORY NOTE}

The Forest Service has two main purposes in collecting and compiling this record of f. o. b. mill rices: first, to have a continuous statistical record of such prices of the various commercial woods; and, sond, to show, in contrast to market prices-which include the important items of freight charges and lling costs-just what the manufacturers of lumber receive for their product at the mill. The prices ven are wholesale, based on actual sales f. o. b. mill, for delivery outside of local territory. Only a few presentative grades and the mill run are included. By mill run is meant the average of all grades of imber produced. The record is compiled by states, and is made up from reports received from approxistely three thousand of the largest manufacturers scattered throughout the country. It is pubshed quarterly.

The Forest Service wishes to acknowledge the courtesy of the manufacturers for their prompt and ficient coöperation. Their assistance has been of great value in making the record complete, accurate, ad promptly available for distribution.

Note-For this issue of the record a departure has been made from the usual form of compilation. 1 addition to the average prices for the last quarter of the calendar year 1910 there are also reproduced se average prices of the three preceding quarters. This has been done to permit of a comparison for the ur periods of the year. 


\section{SUMMARY}

Lower average prices generally were reported by the manufacturers of western softwoods for October, November, and December, 1910, than for any one of the three preceding quarters. The woods affected include redwood, Douglas fir, western yellow pine, hemlock, red cedar and Sitka spruce. Prices on larch reported from Montana were on the same level as those given for earlier in the year, while a slight advance is shown in pine values in Idaho.

Manufacturers in the chief yellow pine producing states-Texas, Arkansas, Louisiana, Mississippi, Alabama, Missouri, Florida, Georgia and South Carolina-also reported generally lower prices for the last quarter over the preceding quarters. North Carolina pine values for South Carolina, North Carolina and Virginia were of about the same level range for the four quarters. Hemlock in West Virginia showed a verage lower prices for the last quarter, with practically no change in spruce prices. Eastern spruce and hemlock prices when compared reveal but slight changes from one quarter to another. Hemlock prices reported from the Lake States were a trifle lower for the last quarter, and a slight shading of white pine prices from the same region also is shown.

Hardwoods show a greater variation in price than the softwoods. Generally ash, birch, chestnut, gum and hard and soft maple closed higher in price than at the opening of the year. On the other hand, basswood, beech, chestnut, cypress, rock and soft elm, hickory, plain oak, quartered red and white oak and poplar remained stationary in price or showed a decline in value for the last quarter over the preceding quarters. 
$2^{\prime \prime}$ piece stuff, S1S1 E, 2 " $\mathrm{x} 4^{\prime \prime}-16^{\prime}$
Boards, No. 1 , S1S, $1^{\prime \prime} \times 8^{\prime \prime}-16^{\prime} \ldots$

Timbers, rough, $4^{\prime \prime} \times 4^{\prime \prime}$ to $8^{\prime \prime} \times 8^{\prime \prime}-16^{\prime}$.

Fencing No. 1, S1S, 1 " $\times 6$ "

Lath No. $1, \frac{3}{8} n^{\prime \prime}-4^{\prime}$.

Mill run.

$8 / 4$ merch. 4 " to $12, " 10$, to 20 ;

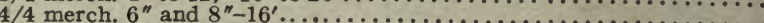

$4 / 4$ merch. $10^{\prime \prime}$ and $12^{\prime \prime}-16^{\prime}$...

$4 / 4$ merch. boards, $6^{\prime \prime}$ and up, $31 \mathrm{~S}^{\prime}$ clipped, $12^{\prime}, 14^{\prime}$ and $16^{\prime}$

$4 / 4$ boards, No. $2,1^{\prime \prime} \times 4^{\prime \prime}-12^{\prime \prime}, 6^{\prime}-20^{\prime}$

Mill run, mill culls out.

Mill culls

Mill run.

Flooring, No. $2, \mathrm{i}^{\prime \prime} \mathrm{x} 4^{\prime \prime} \mathrm{x} 10^{\prime}-16^{\prime}$

Flooring, No $3,1^{\prime \prime} \times 4^{\prime \prime} \times 10^{\prime}-16^{\prime}$

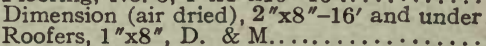

Partition No. $1,13 / 16^{\prime \prime} \times 3 i i^{\prime \prime}, 10^{\prime}-16^{\prime}$........

No. 1 edge $4 / 4$, under 12

Box edge $4 / 4$, under $12^{\prime \prime}$

Mill run.

Selects $C$ and better, $5 / 4$ (M. L.)

Inch finish, C Selects, 10" (M. L.)

Shop No. 1, 8/4 (M. L.).

Shop No. 3, 5/4 (M. L.)

Beveled siding, $\mathrm{C}, 6^{\prime \prime}-16^{\prime}$

Boards No. 2, $1^{\prime \prime} \times 8^{\prime \prime}-16^{\prime}$

Boards No. 3, $12^{\prime \prime}, 10^{\prime}-20^{\prime}$

Boards No. 4, mixed widths, $10,-20^{\prime}$

Fencing No. 2 , S1S, $6^{\prime \prime}-16^{\prime}$

Lath No. 1 (W. P.).

Lath No. 1 (mixed)

Mill run.

Flooring, $\mathrm{B}, \mathrm{v}, \mathrm{g}$. $13 / 16$ " $\mathrm{x} 3$

Flooring, No. 2 , D. \& M., 1 " $\times 4$ "

Flooring, No. 2, S2S and C. M., 1" $\mathrm{x} 6$ "

Flooring, B, flat, 13/16" $\mathrm{x} 3$ 1" $^{\prime \prime}$

Finish, $\mathrm{B}$ and better, $6^{\prime \prime}$ and wider.

Dimension No. 1 , SiS1E, $2^{\prime \prime} \times 8^{\prime \prime}-16^{\prime}$

Com. boards No. 1 , S2S, 1 "x10"

Com. boards, No. 2, S2S, 1 "x $8 "$

Com. boards, No. 2, S2S, 1 " $\times 12$ "

Timbers S1S1E, $6^{n} \times 8^{n}-16^{\prime}$

Car siding, $B$ and better, 1 " $\times 4^{\prime \prime}$ and 6 " ${ }^{\prime \prime} 9^{\prime}-18^{\prime}$

Com. car lining, No. $1,1^{\prime \prime} \times 6^{\prime \prime} \times 10^{\prime}-20^{\prime}$

Lath No. $1, \frac{3}{8}$

Mill run.

Finish, $B$ and better, $6^{\prime \prime}$ and wider

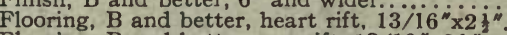

Flooring, $\mathrm{B}$ and better, sap rift, $13 / 16^{\prime \prime} \mathrm{x} 2 \frac{1}{2}$ "

Flooring, $\mathrm{B}$, heart rift, $13 / 16^{\prime \prime} \times 2 \frac{1}{2}$

Flooring, B, sap rift, $13 / 16^{\prime \prime} \times 21^{\prime \prime}$

Flooring, B, sap flat, $13 / 16^{\prime \prime} \times 3 \frac{1}{2}$

Com. boards, No. 1, S2S, $1^{\prime \prime} \times 10^{\prime \prime} \times 10^{\prime}-16$

Com. boards, No. 2, S2S, 1 "x10" $\times 10^{\prime}-16^{\prime}$

Plank and dimensions:

Sizes $2 " x 6^{\prime \prime}$ to 8 " $\times 8^{\prime \prime}$, a verage $24^{\prime}$

Sizes 2 " $\mathrm{x} 9^{\prime \prime}$ to $10^{\prime \prime} \times 10^{\prime \prime}$, average $24^{\prime}$

Sizes 2 "x12" to $12 " \times 12 "$, average 24

Sizes 2 " $\times 14$ " to 14 " $\times 14^{\prime \prime}$, average 24 ".

Sizes $2^{\prime \prime} \times 16^{\prime \prime}$ to $16^{\prime \prime} \times 16^{\prime \prime}$, average $24^{\prime}$

Mill run.

Merch. frames 9 " and under, $24^{\prime}$ and under

Merch. frames $10^{\prime \prime}$ and $12^{\prime \prime}, 24^{\prime}$ and under

Merch. random $10^{\prime \prime}$ and $12^{\prime \prime}, 10^{\prime}$ and up.

Merch. $2^{\prime \prime} \times 7^{\prime \prime}$ and under, $10^{\prime}$ to $24^{\prime}$

Merch. $2^{\prime \prime} \times 8^{\prime \prime}$ and up, $10^{\prime}$ to $24^{\prime}$.

Lath, 1 s $^{n}$

Mill run...

Mill run, mill culis out

No. 1 and clear.

No. 2

No. 3 .

Mili culls

Mill run.

Merch. frames 3 " $\times 4$ " to 8 " $\times 8^{\prime \prime}$, $10^{\prime}-16^{\prime}$

Merch. frames 2 " $\times 12$ " to 12 " $\times 12^{\prime \prime}, 10^{\prime}-16^{\prime}$

Boards, merch., $1^{\prime \prime} \times 12^{\prime \prime}, 10^{\prime}-20^{\prime}$

Boards, box, 1 " $\times 4$ " -12 "

Mill run. 
Line Numbers Refer to Grades Listed on Page 4.

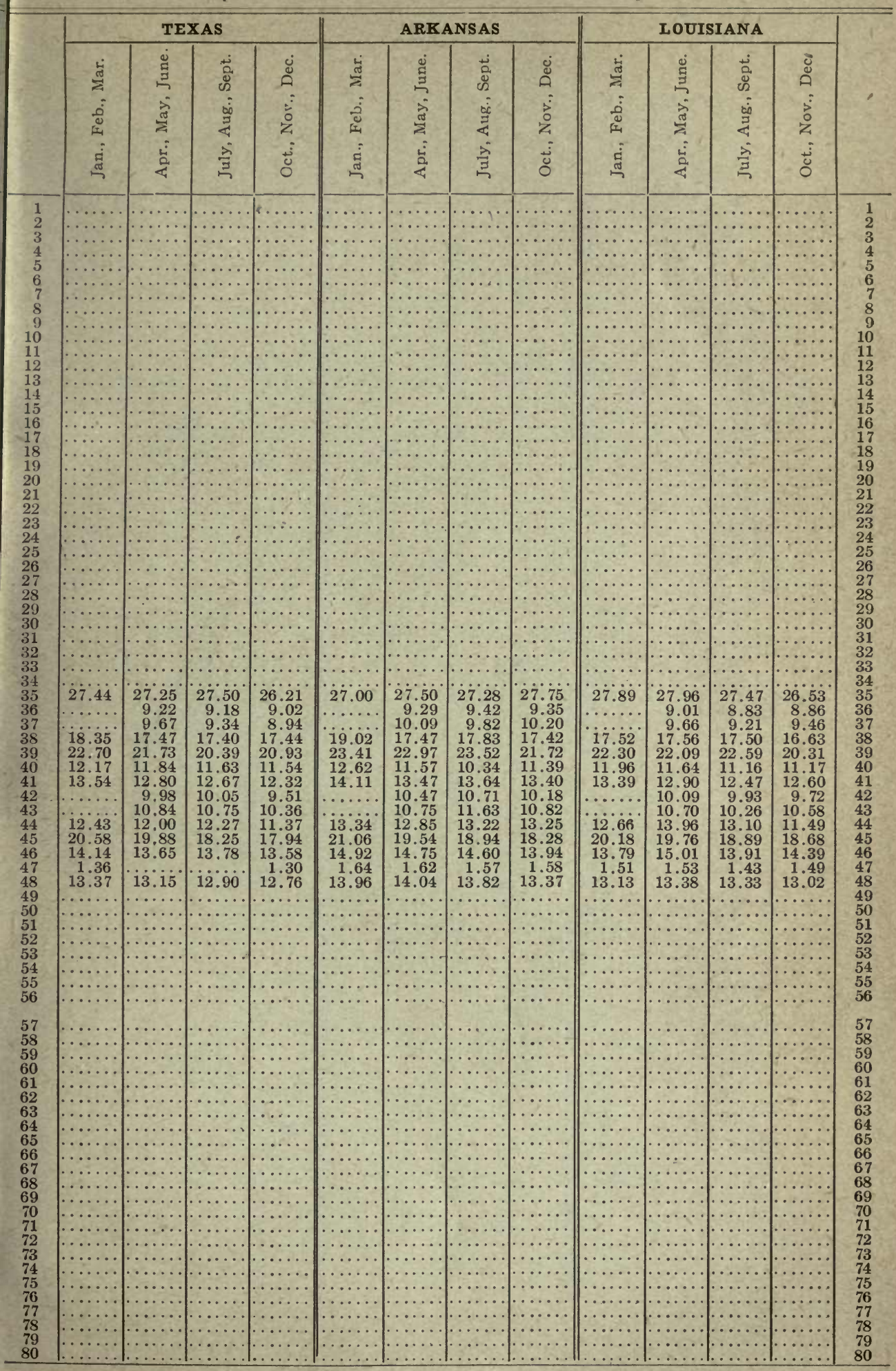


Line Numbers Refer to Grades Listed on Page 4.

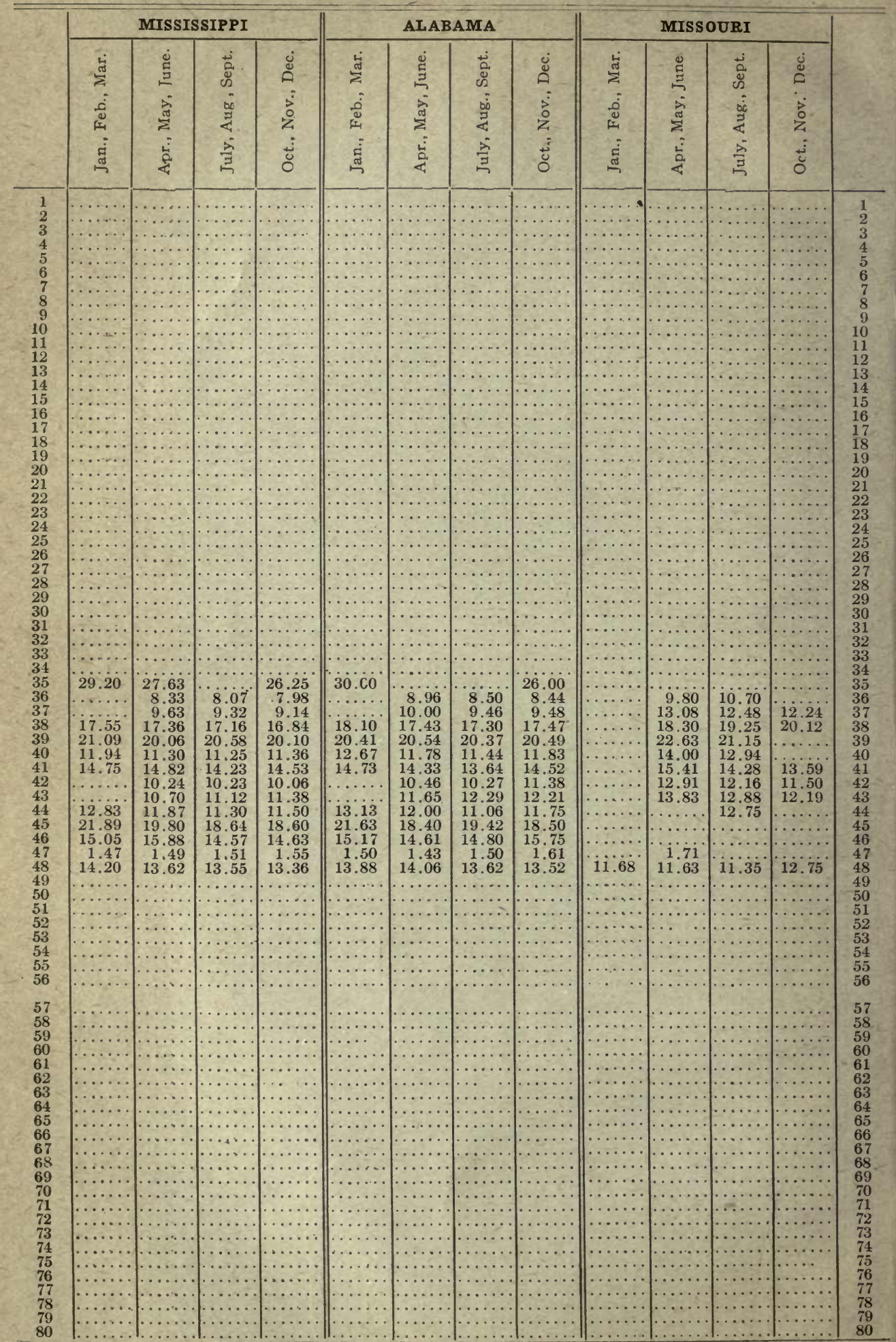


Line Numbers Refer to Grades Listed on Page 4.

\begin{tabular}{|c|c|c|c|c|c|c|c|c|c|c|c|c|c|}
\hline & \multicolumn{4}{|c|}{ FL ORIDA } & \multicolumn{4}{|c|}{ GEORGIA } & \multicolumn{4}{|c|}{ SOUTH CAROLINA } & \\
\hline & 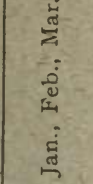 & 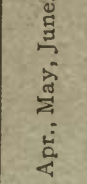 & 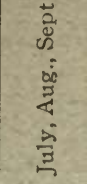 & $\begin{array}{l}\dot{0} \\
0 \\
\dot{0} \\
\dot{0} \\
\dot{0}\end{array}$ & 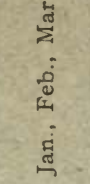 & 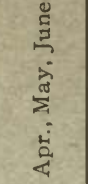 & 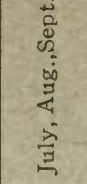 & $\begin{array}{l}0 \\
0 \\
0 \\
\dot{0} \\
0 \\
z \\
\dot{0} \\
0\end{array}$ & 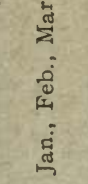 & 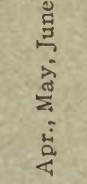 & 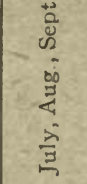 & $\begin{array}{l}0 \\
0 \\
\vdots \\
\dot{0} \\
\check{z} \\
\dot{0} \\
0\end{array}$ & \\
\hline $\begin{array}{c}1 \\
2 \\
3 \\
1 \\
5 \\
6 \\
7 \\
5 \\
9 \\
10 \\
11 \\
12 \\
13 \\
14 \\
15 \\
16 \\
17 \\
18 \\
19 \\
20 \\
21 \\
22 \\
23 \\
24 \\
25 \\
26 \\
27 \\
28 \\
29 \\
30 \\
31 \\
32 \\
33 \\
34 \\
35 \\
36 \\
37 \\
38 \\
39 \\
40 \\
41 \\
42 \\
43 \\
44 \\
45 \\
46 \\
47 \\
48 \\
49 \\
50 \\
51 \\
52 \\
53 \\
54 \\
55 \\
56\end{array}$ & $\begin{array}{l}19.50 \\
16.36 \\
11.43\end{array}$ & $\begin{array}{l}19.94 \\
16.11 \\
13.64\end{array}$ & $\begin{array}{l}\ldots \ldots \ldots \\
40.00 \\
30.03 \\
19.30 \\
15.33 \\
10.48\end{array}$ & $\begin{array}{l}38.00 \\
30.26 \\
18.54 \\
16.60 \\
12.10\end{array}$ & $\begin{array}{l}42.67 \\
32.67 \\
40.00 \\
31.00 \\
19.71 \\
18.43 \\
11.06\end{array}$ & $\begin{array}{l}46.63 \\
33.25 \\
40.00 \\
29.50 \\
19.25 \\
15.93 \\
10.69\end{array}$ & $\begin{array}{l}39.17 \\
28.32 \\
\cdots \ldots . . \\
17.91 \\
13.64 \\
10.50\end{array}$ & $\begin{array}{l}41.25 \\
28.50 \\
38.33 \\
30.00 \\
18.50 \\
15.90 \\
10.25\end{array}$ & $\begin{array}{r}19.83 \\
14.83 \\
10.33 \\
20.00 \\
9.25 \\
13.00 \\
\ldots \ldots \ldots \\
\ldots \ldots \ldots \\
\ldots \ldots \ldots\end{array}$ & $\begin{array}{l}\ldots \ldots \ldots \\
\ldots \ldots \ldots \\
\ldots \ldots \ldots \\
\ldots \ldots \ldots \\
\ldots \ldots \ldots \\
\ldots \ldots \ldots \\
\ldots \ldots \ldots \\
19.63 \\
14.83 \\
11.50 \\
11.83 \\
23.75 \\
21.70 \\
11.00 \\
11.50 \\
\ldots \ldots \ldots \\
\ldots \ldots \ldots .\end{array}$ & $\begin{array}{l}20.37 \\
15.28 \\
11.50 \\
11.73 \\
23.68 \\
23.75 \\
10.12 \\
14.10 \\
\ldots \ldots\end{array}$ & 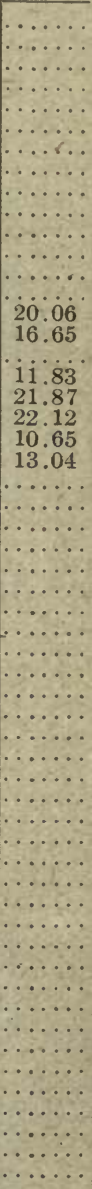 & $\begin{array}{r}1 \\
2 \\
3 \\
4 \\
5 \\
6 \\
7 \\
8 \\
9 \\
10 \\
11 \\
12 \\
13 \\
14 \\
15 \\
16 \\
17 \\
18 \\
19 \\
20 \\
2 \\
22 \\
23 \\
24 \\
25 \\
26 \\
27 \\
28 \\
29 \\
30 \\
31 \\
32 \\
33 \\
34 \\
35 \\
36 \\
37 \\
38 \\
39 \\
40 \\
41 \\
42 \\
43 \\
44 \\
45 \\
46 \\
47 \\
48 \\
49 \\
50 \\
51 \\
52 \\
53 \\
54 \\
55 \\
56\end{array}$ \\
\hline $\begin{array}{l}57 \\
58 \\
59 \\
60 \\
61 \\
62 \\
63 \\
64 \\
65 \\
66 \\
67 \\
68 \\
69 \\
70 \\
71 \\
72 \\
73 \\
74 \\
75 \\
76 \\
77 \\
78 \\
79 \\
80\end{array}$ & $\begin{array}{l}13.31 \\
14.45 \\
17.38 \\
21.70 \\
24.80 \\
13.58\end{array}$ & $\begin{array}{l}12.85 \\
13.97 \\
16.36 \\
18.50 \\
24.08 \\
14.71\end{array}$ & $\begin{array}{l}11.25 \\
12.87 \\
15.41 \\
18.30 \\
23.07 \\
14.68\end{array}$ & $\begin{array}{l}11.44 \\
12.50 \\
14.45 \\
16.93 \\
23.03 \\
14.33\end{array}$ & $\begin{array}{l}12.77 \\
14.23 \\
17.23 \\
20.50 \\
25.00 \\
13.64\end{array}$ & $\begin{array}{l}12.41 \\
13.72 \\
17.10 \\
20.40 \\
24.79 \\
13.35\end{array}$ & $\begin{array}{l}12.18 \\
13.68 \\
15.75 \\
19.31 \\
22.75 \\
11.98\end{array}$ & $\begin{array}{r}9.80 \\
11.00 \\
14.20 \\
16.65 \\
19.50 \\
12.21\end{array}$ & $\begin{array}{l}15.00 \\
15.75 \\
18.00 \\
20.25 \\
25.50\end{array}$ & $\begin{array}{l}14.17 \\
14.67 \\
16.50 \\
19.00 \\
22.33 \\
14.50 \\
\ldots \ldots \ldots \\
\ldots \ldots \ldots\end{array}$ & 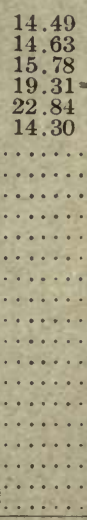 & 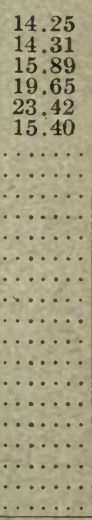 & $\begin{array}{l}57 \\
58 \\
59 \\
60 \\
61 \\
62: \\
63 \\
64 \\
65 \\
66 \\
67 \\
68 \\
69 \\
70 . \\
71 . \\
72 . \\
73 . \\
75 \\
76 \\
77 \\
78 \\
79 \\
80\end{array}$ \\
\hline
\end{tabular}


Line Numbers Refer to Grades Listed on Page 4.

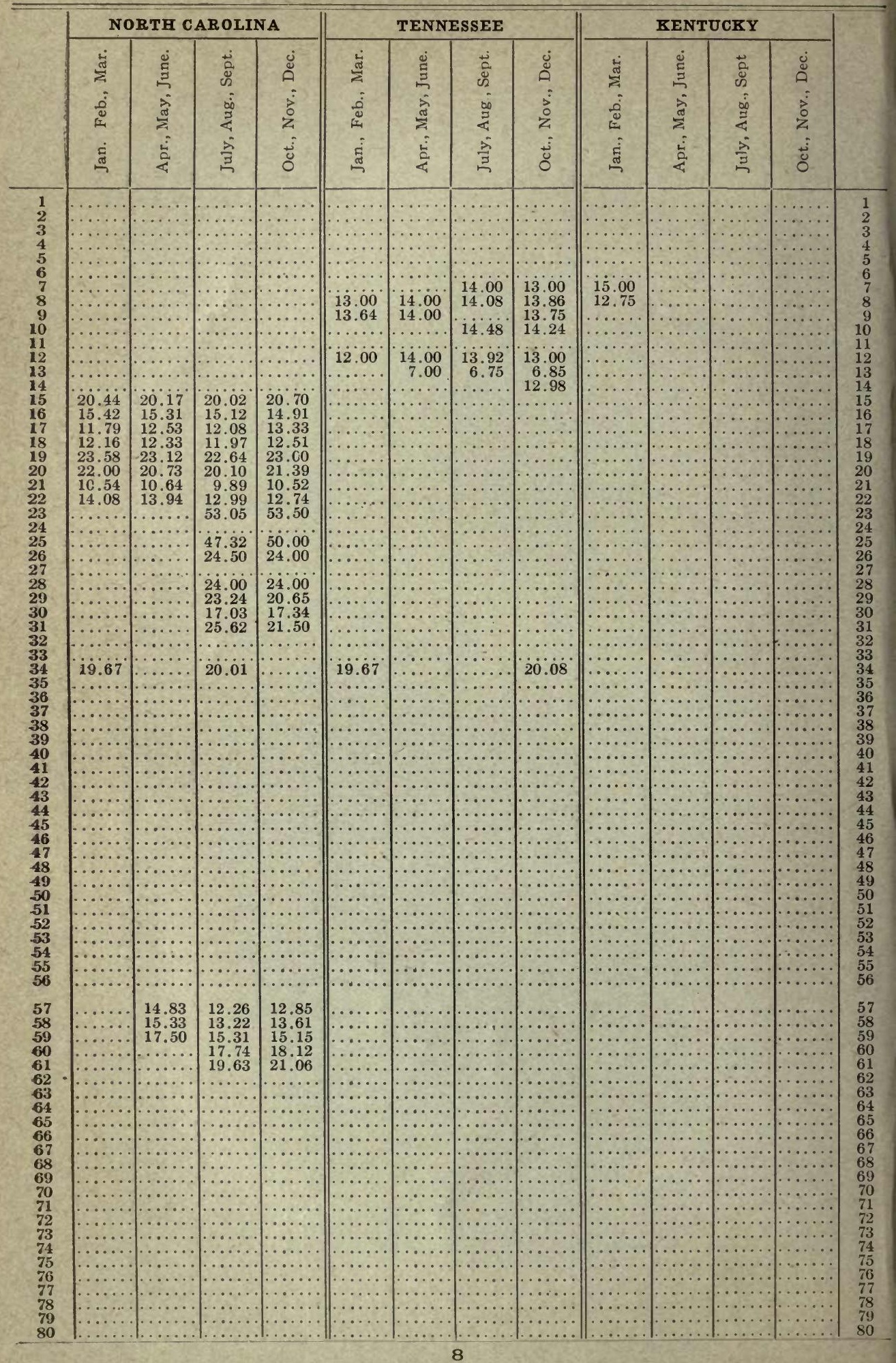


Line Numbers Refer to Grades Listed on Page 4.

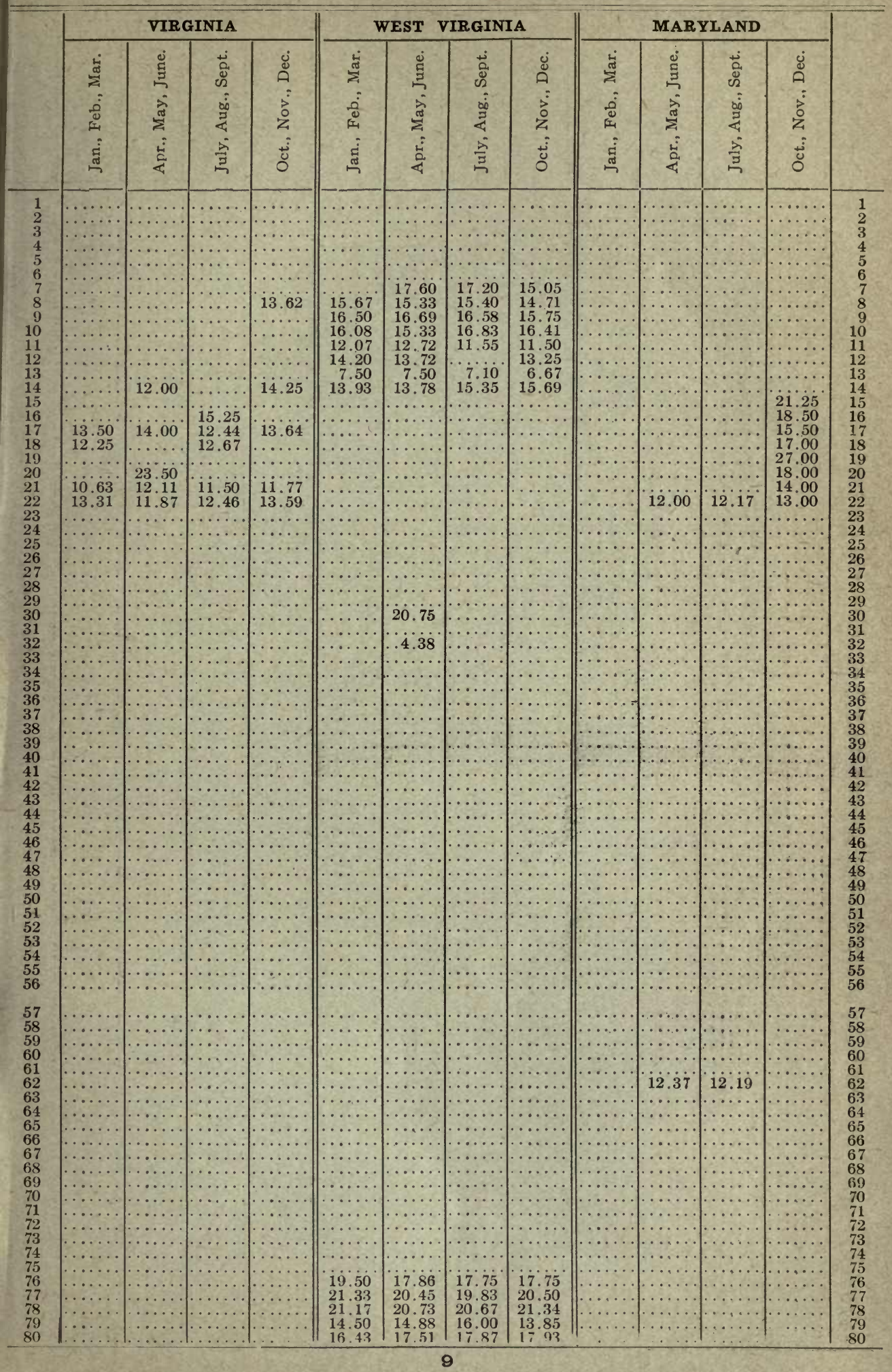


Line Numbers Refer to Grades Listed on Page 4.

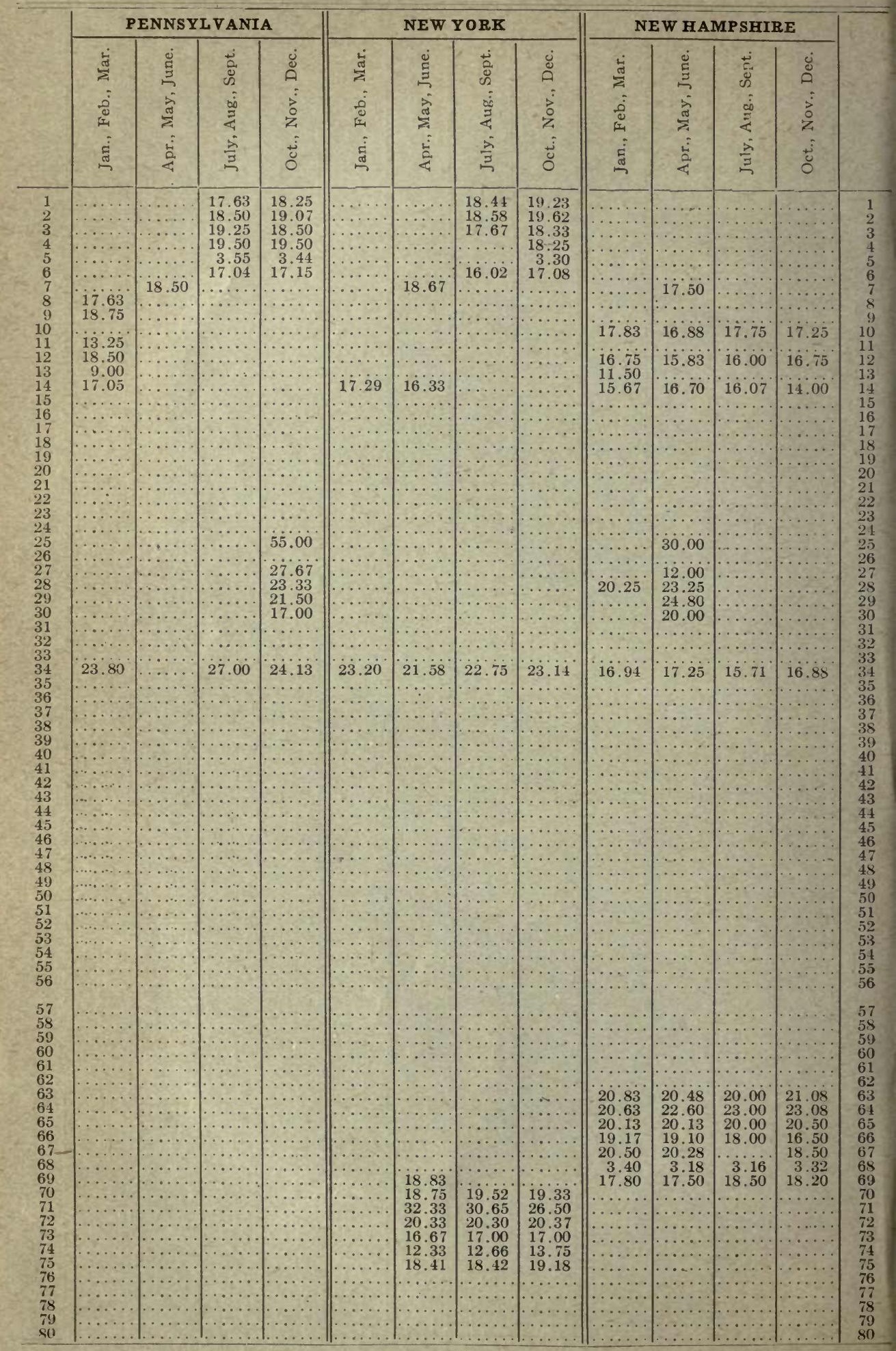


Line Numbers Refer to Grades Listed on Page 4.

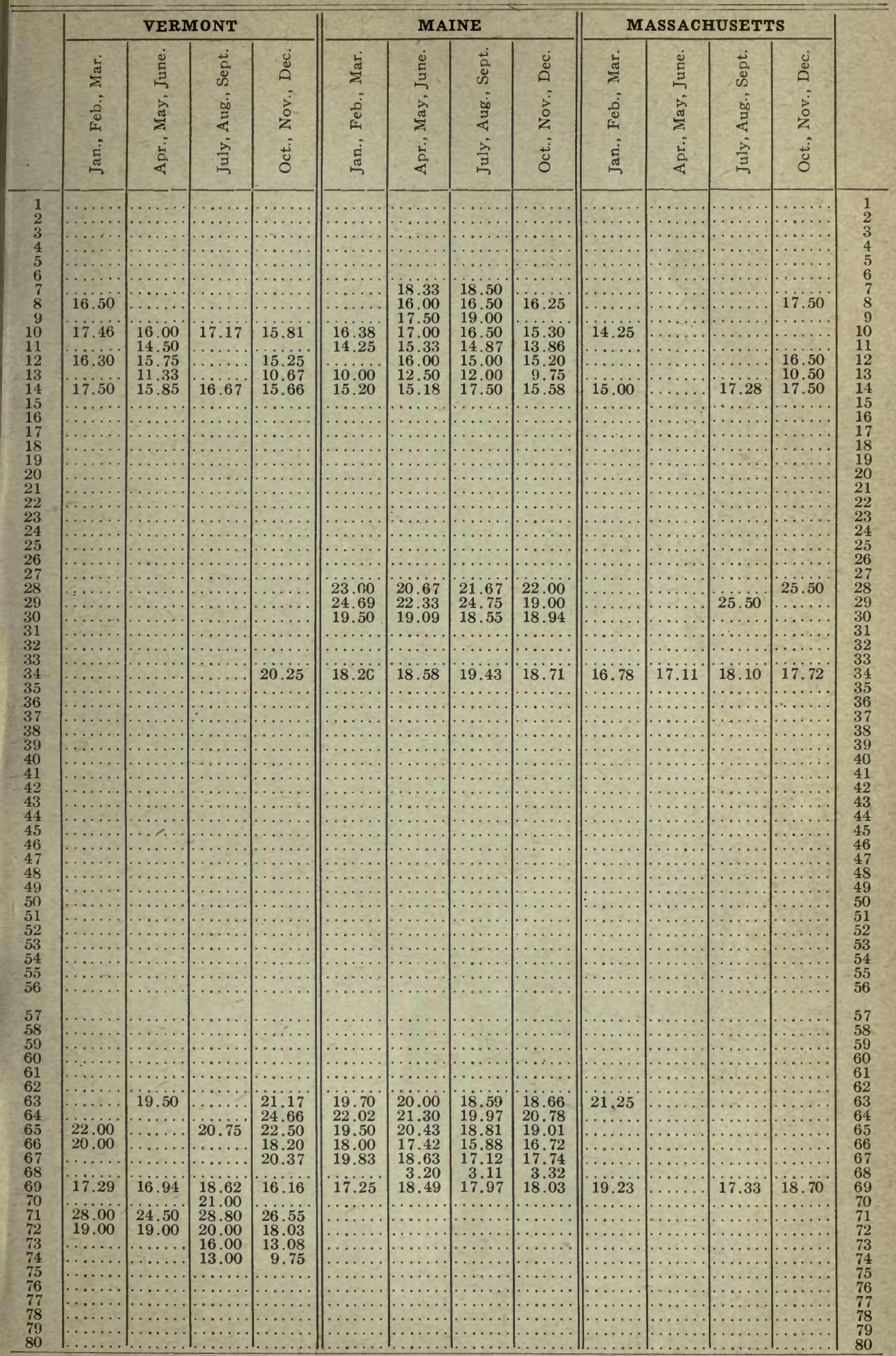


Line Numbers Refer to Grades Listed on Page 4.

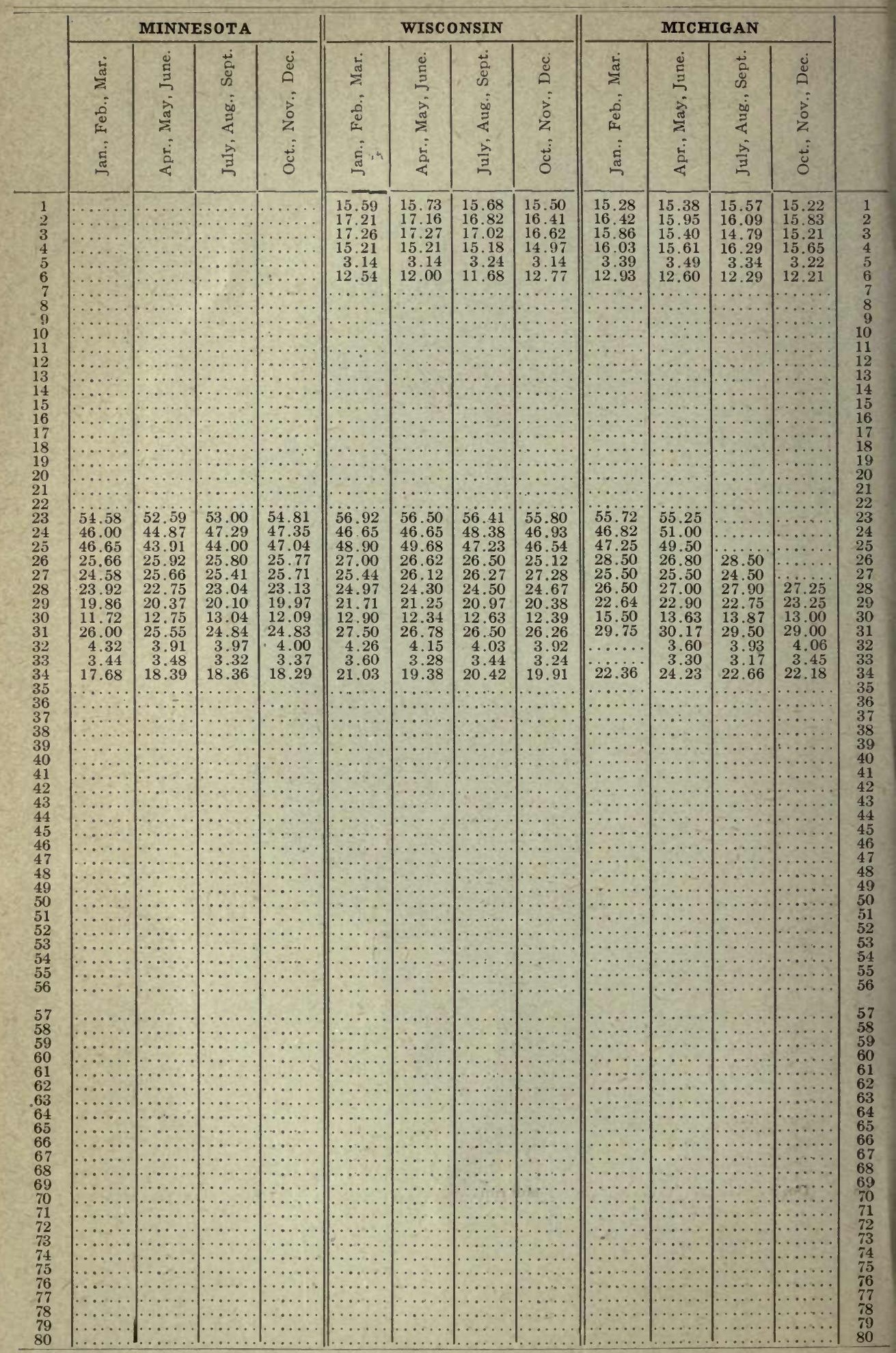


Cedar, Western Red

Do.

Do.

Do

Do

Fir, Douglas

Do...

Do.

Do.

Do.

Do..

Do.

Do.

Do...

Fir, White

Do.

Hemlock, Western

Do.

Do.

Do..

Do.

Larch, Western

Do...

Do.

Do.

Do.

Pine, Sugar

Do

Pine, Western White

Do (Idaho White)

Do.

Do.................

Do.

Do.

Pine, Western Yellow

Do (Including Western Pine, California White Pine, New Mexico White Pine)

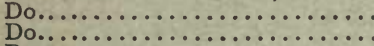

Do.

Do.

Do.

Do.

Do.

Do...

Redwood.

Do.

Do...

Do.

Do.

Do...

Spruce, Sitka.

Do (Western Spruce)

Do.

Do.

Do.

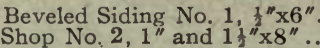

Shop No. 2, 1 " and $11^{\prime \prime} \times$
Shingles, Perfection, $18^{\prime \prime}$

Shingles, Extra Clear, $5 / 2 "$ "16"

Star-A-Star, 6/2"-16"

Mill run.

Flooring No. 1 , v. g., 1 1"x 4

Flooring No. 2 , v. g., 1 " $\mathrm{x} 4$ "

Flooring No. 2 , flat, $1^{\prime \prime} \times 4^{\prime \prime}$.

Finish No. 2 ard better, $6 "$ and 8

Drop Siding. No. 2 slash.

Dimension, Com., S1S1E, 2 "x12 "-16"

Car sills, $5^{\prime \prime} \times 8^{\prime \prime}-36^{\prime}$

Timbers, 12 "x 12 ", a verage 32 '

Cross-ties, 7 " $\mathrm{x} 9$ "

Lath, per $M$

Mill run.

Common boards, 6 " and $8^{\prime \prime}$

Lath, per M.

Mill run.

Flooring, Nos, 1 and $2,{ }^{\prime}, m_{\text {, }}, 1 " \times 4 "$

Finish, Nos. 1 and $2,5^{\prime \prime}$ and wider.

Dimension, No. 1 Com., 2 " $\mathrm{x} 4$ " to 2 " $\mathrm{x} 8$ "

Shiplap, 1"

Shop No. $1,1 \frac{1}{2}$ "x 8 " and wider.

Mill run.

Flooring, $\dot{A}$ and $B$ (Nos. 1 and 2 clear), $i$ " $x 4$ "

Finish, $A$ and $B$ (Nos. 1 and 2 clear), 1 " $\times 8^{\prime \prime}$

Drop siding, $A$ and $B$ (Nos. 1 and 2 clear), $1 " x 6^{\prime \prime} \ldots \ldots \ldots \ldots \ldots \ldots$

Common boards, No. $2,1^{\prime \prime} \times 8^{\prime \prime}-16^{\prime}$.

Dimension, No. 1 Com., $2^{\prime \prime} \times 8^{\prime \prime}-16^{\prime}$

Lath, per M.

Mill run.

Firsts and seconds, clear

Shop No. $1,2^{\prime \prime} \times 8^{\prime \prime}$ and wider.

Shop No. 2, $2^{\prime \prime} \times 8^{\prime \prime}$ and wider

Mill run.

Finish, $\mathrm{C}$ select, $\dot{8}^{\prime \prime}$

Finish, $D$ select, 8

Beveled siding, $\mathrm{B}$ and better, $4^{\prime \prime}$ and $6^{\prime \prime}$

Beveled siding, $\mathrm{C}, 4^{\prime \prime}$ and $6^{\prime \prime}$

Common boards, No. 2, $6^{\prime \prime}$ and 8 "

Mill run.

Flooring, $B$ and better (Nos, 1 and 2 clear), $4^{\prime \prime}$ and $6^{\prime \prime}-16$

Finish, C select, 8"

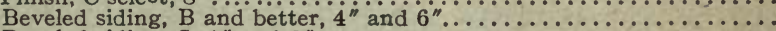

Beveled siding, C, $4^{\prime \prime}$ and $6^{\prime \prime}$

Shop No. $1,6 / 4$.

Shop No. 2, 6/4

Common boards, No. 2,1 i" $\ddot{8} \dot{8}^{i}-1 \dot{6}^{\prime}$

Dimension, No. 1 , Com., $2^{\prime \prime} \times 8^{\prime \prime}-16^{\prime}$

Lath No. 1, per M.

Mill run.

Clear, $6^{\prime \prime}$ to $12^{\prime \prime}, 10^{\prime}$ to $20^{\prime}$

Sappy clear, $6^{\prime \prime}$ to $8^{\prime \prime}, 10^{\prime}$ to $20^{\prime}$

Common boards No. 1

Common boards No. 2

Cross-ties, 6 " $x 8^{\prime \prime}-8^{\prime}$

Shingles No. 1, per M.

Shingles No. 2, per M.

Mill run.

Shop No. 1, 6/4..

Finish No. 2, clear and better, 1 "xi2"

Flooring No. 2, clear and better, 1 "X4"

Beveled Siding, B, "x6"

Common Boards, 1 "x 12 "

Mill run. 
Line Numbers Refer to Grades Listed on Page 13.

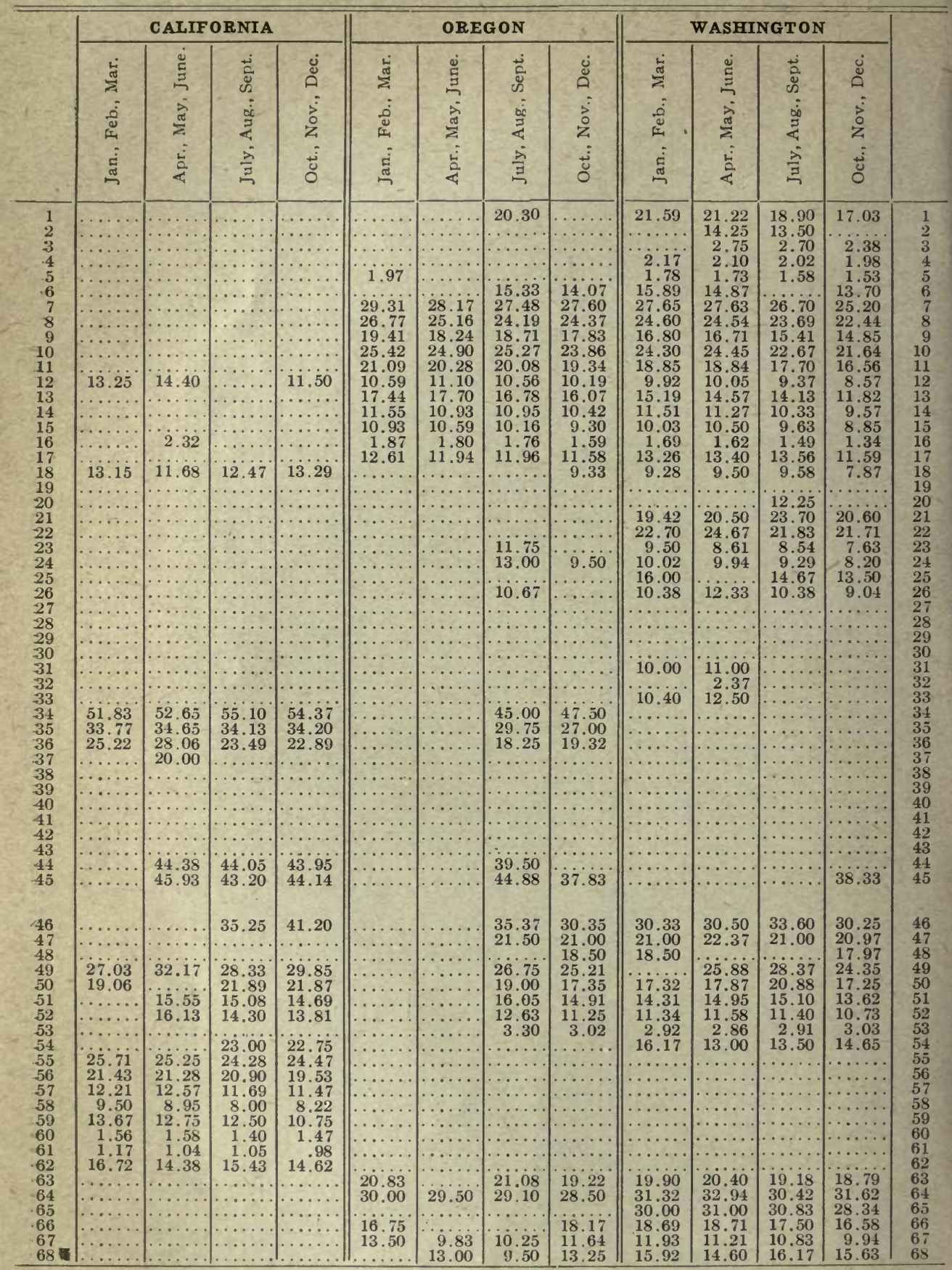


Line Numbers Refer to Grades Listed on Page 13.

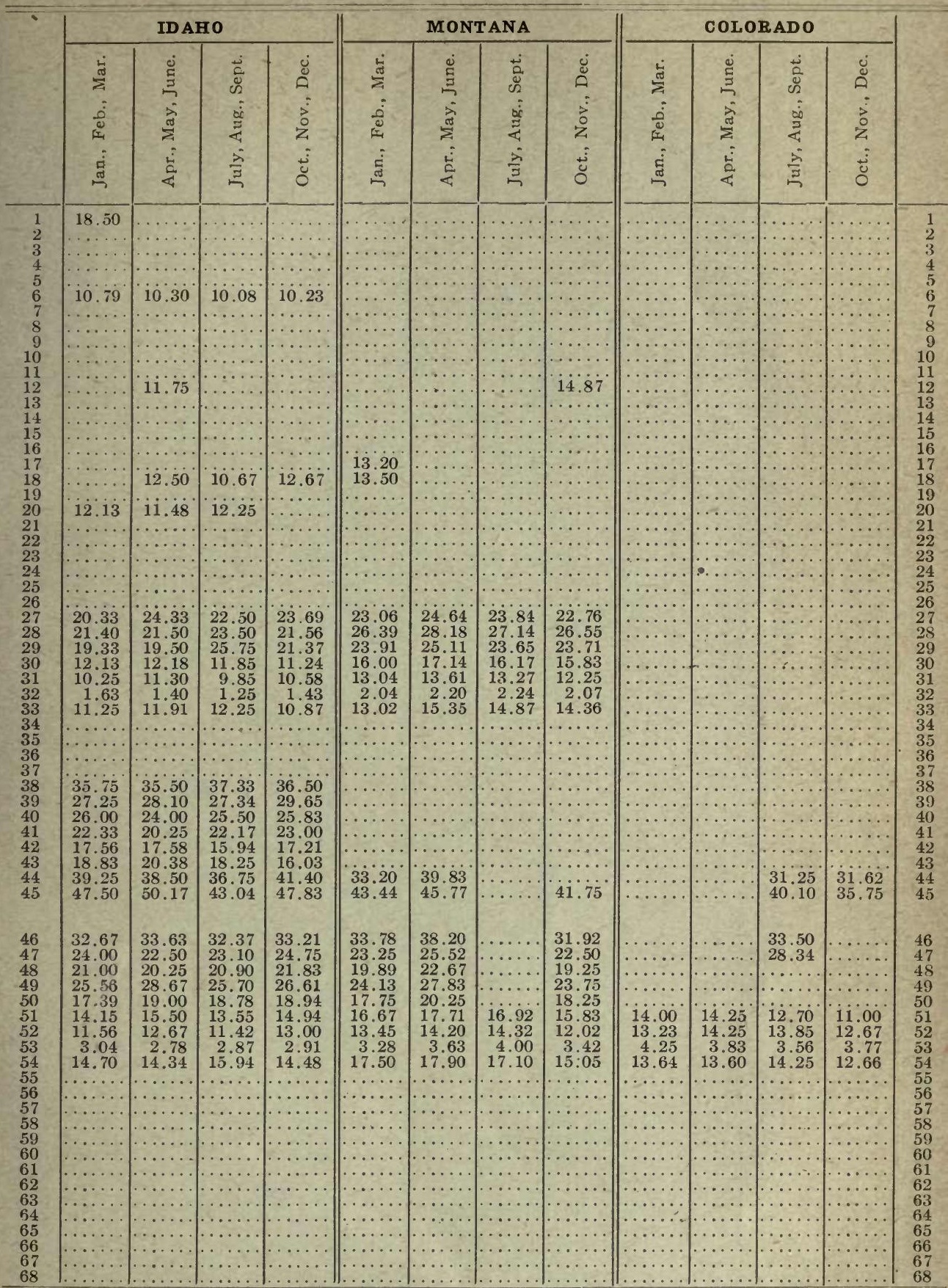


Ash.

Do...

Basswoood...

Do.

Do...

Beech.

Do...

Birch, unselected

Do.

Do.

Do.

Chestnut.

Do.

Do.

Do.

Cottonwood.
Do.
Do.
Do.
Cypres.
Do.
Do.
Do.

Cypress, shingles

Elm, rock.

Do.
Do.
Do.

Elm, soft

Do.

Gum.

Do.

Do.

Do.

Do.

Hickory

Do.

Do.

Maple, hard

Do.

Do.

Do, soft.

Do.

Do..

Oak, plain

Do.

Do..

Do.

Oak, red, quartered

Do..

Do...

Oak, white, quartered

Do..

Do.

Do...

Poplar..

Do.

Do...

Do...

Tupelo (Bay Poplar)

Do...
Firsts and seconds $4 / 4$

No. 1 common $4 / 4$

better, $4 / 4$ or $\log$ ru

Firsts and seconds $4 / 4$.

No. 1 common $4 / 4$. .

No. 2 common $4 / 4$.

Log run.

Mill run.

Firsts and seconds $4 / 4$

No. 1 common $4 / 4$

Mill run.

Firsts and seconds $4 / 4$

No. 1 common $4 / 4$

No. 2 common $4 / 4$

No 2 common and better, $4 / 4$.

Mirsts and seconds $4 \% 4$.

No. 1 common $4 / 4$

No. 2 common and S. W. $4 / 4$

No. 3 common $4 / 4$

Miil run.

(1)......

Firsts and second $4 / 4,6$ " to 12

Boxboards $4 / 4,13^{\prime \prime}$ to 17 .

No. 1 common $4 / 4$

No. 2 common $4 / 4$

Mili run.

Firsts and seconds clear $4 / 4$

Selects $4 / 4$

Shop, No. $1, \dddot{4} / 4$

No. 1 common $4 / 4$, random widths

No. 2 common 4/4, random widths

Mill run

Primes 5

Firsts and seconds $8 / 4$

No. 1 common and better $8 / 4$

No. 2 common and better $8 / 4$.

Mill run.

No. 1 common and better $4 / 4$

No. 2 common and better $4 / 4$

Mill. run

Firsts and seconds $4 / 4$ red.

No. 1 common $4 / 4$, red

Firsts and seconds $4 / 4$, sap.

No. 1 common $4 / 4$, sap..

No. 2 common $4 / 4$

Mill run.

Firsts and seconds $8 / 4$.

No. 1 common $8 / 4$

No. 2 common $8 / 4$

Mill run.

Firsts and seconds $4 / 4$.

No. 1 common $4 / 4$

Nill run......... 1 common and better $4 / 4$

No. 3 common $4 / 4$

Log run.

Mill run

Firsts and seconds, $4 / 4$

No. 1 common $4 / 4$

No. 2 common $4 / 4$.

No. 3 common $4 / 4$

Mili run

Firsts and seconds $4 / 4$

No. 1 common $4 / 4$.

No. 2 common $4 / 4$

Mill run.

Firsts and seconds $4 / 4$

No. 1 common $4 / 4$.

No. 2 common $4 / 4$

Mill run

Firsts and seconds $\ddot{4} \ddot{4}$

Saps or selects $4 / 4$

No. 1 common $4 / 4$

No. 2 common $4 / 4$

Mili run

Firsts and seconds clear, random $4 / 4$

No. 1 common, random $4 / 4$

Mill run. 
Line Numbers Refer to Grades Listed on Page 16.

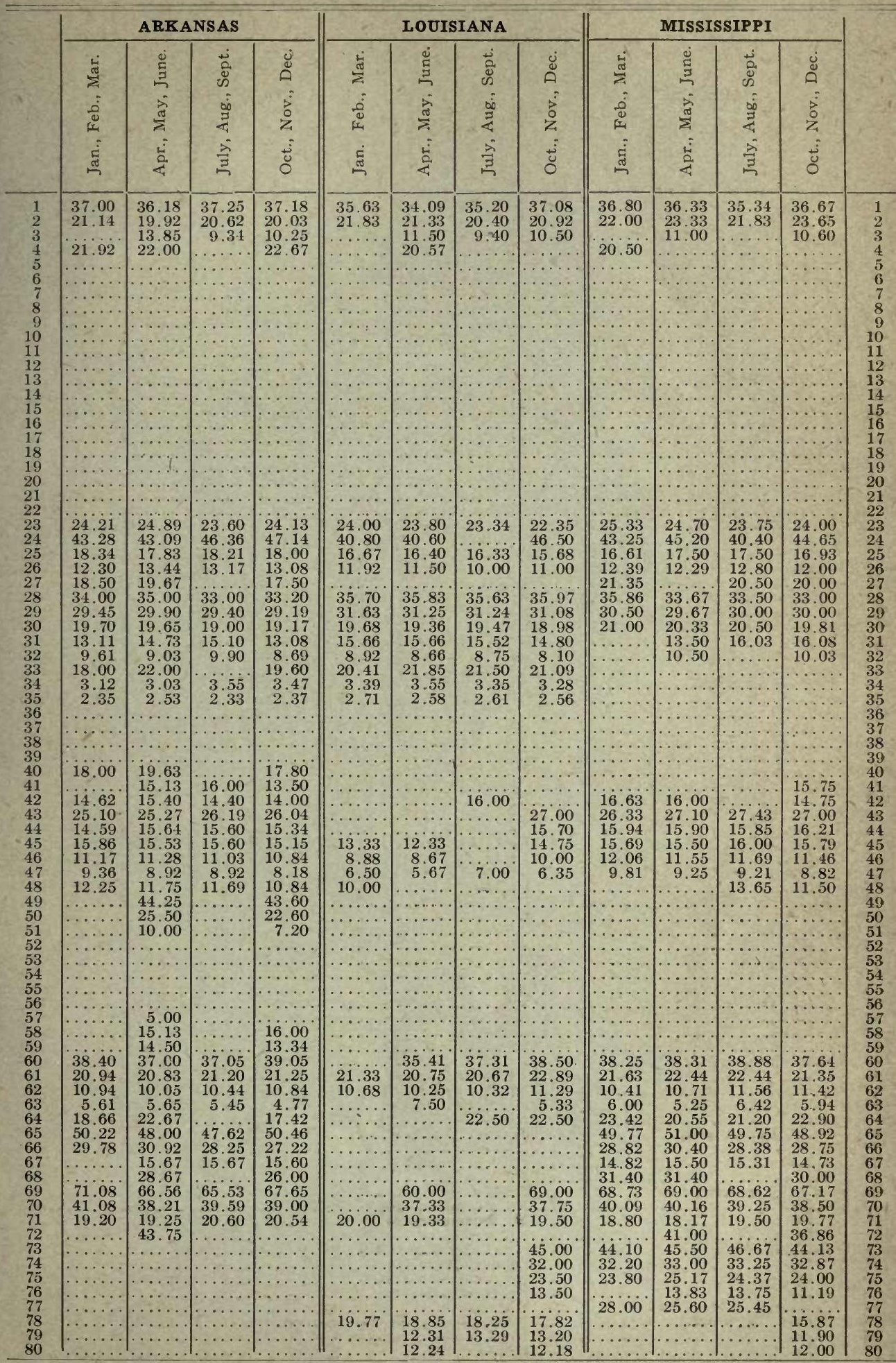


Line Numbers Refer to Grades Listed on Page 16.

\begin{tabular}{|c|c|c|c|c|c|c|c|c|c|c|c|c|c|}
\hline & \multicolumn{4}{|c|}{ FLORIDA } & \multicolumn{4}{|c|}{ SOUTH CAROLINA } & \multicolumn{4}{|c|}{ NORTH CAROLINA } & \\
\hline & 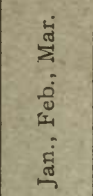 & 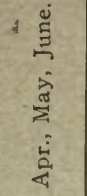 & 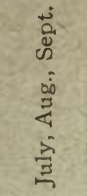 & $\begin{array}{l}\dot{0} \\
\stackrel{0}{0} \\
\dot{0} \\
z \\
\dot{0} \\
\dot{0}\end{array}$ & 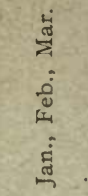 & 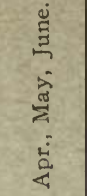 & 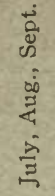 & $\begin{array}{l}\dot{u} \\
\text { ه } \\
\dot{\overrightarrow{0}} \\
\dot{z} \\
\dot{\dot{u}} \\
\dot{0}\end{array}$ & 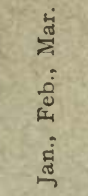 & 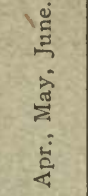 & 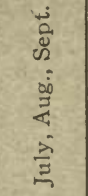 & 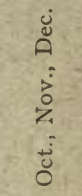 & \\
\hline 33 & $\begin{array}{l}36.00 \\
31.80 \\
22.00 \\
17.60 \\
11.25\end{array}$ & $\begin{array}{l}36.63 \\
30.63 \\
21.21 \\
17.60 \\
11.60 \\
3.56 \\
2.29\end{array}$ & $\begin{array}{r}35.62 \\
31.31 \\
21.44 \\
16.50 \\
11.16 \\
3.64 \\
3.64 \\
2.32\end{array}$ & $\begin{array}{r}35.83 \\
31.50 \\
20.50 \\
16.91 \\
11.00 \\
3.67 \\
2.17\end{array}$ & $\begin{array}{l}32.50 \\
21.00 \\
15.00\end{array}$ & $\begin{array}{l}35.38 \\
32.13 \\
22.63 \\
18.25 \\
12.88\end{array}$ & & $\begin{array}{l}38.90 \\
\ldots \ldots \ldots \\
\cdots \ldots \ldots \\
\ldots \ldots \ldots \\
\ldots \ldots \ldots \\
\ldots \ldots \ldots \\
\ldots \ldots \ldots\end{array}$ & 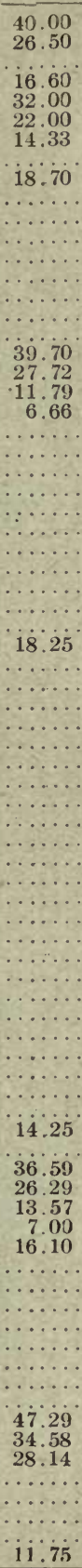 & 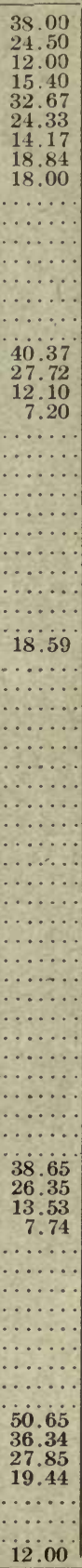 & 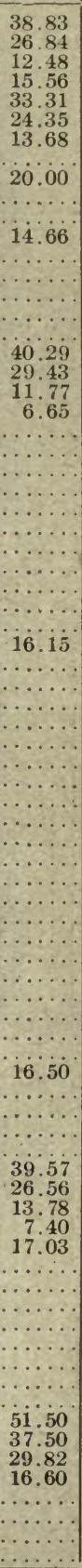 & 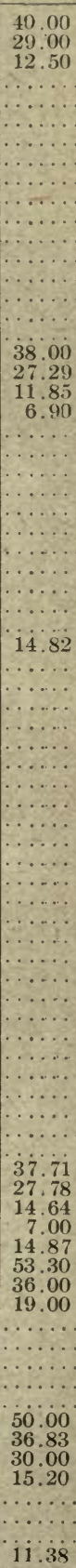 & $\begin{array}{l}73 \\
74 \\
75\end{array}$ \\
\hline
\end{tabular}


Line Numbers Refer to Grades Listed on Page 16.

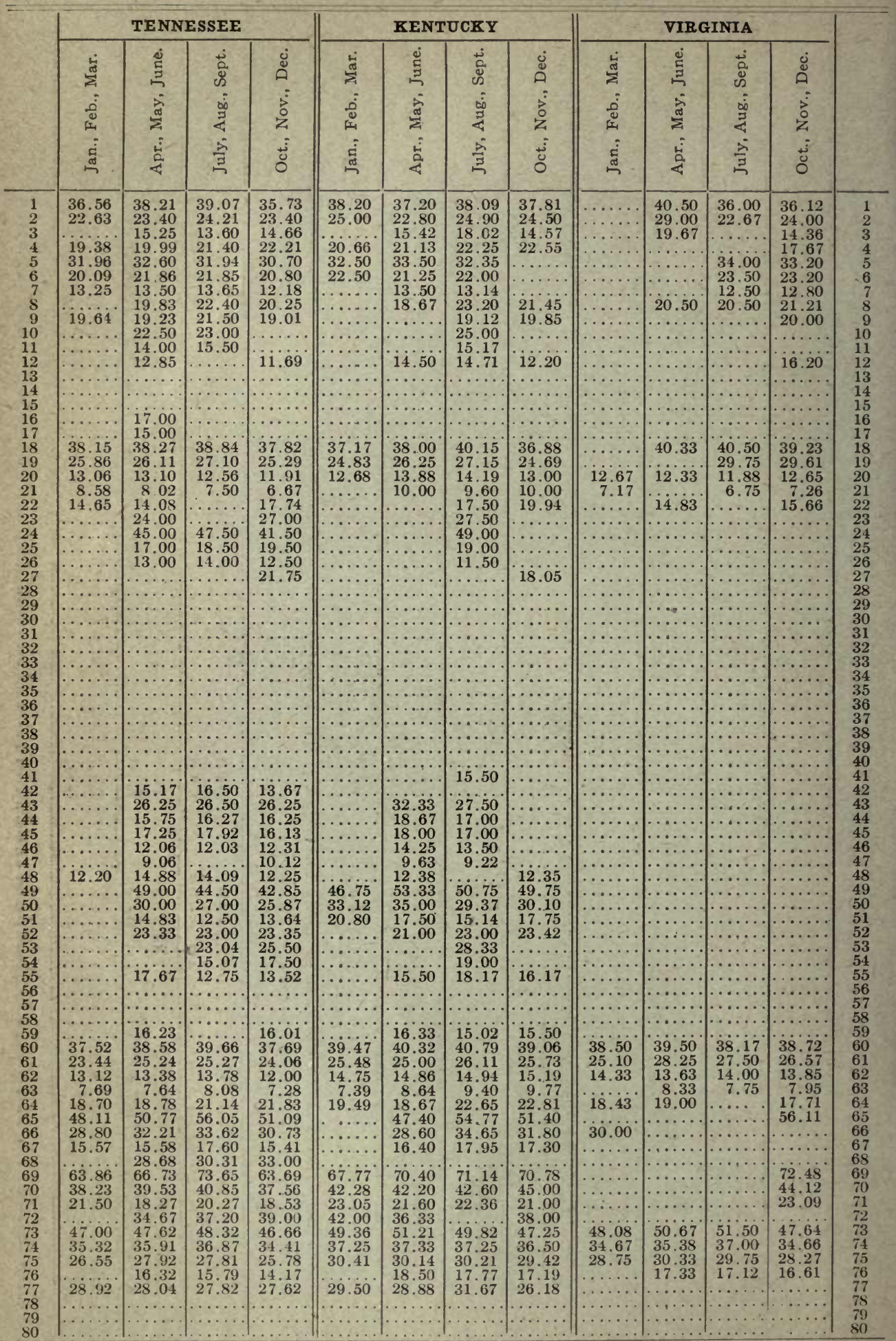


Line Numbers Refer to Grades Listed on Page 16.

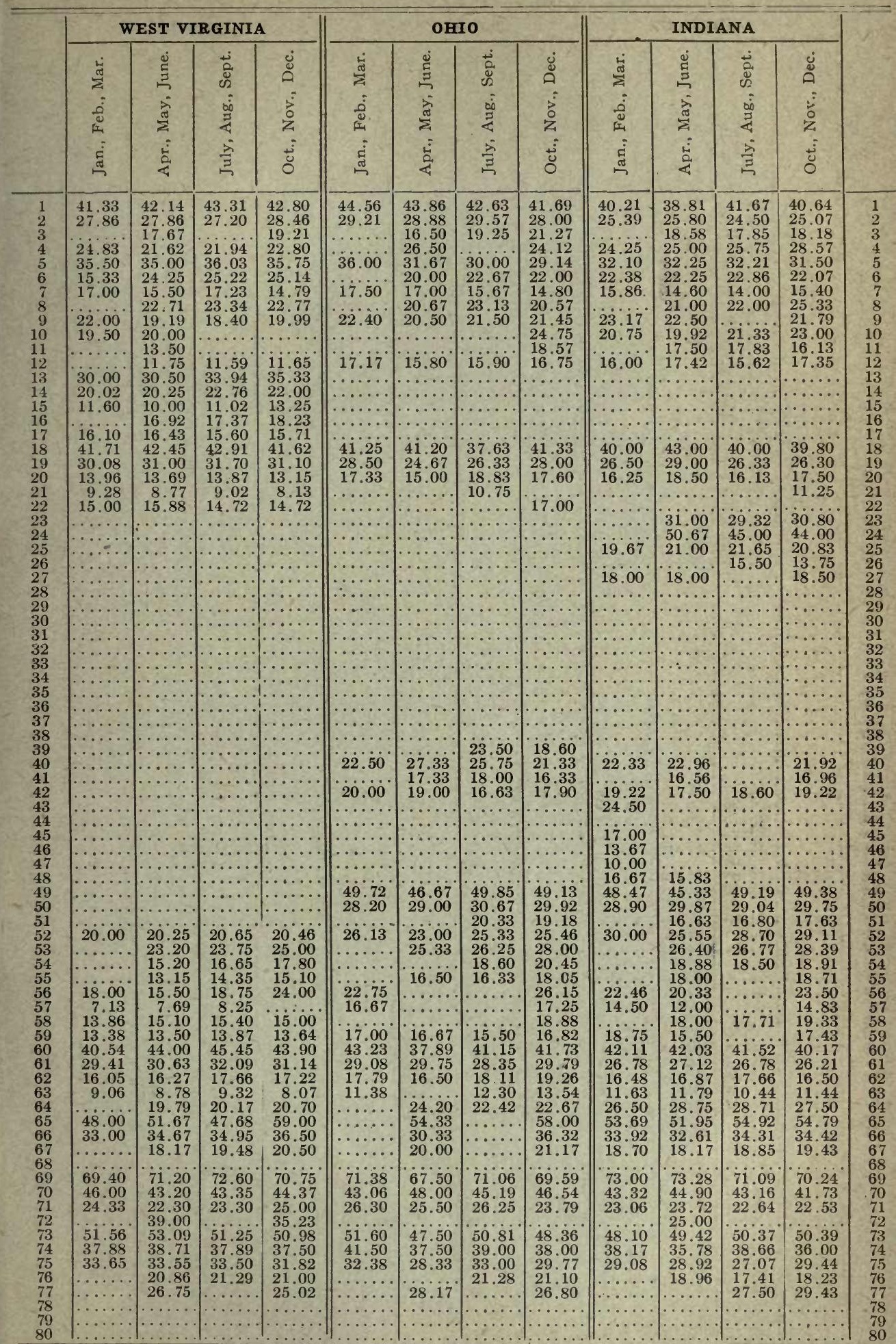


Line Numbers Refer to Grades Listed on Page 16.

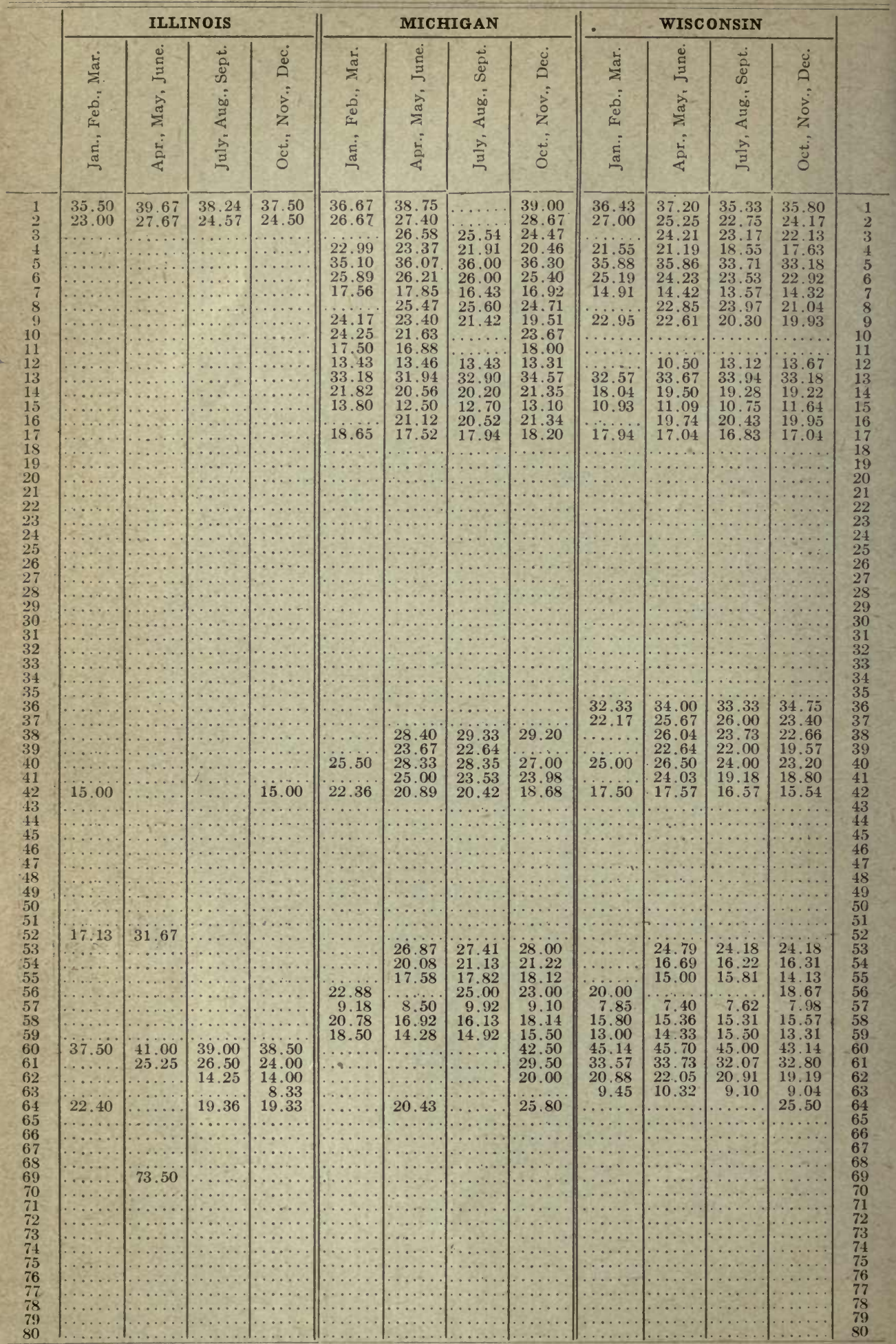


Line Numbers Refer to Grades Listed on Page 16.

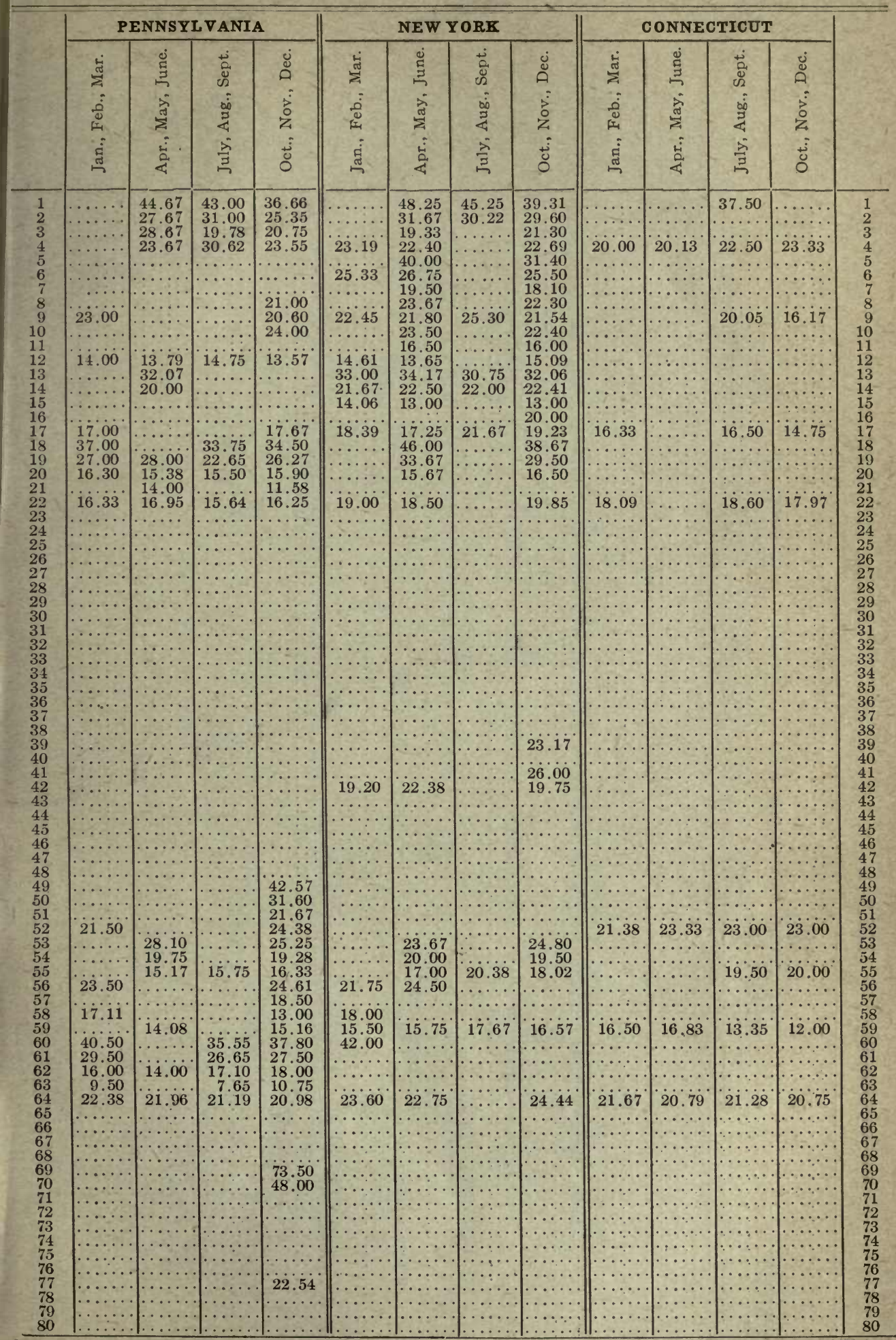


U. S. DEPARTMENT OF AGRICULTURE

FOREST SERVICE

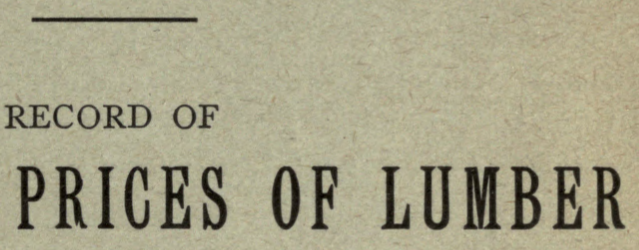

\section{(PER 1,000 FEET B. M.) \\ WHOLESALE PRICES OP LUMBER}

Based on actual sales made F. O. B. Mill

for

JANUARY, FEBRUARY AND MARCH, 1911 


\section{PREFATORY NOTE}

The Forest Service has two main purposes in collecting and compiling this record of f. o. b. mill prices: first, to have a continuous statistical record of such prices of the various commercial woods; and, second, to show, in contrast to market prices-which include the important items of freight charges and selling costs - just what the manufacturers of lumber receive for their product at the mill. The prices given are wholesale, based on actual sales f. o. b. mill, for delivery outside of local territory. Only a few representative grades and the mill run are included. By mill run is meant the average of all grades of lumber produced. The record is compiled by states, and is made up from reports received from approximately five thousand of the largest manufacturers scattered throughout the country. It will be published quarterly.

The Forest Service wishes to acknowledge the courtesy of the manufacturers for their prompt and efficient coöperation. Their assistance has been of great value in making the record complete, accurate, and promptly available for distribution. 


\section{Walter Mulfurd}

\section{SUMMARY}

Average prices reported by manufacturers in the western part of the country for January' February and March, 1911, apparently indicate better conditions in the lumber industry.' Douglas fir items reported upon show prices closely approaching those given in the record for the last three months of 1910. Red cedar, hemlock, western yellow pine and Sitka spruce prices advanced slightly over those for the preceding quarter, while minor reductions are shown in western white pine and redwood values.

Yellow pine prices reported by the Mississippi Valley and Atlantic Coast mills are considerably higher for the first three months of 1911 in comparison with those printed in the record for the last quarter of 1910. White pine prices in the Lake States also advanced. Hemlock figures from eastern and West Virginia mills are a trifle lower, though the Lake States figures remain about the same as for the preceding quarter. Spruce prices reported from West Virginia mills are slightly higher in comparison, though small declines are apparent in the prices given for the eastern and Adirondack mills. North Carolina pine values show little change. Cypress prices are not of the high level of the preceding quarter.

Small changes are to be noted in hardwood prices for the first quarter of the year when compared with the record for the last quarter of 1910. Among the woods showing a tendency to advance in price are basswood, birch, chestnut, cottonwood, hard and soft maple and tupelo. Slight declines are shown generally in the prices reported on beech, rock elm, soft elm, plain oak, and red and white quartered oak, while ash, gum and hickory prices are practically unchanged. 
Cedar, Western Red

Do.

Do.

Do.

Do...........

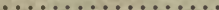

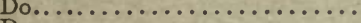

Do.

Do.

Do.

Do.

Do.

Do.

Do.

Fir, White

Do...

Hemlock, Western

Do.

Do.

Do.

Do.

Larch, Western

Do.

Do.

Do.

Do.

Do.... .

Pine, Sugar

Do...

Do.

Pine, Western White.

Do (Idaho White)

Do

Do.

Do.

Pine, Western Ẏellow

Do (Including Western Pine, California White Pine, New Mexico White Pine)

Do.

Do.

Do.

Do.

Do.

Do.

Do.

Redwood.

Do.

Do...

Do.

Do.

Do.

Do.

Spruce, Sitka

Do (Western Spruce)

Do.

Do.

Do.
Beveled Siding No. 1 , ${ }^{\prime \prime} \times 6 "$

Shop No, 2,1 and 1 "

Shingles, Perfection, $18^{\prime \prime}$

Shingles Extra Clear 5/2"-10

"16" Star-A-Star, 6/2"-16"

Mill run.

Flooring No. 1 , v. g., $1^{\prime \prime} \times 4^{\prime \prime}$

Flooring No. 2 , v. g., 1 " $\mathrm{x} 4$ "

Flooring No. 2, flat, $1^{\prime \prime} \times 4^{\prime \prime}$

Finish No. 2 ard better, $6 "$ and 8

Drop Siding, No. 2 slash

Dimension, Com., S1S1E, 2 " $\times 12^{\prime \prime}-16^{\prime}$ '

Car sills, $5^{\prime \prime} \times 8^{\prime \prime}-36^{\prime} \ldots \ldots \ldots \ldots . . . . .$.

Cross-ties, 7 " $\times 9$ "

Lath, per M

Common boards, $6^{\prime \prime}$ and ${ }^{\prime \prime}$

Lath, per M

Mill run.

Flooring, Nos, 1 and 2, v. g., 1 " $\times 4 "$

Finish, Nos. 1 and $2,5^{\prime \prime}$ and wider

Dimension, No. $1 \mathrm{Com} ., 2$ " $\mathrm{x} 4$ " to 2 " $\mathrm{x} 8$ "

Shiplap, 1"

Shop No. $1,1 \frac{1}{2} " \times 8^{\prime \prime}$ and wider

Mill run.

Flooring, $\mathrm{A}$ and $\mathrm{B}$ (Nos. 1 and 2 clear), $i \ddot{ } \dot{ } \dot{ } 4$

Finish, $A$ and $B$ (Nos. 1 and 2 clear), $1^{\prime \prime} \times 8^{\prime \prime}$

Drop siding, $A$ and $B$ (Nos. 1 and 2 clear), $1 " x 6$

Common boards, No. $2,1^{\prime \prime} \times 8^{\prime \prime}-16^{\prime}$

Dimension, No. 1 Com., $2^{\prime \prime} \times 8^{\prime \prime}-16^{i}$

Lath, per M

Mill run

Firsts and seconds, clear.

Shop No. $1,2^{\prime \prime} \times 8^{\prime \prime}$ and wider.

Shop No. $2,2^{\prime \prime} \times 8^{n}$ and wider

Mill run.

Finish, $\mathrm{C}$ select, $8^{\prime \prime}$

Finish, D select, 8

Beveled siding, $\mathrm{B}$ and better, 4 " and ${ }^{\prime \prime}$ ".

Common boards, No, $2,6^{\prime \prime}$ and $8^{\prime \prime}$.

Mill run.

Flooring, $B$ and better (Nos. 1 and 2 clear), $4^{n}$ and $6^{n}-16^{\prime}$.

Finish, B select and better, $11 \times 10^{\prime \prime}-16^{\prime} \ldots$.

Finish, C select, $8^{\prime \prime}$

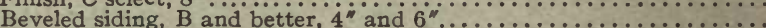

Beveled siding, $\mathrm{C}, 4^{\prime \prime}$ and $6^{\prime \prime}$

Shop No. $1,6 / 4$

Shop No. $2,6 / 4$

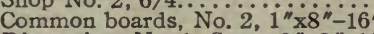

Dimension, No. 1 , Com., $2^{\prime \prime} \times 8^{\prime \prime}-16^{\prime}$

Lath No. 1, per M

Mill run.

Clear, 6 " to $12^{\prime \prime}, 10 ; 0^{\prime}$ to $20^{\prime}$

Sappy clear, $6^{\prime \prime}$ to $8^{\prime \prime}, 10^{\prime}$ to $20^{\prime}$

Common boards No. 1 .

Common boards No. 2

Cross-ties, $6^{\prime \prime} \times 8^{\prime \prime}-8^{\prime}$

Shingles No. 1, per M

Shingles No. 2 , per M.

Mill run.

Shop No. $1,6 / 4$.

Finish No. 2, clear and better, i"xi2"

Flooring No. 2, clear and better, 1 "x4"

Beveled Siding, $\mathrm{B}, \mathrm{1}$ " $\mathrm{x} 6$ "

Common Boards, 1 "x12"

Mill run... 


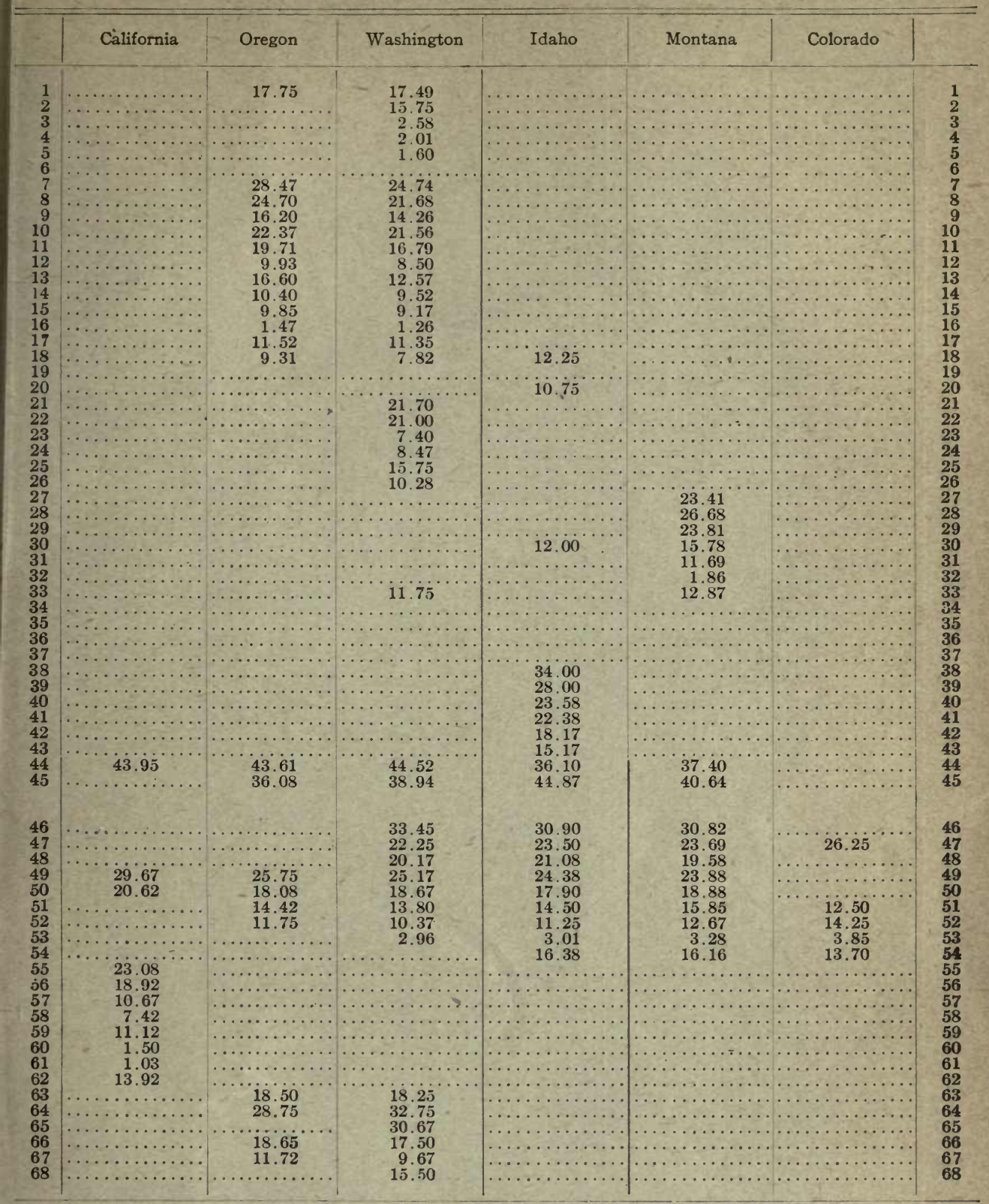


Hemlock

Do (Lake States)

Do.

Do.

Do.

Hemlock

Do (Eastern and West Virginia)

Do.

Do.

Do

Do.

Do

Pine.

Do (North Carolina)

Do.

Do.

Do

Do

Do

Pine, white

Do

Do.

Do.

Do.

Do.

Do.

Do.

Do.

Do.

Pine, yellow

Do (Mississippi Valley Milis)

Do.

Do.

Do.

Do.

Do.

Do.

Do..

Do.

Do.

Pine, yellow.

Do (Atlantic Coast Milis)

Do

Do...

Do

Do.

Do.

Do Merch. grade (Sail)

Do.

Do.

Do.

Spruce (Eastern)

Do.

Do.

Do.

Do.

Do (Ädirondack)

Do.

Do.

Do.

Do (wèt virginia)

Do.

Do.

Do.
2 " piece stuff, S1S1E, 2 " $x 4^{\prime \prime}-16^{\prime}$

Boards, No. 1, S1S, 1 " $\times 8^{\prime \prime}-16^{\prime}$

Timbers, rough, $4^{n} \times 4^{\prime \prime}$ to $8^{\prime \prime} \times 8^{\prime \prime}-16^{\prime}$

Fencing No. 1, S1S, 1"x6"

Lath No. $1, \frac{3}{8}{ }^{\prime \prime}-4^{\prime}$

Mill run.

$8 / 4$ merch 4 in to 12 io to 20

$4 / 4$ merch. $6^{\prime \prime}$ and $8^{\prime \prime}-16^{\prime}$

$4 / 4$ merch. $10^{\prime \prime}$ and $12^{\prime \prime}-16^{\prime} \ldots$

$4 / 4$ merch, boards, $6^{\prime \prime}$ and up, Sis, clipped, $12,14^{\prime}$ and $16^{\prime}$

$4 / 4$ boards, No. $2,1^{\prime \prime} \times 4^{\prime \prime}-12^{\prime \prime}, 6^{\prime}-20^{\prime}$

Mill run, mill culls out.

Mill culls

Mill run

Flooring, No. 2,1 i $\times 4$ " $\times 10$ i $-16^{\prime}$.

Flooring, No. $3,1^{\prime \prime} \times 4^{\prime \prime} \times 10^{\prime}-16^{\prime}$

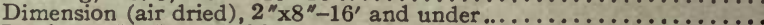

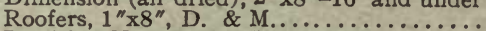

Partition No. $1,13 / 16^{\prime \prime} \times 3 \frac{1}{2} ", 10 ;-16^{\prime}$.

No. 1 edge $4 / 4$, under 12

Box edge $4 / 4$, under 12

Mill run.

Selects $C$ and better, $\ddot{5} / 4$ (M. $\ddot{L}$.

Inch finish, C Selects, $10^{\prime \prime}$ (M. L.)

Shop No. 1, 8/4 (M. L.)

Shop No. 3, 5/4 (M. L.)

Beveled siding, C, $6^{\prime \prime}-16^{\prime}$

Boards No. 2, 1 "x 8 " $-16^{\prime}$

Boards No. $3,12^{\prime \prime}, 10^{\prime}-20^{\prime}$

Boards No. 4 , mixed widths, $100^{\prime}-20^{\prime}$

Fencing No. 2 , S1S, $6^{\prime \prime}-16^{\prime}$

Lath No. 1 (W. P.)

Lath No. 1 (mixed)

Mill run.

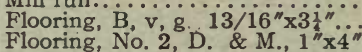

Flooring, No. 2, S2S and C. M., 1 " $\times 6^{n}$

Flooring, B, flat, $13 / 16^{\prime \prime} \times 3 t^{\prime \prime}$

Finish, $\mathrm{B}$ and better, $6^{\prime \prime}$ and wider

Dimension No. 1, S1S1E, 2 "x8" $16^{\prime}$

Com. boards No. 1 , S2S, 1 "x10"

Com. boards, No. 2 , S2S, 1 " $x 8^{\prime \prime}$

Com. boards, No. 2, S2S, 1 " $\times 12$

Timbers S1S1E, $6^{\prime \prime} \times 8^{\prime \prime}-16^{\prime}$

Car siding, $\mathrm{B}$ and better, $1 " \mathrm{x} 4$ " and $6 " \mathrm{n} \times 9^{\prime \prime}-18^{\prime}$

Com. car lining, No. $1,1^{\prime \prime} \times 6^{\prime \prime} \times 10^{\prime}-20^{\prime}$.

Lath No. $1, \frac{3}{8} "$

Mill run.

Finish, $B$ and better, 6 " and wider

Flooring, $\mathrm{B}$ and better, heart rift, $13 / 16$ " $\times 2 \frac{1}{2}$

Flooring, $B$ and better, sap rift, $13 / 16^{\prime \prime} \times 2 \frac{1}{3}$

Flooring, $\mathrm{B}$, heart rift, $13 / 16^{\prime \prime} \times 2 \frac{1}{2}$

Flooring, B, sap rift, $13 / 16^{\prime \prime} \times 2$

Flooring, B, sap flat, $13 / 16^{\prime \prime} \times 3 \frac{1}{1}$ "

Com. boards, No. 1, S2S, $1^{\prime \prime} \times 10^{\prime \prime} \times 10^{\prime}-16^{\prime}$

Com. boards, No. 2, S2S, 1 "x10" $\times 10^{\prime}-16^{\prime}$

Plank and dimensions:

Sizes 2 " $\mathrm{x} 6^{\prime \prime}$ to $8^{\prime \prime} \times 8^{\prime \prime}$, average $24^{\prime}$

Sizes 2 " $\times 9^{\prime \prime}$ to $10^{\prime \prime} \times 10^{\prime \prime}$, average 24

Sizes 2 "x 12 " to 12 "x 12 ", average 24 "

Sizes 2 " $\times 14$ " to $14^{\prime \prime} \times 14 "$ ", average $24^{\prime}$.

Sizes $2 " \times 16^{\prime \prime}$ to $16^{\prime \prime} \times 16^{\prime \prime}$, average $24^{\prime}$

Merch. frames $9^{\prime \prime}$ and under, $\ddot{2} 4^{\prime}$ and under

Merch. frames $10^{\prime \prime}$ and $12^{\prime \prime}, 24^{\prime}$ and under.

Merch, random $10^{\prime \prime}$ and $12^{\prime \prime}, 10^{\prime}$ and up....

Merch. $2^{\prime \prime} \times 7^{\prime \prime}$ and under, $10^{\prime}$ to $24^{\prime}$.

Merch. 2 " $\times 8$ " and up, $10^{\prime}$ to $24^{\prime}$

Lath, 18

Mill run.

Mill run, mili cuilis out

No. 1 and clear.

No. 2

Mili cuil

Mill culls.

Merch. frames 3 " $\times 4$ " to 8 "x $88^{\prime \prime}, 10^{\prime}-16^{\prime}$

Merch, frames 2 "x 12 " to 12 "x 12 ", 10 " 16 '

Boards, merch., $1^{\prime \prime} \times 12 ", 10^{\prime}-20^{\prime}$

Boards, box, 1 " $x 4$ "-12

Mill run. 


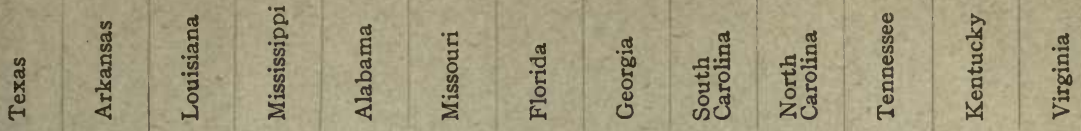
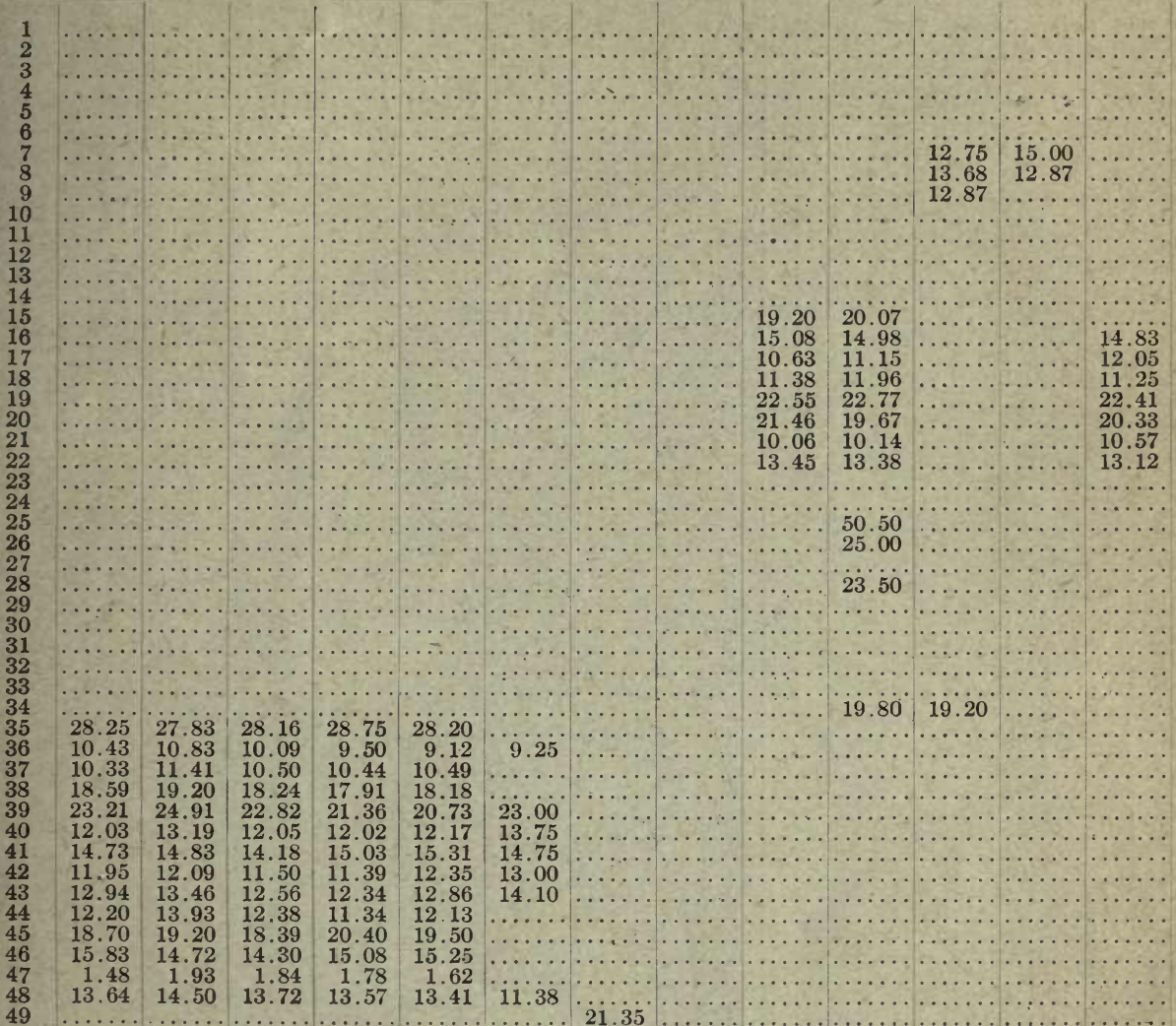

21.35

\begin{tabular}{|c|c|}
\hline$\ldots \ldots$ & 44.00 \\
$\ldots \ldots$ & 28.75 \\
\hdashline$\ldots . .38$ & 28.00 \\
19.50 & 18.00 \\
17.38 & 17.25 \\
12.70 & 11.88
\end{tabular}

\begin{tabular}{ll|l|l}
11.44 & 11.80 & 14.63
\end{tabular}

\begin{tabular}{ll|l|l}
11.50 & 13.30 & 14.91
\end{tabular}

$\begin{array}{llll}15.00 & 16.60 & 16.69\end{array}$

\begin{tabular}{ll|l}
19.25 & 19.50 & 20.82
\end{tabular}

$\begin{array}{lll}12.00 & 22.60 & 24.21\end{array}$

\subsection{9 .20}




\section{Hemlock............. \\ Do. \\ Do. \\ Do.}

Hemioci

Do (Eastern and West Virginia)

Do.

Do.

Do....

Do.......

Do.

Do (North Carolina)

Do.

Do.

Do

Do.

Do.

Pine, white

Do....

Do

Do.

Do

Do.

Do

Do.

Do...

Do..

Pine, yellow

Do (Mississippi Valley Milis)

Do...
Do...
Do..
Do..
Do..
Do...
Do...
Do...
Do...
Do...
Do...
Do.

Pine, yellow.

Do (Atlantic Coast Milis).

Do

Do.

Do.

Do Merch. grade (Sail)

Do...

Do.

Do.

Spruce (Eastern)

Do....

Do...

Do.

Do.

Do (Ädirondack)

Do.

Do.

Do.

Do (ẅest Virginia).

Do.

Do

Do.
2 " piece stuff, S1S1E, 2 " $x 4^{\prime \prime}-16$ "

Boards, No. 1, S1S, $1^{\prime \prime} \times 8^{\prime \prime}-16$

Timbers, rough, 4 " $\mathrm{x} 4^{\prime \prime}$ to $8^{\prime \prime} \times 8^{\prime \prime}-16^{\prime}$

Fencing No. 1 , S1S, 1 "x6".

Mill run

$8 / 4$ merch. 4 " to $12^{\prime \prime}, 10^{\prime}$ to $20^{\prime}$

$4 / 4$ merch. $6^{\prime \prime}$ and $8^{\prime \prime}-16^{\prime}$

$4 / 4$ merch. $10^{\prime \prime}$ and $12^{\prime \prime}-16^{\prime}$.

$4 / 4$ merch. boards, $6^{\prime \prime}$ and............

(14 $12^{\prime}$ and $16^{\prime}$

Mill run, mill culls out.

Mill culls.

Mill run.

Flooring, No. 2 , i ${ }^{\prime \prime} 4^{\prime \prime} \times 10^{\prime}-16^{\prime}$

Flooring, No. 3, 1 " $\times 4$ " $\times 10^{\prime}-16$

Dimension (air dried), 2 " $x 8^{\prime \prime}-16^{\prime}$ and under.

Roofers, $1^{\prime \prime} 8^{\prime \prime}, \mathrm{D}$. \& M.

Partition No. $1,13 / 16^{\prime \prime} \times 3 i \frac{1}{2}, 10 ;-10^{\prime}$.

No. 1 edge $4 / 4$, under 12

Box edge $4 / 4$, under $12^{\prime \prime}$

Mill run.

Selects $\mathrm{C}$ and better, $\overline{5} / 4$ (M. $\dot{\mathrm{L}}$.

Inch finish, C Selects, $10^{\prime \prime}$ (M. L.).

Shop No. $1,8 / 4$ (M. L.)

Beveled siding, C, $6^{n}-16^{\prime}$

Boards No. 2, 1 " $\mathrm{x} 8$ " $-16^{\prime}$.

Boards No. 3, $12^{\prime \prime}, 10^{\prime}-20^{\prime}$

Fencing No. 2, S1S, $6^{\prime \prime}-16^{\prime}$

Lath No. 1 (W. P.)

Lath No. 1 (mixed)

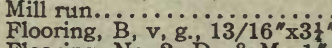

Flooring, No. 2 , D. \& M., 1 " $\times 4$

Flooring, No. 2, S2S and C. M., $1 " \times 66$ "

Flooring, B, flat, 13/16" $\times 3$ t"

Finish, B and better, $6^{\prime \prime}$ and wider.

Dimension No. 1, SiS1E, $2^{\prime \prime} \times 8^{n}-16^{\prime}$

Com. boards No. 1, S2S, 1 "x10"

Com. boards, No. 2, S2S, 1 "x8"
Com. boards, No. 2, S2S, 1 "x12"

Timbers S1S'1E, 6 "'x 8 "-16".

Car siding $B$ and better 1 " $x 4^{\prime \prime}$ and 6 " $x 0^{\prime}-18$ '.

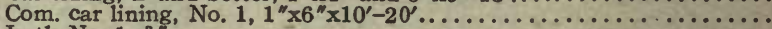

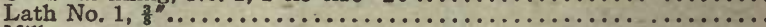

Mill run.

Finish, $B$ and better, 6 " and wider

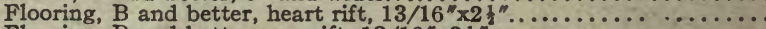

Flooring, $B$ and better, sap rift, $13 / 16^{\prime \prime} \times 2 \frac{1}{2}{ }^{\prime \prime}$

Flooring, $\mathrm{B}$, heart rift, $13 / 16^{\prime \prime} \times 2 \frac{1}{2}$

Flooring, B, sap rift, $13 / 16^{\prime \prime} \times 2$ 1 $^{\prime \prime}$

Flooring, $B$, sap fat, $13 / 16^{\prime \prime} x 3$ ".

Com. boards, No. 1, S2S, $1^{\prime \prime} \times 10^{\prime \prime} \times 10^{\prime}-16^{\prime}$

Com. boards, No. 2, S2S, 1 "x10" $\times 10^{\prime}-16^{\prime}$

Plank and dimensions:

Sizes 2 " $x 6^{\prime \prime}$ to 8 " $x 8^{\prime \prime}$, a verage $24^{\prime}$

Sizes 2 "x 9 " to 10 "x 10 ", average 24

Sizes 2 "x 12 " to $12^{\prime \prime} \times 12$ ", average $24^{\prime \prime}$

Sizes 2 " $\mathrm{x} 14$ " to 14 " $\mathrm{x} 14$ ", a verage 24

average $24^{\prime} . \ldots \ldots \ldots \ldots \ldots \ldots \ldots \ldots \ldots$

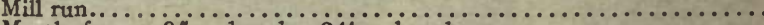

Merch. frames 9 and under, $24^{\prime}$ and under

Merch. frames $10^{\prime \prime}$ and $12^{\prime \prime}, 24^{\prime}$ and under.

(n)

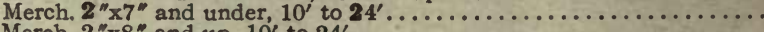

Merch. 2 " $\times 8^{\prime \prime}$ and up, $10^{\prime}$ to $24^{\prime}$.

Lath, $1 \frac{5}{8}$

Mill run.

No. 1 and clear

No. 2

No. 3.

Mill culls

Mill run.

Merch. frames 3 "x $4^{\prime \prime}$ to ${ }^{\prime \prime} \times 8^{\prime \prime}, 10^{\prime}-16^{\prime}$

Merch. frames 2 "x12" to 12 "xi2", $10^{\prime}-16^{\prime}$ "

Boards, merch., 1 "x12"

Boards, box
Mill run... 


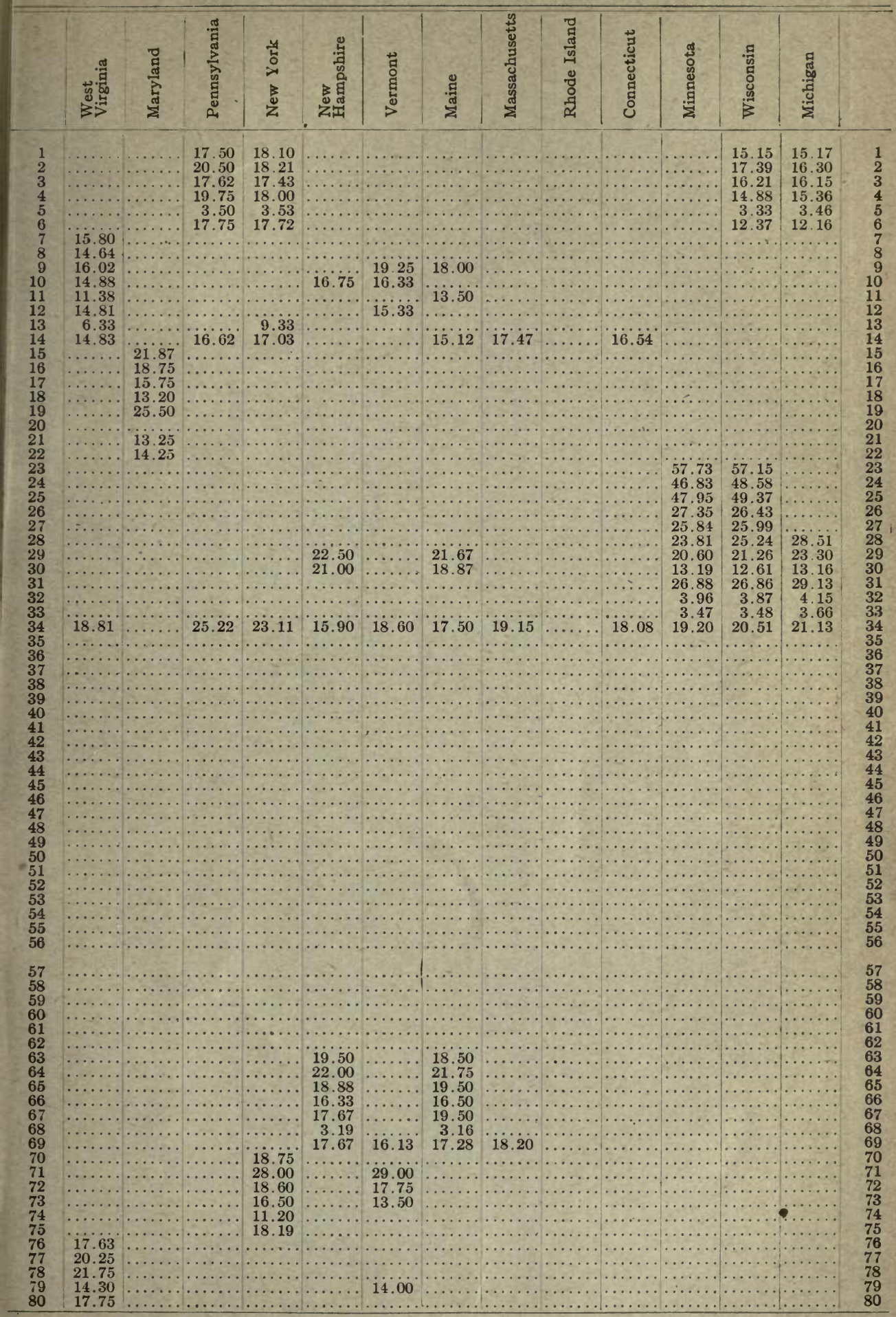


Ash.....
Do....
Do....
Do.....
Basswood
Do....
Do....
Do....
Do....
Beech...
Do....
Do....

Birch, unselected

Do.

Do.

Do.

Chestnut.

Do.

Do.

Cottonwood.

Do.

Do.

Do.

Cypress.

Do.

Do.

Do.

Cypress, shingles

Do....

Elm, rock

Do.

Do.

Elm, soft

Do.

Gum.

Do.

Do.

Do.

Hickory

Do.

Do.

Maple, hard.

Do.

Maple, soft.

Do.

Do.

Oak, plain

Do.

Do..

Do.

Oak, red, quartered

Do.

Do.

Dak, white, quartered.

Do.

Do.

Do.

Poplar.

Do.

Do...

Do...

Tupelo (Bäy Poplär)

Do.
Firsts and seconds $4 / 4$

No. 1 common $4 / 4$

No. 2 common and better, $4 / 4$ or $\log$ run

Mill run.

Firsts and seconds $4 / 4$.

No. 1 common $4 / 4$.

No. 2 common $4 / 4$.

Log run.

Firsts and seconds $4 / 4$

No. 1 common $4 / 4$.

Mill run.

Firsts and seconds $4 / 4$

No. 1 common $4 / 4$.

No. 2 common $4 / 4$

No. 2 common and better, $4 / 4$ or $\log$ rum

Mill run.

Firsts and seconds $4 / 4$.

No. 1 common $4 / 4$

No. 2 common and $\mathrm{S}$.. W. $4 / 4$

No. 3 common $4 / 4$

Mill run

Firsts and seconds $4 / 4,6^{\prime \prime}$ to 12

Boxboards $4 / 4,13^{\prime \prime}$ to 17 "

No. 1 common $4 / 4$

No. 2 common $4 / 4$

Mill run.

Firsts and seconds clear $4 / 4$

Selects $4 / 4$

Shop, No. $1, \ddot{4} / 4$

No. 1 common $4 / 4$, random widths.

No. 2 common $4 / 4$, random widths.

Mill run.

Primes 5

Firsts and seconds $8 / 4$.

No. 1 common and better $8 / 4$

No. 2 common and better $8 / 4$

Mill run...

No. 1 common and better $4 / 4$

No. 2 common and better $4 / 4$

Mill run.

Firsts and seconds $4 / 4$, red.

No. 1 common $4 / 4$, red...

Firsts and seconds $4 / 4$, sap.

No. 1 common $4 / 4$, sap.

No. 2 common $4 / 4$

Mill run.

Firsts and seconds $\ddot{8} / 4$

No. 1 common $8 / 4$

No. 2 common $8 / 4$

Mill run

Firsts and seconds $4 / 4$.

No. 1 common $4 / 4$. .

Mill run.

No. 1 common and better $4 / 4$

No. 3 common $4 / 4$

Log run.

Mill run

Firsts and seconds, $4 / 4$

No. 1 common $4 / 4$.

No. 2 common $4 / 4$

No. 3 common $4 / 4$

Mili run.

Firsts and seconds $4 / 4$

No. 1 common $4 / 4$..

No. 2 common $4 / 4$

Mill run

Firsts and seconds $4 / 4$.

No. 1 common $4 / 4$

No. 2 common $4 / 4$

Mill run.

Firsts and seconds $4 / 4$.

Saps or selects $4 / 4$.

No. 1 common $4 / 4$

No. 2 common $4 / 4$

Mili run.

Firsts and seconds clear, random $4 / 4$

No. 1 common, random $4 / 4$

Mill run. 


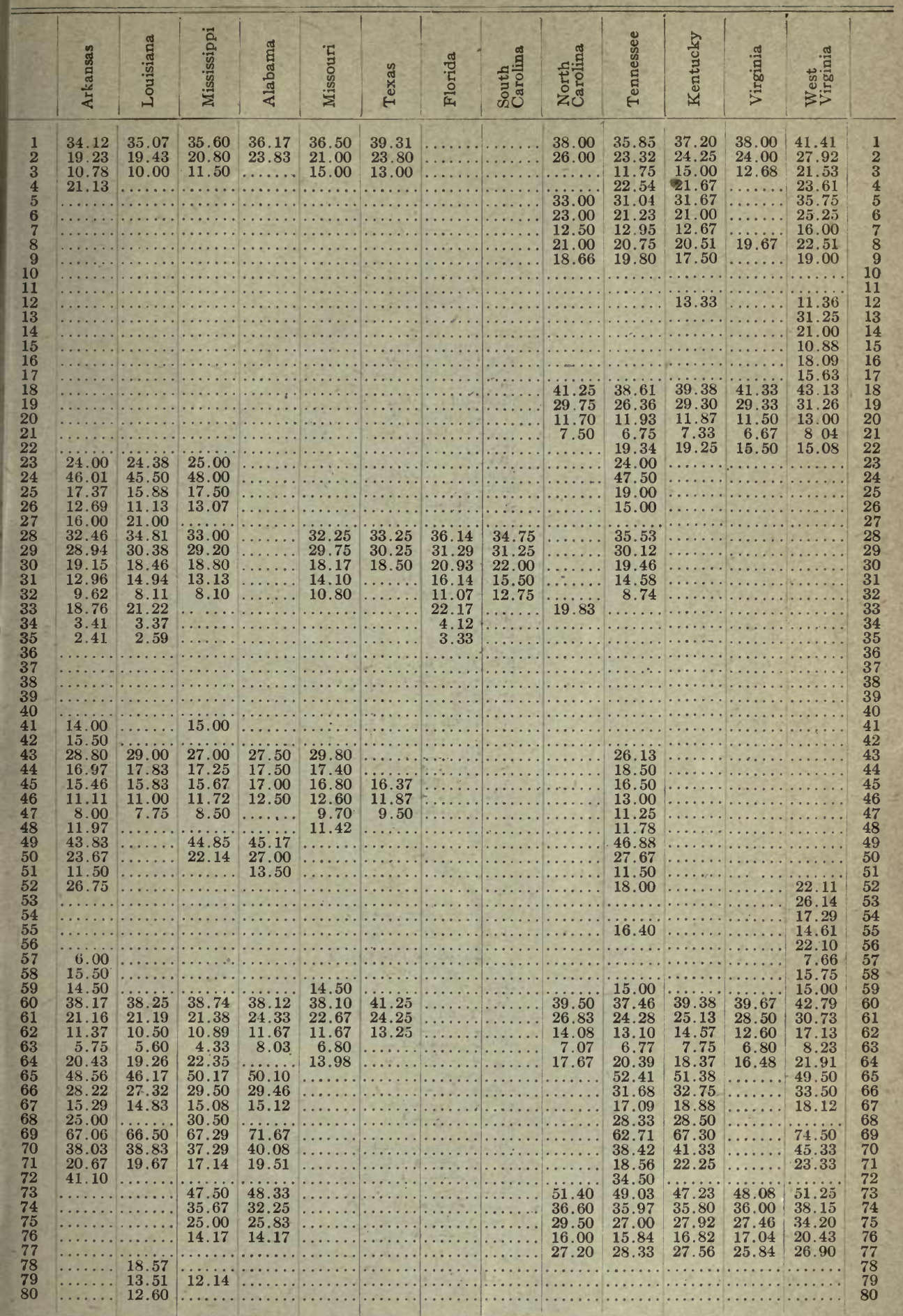


Ash...

Do.

Do.

Basswood...

Do.

Do...

Do.

Beech.

Do...

Birch, unselected

Do..

Do..

Do.

Do

Chestnut.

Do.
Do.
Do.

Do.

Cottonwood.

Do.

Do.

Do

Cypress.

Do...

Do.

Do.

Cypress, shingles

Do.

Elm, rock.

Do.

Do.

EIm, soft

Do..

Gum..

Do.

Do.

Do.

Hickory

Do.

Do.

Maple, hard.

- Do.

Maple, soft

Do.

Do.

Oak, plain

Do.

Do.

Do.

Oak, red, quartered

Do.

Do.

Oak, white, quartered.

Do..

Do.

Poplar.

Do.

Do.

Do.

Tupelo (Bay Pिoplar) Do.
Firsts and seconds $4 / 4$.

No. 1 common $4 / 4$.

No. 2 common and better, $4 / 4$ or $\log$ run

Mili run.

Firsts and seconds $4 / 4$.

No. 1 common $4 / 4$

No. 2 common $4 / 4$.

Log run.

Mill run

Firsts and seconds $4 / 4$

No. 1 common $4 / 4$.

Mill run.

Firsts and seconds $4 / 4$.

No. 1 common $4 / 4$.

No. 2 common $4 / 4$

No. 2 common and better, $4 / 4$ or $\log$ run

Mill run.

Firsts and seconds $4 / 4$

No. 1 common $4 / 4$.

No. 2 common and S. W. $4 / 4$.

No. 3 common $4 / 4$.

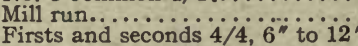

Boxboards $4 / 4,13^{\prime \prime}$ to 17

No. 1 common $4 / 4$

No. 2 common $4 / 4$

Mill run.

Firsts and seconds clear $4 / 4$

Selects $4 / 4$

Shop, No. $1, \ddot{4} / 4$

No. 1 common $4 / 4$, random widths

No. 2 common $4 / 4$, random widths

Mill run.

Bests 5"

Primes 50

Firsts and seconds $8 / 4$

No. 1 common and better $8 / 4$

No. 2 common and better $8 / 4$

Mili run.

No. 1 common and better $4 / 4$

No. 2 common and better $4 / 4$

Mill run.

Firsts and seconds $4 / 4$, red.

No. 1 common $4 / 4$, red..

Firsts and seconds 4/4, sap.

No. 1 common $4 / 4$, sap..

No. 2 common $4 / 4$

Mill run.

Firsts and seconds $8 / 4$

No. 1 common $8 / 4$

No. 2 common $8 / 4$

Mill run..

Firsts and seconds $4 / 4$

No. 1 common $4 / 4$

Mili run...

No. 1 common and better $4 / 4$

No. 3 common $4 / 4$

Log run.

Mill run.

Firsts and seconds, $4 / 4$

No. 1 common $4 / 4$

No. 2 common $4 / 4$...

No. 3 common $4 / 4$

Mill run.

Firsts and seconds $4 / 4$

No. 1 common $4 / 4$

No. 2 common $4 / 4$

Mill run.

Firsts and seconds $4 / 4$

No. 1 common $4 / 4$...

No. 2 common $4 / 4$

Mill run.

Firsts and seconds $4 / 4$

Saps or selects $4 / 4$

No. 1 common $4 / 4$

No. 2 common $4 / 4$

Mili run.

Firsts and seconds clear, random $4 / 4$

No. 1 common, random $4 / 4$

Mill run. 


\begin{tabular}{|c|c|c|c|c|c|c|c|c|c|c|c|c|c|}
\hline & $\frac{}{3}$ & 胥 & 弱 & 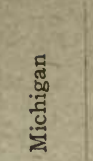 & 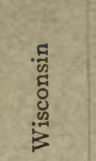 & 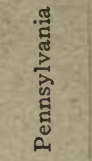 & $\begin{array}{l}\frac{y}{4} \\
0 \\
2 \\
z \\
z \\
z\end{array}$ & 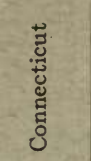 & 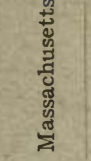 & 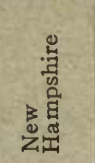 & 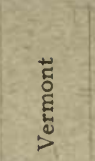 & $\frac{d}{\frac{d}{\pi}}$ & \\
\hline 1 & 42.20 & .55 & & & 35.93 & 36.75 & 39.71 & & & & & & 1 \\
\hline 2 & & 24 & & & 24.06 & 24.00 & 29.33 & & & $\cdots$ & & & 2 \\
\hline 3 & 21.17 & 27 & $\ldots \ldots$ & 25.24 & 22.10 & 19.00 & 21.50 & & & & & & 3 \\
\hline 4 & 25.25 & 24.00 & $\ldots \ldots$ & 20.57 & 18.80 & 23.88 & 22.58 & 22.15 & 21.20 & & 19.42 & & 4 \\
\hline 5 & 31.33 & 30.82 & ....... & 37.11 & 33.65 & $\ldots \ldots$ & 32.20 & $\ldots \ldots$ & $\ldots \ldots$ & $\ldots$ & 27.50 & & 5 \\
\hline 6 & 23.75 & 22.45 & $\ldots \ldots$ & 26.67 & 23.09 & 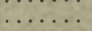 & 25.00 & $\ldots \ldots$ & $\ldots$ & & 20.00 & & 6 \\
\hline 7 & 16.33 & .83 & $\ldots \ldots$ & 17.73 & 13.68 & & 19.80 & $\ldots$ & $\cdots$ & $\ldots \ldots$ & 00 & $\ldots$ & 7 \\
\hline $\begin{array}{l}8 \\
9\end{array}$ & 21.25 & 21.88 & $\ldots \ldots$ & 25.07 & 22.58 & 00 & 23.25 & & & $=6 x^{2}$ & 20.00 & $\cdots$ & 8 \\
\hline 10 & 20.9 & $\begin{array}{l}22.00 \\
21.28\end{array}$ & $\ldots \ldots$ & $\begin{array}{l}18.53 \\
22.00\end{array}$ & $\begin{array}{r}19.80 \\
\ldots \ldots \ldots\end{array}$ & $\begin{array}{l}22.17 \\
18.33\end{array}$ & $\begin{array}{l}22.56 \\
20.50\end{array}$ & 18.00 & 18.25 & $\ldots$ & 19.38 & & $\begin{array}{r}9 \\
10\end{array}$ \\
\hline 11 & 19.00 & 17.08 & $\cdots \cdots$ & 15.93 & & 14.56 & 16.67 & & . & & & & 11 \\
\hline 12 & 16.67 & 15.89 & $\ldots \ldots$ & 12.91 & 13.67 & 13.58 & 14.67 & $\cdots$ & 14.00 & 15.50 & 15.57 & & 12 \\
\hline 13 & $\ldots \ldots$ & $\ldots \ldots$ & $\ldots \ldots$ & 35.25 & 33.84 & $\ldots \ldots$ & 34.75 & $\ldots$ & $\ldots \ldots$ & $\ldots \ldots$ & 25.00 & & 13 \\
\hline $\begin{array}{l}14 \\
15\end{array}$ & $\cdots$ & $\ldots \ldots$ & $\cdots \cdots$ & 20.73 & 20.10 & $\ldots \ldots$ & 24.50 & $\ldots$ & $\ldots \ldots$ & $\ldots \ldots$ & $\ldots \ldots \ldots$ & $\ldots \ldots$ & 14 \\
\hline $\begin{array}{l}15 \\
16\end{array}$ & & $\ldots \ldots$ & $\ldots \ldots$ & 13. 60 & 11.46 & . & 13.00 & $\ldots \ldots$ & $\ldots \ldots$ & $\ldots \ldots$ & $\ldots \ldots$ & t & 15 \\
\hline $\begin{array}{l}10 \\
17\end{array}$ & & $\begin{array}{l}\ldots \ldots \\
\ldots \ldots\end{array}$ & $\begin{array}{l}\ldots \ldots \\
\ldots \ldots \ldots\end{array}$ & $\begin{array}{l}22.77 \\
18.14\end{array}$ & $\begin{array}{l}20.93 \\
17.72\end{array}$ & 18.80 & $\ddot{20} \dot{8} \dot{8}$ & 15.17 & $\ddot{16} \ddot{03}$ & i6 & $\because \because \ddot{9}$ & & 16 \\
\hline 18 & 37.20 & & $\cdots \cdots$ & $\begin{array}{c}18.14 \\
\ldots \ldots \ldots\end{array}$ & $\begin{array}{l}17.72 \\
\ldots \ldots\end{array}$ & 37.56 & 42.00 & & $\begin{array}{c}10.03 \\
\ldots \ldots\end{array}$ & 16.50 & 15.78 & & 17 \\
\hline 19 & 27.50 & & $\ldots \ldots$ & $\ldots \ldots$ & $\ldots \ldots$ & 25.00 & & 20.00 & $\ldots$ & $\begin{array}{l}\ldots \ldots \\
\ldots \ldots\end{array}$ & $\cdots \cdots$ & $\ldots \ldots$ & 8 \\
\hline 20 & 16.00 & $\ldots$ & $\ldots \ldots$ & $\ldots \ldots$ & $\ldots \ldots$ & 16.00 & 17.00 & $\ldots \ldots$ & $\ldots \ldots$ & $\begin{array}{l}\cdots \cdots \\
\cdots \ldots\end{array}$ & $\cdots \cdots$ & $\ldots \ldots$ & 9 \\
\hline 21 & 9.00 & & $\ldots \ldots \ldots$ & $\ldots \ldots$ & $\ldots \ldots$ & 12.50 & & & & $\cdots \cdots$ & $\cdots \cdots$ & $\ldots \ldots$ & 0 \\
\hline 22 & 17.50 & $\ldots \ldots$ & $\ldots \ldots$ & $\ldots \ldots$ & $\ldots \ldots$ & 16.50 & 18.00 & 18.13 & 18.43 & $\ldots \ldots$ & $\cdots$ & & $\begin{array}{l}21 \\
22\end{array}$ \\
\hline 23 & $\ldots \ldots$ & $\ldots \ldots$ & $\ldots \ldots$ & $\ldots \ldots$ & $\ldots \ldots \ldots$ & $\ldots \ldots$ & $\ldots \ldots$ & $\ldots \ldots$ & $\ldots \ldots$ & $\ldots \ldots$ & $\ldots \ldots$ & & 23 \\
\hline 24 & $\ldots \ldots$ & $\ldots \ldots$ & $\ldots \ldots$ & $\ldots \ldots \ldots$ & $\ldots \ldots \ldots$ & $\ldots \ldots$ & $\ldots \ldots$ & $\ldots \ldots$ & $\ldots \ldots$ & $\ldots \ldots$ & $\ldots \ldots$ & & 24 \\
\hline $\begin{array}{l}25 \\
26\end{array}$ & $\ldots \ldots$ & $\ldots \ldots$ & $\cdots \cdots$ & $\ldots \ldots$ & $\ldots \ldots$ & $\ldots \ldots$ & $\ldots \ldots$ & $\ldots \ldots$ & $\ldots \ldots$ & $\ldots \ldots$ & $\ldots \ldots$ & . & 25 \\
\hline $\begin{array}{l}26 \\
27\end{array}$ & $\cdots \cdots \cdots$ & $\cdots \cdots$ & $\cdots \cdots \cdots$ & $\cdots \cdots$ & $\ldots \ldots$ & $\ldots \ldots$ & $\ldots \ldots$ & $\cdots \ldots$ & $\cdots \cdots$ & $\ldots \ldots \ldots$ & $\ldots \ldots$ & & 26 \\
\hline 28 & $\begin{array}{c}\cdots \\
\cdots\end{array}$ & $\begin{array}{c}\cdots \\
\ldots \ldots\end{array}$ & $\cdots \ldots$ & $\cdots \cdots$ & $\cdots \ldots$ & $\begin{array}{l}\cdots \\
\ldots \ldots\end{array}$ & $\begin{array}{l}\ldots \ldots \\
\ldots \ldots\end{array}$ & $\begin{array}{l}\ldots \ldots \\
\ldots \ldots\end{array}$ & $\cdots \ldots \ldots$ & $\cdots \cdots$ & $\ldots \ldots$ & & 27 \\
\hline 29 & $\ldots$ & $\ldots \ldots$ & $\ldots \ldots$ & $\ldots \ldots$ & $\ldots \ldots$ & $\ldots \ldots$ & $\ldots \ldots$ & $\cdots$ & $\cdots \cdots$ & $\ldots \ldots$ & $\ldots \ldots$ & $\ldots$ & 28 \\
\hline 30 & $\ldots$ & $\ldots \ldots$ & $\ldots \ldots$ & $\ldots \ldots$ & $\ldots \ldots \ldots$ & $\ldots \ldots$ & $\ldots \ldots$ & $\ldots \ldots$ & $\ldots$ & $\begin{array}{l}\ldots \ldots \\
\ldots \ldots\end{array}$ & $\cdots \cdots$ & $\cdots$ & 29 \\
\hline 31 & $\ldots$ & $\ldots \ldots$ & $\ldots \ldots$ & $\ldots \ldots$ & $\ldots \ldots$ & $\ldots \ldots$ & $\ldots \ldots$ & $\ldots \ldots$ & $\ldots \ldots$ & $\begin{array}{c}\ldots \ldots \\
\ldots \ldots\end{array}$ & $\cdots \cdots$ & $\ldots \ldots$ & $\begin{array}{l}30 \\
31\end{array}$ \\
\hline 3 & $\ldots \ldots$ & $\ldots \ldots$ & $\ldots \ldots \ldots$ & $\ldots \ldots$ & $\ldots \ldots$ & $\ldots \ldots$ & $\ldots \ldots \ldots$ & $\ldots \ldots$ & $\ldots \ldots$ & $\cdots \cdots$ & $\begin{array}{l}\cdots \\
\cdots \cdots\end{array}$ & $\cdots$ & $\begin{array}{l}31 \\
32\end{array}$ \\
\hline 33 & $\cdots$ & $\ldots \ldots$ & $\cdots \ldots$ & $\ldots \ldots$ & $\ldots \ldots$ & $\ldots \ldots$ & $\ldots \ldots$ & $\ldots \ldots$ & $\ldots \ldots$ & $\ldots \ldots$ & $\ldots \ldots$ & $\ldots \ldots \ldots$ & 33 \\
\hline 34 & $\cdots$ & $\ldots \ldots$ & $\ldots \ldots$ & $\ldots \ldots$ & $\ldots \ldots$ & $\ldots \ldots$ & $\ldots \ldots \ldots$ & $\ldots \ldots$ & $\ldots \ldots$ & $\ldots \ldots$ & $\ldots \ldots$ & $\ldots \ldots$ & 34 \\
\hline & . & $\ldots \ldots$ & $\begin{array}{l}\ldots \ldots \\
\cdots\end{array}$ & $\cdots \cdots \cdots$ & $\ddot{3} \ddot{0} \dot{0}$ & $\cdots \ldots$ & $\ldots \ldots$ & $\ldots \ldots$ & $\ldots \ldots$ & $\ldots \ldots$ & $\ldots \ldots$ & $\ldots \ldots$ & 35 \\
\hline & &. & $\begin{array}{l}\ldots \ldots \\
\cdots \ldots\end{array}$ & $\ldots \ldots \ldots$ & $\begin{array}{l}32.00 \\
23.62\end{array}$ & $\cdots \ldots$ & $\ldots \ldots$ & $\cdots \cdots$ & $\cdots \ldots$ & $\ldots \ldots$ & $\ldots \ldots$ & $\therefore$ & 36 \\
\hline 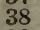 & & & $\ldots \ldots$ & $\ddot{25} . \dot{50}$ & 22.54 & $\begin{array}{l}\cdots \ldots \ldots \\
\ldots \ldots \ldots\end{array}$ & $\begin{array}{l}\ldots \ldots \\
\ldots \ldots\end{array}$ & $\begin{array}{l}\cdots \\
\cdots\end{array}$ & $\cdots \ldots$ & $\ldots \ldots$ & $\ldots \ldots$ & 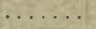 & 37 \\
\hline 39 & 18.50 & & $\ldots \ldots$ & $\ldots \ldots$ & 20.33 & $\ldots \ldots$ & $\begin{array}{l}\ldots \ldots \\
\ldots \ldots\end{array}$ & $\cdots \cdots$ & $\begin{array}{l}\cdots \\
\cdots\end{array}$ & $\begin{array}{r}\ldots \ldots \\
\ldots \ldots\end{array}$ & $\cdots$ & . & 3 \\
\hline 40 & 22.13 & 21.21 & $\ldots \ldots$ & & 23.58 & $\ldots$ & $\ldots \ldots$ & $\ldots \ldots$ & $\ldots$ & $\begin{array}{c}\ldots \ldots \\
\ldots \ldots\end{array}$ & $\ldots \ldots$ & . & 3 \\
\hline 41 & 16.33 & 17.50 & & 23.20 & 19.63 & $\ldots$ & & $\ldots \ldots$ & $\ldots \ldots$ & $\begin{array}{l}\ldots \ldots \\
\ldots \ldots\end{array}$ & $\ldots \ldots$ & & \\
\hline 42 & 17.83 & 18.57 & 14.50 & 17.77 & 18.32 & . & 19.50 & $\ldots \ldots$ & $\ldots \ldots$ & $\ldots \ldots$ & $\cdots \cdots$ & $\because$ & $\begin{array}{l}41 \\
42\end{array}$ \\
\hline $4:$ & $\ldots \ldots$ & $\ldots \ldots$ & $\ldots \ldots$ & $\ldots \ldots$ & $\ldots \ldots$ & $\ldots \ldots$ & $\ldots \ldots$ & $\ldots \ldots$ & $\ldots \ldots$ & $\ldots \ldots$ & $\ldots$ & & 43 \\
\hline 44 & $\ldots \ldots$ & $\cdots \cdots$ & $\ldots \ldots$ & $\ldots \ldots$ & $\ldots \ldots$ & $\ldots \ldots$ & $\ldots \ldots$ & $\ldots \ldots$ & $\ldots \ldots$ & $\ldots \ldots$ & $\ldots \ldots$ & $\cdots$ & 44 \\
\hline $\begin{array}{l}45 \\
46\end{array}$ & $\ldots \ldots$ & $\cdots \cdots$ & $\cdots \ldots$ & $\ldots \ldots$ & $\cdots \ldots$ & $\cdots \ldots$ & $\ldots \ldots \ldots$ & $\ldots \ldots$ & $\ldots \ldots$ & $\ldots \ldots$ & $\ldots \ldots$ & $\ldots$ & 45 \\
\hline 4 & $\cdots$ & $\cdots$ & $\cdots \cdots$ & $\ldots \ldots$ & $\cdots \cdots \cdots$ & $\cdots$ & $\ldots \ldots \ldots$ & $\cdots$ & $\ldots \ldots$ & $\cdots$ & $\ldots \ldots$ & $\ldots$ & 46 \\
\hline 48 & & $\cdots$ & $\begin{array}{l}\ldots \ldots \\
\ldots \ldots\end{array}$ & $\cdots \cdots$ & $\begin{array}{l}\ldots \ldots \\
\ldots \ldots \ldots\end{array}$ & $\cdots$ & $\therefore$ & $\because$ & $\cdots \cdots$ & . & & & 47 \\
\hline 49 & 50.91 & 46.64 & $\ldots \ldots$ & $\ldots \ldots$ & $\ldots \ldots$ & 45.00 & & $\begin{array}{l}\cdots \\
\cdots \ldots\end{array}$ & $\begin{array}{l}\cdots \\
\cdots\end{array}$ & $\cdots$ & & 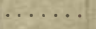 & \\
\hline $50+2-$ & 28.75 & 28.87 & $\ldots \ldots$ & $\ldots \ldots$ & $\ldots \ldots \ldots$ & $\ldots \ldots \ldots$ & $\ldots \ldots$ & $\ldots \ldots$ & $\ldots \ldots$ & $\begin{array}{l}\ldots \ldots \\
\ldots \ldots\end{array}$ & 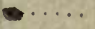 & . & 4 \\
\hline 51 & 21.66 & 18.17 & $\ldots \ldots \ldots$ & $\ldots$ & $\ldots \ldots \ldots$ & & $\ldots \ldots \ldots$ & & $\ldots \ldots$ & $\begin{array}{l}\ldots \ldots \\
\ldots \ldots\end{array}$ & • & & 5 \\
\hline $5^{\circ}$ & 27.40 & 27.94 & $\ldots \ldots$ & $\cdots \cdots$ & & 10 & & 21.00 & & $\cdots$ & .. & & \\
\hline & 27.00 & 25.93 & $\ldots \ldots$ & 28.74 & 24.79 & 22 & 24.56 & . & . & & $\ddot{26.75}$ & & 5 \\
\hline 4 & 20.25 & 19.73 & $\ldots \ldots$ & 20.95 & 17.37 & 15.42 & 17.33 & 00 & $\because$ & & & & 0 \\
\hline 56 & 19.00 & 18.29 & $\ldots \ldots$ & 19.09 & 14.88 & 16.80 & 19.50 & 20.00 & 17.50 & 17.00 & 17.35 & & 5 \\
\hline 56 & 18.83 & $\begin{array}{l}20.42 \\
14.00\end{array}$ & $\ldots \ldots$ & $\because \ddot{7} \dot{8}$ & 17.83 & 23.00 & $\ldots \ldots$ & $\cdots \cdots$ & $\ldots \ldots$ & $\ldots \ldots$ & $\ldots \ldots$ & $\cdots$ & 56 \\
\hline 57 & $\ldots \ldots$ & $\begin{array}{l}14.00 \\
18.75\end{array}$ & $\begin{array}{l}\ldots \ldots \\
\ldots\end{array}$ & 7.58 & 7.69 & & $\ldots \ldots$ & & $\ldots \ldots$ & $\ldots$ & $\ldots \ldots$ & & 57 \\
\hline $\begin{array}{l}58 \\
59\end{array}$ & & $\begin{array}{l}18.75 \\
18.75\end{array}$ & & $\begin{array}{l}17.84 \\
16.25\end{array}$ & 16. & 5 & $\ldots \ldots$ & $\ddot{1} \ddot{70}$ & is & & $\ldots$ & & \\
\hline$a y^{2}$ & & $\begin{array}{l}18.75 \\
40.51\end{array}$ & $\ddot{37.15}$ & $\begin{array}{l}16.25 \\
38.00\end{array}$ & $\begin{array}{r}14.93 \\
40.67\end{array}$ & 16 & $\ldots \ldots$ & 12.79 & 13.04 & 13.14 & $\ldots \ldots$ & & 59 \\
\hline 61 & $\begin{array}{l}41.34 \\
27.67\end{array}$ & 51 & 24.50 & $\begin{array}{l}38.00 \\
24.50\end{array}$ & $\begin{array}{l}40.67 \\
30.39\end{array}$ & $\begin{array}{l}36.56 \\
25.78\end{array}$ & $\cdots \cdots$ & $\ldots \ldots$ & $\ldots \ldots \ldots$ & $\ldots \ldots$ & $\ldots \ldots$ & . & 6 \\
\hline 3 & 19.17 & 17.36 & 15.06 & 24.50 & 19.38 & 19.36 & & & $\cdots$ & $\cdots \cdots$ & $\ldots \ldots$ & & 61 \\
\hline & 11.33 & 12.78 & in & 10.33 & 9.05 & 10 & & & & $\cdots$ & & & 63 \\
\hline & 22. & .00 & 19.67 & $\ldots \ldots$ & 24.50 & 20.43 & 23.66 & 21.50 & 21.14 & . & 20.37 & 19.53 & 64 \\
\hline & 55. & 5 & $\ldots \ldots$ & $\ldots \ldots$ & $\ldots \ldots$ & . & $\ldots \ldots$ & $\ldots \ldots$ & $\ldots \ldots \ldots$ & $\ldots \ldots$ & $\ldots \ldots$ & & 65 \\
\hline & 32.33 & 33. & $\ldots \ldots \ldots$ & $\cdots$ & $\ldots$ & $x^{2}+3$ & & .. & $\ldots \ldots$ & $\ldots \ldots$ & . . & & 66 \\
\hline $6 ?$ & 20.17 & 19.36 & $\ldots \ldots$ & $\ldots \ldots$ & $\cdots$ & . & be & $\cdots$ & $\ldots \ldots \ldots$ & $\ldots \ldots$ & $\ldots$ & & 67 \\
\hline 68 & & $\ddot{7}$ & $\cdots \ldots$ & $\ldots \ldots \ldots$ & $\cdots \cdots$ & $\ldots$ & $\ldots$ & $\ldots \ldots$ & $\ldots$ & . & $\mathrm{F}^{2}$ & & \\
\hline & $\begin{array}{l}73 \\
42\end{array}$ & & $\cdots$ & $\ldots \ldots \ldots$ & $\ldots \ldots$ &. & $\ldots \ldots$ & $\ldots \ldots$ & $\ldots \ldots$ & $\ldots \ldots$ & . & & 6 \\
\hline 71 & $\begin{array}{l}42.92 \\
25.50\end{array}$ & $\begin{array}{l}.61 \\
.79\end{array}$ & $\cdots$ & $\ldots \ldots$ & $\cdots \cdots$ & & $\cdots$ & $\ldots \ldots$ & $\cdots$ & 1 & . & & 70 \\
\hline & & & $\cdots \cdots$ & $\ldots \ldots \ldots$ & $\ldots \ldots$ & . & $\ldots$ & $\cdots$ & $\cdots \cdots \cdots$ & $\cdots \cdots$ & $\ldots \ldots \ldots$ & & 71 \\
\hline & & & $\ldots \ldots$ & $\ldots \ldots$ & $\ldots$ & & .. & & & & & & 73 \\
\hline & & 37.53 & $\ldots \ldots$ & $\ldots \ldots \ldots$ & $\ldots \ldots$ & & $\cdots$ & $\cdots$ & & . & & & 74 \\
\hline & & 28.71 & $\ldots \ldots$ & $\ldots \ldots$ & $\ldots \ldots$ & $\ldots$ & $\ldots \ldots$ & $\ldots \ldots$ & $\ldots \ldots$ & $\ldots \ldots$ & .. & & 75 \\
\hline 76 & 21.52 & 17.58 & 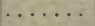 & $\ldots \ldots$ & $\ldots \ldots$ & $\cdots$ & . & & .... & $\cdots$ & $\cdots$ & & 76 \\
\hline 77 & 25.10 & 27.14 & $\ldots$ & $\ldots \ldots$ & $\ldots \ldots$ & $\ldots$ & . & $\ldots$ & $\ldots \ldots \ldots$ & $\ldots \ldots$ & $\ldots$ & & 77 \\
\hline 9 & 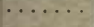 & & $\ldots \ldots$ & $\ldots \ldots$ & $\ldots \ldots$ & 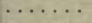 & 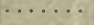 & & $\cdots$ & $\ldots$ & - & & 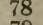 \\
\hline & & & . & $\cdots$ & & - & $\cdots$ & & & 0 & 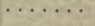 & & \\
\hline & & & & & & & & & & & & & \\
\hline
\end{tabular}



U. S. DEPARTMENT OF AGRICULTURE FOREST SERVICE

RECORD OF

\section{WHOLESALE PRICES OF LUMBER} (PER 1,000 FEET B. M.)

Based on actual sales made F. O. B. Mill FOR

APRIL, MAY AND JUNE, 1911 


\section{PREFATORY NOTE}

The Forest Service has two main purposes in collecting and compiling this record of f. o: b. mill prices: first, to have a continuous statistical record of such prices of the various commercial woods; and, second, to show, in contrast to market prices - which include the important items of freight charges and selling costs - just what the manufacturers of lumber receive for their product at the mill. The prices ) given are wholesale, based on actual sales f. o. b. mill, for delivery outside of local territory. Only a few representative grades and the mill run are included. By mill run is meant the average of all grades of lumber produced. The record is compiled by states, and is made up from reports received from approximately five thousand of the largest manufacturers scattered throughout the country. It is published quarterly.

The Forest Service wishes to acknowledge the courtesy of the manufacturers for their prompt and efficient coöperation. Their assistance has been of great value in making the record complete, accurate, and promptly available for distribution. 
Western softwoods generally fell in price during the second quarter of 1911 . This decline was particu'arly noticeable for Douglas fir in Oregon; for western red cedar, Douglas fir, white fir, western yellow pin , and Sitka spruce in Washington; for western yellow pine in Idaho; and for western larch in Montana. In California, western yellow pine fell, but the distinctive commodity, redwood, advanced, particularly in the Clear $6^{\prime \prime}$ to $12^{\prime \prime}, 10^{\prime}$ to $20^{\prime}$ grade and Common boards No. 2. In Oregon, western yellow pine remained fairly steady while Sitka spruce advanced. Western hemlock averaged about the same at the Washington mills. This was also true of western white pine in Idaho and of western yellow pine in Montana and Colorado. Compared with the corresponding period of 1910 , western softwoods were generally low in price.

Excepting in Louisiana and Mississippi, the eastern softwood prices for the first two quarters of 1911 held substantirlly firm. Louisiana, however, showed an increase over the first quarter in every grade of yellow pine except Flooring, B, v. g. $13 \mid 16^{\prime \prime} \times 3_{4}^{1}{ }^{\prime \prime}$, which fell 24 cents per thousand. This grade was stable in Mississippi while all other grades of yellow pine advanced except B and better car siding, which dropped 90 cents. North Carolina pine advanced in Virginia, especially in the case of No. 1 edge 4|4, under $12^{\prime \prime}$. In Tennessee, Kentucky and New York, the upper grades of hemlock showed improvement. General improvement in hemlock prices was also seen in Wisconsin, Michigan, Pennsylvania, New Hampshire and Vermont. Hemlock mill run prices fell in Maine, Massachusetts and Connecticut. White pine mill run prices fell in Pennsylvania and Massachusetts, and increased in New York, New Hampshire, Vermont, Maine and Connecticut. In the last named State, the advance was slightly better than $\$ 2.00$ per thousand. Michigan and Wisconsin white pine prices averaged about the same, but in Minnesota a decrease was felt in every grade, particularly in Selects C and better, and Shop No. 3. Spruce prices generally held constant in West Virginia, New York and Vermont. In New Hampshire, however, improvement was felt in every grade, particularly Merch. $2^{\prime \prime} \times 8^{\prime \prime}$ and up, $10^{\prime}$ to $24^{\prime}$ boards. The reverse c ondition occurred in Maine and Massachusetts. Merch. $2^{\prime \prime} \times 8^{\prime \prime}$ and up and.Lath, $1 \frac{5}{8}{ }^{\prime \prime}$, especially, declined the mills in Maine.

A comparison of the second quarter of 1911 with the corresponding period of 1910 shows a slight eneral improvement this year in eastern softwood prices. All grades of yellow pine advanced in Texas; I but B and better car siding, in Mississippi; all but B and better car siding and No. 1 Common car lining in Arkansas; and all but Timbers S1S1E, in Alabama. In Louisiana, the upper grades of yellow pine advanced and the lower grades fell. Yellow pine generally declined in North Carolina and Tennessee. Hemlock declined in Tennessee, West Virginia and Maine; advanced in Pennsylvania, New Hampshire and Vermont; and remained generally stable in Wisconsin and Michigan. White pine advanced in Maine and, except for No. 4 Boards, Fencing and Mill Run, in Michigan. In Minnesota and Wisconsin, white pine remained fairly uniform. Spruce showed a decline in West Virginia and Maine, but advanced in Vermont.

Hardwood prices of the second quarter averaged about the same as those of the first quarter of 1911. Ash showed special improvement in Arkansas, Missouri, Tennessee, Virginia, Pennsylvania and New York. In New York, basswood First and Seconds advanced over $\$ 5.00$ per thousand, but remained $\$ 2.50$ below the price received during the same period of 1910. Birch, unselected, advanced in West Virginia, New York and Vermont; declined throughout all grades in Michigan; and was practically stable in Wisconsin. Chestnut showed particular gains in Ohio, Firsts and Seconds advancing nearly $\$ 4.00$, and Mill Run advancing $\$ 2.25$ per thousand. Cottonwood prices were characterized by increases in Arkansas, decreases of all grades in Mississippi, and general stability in the other States. Cypress held substantially firm except in Missouri, where increases of one to two dollars per thousand occurred. Gum remained generally steady but increased for all grades in Mississippi. Hickory brought much better prices at the Pennsylvania mills, and held firm in the other States. Hard maple advanced in West Virginia and Wisconsin. Plain oak showed general improvement; quartered red oak declined in Mississippi, Tennessee and Ohio, but advanced in the other States; while quartered white oak remained about the same. Poplar fell in Mississippi, Alabama, North Carolina, Virginia and West Virginia, but increased in Indiana and Ohio. On the whole, prices for the second quarter of 1911 compared well with the prices of the same period of 1910 . Hard maple showed general improvement, especially at the West Virginia mills. Quartered white oak showed decided improvement in Missouri, but averaged lower in the other States. 


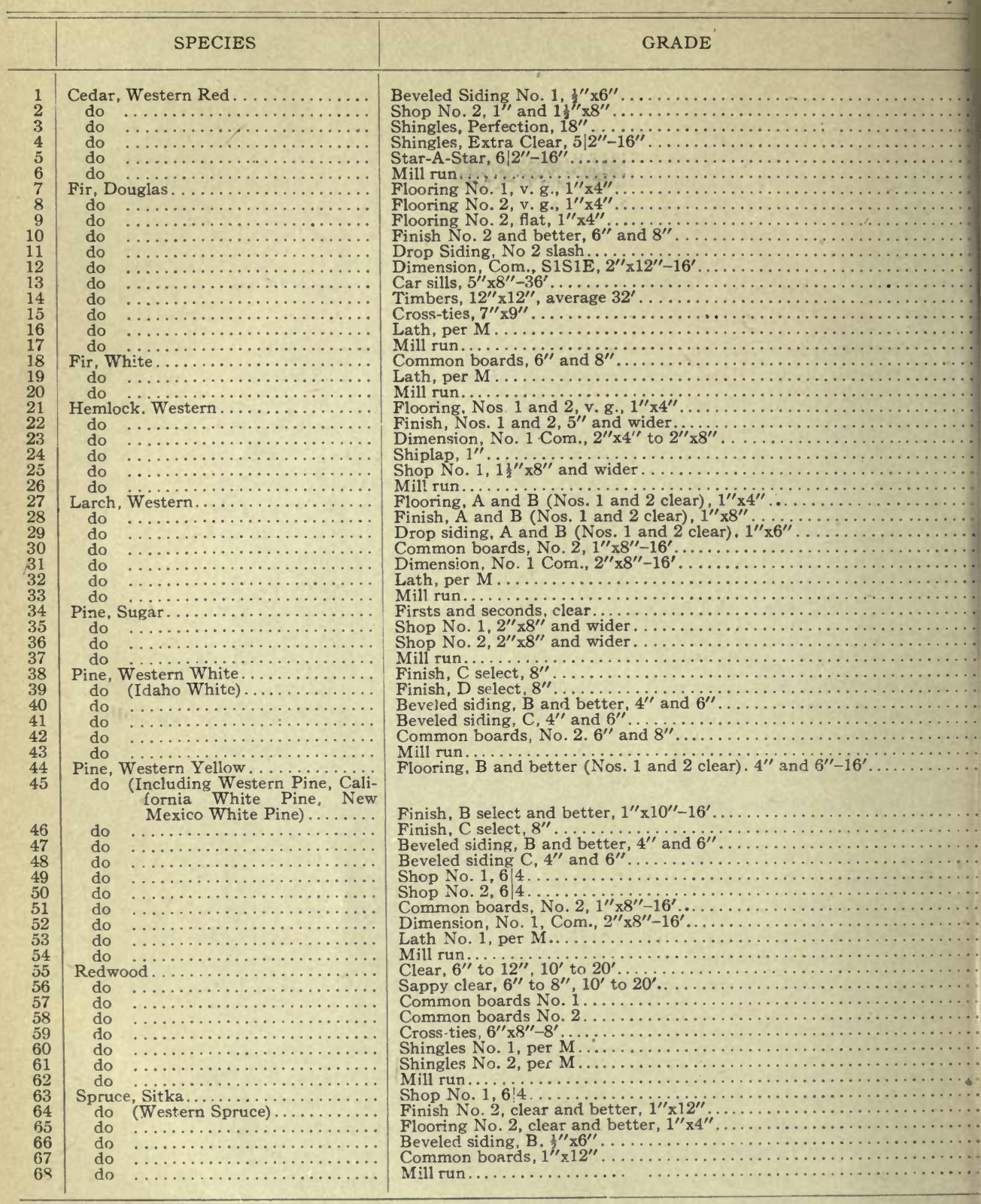




\section{Hemlock}

do (Lake States)
do $\quad \ldots \ldots \ldots \ldots \ldots$
do $\quad \ldots \ldots \ldots \ldots \ldots$
do $\quad \ldots \ldots \ldots \ldots$
do $\ldots \ldots \ldots$

Hemlock

do (Eastern and West Virginia)

do

do

do

do

do

Pine.

do (North Carolina)

do

do

do

do

do

Pine, white

do

do

do

do

do

do

do

do
do

do

Pine, yellow

do (Mississippi Valley Mills)

do

do

do

do

do

do

do

do

do

do

do

Pine, yellow

do (Atlantic Coast Mills)

do

do

do

do

do

do

do

do

do

do

Spruce (Eastern)

do

do

do

do (Ädirondack)

do

do

do

do

do

do

do

do $2^{\prime \prime}$ piece stuff, S1S1E, $2^{\prime \prime} \times 4^{\prime \prime}-16^{\prime}$

Boards, No. 1 , S1S, $1^{\prime \prime} \times 8^{\prime \prime}-16^{\prime}$

Timbers, rough, $4^{\prime \prime} \times 4^{\prime \prime}$ to $8^{\prime \prime} \times 8^{\prime \prime}-16^{\prime}$

Fencing No. 1, S1S, $1^{\prime \prime} \times 6^{\prime \prime}$

Lath No. $1, z^{\prime \prime}-4^{\prime}$

Mill run.

$8 \mid 4$ merch. $4^{\prime \prime}$ to $12^{\prime \prime}, 10^{\prime}$ to $20^{\prime}$

44 merch. $6^{\prime \prime}$ and $8^{\prime \prime}-16^{\prime}$

44 merch. $10^{\prime \prime}$ and $12^{\prime \prime}-16^{\prime}$...

44 merch. boards, $6^{\prime \prime}$ and up, SiS, clipped, $12^{\prime}, 14^{\prime}$ and $16^{\prime}$

44 boards, No. 2, 1" $x 4^{\prime \prime}-12^{\prime \prime}, 6^{\prime}-20^{\prime}$

Mill run, mill culls out.

Mill culls

Mill run.

Flooring, No. 2, $1^{\prime \prime} \times 4^{\prime \prime} \times 10^{\prime}-16^{\prime}$

Flooring, No. 3, $1^{\prime \prime} \times 4^{\prime \prime} \times 10^{\prime}-16^{\prime}$

Dimension (air dried), $2^{\prime \prime} \times 8^{\prime \prime}-16^{\prime}$ and under

Roofers, $1^{\prime \prime} \times 8^{\prime \prime}$. D. \& M

Partition No. $1,13 \mid 16^{\prime \prime} \times 3{ }^{\prime \prime} ", 10^{\prime}-16^{\prime}$

No. 1 edge $4 \mid 4$, under $12^{\prime \prime}$

Box edge $4 \mid 4$, under $12^{\prime \prime}$

Mill run.

Selects $\mathrm{C}$ and better, $5 / 4$ (M. L.)

Inch finish, C Selects, $10^{\prime \prime}$ (M. L.)

Shop No. 1, 814 (M. L.).

Shop No. $3,5 / 4$ (M. L.)

Beveled siding, C, $6^{\prime \prime}-16^{\prime}$

Boards No. 2, $1^{\prime \prime} \times 8^{\prime \prime}-16^{\prime}$

Boards No. $3,12^{\prime \prime}, 10^{\prime}-20^{\prime}$

Boards No. 4 , mixed widths, $10^{\prime}-20^{\prime}$

Fencing No. 2, S1S, $6^{\prime \prime}-16^{\prime}$

Lath No. 1 (W. P.)

Lath No. 1 (mixed)

Mill run

Flooring, B, v, g, $13116^{\prime \prime} \times 3$ s $^{\prime \prime}$

Flooring, No. 2, D. \& M., 1" $x 4^{\prime \prime}$

Flooring, No. 2, S2S and C. M., $1^{\prime \prime} \times 6^{\prime \prime}$

Flooring, B, flat, $13 \mid 16^{\prime \prime} \times 3 \frac{1}{4}$ "

Finish. B and better, $6^{\prime \prime}$ and wider.

Dimension No. 1 , S1S1E, $2^{\prime \prime} \times 8^{\prime \prime}-16^{\prime}$

Com. boards No. $1, \mathrm{~S} 2 \mathrm{~S}, 1^{\prime \prime} \times 10^{\prime \prime}$

Com. boards, No. 2, S2S, $1^{\prime \prime} \times 8^{\prime \prime}$

Com. boards, No. 2 , S2S, $1^{\prime \prime} \times 12^{\prime \prime}$

Timbers S1S1E, $6^{\prime \prime} \times 8^{\prime \prime}-16^{\prime}$

Car siding, $\mathrm{B}$ and better, $1^{\prime \prime} \times 4^{\prime \prime}$ and $6^{\prime \prime} \times 9^{\prime}-18$

Com. car lining, No. $1,1^{\prime \prime} \times 6^{\prime \prime} \times 10^{\prime}-20^{\prime}$.

Lath No. $1, \frac{1}{8}$

Mill run.

Finish, B and better, $6^{\prime \prime}$ and wider

Flooring, B and better, heart rift, $13 \mid 16^{\prime \prime} \times 2{ }^{\prime}{ }^{\prime \prime}$

Flooring, B, heart rift, $13 \mid 16^{\prime \prime} \times 2 \frac{1}{2}$ "

Flooring, B, sap rift, $13 \mid 16^{\prime \prime} \times 2 \frac{1}{2}$

Flooring, B, sap flat, $13 \mid 16^{\prime \prime} \times 3 t^{\prime \prime}$

Com. boards, No. 1, S2S, $1^{\prime \prime} \times 10^{\prime \prime} \times 10^{\prime}-16^{\prime}$

Com. boards, No. 2 , S2S, $1^{\prime \prime} \times 10^{\prime \prime} \times 10^{\prime}-16^{\prime}$

Plank and dimensions:

Sizes $2^{\prime \prime} \times 6^{\prime \prime}$ to $8^{\prime \prime} \times 8^{\prime \prime}$, average $24^{\prime}$

Sizes $2^{\prime \prime} \times 9^{\prime \prime}$ to $10^{\prime \prime} \times 10^{\prime \prime}$, average 2

Sizes $2^{\prime \prime} \times 12^{\prime \prime}$ to $12^{\prime \prime} \times 12^{\prime \prime}$, average $24^{\prime \prime}$

Sizes $2^{\prime \prime} \times 14^{\prime \prime}$ to $14^{\prime \prime} \times 14^{\prime \prime}$, a verage $24^{\prime}$

Sizes $2^{\prime \prime} \times 16^{\prime \prime}$ to $16^{\prime \prime} \times 16^{\prime \prime}$, average $24^{\prime}$.

Mill run...

Merch. frames $9^{\prime \prime}$ and under, $24^{\prime}$ and unde

Merch. frames $10^{\prime \prime}$ and $12^{\prime \prime}, 24^{\prime}$ and under.

Merch. random $10^{\prime \prime}$ and $12^{\prime \prime}, 10^{\prime}$ and up.

Merch. $2^{\prime \prime} \times 7^{\prime \prime}$ and under, $10^{\prime}$ to $24^{\prime}$.

Merch. $2^{\prime \prime} \times 8^{\prime \prime}$ and up, $10^{\prime}$ to $24^{\prime}$

Lath, $16^{\prime \prime}$

Mill run.

Mill run. mill culls out.

No. 1 and clear.

No. 2 .

No. 3

Mill cull

Mill run

Merch. frames $3^{\prime \prime} \times 4^{\prime \prime}$ to $8^{\prime \prime} \times 8^{\prime \prime}, 10^{\prime}-16^{\prime}$

Merch. frames $2^{\prime \prime} x 12^{\prime \prime}$ to $12^{\prime \prime} \times 12^{\prime \prime}, 10^{\prime}-16^{\prime}$

Boards, merch., $1^{\prime \prime} \times 12^{\prime \prime}, 10^{\prime}-20^{\prime}$

Boards, merch.. $1^{\prime \prime} \times 12^{\prime \prime}{ }^{\prime} 1$
Boards, box, $1^{\prime \prime} \times 4^{\prime \prime}-12^{\prime \prime}$

Mill run. 


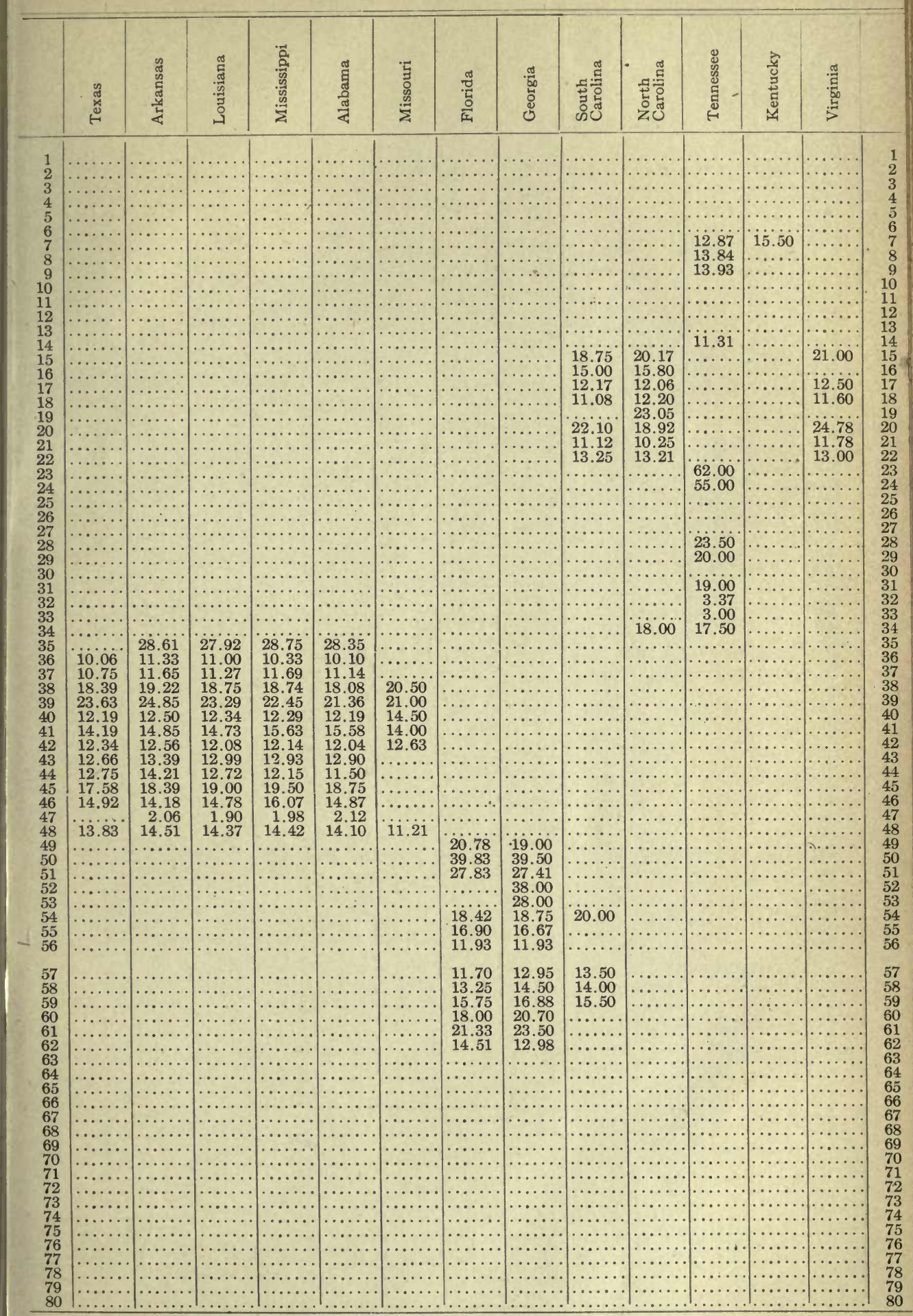


Hemlock

do (Lake States).

do $\ldots \ldots \ldots \ldots . . . .$.

do

do

Hemlock

do (Eastern and West Virginia)

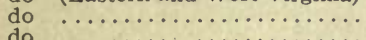

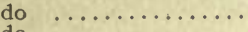

do

do

do

Pine

do (North Carolina)

do

do

do

do

do

do white

do

do

do

do

do

do

do

do

do

do

Pine, yellow

do (Mississippi Valley Mills)

do

do

do

do

do

do

do

do

do

do

do

Pine, yellow

do (Atlantic Coast Mills)

do

do

do

do

do

do

Merch. grade (Sail)

do

do

do

Spruce (Eastern)

do

do

do

do

do

do (Adirondack).

do

do

do

do

do (West Virginia)

do

do

do $2^{\prime \prime}$ piece stuff, S1S1E, $2^{\prime \prime} \times 4^{\prime \prime}-16^{\prime}$

Boards, No. 1 , S1S, $1^{\prime \prime} \times 8^{\prime \prime}-16$

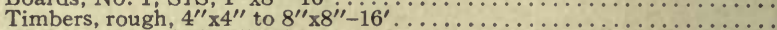

Fencing No. 1 , S1S, $1^{\prime \prime} \times 6^{\prime \prime}$.

Lath No. $1, t^{\prime \prime}-4^{\prime}$

Mill run

$8 / 4$ merch. $4^{\prime \prime}$ to $12^{\prime \prime}, 10^{\prime}$ to $20^{\prime}$

44 merch. $6^{\prime \prime}$ and $8^{\prime \prime}-16^{\prime}$

44 merch. $10^{\prime \prime}$ and $12^{\prime \prime}-16^{\prime}$.

44 merch. boards, $6^{\prime \prime}$ and up, SiS, clipped, $12^{\prime}, 14^{\prime}$ and $16^{\prime}$

44 boards, No. $2,1^{\prime \prime} \times 4^{\prime \prime}-12^{\prime \prime}, 6^{\prime}-20^{\prime}$

Mill run, mill culls out.

Mill culls.

Mill run.

Flooring, No. $2,1^{\prime \prime} \times 4^{\prime \prime} \times 10^{\prime}-16^{\prime}$

Flooring, No. $3,1^{\prime \prime} \times 4^{\prime \prime} \times 10^{\prime}-16^{\prime}$

Dimension (air dried), $2^{\prime \prime} \times 8^{\prime \prime}-16^{\prime}$ and under

Roofers $1^{\prime \prime} \times 8^{\prime \prime}$ D. \& M

Partition No. $1,1316^{\prime \prime} \times 3 \frac{1}{2},{ }^{\prime}, 10^{\prime}-16^{\prime}$

No. 1 edge $4 \mid 4$, under $12^{\prime \prime}$

Box edge $4 / 4$, under $12^{\prime \prime}$

Mill run

Selects $C$ and better, $5 / 4$ (M. L.)

Inch finish, C Selects, $10^{\prime \prime}$ (M. L.).

Shop No. 1, 844 (M. L.)

Shop No. 3, $5 \mid 4$ (M. L.)

Beveled siding, C, $6^{\prime \prime}-16^{\prime}$

Boards No. 2, $1^{\prime \prime} \times 8^{\prime \prime}-16^{\prime}$

Boards No. 3, $12^{\prime \prime}, 10^{\prime}-20^{\prime}$

Boards No. 4 , mixed widths, $10^{\prime}-20^{\prime}$

Fencing No. 2, S1S, 6" $6^{\prime \prime}-16^{\prime}$

Lath No. 1 (W. P.)

Lath No. 1 (mixed)

Mill run.

Flooring, B, v, g, $13116^{\prime \prime} \times 3$ ' $^{\prime \prime}$

Flooring, No. 2 , D. \& M., $1^{\prime \prime} \times 4^{\prime \prime}$

Flooring, No. 2, S2S and C. M., $1^{\prime \prime} \times 6^{\prime \prime}$

Flooring, B, flat. $13 \mid 16^{\prime \prime} \times 33^{\prime \prime}$

Finish, $\mathrm{B}$ and better, $6^{\prime \prime}$ and wider

Dimension No. 1 , S1S1E, $2^{\prime \prime} \times 8^{\prime \prime}-16^{\prime}$

Com. boards, No. 1 , S2S, $1^{\prime \prime} \times 10^{\prime \prime}$.

Com. boards, No. 2 , S2S, $1^{\prime \prime} \times 8^{\prime \prime}$

Com boards, No. 2, S2S, $1^{\prime \prime} \times 12^{\prime \prime}$

Timbers S1S1E, $6^{\prime \prime} \times 8^{\prime \prime}-16^{\prime}$

Car siding, $B$ and better, $1^{\prime \prime} \times 4^{\prime \prime}$ and $66^{\prime \prime} \times 9^{\prime}-18^{\prime}$

Com. car lining, No. $1,1^{\prime \prime} \times 6^{\prime \prime} \times 10^{\prime}-20^{\prime}$.

Lath No. $1, \frac{3}{8} "$

Mill run

Finish, $B$ and better, $6^{i \prime}$ and wider

Flooring, $\mathrm{B}$ and better, heart rift, $1316^{\prime \prime} \times 2 \frac{1}{\prime \prime}$

Flooring, $B$ and better, sap rift, $13 \mid 16^{\prime \prime} \times 22^{\prime \prime}$

Flooring, $\mathrm{B}$, heart rift, $1316^{\prime \prime} \times 22^{\prime \prime}$

Flooring, B, sap rift, $1316^{\prime \prime}{ }^{\prime} \times 22^{\prime \prime}$

Flooring, B, sap flat, $13 \mid 16^{\prime \prime} \times 33^{\prime \prime}$

Com. boards, No. 1, S2S, $1^{\prime \prime} \times 10^{\prime \prime} \times 10^{\prime}-16^{\prime}$

Com. boards, No. 2, S2S, $1^{\prime \prime} \times 10^{\prime \prime} \times 10^{\prime}-16^{\prime}$

Plank and dimensions:

Sizes $2^{\prime \prime} \times 6^{\prime \prime}$ to $8^{\prime \prime} \times 8^{\prime \prime}$, average $24^{\prime}$

Sizes $2^{\prime \prime} \times 9^{\prime \prime}$ to $10^{\prime \prime} \times 10^{\prime \prime}$, a verage 24

Sizes $2^{\prime \prime} \times 12^{\prime \prime}$ to $12^{\prime \prime} \times 12^{\prime \prime}$, average $24^{\prime}$.'.

Sizes $2^{\prime \prime} \times 14^{\prime \prime}$ to $14^{\prime \prime} \times 14^{\prime \prime}$ average $24^{\prime}$. .

Sizes $2^{\prime \prime} \times 16^{\prime \prime}$ to $16^{\prime \prime} \times 16^{\prime \prime}$, average $24^{\prime}$

Mill run

Merch. frames $9^{\prime \prime}$ and under, $24^{\prime}$ and under

Merch. frames $10^{\prime \prime}$ and $12^{\prime \prime} .24^{\prime}$ and under.

Merch. random $10^{\prime \prime}$ and $12^{\prime \prime}, 10^{\prime}$ and up.

Merch. $2^{\prime \prime} \times 7^{\prime \prime}$ and under, $10^{\prime}$ to $24^{\prime}$.

Merch. $2^{\prime \prime} \times 8^{\prime \prime}$ and up, $10^{\prime}$ to $24^{\prime}$

Lath, $15^{\prime \prime}$

Mill run.

Mill run, mill culls out

No. 1 and clear.

No. 2

No. 3 .

Mill culls

Mill run

Merch. frames $3^{\prime \prime} \times 4^{\prime \prime}$ to $8^{\prime \prime} \times 8^{\prime \prime}, 10^{\prime}-16^{\prime}$

Merch. frames $2^{\prime \prime} \times 12^{\prime \prime}$ to $12^{\prime \prime} \times 12^{\prime \prime}, 10^{\prime}-16^{\prime}$

Boards, merch ., $1^{\prime \prime} \times 12^{\prime \prime}, 10^{\prime}-20^{\prime}$

Boards, box, 1 " $\times 4^{\prime \prime}-12^{\prime \prime}$

Mill run... 


\begin{tabular}{|c|c|c|c|c|c|c|c|c|c|c|c|c|c|c|}
\hline & 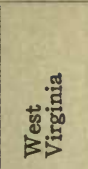 & 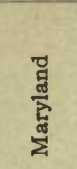 & 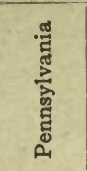 & 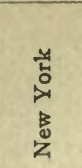 & 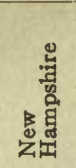 & 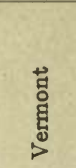 & 营 & 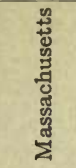 & 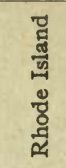 & 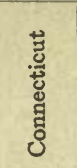 & 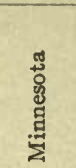 & 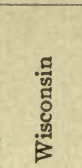 & 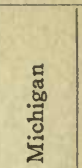 & \\
\hline 1 & & & 18.00 & 18.38 & & & & & & & & 5.99 & 5.30 & \\
\hline$\overline{2}$ & & & ........ & 18.61 & & 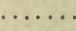 & & $\cdots$ & $\cdots$ & & & 17.21 & 16.59 & \\
\hline $\begin{array}{l}3 \\
4\end{array}$ & & & 16.50 & $\begin{array}{l}17.50 \\
17.75\end{array}$ & & & & & $\cdots$ & & & $\begin{array}{l}16.54 \\
15.84\end{array}$ & $\begin{array}{l}15.86 \\
16.05\end{array}$ & 3 \\
\hline 5 & & & 3.68 & 3.77 & & & & & & & & 3.31 & 3.44 & $\begin{array}{l}4 \\
5 \\
\end{array}$ \\
\hline $\begin{array}{l}6 \\
7\end{array}$ & 15.25 & & $\begin{array}{l}18.00 \\
18.75\end{array}$ & 16.70 & & & 18.00 & & & & & 12.75 & & $\begin{array}{l}6 \\
7\end{array}$ \\
\hline 8 & 14.92 & & 19.75 & ……... & & . & & & & & & & & 0 \\
\hline 10 & $\begin{array}{l}16.25 \\
15.38\end{array}$ & ......... & $\begin{array}{l}21.25 \\
19.50\end{array}$ & .... & 17.60 & 16.80 & 16.60 & $\cdots$ & $\cdots$ & & & & & $\begin{array}{r}9 \\
10\end{array}$ \\
\hline 11 & $1^{11} .36$ & ......... & 14.25 & & 1675 & 1667 & 14.40 & ....... & & & & & & 11 \\
\hline 13 & \begin{tabular}{|r|}
14.79 \\
6.83
\end{tabular} & & 10.75 & …… & 16.75 & 16.67 & $\begin{array}{r}14.83 \\
9.75\end{array}$ & ...... & & & & & & $\begin{array}{l}12 \\
13\end{array}$ \\
\hline 14 & 14.08 & & 16.52 & 17.00 & .... & 16.22 & 14.70 & 15.00 & & 16.00 & & & & 14 \\
\hline $\begin{array}{l}10 \\
16\end{array}$ & & & & $\ldots \ldots$ & & $\ldots$ & & & & & & & & $\begin{array}{l}15 \\
16\end{array}$ \\
\hline 17 & & 15.50 & & ..... & & ...... & & ...... & ... & & & & .... & 17 \\
\hline $\begin{array}{l}18 \\
19\end{array}$ & & & & ...... & & . & & . & & & & & & 18 \\
\hline 20 & & & & …........ & & ...... & & & & & & & & $\begin{array}{l}19 \\
20\end{array}$ \\
\hline 22 & & 12.12 & & ... & & ... & & & & & & & & $\begin{array}{l}21 \\
22\end{array}$ \\
\hline $\begin{array}{l}23 \\
24\end{array}$ & & & & & & & & & & & 54.64 & 56.77 & 57.00 & 23 \\
\hline 25 & & & & & & . & & & $\ldots$ & & $\begin{array}{l}46.10 \\
46.64\end{array}$ & $\begin{array}{l}49.00 \\
51.45\end{array}$ & 51.80 & $\begin{array}{l}24 \\
25\end{array}$ \\
\hline $\begin{array}{l}26 \\
27\end{array}$ & & & $\ldots$ & $\ldots$ & $\cdots$ & $\cdots$ & & $\ldots$ & & & 24.63 & 26.58 & $\begin{array}{l}29.15 \\
26.08\end{array}$ & 26 \\
\hline 28 & & & & & & & 21.17 & & & & 23.45 & 23.92 & 28.33 & \\
\hline $\begin{array}{l}29 \\
30\end{array}$ & & & 20.75 & & $\begin{array}{r}23.67 \\
\ldots \ldots .\end{array}$ & $\therefore \ldots$ & $\begin{array}{l}23.00 \\
19.82\end{array}$ & & & & $\begin{array}{l}20.00 \\
12.50\end{array}$ & $\begin{array}{l}20.98 \\
12.45\end{array}$ & $\begin{array}{l}24.71 \\
13.00\end{array}$ & $\begin{array}{l}29 \\
30\end{array}$ \\
\hline 31 & & & 375 & & & 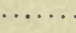 & & & & & 25.65 & 26.63 & 29.67 & 31 \\
\hline 33 & & & 3.00 & & & & 300 & & & & $\begin{array}{l}3.79 \\
3.32\end{array}$ & $\begin{array}{l}3.72 \\
3.10\end{array}$ & $\begin{array}{l}3.76 \\
3.50\end{array}$ & 32 \\
\hline 34 & & & 23.25 & 23.73 & 17.50 & 19.38 & 19.23 & 17.25 & & 20.11 & 18.80 & 21.25 & 21.31 & 34 \\
\hline 36 & & & & $\ldots$ & 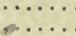 & …...... & & ...... & & & & & & 36 \\
\hline 37 & & & & & & & & & & & & & & 37 \\
\hline 39 & & & & & & $\cdots$ & & & & & & & & $\begin{array}{l}38 \\
39\end{array}$ \\
\hline 40 & & & & $\ldots$ & & ... & ... & .. & ... & & & $\ldots$ & & 40 \\
\hline 42 & & & & & & $\ldots$ & $\cdots$ & $\ldots$ & ... & & $\ldots$ & & & $\begin{array}{l}41 \\
42\end{array}$ \\
\hline 43 & & & & & & $\ldots \ldots$ & $\cdots$ & ... & & & & & & 43 \\
\hline $1-$ & & & & & & & & $\cdots$ & & & & & & $\begin{array}{l}44 \\
45\end{array}$ \\
\hline 46 & & & & & & & & & & & & & & 46 \\
\hline 18 & & & & & & & & & & & & & & $\begin{array}{l}47 \\
48\end{array}$ \\
\hline 49 & & & $\ldots$ & & & & & ..... & & & & & & 49 \\
\hline 1 & & & & & & & & & & & & & & 51 \\
\hline 52 & & & & & & & & & & & & & & $\begin{array}{l}52 \\
53\end{array}$ \\
\hline & & & . & $\ldots$ & & & & & & & & & & 54 \\
\hline 56 & & & $\because$ & $\cdots$ & & $\ldots$ & & & & & & & & $\begin{array}{l}55 \\
56\end{array}$ \\
\hline 57 & & & & & & & & & & & & & & 57 \\
\hline & & & & & & & & & & & & & & 58 \\
\hline & & & & & & & & & & & & & & 59 \\
\hline & & & & & & & & $\ldots$ & & & & $\ldots$ & & 61 \\
\hline 63 & & & & & 21.00 & 22.17 & 18.22 & & & & & … & & $\begin{array}{l}62 \\
63\end{array}$ \\
\hline 64 & & & & & 23.00 & 25.00 & 20.96 & & & & & & & 64 \\
\hline 65 & & & & & $\begin{array}{l}20.67 \\
18.33\end{array}$ & 22.50 & $\begin{array}{l}17.67 \\
15.42\end{array}$ & & & & & & & 65 \\
\hline 67 & & & & & 20.67 & 22.00 & 16.32 & & & & & & & 67 \\
\hline $\begin{array}{l}68 \\
69\end{array}$ & & & & & $\begin{array}{r}3.37 \\
18.50\end{array}$ & $187 i$ & $\begin{array}{r}2.91 \\
16.42\end{array}$ & 1700 & & & & & & $\begin{array}{l}68 \\
69\end{array}$ \\
\hline 70 & & & & 18.00 & & & & & & & & & & 70 \\
\hline 72 & & & & $\begin{array}{l}31.67 \\
19.67\end{array}$ & & $\begin{array}{l}26 \\
18\end{array}$ & $\ldots$ & ….... & $\ldots$ & & & & & 72 \\
\hline 73 & & & $\ldots$ & 16.00 & & 12.50 & & & & & & & & 73 \\
\hline 75 & & & & 17.92 & & & & & & & & $\ldots$ & & 75 \\
\hline 76 & $\begin{array}{l}17.70 \\
19.50\end{array}$ & & & & & & & $\cdots$ & & & & & & $\begin{array}{l}76 \\
77\end{array}$ \\
\hline 70 & 2 & & & & & & & & & & & & & 78 \\
\hline 80 & \begin{tabular}{|l}
14.37 \\
17.32
\end{tabular} & & & & & Ua & . & . & ... & & $\ldots$ & $\ldots$ & 3. & $\begin{array}{l}79 \\
80\end{array}$ \\
\hline
\end{tabular}




\begin{tabular}{|c|c|c|}
\hline & SPECIES & GRADE \\
\hline 1 & Isn. & First \\
\hline 2 & & 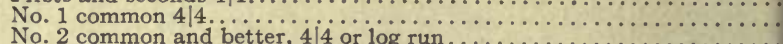 \\
\hline $\begin{array}{l}3 \\
4\end{array}$ & do $\begin{array}{l}\text { do } \\
\text { do }\end{array} \ldots \ldots \ldots \ldots \ldots \ldots \ldots \ldots \ldots \ldots \ldots$ & 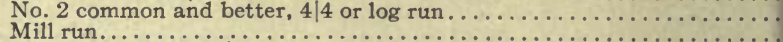 \\
\hline 5 & 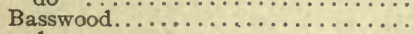 & 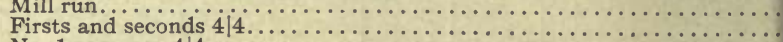 \\
\hline 6 & do $\quad \ldots \ldots \ldots \ldots \ldots \ldots \ldots \ldots$ & 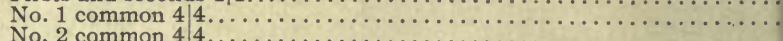 \\
\hline $\begin{array}{l}7 \\
8\end{array}$ & 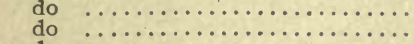 & 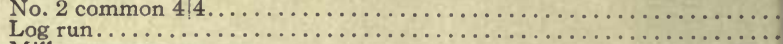 \\
\hline 9 & do $\quad \ldots \ldots \ldots \ldots \ldots \ldots \ldots \ldots \ldots$ & 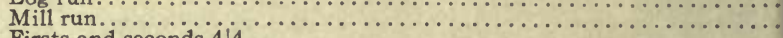 \\
\hline 10 & Beech.$\ldots \ldots \ldots \ldots \ldots \ldots \ldots \ldots \ldots$ & 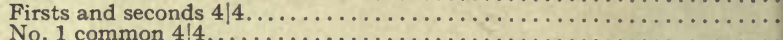 \\
\hline 12 & $\cdots \cdots \cdots \cdots \cdots \cdots \cdots \cdots$ & 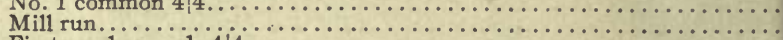 \\
\hline 13 & Birch, unselected............... & 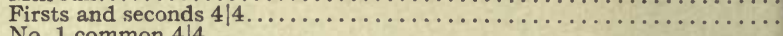 \\
\hline $\begin{array}{l}14 \\
15\end{array}$ & 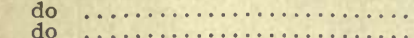 & 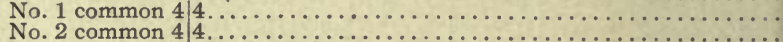 \\
\hline 16 & 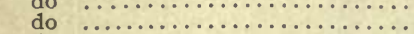 & 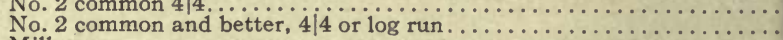 \\
\hline 17 & $\ldots \ldots \ldots \ldots$ & 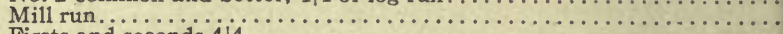 \\
\hline 18 & Chestnut.................... & 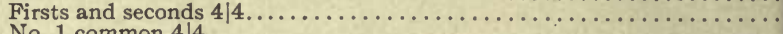 \\
\hline 19 & 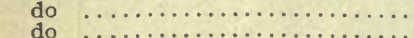 & 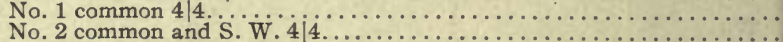 \\
\hline 21 & 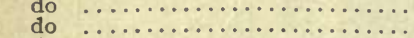 & 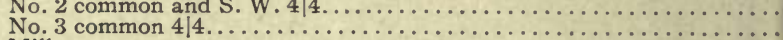 \\
\hline 22 & $\ldots \ldots \ldots \ldots \ldots$ & (i $\cdots \ldots \ldots \ldots \ldots \ldots \ldots \ldots \ldots \ldots \ldots \ldots$ \\
\hline 23 & Cottonwood................... & Firsts and seconds $4 \mid 4,6^{\prime \prime}$ to $12^{\prime \prime} \ldots \ldots \ldots \ldots \ldots \ldots \ldots \ldots \ldots$ \\
\hline 24 & do $\quad \ldots \ldots \ldots \ldots \ldots \ldots \ldots \ldots \ldots \ldots$ & 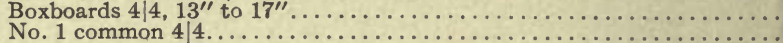 \\
\hline $\begin{array}{l}25 \\
26\end{array}$ & 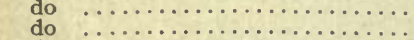 & 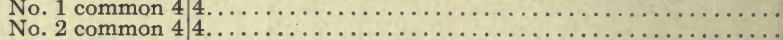 \\
\hline 27 & do & 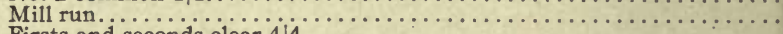 \\
\hline 28 & Cypress...................... & 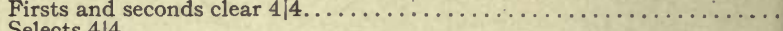 \\
\hline $\begin{array}{l}29 \\
30\end{array}$ & $\cdots \cdots \cdots \cdots \cdots \cdots \cdots \cdots \cdots \cdots \cdots$ & 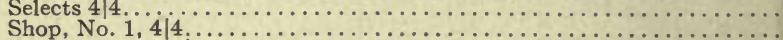 \\
\hline 31 & 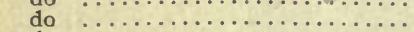 & 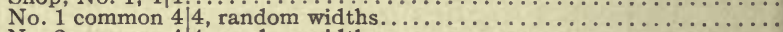 \\
\hline 32 & . $\ldots \ldots \ldots \ldots \ldots \ldots \ldots \ldots \ldots$ & 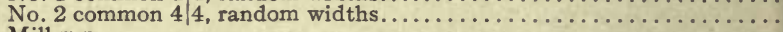 \\
\hline 33 & do $\ldots \ldots \ldots \ldots \ldots \ldots \ldots \ldots$ & \\
\hline $\begin{array}{l}34 \\
35\end{array}$ & Cypress, shingles................ & 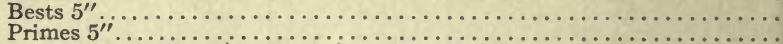 \\
\hline 36 & 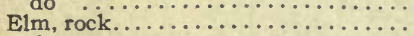 & 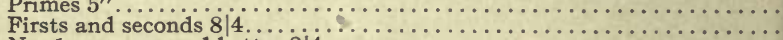 \\
\hline 37 & do $\quad \ldots \ldots \ldots \ldots \ldots \ldots \ldots \ldots$ & 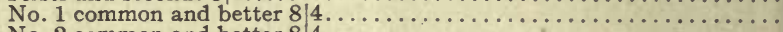 \\
\hline $\begin{array}{l}38 \\
39\end{array}$ & do $\ldots \ldots \ldots \ldots \ldots \ldots \ldots \ldots \ldots \ldots \ldots$ & 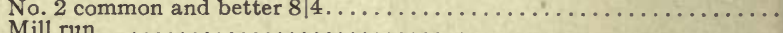 \\
\hline 40 & 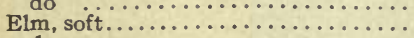 & Mo. 1 common and better $4|3| \ldots$ \\
\hline 41 & do $\quad \ldots \ldots \ldots \ldots \ldots \ldots \ldots \ldots \ldots \ldots$ & 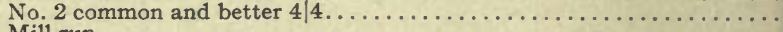 \\
\hline 42 & do $\quad \ldots \ldots \ldots \ldots \ldots \ldots \ldots \ldots \ldots$ & 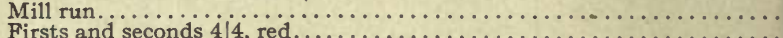 \\
\hline $\begin{array}{l}43 \\
44\end{array}$ & 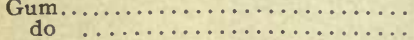 & 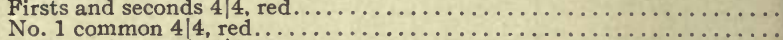 \\
\hline 45 & do $\quad . . \ldots \ldots \ldots \ldots \ldots \ldots \ldots \ldots \ldots$ & 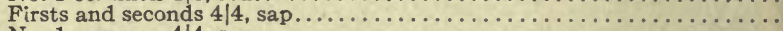 \\
\hline 46 & do $\quad \ldots \ldots \ldots \ldots \ldots \ldots \ldots \ldots \ldots \ldots$ & 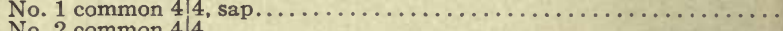 \\
\hline $\begin{array}{l}47 \\
48\end{array}$ & do $\quad \cdots \cdots \cdots \cdots \cdots \cdots \cdots \cdots \cdots \cdots \cdots \cdots$ & 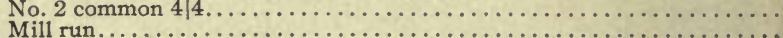 \\
\hline 49 & 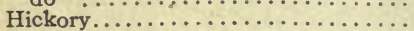 & 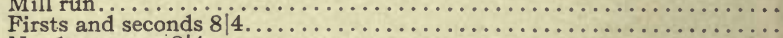 \\
\hline 50 & $\ldots \ldots \ldots \ldots \ldots$ & 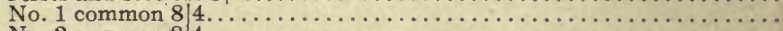 \\
\hline 51 & $\ldots \ldots \ldots \ldots \ldots \ldots \ldots \ldots \ldots$ & 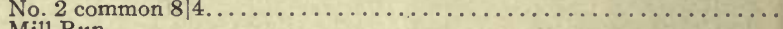 \\
\hline $\begin{array}{l}52 \\
53\end{array}$ & 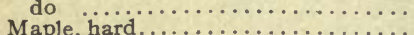 & 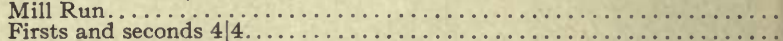 \\
\hline 54 & do $\ldots \ldots \ldots \ldots \ldots \ldots \ldots \ldots \ldots \ldots \ldots \ldots \ldots \ldots$ & 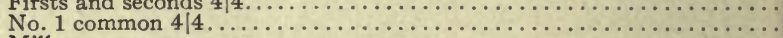 \\
\hline 55 & do & 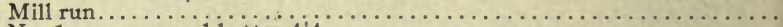 \\
\hline 56 & Maple, soft.................... & No. 1 common and better $4 \mid 4 \ldots \ldots \ldots \ldots \ldots \ldots \ldots \ldots \ldots \ldots \ldots \ldots \ldots \ldots \ldots \ldots \ldots$ \\
\hline 57 & . $\ldots \ldots \ldots \ldots \ldots \ldots \ldots \ldots \ldots$ & 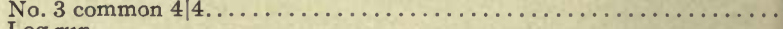 \\
\hline 58 & 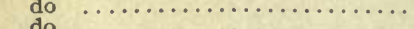 & 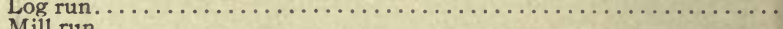 \\
\hline 60 & 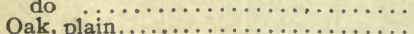 & $\cdots \cdots \cdots \cdots \cdots \cdots \cdots \cdots \cdots \cdots \cdots \cdots \cdots \cdots \cdots \cdots \cdots \cdots$ \\
\hline 61 & $\begin{array}{l}\text { Oak, plain } \ldots \ldots \ldots \ldots \ldots \ldots \ldots \ldots \ldots \ldots \ldots \ldots \ldots \\
\text { do }\end{array}$ & $\begin{array}{l}\text { Firsts and seconds } 4 \mid 4 . \ldots \ldots \ldots \\
\text { No. } 1 \text { common } 4 \mid 4.1\end{array}$ \\
\hline 62 & do $\quad \ldots \ldots \ldots \ldots \ldots \ldots \ldots \ldots \ldots$ & \\
\hline & 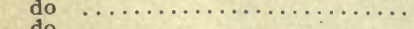 & 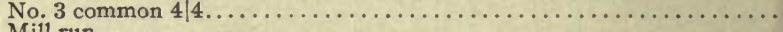 \\
\hline & & $\cdots \cdots \cdots \cdots \cdots \cdots \cdots \cdots \cdots \cdots \cdots \cdots \cdots \cdots \cdots$ \\
\hline 65 & Oak, red, quartered.............. & 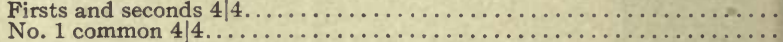 \\
\hline 67 & $\ldots \ldots \ldots \ldots \ldots \ldots \ldots \ldots \ldots$ & 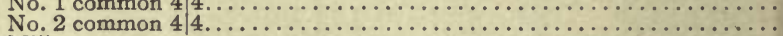 \\
\hline 68 & ........... & 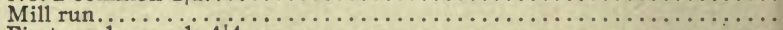 \\
\hline 69 & Oak, white, quartered............ & 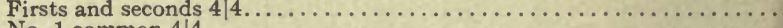 \\
\hline 70 & . $\ldots \ldots \ldots \ldots \ldots \ldots \ldots \ldots$ & 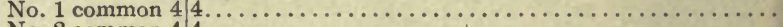 \\
\hline 71 & ................. & 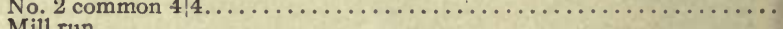 \\
\hline 73 & Poplar.... & 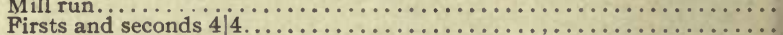 \\
\hline 74 & do & 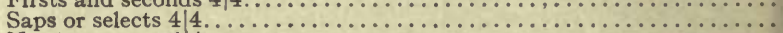 \\
\hline 75 & . $\ldots \ldots \ldots \ldots \ldots \ldots \ldots \ldots$ & $\ldots \ldots \ldots \ldots \ldots \ldots \ldots \ldots \ldots \ldots \ldots \ldots \ldots$, \\
\hline 77 & $\cdots \cdots$ & No. 2 common $4 \mid 4 \ldots \ldots \ldots \ldots$ \\
\hline 78 & Tupelo (Bä Poplar) & Mill run. \\
\hline$\because 0$ & $\begin{array}{l}\text { Tupelo (Bay Poplar). } \\
\text { do } . . . . . . . . . .\end{array}$ & $\begin{array}{l}\text { Firsts and seconds clear, random } 4 \mid 4 \ldots \ldots \ldots \\
\text { No. } 1 \text { common, random } 4 \mid 4 \ldots \ldots \ldots \ldots\end{array}$ \\
\hline & & ill run... \\
\hline
\end{tabular}




\begin{tabular}{|c|c|c|c|c|c|c|c|c|c|c|c|c|c|}
\hline & 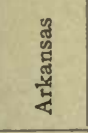 & 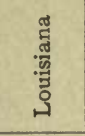 & 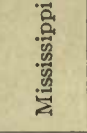 & 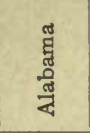 & 总 & & 营 & 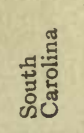 & 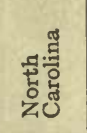 & 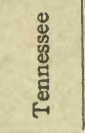 & 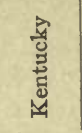 & 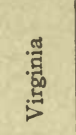 & 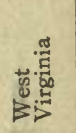 \\
\hline & & 35.60 & .29 & 5.00 & 40.83 & 39.50 & & & 9.00 & 8.31 & 7.21 & 38.50 & 40.11 \\
\hline $\begin{array}{l}2 \\
3\end{array}$ & & $\begin{array}{l}19.30 \\
10.20\end{array}$ & 19.33 & $\begin{array}{l}1.50 \\
3.25\end{array}$ & 23.00 & $\begin{array}{l}21.00 \\
12.00\end{array}$ & & & $\begin{array}{l}26.50 \\
13.55\end{array}$ & $\begin{array}{l}4.22 \\
4.40\end{array}$ & 4.86 & & 28.93 \\
\hline 4 & 20.5 & & 24.00 & 0 & 20.00 & & & & 15.50 & 21.38 & 22.00 & 0 & $\begin{array}{l}21 . \\
21 .\end{array}$ \\
\hline 5 & & & & & & & & & $\begin{array}{l}3.00 \\
1.75\end{array}$ & $\begin{array}{l}30.54 \\
21.42\end{array}$ & $\begin{array}{l}33.00 \\
21.75\end{array}$ & 2000 & 35. \\
\hline 8 & & & & & & & & & 13.25 & 13.27 & 12.33 & $\begin{array}{l}20.00 \\
11.33\end{array}$ & $\begin{array}{l}25.43 \\
16.40\end{array}$ \\
\hline 8 & & & & & & & & & $\begin{array}{l}21.50 \\
19.33\end{array}$ & $\begin{array}{l}21.75 \\
19.48\end{array}$ & $\begin{array}{l}20.50 \\
20.00\end{array}$ & 19.87 & 22.71 \\
\hline 10 & & & & & & & & & & & & & $\begin{array}{l}18.17 \\
21.50\end{array}$ \\
\hline & & & & & & & & & & & 12.90 & & 16.50 \\
\hline 14 & & & & & & & & & & & & & $\begin{array}{l}11.60 \\
31.42\end{array}$ \\
\hline 15 & & & & & & & & & & & & & $\begin{array}{l}21.08 \\
11.00\end{array}$ \\
\hline & & & & & & & & & & & $\cdots$ & ....... & $\begin{array}{l}11.00 \\
18.58\end{array}$ \\
\hline 18 & & & & & & & & & 40.88 & 37.43 & 39.93 & 39.60 & $\begin{array}{l}16.64 \\
42.53\end{array}$ \\
\hline 20 & & & & & & & & & $\begin{array}{l}28.63 \\
11.83\end{array}$ & $\begin{array}{l}25.34 \\
11.86\end{array}$ & $\begin{array}{l}28.03 \\
12.68\end{array}$ & $\begin{array}{r}27.50 \\
11.00\end{array}$ & $\begin{array}{l}30.89 \\
3\end{array}$ \\
\hline $\begin{array}{l}21 \\
22\end{array}$ & & & $\cdots$ & & $\cdots$ & & & & 7.08 & 6.75 & $\begin{array}{r}12.08 \\
7.50\end{array}$ & $\begin{array}{r}11.00 \\
6.25\end{array}$ & $\begin{array}{r}13.00 \\
8.45\end{array}$ \\
\hline 23 & 24.50 & 22.10 & 24.79 & .... & 26.33 & ...... & & & ... & $\begin{array}{l}18.69 \\
25.00\end{array}$ & $\begin{array}{l}17.08 \\
27.75\end{array}$ & 15.75 & 13.58 \\
\hline $\begin{array}{l}24 \\
25\end{array}$ & $\begin{array}{l}47.63 \\
18.23\end{array}$ & $\begin{array}{l}45.75 \\
15.63\end{array}$ & $\begin{array}{l}46.50 \\
16.92\end{array}$ & & $\begin{array}{l}49.50 \\
18.17\end{array}$ & & & & $\cdots \cdots$ & 47.75 & 49.50 & & \\
\hline 26 & $\begin{array}{l}11.93 \\
20.33\end{array}$ & 11.20 & $\begin{array}{l}11.92 \\
10.55\end{array}$ & & $15.50^{\circ}$ & & & & & $\begin{array}{l}18.50 \\
14.50\end{array}$ & $\begin{array}{l}18.50 \\
12.25\end{array}$ & & \\
\hline 28 & $\begin{array}{l}20.33 \\
32.85\end{array}$ & $\begin{array}{l}18.60 \\
34.90\end{array}$ & $\begin{array}{l}19.55 \\
31.50\end{array}$ & & 35.37 & 33.37 & 35.10 & & & 3500 & 14.87 & & \\
\hline 29 & $\begin{array}{l}29.00 \\
18.63\end{array}$ & $\begin{array}{l}29.91 \\
18.28\end{array}$ & 27.83 & & 30.98 & 30.37 & 31. & 31.8 & & $\begin{array}{l}35.00 \\
30.50\end{array}$ & & & \\
\hline $\begin{array}{l}30 \\
31\end{array}$ & $\begin{array}{l}18.63 \\
12.25\end{array}$ & $\begin{array}{l}18.28 \\
14.78\end{array}$ & $\begin{array}{l}17.50 \\
13.50\end{array}$ & & $\begin{array}{l}19.57 \\
15.70\end{array}$ & $\begin{array}{l}18.09 \\
14.00\end{array}$ & $\begin{array}{l}20.75 \\
16.67\end{array}$ & 24. & & 18.00 & & & \\
\hline 32 & 8.38 & 8.19 & 9.05 & $\cdots$ & 11.30 & & $\begin{array}{l}16.08 \\
11.75\end{array}$ & $\begin{array}{l}10.25 \\
11.38\end{array}$ & & 13.50 & & & \\
\hline 33 & $\begin{array}{r}19.20 \\
3.45\end{array}$ & $\begin{array}{r}21.27 \\
3.40\end{array}$ & ... & & & $\ldots$ & 24.08 & & & & & & \\
\hline 36 & 2.45 & 2.68 & & & & $\cdots$ & 3.29 & & & & & $\cdots$ & \\
\hline $\begin{array}{l}37 \\
37 \\
38\end{array}$ & & & & & & 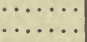 & $\ldots$ & & & & & & \\
\hline 3 & & $\ldots$ & & & & & & & & & & & \\
\hline $\begin{array}{l}40 \\
41\end{array}$ & $\begin{array}{l}21.08 \\
16.14\end{array}$ & $\cdots$ & & & & & & & & & & & \\
\hline 42 & $\begin{array}{l}16.14 \\
15.88\end{array}$ & 15.50 & $\begin{array}{l}15.00 \\
15.00\end{array}$ & & & & & & & & & & \\
\hline & $\begin{array}{l}29.00 \\
16.66\end{array}$ & & 29. & & 29.50 & & & & & & & & \\
\hline & & $\begin{array}{l}17.6 \\
161\end{array}$ & 19.0 & & & & & & & 17.25 & & & \\
\hline 46 & $\begin{array}{l}15.55 \\
11.27\end{array}$ & 10.33 & $\begin{array}{l}16.33 \\
12.67\end{array}$ & $\ldots$ & $\begin{array}{l}16 . \\
13 .\end{array}$ & 13.0 & :. & & & & & & \\
\hline 47 & 8.32 & 6.87 & 9.17 & $\ldots$ & 10.13 & 10.00 & $\cdots$ & & & 10.42 & & & \\
\hline $\begin{array}{l}48 \\
49\end{array}$ & $\begin{array}{l}13.41 \\
43.29\end{array}$ & & $\begin{array}{l}12.25 \\
44.92\end{array}$ & 47.5 & 12.17 & & $\cdots$ & & & 12.87 & 12.12 & & \\
\hline 50 & 22.60 & & & 28.5 & & & & & & 26.86 & 30.75 & & \\
\hline $\begin{array}{l}51 \\
52\end{array}$ & $\begin{array}{r}9.00 \\
28.00\end{array}$ & & & 11.7 & & & & & & 11.00 & 21.50 & & \\
\hline 53 & & & & & & & & & & 23.33 & 21.00 & & 26.25 \\
\hline$=0$ & & & & & & $\cdots$ & & & & 16.15 & 15.05 & & $\begin{array}{l}18 \\
15\end{array}$ \\
\hline 56 & $\begin{array}{r}18.50 \\
5.50\end{array}$ & & & & & & & & & & & & 24.00 \\
\hline 58 & 17.50 & & & & & & & & & & & & $\begin{array}{r}7.25 \\
16.50\end{array}$ \\
\hline $\begin{array}{l}59 \\
60\end{array}$ & $\begin{array}{l}16.00 \\
38.52\end{array}$ & 39.40 & 39.6 & 37.5 & $\begin{array}{l}16.25 \\
35.12\end{array}$ & 41. & & & & & 14 & & 15. \\
\hline 61 & 21.45 & 21.33 & 22 & & 22.75 & 22 & & & & & 26 & & $\begin{array}{l}43.28 \\
30.81\end{array}$ \\
\hline & & 10.60 & & 11. & 12.33 & 12.50 & & & $\cdot 14.50$ & 12.61 & 15.41 & 13. & 17.53 \\
\hline 64 & $\begin{array}{l}5.82 \\
20.82\end{array}$ & & $\begin{array}{r}5.33 \\
19.53\end{array}$ & 8.51 & $\begin{array}{r}6.17 \\
14.50\end{array}$ & $\ldots$ & & & $\begin{array}{r}7.07 \\
16.67\end{array}$ & $\begin{array}{r}7.18 \\
19.53\end{array}$ & $\begin{array}{r}8.98 \\
19.24\end{array}$ & $\begin{array}{r}7.67 \\
15.71\end{array}$ & $\begin{array}{r}8.43 \\
22.75\end{array}$ \\
\hline & $\begin{array}{l}50 \\
29\end{array}$ & $\begin{array}{l}48.08 \\
28\end{array}$ & $\begin{array}{l}49.50 \\
28.33\end{array}$ & & & & & & & $\begin{array}{r}49.93 \\
3.11\end{array}$ & $\begin{array}{l}53.86 \\
3\end{array}$ & & \\
\hline 67 & 15 & ... & $\begin{array}{l}28.33 \\
14.67\end{array}$ & ........ & ....... & & & & . & $\begin{array}{l}30.11 \\
15.46\end{array}$ & $\begin{array}{l}32.14 \\
19.67\end{array}$ & $\cdots$ & \\
\hline $\begin{array}{l}68 \\
69\end{array}$ & & 68.2 & & 65.8 & 70.3 & & & & & 64.07 & & & \\
\hline 70 & 39 & 38. & 36 . & 37. & 41 & & & & & & & & \\
\hline 72 & $\begin{array}{l}19.71 \\
39.60\end{array}$ & 19.50 & 17.33 & 18.0 & 21.00 & & & & ..... & $\begin{array}{l}17.98 \\
35.80\end{array}$ & 22.25 & & \\
\hline $75^{2}$ & & & $\begin{array}{l}47.00 \\
25.33\end{array}$ & 45.2 & & $\cdots$ & & & 50.00 & 47.48 & 47.89 & 47.38 & 50.05 \\
\hline & & & 24. & 24 . & & & & & & & & & $\begin{array}{l}35.44 \\
32.00\end{array}$ \\
\hline & & & 14.0 & 13.00 & & & & & 15.44 & & & 15.21 & \\
\hline 78 & & & 20.80 & $\ldots$ & & & & & ..... & 28.00 & 28.00 & & 26.25 \\
\hline 8 & & $\begin{array}{l}13.20 \\
13.72\end{array}$ & 12.25 & & & & & & 12.00 & & & & \\
\hline & & & & & & & & & & & & & \\
\hline
\end{tabular}


Ash

do

do

Basswood.

do

do

do

Beech

do

Birch, unselected.

do

do

do

Chestnut.

do

do

do

do

Cottonwood

do

do

do

do

do

do

do

do

Cypress, shingles

$$
\text { do }
$$

Elm, rock.

do

do

do

Elm, soft

do

do

Gum.

do

do

do

do

Hickory

do

do

Maple, hard.

do

Maple, soft

do

do

do

Oak, plain

do
do

do

do

Oak, red, quartered

do

do

do

Oak, white, quartered

do
do

do

Poplar.

do

do

do

Tupelo (Bay Poplar)

do
Firsts and seconds $4 \mid 4$

No. 1 common $4 \mid 4$

No. 2 common and better, $4 \mid 4$ or $\log$ run

Mill run.

Firsts and seconds $4 \mid 4$

No. 1 common $4 \mid 4$

No. 2 common 44

Log run

Mill run.

Firsts and seconds $4 \mid 4$

No. 1 common $4 \mid 4$

Mill run.

Firsts and seconds $4 \mid 4$

No. 1 common $4 \mid 4$

No. 2 common 44

No. 2 common and better, $4 \mid 4$ or $\log$ run

Mill run

Firsts and seconds $4 \mid 4$

No. 1 common $4 \mid 4$

No. 2 common and S. W. $4 \mid 4$

No. 3 common $4 \mid 4$

Mill run.

Firsts and seconds $4 \mid 4,6^{\prime \prime}$ to $12^{\prime \prime}$

Boxboards $4 \mid 4,13^{\prime \prime}$ to $17^{\prime \prime}$

No. 1 common $4 \mid 4$

No. 2 common $4 \mid 4$

Mill run.

Firsts and seconds clear $4 \mid 4$

Selects $4 \mid 4$

Shop, No. $1,4 \mid 4$

No. 1 common $4 \mathrm{i}$, random widths

No. 2 common 44 , random widths.

Mill run

Bests $5^{\prime \prime}$

Primes $5^{\prime \prime}$

Firsts and seconds 84

No. 1 common and better 8

No. 2 common and better 84

Mill run.

No. 1 common and better $4 \dot{4}$

No. 2 common and better $4 \mid 4$

Mill run

Firsts and seconds $4 \mid \vec{i}$, red

No. 1 common $4 \mid 4$, red.

Firsts and seconds $4 \mid 4$, sap.

No. 1 common $4[4$, sap

No. 2 common $4 \mid 4$

Mill run

Firsts and seconds $8 \mid 4$

No. 1 common $8 \mid 4$

No. 2 common 84

Mill Run

Firsts and seconds $4 \mid 4$

No. 1 common $4 \mid 4$

Mill run...

No. 1 common and better $4 \mid 4$

No. 3 common $4 \mid 4$

Log run

Mill run.

Firsts and seconds 4 .

No. 1 common $4 \mid 4$.

No. 2 common 44

No. 3 common $4 / 4$.

Mill run

Firsts and seconds $4 / 4$

No. 1 common $4: 4$.

No. 2 common $4 / 4$

Mill run

Firsts and seconds 4,4

No. 1 common $4 \mid 4$

No. 2 common $4 / 4$

Mill run.

Firsts and seconds $4 \mid 4$

Saps or selects $4: 4$

No. 1 common 4.4

No. 2 common $4 \mid 4$

Mill run

Firsts and seconds clear, random 4

No. 1 common, random $4 \mid 4$. .

Mill run. 


\begin{tabular}{|c|c|c|c|c|c|c|c|c|c|c|c|c|c|c|}
\hline & ఝ̊ & 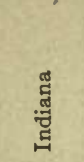 & 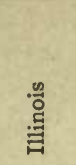 & 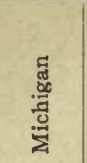 & 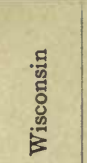 & 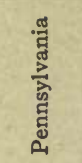 & 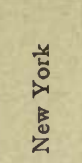 & 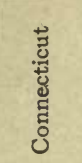 & 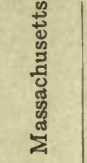 & 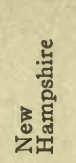 & $\begin{array}{l}\text { : } \\
\end{array}$ & 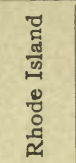 & $\begin{array}{l}\frac{\pi}{60} \\
5 \\
0 \\
0\end{array}$ & \\
\hline & 42.00 & 40.00 & & & 37.53 & 37.50 & 46.00 & & & & & & & 1 \\
\hline $\begin{array}{l}\overline{2} \\
3\end{array}$ & $\begin{array}{l}28.56 \\
16.50\end{array}$ & $\begin{array}{l}25.16 \\
19.25\end{array}$ & & 25.75 & $\begin{array}{l}22.84 \\
22.20\end{array}$ & $\begin{array}{l}27.50 \\
22.00\end{array}$ & $\begin{array}{l}31.33 \\
23.37\end{array}$ & & & & & & & 2 \\
\hline 4 & 26.50 & 26.86 & ..... & 24.26 & 18.91 & 24.75 & $\begin{array}{l}24.31 \\
24.11\end{array}$ & 21.80 & 22.50 & 20.50 & 20.84 & & & $\begin{array}{l}3 \\
4\end{array}$ \\
\hline $\begin{array}{l}5 \\
6\end{array}$ & $\begin{array}{l}31.75 \\
22.66\end{array}$ & $\begin{array}{l}32.00 \\
22.38\end{array}$ & $\ldots$ & $\begin{array}{l}37.40 \\
24.00\end{array}$ & $\begin{array}{l}34.03 \\
23.47\end{array}$ & & $\begin{array}{l}37.50 \\
26.33\end{array}$ & $\ldots$ & $\ldots \ldots$ & & $\begin{array}{l}27.75 \\
20.00\end{array}$ & & & $\begin{array}{l}5 \\
6\end{array}$ \\
\hline 7 & 15.16 & 15.83 & $\cdots$ & 17.00 & $\begin{array}{l}13.48 \\
0.69\end{array}$ & & 20.00 & & $\ldots$ & & & & & 7 \\
\hline $\begin{array}{r}8 \\
9\end{array}$ & $\begin{array}{l}21.12 \\
21.71\end{array}$ & $\begin{array}{l}21.38 \\
22.33\end{array}$ & & $\begin{array}{l}23.71 \\
21.23\end{array}$ & $\begin{array}{l}22.65 \\
19.20\end{array}$ & $\begin{array}{l}21.75 \\
23.50\end{array}$ & $\begin{array}{l}22.67 \\
22.00\end{array}$ & & ${ }^{\ldots \ldots} \ldots$ & 22.00 & $\begin{array}{l}19.70 \\
18.75\end{array}$ & & & $\begin{array}{l}8 \\
9\end{array}$ \\
\hline $\begin{array}{l}10 \\
11\end{array}$ & & $\begin{array}{l}22.67 \\
17.10\end{array}$ & & $\begin{array}{l}21.50 \\
17.75\end{array}$ & & 20.00 & $\begin{array}{l}22.75 \\
16.67\end{array}$ & & & 20.00 & 18.67 & & & 10 \\
\hline 12 & 16.93 & 17.63 & & 13.07 & 12.88 & 15.54 & 14.50 & & 14.25 & $\cdots$ & $\begin{array}{l}15.00 \\
15.32\end{array}$ & & & $\begin{array}{l}11 \\
12\end{array}$ \\
\hline 14 & & & & $\begin{array}{l}35.53 \\
19.00\end{array}$ & $\begin{array}{l}34.28 \\
19.52\end{array}$ & 20.00 & $\begin{array}{l}36.50 \\
26.58\end{array}$ & & & & $\begin{array}{l}20.67 \\
25.00\end{array}$ & & & $\begin{array}{l}13 \\
14\end{array}$ \\
\hline $\begin{array}{l}15 \\
16\end{array}$ & & & & $\begin{array}{l}12.00 \\
21.85\end{array}$ & $\begin{array}{l}11.50 \\
20.72\end{array}$ & & 14.50 & & & & & & & 15 \\
\hline 17 & 4117 & & & 17.27 & 17.44 & 20.15 & 20.00 & 14.38 & 16.40 & 16.33 & 1789 & & & 17 \\
\hline $\begin{array}{l}19 \\
19\end{array}$ & 28.56 & & & & & & $\begin{array}{l}43.50 \\
32.00\end{array}$ & & & & & & & $\begin{array}{l}18 \\
19\end{array}$ \\
\hline $\begin{array}{l}20 \\
21\end{array}$ & 16.25 & 16.88 & & & & $\begin{array}{l}18.50 \\
15.25\end{array}$ & & * & $\cdots$ & & & & & 20 \\
\hline 22 & 19.75 & 30.50 & & & $\because$ & 17.69 & 20.50 & 18.25 & 17.80 & 18.00 & & 18.87 & & 22 \\
\hline 24 & & & & & & & $\cdots$ & & $\cdots$ & & & & & 24 \\
\hline 26 & & & & & & 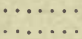 & $\cdots$ & $\ldots$ & $\ldots$ & & & & & $\begin{array}{l}25 \\
26\end{array}$ \\
\hline $\begin{array}{l}27 \\
28\end{array}$ & $\because$ & . & & & & $\ldots$. & ....... & … & ....... & & $\cdots$ & $\cdots$ & & 27 \\
\hline $\begin{array}{l}29 \\
30\end{array}$ & & & & & & - & $\cdots$ & ... & $\ldots$ & & & & & $\begin{array}{l}28 \\
29\end{array}$ \\
\hline 31 & & & & & & & $\cdots$ & $\ldots$ & .... & & . & & & 30 \\
\hline $\begin{array}{l}32 \\
33\end{array}$ & & & & & & & $\ldots$. & & .. & & & & & $\begin{array}{l}31 \\
32 \\
\end{array}$ \\
\hline 34 & .. & & & & & $\ldots$. & ..... & $\cdots$ & $\cdots$ & & & & & 33 \\
\hline $\begin{array}{l}35 \\
36\end{array}$ & & $\cdots$ & & & 207 & $\cdots$ & ....... & $\ldots$ & ……… & & $\ldots$ & & & 35 \\
\hline 37 & & $\cdots$ & & & 23.80 & ..... & …... & .... & …… & . & ......... & $\cdots$ & & $\begin{array}{l}36 \\
37\end{array}$ \\
\hline $\begin{array}{l}38 \\
39\end{array}$ & 18.25 & 1900 & & $\begin{array}{l}23.56 \\
24.00\end{array}$ & 22.44 & & & & & & & & & 80 \\
\hline 40 & 20.25 & 24.44 & & & 25.00 & & 22.50 & & & & 15.83 & & & $\begin{array}{l}39 \\
40\end{array}$ \\
\hline $\begin{array}{l}41 \\
42\end{array}$ & $\begin{array}{l}15.67 \\
20.00\end{array}$ & $\begin{array}{l}17.93 \\
18.86\end{array}$ & & $\begin{array}{l}24.20 \\
19.51\end{array}$ & $\begin{array}{l}19.77 \\
17.71\end{array}$ & & 21.50 & & & & & & & 41 \\
\hline $\begin{array}{l}43 \\
44\end{array}$ & .. & 2250 & & & & & ........ & & & & 16.67 & & & $\begin{array}{l}42 \\
43\end{array}$ \\
\hline 45 & & 20.17 & & ...... & $\ldots$ & & …..... & $\ldots$ & $\therefore$ & & ……... & & & 44 \\
\hline $\begin{array}{l}46 \\
47\end{array}$ & .. & 10.50 & & & & & & & & & $\ldots$ & & & $\begin{array}{l}45 \\
46\end{array}$ \\
\hline $\begin{array}{l}48 \\
49\end{array}$ & 5125 & & & & & & .. & & & & ... & & & 47 \\
\hline 50 & 51.25 & $\begin{array}{l}49.14 \\
31.55\end{array}$ & 26.00 & & & 51.25 & $\ldots$ & ... & ... & & & & & 49 \\
\hline $\begin{array}{l}51 \\
52\end{array}$ & $\begin{array}{l}20.00 \\
24.95\end{array}$ & 19.75 & 3088 & ..... & …..... & 25.00 & …..... & $\ldots .$. & & & .... & & & $\begin{array}{l}50 \\
51\end{array}$ \\
\hline 53 & 25.63 & $\begin{array}{l}29.00 \\
25.40\end{array}$ & 30.88 & 28.09 & 25.43 & $\begin{array}{l}27.50 \\
28.00\end{array}$ & 26.90 & $\ldots$ & & & 2500 & & & $\begin{array}{l}52 \\
53\end{array}$ \\
\hline $\begin{array}{l}54 \\
55\end{array}$ & $\begin{array}{l}18.32 \\
18.66\end{array}$ & 19.44 & & $\begin{array}{l}20.31 \\
10\end{array}$ & 17.48 & $\begin{array}{l}22.71 \\
17.64\end{array}$ & 19.10 & & & & . & & & 54 \\
\hline 56 & 21.86 & 22.75 & & 19.08 & $\begin{array}{l}15.91 \\
18.88\end{array}$ & $\begin{array}{l}1.04 \\
21.50\end{array}$ & 17.39 & & 17.00 & 18.25 & 17.11 & & & $\begin{array}{l}55 \\
56\end{array}$ \\
\hline $\begin{array}{l}58 \\
59\end{array}$ & & 19.00 & & $\begin{array}{r}8.12 \\
17.98\end{array}$ & $\begin{array}{r}7.56 \\
15.68\end{array}$ & & & & & & & & & $\begin{array}{l}57 \\
58\end{array}$ \\
\hline $\begin{array}{l}59 \\
60\end{array}$ & $\begin{array}{l}17.25 \\
43.71\end{array}$ & $\begin{array}{l}18.44 \\
41.32\end{array}$ & 38.00 & 14.60 & $\begin{array}{l}14.67 \\
44.77\end{array}$ & 13.00 & 16.50 & 12.00 & 15.00 & $\cdots$ & & & & 59 \\
\hline 61 & 28.93 & 27.10 & 23.67 & ... & 31.88 & 27.43 & .. & . & $\ldots$ & & 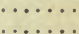 & & & $\begin{array}{l}60 \\
61\end{array}$ \\
\hline $\begin{array}{l}62 \\
63\end{array}$ & $\begin{array}{l}20.56 \\
13.64\end{array}$ & $\begin{array}{l}17.92 \\
10.67\end{array}$ & $\begin{array}{l}15.00 \\
10.00\end{array}$ & 10.00 & $\begin{array}{r}22.93 \\
9.22\end{array}$ & 19.50 & & & & $\cdots$ & $\ldots$ & & & 62 \\
\hline $\begin{array}{l}64 \\
65\end{array}$ & 52.00 & $\begin{array}{l}25.40 \\
54.86\end{array}$ & 19.23 & & 27.13 & 21.50 & 22.88 & 20.67 & 20.38 & 20.00 & 20.50 & & & 64 \\
\hline 66 & 33.00 & 35.17 & & $\cdots$ & & $\ldots$. & $\ldots$ & & & & & & & $\begin{array}{l}60 \\
66\end{array}$ \\
\hline 68 & $\begin{array}{l}20.00 \\
18.38\end{array}$ & 21.04 & & . & & & & & $\ldots$ & & & & & 67 \\
\hline $\begin{array}{l}69 \\
70\end{array}$ & $\begin{array}{l}72.50 \\
43.20\end{array}$ & 70.36 & & & & & ... & $\ldots$ & $\ldots$ & $\therefore$ & ... & $\cdots$ & & 69 \\
\hline 71 & 23.25 & $\begin{array}{l}42.27 \\
23.50\end{array}$ & & & & & & & & & & & & 70 \\
\hline 73 & 52.43 & 50.21 & & & & 24.12 & & & & & & & 52,50 & 72 \\
\hline $\begin{array}{l}74 \\
75\end{array}$ & $\begin{array}{l}40.14 \\
32.44\end{array}$ & $\begin{array}{l}38.20 \\
31.32\end{array}$ & & & & & & & & & & & & \pm \\
\hline $\begin{array}{l}76 \\
77\end{array}$ & 20.60 & 19.33 & & & & & & & & & & & $\begin{array}{l}30.50 \\
14.50\end{array}$ & 76 \\
\hline 78 & 25.00 & & & & & 23.50 & & & & & & & 20.00 & 77 \\
\hline $\begin{array}{l}79 \\
80\end{array}$ & & & & & & & & & & & & & & 79 \\
\hline
\end{tabular}





\section{U. S. DEPARTMENT OF AGRICULTURE,} FOREST SERVICE. HENRY S, GRAVES, Forester.

\section{RECORD OF WHOLESALE PRICES OE LUMBER.}

(PER 1,000 FEET B. M.)

BASED ON ACTUAL SALES MADE F. O. B. MILL FOR

JULY, AUGUST, AND SEPTEMBER, 1911. 


\section{PREFATORY NOTE.}

The Forest Service has two main purposes in collecting and compiling this record of f. o.b. mill prices: First, to have a continuous statistical record of such prices of the various commercial woods; and, second, to show, in contrast to market prices-which include the important items of freight charges and selling costs-just what the manufacturers of lumber receive for their product at the mill. The prices given are wholesale, based on actual sales f. o. b. mill, for delivery outside of local territory. Only a few representative grades and the mill run are included. By "mill run" is meant the average of all grades of lumber produced. The record is compiled by States, and is made up from reports received from approximately 3,000 of the largest manufacturers scattered throughout the country. It is published quarterly.

The Forest Service wishes to acknowledge the courtesy of the manufacturers for their prompt and efficient cooperation. Their assistance has been of great value in making the record complete, accurate, and promptly available for distribution.

2

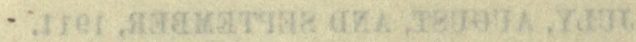




\section{SUMMARY.}

Comparing the prices of western softwoods for the third quarter with the preceding quarter for 1911, there was a slight general decline, though a few woods showed improvement. Douglas fir was slightly lower. Flooring No. 2 flat, $1^{\prime \prime} \times 4^{\prime \prime}$, decreased 80 cents in Oregon and $\$ 1.40$ in Washington. There was a fall in the prices of western red cedar, and also white fir, western hemlock, larch, Sitka spruce, and western spruce as well. The better grades of western yellow pine were slightly lower in Oregon, though in other States all grades generally improved. Sugar pine showed the greatest increase of the western softwoods. Shop No. 2, $2^{\prime \prime} \times 8^{\prime \prime}$ and wider, brought $\$ 2.16$ more, and firsts and seconds clear $\$ 5.60$ more than in the second quarter. Prices of western white pine, including Idaho white pine, were generally higher. In Idaho the increase was from $\$ 1.50$ to $\$ 3.25$, according to. the grade. California redwood was the other western softwood to record a notable increase. The advance of common boards No. 1 amounted to $\$ 3.16$.

Of the eastern softwoods, hemlock in the Lake States and Eastern States held substantially firm with the prices of the second quarter. The greatest variation was in Michigan, where a few of the upper grades showed a reduction of 60 cents. The prices of spruce in New England fell, the decrease in Vermont and Maine ranging for the lower grades from $\$ 1.33$ to $\$ 1.50$. The reverse was the status in West Virginia. Here merchantable spruce boards $1^{\prime \prime} \times 12^{\prime \prime} 10^{\prime}$ to $20^{\prime}$ and box boards $1^{\prime \prime} \times 4^{\prime \prime} \times 12^{\prime}$ rose in price. The latter increased 73 cents and the former $\$ 1.03$. Prices for white pine were recorded from 12 States. For the mill-run grade there was general uniformity with prices of the second quarter except in Wisconsin and Minnesota, where the decrease ranged from $\$ 1$ to $\$ 1.50$. In Tennessee this grade scored the only marked improvement; the increase was $\$ 1.88$. The upper grades of white pine brought better prices, "selects" making an advance of from $\$ 3.30$ to $\$ 4$ in Wisconsin and Michigan No. 1 shop rose to $\$ 2.95$ in Michigan and in Minnesota to $\$ 1.67$. In Wisconsin, West Virginia, and Tennessee this grade of white pine was staple. Prices of yellow pine, the most abundant of the eastern softwoods, showed slight general improvement in all grades, especially throughout the Mississippi Valley States. The most notable increase was in Alabama, where common boards No. 1, S2S $1^{\prime \prime} \times 10^{\prime \prime}$, and No. 2, S2S $1^{\prime \prime} \times 8^{\prime \prime}$ amounted to, respectively, $\$ 1.07$ and 74 cents. The most marked decrease was in Georgia and Florida, where the three grades of B and better flooring showed a decline of from $\$ 1.75$ to $\$ 5$. Generally there were indications of slight improvement in South Carolina, but in North Carolina there was no appreciable change.

Compared with the second quarter, hardwood prices varied considerably, according to species and locality. Ash showed improvement in Ohio, Tennessee, and Kentucky, but in Virginia and West Virginia experienced a decline. Basswood increased in the Southern States, but in the Lake States the prices were slightly depressed. Birch, firsts and seconds, scored an advance of over $\$ 2$ in West Virginia, and in Michigan $\$ 1.15$, but in New York and Vermont prices were lower. No decreases were noted in any State in the prices of chestnut; the largest increase was in Tennessee and West Virginia, where firsts and seconds rose as much as $\$ 2$ per M. Cypress prices improved in all States, while gum remained generally staple except in Mississippi, where firsts and seconds advanced $\$ 1.75$. Hickory prices were higher in Wisconsin and West Virginia, remained generally firm in the Southern States, and showed recessions 
in Ohio and Indiana. The prices for both plain and quartered oak were characterized by decided gains. The average increase of all the grades probably amounted to over \$1.50. Poplar prices were exceptionally staple. In Louisiana tupelo made an advance in all grades, while hard maple generally, except in Pennsylvania, showed uniformly slight improvement.

A comparison of prices for the third quarter of 1911 with the corresponding quarter of 1910 shows western softwoods generally lower except western hemlock and western white pine; in these there are slight indications of improvement. Fastern softwoods as a whole showed a fairly uniform increase. Nearly all grades of yellow pine, particularly in the Mississippi Valley, made advances. In Georgia, Florida, and South Carolina the conditions only slightly improved, while in North Carolina prices remained uniformly staple. Hemlock in the Lake States changed for the better, but held constant in West Virginia and Pennsylvania. White pine, eastern spruce, and West Virginia spruce showed improvement.

Hardwoods, more than either the western softwoods or the eastern softwoods, showed generally larger and more decided gains over the same period in 1910. The most notable improvements were in the general prices of oak, ash, and chestnut.

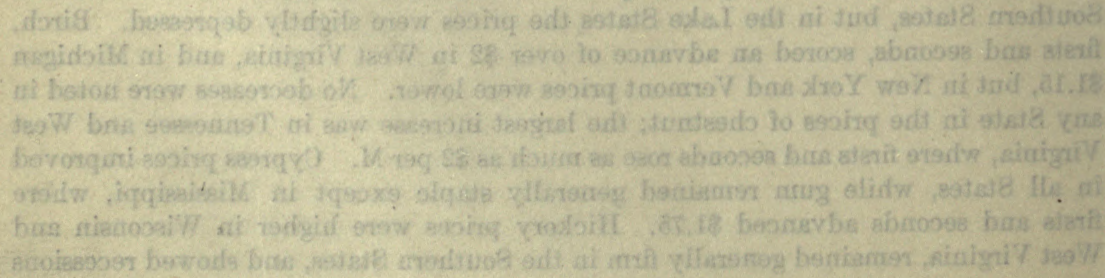




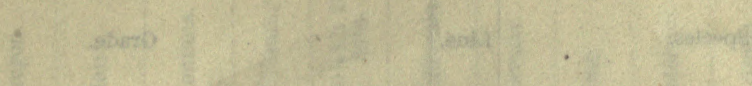

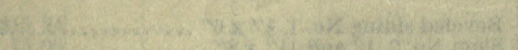

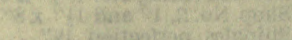

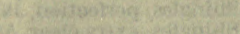

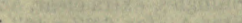

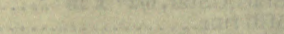

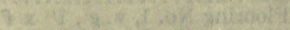

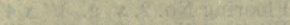

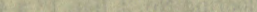

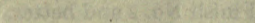

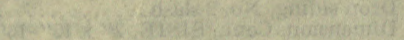

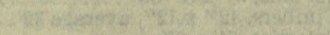

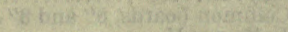

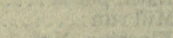
Whate

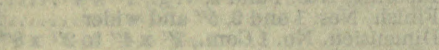

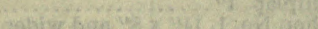

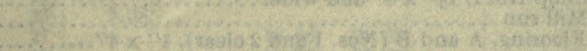
- . W

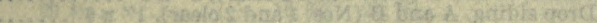

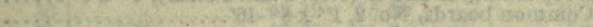

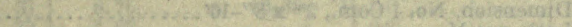

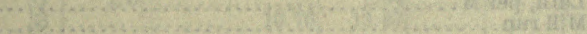

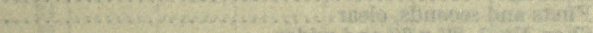

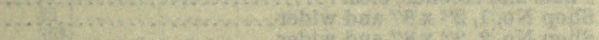
H. 3. W. a.6... nabio ty ar. w...

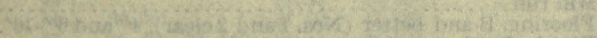
wa.t....

Whom

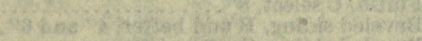

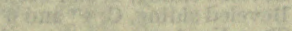

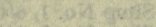

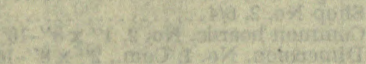

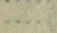
to

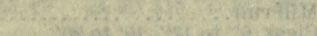

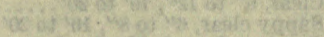

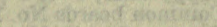
opt.

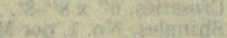

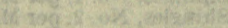

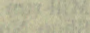

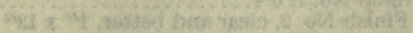

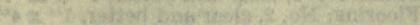

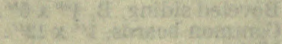
atarisgas

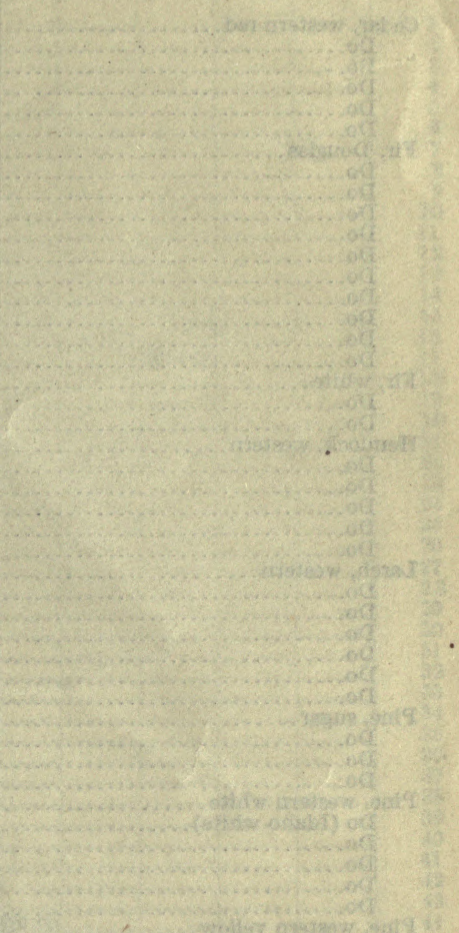

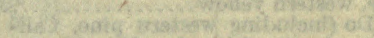

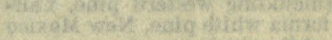

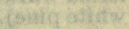

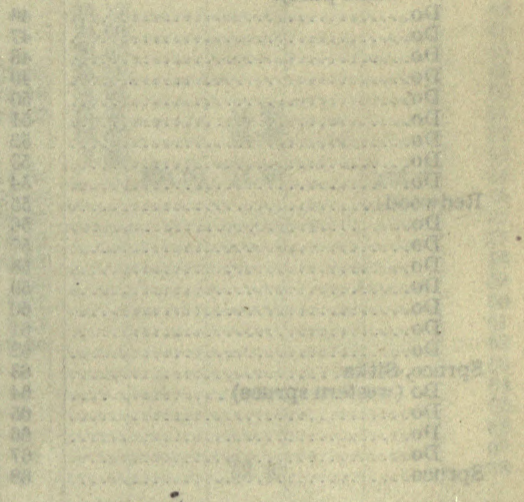




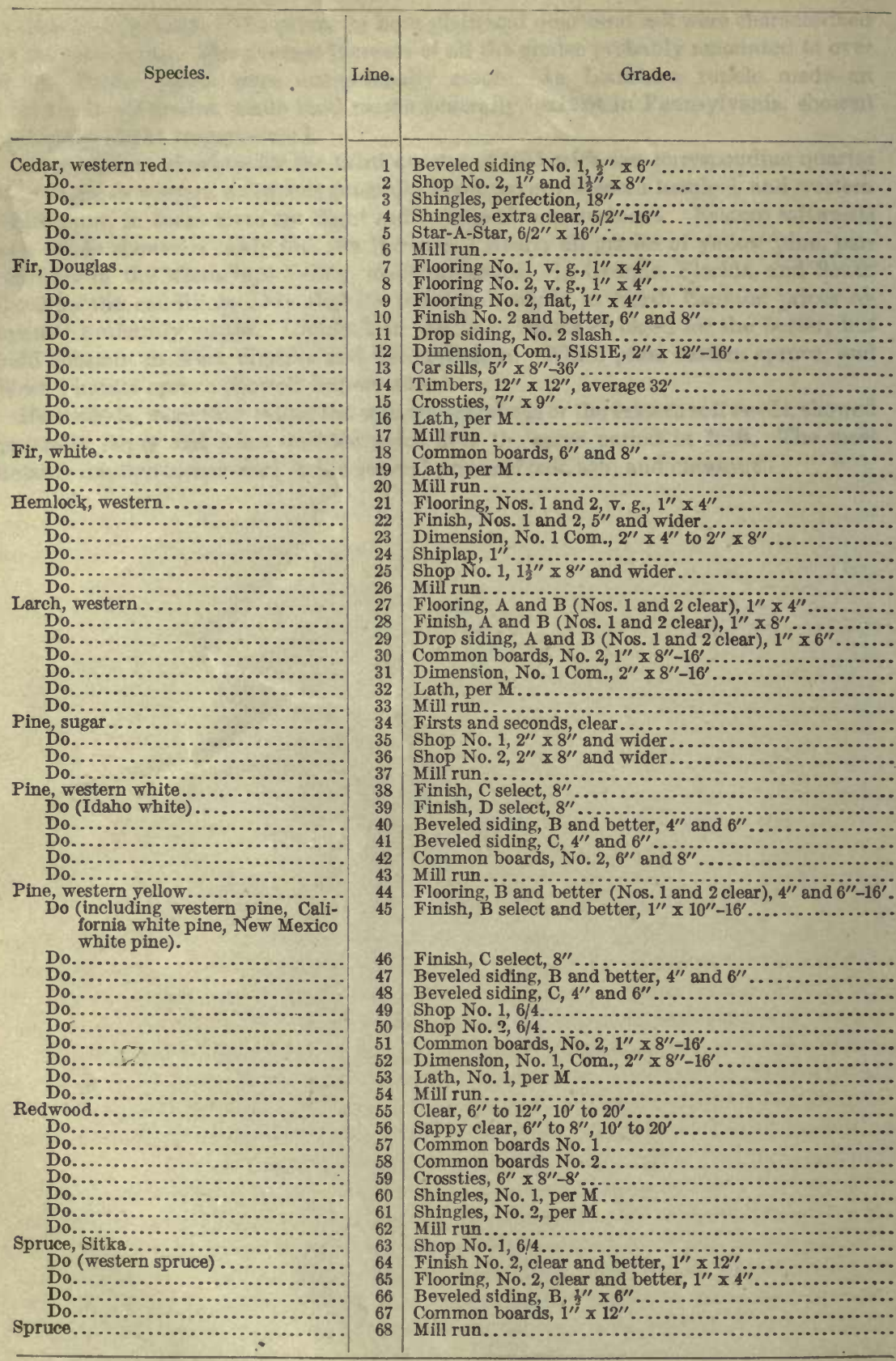




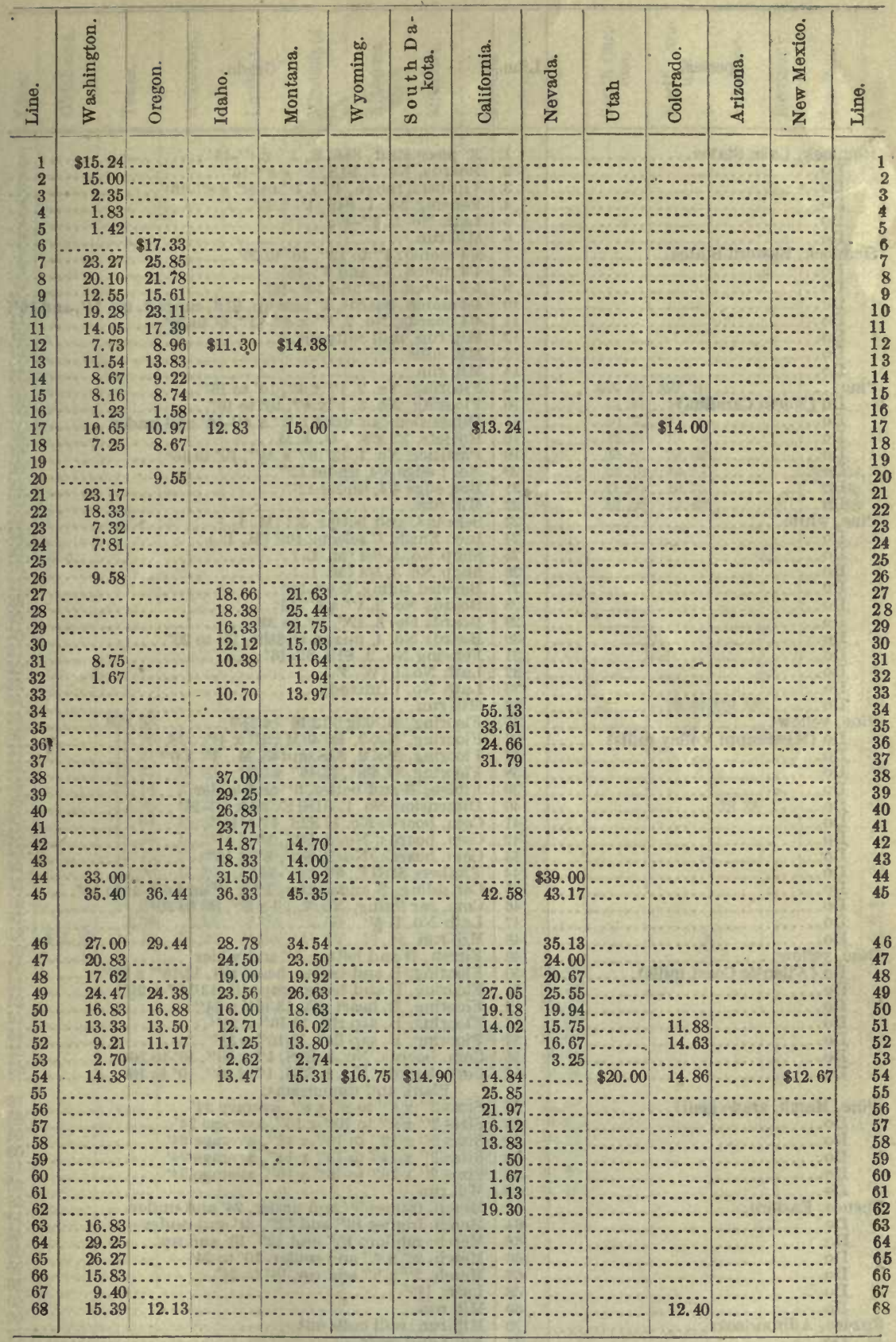




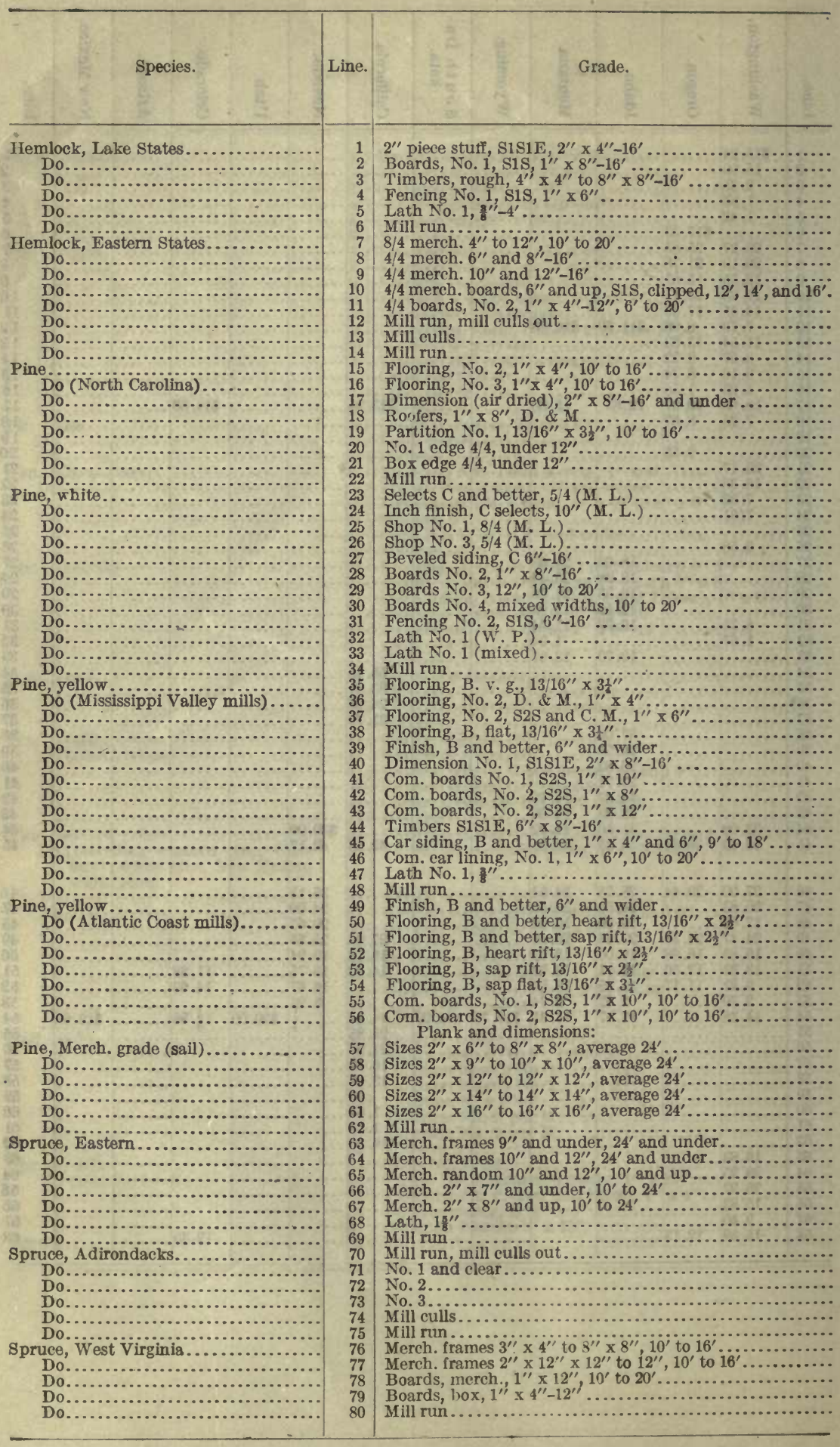


WHOLESALE PRICES OF LUMBER.

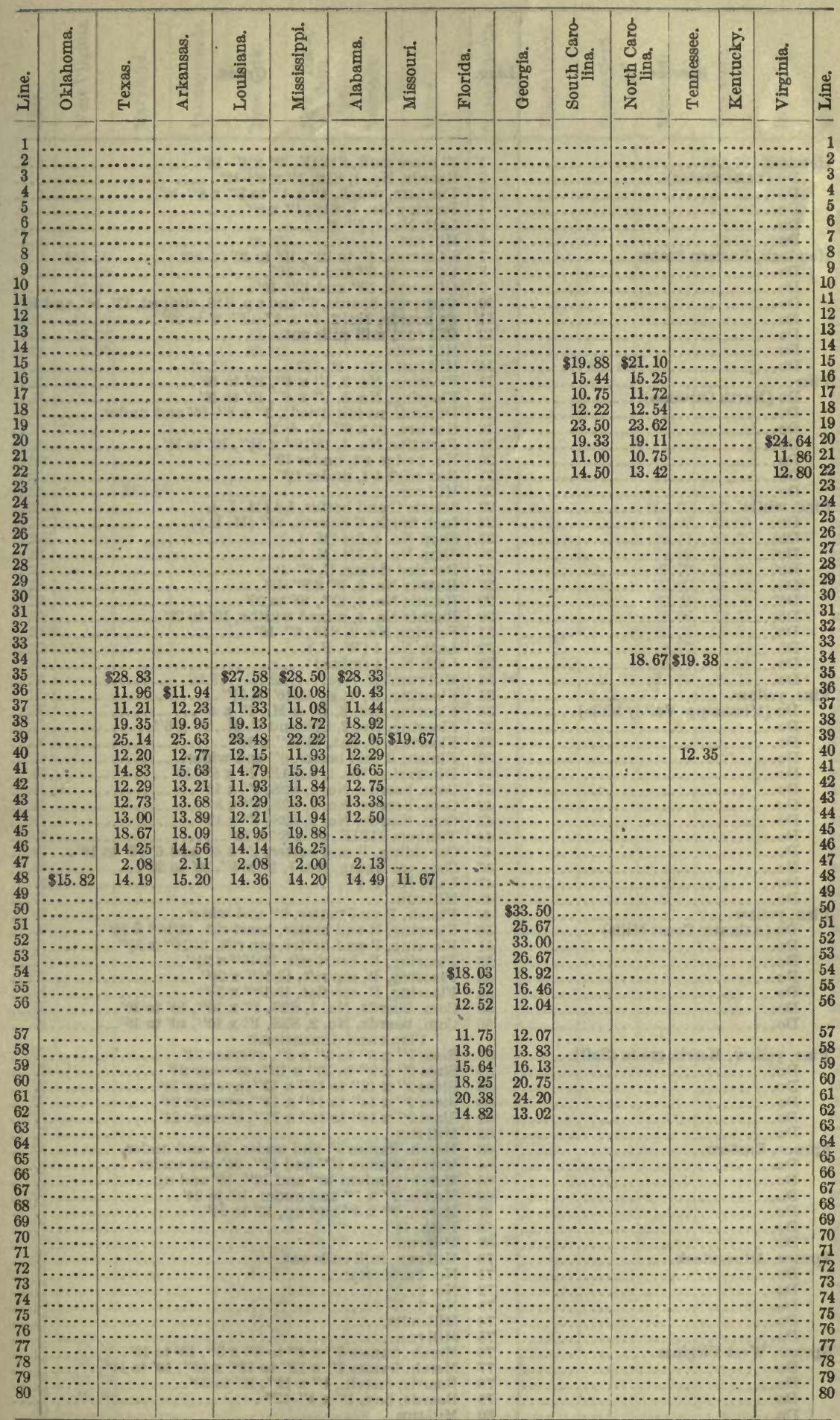




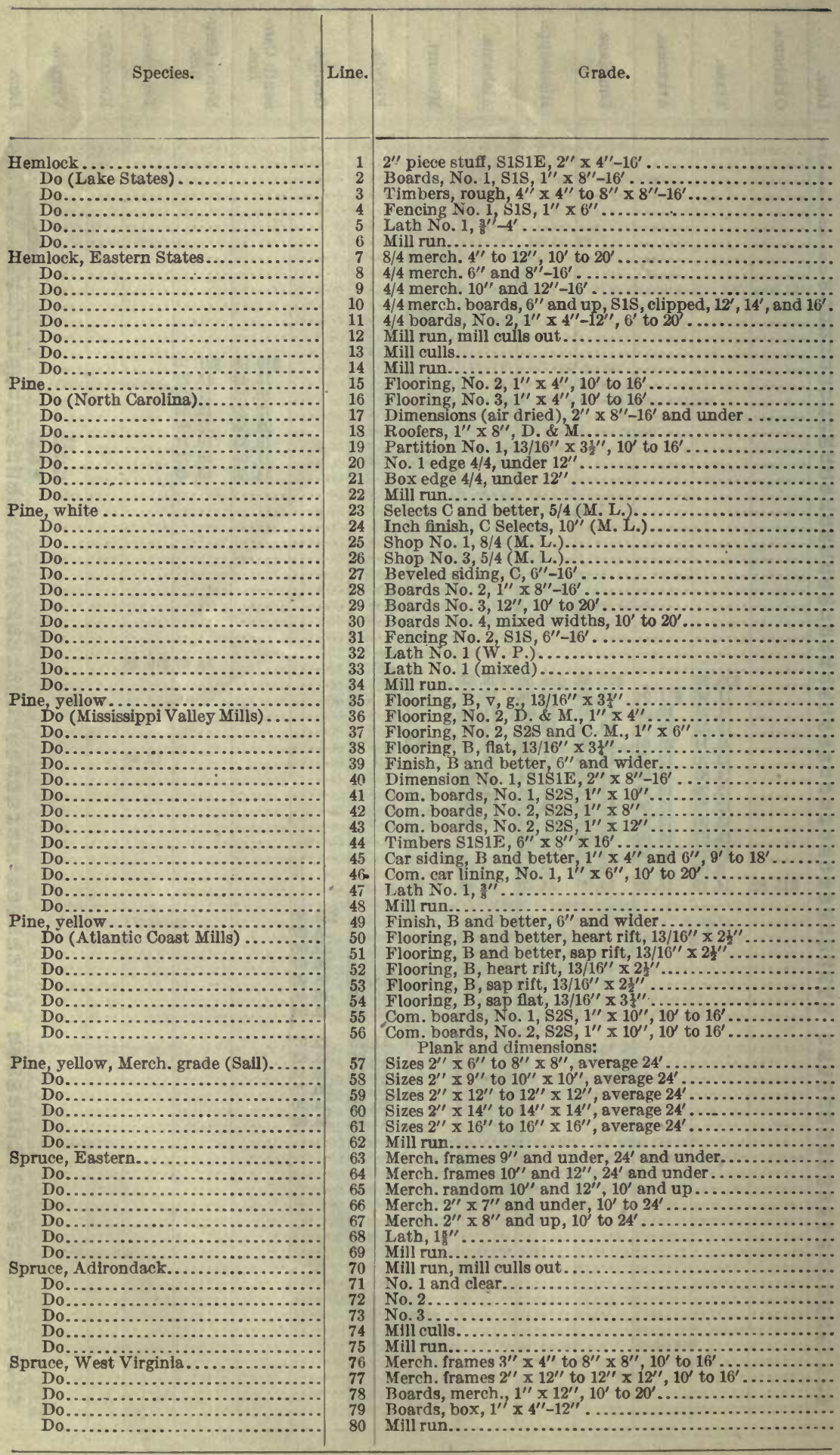




\begin{tabular}{|c|c|c|c|c|c|c|c|c|c|c|c|c|c|c|}
\hline 竎 & 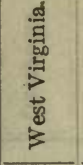 & 总 & 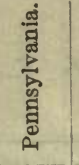 & 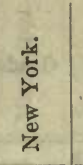 & 密. & 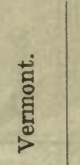 & $\frac{\stackrel{\Xi}{\Xi}}{\Xi_{\Sigma}}$ & 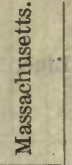 & 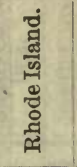 & 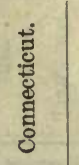 & 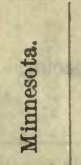 & 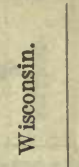 & 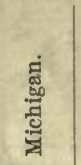 & 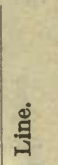 \\
\hline $\begin{array}{l}1 \\
2 \\
3 \\
4 \\
5 \\
6\end{array}$ & & & & \begin{tabular}{r}
$\$ 18.20$ \\
17.90 \\
$\ldots \ldots . .$. \\
\hdashline$\ldots . .$. \\
16.88
\end{tabular} & & & & & 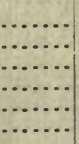 & & $\cdots$ & $\begin{array}{r}\$ 15.72 \\
16.85 \\
16.87 \\
15.54 \\
3.29 \\
12.72\end{array}$ & $\begin{array}{r}\$ 14.94 \\
15.98 \\
15.96 \\
15.40 \\
3.45 \\
12.65\end{array}$ & $\begin{array}{l}2 \\
3 \\
4\end{array}$ \\
\hline $\begin{array}{l}7 \\
8\end{array}$ & $\begin{array}{r}\$ 15.50 \\
14.55\end{array}$ & & $\$ 18.25$ & ... & & $\$ 15.50$. & & & …...... & & & & ….... & 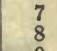 \\
\hline 9 & 16.20 & & & & & 16.21 & $\$ 16.25$ & & & & & & & ${ }_{10}^{9}$ \\
\hline & 11.60 & & & & & . & $\ldots$ & &.. & & ... & & $\cdots$ & 11 \\
\hline & $\begin{array}{r}15.92 \\
6.00\end{array}$ & & & $\begin{array}{l}17.17 \\
10.00\end{array}$ & & $\begin{array}{c}16.25 \\
\ldots . . .\end{array}$ & $\begin{array}{r}16.50 \\
\ldots \ldots \ldots\end{array}$ & & & & $\cdots$ & & & $\begin{array}{l}12 \\
13\end{array}$ \\
\hline $\begin{array}{l}14 \\
15\end{array}$ & & & $\begin{array}{r}16.53 \\
\ldots . . . .\end{array}$ & …....... & $\$$ & 16.11 & 13.73 & $\$ 16.67$ & …..... & $\$ 17.00$. & $\cdots$ & & & 15 \\
\hline 1 & & & .. & .......... & $\cdots$ & . & $\cdots$ & & …...... & & & & $\because$ & 16 \\
\hline 1 & $\cdots \cdots$ & & & …..... & & ....... & & & & & & & & 17 \\
\hline 18 & & & $\therefore$ & …....... & & & & & & & & & & $\begin{array}{l}18 \\
19\end{array}$ \\
\hline & ...... & & ... & $\ldots . .$. & 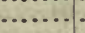 & 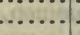 & $\ldots$ & & ........ & & & & ..... & 20 \\
\hline 2 & …. & & & & & & & & & & & & & 21 \\
\hline 23 & & & & & & & & & $\cdots$ & & $\$ 53.69$ & 60.15 & 64.50 & 23 \\
\hline & $\cdots$ & & & & & & & & & & 46.95 & 48.80 & 52.33 & 2 \\
\hline & & & & & & & 26.67 & & $\cdots$ & & 48.31 & 51.25 & \begin{tabular}{|r|}
54.75 \\
30.00
\end{tabular} & ภ: \\
\hline 2 & $\cdots$ & & & $\cdots$ & & & ... & & & & & $\begin{array}{l}25.59 \\
26.25\end{array}$ & \begin{tabular}{|}
30.00 \\
26.63
\end{tabular} & 2 \\
\hline & & & & & 2 & & 21.00 & & .. & & 23.22 & 24. 52 & 26.58 & 28 \\
\hline 2 & $\cdots$ & & & & & & & & & & 20.41 & 21.30 & 23.83 & 29 \\
\hline & $\cdots \cdot \cdot$ & & & & & & 16.75 & & ........ & & 12.67 & 12. 53 & 13. 38 & 30 \\
\hline 3 & $\ldots .$. & & $\because \cdot$ & & & & ....... & & ....... & & $\begin{array}{r}26.58 \\
3.70\end{array}$ & $\begin{array}{r}26.50 \\
3.61\end{array}$ & $\begin{array}{r}26.50 \\
3.78\end{array}$ & 31 \\
\hline $\begin{array}{l}3 \\
3\end{array}$ & .......... & & & & & & & & & & 3.11 & $\begin{array}{l}5.01 \\
3.28\end{array}$ & 3.43 & 3 \\
\hline & $\ldots . .$. &. & 22.75 & 23.90 & 17.43 & 19.00 & 19.20 & 17.80 & $\ldots$ & 18.32 & 17.62 & 19.75 & 21.14 & 34 \\
\hline & & & 1 &.. & & & & & $\cdots$ & & & & $\cdots \cdots$ & 35 \\
\hline & & & - & & & & & & & & & & & 36 \\
\hline 3 &.- & & - & .. & & & & & $\because$. & & & & $\because$ & 38 \\
\hline 38 & .. & & .. & $\cdots$ & & & & & $\therefore . . .$. & & & & $\cdots \cdots$ & 39 \\
\hline & $\cdots$ & & $\because$ & & & & & & & & & & & 40 \\
\hline & $\ldots$ & & & & & & & & & & & & ..... & 41 \\
\hline & & & & & & & & & $\cdots$ & & & & & 43 \\
\hline & & & & & & & & & $\cdots$ & & & & $\ldots$ & 44 \\
\hline & ... & & & & & & $\ldots$ & & $\cdots$ & & & & ... & 45 \\
\hline & $\ldots$ & & & & & & & & - & & & & & 46 \\
\hline & . & & & & & & & & $\ddot{. .}$ & & & & 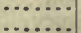 & 48 \\
\hline & & & & & & & & & & & & & ... & 49 \\
\hline & $\cdots$ & & & & & & & & & & & & $\cdots$ & 50 \\
\hline & & & & & & & & & 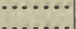 & & $\cdots$ & & & 51 \\
\hline & …...... & & $\cdots$ & 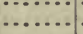 & & & & & $\because$. & & & & & \\
\hline & $\cdots$ & & & & & & & & & & & & & 5 \\
\hline & ... & & & & & & & & & & & & & 5 \\
\hline & & & & & & & & & & & & & & 5 \\
\hline & & & & & & & & & & & & & & \\
\hline & …........ & & 0. & & & & . & & & & & & & 50 - \\
\hline & & & & & & & & & & & & & & 60 \\
\hline & & & & & & & & & & & & & ......... & \\
\hline & & & & & 20 & 0 & 1 & & & & & & & 6 \\
\hline & $\ldots .$. & & $\ldots$ & & & 23.50 & 2 & & & & & & & \\
\hline & & & & & & & & & & & & & & \\
\hline & 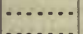 & & $\because$ & $\cdots$ & & 19. & & & & & & & & 6 \\
\hline & & & & & & 20.67 & $\begin{array}{r}18.04 \\
2.83\end{array}$ & & & & & & $\because$ & \\
\hline & & & & $\ldots$ & 19 & 17. 33 & 16.82 & 17.33 & & &. & ....... & 16.38 & \\
\hline & & & & & & & & & & & & 1 & 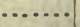 & \\
\hline & $\ldots$ & & ... & 31.67 & & & & & & & & & & 7 \\
\hline & & & & 1 & & 13.25 & & & & & & & & \\
\hline & & & & & & & & & & & & & & 7 \\
\hline & & & & 17.00 & & & & & & & & & & \\
\hline & 17 & & & & & & & & & & & & & 7 \\
\hline & 21. & & & & & & & & & & & & & $\begin{array}{l}7 \\
7\end{array}$ \\
\hline & 15.00 & & & & & & & & & & & & & \\
\hline & & & & & & & & & & & & & & 80 \\
\hline
\end{tabular}




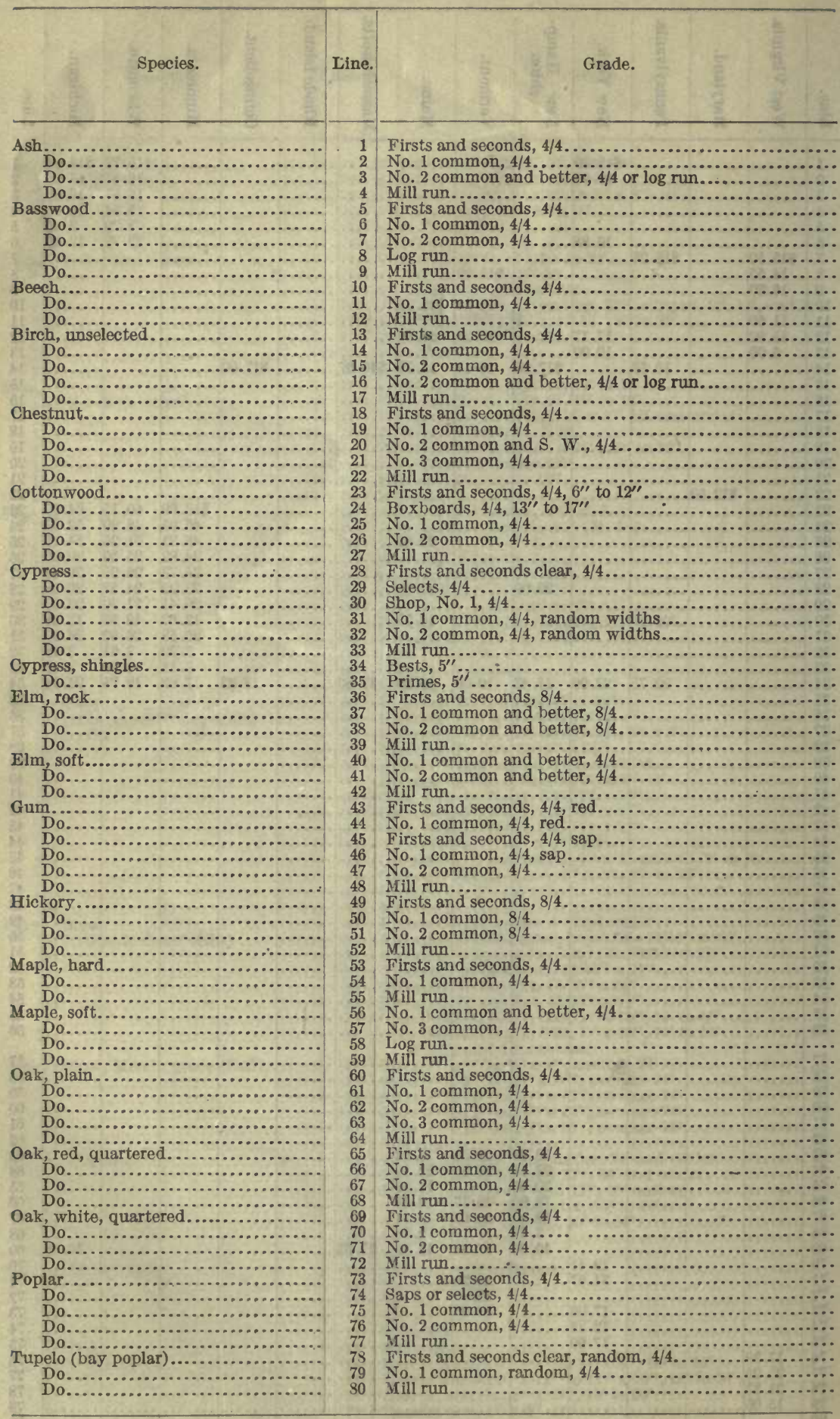




\begin{tabular}{|c|c|c|c|c|c|c|c|c|c|c|c|c|c|c|c|}
\hline 喬 & 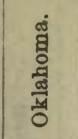 & 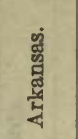 & 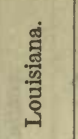 & 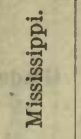 & 丞 & 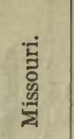 & 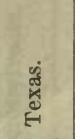 & 总 & 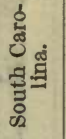 & 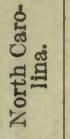 & 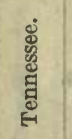 & 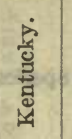 & 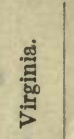 & 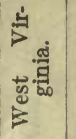 & 离 \\
\hline 1 & & $\$ 36.29$ & $\$ 34.40$ & $\$ 36.00$ & & & & & & $\$ 38.50$ & $\$ 39.69$ & 839.09 & S & $\$ 43.46$ & 1 \\
\hline 2 & & 21. 03 & 19.50 & 21.17 & & & & & & 25.25 & & & 23.67 & 28. 71 & 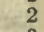 \\
\hline $\begin{array}{l}3 \\
4\end{array}$ & & $\begin{array}{l}11.50 \\
20.10\end{array}$ & $\begin{array}{r}10.13 \\
.\end{array}$ & 10.00 & & $\$ 23.33$ & & & & 16.33 & $\begin{array}{l}14.65 \\
20.67\end{array}$ & $\begin{array}{l}18.89 \\
19.00\end{array}$ & & $\begin{array}{l}15 \\
85\end{array}$ & 3 \\
\hline 4 & & $\begin{array}{r}20.10 \\
\cdots \cdots\end{array}$ & '… & …… & & ........ & & & & 33.25 & 33.00 & & 31.67 & & 4 \\
\hline 6 & & ........ & & & & & & & & 22.75 & 22. & & & & 0 \\
\hline 7 & & & & & & & & & & 13.00 & 14. 22 & & 11 & & 8 \\
\hline 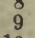 & & & & & & & & & & ....... & 19.13 & 21.50 & 21.13 & 20 & 8 \\
\hline & $\cdots$ & $\cdots$ & & & & & 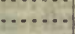 & & & & 23.83 & $\begin{array}{l}20 \\
\therefore\end{array}$ & & 18.50 & 10 \\
\hline & & & & & & & & & & & 16.50 & & & ....... & 11 \\
\hline & $\cdots$ & & $\cdots \cdot$ & …..... & & & & & & & 15.33 & 11.75 & & 12. 78 & 12 \\
\hline & & ...... & ……. & & & & & & & … & ....... & & & 34.25 & 13 \\
\hline & & $\cdots$ & . & & & & & & & & & & & $\begin{array}{l}23.17 \\
12.33\end{array}$ & 14 \\
\hline & & & .. & & & & & & & & & & & $\begin{array}{l}12.55 \\
18.79\end{array}$ & $\begin{array}{l}15 \\
16\end{array}$ \\
\hline & & & & & & & & & & & & & & 17.08 & 17 \\
\hline & & & $\cdots$ & & & & & & & 40.14 & 39.64 & 39.52 & 40.00 & 44.50 & 18 \\
\hline & & & & & & & & & & $\begin{array}{l}28.86 \\
11.14\end{array}$ & $\begin{array}{l}27.14 \\
13.18\end{array}$ & 26 & $\begin{array}{l}29.29 \\
11.81\end{array}$ & $\begin{array}{l}32.55 \\
13.20\end{array}$ & 19 \\
\hline & & $\cdots$ & & 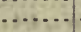 & & . & & & & $\begin{array}{r}11.14 \\
7.25\end{array}$ & $\begin{array}{r}13.18 \\
6.92\end{array}$ & $\begin{array}{r}13.20 \\
7.27\end{array}$ & $\begin{array}{r}11.81 \\
6.50\end{array}$ & $\begin{array}{r}13.20 \\
8.44\end{array}$ & $\begin{array}{l}20 \\
21\end{array}$ \\
\hline & & & & & & & & & & & 20.00 & 18.94 . & & 15.75 & 22 \\
\hline & $\cdots$ & $\begin{array}{l}24.61 \\
48.20\end{array}$ & 22.06 & 24.83 & & $\begin{array}{l}25.75 \\
48.67\end{array}$ & & & & & 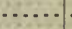 & $\cdots$ & & $\cdots$ & 23 \\
\hline & ... & $\begin{array}{l}40.20 \\
17.95\end{array}$ & $\begin{array}{l}44.00 \\
15.88\end{array}$ & $\begin{array}{l}47.50 \\
17.80\end{array}$ & & 19.00 & & & & & & & & & 24 \\
\hline & 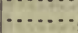 & 13.25 & 11.13 & 13.90 & & 15.33 & & & & & & & & & 25 \\
\hline & & 19.00 & & & & & & & & & & & & & $\begin{array}{l}20 \\
27\end{array}$ \\
\hline & $\cdots$ & & 35.31 & 34. & & & & & & & & & & & 28 \\
\hline & - & $\begin{array}{l}29.93 \\
19.43\end{array}$ & $\begin{array}{l}30.20 \\
17.92\end{array}$ & $\begin{array}{l}30.00 \\
19.25\end{array}$ & & $\begin{array}{l}29.05 \\
19.13\end{array}$ & & $\begin{array}{l}30.75 \\
20.42\end{array}$ & & & & & & $\cdots \cdots \cdots$ & 29 \\
\hline & . & 13.83 & 14.46 & 13.50 & & 14. 06 & & 16.00 & & & & & & $\cdots \cdots \cdots$ & 30 \\
\hline & $\ldots$ & 9.30 & 8. 23 & 11.00 & & 10.00 & & 11.00 & & & & & & & $\begin{array}{l}31 \\
32\end{array}$ \\
\hline & $\ldots$. & 19.17 & 20.67 & ....... & & ......... & $\cdots$ & $\cdots$ & & & & & & & 33 \\
\hline & .... & …. & 3.45 & 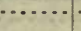 & & & - & $\cdots$ & & & & & & & 34 \\
\hline & & $\because$ & 2.61 & ". & & N. & & & & & & & & & 35 \\
\hline & & $\ddot{*}$ & $\cdots \cdot$ & $\cdots$ & & & & & & & & & & .. & $\begin{array}{l}36 \\
37\end{array}$ \\
\hline & 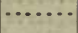 &. & $\because$ & 1 & & & & & & & & & & $\ldots$ & 38 \\
\hline & &. & & & & & & & & & & & & & 39 \\
\hline & . & 14.83 & & & & & & & & & & & & & 40 \\
\hline & & 15.00 & & & & 16.00 & & & & & & & & & $\begin{array}{l}41 \\
42\end{array}$ \\
\hline & - & 29.66 & & 31. & & 31.25 & & & & & & & & $\cdot$ & $\begin{array}{l}42 \\
43\end{array}$ \\
\hline & ... & 16.92 & & & & 19.00 & & & & & & & & & 44 \\
\hline & . & $\begin{array}{l}58 \\
31\end{array}$ & 15.00 & 16. & & 16 & & & & & & & & & 45 \\
\hline & • & $\begin{array}{r}11.31 \\
8.65\end{array}$ & $\begin{array}{r}10.50 \\
7.50\end{array}$ & $\begin{array}{r}12.17 \\
9.45\end{array}$ & & $\begin{array}{l}13.00 \\
10.13\end{array}$ & & & & & & & $\cdots$ & & 46 \\
\hline & - & 11.42 & ..... & 15.25 & & & & & & & & & 12.00 & & $\begin{array}{l}47 \\
48\end{array}$ \\
\hline & . & 44.17 & & $\cdots$ & & ... & & & & & 46.25 & 51. & & & 49 \\
\hline 5 & .... & 25.00 & 1 & $\ldots$ & & $\cdots$ & & & & & & 31.25 & & 37 & 50 \\
\hline & .. & 11.20 & & 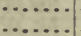 & & & & & & & 11.00 & 22,75 & & $\begin{array}{l}17.00 \\
22.80\end{array}$ & 51 \\
\hline & & & & & & & & & & & 23.67 & 22.70 & & 29.00 & $\begin{array}{l}52 \\
53\end{array}$ \\
\hline & & & & & & & & & & & 16. 07 & & ... & 19.87 & 54 \\
\hline & & & & & & & & & & & & & & 15. 74 & 55 \\
\hline & & & & & & & & & & & & & & 23.00 & 56 \\
\hline & & & & & & & & & & & & & & 16.83 & $\begin{array}{l}57 \\
58\end{array}$ \\
\hline & & 16. 50 & & & & 13. 7 & & & & & & & & & $\begin{array}{l}50 \\
59\end{array}$ \\
\hline & .67 & $\begin{array}{l}38.33 \\
21.77\end{array}$ & 39.00 & 39.40 & $\$ 38$ & 1 & & & & 3 & 38. & 40 & & & 60 \\
\hline & & & 20.67 & $\begin{array}{l}22.20 \\
11\end{array}$ & 23 & 22.67 & $\cdots$ & 8 & & 26.00 & 24.80 & & 33 & 31.47 & 61 \\
\hline & & $\begin{array}{r}11.37 \\
5.46\end{array}$ & $\begin{array}{r}10.50 \\
5.00\end{array}$ & $\begin{array}{r}11.39 \\
5.50\end{array}$ & $\begin{array}{c}11.67 \\
\ldots . . .\end{array}$ & $\begin{array}{r}1.94 \\
6.25\end{array}$ & & & & $\begin{array}{r}14.00 \\
7.60\end{array}$ & 13. & $\begin{array}{r}15 \\
8\end{array}$ & $\begin{array}{r}14.22 \\
6.89\end{array}$ & $\begin{array}{r}17.54 \\
8.42\end{array}$ & 62 \\
\hline & .. & 17.57 & 21.27 & 21.33 & & 18.50 & & & & 17.83 & 21.10 & 20.79 & $\begin{array}{r}0.00 \\
15.21\end{array}$ & 20.42 & $\begin{array}{l}03 \\
64\end{array}$ \\
\hline & $\cdots$ & 50.7 & $\cdots$ & 40 & & 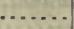 & & & & & 53.81 & 51.67 & & . & 65 \\
\hline & $\ldots$ & 31.14 & 6 & 30.33 & & & & & & & 31.22 & 30 & & & 66 \\
\hline & & 17.18 & & 16.08 & & & & & & & $\begin{array}{l}16.67 \\
33.00\end{array}$ & 19.00 & & & 67 \\
\hline & & 66 & & 70 & 68. & 72 & & & & & 65 & & & 73. & $\begin{array}{l}68 \\
69\end{array}$ \\
\hline & & & & 39. & 39.33 & 41.75 & & & & & & & & 45.50 & 7 \\
\hline & .. & 19.93 & & 19.85 & 18.67 & 21.33 & & & & & & 22.41 & & 23.75 & 71 \\
\hline 7 & - & & & $\cdots$ & ........ & & & & & & & & & & 72 \\
\hline & & & & & & & & & & $\begin{array}{l}50 . \\
35 .\end{array}$ & & 9 & $\begin{array}{l}48 \\
36\end{array}$ & 0 & $\begin{array}{l}73 \\
74\end{array}$ \\
\hline & & & & & & & & & & 28. & 26. 22 & 13 & 29 & 33 & 75 \\
\hline & & & & & & & & & & 15.14 & 14.85 & 16.79 & 17.88 & 21.55 & 76 \\
\hline & & & & & & & & & & & 28.27 & 28.40 & ....... & 27.42 & 77 \\
\hline & & & 12.81 & & & & & & & & & $\cdots \cdots$ & & in & 78 \\
\hline 80 & & & 12.27 & & & & & & & & & & & & 80 \\
\hline
\end{tabular}




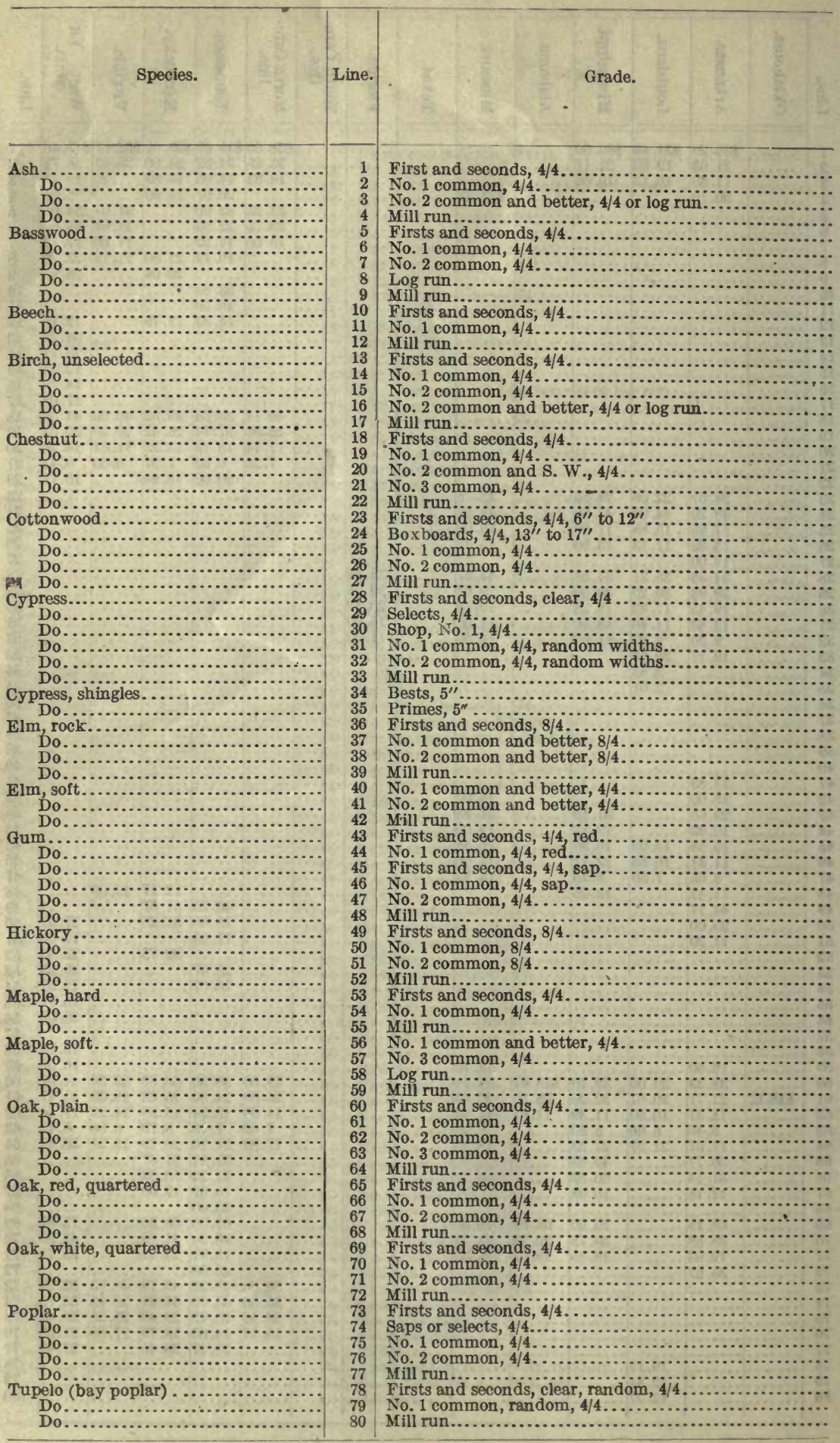




\begin{tabular}{|c|c|c|c|c|c|c|c|c|c|c|c|c|c|c|c|}
\hline$\stackrel{\mathscr{Z}}{3}$ & క్ర & $\frac{\dot{0}}{0}$ & 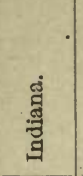 & 音 & 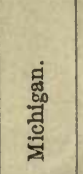 & 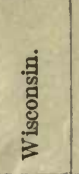 & 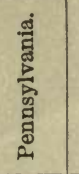 & 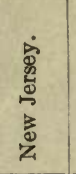 & 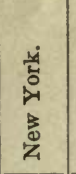 & 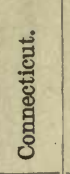 & 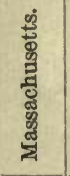 & 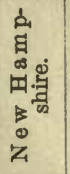 & 율 & 唸 & $\frac{8}{\not 1}$ \\
\hline 1 & & 3. 67 & $\$ 40.88$ & $\$ 41.25$ & & 37.30 & & & & & & & & & \\
\hline 2 & & & 25.63 & 25.00 & & 3.81 & & & 6.00 & & & & & & \\
\hline 3 & & & $\begin{array}{l}19 \\
30\end{array}$ & 17.38 & & $\begin{array}{r}21.49 \\
18.88\end{array}$ & & & 24.70 & 00 & $\$ 21$ & & $\$ 17.00$ & & \\
\hline 4 & & & $\begin{array}{l}30.00 \\
32.38\end{array}$ & & & $\begin{array}{l}18.88 \\
34.19\end{array}$ & & & 33.00 & &. & & $\begin{array}{l}21.40 \\
28.33\end{array}$ & & \\
\hline 6 & & 22 & 22.29 & & & 22.59 & & & & & & & 20.00 & & \\
\hline 7 & & 15. & 1 & & & 13.19 & & & 7 & & & & & & \\
\hline $\begin{array}{l}8 \\
9\end{array}$ & & 20. & $\begin{array}{l}50 \\
\ldots\end{array}$ & & & $\begin{array}{l}22.13 \\
19.45\end{array}$ & & & & & 19.33 & & $\begin{array}{l}19.33 \\
19.30\end{array}$ & & \\
\hline & & 21.43 & 22.60 & & & & & & & & & & $\begin{array}{l}19.30 \\
20.33\end{array}$ & & \\
\hline & & 17. & 16.67 & & & & & & & & & & & & \\
\hline 2 & & 14.44 & $\begin{array}{r}16.56 \\
\end{array}$ & & & $\begin{array}{l}13.17 \\
34.41\end{array}$. & & & & 15.83 & 15.50 & & & & \\
\hline 4 & & $\ldots$ & & & & $\begin{array}{l}34.41 \\
19.14\end{array}$ & & & & & & & 24.33 & & \\
\hline & & & & & & 11.25 & & & & & & & & & \\
\hline 6 & & & & & & 20.53 & & & & & & & & & \\
\hline 17 & & 39 & 4100 & & 16 & 17.08 & & & & 15.58 & 15.40 & $\$ 15$ & 15.89 & & \\
\hline 8 & & $\begin{array}{l}39.60 \\
26.83\end{array}$ & $\begin{array}{l}41.00 \\
27.00\end{array}$ & & & '........ & $\begin{array}{l}36.00 \\
26.40\end{array}$ & $\$ 31.25$ & &. & ….... & & & & \\
\hline & & 15.40 & 15.25 & & & . & 16.70 . & & & & & & & & \\
\hline & & 13 & - & & & & & & & & & & & & \\
\hline 23 & & 19 & & & & & 17.45 & 23.50 & 19.20 & 19.58 & $\begin{array}{c}18.71 \\
\ldots .\end{array}$ & 18.17 & & & \\
\hline & & & & & & & & & & & $\cdots$ & & & & \\
\hline & & & . & & & & & & & & & & & & \\
\hline 27 & $\$ 17.50$ & .... & 18.00 & & & & & & & & & & & & \\
\hline & $\cdots$ & & .... & & & & & & & & & & & & \\
\hline 30 & & & & & & & & & & & & & & & \\
\hline & & & & & & & & & & & & & & & 3 \\
\hline & & & & & & & & & & & & & & & \\
\hline 34 & & & & & & & & & & & & & & & 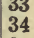 \\
\hline & & & & & & 34,20 & & & & & & & & .. & \\
\hline 37 & & & & & & $\begin{array}{l}34.20 \\
28.80\end{array}$ & & & & & & & & & \\
\hline 38 & & & & & 23.82 & 22.40 & & & & & & & & & \\
\hline 3. & & & & & & 17.85 & & & & & & & & & \\
\hline 40 & & 22.75 & 24.82 & & 3 & 26.00 & & & & $\bullet$ & & & & & \\
\hline 42 & 17.17 & $\begin{array}{l}19.50 \\
18.50\end{array}$ & $\begin{array}{l}19.45 \\
18.33\end{array}$ & & $\begin{array}{l}25.00 \\
18.38\end{array}$ & $\begin{array}{l}19.38 \\
15.33\end{array}$ & & & & & & & $\ldots$ & - & \\
\hline $\begin{array}{l}42 \\
43\end{array}$ & $\begin{array}{r}17.17 \\
\ldots . . . . .\end{array}$ & $\begin{array}{c}18.50 \\
\ldots . . .\end{array}$ & $\begin{array}{l}18.33 \\
31.33\end{array}$ & & 18.38 & 10.00 & & & & & & & & & \\
\hline 4 & & & 18.25 & & & & & & & & & & & .. & \\
\hline 46 & & $\cdots$ & 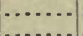 & & & & & & & & & & & & \\
\hline 4 & & & & & & & & & & & & & & . & \\
\hline 48 & & & 16.08 & & & & & & & & & & & & \\
\hline & & & 47.54 & & & & & & & & & & & $\cdots$ & \\
\hline 5 & ....... & & $\begin{array}{l}30.42 \\
18.75\end{array}$ & $\begin{array}{l}32.00 \\
24.38\end{array}$ & & $\cdots$ & & 54.17 & & & & & & $\cdots$ & \\
\hline 5 & & & 31.58 & & & & 26.50 & 38.75 & & 23.00 & & & & & \\
\hline 53 & & 2 & 25.70 & & 76 & 26.68 & 26 & $\ldots$ & 26 & $\ldots$ & & & 33 & & \\
\hline 5 & ... & & 19.56 & & 21.25 & 17.52 & 16 & .. & 18.63 & & & & 67 & & \\
\hline 5 & $\cdots$ & 17.30 & 20.09 & & 19.13 & 16.02 & 17.20 & $\cdots$ & 19.36 & 17.10 & 19.00 & & 16.85 & ... & \\
\hline $\begin{array}{l}56 \\
5\end{array}$ & & 23.40 & 24.67 & & 8.33 & $\begin{array}{r}21.58 \\
7.58\end{array}$ & & & $N$ & & & & .. & & \\
\hline & & 19.25 & 17.70 & & & 16.05 & & & & & & & & & \\
\hline 5 & 15.83 & 1 & A & & 16.16 & 14.25 & 16.50 & & 17.81 & 14.00 & 14.40 & & 14.25 & & \\
\hline & ….... & & 41.67 & 40.60 & .... & 45. 22 & 34.50 & 43.33 & ....... & ....... & ...... & & $\cdots$ & & \\
\hline & …… & $\begin{array}{l}2 \\
2\end{array}$ & 27. & $\begin{array}{l}27.50 \\
16.13\end{array}$ & & $\begin{array}{l}31 . \\
18 .\end{array}$ & 26. & $\cdots$ & & & & & & & \\
\hline 6 & & & $\begin{array}{l}17.77 \\
11.13\end{array}$ & $\begin{array}{l}16.13 \\
12.67\end{array}$ & & $\begin{array}{r}18.69 \\
9.11\end{array}$ & & & & & & & & & \\
\hline 6 & & & 28.20 & & & 27.49 & 22.18 & 30.00 & 25.20 & 21.23 & 22.14 & 21.25 & & 20.67 & \\
\hline & & & & & & ..... & ….... & ….... & ........ & ....... & ....... & & & ....... & \\
\hline 6 & & $\begin{array}{l}33.00 \\
20.50\end{array}$ & $\begin{array}{l}34.64 \\
19.29\end{array}$ & & & & & & & & & & & & \\
\hline & & & & & & & & & & & & & & & \\
\hline & & $\begin{array}{l}73.56 \\
45.81\end{array}$ & & & & & & & & & & & & & \\
\hline & & $\begin{array}{l}45 \\
26\end{array}$ & & & & & & & & & & & & & \\
\hline & 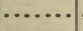 & & & & & & & & & & & & & & \\
\hline & & 5 & 50.79 & & & & & & & & & & & & \\
\hline & & & & & 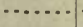 & & & & & & & & & $\cdots$ & \\
\hline 76 & & 21 & 18.90 & 17.67 & & 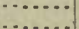 & (a) & & & & & & & & \\
\hline 77 & & $32.8 \varepsilon$ & ..... & & & & 22.35 & & & & & & & & \\
\hline 7 & & …. & & & & & & & & & & & & & \\
\hline 80 & & & & & & & & & & & & & & & \\
\hline & & & & & & & & & & & & & & & \\
\hline
\end{tabular}




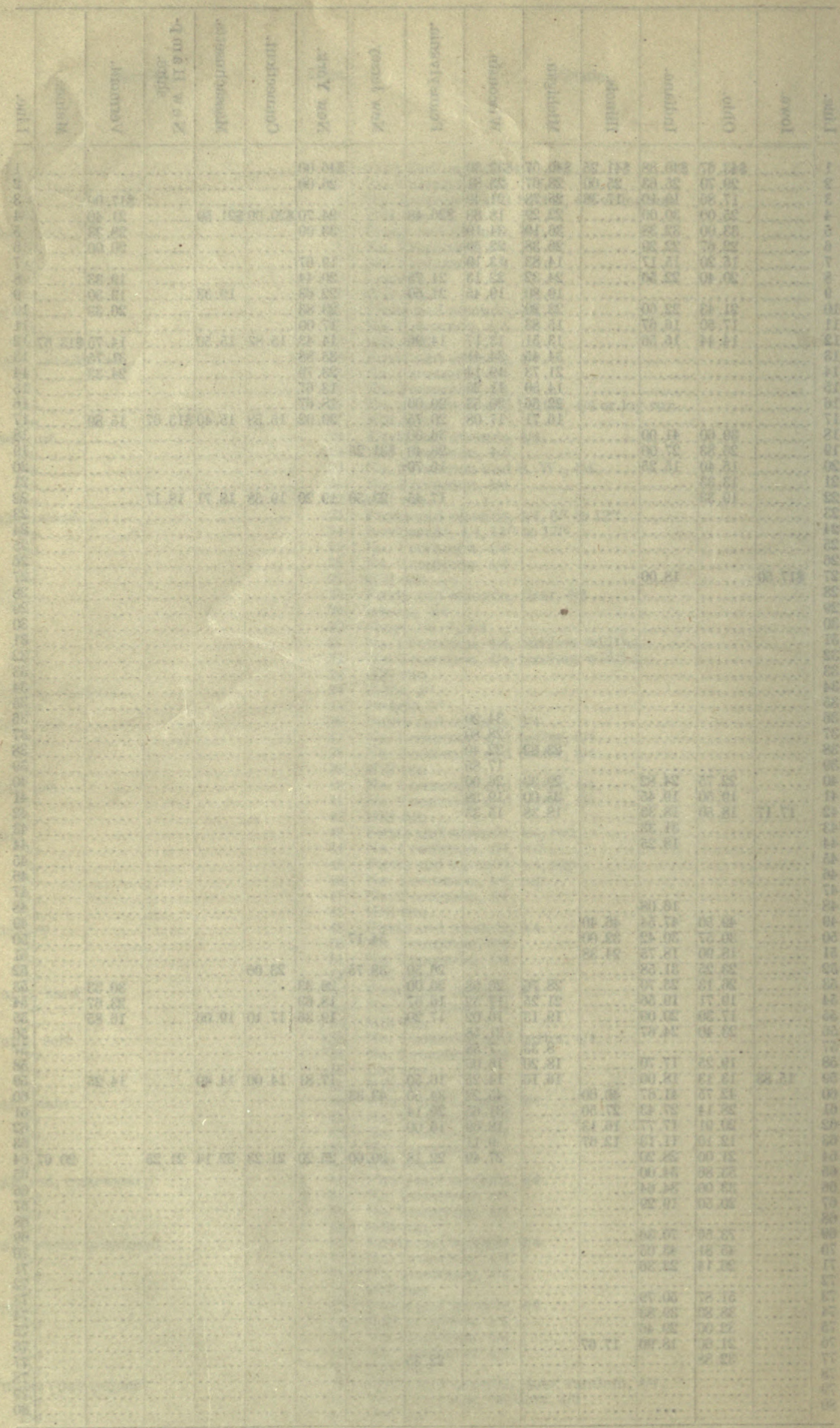


U. S. DEPARTMENT OF AGRICULTURE, FOREST SERVICE. HENRY S. GRAVES, Forester.

\section{RECORD OF WHOLESALE PRICES OF LUMBER. \\ (PER 1,000 FEET B. M.)}

BASED ON ACTUAL SALES MADE F. O. B. MILL FOR

EACH QUARTER OF THE CALENDAR YEAR 1911. 
The Forest Service is engaged in many investigations of interest to lumber manufacturers. A copy of any of the following recent reports may be obtained by addressing the Editor and Chief, Division of Publications, United States Department of Agriculture, Washington, D. C.:

Forest Service Circular 180-Lumber Saved by Using Odd Lengths.

Forest Service Circular 187-Manufacture and Utilization of Hickory.

Forest Service Circular 189-Strength Values for Structural Timbers.

Forest Service Circular 192-The Prevention of Sap Stain in Lumber.

Division of Publications Circular 11-List of Available Publications of the Forest Service. 


\section{- PREFATORY NOTE.}

The Forest Service has two main purposes in collecting and compiling this record of f. o. b. mill prices: First, to have a continuous statistical record of such prices of the various commercial woods; and, second, to show, in contrast to market prices-which include the important items of freight charges and selling costs-just what the manufacturers of lumber receive for their product at the mill. The prices given are wholesale, based on actual sales f. o. b. mill, for delivery outside of local territory. Only a few representative grades and the mill run are included. By mill run is meant the average of all grades of lumber produced. The record is compiled by States, and is made up from reports received from approximately 3,000 of the largest manufacturers scattered throughout the country. It is published quarterly.

The Forest Service wishes to acknowledge the courtesy of the manufacturers for their prompt and efficient cooperation. Their assistance has been of great value in making the record complete, accurate, and promptly available for distribution.

NoтE.-For this issue of the record a departure has been made from the usual form of compilation. In addition to the average prices for the last quarter of the calendar year 1911 there are also reproduced the average,prices of the three preceding quarters. This has been done to permit of a comparison for the four periods of the year.

Figures in bold-faced type indicate an average for the last two quarters. 


\section{SUMMARY.}

Lumber prices for the last three months of 1911 were generally lower than for any of the preceding quarters. In some cases, however, the period showed important advances.

The prices obtained for Douglas fir, following an almost constant decline during the year, were lowest during the fourth quarter. Flooring and finish in Washington and Oregon dropped $\$ 1$ to $\$ 4$ under prices of the spring and summer. The lower grades do not show much change during the latter half of the year, and timbers and crossties in particular remained nearly stationary. Western hemlock prices reached bottom for the year in the fourth quarter. Flooring Nos. 1 and 2 was $\$ 4.50$ lower than in the third quarter, and the other grades fell about $\$ 1$ during the same period. Sugar pine sold at prices lower by $\$ 2$ for shop No. 1 and by $\$ 5$ for Nos. 1 and 2 clear than in the third quarter. Idaho pine prices for the last quarter were the lowest for the year. The decline from the third quarter prices amounted to from $\$ 3$ to $\$ 5$ in finish, C and D select, and from $\$ 2$ to $\$ 3$ in beveled siding, B and C. Common boards, however, show a rise of nearly one-half dollar. Western pine prices were generally lower for the fourth quarter, but while some items sold for from $\$ 1$ to $\$ 3$ less, other items suffered no decline. Redwood clears were lower by about $\$ 2$, but common boards and crossties sold at better prices during October, November, and December than during the first six months of the year. Sitka spruce prices show little change during the latter half of the year.

Except in Mississippi, yellow pine sold generally in the Mississippi Valley States for the lowest prices of the year. In Texas and Arkansas the fall amounted to from $\$ 1$ to $\$ 2$ in flooring, finish, etc., and in Louisiana to somewhat less. In Mississippi the general average for the fourth quarter about equaled that for the third. Alabama prices suffered a decline of from $\$ 0.50$ to $\$ 2$. In Florida and Georgia yellow pine prices improved during the last few months of the year, and the grades of flooring show an advance for the fourth quarter of from $\$ 2$ to $\$ 6$ over the third; common boards of from $\$ 1$ to $\$ 2$; plank and dimension stock, $\$ 0.50$ to $\$ 4$. North Carolina pine prices also improved in the last few months of 1911 , the advance averaging somewhat less than $\$ 1$ in South Carolina and North Carolina. In West Virginia spruce, merchantable frames and boards sold at from $\$ 1$ to $\$ 2$ in advance of the prices for the preceding: months of the year. Adirondack and New England spruce and hemlock generally brought the lowest prices for the year during the fourth quarter. Hemlock in Wisconsin was lower by from 25 to 50 cents; in Michigan higher by about the same amounts. White pine prices were the lowest for the entire year, the decline being more marked in Minnesota than in Wisconsin or Michigan, the latter holding up the best. It is noticeable that prices obtained for No. 4 boards in the Lake States were higher for the last quarter of the year.

Prices of ash fell off by amounts up to $\$ 5$ and $\$ 6$ under third quarter prices, but in very many cases sales were made at prices equal to those obtained during the first three months of the year. In basswood most items were lower by a few cents to $\$ 3$, but in West Virginia, firsts and seconds sold at $\$ 3$ and No. 1 common at $\$ 0.67$ over third quarter prices, while in Michigan and Wisconsin firsts and seconds fell off about $\$ 1$; No. 1 common, from $\$ 0.25$ to $\$ 1.50$; while No. 2 common rose $\$ 2$ in Michigan and 
$\$ 1.25$ in Wisconsin. Beech sold at lower figures in West Virginia and higher in Indiana. In Michigan firsts and seconds rose $\$ 0.50$ and No. 1 common over $\$ 2$.

Birch prices declined slightly throughout the country. In West Virginia the decline amounted to as much as $\$ 4$ in firsts and seconds; and in New York prices fell by from $\$ 1$ to $\$ 2$. However, in Michigan and Wisconsin there were almost no changes in prices reported for sales of graded lumber, but the mill-run average rose $\$ 1$ in Michigan, while in Wisconsin the mill-run average fell off $\$ 1.50$ from third-quarter reports.

Chestnut prices were about equal to those of the third quarter. In Virginia firsts and seconds advanced $\$ 1$, while No. 1 common declined $\$ 1$. In Ohio prices were $\$ 0.50$ to $\$ 2$ lower. In cottonwood items, box boards suffered no decline in Mississippi, but declined nearly $\$ 3$ in Arkansas and nearly $\$ 2$ in Louisiana. Firsts and seconds fell off $\$ 1.50$ in Arkansas and rose $\$ 2.50$ in Louisiana and $\$ 1$ in Missouri. No. 1 and No. 2 common rose by about $\$ 1$ in Arkansas, Louisiana, and Mississippi.

Cypress was generally sold for lower prices in the Mississippi Valley States, exceptions being No. 2 common in Arkansas and selects in Louisiana. In Florida cypress firsts and seconds, selects, and No. 2 common rose by from $\$ 1$ to $\$ 1.50$ over the third quarter prices, reaching the highest point for the year. Shop No. 1 and No. 1 common sold for the lowest prices reported throughout the year.

In oak many changes may be noted. In Arkansas, Louisiana, Mississippi, North Carolina, Tennessee, and Kentucky fourth quarter prices held well with those obtained during the third quarter, but in Indiana, Alabama, Missouri, and Virginia firsts and seconds fell off by from $\$ 2$ to $\$ 4$, No. 1 common by from $\$ 1.50$ to $\$ 3.25$, and No. 2 common by from $\$ 0.50$ to $\$ 1$. In West Virginia oak sold for the highest prices reported in any quarter. Firsts and seconds rose by $\$ 1.50$ over the third quarter and No. 1 common by $\$ 1$.

The prices of poplar suffered no decline in the last three months of the year in Tennessee, Kentucky, and North Carolina. In Virginia the prices obtained for poplar were the lowest of the year. Compared with third quarter prices, firsts and seconds fell off $\$ 4$, saps $\$ 3$, No. 1 common $\$ 2.50$, No. 2 common $\$ 3$. In West Virginia poplar prices touched the highest point of the year. Firsts and seconds and saps rose $\$ 1$ over third quarter prices, and No. 1 common rose \$2. In Ohio and Indiana poplar prices suffered no decline except in the case of saps, which fell off $\$ 2$ in Ohio, $\$ 1$ in Indiana, and No. 1 common, which fell off $\$ 1$ in Indiana. 


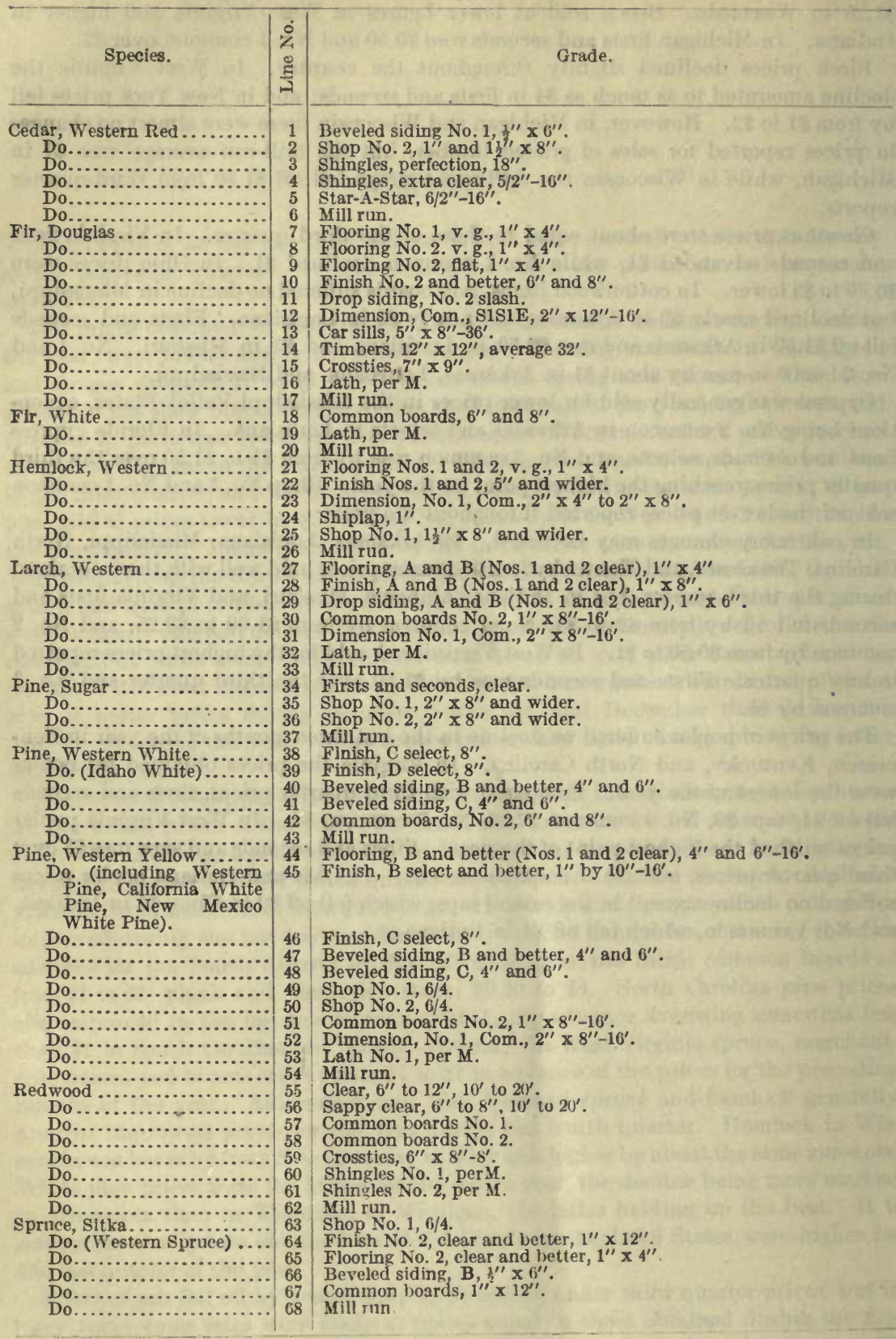


WHOLESALE PRICES OF LUMBER.

Line Numbers Refer to Grades Listed on Page 6.

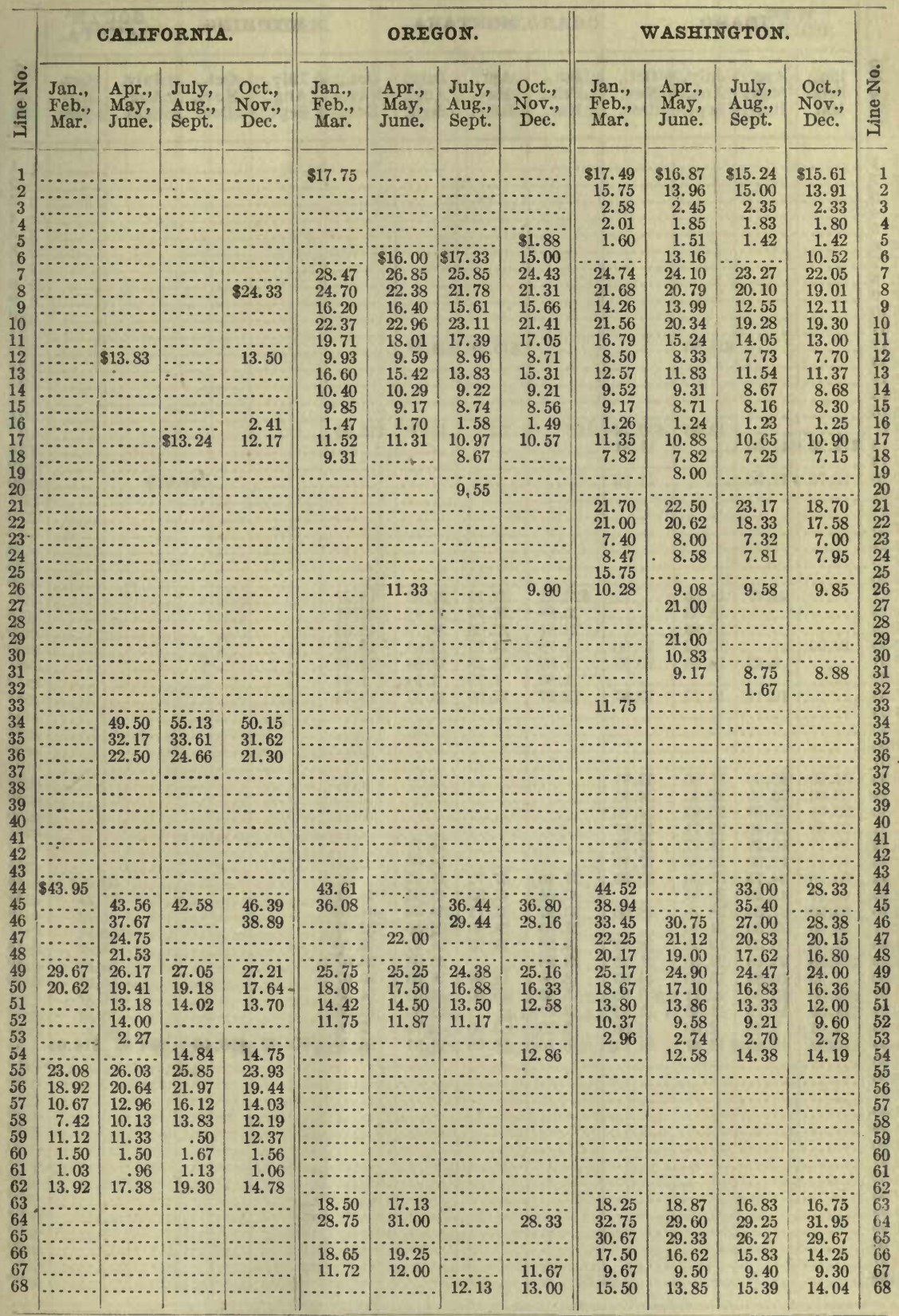


WHOLESALE PRICES OF LUMBER.

Line Numbers Refer to Grades Listed on Page 6.

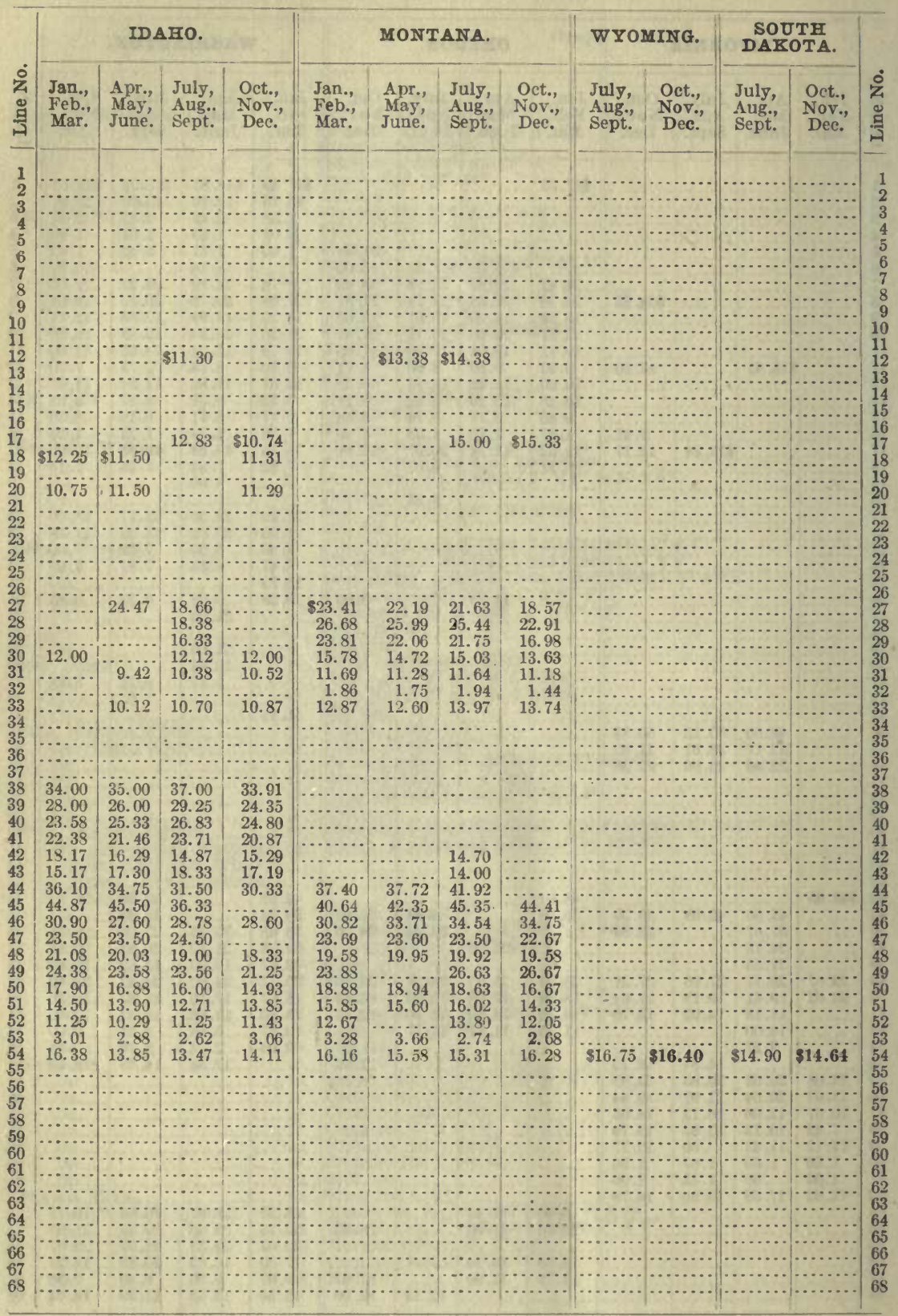


WHOLESALE PRIOES OF LUMBER.

Line Numbers Refer to Grades Listed on Page 6.

\begin{tabular}{|c|c|c|c|c|c|c|c|c|c|c|c|}
\hline \multirow[b]{2}{*}{ 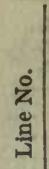 } & \multicolumn{2}{|c|}{ NEVADA. } & \multicolumn{2}{|c|}{ ШТАН. } & \multicolumn{3}{|c|}{ COLORADO. } & \multirow[b]{2}{*}{$\begin{array}{l}\text { Oct., } \\
\text { Nov., } \\
\text { Dec. }\end{array}$} & \multicolumn{2}{|c|}{$\begin{array}{c}\text { NEW } \\
\text { MEXICO. }\end{array}$} & \multirow[b]{2}{*}{ 总 } \\
\hline & $\begin{array}{l}\text { July, } \\
\text { Aug.; } \\
\text { Sept. }\end{array}$ & $\begin{array}{c}\text { Oet., } \\
\text { Nov., } \\
\text { Dec. }\end{array}$ & $\begin{array}{l}\text { July, } \\
\text { Aug., } \\
\text { Sept. }\end{array}$ & $\begin{array}{l}\text { Oct., } \\
\text { Nov.. } \\
\text { Dec. }\end{array}$ & $\begin{array}{l}\text { Jan., } \\
\text { Feb., } \\
\text { Mar. }\end{array}$ & $\begin{array}{l}\text { Apr., } \\
\text { May, } \\
\text { June. }\end{array}$ & $\begin{array}{l}\text { July, } \\
\text { Aug., } \\
\text { Sept. }\end{array}$ & & $\begin{array}{l}\text { July, } \\
\text { Aug., } \\
\text { Sept. }\end{array}$ & $\begin{array}{l}\text { Oct., } \\
\text { Nov., } \\
\text { Dec. }\end{array}$ & \\
\hline 1 & & & & & & & & & & & 1 \\
\hline $\begin{array}{l}3 \\
4\end{array}$ & & & & & & & & & & & 3 \\
\hline 5 & & & & & & & & & & & $\begin{array}{l}4 \\
5\end{array}$ \\
\hline $\begin{array}{l}6 \\
7\end{array}$ & & & & & & & & & & & 6 \\
\hline $\begin{array}{l}8 \\
9\end{array}$ & & & & & & & & & & & $\begin{array}{l}7 \\
8\end{array}$ \\
\hline 10 & & & & & & & & & ......... & & 9 \\
\hline $\begin{array}{l}11 \\
12\end{array}$ & & & & & & & $\cdots$ & & & & $\begin{array}{l}10 \\
11\end{array}$ \\
\hline $\begin{array}{l}12 \\
13\end{array}$ & $\cdots$ & & & & & & $\begin{array}{l}\cdots \\
\cdots\end{array}$ & & & & 12 \\
\hline $\begin{array}{l}14 \\
15\end{array}$ & & & & & & & & & & & $\begin{array}{l}13 \\
14\end{array}$ \\
\hline 16 & & & & & & & & & & & $\begin{array}{l}15 \\
16\end{array}$ \\
\hline $\begin{array}{l}17 \\
18\end{array}$ & & & & & & $\$ 15.00$ & $\$ 14.00$ & & & & $\begin{array}{l}10 \\
17\end{array}$ \\
\hline $\begin{array}{l}19 \\
20\end{array}$ & & & & & & & & & & & $\begin{array}{l}18 \\
19\end{array}$ \\
\hline 20 & & $\$ 13.36$ & & & & & & & & & 20 \\
\hline 22 & & & & & & & & & & & $\begin{array}{l}21 \\
22\end{array}$ \\
\hline & & & & & & & & & & & 23 \\
\hline $\begin{array}{l}25 \\
26\end{array}$ & & & & & & & & & & & $\begin{array}{l}24 \\
25\end{array}$ \\
\hline 28 & & & & & & & & & & & 26 \\
\hline 28 & & & & & & & & & & & $\begin{array}{l}27 \\
28\end{array}$ \\
\hline 30 & & & & & & & & & & & 29 \\
\hline $\begin{array}{l}31 \\
32\end{array}$ & & & & & & & & & & & 31 \\
\hline 33 & & & & & & & .... & $\cdots$ & & $\cdots$ & 32 \\
\hline 35 & & & & $\cdots$ & & & ....... & ..... & $\cdots \cdots \cdot$. & $\cdots$. & $\begin{array}{l}33 \\
34\end{array}$ \\
\hline 36 & & & & & ... & & (n....... & $\cdots$ & …... & ……. & 35 \\
\hline 38 & & & & & & & $\cdots$ & $\ldots$ & $\cdots \cdots$ & …. & $\begin{array}{l}50 \\
37\end{array}$ \\
\hline $\begin{array}{l}39 \\
40\end{array}$ & & & & & & & & & & … & $\begin{array}{l}38 \\
39\end{array}$ \\
\hline 41 & & & & & & & & & & & 40 \\
\hline 42 & & & & & & & & $\cdots$ & $\cdots$ & $\cdots$ & 41 \\
\hline 44 & $\$ 39.00$ & & & & & & & & & & 43 \\
\hline & 43.17 & & & & $\cdots$ & & & & .... & : & $\begin{array}{l}44 \\
45\end{array}$ \\
\hline $\begin{array}{l}46 \\
47\end{array}$ & $\begin{array}{l}35.13 \\
24.00\end{array}$ & & & & 82625 & & & & & & $\begin{array}{l}70 \\
46\end{array}$ \\
\hline 48 & 20.67 & & & & & & $\cdots$ & & & ... & $\begin{array}{l}47 \\
48\end{array}$ \\
\hline $\begin{array}{l}49 \\
50\end{array}$ & $\begin{array}{l}25.55 \\
19.94\end{array}$ & & & & ...... & & $\cdots$ & $\cdots$ & .. & $\$ 23.67$ & 49 \\
\hline $\begin{array}{l}51 \\
52\end{array}$ & 15. 75 & ........ & .... & & 12. 50 & 13.17 & ii. 88 & $\$ 13.00$ & & 14.00 & $\begin{array}{l}50 \\
51\end{array}$ \\
\hline 52 & $\begin{array}{r}16.67 \\
3.25\end{array}$ & & & & $\begin{array}{r}14.25 \\
3.85\end{array}$ & $\begin{array}{r}14.00 \\
3.53\end{array}$ & 14. 63 & 14. 83 & & 14.67 & 52 \\
\hline 54 & & 15.17 & $\$ 20.00$ & $\$ 21.50$ & 13.70 & 13.73 & 14. 86 & 13.94 & $\$ 12.67$ & 13.75 & 54 \\
\hline $\begin{array}{l}56 \\
57\end{array}$ & & & & & & & & & & & $\begin{array}{l}55 \\
56\end{array}$ \\
\hline 58 & & .... & & ...... & & …... & ..... & $\ldots$ & $\cdots$ & ……... & 57 \\
\hline 60 & & & & & & & & $\cdots$ & & & 59 \\
\hline 61 & & . & & & $\ldots$ & $\therefore$ & $\ldots$ & 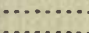 & & & 60 \\
\hline 63 & & & & & & & ......... & & $\ldots \ldots \ldots$ & … & 62 \\
\hline 64 & & & & ...... & & & ...... & & & & 63 \\
\hline 00 & & & & & & & & & ... & & 65 \\
\hline 67 & & & & & & 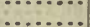 & ..... & $\ldots$ & $\cdots$ & .... & $\begin{array}{l}00 \\
67\end{array}$ \\
\hline 68 & & & & & & & 12. 40 & & & & 68 \\
\hline
\end{tabular}

$27722-12-2$ 


\begin{tabular}{|c|c|c|c|c|}
\hline \multirow[b]{2}{*}{ Species. } & \multirow[b]{2}{*}{$\begin{array}{l}\stackrel{0}{Z} \\
\stackrel{9}{3}\end{array}$} & \multirow[b]{2}{*}{ Grade. } & \multicolumn{2}{|c|}{ OKLAHOMA. } \\
\hline & & & $\begin{array}{l}\text { July, } \\
\text { Aug., } \\
\text { Sept. }\end{array}$ & $\begin{array}{l}\text { Oct., } \\
\text { Nov., } \\
\text { Dec. }\end{array}$ \\
\hline mlocl & 1 & $2^{\prime \prime}$ plece stuff, S1S1E, $2^{\prime \prime} \times 4^{\prime \prime}-16^{\prime}$ & & \\
\hline Do.. & 2 & Boards, No. 1 , S1S, $1^{\prime \prime} \times 8^{\prime \prime}-16^{\prime} \ldots$ & & \\
\hline I & 3 & Timbers, rough, $4^{\prime \prime} \times 4^{\prime \prime}$ to $8^{\prime \prime} \times 8^{\prime \prime}$ & & \\
\hline $\begin{array}{l}\text { Do. } \\
\text { Do. }\end{array}$ & $\begin{array}{l}4 \\
5\end{array}$ & 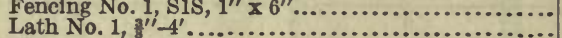 & & \\
\hline & 6 & 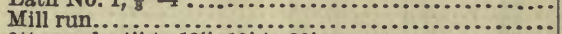 & & \\
\hline Hemlock (Easter & 7 & $8 / 4$ merch. $4^{i i}$ to $12^{\prime}, 10^{\prime}$ to $20^{\prime}$ & & \\
\hline Do.... & 8 & and $8^{\prime \prime}-16^{\prime} \ldots \ldots$ & & \\
\hline D & $\begin{array}{r}9 \\
10\end{array}$ & erch. $10^{\prime \prime}$ and $12^{\prime \prime}-16^{\prime} \ldots \ldots \ldots$ & & \\
\hline Do. & 11 & $4 / 4$ boards, No. $2,1^{\prime \prime} \times 4^{\prime \prime}-12^{\prime \prime}, 6^{\prime}-20^{\prime}$. & & \\
\hline Do.. & 12 & Mill run, mill culls out............... & & \\
\hline$\cdots$ & 13 & s......................... & & \\
\hline no, Nor & $\begin{array}{l}14 \\
15\end{array}$ & Flooring, No. $2,1^{\prime i} \times 4^{\prime \prime} \times{ }^{\prime} 0^{\prime}-16^{\prime}$ & & \\
\hline D́o.... & 16 & Flooring, No. $3,1^{\prime \prime} \times 4^{\prime \prime} \times 10^{\prime}-16^{\prime}$ & & \\
\hline Do. & 17 & Dimension (air dried), $2^{\prime \prime} \times 8^{\prime \prime}-16^{\prime}$ and & & \\
\hline Do & 18 & Roofers, $1^{\prime \prime} \times 8^{\prime \prime}$, D \& M $\ldots \ldots \ldots$ & & \\
\hline$+\quad$ Do & $\begin{array}{l}19 \\
20\end{array}$ & Partition No. 1, 13/16" $\times 33^{\prime \prime \prime}, 10^{\prime}-16$ & & \\
\hline Do. & 21 & 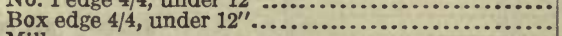 & & \\
\hline Do. & 22 & Mill I & & \\
\hline $\begin{array}{l}\text { Pine, W } \\
\text { Do. }\end{array}$ & 23 & $\mathrm{C}$ and better, $5 / 4$ (M. L.). & & \\
\hline $\begin{array}{l}\text { Do } \\
\text { Do }\end{array}$ & $\begin{array}{l}24 \\
25\end{array}$ & $\begin{array}{l}\text { C selects, } 10^{\prime \prime} \\
3 / 4 \text { (M. L.) }\end{array}$ & & \\
\hline & 26 & Shop No. $3,5 / 4$ (M. L.)... & & \\
\hline D & 27 & Beveled siding, $\mathbf{C}, 6^{\prime \prime} \times 16^{\prime}$. & & \\
\hline $\mathrm{D}$ & 28 & $1^{\prime \prime} \times 8^{\prime \prime}-16^{\prime} \ldots$ & & \\
\hline$\cdots$ & $\begin{array}{l}29 \\
30\end{array}$ & $12^{\prime \prime}, 10^{\prime}-20^{\prime} \ldots \ldots \ldots \ldots$ & & \\
\hline$\cdots$ & $\begin{array}{l}30 \\
31\end{array}$ & $\begin{array}{l}\text { Boards No. } 4, \text { mixed widths, } 10^{\prime}-20^{\prime} \ldots \\
\text { Fencing No. } 2, \text { S1S, } 6^{\prime \prime} \times 16^{\prime} \ldots \ldots \ldots\end{array}$ & & \\
\hline & 32 & 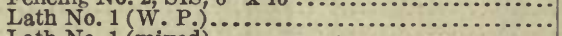 & & \\
\hline $\mathrm{D}$ & 33 & Lath No. 1 (mixed). & & \\
\hline Do.: & $\begin{array}{l}34 \\
35\end{array}$ & 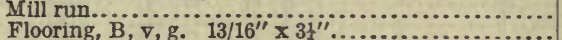 & & \\
\hline ississippi v & 36 & Flooring, No. 2, D. \& M., $1^{\prime \prime} \times 4^{\prime \prime}$.... & & \\
\hline Do. & 37 & S2S and C. M., $1^{\prime \prime} \times 6$ & & \\
\hline Do. & 38 & lat, $13 / 16^{\prime \prime} \times 3 t^{\prime \prime}$. & & \\
\hline D & 39 & nd better, $6^{\prime \prime}$ and wider & & \\
\hline$\ldots$ & $\begin{array}{l}40 \\
41\end{array}$ & $\begin{array}{l}\text { Dimension No. } 1 \text {, S1S1E, } 2^{\prime \prime} \times 8^{\prime \prime}-16^{\prime} \\
\text { Com boards No. } 1 \text { S2S, } 1^{\prime \prime} \times 10^{\prime \prime}\end{array}$ & & 13,50 \\
\hline Do. & 42 & No. $2, \mathrm{~S} 2 \mathrm{~S}, 1^{\prime \prime} \times 8^{\prime \prime}$ & & 10.50 \\
\hline Do. & 43 & Com. boards, No. 2 , S2S, $1^{\prime \prime} \times 12^{\prime \prime}$.. & & 11.44 \\
\hline Do. & 44 & $1 S 1 \mathrm{E}, 6^{\prime \prime} \times 8^{\prime \prime}-16^{\prime} \ldots \ldots$ & & 14.08 \\
\hline$\cdots$ & $\begin{array}{l}45 \\
46\end{array}$ & $\begin{array}{l}\text { Car siding, } B \text { and better, } 1^{\prime \prime} \times 4^{\prime \prime} \text { and } 6 \\
\text { Com. car lining No. } 1,1^{\prime \prime} \times 6^{\prime \prime} \times 10^{\prime}-20\end{array}$ & & \\
\hline & $\begin{array}{l}40 \\
47\end{array}$ & $1, \frac{3}{8}, \ldots \ldots \ldots \ldots \ldots \ldots \ldots$ & & \\
\hline & 48 & Mi & $\$ 15.82$ & 13. 38 \\
\hline ine, Yel & 49 & etter. $6^{\prime \prime}$ and wider. & & \\
\hline ls). & 50 & $\begin{array}{l}\text { better, heart rift, } 13 / 16^{\prime} \\
\text { d better, sap rift, } 13 / 16^{\prime \prime}\end{array}$ & & \\
\hline Do. & $\begin{array}{l}51 \\
52\end{array}$ & $\begin{array}{l}\text { better, sap rift, } 13 / 16^{\prime \prime} \\
\text { art rift, } 13 / 16^{\prime \prime} \times 23^{\prime \prime} \ldots .\end{array}$ & & \\
\hline Do. & 53 & rift, $13 / 16^{\prime \prime} \times 22^{\prime \prime}$. & & \\
\hline Do. & 54 & flat, $13 / 16^{\prime \prime} \times 3 f^{\prime \prime}$ & & \\
\hline $\begin{array}{l}\text { Do. } \\
\text { Do. }\end{array}$ & $\begin{array}{l}55 \\
56\end{array}$ & $\begin{array}{l}\text { Com. boards, No. } 1, \text { S } 2 S, 1^{\prime \prime} \times 10^{\prime \prime} \times 10^{\prime} \\
\text { Com. boards, No. } 2, \text { S2S, } 1^{\prime \prime} \times 10^{\prime \prime} \times 1\end{array}$ & & \\
\hline & & Plank and dimensions & & \\
\hline $\begin{array}{l}\text { Pine, Yellow, merch. grade } \\
\text { (Sail). }\end{array}$ & 57 & Sizes $2^{\prime \prime} \times 6^{\prime \prime}$ to $8^{\prime \prime} \times 8^{\prime \prime}$, average & & \\
\hline Do.. & 58 & Sizes $2^{\prime \prime} \times 9^{\prime \prime}$ to $10^{\prime \prime} \times 10$ & & \\
\hline & 59 & & & \\
\hline & 60 & $14^{\prime \prime} \mathrm{x}$ & & \\
\hline & $\begin{array}{l}61 \\
62\end{array}$ & $\mathrm{Si}_{\mathrm{M}}$ & & \\
\hline Spruc & 63 & frames $9 "$ and under, & & \\
\hline & 64 & $10^{\prime \prime}$ and $12^{\prime \prime}, 24^{\prime}$ and under & & \\
\hline & 65 & m $10^{\prime \prime}$, and $12^{\prime \prime}, 10^{\prime}$ and & & \\
\hline & 66 & $7^{\prime \prime}$ and under, $10^{\prime}$ to $24^{\prime}$. & & \\
\hline & 67 & Merch. $2^{\prime \prime}{ }^{2}$ & & \\
\hline & $\begin{array}{l}68 \\
69\end{array}$ & $1 \xi^{\prime \prime} \ldots$ & & \\
\hline idack).... & 70 & 1 culls ou & & \\
\hline D & 71 & and clear & & \\
\hline & 72 & & & \\
\hline & 73 & M & & \\
\hline & 74 & & & \\
\hline Spruce (West Virginia).. & 76 & Merch. frames $3^{i} x^{\prime \prime}$ to $8^{i},{ }^{\prime \prime}, 10^{\prime}-16^{\prime} \ldots$ & & \\
\hline D & 77 & frames $2^{\prime \prime} \times 12^{\prime \prime}$ to 12 & & \\
\hline & $\begin{array}{l}78 \\
79\end{array}$ & $\begin{array}{l}\text { ls, merch., } 1^{\prime \prime} \times 12^{\prime \prime} \\
\text { s, box, } 1^{\prime \prime} \times 4^{\prime \prime}-12^{\prime}\end{array}$ & & \\
\hline & 80 & $\mathrm{~B}$ & & \\
\hline
\end{tabular}


Line Numbers Refer to Grades Listed on Page 10.

\begin{tabular}{|c|c|c|c|c|c|c|c|c|c|c|c|c|c|}
\hline \multirow[b]{2}{*}{$\begin{array}{l}\stackrel{\circ}{Z} \\
\frac{0}{3} \\
\frac{1}{3}\end{array}$} & \multicolumn{4}{|c|}{ TEXAS. } & \multicolumn{4}{|c|}{ ARKANSAS. } & \multicolumn{4}{|c|}{ LOUISIANA. } & \multirow[b]{2}{*}{$\begin{array}{l}0 \\
z \\
0 \\
9 \\
13\end{array}$} \\
\hline & $\begin{array}{l}\text { Jan., } \\
\text { Feb., } \\
\text { Mar. }\end{array}$ & $\begin{array}{l}\text { Apr., } \\
\text { May, } \\
\text { June. }\end{array}$ & $\begin{array}{l}\text { July, } \\
\text { Aug., } \\
\text { Sept. }\end{array}$ & $\begin{array}{l}\text { Oct., } \\
\text { Nov., } \\
\text { Dec. }\end{array}$ & $\begin{array}{l}\text { Jan., } \\
\text { Feb., } \\
\text { Mar. }\end{array}$ & $\begin{array}{l}\text { Apr., } \\
\text { May, } \\
\text { June. }\end{array}$ & $\begin{array}{l}\text { July, } \\
\text { Aug., } \\
\text { Sept. }\end{array}$ & $\begin{array}{l}\text { Oct., } \\
\text { Nov., } \\
\text { Dec. }\end{array}$ & $\begin{array}{l}\text { Jan., } \\
\text { Feb., } \\
\text { Mar. }\end{array}$ & $\begin{array}{l}\text { Apr., } \\
\text { May, } \\
\text { June. }\end{array}$ & $\begin{array}{l}\text { July, } \\
\text { Aug., } \\
\text { Sept. }\end{array}$ & $\begin{array}{c}\text { Oct., } \\
\text { Nov.. } \\
\text { Dec. }\end{array}$ & \\
\hline 1 & & & & & & & & & & & & . & \\
\hline $\begin{array}{l}2 \\
3\end{array}$ & & & & & & $\cdots$ &. & $\cdots$ & 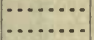 & $\cdots \ldots$ & $\cdots$ & $\ldots$ & \\
\hline 4 & & & & & & $\cdots$ & $\cdots$ & & .... & ........ & $\ldots$ & $\cdots$ & \\
\hline 5 & & & & & & & & $\cdots$ & $\cdots \cdot$ & $\ldots$ & & $\cdots$ & \\
\hline 6 & $\cdots$ & & & & $\mid \begin{array}{l}\ldots \ldots \\
\ldots \ldots \ldots\end{array}$ & $\begin{array}{l}\ldots \\
\ldots\end{array}$ & & $\cdots$ & $\ldots$ & & & $\cdots$ & \\
\hline 0 & $\begin{array}{c}\cdots \\
\cdots\end{array}$ & & $\cdots$ & $\mid \cdots \ldots \ldots$ & $\cdots$ & $\cdots \cdots$ & $\cdots$ & $\cdots$ & $\cdots$ & $\cdots$ & $\cdots$ & $\cdots$ & \\
\hline 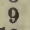 & & & & & & ..... & & & & & & & \\
\hline 10 & & & & & & - & - & & $\cdots$ & & $\cdots$ & $\cdots$ & 10 \\
\hline 11 & & & & & & $\cdot$ &. & & $\cdots$ & & $\cdots$ & $\cdots$ & 11 \\
\hline 12 & $\ldots$ & $\cdots$ & & & & & & $\cdots$ & $\cdots$ & $\cdots \cdots$ & $\cdots$ & $\cdots$ & 12 \\
\hline 13 & $\cdots$ & & & & & & & $\cdots$ & $\cdots$ & $\cdots$ & $\cdots$ &. & 13 \\
\hline 14 & & & & & & . & & $\begin{array}{l}\cdots \\
\cdots\end{array}$ & $\cdots$ &. & & $\ldots$ & $\begin{array}{l}14 \\
15\end{array}$ \\
\hline 16 & & $\cdots$ & $\cdots$ & $\ldots$ & ......... & $\ldots \ldots$ & ......... & (n....... & ( & $\cdots$ & 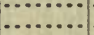 & $\cdots$ & 16 \\
\hline 17 & .. & ........ & ..... & .... & ........... & $\ldots \ldots$ & ........... & ......... & .......... & .... & ... & .......... & 17 \\
\hline 18 & $\cdots$ & $\cdots$ & $\cdots$ & $\cdots$ & $\ldots \ldots$ & ....... & ......... & $\cdots$ & ... & .... & $\ldots$ & .......... & 18 \\
\hline 19 & $\cdots$ & & & $\cdots$ & $\cdots \cdots$ & $\cdots$ & $\cdots$ & $\ldots$ & $\ldots$ & .. & $\cdots$ & $\ldots$. & 19 \\
\hline 20 & $\cdots$ & $\cdots$ & & & & - & & ... & .. & .. & $\cdot$ & ... & 20 \\
\hline 21 & & & & & & & & - & $\cdots$ & $\cdots$ & $\cdots$ & $\cdots$ & 21 \\
\hline 22 & & & & & & & 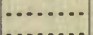 & $\cdots$ & & $\cdots \cdot$ & - & & 22 \\
\hline 23 & & & & & & & - & $\cdots$ & $\cdots$ & $\cdots$ & $\cdots$ & $\because$ & 23 \\
\hline 24 & & & & $\cdots$ &. & & & & 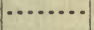 & $\cdots$ & - & . & $\begin{array}{l}24 \\
25\end{array}$ \\
\hline 26 & $\cdots$ & $\cdots$ & & $\cdots$ & & $\cdots$ & $\cdots$ & . & $\cdots$ & $\cdots$ & & . & 26 \\
\hline 27 & -. & $\ldots$ & $\ldots$ & $\ldots$ & ..... & ........ & $\ldots$ & ... & ........ & ... & $\cdots$ & $\cdots$ & 27 \\
\hline 28 & $\cdots$ & $\cdots$ & ..... & $\ldots .$. & ..... & ...... & $\cdots$ & $\ldots$ & $\ldots$ & $\ldots$ & $\ldots$ & $\ldots$ & 28 \\
\hline 29 & $\cdots$ & $\cdots$ & & $\cdots$ & $\cdots$ & $\cdots$ & $\cdots$ & $\cdots$ & $\cdots$ & $\cdots$ & $\cdots$ & $\ldots$ & 29 \\
\hline 30 & $\cdots$ & . . . . . . & & $\cdots$ & $\cdots$ & & $\cdot$ & $\cdots$ & & & $\cdot$ & $\ldots$ & 30 \\
\hline 31 & - & $\cdots$ & & $\cdots$ & $\cdots$ & . & - & - & & & $\cdots$ & $\cdots$ & 31 \\
\hline 32 & & - & & $\because$ & $\cdots$ & & & . & & - & $\cdots$ & $\cdots$ & 32 \\
\hline 33 & $\cdots$ & $\cdots$ & $\cdots$ & $\cdots$ & $\cdots$ & $\cdot$ & & $\cdots$ & & & $\cdots$ & $\cdots$ & 33 \\
\hline $\begin{array}{l}34 \\
35\end{array}$ & $\$ 28.25$ & & $\$ 28.83$ & $\$ 27.48$ & $\$ 27.83$ & $\$ 28.61$ & & $\$ 27.53$ & $\$ 28.16$ & $\ddot{2}$ & $58^{\circ}$ & 53 & 35 \\
\hline 36 & 10.43 & $\$ 10.06$ & 11.96 & 10.33 & 10.83 & 11.33 & $\$ 11.94$ & 10.80 & 10.09 & 11.00 & 11.28 & 61 & 36 \\
\hline 37 & 1 & 10.75 & 11.21 & 64 & 11.41 & 11.65 & 12.23 & 10.28 & 10.50 & 11.27 & 11 & 98 & 37 \\
\hline 38 & & 18. 39 & 1 & 25 & 19.20 & 19.22 & 19.95 & 80 & 18. 24 & 5 & 3 & 10 & 38 \\
\hline 39 & 2 & 23. & 2 & 20 & .91 & 5 & .63 & 1 & 22.82 & 9 & 8 & 78 & 39 \\
\hline 40 & 1 & 12 & 1 & 2 & 19 & 0 & .77 & 0 & 12 & 4 & 5 & 2 & 40 \\
\hline 41 & 1 & 1. & 1 & 1 & .83 & 5 & 3 & 8 & 14 & 3 & 9 & 38 & 41 \\
\hline 42 & 1 & 12 & 1 & 6 & 09 & 6 & 21 & 7 & 11 & 12.08 & 3 & 27 & 42 \\
\hline 43 & 12 & 12 & 1 & 3 & 46 & 9 & 8 & 9 & 12 & 9 & 9 & 21 & 43 \\
\hline 44 & 1 & 12 & 1 & 4 & .93 & 1 & 89 & 5 & 12. & 2 & 1 & 28 & 44 \\
\hline 45 & 1 & 17.5 & 1 & 2 & 19.20 & 9 & 18.09 & 5 & 18. & 0 & 5 & 0 & 45 \\
\hline 46 & 15 & 14.92 & 14. 25 & 14.00 & $\begin{array}{r}14.72 \\
1.93\end{array}$ & 14. 18 & 14. 56 & 12 & 14. 30 & 14. & 14. & 32 & 46 \\
\hline $\begin{array}{l}47 \\
48\end{array}$ & $\begin{array}{r}1.48 \\
13.64\end{array}$ & $\ddot{13} \ddot{83}$ & $\begin{array}{r}2.08 \\
14.19\end{array}$ & $\ddot{13.68}$ & $\begin{array}{r}1.93 \\
14.50\end{array}$ & $\begin{array}{r}2.06 \\
14.51\end{array}$ & $\begin{array}{r}2.11 \\
15.20\end{array}$ & $\begin{array}{r}1.76 \\
13.47\end{array}$ & $\begin{array}{r}1.84 \\
13.72\end{array}$ & $\begin{array}{r}1.90 \\
14.37\end{array}$ & $\begin{array}{r}2.08 \\
14.36\end{array}$ & $\begin{array}{r}1.87 \\
13.88\end{array}$ & $\begin{array}{l}47 \\
48\end{array}$ \\
\hline 49 & ........ & ........ & $\ldots \ldots$ & a......... & -........ & - $\ldots \ldots \ldots$ & .......... & |......... & . $\ldots \ldots$ & ......... & ......... & ........ & 49 \\
\hline 50 & $\cdots$ & . $\ldots \ldots$ & & $\cdots$ & ..... & $\ldots \ldots$ & ....... & $\ldots$ & $\ldots \ldots$ & .... & ... & $\ldots$ & 50 \\
\hline 51 & $\cdots$ & $\cdots \ldots \ldots$ & $\cdots$ & $\cdots$ & $\ldots .$. & $\ldots \ldots$ & $\ldots \ldots$ & $\ldots$ & $\ldots \ldots$ & .1 & $\cdots$ & . & 51 \\
\hline 52 & & & & $\cdots$ & .... & $\cdots$ & ...... & $\cdots$ & $\cdots$ &. & - &. & 52 \\
\hline 53 & - & - & - & $\ldots$ & $\ldots \ldots$ & $\cdots$ & …... & ...... & $\ldots$ & $\cdots$ & - & $\ldots$ & 53 \\
\hline 54 & $\cdots$ & 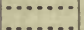 & . & $\cdots$ & . $\ldots \ldots \ldots$ & $\ldots \ldots$ & $\ldots \ldots$ & . & $\cdots$ & $\cdots$ & $\cdots$ & $\cdots$ & 54 \\
\hline 55 & $\cdots$ & & & ... & $\ldots \ldots$ & $\ldots \ldots$ & $\cdots$ & ........... & $\ldots$ & $\cdots$ & $\cdots$ & $\cdots$ & 55 \\
\hline 56 & $\because$ & & & & & - & $\therefore$. & . & $\cdots$ & $\cdots$ & $\cdots$ & $\cdots$ & 56 \\
\hline 57 & $\cdots$ & & & $\cdots$ & $\cdots$ & - & $\ldots \ldots \ldots$ & $\cdots$ & $\cdots$ & $\cdots$ & $\cdots$ & $\cdots$ & 57 \\
\hline 58 & $\cdots$ & $\because$ & & $\cdots$ & ...... & $\cdots$ & . & $\cdots$ & $\cdots$ &. & $\cdot \cdot$ & $\cdots$ & 58 \\
\hline 59 & 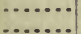 & . & & $\cdots$ & $\cdots$ & $\cdots \cdots$ & $\ldots \ldots$ & $\cdots$ & .. & $\cdots \cdots$ & $\cdots$ & . & 59 \\
\hline $\begin{array}{l}60 \\
61\end{array}$ & & & & $\cdots$ & $\cdots$ & $\cdots$ & - & $\cdots$ & $\cdots$ & - & $\cdots$ & - & 60 \\
\hline $\begin{array}{l}61 \\
62\end{array}$ & & . & & & & $\cdots$ & $\cdots$ & $\cdots$ & $\because$ & & $\cdots$ & 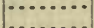 & $\begin{array}{l}61 \\
62\end{array}$ \\
\hline 63 & & & & &. & & $\cdots$ & & & & & & 6 \\
\hline 64 & & $\cdots$ & & 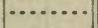 & $\ldots$ & $\cdots$ & $\cdots$ & ... & & & .. & . & 64 \\
\hline 65 & $\cdots$ & $\cdot$ & & & $\ldots \ldots$ & $\cdots$ & & & & -1 & & & \\
\hline 66 & $\cdots$ & & & & & & & & & & & & \\
\hline & $\cdots$ & - & & & & & & & & $\ldots$ & .0 & $\ldots$ & 67 \\
\hline & & & & $\cdots$ & $\cdots$ & $\cdots$ & & & & $\cdots \cdot$ & & $\cdots$ & \\
\hline 70 & & 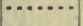 & & $\cdots$ & $\cdots$ & $\cdots$ & & & & & & & \\
\hline 71 & & & & & & & . & & & & - & & $\begin{array}{l}70 \\
71\end{array}$ \\
\hline 72 & & & & & .. & &. & & $\cdots$ &. & & & 7 \\
\hline 73 & & & & & $\because$ & & - & $\cdots$ & $\cdots$ & & & & 73 \\
\hline 74 & & & & 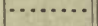 & $\cdots$ & & 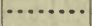 & $\cdots$ & & & & & 74 \\
\hline 75 & & & & & . & & & & & & & & 75 \\
\hline 76 & & & & & 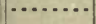 & & & & & & & & 76 \\
\hline 77 & & & & & - & & & & & & & & 7 \\
\hline 78 & & & & & . & & & & & & & & 7 \\
\hline 80 & & & & & & & & & & & & & $\begin{array}{l}79 \\
80\end{array}$ \\
\hline
\end{tabular}


Line Numbers Refer to Grades Listed on Page 10.

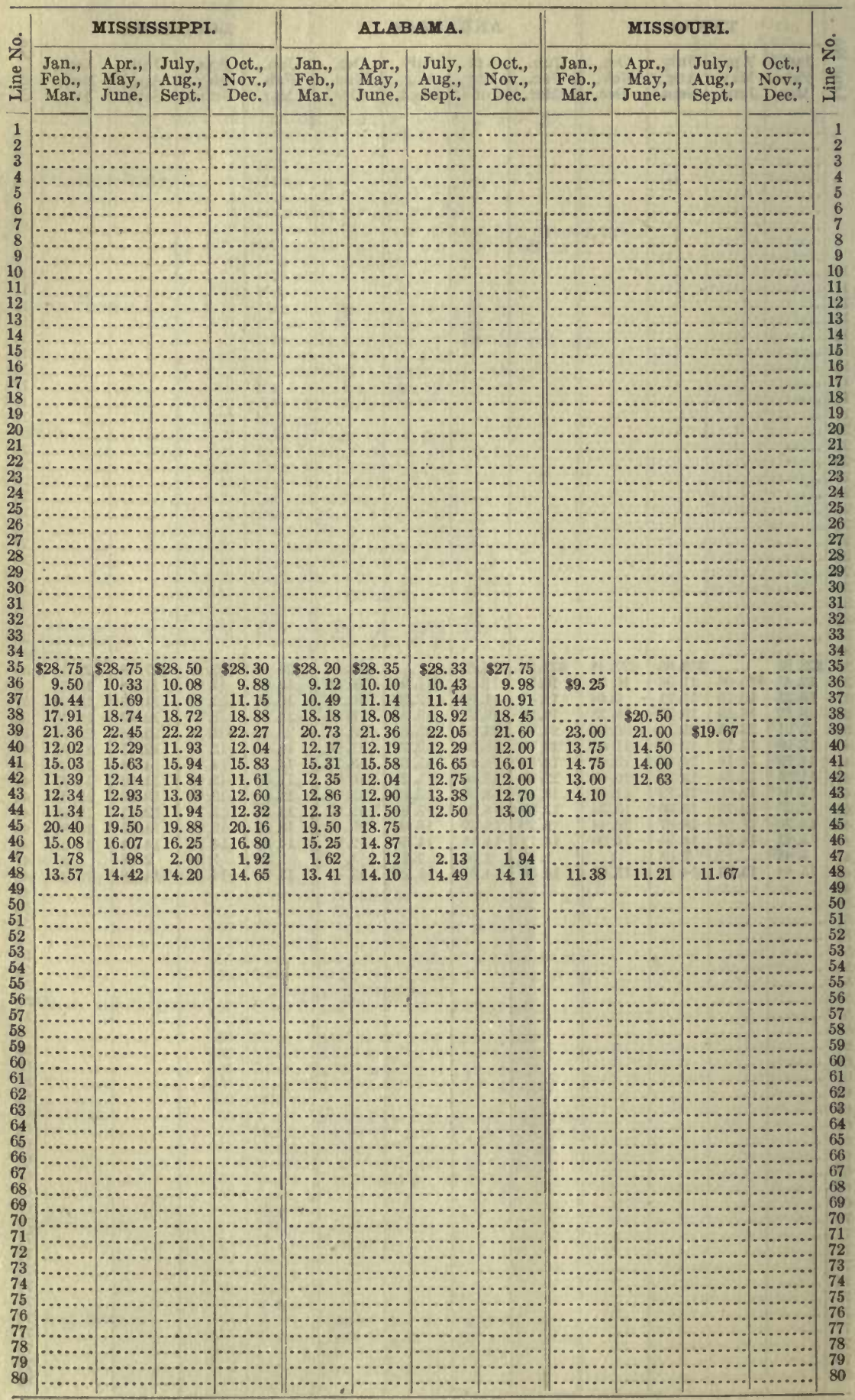


Line Numbers Refer to Grades Listed on Page 10.

\begin{tabular}{|c|c|c|c|c|c|c|c|c|c|c|c|c|c|}
\hline \multirow{2}{*}{$\begin{array}{l}0 \\
z \\
0 \\
0 \\
\frac{\Xi}{3}\end{array}$} & \multicolumn{4}{|c|}{ FLORIDA. } & \multicolumn{4}{|c|}{ GEORGIA. } & \multicolumn{4}{|c|}{ SOUTH CAROLINA. } & \multirow[b]{2}{*}{ 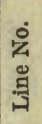 } \\
\hline & $\begin{array}{l}\text { Jan., } \\
\text { Feb., } \\
\text { Mar. }\end{array}$ & $\begin{array}{l}\text { Apr., } \\
\text { May, } \\
\text { June. }\end{array}$ & $\begin{array}{l}\text { July, } \\
\text { Aug., } \\
\text { Sept. }\end{array}$ & $\begin{array}{l}\text { Oct., } \\
\text { Nov., } \\
\text { Dec. }\end{array}$ & $\begin{array}{l}\text { Jan., } \\
\text { Feb., } \\
\text { Mar. }\end{array}$ & $\begin{array}{l}\text { Apr., } \\
\text { May, } \\
\text { June. }\end{array}$ & $\begin{array}{l}\text { July, } \\
\text { Aug., } \\
\text { Sept. }\end{array}$ & $\begin{array}{l}\text { Oct., } \\
\text { Nov., } \\
\text { Dec. }\end{array}$ & $\begin{array}{l}\text { Jan., } \\
\text { Feb., } \\
\text { Mar. }\end{array}$ & $\begin{array}{l}\text { Apr., } \\
\text { May, } \\
\text { June. }\end{array}$ & $\begin{array}{l}\text { July, } \\
\text { Aug., } \\
\text { Sept. }\end{array}$ & $\begin{array}{l}\text { Oct., } \\
\text { Nov., } \\
\text { Dec. }\end{array}$ & \\
\hline 1 & & & & & & & & & & & & & 1 \\
\hline 4 & & & & & & & & & & & & & 3 \\
\hline $\begin{array}{l}4 \\
5\end{array}$ & & & & & & & & & & & & & $\begin{array}{l}4 \\
5\end{array}$ \\
\hline $\begin{array}{l}6 \\
7\end{array}$ & & & & & & & & & & & & & $\begin{array}{l}6 \\
7\end{array}$ \\
\hline 8 & & & & & & & & & & & & & $\begin{array}{l}7 \\
8\end{array}$ \\
\hline $\begin{array}{r}9 \\
10\end{array}$ & & & & & & & & & & & & & 9 \\
\hline 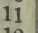 & & & & & & & & & & & & & 11 \\
\hline & & & & & & & & & & & & & 12 \\
\hline & & & & & & & & & & & & & 13 \\
\hline 5 & & & & & & & & & & & & & $\begin{array}{l}14 \\
15\end{array}$ \\
\hline & & & & & & & & & & & & & 16 \\
\hline & & & & & & & & & & & & & 17 \\
\hline 19 & & & & & & & & & & 18 & & & 18 \\
\hline 0 & & & & & & & & & & $\because$ & & & 20 \\
\hline & & & & & & & & & & & & & 21 \\
\hline & & - & & & & & & & & & & & 22 \\
\hline & & & & & & & & & & & & & 24 \\
\hline 20 & & & & & & & & & & & & & 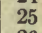 \\
\hline 28 & & & & & & & & & & & & & 26 \\
\hline & & & & & & & & & & & & & 27 \\
\hline & & & & & & & & & & & & & 29 \\
\hline & & & & & & & & & & & & & 20 \\
\hline 32 & & & & & & & & & & & & & 31 \\
\hline 3 & & & & & & & & & & & & & \\
\hline 34 & & & & & & & & & & & & & \\
\hline 30 & & & & & & & & & & & & & \\
\hline 3 & & & & & & & & & & & & & \\
\hline 38 & & & & & & & & & & & & & \\
\hline $\begin{array}{l}39 \\
40\end{array}$ & & & & & & & & & & & & & \\
\hline 41 & & . & $\cdots$ & & & & & & & & & & 4 \\
\hline 42 & & & 1 & & & & & & & & & & 41. \\
\hline 43 & & & $\cdots$ & & & & & & & & & & \\
\hline 4 & & & & & & & & & & & & & 44 \\
\hline 46 & & & & & & & & & & & & & 45 \\
\hline 47 & & & & & & & & & & & & & 46 \\
\hline & & & & & & & & . & & & & $\cdots$ & 18 \\
\hline 49 & 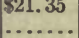 & & & & & & & $\$ 22.83$ & & & & & $\begin{array}{l}48 \\
49\end{array}$ \\
\hline 5 & 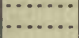 & 27.83 & $\cdots$ & & & & & & & & & & 50 \\
\hline 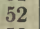 & 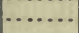 & & $\cdots$ & & & & & & & & & & 51 \\
\hline $5:$ & & & & & & & & & & & & & \\
\hline 54 & & & & & & & & & & 20.00 & & & $\begin{array}{l}53 \\
54\end{array}$ \\
\hline & & & & 18 & & & & & & & & & \\
\hline 56 & & & & & & & & & & & & & 56 \\
\hline & & & & 14. & & & & & & & & & \\
\hline 58 & & & & & & & & & & & & & \\
\hline & & & & 19 & & & & & & 15.50 & & & 59 \\
\hline 6 & & & & $\cdots$ & & & & & & & & & 30 \\
\hline & & 2 & & & & & & & 2 & & & & 61 \\
\hline 62 & 13 & 14.51 & 14. & .... & 7 & 1 & & 7 & 15. & & & & $\begin{array}{l}62 \\
63\end{array}$ \\
\hline 64 & & & & & & & & & & & & & \\
\hline 6 & & & & & & & & & & & & & \\
\hline & & & & & & & & & & & & & 66 \\
\hline & & & & & & & & & & & & & 68 \\
\hline & & & & & & & & & & & & & 69 \\
\hline & & & & & & & & & & & & & 70 \\
\hline & & & & & & & & & & & & & 71 \\
\hline 7 & & & & & & & & & & & & & $\begin{array}{l}72 \\
73\end{array}$ \\
\hline 7 & & & & & & & & & & & & & 74 \\
\hline & & & & & & & & & & & & & 75 \\
\hline & & & & & & & & & & & & & 76 \\
\hline & & & & & & & & & & & & & 77 \\
\hline 80 & & & & & & & & & $\ldots$ & & & & 7 \\
\hline 80 & & & & & & & & & & & & & 80 \\
\hline
\end{tabular}


Line Numbers Refer to Grades Listed on Page 10.

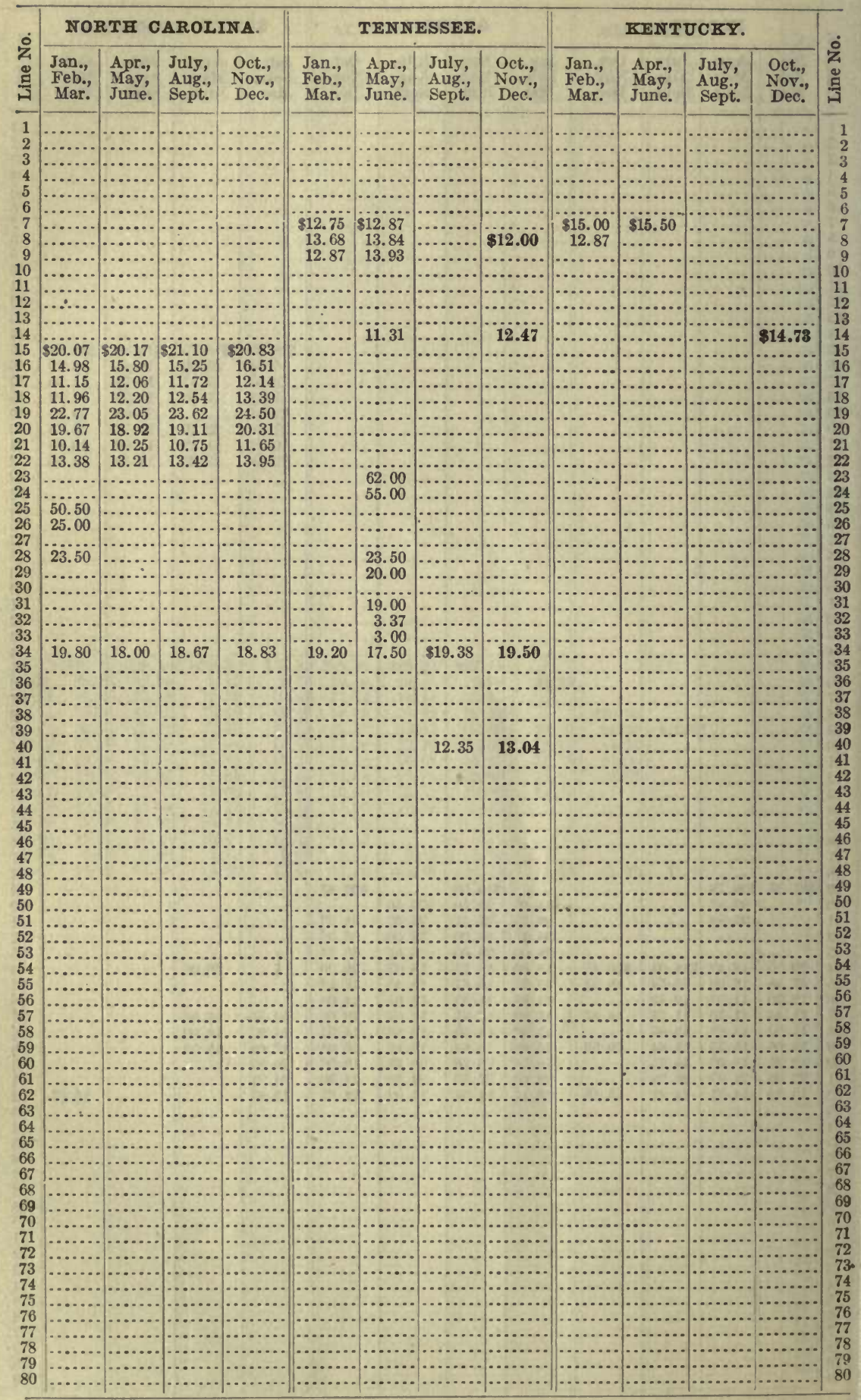


WHOLESALE PRICES OF LUMBER.

Line Numbers Refer to Grades Listed on Page 10.

\begin{tabular}{|c|c|c|c|c|c|c|c|c|c|c|c|c|c|}
\hline \multirow[b]{2}{*}{ 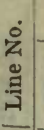 } & \multicolumn{4}{|c|}{ VIRGINIA. } & \multicolumn{4}{|c|}{ WEST VIRGINIA. } & \multicolumn{4}{|c|}{ MARYLAND. } & \multirow[b]{2}{*}{ 索 } \\
\hline & $\begin{array}{l}\text { Jan., } \\
\text { Feb., } \\
\text { Mar. }\end{array}$ & $\begin{array}{l}\text { Apr., } \\
\text { May, } \\
\text { June. }\end{array}$ & $\begin{array}{l}\text { July, } \\
\text { Aug., } \\
\text { Sept. }\end{array}$ & $\begin{array}{l}\text { Oct., } \\
\text { Nov., } \\
\text { Dec. }\end{array}$ & $\begin{array}{l}\text { Jan., } \\
\text { Feb., } \\
\text { Mar. }\end{array}$ & $\begin{array}{l}\text { Apr., } \\
\text { May,, } \\
\text { June. }\end{array}$ & $\begin{array}{l}\text { July, } \\
\text { Aug., } \\
\text { Sept. }\end{array}$ & $\begin{array}{l}\text { Oct., } \\
\text { Nov., } \\
\text { Dec. }\end{array}$ & $\begin{array}{l}\text { Jan., } \\
\text { Feb., } \\
\text { Mar. }\end{array}$ & $\begin{array}{l}\text { Apr., } \\
\text { May, } \\
\text { June. }\end{array}$ & $\begin{array}{l}\text { July, } \\
\text { Aug., } \\
\text { Sopt. }\end{array}$ & $\begin{array}{l}\text { Oct., } \\
\text { Nov., } \\
\text { Dec. }\end{array}$ & \\
\hline & & & & & & & & & & & & & 1 \\
\hline & & & & & & & & & & & & & $\frac{2}{3}$ \\
\hline & & & & & & & & & & & & & 5 \\
\hline & & & & & & & & & & & & & 6 \\
\hline & & & & & $\begin{array}{r}\$ 15.80 \\
14.64\end{array}$ & $\begin{array}{r}\$ 15.25 \\
14.92\end{array}$ & $\begin{array}{r}\$ 15.50 \\
14.55\end{array}$ & $\begin{array}{r}\$ 16.50 \\
15.60\end{array}$ & & & & & $\begin{array}{l}7 \\
8\end{array}$ \\
\hline & & & & & 16.02 & $\begin{array}{l}16.25 \\
15.38\end{array}$ & 16.20 & 17.42 & & & & & 9 \\
\hline & & & & & $\begin{array}{l}14.88 \\
11.38\end{array}$ & $\begin{array}{l}15.38 \\
11.36\end{array}$ & 1100 & $\begin{array}{l}14.00 \\
11.83\end{array}$ & & & & & 10 \\
\hline & & & & & 14.81 & 14.79 & 15.92 & 15.00 & & & & & 12 \\
\hline & & & & $\$ 13.75$ & $\begin{array}{r}6.35 \\
14.83\end{array}$ & $\begin{array}{r}6.83 \\
14.08\end{array}$ & & $\begin{array}{r}6.50 \\
15.08\end{array}$ & & & & & $\begin{array}{l}13 \\
14\end{array}$ \\
\hline & & $\$ 21.00$ & & 23.13 & & & & & $\$ 21.87$ & & & & 15 \\
\hline & $\begin{array}{l}\$ 14.83 \\
12.05\end{array}$ & 12.50 & & $\begin{array}{l}18.00 \\
12.08\end{array}$ & & & & & $\begin{array}{l}18.75 \\
15.75\end{array}$ & $\$ 15.50$ & & & $\begin{array}{l}16 \\
17\end{array}$ \\
\hline & $\begin{array}{l}11.25 \\
22.41\end{array}$ & 11.60 & ........ & 15.63 & & & & & 13.20 & & & & 18 \\
\hline & $\begin{array}{l}20.33 \\
10.57\end{array}$ & $\begin{array}{l}24.78 \\
11.78\end{array}$ & $\begin{array}{r}\$ 24.64 \\
11.86\end{array}$ & 23.83 & & & & & & & & & $\begin{array}{l}19 \\
20\end{array}$ \\
\hline & 13.12 & 13.00 & 12.80 & $\begin{array}{l}11.32 \\
13.24\end{array}$ & & & & & $\begin{array}{l}13.25 \\
14.25\end{array}$ & & & & 21 \\
\hline & & & & & & & & & 14.20 & 12.12 & $\$ 12.50$ & & 23 \\
\hline & & & & & & & & & & & & & $\begin{array}{l}24 \\
25\end{array}$ \\
\hline & & & & & & & & & & & & & $\begin{array}{l}28 \\
27\end{array}$ \\
\hline & & & & & & & & & & $\because$. & .... & & 28 \\
\hline & & & & & & & & & & & & & $\begin{array}{l}29 \\
30\end{array}$ \\
\hline & & & & & & & & & & & & & 31 \\
\hline & & & & & & & & & & & & & $\begin{array}{l}32 \\
33\end{array}$ \\
\hline & & & & 18.75 & 18.81 & & & & & & & & 34 \\
\hline & & & & & & $\because 8$ & & & ...... & 1 & $\cdots$ & & $\begin{array}{l}30 \\
30\end{array}$ \\
\hline & & & & & & & & $\ddot{\ddot{*}}$ & $\cdots$ & - & $\cdots$ & & $\begin{array}{l}37 \\
38\end{array}$ \\
\hline & & $\because$ & & & & & & & .. & & & & 39 \\
\hline & & $\cdots$ & & & & & & & & & & & $\begin{array}{l}40 \\
41\end{array}$ \\
\hline & & & & & & & & & . & & & & 42 \\
\hline & & & & & & & & & & & $\ldots$. & & 44 \\
\hline & & & & & & & & & .. & & & & $\begin{array}{l}45 \\
46\end{array}$ \\
\hline & & & : & ..... & 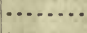 & & & & $\therefore$ & 9 & $\cdots$ & … & 47 \\
\hline & & & & 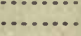 & $\because$ & & $\cdots$ & & -... & *. & & & $\begin{array}{l}48 \\
49\end{array}$ \\
\hline & & & & & & & & & & & & & 50 \\
\hline & & & & & & & 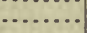 & & & & & & $\begin{array}{l}51 \\
52\end{array}$ \\
\hline & & & & & & & & & & & & & 53 \\
\hline & & & & & & & & & & & & & $\begin{array}{l}54 \\
55\end{array}$ \\
\hline & & & & & & & $\ldots$. & & $\because$. & & & & 56 \\
\hline & & & & & & & & & & & & & $\begin{array}{l}51 \\
58\end{array}$ \\
\hline & & & & & & & & & & & & & $\begin{array}{l}59 \\
60\end{array}$ \\
\hline & & & & & & & & & & & & & 61 \\
\hline & & & & & & & & & & & & & $\begin{array}{l}62 \\
63\end{array}$ \\
\hline & & & & & & & & & & & & & 64 \\
\hline & & & & & & & & & $\cdots$ & & & & $\begin{array}{l}65 \\
66\end{array}$ \\
\hline & & .... & $\because$ & & $\cdots$ & & & & 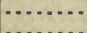 & & & & 67 \\
\hline & & & & & & & & & & & & & $\begin{array}{l}68 \\
69\end{array}$ \\
\hline & & & & & & & & & & & & & 70 \\
\hline & & & & & & & & & & . & & & $\begin{array}{l}71 \\
72\end{array}$ \\
\hline & & & & & & & & & & & & $\cdots \cdot$ & $\begin{array}{l}73 \\
74\end{array}$ \\
\hline & & 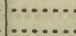 & $\ldots$ & & & & & & & & & & 75 \\
\hline & & & & & $\begin{array}{l}1.63 \\
20.25\end{array}$ & 19.50 & $\begin{array}{l}7.38 \\
20.25\end{array}$ & $\begin{array}{l}18.25 \\
21.50\end{array}$ & & & & & $\begin{array}{l}76 \\
77\end{array}$ \\
\hline & & & $\cdots$. & & $\begin{array}{r}21.75 \\
11.75\end{array}$ & 20.33 & 21.33 & $\begin{array}{r}22.25 \\
2.62\end{array}$ & .... & $\cdots \cdots$ & ... & & 78 \\
\hline & & & & …....... & $\begin{array}{l}17.50 \\
17.75\end{array}$ & 17.32 & & $\begin{array}{l}4.05 \\
16.83\end{array}$ & .......... & & & & $\begin{array}{l}79 \\
80 \\
\end{array}$ \\
\hline
\end{tabular}


Line Numbers Refer to Grades Listed on Page 10.

\begin{tabular}{|c|c|c|c|c|c|c|c|c|c|c|c|c|c|}
\hline & \multicolumn{4}{|c|}{ PENNSYLVANIA. } & \multicolumn{4}{|c|}{ NEW YORK. } & \multicolumn{4}{|c|}{ NEW HAMPSHIRE." } & \\
\hline & $\begin{array}{l}\text { Jan., } \\
\text { Feb., } \\
\text { Mar. }\end{array}$ & $\begin{array}{l}\text { A pr., } \\
\text { May, } \\
\text { June. }\end{array}$ & $\begin{array}{l}\text { July, } \\
\text { Aug., } \\
\text { Sept. }\end{array}$ & $\begin{array}{l}\text { Oct., } \\
\text { Nov., } \\
\text { Dec. }\end{array}$ & $\begin{array}{l}\text { Jan., } \\
\text { Feb., } \\
\text { Mar. }\end{array}$ & $\begin{array}{l}\text { Apr. } \\
\text { May, } \\
\text { June. }\end{array}$ & $\begin{array}{l}\text { July, } \\
\text { Aug., } \\
\text { Sept. }\end{array}$ & $\begin{array}{l}\text { Oct., } \\
\text { Nov., } \\
\text { Dec. }\end{array}$ & $\begin{array}{l}\text { Jan., } \\
\text { Feb., } \\
\text { Mar. }\end{array}$ & $\begin{array}{l}\text { Apr., } \\
\text { May, } \\
\text { June. }\end{array}$ & $\begin{array}{l}\text { July, } \\
\text { Aug., } \\
\text { Sept. }\end{array}$ & $\begin{array}{l}\text { Oct., } \\
\text { Nov., } \\
\text { Dec. }\end{array}$ & \\
\hline & & $\$ 18.00$ & & & 3.10 & $\$ 18.38$ & & $\$ 17.93$ & & & & & \\
\hline & & 16.50 & & & 1 & $\begin{array}{l}18.61 \\
17.50\end{array}$ & 0 & & & & & & \\
\hline & & $\cdots$ & & & 18.00 & 17.75 & & & & & & & \\
\hline & $\begin{array}{r}3.50 \\
17.75\end{array}$ & 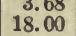 & & .......... & $\begin{array}{r}3.53 \\
17.72\end{array}$ & $\begin{array}{r}3.77 \\
16.70\end{array}$ & 16.88 & $\begin{array}{r}4.17 \\
17.40\end{array}$ & $\ldots$ & & & & \\
\hline & & 18.75 & $\$ 18.25$ & $\$ 19.40$ & & & & & & & & $\$ 19.00$ & \\
\hline & & $\begin{array}{l}19.75 \\
21.25\end{array}$ & & $\begin{array}{l}18.93 \\
19.25\end{array}$ & & & & & .. & & & 17.90 & \\
\hline & & 19.50 & & & & - & & & $\$ 16.75$ & $\$ 17.60$ & & 17.25 & \\
\hline & & & & & & & “ij & "is.33 & & 10.75 & & & \\
\hline & 16.62 & $\begin{array}{l}10.75 \\
16.52\end{array}$ & 16.53 & 16.87 & $\begin{array}{r}9.33 \\
17.03\end{array}$ & 17.00 & & 9.00 & & & & & \\
\hline & & & & & & & & & & & $\$ 17.00$ & 15.33 & \\
\hline & & & & & & & & & & & & & \\
\hline & & & & & & $\cdots$ & & & $\cdots$... & & & & \\
\hline & & & & & & $\cdots$... & & & $\ldots$. & & & & \\
\hline & & & & & & $\cdots$ & & & $\cdots$ & & & & \\
\hline & & & & & & & & & 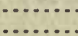 & & & & \\
\hline & & & & & & & & & & & & 34.67 & \\
\hline & & & & & & & & & & & & 27.50 & \\
\hline & & & & & & & & & .... & & & & \\
\hline & & 23.25 & & ... & & .... & & & 22.50 & 23.67 & 22.00 & 21.90 & \\
\hline & & 20 & & & & & & & 21.00 & & & 18.13 & \\
\hline & & & & & & & & 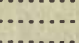 & ....... & & & & \\
\hline & 25.22 & 23.25 & 22.75 & 22.25 & 23.11 & 23.73 & 23.90 & 21.12 & 15.90 & 17.50 & $17.43^{\circ}$ & 18.28 & \\
\hline & & & & & & & & & & & & & \\
\hline & & & 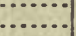 & & & 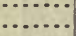 & & & & & & & \\
\hline & & & & & & 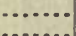 & & & & & & & \\
\hline & & & &. & & & & & & & & & \\
\hline & & & & $\because$ & & $\because$ & & & & & & & \\
\hline & & & & & & & & & & & & & \\
\hline & & & & & & & & & & & & & \\
\hline & & & & & & & & & & & & & \\
\hline & & & & .. & & & & & & & & & \\
\hline & & & … & …. & & & & & & & & & \\
\hline & & & & $\because$. & $\cdots$ & & & & & & & & \\
\hline & & & & $\because$ & & & & & & & & & \\
\hline & & & & 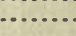 & 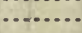 & & & .. & & & & & \\
\hline & & & & .. & & & & & & & & & \\
\hline & & & & & & & & & & & & & \\
\hline & & & & & & & & & & & & & \\
\hline & & & & & & & & & . & & & ….... & \\
\hline & & & & $\cdots$ & & & & & & & & 21.18 & \\
\hline & & & & $\cdots$ & & & & & & & & 24.68 & \\
\hline & & & & & & & & & & & & & \\
\hline & & & & & & & & & & & & 3.35 & \\
\hline & & & & & & & & & 17.67 & 18.50 & 19.00 & 18.33 & \\
\hline & & & & & & & $\begin{array}{l}19.41 \\
31.67\end{array}$ & & & & & & \\
\hline & & & & & & & & & & & & & \\
\hline & & & & & & & & & & & & & \\
\hline & & & & & 18.19 & 17.92 & 17.00 & 17.30 & & & & & \\
\hline & & & & & & & & & & & & & \\
\hline & & & & & & & & & & & & & \\
\hline & & & & & & & & & & & & & \\
\hline
\end{tabular}


WHOLESALE PRICES OF LUMBER.

Line Numbers Refer to Grades Listed on Page 10.

\begin{tabular}{|c|c|c|c|c|c|c|c|c|c|c|c|c|c|}
\hline \multirow[b]{2}{*}{ 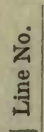 } & \multicolumn{4}{|c|}{ VERMONT. } & \multicolumn{4}{|c|}{ MAINE. } & \multicolumn{4}{|c|}{ MASSACHUSETTS. } & \multirow[b]{2}{*}{ 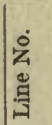 } \\
\hline & $\begin{array}{l}\text { Jan., } \\
\text { Feb., } \\
\text { Mar. }\end{array}$ & \begin{tabular}{|l} 
Apr., \\
May, \\
June.
\end{tabular} & $\begin{array}{l}\text { July, } \\
\text { Aug., } \\
\text { Sept. }\end{array}$ & $\begin{array}{l}\text { Oct., } \\
\text { Nov., } \\
\text { Dec. }\end{array}$ & $\begin{array}{l}\text { Jan., } \\
\text { Feb., } \\
\text { Mar. }\end{array}$ & $\begin{array}{l}\text { Apr., } \\
\text { May,, } \\
\text { June. }\end{array}$ & $\begin{array}{l}\text { July, } \\
\text { Aug., } \\
\text { Sept. }\end{array}$ & $\begin{array}{l}\text { Oct., } \\
\text { Nov., } \\
\text { Dec. }\end{array}$ & $\begin{array}{l}\text { Jan., } \\
\text { Feb., } \\
\text { Mar. }\end{array}$ & $\begin{array}{l}\text { Apr., } \\
\text { May, } \\
\text { June. }\end{array}$ & $\begin{array}{l}\text { July, } \\
\text { Aug., } \\
\text { Sept. }\end{array}$ & $\begin{array}{l}\text { Oct., } \\
\text { Nov., } \\
\text { Dec. }\end{array}$ & \\
\hline 1 & & & & & & & & & & & & & 1 \\
\hline 4 & & & & & & & & & & & & & $\begin{array}{l}2 \\
3\end{array}$ \\
\hline 4 & & & & & & & & & & & & & 4 \\
\hline 7 & & & & $\$ 16.88$ & & $\$ 18.00$ & & $\$ 17.01$ & & & & & .06 \\
\hline $\begin{array}{l}8 \\
9\end{array}$ & $\$ 19.25$ & & $\$ 15.50$ & $\begin{array}{l}17.83 \\
18.33\end{array}$ & $\$ 18.00$ & & & 15.80 & & & & & 8 \\
\hline 10 & 16.33 & $\$ 16.80$ & 16.21 & 16.25 & 1350 & 16.60 & $\$ 16.25$ & 16.60 & & & & $\$ 19.00$ & $\begin{array}{r}99 \\
10\end{array}$ \\
\hline 12 & 15.33 & 16.67 & $\because 6.25$ & $\begin{array}{l}15.85 \\
11.38\end{array}$ & 13.50 & $\begin{array}{r}14.40 \\
14.83 \\
9.75\end{array}$ & 16.50 & 10.67 & & & & 17.25 & 政 \\
\hline 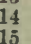 & & 16.22 & 16.i1 & 15.58 & 15.12 & 14.70 & 13.73 & 15.00 & $\$ 17.47$ & $\$ 15.00$ & $\$ 16.67$ & 16.88 & 13 \\
\hline & & & & & & & & & & & & & $\begin{array}{l}15 \\
16\end{array}$ \\
\hline & & & & & & & & & & & & & 17 \\
\hline & & & & & & & ….... & & & & & & $\begin{array}{l}15 \\
19\end{array}$ \\
\hline & & & $\cdots$ & & $\begin{array}{l}\cdots \\
\cdots\end{array}$ & ?... & $\cdots . .$. & $\cdots$ & & & & & 20 \\
\hline & & & & & & & ....... & & & & & & $\begin{array}{l}21 \\
22\end{array}$ \\
\hline & & & & & $\cdots$ & .. & ..... & & & & & & 23 \\
\hline & & $\cdots$ & & & & & 26.67 & & & & & & 25 \\
\hline & & & & & & & no & & & & & & $\begin{array}{l}26 \\
27\end{array}$ \\
\hline & & & & & 21.67 & $\begin{array}{l}21.17 \\
23.00\end{array}$ & 21.00 & & & & & 28.00 & $\begin{array}{l}28 \\
29\end{array}$ \\
\hline & & $\cdots$ & $\cdot$ & & 18.87 & 19.82 & 16.75 & & & & & & 30 \\
\hline & & & & & .... & 3,00 & $\ldots$ & & & & & & $\begin{array}{l}31 \\
32\end{array}$ \\
\hline & 18.60 & 19.38 & 19.00 & 18.38 & 17.50 & $\begin{array}{r}3.00 \\
19.23\end{array}$ & 19.20 & $\begin{array}{r}3.12 \\
19.64\end{array}$ & 19.15 & 17.25 & 17.80 & & $\begin{array}{l}02 \\
33 \\
03\end{array}$ \\
\hline & & & & & & & & & & 10.20 & 17.80 & 18.35 & $\begin{array}{l}34 \\
35\end{array}$ \\
\hline & & & & & & & & & & & & & 36 \\
\hline & & & & & & & & & & & & & $\begin{array}{l}37 \\
38\end{array}$ \\
\hline & & & & & & & $\cdots$ & & & & & & 39 \\
\hline 41 & & .. & & & ........ & $\cdots$ & & & & & & & $\begin{array}{l}40 \\
41\end{array}$ \\
\hline 4 & & & & & $\cdots$ & ….. & .... & $\cdots$. & $\cdots$ & & & & 42 \\
\hline & & & & & ......... & & $\cdots$. & .... & $\cdots$. & & & & $\begin{array}{l}43 \\
44\end{array}$ \\
\hline & & & & & $\ldots$ & & & & & & & & 45 \\
\hline & & & & & ........ & & & $\cdots$ & & & & & $\begin{array}{l}46 \\
47\end{array}$ \\
\hline & & & & & & & & & $\cdots$ & & & & $\begin{array}{l}48 \\
49\end{array}$ \\
\hline & & & & & ......... & & & & & & & & 50 \\
\hline & & & & & $\ldots$ & & & & . & & & & $\begin{array}{l}51 \\
52\end{array}$ \\
\hline & & & & & ....... & & & & & & & & 53 \\
\hline & & & & & $\ldots \ldots \ldots$ & & $\cdots$ & $\cdots$ & & & & & $\begin{array}{l}54 \\
55\end{array}$ \\
\hline & & & & & ........ & & 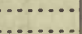 & & & & & & 56 \\
\hline & & & & & & & & & & & & & $\begin{array}{l}57 \\
58\end{array}$ \\
\hline & & & & & & & . & & & & & & 59 \\
\hline & & & & & ..... & ..... & ..... & ... & & & & & 61 \\
\hline & $\cdots \cdot \cdot$ & & 21.50 & 20.00 & 18.50 & 18.22 & 19.52 & 19.92 & & & & & 62 \\
\hline & & & 23.50 & $\begin{array}{l}20 \\
20\end{array}$ & & $\begin{array}{l}20.96 \\
17.67\end{array}$ & $\begin{array}{l}22.89 \\
118\end{array}$ & 21.96 & & . & & & 64 \\
\hline & & & 19 & 21. & & 15.42 & & & & & & & $\begin{array}{l}65 \\
66\end{array}$ \\
\hline & & 22.00 & 2 & 22.00 & 19. & 16. 32 & $\begin{array}{l}18.04 \\
2.83\end{array}$ & $\begin{array}{l}16.92 \\
3.13\end{array}$ & $\ldots$ & $\ldots$ & ... & $\ddot{*}$ & 67 \\
\hline 69 & 16.13 & 18.71 & 17.33 & 18.51 & 17.28 & 16.42 & 16.82 & 17.32 & 18.20 & 17.00 & 17.33 & 18.33 & $\begin{array}{l}68 \\
69\end{array}$ \\
\hline 71 & 29.00 & 26.25 & 2 & 26. & & & & & & & & & 71 \\
\hline 73 & $\begin{array}{l}17.75 \\
13.50\end{array}$ & $\begin{array}{l}18.70 \\
12.50\end{array}$ & 13.25 & 17.75 & & & & & & & & & 72 \\
\hline & & & 200 & & & & & & & & & & $\begin{array}{l}73 \\
74\end{array}$ \\
\hline & & & & & & & & & & & & & 75 \\
\hline & & & & & & & & & & & & & $\begin{array}{l}76 \\
77\end{array}$ \\
\hline & 14.00 & & & & & 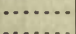 & & & & & & & 78 \\
\hline & & & & & & & & & & & & & 80 \\
\hline
\end{tabular}


Line Numbers Refer to Grades Listed on Page 10.

\begin{tabular}{|c|c|c|c|c|c|c|c|c|c|c|c|c|c|}
\hline \multirow[b]{2}{*}{$\begin{array}{l}0 \\
z \\
\text { ż } \\
1\end{array}$} & \multicolumn{4}{|c|}{ MINNESOTA. } & \multicolumn{4}{|c|}{ WISCONSIN. } & \multicolumn{4}{|c|}{ MICHIGAN. } & \multirow[b]{2}{*}{$\begin{array}{l}0 \\
z \\
\vdots \\
\frac{1}{1}\end{array}$} \\
\hline & $\begin{array}{l}\text { Jan., } \\
\text { Feb., } \\
\text { Mar. }\end{array}$ & $\begin{array}{l}\text { Apr., } \\
\text { May, } \\
\text { June. }\end{array}$ & \begin{tabular}{|l|} 
July, \\
Aug., \\
Sept.
\end{tabular} & $\begin{array}{l}\text { Oct., } \\
\text { Nov., } \\
\text { Dec. }\end{array}$ & $\begin{array}{l}\text { Jan., } \\
\text { Feb., } \\
\text { Mar. }\end{array}$ & $\begin{array}{l}\text { Apr., } \\
\text { May, } \\
\text { June. }\end{array}$ & $\begin{array}{l}\text { July, } \\
\text { Aug., } \\
\text { Sept. }\end{array}$ & $\begin{array}{l}\text { Oct., } \\
\text { Nov., } \\
\text { Dec. }\end{array}$ & $\begin{array}{l}\text { Jan., } \\
\text { Feb., } \\
\text { Mar. }\end{array}$ & $\begin{array}{l}\text { Apr., } \\
\text { May, } \\
\text { June. }\end{array}$ & $\begin{array}{l}\text { July, } \\
\text { Aug., } \\
\text { Sept. }\end{array}$ & $\begin{array}{l}\text { Oct., } \\
\text { Nov., } \\
\text { Dec. }\end{array}$ & \\
\hline $\begin{array}{l}1 \\
2 \\
3 \\
4 \\
5 \\
6 \\
7\end{array}$ & & & & & $\begin{array}{r}\$ 15.15 \\
17.39 \\
16.21 \\
14.88 \\
3.33 \\
12.37\end{array}$ & \begin{tabular}{|r|}
15.99 \\
17.21 \\
16.54 \\
15.84 \\
3.31 \\
12.75
\end{tabular} & $\begin{array}{r}\$ 15.72 \\
16.85 \\
16.87 \\
15.54 \\
3.29 \\
12.72\end{array}$ & $\begin{array}{r}16.38 \\
16.20 \\
15.09 \\
3.22 \\
11.98\end{array}$ & $\begin{array}{r}16.30 \\
16.15 \\
15.36 \\
3.46 \\
12.16\end{array}$ & $\begin{array}{r}16.59 \\
15.86 \\
16.05 \\
3.44 \\
12.33\end{array}$ & $\begin{array}{r}\$ 14.94 \\
15.98 \\
15.96 \\
15.40 \\
3.45 \\
12.65\end{array}$ & $\begin{array}{r}\$ 15.10 \\
16.27 \\
15.96 \\
15.64 \\
3.43 \\
12.39\end{array}$ & $\begin{array}{l} \\
5 \\
6\end{array}$ \\
\hline $\begin{array}{l}7 \\
8 \\
9\end{array}$ & & & & & & & & & & & & & $\begin{array}{l}7 \\
8\end{array}$ \\
\hline & & & & & & & & & & & & & $\begin{array}{r}9 \\
10\end{array}$ \\
\hline 12 & & & & & & & & & 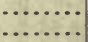 & & & & $\begin{array}{l}11 \\
12\end{array}$ \\
\hline 13 & & & & & & & & & & & & & 13 \\
\hline 5 & & & & & & & & & & & & & 14 \\
\hline 16 & & & & & & & & & & & & & $\begin{array}{l}15 \\
16\end{array}$ \\
\hline 17 & & & & & & & & & & & & & 17 \\
\hline 19 & & & & & & & & & $\begin{array}{l}\cdots \\
\cdots\end{array}$ & 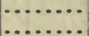 & & & $\begin{array}{l}18 \\
19\end{array}$ \\
\hline 20 & & & & & & & & & & & & & 20 \\
\hline 21 & & & & & & & & & & . & & & 21 \\
\hline 23 & $\$ 57.73$ & 64 & $\ddot{\$} 5$ & & 57. & & & & & 57.00 & 0 & & 23 \\
\hline 24 & & 4 & & & & & & & & & & & 24 \\
\hline & & & & & & & & & & & & & 25 \\
\hline 20 & & 2 & & & 26. & & 25 & & & & & & 26 \\
\hline 27 & & 2 & & & & & & & & & & & 27 \\
\hline 28 & 1 & 2 & & & & & & & & & & & 28 \\
\hline 30 & & & & & & & & & & & & & 29 \\
\hline 30 & & & & & & & & & & & & & 30 \\
\hline 31 & 2 & 5 & 2 & & 26 & 26 & 2 & & 29 & & 26. & & 31 \\
\hline 3 & 96 & & & & & & & & & & & & 32 \\
\hline $\begin{array}{l}33 \\
34\end{array}$ & 3.47 & 3.32 & 17 & 5. & 3.48 & 3. & 3. & & & & & & 33 \\
\hline ? & 19.20 & 18.80 & 17.62 & 19.06 & 20.51 & 21.25 & 19.75 & 12 & 21.13 & 21.31 & 21.14 & 20.65 & 34 \\
\hline 36 & & & & & & & & & & & & & \\
\hline 37 & & & & & & & & & & & & & 3 \\
\hline 39 & & & & & & & & & & & & & 38 \\
\hline 40 & & & & & & & & & & & & & 39 \\
\hline 41 & & & & & & & & & & & & & 40 \\
\hline 42 & & & & & & & & & & & & & 42 \\
\hline $\begin{array}{l}43 \\
44\end{array}$ & & & & & & & & & & & & & $\infty$ \\
\hline 45 & & & & & & & & & & & & & 44 \\
\hline 46 & & & & & & & & & & & & & $\begin{array}{l}45 \\
46\end{array}$ \\
\hline 47 & & & & & & & & & & & & & $\begin{array}{l}40 \\
47\end{array}$ \\
\hline $\begin{array}{l}48 \\
49\end{array}$ & & & & & & & & & $\cdots$ & & & & 48 \\
\hline 50 & & & & & & & & & & & & & 49 \\
\hline 51 & & & & & & & & & & & & & 50 \\
\hline 52 & ....... & ... & & & & & & & & & & & $\begin{array}{l}51 \\
52\end{array}$ \\
\hline 34 & & & & & & & & & & & & & 53 \\
\hline $\begin{array}{l}54 \\
55\end{array}$ & $\cdots$ & & & & & & & & & & & & 54 \\
\hline 5 & & & & & & & & & & & & & 55 \\
\hline 5 & . & & & & & & & & & & & & $\begin{array}{l}50 \\
57\end{array}$ \\
\hline & & & & & & & & & & & & & 58 \\
\hline 69 & & & & & & & & & & & & & 59 \\
\hline 6 & & & & & & & & & & & & & 60 \\
\hline 62 & & & & & & & & & & & & & $\begin{array}{l}01 \\
62\end{array}$ \\
\hline 6 & & & & & & & & & & & & & 6 \\
\hline 6 & & & & & & & & & & & & & 6 \\
\hline 6 & & & & & & & & & & & & & $\begin{array}{l}65 \\
66\end{array}$ \\
\hline $\begin{array}{l}6 \\
6\end{array}$ & & & & & & & & & & & & & 67 \\
\hline 6 & & & & & & & & & & & & & \\
\hline 7 & & & & & & & & & & & 16.38 & & 69 \\
\hline 7. & & & & & & & & & & & & & $\begin{array}{l}70 \\
71\end{array}$ \\
\hline 7 & & & & & & & -. & & & & & & 72 \\
\hline 7 & & & & & & & & & ....... & & & & 73 \\
\hline 7 & & & & & & & & & & & & & \\
\hline 7 & & & & & & & & & & & & & \\
\hline & - & & & & & & … & & ......... & & & & 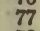 \\
\hline & & & & & & & & & & & & & 7 \\
\hline 80 & & & & & & & & & & & & & \\
\hline & & & & & & & & & & & & & \\
\hline
\end{tabular}


Line Numbers Refer to Grades Listed on Page 10.

\begin{tabular}{|c|c|c|c|c|c|c|c|c|c|c|c|c|c|}
\hline \multirow[b]{2}{*}{ 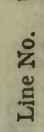 } & \multicolumn{4}{|c|}{ CONNECTICUT. } & \multicolumn{2}{|c|}{$\begin{array}{l}\text { RHODE } \\
\text { ISLAND. }\end{array}$} & \multicolumn{2}{|c|}{$\begin{array}{c}\text { NEW } \\
\text { JERSEY. }\end{array}$} & \multicolumn{2}{|c|}{ DELAWARE. } & \multicolumn{2}{|l|}{60} & \multirow[b]{2}{*}{ 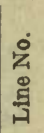 } \\
\hline & $\begin{array}{l}\text { Jan., } \\
\text { Feb., } \\
\text { Mar. }\end{array}$ & $\begin{array}{l}\text { Apr., } \\
\text { May, } \\
\text { June. }\end{array}$ & \begin{tabular}{|l} 
July, \\
Aug., \\
Sept.
\end{tabular} & \begin{tabular}{|l} 
Oct., \\
Nov., \\
Dec.
\end{tabular} & $\begin{array}{l}\text { July, } \\
\text { Aug., } \\
\text { Sept. }\end{array}$ & $\begin{array}{l}\text { Oct., } \\
\text { Nov., } \\
\text { Dec. }\end{array}$ & $\begin{array}{l}\text { July, } \\
\text { Aug., } \\
\text { Sept. }\end{array}$ & $\begin{array}{l}\text { Oct., } \\
\text { Nov., } \\
\text { Dec. }\end{array}$ & $\begin{array}{l}\text { July, } \\
\text { Aug., } \\
\text { Sept. }\end{array}$ & $\begin{array}{l}\text { Oct., } \\
\text { Nov., } \\
\text { Dec. }\end{array}$ & & & \\
\hline 1 & & & & & & & & & & & & & 1 \\
\hline $\begin{array}{l}2 \\
3\end{array}$ & & & & & & & & & & & & & 3 \\
\hline 4 & & & & & & & & & & & & & 4 \\
\hline 6 & & & & & & & & & & & & & 6 \\
\hline $\begin{array}{l}7 \\
8\end{array}$ & & & & & & & & & & & & & $\begin{array}{l}7 \\
8\end{array}$ \\
\hline $\begin{array}{r}9 \\
10\end{array}$ & & & & & & & & & & & & & 9 \\
\hline & & & & & & & & & & & & & $\begin{array}{l}10 \\
11\end{array}$ \\
\hline 13 & & & & & & & & & & & & & 12 \\
\hline 14 & \$i6. 54 & $\$ 16.00^{\circ}$ & $\$ 17.00$ & $\$ 14.50^{\circ}$ & & & & & & & & & $\begin{array}{l}13 \\
14\end{array}$ \\
\hline 5 & & & & & & & & & & & & & 15 \\
\hline 7 & & & & & & & & & & & & & $\begin{array}{l}10 \\
17\end{array}$ \\
\hline 9 & & & & & & & & & & & & & 18 \\
\hline 5 & & & & & & & & & & & & & 20 \\
\hline 1 & & & & & & & & & & & & & 21 \\
\hline $\begin{array}{l}23 \\
24\end{array}$ & & & & & & & & & & & & & 23 \\
\hline 25 & & & & & & & & & & & & & 24 \\
\hline 26 & & & & & & & & & $\because$ & & & & 26 \\
\hline 28 & & & & $\ldots$ & & $\cdots$ & & & & & & & $\begin{array}{l}27 \\
28\end{array}$ \\
\hline 29 & & & & {$[\cdots \cdots, \cdot$} & & .... & & .... & $\cdots$ & & - & & 29 \\
\hline 31 & $\cdots$ & .... & & …..... & & ........ & & ... & & & & & $\begin{array}{l}30 \\
31\end{array}$ \\
\hline 33 & …... & $\cdots$ & $\cdots$ & $\cdots$ & & ר........ & & & $\because \because$ & & & & 32 \\
\hline 34 & 18.08 & 20.11 & 18.32 & $\because 19.50$ & & $\$ 18.50$ & & & & & & & 列 \\
\hline 3 & & & & & & & & - & & 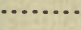 & & & 35 \\
\hline 37 & & & & & & & & ... & $\because$. & & & & $\begin{array}{l}50 \\
37\end{array}$ \\
\hline $\begin{array}{l}08 \\
39\end{array}$ & & & & & & & & & $\because$ & & & & 38 \\
\hline & & & & & & & & & & & ... & & 40 \\
\hline $\begin{array}{l}41 \\
42\end{array}$ & & & & & & & & & & & & & 41 \\
\hline 43 & $\cdots$ & . & 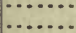 & $\because \cdots$. & & & $\because$. & & $\because \because$ & $\cdots$ & ‥ & & 43 \\
\hline $\begin{array}{l}44 \\
45\end{array}$ & & & & & & & $\cdot \cdot$ & & & ... & $\ldots$ & & 44 \\
\hline 46 & & & & & & & & & & & & & 46 \\
\hline 47 & & & & & & & & & & & $\ldots$ & & $\begin{array}{l}47 \\
48\end{array}$ \\
\hline $\begin{array}{l}70 \\
49\end{array}$ & & & & & & & & & & & & & 49 \\
\hline & & & & & & & & & $\because$ & & & & $\begin{array}{l}50 \\
51\end{array}$ \\
\hline 52 & & & & & & & & & $\because$ & & & & 52 \\
\hline $\begin{array}{l}53 \\
54\end{array}$ & & $\cdots$ & & $\cdots$ & & $\cdots$ & & & & & & & $\begin{array}{l}53 \\
54 \\
5\end{array}$ \\
\hline 55 & & $\cdots$ & & .. & . & & & & & & & & 55 \\
\hline $\begin{array}{l}56 \\
57\end{array}$ & ... & $\cdots$ & & & *. & $\cdots$ & & & & $\cdots$ & & & $\begin{array}{l}56 \\
57\end{array}$ \\
\hline 58 & .. & & & &. & & & & & & & & 58 \\
\hline 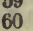 & & & & & & & & &. & & & & $\begin{array}{l}59 \\
60\end{array}$ \\
\hline & & & & & & & & & & & & & 61 \\
\hline 62 & & & & & & & & $\$ 23.17$ & & $\$ 15.63$ & & & $\begin{array}{l}62 \\
63\end{array}$ \\
\hline 64 & & & & & & & & & & $\ldots$ & & & 64 \\
\hline 66 & & & &. & ... & $\cdots$ & & & $\because$ & & & & 66 \\
\hline 67 & & & & & & $\ldots$ & & & & & & & 67 \\
\hline 0 & & & & & & .... & & & & & & & 69 \\
\hline & & & & & & & & & & & & .... & 70 \\
\hline 72 & & & & & & & & & & & & & 72 \\
\hline & & & & & & & & & & $\ldots$. & .... & …...... & 73 \\
\hline 80 & & & & & & & & & & ‥ & & & $\begin{array}{l}74 \\
75\end{array}$ \\
\hline 76 & & & & & & & & & & & & & 76 \\
\hline $\begin{array}{l}77 \\
78\end{array}$ & & & & 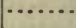 & & $\cdots \cdots$ & & & & & & & 77 \\
\hline 79 & & & & 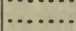 & & ........ & & & $\cdots$ & & & & 79 \\
\hline 80 & & & & & & & & & & & & & 80 \\
\hline
\end{tabular}




\begin{tabular}{|c|c|c|c|c|}
\hline & & 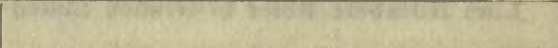 & OKLA & HOMA. \\
\hline Species. & 学 & Grade. & $\begin{array}{l}\text { July, } \\
\text { Aug., } \\
\text { Sept. }\end{array}$ & $\begin{array}{l}\text { Oct., } \\
\text { Nov., } \\
\text { Dec. }\end{array}$ \\
\hline . & 1 & Firsts and seconds $4 / 4$ & & \\
\hline Do. & 2 & No. 1 common $4 / 4 \ldots$ & & 33 \\
\hline $\begin{array}{l}\text { Do... } \\
\text { Do... }\end{array}$ & 3 & No. 2 common and better $4 / 4$ & & 9.67 \\
\hline $\begin{array}{l}\text { Do...: } \\
\text { Basswood }\end{array}$ & $\begin{array}{l}4 \\
5\end{array}$ & $\begin{array}{l}\text { Mill run } \\
\text { Firsts and seconds } 4 / 4 .\end{array}$ & & \\
\hline $\begin{array}{r}\text { Basswood } \\
\text { Do... }\end{array}$ & 6 & No. 1 common $4 / 4$.... & & \\
\hline Do... & 7 & No. 2 common $4 / 4 \ldots$ & & \\
\hline & 8 & Log run........... & & \\
\hline $\begin{array}{l}\text { Do.. } \\
\text { eech... }\end{array}$ & $\begin{array}{r}9 \\
10\end{array}$ & $\begin{array}{l}\text { Mill run..................... } \\
\text { Firsts and seconds } 4 / 4 . . .\end{array}$ & & \\
\hline $\begin{array}{l}\text { eech..... } \\
\text { Do.... }\end{array}$ & 11 & No. 1 common $4 / 4 . . . . .$. . & & \\
\hline Do... & 12 & Mill run.............. & & \\
\hline irch, un & 13 & Firsts and seconds & & \\
\hline Do.. & 14 & $\begin{array}{l}\text { No. } 1 \text { common } 4 / 4 \text {. } \\
\text { No. } 2 \text { common } 4 / 4 .\end{array}$ & & \\
\hline $\begin{array}{l}\text { Do.... } \\
\text { Do... }\end{array}$ & $\begin{array}{l}15 \\
16\end{array}$ & $\begin{array}{l}\text { No. } 2 \text { common } 4 / 4, \ldots \ldots \ldots \ldots \ldots \\
\text { No. } 2 \text { common and better } 4 / 4 \text { or } \log \text { run }\end{array}$ & & \\
\hline Do.... & 17 & 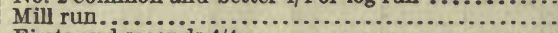 & & \\
\hline hestnut & 18 & Firsts and seconds & & \\
\hline Do. & 19 & No. 1 common $4 / 4, \ldots \ldots ̈ \%$ & & \\
\hline Do... & $\begin{array}{l}20 \\
21\end{array}$ & $\begin{array}{l}\text { No. } 2 \text { common and } S \text {. W. } 4 / 4 \\
\text { No. } 3 \text { common } 4 / 4 . \ldots \ldots \ldots .\end{array}$ & & \\
\hline Do..... & 22 & Mill run............... & & \\
\hline ottonw & 23 & Firsts and seco & & \\
\hline Do.. & 24 & Boxboards 4/4, 13 & & \\
\hline Do.. & $\begin{array}{l}25 \\
26\end{array}$ & $\begin{array}{l}\text { No. } 1 \text { common } 4 / 4 \ldots \ldots \\
\text { No. } 2 \text { common } 4 / 4 \ldots \ldots\end{array}$ & & \\
\hline Do.... & 27 & $\begin{array}{l}\text { No. } 2 \text { comm } \\
\text { Mill run... }\end{array}$ & & \\
\hline Cypress. & 28 & Firsts and seconds clear $4 / 4$. & & \\
\hline Do... & 29 & Selects $4 / 4 \ldots \ldots \ldots \ldots$ & & \\
\hline Do... & $\begin{array}{l}30 \\
31\end{array}$ & $\begin{array}{l}\text { Shop, No. } 1,4 / 4, \ldots \\
\text { No. } 1 \text { common } 4 / 4, \text { random widths... }\end{array}$ & & \\
\hline Do... & 32 & $\begin{array}{l}\text { No. } 1 \text { common } 4 / 4 \text {, random widths.. } \\
\text { No. } 2 \text { common } 4 / 4 \text {, random widths.. }\end{array}$ & & \\
\hline Do.. & 33 & Mill run ......... & & \\
\hline Cypress, shingles.. & 34 & Bests $5^{n} \ldots \ldots \ldots$ & & \\
\hline Do.... & 35 & & & \\
\hline $\begin{array}{l}\text { Elm, R } \\
\text { Do }\end{array}$ & $\begin{array}{l}36 \\
37\end{array}$ & $\begin{array}{l}\text { Firsts and seconds } 8 / 4 \ldots \ldots \\
\text { No. } 1 \text { common and better } 8 / 4\end{array}$ & & \\
\hline Do. & 38 & No. 2 common and better $8 / 4$ & & \\
\hline Do. & 39 & Mill run........................... & & \\
\hline Elm, Soft & 40 & No. 1 comm & & \\
\hline$\cdots \cdots \cdots$ & 41 & No. 2 comm & & \\
\hline $\begin{array}{l}\text { Do. } \\
\text { Gum... }\end{array}$ & $\begin{array}{l}42 \\
43\end{array}$ & $\begin{array}{l}\text { Mill run. } \\
\text { Firsts and seconds } 4 / 4, \text { red. }\end{array}$ & & \\
\hline Do.. & 44 & No. $1 \mathrm{c}$ & & \\
\hline Do.. & 45 & Firsts and $\mathrm{s}$ & & \\
\hline Do & 46 & No.1 c & & \\
\hline Do $\ldots . . . \ldots \ldots$ & 47 & No. 2 common $4 / 4$ & & \\
\hline Hickory............. & $\begin{array}{l}48 \\
49\end{array}$ & $\begin{array}{l}\text { Mill run............ } \\
\text { Firsts and seconds } 8 / 4 .\end{array}$ & & \\
\hline Do... & 50 & No. 1 comm & & \\
\hline $\mathrm{D}$ & 51 & mmon 8/4. & & \\
\hline Do $\ldots . . . . . . .$. & 52 & Mill run. $. \ldots . . . \ldots \ldots \ldots . .$. & & \\
\hline $\begin{array}{l}\text { Maple, Hard ........... } \\
\text { Do............ }\end{array}$ & $\begin{array}{l}53 \\
54\end{array}$ & $\begin{array}{l}\text { Firsts and seconds } 4 / 4 \ldots \ldots \\
\text { No. } 1 \text { common } 4 / 4 \ldots \ldots . .\end{array}$ & & \\
\hline Do. & 55 & Mill run... & & \\
\hline Maple, So & & No. 1 common a & & \\
\hline ...... & 57 & No. 3 & & \\
\hline Do.............. & $\begin{array}{l}58 \\
59\end{array}$ & $\begin{array}{l}\text { Log run............ } \\
\text { Mill run...... }\end{array}$ & & \\
\hline Oak, Plain.......... & 60 & Firsts and seconds $4 / 4$. & & 33.00 \\
\hline Do. & 61 & $\mathrm{~N}$ & $\$ 18.67$ & 18.00 \\
\hline D & 62 & $\mathbf{N}$ & …… & 8.67 \\
\hline Do. & 63 & $4 / 4$ & & $\cdots$ \\
\hline ered................ & $\begin{array}{l}64 \\
65\end{array}$ & nds $4 / 4 \ldots \ldots$ & & \\
\hline quartered. & $\begin{array}{l}05 \\
66\end{array}$ & N & & .... \\
\hline Do. & 67 & No. 2 common $4 / 4$ & & $\cdots \ldots$ \\
\hline Do $\ldots \ldots \ldots \ldots \ldots \ldots \ldots$ & 68 & 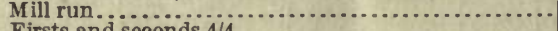 & & . $\ldots \ldots$ \\
\hline Oak, White, quartered ....... & 69 & Firsts and sec & & $\because$ \\
\hline $\begin{array}{l}\text { Do.... } \\
\text { Do... }\end{array}$ & $\begin{array}{l}70 \\
71\end{array}$ & $\begin{array}{l}\text { No. } 1 \text { commc } \\
\text { No. } 2 \text { comm }\end{array}$ & & \\
\hline Do. & 72 & Mill run. & & \\
\hline Poplar & 73 & nd 3 & & \\
\hline Do.. & 74 & Saps or selec & & \\
\hline $\begin{array}{l}\text { Do... } \\
\text { Do... }\end{array}$ & $\begin{array}{l}75 \\
76\end{array}$ & $\begin{array}{l}\text { No. } 1 \text { comm } \\
\text { No. } 2 \text { comm }\end{array}$ & & $\cdots$ \\
\hline Do & 77 & Mill run.. & & (......... \\
\hline Tupelo (Bay Poplar).. & 78 & random, $4 / 4 \ldots .$. & & 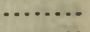 \\
\hline Do.. & $\begin{array}{l}79 \\
80\end{array}$ & $\begin{array}{l}\text { No. } 1 \text { comm } \\
\text { Mill run. }\end{array}$ & & \\
\hline & & Mill run. & & \\
\hline
\end{tabular}


Line Numbers Refer to Grades Listed on Page 20.

\begin{tabular}{|c|c|c|c|c|c|c|c|c|c|c|c|c|c|}
\hline \multirow{2}{*}{$\begin{array}{l}0 \\
Z \\
\pm \\
\dot{\Xi} \\
\vec{H}\end{array}$} & \multicolumn{4}{|c|}{ ARKANSAS. } & \multicolumn{4}{|c|}{ LOUISIANA. } & \multicolumn{4}{|c|}{ MISSISSIPPI. } & \multirow{2}{*}{ 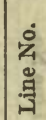 } \\
\hline & $\begin{array}{l}\text { Jan., } \\
\text { Feb., } \\
\text { Mar. }\end{array}$ & $\begin{array}{l}\text { Apr., } \\
\text { May, } \\
\text { June. }\end{array}$ & $\begin{array}{l}\text { July, } \\
\text { Aug., } \\
\text { Sept. }\end{array}$ & $\begin{array}{l}\text { Oct., } \\
\text { Nov., } \\
\text { Dec. }\end{array}$ & $\begin{array}{l}\text { Jan., } \\
\text { Feb., } \\
\text { Mar. }\end{array}$ & $\begin{array}{l}\text { Apr., } \\
\text { May, } \\
\text { June. }\end{array}$ & $\begin{array}{l}\text { July, } \\
\text { Aug., } \\
\text { Sept. }\end{array}$ & $\begin{array}{l}\text { Oct., } \\
\text { Nov., } \\
\text { Dec. }\end{array}$ & $\begin{array}{l}\text { Jan., } \\
\text { Feb., } \\
\text { Mar. }\end{array}$ & $\begin{array}{l}\text { Apr., } \\
\text { May, } \\
\text { June. }\end{array}$ & $\begin{array}{l}\text { July, } \\
\text { Aug., } \\
\text { Sept. }\end{array}$ & $\begin{array}{l}\text { Oct., } \\
\text { Nov., } \\
\text { Dec. }\end{array}$ & \\
\hline 1 & 12 & .44 & & 1 & .07 & $\$ 35.60$ & & & 0 & & & 16 & \\
\hline 2 & & & & & & & & & & & & & \\
\hline 3 & & 10 & 1. & 10. & 10.00 & 10. & & & & & & & \\
\hline $\begin{array}{l}4 \\
5\end{array}$ & 21 & 20.56 & 20.10 & & & & & & & & & & \\
\hline 6 & & & & & & & & & & & & & \\
\hline $\begin{array}{l}7 \\
8\end{array}$ & & & & & & & & & & & & & \\
\hline $\begin{array}{l}8 \\
9\end{array}$ & & & & & & & & & & & & & 9 \\
\hline 0 & & & & & & & & & & & & & 10 \\
\hline 1 & & & & & & & & & & & & & 11 \\
\hline 2 & & & & & & & & & & & & & 12 \\
\hline 4 & & & & & & & & & & & & & 14 \\
\hline & & & & & & & & & & & & & 15 \\
\hline j & & & & & & & & & & & & & 16 \\
\hline 18 & & & & & & & & & & & & & 17 \\
\hline & & & i & & & & & & & & & & $\begin{array}{l}18 \\
19\end{array}$ \\
\hline 20 & & & & & & & & & & & & & 20 \\
\hline 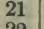 & 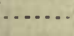 & *. & 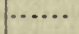 & 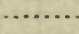 & 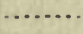 & 年 & & & 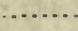 & $4 y^{2}$ & & & 21 \\
\hline 23 & 2 & 24.50 & 24. & 2 & 24.38 & 22. & & & 0 & 9 & & & \\
\hline 24 & & & 4 & & .50 & 45 & & & & & & & \\
\hline 2. & & & 17 & & 8 & & & & & & & & \\
\hline 26 & 1 & 11.93 & 13.25 & 15. & 11.13 & 11. & 11 & & 13 & & 13.90 & & \\
\hline 2 & & & 1 & & 0 & & & & & & & & \\
\hline 28 & 46 & 32.85 & 34. & & 34.81 & 34 & & & & & & & \\
\hline & & 29 & 29 . & & 8 & & & & & & & & \\
\hline 30 & & 18 & 1 & & & 18 & & & & & & & \\
\hline 31 & & 12 & 13 & & 4 & 14. & & & & & & & 1 \\
\hline 52 & & & 9. & & & & & & & 9.05 & & & \\
\hline 33 & 18. & 19. & 19.17 & 18.66 & 21.22 & 21. & & & & & ... & $\ldots$ & \\
\hline 3 & & 3.45 & ....... & $\ldots \ldots$ & 3.37 & 3.40 & & & & & & & 4 \\
\hline 35 & 2.41 & 2.45 & $\ldots$ & & 2.59 & 2.68 & & & & & & & 35 \\
\hline $\begin{array}{l}36 \\
37\end{array}$ & ….... & an. & $\cdots \cdots$ & & $\ldots .$. & ....... & & . & & & & & 36 \\
\hline 38 & & & & & & & & & & & & & 8 \\
\hline 39 & & & 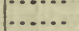 & & & & & & & & & & 9 \\
\hline 40 & & 21. & & & & & & & & & & & 0 \\
\hline 41 & 1 & 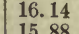 & 1 & 17.50 & ...... & & & & & & & 75 & 41 \\
\hline $\begin{array}{l}42 \\
43\end{array}$ & 2 & 2 & 29 & 2 & 29.00 & 29. & & & & & & & 43 \\
\hline 44 & & 1 & 2 & & 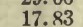 & 17 & & & & & & & $\mathbf{x}$ \\
\hline 45 & & & & & 1 & & & & & & & & 5 \\
\hline 46 & 11 & 11 & 1 & & 11 & 10. & 10 & & & & & 5 & \\
\hline 47 & & & & & 7.75 & 6.87 & & & 0.00 & & & 9.16 & \\
\hline 48 & 11.97 & 13.41 & 11 & 12 & & ....... & & & & & 15. & & 8 \\
\hline 49 & & 4 & & 49.41 & & & & & & 44.92 & & 59.33 & 49 \\
\hline 50 & & 2 & 2 & & & & & & & & & & 50 \\
\hline 51 & 1. & & 11.20 & & & & & & - . & & & & 5. \\
\hline 52 & 26.75 & 28.00 & & & & & & & & & & . & \\
\hline & $\ldots$ & ...... & ... & . & & & & & 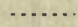 & & & & \\
\hline 54 & $\cdots$ & .... & 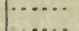 & & & & & & & & & & 55 \\
\hline & & 18 & & & & & & & & & & & 56 \\
\hline 57 & & & & & & & & & & & & & 57 \\
\hline & & & & & & & & & & & & & \\
\hline 59 & & & & & & & & & & & & & \\
\hline & & & & & & & & & & & & & \\
\hline 61 & & & & & & & & & & & & & \\
\hline & & & & & & 10.60 & & 10. & & & & & \\
\hline 63 & & & & & & & & & & & & & \\
\hline 84 & & 20 & 1 & & & & 21.27 & & & & & & 64 \\
\hline 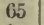 & & & & & & 48 & & & & & & & \\
\hline ifi & & & 3 & & 27.32 & 28.66 & & & & & & & 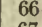 \\
\hline 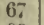 & & & 17.1\{ & & 14.83 & & & & & & 16.08 & 16.75 & 67 \\
\hline 68 & & & & & & & & & & & & & \\
\hline & & & & & & & & & & & & & \\
\hline 70 & & & & & & & & & & & & & \\
\hline & & & & & 19.67 & 19.50 & & & 17.14 & 17.33 & 19.85 & 19.00 & \\
\hline 72 & 41.1 & 39.60 & 35.6 & & & & & & & & & & \\
\hline & +5 & $\ldots$ & & & & & & & & & & & \\
\hline & & & & & & 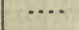 & & & & & & & 75 \\
\hline & & & & & & & & & & & & & 76 \\
\hline & & & & & & & & & & 25.80 & & & 77 \\
\hline & $\cdots$ & -. & & & & & & & & & & & \\
\hline & & & & 13.6 & 13.51 & 13.20 & 12. & 13. & 12.14 & & & & \\
\hline & & & & & 12.60 & 13.72 & 12.27 & & $\cdots$ & 12.25 & & & \\
\hline
\end{tabular}


Line Numbers Refer to Grades Listed on Page 20.

\begin{tabular}{|c|c|c|c|c|c|c|c|c|c|c|c|c|c|}
\hline \multirow[b]{2}{*}{ 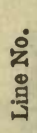 } & \multicolumn{4}{|c|}{ ATABAMA. } & \multicolumn{4}{|c|}{ MISSOURI. } & \multicolumn{4}{|c|}{ TEXAS. } & \multirow[b]{2}{*}{$\begin{array}{l}0 \\
z \\
z \\
0 \\
ㅁ\end{array}$} \\
\hline & $\begin{array}{l}\text { Jan., } \\
\text { Feb., } \\
\text { Mar. }\end{array}$ & $\begin{array}{l}\text { Apr., } \\
\text { May, } \\
\text { June. }\end{array}$ & $\begin{array}{l}\text { July, } \\
\text { Aug., } \\
\text { Sept. }\end{array}$ & $\begin{array}{l}\text { Oct., } \\
\text { Nov., } \\
\text { Dec. }\end{array}$ & $\begin{array}{l}\text { Jan., } \\
\text { Feb., } \\
\text { Mar. }\end{array}$ & $\begin{array}{l}\text { Apr., } \\
\text { May, } \\
\text { June. }\end{array}$ & $\begin{array}{l}\text { July, } \\
\text { Aug., } \\
\text { Sept. }\end{array}$ & $\begin{array}{l}\text { Oct., } \\
\text { Nov., } \\
\text { Dec. }\end{array}$ & $\begin{array}{l}\text { Jan., } \\
\text { Feb., } \\
\text { Mar. }\end{array}$ & $\begin{array}{l}\text { Apr., } \\
\text { May, } \\
\text { June. }\end{array}$ & $\begin{array}{l}\text { July, } \\
\text { Aug., } \\
\text { Sept. }\end{array}$ & $\begin{array}{l}\text { Oct., } \\
\text { Nov, } \\
\text { Dec. }\end{array}$ & \\
\hline 1 & $\$ 36.17$ & $\$$ & & & & & & & & & & & \\
\hline 2 & & & & & & & & & & & & & \\
\hline $\begin{array}{l}3 \\
4\end{array}$ & & & & & & 20.00 & $\$ 23.33$ & 19.20 & & & & & \\
\hline 5 & & & & & & ........... & ......... & & & & & & \\
\hline $\begin{array}{l}6 \\
7\end{array}$ & & & & & & & & & & & & & \\
\hline 8 & & & & & & & & & & & & & \\
\hline $\begin{array}{r}9 \\
10\end{array}$ & & & & & & & …...... & & & & & & 10 \\
\hline . & & & & & & & $\cdots$ & & & & & & $\begin{array}{l}10 \\
11\end{array}$ \\
\hline 12 & & & & & & & ................ & & & & & & 12 \\
\hline & & & & & & & & & & & & & 13 \\
\hline 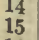 & & & & & & $\because$ & & & & & & & 14 \\
\hline & & $\cdots$ & & & & $\ldots$ & $\ldots \ldots \ldots$ & & & & & & $\begin{array}{l}15 \\
16\end{array}$ \\
\hline 1 & & & & & & & & & & & & & 17 \\
\hline 19 & & 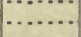 & & & & $\because$ & (n......... & & & & & & 18 \\
\hline & & & & & & & …...... & & & & & & $\begin{array}{l}19 \\
20\end{array}$ \\
\hline 21 & & & & & & & ........ & & & & & & 21 \\
\hline 23 & & & & & & 26.33 & 25.75 & & & & & & 22 \\
\hline 24 & & $\ldots$. & & & ... & 49 & & & & & & & 23 \\
\hline & & & & & $\ldots \ldots \ldots$ & 18.17 & & & & & & & $\begin{array}{l}24 \\
25\end{array}$ \\
\hline & & & & & & 15.50 & 15.33 & & & & & & 26 \\
\hline & & & & & 32.25 & 35.37 & 34.67 & $\begin{array}{l}15 \\
33\end{array}$ & & & & & 27 \\
\hline & & & & & & 30 & & & & & & & 28 \\
\hline 30. & $\cdots$ & ..... & & & 7 & 19 & & & & & & & 30 \\
\hline & & & & & $\begin{array}{l}14.10 \\
10.80\end{array}$ & 15 & & & & & & & 31 \\
\hline 32 & & & & & $\begin{array}{c}10.80 \\
\cdots \ldots\end{array}$ & $\begin{array}{r}11.30 \\
\ldots . . .\end{array}$ & $\begin{array}{r}10 \\
. .\end{array}$ & 33 & & & & & 32 \\
\hline 34 & $\cdots$ & & & & & . & …......... & & & & & & $\begin{array}{l}33 \\
34\end{array}$ \\
\hline & & & & & & & & & & & & & 35 \\
\hline & & & & & & & & & & & & & 36 \\
\hline 38 & $\cdot$ & . & & & & & & & & & & & 37 \\
\hline 40 & . & & & & & - & - & & & & & & $\begin{array}{l}38 \\
39\end{array}$ \\
\hline 40 & $\cdots$ & $\cdots \cdots$ & & & & & …..... & & & & & & $\begin{array}{l}39 \\
40\end{array}$ \\
\hline $\begin{array}{l}41 \\
42\end{array}$ & & & & & & $\because$ & 16.00 & & & & & & 41 \\
\hline 43 & & . & & & 80 & 29. & & & & & & & 42 \\
\hline 44 & $\begin{array}{l}17 \\
17\end{array}$ & . & 1 & & 0 & 1 & & & & & & & 43 \\
\hline 15. & $\begin{array}{l}17.00 \\
12.50\end{array}$ & & & & & & & & & & & & 44 \\
\hline 47 & $\begin{array}{l}12.50 \\
\ldots \ldots \ldots\end{array}$ & & & & 12 & 13 & & & & & & & 46 \\
\hline 48 & & & & & $\begin{array}{r}9.70 \\
11.42\end{array}$ & 10. & 10.13 & & & 10 & & 37 & 47 \\
\hline 49 & 45.17 & 47.5 & & & $\begin{array}{c}11.42 \\
\cdots \ldots \ldots\end{array}$ & \begin{tabular}{|c|}
12.17 \\
$\ldots \ldots$
\end{tabular} & an....... & & & $\cdots$ & & & 48 \\
\hline 51 & & 2 & & & $\cdots$ & 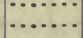 & & & & & & & $\begin{array}{l}49 \\
50\end{array}$ \\
\hline 51 & 13.50 & 11.75 & $\ldots$ & & -. & & & & & & & & 51 \\
\hline 52 & '.......... & …..... & & & $\cdots$ & & & & & & & & 52 \\
\hline 54 & & & & & & & & & & & & & 53 \\
\hline & & & & & & 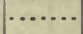 & & & & & & & $\begin{array}{l}54 \\
55\end{array}$ \\
\hline & & & & & & $\cdots$ & & & & & & & $\begin{array}{l}55 \\
56\end{array}$ \\
\hline nx & & & & & $\cdots$ & . & , & & & & & & 57 \\
\hline $59-2$ & & & & & 50 & i. & & & & & & & 58 \\
\hline 61 & & & & & & & & & & & & & 60 \\
\hline 62 & $\begin{array}{l}24 \\
11\end{array}$ & $\begin{array}{l}24.75 \\
11.33\end{array}$ & $\begin{array}{l}23.5 \\
11 .\end{array}$ & & & 12 & 11. & & & & & & 61 \\
\hline 63 & 8.03 & 8.51 & & & $\begin{array}{r}11.67 \\
6.80\end{array}$ & $\begin{array}{r}12.33 \\
6.17\end{array}$ & $\begin{array}{r}11.94 \\
6.25\end{array}$ & 11.50 & 13.25 & 12.50 & & & 62 \\
\hline 34 & & $\cdots$ & & & 13.98 & 14.50 & 18.50 & 13.29 & & & & & $\begin{array}{l}63 \\
64\end{array}$ \\
\hline 66 & & & & & $\cdots$ & - & & & & & & & 65 \\
\hline in & 15.12 & & & & & & & & & & & & 66 \\
\hline 35 & & & & & & & & & & & & & 67 \\
\hline 10 & & & & & & & & & & & & & 69 \\
\hline 7 & 19.51 & 18.00 & 18.67 & & ... & & & & & & & & 70 \\
\hline $\begin{array}{l}72 \\
73\end{array}$ & & & 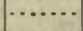 & & & 21.00 & 21.33 & & & & & & 71 \\
\hline 73 & & & & & & & & & & & & & 72 \\
\hline-1 & & & & & & & & & & & & & $\begin{array}{l}73 \\
74\end{array}$ \\
\hline 76 & 14.17 & 13.00 & & & & & & & & & & & 4 \\
\hline 7 & & t & -.. & & & & & & & & & & \\
\hline & & & & & & & & & & & & & 7 \\
\hline & & & & & & & & & & & & & 79 \\
\hline & & & & & & & & & & & & & 80 \\
\hline
\end{tabular}


Line Numbers Refer to Grades Iisted on Page 20.

\begin{tabular}{|c|c|c|c|c|c|c|c|c|c|c|c|c|c|}
\hline \multirow[b]{2}{*}{ 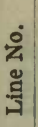 } & \multicolumn{4}{|c|}{ LORIDA. } & \multicolumn{4}{|c|}{ SOUTH CAROLINA. } & \multicolumn{4}{|c|}{ NORTH CAROLINA. } & \multirow[b]{2}{*}{$\begin{array}{l}0 \\
z \\
0 \\
\vdots\end{array}$} \\
\hline & $\begin{array}{l}\text { Jan., } \\
\text { Feb., } \\
\text { Mar. }\end{array}$ & May, & $\begin{array}{l}\text { July, } \\
\text { Aug., } \\
\text { Sept. }\end{array}$ & $\begin{array}{l}\text { Nov., } \\
\text { Dec. }\end{array}$ & $\begin{array}{l}\text { Feb., } \\
\text { Mar. }\end{array}$ & $\begin{array}{l}\text { Apr., } \\
\text { May, } \\
\text { June. }\end{array}$ & $\begin{array}{l}\text { Aug., } \\
\text { Sept. }\end{array}$ & $\begin{array}{l}\text { Oct., } \\
\text { Nov., } \\
\text { Dec. }\end{array}$ & $\begin{array}{l}\text { Jan., } \\
\text { Feb., } \\
\text { Mar. }\end{array}$ & $\begin{array}{l}\text { Apr., } \\
\text { May, } \\
\text { June. }\end{array}$ & $\begin{array}{l}\text { July, } \\
\text { Aug., } \\
\text { Sept. }\end{array}$ & $\begin{array}{l}\text { Oct., } \\
\text { Nov., } \\
\text { Dec. }\end{array}$ & \\
\hline 1 & & & & & & & & & & & & & \\
\hline 3 & & & & & & & & & $\ldots \ldots$ & & & & \\
\hline & & & & & & & & & $\cdots$ & & & & \\
\hline & & & & & & & & & & & & & \\
\hline & & & & & & & & & $\begin{array}{l}12 \\
21\end{array}$ & & & & \\
\hline & & & & & & & & & & 19.33 & & 20.00 & \\
\hline & & & & & & & & & $\cdots \cdots$ & $\cdots$ & & $\cdots \cdot$ & $\begin{array}{l}10 \\
11\end{array}$ \\
\hline & & & & & & & & & & & & & $\begin{array}{l}11 \\
12\end{array}$ \\
\hline & & & & & & & & & & & & & 13 \\
\hline & & & & & & & & & & & & & 14 \\
\hline & & & & & & & & & & & & & $\begin{array}{l}15 \\
16\end{array}$ \\
\hline & & & & & & & & & & & & & $\begin{array}{l}16 \\
17\end{array}$ \\
\hline & & & & & & & & & 41 & & & & 18 \\
\hline & & & & & & & & & & & & & \\
\hline & & & & & & & & & 7.50 & & & & 20 \\
\hline & & & & & & & & & (......... & $\cdots$ & & & $\begin{array}{l}21 \\
22\end{array}$ \\
\hline & & & & & & & & & $\because$ & & & & 23 \\
\hline & & & & & & & & & $\cdots$ & & & & 24 \\
\hline 27 & & & & & & & & & & & & & 26 \\
\hline 28 & $\$$ & $\$ 35$ & $\$ 35$ & & & & & & & & & $\because$ & 27 \\
\hline 29 & & & & & & $\$ 31$ & & & & & & & 28 \\
\hline & & & & & & & & & & & & & 3 \\
\hline & & & 16. & & & 16. & & & $\ldots .$. & & & & 0 \\
\hline & & & 11.00 & & 12.75 & 11.38 & & & $\cdots$ & & & .. & 02 \\
\hline 34 & $\begin{array}{r}22.17 \\
4.12\end{array}$ & $\begin{array}{r}24 \\
4\end{array}$ & $\because$ & & $\cdots$ & & & & $\begin{array}{l}19.83 \\
\ldots . . .\end{array}$ & & & & 33 \\
\hline & & & & & & & & & $\because \cdots$ & & & & 3. \\
\hline 36 & .. & & & & & & & & ......... & & & & 3 \\
\hline 37 & & & & & & & & & & & & & 37 \\
\hline & & & & & & & & & $\because$. & & & & \\
\hline 41 & & & & & & & & & a........ & & & & 4 \\
\hline 42 & & & & & & & & & $\ldots \ldots$ & $\cdots$ & & $\because$ & \\
\hline 43 & & & & & & & & & & & & $\because$ & \\
\hline 44 & & & & & & & & & & & & & \\
\hline $\begin{array}{l}45 \\
46\end{array}$ & & & & & & & & & . & & & & $\begin{array}{l}4 \\
4\end{array}$ \\
\hline 4 & & & & & & & & & .. & ... & & $\cdots$ & 4 \\
\hline 48 & & & & & & & & & $\because$ & & &. & \\
\hline 4 & & & & & & & & & . & & & & \\
\hline 5 & & & & & & & & & & ... & & $\because$ & \\
\hline 52 & & & & & & & & & & & & & \\
\hline 5 & - & & & & & & & & & & & & \\
\hline 5 & & & & & & & & & & & & & \\
\hline & & & & & & & & & & & & $\ddot{0}$ & \\
\hline 5 & & & & & & & & & & & & ・・ & \\
\hline & & & & & & & & & & & & $\ddot{3}$ & \\
\hline & & & & & & & & & & & & 33 & \\
\hline & & & & & & & & & & & & & 60 \\
\hline & & & & & & & & & & & & & 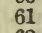 \\
\hline 6 & & & & & & & & & & & & & s \\
\hline 6 & & & & & & $\ldots$ & & & 17.67 & $\begin{array}{r}7.07 \\
16.67\end{array}$ & & 18.50 & 6 \\
\hline 66 & & & & & & & & & & & & & \\
\hline & & & & & & & & & & & & & \\
\hline & & & & & & & & & & & & & $\begin{array}{l}6 \\
6\end{array}$ \\
\hline & & & & & & & & & & & & & 6 \\
\hline & & & & & & & & & & & & & 7 \\
\hline & & & & & & & & & & & & & 7 \\
\hline & & & & & & & & & & & & & 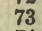 \\
\hline & & & & & & & & & & & & & 7 \\
\hline & & & & & & & & & & & & & \\
\hline & & & & & & & & & & 15.44 & 15.14 & 00 & 76 \\
\hline & & & & & & & & & & $\cdots$ & $\cdots$ & 66 & $\begin{array}{l}7 \\
7\end{array}$ \\
\hline & & & & & & & & & & & & & 7 \\
\hline 80 & & & & & & & & & & 12.00 & & & \\
\hline
\end{tabular}


Line Numbers Refer to Grades Listed on Page 20.

\begin{tabular}{|c|c|c|c|c|c|c|c|c|c|c|c|c|c|}
\hline \multirow[b]{2}{*}{ 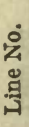 } & \multicolumn{4}{|c|}{ TENNESSEE. } & \multicolumn{4}{|c|}{ KENTUCKY. } & \multicolumn{4}{|c|}{ VIRGINIA. } & \multirow[b]{2}{*}{ 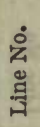 } \\
\hline & $\begin{array}{l}\text { Jan., } \\
\text { Feb., } \\
\text { Mar. }\end{array}$ & $\begin{array}{l}\text { Apr., } \\
\text { May, } \\
\text { June. }\end{array}$ & $\begin{array}{l}\text { July, } \\
\text { Aug., } \\
\text { Sept. }\end{array}$ & $\begin{array}{l}\text { Oct., } \\
\text { Nov., } \\
\text { Dec. }\end{array}$ & $\begin{array}{l}\text { Jan., } \\
\text { Feb., } \\
\text { Mar. }\end{array}$ & $\begin{array}{l}\text { Apr., } \\
\text { May, } \\
\text { June. }\end{array}$ & $\begin{array}{l}\text { July, } \\
\text { Aug., } \\
\text { Sept. }\end{array}$ & $\begin{array}{l}\text { Oct., } \\
\text { Nov., } \\
\text { Dec. }\end{array}$ & $\begin{array}{l}\text { Jan., } \\
\text { Feb., } \\
\text { Mar. }\end{array}$ & $\begin{array}{l}\text { Apr., } \\
\text { May, } \\
\text { June. }\end{array}$ & $\begin{array}{l}\text { July, } \\
\text { Aug.; } \\
\text { Sept. }\end{array}$ & $\begin{array}{l}\text { Oct., } \\
\text { Nov., } \\
\text { Dec. }\end{array}$ & \\
\hline 1 & $\$ 35.85$ & 31 & & & 0 & 21 & & & 38.00 & & & & \\
\hline 2 & & & & & & & 0 & 0 & & & & & 2 \\
\hline 3 & & & & & & 1 & & 15. 00 & 12.68 & 16.00 & & 00 & 3 \\
\hline 4 & 2 & 2 & 2 & 23. & 21. & 22.00 & 19.00 & & & & & & \\
\hline 5 & 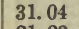 & 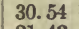 & & 21 & 31.67 & 33.00 & ........ & & ... & & & & 5 \\
\hline 6 & 21 . & 2 & 22. & & 21. 00 & 21. 75 & & & & 20.00 & & & c \\
\hline 7 & 1. & 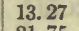 & 14. & & & 12. 33 & & & 1007 & & & & 7 \\
\hline 8 & 20 & 5 & 19.1 & & 1 & 20.50 & 21. 50 & 24.33 & 19.67 & 19.87 & 13 & 33 & \\
\hline $\begin{array}{r}9 \\
10\end{array}$ & 19.80 & $\begin{array}{c}19.48 \\
\ldots \ldots .\end{array}$ & 23.83 & $\begin{array}{l}20.11 \\
27.00\end{array}$ & 17 & 20.00 & 20. & & $\cdots$ & & & & 10 \\
\hline 1 & & & 16.50 & 17.25 & & $\bullet$ & & & & & & & $\begin{array}{l}10 \\
11\end{array}$ \\
\hline 2 & .... & ...... & 15. & 19.67 & 13.33 & 12.90 & ii. 75 & & & & & & 12 \\
\hline & & & & $\ldots \ldots$ & & & & & & & & & 13 \\
\hline 5 & $\cdots$ & & & & & & & & & & & & 14 \\
\hline 6 & 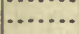 & & & & & & & & & & & & $\begin{array}{l}15 \\
16\end{array}$ \\
\hline & & & & & & & & & & & & & $\begin{array}{l}10 \\
17\end{array}$ \\
\hline 9 & \begin{tabular}{|l|}
38.61 \\
26.36
\end{tabular} & 4 & & & & 39.93 & 39.52 & & 1.33 & 39.60 & & & 18 \\
\hline & 11.93 & 6 & 13. & $\begin{array}{l}25.14 \\
12.79\end{array}$ & $\begin{array}{l}29.30 \\
11.87\end{array}$ & $\begin{array}{l}3 \\
8\end{array}$ & 2 & & & & & & 19 \\
\hline & 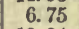 & & & 7.11 & 7.33 & 7.50 & 7.27 & 67 & $\begin{array}{r}1.50 \\
6.67\end{array}$ & $\begin{array}{r}11.00 \\
6.25\end{array}$ & .81 & & $\begin{array}{l}20 \\
21\end{array}$ \\
\hline 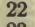 & 19.34 & 18. 69 & 20.00 & 20.0 & 19.25 & 17.08 & 18.94 & & 15. 50 & 15. 75 & & 14. & 22 \\
\hline & 2 & 25. 0 & 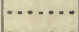 & $\because$ & 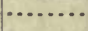 & 27.75 & & & $\cdots$ & & & & 23 \\
\hline 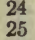 & 47.50 & 47.75 & & & ...... & 49. 50 & & & & & & & 24 \\
\hline & 00 & 1 & & & .. & $\begin{array}{l}18.50 \\
12.25\end{array}$ & & & & & & & 25 \\
\hline 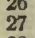 & 15.00 & 1 & & & & 14.87 & & & & & & & $\begin{array}{l}26 \\
27\end{array}$ \\
\hline 8 & 35.53 & 00 & & & & & & & & & & & $\begin{array}{l}28 \\
28\end{array}$ \\
\hline 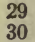 & 12 & 3 & & & & & & & & & & & 29 \\
\hline & 46 & 1 & & & & & & & 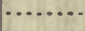 & & & & 30 \\
\hline 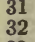 & $\begin{array}{r}14.58 \\
8.74\end{array}$ & 13.50 & .. & ... & & & & & & & & & 31 \\
\hline 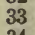 & $\begin{array}{c}8.14 \\
\ldots . . . .\end{array}$ & & & & & & & & & & & & 33 \\
\hline 34 & & & & & & & & & & & & & 34 \\
\hline & & & & & & & & & & & & & 35 \\
\hline 37 & & & & & ... & & & & & & & & 36 \\
\hline & & & & & & & & & & & & & $\begin{array}{l}37 \\
38\end{array}$ \\
\hline & $\cdots$ & & & & $\cdots$ & & & & & & & & 39 \\
\hline & & & & & & & & & & & & & 40 \\
\hline & & & & & & & & & & & & & 41 \\
\hline 4. & 26.13 & & & & & & & & & & & & $\begin{array}{l}42 \\
43\end{array}$ \\
\hline 4 & 50 & 17.25 & & & & & & & & & & & 44 \\
\hline & & & & & & & & & & & & & 45 \\
\hline 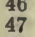 & 1 & & & & & & & & & & & & 46 \\
\hline $48-2$ & 11. 78 & 1 & & & & 12. 12 & 12. 17 & & & & 12.00 & 11. 27 & 48 \\
\hline 4 & 46.88 & .29 & 25 & 49 & & & 51.67 & 48.33 & & & & & 49 \\
\hline & 2 & .8 & 28.8 & & $\ldots$ & 30.75 & 31.25 & & & & & & 50 \\
\hline 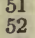 & $\begin{array}{l}11.50 \\
18.00\end{array}$ & .00 & 11.00 & 14. 21 & & 21.50 & .75 & & & & & & 51 \\
\hline 53 & 10.00 & 3. 33 & 3.67 & & & & .60 & & & & & & $\begin{array}{l}52 \\
53\end{array}$ \\
\hline & 1 & & 16.67 & & & & & & & & & & 54 \\
\hline 55 & 16.40 & 16.15 & $\cdots$ & & & 15.05 & & & & & & & \\
\hline & ;...... & & & & & & & & & & & & $\begin{array}{l}56 \\
57\end{array}$ \\
\hline 5 & & & & & & & & & & & & & 58 \\
\hline & & & & & & & & & & & & & \\
\hline 6 & & 2 & & & & & & & & & & & 60 \\
\hline 6 & & & & & & & & & & & & & 61 \\
\hline 6 & & & & & & & & & & & & & 63 \\
\hline & 20 & & & & & & & & 16.48 & 15.71 & 15. & & 64 \\
\hline & & & & & & & & & & & & & \\
\hline & & & & & & & & & & & & & 67 \\
\hline & & .4 & & & & 19. & 00 & 10.00 & & & & & \\
\hline 6 & & & & & & & & & & & & & $\begin{array}{l}05 \\
69\end{array}$ \\
\hline 7 & 3 & & & & & & & & & & & & 70 \\
\hline & & & & & 22.25 & 22 & 11 & & & & & & 71 \\
\hline & & & & & & & & & & & & & \\
\hline & & & & & & & & & & & & & 73 \\
\hline & & & & & & & & & & & & & 74 \\
\hline 7 & 2 & & 2 & & & & & & & & & & 75 \\
\hline 7 & & & 14.85 & & & & & & 17. & 15. 21 & 17.88 & & 76 \\
\hline 7 & 28.33 & 28.00 & 28.27 & 28.29 & 27.56 & 28.00 & 28.40 & 25.75 & 25.84 & & ... & 16.87 & 77 \\
\hline & & & & & & & & & & & & & 79 \\
\hline 80 & & & & & & & & & & & & & 80 \\
\hline
\end{tabular}


Line Numbers Refer to Grades Listed on Page 20.

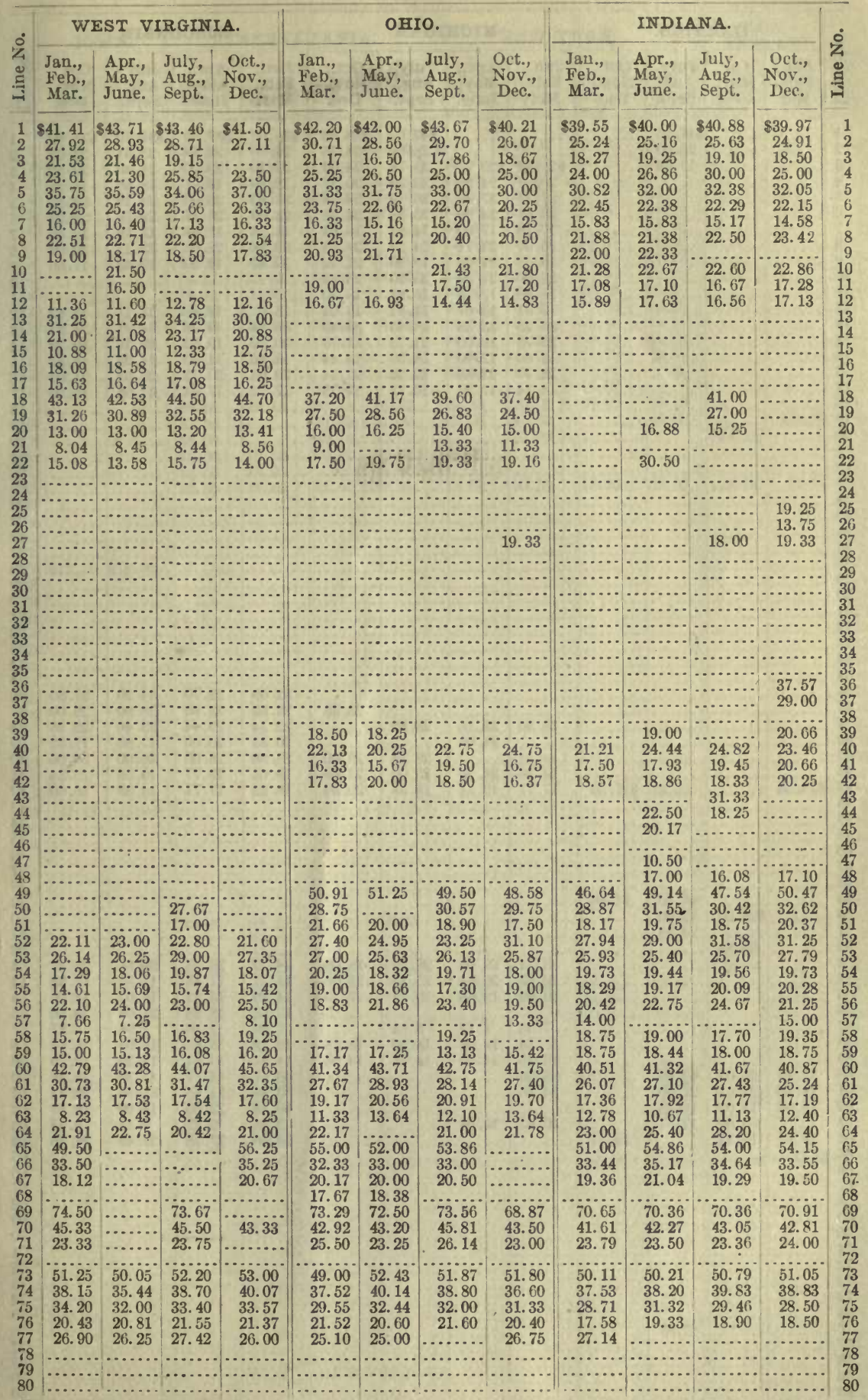


Line Numbers Refer to Grades Listed on Page 20.

\begin{tabular}{|c|c|c|c|c|c|c|c|c|c|c|c|c|c|}
\hline \multirow{2}{*}{ 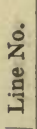 } & \multicolumn{4}{|c|}{ IILINOIS. } & \multicolumn{4}{|c|}{ MICHIGAN. } & \multicolumn{4}{|c|}{ WISCONSIN. } & \multirow[b]{2}{*}{ 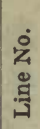 } \\
\hline & $\begin{array}{l}\text { Jan., } \\
\text { Feb., } \\
\text { Mar. }\end{array}$ & $\begin{array}{l}\text { Apr., } \\
\text { May, } \\
\text { June. }\end{array}$ & $\begin{array}{l}\text { July, } \\
\text { Aug., } \\
\text { Sept. }\end{array}$ & $\begin{array}{l}\text { Oct., } \\
\text { Nov., } \\
\text { Dec. }\end{array}$ & $\begin{array}{l}\text { Jan., } \\
\text { Feb., } \\
\text { Mar. }\end{array}$ & $\begin{array}{l}\text { Apr., } \\
\text { May, } \\
\text { June. }\end{array}$ & $\begin{array}{l}\text { July, } \\
\text { Aug., } \\
\text { Sept. }\end{array}$ & $\begin{array}{l}\text { Oct., } \\
\text { Nov., } \\
\text { Dec. }\end{array}$ & $\begin{array}{l}\text { Jan., } \\
\text { Feb., } \\
\text { Mar. }\end{array}$ & $\begin{array}{l}\text { Apr., } \\
\text { May,, } \\
\text { June. }\end{array}$ & $\begin{array}{l}\text { July, } \\
\text { Aug., } \\
\text { Sept. }\end{array}$ & $\begin{array}{l}\text { Oct., } \\
\text { Nov., } \\
\text { Dec. }\end{array}$ & \\
\hline 1 & & & & & & & & 6 & $\$ 35.93$ & 37.53 & $\$ 37.30$ & 90 & \\
\hline 2 & & & & & & & & & & & & & $\frac{1}{2}$ \\
\hline $\begin{array}{l}3 \\
4\end{array}$ & & & 17.38 & & 24 & & 2 & & & & & & 3 \\
\hline $\begin{array}{l}4 \\
5\end{array}$ & & & & & $\begin{array}{l}20.57 \\
37.11\end{array}$ & 24. & 22. & & $\begin{array}{l}18 \\
33\end{array}$ & & & & 4 \\
\hline 6 & & & & & 26.67 & 24.00 & $\begin{array}{l}50 \text {. } \\
26 .\end{array}$ & & $\begin{array}{l}33.00 \\
23.09\end{array}$ & $\begin{array}{l}34 . \\
23 .\end{array}$ & $\begin{array}{l}34 . \\
22 .\end{array}$ & 23 & $\begin{array}{l}5 \\
6\end{array}$ \\
\hline & & & & & 17.73 & 17.00 & & & 13.68 & & & 14. 48 & 7 \\
\hline & & & & & 25.07 & 23.71 & 24 & & 22. & & 22 & 22.00 & 8 \\
\hline 10 & & & & & $\begin{array}{l}18.53 \\
22.00\end{array}$ & $\begin{array}{l}21.23 \\
21.50\end{array}$ & $\begin{array}{l}19 . \\
23 .\end{array}$ & & 19. & 19 & 19 & 6 & 9 \\
\hline 1 & & & & & 15.93 & 17.75 & & & $\cdots$ & $\cdots$ & $\because$ & & $\begin{array}{l}10 \\
11\end{array}$ \\
\hline 10 & & & & & & 13 & & & 13. 67 & 12. 88 & 13.17 & 13.42 & 12 \\
\hline 14 & & & & & 5 & & 34. & & & & & & 13 \\
\hline & & & & & & & $\begin{array}{l}21 \\
14\end{array}$ & & $\begin{array}{l}20 . \\
11 .\end{array}$ & 19. & & & 14 \\
\hline 16 & & & & & 7 & & & & 20. & 20 & 20 & & $\begin{array}{l}15 \\
16\end{array}$ \\
\hline 17 & & & & & 18.14 & & & & 17.72 & 17.44 & 17.08 & 15.60 & 17 \\
\hline 19 & & & & & & & & & & & & & 18 \\
\hline & & & & & & & & & & & & & 19 \\
\hline 2 & & & & & & & & & & & & & $\begin{array}{l}20 \\
21\end{array}$ \\
\hline & & & & & & & & & & & & $\cdots$ & 22 \\
\hline & & : & & & & & & & & & & & 23 \\
\hline 26 & & & & & & & & & - & 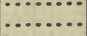 & : & & $\begin{array}{l}24 \\
25\end{array}$ \\
\hline & & & & & & & & & & & & $\because$ & $\begin{array}{l}25 \\
26\end{array}$ \\
\hline 2 & & & & & & & & & & & & & 27 \\
\hline 2 & & & & & & & & & . & $\cdots$ & & & $\begin{array}{l}28 \\
29\end{array}$ \\
\hline $\begin{array}{l}3 . \\
3\end{array}$ & & & & & & & & & +2 & & & & 30 \\
\hline & & & & & & & & & - & & & & $\begin{array}{l}31 \\
32\end{array}$ \\
\hline & & & & & & & & & & & & & $\begin{array}{l}32 \\
33\end{array}$ \\
\hline 35 & & & & & & & & & $\ldots$ & 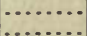 & 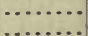 & 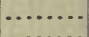 & 34 \\
\hline 3 & & & & & & & & & 32.00 & 0 & 34 & 31. & 36 \\
\hline 3 & & & & & 25.50 & 23.56 & & 23.33 & 2 & & & 29 & 37 \\
\hline 40 & & & & & & 24.00 & 32 & & $\begin{array}{l}22 . \\
20 .\end{array}$ & $\begin{array}{l}22 \\
20\end{array}$ & $\begin{array}{l}22.40 \\
17.85\end{array}$ & $\begin{array}{l}6 \\
2\end{array}$ & 38 \\
\hline 4 & & & & & & & & & 23. & 25 & 26. & 26. & $\begin{array}{l}39 \\
40\end{array}$ \\
\hline 42 & $\$ 14.50$ & - & . & $\$ 17.33$ & $\begin{array}{l}23.20 \\
17.77\end{array}$ & & $\begin{array}{l}25.00 \\
18.38\end{array}$ & & & & & 19. & 41 \\
\hline 44 & & & & & 16. & 19.51 & 38 & 20 & 18.32 & 17.71 & 15.33 & 15.60 & 42 \\
\hline 45 & & & & & & & & & $\cdots \cdots$ & …......... & $\because$ & $\ddot{~}$ & $\begin{array}{l}43 \\
44\end{array}$ \\
\hline 4 & & 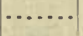 & & & & & & & $\cdots$ & $\cdots$ & & & 45 \\
\hline $\begin{array}{l}4 \\
4 \\
4\end{array}$ & - & & & & & & & & $\cdots$ & $\because$ & & & $\begin{array}{l}46 \\
47\end{array}$ \\
\hline 4 & & & 46.40 & 51.66 & & & & & & & & & 48 \\
\hline 5 & & $\$ 26.00$ & 32.00 & & & & & & & .... & 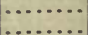 & & 49 \\
\hline 5 & & 30 & 24.38 & & & & & & & & & $\cdots$ & $\begin{array}{l}50 \\
51\end{array}$ \\
\hline 5. & & ........ & & & 74 & 28 & & & & & & & 5 \\
\hline 5 & & ......... & . & & 20 & 20. & $\begin{array}{l}28 \\
21\end{array}$ & & & 17 & & $\begin{array}{l}7 \\
8\end{array}$ & 5 \\
\hline & & & & & 19.09 & 19.08 & 19.13 & 17.10 & & & & 86 & $\begin{array}{l}54 \\
55\end{array}$ \\
\hline & & & & & & & & $\cdots$ & 17 & 18 & 21 & 20 & 56 \\
\hline & & $\cdots$ & & & $\begin{array}{r}7.58 \\
17.84\end{array}$ & $\begin{array}{r}8.12 \\
17.98\end{array}$ & 18.2 & 18 & 16. & & 16. & 7 & 57 \\
\hline 60 & & & & & 16.25 & 14. 60 & 16.16 & 14.08 & & & & & $\begin{array}{l}58 \\
59\end{array}$ \\
\hline 6. & $\begin{array}{l}37.15 \\
24.50\end{array}$ & & 2 & & 0 & & & & & & & & 60 \\
\hline & 15.06 & 1 & $\begin{array}{l}27.5 \\
16.1\end{array}$ & & 24 & & & & & & & & 61 \\
\hline 6 & & 10.00 & 12.67 & & 10.33 & 10.00 & .. & & & 22. & 18. & & 62 \\
\hline 6 & 19.67 & 19.23 & ........ & 19.17 & & & & & $\begin{array}{r}9.05 \\
24.50\end{array}$ & $\begin{array}{r}9.22 \\
27.13\end{array}$ & $\begin{array}{r}9.11 \\
27.49\end{array}$ & $\begin{array}{r}8.45 \\
22.36\end{array}$ & $\begin{array}{l}63 \\
64\end{array}$ \\
\hline 6 & & & & & & & & & & & & .. & 65 \\
\hline & & & & & & & & & & & & & \\
\hline & & & & & & & & & & & & & \\
\hline 7 & & & & & & & & & & & & - & 69 \\
\hline 7 & & & & & & & & & & & & .. & 70 \\
\hline & & & & & & & & & & & & & $\begin{array}{l}71 \\
72\end{array}$ \\
\hline & & & & & & & & & & & & & 7 \\
\hline & & & & & & & & & & & & & 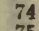 \\
\hline 7 & & ....... & 17.67 & & & & & & & & & & \\
\hline & & & & & & & & & & & & & 77 \\
\hline & & & & & & & & & & & & & \\
\hline & & & & & & & & & & & & & 80 \\
\hline
\end{tabular}


WHOLESALE PRICES OF LUMBER.

Line Numbers Refer to Grades Listed on Page 20.

\begin{tabular}{|c|c|c|c|c|c|c|c|c|c|c|c|c|c|}
\hline \multirow[b]{2}{*}{ 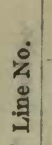 } & \multicolumn{2}{|c|}{ IOWA. } & \multicolumn{4}{|c|}{ PENNSYLVANIA. } & \multicolumn{4}{|c|}{ NEW YORK. } & \multicolumn{2}{|c|}{$\begin{array}{c}\text { NEW } \\
\text { JERSEY. }\end{array}$} & \multirow[b]{2}{*}{ 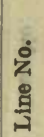 } \\
\hline & $\begin{array}{l}\text { July, } \\
\text { Aug., } \\
\text { Sept. }\end{array}$ & \begin{tabular}{|l} 
Oct., \\
Nov., \\
Dec.
\end{tabular} & $\begin{array}{l}\text { Jan., } \\
\text { Feb., } \\
\text { Mar. }\end{array}$ & $\begin{array}{l}\text { Apr., } \\
\text { May, } \\
\text { June. }\end{array}$ & $\begin{array}{l}\text { July, } \\
\text { Aug,; } \\
\text { Sept. }\end{array}$ & \begin{tabular}{|l} 
Oct., \\
Nov., \\
Dec.
\end{tabular} & $\begin{array}{l}\text { Jan., } \\
\text { Feb., } \\
\text { Mar. }\end{array}$ & $\begin{array}{l}\text { Apr., } \\
\text { May, } \\
\text { June. }\end{array}$ & $\begin{array}{l}\text { July, } \\
\text { Aug., } \\
\text { Sept. }\end{array}$ & $\begin{array}{l}\text { Oct., } \\
\text { Nov., } \\
\text { Dec. }\end{array}$ & $\begin{array}{l}\text { July, } \\
\text { Aug,, } \\
\text { Sept. }\end{array}$ & $\begin{array}{l}\text { Oct., } \\
\text { Nov., } \\
\text { Dec. }\end{array}$ & \\
\hline$\frac{1}{2}$ & & & $\begin{array}{l}\$ 36.75 \\
24.00\end{array}$ & $\begin{array}{l}\$ 37.50 \\
27.50\end{array}$ & & $\$ 36.58$ & $\begin{array}{l}\$ 3 y .71 \\
29.33\end{array}$ & $\begin{array}{r}\$ 46.00 \\
31.33\end{array}$ & 6.00 & $\$ \$ 40.14$ & & & 1 \\
\hline 2 & & & $\begin{array}{l}24.00 \\
19.00\end{array}$ & 22.00 & & & $\begin{array}{l}29.33 \\
21.00\end{array}$ & $\begin{array}{l}31.33 \\
23.37\end{array}$ & & & & & 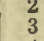 \\
\hline $\begin{array}{l}4 \\
5\end{array}$ & & & 23.88 & 24.75 & $\$ 26.48$ & $\begin{array}{l}25.25 \\
31.00\end{array}$ & $\begin{array}{l}22.58 \\
32.20\end{array}$ & $\begin{array}{l}24.11 \\
37.50\end{array}$ & $\begin{array}{l}24.70 \\
33.00\end{array}$ & $\begin{array}{l}23.70 \\
34.20\end{array}$ & & & 4 \\
\hline$\frac{6}{7}$ & & & & & & & 25.00 & 26. & & & & & $\begin{array}{l}5 \\
6\end{array}$ \\
\hline $\begin{array}{l}8 \\
9\end{array}$ & & & 23.00 & 21.75 & 21.75 & 22.71 & $\begin{array}{l}19.80 \\
23.25\end{array}$ & 20 & $\begin{array}{l}19.67 \\
20.44\end{array}$ & & & & $\begin{array}{l}7 \\
8\end{array}$ \\
\hline & & & 22.17 & 23. & 21.50 & 23.00 & 22. & 22 & & & & & $\stackrel{8}{9}$ \\
\hline & & & $\begin{array}{l}14.56 \\
14.50\end{array}$ & & & & $\begin{array}{l}20.50 \\
16.67\end{array}$ & $\begin{array}{l}22 \\
16\end{array}$ & & $\begin{array}{l}23.60 \\
19.30\end{array}$ & & & $\begin{array}{l}10 \\
11\end{array}$ \\
\hline & & & 13.58 & 15.54 & 14.96 & 15.39 & $\begin{array}{l}14.67 \\
34.75\end{array}$ & 14. & & 14.11 & & & 12 \\
\hline & & & $\ldots$. & 20.00 & & .... & $\begin{array}{l}24.50 \\
24.50\end{array}$ & $\begin{array}{l}36 . \\
26 .\end{array}$ & & $\begin{array}{l}34 . \\
22 .\end{array}$ & & & $\begin{array}{l}13 \\
14\end{array}$ \\
\hline & & & & & 20.00 & & & 14. & 7 & 12. & & & $\begin{array}{l}14 \\
15 \\
16\end{array}$ \\
\hline & & & $18.80^{\circ}$ & 20.15 & 20.75 & $16.37^{\circ}$ & 20.88 & 20.00 & 20.92 & 10 & & & $\begin{array}{l}16 \\
17\end{array}$ \\
\hline & & & $\begin{array}{l}37.56 \\
25.00\end{array}$ & & $\begin{array}{l}36.00 \\
26.40\end{array}$ & $\begin{array}{l}37.50 \\
27.83\end{array}$ & & $\begin{array}{l}43.50 \\
32.00\end{array}$ & & & 831.25 & $\$ 38.33$ & 18 \\
\hline & & & 16.00 & 18.50 & 16.70 & 16.75 & 17.00 & & & & $\$ 31.25$ & & $\begin{array}{l}19 \\
20\end{array}$ \\
\hline & & & 12.50 & $\begin{array}{l}15.25 \\
17.69\end{array}$ & 17.45 & $\begin{array}{l}11.00 \\
17.37\end{array}$ & 18.00 & 20.50 & 19.20 & & & & 21 \\
\hline 2 & & & & & & & & & & 20.50 & 23.50 & 25.00 & 22 \\
\hline 2 & & & & & & & & & & & & & 24 \\
\hline${ }_{2}^{2}$ & $\$ 17.50$ & $\$ 18.00^{\circ}$ & & & & & & & & & & & $\begin{array}{l}25 \\
26\end{array}$ \\
\hline 2 & & & & & & & & & & & & & $\begin{array}{l}27 \\
28\end{array}$ \\
\hline $\begin{array}{l}3 \\
3\end{array}$ & & & & & & & & & & & & & 29 \\
\hline 3 & & & $\cdots$ & & & & & & & & & & $\begin{array}{l}30 \\
31\end{array}$ \\
\hline $\begin{array}{l}3 \\
3 \\
3\end{array}$ & & & & & & & $\cdots$ & & & & & & 32 \\
\hline 3 & & & . & $\cdots$ & & $\cdots$ & .... & & & & & & 33 \\
\hline $\begin{array}{l}3 \\
3\end{array}$ & & & $\therefore$ & -0 & & …..... & …. & & & & & & 35 \\
\hline & & & ... & $\cdots$ & & ....... & $\cdots .$. & & 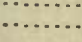 & & & & $\begin{array}{l}36 \\
37\end{array}$ \\
\hline & & & $\cdots \cdots$ & ....... & 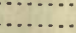 & ..... & ……… & 22.50 & • & & & & 20 \\
\hline & & & & & & $\cdots$ & ....... & & & & & & 10 \\
\hline & $\begin{array}{c}17.17 \\
\ldots \ldots . .\end{array}$ & 17.00 & & $\cdots$ & ..... & 17.67 & $19.50^{\circ}$ & 21.50 & & & & & 41 \\
\hline & & & & & & & $\cdots$ & & & & & & . \\
\hline & & & & & & & & & & & & & 14 \\
\hline & & & & & & & .. & & & & & & 6 \\
\hline & & & 45,00 & & & & & & & & & & \\
\hline 5 & & & $\begin{array}{l}43.00 \\
\cdots \cdots\end{array}$ & $\begin{array}{l}51.25 \\
35.67\end{array}$ & & 37.20 & & & & & 54,17 & 53.33 & 49 \\
\hline 5 & & & & 25 & & 25.33 & & & & & 04.18 & & 51 \\
\hline $\begin{array}{l}5 \\
5 \\
\end{array}$ & & & 22.38 & $\begin{array}{l}27.50 \\
28.00\end{array}$ & $\begin{array}{l}26.50 \\
26.00\end{array}$ & $\begin{array}{l}21.50 \\
27.15\end{array}$ & 24 & 26. & 26 & 27.66 & 38.75 & & 52 \\
\hline 5 & & .. & \begin{tabular}{|l}
15.42 \\
16.80
\end{tabular} & 22.71 & 16.67 & 17.28 & $\begin{array}{l}17.33 \\
19.50\end{array}$ & 19. & & 13.00 & & & $\begin{array}{l}53 \\
54\end{array}$ \\
\hline 5 & & & 23.00 & $\begin{array}{l}17.64 \\
21.50\end{array}$ & 17.20 & & 19.50 & 17.39 & 19.36 & 19.26 & & & 55 \\
\hline $\begin{array}{l}5 \\
5 \\
.\end{array}$ & 1E. 83 & & 17.25 & & & & & & & & & & 58 \\
\hline & $10.0,3$ &.. & $\begin{array}{l}16.75 \\
36.56\end{array}$ & $\begin{array}{l}13.00 \\
36.33\end{array}$ & 16.50 & 16.42 & 0 & 16.50 & $17.81^{\circ}$ & & 12 22 & & $\begin{array}{l}58 \\
59\end{array}$ \\
\hline 6 & & 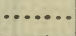 & 25.78 & 27.43 & & 30.50 & & & & $\begin{array}{l}43.00 \\
28.33\end{array}$ & 43.33 & & 61 \\
\hline $\begin{array}{l}6 \\
6\end{array}$ & & & $\begin{array}{l}19.36 \\
10.40\end{array}$ & 19.50 & 16 & $\begin{array}{l}20.14 \\
15.25\end{array}$ & & & & & & & 62 \\
\hline & & & 20.43 & 21.50 & 22.18 & 21.57 & 23.66 & 22.88 & 25.20 & 23.78 & 30.00 & 30.00 & 64 \\
\hline & & & & & & & & & & & & & \\
\hline & & & & & & & & & & & & & 68 \\
\hline & & & & & & & & & & & & & 69 \\
\hline $\begin{array}{l}72 \\
73\end{array}$ & & & & 24.12 & & & & & & & & & 71 \\
\hline 7 & $\because$ & & & & & & & & & & & & 73 \\
\hline & & & & & & & & & & & & & 75 \\
\hline 7 & & & & 23.50 & 22.35 & 22.17 & & & & & & & 76 \\
\hline & & & & & & & & & & & & & 78 \\
\hline & & & & & & & & & & & & & 80 \\
\hline
\end{tabular}


Line Numbers Refer to Grades Listed on Page 20.

\begin{tabular}{|c|c|c|c|c|c|c|c|c|c|c|c|c|c|}
\hline \multirow[b]{2}{*}{$\begin{array}{l}z \\
0 \\
3 \\
3\end{array}$} & \multicolumn{4}{|c|}{ CONNECTICUT. } & \multicolumn{4}{|c|}{ MASSACHUSETTS. } & \multicolumn{4}{|c|}{ NEW HAMPSHIRE. } & \multirow[b]{2}{*}{$\begin{array}{l}\text { Z } \\
\text { 咅 }\end{array}$} \\
\hline & $\begin{array}{l}\text { Jan., } \\
\text { Feb., } \\
\text { Mar. }\end{array}$ & $\begin{array}{l}\text { Apr., } \\
\text { May, } \\
\text { June. }\end{array}$ & $\begin{array}{l}\text { July, } \\
\text { Aug., } \\
\text { Sept. }\end{array}$ & $\begin{array}{l}\text { Oct., } \\
\text { Nov., } \\
\text { Dec. }\end{array}$ & $\begin{array}{l}\text { Jan., } \\
\text { Feb., } \\
\text { Mar. }\end{array}$ & $\begin{array}{l}\text { Apr., } \\
\text { May, } \\
\text { June. }\end{array}$ & $\begin{array}{l}\text { July, } \\
\text { Aug., } \\
\text { Sept. }\end{array}$ & $\begin{array}{l}\text { Oct., } \\
\text { Nov., } \\
\text { Dec. }\end{array}$ & $\begin{array}{l}\text { Jan., } \\
\text { Feb., } \\
\text { Mar. }\end{array}$ & $\begin{array}{l}\text { Apr., } \\
\text { May, } \\
\text { June. }\end{array}$ & t. & $\begin{array}{l}\text { Oct., } \\
\text { Nov., } \\
\text { Dec. }\end{array}$ & \\
\hline 1 & & & & & & & & & & & & & $\begin{array}{l}1 \\
2 \\
3\end{array}$ \\
\hline $\begin{array}{l}4 \\
j\end{array}$ & $\begin{array}{l}2.15 \\
\ldots \ldots\end{array}$ & $\$ 21.80$ & $\$ 20.00$ & 21.50 & $\$ 21.20$ & $\$ 22.50$ & $\$ 21.50$ & $\$ 21$ & & $\$ 20.50$ & & & 4 \\
\hline 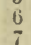 & & & & $\cdots$ & $\cdots \cdots$ & & $\cdots$ & ... & & & & & $\begin{array}{l}5 \\
6\end{array}$ \\
\hline & & & & & & & & & & & & & $\begin{array}{l}7 \\
8\end{array}$ \\
\hline 9 & 18.00 & & & 19.00 & 18.25 & & 19.33 & & & 22.00 & & & 9 \\
\hline & & & & ... & ..... & & & & & & & & $\begin{array}{l}10 \\
11\end{array}$ \\
\hline & ... & & 15.83 & 13.16 & 14.00 & 14.25 & 15.50 & 15.42 & $\$ 15.50$ & & & & 12 \\
\hline & & & & ... & & & $\ddot{*}$ & & & & & & 13 \\
\hline & 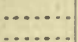 & & & & & & $\cdots$ & $\cdots$ & & & & & $\begin{array}{l}14 \\
15\end{array}$ \\
\hline & 15.17 & 14.38 & 15.58 & 15.00 & 16.03 & 16.40 & 15.40 & 100 & 16.50 & 16.33 & & & 16 \\
\hline & 20.00 & & & & & & & & & & & & 18 \\
\hline & ....... & & * & 21.00 & & & & & & & & & 19 \\
\hline & 18.13 & 18.25 & 19.58 & 18.88 & 18.43 & 17.8 & & & & & & & $\begin{array}{l}20 \\
21\end{array}$ \\
\hline & (....... & $\because$ & 然 & & ........ & & 部 & & & $18: 00$ & & & 22 \\
\hline & & & & & & & & & & $\cdots \cdot$ & & & $\begin{array}{l}23 \\
24\end{array}$ \\
\hline & $\cdots \cdots$ & & & & & & & & & & & & $\begin{array}{l}24 \\
2.5\end{array}$ \\
\hline & ..... & & & & & & & & & & & & 26 \\
\hline & …. & .. & ... & & & & & & & & & & 27 \\
\hline & . & & & & & & & & & $\cdots$ & & & $\begin{array}{l}28 \\
29\end{array}$ \\
\hline & $\cdots$ & & & & & & & & & & & & 30 \\
\hline & $\cdots$ & & & & & & & & & & & & 31 \\
\hline & $\cdots$ & & & & & & & & & & & & $\begin{array}{l}32 \\
33\end{array}$ \\
\hline & $\cdots$. & .... & & & & & & & & & & & 34 \\
\hline & (n... & . & 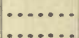 & & & & & & & & & & $\begin{array}{l}35 \\
36\end{array}$ \\
\hline & & & & & & & & & & & & & 37 \\
\hline & & & & & $\cdots$ & & & & & & & & 38 \\
\hline & & $\cdots$ & & & $\cdots$ & & & & & & & & 39 \\
\hline & $\cdots \cdots$ & & & & -5 & & & & & & & & 40 \\
\hline & $\cdots \cdot$ & $\cdots$ & & & ... & & & & & & & & $\begin{array}{l}41 \\
42\end{array}$ \\
\hline & $\ldots$. & & & & 烈 & & & & & & & & 43 \\
\hline & & & & & ..... & & & & & & & & $\begin{array}{l}44 \\
45\end{array}$ \\
\hline & . & . & & & $\cdots$ & & & & & & & & 46 \\
\hline & . & & 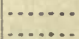 & & & & & & & & & & $\begin{array}{l}47 \\
48\end{array}$ \\
\hline & & & & & ... & & & & & $\because \cdots$ & & & $\begin{array}{l}48 \\
49\end{array}$ \\
\hline & & & & & & & & & & - & & & 50 \\
\hline & 21.00 & .. & 23.00 & 22.66 & .. & & & & & & & & 52 \\
\hline & $\cdots$ & & & & & & & & & & & & 54 \\
\hline & 20.00 & $\ldots$ & & 18.20 & 17.50 & 17.00 & 19.00 & 75 & 17.00 & 18.25 & & & 55 \\
\hline & $\cdots$ & $\because \cdots$ & 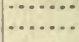 & …......... & $\ldots$ & & $\cdots$ & & & .. & & & 56 \\
\hline & 12.79 & 2.00 & 1 & $1+02$ & 13. & & & & & & & & 58 \\
\hline & & & & $17+$ & & & & & 13 & & & & 59 \\
\hline & & & & & & & & & & & & & $\begin{array}{l}60 \\
61\end{array}$ \\
\hline & & & & & & & & & & & & & 62 \\
\hline 65 & 21.50 & 20.67 & 21.23 & 19.69 & 21.14 & 20.38 & 22.14 & 20.33 & & 20.00 & 21.25 & & 64 \\
\hline & & & & & $\cdots$ & & & & & & & & \\
\hline & & & & " & & & & & & & & & $\begin{array}{l}66 \\
67\end{array}$ \\
\hline 6. & & & & & & & & & & & & & 68 \\
\hline 7 & & & & & & & & & & & & & 69 \\
\hline & & & & & & & & & & & & & 71 \\
\hline & & & & & & & & & & & & & \\
\hline & & & & & .. $>>>$ & & & & 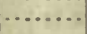 & & & & 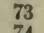 \\
\hline & & & & & & & & & & & & & 75 \\
\hline & & & & & & & & & & & & & 76 \\
\hline 78 & & & & & & & & & & & & & 7 \\
\hline & & & & & F. & & & & & & & & 70 \\
\hline & & & & & & & & & & & & & 80 \\
\hline
\end{tabular}


Line Numbers Refer to Grades Listed on Page 20.

\begin{tabular}{|c|c|c|c|c|c|c|c|c|c|c|c|c|c|}
\hline \multirow[b]{2}{*}{ ๕ } & \multicolumn{4}{|c|}{ VERMONT. } & \multicolumn{4}{|c|}{ MAINE. } & \multicolumn{2}{|c|}{$\begin{array}{l}\text { RHODE } \\
\text { ISLAND. }\end{array}$} & \multirow{2}{*}{$\begin{array}{l}\text { GA. } \\
\text { Apr., } \\
\text { May, } \\
\text { June. }\end{array}$} & \multirow{2}{*}{$\begin{array}{l}\text { MD., } \\
\text { DEL. } \\
\text { Oct., } \\
\text { Nov., } \\
\text { Dec. }\end{array}$} & \multirow[b]{2}{*}{ 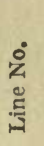 } \\
\hline & $\begin{array}{l}\text { Jan., } \\
\text { Feb., } \\
\text { Mar. }\end{array}$ & $\begin{array}{l}\text { Apr., } \\
\text { May, } \\
\text { June. }\end{array}$ & $\begin{array}{l}\text { July, } \\
\text { Aug., } \\
\text { Sept. }\end{array}$ & $\begin{array}{l}\text { Oct., } \\
\text { Nov., } \\
\text { Dec. }\end{array}$ & $\begin{array}{l}\text { Jan., } \\
\text { Feb., } \\
\text { Mar. }\end{array}$ & $\begin{array}{l}\text { Apr., } \\
\text { May, } \\
\text { June. }\end{array}$ & $\begin{array}{l}\text { July, } \\
\text { Aug., } \\
\text { Sept. }\end{array}$ & $\begin{array}{l}\text { Oct., } \\
\text { Nov., } \\
\text { Dec. }\end{array}$ & $\begin{array}{l}\text { Apr., } \\
\text { May, } \\
\text { June. }\end{array}$ & $\begin{array}{l}\text { Oct., } \\
\text { Nov., } \\
\text { Dec. }\end{array}$ & & & \\
\hline & & & & & & & & & & & & & $\frac{1}{2}$ \\
\hline & $\begin{array}{r}\$ 19.42 \\
27.50\end{array}$ & $\begin{array}{r}\$ 20.84 \\
27.75\end{array}$ & $\begin{array}{r}\$ 17.00 \\
21.40 \\
28.33\end{array}$ & $\$ 19.36$ & & & & $\begin{array}{r}\$ 16.25 \\
\ldots \ldots \ldots\end{array}$ & & & & & $\begin{array}{l}3 \\
4 \\
5\end{array}$ \\
\hline & 20.00 & $\begin{array}{l}27.75 \\
20.00\end{array}$ & 20.00 & 22.00 & & & & & & & & & $\begin{array}{l}5 \\
6 \\
-\end{array}$ \\
\hline & $\begin{array}{l}20.00 \\
19.38\end{array}$ & $\begin{array}{l}19.70 \\
18.75\end{array}$ & $\begin{array}{l}19.33 \\
19.30\end{array}$ & 18.75 & & & & 30 & & & & & $\begin{array}{l}7 \\
8\end{array}$ \\
\hline & 19.38 & $\begin{array}{l}18.67 \\
1.00\end{array}$ & 20.33 & & & & & 18.00 & & & & & $\begin{array}{r}9 \\
10\end{array}$ \\
\hline 12 & 15.57 & $\begin{array}{l}10.00 \\
15.32 \\
26.67\end{array}$ & 14.75 & 15.85 & & .... & $\$ 13.67$ & & & & & & $\begin{array}{l}11 \\
12\end{array}$ \\
\hline & & $\begin{array}{l}26.67 \\
25.00\end{array}$ & 24.33 & 22.66 & $\cdots$ & & & & & & & & 13 \\
\hline & & & & & & & & & & & & & $\begin{array}{l}14 \\
15\end{array}$ \\
\hline & 15.78 & 17.89 & 15.89 & 17.32 & & & & & .. & $\$ 15.50$ & & & 16 \\
\hline & & & & & & & & & & & & & $\begin{array}{l}17 \\
18\end{array}$ \\
\hline & & & & & & & & & $\cdots$ & & & & 19 \\
\hline & & & $\cdots \cdot$ & & & & & & $\$ 18.87$ & 18.33 & & & $\begin{array}{l}20 \\
21\end{array}$ \\
\hline & & & $\cdots$ & & & & & & & 18.33 & & $\$ 17.00$ & $\begin{array}{l}22 \\
23\end{array}$ \\
\hline & & & $\cdots .$. & & & & & & & $\cdots$ & & $\cdots$ & 24 \\
\hline & & & $\cdots$ & 14.00 & & & & & & $\cdots$ & & $\cdots$ & $\begin{array}{l}25 \\
26\end{array}$ \\
\hline & & & & & & & & & $\cdots$ & .... & & …..... & 27 \\
\hline & & & & & & & & & & & & …....... & $\begin{array}{l}28 \\
29\end{array}$ \\
\hline & & & & & & & & & & ... & & …..... & 30 \\
\hline & & & $\cdots \cdots$ & . & & & & & 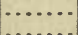 & $\cdots \cdot$ & & …....... & $\begin{array}{l}31 \\
32\end{array}$ \\
\hline & & & & . & & & & & $\cdots$ & $\ddot{. .}$ & & …...... & 33 \\
\hline & & & & & & & & . & & $\ddot{*}$ & & & $\begin{array}{l}34 \\
35\end{array}$ \\
\hline & & & & & & & & & & & & $\ldots$ & 36 \\
\hline & & 15.83 & & & & & & & .. & & & & $\begin{array}{l}37 \\
38\end{array}$ \\
\hline & & & & . & & & & & & . & & …...... & 39 \\
\hline & .. & 16.67 & $\cdots \cdots$ & 18.33 & & $\ldots$ & & & & & & & $\begin{array}{l}40 \\
41\end{array}$ \\
\hline & & & $\cdots \cdot$. & & & & & & $\cdots$ & ….. & $\begin{array}{l}\cdots \\
\cdots\end{array}$ & …..... & 42 \\
\hline & & & $\cdots \cdots$ & & & & & & ... & & & & $\begin{array}{l}43 \\
44\end{array}$ \\
\hline & & $\cdots$ & & $\cdots$ & & & & & & $\cdots$. & .. & ……... & 45 \\
\hline & & & & & & & & & & & & & $4 t$ \\
\hline & & & & & & & & & & & & 15.12 & $\begin{array}{l}48 \\
49\end{array}$ \\
\hline & & $\cdots$ & ....... & ........ & & & & & & & & $\cdots$ & $\begin{array}{l}49 \\
50\end{array}$ \\
\hline & 26.75 & 25.00 & 30.33 & 27.00 & & & & & & 28.38 & & & $\begin{array}{l}51 \\
52\end{array}$ \\
\hline & 17.35 & 17.11 & $\begin{array}{l}23.67 \\
16.85\end{array}$ & 17.83 & & & & & & & & .. & $\begin{array}{l}53 \\
54\end{array}$ \\
\hline & & & & & & & & & & & & ……. & 55 \\
\hline & . & & & & & & & & & & & & $\begin{array}{l}56 \\
57\end{array}$ \\
\hline & $\cdots$ & $\cdots$ & 14.25 & & & & & & & & & & $\begin{array}{l}58 \\
59\end{array}$ \\
\hline & & & & & & & & & & ... & & 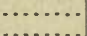 & 60 \\
\hline 4 & 20.37 & & & & .... & & & & & . & & & 62 \\
\hline & & 20.00 & & 20.66 & $\$ 19.53$ & & 20.67 & 21.25 & 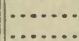 & $\begin{array}{l}25.00 \\
\ldots \ldots \ldots\end{array}$ & & 21.00 & 64 \\
\hline & & & & & & & & & & & & …..... & 66 \\
\hline & & & & & & & & & & & & & $\begin{array}{l}67 \\
69\end{array}$ \\
\hline & & & & & & & & & & & & $\cdots$. & 69 \\
\hline & & & & & & & & & & & $\ldots \ldots$ & $\cdots \cdot$ & 71 \\
\hline & & & & & & & & & & & $\$ 52.50$ & ……, & 73 \\
\hline & & & & & & & & & & & 30.50 & & $\begin{array}{l}74 \\
75\end{array}$ \\
\hline 7 & & & & & & & & & & & $\begin{array}{l}14.50 \\
20.00\end{array}$ & 18.63 & 76 \\
\hline & & & & & & & & & & & & ........ & 78 \\
\hline & & & & & & & & & & . & ...... & & $\begin{array}{l}79 \\
80\end{array}$ \\
\hline
\end{tabular}





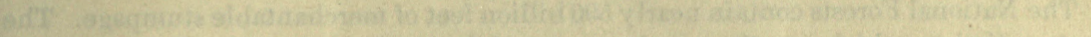

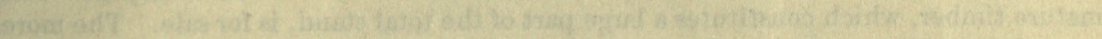

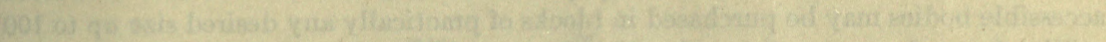

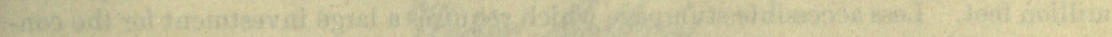

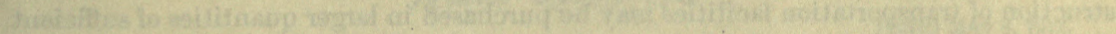

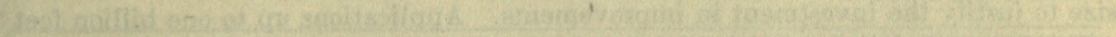

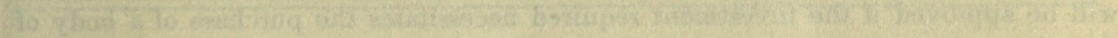

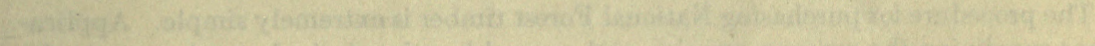

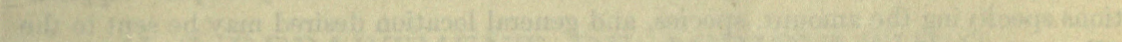

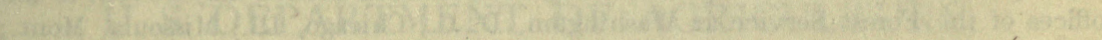

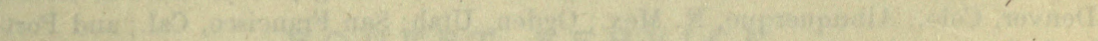

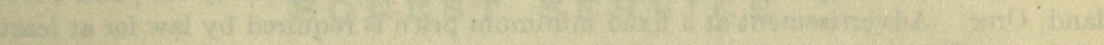

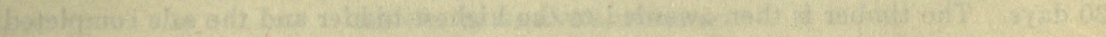

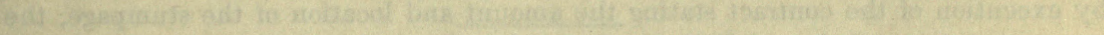

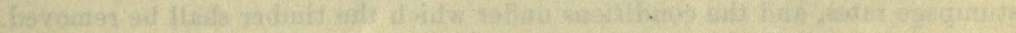

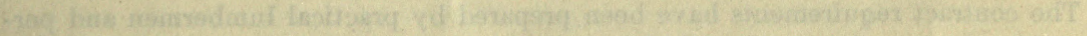

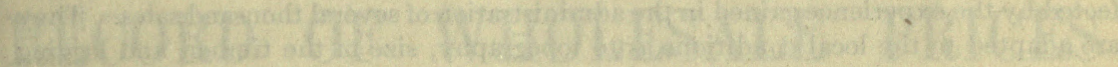

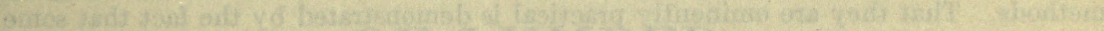

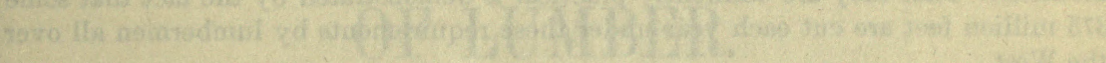

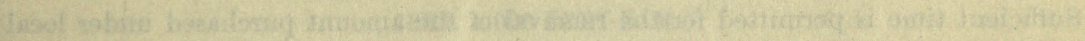

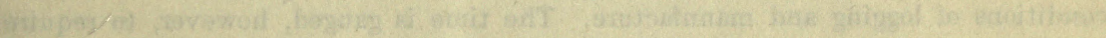

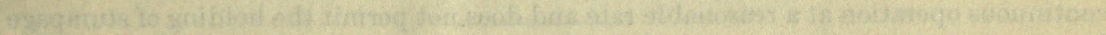

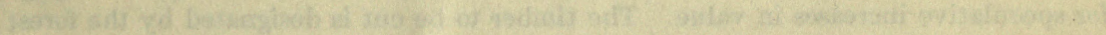

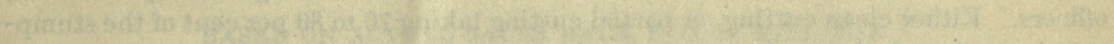

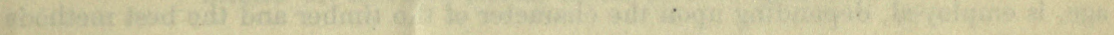

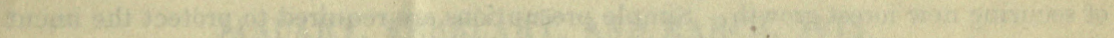

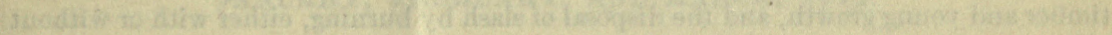
II

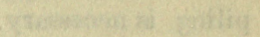

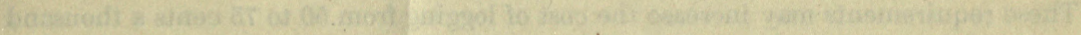

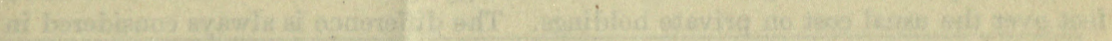

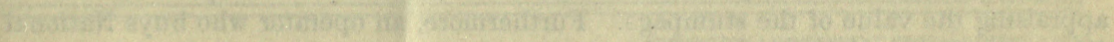

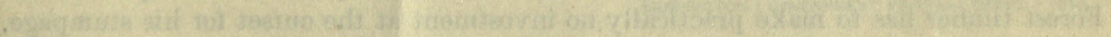

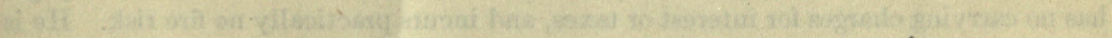

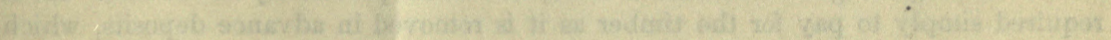

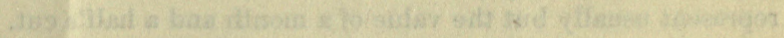

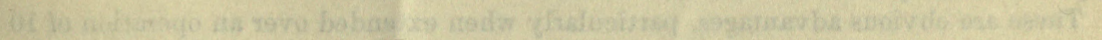

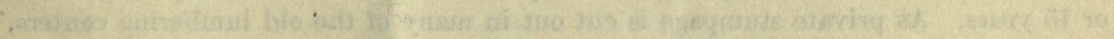

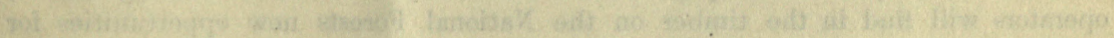

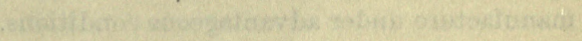

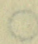




\section{OPPORTUNITIES FOR PURCHASING NATIONAL FOREST TIMBER.}

The National Forests contain nearly 590 billion feet of merchantable stumpage. The mature timber, which constitutes a large part of the total stand, is for sale. The more accessible bodies may be purchased in blocks of practically any desired size up to 100 million feet. Less accessible stumpage which requires a large investment for the construction of transportation facilities may be purchased in larger quantities of sufficient size to justify the investment in improvements. Applications up to one billion feet will be approved if the investment required necessitates the purchase of a body of that size under one contract.

The procedure for purchasing National Forest timber is extremely simple. Applications specifying the amount, species, and general location desired may be sent to the offices of the Forest Service at Washington, D. C.; Chicago, Ill.; Missoula, Mont.; Denver, Colo.; Albuquerque, N. Mex.; Ogden, Utah; San Francisco, Cal.; and Portland, Oreg. Advertisement at a fixed minimum price is required by law for at least 30 days. The timber is then awarded to the highest bidder and the sale completed by execution of the contract stating the amount and location of the stumpage, the stumpage rates, and the conditions under which the timber shall be removed.

The contract requirements have been prepared by practical lumbermen and perfected by the experience gained in the administration of several thousand sales. They are adapted to the local conditions as to topography, size of the timber, and logging methods. That they are eminently practical is demonstrated by the fact that some 375 million feet are cut each year under these requirements by lumbermen all over the West.

Sufficient time is permitted for the removal of the amount purchased under local conditions of logging and manufacture. The time is gauged, however, to require continuous operation at a reasonable rate and does not permit the holding of stumpage for speculative increases in value. The timber to be cut is designated by the forest officers. Either clean cutting, or partial cutting taking 70 to 80 per cent of the stumpage, is employed, depending upon the character of the timber and the best methods of securing new forest growth. Simple precautions are required to protect the uncut timber and young growth, and the disposal of slash by burning, either with or without piling, is necessary.

These requirements may increase the cost of logging from 50 to 75 cents a thousand feet over the usual cost on private holdings. The difference is always considered in appraising the value of the stumpage. Furthermore, an operator who buys National Forest timber has to make practically no investment at the outset for his stumpage, has no carrying charges for interest or taxes, and incurs practically no fire risk. He is required simply to pay for the timber as it is removed in advance deposits; which represent usually but the value of a month and a half's cut.

These are obvious advantages, particularly when extended over an operation of 10 or 15 years. As private stumpage is cut out in many of the old lumbering centers, operators will find in the timber on the National Forests new opportunities for manufacture under advantageous conditions. 
U. S. DEPARTMENT OF AGRICULTURE, FOREST SERVICE. HENRY S. GRAVES, Forester.

\section{RECORD OF WHOLESALE PRICES OF LUMBER.}

(PER 1,000 FEET B. M.)

BASED ON ACTUAL SALES MADE F. O. B. MILL FOR

JANUARY, FEBRUARY, AND MARCH, 1912. 


\section{FOREST SERVICE.}

Henry S. Graves, Forester.

Albert F. Potter, Associate Forester. Herbert A. Smith, Editor.

Branch of Products: McGarvey Cline, in charge.

Office of Wood Utilization: H. S. SACKETT, in charge.

Washington Office of Products: O. T. SwaN, in charge

Statistician in Forest Products: J. C. NeLuIs.

2 


\section{P REFATORY NOTE.}

The Forest Service has two main purposes in collecting and compiling this record of f. o.b. mill prices: First, to have a continuous statistical record of such prices of the various commercial woods; and, second, to show, in contrast to market prices-which include the important items of freight charges and selling costs-just what the manufacturers of lumber receive for their product at the mill. The prices given are wholesale, based on actual sales f. o. b. mill, for delivery outside of local territory. Only a few representative grades and the mill run are included. By "mill run" is meant the average of all grades of lumber produced. The record is compiled by States, and is made up from reports received from approximately 3,000 of the largest manufacturers scattered throughout the country. It is published quarterly.

The Forest Service wishes to acknowledge the courtesy of the manufacturers for their prompt and efficient cooperation. Their assistance has been of great value in making the record complete, accurate, and promptly available for distribution.

The Forest Service is engaged in many investigations of interest to lumber manufacturers. The work as now organized comprises studies in the physical properties of wood; air-seasoning and kiln-drying; strength tests upon commercial timbers of the United States; wood preservation, including the study of different preservatives and methods of impregnation; softwood and hardwood distillation; wood pulp and paper; naval stores; and wood utilization, which includes studies of the wood-using industries of various States, the collection and compilation of statistics of forest products and wholesale lumber prices, etc. Reports on these investigations are published from time to time, and are available to the trade upon request.

A copy of any of the following recent statistical reports may be obtained by addressing the Forester, Forest Service, Washington, D. C.:

Forest Products, No. 1, Pulp-Wood Consumption, 1910.

Forest Products, No. 2, Lumber, Lath, and Shingles, 1910.

Forest Products, No. 3, Slack Cooperage Stock, 1910.

Forest Products, No. 5, Veneers, 1910.

Forest Products, No. 6, Tight Cooperage Stock, 1910.

Forest Products, No. 7, Wood Distillation, 1910.

Forest Products, No. 8, Crossties Purchased, 1910.

Forest Products, No. 9, Poles Purchased, 1910. 


\section{SUMMARY.}

Reports received for the first quarter of 1912 show decided improvements in the prices received for yellow pine, North Carolina pine, and eastern hemlock, but nogeneral gains are apparent in the prices for other softwoods. Hardwoods advanced in Virginia, Michigan, and Wisconsin.

In Washington, Sitka spruce shop No. 1 declined $\$ 1$; finish No. 2 clear and better $\$ 2.50$, while beveled siding B advanced $\$ 1.85$. In the same State western yellow pine finish $\mathrm{C}$ select declined $\$ 2.50$. In Montana western larch flooring $\mathrm{A}$ and $\mathrm{B}$ declined $\$ 1.80$; finish A and B, $\$ 3.45$; dimension No. 1 common, $\$ 1$.

In Texas flooring No. 2 S2S and C. M. advanced $\$ 1.35$; flooring B flat, $\$ 1$; common boards No. 2 S2S, 1 by 12 inches, $\$ 1.10$, and car siding B and better, $\$ 1.85$. In Arkansas the important changes were the advance in car siding $B$ and better of $\$ 1.50$, and in common car lining No. 1 of $\$ 1.30$. Car siding B and better advanced $\$ 2.10$ in Louisiana and $\$ 2.60$ in Mississippi. In Florida common boards No. 1 declined $\$ 2.30$ and plank and dimensions $\$ 1$ to $\$ 2.45$. In Georgia finish $B$ and better declined $\$ 1.25$; flooring B heart rift, $\$ 4$; while common boards No. 1 advanced $\$ 1.75$ and plank and dimension items $\$ 1$ to $\$ 2.40$.

In South Carolina, North Carolina pine items advanced as follows: Flooring No. 2, $\$ 2.35$; flooring No. $3, \$ 1.35$; dimension 2 by 8 inches by 16 feet, $\$ 1.15$; roofers, $\$ 1.20$; box edge, nearly $\$ 1$. In North Carolina flooring No. 2 advanced 60 cents; flooring No. $3, \$ 1.50$. In Virginia box edge advanced $\$ 1.60$.

West Virginia spruce box boards advanced $\$ 1$, while merchantable frames 2 by 12 inches to 12 by 12 inches declined $\$ 1.75$; and merchantable boards 1 by 12 inches, $\$ 1.40$. In New York hemlock mill run M. C. O. advariced over $\$ 2$. In Vermont spruce merchantable frames 9 inches and under advanced $\$ 1.80 ; 10$ and 12 inches, $\$ 2.60$; merchantable 2 by 7 inches and under, nearly $\$ 1$.

Minnesota white pine selects $\mathrm{C}$ and better advanced $\$ 1.50$; and boards No. 4, $\$ 1.25$, while beveled siding $\mathrm{C}$ declined $\$ 1.30$. In Wisconsin the only advance in white pine was 70 cents on boards No. 4 ; inch finish $\mathrm{C}$ selects, 10 inches, declined $\$ 1.25$; shop No. 1, 3/4, over $\$ 2$; shop No. $3,5 / 4, \$ 1.80$, etc. Hemlock in Wisconsin advanced as follows: 2 -inch piece stuff, nearly 50 cents; boards No. 1, 75 cents; and fencing No. 1, over $\$ 1$. Hemlock also advanced in Michigan; 2-inch piece stuff, $\$ 1.20$; boards No. 1, 90 cents; fencing No. 1, $\$ 1.35$.

In Arkansas cottonwood made advance as follows: Firsts and seconds, 70 cents; box boards, $\$ 1.75$; No. 1 common, $\$ 2.35$; No. 2 common, $\$ 1.40$; red gum firsts and seconds declined nearly $\$ 2$. In Louisiana cottonwood firsts and seconds declined $\$ 1.75$, but other items advanced as follows: Box boards, nearly $\$ 3$; No. 1 common, $\$ 2.30$; and No. 2 common, $\$ 1.70$; cypress firsts and seconds declined nearly $\$ 1$; selects, $\$ 1.35$; tupelo (bay poplar) firsts and seconds advanced 75 cents; and No. 1 common, 95 cents. In Mississippi and Alabama plain oak firsts and seconds and No. 1 common declined about \$1. In Missouri cypress shop No. 1 and No. 1 common declined \$1.10; plain 
oak firsts and seconds declined $\$ 2$; No. 1 common advanced $\$ 2.45$. Florida cypress firsts and seconds declined $\$ 1.65$, and box boards $\$ 2.40$. In North Carolina chestnut firsts and seconds declined $\$ 2$; No. 1 common, $\$ 1.25$; plain oak and poplar firsts and seconds declined $\$ 1$. In Tennessee ash firsts and seconds declined $\$ 3$ and No. 1 common $\$ 1.85$; basswood firsts and seconds and No. 1 common, $\$ 1$; and No. 2 common, 75 cents; chestnut firsts and seconds, $\$ 2$; plain oak firsts and seconds and No. 1 and No. 3 common, over $\$ 1$; poplar firsts and seconds, $\$ 1.35$; No. 1 common, $\$ 1.20$; and No. 2 common, 90 cents. In Kentucky ash firsts and seconds and No. 2 common declined over $\$ 1$; chestnut firsts and seconds and No. 1 common, nearly $\$ 1$; plain oak firsts and seconds and No. 2 common, $\$ 1.25$; poplar firsts and seconds, over $\$ 1$; and No. 1 common, $\$ 1.60$.

In Virginıa ash No. 1 common advanced $\$ 2.75$ and No. 2 common $\$ 2.35$; basswood No. 1 common, $\$ 1.25$, and No. 2 common, $\$ 1.75$; chestnut firsts and seconds, 75 cents; No. 1 common, over $\$ 2$; plain oak firsts and seconds, $\$ 2$; No. 1 common, $\$ 2.65$; poplar firsts and seconds, $\$ 3.45$; saps and selects, $\$ 3.70$; No. 1 common, $\$ 1.30$; and No. 2 common, $\$ 1.60$. In West Virginia ash firsts and seconds declined $\$ 2$, while No. 1 common advanced 70 cents; basswood firsts and seconds and No. 1 common declined $\$ 1.50$; chestnut firsts and seconds, $\$ 1.80$; No. 1 common, 85 cents; plain oak firsts and seconds, \$1.80; poplar firsts and seconds, \$1.35; saps and selects, $\$ 2.70$; and No. 1 common, $\$ 1.45$. In Ohio ash firsts and seconds declined $\$ 3.50$; No. 1 common advanced $\$ 2.70$; basswood firsts and seconds and No. 1 common advanced $\$ 1.20$; plain oak firsts and seconds declined $\$ 2.75$, and No. 3 common, $\$ 1.50$. Indiana ash firsts and seconds declined $\$ 2.75$, and No. 1 common, 75 cents; basswood firsts and seconds declined nearly $\$ 1$, but No. 1 common advanced 60 cents, and No. 2 common over $\$ 1$; plain oak firsts and seconds declined over $\$ 1$, but No. 1 common advanced $\$ 1.45$.

In Michigan ash firsts and seconds advanced $\$ 2$, and No. 1 common $\$ 2.90$; basswood firsts and seconds, $\$ 1.20$; beech firsts and seconds advanced $\$ 1.35$, but No. 1 common declined $\$ 1$; unselected birch firsts and seconds advanced $\$ 2.40$; No. 1 common, $\$ 1$, and No. 2 common, \$1.40; hard maple firsts and seconds, \$1.80. In Wisconsin ash, basswood, and birch prices improved slightly; rock elm firsts and seconds advanced $\$ 1.35$, but No. 1 common and better declined $\$ 6$; soft maple No. 1 common and better advanced $\$ 1.70$. In New York ash firsts and seconds advanced $\$ 3.25$, and No. 1 common $\$ 1$; beech No. 1 common declined $\$ 2.60$; unselected birch No. 1 common, $\$ 1.40$, while No. 2 common advanced $\$ 1.25$; hard maple firsts and seconds, $\$ 1.35$. 


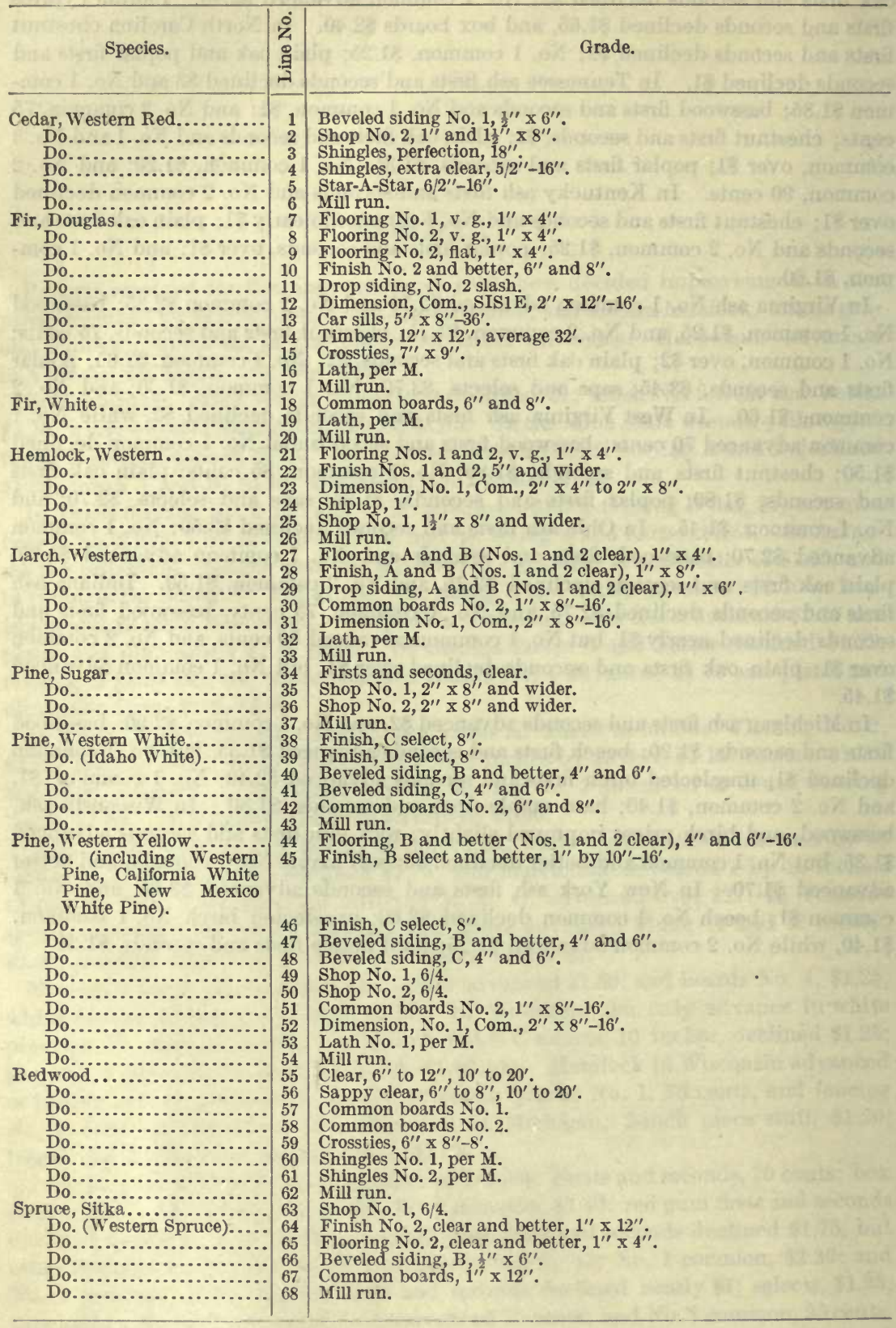


WHOLESALE PRICES OF LUMBER.

\begin{tabular}{|c|c|c|c|c|c|c|c|}
\hline & California. & Oregon. & Washington. & Idaho. & Montana. & Colorado. & \\
\hline 1 & - & $\cdots$ & 0.96 & ..... & •......... & $\cdots \cdots$ & \\
\hline 2 & $\cdots$ & $\ldots \ldots$ & 88 & ...... & .......... & $\ldots \ldots \ldots$ & \\
\hline$\overline{3}$ & $\ldots \ldots$ & ............... & & $\ldots \ldots$ & ............... & $\ldots \ldots \ldots$ & \\
\hline 4 & $\ldots \ldots$ & $\ldots \ldots \ldots \ldots$ & 81 & $\ldots \ldots \ldots$ & .......... & $\ldots \ldots$ & \\
\hline 5 & $\ldots \ldots$ & $\ldots \ldots \ldots$ & $\begin{array}{r}1.51 \\
12.59\end{array}$ & .......... & . $\ldots \ldots \ldots$ & $\ldots \ldots \ldots$ & \\
\hline 6 & $\ldots \ldots$ & ......... & 12.52 & ......... & 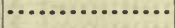 & $\ldots \ldots \ldots$ & \\
\hline $\begin{array}{l}7 \\
8\end{array}$ & $\cdots \cdots$ & $\begin{array}{r}\$ 24.83 \\
20.28\end{array}$ & $\begin{array}{l}22.00 \\
18.47\end{array}$ & ........ & . $\ldots \ldots \ldots$ & a...... & \\
\hline $\begin{array}{l}8 \\
9\end{array}$ & $\ldots \ldots$ & $\begin{array}{l}20.28 \\
13.42\end{array}$ & $\begin{array}{l}18.47 \\
13.29\end{array}$ & (......... & $\begin{array}{l}\cdots \ldots \ldots \ldots \\
\cdots \ldots \ldots \ldots\end{array}$ & $\begin{array}{l}\cdots \ldots \ldots \ldots \ldots \ldots \\
\cdots \ldots \ldots \ldots \ldots \ldots\end{array}$ & \\
\hline 10 & $\ldots \ldots$ & 20.60 & 19.26 & (n........ & … & $\ldots \ldots \ldots \ldots \ldots$ & 10 \\
\hline 11 & $\ldots . .$. & 15.30 & 13.67 & $\ldots .$. & ........... & $\ldots \ldots \ldots$ & 11 \\
\hline 12 & & 8.66 & 8.12 & $\ldots \ldots$ & ........... & .......... & \\
\hline 13 & $\ldots$ & 12.17 & 12.48 & $\ldots$ & ............ & $\ldots \ldots \ldots$ & \\
\hline 14 & $\ldots$ & 9.45 & 9.15 & ....... & ............ & $\therefore \ldots \ldots$ & \\
\hline 15 & $\ldots$ & 8.74 & 8.59 & $\ldots \ldots$ & ........... & $\ldots \ldots \ldots$ & \\
\hline 16 & $\ldots \ldots$ & 1.30 & 1.28 & & .......... & ......... & \\
\hline 17 & $\ldots \ldots$ & 11.14 & 10.99 & $\$ 10.92$ & … & $\ldots \ldots$ & 17 \\
\hline 18 & $\ldots \ldots \ldots$ & 9.67 & 7.50 & 10.83 & …........... & .......... & \\
\hline 19 & $\ldots \ldots \ldots$ & ...... & & iano & $\ldots \ldots \ldots$ & $\ldots \ldots$ & \\
\hline 20 & $\ldots \ldots \ldots$ & ............. & 9.83 & 10.42 & $\ldots \ldots \ldots$ & $\ldots \ldots$ & \\
\hline 21 & $\ldots \ldots \ldots$ & ................. & 19.38 & $\ldots$ & . & $\ldots \ldots$ & 2 \\
\hline 22 & $\ldots \ldots \ldots$ & ............... & 17.83 & $\ldots$ & ........... & $\ldots \ldots$ & \\
\hline 23 & .......... & .............. & 7.14 & $\ldots \ldots$ & ... & ......... & \\
\hline 24 & ......... & ............... & 8.17 & $\ldots$ & ... & .......... & \\
\hline 25 & ........... & ........ & 12.33 & $\ldots$ & $\ldots \ldots$ & .......... & \\
\hline 26 & $\ldots \ldots \ldots$ & ............. & 8.50 & $\because \cdots$ & & .......... & \\
\hline 27 & $\ldots \ldots \ldots$ & $\ldots \ldots \ldots$ & ....... & 19.33 & $\$ 16.75$ & $\ldots \ldots$ & 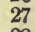 \\
\hline 28 & ........... & $\ldots$ & & $\ldots$ & 19.56 & ........ & \\
\hline 2 & ......... & $\ldots$ & . & . & 17.19 & ....... & \\
\hline 30 & ......... & $\ldots$ & $\cdots \ldots$ & 11.67 & 13.00 & $\ldots \ldots$ & \\
\hline 3. & .......... & $\ldots$ & 8.80 & 11.33 & 10.19 & ...... & \\
\hline 32 & $\ldots \ldots \ldots$ & ............. & ... & $\cdots$ & 1.62 & $\ldots .$. & \\
\hline 33 & $\ldots \ldots \ldots$ & $\bullet$ & & 10 & 12.08 & $\ldots \ldots \ldots$ & \\
\hline 34 & $\ldots \ldots \ldots$ & $\ldots$ & - & $\ldots$ & ............. & $\ldots \ldots$ & \\
\hline 3. & $\ldots \ldots \ldots$ & $\ldots$ & ..... & $\ldots$ & .......... & $\ldots \ldots$ & \\
\hline 36 & .......... & $\ldots$ & $\ldots \ldots$ & $\ldots$ & ............ & . & \\
\hline 3 & $\ldots \ldots \ldots$ & $\cdots$ & $\cdots$ & $\ldots$ & ............. & $\ldots \ldots$ & \\
\hline 38 & $\ldots$. & - & & 35.75 & ................ & . $\ldots \ldots$. & \\
\hline 39 & ............ & $\ldots$ & -. & 24.33 & ................ & .......... & \\
\hline 40 & ........... & ...... & $\cdots$ & ............... & \#........... & . $\ldots \ldots$ & \\
\hline 41 & .......... & ... & & 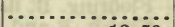 & - $\ldots \ldots \ldots \ldots$ & . . . . & \\
\hline 42 & $\ldots \ldots \ldots$ & ... & & 13.50 & $\ldots$ & $\ldots \ldots$ & \\
\hline 43 & ......... & $\ldots$ & & 18.00 & 13.73 & $\cdots$ & \\
\hline 44 & ............ & $\ldots \ldots$ & & $\ldots \ldots \ldots$ & $\ldots \ldots \ldots \ldots$ & .50 & \\
\hline 4 & $\ldots \ldots$ & $\ldots \ldots$ & 17 & ....... & 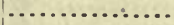 & . $\ldots \ldots$ & \\
\hline 46 & $\ldots \ldots \ldots$ & ...... & 25.90 & $\ldots \ldots$ & $\ldots \ldots \ldots \ldots \ldots$ & $\ldots \ldots$ & \\
\hline 47 & $\ldots \ldots \ldots$ & ...... & 19.50 & $\ldots$. & ............ & $\ldots \ldots$ & 4 \\
\hline 48 & …..... & ...... & 16.10 & $\ldots$ & $\ldots \ldots \ldots \ldots$ & ... & \\
\hline 49 & $\$ 2$ & ........ & 23.42 & $\ldots$ & $\ldots$ &. & 4 \\
\hline 50 & 28 & $\ldots \ldots$ & 16.25 & $\ldots \ldots$ & ............. & .. & \\
\hline 51 & & $\ldots \ldots \ldots$ & $\cdots$ & 12.83 & ................ & 13.63 & 5 \\
\hline 5 & $\ldots \ldots \ldots$ & (........ & & .......... & $\ldots$ & 14.83 & \\
\hline 5 & $\ldots \ldots \ldots \ldots \ldots$ & $\cdots$ & 2.50 & $\cdots$ & 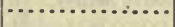 & $\ldots \ldots$ & \\
\hline 5 & $\cdots \ldots \ldots{ }_{2 i}$ & $\cdots$ & 12.27 & 13 & $\ldots \ldots \ldots \ldots$ & 10 & \\
\hline 5 & 2 & $\cdots$ & $\cdots$ & $\cdots$ & $\cdots$ & . $\ldots \ldots$ & \\
\hline & 1 & $\cdots$ & & . & $\ldots . . x_{2}-2$ & $\cdots$ & \\
\hline 5 & 13 & & & & & $\mid \begin{array}{l}\ldots \ldots \\
\ldots \ldots\end{array}$ & \\
\hline 5 & 00 & ..... & $1-$ & . & $\cdots$ & $\ldots \ldots$ & \\
\hline 6 & 1.34 & $\ldots \ldots \ldots$ & . & - & & . & \\
\hline$c^{\circ} \longrightarrow$ & 85 & .... & & $\cdots$ & . & $\ldots \ldots$ & \\
\hline 6 & & & E & & $\ldots$ & ... & \\
\hline & $\cdots \cdots$ & & & & ... & $\ldots \ldots \ldots$ & \\
\hline 6 & & $\cdots$ & 29 & & -. & $\ldots \ldots$ & \\
\hline & $\cdots$ & .. & & $\therefore$ & 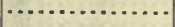 & $\cdots$ & \\
\hline 6 & 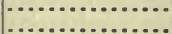 & & 16.10 & $\cdots$ & $\cdots$ & & \\
\hline 68 & - & & 13.75 & 列 & & & \\
\hline
\end{tabular}




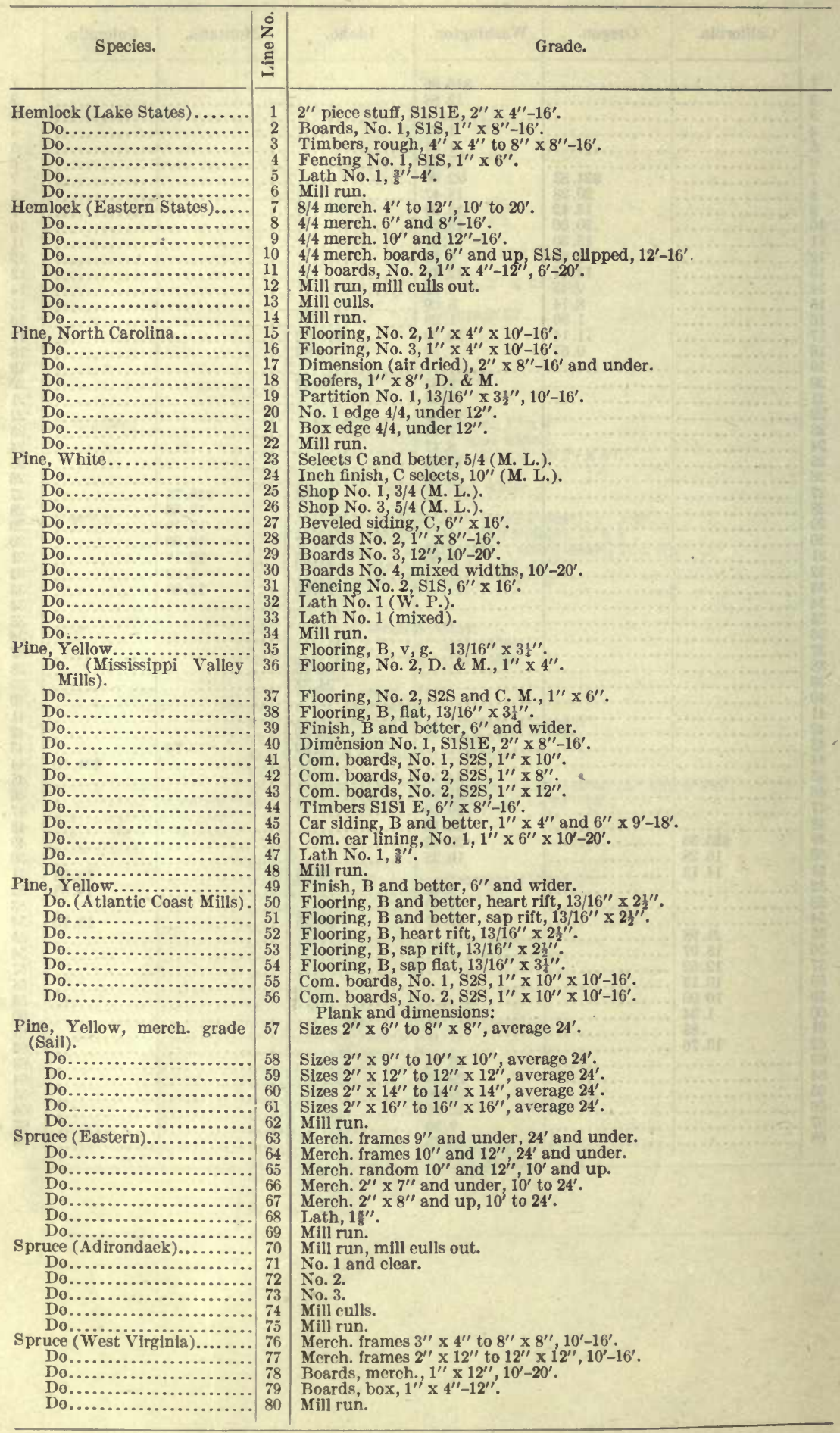




\begin{tabular}{|c|c|c|c|c|c|c|c|c|c|c|c|c|c|c|}
\hline & Texas. & $\begin{array}{l}\text { Ar- } \\
\text { kansas }\end{array}$ & $\begin{array}{l}\text { Louisi- } \\
\text { ana. }\end{array}$ & $\begin{array}{l}\text { Missis-s- } \\
\text { sippi. }\end{array}$ & $\begin{array}{l}\text { Ala- } \\
\text { bama. }\end{array}$ & $\begin{array}{l}\text { Mis- } \\
\text { souri. }\end{array}$ & $\begin{array}{l}\text { Flor- } \\
\text { ida. }\end{array}$ & $\begin{array}{l}\text { Geor- } \\
\text { gia. }\end{array}$ & $\begin{array}{l}\text { South } \\
\text { Caro- } \\
\text { lina. }\end{array}$ & $\begin{array}{l}\text { North } \\
\text { Caro- } \\
\text { lina. }\end{array}$ & $\begin{array}{c}\text { Ten- } \\
\text { nessee. }\end{array}$ & $\begin{array}{l}\text { Ken- } \\
\text { tucky. }\end{array}$ & $\begin{array}{l}\text { Vir- } \\
\text { ginia. }\end{array}$ & \\
\hline & & & & & & & & & & & & & & \\
\hline & & & & & & & & & & & & & ..... & \\
\hline & & & & & & & & & & & ... & & .... & \\
\hline & & & & & & & & & & & & & & \\
\hline & & & & & & & & & $\ldots$ & & & & & \\
\hline & & & & & & & & & & & & & & \\
\hline & & & & & & & & & & & & & …. & \\
\hline & & & & & & & & & & & .. & & ..... & \\
\hline & & & & & & & & & & & .. & & $\$ 13.69$ & \\
\hline & & & & & & & & & $\$ 21.46$ & $\$ 21.45$ & $\ldots \ldots$ & & 22.80 & \\
\hline & & & & & & & & …... & $\begin{array}{l}17.47 \\
12.17\end{array}$ & $\begin{array}{l}18.02 \\
11.92\end{array}$ & & & $\begin{array}{l}1.30 \\
12.42\end{array}$ & \\
\hline & & & & & & & .... & ...... & 13.10 & 13.31 & $\ldots$ & & 15.90 & \\
\hline & & & & & & & .... & ....... & 23.67 & 24. 72 & & & & \\
\hline 2 & & & & & & & ...... & ...... & 21.67 & & & ( & 12.95 & \\
\hline 2 & & & & . & & & ….... & ….. & $\begin{array}{l}11.50 \\
13.30\end{array}$ & $\begin{array}{l}11.85 \\
13.55\end{array}$ & …... & & $\begin{array}{l}12.95 \\
12.71\end{array}$ & \\
\hline & & & & & & & & & & & & & & \\
\hline & 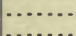 & & $\cdots$ & & $\cdots$ & & $\cdots$ & & & & $\cdots$ & & - & 2 \\
\hline & & & & & & & & …. & & & $\cdots$ & $\cdots$ & $\because$ & \\
\hline & & & & & & & .... & ..... & & & ….... & ….... & …... & \\
\hline & & & & & & & …. & $\ldots$ & $\cdots$ & & $\ldots$ & ….... & $\cdots$ & 2 \\
\hline & & & & & & & 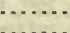 & 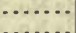 & & & ;.n. & …... & … & $\begin{array}{l}36 \\
3 \\
\end{array}$ \\
\hline & & & & & & & .. & ... & & & . & & ....... & \\
\hline & & & & & & & $\ldots$ & $\ldots \ldots$ & & 19.67 & $\$ 20.00$ & $\ldots$ & $19.6 \overline{7}$ & $\begin{array}{l}3 \\
3 \\
3\end{array}$ \\
\hline & $\$ 27.62$ & $\$ 27.81$ & $\$ 27.82$ & $\$ 28.25$ & $\$ 28.40$ & & & & & & & & & 3 \\
\hline 36 & 10.93 & $\begin{array}{l}10.84 \\
11.71\end{array}$ & 10.69 & 10. 08 & 10. 64 & & & & & & & & $\ldots$ & $\begin{array}{l}3 \\
3 \\
3\end{array}$ \\
\hline 5 & $\begin{array}{l}19.20 \\
19.28\end{array}$ & $\begin{array}{l}11.78 \\
18.54\end{array}$ & $\begin{array}{l}11.30 \\
18.62\end{array}$ & $\begin{array}{l}18.17 \\
18.93\end{array}$ & 18.53 & $\$ 20.00$ & & & & & & & $\ldots$ & $\begin{array}{l}3 \\
3 \\
3 \\
\varepsilon\end{array}$ \\
\hline 38 & 23. 92 & 23.98 & 22.63 & 21.79 & 21.81 & & & & & & & & & 3 \\
\hline 4 & & 11.60 & 11 & & & 15.32 & & & & & & & & \\
\hline 4 & & & & & & & & & & & & & . & 4 \\
\hline $4:$ & & & & & & 13. & & & & & & & .. & 4 \\
\hline 4 & & & & & & & & & & & & & 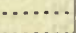 & \\
\hline 4 & 13. 00 & & & & & & & & & & & 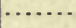 & & \\
\hline$d$ & 22.17 & & 21 & 22.75 & & & ... & ..... & & & ….... & …... & 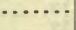 & $\begin{array}{l}4 \\
4\end{array}$ \\
\hline . & 14.40 & $\begin{array}{r}14.25 \\
1.75\end{array}$ & $\begin{array}{r}15.00 \\
1.71\end{array}$ & $\begin{array}{r}10.50 \\
1.89\end{array}$ & $\begin{array}{r}10.41 \\
1.70\end{array}$ & ....... & …... & $\ldots$ & & .......... & $\cdots \cdots$ & & & \\
\hline 48 & 13.52 & 13.87 & 13.89 & 14.05 & 13.49 & 11.40 & 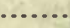 & & & & 13.58 & & .. & 4 \\
\hline & & & & & & & & $\$ 21.60$ & & & & & & $\begin{array}{l}4 \\
5 \\
\end{array}$ \\
\hline & & & & & & & & & & & & & & 5 \\
\hline & $\cdots$ & & & & & & ... & $\begin{array}{l}35.00 \\
28.80\end{array}$ & & & & & & $\begin{array}{l}5 \\
5 \\
5\end{array}$ \\
\hline & . & & & & & & $\$ 21$ & & & & & & $\cdots$ & 5 \\
\hline & & & & & & & & & & & & & $\cdots$ & 5 \\
\hline 5 & … & & & & & $\cdots$ & & & & & & & . & $\begin{array}{l}5 \\
5\end{array}$ \\
\hline & & & … & & & & & & & & & & ..... & $\xi$ \\
\hline & $\cdots$ & & & & & ... & & & & & & & & 5 \\
\hline & & & & & & & 21 & & & & & & & 6 \\
\hline & & & & & & & $\begin{array}{l}2.35 \\
13.56\end{array}$ & $\begin{array}{l}20.45 \\
14.05\end{array}$ & & & & & & 6 \\
\hline & & & & & & & & & & & & & & \\
\hline & & & & & & & & & & & & & $\ddot{.}$ & 6 \\
\hline & .. & & & & & & & & & & & & & \\
\hline & & & & & & & & & & & & $\because \cdots$ & "* & 6 \\
\hline & & & ..... & & $\cdots$ & & & & . & & & & $\cdots$ & \\
\hline 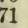 & & & $\ldots$ & & & & & & . & & & & .. & \\
\hline & & & & & & & & & & & & & & \\
\hline & & & & & & & & & & & & & & 7 \\
\hline & & & & & & & & & & & & & & 7 \\
\hline & & & & & & & & & & & & & & \\
\hline & & & & & & & & & & & & & $\cdots$ & \\
\hline (1) & & & & & & & & & & & & & & \\
\hline & & & & & & & & & & & & & & \\
\hline
\end{tabular}




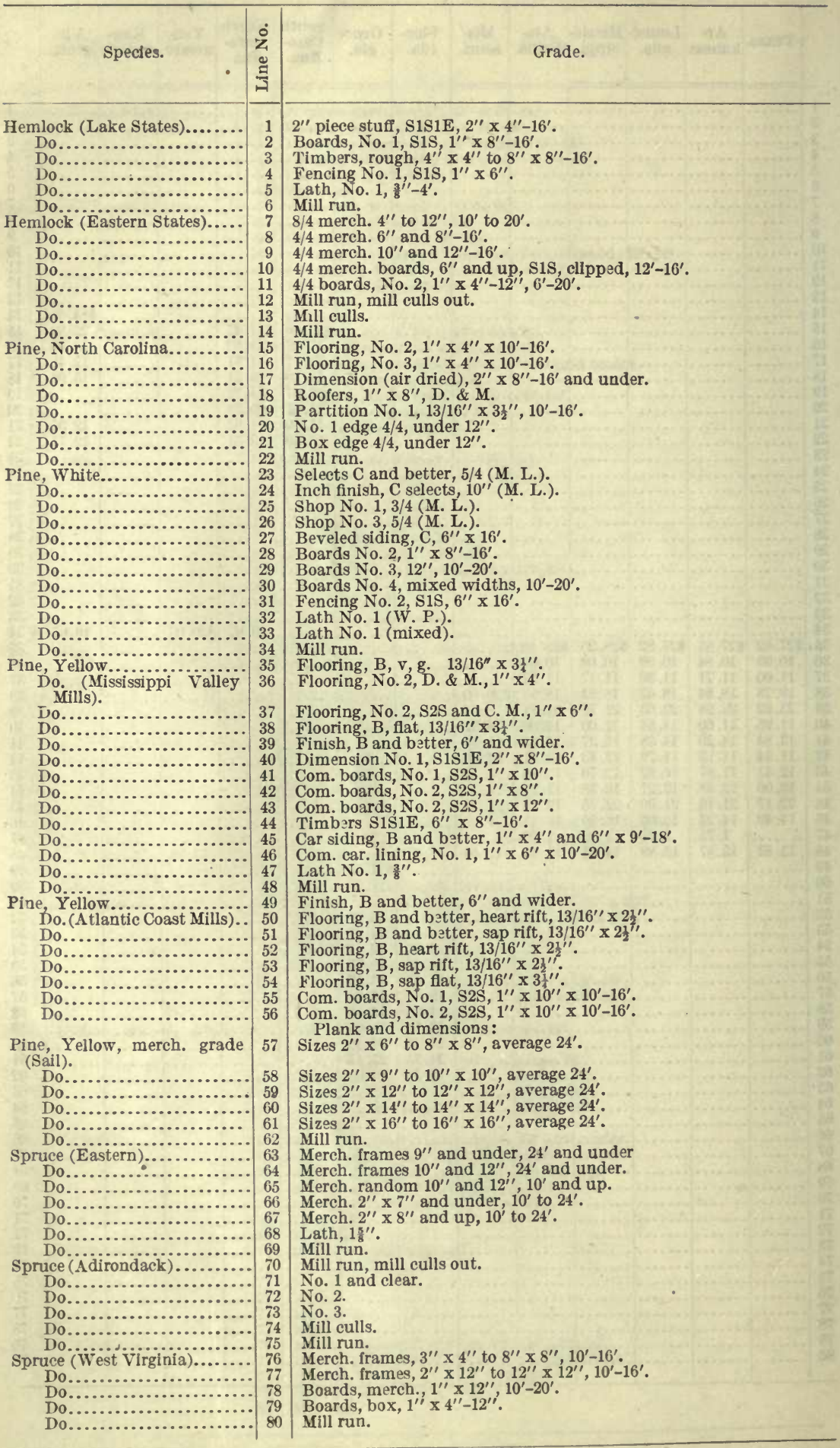




\begin{tabular}{|c|c|c|c|c|c|c|c|c|c|c|c|c|}
\hline & $\begin{array}{l}\text { West } \\
\text { Vir- } \\
\text { ginia. }\end{array}$ & $\begin{array}{l}\text { Mary- } \\
\text { land. }\end{array}$ & $\begin{array}{l}\text { Penn- } \\
\text { sylva- } \\
\text { nia. }\end{array}$ & $\begin{array}{l}\text { New } \\
\text { York. }\end{array}$ & $\begin{array}{l}\text { New } \\
\text { Hamp- } \\
\text { shire. }\end{array}$ & $\begin{array}{l}\text { Ver- } \\
\text { mont: }\end{array}$ & Maine. & $\begin{array}{l}\text { Massa- } \\
\text { chu- } \\
\text { setts. }\end{array}$ & $\begin{array}{l}\text { Con- } \\
\text { necti- } \\
\text { cut. }\end{array}$ & $\begin{array}{c}\text { Minne- } \\
\text { sota. }\end{array}$ & $\begin{array}{l}\text { Wis- } \\
\text { consin. }\end{array}$ & $\begin{array}{l}\text { Michi- } \\
\text { gan. }\end{array}$ \\
\hline 1 & & & & $\$ 18.44$ & & & & & & & 91 & \\
\hline 2 & & & & & & & & & & $\ldots$ & & \\
\hline 3 & & ... & & & & & & & & ... & & 61 \\
\hline 4 & & ... & $\cdots$ & $\ldots \ldots$ & & & & & & .... & 16. 22 & 00 \\
\hline 5 & & ... & & \#...... & & & & & & & 33 & 54 \\
\hline 6 & & $\cdots$ & $\ldots$ & & & & & & & $\cdots$ & 12.85 & 19 \\
\hline 7 & & $\cdots$ & $\cdots$ & & 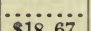 & $\ldots$ & & $\cdots$ & & $\cdots$ & ......... & 33 \\
\hline 8 & $\cdots$ & ...... & $\ldots \ldots$ & 18.75 & $\$ 18.67$ & & $\cdots$ & $\cdots$ & & $\ldots \ldots \ldots$ & $\cdots \ldots$ & $\cdots$ \\
\hline g & & $\cdots$ & $\cdots$ & $\cdots \ldots$ & $\ddot{18.80}$ & $\begin{array}{l}50 \\
25\end{array}$ & & . & & $\cdots$ & $\cdots$ & \\
\hline & & $\cdots$ & .. & & & & & & & ... & 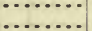 &. \\
\hline$D$ & & & & 17.50 & & 16.83 & 16.25 & & $\$ 17.00$ & $\cdots$ & ... & $\ldots$ \\
\hline 13 & & $\cdots$ & & & & & & & & $\ldots$ & & $\ldots$ \\
\hline 14 & 15.00 & ...... & $\$ 17$. & 16.60 & 25 & 15.42 & 15.00 & $\$ 15.08$ & 15.00 & .......... & $\ldots$ & $\ldots$ \\
\hline 10 & -. & $\cdots$ & ... & $\cdots$ & $\cdots$ & & & 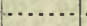 & $\cdots$ & $\cdots$ & &. \\
\hline 16 & . & ..... & & & & & & & & $\cdots$ & & $\bullet$ \\
\hline 17 & . & ..... & $\cdots$ & & & & & & & & $\ldots$ & \\
\hline 18 & $\cdots$ & ...... & $\cdots$ & & & $\cdot$ & & $\ldots$ & & $\cdots$ & & \\
\hline & $\cdots$ & ...... & $\cdots$ & & & $\cdot$ & $\cdots$ & $\cdots$ & & $\cdots$ & $\cdots$ & - \\
\hline & $\cdots$ & $\cdots$ & $\cdots$ & & & - & $\cdots$ & & & $\cdots$ & & $\because$ \\
\hline & $\cdots$ & $\cdots$ & & & & $\cdot$ & $\cdots$ & & & $\cdots$ & & $\cdot$ \\
\hline 23 & - & $\cdots \ldots$ & & & & 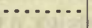 & & & & $\ddot{3}$ & & \\
\hline & - & $\cdots \cdots$ & $\cdots$ & & & & & $\cdots$ & & & & \\
\hline & - & $\cdots$ & $\cdots$ & & & $\cdots$ & & $\cdots$ & & & & $\cdots$ \\
\hline 20 & . & $\cdots$ & & & $\ddot{28.93}$ & & & & & $\begin{array}{l}50 \\
17\end{array}$ & $\begin{array}{l}48.00 \\
24.05\end{array}$ & $\cdots$ \\
\hline 27 & . & . & & & ... & $\therefore$ & & & & 23 & 24 & $\cdots$ \\
\hline 28 & $\cdots$ & ... & & & 88 & & 71 & & & 17 & 43 & \\
\hline$y$ & $\cdots$ & ...... & $\ldots$ & & & & 30 & & & & 20 & \\
\hline 30 & $\cdots$ & ...... & ..... & & 14.75 & $\ldots$ & ... & & & & 13 & 13.50 \\
\hline & $\ldots$ & ...... & ..... & & ........ & - & $\ldots$ & 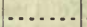 & & 24 & 25 & \\
\hline ve & $\ldots$ & ...... & ...... & & .. & - & .. & . & & 3 & 3.58 & 55 \\
\hline & $\cdots$ & $\cdots$ & & & & & & & & 3.30 & 3.24 & 30 \\
\hline 3 & . & $\cdots$ & 21 & 22.04 & 28 & 18.63 & 18.97 & 17.00 & 19.19 & 19.00 & 20.57 & 22.18 \\
\hline & $\cdots$ & ....... & $\cdots \cdots$ & $\cdots$ & $\cdots$ & $\cdots$ & ......... & ...... & $\cdots$ & ........ & $\ldots \ldots$ & $\cdots$ \\
\hline & .... & ...... & $\cdots$ & & $\cdots$ & ... & $\ldots$ & ...... & $\ldots$ & ....... & ....... & $\ldots \ldots$ \\
\hline 3 & $\ldots$ & ...... & $\cdots \cdots$ & & $\cdots$ & $\ldots$ & ......... & ...... & $\cdots$ & $\ldots . . .$. & ........ & $\ldots$ \\
\hline 38 & $\cdots$ & $\cdots \cdots$ & ..... & & $\cdots$ & $\ldots \ldots$ & ........ & $\ldots$ & $\ldots$ & ........ & .......... & $\cdots$ \\
\hline 39 & - & $\cdots$ & $\cdots$ & & $\cdots$ & $\bullet$ & . & $\cdots$ & $\ldots$ & ... & $\ldots$ & - \\
\hline 40 & $\cdots$ & $\cdot$ & $\cdots$ & & & $\because$ & . & $\cdots$ & 1 & .. & $\ldots$ & - \\
\hline 4 & $\cdots$ & $\cdots$ & $\cdots$ & & $\cdots$ &. & $\ldots \ldots$ & $\ldots$ & $\cdots$ &. & .. & - \\
\hline 4 & $\bullet$ & $\cdots$ & $\cdot$ & & $\cdots$ & $\because$ & $\cdots$ & $\cdots$ & $\ldots$ & $\cdots$ & ... & - \\
\hline 43 & • & $\cdots$ & $\cdots$ & & $\cdots$ & - & . & $\cdots$ & 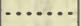 & $\cdots$ & $\ldots$ & - \\
\hline 44 & • & $\cdots$ & $\cdots$ & & $\cdots$ & - & $\cdots$ & $\cdots$ & - & $\cdots$ & $\cdots$ & - \\
\hline & & 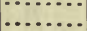 & & & $\cdots$ & $\cdot$ & $\cdots$ & $\cdots$ & - & $\cdots$ & $\cdots$ & $\cdot$ \\
\hline 47 & $\cdots$ & ….... & $\cdots$ & & $\cdots$ &. & $\cdots$ & $\cdots$ & $\because$ & -...... & $\cdots$ & - \\
\hline $48-2$ & .. & ...... & $\ldots \ldots$ & & $\cdots$ & $\cdots$ & $\cdots$ & $\cdots$ & $\ldots$ & $\cdots$ & $\cdots$ & - \\
\hline 4 & $\bullet$ & ...... & $\cdots$ & & $\cdots$ &. & $\cdots$ & $\cdots$ & $\ldots$ & $\cdots$ & $\cdots$ & $\cdot$ \\
\hline & $\cdots$ & . & .. & & & 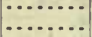 & $\cdots$ & $\cdots$ & $\cdots$ & $\cdots$ & $\cdots$ & - \\
\hline 51 & $\cdots$ & $\cdots$ & .. & & & $\cdot$. & & & & $\cdots$ & $\cdots$ & \\
\hline 52 & $\cdots$ & $\cdots$ & $\cdots$ & & .. & . & & & & & $\cdots$ & \\
\hline 58 & ...... & ....... & $\cdots$ & & . & $\cdots$ & $\ldots$ & ... & - & . & $\ldots$ & \\
\hline 4 & $\cdots \cdots$ & $\ldots \ldots$ & $\ldots \ldots$ & & - & & - & $\cdots$ & 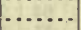 & ... & $\ldots$ & \\
\hline & $\cdots$ & ....... & $\cdots$ & & $\cdots$ & & $\because$ & $\cdots$ & - & .... & $\ldots$ & - \\
\hline 5 & . . . & ....... & $\ldots \ldots$ & $\cdots$ & $\cdots$ & 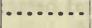 & $\cdots$ & $\cdots$ & - & .... & $\ldots . .$. & - \\
\hline & ..... & ....... & $\cdots$ & & & & - & $\cdots$ & & .... & $\ldots$ & - \\
\hline & $\cdots \cdots$ & . . . . & $\ldots \ldots$ & & $\cdot$ & & & .. & $\ldots$ & .... & $\ldots$ & - \\
\hline & $\cdots$ & . $\ldots$ & $\cdots$ & & $\cdots$ & $\cdot$ & - & $\cdots$ & $\ldots$ & ..... & $\ldots$ & . \\
\hline & - & - & $\cdots$ & & $\cdots$ & - & $\cdots$ & $\cdots$ & $\cdots$ & $\ldots$ & $\ldots$ & - \\
\hline & $\cdot$ & * & 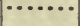 & & - & $\cdot$ & & $\cdots$ & $\cdots$ & ....... & ....... & $\cdots$ \\
\hline & & 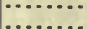 & $\cdots$ & & $\cdots$ & & & & & $\cdots$ & $\cdots$ & $\ldots$ \\
\hline & - & 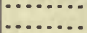 & & & & & 2 & & & & 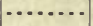 & \\
\hline 6 & & & & & & & & & & & . & \\
\hline 66 & & & & & 20.30 & & & & & & $\ldots$ & \\
\hline 6 & & & & & $\ldots$ & 22.50 & 19 & & & 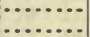 & . & .. \\
\hline 68 & & & & & & & & & & & & \\
\hline & & & & & 88 & 18.04 & 17.70 & & & & $\cdots$ & \\
\hline & & - & $\cdots$ & & $\ldots$ & ... & $\ldots$ & & & 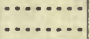 & - & \\
\hline 7 & & & .. & 29.75 & & & & & & $\because$ & ........ & \\
\hline 7 & 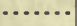 & & & $\cdots$ & & & & $\ldots$ & & $\ldots$ & & \\
\hline 7 & $\cdots$ & - & & & & 15.33 & $\cdots$ & & & ....... & $\cdots$ & \\
\hline & $\cdots$ & & & & & $\cdots$ & $\cdots$ & $\ldots$ & & & $\cdots$ & \\
\hline & & & & 17.79 & & & & 政 & & & & \\
\hline & & $\ldots \ldots$ & -. & ...... & & $\cdots$ & & $\cdots$ & & & & \\
\hline & & ...... & & & & . & & & & & & \\
\hline & & $\cdots$ & $\cdots$ & & & $\cdots$ & & & & $\cdots$ & $\cdots$ & \\
\hline & & & & & & & & & & 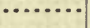 & & \\
\hline & & & & & & & & & & & & \\
\hline
\end{tabular}




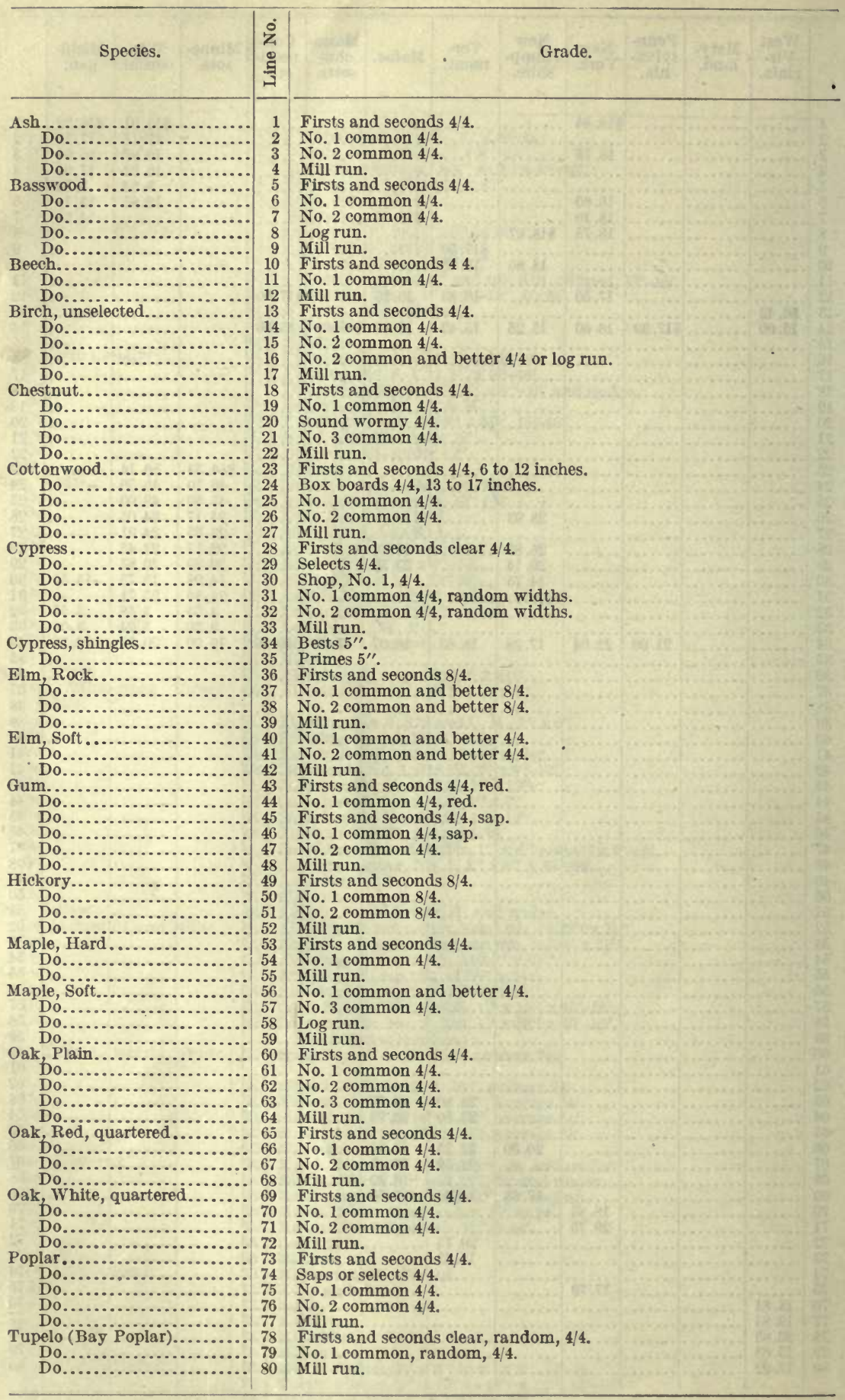




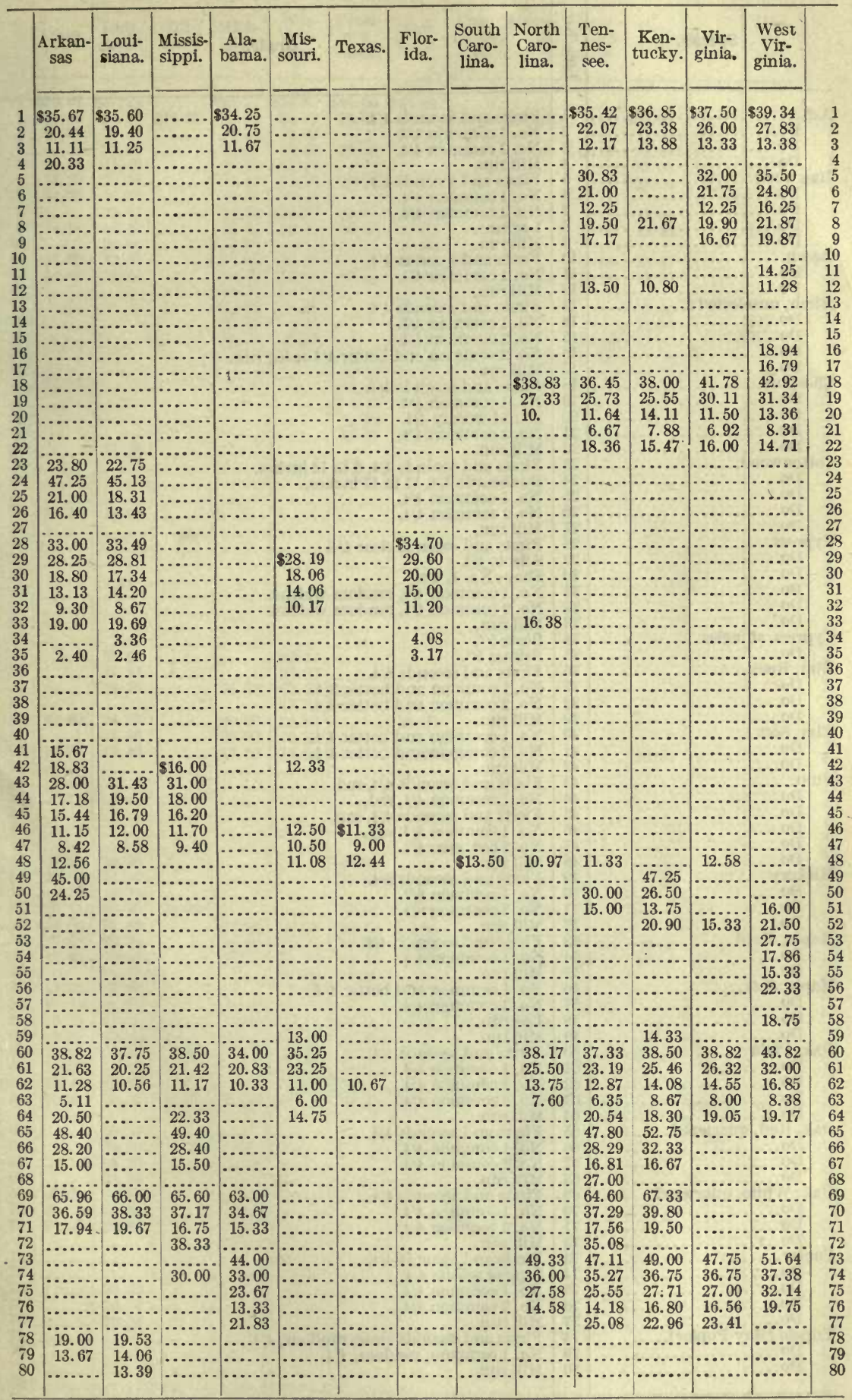




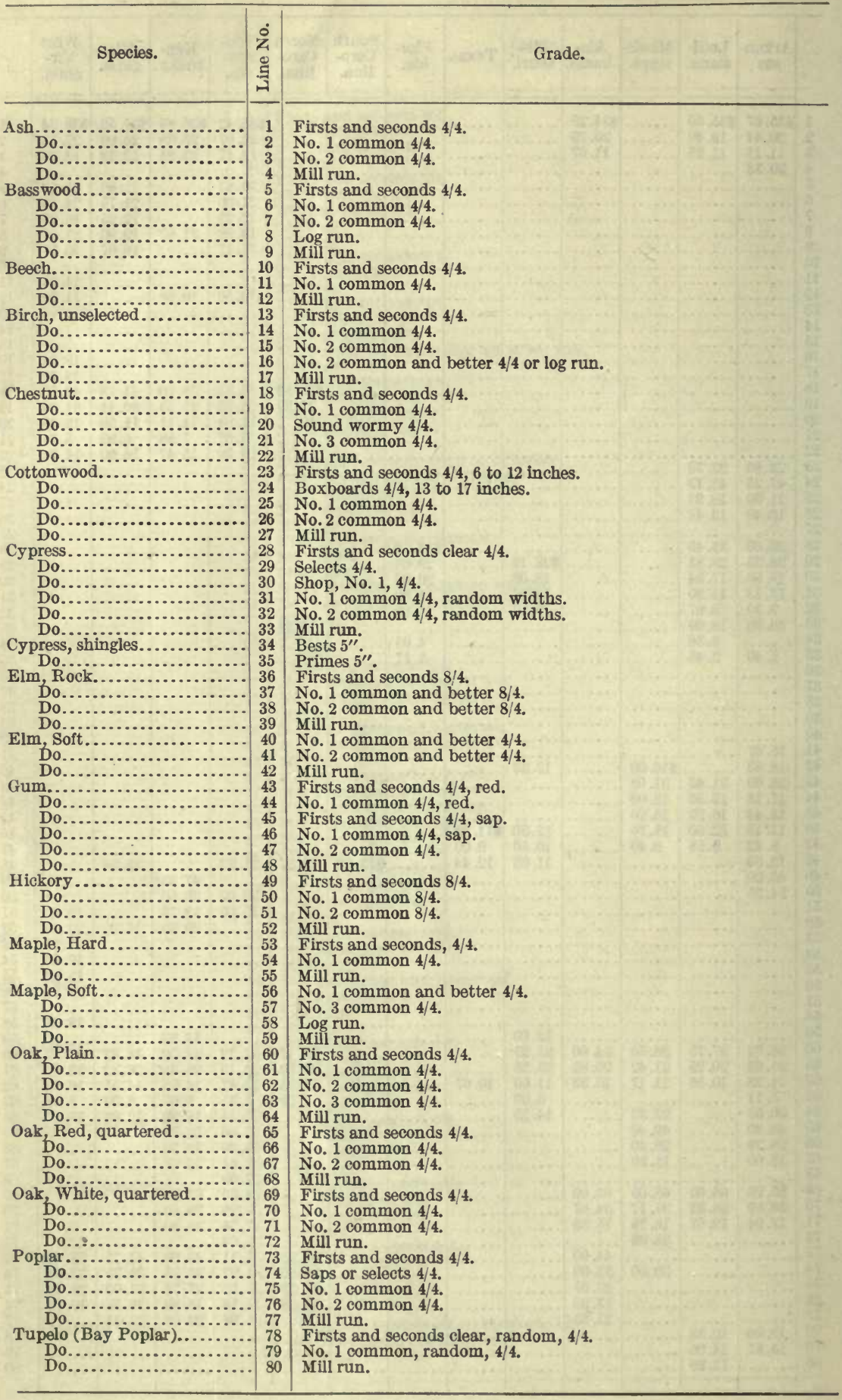




\begin{tabular}{|c|c|c|c|c|c|c|c|c|c|c|c|c|c|c|}
\hline & Ohio. & $\begin{array}{l}\text { Indi- } \\
\text { ana. }\end{array}$ & $\begin{array}{l}\text { Illi- } \\
\text { nois. }\end{array}$ & $\begin{array}{l}\text { Mich- } \\
\text { igan. }\end{array}$ & $\begin{array}{l}\text { Wis- } \\
\text { con- } \\
\text { sin. }\end{array}$ & $\begin{array}{c}\text { Penn- } \\
\text { syl- } \\
\text { vania. }\end{array}$ & $\begin{array}{l}\text { New } \\
\text { York. }\end{array}$ & $\begin{array}{c}\text { Con- } \\
\text { necti- } \\
\text { cut. }\end{array}$ & $\begin{array}{c}\text { Massa- } \\
\text { chu- } \\
\text { setts. }\end{array}$ & $\begin{array}{c}\text { New } \\
\text { Hamp- } \\
\text { shire. }\end{array}$ & $\begin{array}{l}\text { Ver- } \\
\text { mont. }\end{array}$ & Maine. & $\begin{array}{c}\text { Min- } \\
\text { ne- } \\
\text { sota. }\end{array}$ & \\
\hline 1 & 67 & $\$ 37.21$ & & $\$ 40.71$ & $\$ 36.62$ & $\$ 40.00$ & $\$ 43.40$ & & & & & & & \\
\hline 2 & 0 & 24 & $\$ 24.67$ & & 23. & & & $\$ 23.75$ & $\$ 24.20$ & & $\$ 26.00$ & & ........ & \\
\hline 3 & 16.33 & 16. & $\ldots \ldots \ldots$ & 18 & 13.92 & & 17.33 & & & & & & & \\
\hline $\begin{array}{l}4 \\
5\end{array}$ & 31.20 & & $\ldots . .$. & 21 & 17.10 & 22.38 & 21.00 & 18.17 & 18.50 & $\$ 18.67$ & 21.43 & $\cdots$. & ..... & \\
\hline $\begin{array}{l}5 \\
6\end{array}$ & $\begin{array}{l}31.20 \\
21.25\end{array}$ & $\begin{array}{l}31 \\
22\end{array}$ & $\ldots .$. & $\begin{array}{l}35.96 \\
24.61\end{array}$ & $\begin{array}{l}33.94 \\
23.20\end{array}$ & 24.50 & 25.67 & - & a $\ldots \ldots$ & $\cdots$ & $\begin{array}{l}35.00 \\
25.50\end{array}$ & 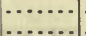 & $\ldots \ldots$ & \\
\hline 7 & 14.75 & & & 16.05 & 14.90 & & & & & & & $\cdots$ & $\cdots$ & \\
\hline 8 & 10... & & ... & 8 & 22.92 & 20 & 32 & & 20.80 & & 21.80 & & & 8 \\
\hline 9 & 18.67 & & $\cdots$ & 7 & 18.33 & 16.67 & & $\ldots$. & $\ldots . .$. & 17.00 & 18.30 & .... & $\$ 14.33$ & 9 \\
\hline $\begin{array}{l}10 \\
11\end{array}$ & 17.80 & 16.95 & $\ldots$ & $\begin{array}{l}25.00 \\
17.18\end{array}$ & 16.33 & 16.17 & $\begin{array}{l}23.88 \\
16.67\end{array}$ & 18.00 & & 19.00 & $\ddot{7}$ & & $\cdots$ & 10 \\
\hline 12 & 14.00 & 16.65 & $\cdots$ & 13.42 & 11.50 & 13.38 & 14.50 & $\begin{array}{c}10.00 \\
\ldots . . .\end{array}$ & 14.08 & 13.83 & 14.25 & …. & 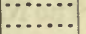 & 12 \\
\hline 1 & $\cdot$ & $\ldots \ldots$ & & 33 & 34.73 & $\cdots$ & 35.40 & & $\cdots$ & ........ & ....... & $\ldots$. & ....... & 13 \\
\hline c & & $\cdots$ & ... & 1 & 19.50 & $\cdots$ & 21.20 & & $\ldots$ & ........ & 22.25 & & $\ldots$ & 14 \\
\hline 15 & & $\cdots$ & $\ldots$ & 30 & 11.28 & $\cdots$ & 0 & $\ldots$ & $\cdots$ & $\ddot{i} \cdot$ & & ..... & $\ldots \ldots$ & 15 \\
\hline 16 & & $\cdots$ & ........ & 76 & 21.20 & & 38 & & & 25 & & ...... & $\ldots$. & 16 \\
\hline 17 & & $\cdots$ & . . . . . & 17.81 & 17.49 & 17.50 & 38 & 15.21 & 13.75 & 16.07 & 17.36 & $\cdots \cdots$ & - . . . & 17 \\
\hline 19 & 28.33 & & $\cdots$ & $\ldots \ldots \ldots$ & ....... & $\begin{array}{l}35.00 \\
22.83\end{array}$ & 39 & $\ldots \ldots$ & $\ddot{26}$ & $\cdots \ldots$ & $\ldots \ldots \ldots$ & $\cdots \cdot$ & $\cdots \cdots$ & $\begin{array}{l}18 \\
19\end{array}$ \\
\hline 20 & & & & & $\cdots$ & 17.25 & 16.67 & $\cdots$ & $\begin{array}{c}20.01 \\
\ldots . . .\end{array}$ & 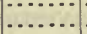 & $\cdots$ & a...... & $\cdots$ & 20 \\
\hline 21 & & & & & & 14.00 & & & & &. & & & 21 \\
\hline 22 & & & & & & 15.92 & 17.25 & 17.46 & 18.40 & 18.17 & & $\ldots$. & & 22 \\
\hline 23 & & 27.10 & $\cdots$ & $\cdots$ & & $\cdots$ & . & $\cdots$ & $\cdots$ & ........ & $\cdots$ & $\ldots \ldots$ & $\ldots$. & 23 \\
\hline $\begin{array}{l}24 \\
25\end{array}$ & & $\begin{array}{l}\ldots \\
\ldots\end{array}$ & $\ldots$ & & & & & & & $=$ & & $\cdot$ & $\cdot$ & 24 \\
\hline 20 & & & $\cdots$ & & $\cdots$ & & & & & . & & $\cdots$ & $\mid \begin{array}{l}\cdots \\
\ldots\end{array} \ldots$ & 26 \\
\hline 27 & 16.13 & 17.88 & & 1 & $\cdots$ & $\cdots$ & & $\cdots$ & & $\cdots$ & $\cdots$ & ...... & $\ldots \ldots$ & 27 \\
\hline 28 & $\cdots$ & $\ldots \ldots$ & $\ldots \ldots$ & $\cdots$ & $\cdots \ldots$ & $\cdots$ & ... & - & - & - & $\cdots$ & ..... & $\ldots \ldots$ & 28 \\
\hline $\begin{array}{l}29 \\
30\end{array}$ & & & & & & & & & & &. & $\cdots$ & & 29 \\
\hline $\begin{array}{l}30 \\
31\end{array}$ & & & & & & & & & $\cdots$ & $\cdots$ & $\cdot$. & ..... & $\ldots \ldots$ & 30 \\
\hline 32 & & & & & & -1 & & & & $\cdots$ & & $\cdots$ & $\ldots \ldots$ & 32 \\
\hline 33 & & $\cdots$ & $\ldots \ldots$ & ..... & {$\left[\begin{array}{lll}\cdots & \ldots\end{array}\right.$} & & $\ldots$ & $\cdots$ & $\cdots$ & $\cdots$ & $\cdots$ & - ....... & $\left.\begin{array}{ll}\cdots \\
\cdots\end{array}\right]$ & 33 \\
\hline 34 & & $\ldots \ldots$ & $\ldots \ldots$ & ..... & $\ldots \ldots$ & & $\cdots$ & & $\cdots$ & $\cdots$ & & ........ & $\ldots \ldots$ & 34 \\
\hline $\begin{array}{l}35 \\
36\end{array}$ & & 35.67 & & & 33.14 & & & & & & & . & & 6 \\
\hline $\begin{array}{l}36 \\
37\end{array}$ & & 27.33 & & & 23.00 & & & & & &. & $\begin{array}{l}\ldots . \\
\ldots . \\
\ldots\end{array}$ & .. & $\begin{array}{l}36 \\
37\end{array}$ \\
\hline 38 & & 22.75 & $\cdots$ & 25.83 & 22.30 & & $\cdots$ & & & & & $\mid \begin{array}{lll}\cdots & \cdots & \ldots \\
\cdots & \ldots & \ldots\end{array}$ & $\cdots$ & 38 \\
\hline 40 & & & & & 17.35 & & & & & & & $\cdots$ & $\cdot \cdot$ & 39 \\
\hline 40 & & $\begin{array}{l}24.07 \\
21.38\end{array}$ & & & 26.50 & & 00 & & & $\cdots$ & & $\ldots$. & $\ldots$ & 40 \\
\hline 42 & 15.75 & 17.40 & - & $\begin{array}{l}25.97 \\
17.50\end{array}$ & $\begin{array}{l}19.97 \\
15.64\end{array}$ & $\ldots$ & $\ddot{19.67}$ & & & . & $\because$ & -....... & .. & 41 \\
\hline $\begin{array}{l}42 \\
43\end{array}$ & & ....... & $\mid \begin{array}{ll}\cdots \\
\cdots\end{array} \ldots \ldots$ & $\begin{array}{c}17.50 \\
\ldots \ldots \ldots\end{array}$ & $\begin{array}{c}15.64 \\
\ldots \ldots\end{array}$ & & & & & & 67 & ...... & $\cdot$ & 42 \\
\hline 44 & & & $\ldots \ldots .$. & $\cdots$ & $\cdots$ & & $\cdots$ & & & $\cdots$ & $\because$ & ...... & $\ldots \ldots \ldots$ & $\begin{array}{l}43 \\
44\end{array}$ \\
\hline 4 & & & $\ldots \ldots$ & $\cdots$ & $\ldots \ldots$ & & & $\cdots$ & $\cdots$ & $\ldots \ldots$ & $\cdots$ & $\cdots \cdot$ & $\left(\begin{array}{l}\cdots \\
\cdots\end{array} \ldots\right.$ & $\begin{array}{l}44 \\
45\end{array}$ \\
\hline 4 & & & $\ldots \ldots$ & $\cdots$ & - & & & $\cdots$ & $\cdots$ & $\ldots \ldots$ & $\bullet$ & ......... & ........ & 46 \\
\hline 4 & & . & $\ldots$ & $\cdots$ & & & $\cdots$ & . & & $\ldots \ldots$ & & .... & $\ldots \ldots$ & 47 \\
\hline $\begin{array}{l}48 \\
49\end{array}$ & 88 & 49.20 & & & & $7 \overline{5}^{-}$ & & & & & & - & & 49 \\
\hline 50 & & 31.27 & & & & 35.00 & & & & & & … & & $\begin{array}{l}49 \\
50\end{array}$ \\
\hline 51 & 17 & 19.71 & & -1 & $\cdots$ & & & & & $\cdots \cdot \cdot$ & & $\cdots \cdot$ & .0 & 51 \\
\hline 5 & & 75 & 20.08 & & & & & 22.00 & 17.50 & & & .... & $\ldots \ldots$ & 52 \\
\hline 53 & 00 & 2 & ........ & 29.81 & 26. 12 & 13 & 00 & $\cdots$ & $\ldots$ & & & .... &. & 53 \\
\hline 5 & 67 & 20 & $\ldots$ & 21.80 & 17.77 & 00 & $42 !$ & & & 20.00 & 0 & 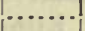 & & 54 \\
\hline 5 & 17.40 & 18 & ........ & 16.72 & 14. 71 & 32 & 16.35 & 16. 17 & 16.13 & 16.38 & 17.20 & ....... & $\ldots$ & 55 \\
\hline 57 & 13.00 & $\begin{array}{l}79 \\
62\end{array}$ & . & $\ldots$ & $\begin{array}{r}22.25 \\
7.36\end{array}$ & 21.00 & $\cdots$ & $\ldots$ & $\ldots$ & $\ldots \ldots$ & $\ldots$ & $\ldots \ldots \ldots$ & & $\begin{array}{l}56 \\
57\end{array}$ \\
\hline 58 & & & & $\ddot{3}$ & 16.74 & & & & & 18.67 & & $\cdots$ & & 58 \\
\hline 5 & & 1 & & 13.46 & 13.15 & & 14.17 & 13.63 & 1.3. 25 & . . . . . . & $\cdots$ & ........ & .. & 59 \\
\hline 60 & 3 & & & $\ldots \ldots$ & 43.33 & & & & & & & 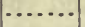 & & 60 \\
\hline 61 & 50 & 7 & 26.67 & $\ldots \ldots$ & 28.86 & 39 & 29.00 & 26.75 & 27.40 &. & 26.00 & & & 61 \\
\hline $\begin{array}{l}62 \\
63\end{array}$ & 1 & 17 & . . . . . . . & $\ldots \ldots$ & $\begin{array}{r}18.86 \\
8.32\end{array}$ & 23 & $\ldots \ldots$ & $\ldots \ldots \ldots$ & $\cdots \ldots$ & . & $\cdots$ & $\mid \ldots \ldots \ldots$ & .. & 62 \\
\hline 64 & 23.88 & $\begin{array}{l}10.78 \\
20.33\end{array}$ & 19.63 & 22.00 & $\begin{array}{c}8.32 \\
\ldots . . .\end{array}$ & $\begin{array}{l}13.33 \\
19.17\end{array}$ & 21.17 & 19.06 & $\ddot{18.39}$ & 19.50 & 19.75 & $\$ 24.00$ & 20.67 & $\begin{array}{l}63 \\
64\end{array}$ \\
\hline 65 & & & & & & & & & & & & & & 5 \\
\hline 6 & & & $\cdots$ & & & & & & & & & & & 66 \\
\hline 67 & & 18.20 & 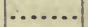 & & & & & & & & $\ldots$ & $\ldots$ & & 67 \\
\hline 68 & & 34.00 & & & & & & & & & & & & 68 \\
\hline 69 & & & $\ldots$ & & & & & & & & & & & an \\
\hline 70 & 13 & 4 & & & $\ldots$ & & & $\ldots$. & & ... & $\ldots$ & .... & $\cdots$ & 70 \\
\hline 71 & 22.33 & 22.55 & , & ........ & .. & . & $\cdots$ & .. & $\ldots$. & $\cdots$ & $\cdots$ & .... & $\cdots$ & 71 \\
\hline 72 & & & & & & & & & & & & & & 7 \\
\hline 73 & & & & & & & & & & & & & & 10 \\
\hline 74 & & & & & & & & & & & & 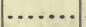 & & 7 \\
\hline 75 & & & & & & & & & & & & & .. & 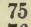 \\
\hline 76 & & 19.14 & & & & & & & & & & . & $\cdots$ & \\
\hline 77 & & $\cdots$ & & & & & & & & & & & $\cdots$ & \\
\hline 79 & & & & & & & & & & & & & & \\
\hline s & & & & & & & & & & & & & & \\
\hline & & & & & & & & & & & & & & \\
\hline
\end{tabular}




\section{OPPORTUNITIES FOR PURCHASING NATIONAL FOREST TIMBER.}

The National Forests contain nearly 590 billion feet of merchantable stumpage. The mature timber, which constitutes a large part of the total stand, is for sale. The more accessible bodies may be purchased in blocks of practically any desired size up to 100 million feet. Less accessible stumpage which requires a large investment for the construction of transportation facilities may be purchased in larger quantities of sufficient size to justify the investment in improvements. Applications up to 1 billion feet will be approved if the investment required necessitates the purchase of a body of that size under one contract.

The procedure for purchasing National Forest timber is extremely simple. Applications specifying the amount, species, and general location desired may be sent to the offices of the Forest Service at Washington, D. C.; Chicago, Ill.; Missoula, Mont.; Denver, Colo.; Albuquerque, N. Mex.; Ogden, Utah; San Francisco, Cal.; and Portland, Oreg. Advertisement at a fixed minimum price is required by law for at least 30 days. The timber is then awarded to the highest bidder and the sale completed by execution of the contract stating the amount and location of the stumpage, the stumpage rates, and the conditions under which the timber shall be removed.

The contract requirements have been prepared by practical lumbermen and perfected by the experience gained in the administration of several thousand sales. They are adapted to the local conditions as to topography, size of the timber, and logging methods. That they are eminently practical is demonstrated by the fact that some 375 million feet are cut each year under these requirements by lumbermen all over the West.

Sufficient time is permitted for the removal of the amount purchased under local conditions of logging and manufacture. The time is gauged, however, to require continuous operation at a reasonable rate and does not permit the holding of stumpage for speculative increases in value. The timber to be cut is designated by the forest officers. Either clean cutting, or partial cutting taking 70 to 80 per cent of the stumpage, is employed, depending upon the character of the timber and the best methods of securing new forest growth. Simple precautions are required to protect the uncut timber and young growth, and the disposal of slash by burning, either with or without piling, is necessary.

These requirements may increase the cost of logging from 50 to 75 cents a thousand feet over the usual cost on private holdings. The difference is always considered in appraising the value of the stumpage. Furthermore, an operator who buys National Forest timber has to make practically no investment at the outset for his stumpage, has no carrying charges for interest or taxes, and incurs practically no fire risk. He is required simply to pay for the timber as it is removed in advance deposits, which represent usually but the value of a month and a half's cut.

These are obvious advantages, particularly when extended over an operation of 10 or 15 years. As private stumpage is cut out in many of the old lumbering centers, operators will find, in the timber on the National Forests, new opportunities for manufacture under advantageous conditions. 


\section{Wattex Mulford}

\section{U. S. DEPARTMENT OF AGRICULTURE,}

FOREST SERVICE. HENRY S. GRAVES, Forester.

\section{RECORD OF WHOLESALE PRICES OF LUMBER.}

(PER 1,000 FEET B. M.)

BASED ON ACTUAL SALES MADE F. O. B. MILL FOR JULY, AUGUST, AND SEPTEMBER, 1912. 


\section{FOREST SERVICE.}

Henry S. Graves, Forester.

Albert F. Potter, Associate Forester.

Herbert A. Smith, Editor.

Branch of Products: McGarvey Cline, in charge.

Washington Office of Products: O. T. SwaN, in charge.

J. C. Nellis, Statistician in Forest Products.

2 


\section{PREFATORY NOTE.}

The purposes of the Forest Service in collecting and compiling this record of f. o. b. mill prices is to have a continuous statistical record of such prices of the various commercial woods. The prices given are wholesale, based on actual sales 1. o. b. mill, for delivery outside of local territory. Only a few representative grades and the mill run are included. By " mill run" is meant the average of all grades of lumber produced. The record is compiled by States, and is made up from reports received from the largest manufacturers throughout the country.

The Forest Service wishes to acknowledge the courtesy of the manufacturers for their prompt and efficient cooperation.

The Forest Service is engaged in many investigations of interest to lumber manufacturers. The work as now organized comprises studies in the physical properties of wood; air-seasoning and kiln-drying; strength tests upon commercial timbers of the United States; wood preservation, including the study of different preservatives and methods of impregnation; softwood and hardwood distillation; wood pulp and paper; naval stores; and wood utilization, which includes studies of the wood-using industries of various States, the collection and compilation of statistics of forest products, etc. Reports on these investigations are published from time to time, and are available to the trade upon request.

A copy of any of the following recent reports may be obtained by addressing the Editor and Chief, Division of Publications, United States Department of Agriculture, Washington, D. C.:

Forest Service Bulletins:

108. Tests of Structural Timbers.

109. Distillation of Resinous Wood by Saturated Steam.

110. The Specific Heat of Wood.

112. Fire-killed Douglas Fir; A Study of its Rate of Deterioration, Usability, and Strength.

Forest Service Circulars:

198. Condition of Experimental Chestnut Poles in the Warren-Buffalo and Poughkeepsie-Newton Square Lines After Five and Eight Years' Service. 200. Absorption of Creosote by Cell Walls of Wood.

206. Commercial Creosotes-With Special Reference to Protection of Wood from Decay.

Division of Publications Circular 11-List of Available Publications of the Forest Service. 


\section{SUMMARY.}

The advance in wholesale lumber prices during April, May, and June, 1912, continued during the months of July, August, and September. The Pacific coast species which continued to rise were red cedar, Douglas fir, western hemlock, and redwood. Western yellow pine and Sitka spruce failed to follow the advance, but western larch, which showed no change during the second quarter, sold at better prices. In eastern softwoods yellow pine made decided advances; North Carolina pine and hemlock advanced somewhat, while the prices of white pine and spruce made no general change. Among the hardwoods prices were generally higher in the Southern and Central States, except on gum, while in the Northern States ash, basswood, beech, and birch were somewhat lower and maple somewhat higher.

In Washington western red cedar beveled siding No. 1 rose $\$ 2$; shop No. 2 over $\$ 3$, and the grades of shingles 25 cents to 50 cents. Douglas fir flooring No. 1 V. G. advanced $\$ 2.80$ in Oregon and Washington, while timbers 12 inches by 12 inches, average 32 feet, rose about $\$ 1$ in both States. The following advances occurred in western hemlock sales in Washington: Flooring Nos. 1 and 2 over $\$ 1$, finish Nos. 1 and 2 nearly $\$ 4$, dimension No. 1 , common, $\$ 1.60$, and ship-lap $\$ 1.25$. Western larch prices show the following advances in Montana: Flooring A and B $\$ 1.25$, finish A and B $\$ 2$, drop siding A and B $\$ 1.50$, common boards No. 2 over $\$ 2$, and dimension No. 1 , common, $\$ 4$. In Idaho western white pine finish $\mathrm{C}$ select advanced $\$ 2$ and finish D select declined $\$ 4$. Western yellow pine shop No. $1,6 / 4$, rose 70 cents in California, $\$ 1.15$ in Washington, but declined 80 cents in Idaho, while common boards No. 2 rose $\$ 1$ in California but declined in both Washington and Idaho. In California redwood sales clears advanced slightly, sap clears declined $\$ 1.25$, while common boards No. 1 advanced $\$ 2$ and common boards, No. 2, 75 cents. In Washington Sitka spruce shop No. 1 advanced $\$ 1.80$, finish No. 2 clear and better declined $\$ 1.33$, and flooring No. 2 clear and better more than $\$ 3$, but beveled siding $B$ advanced $\$ 2.50$ and common boards advanced $\$ 2$.

The advance in yellow-pine prices applies almost without exception to all grades in all producing States. Finish $B$ and better, 6 inches and wider, shows the following advances: Arkansas, $\$ 1.43$; Louisiana, $\$ 1.36$; Mississippi, $\$ 3.16$; Alabama, $\$ 1.10$; Missouri, 50 cents; Georgia, $\$ 1.80$. Dimension No. 1, S1S1E 2 inches by 8 inches, 16 feet, made advances as follows: Texas, $\$ 2.62$; Arkansas, $\$ 1.49$; Louisiana, $\$ 3.17$; Mississippi, \$3.26; Alabama, \$1.55. Mill-run values show the following advances: Texas, $\$ 1.42$; Arkansas, $\$ 1.42$; Louisiana, $\$ 1.80$; Mississippi, 93 cents; Alabama, 88 cents; Missouri, $\$ 2.08$; Florida, 63 cents. All grades of North Carolina pine quoted in this Record advanced except dimension 2 inches by 8 inches, 16 feet, which declined slightly in South Carolina and North Carolina, and box edge, 4/4, which advanced in North Carolina but made no change whatever in South Carolina. The advance on No. 1 edge $4 / 4$ amounted in North Carolina to $\$ 1.38$.

Hemlock prices were higher in the Lake States, but not generally in the Eastern States. Two-inch piece stuff advanced $\$ 1.08$ in Wisconsin, but only 57 cents in Michigan. Boards No. 1 advanced $\$ 1.34$ in Wiscousin and $\$ 1.42$ in Michigan. In white-pine sales prices obtained for the upper grades were generally lower, while the lower grades sold at advanced prices. Selects C and better declined $\$ 2.80$ in Minnesota and $\$ 4.45$ in Wisconsin, while boards No. 4 advanced $\$ 1.39$ in Minnesota and $\$ 1.37$ in Wisconsin, and fencing No. 2 rose \$2.09 in Minnesota and slightly in Wisconsin. Prices of New England and West Virginia spruce were generally lower, while Adirondack values were higher, except in the case of No. 1 and clear, which declined slightly.

Basswood firsts and seconds advanced $\$ 2.20$ in Tennessee, while in New York there was a fall of $\$ 1.50$. Unselected birch firsts and seconds advanced 65 cents in Michigan, $\$ 1.55$ in Wisconsin, and $\$ 1.20$ in New York. Hard maple 
firsts and seconds advanced $\$ 2.25$ in Ohio, $\$ 1.13$ in Indiana, 83 cents in Michigan, $\$ 1.82$ in Wisconsin, 75 cents in New York, but declined $\$ 3.17$ in Pennsylvania. Chestnut values were generally higher throughout the chestnutproducing States. Firsts and seconds advanced slightly in North Carolina and West Virginia, \$2.26 in Tennessee, \$1 in Kentucky, \$2.37 in Virginia, and $\$ 4.53$ in Ohio. The prices of plain oak were generally higher except in North Carolina. The following advances are shown in firsts and seconds: Arkansas, $\$ 1.96$; Mississippi, $\$ 3.08$; Missouri, $\$ 3.60$; Tennessee, $\$ 2.14$; Kentucky, $\$ 4.60$; Virginia, \$2; West Virginia, \$2.41; and Ohio, \$5.33. Yellow poplar values advanced in several States, but in Virginia and Tennessee all grades quoted declined. In other States the advances on firsts and seconds were as follows: North Carolina, nearly $\$ 3$; Kentucky, $\$ 2.50$; West Virginia, 89 cents; Indiana, nearly $\$ 4$. Cypress firsts and seconds advanced $\$ 1.36$ in Arkansas, held firm in Louisiana, and in Florida advanced $\$ 1.27$. Red gum firsts and seconds declined 82 cents in Arkansas, $\$ 1.50$ in Louisiana, but rose $\$ 2$ in Mississippi. No. 1 common in both sap and red declined in Arkansas and Louisiana, but not in Mississippi. Tupelo firsts and seconds declined $\$ 2.46$ and No. 1 common $\$ 1.45$ in Louisiana. 


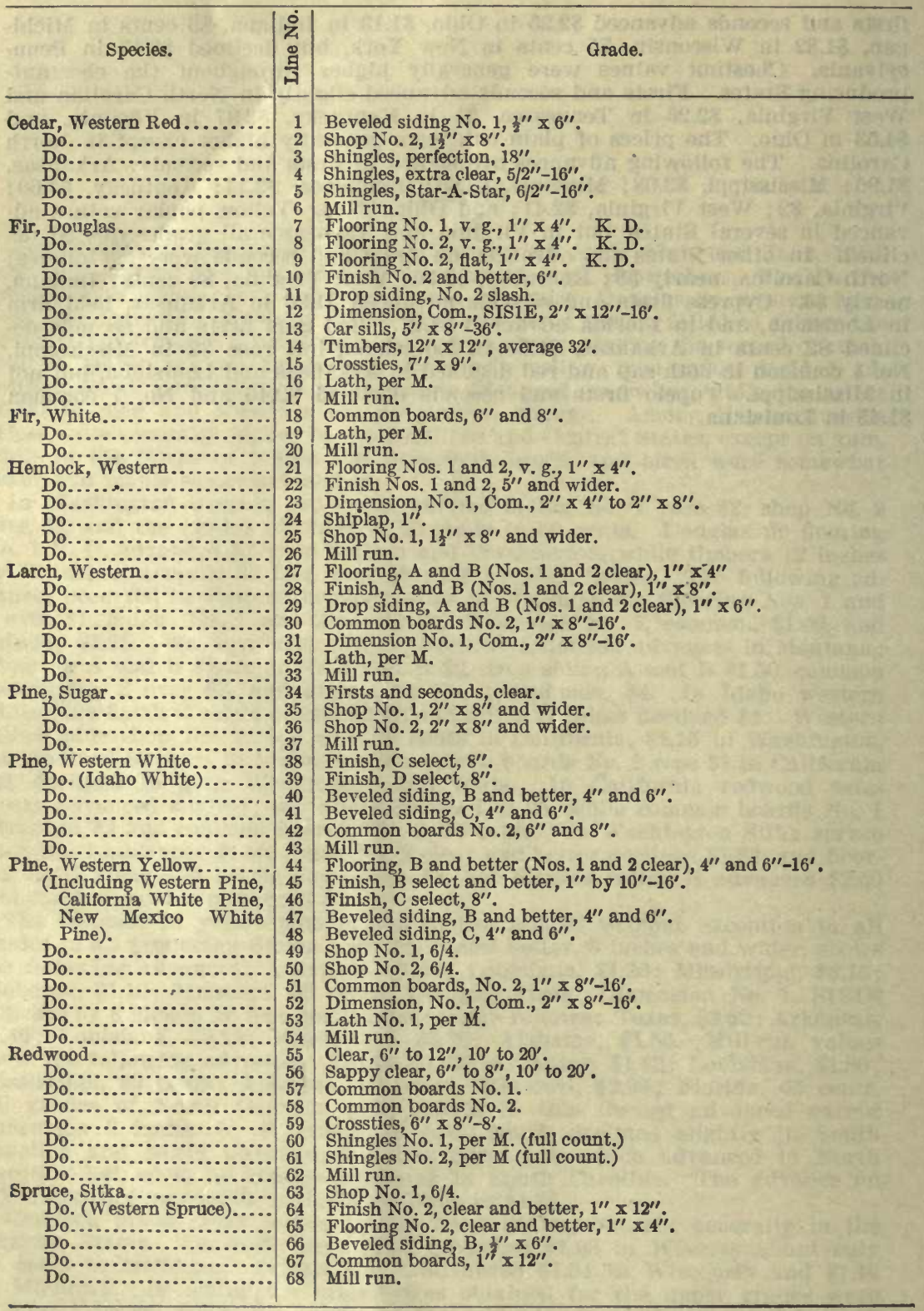


RECORD OF WHOLESALE PRICES OF LUMBER.

\begin{tabular}{|c|c|c|c|c|c|c|c|}
\hline & California. & Oregon. & Washington. & Idaho. & Montana. & Colora & \\
\hline 1 & & & 35 & & & & \\
\hline 2 & $\cdots$ & $\cdots$ & & $\ldots \ldots$ & 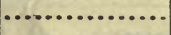 & $\cdots$ & \\
\hline $\begin{array}{l}3 \\
4\end{array}$ & $\cdots$ & $\cdots$ & & $\ldots \ldots$ & $\cdots$ & $\cdots$ & \\
\hline$\frac{4}{5}$ & $\because \cdots$ & $\ldots \ldots$ & & (....... & $\cdots \cdots$ & $\cdots \cdots$ & \\
\hline $\begin{array}{l}0 \\
6\end{array}$ & & & 16.37 & $\ldots \ldots$ & $\ldots \ldots$ & $\cdots$ & \\
\hline 7 & $\cdots$ & $\$ 27.25$ & 63 & $\ldots \ldots$ & ......... & $\ldots \ldots$ & \\
\hline 8 & $\cdots$ & & & ..... & $\cdots$ & $\ldots \ldots$ & \\
\hline $\begin{array}{r}9 \\
10\end{array}$ & $\cdots$ & 1 & $\begin{array}{l}1 b . \\
21 .\end{array}$ & $\begin{array}{l}\cdots \\
\cdots \ldots\end{array}$ & $\ldots$ & $\cdots$ & \\
\hline 11 & & 17.00 & 17 & & $\ldots \ldots$ & & \\
\hline 12 & $\cdots$ & 10 & 5 & $\$ 11.31$ & $\ldots \ldots \ldots$ & $\ldots$ & \\
\hline 13 & -. & & & ....... & $\ldots \ldots \ldots$ & $\cdots$ & \\
\hline 14 & $\cdots$ & 10 & & $\ldots \ldots$ & $\ldots \ldots \ldots$ & $\cdots$ & \\
\hline & -. & 5 & & ........... & ........ & $\ldots$ & \\
\hline 16 & ........ & 12 & & $\cdots \ldots \ldots$ & & $\ldots$ & \\
\hline $\begin{array}{l}17 \\
18\end{array}$ & $\begin{array}{r}\$ 12 \\
\ldots . . . . . .\end{array}$ & $\begin{array}{l}12.68 \\
\ldots \ldots\end{array}$ & 8.64 & $\begin{array}{l}12.67 \\
10.44\end{array}$ & $\ldots \ldots$ & $\ldots$ & \\
\hline 19 & $\ldots \ldots$ & $\cdots \cdots$ & $\begin{array}{c}0.0 \pm \\
\ldots . . . .\end{array}$ & & & & \\
\hline 20 & $\ldots \ldots \ldots$ & & & 9.33 & ....... & - & \\
\hline 21 & $\ldots \ldots$ & $\ldots \ldots$ & & $\ldots \ldots$ & ....... & - & \\
\hline 22 & ........... & ........ & 2 & $\ldots \ldots$ & ...... & $\cdots$ & \\
\hline & $\ldots \ldots \ldots \ldots$ & $\cdots \cdots$ & 0 & $\ldots \ldots \ldots$ & $\cdots \cdots$ & $\cdots$ & \\
\hline 24 & $\ldots \ldots \ldots$ & 9.33 & 9.21 & . $\ldots \ldots \ldots$ & $\ldots \ldots$ & $\cdots$ & \\
\hline 25 & ............ & $\cdots$ & $\cdots$ & $\cdots .$. & - & $\cdot$ & \\
\hline 2 & $\ldots \ldots \ldots$ & …....... & & $\cdots \ldots \ldots$ & $\ddot{0}$ & & \\
\hline 2 & $\ldots \ldots$ & 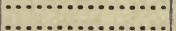 & & & 23.42 & & \\
\hline 29 & ....... & $\ldots \ldots$ & & 58 & 18.70 & & \\
\hline $50+2+3$ & ........ & .......... &. & & 15. & & \\
\hline 3 & ......... & $\cdots$ & & & 14.18 & . & \\
\hline 32 & $\ldots \ldots \ldots$ & $\cdots$ & $\because$ & 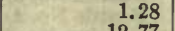 & $\cdots \cdots$ & $\cdots$ & \\
\hline 33 & $\ldots \ldots$ & (.............. & (..... & 12.77 & & $\because$ & \\
\hline 34 & ๑........... & . $\ldots \ldots \ldots \ldots \ldots$ & $\ldots \ldots$ & ‥ & $\cdots$ & $\because$ & \\
\hline & $\ldots \ldots \ldots$ & $\cdots$ & & $\cdots$ & $1^{\bullet}$ & $\because$ & \\
\hline 36 & 18 & $\ldots \ldots$ & -1 & $\cdots \cdots$ & (.). & $\ldots$ & \\
\hline & $\ldots \ldots \ldots$ & $\ldots \ldots$ & & $\cdots \cdots$ & $\ldots \ldots$ & 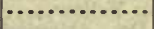 & \\
\hline & $\ldots \ldots$ & $\cdots$ & & & $\ldots \ldots$ & $\cdots$ & \\
\hline & $\ldots \ldots$ & $\cdots$ & & 50 & $\cdots \cdots$ & $\ldots$ & \\
\hline & (........ & $\cdots$ & & & $\cdots \cdots$ & .. & \\
\hline & $\ldots \ldots$ & $\cdots$ & & $\begin{array}{l}34 \\
38\end{array}$ & $\cdots \ldots$ & $\boldsymbol{*}$ & \\
\hline & $\ldots \ldots$ & $\cdots$ & & 8 & $\cdots \ldots$ & $\bullet$ & \\
\hline 44 & $\cdots$ & $\cdots$ & & & $\cdots \ldots$ & $\cdots$ & \\
\hline 45 & $\cdots$ & $\cdots$ & & & $\cdots \cdots$ & $\cdots$ & \\
\hline 46 & $\cdots$ & $\cdots$ & & & $\ldots \ldots$ & - & \\
\hline 47 & $\cdots \cdots$ & $\cdots$ & & & $\ldots \ldots$ & . & \\
\hline & 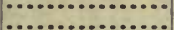 & $\cdots$ & & & $\cdots \cdots$ & •• & \\
\hline 49 & $24 . \ddot{7} \overline{7}$ & $\cdots$ & $\ddot{5}$ & & $\ldots \ldots$ & 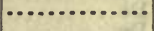 & \\
\hline & 88 & .. & 1 & & $\cdots \ldots \ldots$ & $\cdots$ & \\
\hline & 01 & $\cdots$ & 13 & & $\cdots$ & $\because$ & \\
\hline & 14.33 & & & & $\ldots$ & $\$$ & \\
\hline 5 & 19 & 列 & 08 & 19 & ........... & $\cdots$ & \\
\hline 5 & 10 & $\cdots$ & .. & 13.75 & $\cdots$ & $\cdot$ & \\
\hline & & $\cdots$ & & -..... & $\ldots \ldots$ & $\cdots$ & \\
\hline & & $\cdots$ & & 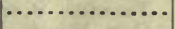 & $\ldots \ldots \ldots$ & & \\
\hline & & $\cdots$ & & $\cdots$ & $\ldots \ldots$ & & \\
\hline & & & & & $\ldots \ldots$ & $\cdots$ & \\
\hline & $\cdots \cdots$ & $\cdots$ & & $\cdots$ & ......... & $\cdots$ & \\
\hline & $\begin{array}{l}1.01 \\
1.48\end{array}$ & $\because$ & & $\cdots$ & $\cdots$ & $\because$ & \\
\hline & 14.33 & . . . . . & & & -. & & \\
\hline & •.... & ... & & $\ldots \ldots$ & ....... & $\cdots$ & \\
\hline 6 & & $\cdots$ & & $\ldots \ldots$ & ...... & .. & \\
\hline & & 25 & & $\ldots \ldots$ & $\ldots \ldots$ & & \\
\hline 6 & $\cdots$ & 2 & & ............ & $\ldots . .$. & & \\
\hline & & $\cdots$ & & $\ldots \ldots$ & ...... & & \\
\hline & & & 08 & $\cdots$ & $\cdots$ & & \\
\hline
\end{tabular}




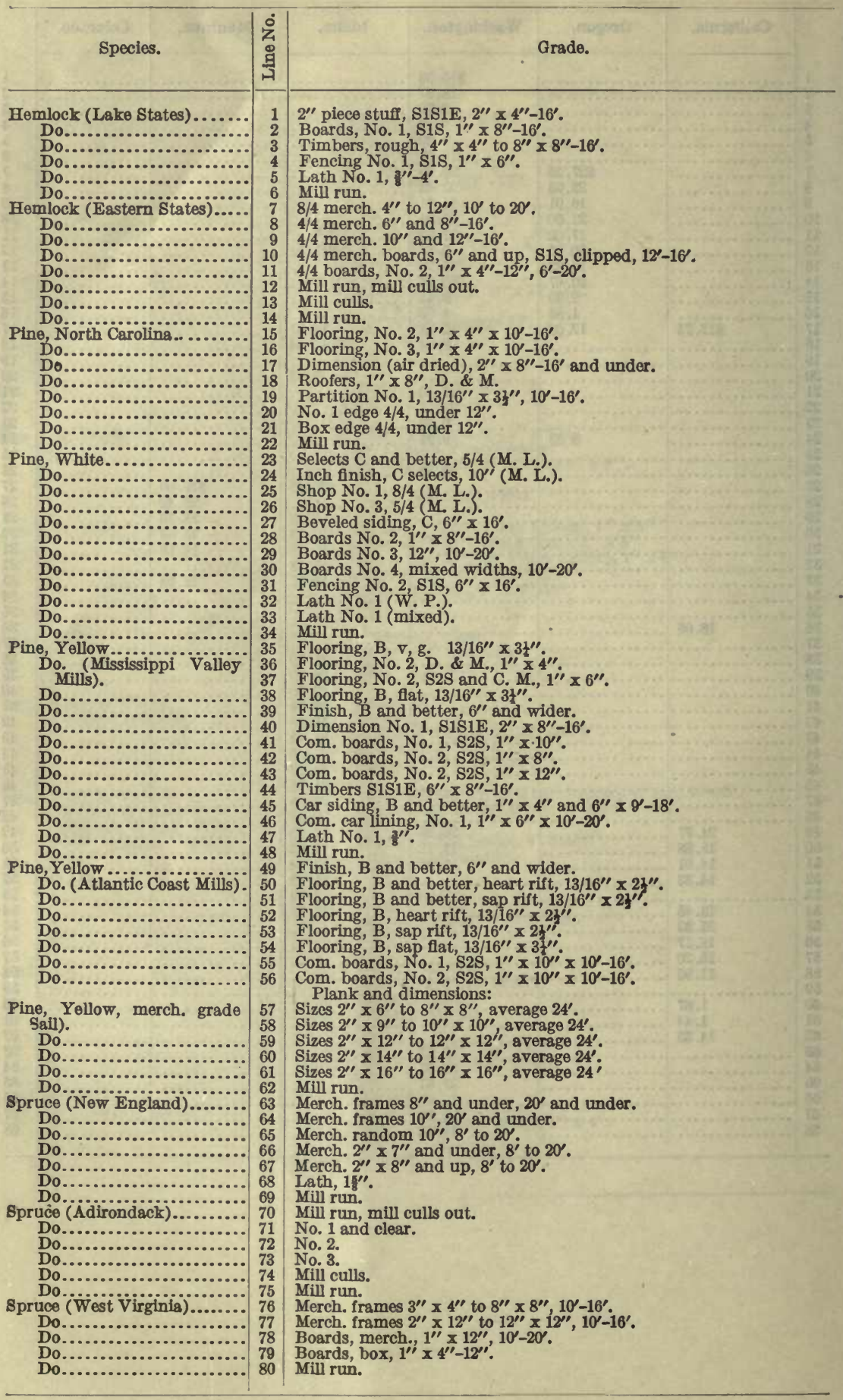




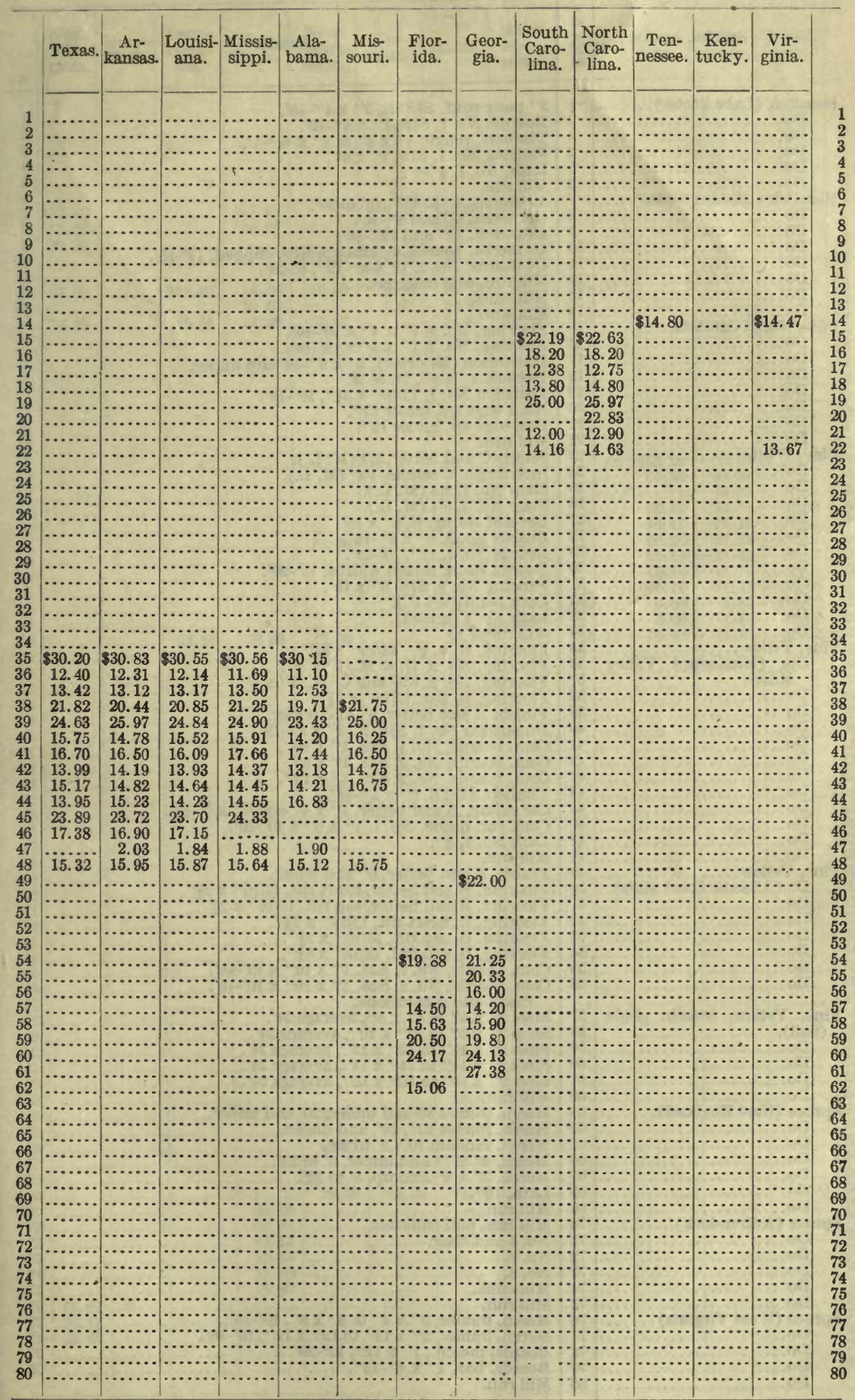




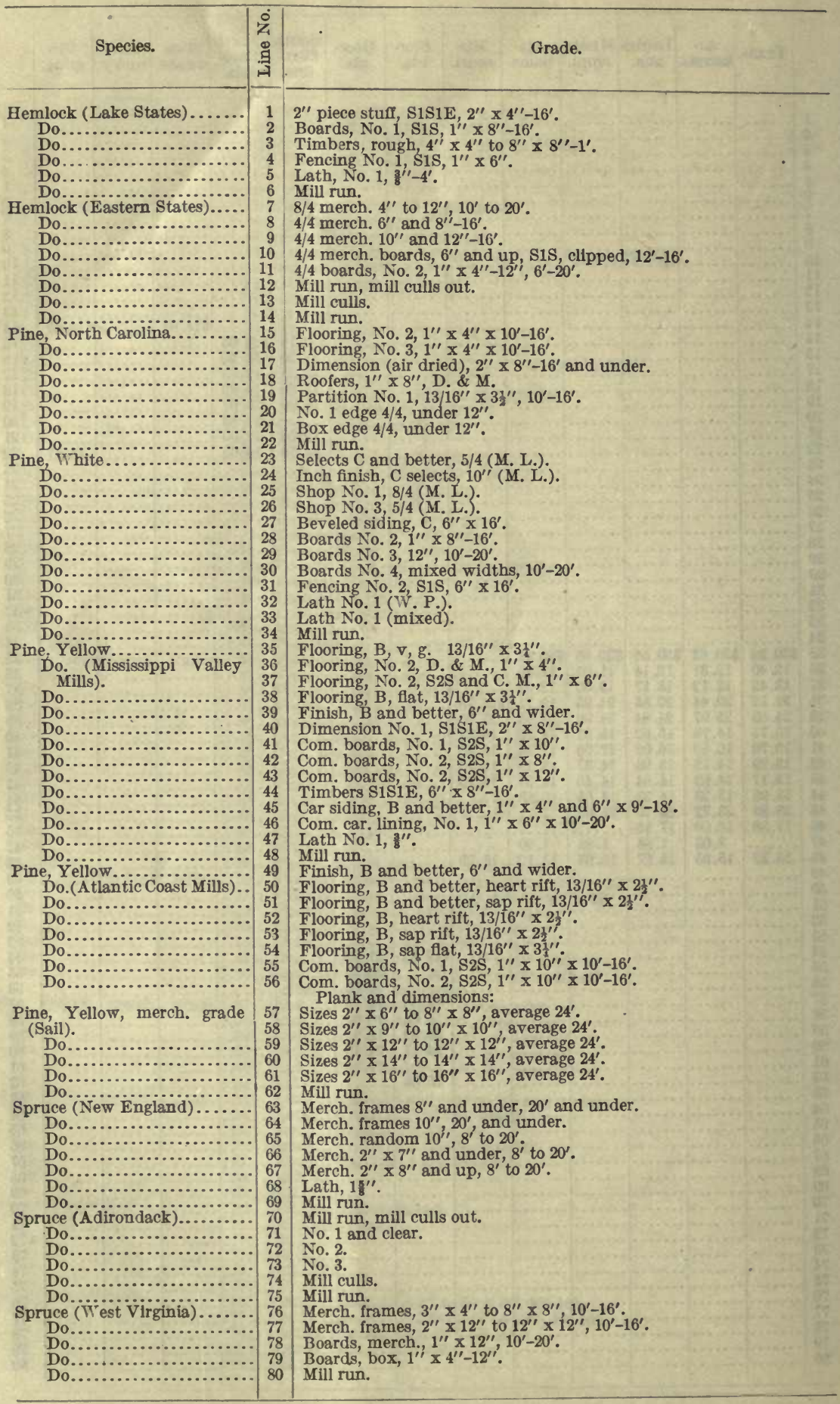


RECORD OF WHOLESALE PRICES OF LUMBER.

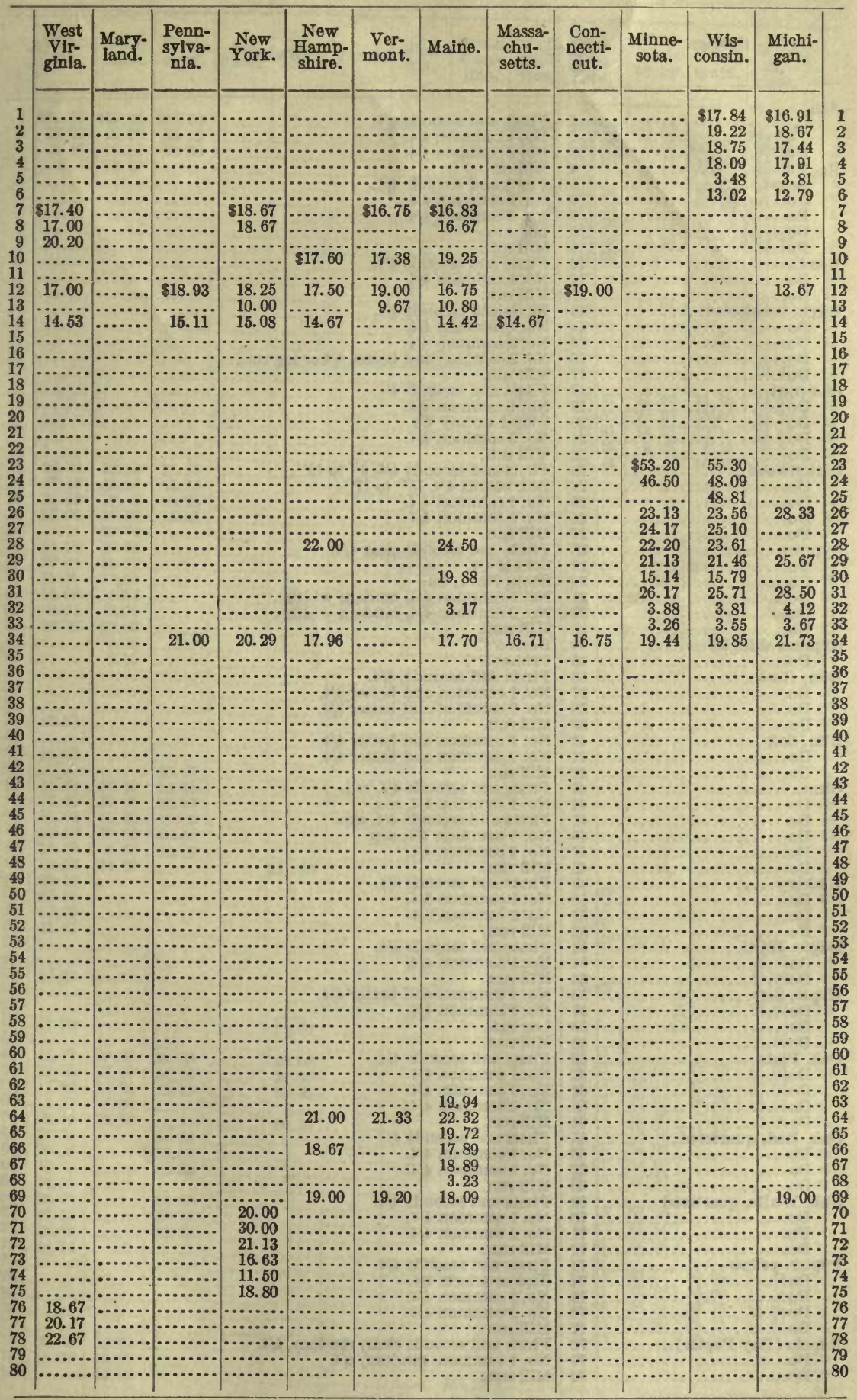




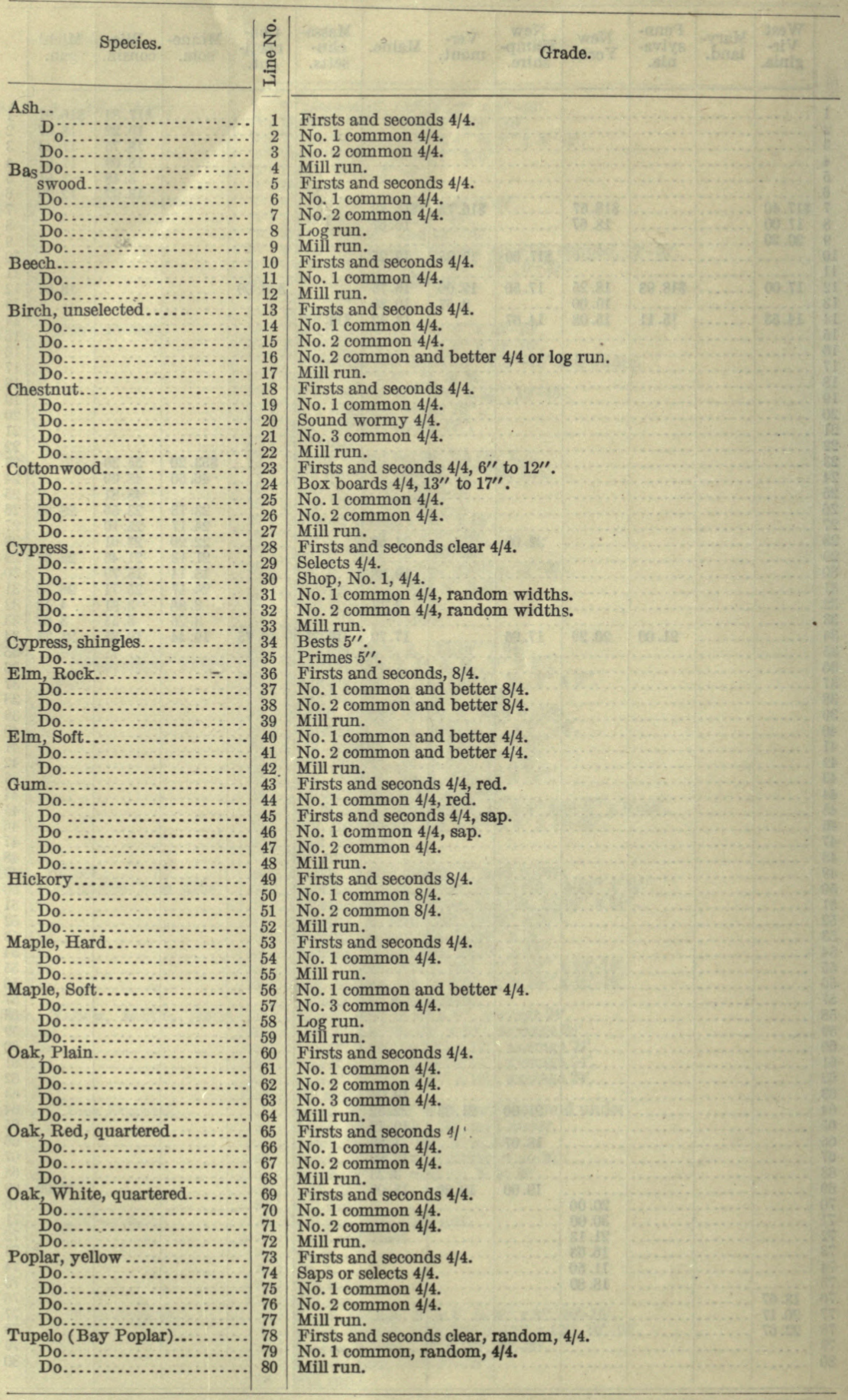




\begin{tabular}{|c|c|c|c|c|c|c|c|c|c|c|c|c|c|c|}
\hline & $\begin{array}{c}\text { Arkan- } \\
\text { sas. }\end{array}$ & 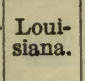 & $\begin{array}{l}\text { Missis- } \\
\text { sippi. }\end{array}$ & Ala- & $\begin{array}{l}\text { Mis- } \\
\text { souri. }\end{array}$ & Texas. & $\begin{array}{l}\text { Flor- } \\
\text { ida. }\end{array}$ & $\begin{array}{l}\text { South } \\
\text { Caro- } \\
\text { lina. }\end{array}$ & $\begin{array}{l}\text { North } \\
\text { Caro- } \\
\text { lina. }\end{array}$ & $\begin{array}{l}\text { Ten- } \\
\text { nes- } \\
\text { seo. }\end{array}$ & $\begin{array}{c}\text { Ken- } \\
\text { tucky. }\end{array}$ & $\begin{array}{c}\text { Vir- } \\
\text { ginia. }\end{array}$ & $\begin{array}{l}\text { West } \\
\text { Vir- } \\
\text { ginia. }\end{array}$ & \\
\hline 1 & $\$ 37.53$ & $\$ 37.00$ & $\$ 35.00$ & & & & & & $\$ 39.00$ & $\$ 37.42$ & $\$ 41.63$ & & & 1 \\
\hline 2 & 23.03 & 20.08 & 23.25 & & & & & & & 23.08 & & $\$ 27.67$ & & 2 \\
\hline $\begin{array}{l}3 \\
4\end{array}$ & $\begin{array}{c}11.85 \\
\ldots . . .\end{array}$ & $\begin{array}{l}10.50 \\
18.67\end{array}$ & 11.33 & & & & . & ........ & 12.67 & 12.63 & 71 & 11.67 & 16 & 3 \\
\hline 5 & $:$ & $\begin{array}{ll}18.06 \\
\cdots . . . . .\end{array}$ & & & & & & & 33.00 & 32.14 & $\begin{array}{c}19.75 \\
\ldots . . .\end{array}$ & 32.33 & & $\begin{array}{l}4 \\
5\end{array}$ \\
\hline 6 & & $\cdots \cdots$ & & & & & & & & & & 22.33 & & 6 \\
\hline $\begin{array}{l}7 \\
8\end{array}$ & $\ldots$ & ..... & & & & & & $\cdots \cdots \cdot$ & 13 & $\begin{array}{l}12.56 \\
20.69\end{array}$ & 22.33 & 11.33 & & 7 \\
\hline 9 & & & & & & & & & & 17.00 & $\begin{array}{l}22.00 \\
. . . . . . .\end{array}$ & $\begin{array}{l}21.38 \\
\ldots . . . .\end{array}$ & $\begin{array}{l}22.18 \\
\ldots \ldots \ldots\end{array}$ & $\begin{array}{l}8 \\
9\end{array}$ \\
\hline 10 & & . & & & & & & ......... & & $\ldots \ldots$. & & & & 10 \\
\hline 12 & $\cdots$ & ....... & & & & & & & & & 12.67 & & 11.50 & 11 \\
\hline 3 & & & & & & & & & & & ........ & & $\begin{array}{l}11.50 \\
\ldots \ldots .\end{array}$ & 12 \\
\hline $\begin{array}{l}14 \\
15\end{array}$ & $\cdots$ & & & & & & & ......... & & & & & $\cdots$ & $\begin{array}{l}13 \\
14\end{array}$ \\
\hline 6 & & & & & & & & & & & & & & 15 \\
\hline 18 & & & & & & & & & & & & & 19.40 & 16 \\
\hline 19 & & & & & & & & . & 42.17 & 47 & 41.20 & 41.80 & $3.73^{\circ}$ & $\begin{array}{l}17 \\
18\end{array}$ \\
\hline 20 & $\cdots$ & & & & & & & ........ & & & 28.10 & 30.60 & & $\begin{array}{l}18 \\
19\end{array}$ \\
\hline 21 & $\ldots$ & $\cdots$ & & & & & & $\mid \begin{array}{l}\cdots \\
\cdots \\
\cdots\end{array}$ & $\begin{array}{r}11.58 \\
7.30\end{array}$ & $\begin{array}{r}12.81 \\
8.16\end{array}$ & 14. 33 & 12.10 & 5 & 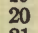 \\
\hline & $\dddot{26.43}$ & & & & & & & …...... & $\begin{array}{r}7.30 \\
\ldots . . .\end{array}$ & $\begin{array}{r}8.16 \\
18.44\end{array}$ & $\begin{array}{r}9.25 \\
\ldots . . .\end{array}$ & $\begin{array}{r}7.30 \\
16.40\end{array}$ & $\begin{array}{r}9.22 \\
17.25\end{array}$ & $\begin{array}{l}21 \\
22\end{array}$ \\
\hline 24 & $\begin{array}{l}26.43 \\
47.14\end{array}$ & $\begin{array}{l}23.80 \\
43.80\end{array}$ & 27.25 & & & & & & & & & ......... & ........ & 23 \\
\hline 25 & $\begin{array}{l}47.14 \\
21.50\end{array}$ & $\begin{array}{l}43.80 \\
19.40\end{array}$ & $\begin{array}{l}44.75 \\
20.25\end{array}$ & & & & $\because$ & ......... & & & & & & 24 \\
\hline 2 & 16.00 & $\begin{array}{l}19.40 \\
15.50\end{array}$ & $\begin{array}{l}20.20 \\
15.25\end{array}$ & & & & & ....... & & & & & & $=$ \\
\hline & & 20.62 & & & & & & …...... & & & & $\cdots$ & .... & $\begin{array}{l}26 \\
27\end{array}$ \\
\hline & $\begin{array}{l}34.50 \\
29.04\end{array}$ & & & & & & $\$ 36.17$ & …...... & & & & & & \\
\hline & 18.36 & $\begin{array}{l}30.28 \\
18.07\end{array}$ & & & & & $\begin{array}{l}31.50 \\
21.17\end{array}$ & ......... & & & & & & 9 \\
\hline 31 & 13.08 & 15.23 & & & & & \begin{tabular}{|l|}
21.17 \\
16.08
\end{tabular} & 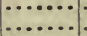 & $\ldots$ & $\because$ & & (......... & & 0 \\
\hline 32 & 8.91 & 9.70 & & & & & 12.33 & & & & , & $\mid \begin{array}{l}\cdots \\
\cdots \\
\cdots\end{array}$ & ….... & $\frac{1}{2}$ \\
\hline & 19.63 & 20.62 & $\cdots$ & ‥ & & & ........ & ........ & 18.13 & ......... & $\ldots$. & & & $\begin{array}{l}32 \\
33\end{array}$ \\
\hline & . & $\begin{array}{l}3.46 \\
2.65\end{array}$ & & ... & $\cdots$ & & & ......... & $\cdots \cdots$ & ........ & ......... & . & $\cdots$ & $\begin{array}{l}35 \\
34\end{array}$ \\
\hline 6 & …..... & $\begin{array}{c}2.65 \\
\cdots \ldots . .\end{array}$ & & & & & & …...... & & & & & & 5 \\
\hline & .......... & $\cdots$ & & & & & $\cdots$ & .......... & & $\cdots$ & $\begin{array}{l}\cdots \\
\ldots \ldots\end{array}$ & $\mid \begin{array}{l}\cdots \\
\cdots \\
\cdots\end{array}$ & : & 6 \\
\hline & 16.33 & 1 & & & & & & .......... & & & & & - & 8 \\
\hline 39 & 16.33 & -...". & & $\cdots$ & & & $\cdots$ & .. & $\ldots$ & & & - & . & 3 \\
\hline 41 & 18.50 & 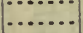 & & & & & & $\left.\mid \begin{array}{ll}\cdots \\
\cdots\end{array}\right]$ & & & & & & 40 \\
\hline 13 & & & 67 & & & & & & & & & & & 41 \\
\hline 43 & $\begin{array}{l}30.33 \\
17.97\end{array}$ & \begin{tabular}{|l|}
30.38 \\
17.75
\end{tabular} & $\begin{array}{l}.33 \\
50\end{array}$ & - & & & & 1 & & & & & & 43 \\
\hline 45 & $\begin{array}{l}17.97 \\
16.94\end{array}$ & $\begin{array}{l}17.75 \\
16.40\end{array}$ & $\begin{array}{l}50 \\
50\end{array}$ & .. & & & .. & - & & b. & & & 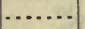 & 44 \\
\hline 46 & 12.22 & $\begin{array}{l}10.40 \\
11.08\end{array}$ & $\begin{array}{l}17.50 \\
13.50\end{array}$ & & & & • & $\mid \begin{array}{l}\cdots \\
\cdots\end{array}$ & & & & & & 15 \\
\hline 47 & 10.29 & 8.60 & 11.00 & & & & & $\cdots$ & & & $\because$. & $\ldots$ & . & 46 \\
\hline 48 & 13.47 & 14.67 & ........ & & $\$ 11.83$ & & & & & & . & & $\cdots$ & $\begin{array}{l}47 \\
48\end{array}$ \\
\hline 4 & 50.13 & …....... & & & $\cdots$ & .... & - & . & - & 00 & & & $\cdots$ & 49 \\
\hline & $\begin{array}{l}26.57 \\
12.00\end{array}$ & $\mid \cdots \cdots \cdot \cdot$ & & & t & & :... & $\begin{array}{l}\cdots \\
\cdots\end{array}$ & $\cdots$ & & & & & 50 \\
\hline 5 & $\begin{array}{l}12.00 \\
31.67\end{array}$ & $\cdots$ & & & & & & 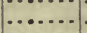 & $\cdots$ & $\begin{array}{l}10.00 \\
22.33\end{array}$ & $\dddot{22.00}$ & . & & 51 \\
\hline & ........ & ......... & & & & & & $\cdots$ & & 22.00 & & $\cdots$ & 8.83 & 5 \\
\hline 5 & 16.83 & $\ldots$ & & & & & & & 0 & & & & 19.00 & \\
\hline & ........ & $\cdots$ & & & & & & & .. & 15.83 & & & 0.67 & \\
\hline & 17.00 & & & & & & & ○. & & & & & 20.67 & \\
\hline 50 & 18.00 & & & & 18 & & & .. & & & & & 15.50 & \\
\hline 6 & 41.77 & 40.57 & 4 & & & & & & 41.00 & & & & & \\
\hline & 23.9 & 21.67 & & & & & & & & & & & & \\
\hline 62 & 12.89 & 10.75 & 13.50 & & 13. 40 & & & & 15 & & & 16.1 & 19.6 & \\
\hline $6^{2}$ & 6.77 & 6.00 & ........ & $\cdots$ & & -. & .. & $\ldots$ & 8.67 & & & 7.60 & 9.86 & \\
\hline 64 & $\begin{array}{l}20.50 \\
51.75\end{array}$ & 21.25 & 5 & & 16.25 & & & & ........ & 20 & & 15.00 & ....... & \\
\hline 6 & 25 & …..... & 67 & & $\cdots$ & & & & & $\begin{array}{l}51 \\
30\end{array}$ & 34 & ........ & & \\
\hline 6 & 15.63 & $\ldots \ldots$. & 18.33 & & & & & & & 18.10 & 21.50 & & & \\
\hline 6 & 34.3 & ........ & & & & & & & . & & & & & \\
\hline & 4 & $\ldots \cdots$ & $\begin{array}{l}68.00 \\
40.75\end{array}$ & & & & & & & & 68 & & & \\
\hline & 20.6 & & 20.25 & & & & & & & & $\begin{array}{l}43.14 \\
24.00\end{array}$ & & & \\
\hline & 44.74 & ... & & & & & & & & & & & & \\
\hline & & & & & & & & & 52 & 1 & & .25 & 51.89 & \\
\hline & & & & & & & & & & & & 35. & 27 ? & \\
\hline 10 & & & & & & & & & & & & 27.75 & 218 & \\
\hline 77 & .. & 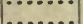 & & & & & & & $\begin{array}{l}15.83 \\
22.50\end{array}$ & 14.76 & 18.80 & 15. 25 & 21.6 & \\
\hline 78 & 20.00 & 1 & & & & & & & & 24.00 & 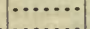 & 23.35 &. & \\
\hline 70 & 13.67 & 82 & & & & & & & & & . & & & 7 \\
\hline 80 & & 13.83 & & & & & & $\$ 13.67$ & & & & & & 80 \\
\hline
\end{tabular}




\begin{tabular}{|c|c|c|c|c|c|c|}
\hline Species. & 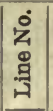 & Grade. & & fith & & \\
\hline 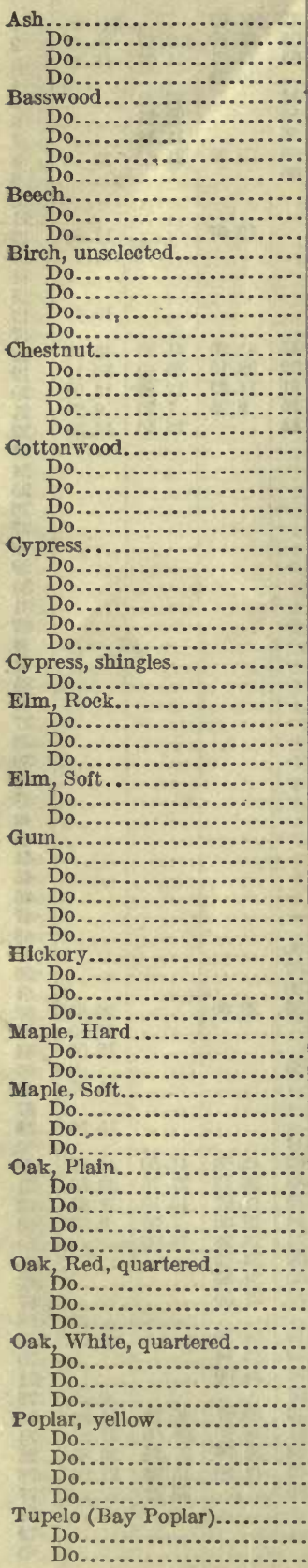 & $\begin{array}{c}1 \\
2 \\
3 \\
4 \\
5 \\
6 \\
7 \\
8 \\
9 \\
10 \\
11 \\
12 \\
13 \\
14 \\
15 \\
16 \\
17 \\
18 \\
19 \\
20 \\
21 \\
22 \\
23 \\
24 \\
25 \\
26 \\
27 \\
73 \\
72 \\
73 \\
75 \\
76 \\
77 \\
78 \\
79 \\
80 \\
30 \\
69 \\
69 \\
65 \\
32 \\
65 \\
33 \\
34 \\
35 \\
36 \\
37 \\
38 \\
39 \\
40 \\
41 \\
42 \\
43 \\
44 \\
45 \\
46 \\
47 \\
48 \\
49 \\
50 \\
51 \\
52 \\
53 \\
54 \\
55 \\
56 \\
57 \\
58 \\
60 \\
\end{array}$ & 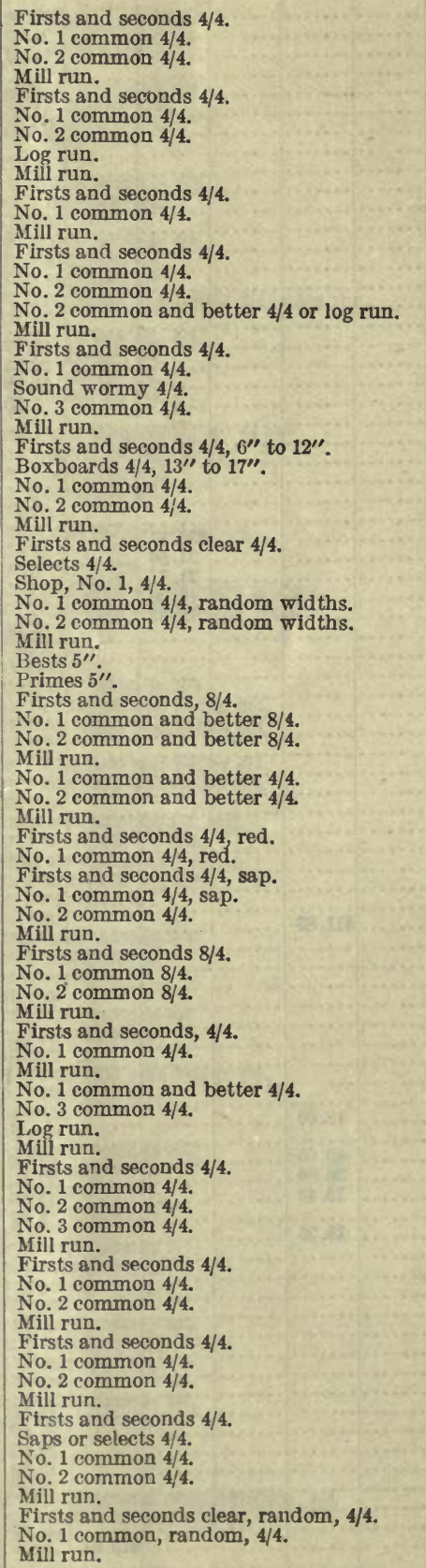 & 022 & 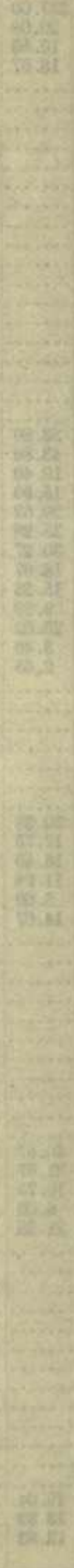 & Who & \\
\hline
\end{tabular}




\begin{tabular}{|c|c|c|c|c|c|c|c|c|c|c|c|c|c|c|}
\hline & Ohio. & $\begin{array}{l}\text { Indi- } \\
\text { ana. }\end{array}$ & $\begin{array}{l}\text { Illi- } \\
\text { nois. }\end{array}$ & $\begin{array}{l}\text { Mich- } \\
\text { igan. }\end{array}$ & $\begin{array}{l}\text { Wis- } \\
\text { con- } \\
\text { sin. }\end{array}$ & $\begin{array}{c}\text { Penn- } \\
\text { syl- } \\
\text { vania. }\end{array}$ & $\begin{array}{l}\text { New } \\
\text { York. }\end{array}$ & $\begin{array}{c}\text { Con- } \\
\text { necti- } \\
\text { cut. }\end{array}$ & $\begin{array}{c}\text { Massa- } \\
\text { chu- } \\
\text { setts. }\end{array}$ & $\begin{array}{c}\text { New } \\
\text { Hamp- } \\
\text { shire. }\end{array}$ & $\begin{array}{c}\text { Ver- } \\
\text { mont. }\end{array}$ & Mai & $\begin{array}{l}\text { Mary- } \\
\text { land. }\end{array}$ & \\
\hline $\begin{array}{l}1 \\
2\end{array}$ & $\begin{array}{r}\$ 41.00 \\
28.29\end{array}$ & $\begin{array}{r}\$ 42.77 \\
27.15\end{array}$ & & & $\begin{array}{r}\$ 39.33 \\
24.00\end{array}$ & $\$ 28.17$ & $\begin{array}{r}36.67 \\
\$ 26.40\end{array}$ & & & & & & & 1 \\
\hline 3 & 18.50 & 16.33 & & & 15.50 & & & & & & & & & 3 \\
\hline $\begin{array}{l}4 \\
5\end{array}$ & $\ddot{32.00}$ & $\ddot{35.00}$ & & & \begin{tabular}{|l|}
18.33 \\
35.15
\end{tabular} & $\cdots$ & $\begin{array}{l}19.83 \\
30.00\end{array}$ & $\$ 17$ & $\$ 19.33$ & $\$ 20.00$ & $\$ 18.00$ & & & 4 \\
\hline 6 & 22.67 & & & & 23.70 & & $\begin{array}{l}30.00 \\
25.10\end{array}$ & & & & 00 & & & 5 \\
\hline 7 & $\cdots$ & & & & 17. 30 & & & & & & & & & $\begin{array}{l}6 \\
7\end{array}$ \\
\hline $\begin{array}{l}8 \\
9\end{array}$ & 21.25 & 38 & & & 23.70 & 22.29 & & & 19.33 & 21 & & & & 8 \\
\hline 10 & 25.67 & & & & ... & & $\begin{array}{l}20.25 \\
22.33\end{array}$ & 16 & & 18 & 3 & & & 9 \\
\hline 12 & $\cdots \ldots$ & 17.50 & & & $\cdots$ & 15.83 & 16.20 & & & & & & & $\begin{array}{l}10 \\
11\end{array}$ \\
\hline 13 & 15.20 & 15.50 & & & & 12.71 & & & 12.67 & 14.83 & & & & 12 \\
\hline (1) & $\ldots$ & ... & & & $\begin{array}{l}37.02 \\
21.00\end{array}$ & $\ldots$ & & & & & & & & 13 \\
\hline 15 & & & & & 13.14 & & & & & & 2.00 & & & 14 \\
\hline 1 & & & & & 22.90 & & & & & 19.66 & 21.33 & & & $\begin{array}{l}15 \\
16\end{array}$ \\
\hline 18 & $\cdots 39.20$ & & & 18 & 17.67 & $\begin{array}{l}17.17 \\
34.00\end{array}$ & 16 & 14 & 15.17 & 16.71 & & & & 17 \\
\hline 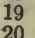 & 29.50 & & & & $\cdots$ & $\begin{array}{l}3 \\
2\end{array}$ & 20.33 & & & $\ldots$ & & & & 18 \\
\hline & 16.67 & $\cdots$ & & & & 38 & & & & & & & & 20 \\
\hline & ... & & & & ......... & & & & & & & & & 21 \\
\hline & & & & & & 1 & 19.25 & & 19.14 & 33 & & & & 0 \\
\hline & & & & & & & & & & & & & & 24 \\
\hline 2 & & $\cdots$ & & & & & & & & & & & & 25 \\
\hline & & $\cdots$ & & & & & & & & & 15.67 & & & $\Omega$ \\
\hline & & & & & & & & & & & ... & & & 2 \\
\hline 3 & & & & & & & & & & & & & & \\
\hline 31 & & 的 & & & & & & & & & & & & \\
\hline 3 & $\cdots$ & .. & & & & & & & & & & & & 1 \\
\hline 3 & $\ldots$ & 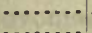 & & & & & & & & & & & & \\
\hline & & $\ldots$ & & & & & & & & & & & & \\
\hline 36 & & 37.00 & & & & & & & & & & & & 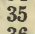 \\
\hline 3 & $\cdots$ & 27.67 & & & & & & & & & & & & 36 \\
\hline 3 & 16.33 & a........ & & 26.70 & 22.22 & & & & & & & & & 38 \\
\hline 40 & 27.00 & 22.40 & & 26.33 & 27.17 & & & & & & & & & 39 \\
\hline 4 & 20.67 & 17 & & & 25 & & & & & & & & & $\begin{array}{l}40 \\
41\end{array}$ \\
\hline 42 & 15.67 & 18.11 & & & 15.40 & & 18.00 & & & & & & .. & 41 \\
\hline $\begin{array}{l}4 . \\
4 \\
4\end{array}$ & & $\cdots$ & & & & & & & & & & & & 4 \\
\hline 4 & & .......... & & & & & & & & & & & & 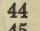 \\
\hline 4 & & $\ldots$ & & & & & & & & & & & & \\
\hline & & 17.67 & & & & & & & & & & & 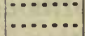 & 47 \\
\hline 4 & 48.71 & 11 & & & & & & & & & & & & 10 \\
\hline & 3 & & & & *. & 28.33 & & & & & & & & 50 \\
\hline & 21. & 1 & & . & .......... & $\cdots$ & $\cdots$ & & & & & & & 5. \\
\hline & & $\begin{array}{l}28.75 \\
27.13\end{array}$ & & .86 & 0 & & 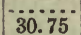 & & 20.33 & & & & & 5 \\
\hline & $\begin{array}{l}20.50 \\
18.67\end{array}$ & $\begin{array}{l}27.13 \\
19.83\end{array}$ & $\cdots$ & 33 & 15 & & $\begin{array}{l}0 \\
5\end{array}$ & & $\cdots$ & $\cdots$ & $\ddot{0}$ & & & 5 \\
\hline & 15. 33 & & & 46 & 15.23 & 75 & 16. 79 & & 15.83 & 16.50 & $\begin{array}{l}21.00 \\
16.20\end{array}$ & & & 5 \\
\hline & …....... & 20.67 & & $\begin{array}{r}22.88 \\
9.67\end{array}$ & $\begin{array}{r}23.67 \\
9.75\end{array}$ & 21.30 & 20.67 & & & & & & & 5 \\
\hline 5 & 18.00 & 19.38 & & $\begin{array}{r}9.67 \\
18.88\end{array}$ & $\begin{array}{r}9.75 \\
17.89\end{array}$ & 17.00 & 92 & & & & & & & \\
\hline & & & & 14.92 & & & & & ii. 58 & 13.83 & & & & \\
\hline & $\begin{array}{l}4 \\
2\end{array}$ & $\begin{array}{l}42.13 \\
27.93\end{array}$ & $\$ 29.67$ & .. & .75 & 0 & $?$ & & & & & & & 60 \\
\hline & 18 & & 17.00 & & .25 & & 27.86 & & & 26.67 & & & & \\
\hline 63 & $\begin{array}{c}12.38 \\
\ldots \ldots\end{array}$ & $\begin{array}{c}10.00 \\
\ldots \ldots . .\end{array}$ & $\cdots$ & & 10.25 & & $\cdots$ & $\cdots$ & & $\cdots$ & & & & \\
\hline & ....... & 34.00 & & & $\cdots$ & 19.39 & & 19.50 & 19.50 & $18.43^{\circ}$ & & & & \\
\hline & & & & & & $\cdots$ & & & $\cdots$ & ....... & & & & \\
\hline & $\cdots$ & 20.38 & & & & & & & & & & & & U \\
\hline & 69.00 & 7 & & & & & & & & & & & & \\
\hline & 4 & & & & & & & & & & & & & \\
\hline & 26.67 & 25.22 & & & & & & & & & & & & \\
\hline & $\begin{array}{l}34.00 \\
49.20\end{array}$ & * & $\cdot$ & & & & & & & & & & & \\
\hline & $\begin{array}{l}4 \\
4\end{array}$ & & & & & & & & & & & & & 7 \\
\hline & 32.83 & 3 & & & & & & & & . & & & & 7 \\
\hline & 21.00 & 19.50 & & & & & & & & & & & & 7 \\
\hline & ...... & …...... & & & & 24.50 & $\cdots$ & & & & & & & 7 \\
\hline & & & & & & & & & & & & & & 7 \\
\hline & & & & & & & & & & & & & & 80 \\
\hline
\end{tabular}




\section{OPPORTUNITIES FOR PURCHASING NATIONAL FOREST TIMBER.}

The National Forests contain nearly 590 billion feet of merchantable stumpage. The mature timber, which constitutes a large part of the total stand, is for sale. The more accessible bodies may be purchased in blocks of practically any desired size up to 100 million feet. Less accessible stumpage which requires a large investment for the construction of transportation facilities may be purchased in larger quantities of sufficient size to justify the investment in improvements. Applications up to 1 billion feet will be approved if the investment required necessitates the purchase of a body of that size under one contract.

The procedure for purchasing National Forest timber is extremely simple. Applications specifying the amount, species, and general location desired may be sent to the offices of the Forest Service at Washington, D. C.; Chicago, Ill.; Missoula, Mont.; Denver, Colo.; Albuquerque, N. Mex.; Ogden, Utah; San Francisco, Cal.; and Portland, Oreg. Advertisement at a fixed minimum price is required by law for at least 30 days. The timber is then awarded to the highest bidder and the sale completed by execution of the contract stating the amount and location of the stumpage, the stumpage rates, and the conditions under which the timber shall be removed.

The contract requirements have been prepared by practical lumbermen and perfected by the experience gained in the administration of several thousand sales. They are adapted to the local conditions as to topography, size of the timber, and logging methods. That they are eminently practical is demonstrated by the fact that some 375 million feet are cut each year under these requirements by lumbermen all over the West.

Sufficient time is permitted for the removal of the amount purchased under local conditions of logging and manufacture. The time is gauged, however, to require continuous operation at a reasonable rate and does not permit the holding of stumpage for speculative increases in value. The timber to be cut is designated by the forest officers. Either clean cutting, or partial cutting taking 70 to 80 per cent of the stumpage, is employed, depending upon the character of the timber and the best methods of securing new forest growth. Simple precautions are required to protect the uncut timber and young growth, and the disposal of slash by burning, either with or without piling, is necessary.

These requirements may increase the cost of logging from 50 to 75 cents a thousand feet over the usual cost on private holdings. The difference is always considered in appraising the value of the stumpage. Furthermore, an operator who buys National Forest timber has to make practically no investment at the outset for his stumpage, has no carrying charges for interest or taxes, and incurs practically no fire risk. He is required simply to pay for the timber as it is removed in advance deposits, which represent usually but the value of a month and a half's cut.

These are obvious advantages, particularly when extended over an operation of 10 or 15 years. As private stumpage is cut out in many of the old lumbering centers, operators will find, in the timber on the National Forests, new opportunities for manufacture under advantageous conditions. 
U. S. DEPARTMENT OF AGRICULTURE,

BUREAU OF STATISTICS-BULLETIN 96.

VICTOR H. OLMSTED, Chief of Bureau.

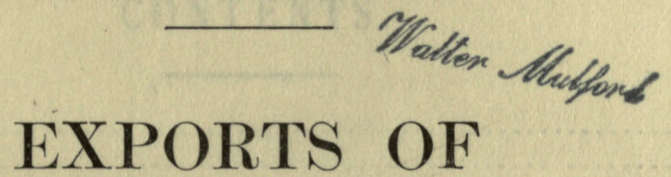

\section{FARM AND FOREST PRODUCTS,}

$$
\text { 1909-1911, }
$$

BY COUNTRIES TO WHICH CONSIGNED.

DIVISION OF PRODUCTION AND DISTRIBUTION.

WASHINGTON :

GOVERNMENT PRINTING OFFICE.

1912. 


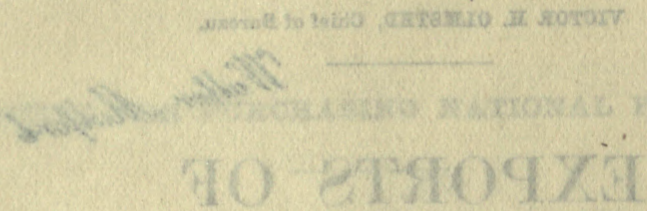

\section{LETTER OF TRANSMITTAL.}

U. S. Department of Agriculture, Bureau of Statistics, Washington, D. C., June 20, 1912.

SIR: I have the honor to transmit herewith a compilation of statistics of the exports of farm and forest products from the United States for the year ending June 30,1911, with those for two previous years given for comparison. The data have been derived from the Bureau of Statistics of the Department of Commerce and Labor, and the work of compiling has been done by the Division of Production and Distribution, Bureau of Statistics, Department of Agriculture.

This report is a continuation of a series of bulletins on the same subject designed for the use of this department and to meet the demands of a large number of correspondents. They contain an arrangement of the statistics and a determination of totals, with various comparisons, not presented in any other publication.

It is respectfully recommended that this report be published as Bulletin 96 of this bureau.

Very respectfully,

Hon. James Wilson, Victor H. Olmsted, Chief of Bureau.

Secretary of Agriculture. 


\section{CONTENTS.}

Explanation of terms......................... ${ }_{5}^{\text {Page. }}$

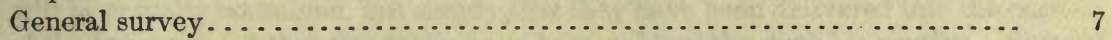

TABLE 1.-Balance of trade and relative magnitude of imports and exports of

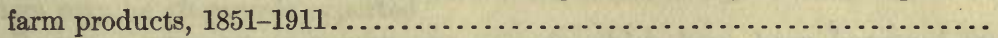

TABLE 2.-Exports of domestic and foreign forest products from the United

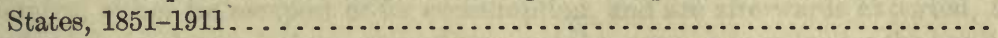

TABLE 3.-Value of exports of domestic farm and forest products, 1909-1911, by grand divisions to which consigned. .........................

TABLE 4.-Value of exports of domestic farm products, 1909-1911, by countries

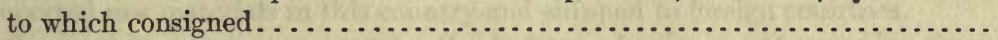

TABLE 5.-Value of exports of domestic forest products, 1909-1911, by countries

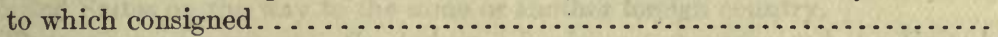

TABLE 6.-Value of principal groups of exports of domestic farm and forest

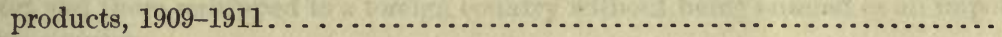

TABLE 7.-Balance of trade and relative magnitude of value of farm products in the trade of the United States with its noncontiguous possessions, 19011911.

TABLE 8.- Value of shipments of domestic farm and forest products from the United States to its noncontiguous possessions, 1909-1911..............

TABLE 9.-Value of shipments of principal groups of domestic farm and forest products from the United States to its noncontiguous possessions, 1909-1911. .

TABLE 10.-Shipments of domestic farm and forest products from the United

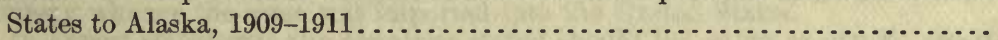

TABLE 11.-Receipts of farm and forest products from the United States into

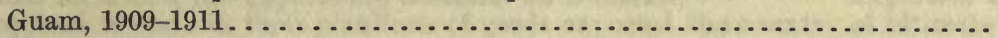

TABLE 12.-Shipments of domestic farm and forest products from the United

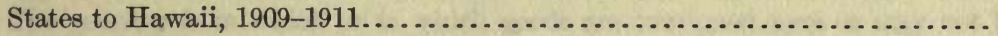

TABLE 13.-Exports of domestic farm and forest products from the United

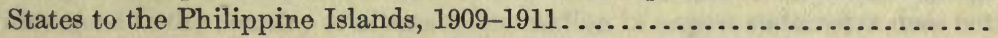

TABLE 14.-Shipments of domestic farm and forest products from the United States to Porto Rico, 1909-1911...............................

TABLE 15.-Shipments of domestic farm and forest products from the United

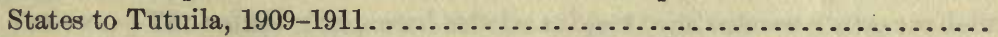

TABLE 16.-Quantity and value of principal groups of exports of foreign farm

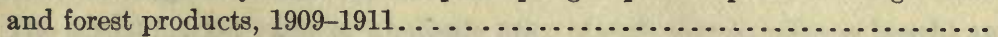

TABLE 17.-Quantity and value of exports of domestic farm and forest products, 1909-1911, by articles and by countries to which consigned.........

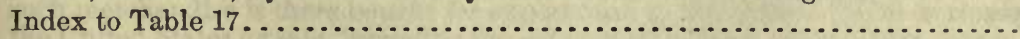





\section{EXPLANATION OF TERMS.}

IMPORTS.-Goods from a foreign country entered at a customhouse.

IMPORTS FOR CONSUMPTION.- The term "entry for consumption" is the technical name of the import entry made at the customhouse, and does not imply that the goods will be actually consumed, but simply that they have been delivered into the custody of the importer and that the duties have been paid on the dutiable portion. Some of them may be afterwards exported.

FOREIGN EXPORTS OR REEXPORTS.-Goods which have been imported into this country, either for reexport or for consumption, and are afterwards exported, having undergone no change in form or condition or enhancement in value by the application of labor in the United States.

DoMESTIC EXPORTS.-Goods produced and manufactured from either domestic or imported raw materials in this country and shipped to foreign countries.

Transit or IN-TRANSIT TRADE.-Goods from a foreign country passing through the United States on the way to the same or another foreign country.

Transshipment TRADE. - Goods from a foreign country received at a United States port and there reshipped to a foreign country without being entered as an import into this country.

In-transit and transshipment trade is not included in the imports and exports of the United States, but is reported separately.

The country of consignment is that which is mentioned in the exporting or importing documents as the one to which or from which the merchandise is to be shipped. The regulations of the Bureau of Statistics, Department of Commerce and Labor, are:

Collectors will consider the country in which merchandise was invoiced as the country whence the same was imported into the United States.

In export statements the countries stated should be, so far as can be ascertained, those for which the exports are destined for a market. *** Exporters will be required to state in their manifests of goods exported the country of ultimate destination.

The country from which or to which goods are consigned may or may not be the country of origin or ultimate destination, as the case may be; the foregoing regulation with regard to the country of ultimate destination in export statements does not result in a material representation of countries of ultimate destination in place of countries of consignment in the records of the exports of this country, when these two countries are not the same.

VALUES.-The values of imported articles subject to ad valorem duties are defined by the Act of Congress of June 10, 1890, as-

! The actual market value or wholesale price of such merchandise as bought and sold in usual wholesale quantities at the time of exportation to the United States in the principal markets of the country from whence imported, and in the condition in which such merchandise is there bought for exportation to the United States or consigned to the United States for sale, including the value of all cartons, cases, crates, boxes, sacks, and coverings of any kind, and all other costs, charges, and expenses incident to placing the merchandise in condition ready for shipment to the United States.

The value of all other imports, whether subject to specific duty or free of duty, is also determined according to the law just quoted.

: The value of domestic exports is their declared value at the time of exportation in the ports of the United States whence they are exported, which the law requires to be stated under oath with penalty for misstatement. 
The value of foreign exports when shipped directly from bonded warehouses (usually dutiable goods) is their import value, but when not shipped from bonded warehouses (usually free goods) the value is determined in the same manner as that of domestic exports.

Goods in transit through the United States from one foreign country to another are valued in the same manner as imports.

Valuation deceptions. - The value of imported articles subject to ad valorem duties is believed to be determined with more accuracy, according to the legal method of valuation, than the value of imports with specific duties or free of duty, or the value of exported articles; the valuations of dutiable imports and of exports dutiable in foreign countries tend to understatement; and the valuations of imports that are free of duty are liable to inflation for the purpose of trade deception.

WEIGHTs.-In the official trade returns of the United States the weights of articles exported are usually net weights, and also the weights of all imports, except those which are subject to a specific duty levied upon the weight of the packages, including the weight of the article itself, together with some or all of its coverings.

All tons mentioned in this bulletin, except where it is otherwise stated, are long tons of 2,240 pounds.

DISCREPANCIES IN FOREIGN TRADE STATISTICS of various countries are partly due to different methods of estimating values, of determining countries of origin and destination, and of classifying merchandise, and to differences in dates. The United States does not regard a c. i. f. value (cost, insurance, freight) as the value of either exports or imports (except some foreign exports), while the United Kingdom, for instance, includes these in the value of its imports. It is said that these charges are often erroneously included by British shippers in their statement of export values, especially when the selling price includes insurance and freight.

In consequence of various sources of discrepancy, it is generally futile to undertake to balance an export of this country by any official statement of import into a foreign country, and often there is not an approximate agreement.

Noncontiguous Possessions.- The "noncontiguous" possessions of the United States are all those not included between Canada on the north and Mexico and the Gulf of Mexico on the south, and between the Atlantic and Pacific oceans.

The trade returns of all the possessions of this country, except the Philippine Islands, are included in the total trade of the United States. In the trade statistics for any noncontiguous possession, all other noncontiguous possessions, except the Philippine Islands, are included with the United States; thus, shipments from Hawaii to Porto Rico are included in the total shipments from Hawaii to the United States.

AbBreviation.- "n. e. s." =not elsewhere specified. 


\section{EXPORTS OF DOMESTIC FARM AND FOREST PRODUCTS, 1909-1911}

\section{GENERAL SURVEY.}

The exports of domestic farm and forest products during the year ending June 30,1911 , valued at $\$ 1,031,000,000$, show an increase over the preceding year of nearly $\$ 160,000,000$, and, with the exception of 1907, are larger than for any previous year. The farm products exported during the year form 51.2 per cent of the total exports of domestic merchandise, as compared with 50.9 per cent in 1910 and 55.1 per cent in 1909. The domestic and foreign farm products exported minus the imports of the same commodities show a balance of trade of $\$ 365,000,000$ in favor of the United States in 1911 , as compared with $\$ 198,000,000$ in 1910 and $\$ 274,000,000$ in 1909. Exports of domestic forest products in 1911 show an increase of $\$ 18,000,000$ compared with the preceding year, and are valued at $\$ 103,000,000$, which was more than for any previous year. The foreign forest products reexported for the same period were valued at more than $\$ 7,600,000$. (Tables 1 and 2.)

Exports of domestic farm products consigned to Europe in 1911 were valued at $\$ 877,000,000$, an increase of $\$ 136,000,000$ over the preceding year. Consignments to other grand divisions for the same period show an increase of $\$ 10,000,000$ each to North America and to Asia, and $\$ 2,000,000$ to South America. Domestic forest products shipped to Europe in 1911 were valued at $\$ 56,000,000$, an increase of $\$ 8,000,000$ compared with 1910 and $\$ 13,000,000$ more than in 1909. The same commodities sent to North American countries were valued at nearly $\$ 25,000,000$, an increase of more than $\$ 5,000,000$ over the preceding year and nearly $\$ 11,000,000$ more than in 1909 . (Table 3.)

As shown in Table 4, 40 per cent of the consignments of domestic farm products were sent to the United Kingdom; 20 per cent to Germany; and the remaining 40 per cent was consigned to 89 different countries. The farm products consigned to the United Kingdom were valued at $\$ 413,000,000$ in 1911 , as compared with $\$ 344,000,000$ in 1910 and $\$ 376,000,000$ in 1909 . An increase of $\$ 69,000,000$ is shown in 1911 as compared with the preceding year, due to an increase in shipments of cotton of $\$ 81,000,000$; corn, $\$ 2,000,000$. 
These increases were offset by a falling off in exports of wheat, $\$ 12,000,000$; fresh beef, $\$ 3,000,000$, and lard, $\$ 1,000,000$.

Shipments of farm products to Germany in 1911 were valued at $\$ 207,000,000$, an increase of $\$ 29,000,000$ over the preceding year and $\$ 35,000,000$ more than in 1909 . The principal commodities showing increases as compared with 1910 were: Cotton, $\$ 25,000,000$; lard, $\$ 5,000,000$; corn, $\$ 1,000,000$. An increase of $\$ 45,000,000$ is shown in cotton as compared with 1909.

Exports of domestic forest products (Table 5) were consigned to 77 different countries in 1911 and were valued at $\$ 103,000,000$, as compared with $\$ 85,000,000$ for 1910 and $\$ 72,000,000$ for 1909 . The greatest increase shown in the exports to any one country was in the case of Canada, which shows an increase of $\$ 5,000,000$ compared with 1910 and $\$ 8,000,000$ more than in 1909 . This increase is mostly due to increased shipments of lumber to that country. Other important increases were $\$ 3,000,000$ for United Kindgom as compared with 1910 and $\$ 5,000,000$ compared with 1909 . Germany shows an increase of $\$ 2,700,000$ as compared with 1910 and $\$ 3,000,000$ compared with 1909. As shown in this table, the six leading countries that held the same relative position for each of the three years under discussion received 67 per cent of forest products exported in 1911, 66 per cent in 1910, and 65 in 1909.

Shipments of farm and forest products from the United States to its noncontiguous possessions in 1911 were valued at $\$ 28,300,000$, as compared with $\$ 27,900,000$ in 1910 and $\$ 25,300,000$ in 1909 . As a destination of farm products Porto Rico held first place for each of the three years under consideration, but as a destination of forest products Porto Rico rose from third place in 1909 to second place in 1910 , and to first place in 1911. The farm products sent to the noncontiguous possessions consisted principally of prepared foods, such as cured meats, grain and grain products, and rice, rice meal, etc.

Exports of foreign farm products in 1911 were valued at $\$ 15,000,000$, as compared with a like amount for 1910 and $\$ 10,000,000$ in 1909 . Foreign forest products exported in 1911 were worth $\$ 8,000,000$, compared with $\$ 10,000,000$ for 1910 and $\$ 5,000,000$ for 1909 . The decrease shown in 1911 as compared with the preceding year is due to a falling off in shipments of india rubber of $\$ 2,000,000$, while the increase of $\$ 3,000,000$ as compared with 1909 is due to an increase in consignments of india rubber of that amount. (Tables 7 to 16.) 
EXPORTS OF FARM AND FOREST PRODUCTS, 1909-11.

TABLE 1.-BALANCE OF TRADE and relative magnitude of IMPORTS and EXPORTS of FARM products, 1851-1911.1

[All values are gold.]

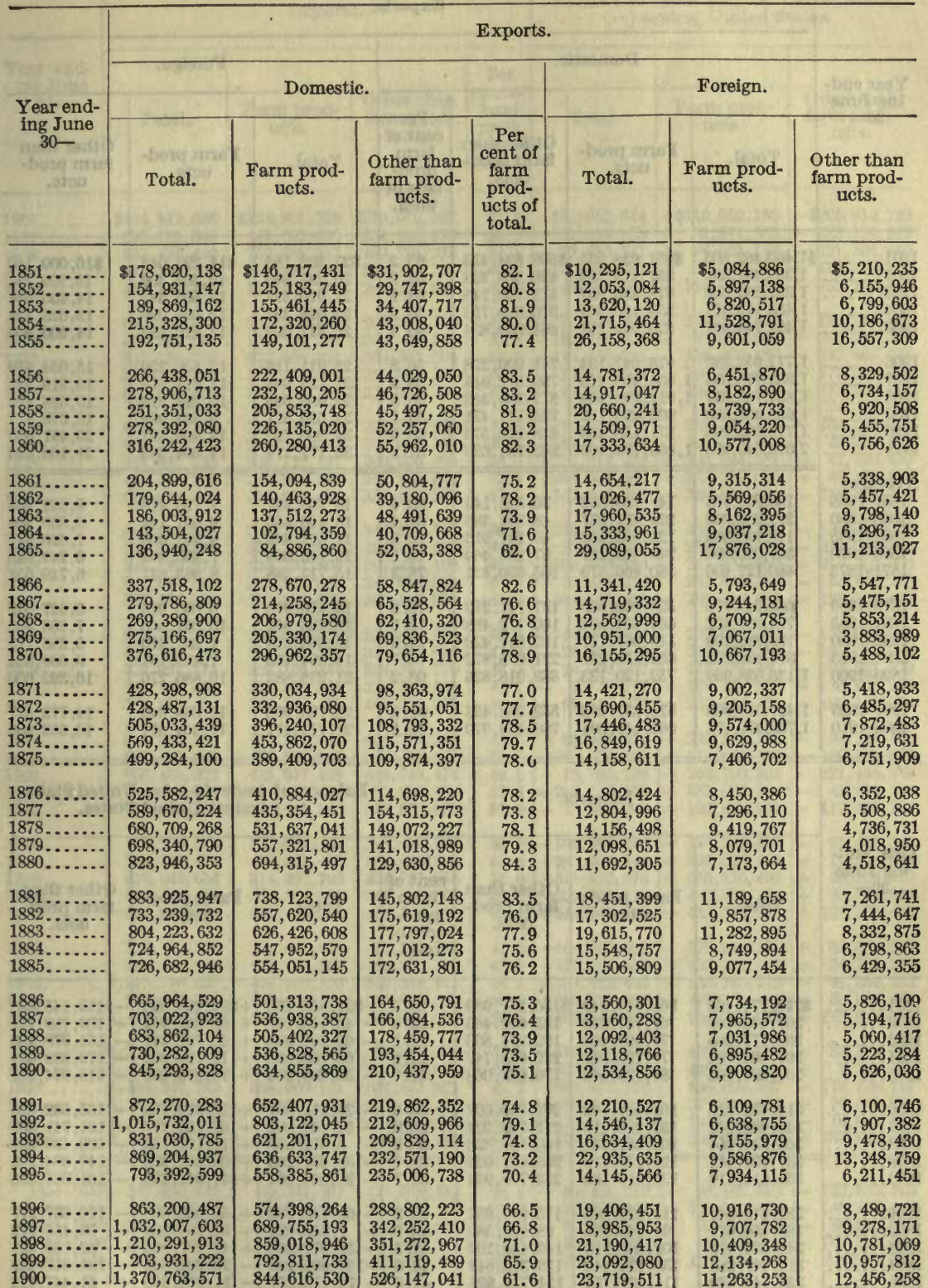

1 The values of exports of domestic merchandise for the fiscal years 1862-1879, inclusive, were originally given in gold for all trade going through the Pacific ports and in currency for exports from all other ports. In the above table all values are expressed in gold, with the exception of the following irregularity in 1866: For this year no returns of exports by articles and ports are available, and the gold value of farm products was computed by reducing the total mixed value of this class of articles as if it were all in currency. The result thus computed was subtracted from the gold value of all domestic exports to obtain the figure for exports other than farm products.

The values in gold of $\$ 1$ in currency, as used in this computation, were: For $1862, \$ 0.985 ; 1863, \$ 0.729$; $1864, \$ 0.640 ; 1865, \$ 0.495 ; 1866, \$ 0.712 ; 1867, \$ 0.709 ; 1868, \$ 0.715 ; 1869, \$ 0.727 ; 1870, \$ 0.811 ; 1871, \$ 0.887 ; 1872$, $\$ 0.894 ; 1873, \$ 0.873 ; 1874, \$ 0.893 ; 1875, \$ 0.888 ; 1876, \$ 0.878 ; 1877, \$ 0.927 ; 1878, \$ 0.976 ; 1879, \$ 0.998$

Values of imports and of foreign exports are given in gold, as originally reported. 
TABLE 1.-BALANCE OF TRADE and relative magnitude of IMPORTS and EXPORTS of FARM products, 1851-1911-Continued.

\begin{tabular}{|c|c|c|c|c|c|c|c|}
\hline \multirow{2}{*}{$\begin{array}{l}\text { Year end- } \\
\text { Ing June } \\
30-\end{array}$} & \multicolumn{4}{|c|}{ Domestic. } & \multicolumn{3}{|c|}{ Foreign. } \\
\hline & Total. & $\begin{array}{c}\text { Farm prod- } \\
\text { ucts. }\end{array}$ & $\begin{array}{l}\text { Other than } \\
\text { farm prod- } \\
\text { ucts. }\end{array}$ & $\begin{array}{l}\text { Per } \\
\text { cent of } \\
\text { farm } \\
\text { prod- } \\
\text { ucts of } \\
\text { total. }\end{array}$ & Total. & $\begin{array}{l}\text { Farm prod- } \\
\text { ucts. }\end{array}$ & $\begin{array}{l}\text { Other than } \\
\text { farm prod- } \\
\text { ucts. }\end{array}$ \\
\hline $\begin{array}{l}1901 \ldots \ldots . \\
1902 \ldots \ldots . \\
1903 \ldots \ldots . \\
1904 \ldots \ldots \\
1905 \ldots \ldots . \\
\end{array}$ & $\begin{array}{l}\$ 1,460,462,806 \\
1,355,481,861 \\
1,392,231,302 \\
1,435,179,017 \\
1,491,744,641\end{array}$ & $\begin{array}{r}\$ 951,628,331 \\
857,113,533 \\
878,480,557 \\
859,160,264 \\
826,904,777\end{array}$ & $\begin{array}{r}\$ 508,834,475 \\
498,368,328 \\
513,750,745 \\
576,018,753 \\
664,839,864\end{array}$ & $\begin{array}{l}65.2 \\
63.2 \\
63.1 \\
59.9 \\
55.4\end{array}$ & $\begin{array}{r}\$ 27,302,185 \\
26,237,540 \\
27,910,377 \\
25,648,254 \\
26,817,025\end{array}$ & $\begin{array}{r}\$ 11,293.045 \\
10,308,306 \\
13,505,343 \\
12,625,026 \\
12,316,525\end{array}$ & $\begin{array}{r}\$ 16,009,140 \\
15,929,234 \\
14,405,034 \\
13,023,228 \\
14,500,500\end{array}$ \\
\hline $\begin{array}{l}1906 \ldots \ldots . . \\
1907 \ldots \ldots . \\
1908 \ldots \ldots . \\
1909 \ldots \ldots . \\
1910 \ldots \ldots . \\
1911 \ldots \ldots .\end{array}$ & $\begin{array}{l}1,717,953,382 \\
1,853,718,034 \\
1,834,786,357 \\
1,638,355,593 \\
1,710,083,998 \\
2,013,549,025 \\
\end{array}$ & $\begin{array}{r}976,047,104 \\
1,054,405,416 \\
1,017,396,404 \\
903,238,122 \\
871,158,425 \\
1,030,794,402 \\
\end{array}$ & $\begin{array}{l}741,906,278 \\
799,312,618 \\
817,389,953 \\
735,117,471 \\
838,925,573 \\
982,754,623 \\
\end{array}$ & $\begin{array}{l}56.8 \\
56.9 \\
55.5 \\
55.1 \\
50.9 \\
51.2 \\
\end{array}$ & $\begin{array}{l}25,911,118 \\
27,133,044 \\
25,986,989 \\
24,655,511 \\
34,900,722 \\
35,771,174 \\
\end{array}$ & $\begin{array}{r}10,856,259 \\
11,613,519 \\
10,298,514 \\
9,584,934 \\
14,469,627 \\
14,664,548 \\
\end{array}$ & $\begin{array}{l}15,054,859 \\
15,519,525 \\
15,688,475 \\
15,070,577 \\
20,431,095 \\
21,106,626 \\
\end{array}$ \\
\hline $\begin{array}{l}\text { A verage: } \\
1851-18.55 \\
1856-1860 \\
1861-1865 \\
1866-1870 \\
1871-1875\end{array}$ & $\begin{array}{l}186,299,976 \\
278,266,060 \\
170,198,365 \\
307,695,596 \\
486,127,400\end{array}$ & $\begin{array}{l}149,756,832 \\
229,371,677 \\
123,950,452 \\
240,440,127 \\
380,496,579\end{array}$ & $\begin{array}{r}36,543,144 \\
48,894,383 \\
46,247,913 \\
67,255,469 \\
105,630,821\end{array}$ & $\begin{array}{l}80.4 \\
82.4 \\
72.8 \\
78.1 \\
78.3\end{array}$ & $\begin{array}{l}16,768,431 \\
16,440,453 \\
17,612,849 \\
13,146,009 \\
15,713,288\end{array}$ & $\begin{array}{l}\mathbf{7}, 786,478 \\
\mathbf{9}, 601,144 \\
9,992,002 \\
7,896,364 \\
8,963,637\end{array}$ & $\begin{array}{l}8,981,953 \\
6,839,309 \\
7,620,847 \\
5,249,645 \\
6,749,651\end{array}$ \\
\hline $\begin{array}{l}1876-1880 \\
1881-1885 \\
1886-1890 \\
1891-1895 \\
1896-1900\end{array}$ & $\begin{array}{r}663,649,776 \\
774,607,422 \\
725,685,199 \\
876,326,123 \\
1,136,038,959\end{array}$ & $\begin{array}{l}525,902,563 \\
604,834,934 \\
543,067,777 \\
654,350,251 \\
752,120,133\end{array}$ & $\begin{array}{l}137,747,213 \\
169,772,488 \\
182,617,422 \\
221,975,872 \\
383,918,826\end{array}$ & $\begin{array}{l}79.2 \\
78.1 \\
74.8 \\
74.7 \\
66.2\end{array}$ & $\begin{array}{l}13,110,975 \\
17,285,052 \\
12,693,323 \\
16,094,455 \\
21,278,882\end{array}$ & $\begin{array}{r}8,083,926 \\
10,031,556 \\
7,307,210 \\
7,485,101 \\
10,886,276\end{array}$ & $\begin{array}{r}5,027,049 \\
7,253,496 \\
5,386,113 \\
8,609,354 \\
10,392,606\end{array}$ \\
\hline $\begin{array}{l}1901-1905 \\
1906-1910\end{array}$ & $\begin{array}{l}1,427,019,925 \\
1,750,979,473\end{array}$ & $\begin{array}{l}874,657,492 \\
964,449,094\end{array}$ & $\begin{array}{l}552,362,433 \\
786,530,379\end{array}$ & $\begin{array}{l}61.3 \\
55.1\end{array}$ & $\begin{array}{l}26,783,076 \\
27,717,477\end{array}$ & $\begin{array}{l}12,009,649 \\
11,364,571\end{array}$ & $\begin{array}{l}14,773,427 \\
16,352,906\end{array}$ \\
\hline
\end{tabular}

\begin{tabular}{|c|c|c|c|c|c|c|c|}
\hline \multirow[b]{2}{*}{$\begin{array}{l}\text { Year end- } \\
\text { ing June } \\
30-\end{array}$} & \multicolumn{3}{|c|}{ Imports. } & \multirow[b]{2}{*}{$\begin{array}{c}\text { Per } \\
\text { cent of } \\
\text { farm } \\
\text { prod- } \\
\text { ucts of } \\
\text { total. }\end{array}$} & \multicolumn{3}{|c|}{$\begin{array}{c}\text { Balance of trade }(+) \text { for United States, } \\
(-) \text { against United States. }\end{array}$} \\
\hline & Total. & $\begin{array}{l}\text { Farm prod- } \\
\text { ucts.1 }\end{array}$ & $\begin{array}{l}\text { Other than } \\
\text { farm prod- } \\
\text { ucts. }\end{array}$ & & Total. & $\begin{array}{l}\text { Farm prod- } \\
\text { uets. }\end{array}$ & $\begin{array}{l}\text { Other than } \\
\text { farm prod- } \\
\text { ucts. }\end{array}$ \\
\hline $\begin{array}{l}851 . \\
852 .\end{array}$ & $\begin{array}{r}\$ 210,771,429 \\
207,440,398 \\
263,777,265 \\
297,803,794 \\
257,808,708\end{array}$ & $\begin{array}{r}\$ 60,513,449 \\
61,747,933 \\
71,499,465 \\
71,720,047 \\
81,726,640\end{array}$ & $\begin{array}{r}\$ 150,257,980 \\
145,692,465 \\
192,277,800 \\
226,083,747 \\
176,082,068\end{array}$ & $\begin{array}{l}28.7 \\
29.8 \\
27.1 \\
24.1 \\
31.7\end{array}$ & $\begin{array}{l}-\$ 21,856,170 \\
-40,456,167 \\
-\quad 60,287,983 \\
-60,760,030 \\
-38,899,205\end{array}$ & $\begin{array}{r}+\$ 91,288,868 \\
+\quad 69,332,954 \\
+90,782,497 \\
+112,129,004 \\
+\quad 76,975,696\end{array}$ & $\begin{array}{l}-\$ 113,145,038 \\
-109,789,121 \\
-151,070,480 \\
-172,889,034 \\
-115,874,901\end{array}$ \\
\hline 1856 . & $\begin{array}{l}310,432,310 \\
348,428,342 \\
263,338,654 \\
331,333,341 \\
353,616,119\end{array}$ & $\begin{array}{l}102,541,703 \\
133,226,318 \\
102,482,331 \\
126,236,317 \\
129,816,165\end{array}$ & $\begin{array}{l}207,890,607 \\
215,202,024 \\
160,856,323 \\
205,097,024 \\
223,799,954\end{array}$ & $\begin{array}{l}33.0 \\
38.2 \\
38.9 \\
38.1 \\
36.7\end{array}$ & $\begin{array}{r}-29,212,887 \\
-54,604,582 \\
+\quad 8,672,620 \\
-38,431,290 \\
-20,040,062\end{array}$ & $\begin{array}{r}+126,319,168 \\
+107,136,777 \\
+117,111,150 \\
+108,952,923 \\
+141,041,256\end{array}$ & $\begin{array}{l}-155,532,055 \\
-161,741,359 \\
-108,438,530 \\
-147,384,213 \\
-161,081,318\end{array}$ \\
\hline $\begin{array}{l}1861 \ldots \\
1862 \ldots \\
1863 \ldots \\
1864 \ldots \\
1865 \ldots\end{array}$ & $\begin{array}{l}289,310,542 \\
189,356,677 \\
243,335,815 \\
316,447,283 \\
238,745,580\end{array}$ & $\begin{array}{r}113,329,585 \\
91,263,088 \\
102,886,713 \\
138,124,440 \\
114,031,753\end{array}$ & $\begin{array}{r}175,980,957 \\
98,093,589 \\
140,449,102 \\
178,322,843 \\
124,713,827\end{array}$ & $\begin{array}{l}39.2 \\
48.2 \\
42.3 \\
43.6 \\
47.8\end{array}$ & $\begin{array}{r}69,756,709 \\
+\quad 1,313,824 \\
-39,371,368 \\
-157,609,295 \\
-\quad 72,716,277\end{array}$ & $\begin{array}{r}50,080,568 \\
+\quad 54,769,896 \\
+\quad 42,787,955 \\
-26,292,863 \\
-11,268,865\end{array}$ & $\begin{array}{r}119,837,277 \\
-\quad 53,456,072 \\
-\quad 82,159,323 \\
-\quad 131,316,432 \\
-\quad 61,447,412\end{array}$ \\
\hline
\end{tabular}

1 The classification employed from 1890 to 1901 differs from the present classification by including prepared opium and (in 1896-1901) gelatine, but not cochineal, licorice root, nor (in 1891-1893) beer extract. The value of the products included in this table for 1890-1901, but not subsequently, was as follows: Prepared oplum, 1890, \$269,586; 1891, \$567,035; 1892, \$547,528; 1893, \$446,422; 1894, \$310,771; 1895, \$920,006; 1896, $\$ 735,134 ; 1897, \$ 1,132,861 ; 1898, \$ 652,341 ; 1899, \$ 828,203 ; 1900, \$ 1,065,965 ; 1901, \$ 972,582 ;$ gelatine, 1896, \$15,386; $1897, \$ 5,748 ; 1898, \$ 25,907 ; 1899, \$ 21,961 ; 1900, \$ 30,361 ; 1901, \$ 23,230$. The value of the products now included, but not in 1890-1901, was as follows: Cochineal, 1890, \$42,435; 1891, \$19,779; $1892, \$ 55,883 ; 1893, \$ 52,572 ; 1894$, $\$ 28,124 ; 1895, \$ 38,568 ; 1896, \$ 50,988 ; 1897, \$ 41,943 ; 1898, \$ 45,762 ; 1899, \$ 23,207 ; 1900$, \$31, 211; 1901, \$20,414; licorice root, $1890, \$ 794,503 ; 1891, \$ 896,597 ; 1892, \$ 1,601,028 ; 1893, \$ 1,688,716 ; 1894, \$ 1,209,728 ; 1895, \$ 1,404,563 ; 1896$, $\$ 1,401,748 ; 1897, \$ 1,022,650 ; 1898, \$ 1,171,621 ; 1899, \$ 1,566,830 ; 1900, \$ 1,667,256 ; 1901, \$ 1,737,097$; beer extract, $1891, \$ 6,470 ; 1892, \$ 5,411 ; 1893, \$ 2,291$. 
TABLE 1.-BALANCE OF TRADE and relative magnitude of IMPORTS and EXPORTS of FARM products, 1851-1911-Continued.

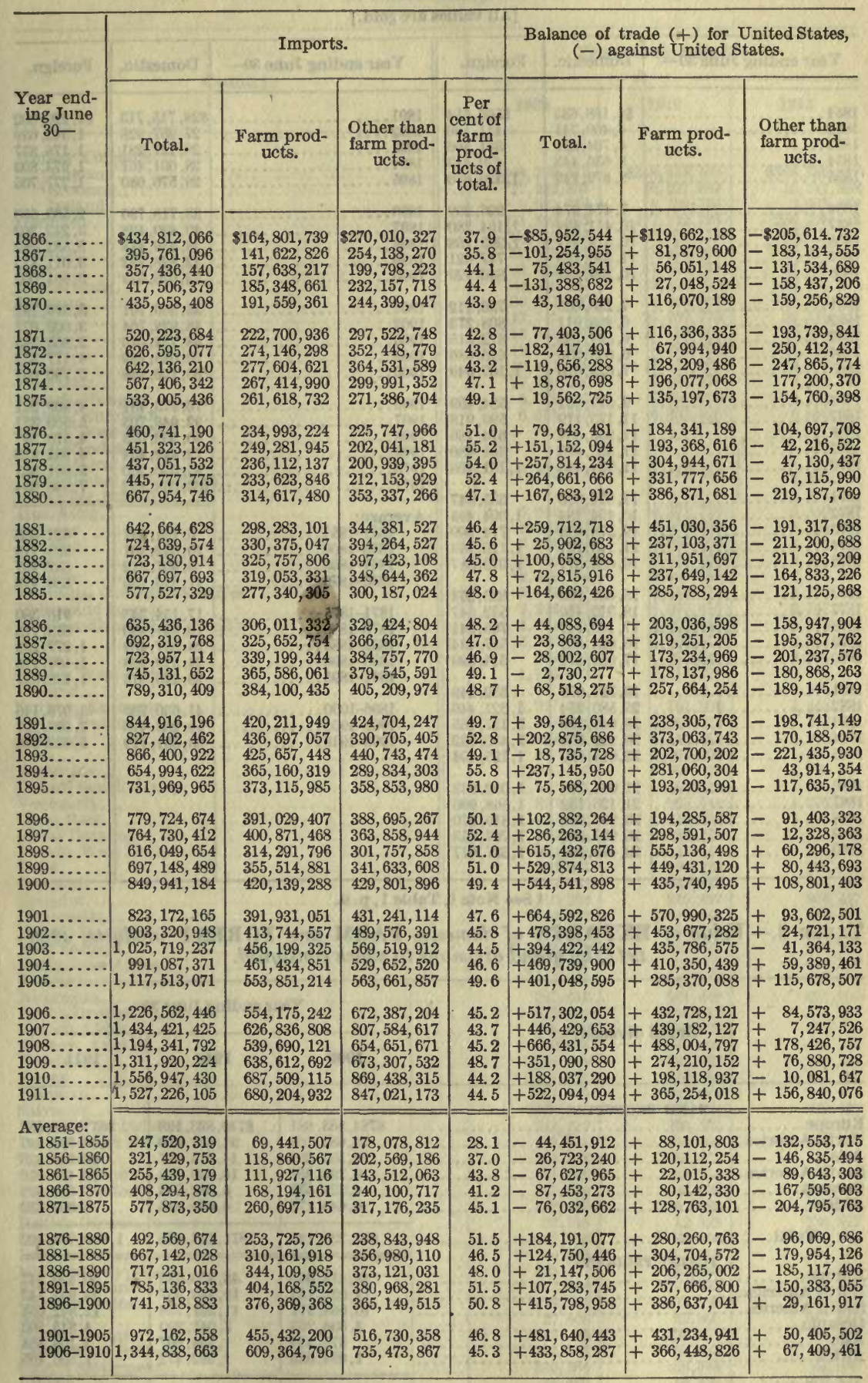


TABLE 2.- EXPORTS of domestic and FOREIGN FOREST PRODUCTS from the United States, 1851-1911.1

[All values are gold.]

\begin{tabular}{|c|c|c|c|c|c|}
\hline ng June 30- & Domestic. & Foreign. & Year endi & Domestic. & Foreign. \\
\hline $\begin{array}{l}1851 \ldots \ldots \ldots \ldots \\
1852 \ldots \ldots \ldots \ldots \\
1853 \ldots \ldots \ldots \ldots \\
1854 \ldots \ldots \ldots \\
1855 \ldots \ldots \ldots\end{array}$ & $\begin{array}{r}\$ 4,188,635 \\
4,400,741 \\
4,704,394 \\
8,636,443 \\
8,879,743\end{array}$ & $\begin{array}{r}\$ 566,554 \\
411,166 \\
341,566 \\
470,483 \\
1,320,670\end{array}$ & $\begin{array}{l}1891 \ldots \ldots \\
1892 \ldots \ldots \\
1893 \ldots \ldots \\
1894 \ldots \ldots \\
1895 \ldots .\end{array}$ & $\begin{array}{r}\$ 28,715,713 \\
27,957,928 \\
28,127,281 \\
28,001,461 \\
28,576,680\end{array}$ & $\begin{array}{r}\$ 1,220,002 \\
1,542,639 \\
1,178,837 \\
1,973.803 \\
1,277,705\end{array}$ \\
\hline $\begin{array}{l}1856 \ldots \ldots \ldots \ldots \\
1857 \ldots \ldots \ldots \ldots \\
1858 \ldots \ldots \ldots \\
1859 \ldots \ldots \ldots \\
1860 \ldots \ldots \ldots \\
\end{array}$ & $\begin{array}{r}7,474,074 \\
10,411,894 \\
10,579,417 \\
11,396,163 \\
10,299,959\end{array}$ & $\begin{array}{r}926,299 \\
1,164,280 \\
1,295,768 \\
747,621 \\
846,929\end{array}$ & $\begin{array}{l}1896 \ldots \ldots \\
1897 \ldots \ldots \\
1898 \ldots \ldots \\
1899 \ldots \ldots \\
1900 \ldots\end{array}$ & $\begin{array}{l}33,718,790 \\
40,490,428 \\
38,439,418 \\
42,828,732 \\
52,676,575\end{array}$ & $\begin{array}{l}2,563,550 \\
3,242,262 \\
2,582,082 \\
3,011,832 \\
3,981,002\end{array}$ \\
\hline $\begin{array}{l}1861 \ldots \\
1862 \ldots \\
1863 \ldots \\
1864 \ldots \\
1865 \ldots\end{array}$ & $\begin{array}{l}7,286,605 \\
6,468,911 \\
6,544,788 \\
6,608,236 \\
7,629,020\end{array}$ & $\begin{array}{r}756,112 \\
808,273 \\
872,515 \\
616,086 \\
1,109,049\end{array}$ & $\begin{array}{l}1901 \ldots \ldots \\
1902 \ldots . . \\
1903 \ldots \ldots \\
1904 \ldots \ldots \\
1905 \ldots .\end{array}$ & $\begin{array}{l}55,369,161 \\
48,928,764 \\
58,734,016 \\
70,085,789 \\
63,199,348\end{array}$ & $\begin{array}{l}3,599,192 \\
3,609,071 \\
2,865,325 \\
4,177,352 \\
3,790,097\end{array}$ \\
\hline $\begin{array}{l}1866 . \\
1867 . \\
1868 . \\
1869 \\
1870 .\end{array}$ & $\begin{array}{r}9,579,561 \\
11,175,119 \\
11,956,584 \\
11,885,488 \\
11,984,445\end{array}$ & $\begin{array}{r}584,459 \\
599,918 \\
674,786 \\
361,480 \\
1,181,708\end{array}$ & 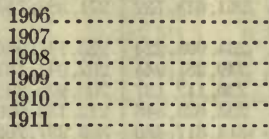 & $\begin{array}{r}76,975,431 \\
92,948,705 \\
90,362,073 \\
72,442,454 \\
85,030,230 \\
103,038,892\end{array}$ & $\begin{array}{l}4,809,261 \\
5,500,331 \\
4,570,397 \\
4,982,810 \\
9,801,881 \\
7,586,854\end{array}$ \\
\hline $\begin{array}{l}1871 \ldots \\
1872 \ldots \\
1873 \ldots \\
1874 \ldots \\
1875 \ldots \\
1876\end{array}$ & $\begin{array}{l}11,874,850 \\
16,494,184 \\
19,578,615 \\
21,143,701 \\
16,680,377\end{array}$ & $\begin{array}{r}635,847 \\
1,004,495 \\
774,909 \\
1,116,763 \\
1,019,887\end{array}$ & $\begin{array}{r}\text { Average: } \\
1851-1855 . \\
1856-1860 . \\
1861-1865 . \\
1866-1870\end{array}$ & $\begin{array}{r}6,161,991 \\
10,032,301 \\
6,907,512 \\
11,316,239\end{array}$ & $\begin{array}{l}622,088 \\
996,179 \\
832,407 \\
680,470\end{array}$ \\
\hline $\begin{array}{l}1876 . \\
1877 . \\
1878 . \\
1879 . \\
1850 .\end{array}$ & $\begin{array}{l}15,636,980 \\
18,312,446 \\
17,180,147 \\
16,023,005 \\
17,056,870\end{array}$ & $\begin{array}{l}883,254 \\
532,547 \\
705,941 \\
557,434 \\
614,399\end{array}$ & $\begin{array}{l}1871-1875, \ldots \ldots \ldots \\
1876-1880 \ldots \ldots \ldots \\
1881-1885 \ldots \ldots \\
1886-1890 \ldots \ldots \\
1891-1895 . \ldots \ldots\end{array}$ & $\begin{array}{l}17,154,345 \\
16,841,890 \\
24,357,469 \\
24,529,928 \\
28,275,813\end{array}$ & $\begin{array}{r}910,380 \\
658,715 \\
1,277,259 \\
1,409,176 \\
1,438,597\end{array}$ \\
\hline $\begin{array}{l}1881 . \\
1882 . \\
1883 . \\
1884 \\
1885 .\end{array}$ & $\begin{array}{l}19,324,096 \\
25,580,254 \\
28,645,199 \\
26,222,959 \\
22,014,839\end{array}$ & $\begin{array}{r}352,249 \\
1,321,446 \\
2,137,165 \\
1,450,032 \\
1,125,404\end{array}$ & $\begin{array}{l}1896-1900 \ldots \ldots \\
1901-1905 \ldots \ldots \\
1906-1910 \ldots \ldots\end{array}$ & $\begin{array}{l}41,630,789 \\
59,263,416 \\
83,551,779\end{array}$ & $\begin{array}{l}3,076,146 \\
3,608,207 \\
5,932,936\end{array}$ \\
\hline $\begin{array}{l}1886 \ldots \ldots \ldots \\
1887 \ldots \ldots \ldots \\
1888 \ldots \ldots \\
1889 \ldots \ldots \\
1890 \ldots \ldots\end{array}$ & $\begin{array}{l}21,061,708 \\
21,126,152 \\
23,991,092 \\
26,997,602 \\
29,473,084\end{array}$ & $\begin{array}{l}1,052,083 \\
1,568,996 \\
1.319,270 \\
1,767,853 \\
1,337,677\end{array}$ & 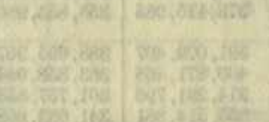 & ${ }^{\circ}$ & \\
\hline
\end{tabular}

1 See Note ${ }^{1}$, Table 1, p. 9.

TABLE 3.-Value of EXPORTS of domestic FARM and FOREST products, 19091911, by grand divisions to which consigned.

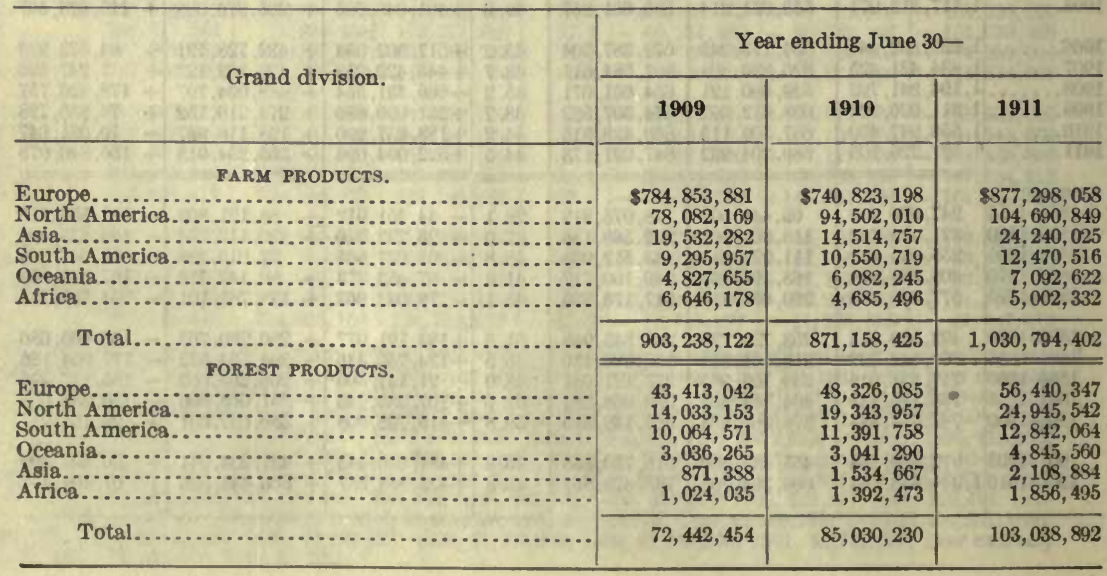


TABLE 4.-Value of EXPORTS of domestic FARM products, 1909-1911, by countries to which consigned.

\begin{tabular}{|c|c|c|c|}
\hline \multirow{2}{*}{ Country. } & \multicolumn{3}{|c|}{ Year ending June 30} \\
\hline & 1909 & 1910 & 1911 \\
\hline United Kingdom: & \multirow[b]{2}{*}{$8348,729.177$} & \multirow[b]{2}{*}{$\$ 318,416,408$} & \\
\hline England...... & & & $\$ 386,389,817$ \\
\hline$\ldots \ldots \ldots \ldots \ldots \ldots$ & $17,952,337$ & $16,227,687$ & $16,247,358$ \\
\hline (.). & $8,993,354$ & $9,150,764$ & $9,935,663$ \\
\hline (1). & $171,592,232$ & $177,742,798$ & $206,926,033$ \\
\hline (1) & $64,489,091$ & $75,871,137$ & $89,528,191$ \\
\hline (n) & $30,375,721$ & $38,494,249$ & $47,419,819$ \\
\hline (1). & $43,603,736$ & $37,231,075$ & $41,717,962$ \\
\hline (n) & $44,659,544$ & $35,828,397$ & $40,359,304$ \\
\hline . & $30,461,220$ & $24,265,061$ & $26,574,760$ \\
\hline & $17,740,614$ & $21,902,778$ & $22,549,165$ \\
\hline - & $15,843,675$ & $15,138,068$ & $20,328,778$ \\
\hline . & $12,320,007$ & $8,285,704$ & $15,808,587$ \\
\hline 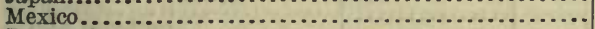 & $10,477,649$ & $14,111,295$ & $12,770,430$ \\
\hline . & $13,429,240$ & $9,581,879$ & $9,223,395$ \\
\hline . & $6,088,652$ & $5,687,994$ & $9,142,939$ \\
\hline Russia, European. & $6,513,450$ & $6,303,826$ & $6,856,662$ \\
\hline British West Indies: & & & \\
\hline Jamaica............. & & & $\begin{array}{r}818,804 \\
1,847,504\end{array}$ \\
\hline Trinidad and $\mathrm{T}$ & $6,492,477$ & $5,772,253$ & $\begin{array}{l}1,848,004 \\
1,605,834\end{array}$ \\
\hline Other British.. & & & $1,394,477$ \\
\hline . & $5,041,599$ & $4,371,718$ & $5,340,327$ \\
\hline 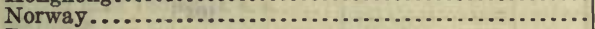 & $3,793,601$ & $3,809,439$ & $5,194,661$ \\
\hline 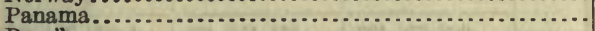 & $3,725,319$ & $4,095,650$ & $4,738,070$ \\
\hline (1) & $2,490,377$ & $3,011,901$ & $3,805,581$ \\
\hline Sweden............... & $2,499,164$ & $2,467,555$ & $3,554,283$ \\
\hline Australia, Commonwealth of.... & $1,892,047$ & $2,315,171$ & $3,262,068$ \\
\hline Philippine Islands. . & $2,246,423$ & $3,097,416$ & $2,743,271$ \\
\hline Newfoundland and Labrador........................... & $1,914,178$ & $2,003,641$ & $2,373,474$ \\
\hline Haiti................ & $1,563,781$ & $1,966,577$ & $2,213,294$ \\
\hline (2) & 807,122 & 957,340 & $2,094,043$ \\
\hline (.). & $1,756,013$ & $1,914,225$ & $1,710,850$ \\
\hline 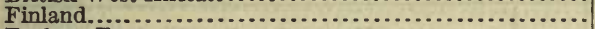 & & & $1,561,912$ \\
\hline 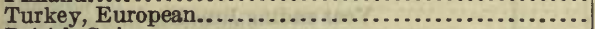 & $1,267,629$ & 761,200 & $1,448,778$ \\
\hline 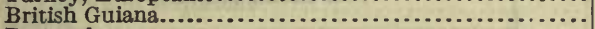 & $1,238,866$ & $1,262,032$ & $1,302,025$ \\
\hline 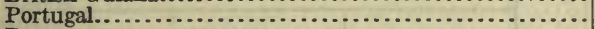 & $2,599,106$ & $1,745,859$ & $1,293,581$ \\
\hline . & 807,269 & $1,302,305$ & $1,283,015$ \\
\hline (n) & $1,000,780$ & 857,939 & $1,261,108$ \\
\hline (n) & $1,312,161$ & 864,018 & $1,203,121$ \\
\hline Venezuela......... & 920,606 & 968,044 & $1,070,243$ \\
\hline (n) & 733,190 & 910,505 & $1,009,487$ \\
\hline (n) & 703,858 & 884,923 & 945,006 \\
\hline (n. & 854,221 & 743,049 & 883,201 \\
\hline Chile & 450,871 & 594,430 & 869,972 \\
\hline . & 630,782 & 645,337 & 841,435 \\
\hline (2. & 710,294 & 819,897 & 806,457 \\
\hline 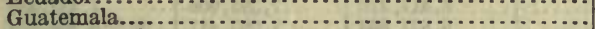 & 634,572 & 565,248 & 780,271 \\
\hline 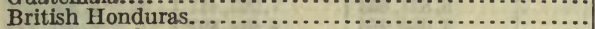 & 504,667 & 566,215 & 683,978 \\
\hline 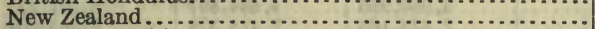 & 506,912 & 462,209 & 670,208 \\
\hline 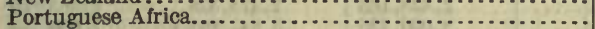 & $1,674,430$ & 705,059 & 641,902 \\
\hline (2) & 569,719 & 542,637 & 629,956 \\
\hline 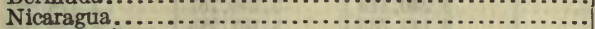 & 397,612 & 591,440 & 601,902 \\
\hline Dutch Guiana & 452,604 & 496,257 & 514,469 \\
\hline French Africa.... & 845,670 & 695,009 & 470,083 \\
\hline (n) & 192,606 & 240,369 & 428,245 \\
\hline (n) & 404,228 & 388,965 & 423,491 \\
\hline (1) & 687,310 & 174,038 & 423,195 \\
\hline (1) & 251,713 & 283,899 & 346,401 \\
\hline Salvador.. & 323,549 & 345,902 & 329,822 \\
\hline Dutch Wes & 341,439 & 290,824 & 328,271 \\
\hline Danish West Indies.... & 948 & 308,856 & 325,391 \\
\hline Ro & 334,878 & 137,675 & 319,537 \\
\hline ds...... & 151,356 & 83,850 & 298,154 \\
\hline French Guiana.... & 313,314 & 245,909 & 251,761 \\
\hline Gibraltar & 422,830 & 160,880 & 248,257 \\
\hline British $\mathrm{O}$ & 27,755 & 12,528 & 226,877 \\
\hline 年 & 942,716 & 86,656 & 213,028 \\
\hline British & 533 & 154,257 & 204,142 \\
\hline Malta and Cyprus & 407 & 133,183 & 181,334 \\
\hline French Oceania.. & 137,484 & 181,681 & 174,449 \\
\hline n Africa... & 128,253 & 121,740 & 143,703 \\
\hline Bolivia. & 27,806 & 62,005 & 117,617 \\
\hline Russia, Asi & 473,492 & 226,601 & 114,023 \\
\hline Dutch East Indies. & 56,763 & 63,723 & 96,911 \\
\hline Straits Settlements. & 330,384 & 156,584 & 81,260 \\
\hline
\end{tabular}


TABLE 4.-Value of EXPORTS of domestic FARM products, 1909-1911, by countries to which consigned-Continued.

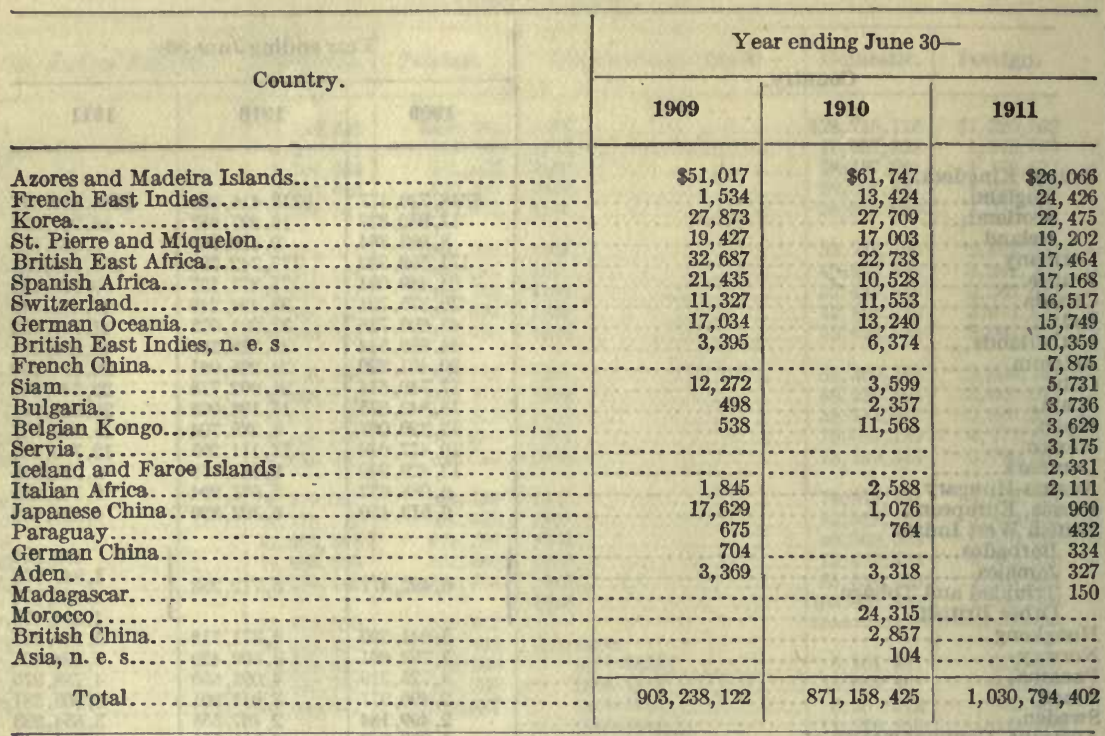

TABLE 5.-Value of EXPORTS of domestic FOREST products, 1909-1911, by countries to which consigned.

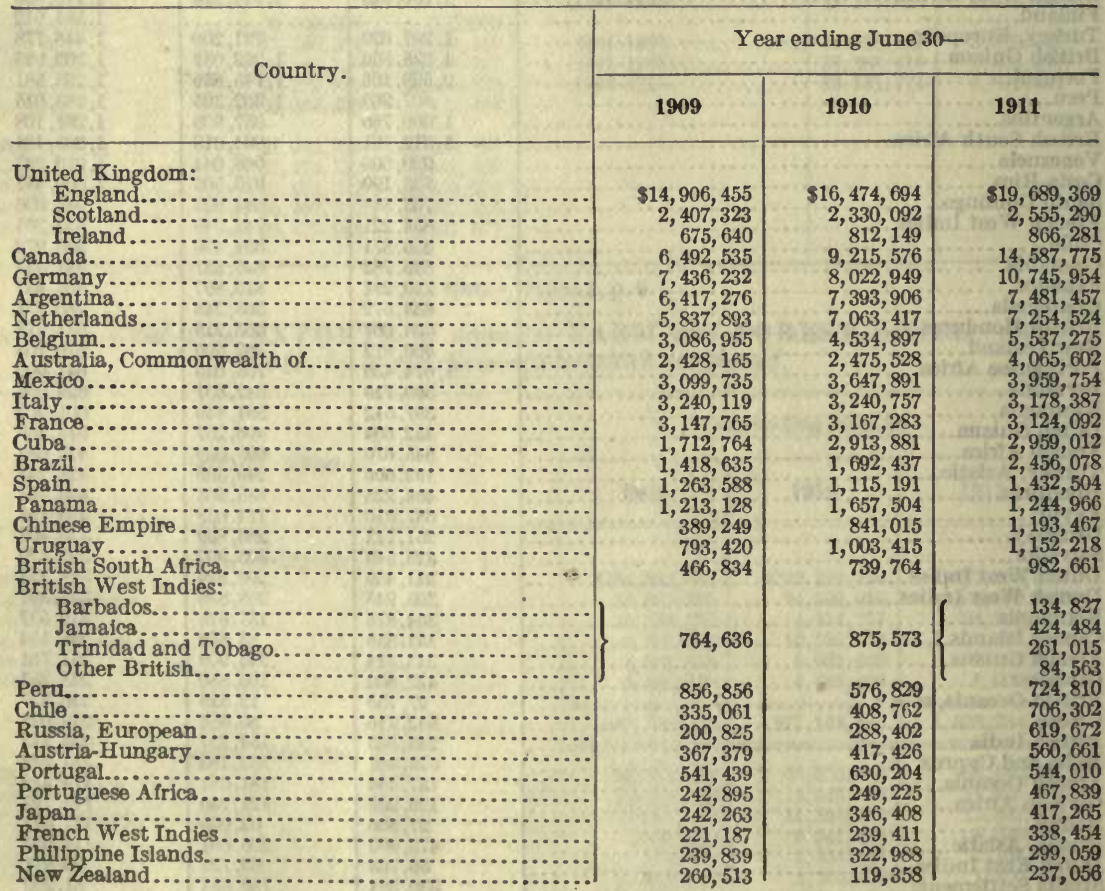


TABLE 5.-Value of EXPORTS of domestic FOREST products, 1909-1911, by countries to which consigned-Continued.

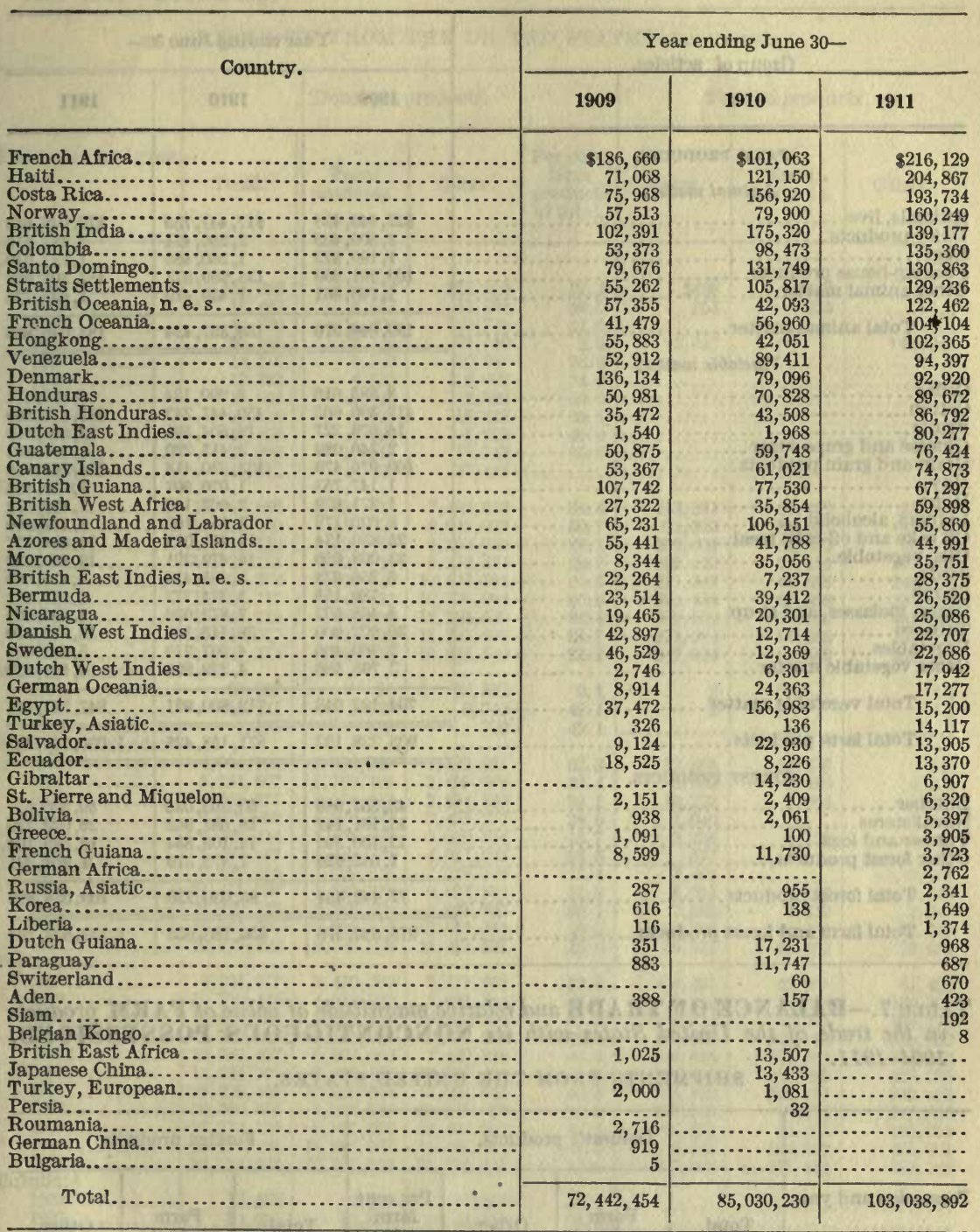


TABLE 6.-Value of principal groups of EXPORTS of domestic FARM and FOREST products, 1909-1911.

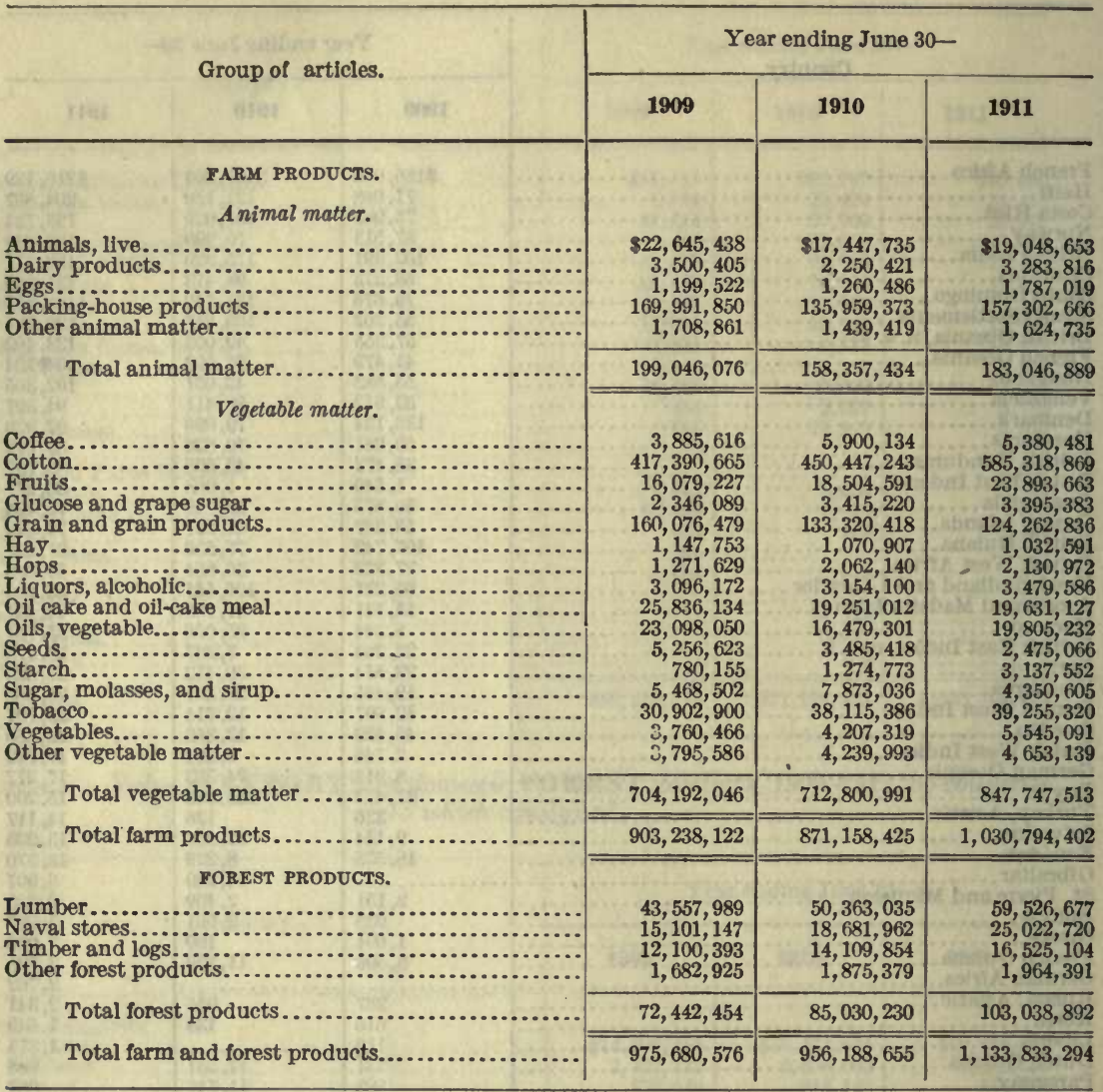

TABLE 7.-BALANCE OF TRADE and relative magnitude of value of FARM products in the trade of the United States with its NONCONTIGUOUS POSSESSIONS, 1901-1911.

\section{SHIPMENTS FROM THE UNITED STATES.}

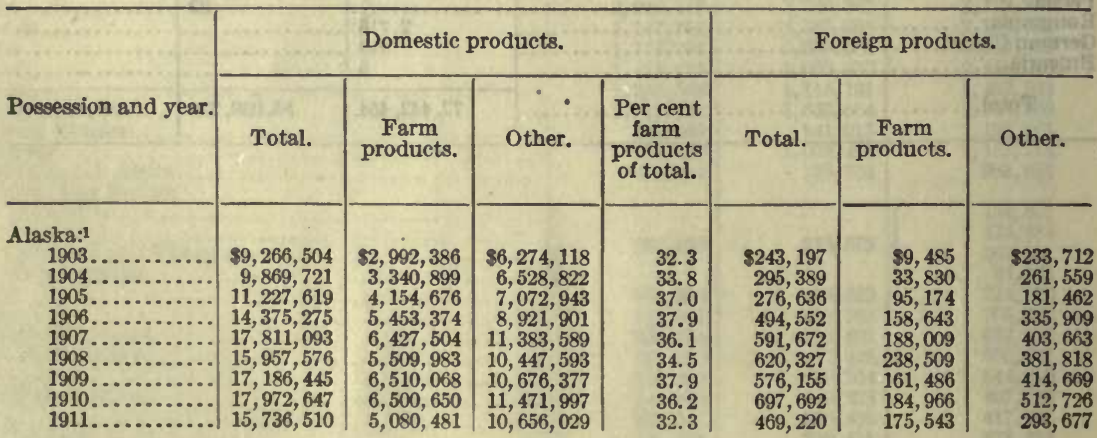

1 Not stated for 1901 and 1902. 
TABLE 7.-BALANCE OF TRADE and relative magnitude of value of FARM products in the trade of the United States with its NONCONTIGUOUS POSSESSIONS, 1901-1911-Continued.

SHIPMENTS FROM THE UNITED STATES-Continued.

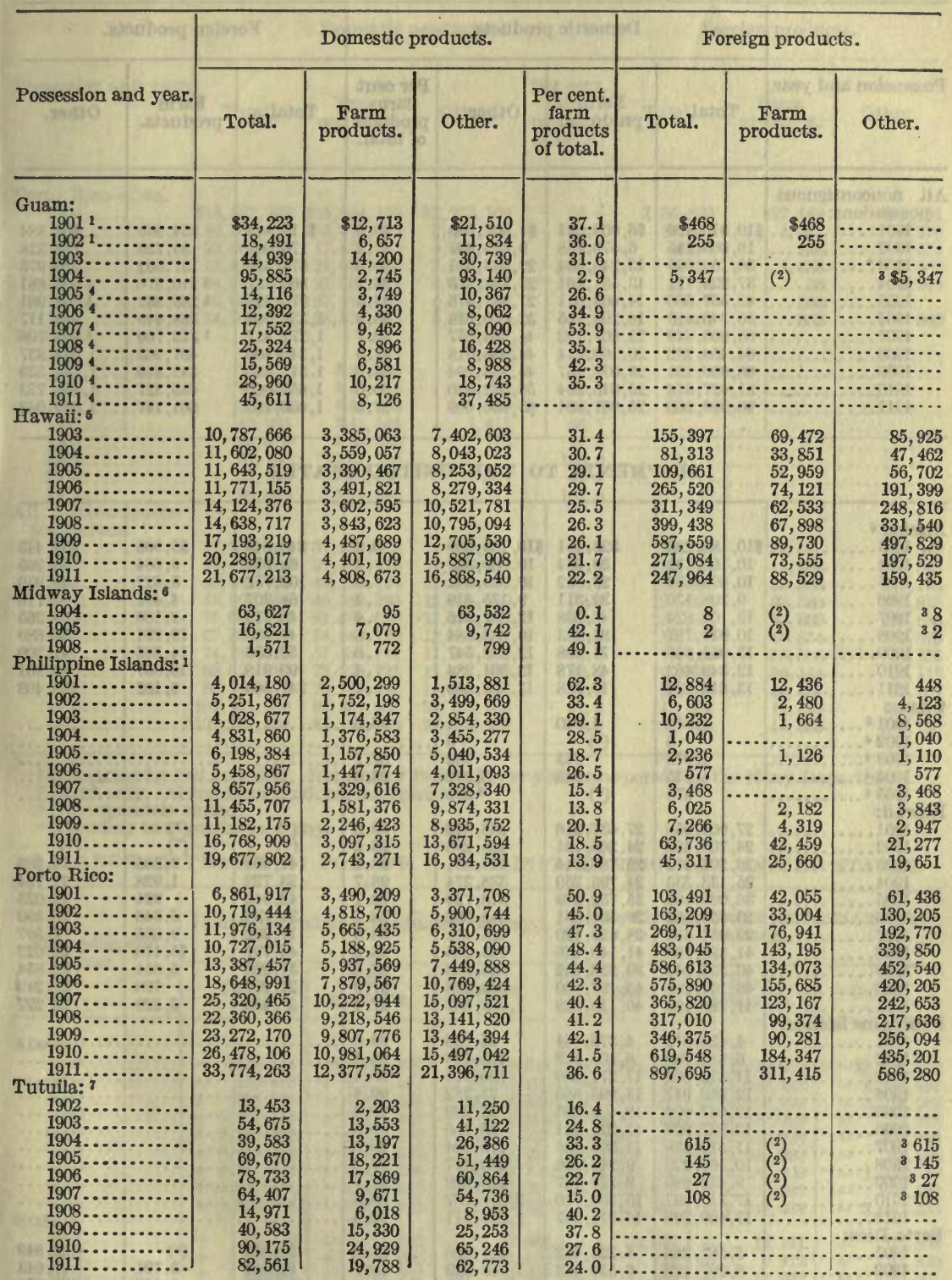

1 Exports from the United States.

Not separately stated.

Including farm products, if any.

4 Receipts into Guam from the United States, including foreign merchandise, if any. Reported by the

6 Not stated for 1901 and 1902.

6 Not stated prior to 1904, and no shipments reported for 1906, 1907, 1909, 1910, or 1911.

7 Not stated prior to 1902 .

$50597^{\circ}-$ Bull. $96-12-2$ 
TABLE 7-BALANCE OF TRADE and relative magnitude of value of FARM products in the trade of the United States with its NONCONTIGUOUS POSSESSIONS, 1901-1911-Continued.

SHIPMENTS FROM THE UNITED STATES-Continued.

\begin{tabular}{|c|c|c|c|c|c|c|c|}
\hline \multirow[b]{2}{*}{ Possession and year. } & \multicolumn{4}{|c|}{ Domestle products. } & \multicolumn{3}{|c|}{ Forelgn products. } \\
\hline & Total. & $\begin{array}{c}\text { Farm } \\
\text { products. }\end{array}$ & Other. & $\begin{array}{l}\text { Per cent } \\
\text { farm } \\
\text { products } \\
\text { of total. }\end{array}$ & Total. & $\begin{array}{l}\text { Farm } \\
\text { products. }\end{array}$ & Other. \\
\hline 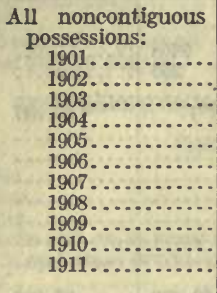 & $\begin{array}{r}\$ 10,910,320 \\
16,003,255 \\
36,158,595 \\
37,229,771 \\
42,557,586 \\
50,345,413 \\
65,995,849 \\
64,454,232 \\
68,890,161 \\
81,627,814 \\
90,993,960\end{array}$ & $\begin{array}{r}\$ 6,003,221 \\
6,579,758 \\
13,244,984 \\
13,481,501 \\
14,669,611 \\
18,294,735 \\
21,601,792 \\
20,169,214 \\
23,073,867 \\
25,015,284 \\
25,037,891\end{array}$ & $\begin{array}{r}\$ 4,907,099 \\
9,423,497 \\
22,913,611 \\
23,748,270 \\
27,887,975 \\
32,050,678 \\
44,394,057 \\
44,285,018 \\
45,816,294 \\
56,612,530 \\
65,956,069\end{array}$ & $\begin{array}{l}55.0 \\
41.1 \\
36.6 \\
36.2 \\
34.5 \\
36.3 \\
32.7 \\
31.3 \\
33.5 \\
30.6 \\
27.5\end{array}$ & $\begin{array}{r}\$ 116,843 \\
170,067 \\
678,537 \\
866,757 \\
975,293 \\
1,336,566 \\
1,272,417 \\
1,342,800 \\
1,517,355 \\
1,652,060 \\
1,660,190\end{array}$ & $\begin{array}{r}\$ 54,959 \\
35,739 \\
157,562 \\
1210,876 \\
1283,332 \\
388,449 \\
1373,709 \\
407,963 \\
345,816 \\
485,327 \\
601,147\end{array}$ & $\begin{array}{r}\$ 61,884 \\
134,328 \\
520,975 \\
1655,881 \\
1691,961 \\
948,117 \\
1898,708 \\
934,837 \\
1,171,539 \\
1,166,733 \\
1,059,043\end{array}$ \\
\hline
\end{tabular}

SHIPMENTS TO THE UNITED STATES.

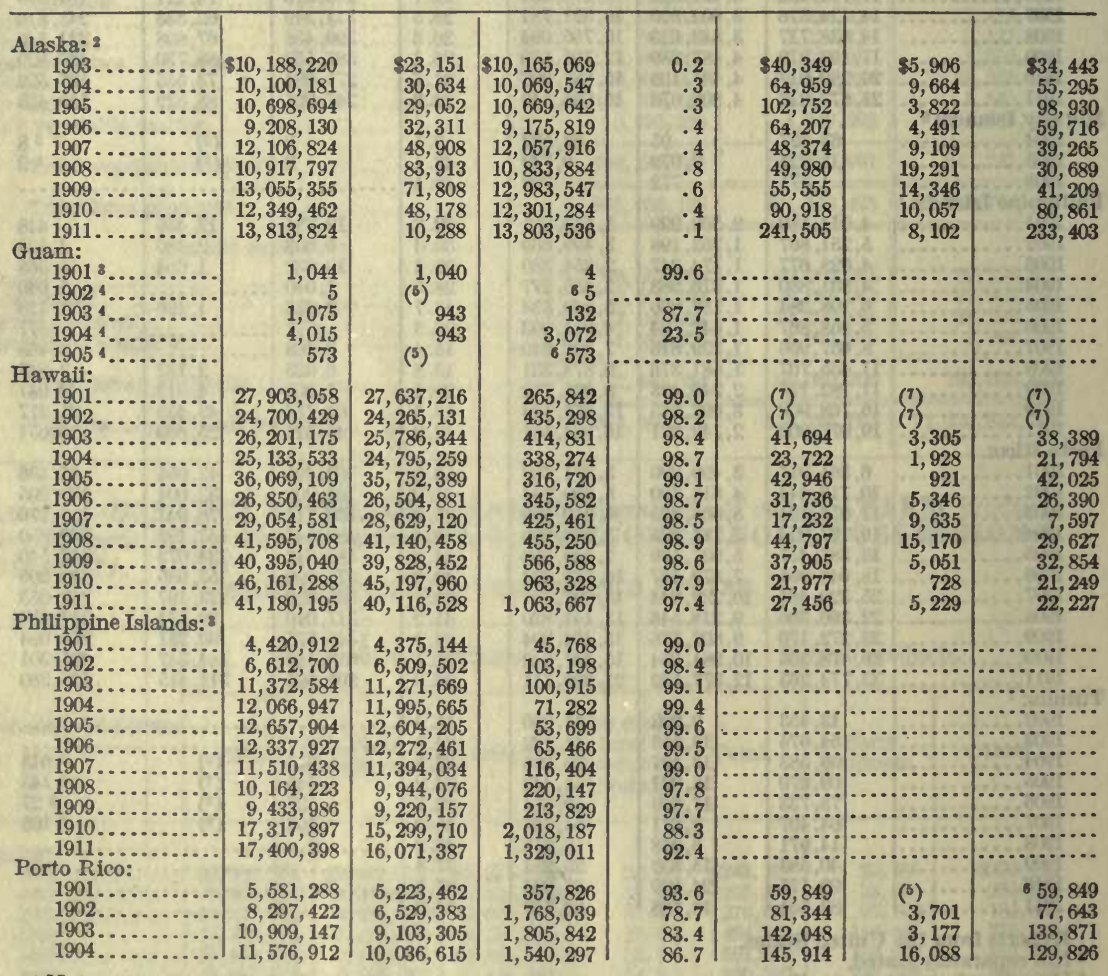

1 Not exact, due to lack of complete returns to show how much foreign merchandise consisted of farm products.

2 Not stated for 1901 and 1902.

Imports into the United States, including foreign merchandise, if any.

4 Shipments to the United States as reported by the Navy Department.

6 Not separately stated.

Including farm products, if any.
7 Not stated. 
TABLE 7.-BALANCE OF TRADE and relative magnitude of value of FARM products in the trade of the United States with its NONCON'TIGUOUS POSSESSIONS, 1901-1911-Continued.

SHIPMENTS TO THE UNITED STATES-Continued.

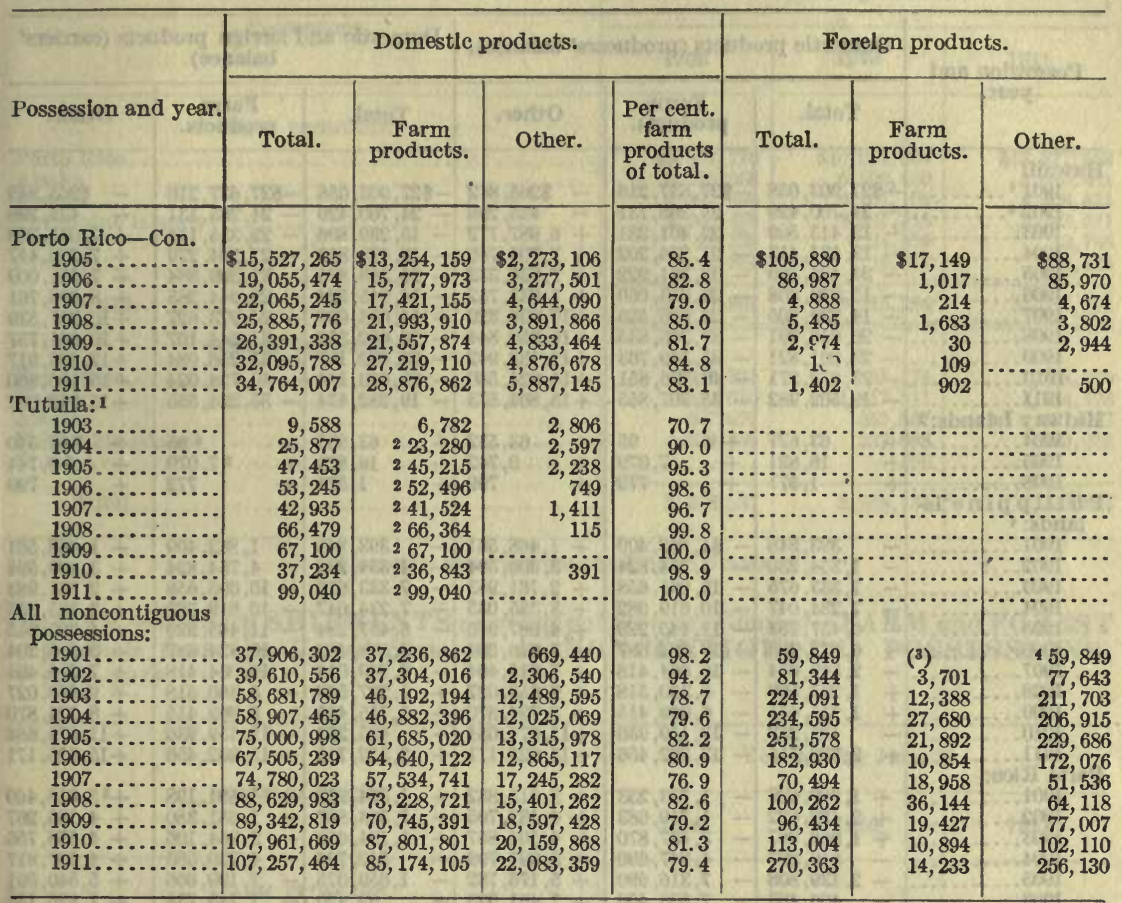

1 Not stated for 1901 and 1902 . Returns for 1903 and later years as reported by the Navy Department.

2 Copra only. Other farm products not specified.

8 Not separately stated.

4 Including farm products, if any.

BALANCE OF TRADE $(+)$ FOR, OR $(\rightarrow$ AGAINST, CONTIGUOUS UNITED STATES.

\begin{tabular}{|c|c|c|c|c|c|c|}
\hline \multirow[t]{2}{*}{ Possession and } & \multicolumn{3}{|c|}{ Domestic products (producers' balance). } & \multicolumn{3}{|c|}{$\begin{array}{l}\text { Domestic and foreign products (carriers' } \\
\text { balance). }\end{array}$} \\
\hline & Total. & $\begin{array}{l}\text { Farm } \\
\text { products. }\end{array}$ & Other. & Total. & $\begin{array}{c}\text { Farm } \\
\text { products. }\end{array}$ & Other. \\
\hline Alaska:1 & & & & & & \\
\hline 1903 & $\$ 921,716$ & $+\$ 2,969,235$ & $-\$ 3,890,951$ & $-\$ 718,868$ & $+\$ 2,972,814$ & $-\$ 3,691,682$ \\
\hline 1904 & & 10,265 & $-3,540,725$ & & +3 & - \\
\hline $\begin{array}{l}1905 . \\
1906 .\end{array}$ & $\begin{array}{r}528,925 \\
+5,167,145\end{array}$ & 25,624 & $\begin{array}{l}-3,596,699 \\
-\quad 253\end{array}$ & + & +4, & \\
\hline 1907 & $\begin{array}{r}+5,108,140 \\
+5,704,269\end{array}$ & $\begin{array}{l}+5 \\
+6\end{array}$ & $\begin{array}{l}253,918 \\
674,327\end{array}$ & $\begin{array}{l}+0 \\
+6\end{array}$ & $\begin{array}{l}+5,08 \\
+6,55\end{array}$ & $\begin{array}{r}22,275 \\
309,929\end{array}$ \\
\hline 1908 & $+5,039,779$ & 26,070 & 386,291 & 126 & +5 & - \\
\hline 190 & $+4,131,090$ & +6 & $-2,307,170$ & & & $-1,93$ \\
\hline 1910 & $+5,623,185$ & 2,472 & $\begin{array}{l}829,287 \\
\end{array}$ & & + & 397 \\
\hline Guam: & + & 193 & $-3,147,507$ & + & 37,634 & $-3,087,233$ \\
\hline 1901. & 33,179 & 11,673 & 21,506 & + & 12 & + \\
\hline & $t$ & i & & & & \\
\hline $\begin{array}{l}19 \\
19 \\
19\end{array}$ & $\stackrel{+}{t}$ & + & + & \pm & + & + \\
\hline & 13,543 & + & $\stackrel{+}{+}$ & $t$ & + & $\begin{array}{r}95,415 \\
9,794\end{array}$ \\
\hline 19 & 12,392 & 4,330 & 8,062 & + & + & 8,062 \\
\hline & 17,552 & + & & + & & 8,090 \\
\hline & 25,324 & + & 16, & & & 16,428 \\
\hline & & & & + & & 8,988 \\
\hline 19 & & $\begin{array}{r}10,217 \\
8,126\end{array}$ & & & 10 , & + \\
\hline & & & & & & \\
\hline
\end{tabular}

1 Not stated for 1901 and 1902 .

2 Not exact, due to lack of complete returns to show how much of foreign merchandise consisted of farm products. 
TABLE 7.-BALANCE OF TRADE and relative magnitude of value of FARM products in the trade of the United States with its NONCONTIGUOUS POSSESSIONS, 1901-1911-Continued.

BALANCE OF TRADE (+) FOR, OR (-) AGAINST, CONTIGUOUS UNITED STATES-Contd.

\begin{tabular}{|c|c|c|c|c|c|c|}
\hline \multirow{2}{*}{$\begin{array}{l}\text { Possession and } \\
\text { year. }\end{array}$} & \multicolumn{3}{|c|}{ Domestic products (producers' balance). } & \multicolumn{3}{|c|}{$\begin{array}{l}\text { Domestic and forelgn products (carrlers' } \\
\text { balance). }\end{array}$} \\
\hline & Total. & & Other. & Total. & & Other. \\
\hline 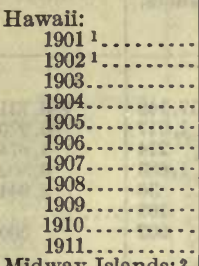 & $\begin{array}{l}-\$ 27,903,058 \\
-24,700,429 \\
-15,413,509 \\
-13,531,453 \\
-24,425,590 \\
-15,079,308 \\
-14,930,205 \\
-26,956,991 \\
-23,201,821 \\
-25,872,271 \\
-19,502,982\end{array}$ & $\begin{array}{l}-\$ 27,637,216 \\
-24,265,131 \\
-22,401,281 \\
-21,236,202 \\
-32,361,922 \\
-23,013,060 \\
-25,026,525 \\
-37,296,835 \\
-35,340,763 \\
-40,796,851 \\
-35,307,855\end{array}$ & $\begin{array}{r}\$ 265,842 \\
-\quad 435,298 \\
+\quad 6,987,772 \\
+7,704,749 \\
+7,936,332 \\
+7,933,752 \\
+10,096,320 \\
+10,339,844 \\
+12,138,942 \\
+14,924,580 \\
+15,804,873\end{array}$ & $\begin{array}{l}-\$ 27,903,058 \\
-24,700,429 \\
-15,299,806 \\
-13,473,862 \\
-24,358,875 \\
-14,845,524 \\
-14,636,088 \\
-26,602,350 \\
-22,652,167 \\
-25,623,164 \\
-19,282,474\end{array}$ & $\begin{array}{l}-\$ 27,637,216 \\
-24,265,131 \\
-22,335,114 \\
-21,204,279 \\
-32,309,884 \\
-22,944,285 \\
-24,973,627 \\
-37,244,107 \\
-35,256,084 \\
-40,724,024 \\
-35,224,555\end{array}$ & $\begin{array}{r}\$ 265,842 \\
-\quad 435,298 \\
+\quad 7,035,308 \\
+7,730,417 \\
+7,951,009 \\
+8,098,761 \\
+10,337,539 \\
+10,641,757 \\
+12,603,917 \\
+15,100,860 \\
+15,942,081\end{array}$ \\
\hline $\begin{array}{r}\text { Iidway Isl } \\
1904 \ldots \\
1905 . . . \\
1908 . .\end{array}$ & $\begin{array}{rr}+\quad 63,627 \\
+\quad 16,821 \\
+\quad 1,571\end{array}$ & $\begin{array}{rr}+ & 95 \\
+ & 7,079 \\
+ & 772\end{array}$ & $\begin{array}{r}+\quad 63,532 \\
+\quad 9,742 \\
+\quad 799\end{array}$ & $\begin{array}{rr}+ & 63,635 \\
+ & 16,823 \\
+ & 1,571\end{array}$ & $\begin{array}{rr} & 395 \\
+ & 39079 \\
+ & 772\end{array}$ & $\begin{array}{r}+\quad 363,540 \\
+\quad 89,744 \\
+\quad 799\end{array}$ \\
\hline 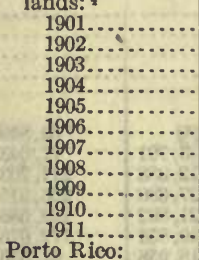 & $\begin{array}{r}393,848 \\
-\quad 1,354,230 \\
-\quad 7,333,675 \\
-\quad 7,234,047 \\
-\quad 6,457,284 \\
-\quad 6,878,483 \\
-\quad 2,849,014 \\
+\quad 1,297,509 \\
+\quad 1,755,455 \\
\quad 485,252 \\
+\quad 2,322,715\end{array}$ & $\begin{array}{r}-\$ 1,862,409 \\
-\quad 4,754,824 \\
-10,095,658 \\
-10,619,082 \\
-11,445,229 \\
-10,824,687 \\
-10,064,418 \\
=\quad 8,360,518 \\
-\quad 6,969,415 \\
-12,159,936 \\
-13,302,456\end{array}$ & $\begin{array}{r}+1,468,561 \\
+3,400,594 \\
+2,761,983 \\
+3,385,035 \\
+4,987,945 \\
+3,946,204 \\
+7,215,404 \\
+9,658,027 \\
+8,724,870 \\
+11,674,684 \\
+15,625,171\end{array}$ & $\begin{array}{l}393,848 \\
-\quad 1,354,230 \\
-\quad 7,333,675 \\
-\quad 7,234,047 \\
-\quad 6,457,284 \\
-\quad 6,878,483 \\
-\quad 2,849,014 \\
+\quad 1,297,509 \\
+\quad 1,755,455 \\
-\quad 485,252 \\
+\quad 2,322,715\end{array}$ & $\begin{array}{r} \\
-\quad 1,862,409 \\
-\quad 4,754,824 \\
-10,095,658 \\
-10,619,082 \\
-11,445,229 \\
-10,824,687 \\
-10,064,418 \\
-\quad 8,360,518 \\
-\quad 6,969,415 \\
-12,159,936 \\
-13,302,456\end{array}$ & $\begin{array}{l}+1,468,5 \\
+3,400,5 \\
+2,761,9 \\
+3,385,0 \\
+4,987,9 \\
+3,946,2 \\
+7,215,4 \\
+9,658,0 \\
+8,724,8 \\
+11,674,6 \\
+15,625,1\end{array}$ \\
\hline $\begin{array}{l}19 \\
19 \\
19 \\
19 \\
19 \\
19 \\
19 \\
19 \\
19 \\
19 \\
19\end{array}$ & $\begin{array}{r}+1,280,629 \\
+2,422,022 \\
+1,066,987 \\
-\quad 849,897 \\
-2,139,808 \\
-\quad 406,483 \\
+3,255,220 \\
-3,525,410 \\
-3,119,168 \\
-5,617,682 \\
-\quad 989,744\end{array}$ & $\begin{array}{r}-\quad 1,733,253 \\
-\quad 1,710,683 \\
-\quad 3,437,870 \\
-\quad 4,847,690 \\
-\quad 7,316,590 \\
-\quad 7,898,406 \\
-\quad 7,198,211 \\
-12,775,364 \\
-11,750,098 \\
-\quad 16,238,046 \\
-16,499,310\end{array}$ & $\begin{array}{r}+3,013,882 \\
+4,132,705 \\
+4,504,857 \\
+3,997,793 \\
+5,176,782 \\
+7,491,923 \\
+10,453,431 \\
+9,249,954 \\
+8,630,930 \\
+10,620,364 \\
+15,509,566\end{array}$ & $\begin{array}{rr}+\quad 1,324,271 \\
+\quad 2,503,887 \\
+\quad 1,194,650 \\
-\quad 512,766 \\
-\quad 1,659,075 \\
+\quad 82,420 \\
+\quad 3,616,152 \\
-\quad 3,213,885 \\
-\quad 2,775,767 \\
-\quad 4,998,243 \\
-\quad 93,451\end{array}$ & $\begin{array}{r} \\
-\quad 81,691,198 \\
-\quad 1,681,380 \\
-\quad 3,364,106 \\
=\quad 4,720,583 \\
-\quad 7,199,666 \\
=\quad 7,743,738 \\
-\quad 7,075,258 \\
-12,677,673 \\
-11,659,847 \\
-\quad 16,053,808 \\
-16,188,797\end{array}$ & $\begin{array}{l}+4,185 \\
+\quad 4,558 \\
+\quad 4,207 \\
+5,540 \\
+7,826 \\
+10,691 \\
+9,463 \\
+8,884 \\
+11,055 \\
+16,095\end{array}$ \\
\hline $\begin{array}{r}\text { rutuila: } 5 \\
1902 . . \\
1903 . . \\
1904 . . \\
1905 . . \\
1906 . . \\
1907 . . \\
1908 . . \\
1909 . . \\
1910 . . \\
1911 . .\end{array}$ & $\begin{array}{c} \\
+\quad 13,453 \\
+\quad 45,087 \\
+\quad 13,706 \\
+\quad 22,217 \\
+\quad 25,488 \\
+\quad 21,472 \\
+\quad 51,508 \\
+\quad 26,517 \\
+\quad 52,941 \\
-\quad 16,479\end{array}$ & $\begin{array}{cc} & \\
+ & 2,203 \\
+ & 6,771 \\
- & 10,083 \\
- & 26,994 \\
- & 34,627 \\
- & 31,853 \\
- & 60,346 \\
- & 51,770 \\
- & 11,914 \\
- & 79,252\end{array}$ & $\begin{array}{rr}+ & 11,250 \\
+ & 38,316 \\
+ & 23,789 \\
+ & 49,211 \\
+ & 60,115 \\
+ & 53,325 \\
+ & 8,838 \\
+ & 25,253 \\
+ & 64,855 \\
+ & 62,773\end{array}$ & $\begin{array}{ll} & \\
+ & 13,453 \\
+ & 45,087 \\
+ & 14,321 \\
+ & 22,362 \\
+ & 25,515 \\
+ & 21,580 \\
+ & 51,508 \\
+ & 26,517 \\
+ & 52,941 \\
+ & 16,479\end{array}$ & $\begin{array}{rr} & \\
+ & 2,203 \\
+ & 6,771 \\
- & 10,083 \\
- & 326,994 \\
- & 834,627 \\
- & 31,853 \\
- & 60,346 \\
- & 51,770 \\
- & 11,914 \\
- & 79,252\end{array}$ & $\begin{array}{rr} & \\
+ & 11,250 \\
+ & 38,316 \\
+\quad 824,404 \\
+\quad 849,356 \\
+\quad 860,142 \\
+\quad 853,433 \\
+\quad 8,858 \\
+\quad 25,253 \\
+\quad 64,855 \\
+\quad 62,773\end{array}$ \\
\hline 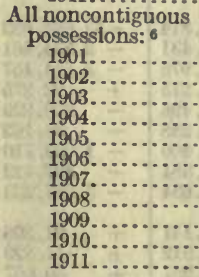 & $\begin{array}{l}-26,983,098 \\
-23,600,698 \\
-22,512,962 \\
-21,676,654 \\
-32,441,176 \\
-17,159,249 \\
-8,780,706 \\
-24,169,726 \\
-20,445,392 \\
-26,270,119 \\
-16,218,193\end{array}$ & $\begin{array}{r} \\
-31,221,205 \\
-30,721,778 \\
-32,945,546 \\
-33,400,895 \\
-47,014,283 \\
-36,345,387 \\
-35,932,949 \\
-53,057,325 \\
-47,667,205 \\
-62,744,058 \\
-60,110,554\end{array}$ & $\begin{array}{l} \\
+\quad 4,238,107 \\
+\quad 7,121,080 \\
+10,432,584 \\
+11,724,241 \\
+14,573,107 \\
+19,186,138 \\
+27,152,243 \\
+28,887,599 \\
+27,221,813 \\
+36,473,939 \\
+43,892,361\end{array}$ & $\begin{array}{r}-26,938,988 \\
-23,518,578 \\
-22,068,748 \\
-21,045,532 \\
-31,719,697 \\
-16,006,190 \\
-7,, 582,251 \\
-22,933,213 \\
-19,031,737 \\
-24,794,799 \\
-14,873,677\end{array}$ & $\begin{array}{r} \\
-31,178,682 \\
-30,692,220 \\
-32,802,036 \\
-33,217,699 \\
-46,753,969 \\
-35,967,792 \\
-35,578,193 \\
-52,687,688 \\
-47,345,135 \\
-62,312,084 \\
-59,549,300\end{array}$ & $\begin{array}{l}+28,313,398 \\
+37,517,285 \\
+44,675,623\end{array}$ \\
\hline
\end{tabular}

1 Shipments of domestic products to the United States.

2 Not stated prior to 1904, and no shipments reported for 1906, 1907, 1909, 1910, or 1911.

Not exact, due to lack of complete returns to show how much of foreign merchandise consisted of farm products.

1 For the Philippine Islands the producers' balance of trade can not be computed, owing to lack of necessary data; hence the figures for carriers' balance of trade are repeated in the columns marked "Domestic products (producers' balance)."

Shipments to the United States from Tutuila not reported for 1902; the balance of trade for this year taken to equal the shipments from the United States to Tutuila.

- Balance of trade for all contlguous possessions is computed from corresponding balances for each possession. 
TABLE 10.-SHIPMENTS of domestic FARM and FOREST products from the United States to A LASKA, 1909-1911.

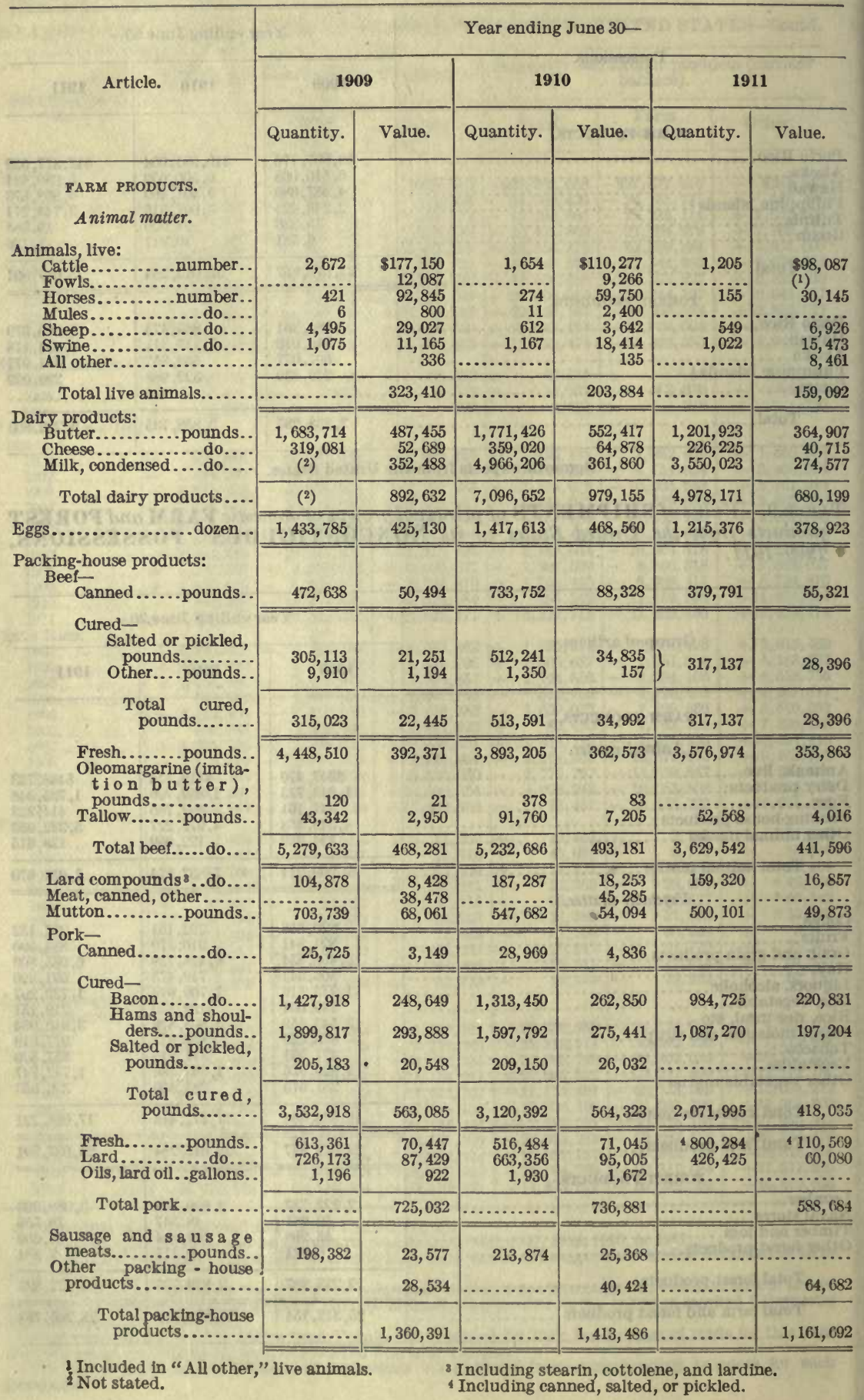


EXPORTS OF FARM AND FOREST PRODUCTS, 1909-11.

TABLE 10.-SHIPMENTS of domestic FARM and FOREST products from the United States to ALASKA, 1909-1911-Continued.

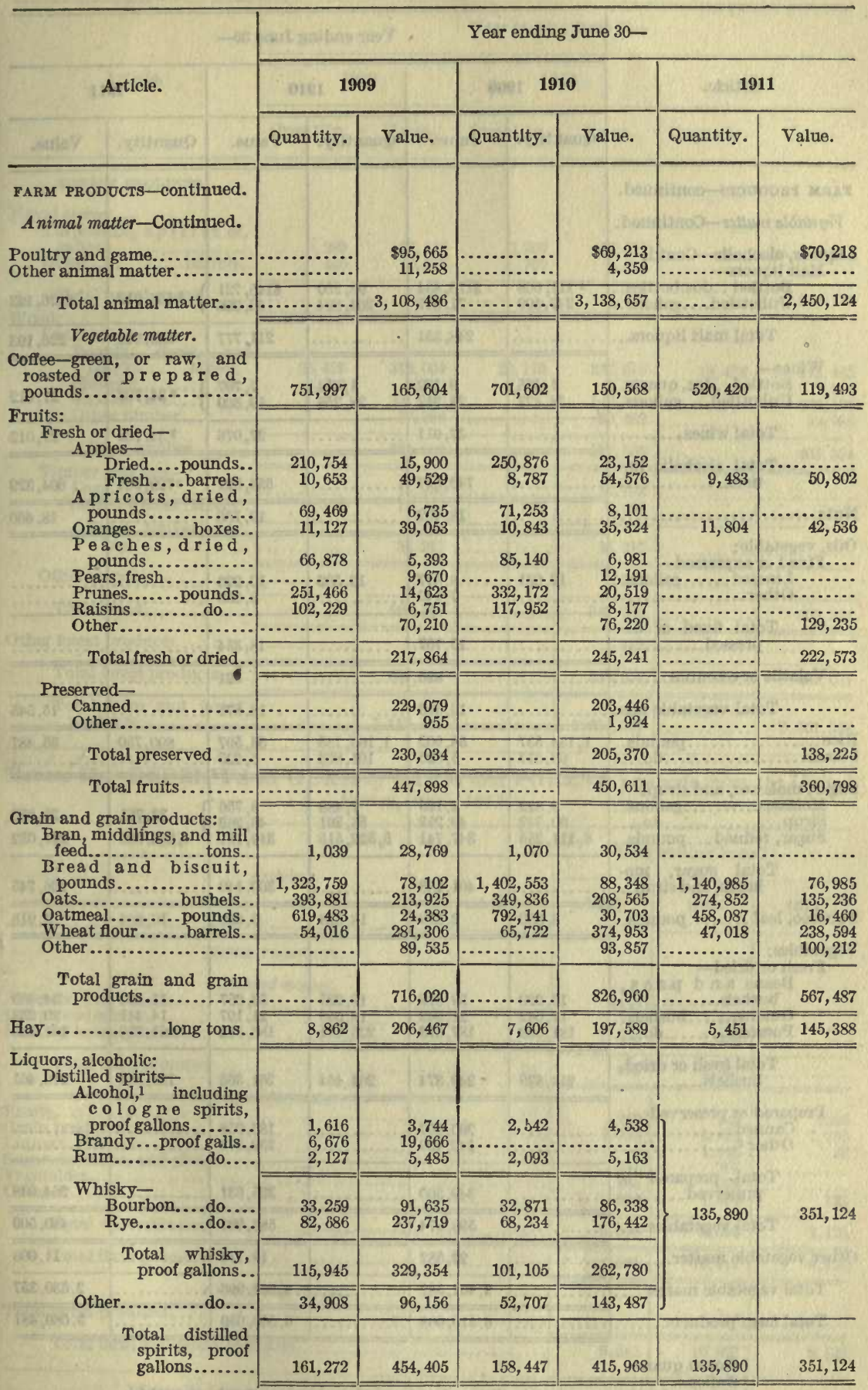

1 Excluding wood alcohol. 
TABLE 10.-SHIPMENTS of domestic FARM and FOREST products from the United States to ALASKA, 1909-1911-Continued.

\begin{tabular}{|c|c|c|c|c|c|c|}
\hline \multirow{3}{*}{ Article. } & \multicolumn{4}{|c|}{ Year ending Junc 30- } & & \\
\hline & \multicolumn{2}{|c|}{\begin{tabular}{|l|l|}
1909 \\
\end{tabular}} & \multicolumn{2}{|c|}{\begin{tabular}{|l|l|}
1910 \\
\end{tabular}} & \multicolumn{2}{|c|}{1911} \\
\hline & Quantity. & Value. & Quantity. & Value. & Quantity. & Value. \\
\hline FARM PRODUCTS-continued. & & & & & & \\
\hline Vegetable matter-Continued. & & & & & ulat & vintivits \\
\hline $\begin{array}{l}\text { Liquors, alcoholic-Contd. } \\
\text { Malt liquors- }\end{array}$ & & & คח & & & 407 \\
\hline $\begin{array}{l}\text { Bottled ..doz.bottles. } \\
\text { Unbottled....gallons.. }\end{array}$ & $\begin{array}{r}1111,668 \\
247,599 \\
\end{array}$ & $\begin{array}{r}\$ 176,834 \\
71,517 \\
\end{array}$ & $\begin{array}{r}93,250 \\
201,894 \\
\end{array}$ & $\begin{array}{r}\$ 145,721 \\
66,056 \\
\end{array}$ & 2558,912 & $\$ 226,193$ \\
\hline Total malt liquors... & & 248,351 & & 211,777 & 2558,912 & 226,193 \\
\hline $\begin{array}{l}\text { Wines- } \\
\text { Bottled...doz. quarts.. } \\
\text { Unbottled....gallons.. }\end{array}$ & $\begin{array}{r}1,565 \\
38,427\end{array}$ & $\begin{array}{r}9,199 \\
28,712 \\
\end{array}$ & $\begin{array}{r}1,414 \\
28,258\end{array}$ & $\begin{array}{r}7,707 \\
19,369\end{array}$ & 234,762 & 27,012 \\
\hline Total wines... & & 37,911 & & 27,076 & 234,762 & 27,012 \\
\hline $\begin{array}{c}\text { Total alcoholic liq- } \\
\text { uors............... }\end{array}$ & & 740,667 & & 654,821 & 2729,564 & 604,329 \\
\hline Nuts......... & & 18,402 & $\cdots$ & 19,166 & $\ldots$ & 18,650 \\
\hline $\begin{array}{l}\text { Oils, vegetable: } \\
\text { Fixed or expressed- } \\
\text { Linseed.......gallons.. } \\
\text { Other................. }\end{array}$ & $\begin{array}{r}13,631 \\
\ldots \ldots \ldots \ldots \\
\end{array}$ & $\begin{array}{l}8,617 \\
7,140 \\
\end{array}$ & $\begin{array}{r}12,562 \\
\cdots \cdots \\
\end{array}$ & $\begin{array}{r}10,296 \\
8,058 \\
\end{array}$ & - & (n.... \\
\hline $\begin{array}{r}\text { Total fixed or ex- } \\
\text { pressed.............. }\end{array}$ & $\ldots \ldots$ & 15,757 & $\ldots$ & 18,354 & $\underline{\cdots}$ & \\
\hline Volatile or essential... & $\cdots \ldots$ & 836 & $\cdots$ & 521 & $\cdots$ & \\
\hline Total vegetable oils. & …......... & 16,593 & n........... & $-18,875$ & n........... & 15,545 \\
\hline 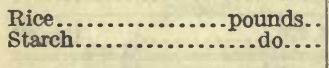 & $\begin{array}{r}1,134,537 \\
93,677 \\
\end{array}$ & $\begin{array}{r}58,902 \\
5,826 \\
\end{array}$ & $\begin{array}{r}1,166,735 \\
101,803 \\
\end{array}$ & $\begin{array}{r}54,597 \\
6,225 \\
\end{array}$ & $\begin{array}{r}890,750 \\
\ldots \ldots \ldots \ldots \ldots \\
\end{array}$ & $\begin{array}{r}36,487 \\
\cdots \cdots \\
\end{array}$ \\
\hline $\begin{array}{l}\text { Sugar, molasses, and sirup: } \\
\text { Molasses........... gallons.. } \\
\text { Sirup............................. } \\
\text { Sugar, refined... pounds.. }\end{array}$ & $\begin{array}{r}8,322 \\
60,342 \\
6,111,255 \\
\end{array}$ & $\begin{array}{r}4,195 \\
49,252 \\
347,741 \\
\end{array}$ & $\begin{array}{r}7,488 \\
53,201 \\
5,522,515 \\
\end{array}$ & $\begin{array}{r}3,756 \\
46,262 \\
319,131 \\
\end{array}$ & $\begin{array}{r}33,761 \\
4,296,000 \\
\end{array}$ & $\begin{array}{r}25,693 \\
241,052 \\
\end{array}$ \\
\hline $\begin{array}{c}\text { Total sugar, mo- } \\
\text { lasses, and sirup... }\end{array}$ & & 401,188 & $\ldots \ldots$ & 369,149 & $\ldots \ldots$ & 266,745 \\
\hline Tobacco, leaf ......... pounds.. & 8,330 & 2,559 & 18,623 & 6,659 & 10,884 & 3,918 \\
\hline 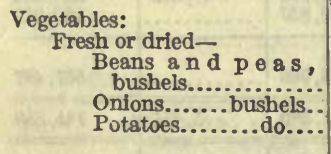 & $\begin{array}{r}16,229 \\
17,042 \\
181,568 \\
\end{array}$ & $\begin{array}{r}39,819 \\
21,942 \\
187,613 \\
\end{array}$ & $\begin{array}{r}19,225 \\
18,658 \\
226,581 \\
\end{array}$ & $\begin{array}{r}53,657 \\
21,197 \\
186,512 \\
\end{array}$ & $\begin{array}{r}11,893 \\
14,441 \\
164,250 \\
\end{array}$ & $\begin{array}{r}34,865 \\
20,233 \\
161,363\end{array}$ \\
\hline $\begin{array}{c}\text { Total fresh or dried, } \\
\text { bushels............. }\end{array}$ & 214,839 & 249,374 & 264,464 & 261,366 & 190,584 & 216,461 \\
\hline $\begin{array}{l}\text { Prepared or preserved- } \\
\text { Canned } \\
\text { Other } 3 . . . \ldots \ldots \ldots \\
\end{array}$ & & $\begin{array}{l}206,097 \\
143,403 \\
\end{array}$ & & $\begin{array}{l}186,058 \\
139,573 \\
\end{array}$ & $\begin{array}{ll} \\
\cdots \ldots \ldots \ldots \\
\cdots\end{array}$ & $\because$ \\
\hline $\begin{array}{l}\text { Total prepared or } \\
\text { preserved......... }\end{array}$ & & 349,500 & & 325,631 & & 264,048 \\
\hline Total vegetables..... & 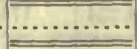 & 598,874 & & 586,997 & $\ldots \ldots \ldots \ldots$ & 480,509 \\
\hline Other vegetable matter. & … & 22,582 & $\cdots$ & 19,776 & $\ldots \ldots \ldots \ldots$ & 11,008 \\
\hline Total vegetable matter. & $\ldots$ & $3,401,582$ & & $3,361,993$ & $\ldots$ & $2,630,357$ \\
\hline Total farm products.. & $\ldots \ldots \ldots \ldots$ & $6,510,068$ & $\ldots \ldots$ & $6,500,650$ & 1............ & $5,080,481$ \\
\hline
\end{tabular}

1 Dozen quarts.

2 Gallons.

Chicfly pickles, sauces, and relishes, but including also some fresh vegetables. 
TABLE 10.-SHIPMENTS of domestic FARM and FOREST products from the United States to ALAS KA, 1909-1911-Continued.

\begin{tabular}{|c|c|c|c|c|c|c|}
\hline \multirow{3}{*}{ Article. } & \multicolumn{6}{|c|}{ Year ending June $30-$} \\
\hline & \multicolumn{2}{|c|}{1909} & \multicolumn{2}{|c|}{1910} & \multicolumn{2}{|c|}{1911} \\
\hline & Quantity. & Value. & Quantity. & Value. & Quantity. & Value. \\
\hline 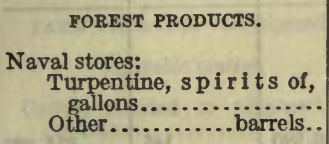 & $\begin{array}{r}5,289 \\
440\end{array}$ & $\begin{array}{r}\$ 3,341 \\
2,527\end{array}$ & $\begin{array}{r}2,769 \\
769\end{array}$ & $\begin{array}{r}\$ 2,039 \\
4,341\end{array}$ & 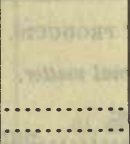 & the \\
\hline Total naval stores.. & ...... & 5,868 & $\ldots \ldots$ & 6,380 & & $\$ 17,753$ \\
\hline 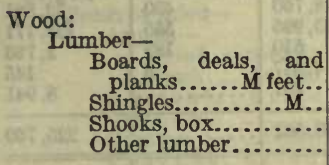 & $\begin{array}{r}23,429 \\
2,742 \\
\ldots \ldots \ldots . \\
\ldots \ldots . . .\end{array}$ & $\begin{array}{r}310,064 \\
5,503 \\
231,986 \\
17,256\end{array}$ & 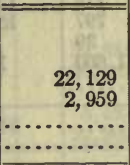 & $\begin{array}{r}334,019 \\
5,754 \\
147,314 \\
30,482 \\
\end{array}$ & 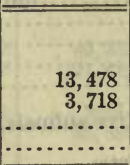 & $\begin{array}{r}213,465 \\
7,766 \\
206,107 \\
35,986\end{array}$ \\
\hline Total lumber........ & $\ldots$ & 564,809 & & 517,569 & $\ldots \ldots \ldots \ldots$ & 463,324 \\
\hline $\begin{array}{l}\text { Timber and logs- } \\
\text { Logs........................ } \\
\text { Sawed timber. }\end{array}$ & 1,377 & $\begin{array}{r}15,936 \\
17,277\end{array}$ & 800 & $\begin{array}{r}16,733 \\
9,484\end{array}$ & $\cdots$ & $\cdots$ \\
\hline $\begin{array}{c}\text { Total timber and } \\
\text { logs............... }\end{array}$ & $\cdots$ & 33,213 & & 26,217 & & \\
\hline Other wood............... & $\ldots$ & 1,337 & $\cdots$ & 202 & & ... \\
\hline Total wood..... & $\cdots$ & 599,359 & $\ldots \ldots$ & 543,988 & $\ldots \ldots \ldots \ldots$ & 463,324 \\
\hline Other forest products...... & ... & 1,850 & & 3,489 & $\ldots \ldots \ldots$ & $\ldots \ldots \ldots \ldots$ \\
\hline Total forest products.... & $\ldots \ldots \ldots \ldots$ & 607,077 & …........ & 553,857 & $\ldots \ldots \ldots$ & 481,077 \\
\hline $\begin{array}{c}\text { Total farm and forest } \\
\text { products................. }\end{array}$ & & $7,117,145$ & & $7,054,507$ & $\cdots$ & $5,561,558$ \\
\hline
\end{tabular}

TABLE 11.-RECEIPTS in GUAM of FARM and FOREST products from the United States, 1909-1911.

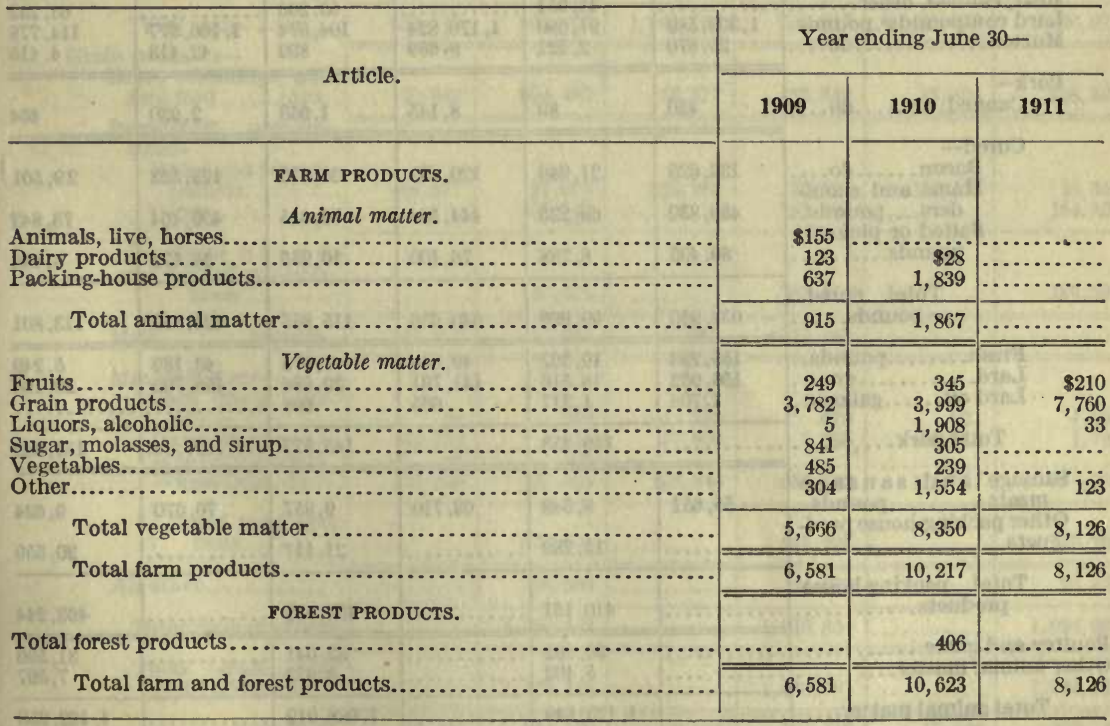

${ }^{1}$ Compiled from returns made by the naval officer in command of Guam. 
TABLE 12.-SHIPMENTS of domestic FARM and FOREST products from the United States to HAWAII, 1909-1911.

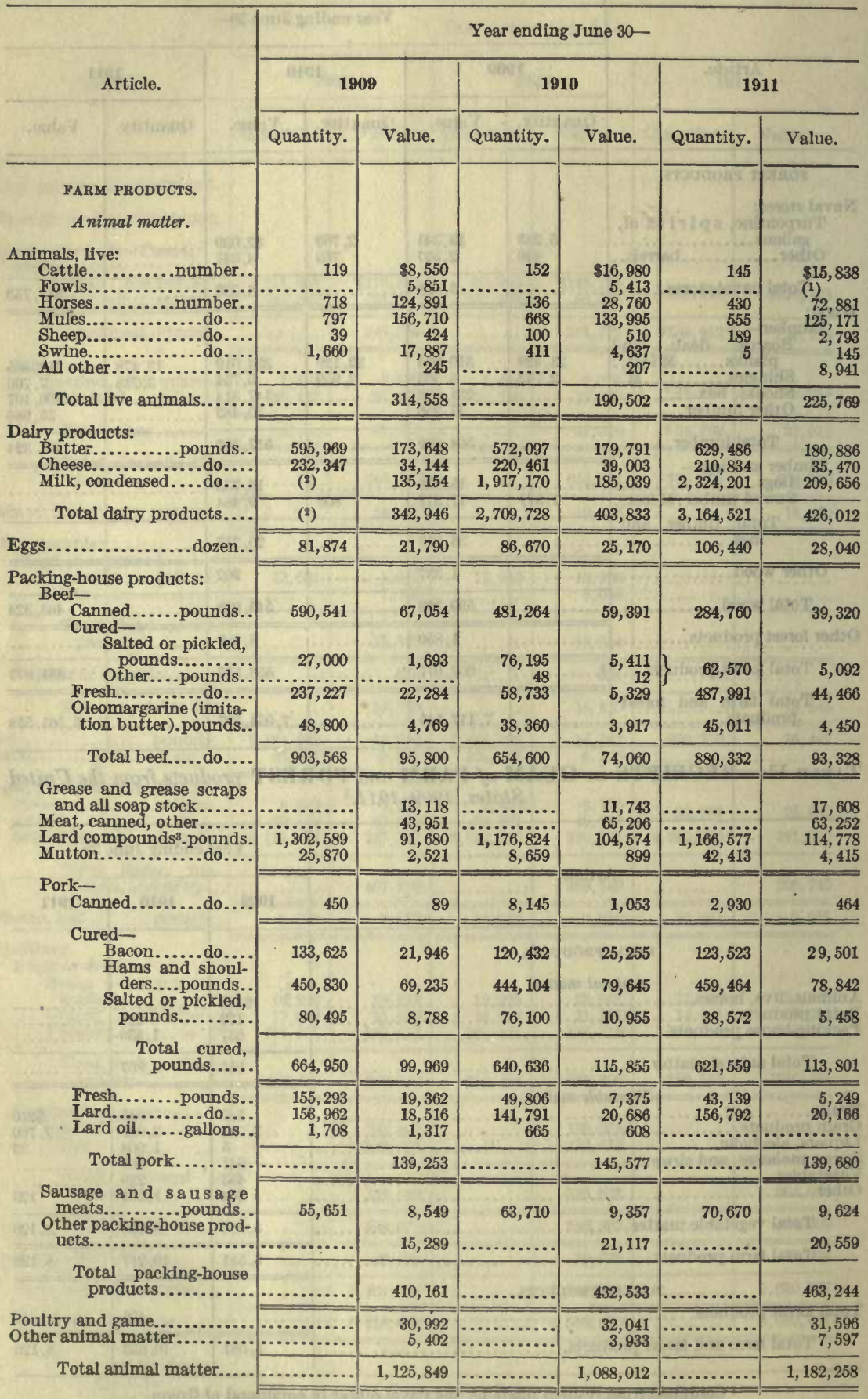

1 Included in "All other," live animals. $\quad 2$ Not stated. Including stearin, cottolene, and lardine. 
TABLE 12.-SHIPMENTS of domestic FARM and FOREST products from the United States to HAWAII, 1909-1911-Continued.

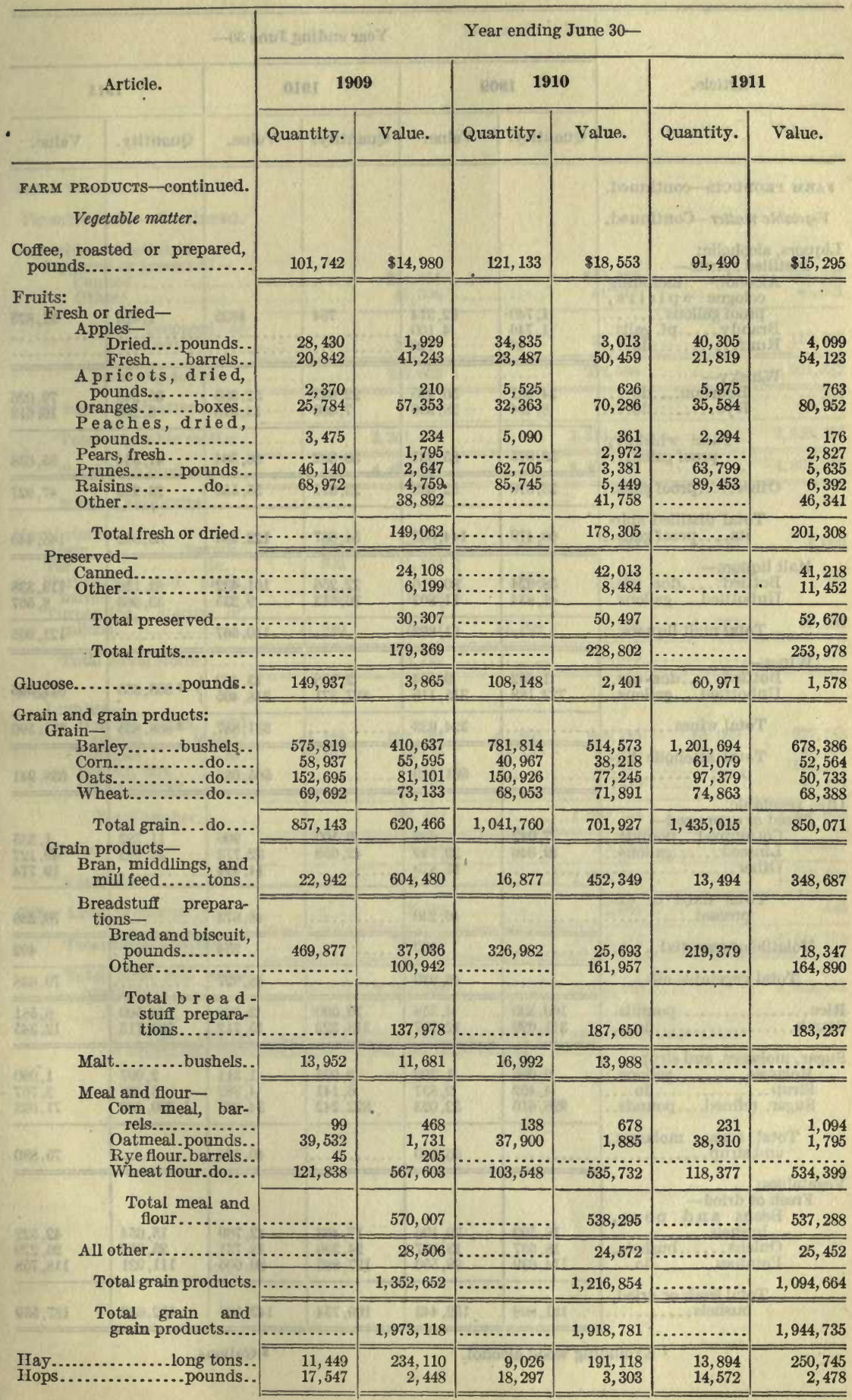


TABLE 12.-SHIPMENTS of domestic FARM and FOREST products from the United States to HAWAII, 1909-1911-Continued.

\begin{tabular}{|c|c|c|c|c|c|c|}
\hline \multirow{3}{*}{ Article. } & \multicolumn{2}{|c|}{ 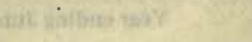 } & \multicolumn{2}{|c|}{ Year ending June $30-$} & & \\
\hline & \multicolumn{2}{|c|}{1909} & \multicolumn{2}{|c|}{1910} & \multicolumn{2}{|c|}{1911} \\
\hline & Quantity. & Value. & Quantity. & Value. & Quantity. & Value. \\
\hline $\begin{array}{l}\text { FARM PRODUCTs-continued. } \\
\text { Vegetable matter-Continued. }\end{array}$ & & & & & Iitios- & part sacy \\
\hline $\begin{array}{l}\text { Liquors, alcoholic: } \\
\text { Distilled spirits- } \\
\text { Alcohol,1 including } \\
\text { cologne spirits, } \\
\text { proof gallons ........ } \\
\text { Brandy......pf. galls.. } \\
\text { Rum...........do.... }\end{array}$ & $\begin{array}{r}1,740 \\
1,746 \\
48 \\
\end{array}$ & $\begin{array}{r}\$ 2,314 \\
4,100 \\
120 \\
\end{array}$ & $\begin{array}{r}754 \\
\cdots \cdots \\
\end{array}$ & $\begin{array}{l}\$ 625 \\
\cdots \cdots \\
\cdots\end{array}$ & $\begin{array}{c}1,016 \\
\cdots \cdots \cdots \\
\end{array}$ & 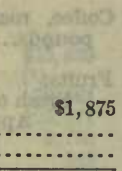 \\
\hline $\begin{array}{l}\text { Whisky- } \\
\quad \text { Bourbon....do..... } \\
\text { Rye........do.... }\end{array}$ & $\begin{array}{r}24,581 \\
8,494 \\
\end{array}$ & $\begin{array}{l}56,425 \\
28,956 \\
\end{array}$ & $\begin{array}{r}22,642 \\
7,660 \\
\end{array}$ & $\begin{array}{l}52,986 \\
13,318\end{array}$ & $\begin{array}{r}35,248 \\
6,286\end{array}$ & $\begin{array}{l}79,026 \\
16,612\end{array}$ \\
\hline $\begin{array}{c}\text { Total whiskey, } \\
\text { proof galls..... }\end{array}$ & 33,075 & 85,381 & 30,302 & 66,304 & 41,534 & 95,638 \\
\hline Other...... proof galls.. & 23,870 & 52,688 & 23,611 & 55,555 & 23,252 & 47,927 \\
\hline $\begin{array}{l}\text { Total distilled spir- } \\
\text { its.... proof galls.. }\end{array}$ & 60,479 & 144,603 & 54,667 & 122,484 & 65,802 & 145,440 \\
\hline $\begin{array}{l}\text { Malt liquors- } \\
\text { Battled.....doz. qts.. } \\
\text { Unbottled....gallons.. }\end{array}$ & $\begin{array}{l}58,624 \\
41,834 \\
\end{array}$ & $\begin{array}{l}80,016 \\
11,807\end{array}$ & $\begin{array}{l}72,256 \\
36,513 \\
\end{array}$ & $\begin{array}{r}101,432 \\
9,235\end{array}$ & $\begin{array}{l}82,138 \\
33,363 \\
\end{array}$ & $\begin{array}{r}113,338 \\
8,567 \\
\end{array}$ \\
\hline Total malt liquors... & & 91,823 & & 110,667 & & 121,905 \\
\hline $\begin{array}{l}\text { Wines- } \\
\text { Bottled......doz.qts.. } \\
\text { Unbottled....gallons.. }\end{array}$ & $\begin{array}{r}1,802 \\
722,188 \\
\end{array}$ & $\begin{array}{r}9,504 \\
315,119 \\
\end{array}$ & $\begin{array}{r}2,358 \\
827,371 \\
\end{array}$ & $\begin{array}{r}13,482 \\
318,405 \\
\end{array}$ & 868,835 & 371,596 \\
\hline Total wines.. & & 324,623 & & 331,887 & 2868,835 & 371,596 \\
\hline $\begin{array}{c}\text { Total alcoholic liq- } \\
\text { uors............. }\end{array}$ & & 561,049 & & 565,038 & & 638,941 \\
\hline $\begin{array}{l}\text { Oils, vegetable: } \\
\text { Fixed or expressed- } \\
\text { Cottonseed...pounds.. } \\
\text { Linseed.......gallons.. } \\
\text { Other................ }\end{array}$ & $\begin{array}{r}7,042 \\
49,046 \\
\cdots\end{array}$ & $\begin{array}{r}602 \\
29,749 \\
15,879 \\
\end{array}$ & $\begin{array}{r}9,590 \\
42,059 \\
\ldots \ldots .\end{array}$ & $\begin{array}{r}906 \\
32,773 \\
14,994\end{array}$ & $\begin{array}{r}11,782 \\
45,942 \\
\cdots . . .\end{array}$ & $\begin{array}{r}1,335 \\
49,127 \\
19,774\end{array}$ \\
\hline $\begin{array}{c}\text { Total fixed or ex- } \\
\text { pressed............... }\end{array}$ & & 46,230 & $\ldots \ldots$ & 48,673 & 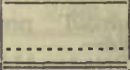 & 70,236 \\
\hline Volatile or essential........ & $\cdots$ & 700 & ............. & 254 & $\ldots \ldots \ldots \ldots$ & 402 \\
\hline Total vegetable olls..... & ......... & 46,930 & $\ldots \ldots \ldots$ & 48,927 & .............. & 70,638 \\
\hline 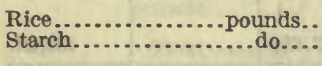 & $\begin{array}{l}109,300 \\
311,029 \\
\end{array}$ & $\begin{array}{r}4,358 \\
12,737 \\
\end{array}$ & $\begin{array}{r}70,000 \\
313,222 \\
\end{array}$ & $\begin{array}{r}2,600 \\
15,712 \\
\end{array}$ & $\begin{array}{l}144,500 \\
226,713 \\
\end{array}$ & $\begin{array}{r}6,581 \\
12,345 \\
\end{array}$ \\
\hline $\begin{array}{l}\text { Sugar, molasses, and sirup: } \\
\text { Molasses.......... gallons.. } \\
\text { Sirup...................... } \\
\text { Sugar, refined....pounds.. }\end{array}$ & $\begin{array}{r}2,986 \\
4,402 \\
926,616\end{array}$ & $\begin{array}{r}1,380 \\
2,837 \\
52,023\end{array}$ & $\begin{array}{r}2,225 \\
6,141 \\
622,242 \\
\end{array}$ & $\begin{array}{r}1,311 \\
4,382 \\
34,965 \\
\end{array}$ & $\begin{array}{r}2,097 \\
6,068 \\
1,290,489 \\
\end{array}$ & $\begin{array}{r}1,090 \\
3,767 \\
71,023 \\
\end{array}$ \\
\hline $\begin{array}{l}\text { Total sugar, molasses, } \\
\text { and sirup.............. }\end{array}$ & & 56,240 & & 40,658 & & 75,880 \\
\hline 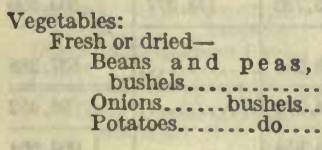 & $\begin{array}{r}18,592 \\
18,637 \\
114,639 \\
\end{array}$ & $\begin{array}{l}39,196 \\
13,697 \\
99,550 \\
\end{array}$ & $\begin{array}{r}17,463 \\
24,396 \\
127,895 \\
\end{array}$ & $\begin{array}{l}42,769 \\
18,731 \\
80,606 \\
\end{array}$ & $\begin{array}{r}15,654 \\
25,067 \\
111,921 \\
\end{array}$ & $\begin{array}{r}42,522 \\
26,279 \\
118,758 \\
\end{array}$ \\
\hline $\begin{array}{c}\text { Total fresh or dried, } \\
\text { bushels............ }\end{array}$ & 151,868 & 152,443 & 169,754 & 142,106 & 152,642 & 187,559 \\
\hline
\end{tabular}


TABLE 12.-SHIPMENTS of domestic FARM and FOREST products from the United States to HAWAII, 1909-1911-Continued.

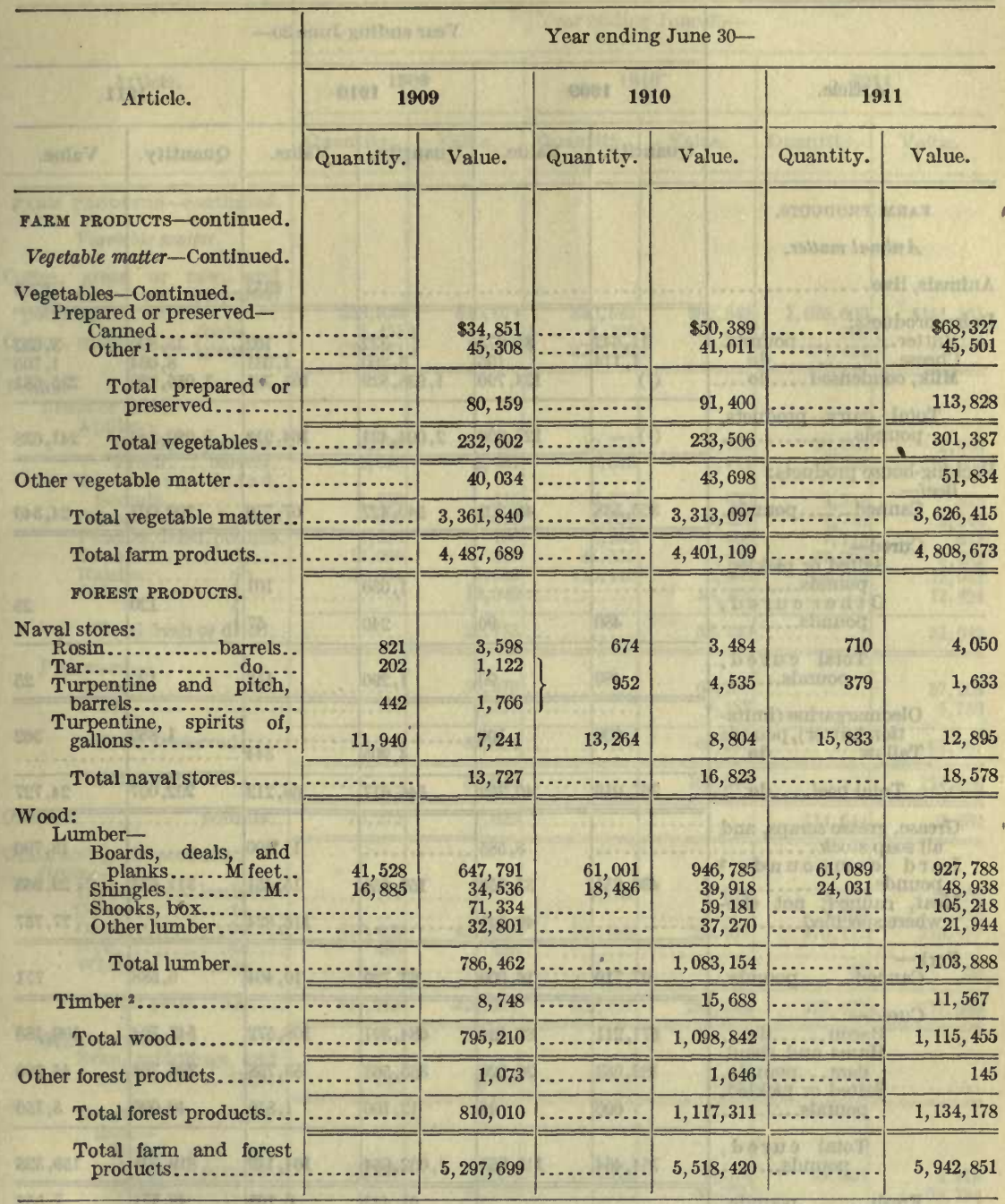

1 Chiefly pickles, sauces, and relishes, but including also some fresh vegetables.

2 Including unmanufactured wood, not elsewhere specified. 
TABLE 13.-EXPORTS of domestic FARM and FOREST products from the United States to the PHILIPPINE ISLANDS, 1909-1911.

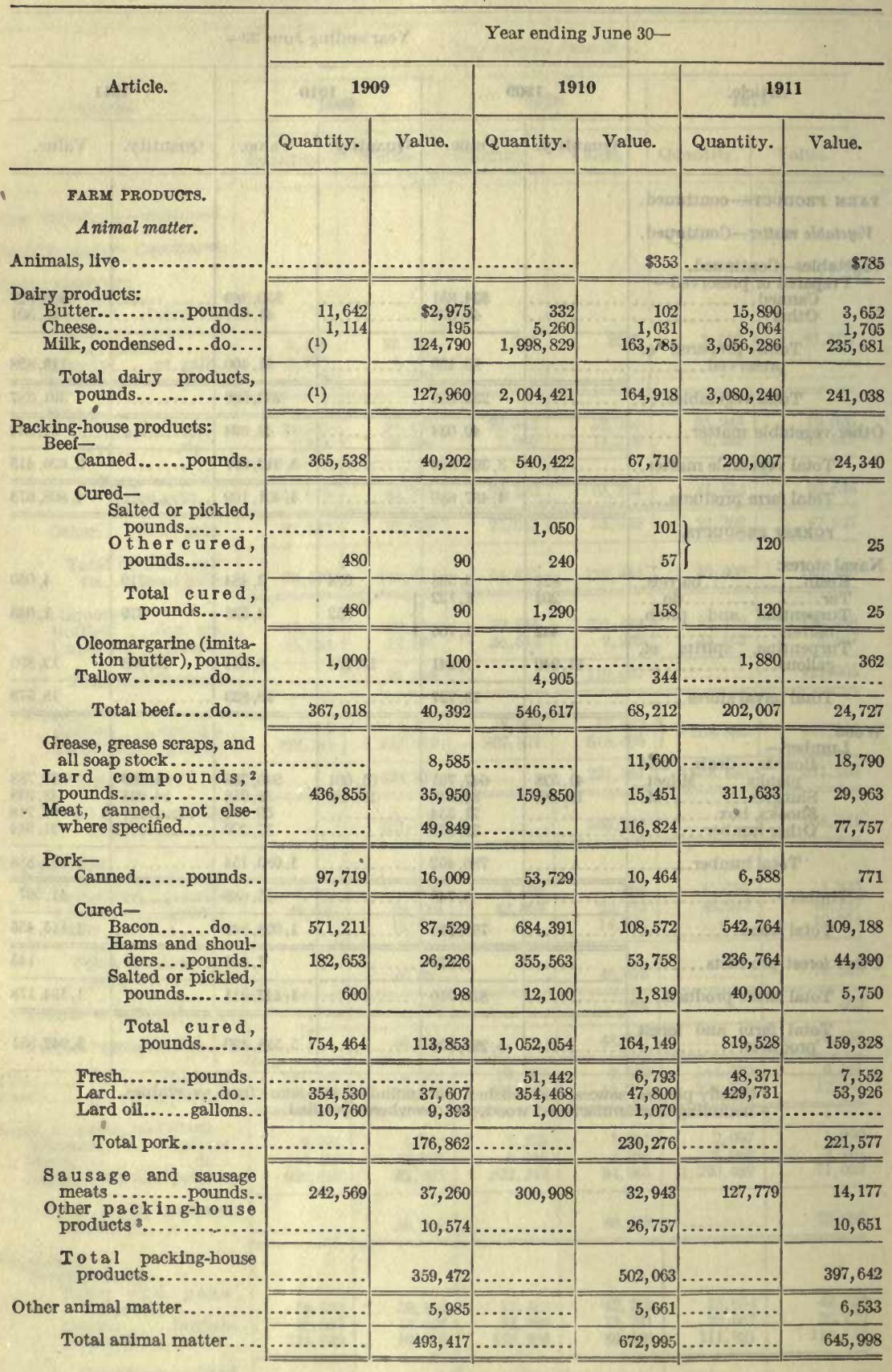

1 Not stated.

2 Including stearin, cottolene, and lardine.

Including meat, if any, not elsewhero specified. 
TABLE 13.-EXPORTS of domestic FARM and FOREST products from the United States to the PHILIPPINE IS LANDS, 1909-1911-Continued.

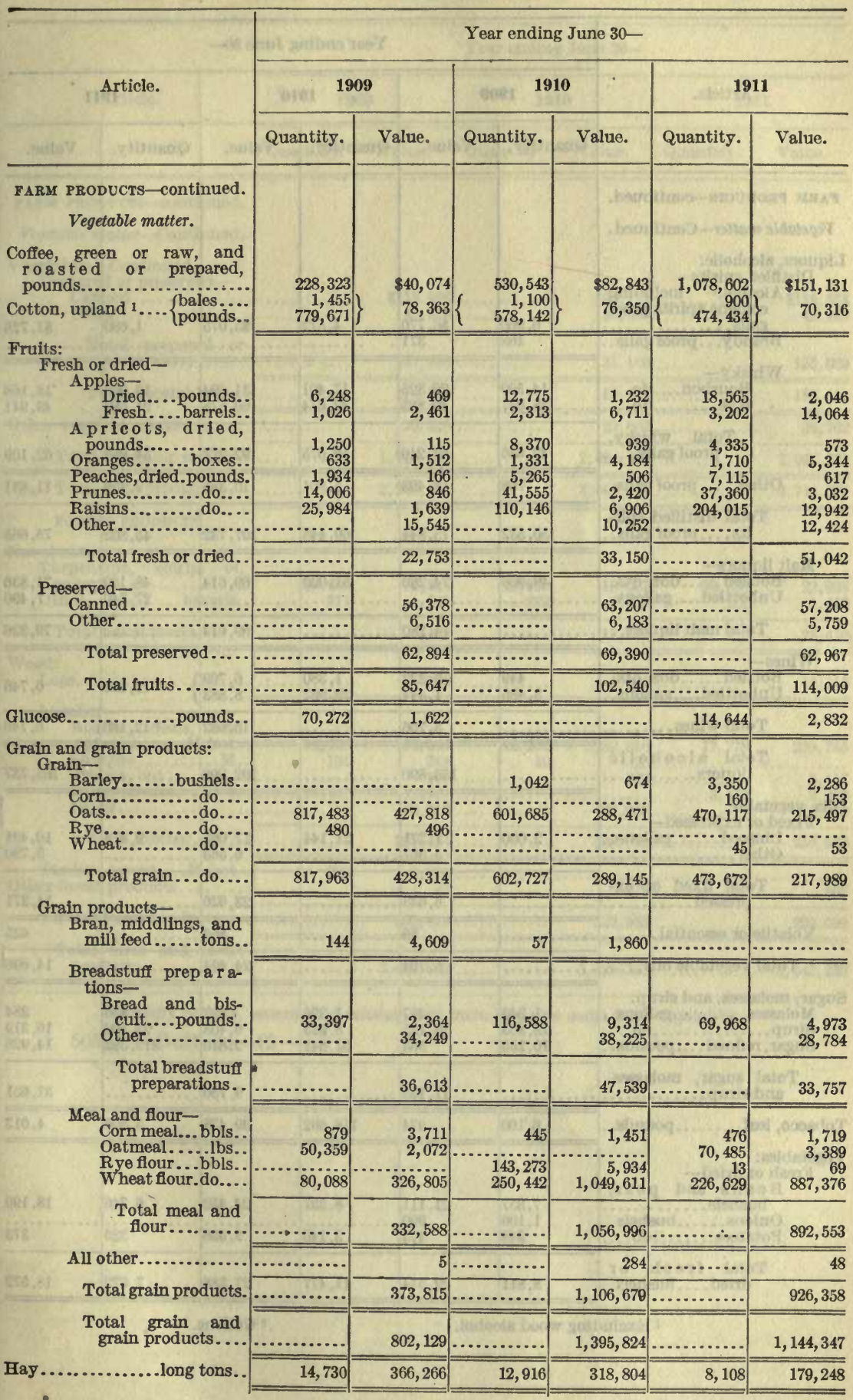

1 Including linters. 
TABLE 13.-EXPORTS of domestic FARM and FOREST products from the United States to the PHILIPPINE ISLANDS, 1909-1911-Continued.

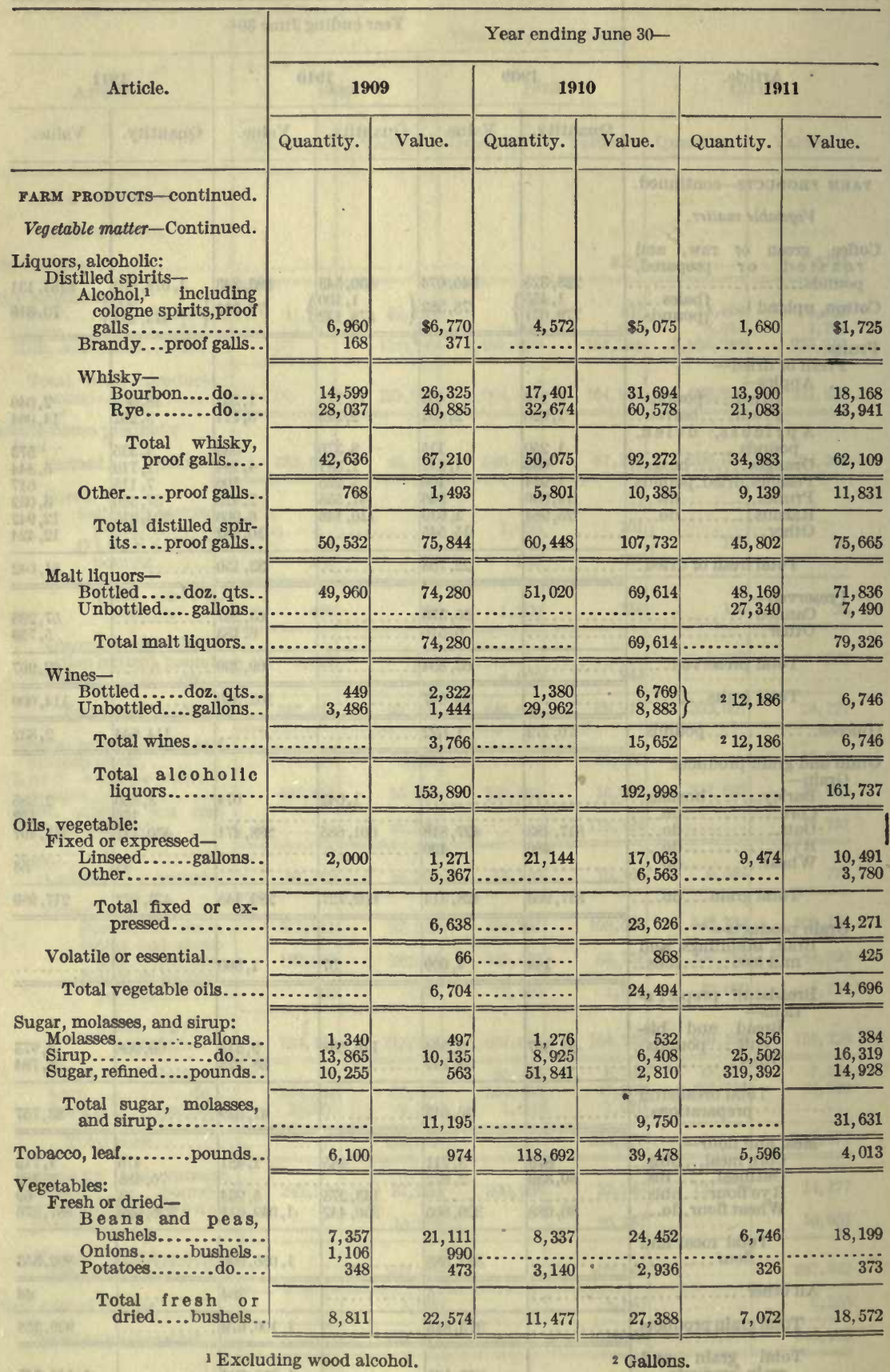

1 Excluding wood alcohol. 
EXPORTS OF FARM AND FOREST PRODUCTS, 1909-11.

TABLE 13.-EXPORTS of domestic FARM and FOREST products from the Uniled States to the PHILIPPINE ISLANDS, 1909-1911-Continued.

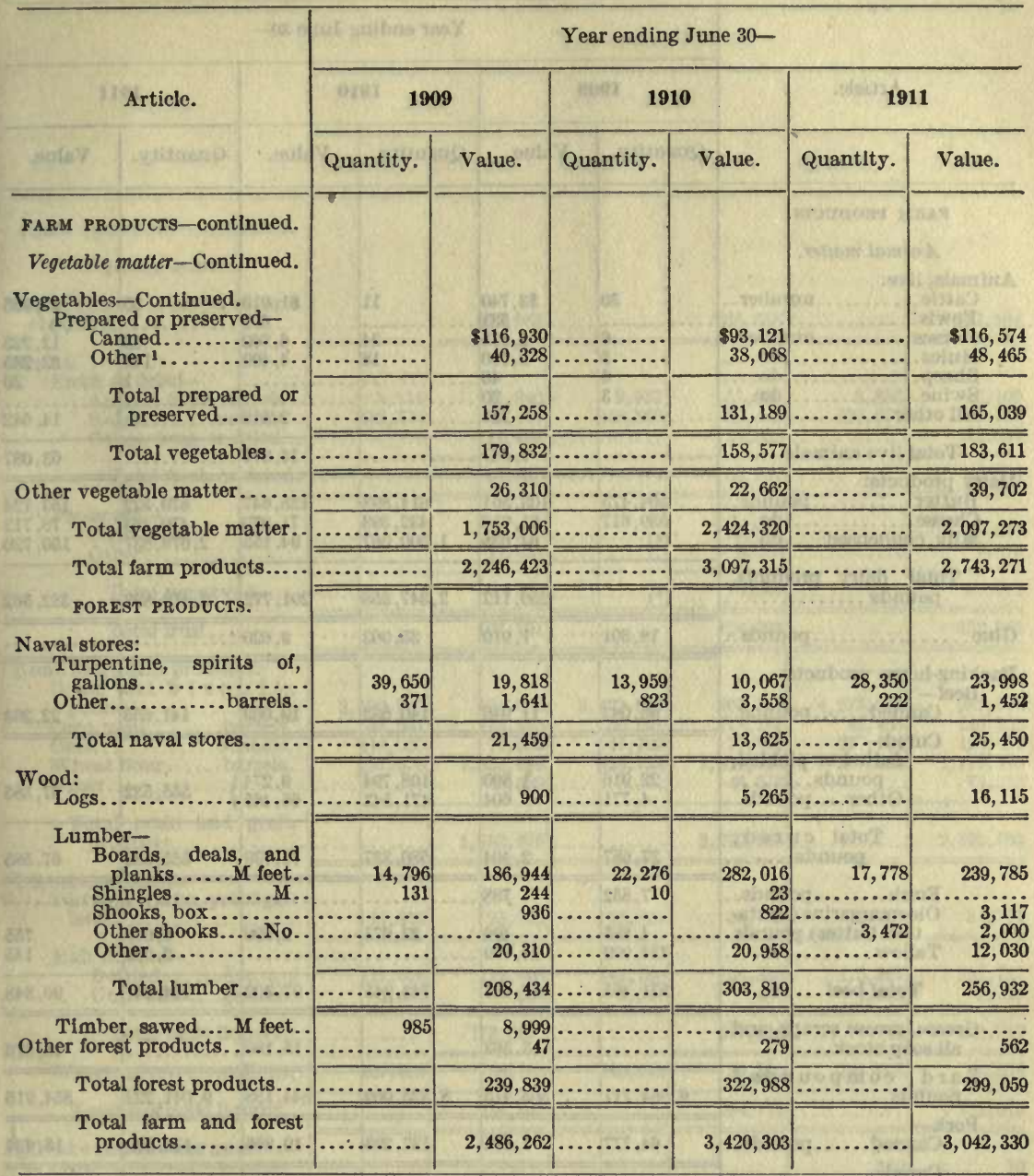

1 Chlefiy plckles, sauces, and relishes, but including also some fresh vegetables. $50597^{\circ}-$ Bull. $96-12-3$ 
TABLE 14.-SHIPMENTS of domestic FARM and FOREST products from the United States to PORTO RICO, 1909-1911.

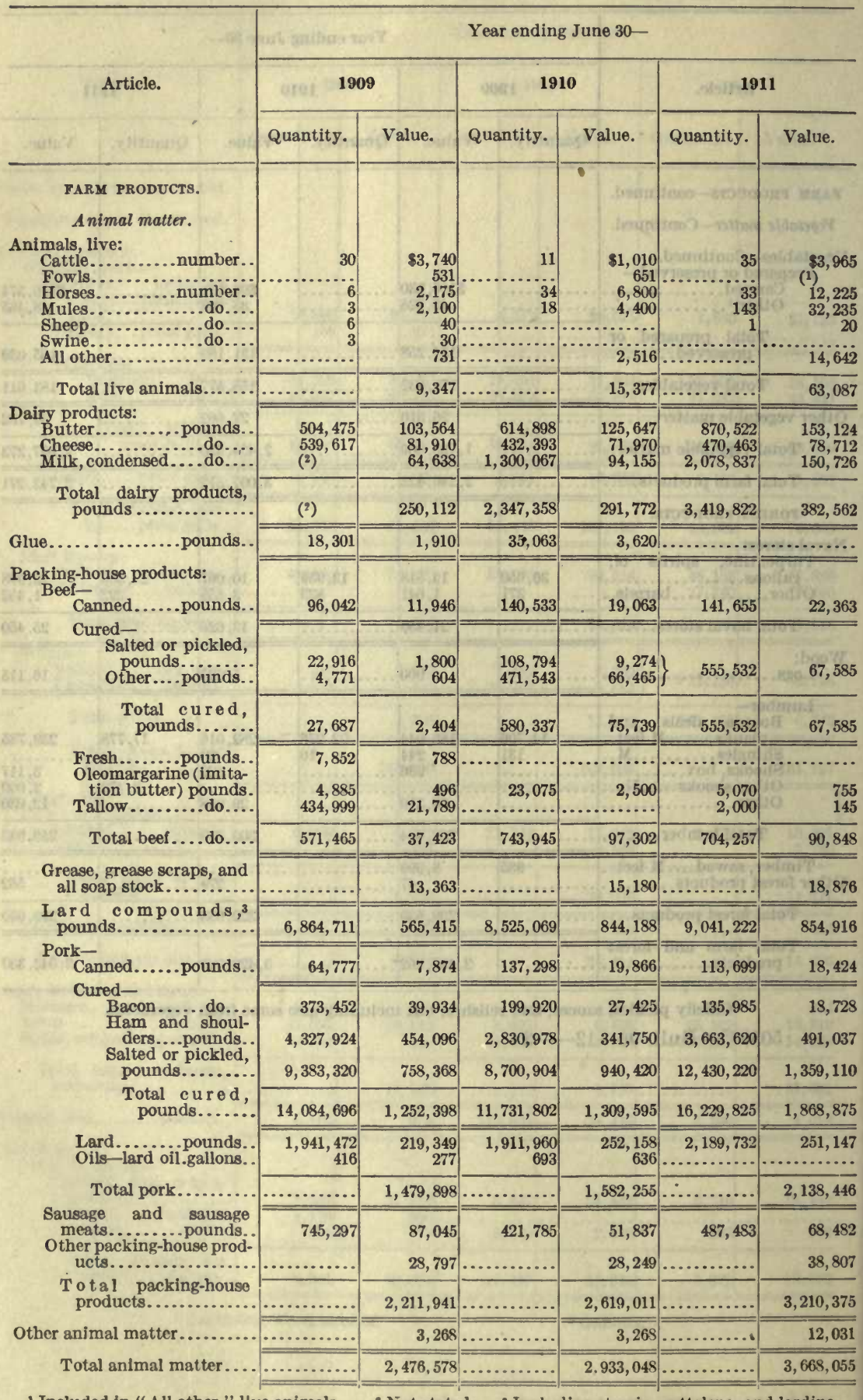

\footnotetext{
1 Included in "All other," llve animals. ' 2 Not stated, ' 3 Including stearin, cottolene, and lardine.
} 
TABLE 14. SHIPMENTS of domestic FARM and FOREST products from the Uniled States to PORTO RICO, 1909-1911-Continued.

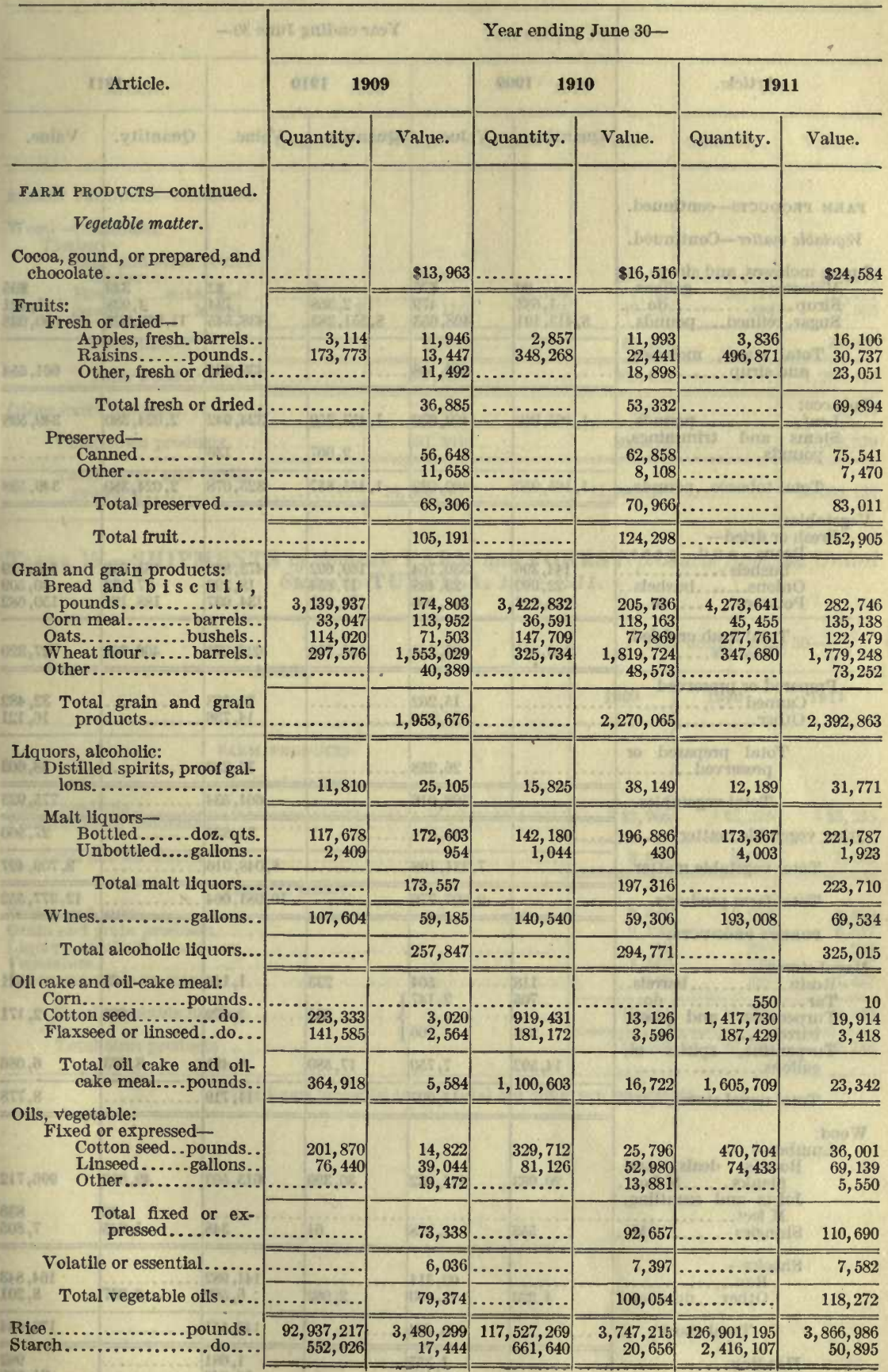


TABLE 14.-SHIPMENTS of domestic FARM and FOREST products from the United States to POR'TO RICO, 1909-1911-Continued.

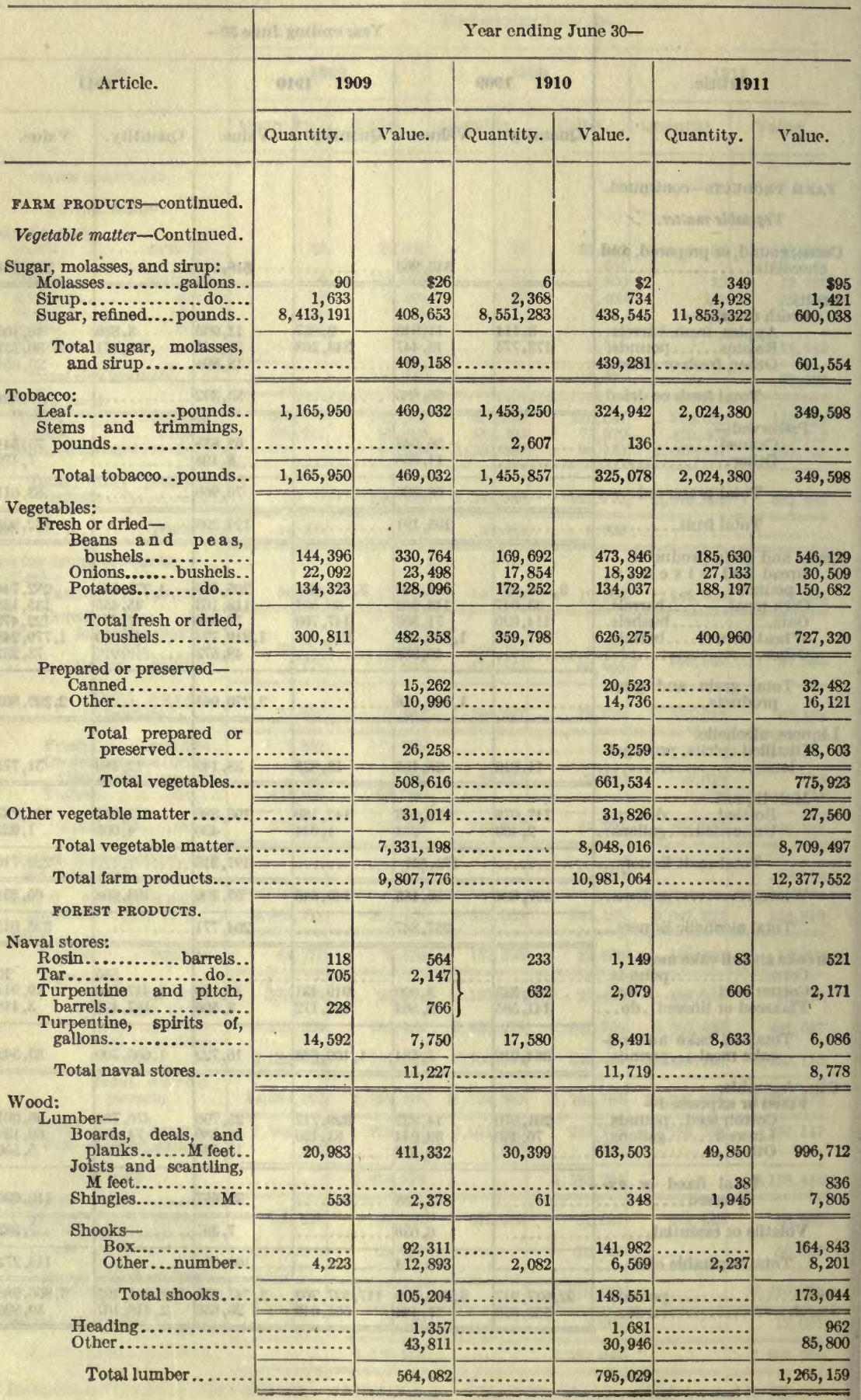


TABLE 16.-Quantity and value of principal groups of EXPORTS of FOREIGN FARM and FOREST products, 1909-1911.

\begin{tabular}{|c|c|c|c|c|c|c|}
\hline \multirow{3}{*}{ Article. } & \multicolumn{6}{|c|}{ Year ending June 30} \\
\hline & \multicolumn{2}{|c|}{1909} & \multicolumn{2}{|c|}{1910} & \multicolumn{2}{|c|}{1911} \\
\hline & Quantity. & Value. & Quantity. & Value. & Quantity. & Value. \\
\hline $\begin{array}{l}\text { FARM PRODUCTs. } \\
\text { A nimal matter. } \\
\text { Animals, live............ }\end{array}$ & & $\$ 163,876$ & & $\$ 260,201$ & & $\$ 374,662$ \\
\hline $\begin{array}{l}\text { Fibers, animal: } \\
\text { Silk............... pounds.. } \\
\text { Wool................... }\end{array}$ & $\begin{array}{r}123,251 \\
3,495,599 \\
\end{array}$ & $\begin{array}{l}410,529 \\
598,252\end{array}$ & $\begin{array}{r}102,988 \\
4,007,953 \\
\end{array}$ & $\begin{array}{l}338,353 \\
859,190 \\
\end{array}$ & $\begin{array}{r}121,828 \\
8,205,699 \\
\end{array}$ & $\begin{array}{r}388,399 \\
1,847,326\end{array}$ \\
\hline Total............. do.... & $3,618,850$ & $1,008,781$ & $4,110,941$ & $1,197,543$ & $8,327,527$ & $2,235,725$ \\
\hline $\begin{array}{l}\text { Packing-house products: } \\
\text { Hides and skins, } 1 \text { other than } \\
\text { furs.............. pounds. . }\end{array}$ & $4,750,273$ & $1,006,737$ & $7,310,207$ & $1,525,062$ & $11,347,055$ & $2,184,994$ \\
\hline 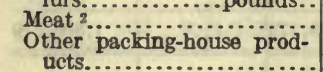 & 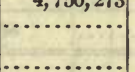 & $\begin{array}{r}1,006,737 \\
32,856 \\
102,020\end{array}$ & $\begin{array}{r}7,310,207 \\
\cdots \ldots \ldots \ldots\end{array}$ & $\begin{array}{r}1,525,062 \\
\cdots \ldots \ldots \ldots\end{array}$ & $\begin{array}{r}11,347,055 \\
\cdots \ldots \ldots \ldots \ldots\end{array}$ & $\begin{array}{r}2,184,994 \\
183,466\end{array}$ \\
\hline Total..... & & $1,141,613$ & & $1,678,074$ & & $2,368,460$ \\
\hline Other animal matter... & $\ldots \ldots \ldots \ldots$ & 59,568 & ............... & 93,565 & $\cdots$ & 103,153 \\
\hline Total animal matter. & $\ldots \ldots$ & $2,373,838$ & $\ldots \ldots$ & $3,229,383$ & & $5,082,000$ \\
\hline Vegetable matter. & & & -5 & 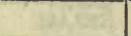 & & $y$ \\
\hline $\begin{array}{l}\text { Cocoa and chocolate..pounds. } \\
\text { Coffee................... do.... }\end{array}$ & $\begin{array}{r}2,891,207 \\
13,277,543 \\
\end{array}$ & $\begin{array}{r}353,963 \\
1,145,229 \\
\end{array}$ & $\begin{array}{r}4,833,491 \\
11,416,167 \\
\end{array}$ & $\begin{array}{r}516,550 \\
1,136,161 \\
\end{array}$ & $\begin{array}{l}4,431,587 \\
5,876,895 \\
\end{array}$ & $\begin{array}{l}488,351 \\
635,334 \\
\end{array}$ \\
\hline 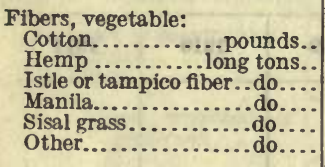 & \begin{tabular}{r|}
$1,515,871$ \\
596 \\
411 \\
3,052 \\
2,116 \\
402 \\
\end{tabular} & $\begin{array}{r}204,120 \\
96,127 \\
39,697 \\
485,783 \\
262,005 \\
42,103\end{array}$ & $\begin{array}{r}5,531,879 \\
413 \\
515 \\
8,724 \\
978 \\
725\end{array}$ & $\begin{array}{r}1,299,245 \\
58,590 \\
43,359 \\
1,345,490 \\
127,569 \\
89,065 \\
\end{array}$ & $\begin{array}{r}2,332,679 \\
133 \\
279 \\
5,742 \\
4,185 \\
813 \\
\end{array}$ & $\begin{array}{r}452,938 \\
19,271 \\
27,028 \\
918,978 \\
436,798 \\
127,805 \\
\end{array}$ \\
\hline Total... & & $1,129,835$ & & $2,963,318$ & & $1,982,818$ \\
\hline $\begin{array}{l}\text { Fruits: } \\
\text { Fresh or dried- } \\
\text { Bananas........ bunches.. } \\
\text { Currants........ pounds.. } \\
\text { Dates............... do.... } \\
\text { Raisins............. do.... } \\
\text { Other ................. }\end{array}$ & $\begin{array}{r}1,209,522 \\
316,309 \\
2,284,302 \\
651,970 \\
\cdots . . . . . . .\end{array}$ & $\begin{array}{r}1,314,416 \\
13,943 \\
56,657 \\
28,806 \\
210,227\end{array}$ & $\begin{array}{r}1,300,463 \\
666,578 \\
2,513,315 \\
620,420 \\
\ldots . . .\end{array}$ & $\begin{array}{r}1,408,207 \\
34,644 \\
61,131 \\
21,712 \\
246,280\end{array}$ & $\begin{array}{r}1,860,988 \\
995,558 \\
4,532,432 \\
73,833 \\
\ldots \ldots \ldots . . .\end{array}$ & $\begin{array}{r}2,088,206 \\
62,344 \\
120,495 \\
5,058 \\
267,979\end{array}$ \\
\hline Total fresh or dried.. & ... & $1,624,049$ & $\ldots$ & $1,771,974$ & & $2,544,082$ \\
\hline Prepared or preserved.. & 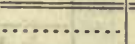 & 9,966 & …...... & 25,129 & & $\overline{6,217}$ \\
\hline Total fruits............. & $\cdots$ & $1,634,015$ & n.............. & $1,797,103$ & & $2,550,299$ \\
\hline $\begin{array}{l}\text { Grain and grain products: } \\
\text { Grain - }\end{array}$ & & & & & & \\
\hline $\begin{array}{l}\text { Oats.............. bushels.. } \\
\text { Wheat...................... } \\
\text { Other................... }\end{array}$ & $\begin{array}{r}105,407 \\
3,772 \\
29,960 \\
\end{array}$ & $\begin{array}{r}43,407 \\
3,325 \\
19,700\end{array}$ & $\begin{array}{r}218,289 \\
136,519 \\
\cdots \cdots\end{array}$ & $\begin{array}{r}89,529 \\
122,173 \\
\cdots\end{array}$ & $\begin{array}{l}1,504 \\
1,361 \\
\cdots \cdots\end{array}$ & $\begin{array}{r}645 \\
1,235 \\
\cdots \cdots \\
\end{array}$ \\
\hline Total grain....... do.... & 139,139 & 66,432 & 354,808 & 211,702 & 2,865 & 1,880 \\
\hline $\begin{array}{l}\text { Grain products } \\
\text { Wheat flour...... barrels.. } \\
\text { Other.................. }\end{array}$ & & $15,63 \mathrm{i}$ & 31 & $\begin{array}{r}250 \\
31,769 \\
\end{array}$ & $\begin{array}{c}8 \\
. .\end{array}$ & $\begin{array}{r}46 \\
28,609\end{array}$ \\
\hline Total grain products.... &. & 15,631 & & 32,019 & & 28,655 \\
\hline $\begin{array}{c}\text { Total grain and grain } \\
\text { products.............. }\end{array}$ & & 82,063 & & 243,721 & & 30,535 \\
\hline 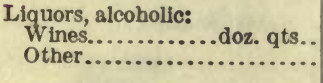 & $\begin{array}{r}10,549 \\
\ldots \ldots \\
\end{array}$ & $\begin{array}{l}86,809 \\
39,359 \\
\end{array}$ & $\begin{array}{r}6,522 \\
\ldots \ldots \ldots \ldots \\
\end{array}$ & $\begin{array}{l}54,554 \\
34,425 \\
\end{array}$ & $\begin{array}{r}7,352 \\
\cdots \cdots \\
\end{array}$ & $\begin{array}{l}37,225 \\
56,244 \\
\end{array}$ \\
\hline Total alcoholic liquors... & .......... & 126,168 & $\ldots$. & 88,979 & & $93,4 f 9$ \\
\hline
\end{tabular}

1 Excluding sheepskins with wool on, bird skins and fish skins. 2 Including meat extracts. 
TABLE 16.-Quantity and value of principal groups of EXPORTS of FOREIGN FARM and FOREST products, 1909-1911-Continued.

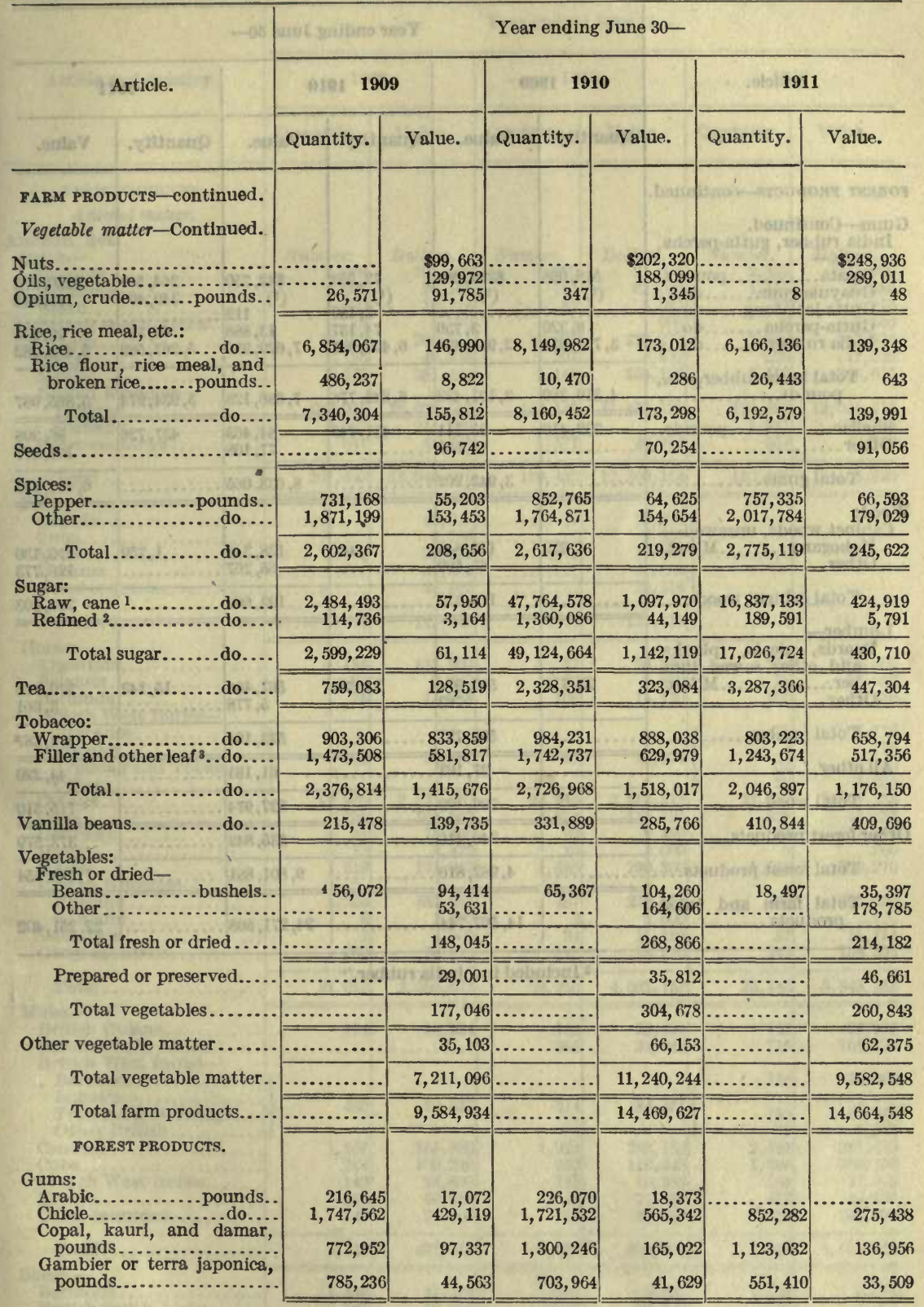

1 Not above No. 16 Dutch standard in color.

2 Including raw sugar above No. 16 Dutch standard in color, and maple sugar and sirup.

Including stems.

1 Including dried peas. 
TABLE 16.-Quantity and value of principal groups of EXPORTS of FOREIGN FARM and FOREST products, 1909-1911-Continued.

\begin{tabular}{|c|c|c|c|c|c|c|c|}
\hline \multirow{3}{*}{\multicolumn{2}{|c|}{ Article. }} & \multicolumn{6}{|c|}{ Year ending June 30- } \\
\hline & & \multicolumn{2}{|c|}{1909} & \multicolumn{2}{|c|}{ 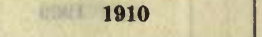 } & \multicolumn{2}{|c|}{1911} \\
\hline & & Quantity. & Value. & Quantity. & Value. & Quantity. & Value. \\
\hline \multicolumn{2}{|c|}{ FOREST PRODUCTS-continued. } & & & & & 4 & $0 a+3+13402$ \\
\hline \multicolumn{2}{|c|}{$\begin{array}{l}\text { Gums-Continued. } \\
\text { India rubber, gutta-percha, } \\
\text { etc.- } \\
\text { Balata............ pounds.. }\end{array}$} & $\begin{array}{l}518,098 \\
(1)\end{array}$ & $\underset{(1)}{\$ 223,207}$ & $\begin{array}{c}73,553 \\
(1)\end{array}$ & $\begin{array}{l}\$ 42,750 \\
(1)\end{array}$ & $\begin{array}{l}264,589 \\
340,405\end{array}$ & $\begin{array}{r}\$ 230,57 \dot{5} \\
175,995\end{array}$ \\
\hline \multicolumn{2}{|c|}{$\begin{array}{l}\text { Gutta-percha......... do.... } \\
\text { India rubber....... do.... }\end{array}$} & $\begin{array}{r}9,320 \\
3,791,971\end{array}$ & $\begin{array}{r}3,730 \\
2,964,496 \\
\end{array}$ & $\begin{array}{r}74,137 \\
6,492,947 \\
\end{array}$ & $\begin{array}{r}13,886 \\
7,629,380 \\
\end{array}$ & $\begin{array}{r}62,391 \\
5,267,589\end{array}$ & $\begin{array}{r}19,230 \\
5,439,282\end{array}$ \\
\hline \multicolumn{2}{|c|}{$\begin{array}{c}\text { Total india rubber, etc., } \\
\text { pounds................. }\end{array}$} & $4,319,389$ & $3,191,433$ & $6,642,776$ & $7,686,128$ & $5,934,974$ & $5,865,087$ \\
\hline \multicolumn{2}{|c|}{ 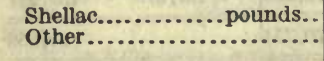 } & $\begin{array}{r}332,410 \\
\cdots\end{array}$ & $\begin{array}{l}95,111 \\
68,567 .\end{array}$ & $\begin{array}{r}431,749 \\
\cdots \cdots \cdots \\
\end{array}$ & $\begin{array}{l}84,463 \\
77,108 \\
\end{array}$ & $\begin{array}{r}437,726 \\
\ldots \ldots \ldots \ldots \\
\end{array}$ & $\begin{array}{r}86,398 \\
100,377 \\
\end{array}$ \\
\hline \multicolumn{2}{|c|}{ Total gums.............. } & $\ldots \ldots$ & $3,943,202$. & $\cdots \cdots \cdots$ & $8,638,065$. & $\cdots$ & $6,497,765$ \\
\hline \multicolumn{2}{|c|}{$\begin{array}{l}\text { Wood: } \\
\text { Cabinet woods, unsawed-. } \\
\text { Mahogany.......... } \\
\text { Other.................... }\end{array}$} & $\begin{array}{r}1,392 \\
\cdots\end{array}$ & $\begin{array}{r}112,843 \\
65,509 \\
\end{array}$ & $\begin{array}{c}\bullet \\
1,467 \\
\cdots \cdots \cdots \\
\end{array}$ & $\begin{array}{r}128,342 \\
65,267 \\
\end{array}$ &, 759 & $\begin{array}{l}170,130 \\
126,773 \\
\end{array}$ \\
\hline \multicolumn{2}{|c|}{ Total cabinet woods..... } & $\cdots \cdots$ & 178,352 & $\cdots$ & $193,609$. & $\cdots$ & 296,903 \\
\hline \multicolumn{2}{|c|}{ 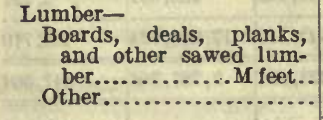 } & $\begin{array}{r}23,711 \\
\end{array}$ & $\begin{array}{r}582,974 \\
763\end{array}$ & $\begin{array}{r}23,320 \\
\cdots \cdots \\
\end{array}$ & $\begin{array}{r}567,406 \\
5,778 \\
\end{array}$ & $\begin{array}{r}15,143 \\
\ldots \ldots \ldots \cdots \\
\end{array}$ & $\begin{array}{r}370,726 \\
3,661 \\
\end{array}$ \\
\hline \multicolumn{2}{|c|}{ Total lumber... } & $\cdots$ & 583,737 . & ... & 573,184 . & ... & 374,387 \\
\hline \multicolumn{2}{|c|}{ All other... } & & 37,103 . & & 61,181 . & & 44,220 \\
\hline \multicolumn{2}{|c|}{ Total wood................ } & $\ldots$ & 799,192 . & n.......... & 827,974 . & .............. & 715,510 \\
\hline \multicolumn{2}{|c|}{ Other forest products........... } & & 240,416 & $\cdots$ & 335,842 & & 373,579 \\
\hline \multicolumn{2}{|c|}{ Total forest products.... } & & $4,982,810$. & & $9,801,881$ & .... & $7,586,854$ \\
\hline $\begin{array}{l}\text { Tot } \\
\text { pr }\end{array}$ & larm and forest & & $14,567,744$ & & $24,271,508$ & & $22,251,402$ \\
\hline
\end{tabular}

1 Included in "India rubber." 
TABLE 17.-Quantity and value of EXPORTS of domestic FARM and FOREST products, 1909-1911, by articles and by countries to which consigned-Continued.

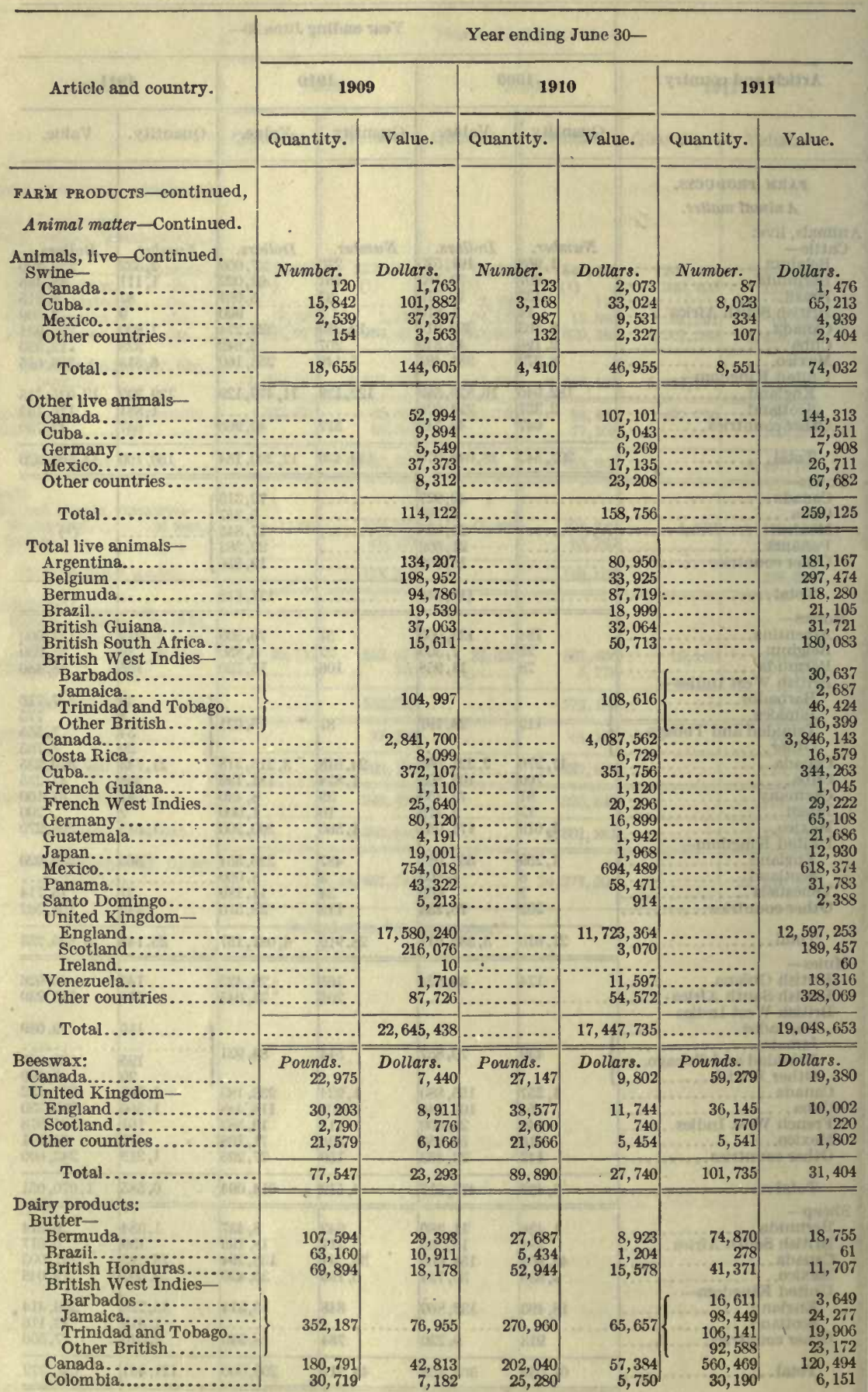


TABLE 17.-Quantity and value of EXPORTS of domestic FARM and FOREST products, 1909-1911, by articles and by countries to which consigned-Continued.

\begin{tabular}{|c|c|c|c|c|c|c|c|}
\hline \multirow{2}{*}{\multicolumn{2}{|c|}{ Article and country. }} & \multicolumn{6}{|c|}{ Year ending June $30-$} \\
\hline & & \multicolumn{2}{|c|}{1909} & \multicolumn{2}{|c|}{1910} & \multicolumn{2}{|c|}{ Anty 1911} \\
\hline $\sin \operatorname{sir}$ & onta & Quantity. & Value. & Quantity. & Value. & Quantity. & Value. \\
\hline \multicolumn{8}{|c|}{ FARM PRODUCTS-continued. } \\
\hline \multicolumn{8}{|c|}{ Animal matter-Contlnued. } \\
\hline \multicolumn{8}{|c|}{$\begin{array}{l}\text { Dairy products-Continued. } \\
\text { Butter-Continued. }\end{array}$} \\
\hline Cuba.. & & 264,346 & 64,089 & 300,370 & 79,658 & 328,734 & 78,604 \\
\hline $\begin{array}{l}\text { Fren } \\
\text { Fren }\end{array}$ & 116 & $\begin{array}{l}116,432 \\
239,031\end{array}$ & $\begin{array}{l}24,628 \\
34,991\end{array}$ & $\begin{array}{r}90,780 \\
241,400\end{array}$ & 20,039 & $\begin{array}{r}69,317 \\
358,100\end{array}$ & 14,844 \\
\hline Hait1 & & 191,595 & 37,772 & 254,209 & $\begin{array}{l}05,351 \\
51,222\end{array}$ & $\begin{array}{l}358,100 \\
371,640\end{array}$ & $\begin{array}{l}79,525 \\
70,985\end{array}$ \\
\hline Hor & & 43,614 & 12,050 & 32,401 & 9,347 & 43,979 & 12,563 \\
\hline $\begin{array}{l}\text { Japai } \\
\text { Mexi }\end{array}$ & & $\begin{array}{r}9,353 \\
554,298\end{array}$ & $\begin{array}{r}2,420 \\
135,481\end{array}$ & $\begin{array}{r}1,028 \\
492,582\end{array}$ & 122,830 & 427,473 & 104,295 \\
\hline Newfor & and an & 25,614 & & & & 3003 & \\
\hline Nicar & & $\begin{array}{l}25,614 \\
42,320\end{array}$ & $\begin{array}{r}6,349 \\
11,492\end{array}$ & $\begin{array}{r}140 \\
40,434\end{array}$ & 12,273 & $\begin{array}{r}3,903 \\
67,577\end{array}$ & $\begin{array}{r}795 \\
18,337\end{array}$ \\
\hline Pan & & 451,748 & 127,173 & 488,423 & 161,997 & 510,764 & 146,235 \\
\hline Sar & & 65,259 & 12,021 & 80,060 & 15,748 & 78,989 & 15,454 \\
\hline En & & $2,612,146$ & 508,757 & 1,998 & 495 & 823,934 & 153,337 \\
\hline & & 60,617 & & & & 974 & 1,274 \\
\hline Vene & & 395,843 & 68,444 & 458,222 & 81,741 & 653,953 & 109,386 \\
\hline Othe & 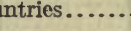 & 104,704 & 25,547 & 74,153 & 20,204 & 112,495 & 25,626 \\
\hline Tota & & $5,981,265$ & $1,268,210$ & $3,140,545$ & 785,771 & $4,877,797$ & $1,059,432$ \\
\hline \multicolumn{8}{|l|}{ Cheese- } \\
\hline $\begin{array}{l}\text { Bermu } \\
\text { British }\end{array}$ & ondur & $\begin{array}{l}30,491 \\
73,554\end{array}$ & $\begin{array}{r}4,737 \\
11,618\end{array}$ & $\begin{array}{l}12,503 \\
64,077\end{array}$ & $\begin{array}{r}1,953 \\
10,869\end{array}$ & $\begin{array}{l}34,399 \\
75,447\end{array}$ & $\begin{array}{r}4,615 \\
12,538\end{array}$ \\
\hline \\
\hline \multirow{3}{*}{\multicolumn{2}{|c|}{ 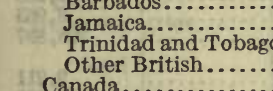 }} & & & & & $\begin{array}{r}1,890 \\
148,965\end{array}$ & $\begin{array}{r}319 \\
25,469\end{array}$ \\
\hline & & 414,442 & 67,241 & 361,116 & 60,668 & 165,939 & 27,204 \\
\hline \multirow{2}{*}{\multicolumn{2}{|c|}{ Canada... }} & 120,844 & 19,362 & 85,415 & 15,435 & $\begin{array}{r}74,965 \\
996,718\end{array}$ & 12,396 \\
\hline & & 81,148 & 12,420 & 69,427 & 12,031 & 54,437 & $\begin{array}{r}113,757 \\
9,310\end{array}$ \\
\hline \multirow{2}{*}{\multicolumn{2}{|c|}{ Colomi }} & 4,989 & 833 & 4,235 & 692 & 4,764 & 854 \\
\hline & & 101,507 & 19,952 & 166,436 & 30,957 & 167,509 & 31,081 \\
\hline \multicolumn{2}{|c|}{ Hongkong } & 109,530 & 17, & 94,259 & 17,022 & 78,208 & 12,984 \\
\hline \multicolumn{2}{|c|}{$\begin{array}{l}\text { Mexico... } \\
\text { Panama. }\end{array}$} & 318,288 & 47,203 & & 59,868 & 32 & 48,037 \\
\hline \multicolumn{2}{|c|}{ United Kingdom - } & 315,718 & 49,097 & 183 & 56,062 & 177 & 68,757 \\
\hline Engl & & $4,916,680$ & 558,248 & 990,123 & 123,433 & $7,395,362$ & 857,115 \\
\hline Scot & d. & 135,593 & 17 & & …... & 307 & 324 \\
\hline Other & antries. & 200,058 & 32,105 & 302,900 & 52,027 & 286,586 & 47,519 \\
\hline Tota & & $6,822,842$ & 857,091 & $2,846,709$ & 441,017 & $10,366,605$ & $1,288,279$ \\
\hline Milk- & & & & & & & \\
\hline Bra & & (1) & $\left\{\begin{array}{r}4,295 \\
1,471\end{array}\right.$ & 112,424 & 7,995 & 201,335 & 13,554 \\
\hline Brit & & & 61,500 & 14,482 & $\begin{array}{l}1,080 \\
1,086\end{array}$ & 61,030 & $\begin{array}{l}2,162 \\
3,803\end{array}$ \\
\hline British & Indie & & & & & & \\
\hline 20) Barb & 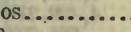 & & & & & 1,545 & 127 \\
\hline $\begin{array}{l}\text { Jan } \\
\text { Tri }\end{array}$ & & (1) & 9,281 & 93,978 & 7,640 & $\begin{array}{r}15,298 \\
3,100\end{array}$ & 1,278 \\
\hline Otr & & & & & & & 6.584 \\
\hline Cana & & & 55,153 & 187,442 & 13,411 & 223 & 18,202 \\
\hline & & & 57,294 & & & & 27,354 \\
\hline & & & 675,301 & $6,882,648$ & 523,283 & $4,257,387$ & 323,833 \\
\hline & & aff & 22,343 & 14,685 & 1,218 & 67,861 & 5,435 \\
\hline Jap & & & $\begin{array}{r}71,749 \\
4,223\end{array}$ & $\begin{array}{r}73,567 \\
27\end{array}$ & 5,397 & 103,827 & 7,865 \\
\hline $\mathrm{Me}$ & & & $\begin{array}{r}4,225 \\
71,900\end{array}$ & 873,426 & $\begin{array}{r}2,450 \\
71,420\end{array}$ & & 76 \\
\hline Nice & & & 6,862 & 100,834 & 8,186 & 125,863 & 10,061 \\
\hline $\mathrm{Pa}$ & & (1) & 98,287 & $1,175,136$ & 86,859 & $1,256,526$ & 96,963 \\
\hline Phi & & & 124,790 & $1,998,829$ & 163,785 & $3,056,286$ & 235,681 \\
\hline $\mathrm{Po}$ & & & 1,707 & 41,422 & 3,305 & 5,380 & 410 \\
\hline & & & 44,603 & 481,294 & 31,294 & 742,105 & 55,156 \\
\hline $\begin{array}{l}\text { Stra } \\
\text { Unit }\end{array}$ & - & & 17 & 30,740 & 2,180 & 23,845 & 472 \\
\hline En & & & 8,257 & 81,000 & 7,381 & 716 & 72 \\
\hline Other & untries. & & $\begin{array}{r}1,109 \\
50,262\end{array}$ & 766,580 & 61,333 & 396,193 & 46,623 \\
\hline Tot & & (1) & $1,375,104$ & $13,311,318$ & $1,023,633$ & $12,180,445$ & 936,105 \\
\hline
\end{tabular}


TABLE 17.-Quantity and value of EXPORTS of domestic FARM and FOREST products, 1909-1911, by articles and by countries to which consigned-Continued.

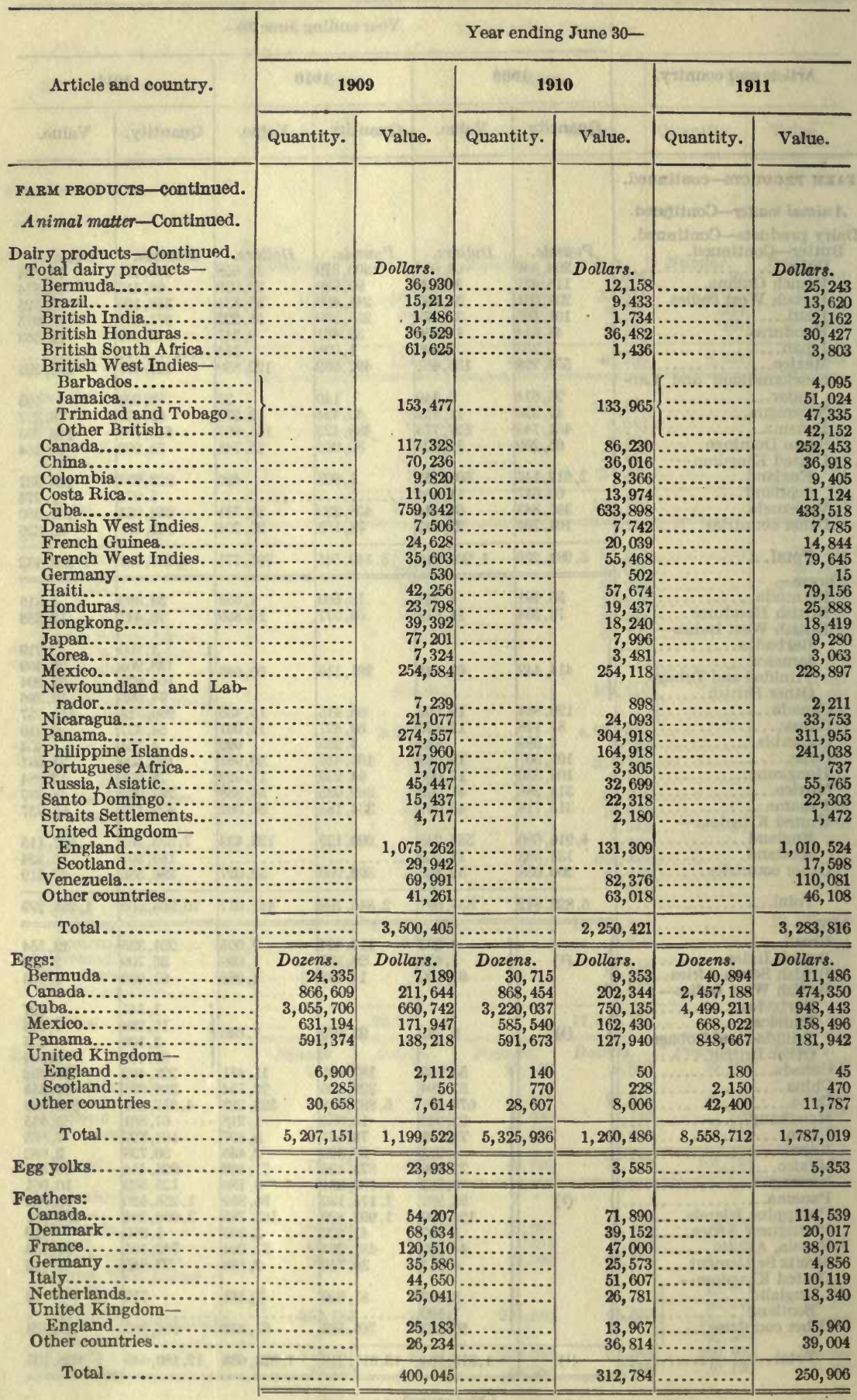


TABLE 17.-Quantity and value of EXPORTS of domestic FARM and FOREST products, 1909-1911, by articles and by countries to which consigned-Continued.

\begin{tabular}{|c|c|c|c|c|c|c|}
\hline \multirow{3}{*}{ Article and country. } & \multicolumn{4}{|c|}{ Year ending June $30-$} & \multirow{2}{*}{\multicolumn{2}{|c|}{1911}} \\
\hline & 19 & & 19 & & & \\
\hline & Quantity. & Value. & Quantity. & Value. & Quantity. & Value. \\
\hline $\begin{array}{l}\text { FARM PRODUCTS-continued. } \\
\text { Animal matter-Continued. }\end{array}$ & & & & Matill & 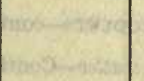 & 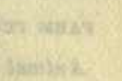 \\
\hline 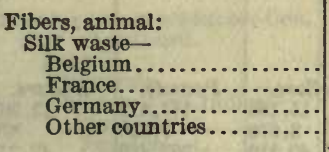 & \begin{tabular}{|r|} 
Pounds. \\
144,573 \\
64,191 \\
36,423 \\
55,366 \\
\end{tabular} & $\begin{array}{r}\text { Dollars. } \\
36,748 \\
17,084 \\
8,450 \\
15,662 \\
\end{array}$ & \begin{tabular}{|r|} 
Pounds. \\
60,003 \\
75,013 \\
69,391 \\
61,800 \\
\end{tabular} & \begin{tabular}{r|} 
Dollars. \\
12,063 \\
19,292 \\
13,620 \\
19,553 \\
\end{tabular} & \begin{tabular}{|r|} 
Pounds. \\
2,385 \\
36,274 \\
57,491 \\
23,651 \\
\end{tabular} & $\begin{array}{r}\text { Dollars. } \\
820 \\
10,748 \\
11,643 \\
7,652 \\
\end{array}$ \\
\hline Total..... & 300,553 & 77,944 & 266,207 & 64,528 & 119,801 & 30,863 \\
\hline $\begin{array}{l}\text { Wool, raw- } \\
\text { Canada........... } \\
\text { United Kingdom } \\
\text { England ....... }\end{array}$ & $\begin{array}{r}780 \\
27,596\end{array}$ & $\begin{array}{r}253 \\
4,415\end{array}$ & $\begin{array}{l}14,897 \\
32,623\end{array}$ & $\begin{array}{l}1,421 \\
8,656\end{array}$ & (1) & (1) \\
\hline Total.. & 28,376 & 4,668 & 47,520 & 10,077 & (1) & (1) \\
\hline 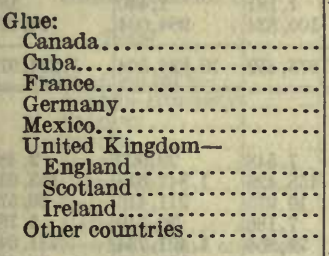 & $\begin{array}{r}367,543 \\
80,912 \\
73,204 \\
388,507 \\
183,810 \\
\\
593,806 \\
387,497 \\
97,470 \\
167,677 \\
\end{array}$ & $\begin{array}{r}39,675 \\
8,723 \\
9,193 \\
47,288 \\
19,697 \\
\\
56,066 \\
36,506 \\
9,542 \\
18,061 \\
\end{array}$ & $\begin{array}{r}328,027 \\
107,997 \\
129,698 \\
532,064 \\
118,785 \\
\\
574,577 \\
396,206 \\
43,467 \\
257,384 \\
\end{array}$ & $\begin{array}{r}36,547 \\
11,459 \\
15,794 \\
62,656 \\
11,779 \\
56,063 \\
36,869 \\
3,743 \\
26,846 \\
\end{array}$ & $\begin{array}{r}252,083 \\
94,432 \\
155,930 \\
639,148 \\
36,520 \\
831,555 \\
11,414 \\
27,617 \\
259,267 \\
\end{array}$ & $\begin{array}{r}25,514 \\
10,773 \\
17,916 \\
71,623 \\
4,781 \\
77,910 \\
959 \\
2,635 \\
30,644 \\
\end{array}$ \\
\hline Total... & $2,340,426$ & 244,751 & $2,488,205$ & 261,756 & $2,307,966$ & 242,755 \\
\hline 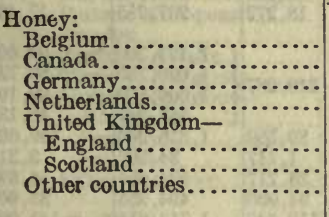 & & $\begin{array}{r}4,087 \\
14,928 \\
15,735 \\
2,192 \\
38,861 \\
2,452 \\
7,323 \\
\end{array}$ & (n........ & $\begin{array}{r}1,471 \\
20,551 \\
59,746 \\
3,429 \\
57,572 \\
1,845 \\
14,787 \\
\end{array}$ & (n) & $\begin{array}{r}\dddot{20}, \ddot{270} \\
38,769 \\
5,232 \\
8,267 \\
483 \\
8,623 \\
\end{array}$ \\
\hline Total. & & 85,578 & $\ldots \ldots \ldots$ & 159,401 & …....... & 81,649 \\
\hline 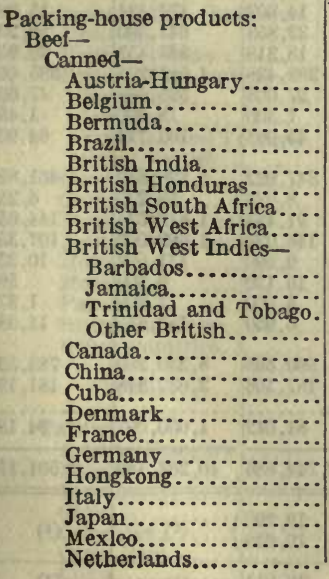 & $\begin{array}{r}177,256 \\
77,233 \\
28,627 \\
261,540 \\
47,830 \\
398,881 \\
497,280 \\
24,090 \\
77,755 \\
10,304 \\
80,080 \\
418,057\end{array}$ & $\begin{array}{r}22,108 \\
\\
10,775 \\
3,024 \\
34,856 \\
4,829 \\
40,470 \\
50,530 \\
2,831 \\
8,247 \\
1,315 \\
8,636 \\
42,425\end{array}$ & $\begin{array}{r}258,390 \\
\\
204,763 \\
6,169 \\
97,401 \\
30,871 \\
225,889 \\
83,022 \\
16,221 \\
22,312 \\
11,591 \\
98,144 \\
298,489\end{array}$ & $\begin{array}{r}33,071 \\
\\
24,024 \\
790 \\
12,230 \\
3,400 \\
22,417 \\
8,677 \\
2,258 \\
2,414 \\
1,359 \\
11,387 \\
30,645\end{array}$ & $\begin{array}{r}280 \\
282,637 \\
62,568 \\
136,343 \\
21,485 \\
132,635 \\
862,569 \\
1,524 \\
\\
33,814 \\
49,408 \\
45,213 \\
113,375 \\
40,884 \\
20,878 \\
282,744 \\
1,350 \\
78,096 \\
17,548 \\
7,497 \\
9,560 \\
5,638 \\
103,470 \\
210,346\end{array}$ & $\begin{array}{r}28 \\
31,292 \\
10,323 \\
16,709 \\
2,798 \\
14,448 \\
102,344 \\
186 \\
4,592 \\
4,382 \\
5,655 \\
14,583 \\
6,795 \\
2,167 \\
33,627 \\
145 \\
8,278 \\
2,203 \\
884 \\
1,162 \\
758 \\
13,239 \\
22,047\end{array}$ \\
\hline
\end{tabular}


TABLE 17.-Quantity and value of EXPORTS of domestic FARM and FOREST products, 1909-1911, by articles and by countries to which consigned-Continued.

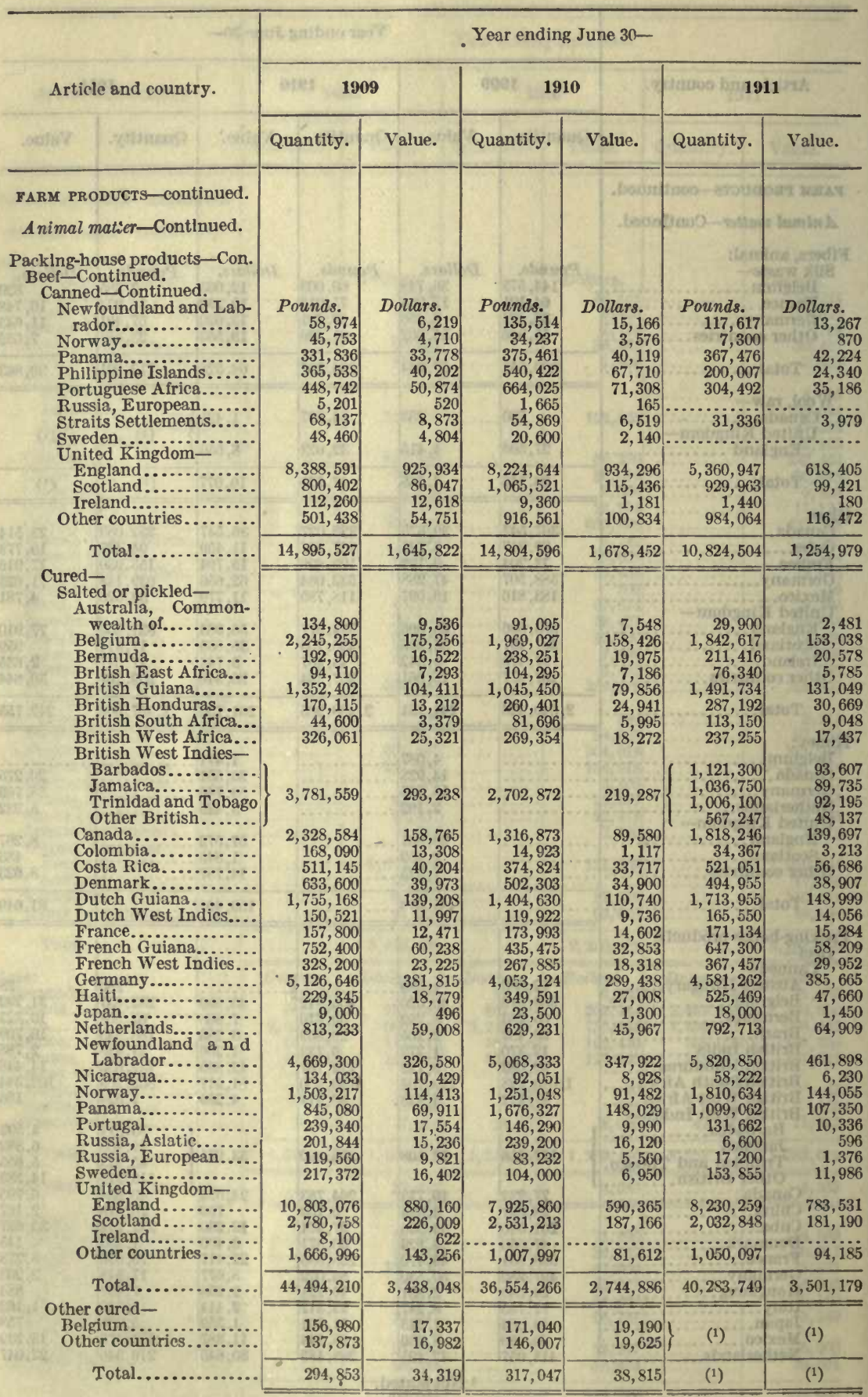

IIncluded in "Salted or pickled" 
TABLE 17.-Quantity and value of EXPORTS of domestic FARM and FOREST products, 1909-1911, by articles and by countries to which consigned-Continued.

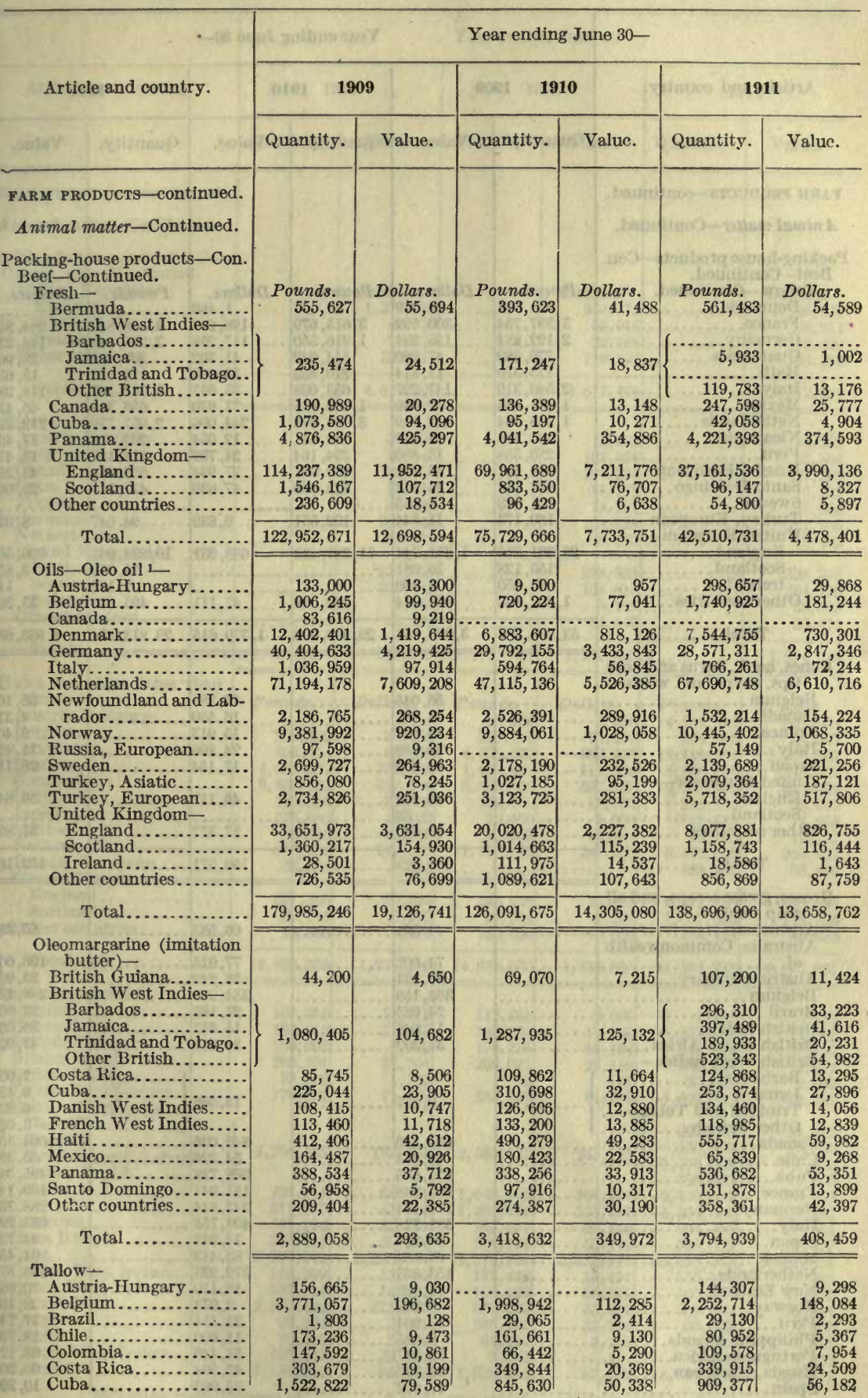

1 Prior to July 1, 1910, including "Neutral lard." 
TABLE 17.-Quantity and value of EXPORTS of domestic FARM and FOREST products, 1909-1911, by articles and by countries to which consigned-Continued.

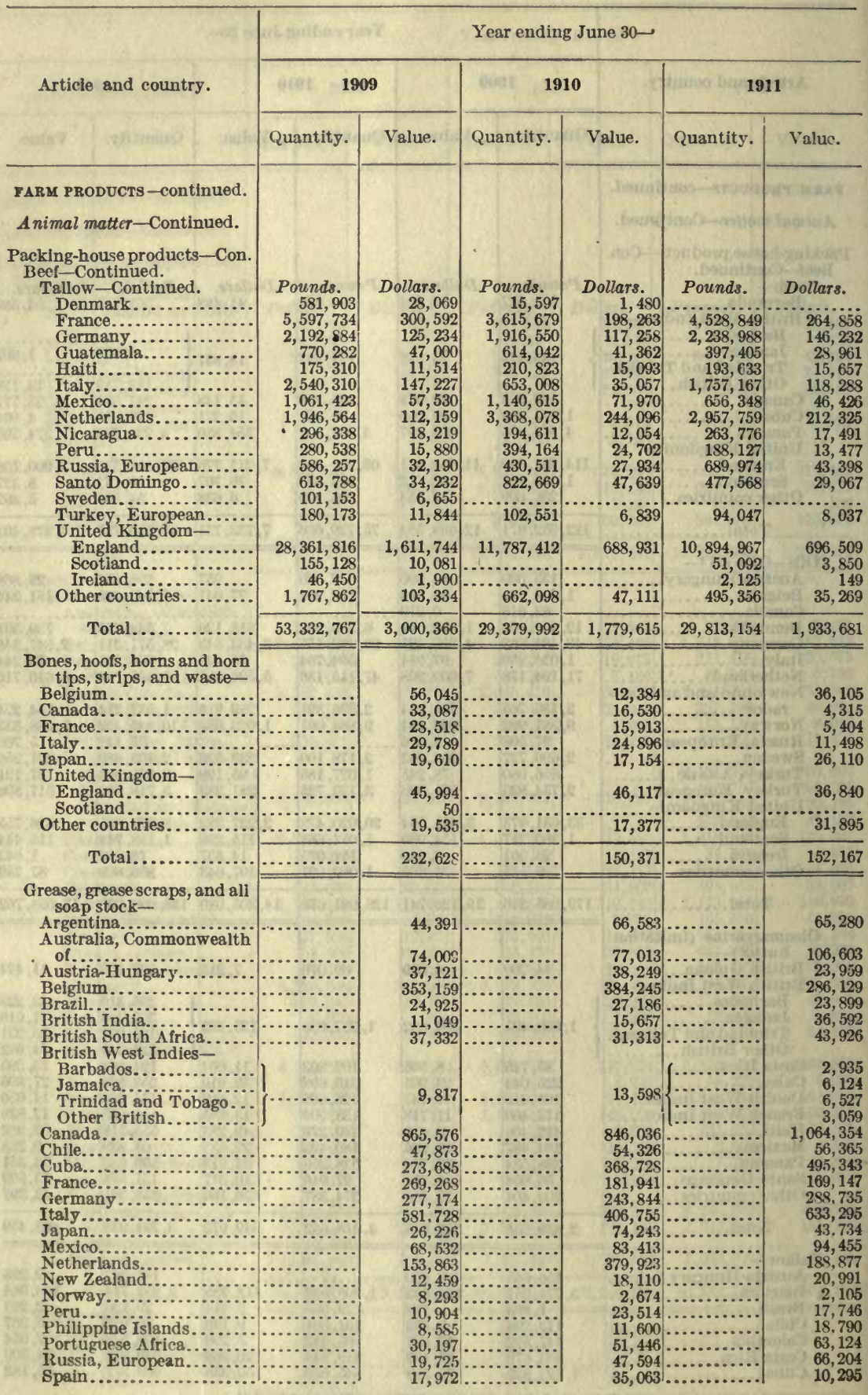


TABLE 17.-Quantity and value of EXPORTS of domestic FARM and FOREST products, 1909-1911, by articles and by countries to which consigned-Continued.

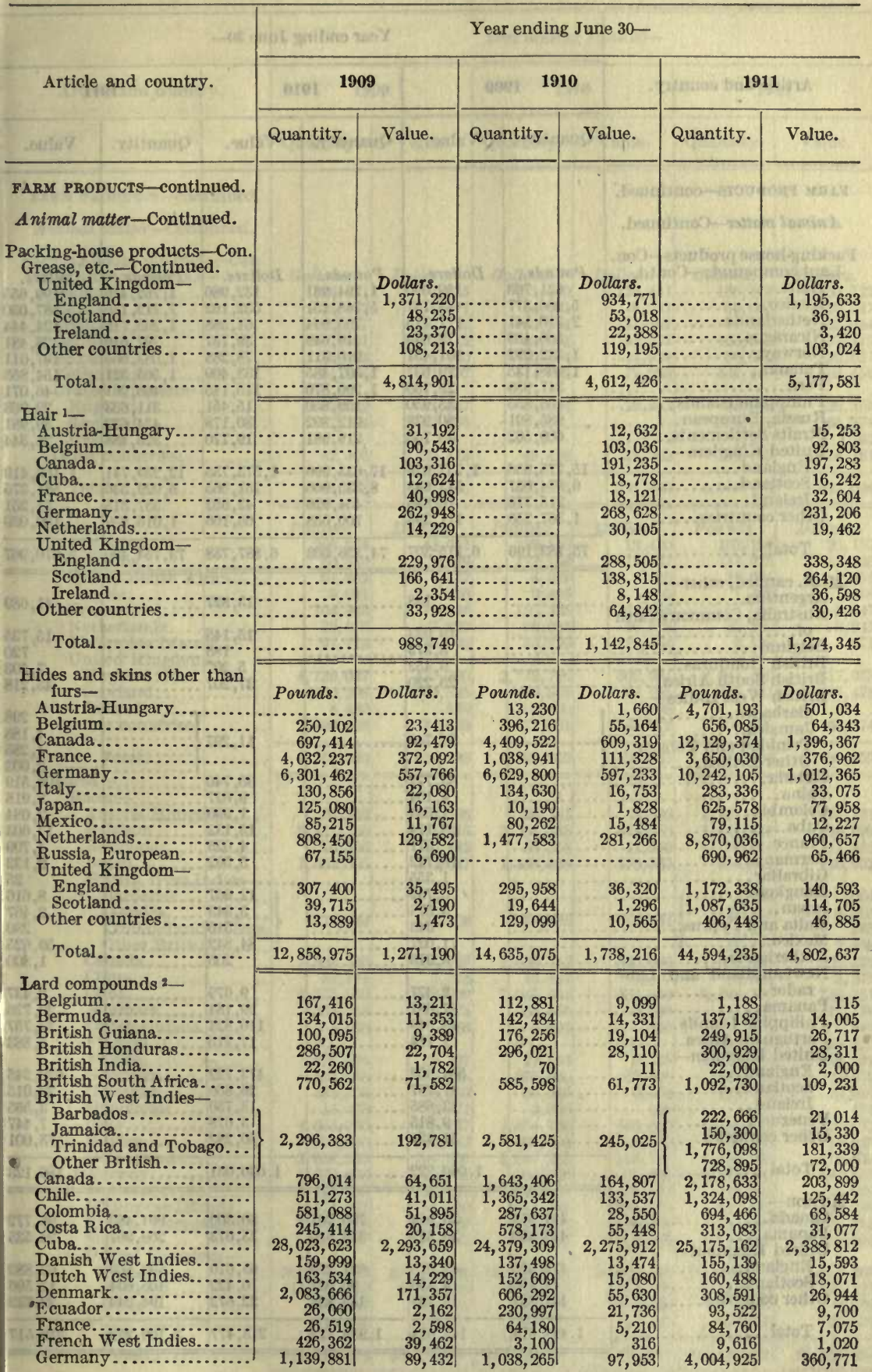

1 Including manufactures of.

2 Including stearin, cottolene, and lardine.

$50597^{\circ}-$ Bull. $96-12-4$ 
TABLE 17.-Quantity and value of EXPORTS of domestic FARM and FOREST products, 1909-1911, by articles and by countries to which consigned-Continued.

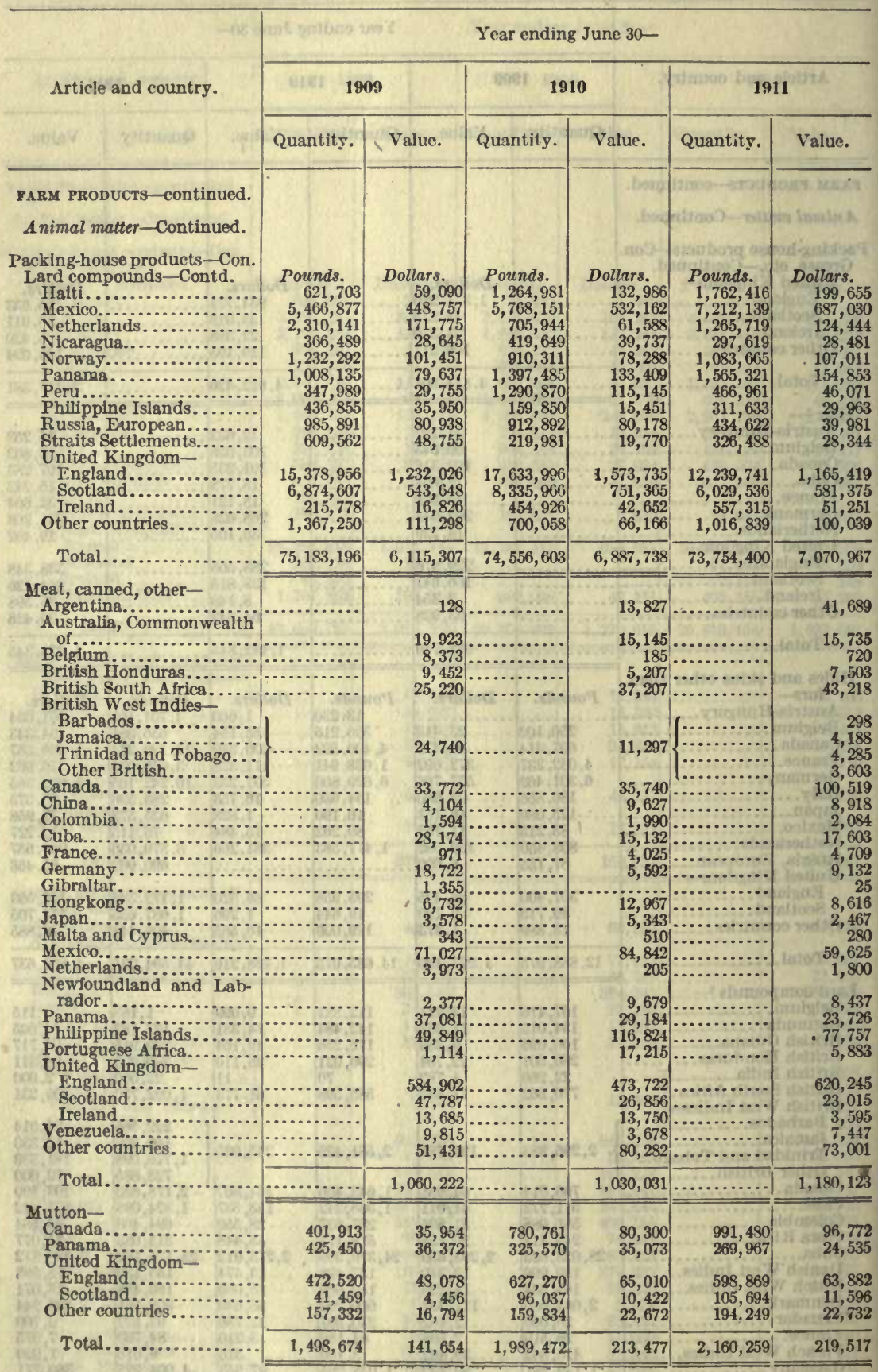


TABLE 17.-Quantity and value of EXPORTS of domestic FARM and FOREST products, 1909-1911, by articles and by countries to which consigned-Continued.

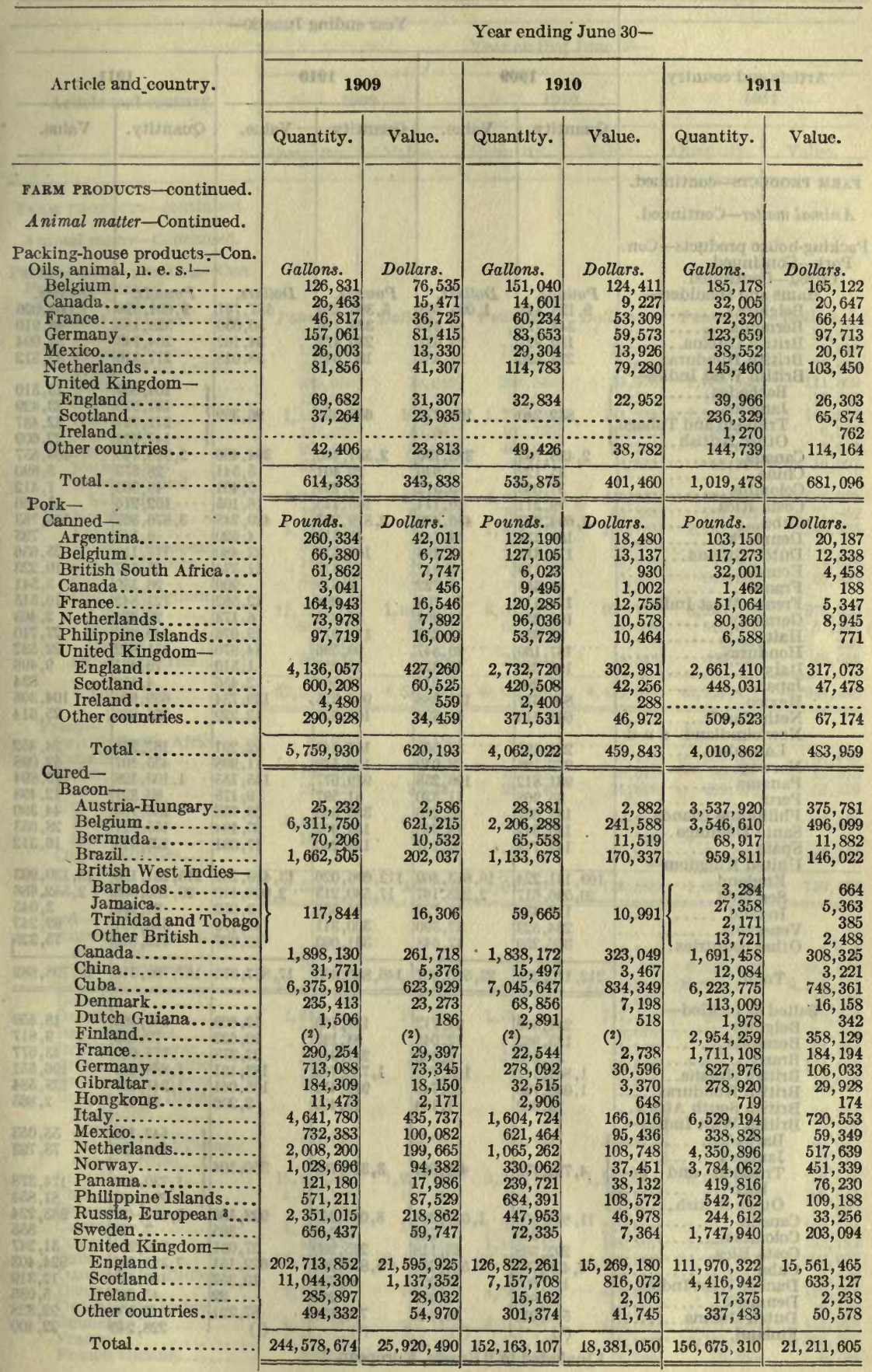

1 Excluding whale and fish oil.

"Included in "Russia, European.".

8 Including "Finland" prior to July 1, 1910. 
TABLE 17.-Quantity and value of EXPORTS of domestic FARM and FOREST products, 1909-1911, by articles and by countries to which consigned - Continued.

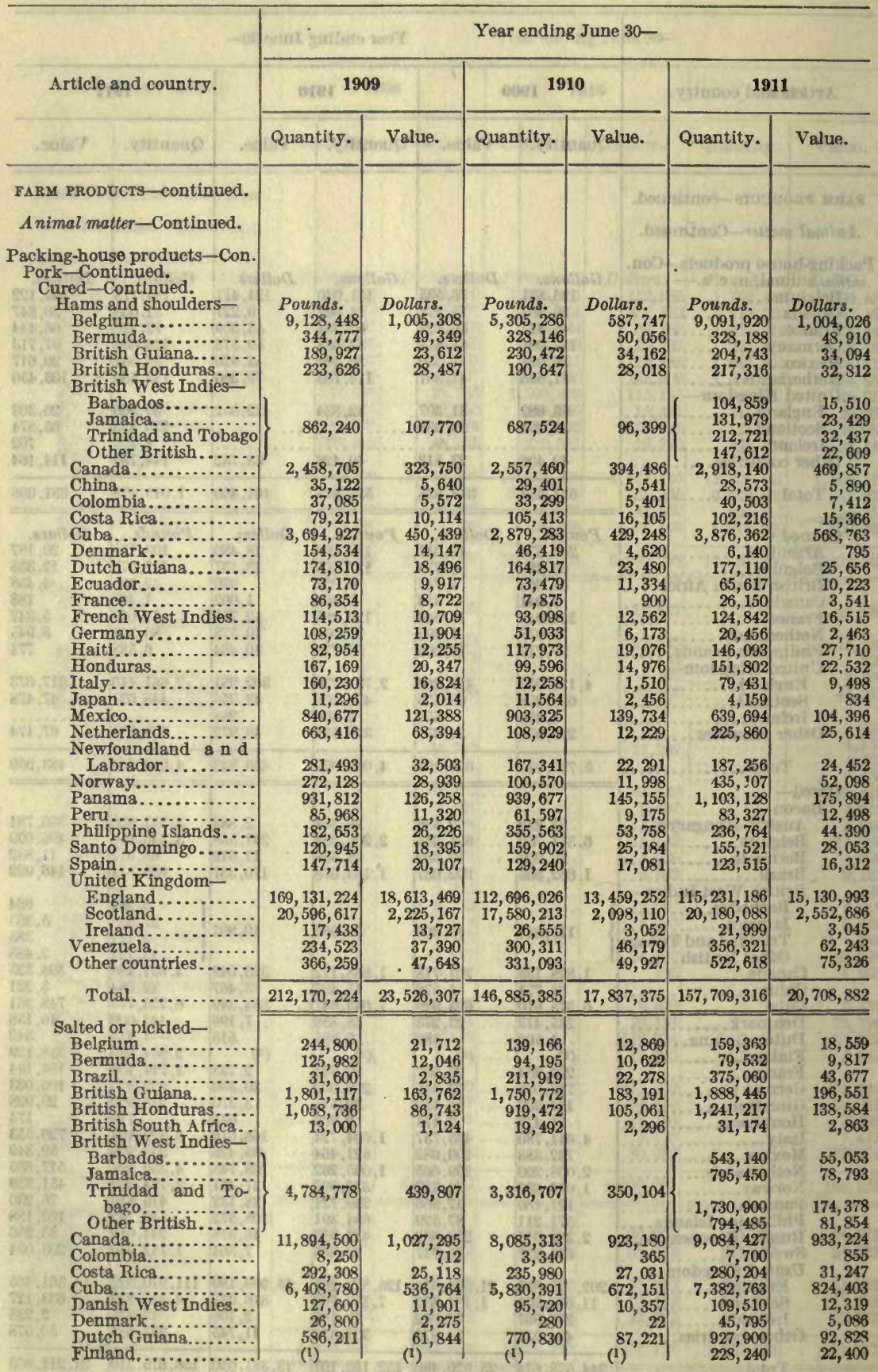

1 Included in "Russia, European." 
TABLE 17.-Quantity and value of EXPORTS of domestic FARM and FOREST products, 1909-1911, by articles and by countries to which consigned-Continued.

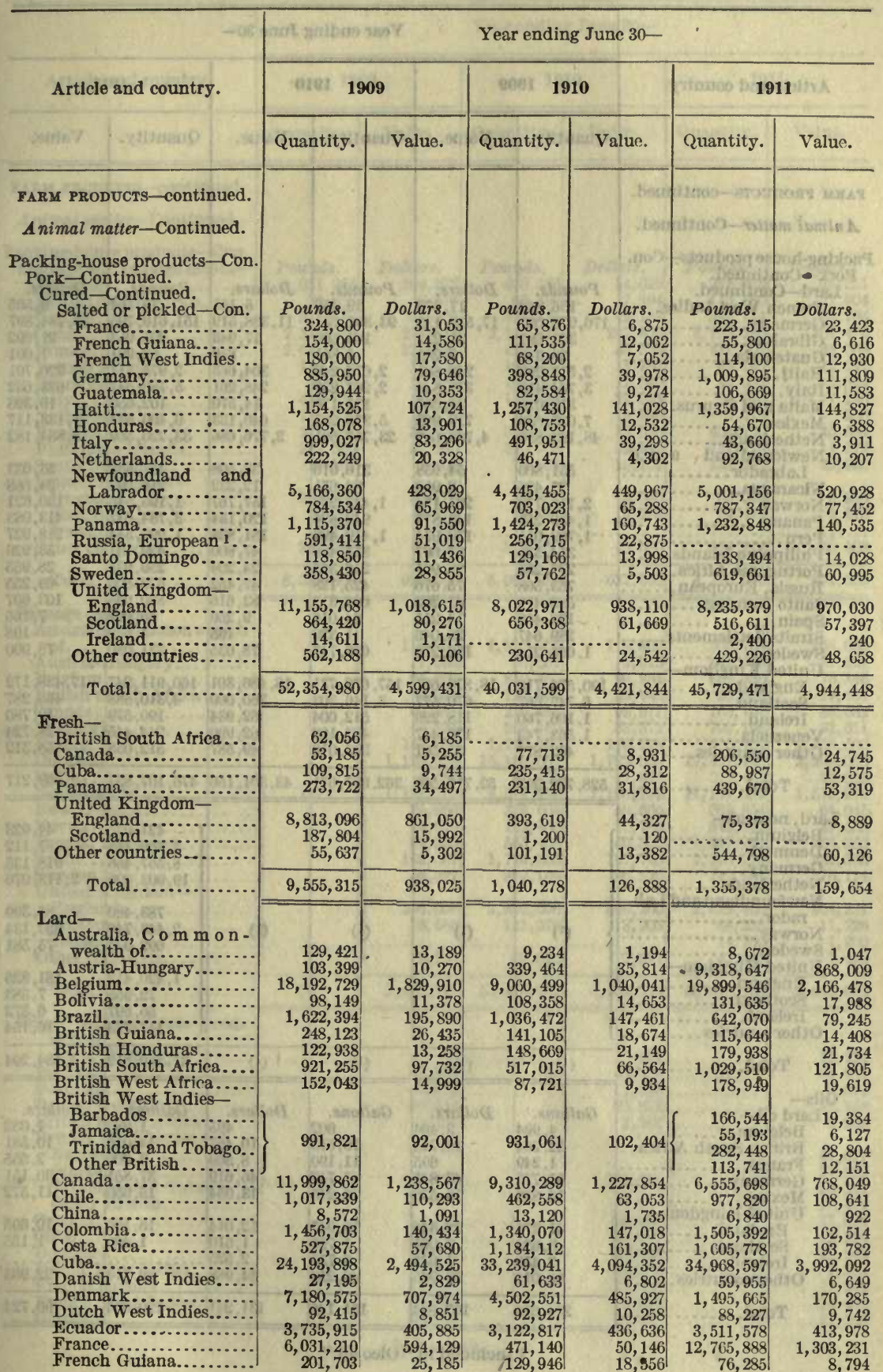

1 Including, "Finland," prior to July 1, 1910. 
TABLE 17.-Quantity and value of EXPORTS of domestic FARM and FOREST products, 1909-1911, by articles and by countries to which consigned-Continued.

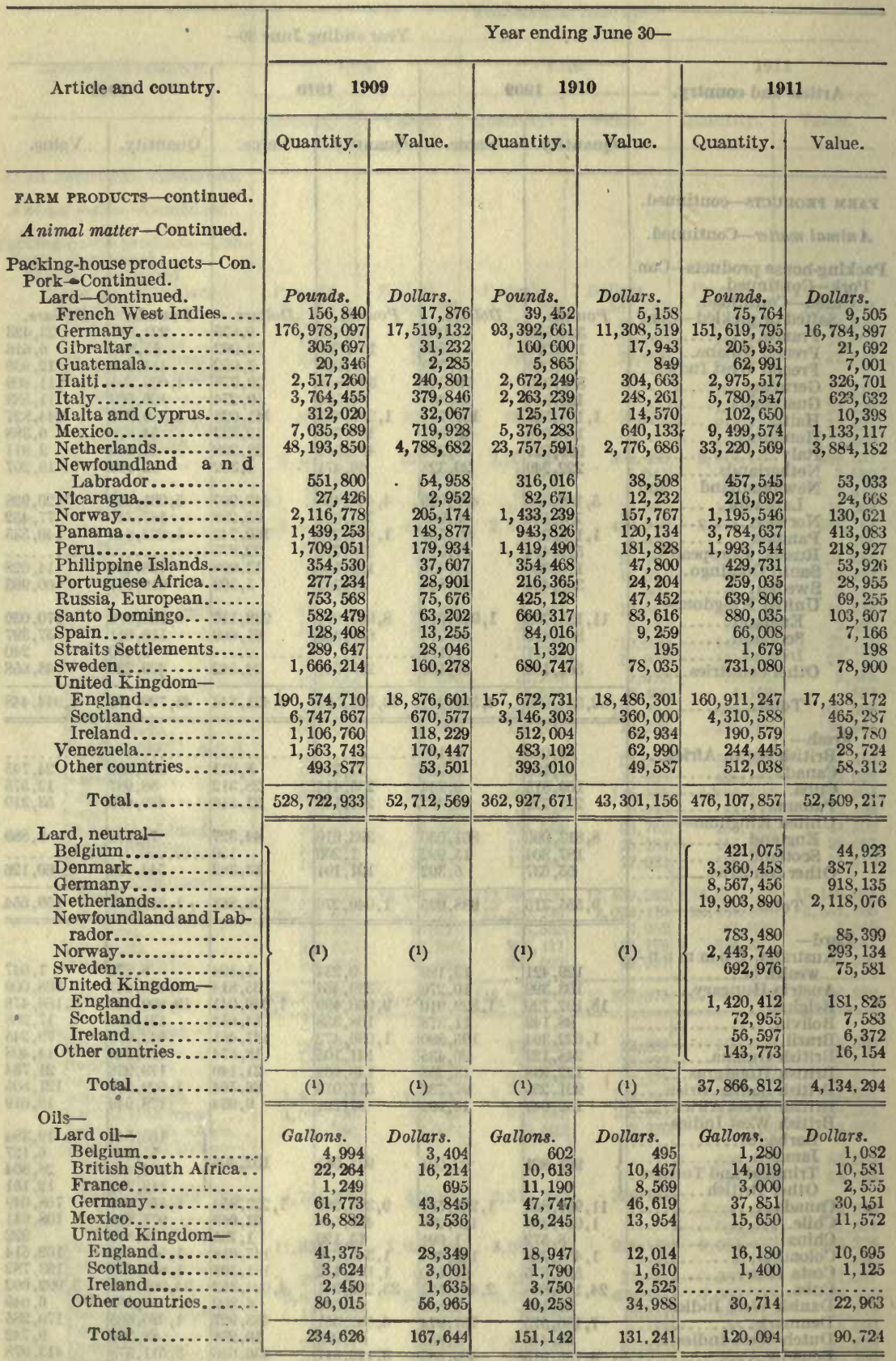

2 Included in "Oleo oil." 
TABLE 17.-Quantity and value of EXPORTS of domestic FARM and FOREST products, 1909-1911, by articles and by countries to which consigned-Continued.

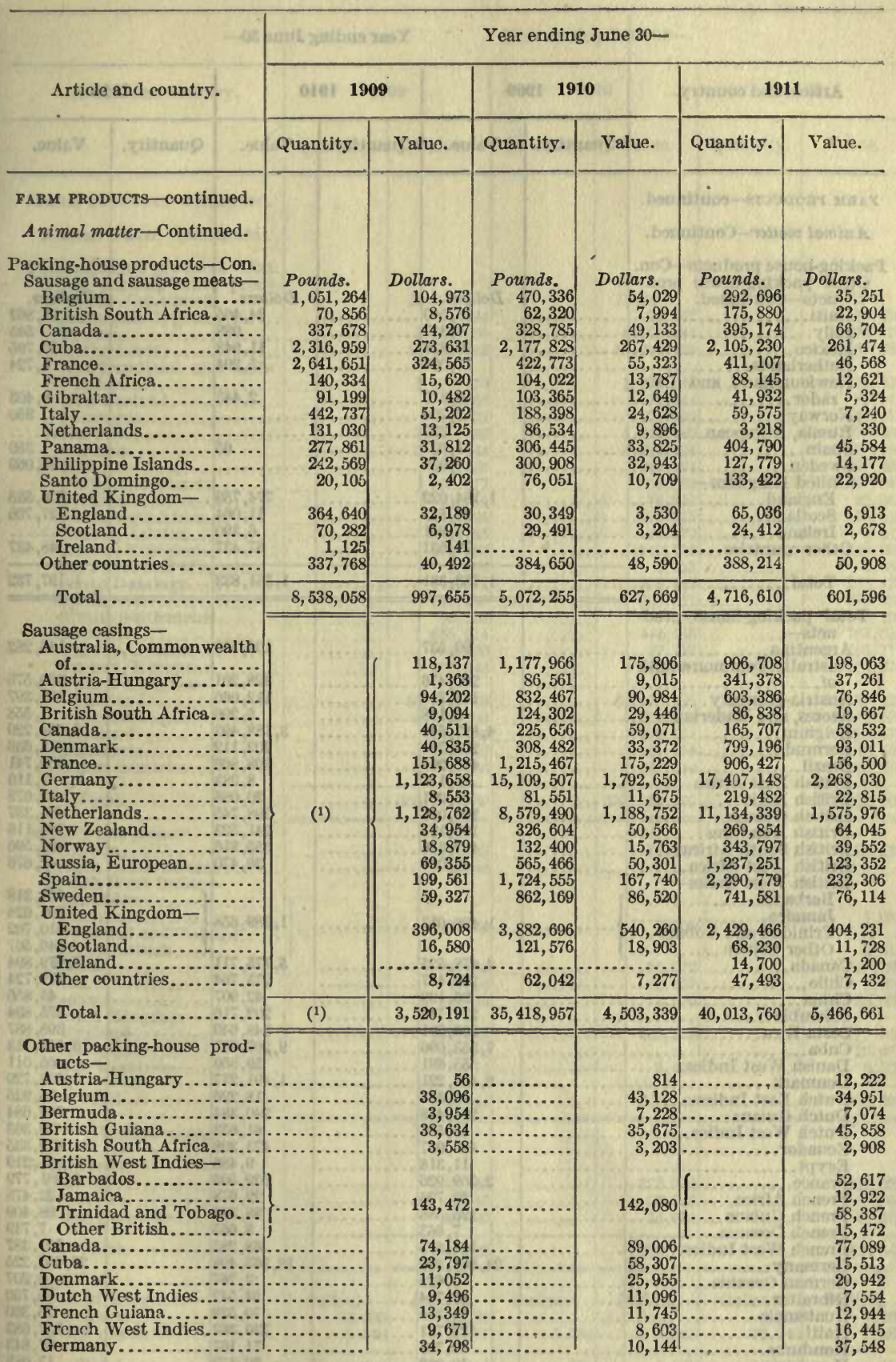

1 Not stated. 
TABLE 17.-Quantity and value of EXPORTS of domestic FARM and FOREST products, 1909-1911, by articles and by countries to which consigned-Continued.

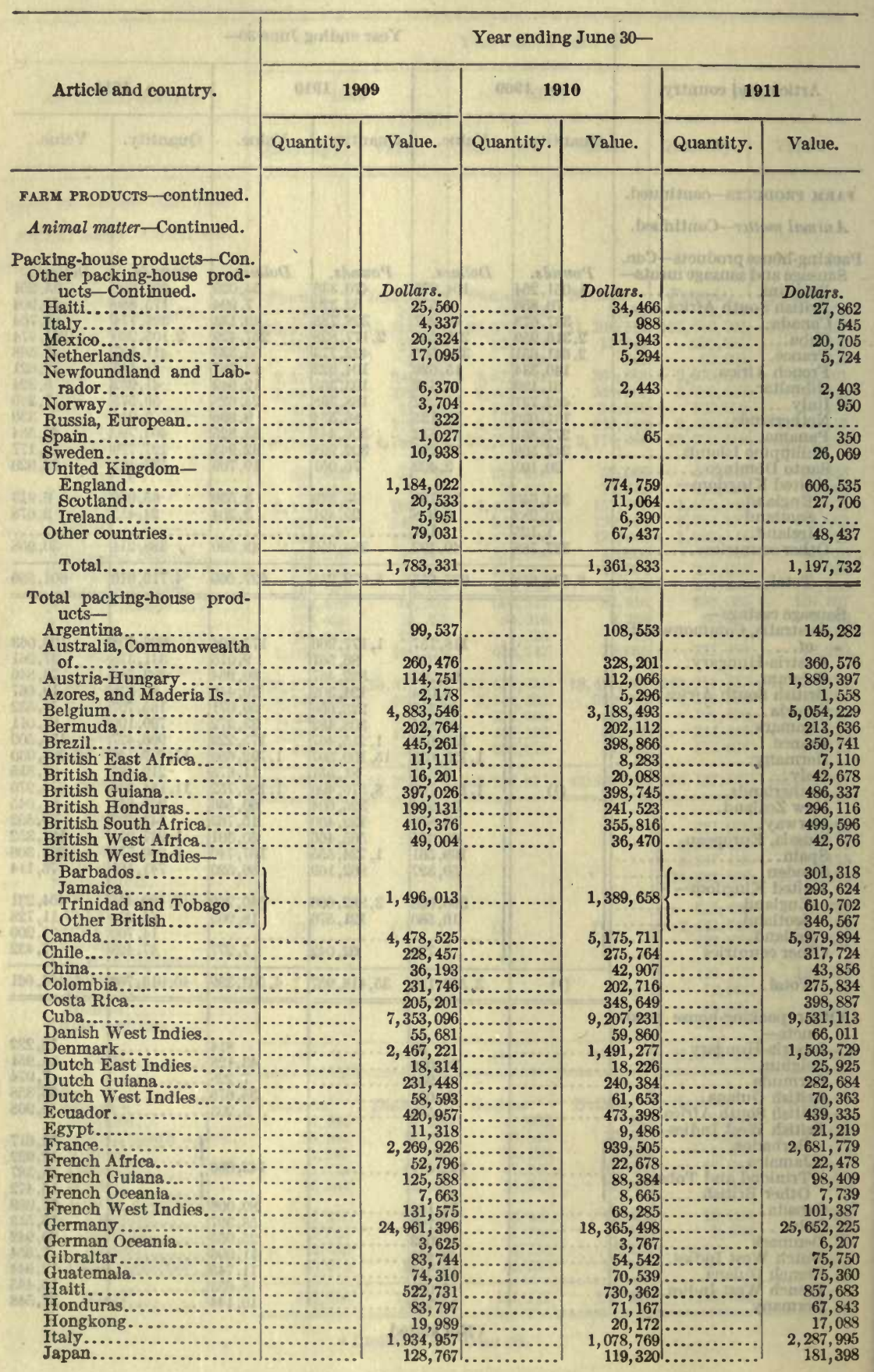


TABLE 17.-Quantity and value of EXPORTS of domestic FARM and FOREST products, 1909-1911, by articles and by countries to which consigned - Continued.

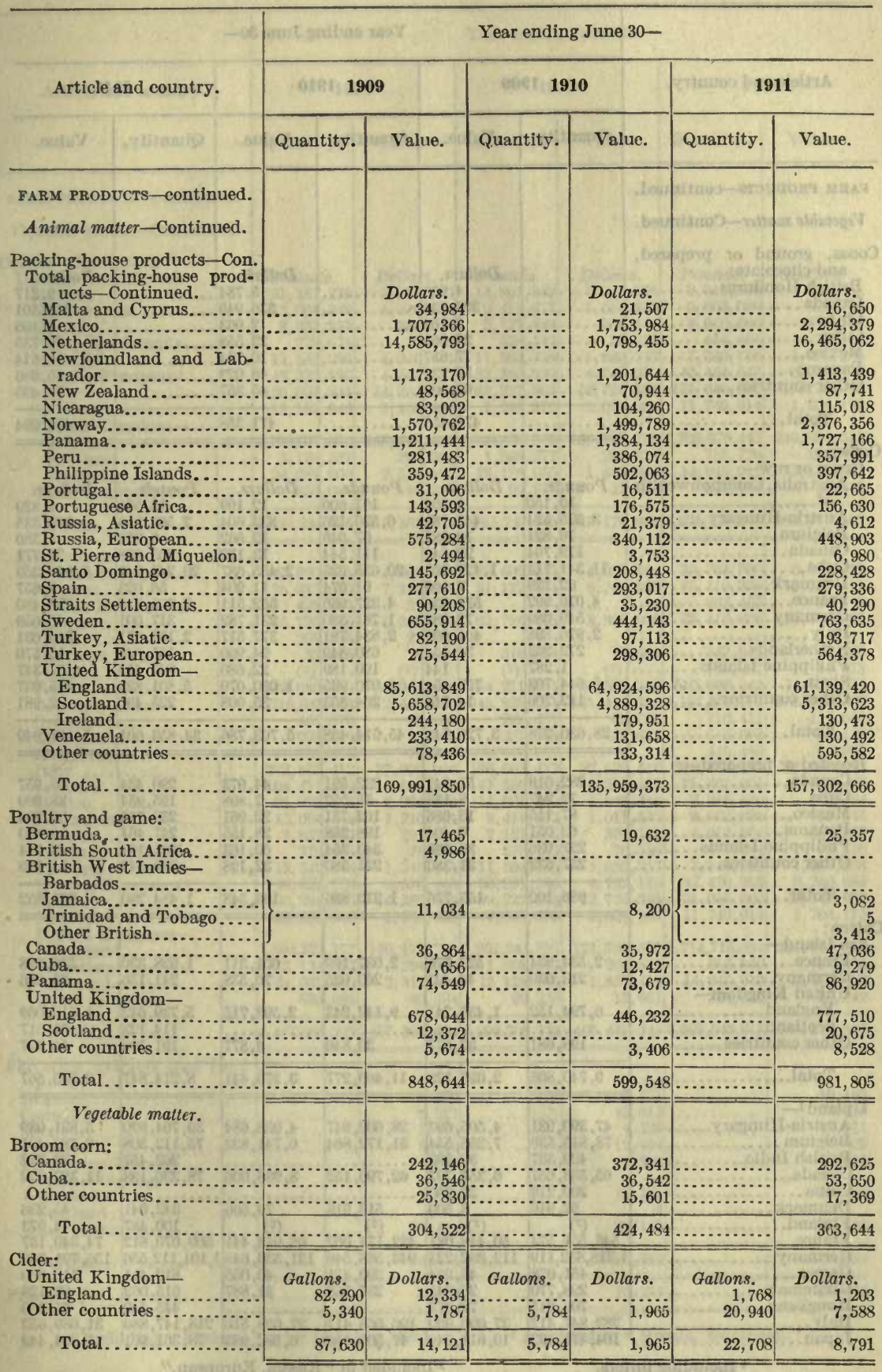


TABLE 17.-Quantity and value of EXPORTS of domestic FARM and FOREST products, 1909-1911, by articles and by countries to which consigned-Continued.

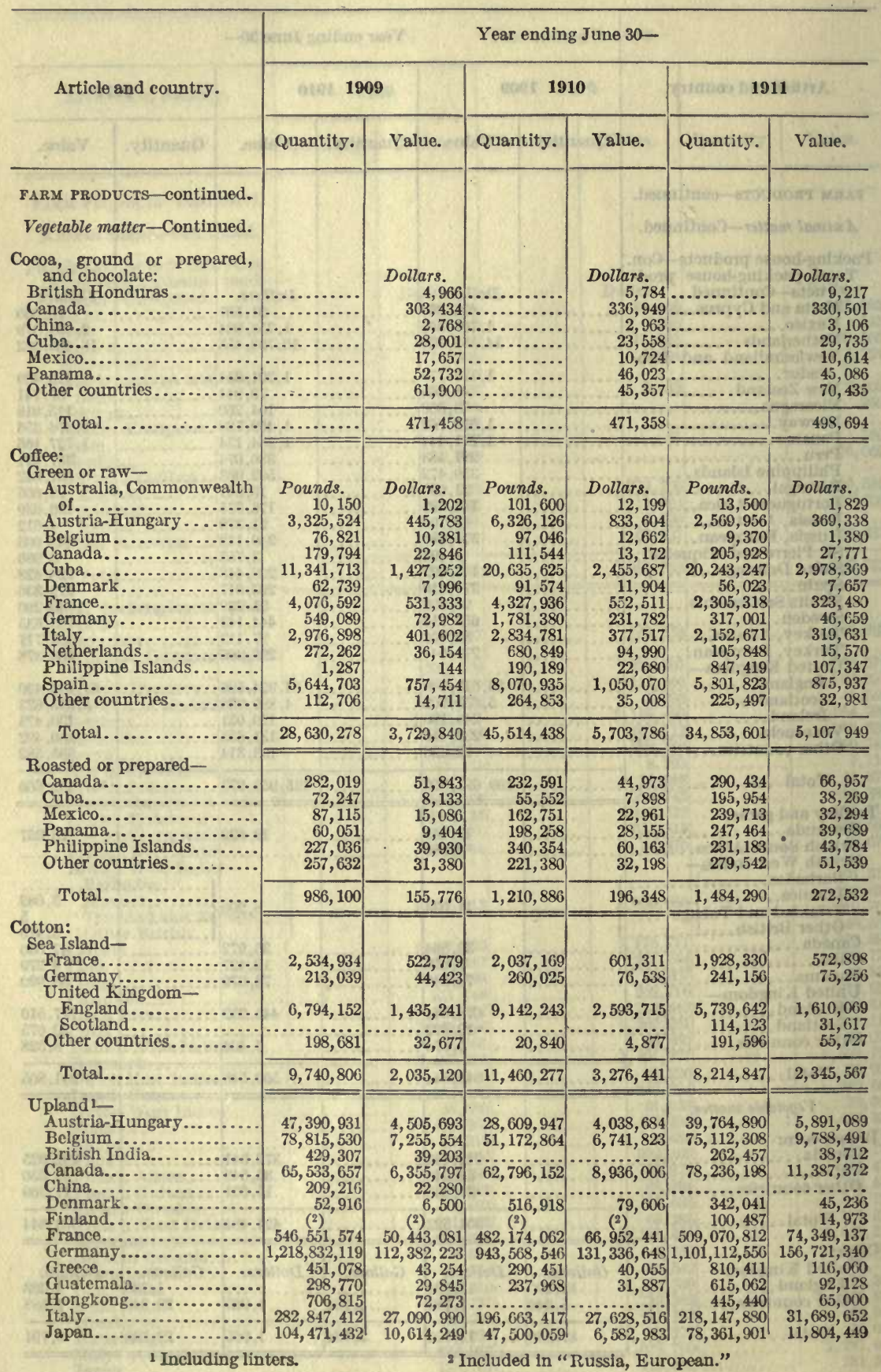


TABLE 17.-Quantity and value of EXPORTS of domestic FARM and FOREST products, 1909-1911, by articles and by countries to which consigned-Continued.

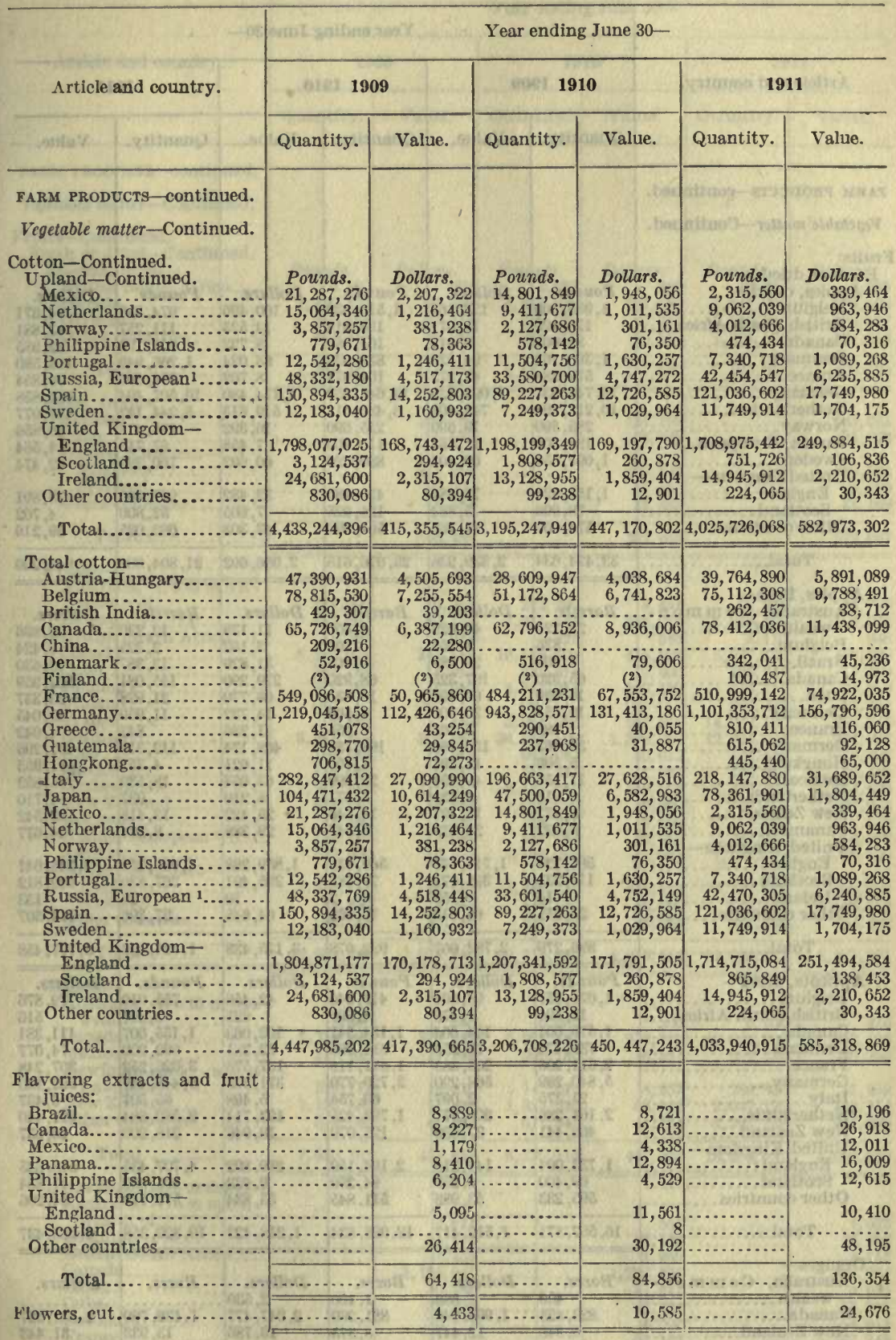


TABLE 17.-Quantity and value of EXPORTS of domestic FARM and FOREST products, 1909-1911, by articles and by countries to which consigned-Continued.

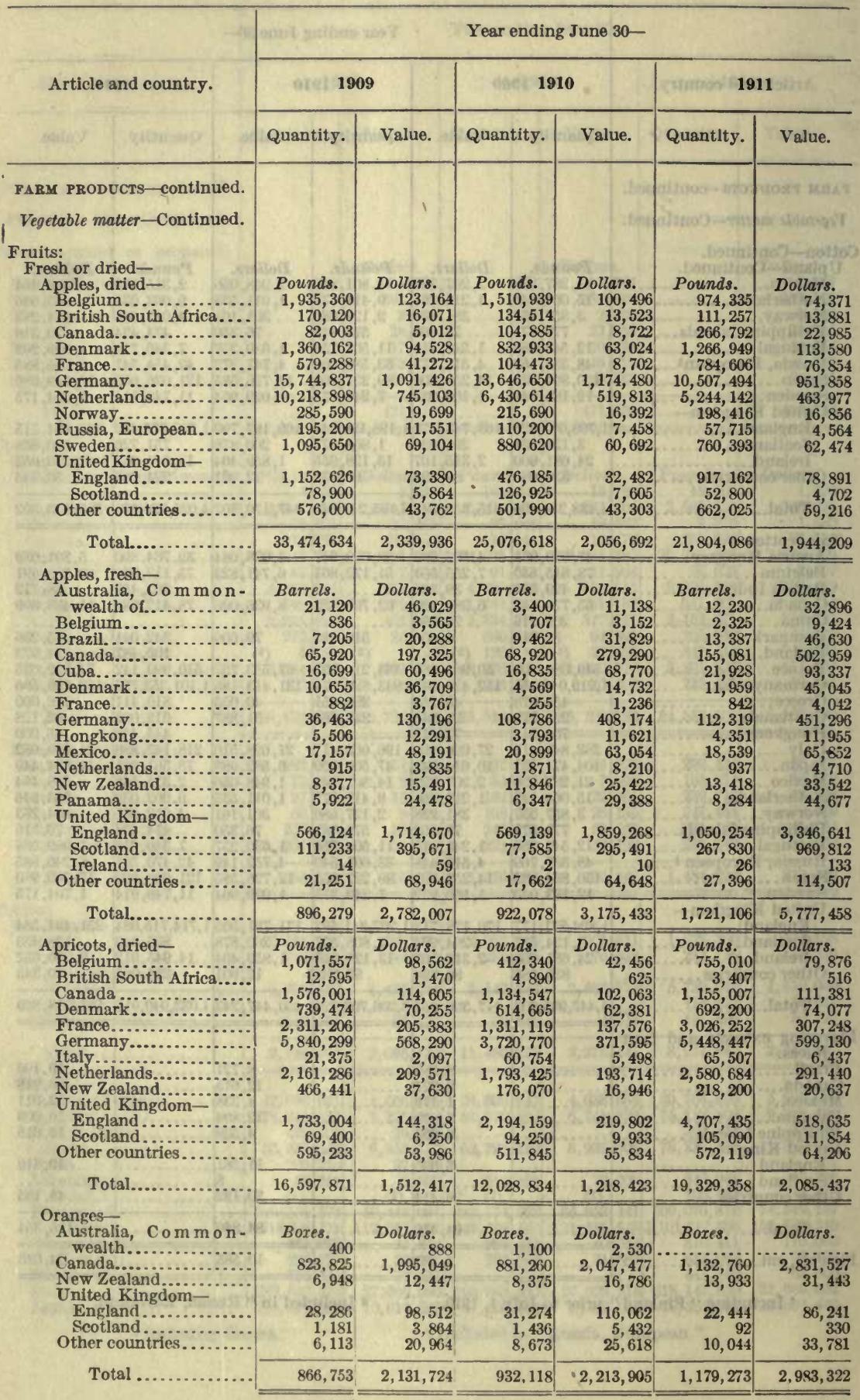


TABLE 17.-Quantity and value of EXPORTS of domestic FARM and FOREST products, 1909-1911, by articles and by countries to which consigned-Continued.

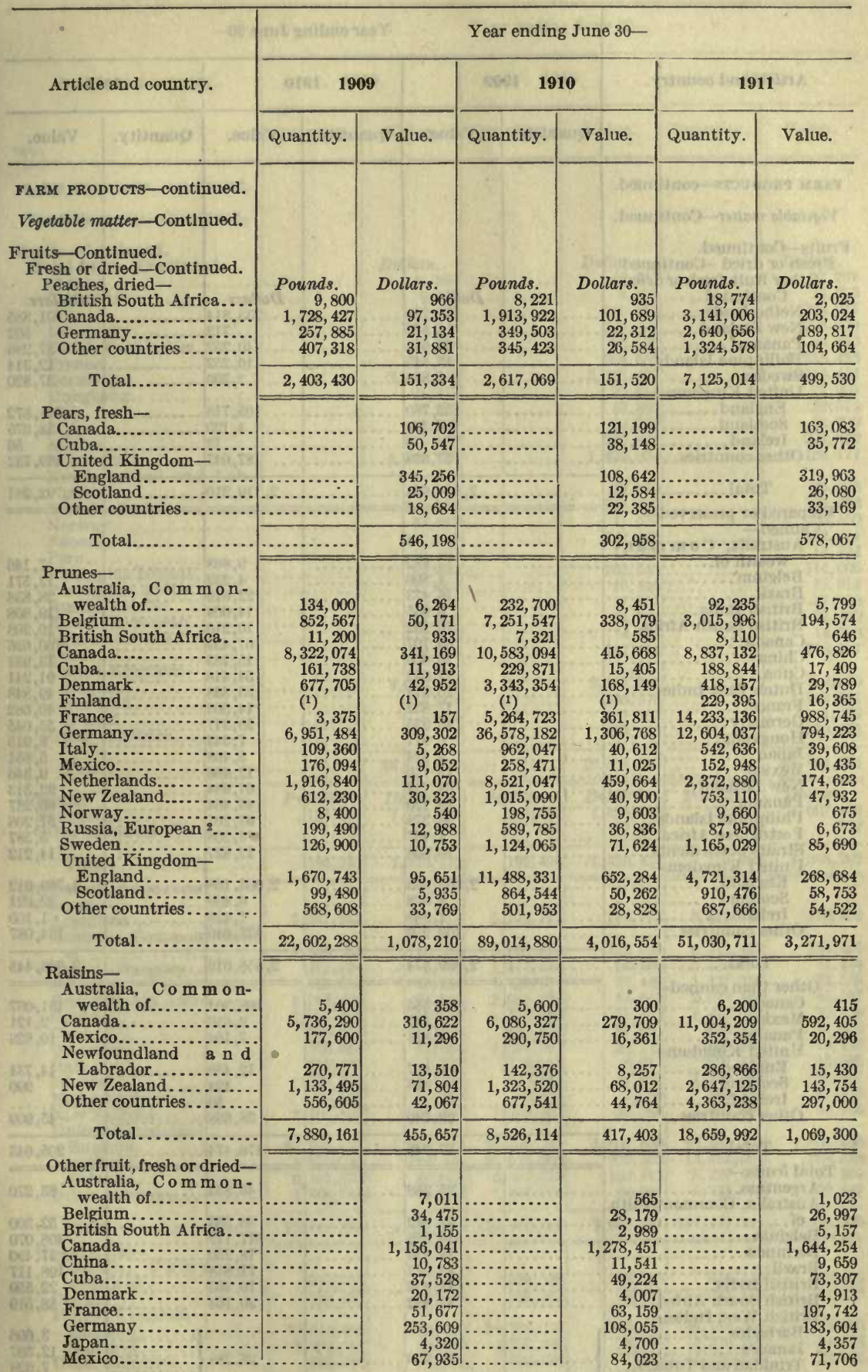


TABLE 17.-Quantity and value of EXPORTS of domestic FARM and FOREST products, 1909-1911, by articles and by countries to which consigned-Continued.

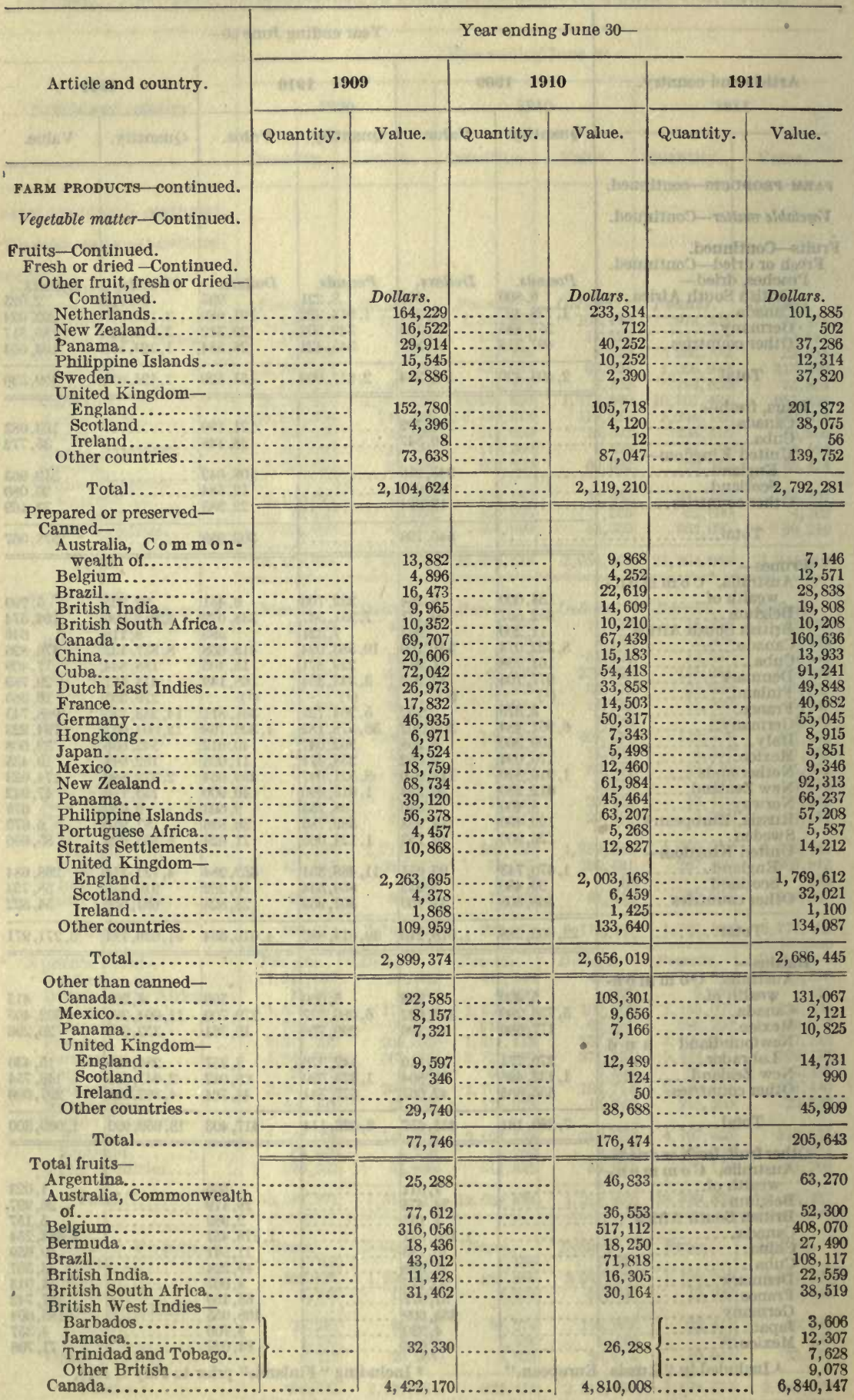


TABLE 17.-Quantity and value of EXPORTS of domestic FARM and FOREST products, 1909-1911, by articles and by countries to which consigned-Continued.

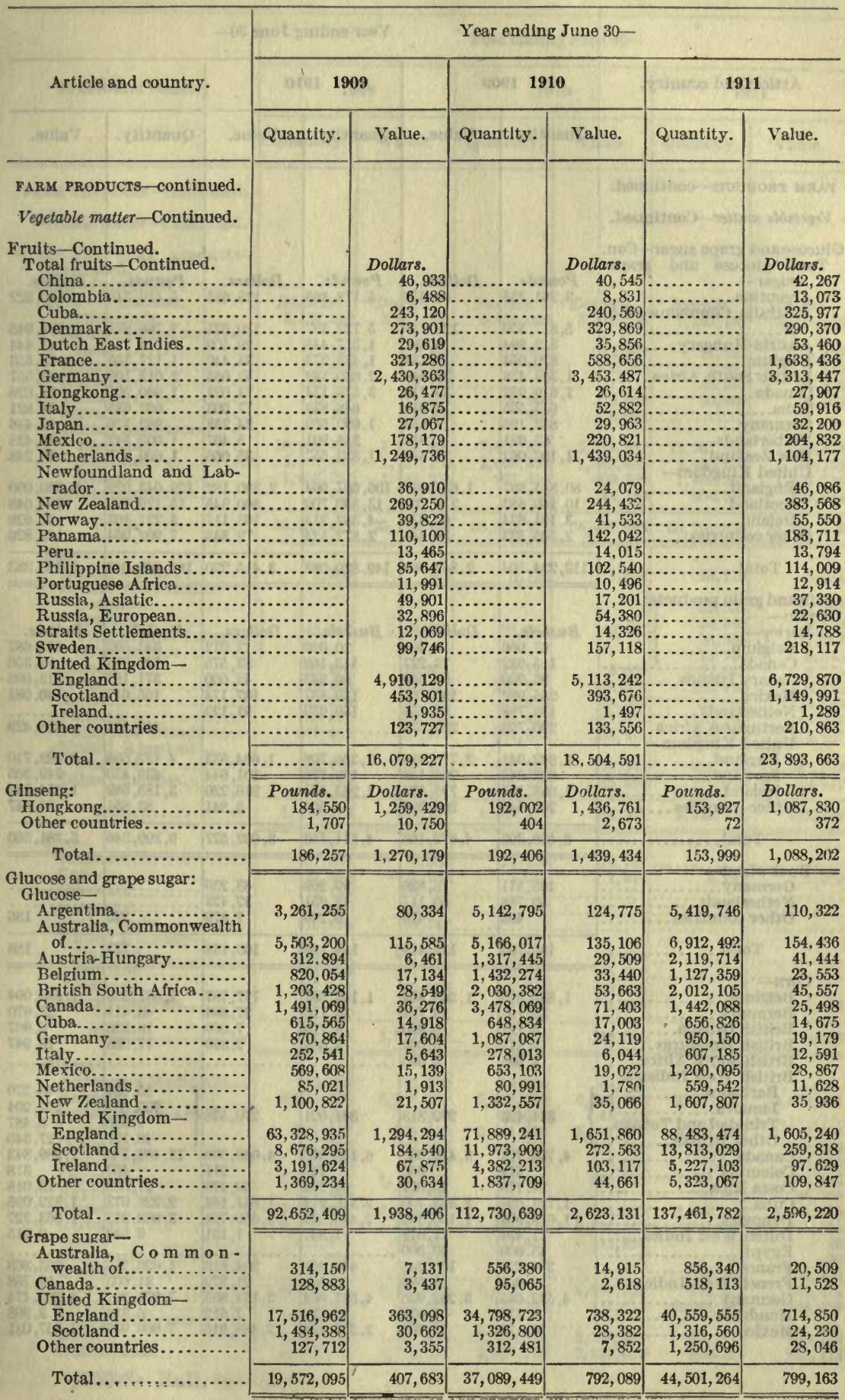


TABLE 17.-Quantity and valus of EXPORTS of domestic FARM and FOREST products, 1909-1911, by articles and by countries to which consigned-Continued.

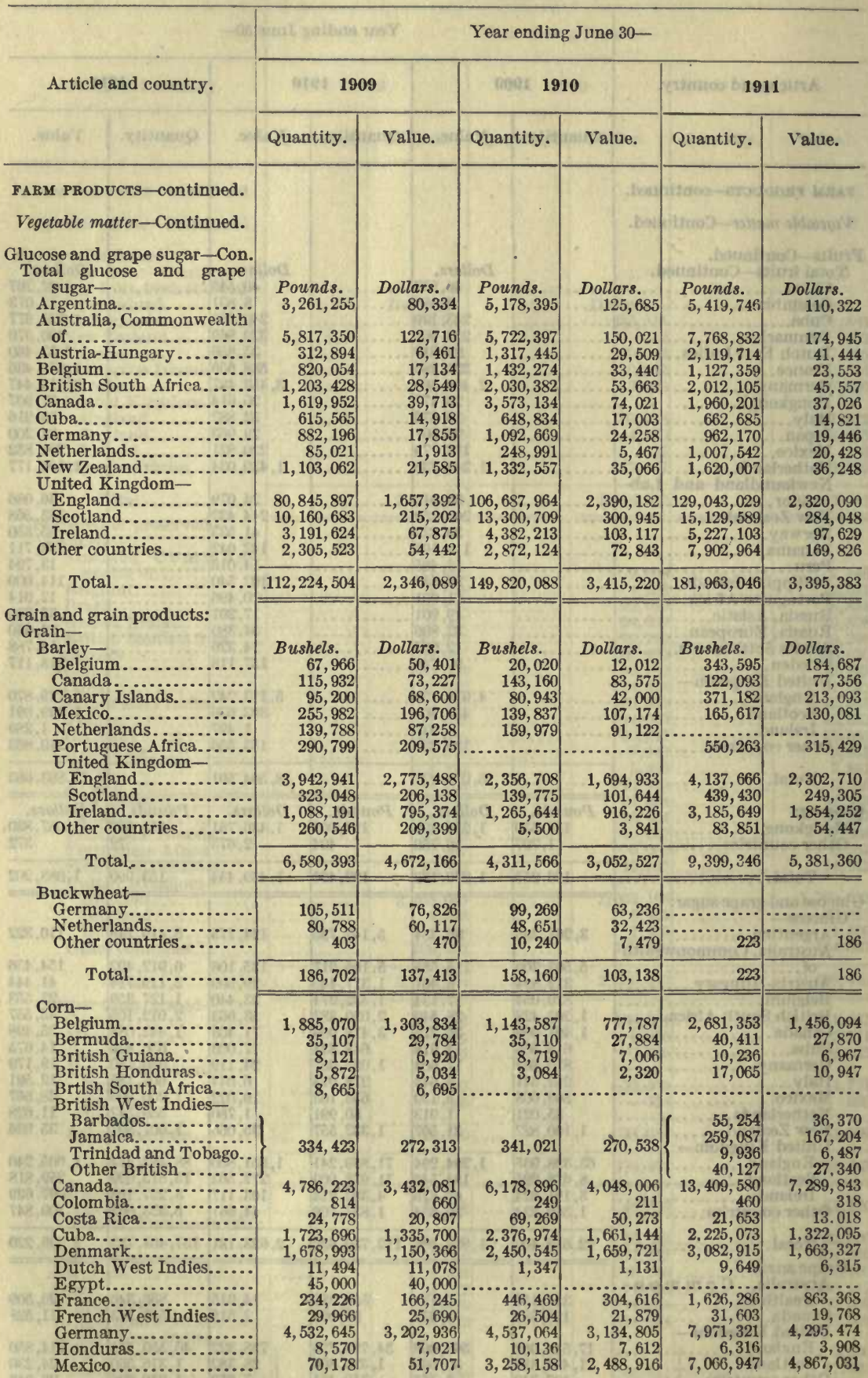


TABLE 17.-Quantity and value of EXPORTS of domestic FARM and FOREST products, 1909-1911, by articles and by countries to which consigned-Continued.

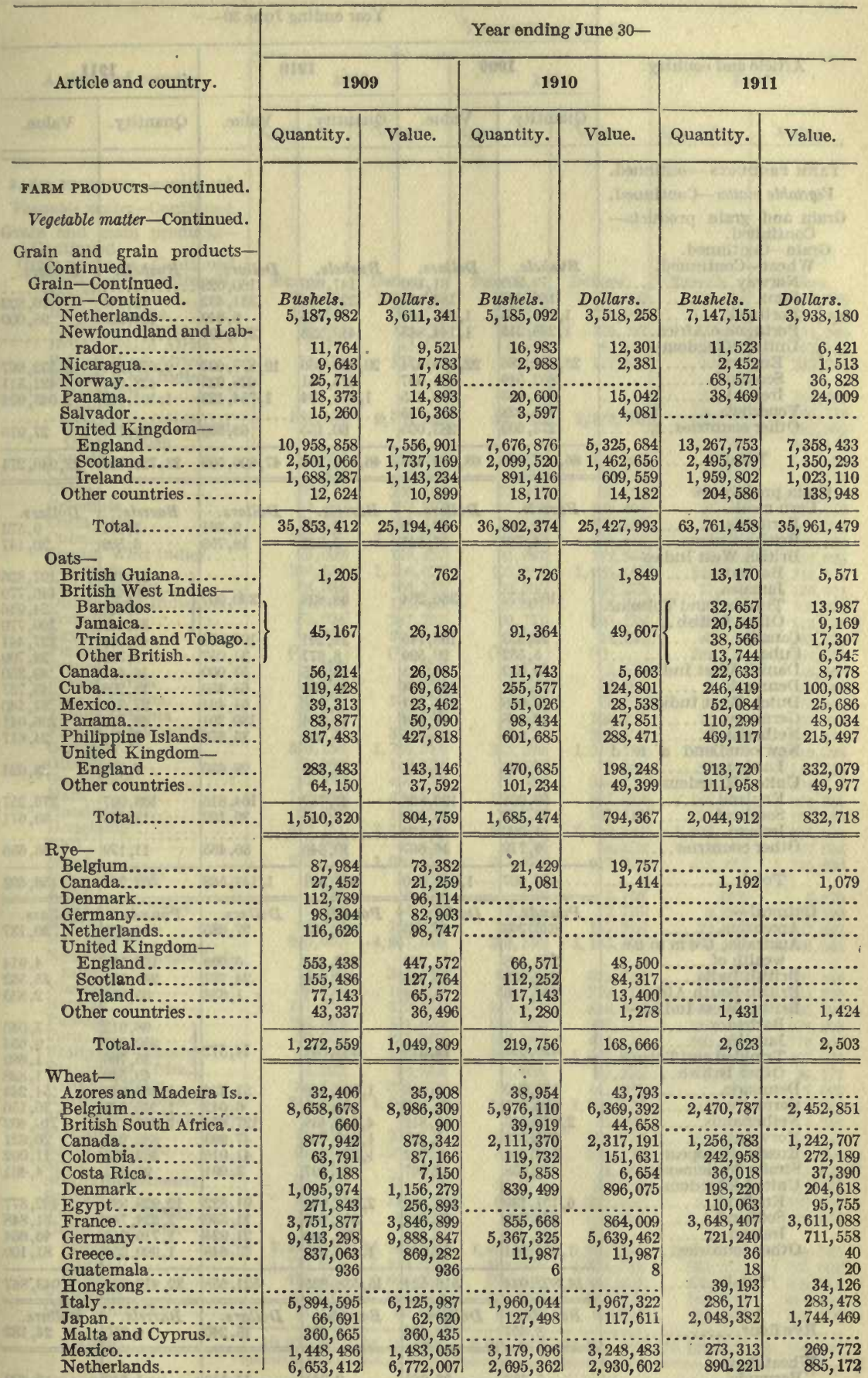

$50597^{\circ}-$ Bull. $96-12 \longrightarrow 5$ 
TABLE 17.-Quantity and value of EXPORTS of domestic FARM and FOREST products, 1909-1911, by articles and by countries to which consigned-Continued.

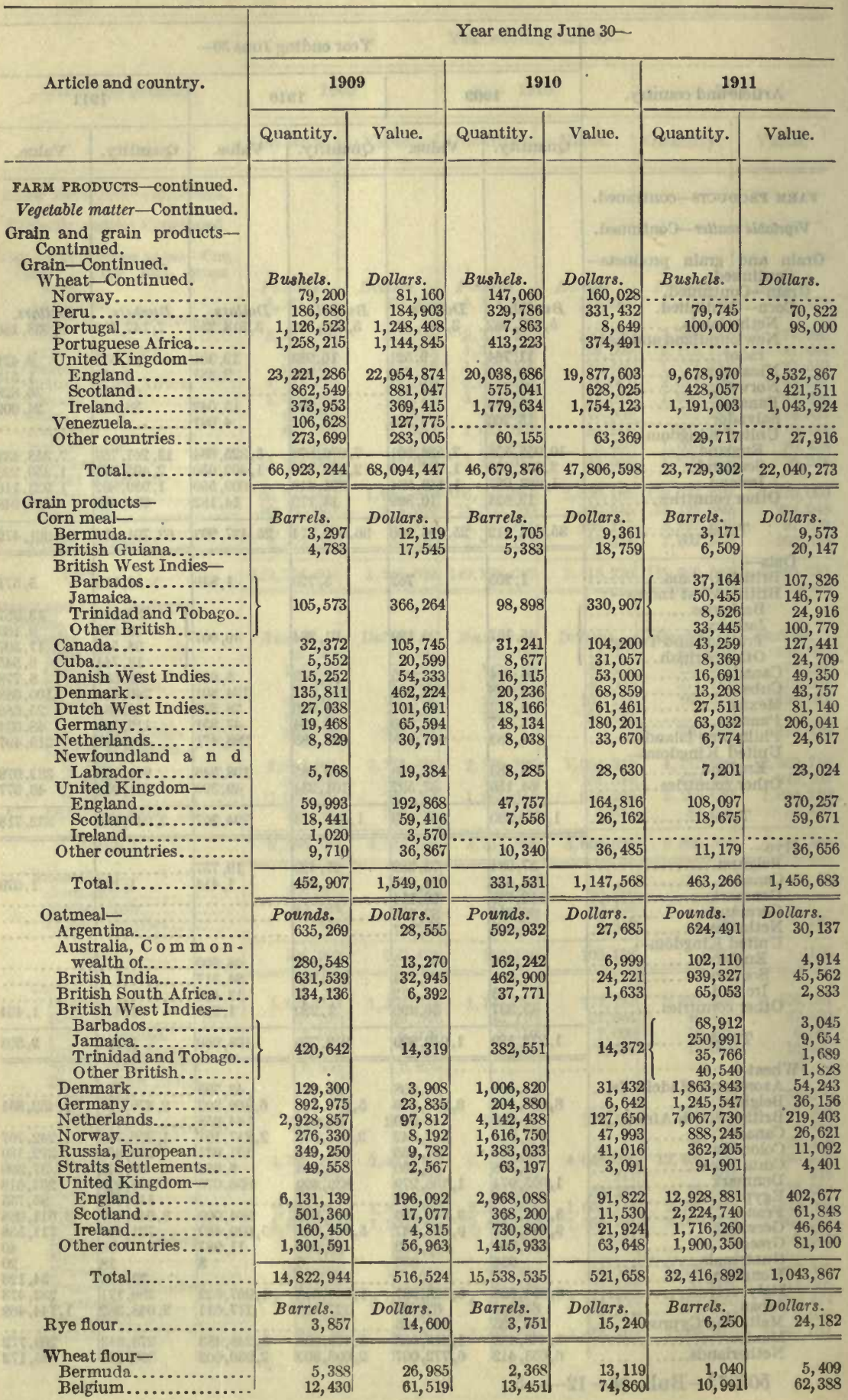


TABLE 17.-Quantity and value of EXPORTS of domestic FARM and FOREST products, 1909-1911, by articles and by countries to which consigned-Continued.

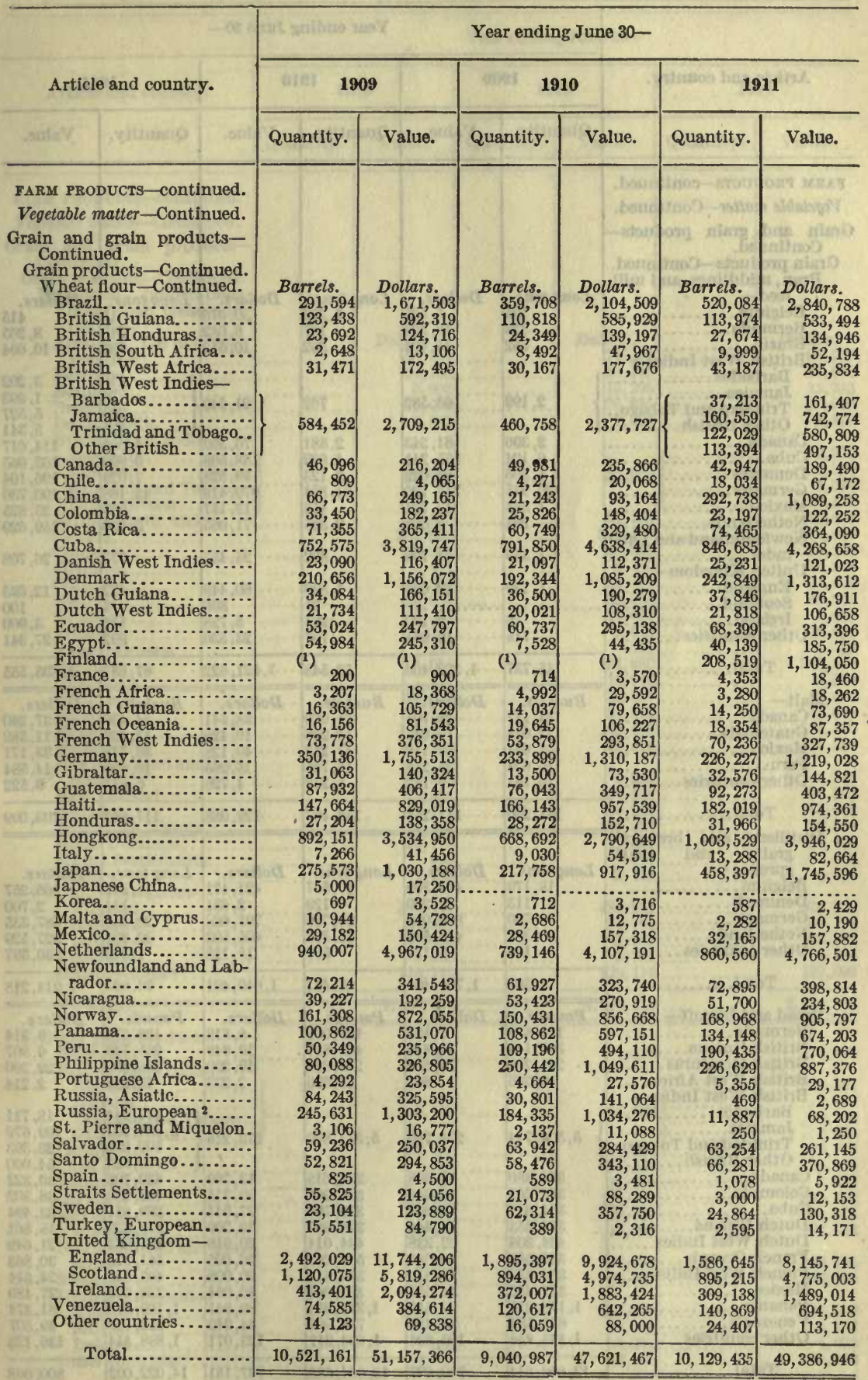


TABLE 17.-Quantity and value of EXPORTS of domestic FARM and FOREST products, 1909-1911, by articles and by countries to which consigned-Continued.

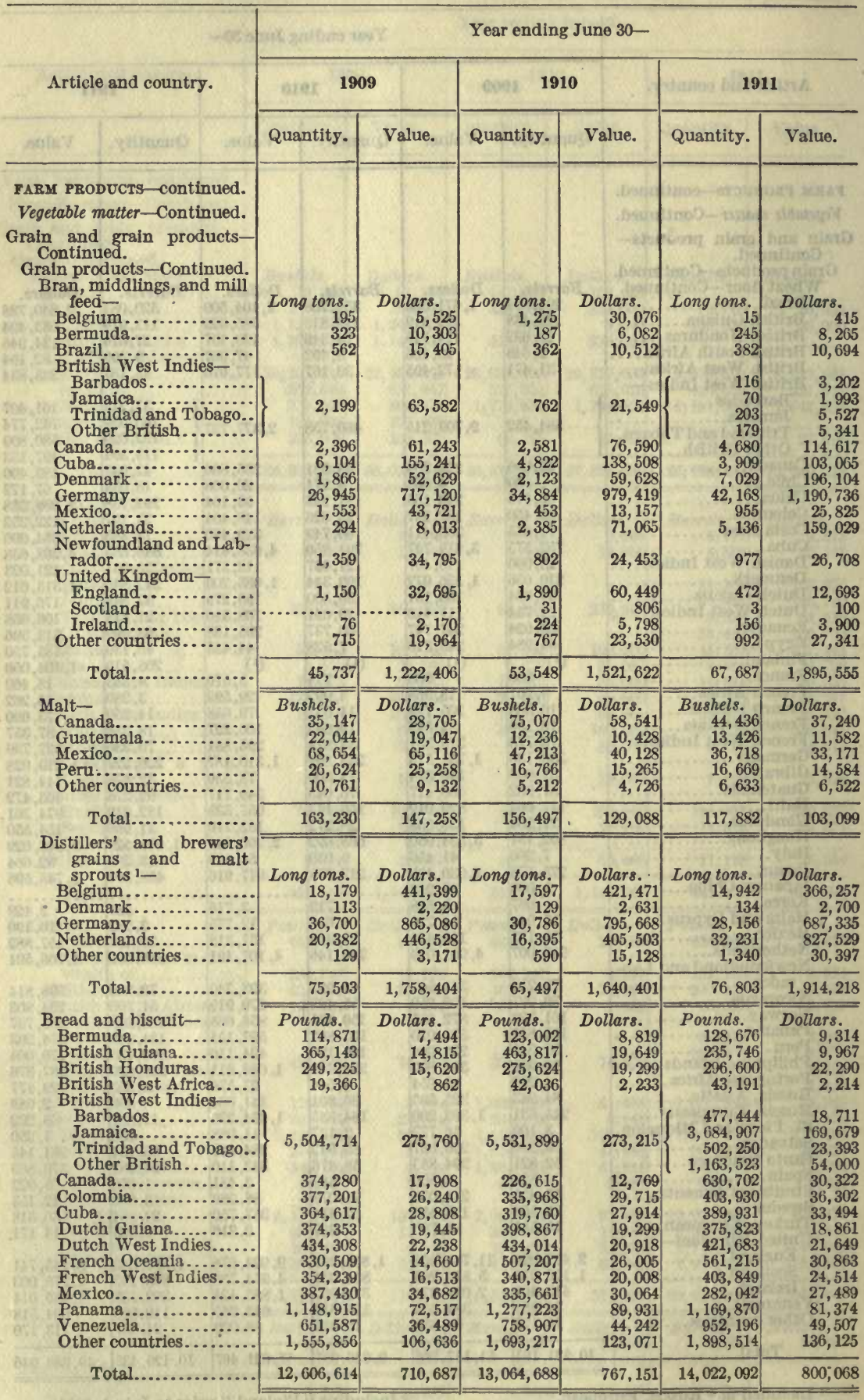

1 Or "Distillery and brewery refuse." 
TABLE 17.-Quantity and value of EXPORTS of domestic FARM and FOREST products, 1909-1911, by articles and by countries to which consigned-Continued.

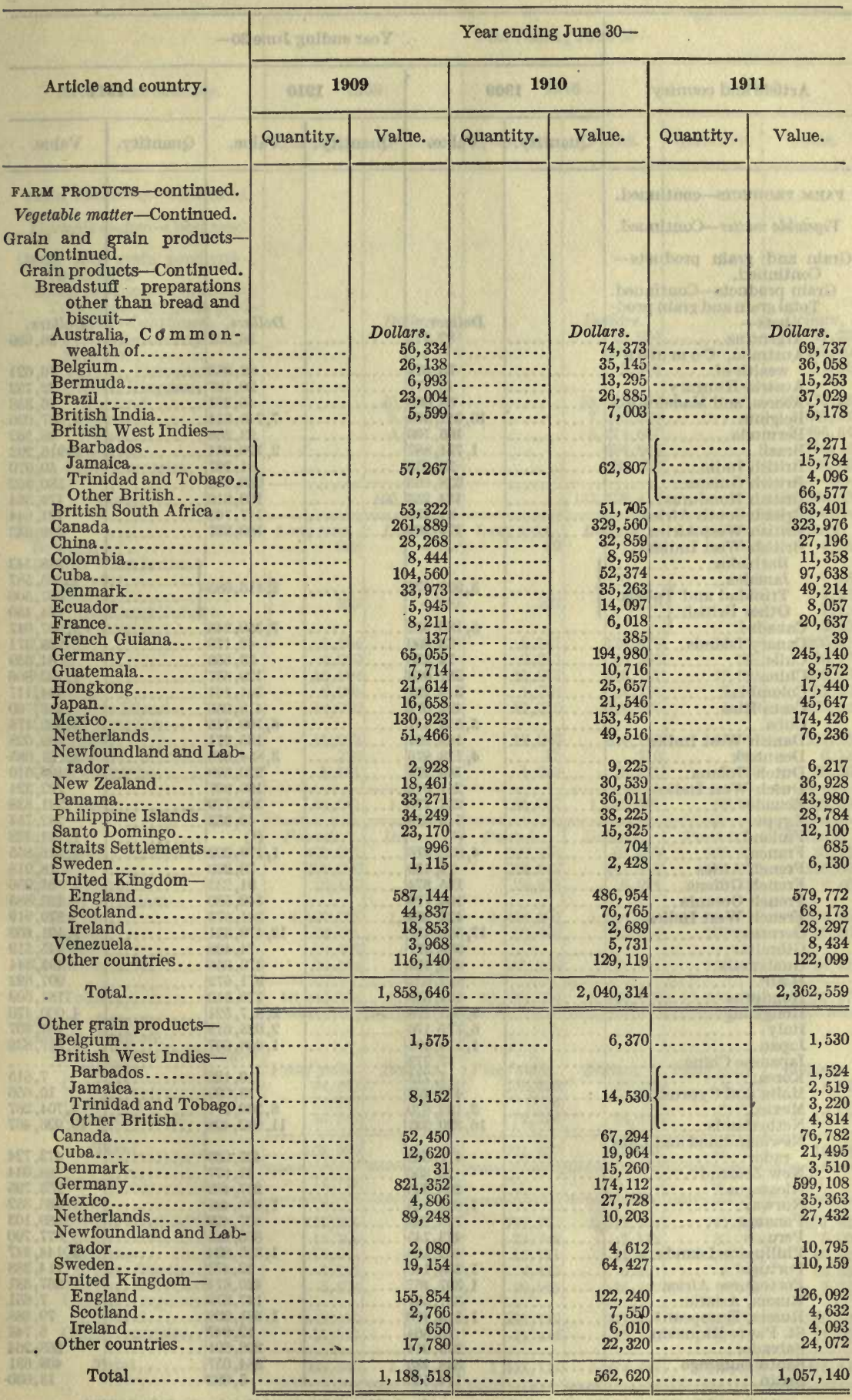


TABLE 17.-Quantity and value of EXPORTS of domestic FARM and FOREST products, 1909-1911, by articles and by countries to which consigned-Continued.

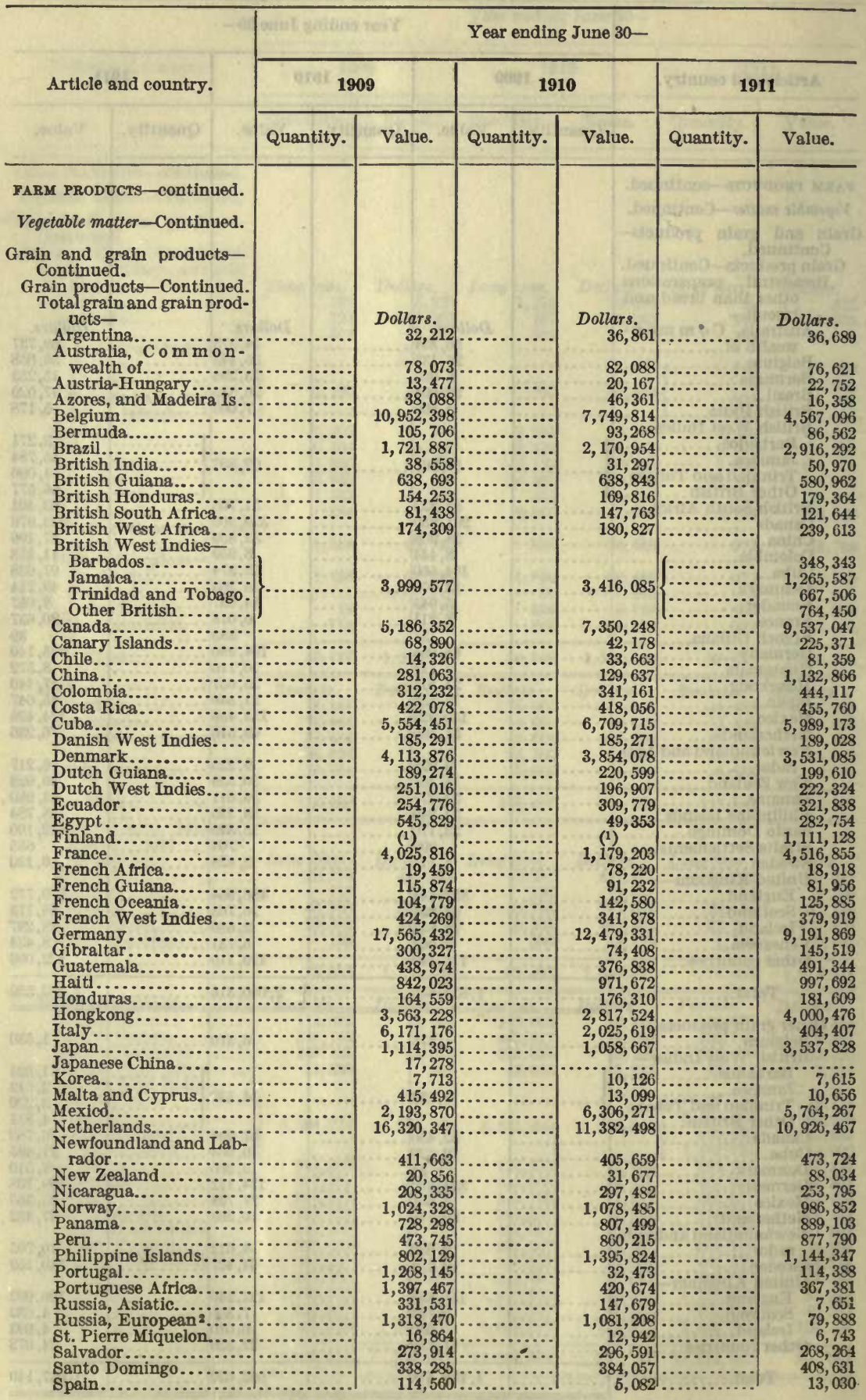

1 Included in "Russia, European."

Including " Finland" prior to July 1, 1910. 
TABLE 17.-Quantity and value of EXPORTS of domestic FARM and FOREST products, 1909-1911, by articles and by countries to which consigned-Continued.

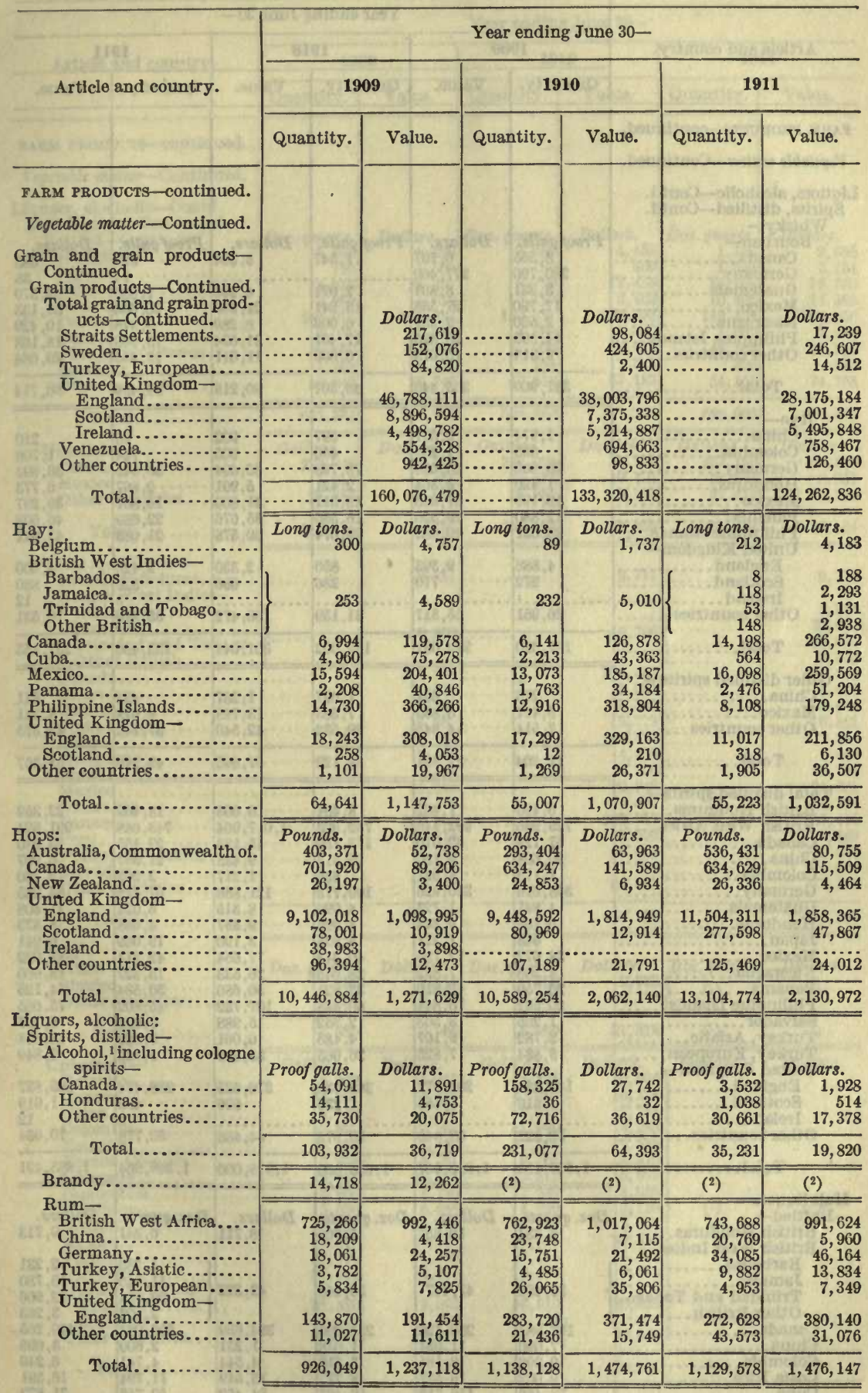

1 Excluding wood alcohol.

2 Included in "Other distilled spirits." 
TABLE 17.-Quantity and value of EXPORTS of domestic FARM and TOREST products, 1909-1911, by articles and by countries to which consigned - Continued.

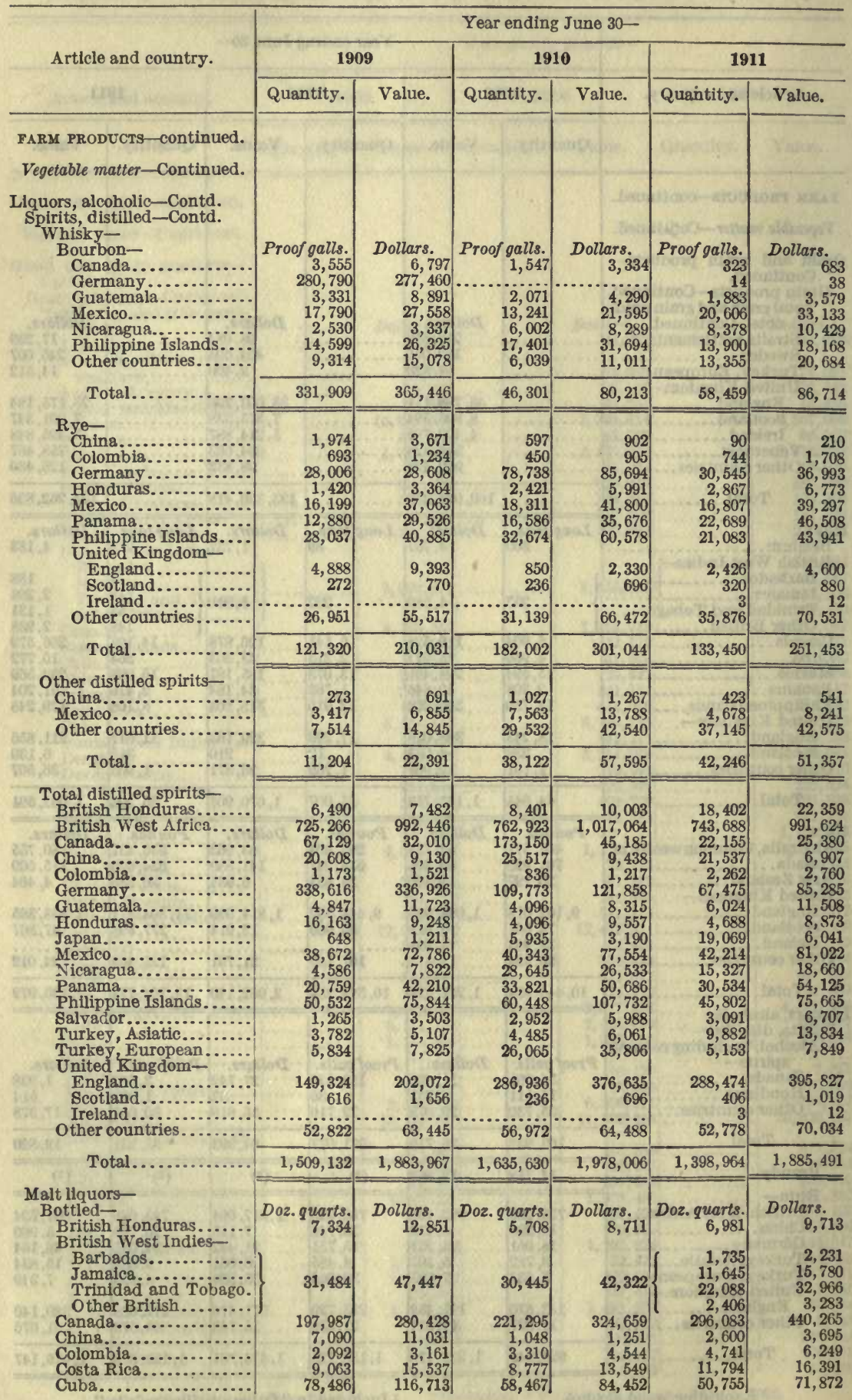


TABLE 17.-Quantity and value of EXPORTS of domestic FARM and FOREST products, 1909-1911, by articles and by countries to which consigned-Continued.

\begin{tabular}{|c|c|c|c|c|c|c|}
\hline & & & ear & une 30 & & \\
\hline Artlcle and country. & 190 & & & & & \\
\hline & Quantity. & Value. & Quantity. & Value. & Quantity. & Value. \\
\hline 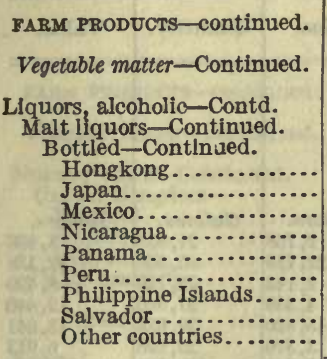 & $\begin{array}{r}\text { Doz. quarts. } \\
5,586 \\
726 \\
14,913 \\
3,988 \\
167,810 \\
4,336 \\
49,960 \\
1,463 \\
53,043\end{array}$ & $\begin{array}{r}\text { Dollars. } \\
8,638 \\
1,509 \\
21,357 \\
6,672 \\
280,334 \\
5,814 \\
74,280 \\
2,474 \\
76,746\end{array}$ & \begin{tabular}{|r|} 
Doz. quarts. \\
$\mathbf{3}, 680$ \\
$\mathbf{1} 80$ \\
8,779 \\
3,423 \\
149,371 \\
4,288 \\
51,020 \\
234 \\
46,858 \\
\end{tabular} & $\begin{array}{r}\text { Dollars. } \\
4,458 \\
300 \\
12,455 \\
5,402 \\
232,553 \\
5,520 \\
69,614 \\
351 \\
67,183 \\
\end{array}$ & \begin{tabular}{|r|} 
Doz. quarts. \\
1,783 \\
1,588 \\
10,168 \\
10,696 \\
149,428 \\
1,952 \\
48,169 \\
325 \\
54,156
\end{tabular} & $\begin{array}{r}\text { Dollar8. } \\
2,686 \\
2,754 \\
15,750 \\
14,363 \\
202,856 \\
2,489 \\
71,836 \\
513 \\
74,703\end{array}$ \\
\hline Total............... & 635,361 & 964 & 883 & 324 & 689,093 & 990 \\
\hline $\begin{array}{l}\text { Unbottled- } \\
\text { Canada.................. } \\
\text { Mexico................... } \\
\text { Other countries......... }\end{array}$ & $\begin{array}{r}\text { Gallons. } \\
222,949 \\
1,919 \\
21,657 \\
\end{array}$ & \begin{tabular}{r|} 
Dollars. \\
38,440 \\
456 \\
6,899 \\
\end{tabular} & $\begin{array}{r}\text { Gallons. } \\
326,221 \\
30,575 \\
33,681\end{array}$ & $\begin{array}{r}\text { Dollars. } \\
53,894 \\
10,491 \\
9,474\end{array}$ & $\begin{array}{r}\text { Gallons. } \\
357,180 \\
36,895 \\
57,619\end{array}$ & $\begin{array}{r}\text { Dollars. } \\
59,543 \\
8,851 \\
16,770\end{array}$ \\
\hline Total ................. & 246,525 & 45,795 & 390,477 & 859 & 451,694 & 85,164 \\
\hline 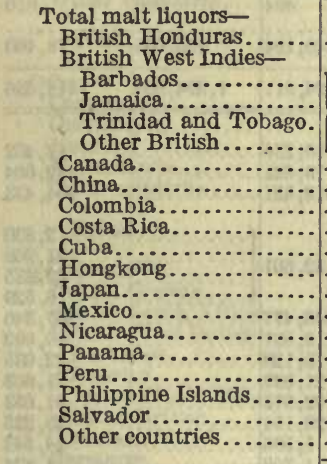 & $\begin{array}{l}\ldots \ldots \\
\ldots \ldots \\
\ldots \ldots \\
\ldots \ldots \\
\ldots \ldots \\
\ldots \ldots \\
\ldots \ldots \\
\ldots \ldots \\
\ldots \ldots \\
\ldots \ldots \\
\ldots \ldots \\
\ldots \ldots \\
\ldots \ldots \\
\ldots \ldots \\
\end{array}$ & $\begin{array}{r}51,870 \\
318,868 \\
11,031 \\
3,221 \\
15,537 \\
117,174 \\
8,638 \\
1,509 \\
21,813 \\
6,672 \\
280,352 \\
5,814 \\
74,280 \\
2,474 \\
78,683 \\
\end{array}$ & \begin{tabular}{l|}
$\cdots$ \\
$\ldots$ \\
$\cdots$ \\
$\cdots$ \\
$\cdots$ \\
$\ldots$ \\
$\cdots$ \\
$\cdots$ \\
$\cdots$ \\
$\ldots$ \\
$\cdots$ \\
$\cdots$ \\
$\cdots$ \\
\end{tabular} & $\begin{array}{r}378,553 \\
1,251 \\
4,544 \\
13,779 \\
84,471 \\
4,458 \\
300 \\
22,946 \\
5,407 \\
232,717 \\
5,520 \\
69,614 \\
351 \\
69,855 \\
\end{array}$ & 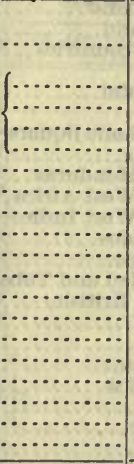 & $\begin{array}{r}2,231 \\
20,648 \\
32,966 \\
3,358 \\
499,808 \\
3,695 \\
6,835 \\
16,391 \\
72,264 \\
2,686 \\
2,754 \\
24,601 \\
14,363 \\
203,491 \\
2,489 \\
79,326 \\
661 \\
77,279 \\
\end{array}$ \\
\hline Total. & & $1,010,787$ & $\cdots$ & 83 & & 1,0 \\
\hline $\begin{array}{l}\text { Vines- } \\
\text { Bottled- } \\
\text { Mexico............................. } \\
\text { Other countries....... }\end{array}$ & $\begin{array}{r}\text { Doz. quarts. } \\
540 \\
3,299 \\
\end{array}$ & $\begin{array}{r}\text { Dollars. } \\
3,117 \\
16,785 \\
\end{array}$ & $\begin{array}{r}\text { Doz. quarts. } \\
486 \\
5,476 \\
\end{array}$ & $\begin{array}{r}\text { Dollars. } \\
2,943 \\
28,371 \\
\end{array}$ & & $\begin{array}{c}\text { Dollars. } \\
\text { (1) }\end{array}$ \\
\hline Total & 3,839 & 19,902 & 5,962 & 31,314 & (1) & (*) \\
\hline 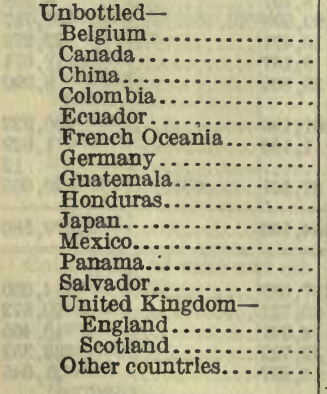 & \begin{tabular}{r|} 
Gallons. \\
2,072 \\
34,081 \\
4,672 \\
15,401 \\
28,479 \\
15,338 \\
48,450 \\
16,966 \\
15,656 \\
34,823 \\
70,526 \\
35,796 \\
27,911 \\
21,880 \\
1,101 \\
42,739 \\
\end{tabular} & $\begin{array}{r}\text { Dollars. } \\
1,018 \\
13,697 \\
2,168 \\
7,262 \\
13,449 \\
5,781 \\
23,381 \\
8,720 \\
6,648 \\
13,089 \\
29,667 \\
11,453 \\
14,678 \\
9,085 \\
540 \\
20,880 \\
\end{array}$ & $\begin{array}{r}\text { Gallons. } \\
4,715 \\
47,267 \\
3,377 \\
11,949 \\
27,166 \\
9,758 \\
35,312 \\
17,849 \\
4,829 \\
61,171 \\
79,575 \\
57,064 \\
19,194 \\
56,819 \\
725 \\
64,578 \\
\end{array}$ & $\begin{array}{r}\text { Dollars. } \\
2,604 \\
16,178 \\
1,731 \\
4,233 \\
14,439 \\
3,376 \\
15,970 \\
8,058 \\
2,128 \\
18,378 \\
32,245 \\
15,793 \\
9,913 \\
20,602 \\
494 \\
27,455 \\
\end{array}$ & Gallons. & Dollars. \\
\hline ............ & 415,891 & 181,516 & 501,348 & 193,597 & 17 & (1) \\
\hline
\end{tabular}

1 Not separately stated. 
TABLE 17.-Quantity and value of EXPORTS of domestic FARM and FOREST products, 1909-1911, by articles and by countries to which consigned-Continued.

\begin{tabular}{|c|c|c|c|c|c|c|}
\hline Hent & 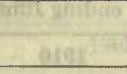 & 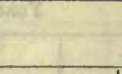 & Year ending & June $30-$ & - & \\
\hline Article and country. & 190 & & 191 & & 19 & \\
\hline & Quantity. & Value. & Quantity. & Value. & Quantity. & Value. \\
\hline FARM PRODUCTS-continued. & & & & & & \\
\hline Vegetable matter-Continued. & & & & & & ef \\
\hline $\begin{array}{l}\text { Liquors, alcohollc-Continued. } \\
\text { Wines-Continued. }\end{array}$ & & & & & & \\
\hline 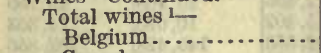 & Gallars. & Dollars. & Gallons. & $\begin{array}{r}\text { Dollars. } \\
2,768\end{array}$ & $\begin{array}{r}\text { Gallons. } \\
21,858\end{array}$ & $\begin{array}{r}\text { Dollars. } \\
8,806\end{array}$ \\
\hline Canada........ & 36,055 & 17,237 & 51,890 & 22,739 & 85,566 & 42,158 \\
\hline 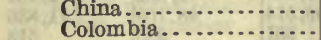 & $\begin{array}{r}4,786 \\
15,440\end{array}$ & $\begin{array}{l}2,348 \\
7,372\end{array}$ & $\begin{array}{r}3,662 \\
12,012\end{array}$ & $\begin{array}{l}2,142 \\
4,359\end{array}$ & $\begin{array}{l}22,123 \\
27,966\end{array}$ & $\begin{array}{r}8,490 \\
12,440\end{array}$ \\
\hline Ecuador............. & 28,785 & 13,887 & 27,712 & 15,320 & 39,636 & 18,641 \\
\hline French Oceani & 15,371 & 5,835 & 9,758 & 3,376 & 23,693 & 6,913 \\
\hline Germany..... & 48,984 & 24,530 & 36,032 & 17,349 & 360,931 & 123,258 \\
\hline Guatemala... & 17,314 & 9,310 & 19,151 & 10,428 & 20,623 & 10,438 \\
\hline Honduras.... & 16,583 & 8,020 & 5,321 & 2,814 & 8,130 & 4,491 \\
\hline Japan.......... & 35,126 & 13,652 & 61,255 & 18,540 & 229,869 & 68,837 \\
\hline Mexico......... & 72,146 & 32,784 & 81,033 & 35,188 & 75,189 & 29,907 \\
\hline 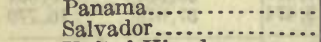 & $\begin{array}{l}36,231 \\
28,370\end{array}$ & $\begin{array}{l}11,961 \\
15,401\end{array}$ & $\begin{array}{l}57,496 \\
19,305\end{array}$ & $\begin{array}{l}16,669 \\
10,132\end{array}$ & $\begin{array}{r}201,718 \\
29,316\end{array}$ & $\begin{array}{l}56,838 \\
14,905\end{array}$ \\
\hline $\begin{array}{l}\text { United Kingdom } \\
\text { England........ }\end{array}$ & 22,015 & 9,370 & 587 & 22,399 & 92,415 & 33,314 \\
\hline Scotland...... & 1,110 & 564 & & 494 & 266 & 610 \\
\hline 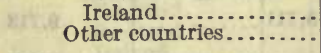 & $\begin{array}{r}6 \\
47,014\end{array}$ & $\begin{array}{r}10 \\
28,119\end{array}$ & 71,484 & 40,194 & 155,695 & $\dddot{78}, 400$ \\
\hline$\frac{169}{20} \times 5$ & 427,408 & 201,418 & 234 & 224,911 & 394,994 & 518,536 \\
\hline Total alcoholic liquors & & & & & & \\
\hline $\begin{array}{l}\text { Bermuda..... } \\
\text { British Hondv }\end{array}$ & & $\begin{array}{r}7,988 \\
21,180\end{array}$ & & $\begin{array}{l}10,236 \\
19,621\end{array}$ & & $\begin{array}{l}12,462 \\
32,604\end{array}$ \\
\hline British West Africa. & & 994,425 & & $1,019,621$ & & 994,433 \\
\hline $\begin{array}{c}\text { British West Indies- } \\
\text { Barbados.......... }\end{array}$ & & & & & & 2,320 \\
\hline Jamaica ............... & & 55,682 & & 52,661 & & 21,969 \\
\hline $\begin{array}{l}\text { Trinidad and Tol } \\
\text { Other British.... }\end{array}$ & & 50,082 & & 02,001 & & $\begin{array}{r}33,235 \\
6,529\end{array}$ \\
\hline Canada... & & 368,115 & & 446,477 & & 567,346 \\
\hline China.:. & & 22,509 & & 12,831 & & 19,092 \\
\hline Colombia & & 12,114 & & 10,120 & & 22,035 \\
\hline Costa Rica & & 19,877 & & 21,023 & & 21,663 \\
\hline Cuba.... & & 133,862 & & 92,971 & & 91,653 \\
\hline Ecuador & & 21,669 & & 20,154 & & 25,235 \\
\hline France. & & 4,086 & & 5,506 & & 14,543 \\
\hline French Oc & & 6,494 & & 4,308 & & 8,824 \\
\hline Germany & & 363,163 & & 140,791 & & 209,702 \\
\hline Guatema & & 33,050 & & 30,255 & & 30,833 \\
\hline Hon & & 23,423 & & 18,106 & & 28,233 \\
\hline Hongkong & & 10,525 & & 5,438 & & 4, 401 \\
\hline Japan. & & 16,372 & & 22,030 & & 77,632 \\
\hline México. & & 127,383 & & 135,688 & & 135,530 \\
\hline Nicaragua & & 16,462 & & 33,605 & & 36,461 \\
\hline Panama... & & 334,523 & & 300,072 & & 314,454 \\
\hline Peru.. & & 7,609 & & 8,197 & & 4,398 \\
\hline Philip & & 153,890 & & 192,998 & & 161,737 \\
\hline Salvad & & 21,378 & & 16,471 & & 22,273 \\
\hline Turkey, As & & 10,403 & & 9,167 & & 18,671 \\
\hline Turkey, E & & 7,888 & & 35,806 & & 8,090 \\
\hline $\begin{array}{l}\text { United King } \\
\text { England.. }\end{array}$ & & 215,827 & & 401,196 & & 430,922 \\
\hline Scotlar & & 2,230 & & 1,190 & & 1,629 \\
\hline $\begin{array}{l}\text { Ireland } \\
\text { Other co }\end{array}$ & & $\begin{array}{r}10 \\
\end{array}$ & & 87561 & & 12 \\
\hline Other coun & & 84,035 & & 87,501 & & 120,000 \\
\hline Total & & $3,096,172$ & & $3,154,100$ & & $3,479,586$ \\
\hline Nursery stock: & & & & & & \\
\hline Canada. & & 171,976 & & 157,683 & & $\begin{array}{r}214,080 \\
20\end{array}$ \\
\hline Cuba... & & $\begin{array}{l}37,191 \\
16,614\end{array}$ & & $\begin{array}{l}30,723 \\
14,341\end{array}$ & & $\begin{array}{l}20,872 \\
10,465\end{array}$ \\
\hline $\begin{array}{l}\text { Germa } \\
\text { Mexico }\end{array}$ & & $\begin{array}{l}16,614 \\
33,779\end{array}$ & & $\begin{array}{l}14,341 \\
42,732\end{array}$ & & 32,353 \\
\hline Netherlands & & 18,221 & & 14,897 & & 21,045 \\
\hline
\end{tabular}

1 Quantity for 1909 and 1910 computed by estimating 3 gallons to 1 dozen quarts. 
TABLE 17.-Quantity and value of EXPORTS of domestic FARM and FOREST products, 1909-1911, by articles and by countries to which consigned-Continued.

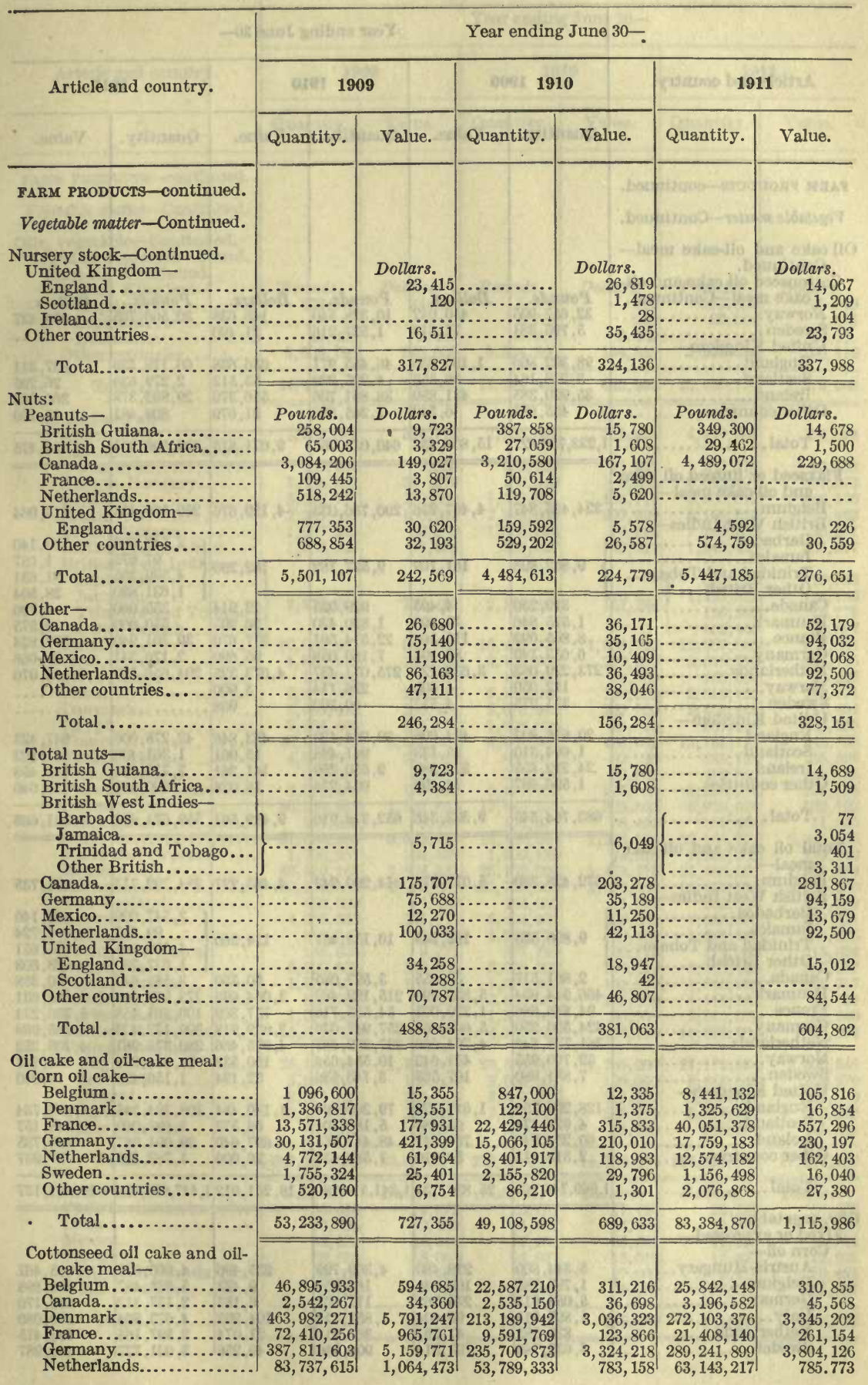


TABLE 17.-Quantity and value of EXPORTS of domestic FARM and FOREST products, 1909-1911, by articles and by countries to which consigned-Continued.

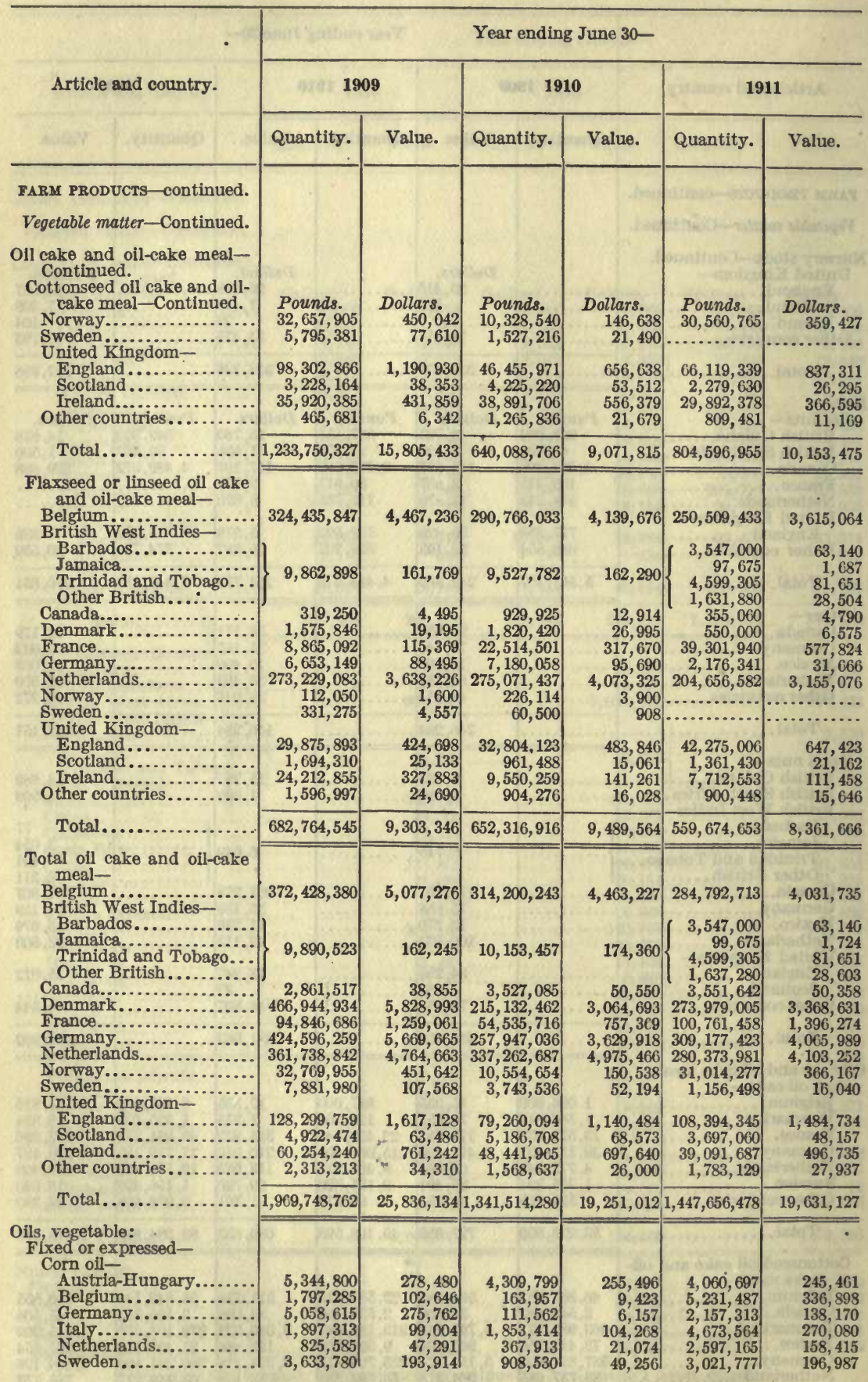


TABLE 17.-Quantity and value of EXPORTS of domestic FARM and FOREST products, 1909-1911, by articles and by countries to which consigned-Continued.

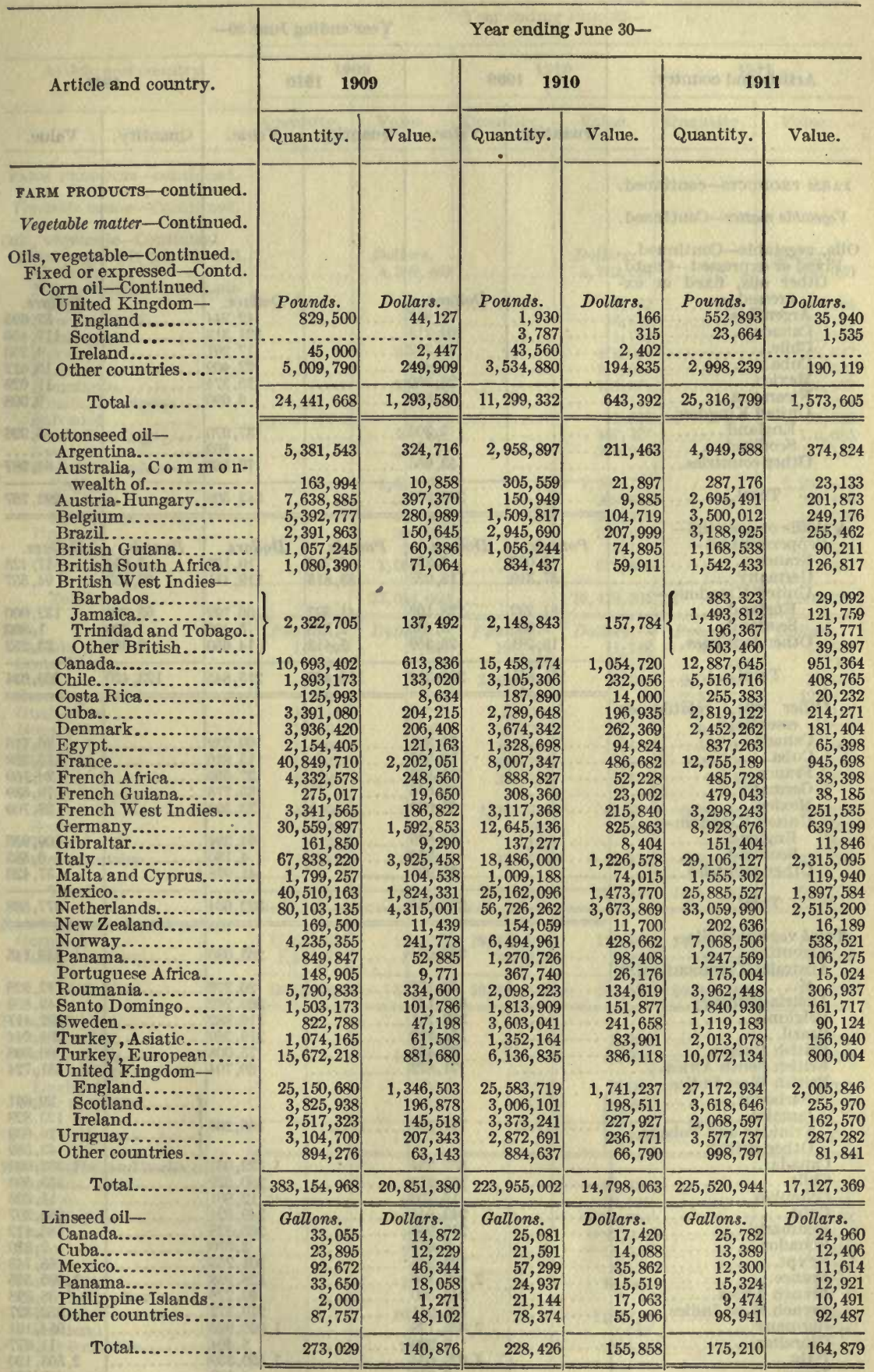


TABLE 17.-Quantity and value of EXPORTS of domestic FARM and FOREST products, 1909-1911, by articles and by countries to which consigned-Continued.

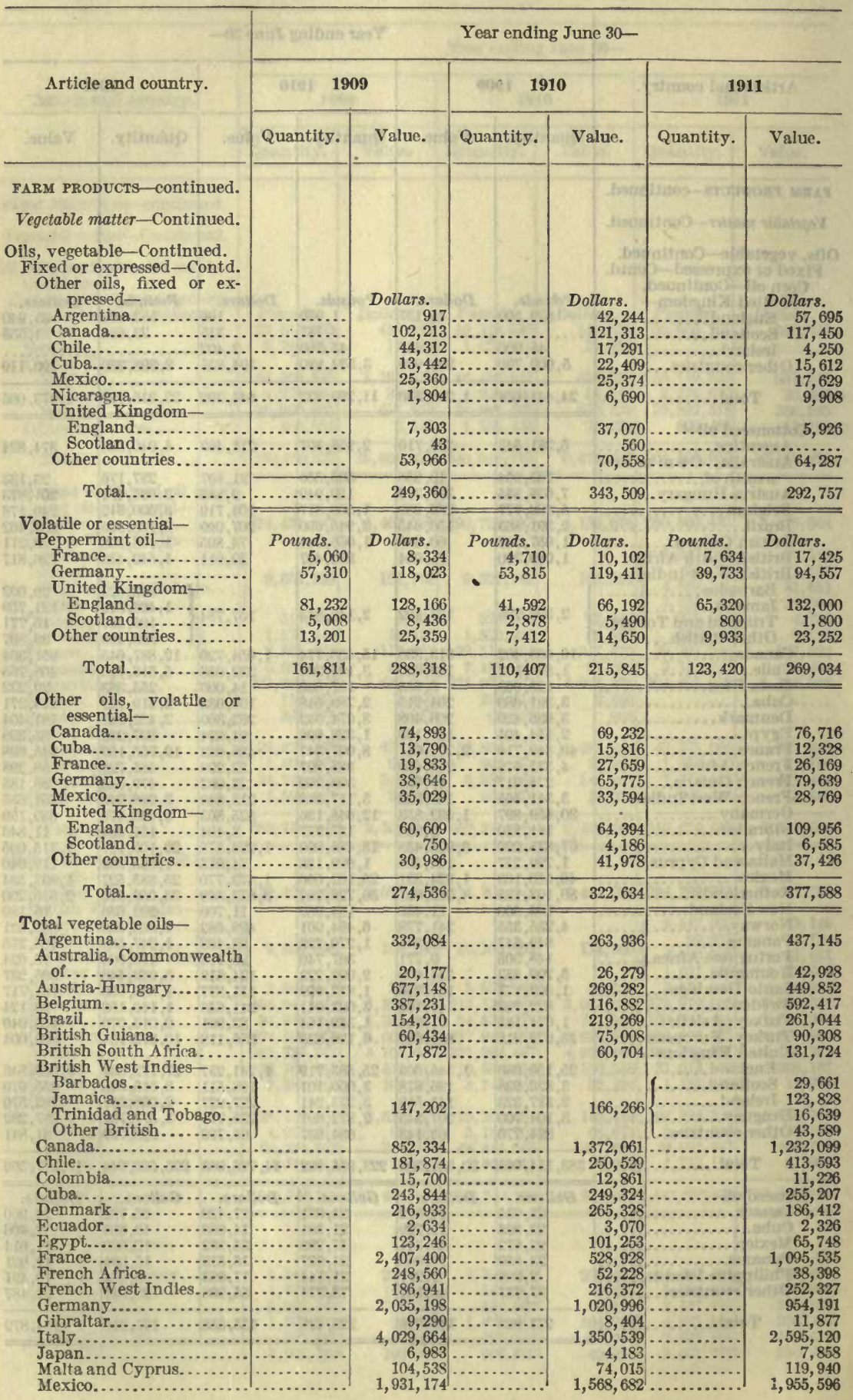


TABLE 17.-Quantity and value of EXPORTS of domestic FARM and FOREST products, 1909-1911, by articles and by countries to which consigned-Continued.

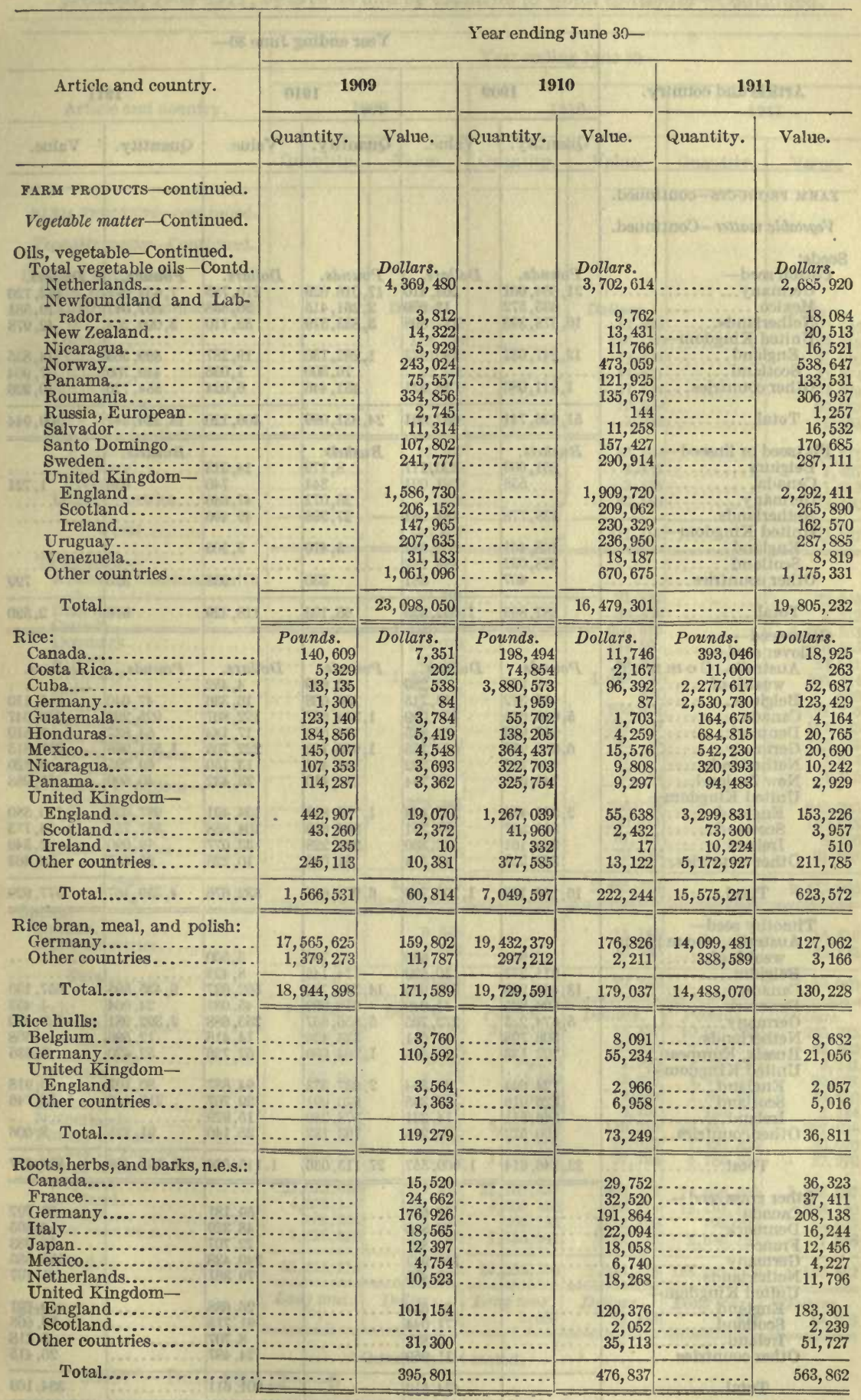


TABLE 17.-Quantity and value of EXPORTS of domestic FARM and FOREST products, 1909-1911, by articles and by countries to which consigned-Continued.

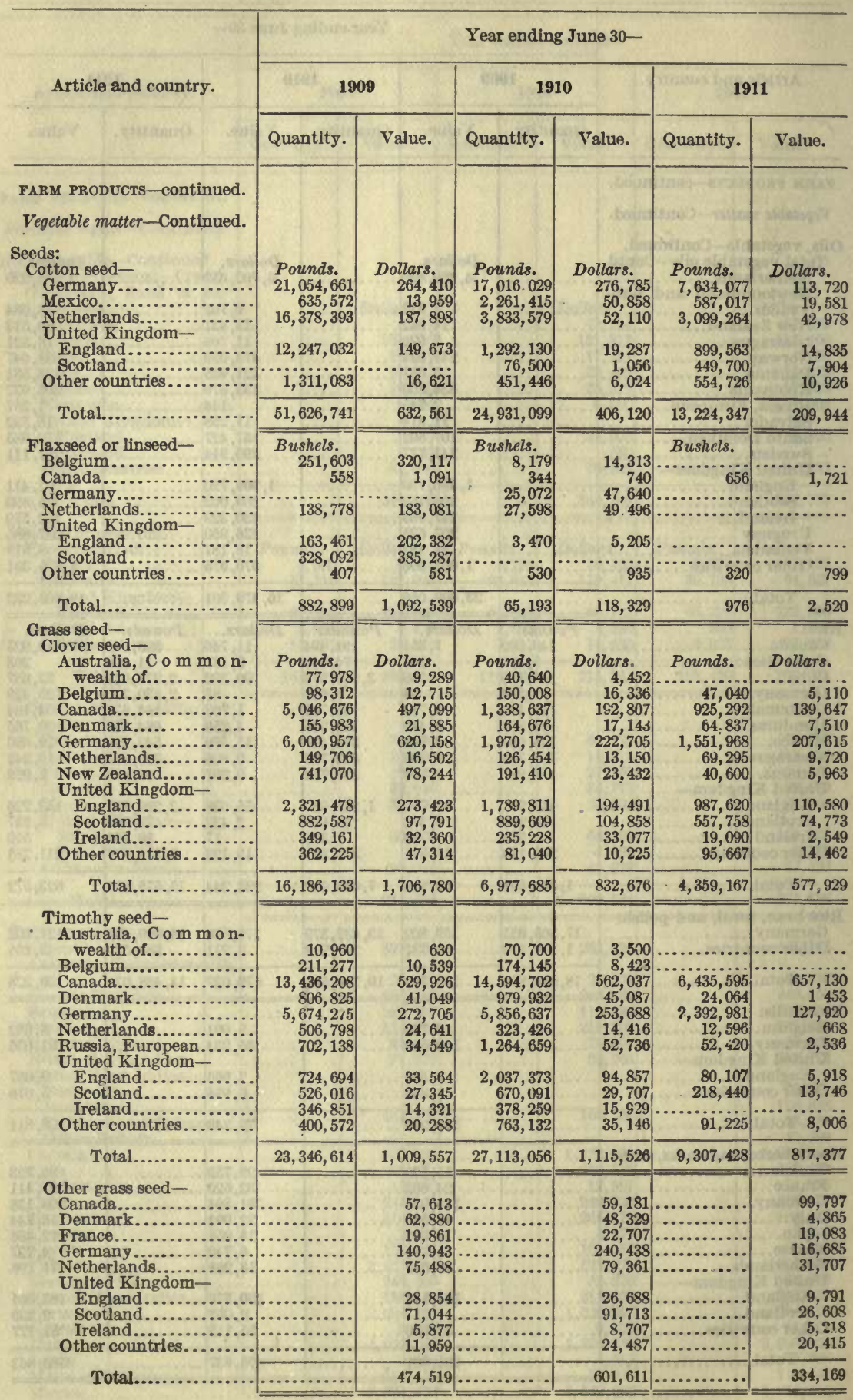


TABLE 17.-Quantity and value of EXPORTS of domestic FARM and FOREST products, 1909-1911, by articles and by countries to which consigned-Continued.

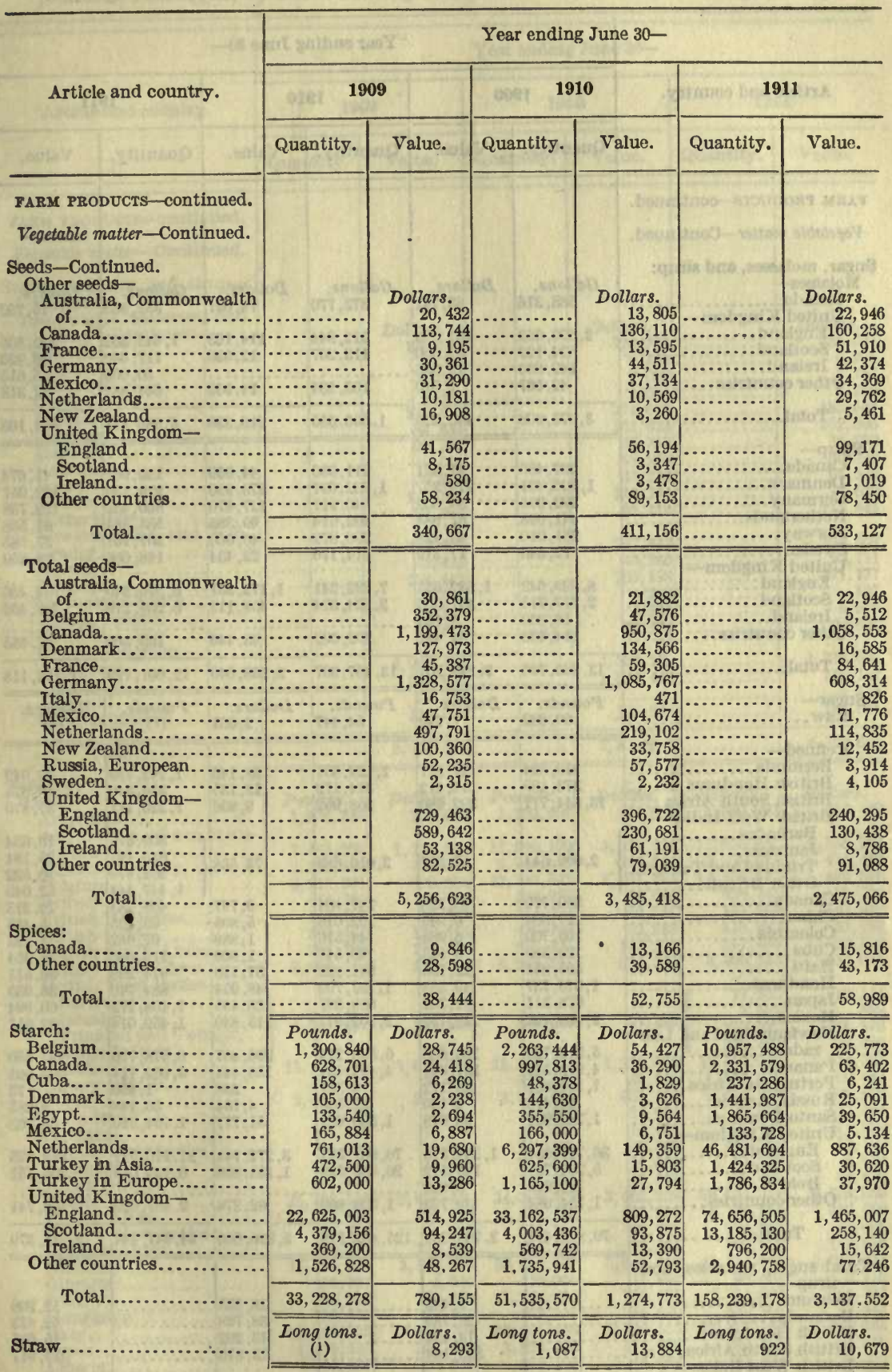

1 Quantity not stated. 
TABLE 17.-Quantity and value of EXPORTS of domestic FARM and FOREST products, 1909-1911, by articles and by countries to which consigned - Continued.

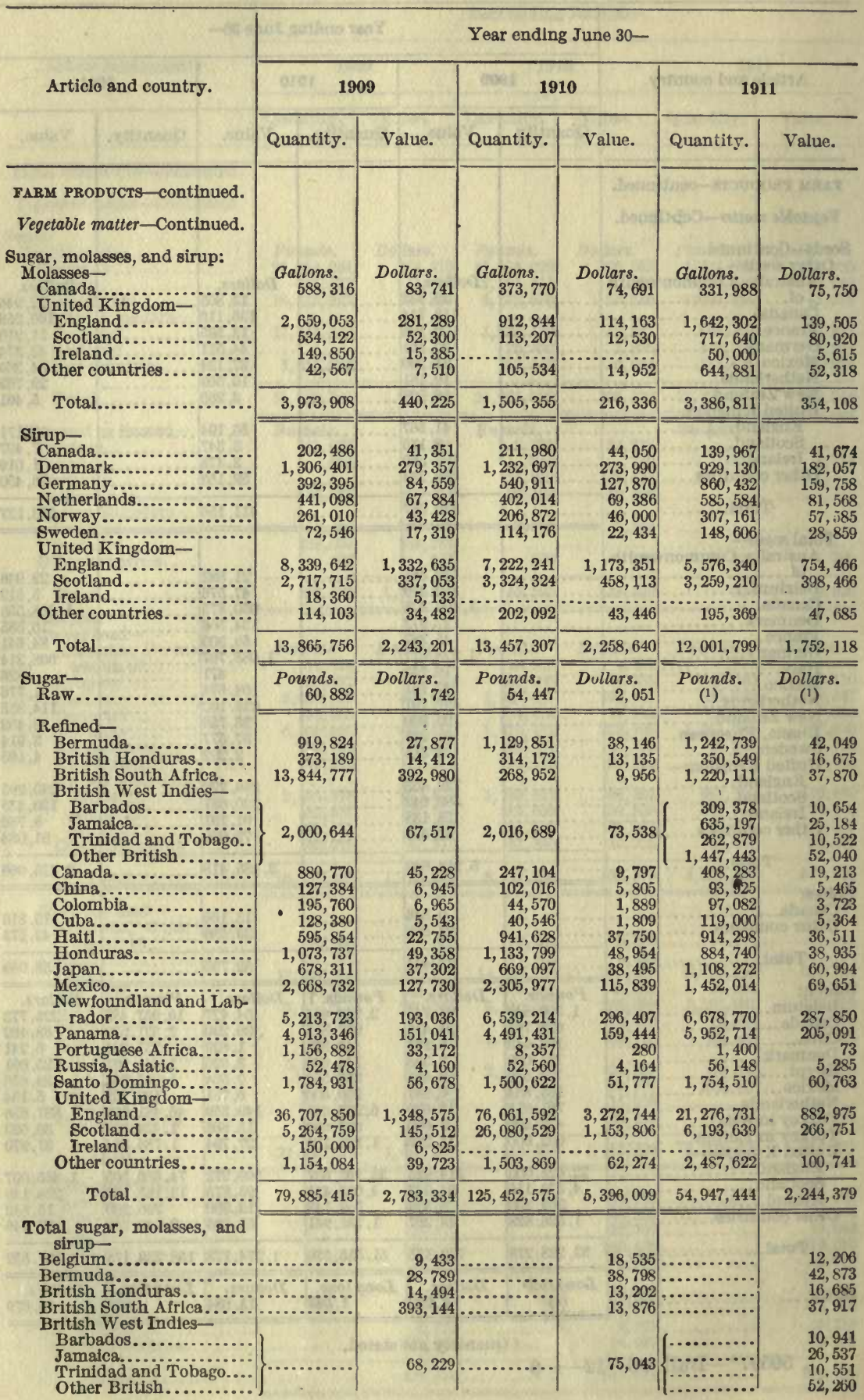

1 Included in "Sugar, refined." 
TABLE 17.-Quantity and value of EXPORTS of domestic FARM and FOREST products, 1909-1911, by articles and by countries to which consigned-Continued.

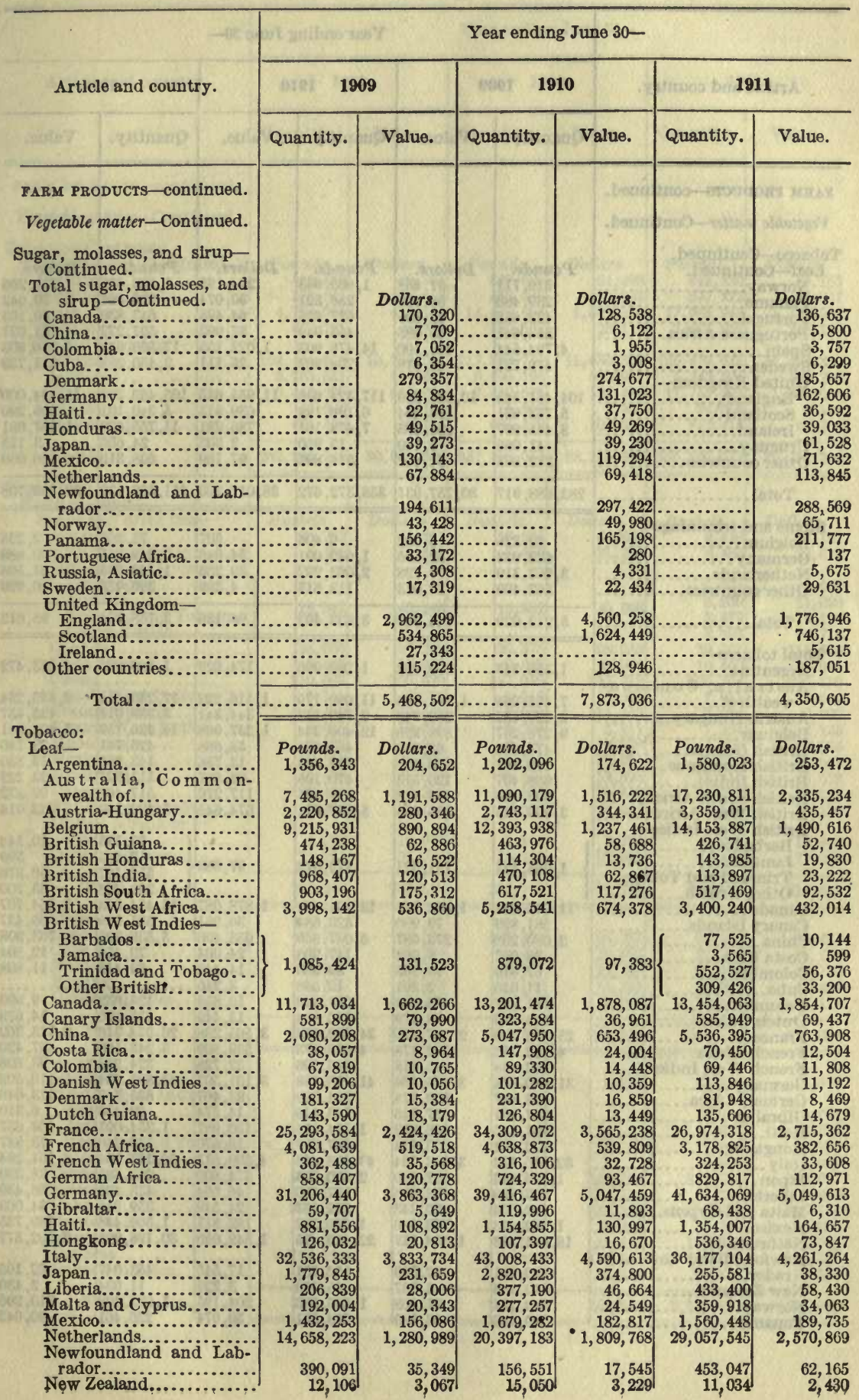


TABLE 17. -Quantity and value of EXPORTS of domestic. FARM and FOREST products, 1909-1911, by articles and by countries to which consigned-Continued.

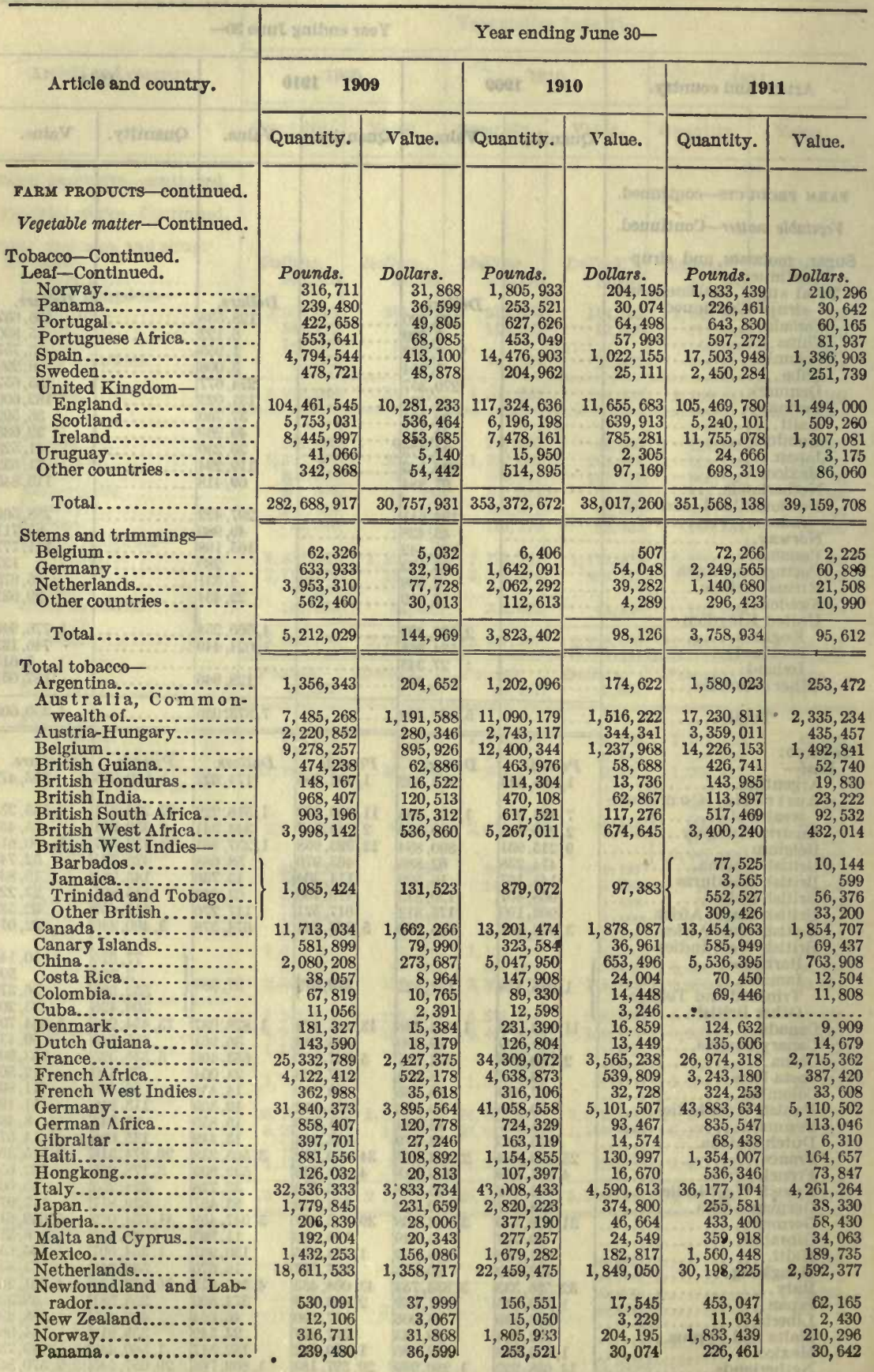


TABLE 17.-Quantity and value of EXPORTS of domestic FARM and FOREST products, 1909-1911, by articles and by countries to which consigned-Continued.

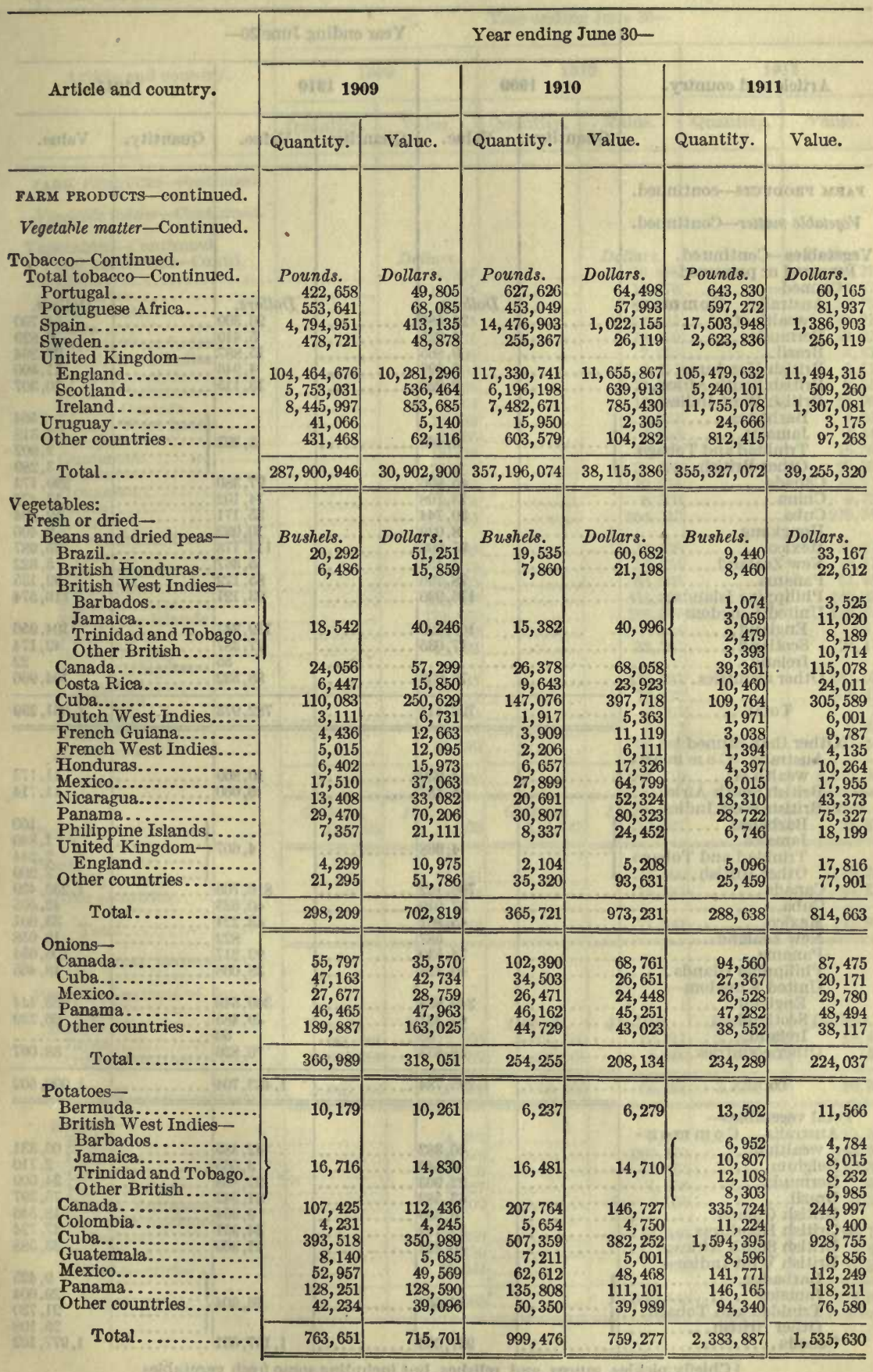


TABLE 17.-Quantity and value of EXPORTS of domestic FARM and FOREST products, 1909-1911, by articles and by countries to which consigned-Continued.

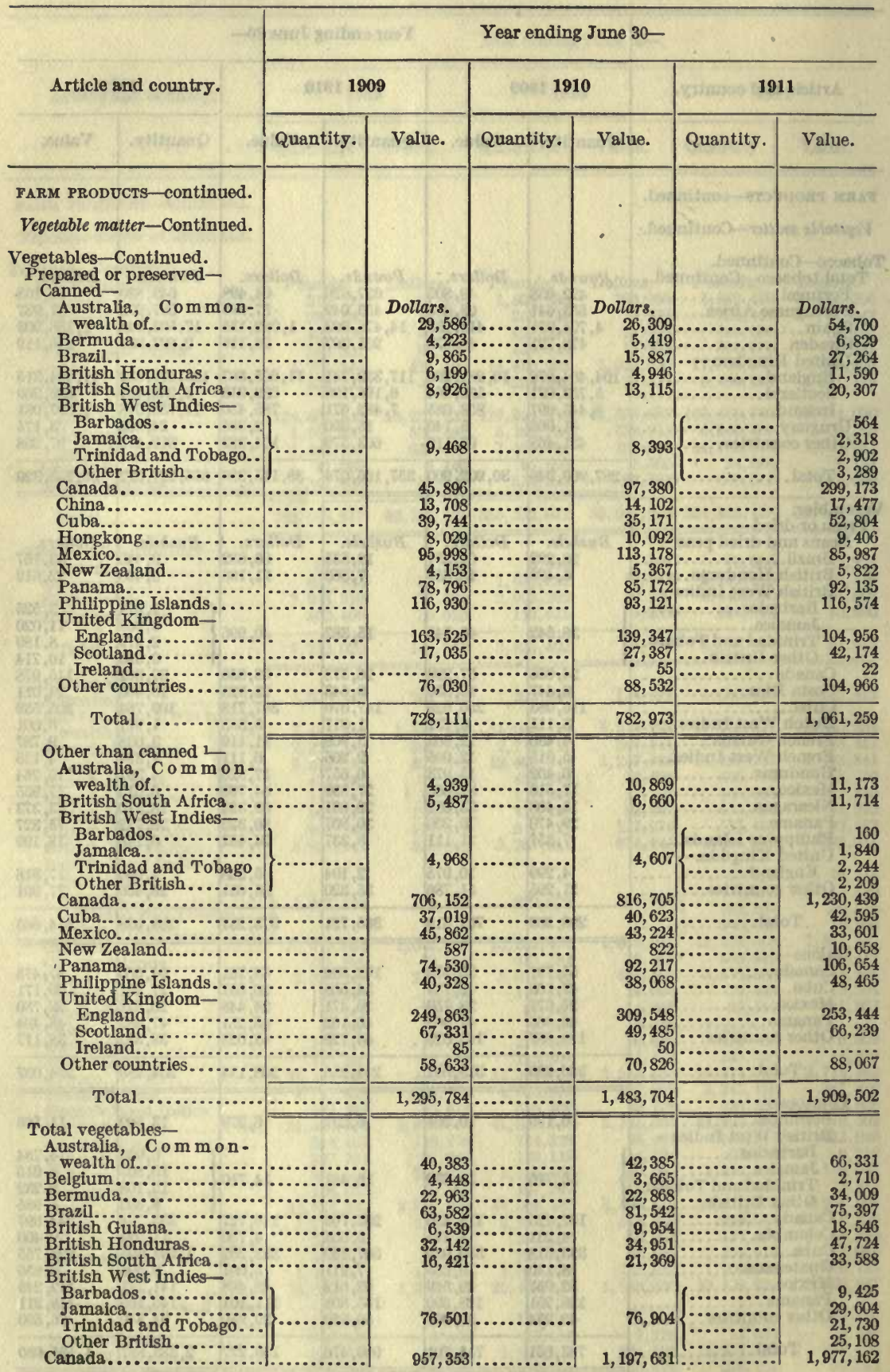

1 Chiefly pickles, sauces, and relishes, but including some fresh vegetables. 
TABLE 17.-Quantity and value of EXPORTS of domestic FARM and FOREST products, 1909-1911, by articles and by countries to which consigned-Continued.

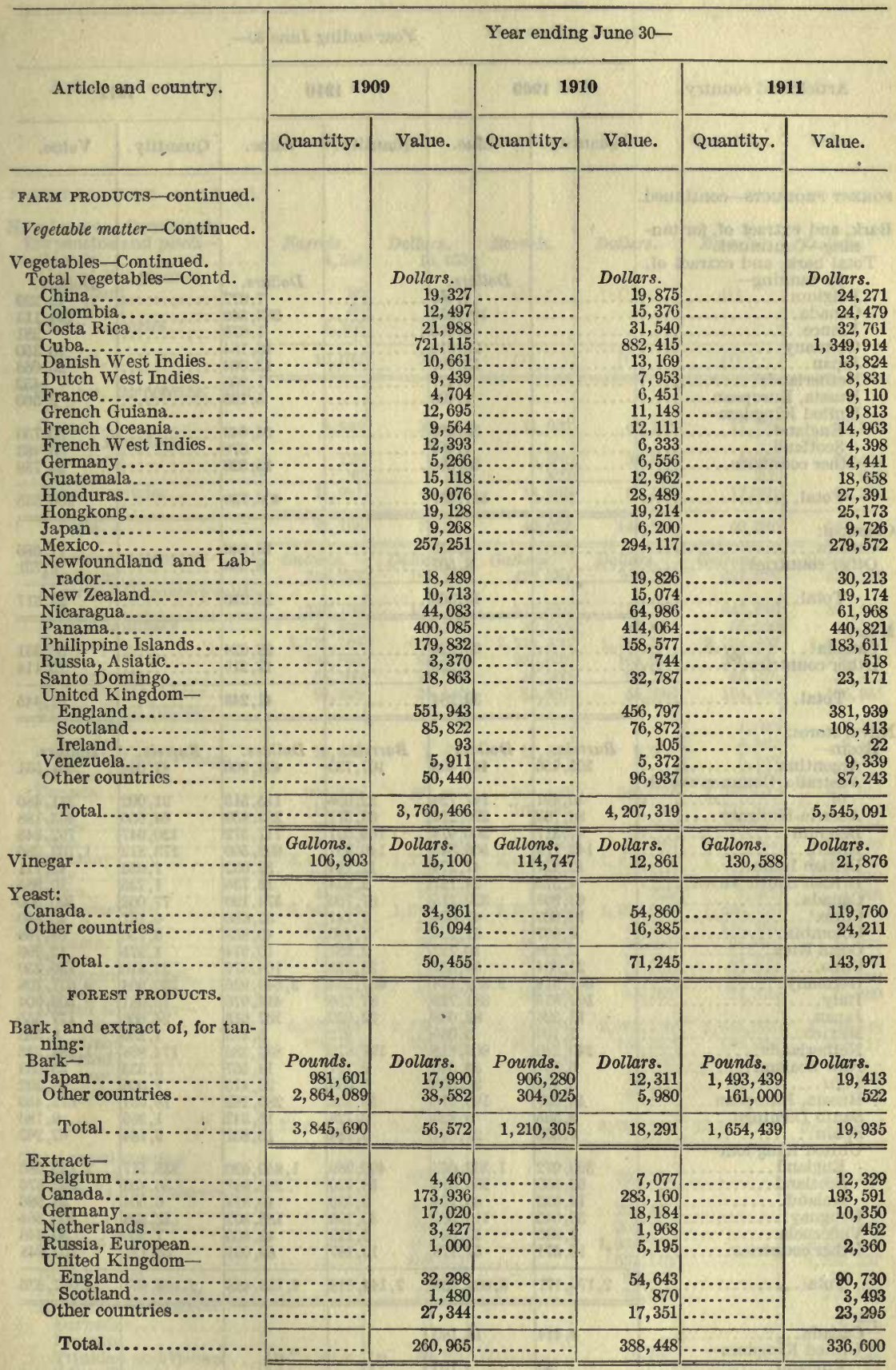


TABLE 17.-Quantity and value of EXPORTS of domestic FARM and FOREST products, 1909-1911, by articles and by countries to which consigned -Continued.

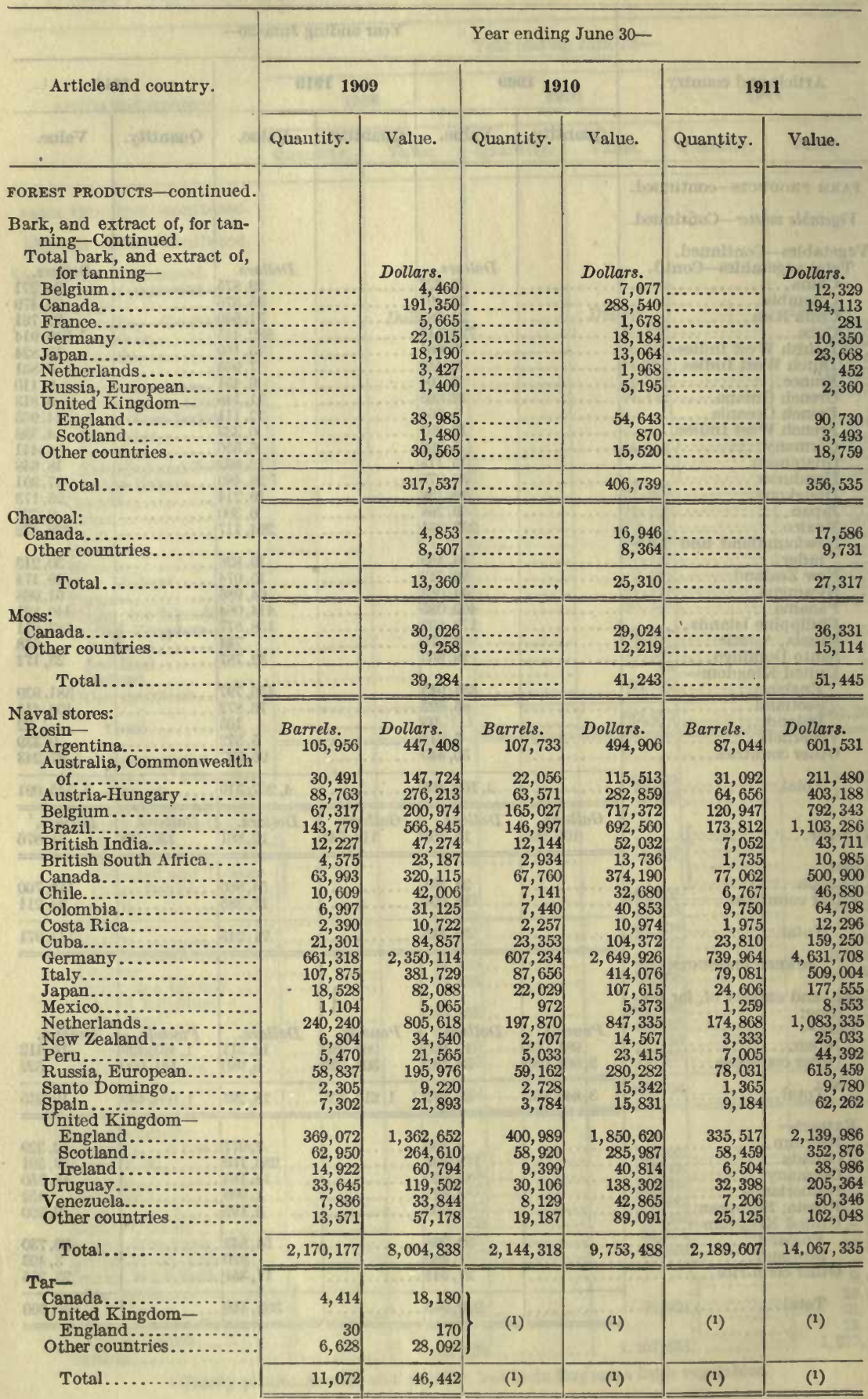

1 Not separately stated. 
TABLE 17.-Quantity and value of EXPORTS of domestic FARM and FOREST products, 1909-1911, by articles and by countries to which consigned-Continued.

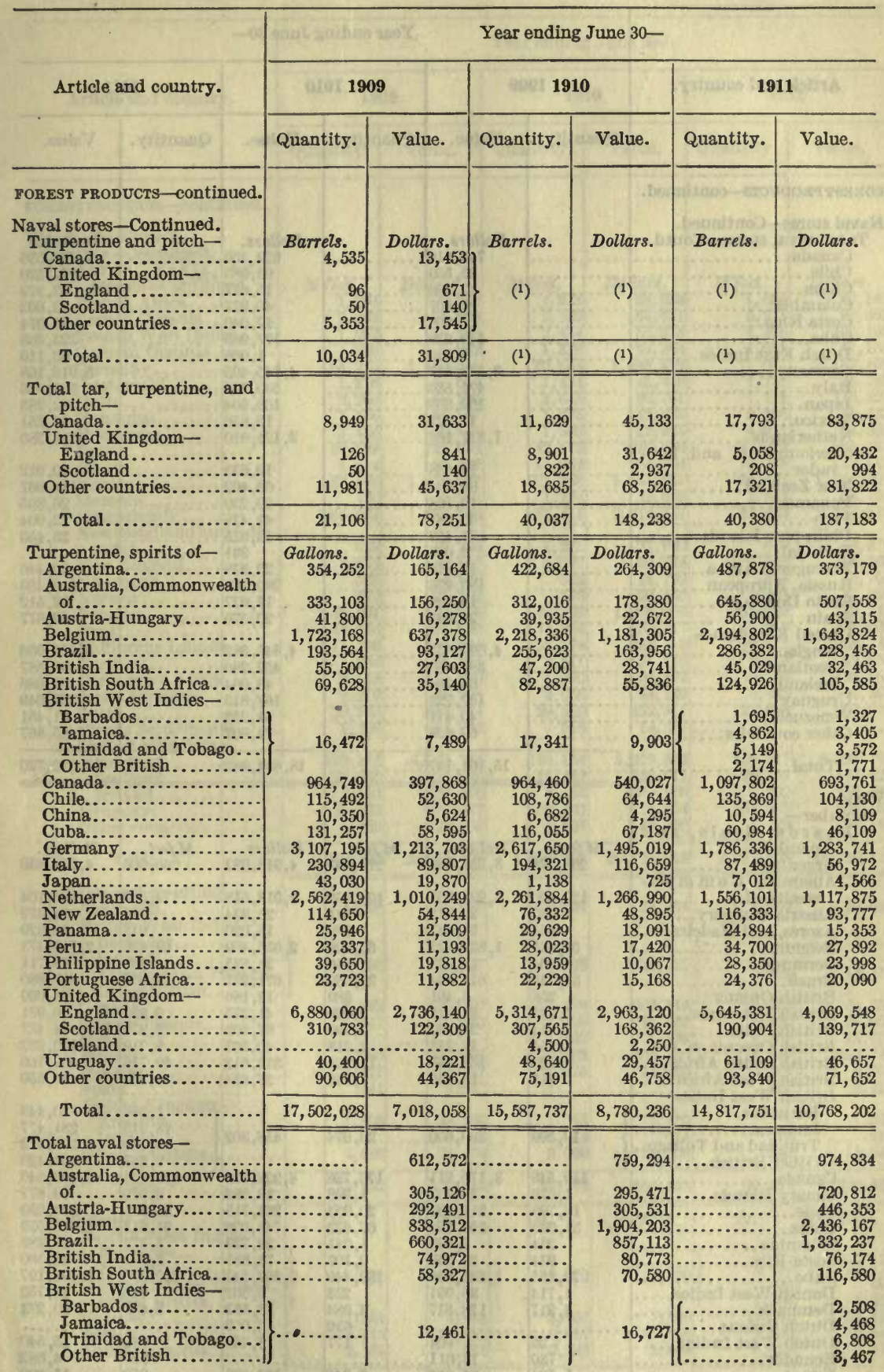

1 Not separately stated. 
TABLE 17.-Quantity and value of EXPORTS of domestic FARM and FOREST products, 1909-1911, by articles and by countries to which consigned-Continued.

\begin{tabular}{|c|c|c|c|c|c|c|c|}
\hline \multirow{2}{*}{\multicolumn{2}{|c|}{ Article and country. }} & \multicolumn{2}{|c|}{ 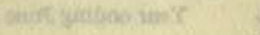 } & \multicolumn{4}{|c|}{ Year ending June 30- } \\
\hline & & \multicolumn{2}{|c|}{1909} & \multicolumn{2}{|c|}{1910} & \multicolumn{2}{|c|}{1911} \\
\hline Shate & +2 thesup & Quant & Value. & Quantity. & Value. & Quantity. & Value. \\
\hline \multicolumn{8}{|c|}{ FOREST PRODUCTS-continued. } \\
\hline \multicolumn{8}{|c|}{$\begin{array}{l}\text { Naval stores-Continued. } \\
\text { Total naval stores-Contd. }\end{array}$} \\
\hline \multirow{2}{*}{\multicolumn{2}{|c|}{ 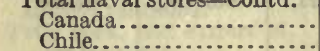 }} & & 749,616 & & 959,350 & & $1,278,536$ \\
\hline & & & 95,539 & & 99,083 & & 152,520 \\
\hline \multicolumn{2}{|l|}{ China.. } & & $\begin{array}{l}12,936 \\
37,807\end{array}$ & & $\begin{array}{l}15,677 \\
46,977\end{array}$ & & $\begin{array}{l}23,979 \\
73,602\end{array}$ \\
\hline \multicolumn{2}{|c|}{ Costa Rica.................. } & & 15,668 & & $\begin{array}{l}40,976 \\
17,046\end{array}$ & & 25,074 \\
\hline \multirow{2}{*}{\multicolumn{2}{|c|}{$\begin{array}{l}\text { Cuba... } \\
\text { Dutch i }\end{array}$}} & & 149,239 & & 177,983 & & $\begin{array}{l}22,, 56 \\
223,563\end{array}$ \\
\hline & & & 1,540 & & 1,968 & & 80,116 \\
\hline \multicolumn{2}{|c|}{ Germany ................... } & & $3,563,817$ & & $4,145,495$ & & $5,916,168$ \\
\hline \multirow{2}{*}{\multicolumn{2}{|c|}{ 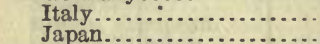 }} &. & 471,536 & & 530,735 & & 565,976 \\
\hline & & & 102,330 & & 108,694 & & 182,283 \\
\hline Mex & & & 17,327 & & 16,856 & & 24,251 \\
\hline $\begin{array}{l}\text { Nethe } \\
\text { Newfo }\end{array}$ & and & & $1,817,162$ & & $2,121,810$ & & $2,218,386$ \\
\hline rad & & & 12,638 . & & 19,633 & & 10,612 \\
\hline New & & & 89,384 . & & 63,462 & & 118,967 \\
\hline Par & & & 19,168 . & & 29,239 & & 26,895 \\
\hline $\begin{array}{l}\text { Per } \\
\text { Phi }\end{array}$ & & & 33,281 & & 41,478 & & 72,904 \\
\hline Port & & & $\begin{array}{r}21,409 \\
3,084\end{array}$ & & $\begin{array}{r}13,625 \\
241\end{array}$ & & 25,450 \\
\hline Port & $\min x+2$ & & 15,818 & & 25,378 & & 30,446 \\
\hline Russ & & & 195,976 . & & 280,282 & & 615,459 \\
\hline Santo & & & 10,899 . & & 17,077 & & 12,512 \\
\hline $\begin{array}{l}\text { Spain } \\
\text { Unite }\end{array}$ & & & 21,893 . & & 20,576 & & 62,677 \\
\hline E & & & $4,099,633$. & & $4,845,382$ & & $6,229,960$ \\
\hline & & & 387,059 & & 457,286 & & 493,587 \\
\hline Ir & & .. & 60,794 & & 43,064 & & 38,986 \\
\hline Uru & & & $137,723$. & & 167,813 & & 252,049 \\
\hline $\begin{array}{l}\text { Ven } \\
\text { Oth }\end{array}$ & & & $\begin{array}{l}40,411 \\
62,628\end{array}$ & & $\begin{array}{l}51,253 \\
74,807\end{array}$ & & $\begin{array}{l}61,481 \\
85,867\end{array}$ \\
\hline Tot & & & 01,147 & & 0,9 & & \\
\hline 100 & & & 01,147 . & & 902 & & \\
\hline Wood: & & & & & & & \\
\hline Lumber- & & & & & & & \\
\hline $\begin{array}{r}\text { B o a r } \\
\text { pla } \\
\text { Arger }\end{array}$ & deals, & $M$ feet. & $\begin{array}{l}\text { Dollars. } \\
3,531,393\end{array}$ & $M$ feet. & $\begin{array}{l}\text { Dollars. } \\
4,913,032\end{array}$ & $M$ feet. & Dollars. \\
\hline Austr & Common- & & & & & & \\
\hline $\begin{array}{l}\text { W } \\
\text { Aus }\end{array}$ & & $\begin{array}{r}120,806 \\
682\end{array}$ & $1,921,301$ & 104,862 & $\begin{array}{r}2,018,618 \\
20,934\end{array}$ & 174,099 & $3,026,104$ \\
\hline $\begin{array}{l}\text { Aust1 } \\
\text { Azore }\end{array}$ & ira Is.. & $\begin{array}{l}682 \\
868\end{array}$ & $\begin{array}{l}22,073 \\
26,087\end{array}$ & $\begin{array}{l}641 \\
589\end{array}$ & $\begin{array}{l}20,934 \\
15,020\end{array}$ & $\begin{array}{l}910 \\
613\end{array}$ & 14,329 \\
\hline Bel & & 54,031 & $1,622,225$ & 65,206 & $2,055,469$ & 69,406 & $2,139,473$ \\
\hline Berm & a. & 394 & 13,975 & 830 & 23,835 & 769 & 18,711 \\
\hline Bra & & 34,742 & 618,334 & 33,989 & 671,251 & 42,586 & 818,880 \\
\hline Brit & & 258 & 6,481 & 589 & 12,186 & 856 & 23,009 \\
\hline Brit & & 1,725 & 33,871 & 2,029 & 41,275 & 2,935 & 70,931 \\
\hline Bri & & 2,414 & 24,892 & 6,999 & 87,609 & 3,278 & 44,437 \\
\hline Briti & e. 8. & 3,354 & 57,283 & 2,218 & 40,507 & 5,719 & 120,982 \\
\hline Briti & rica & 9,328 & 168,883 & 17,361 & 334,612 & 19,716 & 402,766 \\
\hline Briti & Africa.. & 415 & 15,345 & 1,268 & 27,854 & 1,401 & 26,559 \\
\hline $\begin{array}{r}\text { Britis } \\
\text { Bai }\end{array}$ & es- & & & & & 1,386 & 30,449 \\
\hline Jan & & 19,599 & 399,650 & 23,074 & 458,302 & 13,913 & 281,477 \\
\hline $\begin{array}{l}\text { Tri } \\
\text { Otl }\end{array}$ & bago.. & & 399,000 & 20,014 & & $\begin{array}{l}9,100 \\
2,353\end{array}$ & $\begin{array}{r}179,472 \\
53,429\end{array}$ \\
\hline Cana & & 119,548 & $3,179,811$ & 176,736 & $4,922,129$ & 392,733 & $9,102,040$ \\
\hline & & 1,676 & 36,357 & 1,998 & 39,392 & 2,676 & 50,877 \\
\hline Chile & & 16,799 & 211,402 & 20,954 & 284,715 & 38,351 & 504,590 \\
\hline Chi & & 31,095 & 356,554 & 67,622 & 748,026 & 91,613 & $1,018,539$ \\
\hline Colon & & 264 & 7,460 & 1,041 & 22,729 & 1,373 & 37,389 \\
\hline Cos & 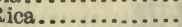 & 934 & 25,063 & 2,707 & 73,885 & 3,282 & 83,380 \\
\hline $\mathrm{Cub}$ & & 79,655 & $1,241,895$ & 139,449 & $2,307,547$ & 130,006 & $2,198,197$ \\
\hline Dani & est Indies..... & 1,714 & 36,991 & 233 & 5,502 & 746 & 18,750 \\
\hline Denn & .... & 4,217 & 124,817 & 2,084 & 70,682 & 2,687 & 80,273 \\
\hline Dutc & s....... & $\ddot{20}$ & $\ddot{904}$ & $\begin{array}{l}632 \\
177\end{array}$ & $\begin{array}{r}16,062 \\
\text { - } 3,458\end{array}$ & 682 & 15,540 \\
\hline Ecu & & 730 & 13,011 . & & & & 4,682 \\
\hline Egyp & $\ldots . .$. & 1,784 & 35,672 & 6,048 & 120,863 & 950 & 15,200 \\
\hline Fran & & 23,980 & 635,136 & 28,110 & 781,918 & 28,022 & 790,743 \\
\hline
\end{tabular}


TABLE 17.-Quantity and value of EXPORTS of domestic FARM and FOR EST products, 1909-1911, by articles and by countries to which consigned-Continued.

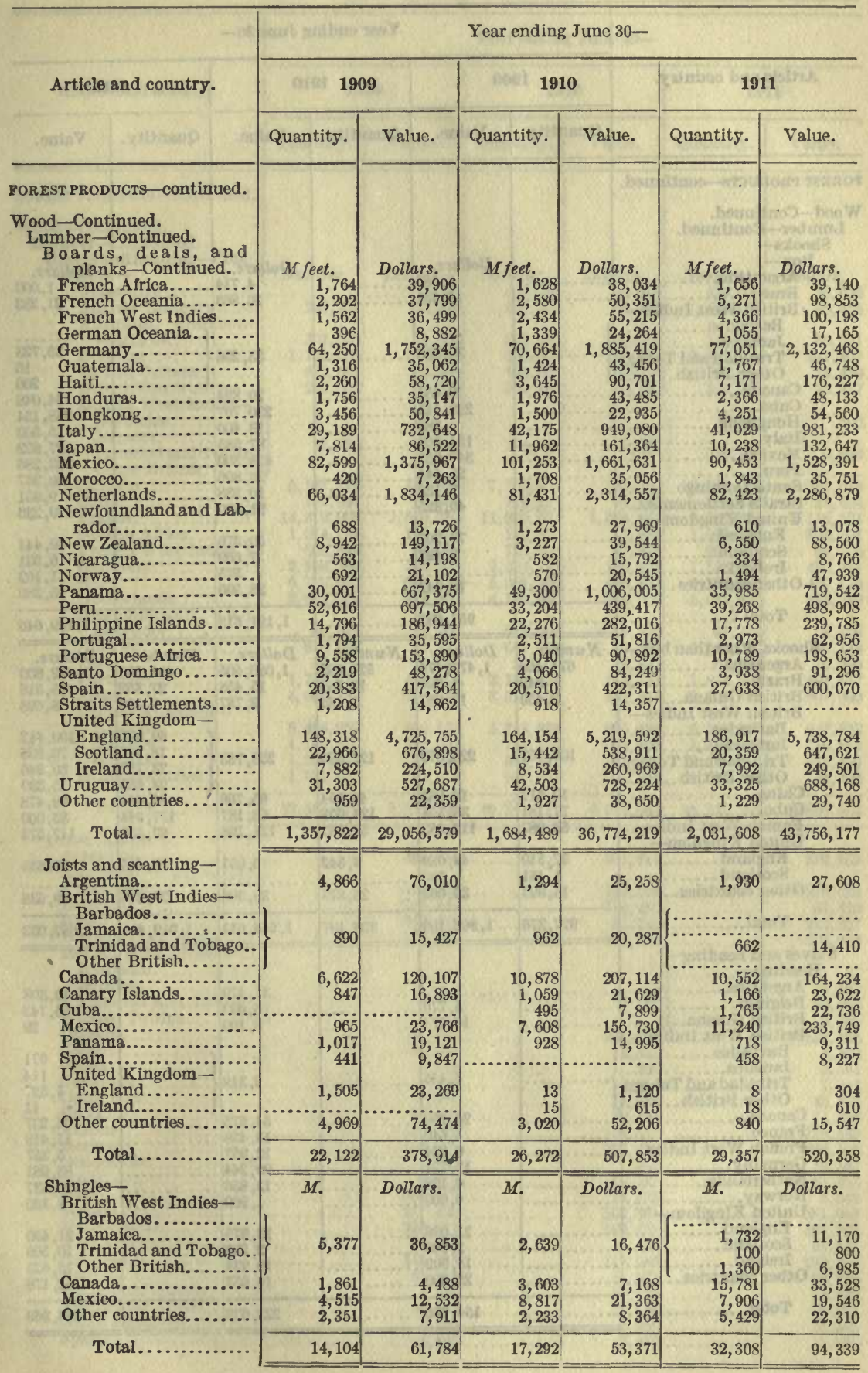


TABLE 17.-Quantity and value of EXPORTS of domestic FARM and FOREST products, 1909-1911, by articles and by countries to which consigned-Continued.

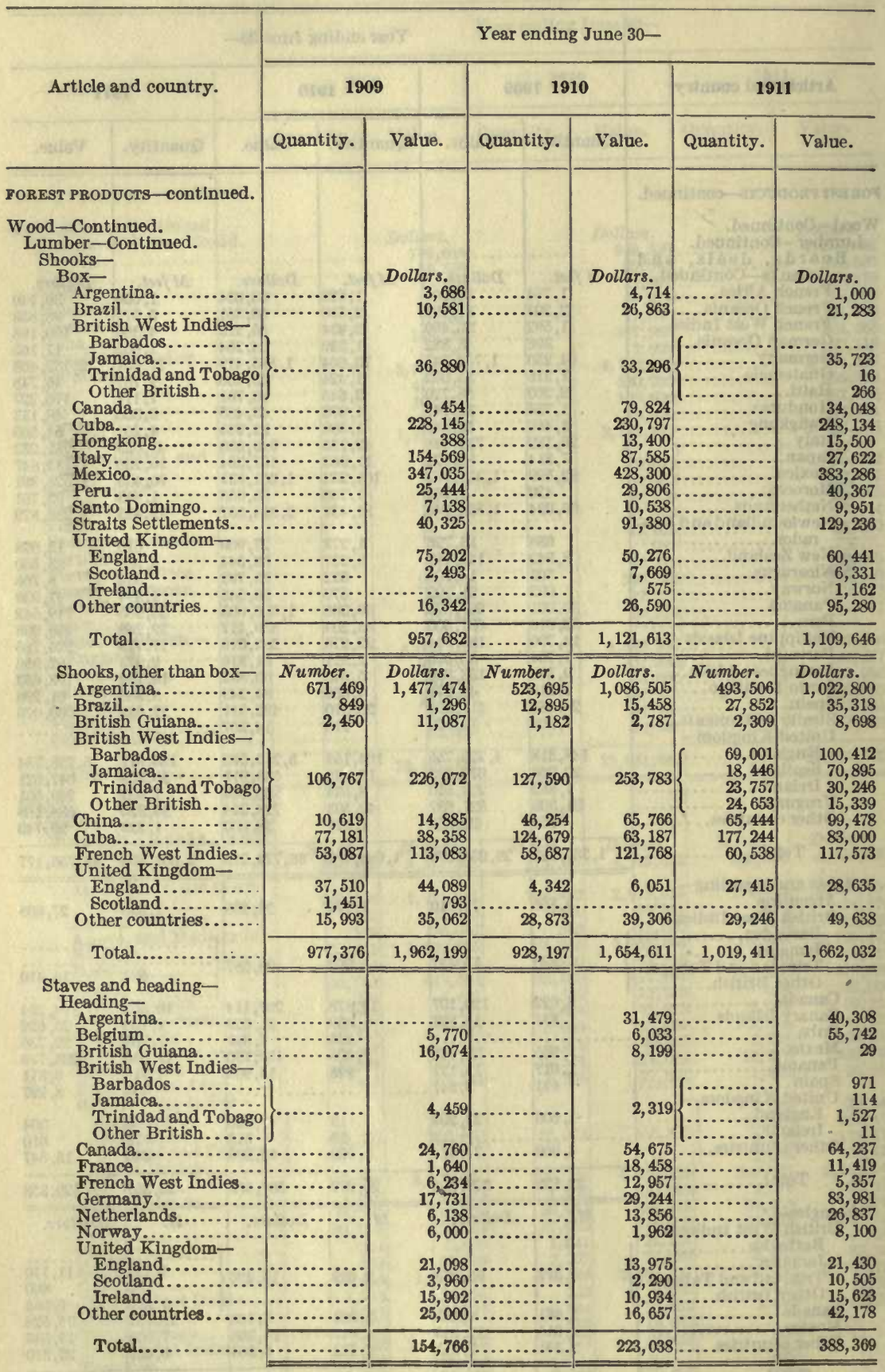


TABLE 17.-Quantity and value of EXPORTS of domestic FARM and FOREST products, 1909-1911, by articles and by countries to which consigned-Continued.

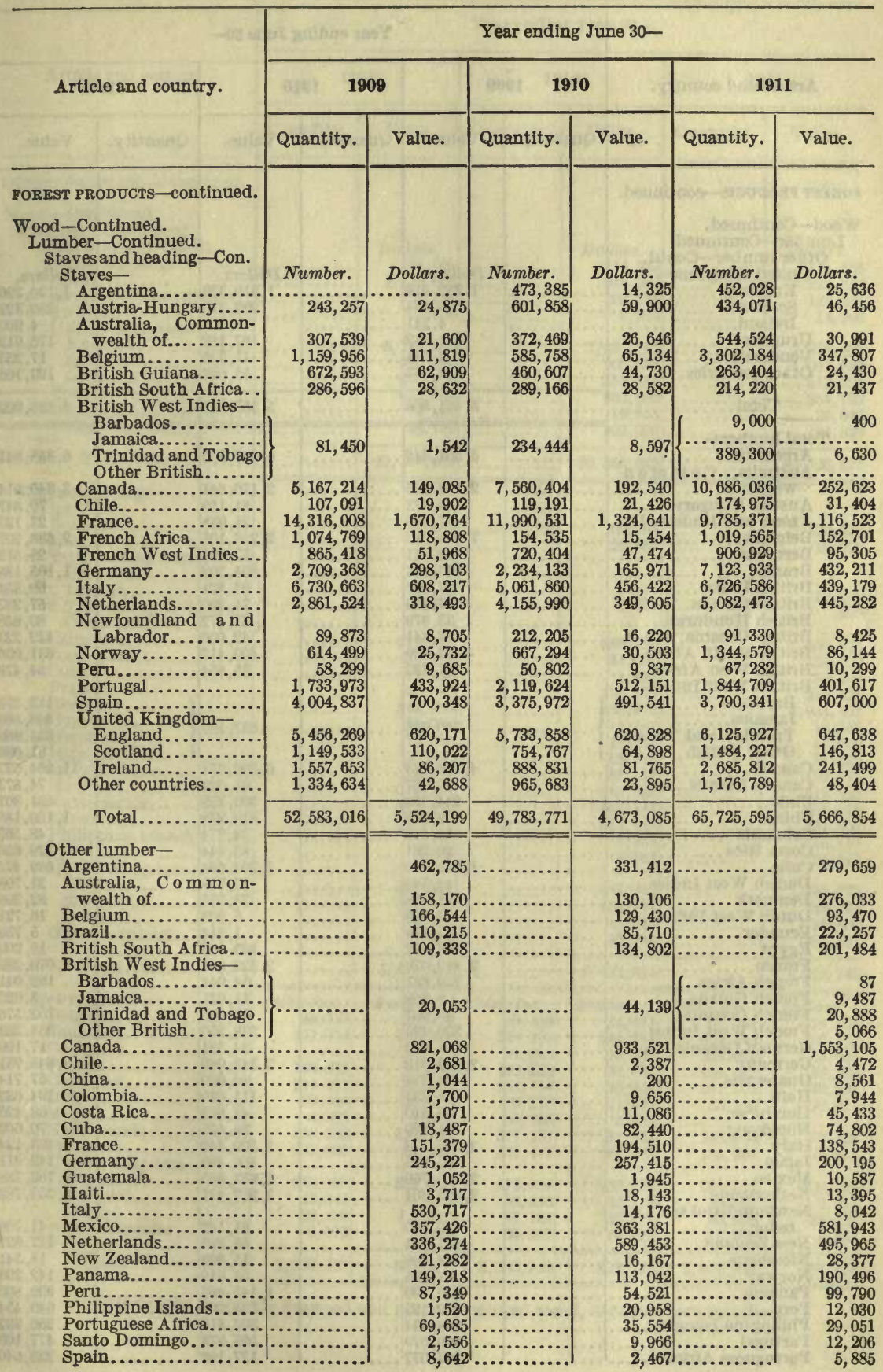


TABLE 17.-Quantity and value of EXPORTS of domestic FARM and FOREST products, 1909-1911, by articles and by countries to which consigned-Continued.

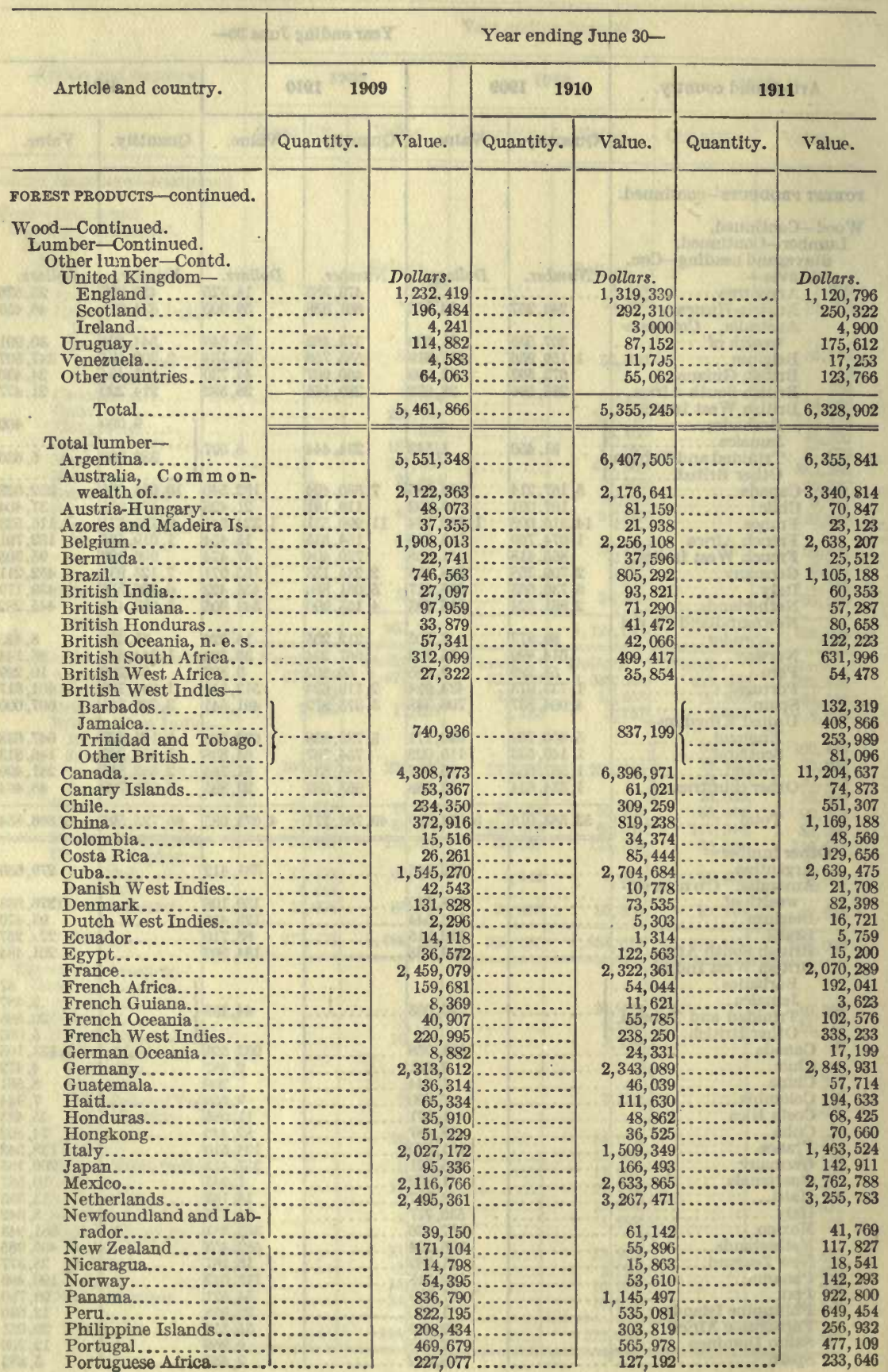


TABLE 17.-Quantity and value of EXPORTS of domestic FARM and FOREST products, 1909-1911, by articles and by countries to which consigned-Continued.

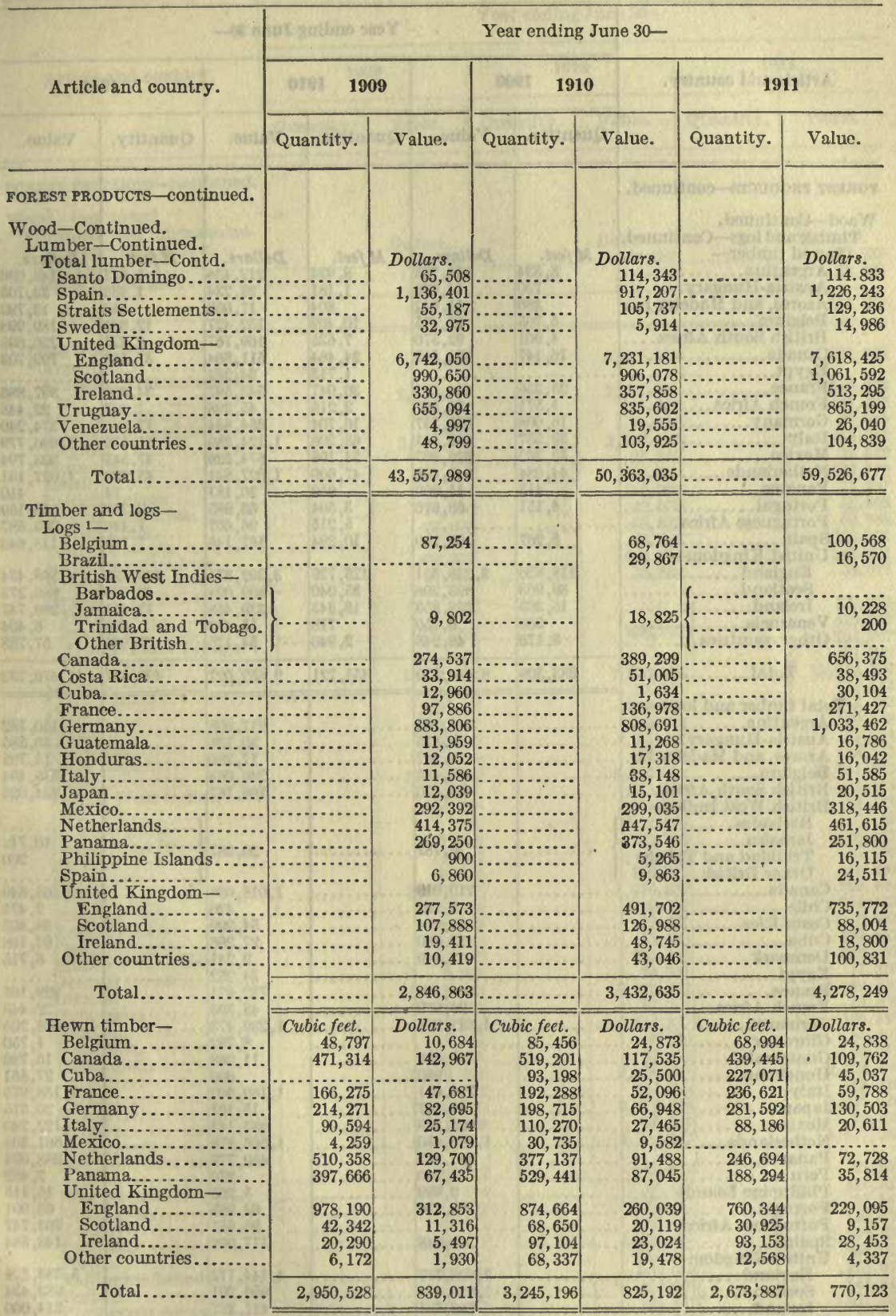

1 Prior to 1909, including firewood and unmanufactured wood, not elsewhere specified. 
TABLE 17.-Quantity and value of EXPORTS of domestic FARM and FOREST products, 1909-1911, by articles and by countries to which consigned-Continued.

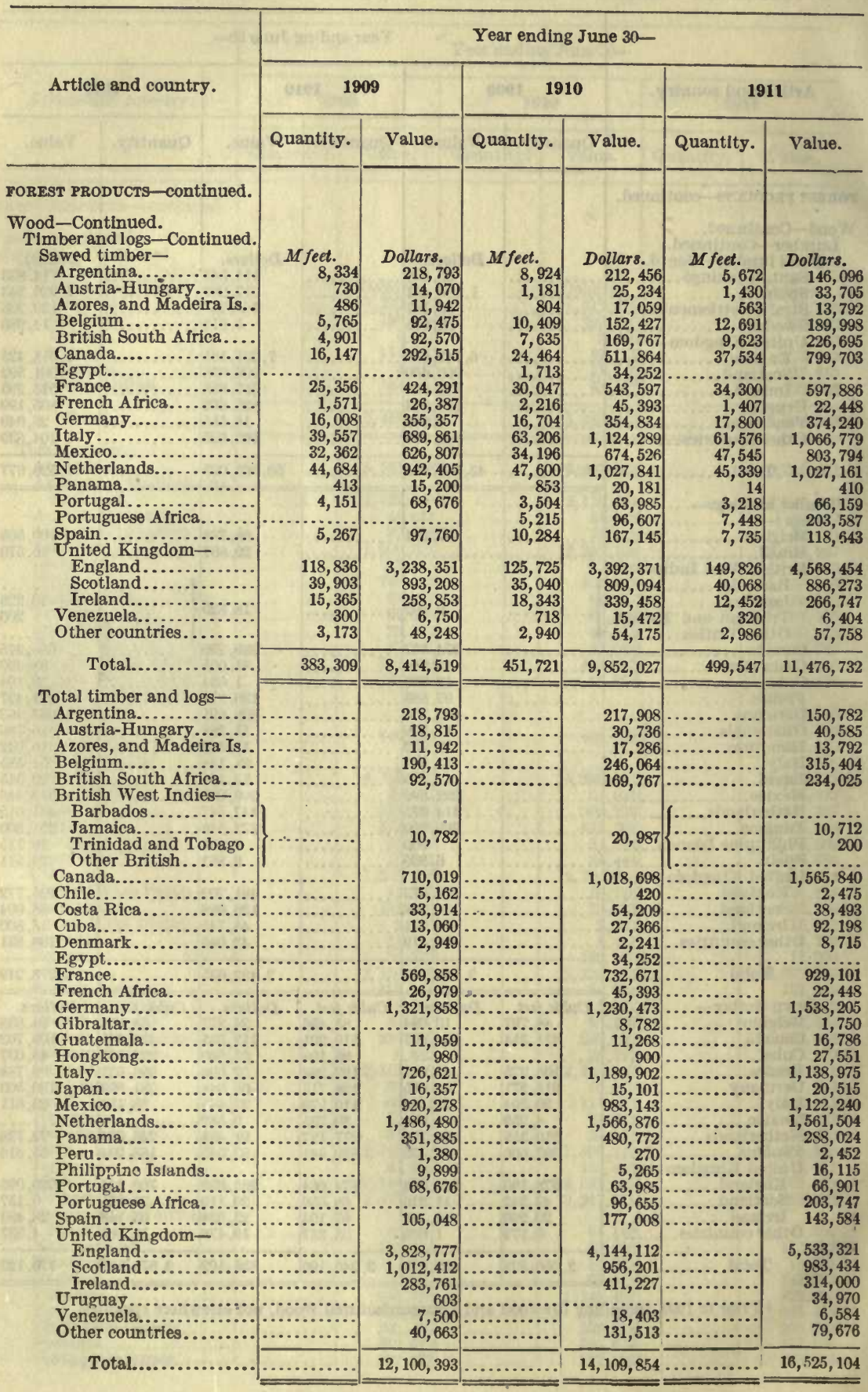


TABLE 17.-Quantity and value of EXPORTS of domestic FARM and FOREST products, 1909-1911, by articles and by countries to which consigned-Continued.

\begin{tabular}{|c|c|c|c|c|c|c|}
\hline \multirow{3}{*}{ Articie and country. } & \multicolumn{6}{|c|}{ Year ending June $30-$} \\
\hline & \multicolumn{2}{|c|}{1909} & \multicolumn{2}{|c|}{1910} & \multicolumn{2}{|c|}{1911} \\
\hline & Quantity. & Value. & Quantity. & Value. & Quantity. & Value. \\
\hline OREST PRODUCTS-cont & & & & & & \\
\hline 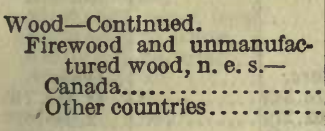 & & $\begin{array}{r}\text { Dollars. } \\
461,157 \\
18,839 \\
\end{array}$ & & $\begin{array}{r}\text { Dollars. } \\
454,387 \\
5,823 \\
\end{array}$ & & $\begin{array}{r}\text { Dollars. } \\
242,232 \\
33,638 \\
\end{array}$ \\
\hline Total. & & 479,996 & & 460,210 & & 275,870 \\
\hline $\begin{array}{l}\text { Total wood- } \\
\text { Argentina........ } \\
\text { Australia, Commo }\end{array}$ & & $5,770,141$ & & $6,625,413$ & & $6,506,623$ \\
\hline $\begin{array}{l}\text { Australla, Commor } \\
\text { of ......................... }\end{array}$ & & $2,122,363$ & & $2,177,141$ & & $3,340,826$ \\
\hline $\begin{array}{l}\text { Austria-Hungary } \ldots . . . . . \\
\text { Azores, and Madeira Is... }\end{array}$ & & $\begin{array}{r}66,888 \\
49,297\end{array}$ & & $\begin{array}{r}111,895 \\
39,224\end{array}$ & & $\begin{array}{r}111,432 \\
36,915\end{array}$ \\
\hline Aelgium ........................... & & $2,098,426$ & & $2,502,172$ & & $\begin{array}{r}36,915 \\
2,953,611\end{array}$ \\
\hline Bern & & 22,741 & & 37,841 & & $\begin{array}{r}25,512 \\
25,51\end{array}$ \\
\hline Braz & & $\begin{array}{r}758,250 \\
97,959\end{array}$ & & 835,159 & & $1,123,770$ \\
\hline $\begin{array}{l}\text { British Guiana..... } \\
\text { British Honduras.. }\end{array}$ & & $\begin{array}{l}97,959 \\
34,056\end{array}$ & & $\begin{array}{l}71,290 \\
42,076\end{array}$ & & $\begin{array}{l}57,287 \\
85,103\end{array}$ \\
\hline Birtish India....... & & $\begin{array}{l}34,050 \\
27,097\end{array}$ & & $\begin{array}{l}42,070 \\
93,821\end{array}$ & & $\begin{array}{l}85,103 \\
60,383\end{array}$ \\
\hline British Oce & & 57,341 & & 42,066 & & 122,391 \\
\hline British Sou & & 404,669 & & 669,184 & & 866,021 \\
\hline $\begin{array}{l}\text { British West Africa.. } \\
\text { British West Indies- }\end{array}$ & & 27,322 & & 35,854 & & 58,978 \\
\hline Barbados.......... & & & & & & 132,319 \\
\hline $\begin{array}{l}\text { Trinidad and Toba } \\
\text { Other British...... }\end{array}$ & & 751,725 & & 858,252 & & $\begin{array}{r}419,845 \\
254,207 \\
81,096\end{array}$ \\
\hline Canada.... & & $5,479,949$ & & $7,870,056$ & & $13,012,709$ \\
\hline Cane & & 53,367 & & 61,021 & & 74,873 \\
\hline Chil & & 239,512 & & 309,679 & & 553,782 \\
\hline Chir & & 372,942 & & 820,738 & & $1,169,488$ \\
\hline $\begin{array}{l}\text { Colo } \\
\text { Cost }\end{array}$ & & $\begin{array}{l}15,516 \\
60,175\end{array}$ & & 51,439 & & 61,664 \\
\hline $\begin{array}{l}\text { Cost } \\
\text { Cub }\end{array}$ & & $\begin{array}{r}60,175 \\
1,558,330\end{array}$ & & 139,653 & & 168,149 \\
\hline $\begin{array}{l}\text { Cuba.... } \\
\text { Danish }\end{array}$ & & $\begin{array}{r}1,538,350 \\
42,543\end{array}$ & & $\begin{array}{r}2,732,050 \\
12,299\end{array}$ & & $2,731,673$ \\
\hline ............ & & 134,777 & & 75,776 & & $\begin{array}{l}21,864 \\
91,113\end{array}$ \\
\hline Dutch G & & & & 16,695 & & \\
\hline Dutc & & $\begin{array}{r}2,296 \\
14,118\end{array}$ & & 5,303 & & 16,721 \\
\hline Ecu: & & $\begin{array}{r}14,118 \\
36,572\end{array}$ & & $\begin{array}{r}1,314 \\
56,815\end{array}$ & & $\begin{array}{r}5,759 \\
15,200\end{array}$ \\
\hline $\begin{array}{l}\text { Egyn } \\
\text { Fran }\end{array}$ & & $\begin{array}{r}36,572 \\
3,032,737\end{array}$ & & $\begin{array}{r}156,815 \\
3,056,032\end{array}$ & & $\begin{array}{r}15,200 \\
2,999,440\end{array}$ \\
\hline Fre & & 186,660 & & $\begin{array}{r}0,000,002 \\
99,437\end{array}$ & & 214,489 \\
\hline Frer & .. & 8,369 & & 11,621 . & & 3,623 \\
\hline Fre & & 40,907 & . & 55,785 & & 102,842 \\
\hline Fr & & 220,995 & & 239,348 & & 338,233 \\
\hline Gern & & 8,882 & & 24,331 & & 17,259 \\
\hline $\mathrm{Ge}$ & & $3,641,470$ & & $3,573,912$ & & $4,389,536$ \\
\hline Gua & & $\begin{array}{l}48,273 \\
65,334\end{array}$ & . & 57,307 & & 74,500 \\
\hline Haitl... & & $\begin{array}{l}65,334 \\
48,068\end{array}$ & & 114,917 & & 195,233 \\
\hline Hondur & & $\begin{array}{l}48,068 \\
52,209\end{array}$ & 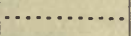 & 66,510 & .. & 85,497 \\
\hline Hongko & & $\begin{array}{r}52,209 \\
2,753,793\end{array}$ & & $\begin{array}{r}37,425 \\
\end{array}$ & & \\
\hline Ital & & $\begin{array}{r}2,753,793 \\
111,693\end{array}$ & : & $2,699,251$ & & $2,602,499$ \\
\hline $\begin{array}{l}\text { Japan } \\
\text { Mexic }\end{array}$ & & $\begin{array}{r}111,693 \\
3,038,846\end{array}$ & & $\begin{array}{r}181,594 \\
3,619,908\end{array}$ & & 163,426 \\
\hline $\begin{array}{l}\text { Mexic } \\
\text { Moroc }\end{array}$ & & $\begin{array}{r}3,038,846 \\
8,179\end{array}$ & & $\begin{array}{r}3,619,908 \\
35,056\end{array}$ & & $\begin{array}{r}3,915,626 \\
35,751\end{array}$ \\
\hline Nether & & $3,985,741$ & & $4,834,347$ & & $4,817,287$ \\
\hline $\begin{array}{l}\text { Newfoundland and Lab- } \\
\text { rador..................... }\end{array}$ & & 49,718 & & 58 & & 41,895 \\
\hline New Zealand... & & 171,104 & & 55,896 & & 117,827 \\
\hline Nicarag & & 14,902 & & 16,445 & & 18,541 \\
\hline Norway & & 56,273 & & 63,518 & & 149,058 \\
\hline Panama......... & & $1,188,675$ & & $1,626,425$ & & $1,210,824$ \\
\hline & 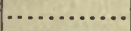 & 823,575 & & 535,351 & & 651,906 \\
\hline Phil & & 218,333 & & 309,084 & & 273,047 \\
\hline Portugal........ & & 538,355 & & 629,963 & & 544,010 \\
\hline Portuguese Africa & $\cdots$ & 227,077 & & 223,847 & & 437,393 \\
\hline Salvador....... & & 8,647 & & 21,787 & & 12,755 \\
\hline Santo Domingo & .. & 68,673 & & 114,573 & & 118,332 \\
\hline $\begin{array}{l}\text { Sp } \\
\text { St }\end{array}$ & & $\begin{array}{r}1,241,449 \\
55,187\end{array}$ & & $1,094,215$ & & $1,369,827$ \\
\hline $\begin{array}{l}\text { Straits Set } \\
\text { Sweden... }\end{array}$ & & $\begin{array}{l}55,187 \\
32,975\end{array}$ & $\begin{array}{l}\cdots \\
\cdots\end{array}$ & $\begin{array}{r}105,737 \\
5,914\end{array}$ & .... & $\begin{array}{r}129,236 \\
15,006\end{array}$ \\
\hline
\end{tabular}


TABLE 17.-Quantity and value of EXPORTS of domestic FARM and FOREST products, 1909-1911, by articles and by countries to which consigned-Continued.

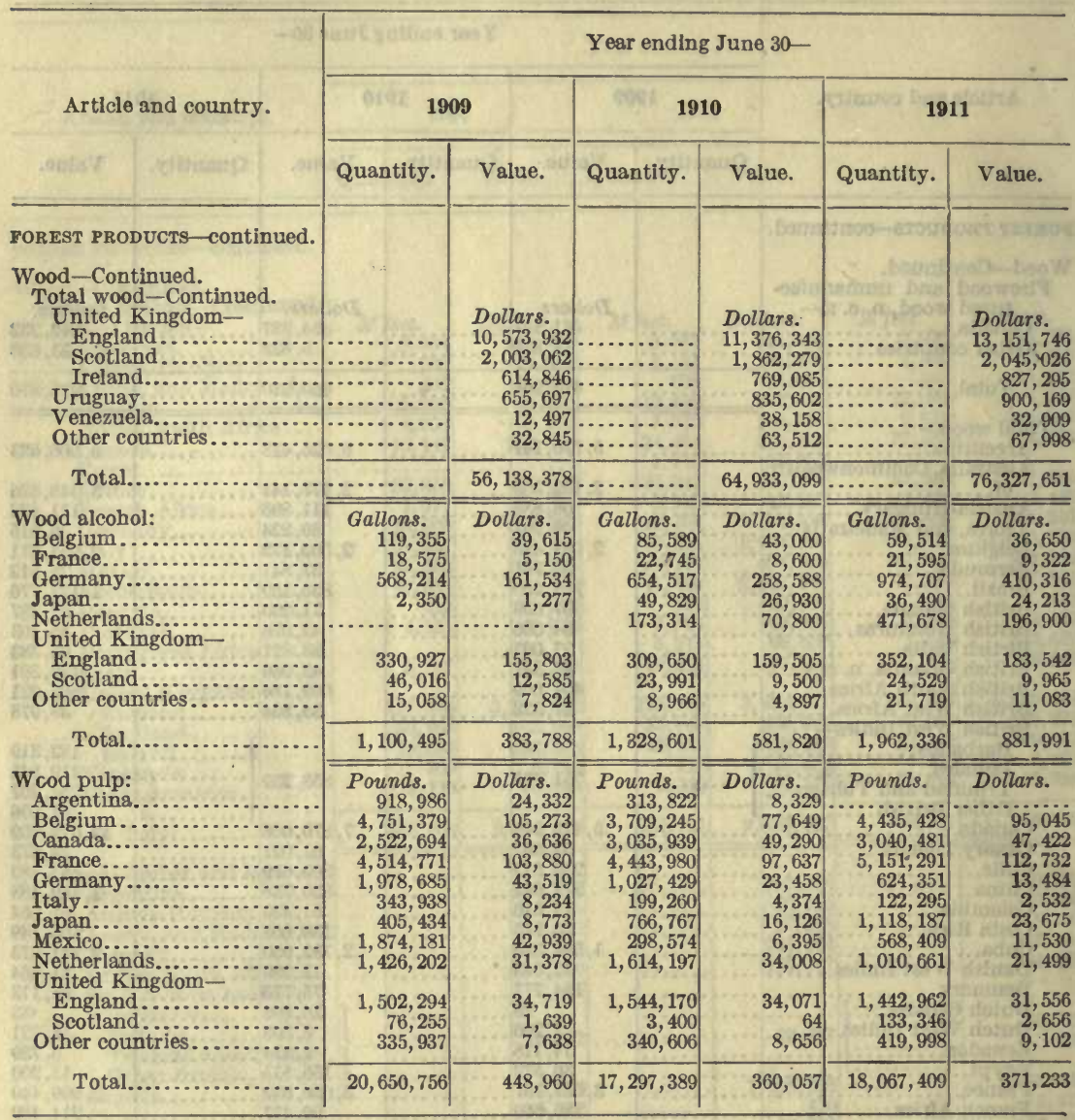


INDEX TO TABLE 17.

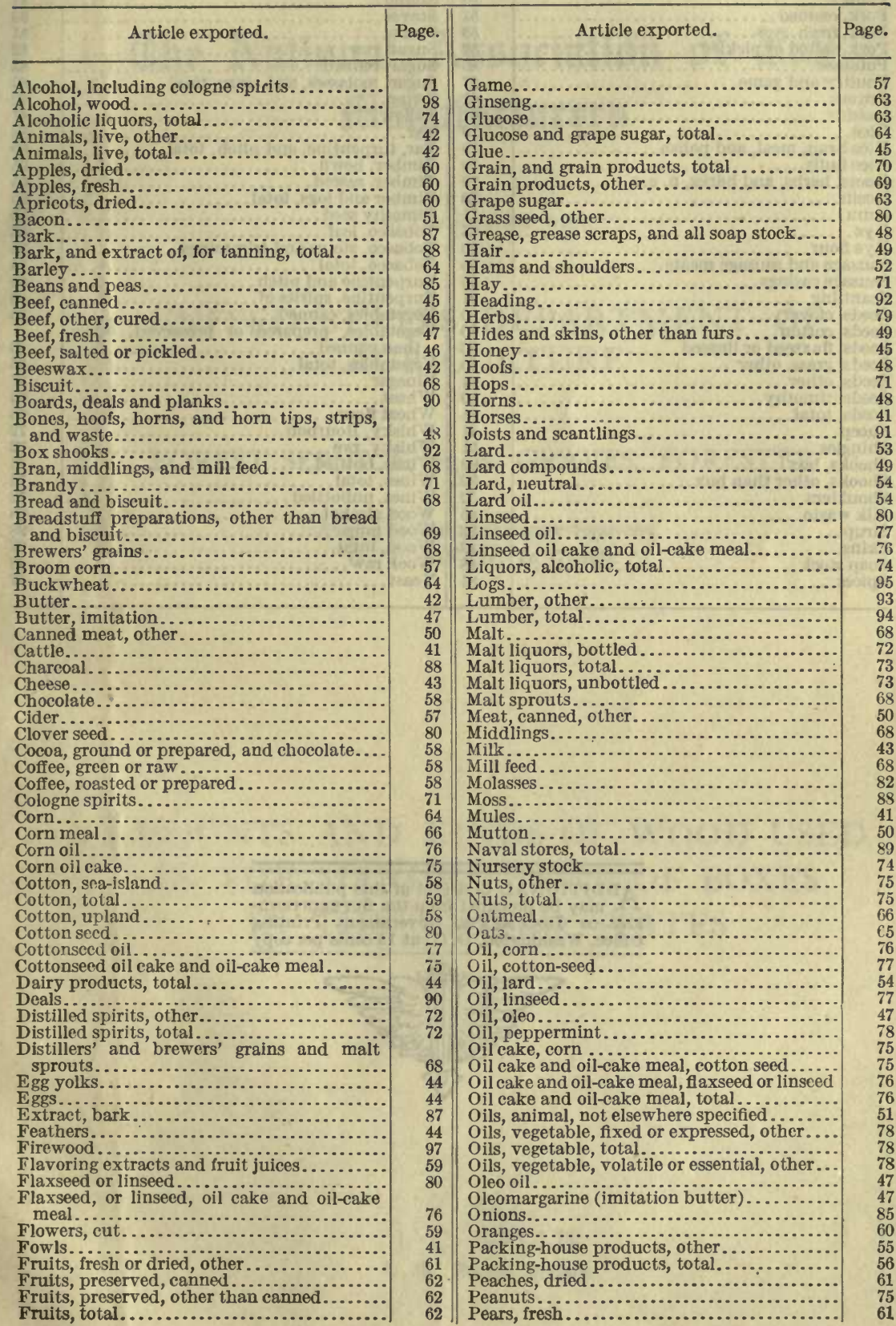


Index to Table 17 -Continued.

\begin{tabular}{|c|c|c|c|}
\hline Article exported. & Page. & Article exported. & Page. \\
\hline ease. & 85 & Spirits, distilled, other. . & 72 \\
\hline Peppermint oil. & 78 & Spirits, distilled, total.... & 72 \\
\hline ................ & 90 & 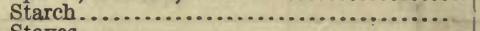 & 81 \\
\hline Pork, canned. & 51 & Staves........... & 93 \\
\hline Pork, fresh... & 53 & Straw............ & 81 \\
\hline Pork, salted or pickled. & 52 & Sugar, raw .. & 82 \\
\hline Potatoes.......... & 85 & Sugar, refined..... & \\
\hline ltry and gam & 57 & Sugar, molasses, ar & 82 \\
\hline s........ & 61 & Swine............. & 42 \\
\hline ns.... & 61 & Tallow........... & 47 \\
\hline$\ldots \ldots$ & 79 & Tar ........... & \\
\hline ran, meal, a & 79 & Tar, turpentine, & 89 \\
\hline hulls........... & 79 & Timber, he & 95 \\
\hline , herbs, and & 79 & ed.. & 96 \\
\hline ................... & 88 & nber and logs, total. & 96 \\
\hline$\ldots \ldots \ldots \ldots$ & 71 & ed........... & 80 \\
\hline & 65 & Tob & 83 \\
\hline$\ldots \ldots \ldots \ldots \ldots \ldots \ldots$ & 66 & s an & 84 \\
\hline $\begin{array}{l}e \text { and sausage meats.. } \\
\theta \text { casings. . . . . . . . . . . }\end{array}$ & 55 & To & 84 \\
\hline 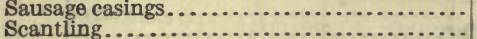 & 55 & $\because \ldots \ldots$ & 89 \\
\hline 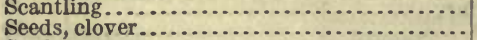 & 91 & s of $\ldots \ldots$. & 89 \\
\hline (n) & $\begin{array}{l}80 \\
80\end{array}$ & $\begin{array}{l}\text { Vegetables, canned.......... } \\
\text { Vegetables, prepared or pr }\end{array}$ & 66 \\
\hline s, flaxseed or linseed... & 80 & 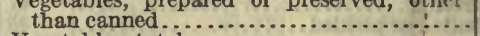 & 86 \\
\hline Seeds, grass, other ... & 80 & Vegetables, total.. & 36 \\
\hline Seeds, other...... & 81 & Vinegar....... & 87 \\
\hline s, tim & 80 & Wheat....... & 65 \\
\hline is, total.... & 81 & Wheat flour... & 56 \\
\hline Sh & 41 & Whisky, Bourbon.... & 72 \\
\hline les... & 91 & Whisky, rye......... & 72 \\
\hline ss, box..... & 92 & , bottled.. & 73 \\
\hline $\mathrm{ks}$, other tha & 92 & Wines, total. & 7 \\
\hline lders....... & 52 & bottled..... & 3 \\
\hline waste. & 45 & Wood alcohol......... & 98 \\
\hline Sir & 82 & 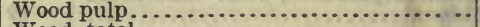 & 98 \\
\hline Skins. . & 49 & 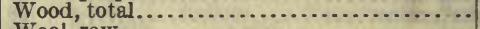 & 97 \\
\hline stock & 48 & 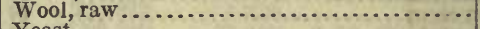 & 45 \\
\hline pices. & 81 & Yeast................................ & \\
\hline
\end{tabular}

ADDITIONAL COPIES of this publication A may be procured from the SUPERINTENDENT OF DocumeNrs, Government Printing Office, Washington, D. C., at 15 cents per copy

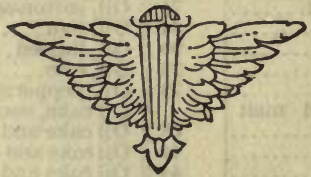




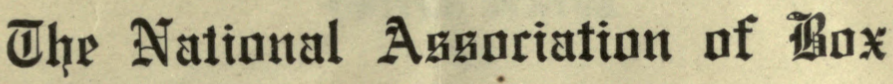 Hanufarturerg
}

\author{
In Cooperation with
}

UNITED STATES DEPARTMENT OF AGRICULTURE

FOREST SERVICE, H. S. GRAVES, FORESTER

Office of Industrial Investigations

O. T. SWAN, In Charge

AMOUNTS AND KINDS OF WOOD USED

IN THE MANUFACTURE OF BOXES

IN THE UNITED STATES

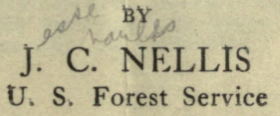





\title{
AMOUNTS AND KINDS OF LUMBER USED IN THE MANUFACTURE OF BOXES IN THE UNITED STATES.
}

\author{
BY \\ J. C. NELLIS, U. S. FOREST SERVICE.
}

Box makers in the United States use $4,547,973,180$ feet of lumber annually, of which softwoods constitute $3,138,278,019$ feet, or 69 per cent, and hardwoods 1,409,695,161 feet, or 31 per cent of the total. Practically all of the wood used for boxes is the product of the sawmill and therefore forms a part of the annual lumber cut. Based on the production in 1912, the last year for which figures are available, 11.6 per cent of all lumber produced in the United States is converted into boxes. In fact, the manufacture of packing boxes and shooks, crates, crating, fruit and vegetable packages and baskets, is the second largest wood-consuming industry of the United States. The manufacture of lumber for construction and building purposes, planing mill products, sash, doors, blinds, and general mill work, is, of course, the leading wood-consuming industry, taking over twothirds of the annual lumber cut.

This paper presents for the first time statistics showing how much of each kind of wood is used by the box industry and the amount consumed by box makers in each of the important regions and States. These statistics are a part of those secured by the Forest Service through its studies of all the wood-using industries.* Investigations were conducted separately in each State. Reports were secured from practically every wood-using plant showing the amount of wood consumed annually, and the uses to which each kind of wood is put, and the accompanying tables are based upon reports secured from box factories during the respective State studies. This information was first used in compiling State reports which have been published for thirty States. This article summarizes the statistical information regarding the box industry. The collection and compilation of the figures, which was carried out State by State, extended over a period of four years, but as one full year was made the basis of statistics in each case the figures shown here give a very clear idea of the quantity of each

* Readers are referred to the various State wood-using bulletins for data as to the industry in each State. Further, this paper is but a preliminary report of the Forest Service investigations of the box industry; an extensive study has recently been undertaken. which will consider specifications for box lumber, methods of manufacturing boxes and shooks with particular attention to the reduction and use of waste, costs of manufacture, marketing, and finally the use of boxes by consumers with special reference to the correlation of consumers' specifications as far as possible. 
kind of lumber used for boxes in the whole country. The total amount of wood used annually in the United States for the manufacture of boxes and the quantity used in each State are shown in Table 1.

\section{TABLE 1-WOOD USED IN THE U. S. FOR BOXES} AND CRATES.

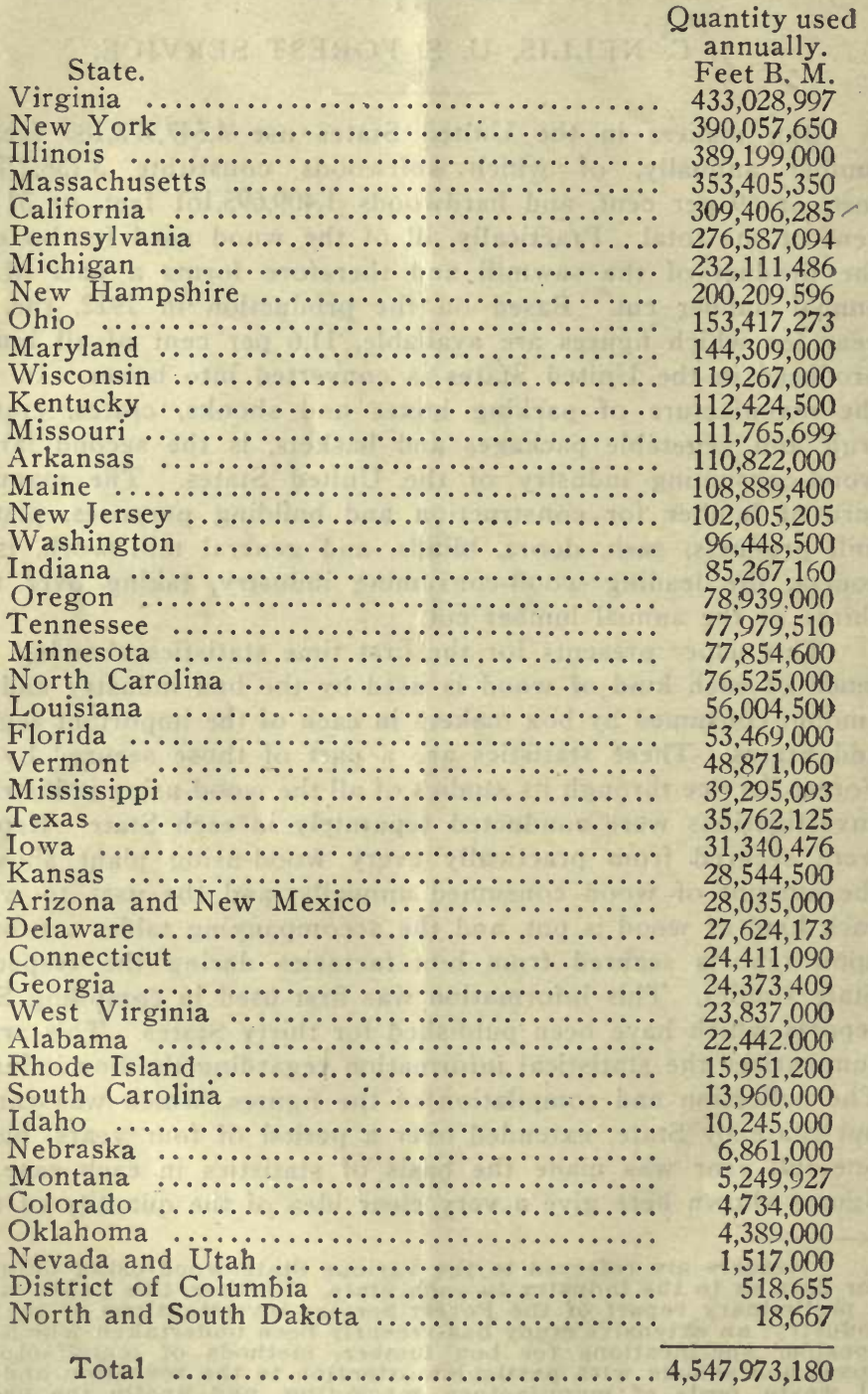

See Map Pages 8 and 9. 


\section{Principal Producing Regions.}

The manufacture of boxes in the United States is conducted on a large scale in certain regions determined by the supply of raw material and the markets for the product. The manufacturing industries turning out products usually shipped in boxes, and the intensive production of fruits and vegetables for wide markets are the consuming channels calling for large box supplies. Among the leading box consumers are manufacturers of oil, pack ng-house products, canned goods, groceries and tobacco, clothing and dry goods, the manufacturers of hardware, tinware and machines, growers of fruit, berries and vegetables. Crates, which are classed in this report with boxes, are used in large quantities by shippers of furniture, hardware, machinery and stone. There are innumerable special demands for boxes and crates, but on the whole it is manufacturing and intensive fruit raising and market gardening which create the demand for boxes, and a careful analysis of the centers of these activities, together with a consideration of the sources of timber supply, will explain the widely varying relative importance of the industries in the several States and regions.

Nearly three-fourths of all the boxes, shooks, crates, crat'ng, etc., are manufactured in the region east of the Mississippi River and north of Tennessee and North Carolina, which, owing to the extent of its industries, offers the best market for boxes, and also embraces or is contiguous to the sources of the woods most used in box making. New England and New York produce and manufacture into boxes a great deal of white pine, hemlock, spruce and balsam fir, though they also secure a portion of the's box material from Canada. Virginia and Maryland produce yellow pine-loblolly, shortleaf and scrub-and use nearly half a billion a year for boxes and shooks, though much of this comes from North Carolina. Wisconsin and Michigan manufacture white pine into boxes, also join with Minnesota in furnishing the wood to box factories in Illinois. The latter State draws also on the southern supply of red gum, cottonwood and yellow poplar, as do Indiana, Ohio, Pennsylvania and New York.

The fourteen States lying east of Ohio, Kentucky and Tenncssee and north of South Carolina produce 50 per cent of all the boxes and shooks manufactured annually. Wisconsin, Michigan, Ill nois, Indiana and Ohio together contribute 20 per cent of the total production, the Pacific Coast States-California, Oregon and Washington-10 per cent; the red gum States-Missouri, Arkansas, Kentucky and Tennessee- 9 per cent, while all the rest of the States together produce only 11 per cent.

Boxes manufactured in the States east of the Mississippi River are largely used in the same region, while Pacific Coast box manufacturers not only supply salmon packers and fruit rais- 
ers in their own region, but have been able to ship the best grades of shooks to the meat packing centers of Chicago and Omaha. With the opening of the Panama Canal, Pacific Coast shooks are likely to enter eastern markets.

\section{Woods Used.}

In general the requirements for box material are that it shall be cheap, plentiful, light in weight, and capable of holding nails without splitting. Other qualities are demanded for particular knds of boxes. Those which are meant to hold certain food stuffs are made from woods that are odorless, tasteless and stainless. Further, some kinds of boxes must be sufficiently light in color to show stenciling and printing. Some strength is required in all boxes, but a great degree of strength is demanded only for export boxes or for boxes in which heavy merchandise is shipped. For this reason, box makers do not demand one kind of wood greatly in excess of other $k$ nds. The species most used differs in different regions, usually according to the local supply.

The quantity of each kind of wood used annually in the United States for the manufacture of boxes is shown in Table 2. This table has been compiled, not by botanical species, but by groups of closely related species which are often classed together in the lumber trade.

\section{TABLE 2-WOOD USED IN THE U. S. FOR BOXES AND CRATES.}

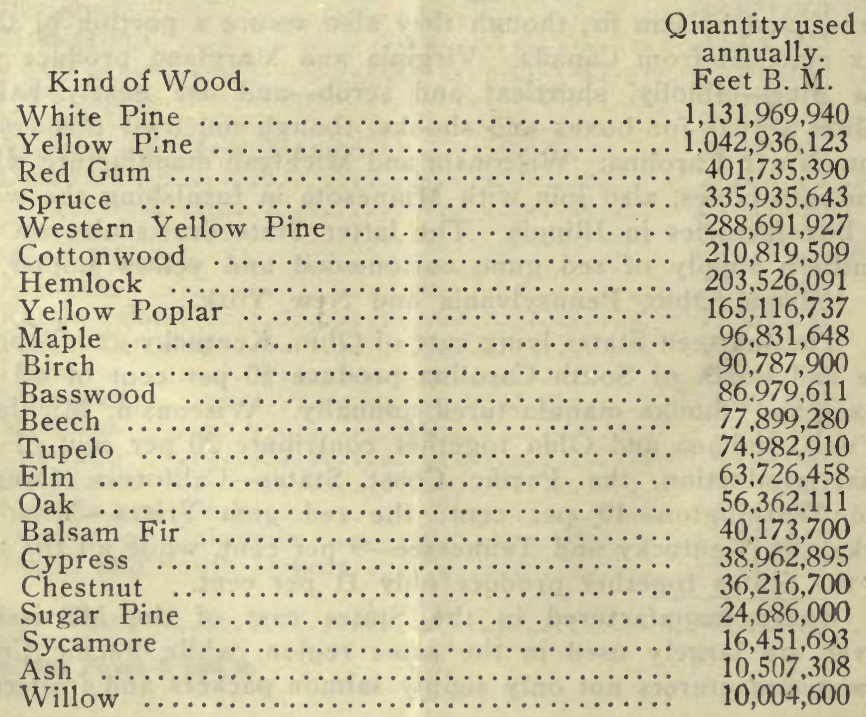




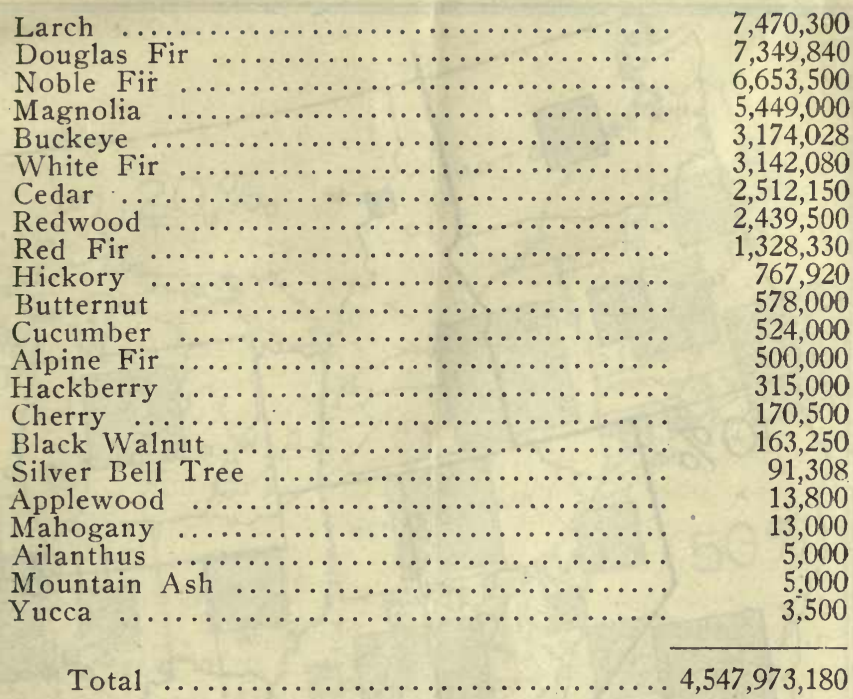

White pine has long been the preferred box material, and still is, where obtainable. The white pine listed in Table 2 is made up of 96 per cent eastern white pine, 2 per cent Norway pine, and 1 per cent each of Jack pine and western white pine. In order of the quantity consumed, white pine is used to the greatest extent in Massachusetts, New York, New Hampshire, Illinois, Maine, Michigan, Minnesota, Pennsylvania, Wisconsin and New Jersey.

The sources of white pine supplies are the Lake States, Canada and New England. The largest amounts of Norway pine are used in Minnesota, Michigan, Wisconsin and New Hampshire, and the largest amounts of Jack pine in Wisconsin and Michigan. Norway pine is lumbered principally in the Lake States and New England and Jack pine in the Lake States only. Western white pine is used to a small extent by box factories in Washington, Oregon, Idaho and Montana, and the supply comes from these States.

The several kinds of southern yellow pine furnish almost as much box material as does white pine. However, the single species, eastern white pine, furnishes over a billion feet annually, while no one kind of yellow pine furnishes over a half-billion. It is not possible to tell accurately just how much of each kind of yellow pine is used for boxes, but an approximate estimate is loblolly 46 per cent, shoftleaf $35 \mathrm{r} / 2$ per cent, longleaf $8 \mathrm{r} / 2$ per cent, scrub 6 per cent, and smaller proportions of Cuban, pitch and the minor yellow pines. Over two-thirds of all the yellow pine manu- 


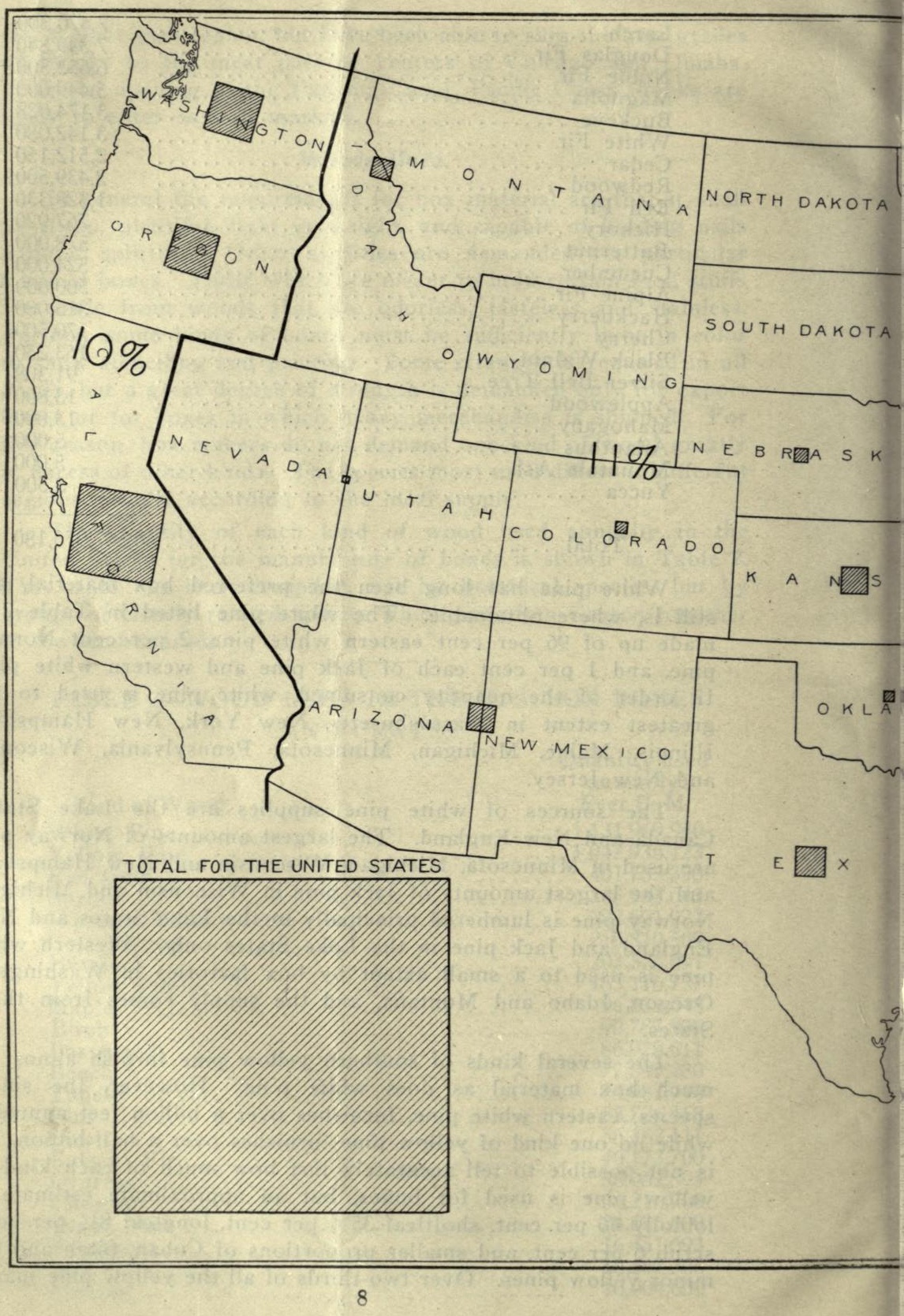




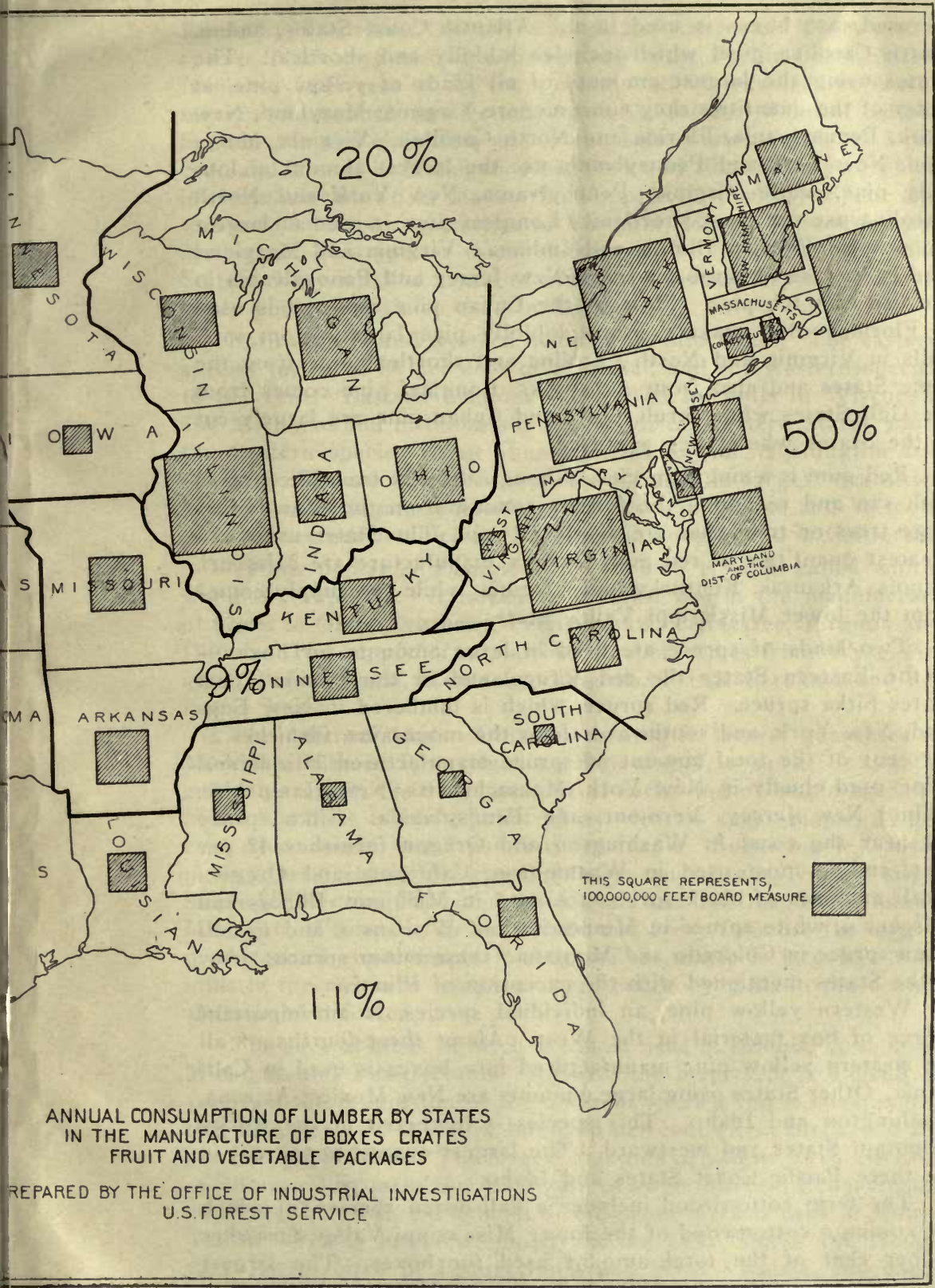


factured into boxes is used in the Atlantic Coast States, and is North Carolina pine, which includes loblolly and shortleaf. The States using the largest amounts of all kinds of yellow pine, in order of the quantities they consume, are Virginia, Maryland, New York, Pennsylvania, Florida and North Carolina. Virginia, Maryland, New York and Pennsylvania use the largest amount of loblolly pine, while Virginia, Pennsylvan:a, New York and North Carolina use the most shortleaf. Longleaf pine is used in largest amounts in Florida, Illinois and Indiana. Virginia and Maryland lead in the use of scrub pine, and New Jersey and Pennsylvania in the use of pitch pine. Most of the Cuban pine reported is used in Florida. Box makers secure loblolly pine largely from sawmills in Virginia and North Carolina and shortleaf pine from the same States and also from Arkansas. Longleaf pine comes from the Gulf States while scrub, pitch and Cuban pine are largely cut in the States where they are used.

Red gum is a single species, although the box trade recognizes both sap and red gum, the former coming from the sapwood of large trees or trees that are nearly all sap. The States using the greatest quantities of red gum for box manufacture are Missouri, Illinois, Arkansas, Kentucky and Virginia, while the supply comes from the lower Mississippi Valley States.

Two kinds of spruce are used in large amounts for boxes, in the Eastern States the red spruce, and in the Pacific Coast States Sitka spruce. Red spruce, which is lumbered in New England, New York, and southward along the mountains, furnishes 57 per cent of the total amount of spruce manufactured into boxes, being used chiefly in New York, Massachusetts, New Hampshire, Maine, New Jersey, Vermont, and Pennsylvania. Sitka spruce cut near the coast in Washington and Oregon furnishes 42 per cent, and is most used in Washington, California and Oregon. Small amounts of black spruce are used in Michigan, Illinois and Wiscons $n$, white spruce in Minnesota and Wisconsin, and Engelmann spruce in Colorado and Montana; these minor spruces grow in the States mentioned with the exception of Illinois.

Western yellow pine, an individual species, is an important source of box material in the West. About three-fourths of all the western yellow pine manufactured into boxes is used in California. Other States using large amounts are New Mexico, Arizona. Washington and Idaho. This species is lumbered in the Rocky Mountain States and westward. The largest quantities are cuit in the three Pacific Coast States and Idaho.

The term cottonwood includes a half-dozen species, of which the common cottonwood of the lower Miss ssippi Valley furnishes 85 per cent of the total amount used for boxes. The largest quantities are employed in Illinois, Tennessee, Missouri, Mississippi, 
Kentucky, Louisiana, Ohio, New York and Arkansas. The western species, black cottonwood, which grows in the Pacific Coast States, furnishes 7 per cent of the total, most of which was used in Wash. ington, and a much smaller amount in California. Balm of Gilead, lumbered in the Northeast and in the Lake States, furnishes 5 per cent, and is used in Michigan, New York and Illinois. Aspen, which is commonly known in the north as popple, formed 3 per cent and was used in largest quantities in Vermont, Maine, Wisconsin, and Michigan. This species is cut mostly in the Northeast and Lake States. Very small amounts of both large toothed aspen and Lombardy poplar were also used in Michigan.

Both eastern and western hemlock go into boxes. The eastern species furnishes 84 per cent of the total, and the western species 16 per cent. Eastern hemlock is suppled by mills in Wisconsin and Michigan and in mountain regious of the eastern States while the western species is cut almost exclusively in Washington and Oregon. Eastern hemlock is used for boxes in largest quantities in Illinois, Michigan, Massachusetts, New Hampshire and Wisconsin, and western hemlock in Washington, Oregon and in California.

Yellow poplar is a single species which is often called whitewood or tulip tree. It is put to greatest use in the manufacture of boxes in Oh:o, Kentucky, Pennsylvania, Tennessee, Virginia and Illinois. The supply of poplar box lumber comes from West Virginia, Pennsylvania, Kentucky, Virginia, North Carolina, and adiacent States.

The different kinds of maple are used in largest quantities in Michigan, Illinois, Pennsylvan'a, Ohio, and New York. It is difficult to ascertain the exact amount of each kind of maple used for boxes, but it is estimated that 63 per cent is sugar maple, 35 per cent silver maple, and 2 per cent red maple. Sugar maple is used most extensively in Michigan, Illinois, and Pennsylvania; silver maple in Ill nois, Ohio and Michigan; and red maple in Illinois. Michigan, Wisconsin, Pennsylvania, and New York are the largest producers of sugar maple lumber; silver maple is largely cut by mills in the northern States, and red maple by mills in the central and southern States.

The several kinds of birch are most used in Illinois, Wisconsin, Michigan and Pennsylvania. As with the maples, it is difficult to ascertain the proportion of the different species, but it is estimated that $84 \mathrm{r} / 2$ per cent is yellow birch, 13 per cent sweet birch, and $21 / 2$ per cent paper birch. The largest amounts of yellow birch are used in Illinois, Wisconsin and Michigan; of sweet birch in Penusylvania and West Virginia, while most of the paper birch is used in Maine. Yellow birch is lumbered mostly in the Lake States and Northeast; sweet birch in Pennsylvania and West Virginia, and paper birch in northern New England. 
The basswood employed in the wood-using industries is cut from three botanical species; one common in the North and two in the South. The lumber is suppled by sawmills in the Lake States, central States and the Northeast. The most important basswood consuming States are Michigan, Wisconsin, Illinois, New York and Minnesota.

There is but one kind of beech native to this country, and it is cut and used most extensively in the northern States. The box factories of Mich gan, Pennsylvania, New York, Ohio, and Indiana use beech in largest quantities. The same five States produce twothirds of all the beech lumber cut in this country.

Tupelo is the common name for lumber cut from cotton gum and black gum trees. The States using the greatest quantity of tupelo in box manufacture are Virginia, Maryland, North Carolina, Pennsylvania, and Louisiana. It is estimated that 51 per cent s cotton gum and 49 per cent black gum. Based on this division, cotton gum is put to greatest use in Louisiana, Virginia, and Illinois, and black gum in Virgin a, Maryland and North Carolina. The largest quantities of cotton gum box lumber come from Louisiana, while black gum box lumber is largely produced in Virginia and North Carolina.

It is estimated that $851 / 2$ per cent of all the elm consumed by the box industry is white elm, wh ch is used in largest quantities in Michigan, New York, Illinois, Ohio, and Indiana. Twelve per cent is estimated to be red or slippery elm, which is used mostly in Illinois and Indiana. These species are cut mostly in the States ment oned with the exception of Illinois and the addition of Wisconsin and Missouri. Small amounts of cork elm are used in several northern States, and a small amount of wing elm in Texas.

One of the minor uses of oak is in the manufacture of boxes. crates, and baskets. In the use of oak, Arkansas leads, followed by Pennsylvania, Indiana and Ohio. It is estimated that 50 per cent of the total is red oak, used mostly in Pennsylvania, Ohio, West Virginia and New York, 20 per cent yellow oak, pract cally all used in Arkansas, $17 \mathrm{r} / 2$ per cent white oak, the largest amounts used in Indiana and Ohio, and 7 per cent Texan oak, reported chiefly from Arkansas. Oak lumber is produced in every hardwood State and that used by box makers was probably cut in the State where used or adjacent States. Small amounts of bur, Garry, post, overcup, chinquapin, pin and willow oak are also used in different States.

Balsam fir is a single species which grows in the northeastern and Lake States, although it is sometimes confused with white fir of the West. It is put to its greatest use in box manufacture in Maine, Massachusetts, New Hampshire and Vermont. The lumber is produced mostly by mills in northern New England and the Lake States. 
Cypress is not an important box material because it is more valuable for other purposes and is suited for only certain kinds of boxes. The largest quantities are used in Missouri, New York and Louisiana. Nearly two-thirds of all the cypress lumber cut comes from Louisiana.

Chestnut is not used to a great extent for boxes, although the lower grades of sound wormy sometimes go into the cheaper kinds of boxes and crates. The States using the largest amounts for boxes are Pennsylvania, Ohio, New York, and Virginia, while the States furnishing th's kind of box lumber are West Virginia, Pennsylvania, Virginia, and Kentucky.

The wood of sugar pine is much like that of white pine, and is therefore very suitable for boxes, but the greater part of the lumber produced by sawmills is of too high grade to allow its use by box factories. Over 80 per cent of the sugar pine used for boxes is consumed in California, and practically all of the balance in Oregon. These States alone supply this wood-the greater part being cut in California.

Sycamore, although rather difficult to work, is used for certain kinds of boxes. The largest amounts are consumed in Kentucky, Virginia, Missouri, and Illinois. The lumber is produced in the central hardwood States.

Ash is not an important box material, but like other hardwoods is used to some extent. The largest quantities are used in Michigan and Illinois. It is estimated that 47 per cent of the total is white ash, the largest quantities being used in Illinois and Michigan; 28 per cent black ash, a large part of which is used in Michigan; and 23 per cent green ash, used mostly in Texas, Georgia, and Arkansas. A small amount of red ash was also used in Georgia. White and black ash are cut mostly in the northern States and green ash in the South.

There are several kinds of willow, but all are listed together in statistics. The most important kind is black willow, which is cut and used largely in the States of Louisiana and Mississippi as a substitute for cottonwood, which it resembles both in appearance and qualities.

The term larch here includes the eastern tamarack and western larch. Ninety-five per cent of the total is tamarack, the largest quantities of wh:ch were used in Michigan and Wisconsin. The greater part of the western larch was used in Montana. Tamarack is lumbered mostly in the Lake States and larch in the Northwest.

A very minor use of Douglas fir is in the manufacture of boxes in the States of California, Colorado, Oregon and Washington. Douglas fir lumber is produced in many of the western States- 
Washington and Oregon furnish nearly two-thirds of the total quantity.

Noble fir is one of the minor western species, and more of it is used by the box industry than by any other. The entire amount shown in Table 2 was reported as used by box makers in Oregon. The lumber is cut by sawmills in Washington and Oregon.

Magnol:a is a wood somewhat resembling yellow poplar and is cut in the southern States; it is used in greatest quantities for boxes in Florida and Louisiana.

Buckeye is one of the minor species of the central hardwood region and Tennessee box factories use the largest quantities.

White fir is a minor western species, well suited to the manufacture of boxes. The greater part of the amount shown in Table 2 was used in California and a very small part in Oregon. The largest quantities of white fir lumber are cut by sawmills in the Pacific Coast States and Idaho.

None of the several kinds of cedar is important as box material. The eastern red and northern white cedar comprise the greater port on of the total, while small amounts of southern white, western red and incense cedar are also reported.

A minor use of redwood is in the manufacture of boxes, and the wood so used is practically all cut and consumed in California.

Red fir is used to some extent in California for the manufacture of boxes. The species is lumbered only in California and Oregon.

The other species listed in Table 2 are used in small quantities only, and fall into two classes-those too valuable for box material, and a few comparatively scarce species which are fit for but little but cheap boxes and crates. Some hickory is employed to make very strong, tough crates for shipping machinery and heavy merchandise. The wood of the cucumber tree resembles that of yellow poplar both in appearance and properties and is put to practically the same uses by box manufacturers. Alpine fir is a Rocky Mountain species resembling balsam fir in appearance, properties and uses. Hackberry and silver bell tree are southern hardwoods little used for any purpose. Butternut, cherry, walnut, applewood, and mahogany are too costly to be used for shipping boxes but are made into expensive boxes for jewelry, silverware, and other expensive merchandise. Woods such as ailanthus and mountain ash serve only for cheap boxes or crating. Yucca is a desert palm from Arizona and California and was used in Missouri for bottle packing. 


\title{
Publications of the U. S. Department of Agriculture Forest Service
}

\author{
Of Interest to Box Manufacturers
}

Departmental Bulletin 24 - Cottonwood in the Mississippi Valley.

Farmer's Bulletin 582 - Uses for Chestnut Timber Killed by Bark Disease.

Departmentel Bulletin 13 - White Pine under Forest Management.

Departmental Bulletin 86 - Tests of Wooden Barrels.

Forest Service Bulletin 13 - Timber pines of southern United Stat S, with discussion of structure of their wood. Paper. 50c.

- Forest Service Bulletin 33 - Western hemlock. Paper, 30c.

Forest Service Bulletin 41 - Scasoning of timber. Paper, $25 \mathrm{c}$.

Forest Service Bulletin 58 - Red gum, with discussion of mechanical properties of red gum wood. Paper, 15c.

Forest Service Bulletin 63 - Natural replacement of white pine on old fields in New England. Paper 10c.

Forest Service Bul etin 70- Effect of moisture upon strength and stiffness of wood. Paper 15c.

Forest Service Bulletin 73-Grades and amount of lumber sawed from yellow poplar. yellow blrch, supar maple, and beech. Paper, 10c.

Forest Service Bulletin 88 - Properties and uses of Douglas fir : pt. 1, Mechanical properties; pt. 2, Commercial uses. Paper, $15 \mathrm{c}$.

Forest Service Bulletin 93 - Aspens, their growth and management. Paper 5c.

Forest Service Bu letin 94-Scrub pine. Pinus viryiniana. Paper 5c.

Forest Service Bulletin 95-Uses of commercial woods of United States; 1, Cedurs. cypresses, and sequoias. Paper, $10 \mathrm{c}$.

Forest Service Bulletin 99-Uses of commercial woods of United States: 2 Pines. Paper, 15c.

Forest Service Bulletin 104 - Principles of drying lumber at atmospheric' pressure and humidity dlagram. Paper, $5 c$.

Forest Service Bulletin 108 - Tt sts of structural timbers. Paper, 20c.

Forest Service Bulletin 115 - Mechanical properties of western hemlock. Paper 15c.

Forest Service Bulletin 122 - Mechaniçal properties of western larch, Paper, $10 \mathrm{c}$.

Forest Service Circular 15-Summary of mechanical tests on 32 species of American woods. Paper, 5 \%.

Forest Service Circular 36-Forest Service, what it is and how it deals with forest problems. Paper, 5 c.

Forest Service Circular $40-$ Utillzation of tupelo, Paper, $5 \mathrm{c}$ :

Forest Service Circular 67-Forest planting leaflet: White pine. Pinus strobus Paper, 5c.

Forest Service Circular 135 - Chestnut oak in the southern Applachians. Paper, 5c.

Forest Service Circular 164 - Properties and uses of southern pines. Paper, 5 c.

Forest Service Circular 166 - Timber supply of United States. Paper, 5c.

Forest Service Circular 177 - Wooden and fiber boxes. Paper, 5c,

Foreat Service Circular 180 - Lumber saved by using odd lengths. Paper, 5 c.

Forest Service Circular 192 - Prevention of sap stain in lumber. Paper, $5 c$.

Forest Service Circular 193 - Mechanical properties of redwood. Paper, 5c.

Forest Service Circular 213- Forest Products Laboratory series: Mechanical properties of woods grown in United States. Paper, 5c.

Forest Service Circular 214 - Forest Products Laboratory series; Tests of packing boxes of various forms. Paper, $5 c$,

(Forest Service bulletins and circulars can be obtained from Superintendent of Documents, Government Printing Office, Washington, D. C.. on receipt of price quoted which should be remitted by posta1 money order, express order or New York draft.) 


\section{State Wood-Using Industry Reports}

\section{Prepared by The Office of Industrial Investigations}

The Forest Service has completed statistical studiesof wood-using industries including box manufacture in a number of States. The reports, primarily of local interest, have been printed by some Department of the Government of the State interested, or by an association or periodical devoted to the interest of lumbering and conservation. Bulletins at present available are indicated below and may be secured from the cooperator whose address is given. In ordering those for which there is no charge, postage should accompany the application.

\begin{tabular}{|c|c|c|}
\hline STATE & COOPERATOR & ADDRESS \\
\hline Ark. & Supt, of Doc. of Gov. Printing Offlce & Washington, D. C. $\quad \$ .05$ \\
\hline Ala. & The Lumber Trade Journal & New Orlerns, La. \\
\hline Cal. & G. M. Homans, State Forester & Sacramento, Cal. \\
\hline Conn. & W. O. Filley, State Forester & New Haven, Conn. \\
\hline Fla. & W. A. McRae, Com'r'of Agric. & Tallahassee, Fla. \\
\hline IIl. & J. C. Blair, Univ. of Ill. & Urbana, Ill. \\
\hline Iowa & Iawa State College & Ames,-Iowa \\
\hline$-K_{y}$ & J. E Barton, State Forester & Frankfort. Ky \\
\hline La. & The Lumber Trade Journat & New Orleans, La. \\
\hline Me. & State Forest Commissioner & Augusta, Me. \\
\hline Mich. & Public Domain Commission & Lansing, Mich. \\
\hline Minn. & W. T. Cox, State Forester & St. Paul, Minn. \\
\hline Miss. & The Lumber Trade Journal & New Orleans, La, \\
\hline Mo. & St. Louis Lumberman & St. Louis, Mo. \\
\hline N. H. & E. A. Hirst. State Forester & Concord, N. H. \\
\hline N. Y. & N. Y. State College of Forestry & Syracuse N. Y. \\
\hline N. C. & J. S. Holmes, State Forester & Chapel Hill, N.C. \\
\hline Ohio & Edmund Secrest, State Forester & Wooster, Ohio \\
\hline $\mathbf{P a}$, & R. S. Conklin, Com'r of Forestry & Harrisburg, Pa. \\
\hline S. C. & E. J. Watson, Com'r of Agric. & Columbia, S. C. \\
\hline Tenn. & Soutbern Lumberman & Nashville, Teno. \\
\hline Texas & The Lumber Trade Journal & New Orieans, La. $\quad .25$ \\
\hline Vt. & A. F. Hawes, State Forester & Burlington, Vt. \\
\hline Va. & G. W. Koiner, Com'r of Agric. & Richmond, V s. \\
\hline Wis. & E. M. Grifflth, State Forester & Madison, Wis. \\
\hline
\end{tabular}

Work on studies in the States listed below is now under way. Application for the bulletins to be sent when ready for distribution can be made as follows:

W. Va. H. E. Williams, Com'r of Agric.

N. J. Alfred Gaskill, State Forester

Ind. The Hardwood Record

Ga, The Lumber Trade Journal
Cbarleston, W. Va.

Trenton, N. J.

Chicago, Ill.

New Orleans, La.

The editions of the wood-using reports in the following States are entirely exhausted: Idaho, Maryland, Massachusetts, Montana, Oregon, and Washington. 




\section{RETURN FORESTRY LIBRARY}

TO $\rightarrow$ Aenlford Hall

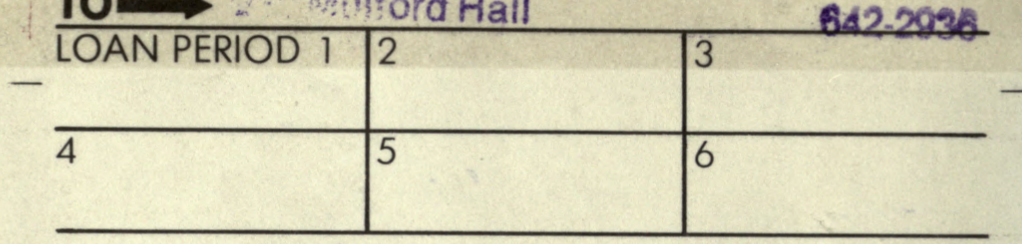

ALL BOOKS MAY BE RECALLED AFTER 7 DAYS

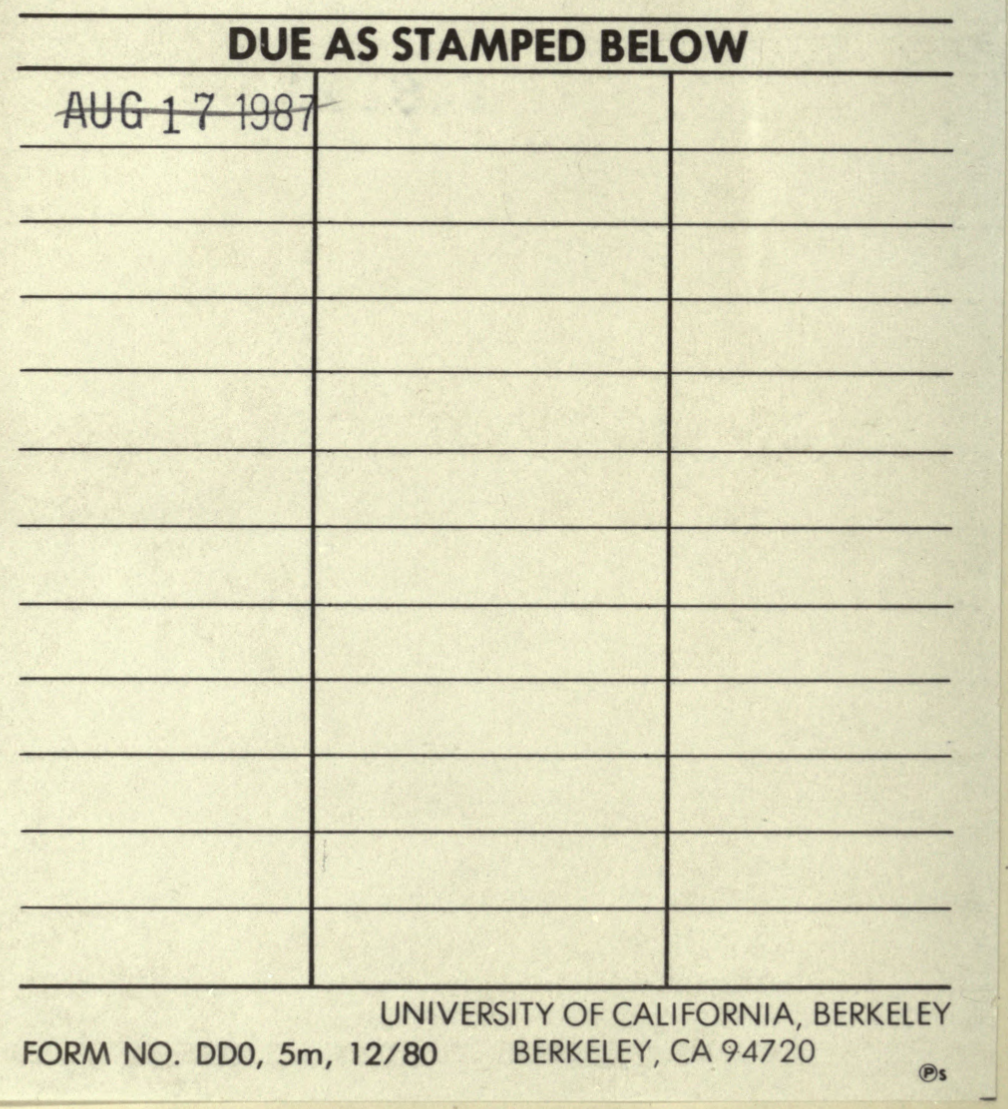




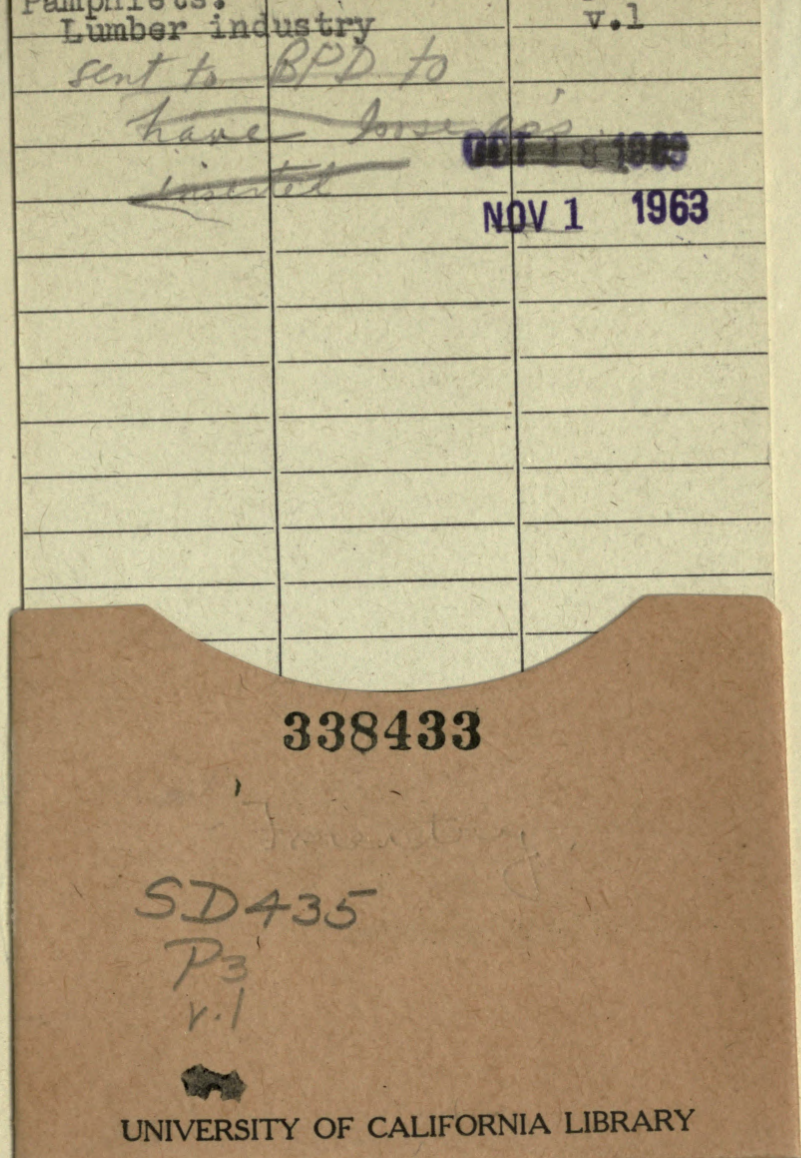


